JOSÉ BERTO NETO

\title{
MEDIDAS DA EMISSÃO DE GASES EM OITO ATERROS \\ DE RESÍDUOS SÓLIDOS URBANOS DO ESTADO DE SÃO
}

PAULO - BRASIL

Tese apresentada à Escola de Engenharia de São Carlos da Universidade de São Paulo, como parte dos requisitos para a obtenção do título de Doutor em Ciências da Engenharia Ambiental.

Orientador: Professor Associado Valdir Schalch

São Carlos - SP

Dezembro/2009 
AUTORIZO A REPRODUÇÃO E DIVULGAÇÃO TOTAL OU PARCIAL DESTE TRABALHO, POR QUALQUER MEIO CONVENCIONAL OU ELETRÔNICO, PARA FINS DE ESTUDO E PESQUISA, DESDE QUE CITADA A FONTE.

Ficha catalográfica preparada pela Seção de Tratamento da Informação do Serviço de Biblioteca - EESC/USP

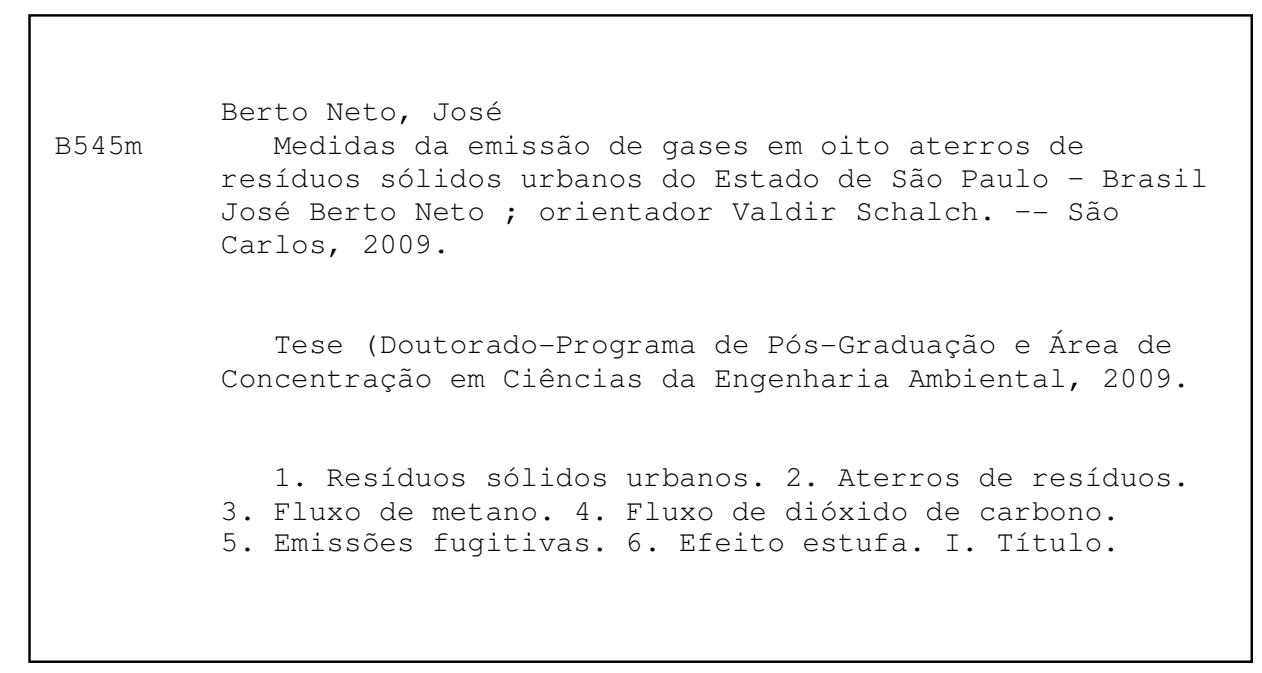


FOLHA DE JULGAMENTO

Candidato(a): Bacharel e Licenciado JOSÉ BERTO NETO.

Tese defendida e julgada em 18.12.2009 perante a Comissão Julgadora:
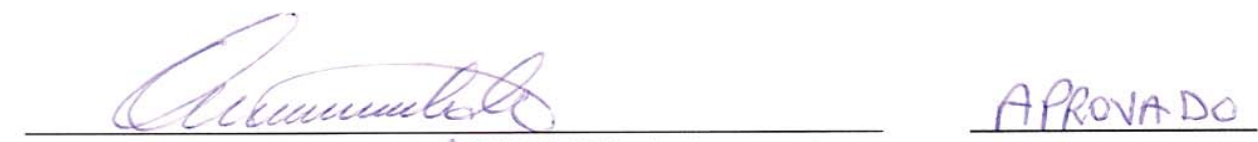

Prof. Associado VALDIR SCHALCH (Orientador)

(Escola de Engenharia de São Carlos/USP)

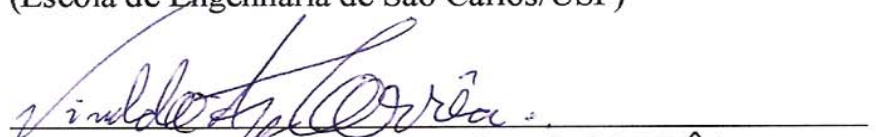

Prof. Dr. NIVACDO APARECIDO CORRÊA

(Escola de Engenharia de São Carlos/USP)
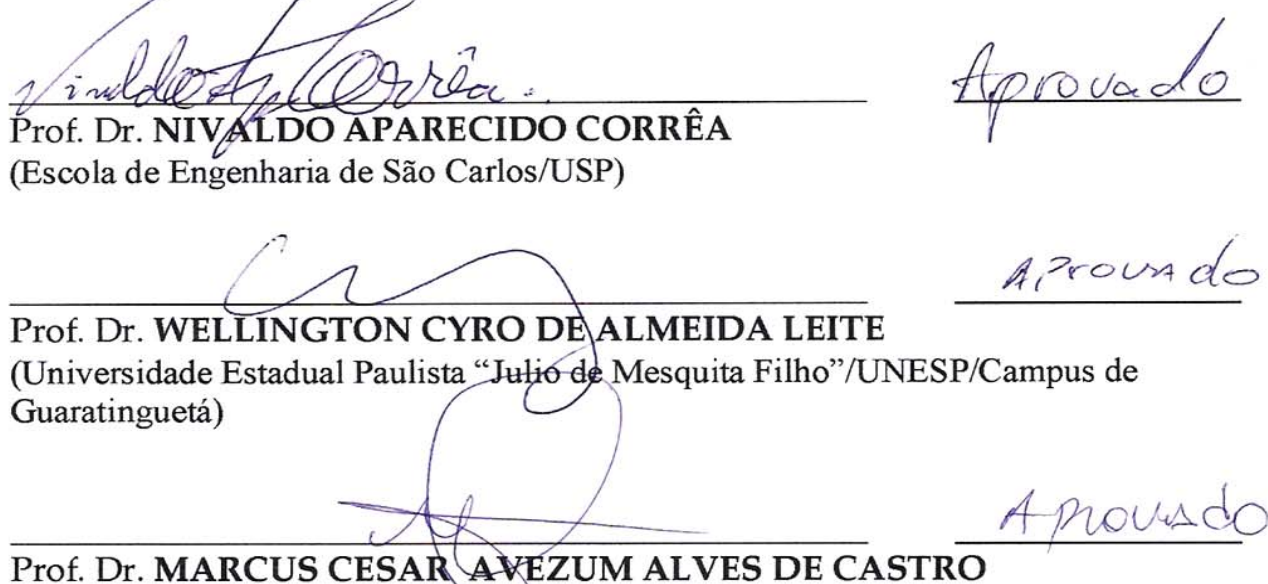

(Universidade Estadual Paulista "Julio de Mesquita Filho"/UNESP/Campus de Rio Claro)

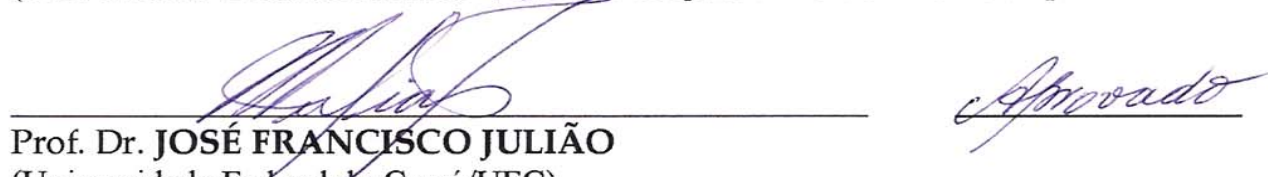

(Universidade Federal to Ceará/UFC)

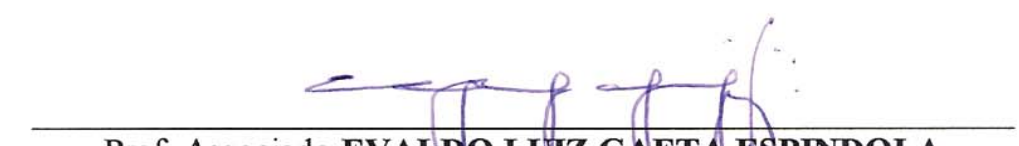

Prof. Associado EVALDO LUIZ GAETA ESPINDOLA

Coordenador do Programa de Pós-Graduação em

Ciências da Engenharia Ambiental

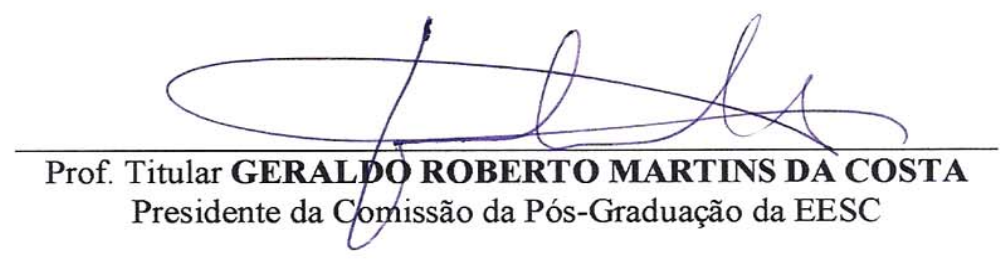


Dedico Este trabalho a (os):

- Teresa Cristina, minha esposa e amiga, significado de força e obstinação, dinamismo, inteligência e discernimento. Dedicação e apoio integral, especialmente, em se tratando de perseguir a edificação da nossa família. Isto me permitiu o enfrentamento desta jornada.

- Juliana, Camila, Raquel e Hugo, por 'ordem de entrada', presentes de Deus para florirem o meu caminho nesta vida, de há muito, sempre muito difícil, mas, adornado pelas Suas presenças.

- Meus Pais, Mundinha e Pedro (in memorian), pela vida, pelo amor; exemplos de luta, dedicação, trabalho e de simplicidade; incentivadores primeiros da minha caminhada na busca do conhecimento. 


\section{AGRADECIMENTOS}

À DEUS, pela vida e por tudo que me tem prodigalizado.

Ao Professor Doutor Valdir Schalch, pela orientação, pela amizade e respeito, pela simplicidade e dedicação demonstradas, pelo exemplo do Grande Homem/Mestre que é. Uma amizade para sempre.

Ao Professor Doutor Bohdan Matvienko Sikar, pela idéia (em momento difícil) e co-orientação deste trabalho, pela capacidade e desapego demonstrados, experiência e segurança no 'fazer-científico'.

Aos diletos Professores Doutores do Programa de Pós-Graduação em Ciências da Engenharia Ambiental (PPG-SEA/CHREA/USP): Antonio Carlos Pião, Evaldo Gaeta, Victor Ranieri e, especialmente, ao Professor Doutor Harry Edmar Schulz, amigo e incentivador, conselheiro exemplar, exemplo de simplicidade a despeito da competência e larga experiência.

Ao professor Doutor Marcelo Pereira de Souza, coordenador do PPG-SEA.

À Física Elizabeth Sikar - Construmaq São Carlos - sinônimo de colaboração e ajuda a qualquer hora.

Ao Professor Doutor José Francisco Julião, 'um dos meus permanentes mestres', desde a graduação na UFC, amigo, incentivador e conselheiro de todas as horas.

À Professora Doutora Nájila Rejanne Alencar Julião Cabral, coordenadora do PQI 106/03-1 no convênio CEFETCE/EESC-USP, pelo desprendimento e boa vontade na condução do programa, sempre disponível às nossas demandas.

Aos Professores Doutores Nivaldo Aparecido Corrêa (SHS-EESC/USP) e Frederico Fábio Mauad (SHS/PPG-SEA), pela ajuda imensurável com alojamento/sala de estudos no Broa, sensibilidade e compreensão, pelo que serei grato eternamente.

À Senhora Maria Angela Tallarico Adorno (Dona Janja) pelo apoio e disponibilidade no Laboratório de Processos Biológicos (LPB) /SHS-EESC/USP. 
À Professora Doutora Maria Bernadete Amâncio Varesche Silva, pela cordialidade e disponibilização do LPB/SHS-EESC/USP, para os experimentos cromatográficos.

Aos meus irmão(a)s/cunhado(a)s/sobrinho(a)s: Francisco de Sales e Conceição/ Carolina, Suyanne e Felipe; Silvana; Inácia - Estes em Fortaleza. Luziana e Zé/Pedro Venício e Vitória - Boa-vistenses/macuxis. Em especial, àquele(a)s residentes nas 'terras bandeirantes' pelo apoio e disponibilidade de ajuda e aconchego: Marcelo e Edineide/Enio Felipe e Ellen Talita; Maria e Paulo/Janaina(c/seus Tesouros) e Jéferson(O Nêgo); Antonio Berto(Tata), ajuda imensurável na reta final desta caminhada, com os filhos Rafael e Juliana; Ana Maria e Zé/Aline e Neide; Denise e Luís Guilherme/Bárbara e Pedro Guilherme.

À Doutora Leny Borghesan, do Laboratório de Resíduos Químicos (EESC/USP), incentivadora do 'primeiro projeto' desta jornada, bem como aos seus 'comandados'.

Às colegas pós-graduandas do LPB/SHS Daniele Vital Vich e Julia Sumiko Hirasawa, pela amizade e imensa ajuda nos primeiros cromatogramas e domínio do cromatógrafo, disponibilidade e solidariedade.

Às funcionárias do SHS/EESC-USP: Márcia Campos, Ma. Cecília Marques, Valderes A. Picon Terroni, Flávia Gialorenço Canova, Fernanda Ma. Struzziatto, e, em especial, à Senhora Rosemeire Aparecida de Jesus (A Rose), todas exemplares nas suas funções e no atendimento aos alunos, por não "se furtarem em ir além das suas responsabilidades" quando ajudam.

Aos Funcionários do CRHEA/EESC-USP: Aquiles Filho, José Rogério Faria, Amandio Nogueira, América Jacinta (D. América, gente muito especial), Carlos Eduardo Matheus, Claudete Poianas, José Roberto Maramarque (O Betão), Joselma Ma. Ferreira (D. Jô/Limpeza), Mara Lúcia Cotrim (D. Mara/Biblioteca), Marcelo Nogueira, Maria de Lourdes (Limpeza), Nelson Emanuel Tessarin, Osni Rizato, Paulo de Luccas, Soemi Cezarinno (D. Soemi/Limpeza), Leondre (Grande Leôncio); Daniel Amaro, Sonia Bueno, e, especialmente a: Aparecido Calderoni Iniesta (O Cido/Restaurante), Edna Regina Viziolli Mantanari (Restaurante), Waldomiro Antonio Filho (O MIRO - grande ajuda técnica e amizade, companheiro das viagens), e mais especial ainda, ao senhor Maurício Viziolli ('SEU MAURíCIO', 
talvez 'o-maior-cientista-das-bandas-do-Broa'), bem como à Senhora Sua esposa Iracema Crivelari Viziolli. TODA (O)S pessoas dignas da minha mais profunda admiração e respeito.

À (o)s funcionária (o)s da Biblioteca da EESC pela disponibilidade e pronto atendimento dispensados quando buscados. São orientações seguras e de boa vontade à hora requerida.

Aos colegas "do lixo", sob o comando do Professor Valdir: Luciana Massukado, Érica Pugliesi, Tássio Lofti, Eduardo Cabral, Fábio Fresca, José da Costa Marques Neto, Ronam Cleber Contrera, Tânia Leme de Almeida, Anne Alessandra Cardoso, Jaqueline Bória, Patrícia C. Silva e, especialmente, à colega Adriana Antunes Lopes, amiga e colaboradora nesta jornada, disponibilidade a toda prova.

À CAPES, pela bolsa e suporte financeiro, via Programa de Qualificação Institucional - PQI 106/03-1 - CEFETCE/EESC-USP.

Aos professores do CEFETCE, colegas do PQI 106/03-1: Adeildo Cabral, Cláudio Turene, Eduardo Cabral, Mariano de Franca e Tássio Lofti; pelo muito que me ajudaram e apoiaram, pelo convívio e companheirismo em São Carlos-SP, na luta desta jornada e curtição 'das saudades alencarinas'.

Aos Professores do CEFETCE: Luisa Pontello e Antonio Uchoa - em nome de toda (o)s os demais colegas -, Luis Orlando Rodrigues - em nome de toda (0)s da GRH, em especial, Antonia Irlenilda Araújo e Ivanilza Silva - e, ao Professor Gilmar Lopes - em nome da Direção Geral.

Aos colegas de turma da EESC/CRHEA-PPG/SEA: James Lacerda e Gisele Queiroz, Alexandre Rossi, Tiago Milani, Fernanda Massaro, Beatriz Pavan, Eduardo Pinheiro (Gaúcho), Juliano Gonçalves, Clara Lemos, Luiz Carlos Correia, Denise Gallo Pizella, Denise Tieme Okumura, Renata Pinassi, Daniela Arantes, Taisa Moretti, Patrícia Vitalli, Ádria Caloto, Cristiane Guedes, Caroline Alves Galharte, Cristina Zorato, Andréa Noveli, Ma. de Lourdes Pizarro, Patrícia Carla Giloni e Stênio Venâncio.

Aos colegas do Núcleo de Hidrometria/Broa, sob o comando do Professor Fred Mauad, pela sadia convivência; muita ajuda e por tão bem me receberem, sem diferenciações, mesmo 'eu sendo do lixo': Felipe Teixeira, Diego Dozzi, César 
Dalmo, Vitor Pioltine, Ivo Gilberto, Márcia Eller, Renato Billia, André Aukar Camargo, Marcus Vinícius Estigoni, Edwardo Albuquerque, Gustavo Scarpinella, ao Wellington Fernando (grande MAMUTE), e, especialmente ao James Lacerda e a Liliane Lazzari.

Aos companheiros das 'noites e dias do Broa', que fizeram e fazem a nossa tranquilidade com seu serviço de Vigilância: Ailton de Souza, Clodoaldo Pereira, Davidson Teixeira, Dirceu Garbuglio, Edieckson Pereira, Eduardo de Oliveira, Elisvaldo dos Santos (BUENO), Jeremias Gonzaga, Juvencino M. Viana, Márcio Meneggin, Nilson Reis, Ralf Arab, Ronaldo Pinto, Samuel Guerreiro, Sérgio de Paula, Valdecir dos Santos e Valmir de Faria, funcionários da Evik Segurança e Vigilância Ltda, TODOS amigos e solidários nos momentos precisos.

À Prefeitura Municipal e ao Departamento Autônomo de Águas e Esgotos de Araraquara, nas pessoas do Professor Doutor Wellington Cyro Leite (Diretor/DAAE) e Agamemnon Brunetti Junior, da Gerência de Operação do Sistema de Resíduos Sólidos (GORES), pela disponibilidade e apóio.

À Prefeitura Municipal de Brotas, Departamento de Meio Ambiente, nas pessoas dos Senhores Marcos Antonio Scarabel e Ângelo Roberto Lazari, pela disponibilidade e ajuda.

À Administração do Aterro Bandeirantes, na pessoa do Senhor Marcus Silva Araújo, Coordenador de Destinação Final da Loga Engenharia, pela atenção e disponibilidade em fornecer as informações sobre o aterro.

À Prefeitura Municipal de Campinas, nas pessoas do Senhor João Roberto Balduíno, DLU/Secretaria de Infra-Estrutura, dos Engenheiros Diná e Fábio Cardoso; do Tecnólogo José Henrique Pilla e da Senhora Tânia Ma. Pires, muito grato pela disponibilidade e ajudas.

À Prefeitura Municipal de Jaú, Secretaria de Serviços Municipais, na pessoa do Senhor Atílio Durval Gasparotto, pela colaboração.

À Prefeitura Municipal de Ribeirão Bonito, via Secretaria de Governo, na pessoa do Senhor Mariano Monteiro do Amaral pela disponibilidade e colaboração. 
À Prefeitura Municipal de Ribeirão Preto, nas pessoas do Senhor Fortunato Spinelli, Marilene Falsarella e Carlos Ferreira (DAERP/PMRP), pela disponibilidade e ajuda.

À Prefeitura Municipal de São Carlos, Secretaria Municipal de Desenvolvimento Sustentável, Ciências e Tecnologia, nas pessoas do senhor Paulo Shiroma e Douglas Minamisako, em especialmente, ao Senhor Miguel Venditi do Aterro Sanitário de São Carlos (Vega Engenharia Ambiental).

Ao povo brasileiro, via CEFETCE, que 'me financia e permite' aperfeiçoar a minha formação, feita sempre em escolas públicas.

Aos membros das bancas examinadoras - qualificação e defesa final - pelos debates e sugestões que enriqueceram o meu trabalho.

Aos meus diletos e queridos alunos, pretéritos e futuros - Colégios Públicos e Privados de Fortaleza; Escola Agrotécnica de Roraima/Universidade Federal de Roraima - UFRR e do CEFETCE. Aos primeiros, pelo rico aprendizado e convivência sadia, aos futuros, pela oportunidade e a certeza de que continuaremos aprendendo.

A toda (o)s que, direta ou indiretamente, contribuíram para a execução desse trabalho. 
[...]

MEU BARRACÃO NO MORRO DO SALGUEIRO

TINHA O CANTAR ALEGRE DE UM VIVEIRO

FOSTE A SONORIDADE QUE ACABOU

E HOJ E, QUANDO DO SOL, A CLARIDADE

FORRA O MEU BARRACÃO, SINTO SAUDADE

DA MULHER POMBA-ROLA QUE VOOU

NOSSAS ROUPAS COMUNS DEPENDURADAS

NA CORDA, QUAL BANDEIRAS AGITADAS

PARECIAM ESTRANHO FESTIVAL!

FESTA DOS NOSSOS TRAPOS COLORIDOS

A MOSTRAR QUE NOS MORROS MAL VESTIDOS

É SEMPRE FERIADO NACIONAL

A PORTA DO BARRACO ERA SEM TRINCO

MAS A LUA, FURANDO O NOSSO ZINCO

SALPICAVA DE ESTRELAS NOSSO CHÃO!

TU PISAVAS OS ASTROS, DISTRAÍDA, SEM SABER QUE A VENTURA DESTA VIDA É A CABROCHA, O LUAR E O VIOLÃO.

\section{Síl VIO CALDAS e ORESTES BARBOSA}

$[\ldots]$

PRA VOCÊ PROCUREI O LUGAR MAIS BONITO...

PRA VOCÊ EU SONHEI O MEU SONHO DE PAZ...

SE VOCÊ NÃO VOLTAR O QUE EU FAÇO DA VIDA? NÃO SEI MAIS PROCURAR A ALEGRIA PERDIDA...

EU NÃO SEI NEM PORQUE TERMINOU TUDO ASSIM $A H, \ldots$ SE EU FOSSE VOCÊ... EU VOLTAVA PRA MIM VOLTAVA, SIM $A H, \ldots$ SE EU FOSSE VOCÊ... AH,... EU VOLTAVA PRA MIM! 
"E... NÃO SABENDO SER IMPOSSÍVEL, FOI LÁ E FEZ". COCTEAU, $J$. 


\section{RESUMO}

BERTO NETO, J. - Medidas da emissão de gases em oito aterros de resíduos sólidos urbanos do Estado de São Paulo - Brasil. São Carlos-SP, 2009. Tese (Doutorado). Escola de Engenharia de São Carlos. Universidade de São Paulo.

Os aterros de disposição de resíduos sólidos urbanos são equipamentos que, necessariamente, devem ser integrados ao sistema de saneamento e proteção à saúde pública das municipalidades. Independente se bem planejados, construídos e operados, os mesmos oferecem impactos ambientais aos locais onde estão implantados e ao seu entorno. Os referidos aterros são fontes de emissão antropogênica de gases indutores do efeito estufa global, como o metano $\left(\mathrm{CH}_{4}\right)$ e o dióxido de carbono $\left(\mathrm{CO}_{2}\right)$. O presente trabalho teve por objetivo medir, estimativamente, in situ, a contribuição destes equipamentos no fluxo destes gases na natureza. Para isso, foram desenvolvidas duas campanhas em oito aterros de municípios do estado de São Paulo (Brasil) nos anos de 2006 e 2007. Foram medidas as concentrações de $\mathrm{CH}_{4}$ e $\mathrm{CO}_{2}$ no ar ambiente dos aterros, a emissão solo-ar e o fluxo a partir dos dissipadores verticais, quando presentes. As amostras coletadas do GAS foram analisadas por cromatografia gasosa. Os resultados evidenciaram que as concentrações de $\mathrm{CH}_{4}$ e $\mathrm{CO}_{2}$ na atmosfera dos aterros foram de 18.000 ppm e 5.500 ppm, respectivamente. Estes valores corresponderam a dez mil vezes e quinze vezes maiores que aquelas medidas em locais distantes dos aterros (background). Os resultados das medidas do fluxo solo-ar apontaram para uma grande variabilidade desta emissão, entre os sítios da coleta, entre os aterros e entre as campanhas. As taxas médias de emissão solo-ar variaram de $5,66 \mathrm{~g} \cdot \mathrm{m}^{-2} \cdot \mathrm{d}^{-1}$ a $148,20 \mathrm{~g} \cdot \mathrm{m}^{-2} \cdot \mathrm{d}^{-1}$ para $\mathrm{CH}_{4}$ e de $17,78 \mathrm{~g} \cdot \mathrm{m}^{-2} \cdot \mathrm{d}^{-1}$ a $223,04 \mathrm{~g} \cdot \mathrm{m}^{-2} \cdot \mathrm{d}^{-1}$ para $\mathrm{CO}_{2} \cdot \mathrm{A}$ emissão estimada solo-ar para os aterros variou de 276,82 a 75.730,20 toneladas 
por ano de $\mathrm{CH}_{4}$ e de 501,02 a 76.312,74 toneladas por ano para o $\mathrm{CO}_{2}$. A emissão estimada para os aterros a partir dos dissipadores verticais variou de 73,52 a 307,31 toneladas por ano para $\mathrm{CH}_{4}$ e de 165,83 a 692,32 toneladas por ano para o $\mathrm{CO}_{2}$. Os resultados também evidenciaram que a concentração dos gases no ar ambiente dos aterros e a emissão solo-ar, especialmente, pareceram independer da operação dispensada: caso aterros sanitários, controlados ou lixões. Todos apresentaram muitas semelhanças no processo de emissão. Mesmo a presença do sistema de sucção do GAS para alimentar a usina termoelétrica (UTEB) no aterro Bandeirantes, São Paulo, Capital, não o diferenciou dos demais. De modo geral, não foi possível correlacionar variáveis que apontassem para tendências gerais na emissão destes sistemas de disposição de RSU. Com base nos resultados supracitados, este trabalho sugere futuras perspectivas de pesquisas.

Palavras-chave: Resíduos Sólidos Urbanos, Aterros de resíduos, Fluxo de metano, Fluxo de dióxido de carbono, Emissões fugitivas, Efeito Estufa. 


\begin{abstract}
BERTO NETO, J. Measurements of gas emissions at eight solid waste landfills of the state of São Paulo - Brazil. São Carlos-SP, 2009. PhD Thesis (Doctoral). Escola de Engenharia de São Carlos. University of São Paulo.
\end{abstract}

Urban solid waste disposal landfills are equipments that must be integrated with the drainage and protection of the public health of municipalities system. Regardless of whether they are well planned, built and operated, they offer environmental impacts to the areas where they are deployed and their surroundings. The present work aimed at measuring, as estimates, in situ, the contribution of the aforementioned equipments in the flux of these gases in nature. The research was developed in 2006 and 2007 in two campaigns in eight municipal solid waste landfills in the state of São Paulo, Brazil. Concentrations of $\mathrm{CH}_{4}$ and $\mathrm{CO}_{2}$ were measured in the air from landfills; the ground-air emission and the flux from vertical drains, when present. The samples collected of the GAS were analyzed utilizing gas chromatography. The results showed that the concentrations of $\mathrm{CH}_{4}$ and $\mathrm{CO}_{2}$ in the atmosphere from landfills were $18,000 \mathrm{ppm}$ and 5,500 ppm, respectively. These values correspond to ten thousand and fifteen times greater than those measured on places far away from landfills (background). The results of the ground-air flux indicated a great variability of this emission, not only among the collection sites, but also among the landfills and between the campaigns. The average ground-air emission ranged from $5.66 \mathrm{~g} \cdot \mathrm{m}^{-2} \cdot \mathrm{d}^{-1}$ to $148.20 \mathrm{~g} \cdot \mathrm{m}^{-2} \cdot \mathrm{d}^{-1}$ for $\mathrm{CH}_{4}$ and from $17.78 \mathrm{~g} \cdot \mathrm{m}^{-2} \cdot \mathrm{d}^{-1}$ to $223.04 \mathrm{~g} \cdot \mathrm{m}^{-2} \cdot \mathrm{d}^{-1}$ for $\mathrm{CO}_{2}$. The estimated ground-air emission for the landfills ranged from 276.82 to $75,730.20$ tons per year of $\mathrm{CH}_{4}$ and from 501.02 to $76,312.74$ tons per year for $\mathrm{CO}_{2}$. The estimated emission for the landfills from the vertical drains ranged from 73.52 to 307.31 tons per year for $\mathrm{CH}_{4}$ and from 165.83 to 692.32 tons per year for $\mathrm{CO}_{2}$. y. The results also showed that the 
concentration of gases in the environment air of landfills and the emission, especially ground-air, seems to be independent of the operation given: whether it is sanitary landfill, controlled landfill, or dump. They all presented many similarities in the emission process, and major differences among them were not elucidated. Even the presence of the suction system of the GAS to feed the thermoelectric plant (UTEB) at the Bandeirantes landfill, located at the capital of São Paulo, did not differentiate it from the other landfills from the $\mathrm{CH}_{4}$ and $\mathrm{CO}_{2}$ emission perspective. In a nutshell, it was not possible to correlate variables that pointed to general trends in the emissions of these USW disposal equipments. Based on these results, future prospects for research are suggested.

Keywords: Urban solid waste, solid waste landfills, Methane flux, Carbon dioxide flux, Fugitive emissions, Greenhouse effect. 


\section{LISTA DE FIGURAS}

Página

Figura 1.7.1 Elementos construtivos de um Aterro Sanitário, com destaque Para a cobertura, sítio das emissões fugitivas.

Figura 3.1.2 Classificação dos RSU's e Responsabilidade pela Disposição Final. 71

Figura 3.3.1 Fluxo da degradação anaeróbica dos constituintes orgânicos em Aterros Sanitários. 80

Figura 3.6.1.1 Distribuição de Comprimentos de Onda $(\lambda)$ da luz emitida e refletida pela superfície terrestre....

Figura 3.6.1.2 Variação na temperatura global média. Destaque a partir $1970 \ldots$

Figura 3.6.1.3 Variações das temperaturas médias superficiais: 1950 a $1997 \ldots$. 102

Figura 3.6.1.4 Fluxo de Luz na troposfera terrestre - efeito estufa. 103

Figura 3.6.3.1 Espectro de absorção do dióxido de carbono no IR térmico.

Figura 3.6.3.2 Intensidade da luz IR térmica que escapa da superfície da terra e aquela que é absorvida.

Figura 3.6.3.3 Crescimento da concentração de metano na atmosfera no último milênio(a) e nas décadas de 80 e 90(b).....

Figura 4.1.1 Câmara de difusão de gases. 120

Figura 4.1.2 Ampola gasométrica (a) e caixa de ampolas gasométricas (b)...... 121

Figura 4.1.3 "Kit" de transferência usado para armazenar e retirar amostras Gasosas das ampolas gasométricas.

Figura 4.1.4 Válvula aberta (a) e fechada (b) 123 
Figura 4.1.5 Rosqueamento de ampola (a), inserção do sacador (b), conjunto ampola/sacador (c) e conjunto ampola/sacador/tubo.

Figura 4.2.1 Detalhe da coleta de amostras Ar-Solo do GAS.

Figura 4.2.1.1 Sistema CG. Componentes (01) e evolução de cromatogramas (02 a 04).

Figura 5.1 Localização geográfica das Áreas de trabalho em relação à América do Sul, Brasil, Estado de São Paulo e suas UGRHI........

Figura 5.2 Mapa do estado de São Paulo, Brasil, seus limites e UGRHI dos municípios pesquisados

Figura 5.3 Mapa do Estado de São Paulo - Municípios pesquisados.

Figura 5.8.1a Foto aérea do Aterro Bandeirantes/São Paulo - Capital. 165

Figura 5.8.1b Foto aérea do aterro Bandeirantes/São Paulo - Capital. 165

Figura 5.8.1c Foto aérea Aterro Bandeirantes/São Paulo/Capital Destaque para UTEB. 166

Figura 5.8.2a/b Entroncamentos do sistema Coletor do GAS - Aterro Bandeirantes/SP.

Figura 5.8.3a Aterro Bandeirantes - Motogeradores. 


\section{LISTA DE TABELAS}

Página

Tabela 1.2.1

Tabela 1.2.2

Tabela 1.5.1

Tabela 3.1.1

Tabela 3.1.2

Tabela 3.3.1

Tabela 3.5.1

Tabela 3.5.2

Tabela 5.1

Tabela 5.2

UGRHI's, População coberta pela coleta e geração de RSD, IQR e Enquadramento (2005). 137

Tabela 5.3 Evolução anual do IQR nos municípios estudados. 138

Tabela 5.4 Evolução do PIB e do PIB per capta dos municípios pesquisados de 2000 a 2003. 141

Tabela 5.9.1 Situação-resumo dos aterros estudados. 171

Tabela 6.3.1 Ar ambiente - Araraquara - Primeira campanha 2006. 189

Tabela 6.3.2 $\quad \mathrm{P}_{1}-$ Araraquara - Primeira campanha 2006 189

Tabela 6.3.3 $\quad \mathrm{P}_{2}-$ Araraquara - Primeira campanha 2006. 190 
Tabela 6.3.4 $\quad \mathrm{P}_{3}-$ Araraquara - Primeira campanha 2006

Tabela 6.3.5 $\quad \mathrm{P}_{4}-$ Araraquara - Primeira campanha 2006 190

Tabela 6.3.6

Drenos - Araraquara - Primeira campanha 2006. 191

Tabela 6.3.7

Ar ambiente - Araraquara - Segunda campanha 2007. 191

Tabela 6.3.8

$\mathrm{P}_{1}$ - Araraquara - Segunda campanha 2007. 191

Tabela 6.3.9

$\mathrm{P}_{2}-$ Araraquara - Segunda campanha 2007. 192

Tabela 6.3.10

$P_{3}-$ Araraquara - Segunda campanha 2007. 192

Tabela 6.3.11 $\quad \mathrm{P}_{4}-$ Araraquara - Segunda campanha 2007 . 192

Tabela 6.2.12 $\quad P_{5}-$ Araraquara - Segunda campanha 2007. 193

Tabela 6.3.13 $\quad \mathrm{P}_{6}-$ Araraquara - Segunda campanha 2007. 193

Tabela 6.3.14 $\quad \mathrm{P}_{7}-$ Araraquara - Segunda campanha 2007. 193

Tabela 6.3.15 $\quad P_{8}-$ Araraquara - Segunda campanha 2007. 194

Tabela 6.3.16 Drenos - Araraquara - Segunda campanha 2007. 194

Tabela 6.3.17 Ar Ambiente - Brotas - Primeira campanha 2006 195

Tabela 6.3.18 $\quad P_{1}-$ Brotas - Primeira campanha 2006. 195

Tabela 6.3.19

$\mathrm{P}_{2}$ - Brotas - Primeira campanha 2006. 195

Tabela 6.3.20 $\quad P_{3}-$ Brotas - Primeira campanha 2006. 196

Tabela 6.3.21 $\quad P_{4}-$ Brotas - Primeira campanha 2006. 196

Tabela 6.3.22 $\quad P_{5}-$ Brotas - Primeira campanha 2006. 196

Tabela 6.3.23 Ar ambiente - Brotas - Segunda campanha 2007... 197

Tabela 6.3.24 $\quad P_{1}-$ Brotas - Segunda campanha 2007. 197 
Tabela 6.3.25 $\quad \mathrm{P}_{2}-$ Brotas - Segunda campanha 2007

Tabela 6.3.26

$\mathrm{P}_{3}-$ Brotas - Segunda campanha 2007 198

Tabela 6.3.27

$\mathrm{P}_{4}-$ Brotas - Segunda campanha 2007 198

Tabela 6.3.28

$P_{5}-$ Brotas - Segunda campanha 2007 198

Tabela 6.3.29

$P_{6}-$ Brotas - Segunda campanha 2007 199

Tabela 6.3 .30

Ar ambiente - Campinas - Primeira campanha 2006 200

Tabela 6.3.31

$\mathrm{P}_{1}$ - Campinas - Primeira campanha 2006 200

Tabela 6.3.32

$\mathrm{P}_{2}$ - Campinas - Primeira campanha 2006 200

Tabela 6.3 .33

$P_{3}$ - Campinas - Primeira campanha 2006 201

Tabela 6.3.34

$\mathrm{P}_{4}$ - Campinas - Primeira campanha 2006 201

Tabela 6.3.35

Drenos - Campinas - Primeira campanha 2006 201

Tabela 6.3.36

Ar ambiente - Campinas - Segunda campanha2007 202

Tabela 6.3.37

$P_{1}$ - Campinas - Segunda campanha 2007 202

Tabela 6.3 .38

$P_{2}$ - Campinas - Segunda campanha 2007 202

Tabela 6.3.39

$P_{3}$ - Campinas - Segunda campanha 2007 203

Tabela 6.3.40

$\mathrm{P}_{4}$ - Campinas - Segunda campanha 2007 203

Tabela 6.3.41

$P_{5}$ - Campinas - Segunda campanha 2007 203

Tabela 6.3.42

$\mathrm{P}_{6}$ - Campinas - Segunda campanha 2007 204

Tabela 6.3.43

$\mathrm{P}_{7}$ - Campinas - Segunda campanha 2007 204

Tabela 6.3.44

$P_{8}$ - Campinas - Segunda campanha 2007 204

Tabela 6.3.45 $P_{9}$ - Campinas - Segunda campanha 2007 205 
Tabela 6.3.46 $\quad \mathrm{P}_{10}-$ Campinas - Segunda campanha 2007 205

Tabela 6.3.47 Drenos - Campinas 2007 205

Tabela 6.3.48

Ar ambiente - Jaú - Primeira campanha 2006 206

Tabela 6.3.49 $P_{1}$ - Jaú - Primeira campanha 2006. 206

Tabela 6.3 .50 $P_{2}$ - Jaú - Primeira campanha 2006. 206

Tabela 6.3.51 $P_{3}$ - Jaú - Primeira campanha 2006. 207

Tabela 6.3.52 $\quad \mathrm{P}_{4}-$ Jaú - Primeira campanha 2006... 207

Tabela 6.3 .53

$P_{5}$ - Jaú - Primeira campanha 2006. 207

Tabela 6.3 .54

Dreno - Jaú - Primeira campanha 2006. 208

Tabela 6.3 .55

Ar ambiente - Jaú - Segunda campanha 2007. 209

Tabela 6.3.56

$P_{1}$ - Jaú - Segunda campanha 2007. 209

Tabela 6.3.57

$P_{2}$ - Jaú - Segunda campanha 2007. 209

Tabela 6.3.58

$P_{3}$ - Jaú - Segunda campanha 2007. 210

Tabela 6.3.59

$P_{4}$ - Jaú - Segunda campanha 2007. 210

Tabela 6.3.60

$P_{5}$ - Jaú - Segunda campanha 2007. 210

Tabela 6.3.61

$P_{6}$ - Jaú - Segunda campanha 2007. 211

Tabela 6.3.62 Dreno - Jaú - Segunda campanha 2007. 211

Tabela 6.3.63 Ar Ambiente - Ribeirão Bonito - Primeira campanha 2006....... 212

Tabela 6.3.64

$\mathrm{P}_{1}$ - Ribeirão Bonito - Primeira campanha 2006. 212

Tabela 6.3.65

$\mathrm{P}_{2}$ - Ribeirão Bonito - Primeira campanha 2006. 212

Tabela 6.3.66 $P_{3}$ - Ribeirão Bonito - Primeira campanha 2006. 213 
Tabela 6.3.67 $\quad P_{4}-$ Ribeirão Bonito - Primeira campanha 2006

Tabela 6.3.68 $\quad P_{5}-$ Ribeirão Bonito - Primeira campanha 2006

Tabela 6.3.69 Ar ambiente - R Bonito - Segunda campanha 2007. 
Tabela 6.3.88 $\quad P_{5}-$ Ribeirão Preto - Segunda campanha 2007

Tabela 6.3.89

$\mathrm{P}_{6}$ - Ribeirão Preto - Segunda campanha 2007.

Tabela 6.3.90

$\mathrm{P}_{7}$ - Ribeirão Preto - Segunda campanha 2007.

222

Tabela 6.3.91

$\mathrm{P}_{8}$ - Ribeirão Preto - Segunda campanha 2007.

222

Tabela 6.3.92

Drenos - Ribeirão Preto - Segunda campanha 2007.

223

Tabela 6.3.93

Ar ambiente - São Carlos - Primeira campanha 2006

224

Tabela 6.3.94

$\mathrm{P}_{1}$ - São Carlos - Primeira campanha 2006.

224

Tabela 6.3.95

$\mathrm{P}_{2}$ - São Carlos - Primeira campanha 2006.

224

Tabela 6.3.96

$P_{3}$ - São Carlos - Primeira campanha 2006

225

Tabela 6.3.97

$\mathrm{P}_{4}$ - São Carlos - Primeira campanha 2006.

225

Tabela 6.3.98

Drenos - São Carlos - Primeira campanha 2006

225

Tabela 6.3.99

Ar ambiente - São Carlos - Segunda campanha 2007.

226

Tabela 6.3.100

$P_{1}$ - São Carlos - Segunda campanha 2007.

226

Tabela 6.3.101

$\mathrm{P}_{2}$ - São Carlos - Segunda campanha 2007.

226

Tabela 6.3.102

$P_{3}$ - São Carlos - Segunda Campanha 2007.

227

Tabela 6.3.103

$\mathrm{P}_{4}$ - São Carlos - Segunda campanha 2007.

227

Tabela 6.3.104

$P_{5}$ - São Carlos - Segunda campanha 2007.

227

Tabela 6.3.105

Drenos - São Carlos - segunda campanha 2007.

228

Tabela 6.3.106

Ar ambiente - Aterro Bandeirantes 2007.

229

Tabela 6.3.107

$P_{1}-$ Bandeirantes 2007.

229

Tabela 6.3.108

$P_{2}-$ Bandeirantes 2007

229 
Tabela 6.5.12 Emissão solo-ar - Sítio $\mathrm{P}_{7}$ - Araraquara 2007

Tabela 6.5.13 Emissão solo-ar - Sítio $\mathrm{P}_{8}$ - Araraquara 2007.

Tabela 6.5.14 Resumo da emissão solo-ar - Araraquara 2007.

Tabela 6.5.15 Emissão solo-ar - Sítio $P_{1}-$ Brotas 2006.

Tabela 6.5.16 Emissão solo-ar - Sítio $\mathrm{P}_{2}$ - Brotas 2006. 284

Tabela 6.5.17 Emissão solo-ar - Sítio $P_{3}-$ Brotas 2006. 285

Tabela 6.5.18 Emissão solo-ar - Sítio $\mathrm{P}_{4}$ - Brotas 2006. 286

Tabela 6.5.19 Emissão solo-ar - Sítio $P_{5}-$ Brotas 2006. 288

Tabela 6.5.20 Resumo da emissão solo-ar - Brotas 2006. 289

Tabela 6.5.21 Emissão solo-ar - Sítio $\mathrm{P}_{1}-$ Brotas 2007 291

Tabela 6.5.22 Emissão solo-ar - Sítio $\mathrm{P}_{2}$ - Brotas 2007. 292

Tabela 6.5.23 Emissão solo-ar - Sítio $P_{3}-$ Brotas 2007. 293

Tabela 6.5.24 Emissão solo-ar - Sítio $\mathrm{P}_{4}$ - Brotas 2007. 295

Tabela 6.5.25

Emissão solo-ar - Sítio $P_{5}-$ Brotas 2007 296

Tabela 6.5.26

Emissão solo-ar - Sítio $P_{6}-$ Brotas 2007 297

Tabela 6.5.27 Resumo da emissão solo-ar - Brotas 2007. 298

Tabela 6.5.28 Emissão solo-ar - Sítio $\mathrm{P}_{1}$ - Campinas 2006. 300

Tabela 6.5.29 Emissão solo-ar - Sítio $\mathrm{P}_{2}$ - Campinas 2006 302

Tabela 6.5.30 Emissão solo-ar - Sítio $\mathrm{P}_{3}-$ Campinas 2006 303

Tabela 6.5.31 Emissão solo-ar - Sítio $\mathrm{P}_{4}$ - Campinas 2006. 304

Tabela 6.5.32 Resumo da emissão solo-ar - Campinas 2006 306 


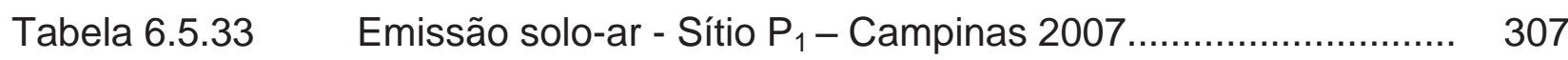

Tabela 6.5.34 Emissão solo-ar - Sítio $P_{2}$ - Campinas 2007......................... 309

Tabela 6.5.35 Emissão solo-ar - Sítio $P_{3}$ - Campinas 2007........................ 310

Tabela 6.5.36 Emissão solo-ar - Sítio $\mathrm{P}_{4}$ - Campinas 2007........................ 312

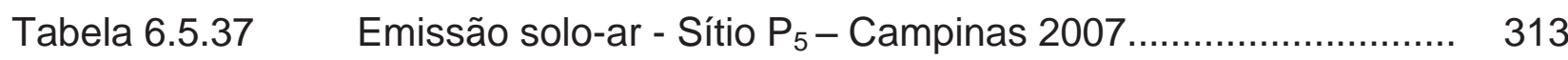

Tabela 6.5.38 $\quad$ Emissão solo-ar - Sítio $\mathrm{P}_{6}$ - Campinas 2007........................ 314

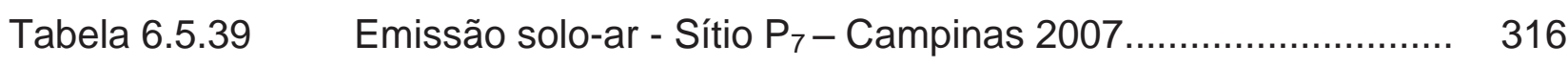

Tabela 6.5.40 Emissão solo-ar - Sítio $\mathrm{P}_{8}$ - Campinas 2007....................... 317

Tabela 6.5.41 $\quad$ Emissão solo-ar - Sítio $P_{9}$ - Campinas 2007........................ 318

Tabela 6.5.42 Emissão solo-ar - Sítio $\mathrm{P}_{10}$ - Campinas 2007....................... 320

Tabela 6.5.43 $\quad$ Resumo da emissão solo-ar Campinas 2007 ....................... 321

Tabela 6.5.44 Emissão solo-ar - Sítio $P_{1}-$ Jaú 2006................................. 323

Tabela 6.5.45 Emissão solo-ar - Sítio $P_{2}-$ Jaú 2006................................. 325

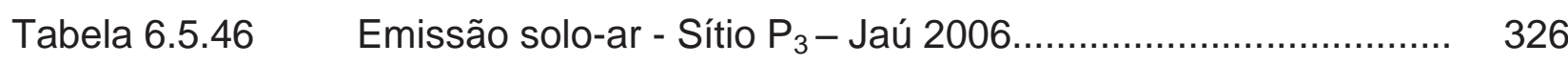

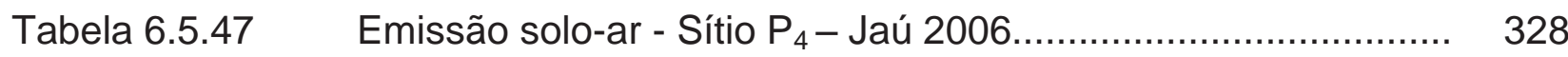

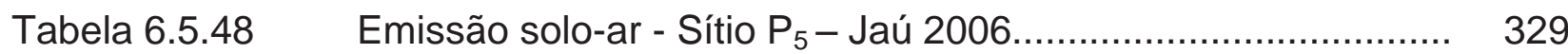

Tabela 6.5.49 $\quad$ Resumo da emissão solo-ar - Jaú 2006............................ 331

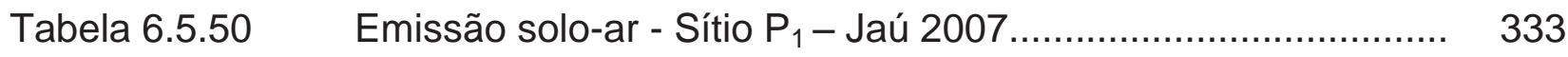

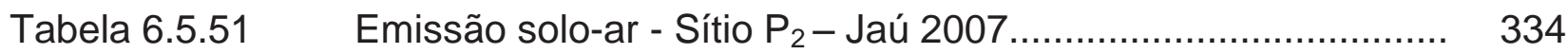

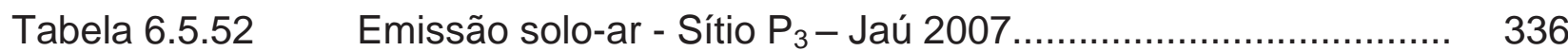

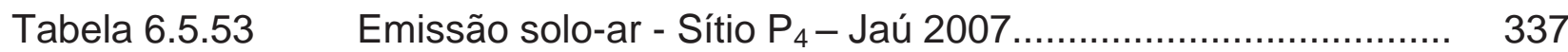


Tabela 6.5.54 Emissão solo-ar - Sítio $\mathrm{P}_{5}$ - Jaú 2007

Tabela 6.5.55 Emissão solo-ar - Sítio $\mathrm{P}_{6}-$ Jaú 2007 340

Tabela 6.5.56 Resumo da emissão solo-ar - Jaú 2007.

Tabela 6.5.57 Emissão solo-ar - Sítio $\mathrm{P}_{1}$ - Ribeirão Bonito 2006.

Tabela 6.5.58 Emissão solo-ar - Sítio $\mathrm{P}_{2}-$ Ribeirão Bonito 2006.......... 345

Tabela 6.5.59 Emissão solo-ar - Sítio $\mathrm{P}_{3}$ - Ribeirão Bonito 2006. 346

Tabela 6.5.60 Emissão solo-ar - Sítio $\mathrm{P}_{4}$ - Ribeirão Bonito 2006. 348

Tabela 6.5.61 Emissão solo-ar - Sítio $P_{5}$ - Ribeirão Bonito 2006. 349

Tabela 6.5.62 Resumo da emissão solo-ar - Ribeirão Bonito 2006. 351

Tabela 6.5.63

Emissão solo-ar - Sítio $\mathrm{P}_{1}$ - Ribeirão Bonito 2007. 352

Tabela 6.5.6

Emissão solo-ar - Sítio $P_{2}$ - Ribeirão Bonito 2007 354

Tabela 6.5 .65

Emissão solo-ar - Sítio $P_{3}-$ Ribeirão Bonito 2007 355

Tabela 6.5 .66

Emissão solo-ar - Sítio $\mathrm{P}_{4}$ - Ribeirão Bonito 2007 356

Tabela 6.5.6

Emissão solo-ar - Sítio $P_{5}-$ Ribeirão Bonito 2007 358

Tabela 6.5.68

Emissão solo-ar - Sítio $\mathrm{P}_{6}-$ Ribeirão Bonito 2007 359

Tabela 6.5.69

Resumo da emissão solo-ar - Ribeirão Bonito 2007. 361

Tabela 6.5.70 Emissão solo-ar - Sítio $P_{1}$ - Ribeirão Preto 2006. 363

Tabela 6.5.71 Emissão solo-ar - Sítio $\mathrm{P}_{2}$ - Ribeirão Preto 2006. 365

Tabela 6.5.72 Emissão solo-ar - Sítio $P_{3}$ - Ribeirão Preto 2006. 366

Tabela 6.5.73 Emissão solo-ar - Sítio $\mathrm{P}_{4}$ - Ribeirão Preto 2006. 367

Tabela 6.5.74 Emissão solo-ar - Sítio $P_{5}$ - Ribeirão Preto 2006. 369 
Tabela 6.5.75 Resumo da emissão solo-ar Ribeirão Preto 2006.

Tabela 6.5.76 Emissão solo-ar - Sítio $P_{1}$ - Ribeirão Preto 2007.

Tabela 6.5.77 Emissão solo-ar - Sítio $\mathrm{P}_{2}$ - Ribeirão Preto 2007.

Tabela 6.5.78

Emissão solo-ar - Sítio $P_{3}-$ Ribeirão Preto 2007.

Tabela 6.5.79

Emissão solo-ar - Sítio $\mathrm{P}_{4}$ - Ribeirão Preto 2007.

375

Tabela 6.5 .80

Emissão solo-ar - Sítio P 5 - Ribeirão Preto 2007.

Tabela 6.5.81

Emissão solo-ar - Sítio $P_{6}-$ Ribeirão Preto 2007.

378

Tabela 6.5.82

Emissão solo-ar - Sítio $\mathrm{P}_{7}$ - Ribeirão Preto 2007.

379

Tabela 6.5.83

Emissão solo-ar - Sítio P 8 - Ribeirão Preto 2007.

381

Tabela 6.5.84

Resumo da emissão solo-ar Ribeirão Preto 2007.

382

Tabela 6.5 .85

Emissão solo-ar - Sítio P 1 - São Carlos 2006.

384

Tabela 6.5.86

Emissão solo-ar - Sítio $\mathrm{P}_{2}$ - São Carlos 2006.

386

Tabela 6.5.87

Emissão solo-ar - Sítio $\mathrm{P}_{3}$ - São Carlos 2006.

387

Tabela 6.5.88

Emissão solo-ar - Sítio $\mathrm{P}_{4}$ - São Carlos 2006.

389

Tabela 6.5.89

Resumo da emissão solo-ar - São Carlos 2006.

390

Tabela 6.5.90

Emissão solo-ar - Sítio $\mathrm{P}_{1}$ - São Carlos 2007.

Tabela 6.5.91

Emissão solo-ar - Sítio $P_{2}$ - São Carlos 2007.

Tabela 6.5.9

Emissão solo-ar - Sítio $\mathrm{P}_{3}$ - São Carlos 2007.

Tabela 6.5.93

Emissão solo-ar - Sítio $\mathrm{P}_{4}$ - São Carlos 2007.

Tabela 6.5.94

Emissão solo-ar - Sítio $P_{5}$ - São Carlos 2007. 398

Tabela 6.5.95 
Tabela 6.5.96 Emissão solo-ar - Sítio $\mathrm{P}_{1}$ - Bandeirantes 2007

Tabela 6.5.97 Emissão solo-ar - Sítio $\mathrm{P}_{2}-$ Bandeirantes 2007. 403

Tabela 6.5.98 Emissão solo-ar - Sítio $\mathrm{P}_{3}-$ Bandeirantes 2007. 405

Tabela 6.5.99 Emissão solo-ar - Sítio $\mathrm{P}_{4}-$ Bandeirantes 2007. 406

Tabela 6.5.100 Emissão solo-ar - Sítio $\mathrm{P}_{5}-$ Bandeirantes 2007. 408

Tabela 6.5.101 Emissão solo-ar - Sítio $\mathrm{P}_{6}-$ Bandeirantes 2007. 409

Tabela 6.5.102 Emissão solo-ar - Sítio $\mathrm{P}_{7}$ - Bandeirantes 2007. 411

Tabela 6.5.103 Emissão solo-ar - Sítio $\mathrm{P}_{8}-$ Bandeirantes 2007.

Tabela 6.5.104 Emissão solo-ar - Sítio $\mathrm{P}_{9}-$ Bandeirantes 2007.

Tabela 6.5.105

Emissão solo-ar - Sítio $\mathrm{P}_{10}$ - Bandeirantes 2007.

Tabela 6.5.106

Emissão solo-ar - Sítio $\mathrm{P}_{11}$ - Bandeirantes 2007.

Tabela 6.5.107 Resumo da emissão solo-ar - Bandeirantes 2007.

Tabela 7.1.1a

Resumo das concentrações $(\mathrm{C})$ medidas para $\left(\mathrm{CH}_{4}\right)$ e $\left(\mathrm{CO}_{2}\right)$

no ar ambiente dos aterros; a concentração media $\left(C_{m}\right)$ por aterro a e concentração média total

Tabela 7.1.1b

Concentração média $\mathrm{CH}_{4}$ e de $\mathrm{CO}_{2}$ do ar ambiente dos aterros, considerando o aterro Bandeirantes, 2007.

Tabela 7.2.1

Síntese dos resultados da taxa de emissão pontual $\left(\mathrm{T}_{\mathrm{x}} \mathrm{E}\right)$ solo-ar; por aterro, campanha, gás e a taxa de emissão média 454 $\left(T_{x} E_{m}\right)$

Tabela 7.2.2

Tabela 7.2.3a

Taxas de emissão média $\left(T_{x} E_{m}\right)$ solo-ar de cada campanha e a média total missão para os aterros estudados.

Valores medidos de maior emissão solo-ar em 2007 e a diferença percentual por campanha

Tabela 7.2.3b

Valores medidos para a maior emissão solo-ar em 2006 e a Diferença percentual. 
Tabela 7.2.4 Emissão média solo-ar de cada campanha e emissão

estimada para os aterros (t.a-1) e o percentual dos gases.......

disposição e número de habitantes/hectares de aterro.

Tabela 7.3.1

Número de drenos total dos aterros, drenos escolhidos e o

Percentual que representaram

Tabela 7.3.2 Emissão média total dos drenos nos aterros em que existiam

Tabela 7.4.1 Emissão estimativa para cada aterro e contribuição 
Página

Gráfico 6.5.1

Sítio $P_{1}$ - Araraquara 2006.

261

Gráfico 6.5.2

Sítio $\mathrm{P}_{2}$ - Araraquara 2006.

263

Gráfico 6.5.3

Sítio $\mathrm{P}_{3}$ - Araraquara 2006.

264

Gráfico 6.5.4

Sítio $\mathrm{P}_{4}$ - Araraquara 2006.

Sítio $P_{1}$ - Araraquara 2007.

Sítio $\mathrm{P}_{2}$ - Araraquara 2007.

Sítio $\mathrm{P}_{3}$ - Araraquara 2007.

Sítio $\mathrm{P}_{4}$ - Araraquara 2007

Sítio $\mathrm{P}_{5}$ - Araraquara 2007

Sítio $\mathrm{P}_{6}-$ Araraquara 2007

Sítio $\mathrm{P}_{7}$ - Araraquara 2007

Gráfico 6.5.12 Sítio $\mathrm{P}_{8}$ - Araraquara 2007.

Sítio $P_{1}-$ Brotas 2006

Sítio $P_{2}-$ Brotas 2006

Sítio $P_{3}-$ Brotas 2006

Sítio $P_{4}-$ Brotas 2006

287

Gráfico 6.5.17 Sítio $P_{5}-$ Brotas 2006.

Gráfico 6.5.18 Sítio $\mathrm{P}_{1}-$ Brotas 2007
288

265

268

270

271

273

274

276

277

278

282

284

285

291 
xxxii

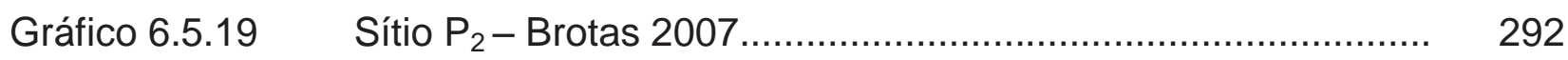

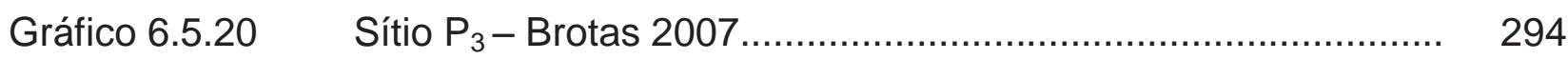

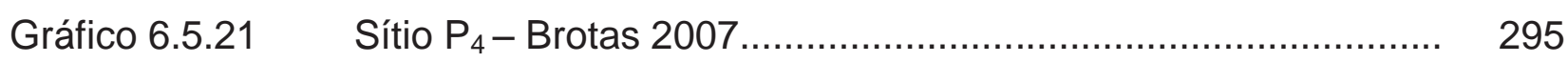

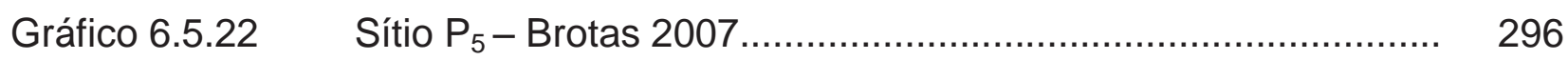

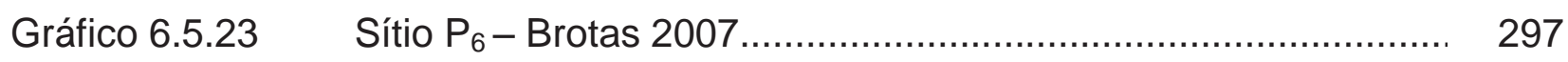

Gráfico $6.5 .24 \quad$ Sítio $P_{1}-$ Campinas 2006............................................... 300

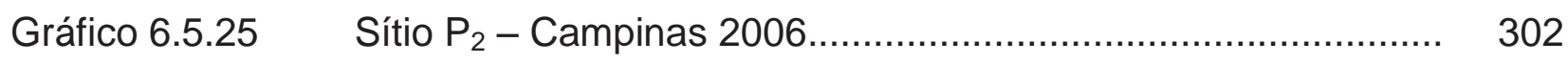

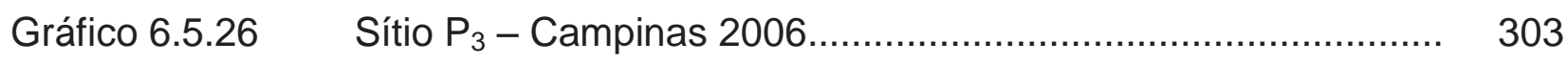

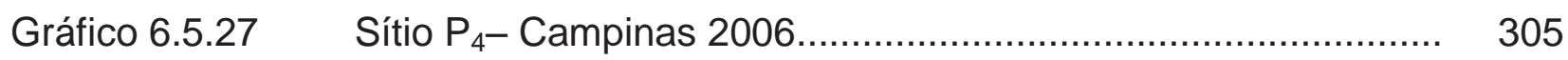

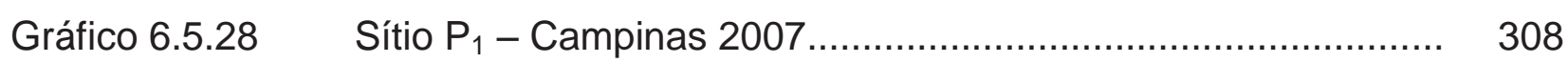

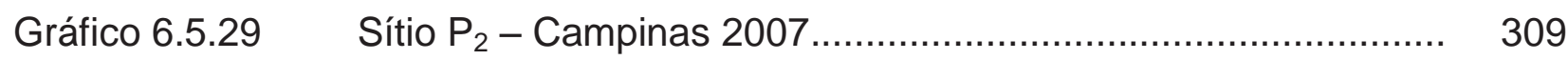

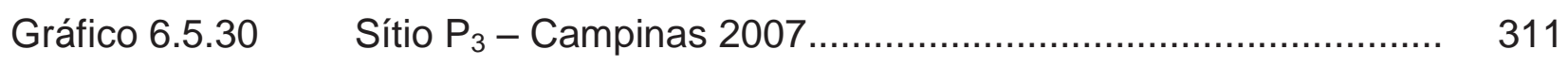

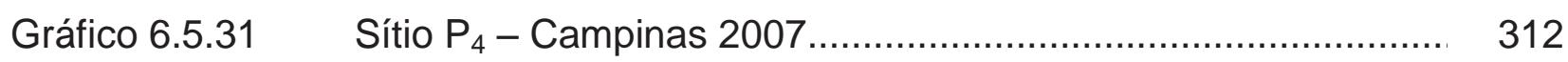

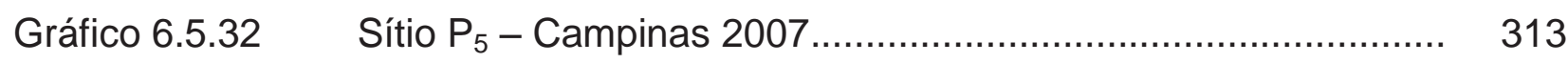

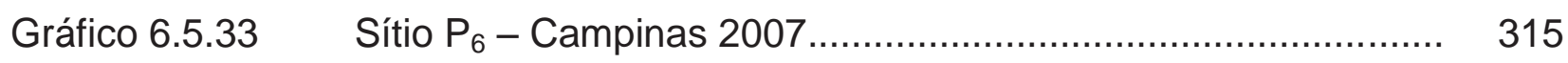

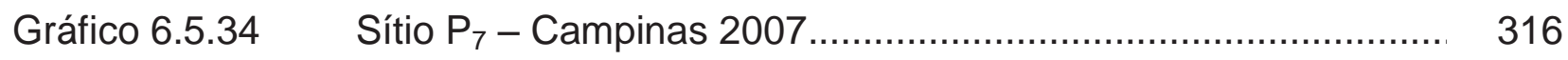

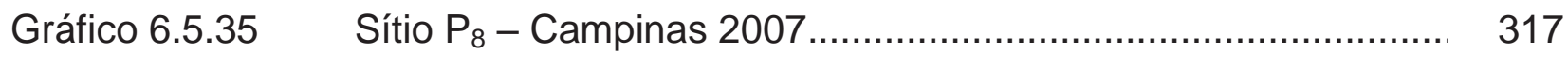

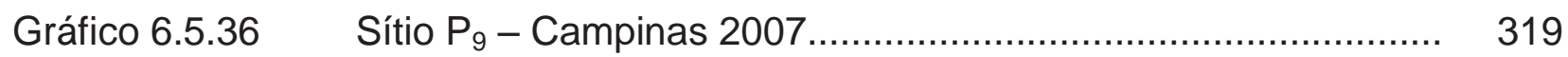

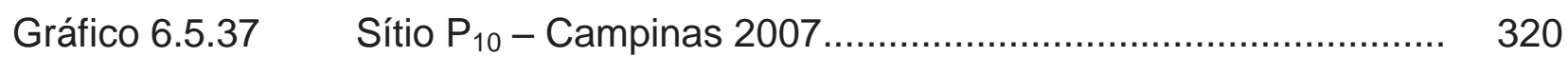

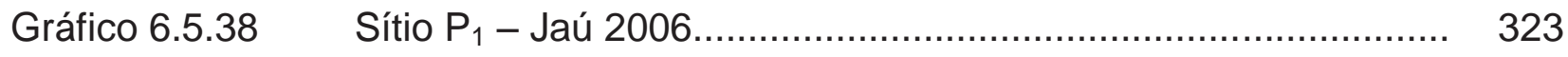

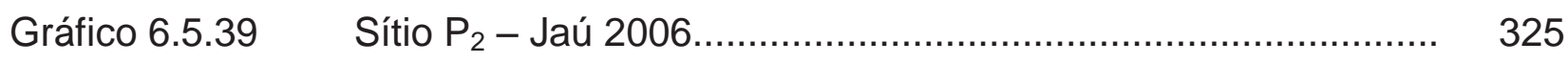


Gráfico 6.5.40 Sítio $\mathrm{P}_{3}-$ Jaú 2006.

Gráfico 6.5.41 S Sítio $P_{4}-$ Jaú 2006.............................................................. 328

Gráfico 6.5.42 S Sítio $P_{5}-$ Jaú 2006............................................................. 330

Gráfico 6.5.43 Sítio $P_{1}-$ Jaú 2007............................................................. 333

Gráfico 6.5.44 Sítio $P_{2}-$ Jaú 2007............................................................ 335

Gráfico 6.5.45 Sítio $P_{3}-$ Jaú 2007......................................................... 336

Gráfico 6.5.46 Sítio $P_{4}$ - Jaú 2007......................................................... 337

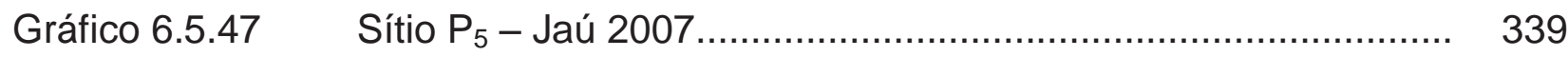

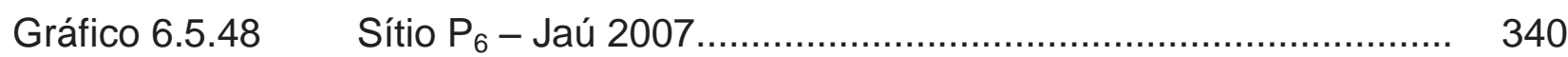

Gráfico 6.5.49 S Sítio $P_{1}-$ Ribeirão Bonito 2006............................................. 343

Gráfico 6.5.50 S Sítio $P_{2}-$ Ribeirão Bonito 2006............................................. 345

Gráfico 6.5.51 Sítio $P_{3}-$ Ribeirão Bonito 2006.............................................. 347

Gráfico 6.5.52 S Sítio $P_{4}-$ Ribeirão Bonito 2006.............................................. 348

Gráfico 6.5.53 S Sítio $P_{5}-$ Ribeirão Bonito 2006............................................. 350

Gráfico 6.5.54 S Sítio $P_{1}-$ Ribeirão Bonito 2007 .............................................. 353

Gráfico 6.5.55 S Sítio $P_{2}-$ Ribeirão Bonito 2007 .............................................. 354

Gráfico 6.5.56 S Sítio $P_{3}$ - Ribeirão Bonito 2007 _............................................. 355

Gráfico 6.5.57 S Sítio $P_{4}$ - Ribeirão Bonito 2007 .............................................. 357

Gráfico 6.5.58 S Sítio $P_{5}-$ Ribeirão Bonito 2007 .............................................. 358

Gráfico 6.5.59 S Sítio $P_{6}-$ Ribeirão Bonito 2007 .............................................. 359

Gráfico 6.5.60 S Sítio $P_{1}$ - Ribeirão Preto 2006................................................ 363 
xxxiv

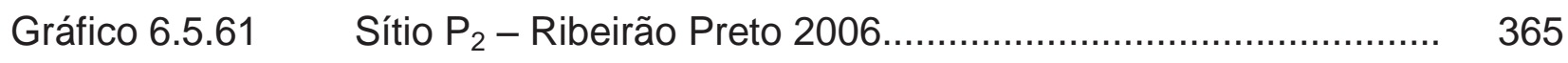

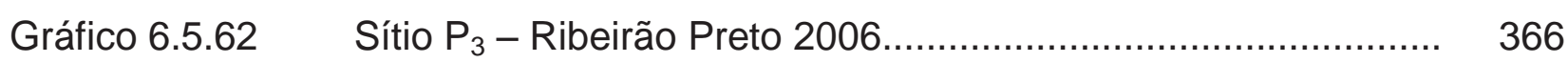

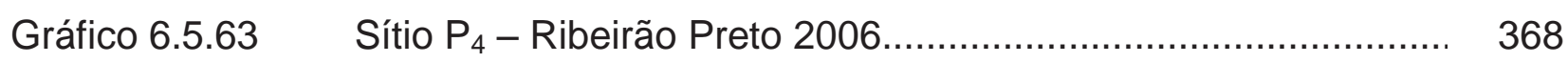

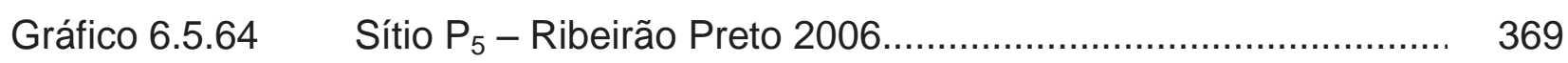

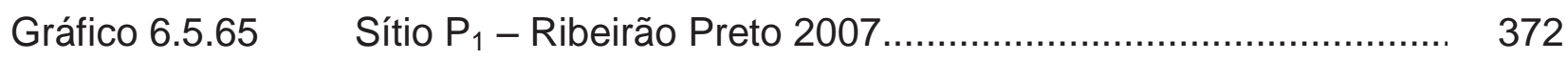

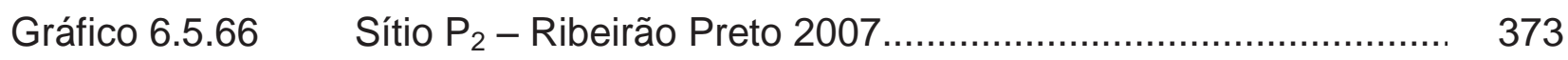

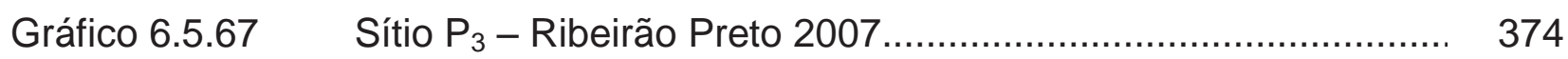

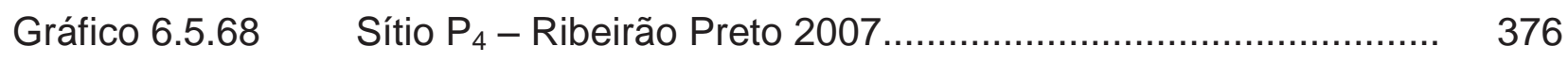

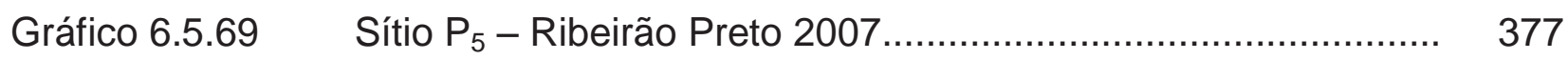

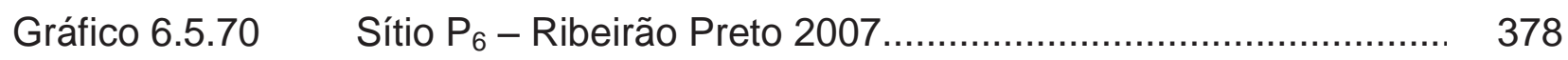

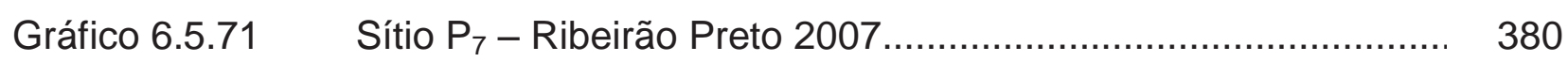

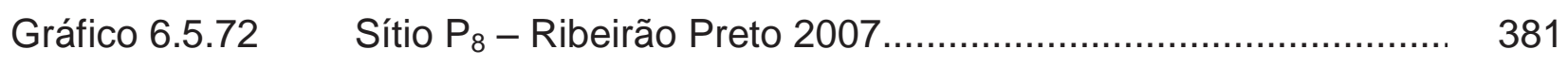

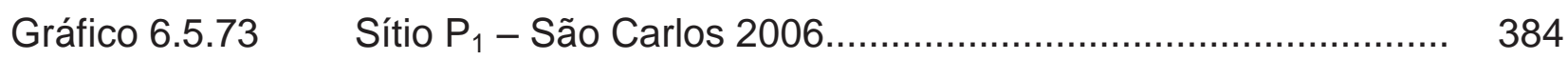

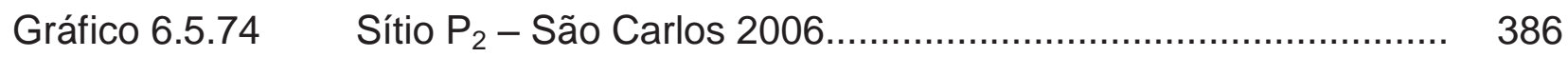

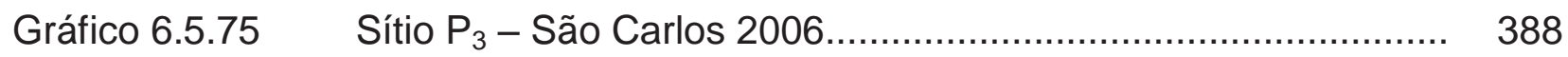

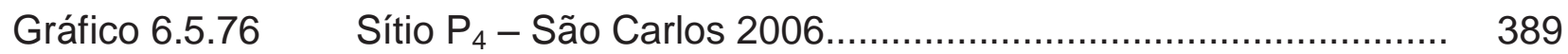

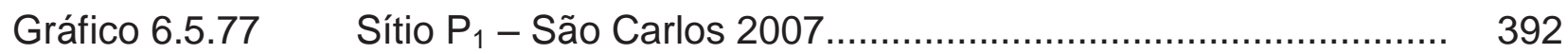

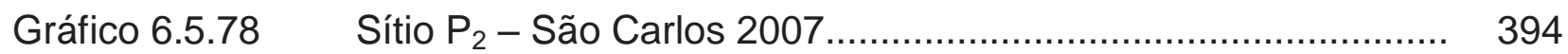

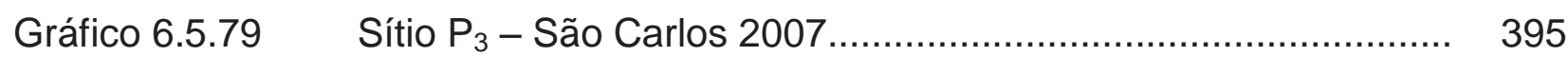

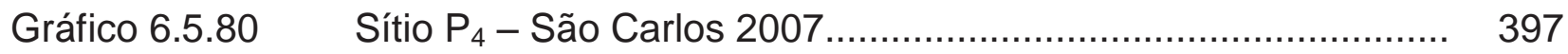

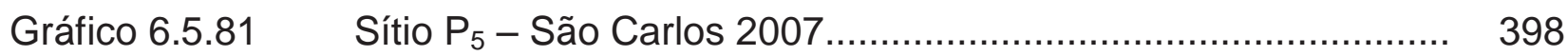


Gráfico 6.5.82 S Sítio $P_{1}-$ Bandeirantes 2007............................................. 401

Gráfico 6.5.83 Sítio $P_{2}-$ Bandeirantes 2007............................................ 403

Gráfico 6.5.84 Sítio $P_{3}-$ Bandeirantes 2007 .............................................. 405

Gráfico 6.5.85 Sítio $P_{4}-$ Bandeirantes 2007 ............................................... 407

Gráfico 6.5.86 Sítio $\mathrm{P}_{5}-$ Bandeirantes 2007 ............................................... 408

Gráfico 6.5.87 Sítio $\mathrm{P}_{6}-$ Bandeirantes 2007 .............................................. 410

Gráfico 6.5.88 S Sítio $\mathrm{P}_{7}-$ Bandeirantes 2007 ............................................. 411

Gráfico 6.5.89 Sítio $\mathrm{P}_{8}-$ Bandeirantes 2007 ............................................. 413

Gráfico 6.5.90 Sítio $P_{9}-$ Bandeirantes 2007 ............................................... 414

Gráfico 6.5.91 Sítio $P_{10}-$ Bandeirantes 2007............................................ 415

Gráfico 6.5.92 Sítio $\mathrm{P}_{11}-$ Bandeirantes 2007 ........................................... 417

Gráfico 7.1.1 Concentração de metano e de dióxido de carbono no ar ambiente dos aterros por campanha e a concentração média.

Gráfico 7.1.2 Concentração de metano $\left(\mathrm{CH}_{4}\right)$ no ar ambiente dos aterros por campanha e concentração média.

Gráfico 7.1.3 Concentração de dióxido de carbono (CO2) no ar ambiente dos aterros por campanha e concentração média.

Gráfico 7.1.4 Comparação entre as concentrações médias de metano e dióxido de carbono por aterro.

Gráfico 7.2.1 Taxas de emissão média solo-ar e a média total p/os aterros

Gráfico 7.2.2 Aterros com maior emissão na campanha de 2007. Destaque para as dif. percentuais e diferenças no Aterro de R Preto....... 
Gráfico 7.2.3 Aterros com maior emissão em 2006. Destaque para diferençc percentuais.

Gráfico 7.2.5 Contribuição percentual de $\mathrm{CH}_{4}$ e $\mathrm{CO}_{2}$ na emissão dos aterros. Sem (a) e com (b) o aterro Bandeirantes. pela coleta......

Gráfico 7.2.7 E missão solo-ar para os aterros e número de habitantes/ha de aterros.

Gráfico 7.2.8 Emissão solo-ar por habitantes/área e idade dos aterros........ 470

Gráfico 7.2.9 Emissão estimativa solo-ar e idade dos aterros. 470

Gráfico 7.2.10 Relaciona a taxa de emissão total (solo-ar) e a área de disposição nos a dos aterros.

Gráfico 7.2.11 Quantidade de resíduos depositada e a taxa de emissão total.. 472 Gráfico 7.2.12 Relação da quantidade de resíduos sólidos depositada e a emissão estimada(solo-ar).

Gráfico 7.3.1 Emissão estimada para os aterros, por gás, a partir dos drenos

Gráfico 7.3.2 Proporções entre a Emissão estimativa pelos drenos e a quantidade de resíduos disposta no aterro.

Gráfico 7.3.3 Relação entre quantidade de resíduos sólidos e a emissão estimada pelos drenos.

Gráfico 7.4.1 Emissão total estimada para os aterros sem e com aterro Bandeirantes... 
Gráfico 7.4.2 Emissão estimada solo-ar, dos drenos e a estimativa total nos Quatro aterros que dispunha dos drenos.

Gráfico 7.4.3 Contribuição percentual dos aterros na emissão total de $\mathrm{CH}_{4}$ e $\mathrm{CO}_{2}$; sem (a) e com (b) a inclusão do aterros Bandeirantes.. 484

Gráfico 7.4.4 E estimada total em relação à quantidade de resíduos sólidos disposta. 


\section{LISTA DE QUADROS}

Página

Quadro 1.2.1 Evoluções do PIB Mundial e da Saúde dos Ecossistemas Naturais 06

Quadro 3.1.1 Gestão Integrada dos RSU's com minimização para os AS......... 48

Quadro 3.1.2 Taxas de reciclagem de RSU's em paises da EU em 2002........... 50

Quadro 3.1.3 Características que distinguem a Gestão do Gerenciamento de

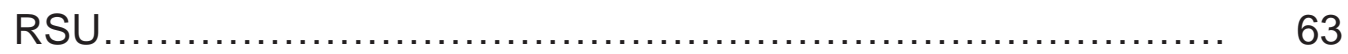

Quadro 3.6.2.1 Vibrações de estiramento de ligação........................... 106

Quadro 3.6.2.2 Vibrações de deformação angular............................... 106

Quadro 3.6.2.3 Estiramentos: Simétrico e Assimétrico.......................... 108

Quadro 6.2.1 Cromatograma ar ambiente de aterro - Bandeirantes 2007........... 175

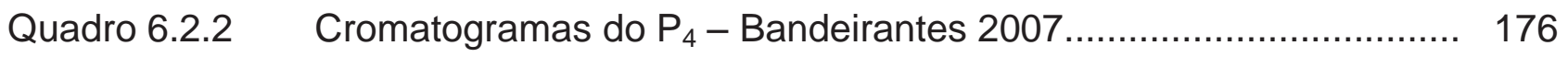

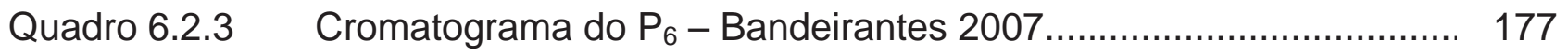

Quadro 6.2.4 Cromatograma do dreno 2 Araraquara 2006......................... 178

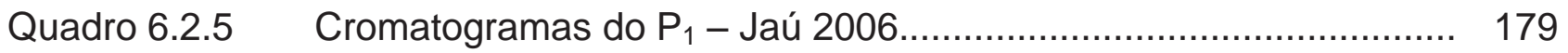

Quadro 6.2.6 Cromatogramas do $\mathrm{P}_{4}$ - Jaú 2006...................................... 180

Quadro 6.2.7 Cromatograma do dreno - Jaú 2006.................................... 181

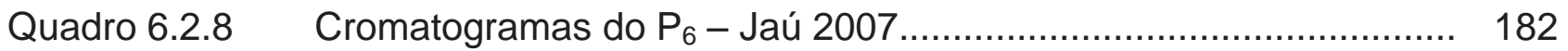

Quadro 6.2.9 Cromatogramas do $P_{3}$ - Ribeirão Preto $2007 \ldots \ldots \ldots \ldots \ldots \ldots \ldots \ldots \ldots \ldots \ldots \ldots$

Quadro 6.2.10 Cromatograma do $\mathrm{P}_{4}$ - Ribeirão Bonito 2007.......................... 184

Quadro 6.2.11 Cromatogramas $\mathrm{P}_{1}$ - São Carlos 2006..................................... 185 
Quadro 6.2.12 Cromatograma dreno 1 - São Carlos 2006.............................. 186

Quadro 6.2.13 Cromatogramas do $P_{2}$ - São Carlos 2007............................. 187

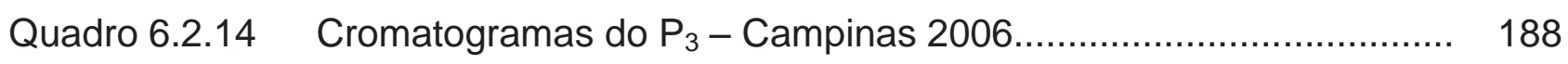




\section{LISTA DE EQUAÇÕES}

Página

Equação 3.3.1 Decomposição orgânica em aterros sanitários. 79

Equação 3.3.2 Produção de gases em aterros sanitários....... 84

Equação 6.1.1.1a Cálculo do número de moles $\left(n_{1}\right)$ do $\mathrm{CH}_{4}$. 172

Equação 6.1.1.1b Cálculo da massa $\left(m_{1}\right)$ do $\mathrm{CH}_{4}$ 173

Equação 6.1.2.1a Cálculo do número de moles $\left(n_{2}\right)$ do $\mathrm{CO}_{2}$ 173

Equação 6.1.2.1b Cálculo da massa $\left(m_{2}\right)$ do $\mathrm{CO}_{2}$. 174

Equação 6.4.1 Equação de estado dos gases ideais. 235 


\section{LISTA DE FOTOS}

Página

Foto 5.1 .1

Foto 5.1 .2

Foto 5.1 .3

Foto 5.1 .4

Foto 5.1 .5

Foto 5.2.1

Foto 5.2 .2

Foto 5.2.3

Foto 5.3.1

Foto 5.4.1

Foto 5.4.2

Foto 5.4.3

Foto 5.5.1

Foto 5.5 .2

Foto 5.5.3

Foto 5.5.4

Foto 5.6.1

Foto 5.6.2

Foto 5.6.3
Aterro controlado de Araraquara 2006 145

Aterro controlado de Araraquara 2006 146

Aterro controlado de Araraquara 2007 146

Aterro controlado de Araraquara 2007.

Aterro controlado de Araraquara 2007.

Aterro em valas de Brotas 2006.

Aterro em valas de Brotas 2006.

Aterro em valas de Brotas 2007

150

Aterros sanitário de Campinas 2006

152

Aterro controlado de Jaú 2006.

153

Aterro controlado de Jaú 2006.

154

Aterro controlado de Jaú 2007.

Aterro em valas de Ribeirão Bonito 2006

Aterro em valas de Ribeirão Bonito 2006

Aterro em valas de Ribeirão Bonito 2007

Aterro em valas de Ribeirão Bonito 2007

Aterro controlado de Ribeirão Preto 2006

Aterro controlado de Ribeirão Preto 2006

Aterro controlado de Ribeirão Preto 2007 
Foto 5.6.4

Foto 5.6 .5

Foto 5.6.6

Foto 5.7.1

Foto 5.7.2

Foto 5.7.3
Aterro controlado de Ribeirão Preto 2007

Aterro controlado de Ribeirão Preto 2007.

161

Aterro controlado de Ribeirão Preto 20076.

161

Aterro sanitário de São Carlos 2006.

Aterro sanitário de São Carlos 2006. 164

Aterro sanitário de São Carlos 2007. 164 
LISTA DE ABREVIATURAS, SIGLAS E SÍMBOLOS

a

A

A

$A_{a t}$

ABNT

ABRELPE

AGV

ANIP

AS's

BEES

BM

C

${ }^{\circ} \mathrm{C}$

C

CBL

CEE

CER'S

CETESB
Ano

Adequada (Classificação dos aterros de São Paulo, CETESB-SP)

Área

Área do aterro

Associação Brasileira de Normas Técnicas

Associação Brasileira de Empresas de Limpeza Pública e Resíduos Especiais

Ácidos Graxos Voláteis

Associação Nacional da Indústria de Pneumáticos

Aterros Sanitários

(Building for Environmental and Economic Sustainability) - Construir para a Sustentabilidade Ambiental e Econômica

Banco Mundial

Carbono

Grau Celcius (ou Grau Centígrado)

Controlado (Classificação dos aterros de São Paulo, CETESB-SP)

Reciclagem de Borrachas Ltda

Comunidade Econômica Européia

(Certified Emission Reductions) - Reduções Certificadas de Emissões

Companhia Ambiental do Estado de São Paulo 
CDM/MDL (Clean Development Mechanism) - Mecanismo de Desenvolvimento Limpo

CFC's Clorofluorcarbonetos

CFR/CRF (Code of Federal Regulations) - Código de Regulamentos Federal

CG Cromatografia Gasosa

CGEE Centro de Gestão e Estudos Estratégicos

$\mathrm{CH}_{4} \quad$ Metano

CGL Cromatografia Gás-Líquido

CNEN Comissão Nacional de Energia Nuclear

CNPq Conselho Nacional de Desenvolvimento Científico e Tecnológico

$\mathrm{CO}_{2} \quad$ Dióxido de Carbono

$\mathrm{CO}_{2} \mathrm{e} \quad$ Carbono Equivalente

CONUMAD Conferência das Nações Unidas sobre o Meio Ambiente e Desenvolvimento

CONAMA Conselho Nacional do Meio Ambiente

COP (Conference of the Parties) - Conferência das Partes

CQNUMC Convenção-Quadro das Nações Unidas sobre Mudança do Clima

d Dia

DAAE Departamento Autônomo de Águas e Esgotos (Araraquara-SP)

DAIA Departamento de Avaliação de Impacto Ambiental

DAERP Departamento de Águas e Esgotos de Ribeirão Preto

DBo Demanda Bioquímica de Oxigênio 
DCT Detector por Condutividade Térmica

DDT Dicloro-Difenil-Tricloroetano

DQO Demanda Química de Oxigênio

Eh Potencial de Òxido-Redução

EIA / RIMA Estudo de Impacto Ambiental / Relatório de Impacto Ambiental

EM Estado do Mundo

EPA (Environmental Protection Agency) - Agência de Proteção Ambiental dos EUA

ETA Estação de Tratamento de Água

ETE Estação de Tratamentos de Esgotos

FIPAI Fundação para o Incremento da Pesquisa e do Aperfeiçoamento Industrial

FE

Fase Estacionária

FM Fase Móvel

FMI Fundo Monetário Internacional

FUNASA Fundação Nacional de Saúde

G Câmara coletora de gás Grande

g Grama

GAS Gás de Aterro Sanitário

GHGIGEE (Greenhouse Gases) - Gases de Efeito Estufa

GIRSU Gerenciamento Integrado de Resíduos Sólidos Urbanos

GORES Gerência de Operação do Sistema de Resíduos Sólidos (Araraquara- 
GPS (Global Positioning System) - Sistema de Posicionamento Global

GWPIPAG (Global Warming Potential) - Potencial de Aquecimento Global

ha Hectare

HC's Hidrocarbonetos

HFC's Hidrofluorcarbonos

$\mathrm{H}_{2} \mathrm{~S} \quad$ Gás sulfídrico/Ácido sulfídrico

I Inadequada (Classificação dos aterros de São Paulo, CETESB-SP)

IBAM Instituto Brasileiro de Administração Municipal

IBGE Instituto Brasileiro de Geografia e Estatística

IERSD Inventário Estadual de Resíduos Sólidos Domiciliares/São Paulo

IPCC (Intergovernamental Panel on Climate Change) - Painel

Intergovernamental sobre Mudança Climática

IPV I Índice Planeta Vivo

IQC Índice de Qualidade de Usinas de Compostagem (CETESBE-SP)

IQR Índice de Qualidade de Aterro de Resíduos (CETESBE-SP)

IQR $_{\mathbf{v}} \quad$ Índice de Qualidade de Aterros em Valas (CETESBE-SP)

IR/IV (Infrared) Infravermelho

LI Licença de Instalação

LO Licença de Operação

LP Licença Prévia 
Massa, g ou $\mu \mathrm{g}$

$\min$

Minutos

$\mathbf{m m}$

Milímetros

MMA

Ministério do Meio Ambiente

MMTCE (Million Metric Tons of Carbon Equivalent) - Milhões de Toneladas Métricas Equivalentes de Carbono

MRE

Ministério das Relações Exteriores

MSWIRSU (Municipal Solid Waste) - Resíduos Sólidos Urbanos

MSWLF (Municipal Solid Waste Landfill) - Aterro de Resíduos Sólidos Municipais

MW

Megawatts

$\mathbf{N}_{2} \quad$ Nitrogênio Molecular

$n$

Número de moles

NBR Norma Brasileira Registrada

nm Nanômetros

NMVOC's Compostos orgânicos voláteis não metânicos

NO’x Óxidos de nitrogênio

$\mathrm{N}_{2} \mathrm{O} \quad$ Óxido nitroso

OGM's Organismos Geneticamente Modificados

ONU Organização das Nações Unidas

OCDE Organização para Cooperação e Desenvolvimento Econômico

P Fósforo 


$\begin{array}{ll}\mathbf{P n}_{\mathbf{n}} & \text { Ponto/sítio de coleta no aterro } \\ \mathbf{p} & \text { Câmara coletora de gás Pequena } \\ \mathbf{P 2} & \text { Prevenção à Poluição } \\ \text { PEAD } & \text { Polietileno de alta densidade } \\ \text { PEV's } & \text { Pontos de Entrega Voluntária } \\ \text { p. ex. } & \text { Por exemplo }\end{array}$

$\begin{array}{ll}\text { PFC's } & \text { Perfluorcarbonos } \\ \text { pH } & \text { Potencial Hidrogeniônico } \\ \text { PIB } & \text { Produto Interno Bruto }\end{array}$

PMB Produto Mundial Bruto

PMRP Prefeitura Municipal de Ribeirão preto

PNUD Programa das Nações Unidas para o Desenvolvimento

ppbv $\quad$ Partes por bilhão por volume

ppmv Partes por milhão por volume

PNEA Programa Nacional de Educação Ambiental

PNSB Pesquisa Nacional de Saneamento Básico

PROINFA Programa de Incentivo às Fontes Alternativas de Energia Elétrica

PROSAB Programa de Pesquisa em Saneamento Básico

Qtd Quantidade

RCD Resíduos de Construção e Demolição

RCE's Reduções Certificadas de Emissões 
RSS's Resíduos de Serviços de Saúde

RSCD e V's Resíduos Sólidos da Construção, Demolição e Volumosos (Araraquara-SP)

RSU

Resíduos Sólidos Urbanos

$\mathrm{SF}_{6}$

Hexafluoreto de Enxofre

$\mathrm{SF}_{5} \mathrm{CF}_{3}$

Trifluorometil pentafluor de Enxofre

$\mathrm{Tg}$

Teragrama (onde $1 \mathrm{Tg}$ equivale a $10^{12} \mathrm{~g}$ )

$\mathbf{t}$

Toneladas

$\mathbf{T}_{\mathbf{x}}$

Taxa

$T_{x} E_{m}$

Taxa de Emissão média

$T_{x} E_{m(A t)}$

Taxa de Emissão média total

EU

União Européia

UK/RU (United Kingdom) - Reino Unido

UGRH Unidades de Gerenciamento de Recursos Hídricos/São Paulo

UNFCCC (United Nations Framework Convention on Climate Change) Convenção-Quadro das Nações Unidas sobre Mudança do Clima USEPA (United States of America Environmental Protection Agency) Agência de proteção Ambiental dos Estados Unidos da América

UTEB Usina Termoelétrica Bandeirantes/Aterro Sanitário Bandeirantes/SP

UV Ultravioleta

V Volume $(\mathrm{L} ; \mathrm{mL})$ 
VOC's/COV's (Volatile Organic Compounds) - Compostos Orgânicos Voláteis

WMO/OMM (World Meteorological Organization) Organização Meteorológica Mundial

WRI (World Resources Institute) - Instituto de Pesquisas Mundial

WWF (World Wildlife Fund) - Fundo Mundial para a Natureza

$\% \quad$ Porcentagem ou percentagem

$\mu \mathrm{m} \quad$ Micrômetros

$\lambda \quad$ Comprimento de Onda

$\mu \mathrm{g} \quad$ Microgramas 


\section{SUMÁRIO}

Página

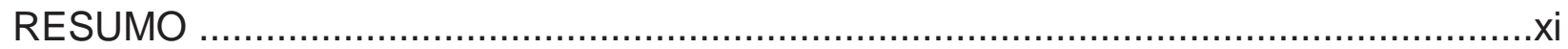

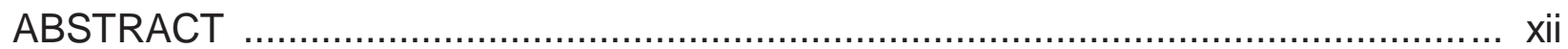

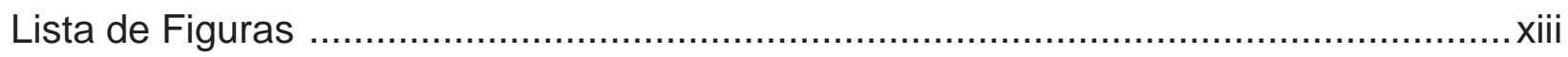

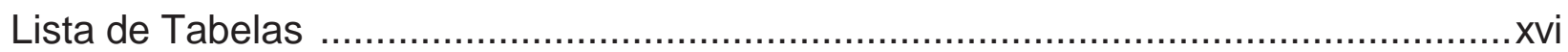

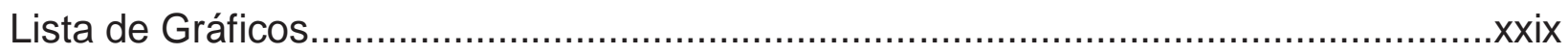

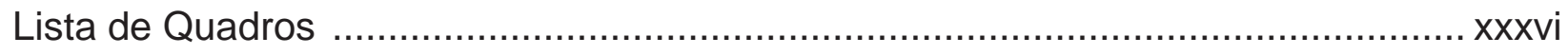

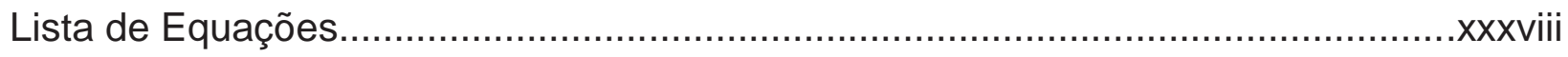

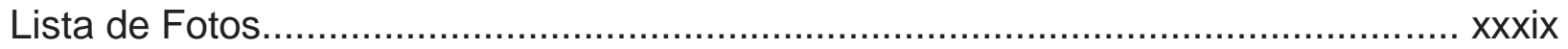

Lista de Abreviaturas, símbolos e Siglas ..........................................................

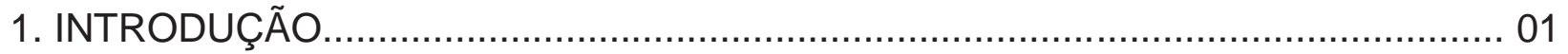

1.1. Desenvolvimento Econômico versus Ambiente Natural.............................. 01

1.2. A revolução Industrial: Impactos populacional e de consumo;

crescimento econômico; degradação ambiental; efeito estufa......................... 04

1.3. O despertar da questão ambiental: Desenvolvimento Sustentável................. 11

1.4. Homem e Natureza: Interdependência e novo paradigma......................... 14

1.5. Questão ambiental e iniquidade................................................... 17

1.6. Resíduos sólidos e a questão ambiental............................................. 25

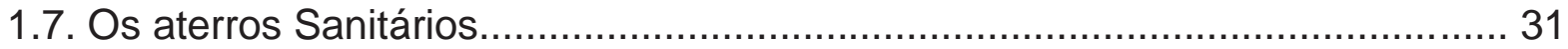


2.1. Geral

2.2. Específicos

3. REVISÃO BIBLIOGRÁFICA.

3.1. Os Resíduos Sólidos Urbanos: problemática, definições e classificações. 38

3.2. A biodegradabilidade dos resíduos sólidos urbanos 72

3.3. Geração e características do GAS (Gás de Aterro Sanitário) .75

3.4. Líquidos percolados: geração e características 88

3.5. Aterros sanitários e a situação brasileira 89

3.6. Efeito Estufa e o Aquecimento Global. 93

3.6.1. O mecanismo do Efeito Estufa. 99

3.6.2. Vibrações moleculares: Absorção de energia pelos gases indutores do Efeito estufa. 105

3.6.3. Os principais gases indutores do efeito estufa. 109

4. METODOLOGIA. 119

4.1 Materiais e Equipamentos.

4.2. Metodologia de trabalho. 126

4.2.1. Determinação instrumental do metano e do dióxido de carbono. 129

5. CARACTERIZAÇÃO DAS ÁREAS DE ESTUDO

5.1. Aterro controlado do município de Araraquara-SP 142

5.2. Aterro em valas do município de Brotas - SP 148 
5.3. Aterro sanitário do município de Campinas - SP

5.4. Aterro controlado do município de Jaú - SP 153

5.5. Aterro em valas do município de Ribeirão Bonito - SP 155

5.6. Aterro contralado do município de Ribeirão Preto - SP 158

5.7. Aterro sanitário do município de São Carlos - SP 162

5.8. Aterro sanitário Bandirantes (São Paulo/Capital) 165

5.9. Situação-resumo dos aterros estudados.

6. RESULTADOS

6.1. Resultados cromatográficos das amostras por aterro, data e tempos de coleta; cálculo do número de moles $(n)$ e da massa $(m ; \mu g)$ para o $\mathrm{CH}_{4}$ e o $\mathrm{CO}_{2}$

6.1.1. Equações para a determinação do número de moles $\left(n_{1}\right)$ e da massa

$$
\left(m_{1} ; \mu g\right) \text { para o metano. }
$$

6.1.2. Equações para a determinação do número de moles $\left(n_{2}\right)$ e da massa

$\left(m_{2} ; \mu g\right)$ para o dióxido de carbono.

6.2. Cromatogramas representativos de algumas amostras do GAS 175

6.3. Tabelas com o cálculo de moles $(n)$ e da massa $(m ; \mu g)$ de $\mathrm{CH}_{4}$ e $\mathrm{CO}_{2}$, para cada amostra, por aterro e tempos de coleta 189

6.3.1-A ${ }_{1}$ Aterro de Araraquara - Primeira campanha - 2006 189

6.3.1-A . Aterro de Araraquara - Segunda campanha- 2007 191

6.3.2-B ${ }_{1}$. Aterro de Brotas - Primeira campanha - 2006 195

6.3.2-B $\mathrm{B}_{2}$. Aterro de Brotas - Segunda campanha - 2007 197

6.3.3- $\mathrm{C}_{1}$. Aterro de Campinas - Primeira campanha - 2006 200

6.3.3- $\mathrm{C}_{2}$. Aterro de Campinas - Segunda campanha - 2007. 202

6.3.4- $\mathrm{D}_{1}$. Aterro de Jaú - Primeira campanha - 2006 206 


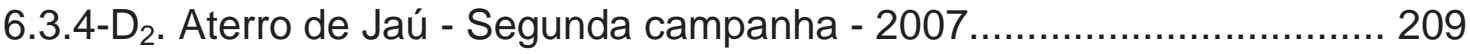

6.3.5- $E_{1}$. Aterro de Ribeirão Bonito - Primeira campanha - 2006................ 212

6.3.5-E $E_{2 .}$ Aterro de Ribeirão Bonito - Segunda campanha - 2007.............. 214

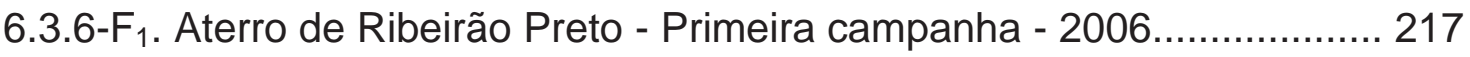

6.3.6-F 2. Aterro de Ribeirão Preto - Segunda campanha - 2007 ................. 220

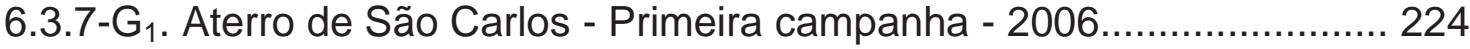

6.3.7-G. Aterro de São Carlos - Segunda campanha - 2007........................226

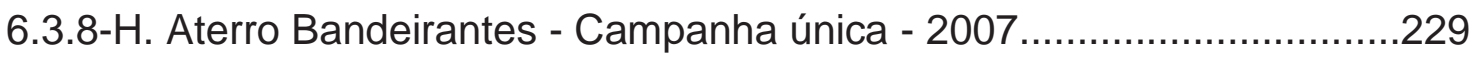

6.4. Cálculo da concentração de metano e de dióxido de carbono no ambiente

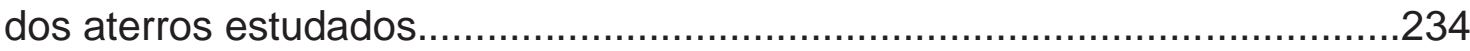

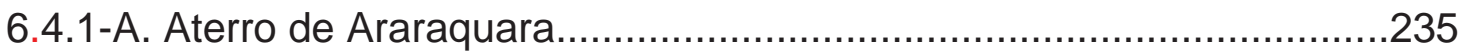

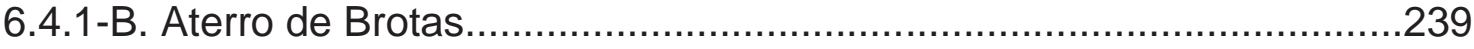

6.4.1-C. Aterro de Campinas.............................................................242

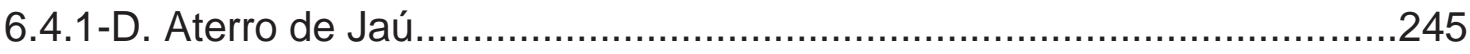

6.4.1-E. Aterro de Ribeirão Bonito.................................................248

6.4.1-F. Aterro de Ribeirão Preto.......................................................251

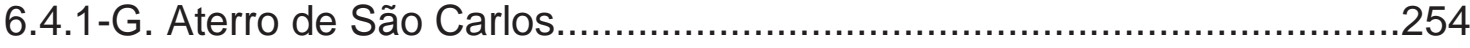

6.4.1-H. Aterro Bandeirantes 2007....................................................257

6.5. Cálculo da emissão solo-ar para $\mathrm{CH}_{4}$ e $\mathrm{CO}_{2}$ de cada sítio de coleta $\left(\mathrm{P}_{\mathrm{n}}\right)$ dos

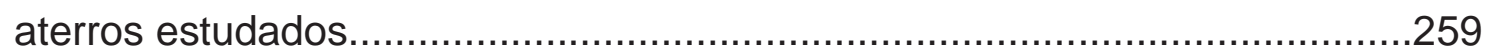

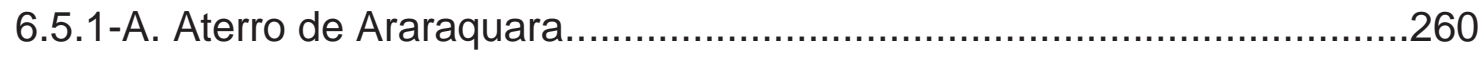

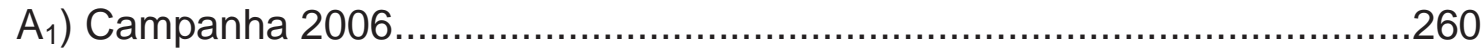

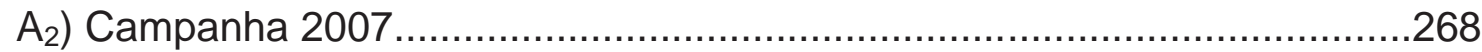

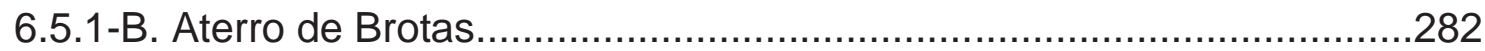


$\left.B_{1}\right)$ Campanha 2006

$\left.B_{2}\right)$ Campanha 2007

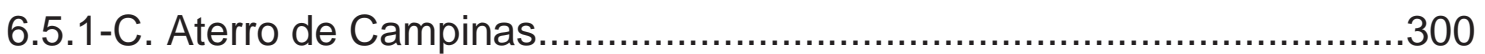

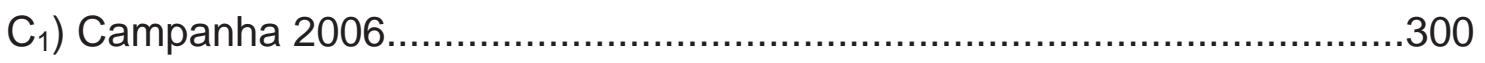

$\mathrm{C}_{2}$ ) Campanha 2007

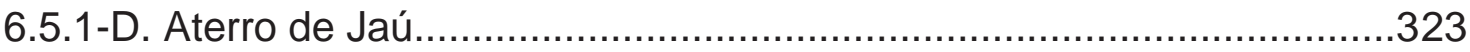

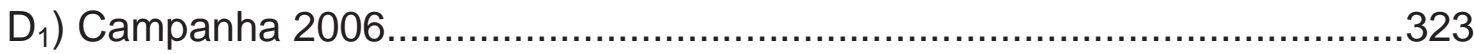

$\left.D_{2}\right)$ Campanha 2007

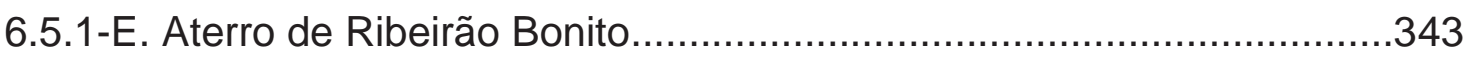

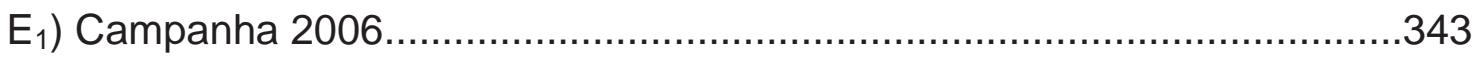

$\left.E_{2}\right)$ Campanha 2007

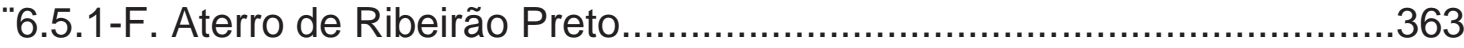

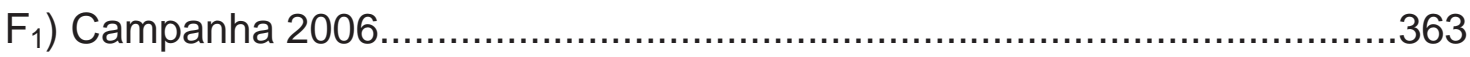

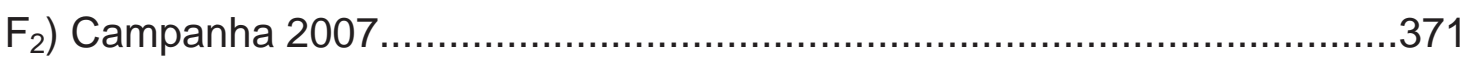

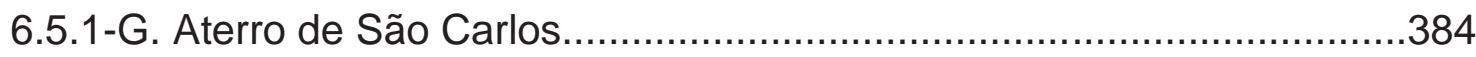

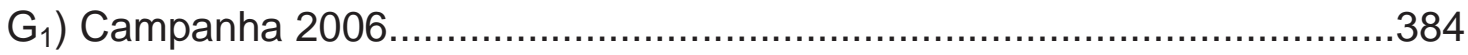

$\mathrm{G}_{2}$ ) Campanha 2007

6.5.1-H. Aterro Bandeirantes - Campanha Única 2007................................401

6.6. Cálculo da emissão dos dissipadores verticais nos aterros que

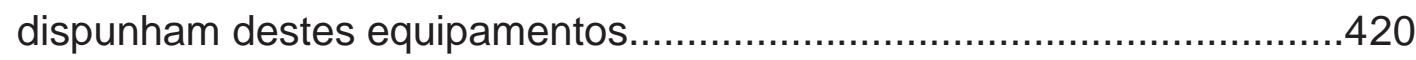

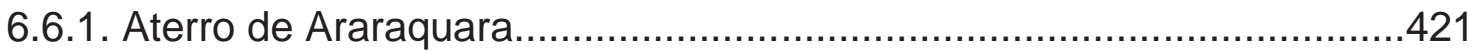

$A_{1}$ ) Campanha 2006

$\mathrm{A}_{2}$ ) Campanha 2007

$A_{3}$ ) Cálculo da Taxa de Emissão Média $\left(T_{x} E_{m}\right)$ pelos dissipadores ...............424

$A_{4}$ ) Cálculo da Taxa média total do aterro $\left(T_{x} E_{m(A t)}\right)$ pelos dissipadores........424 
6.6.2. Aterro de Campinas........................................................425

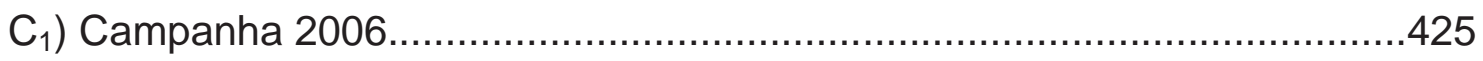

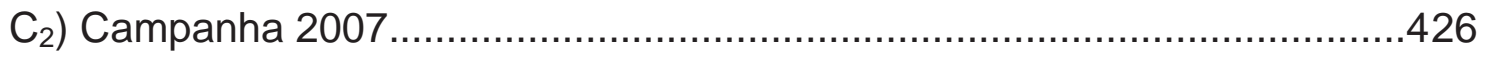

$\mathrm{C}_{3}$ ) Cálculo da Taxa de Emissão Média $\left(\mathrm{T}_{\mathrm{x}} \mathrm{E}_{\mathrm{m}}\right)$ pelos dissipadores .............427

$C_{4}$ ) Cálculo da Taxa média total do aterro $\left(T_{x} E_{m(A t)}\right)$ pelos dissipadores.......428

6.6.3. Aterro de Jaú................................................................429

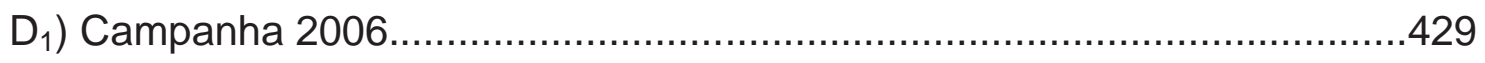

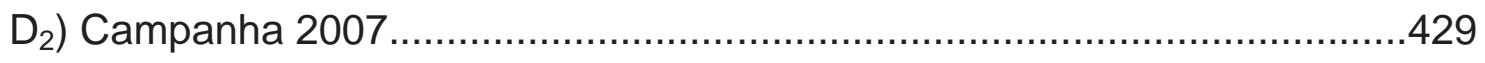

$\left.D_{3}\right)$ Cálculo da Taxa de Emissão Média $\left(T_{x} E_{m}\right)$ pelos dissipadores ..............429

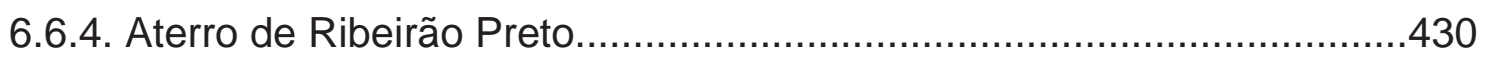

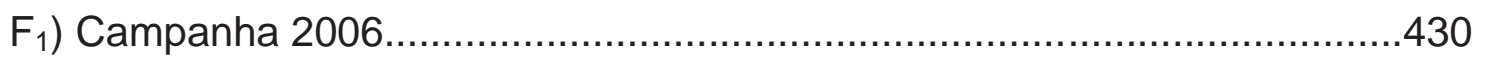

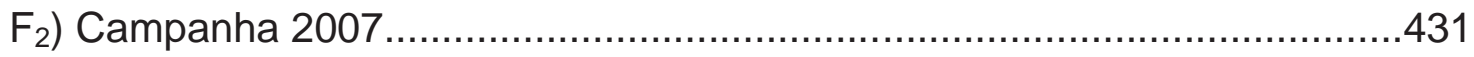

$F_{3}$ ) Cálculo da Taxa de Emissão Média $\left(T_{x} E_{m}\right)$ pelos dissipadores ..............433

$F_{4}$ ) Cálculo da Taxa média total do aterro $\left(T_{x} E_{m(A t)}\right)$ pelos dissipadores.......433

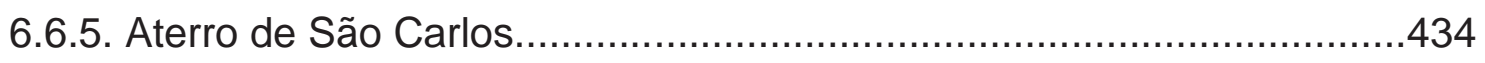

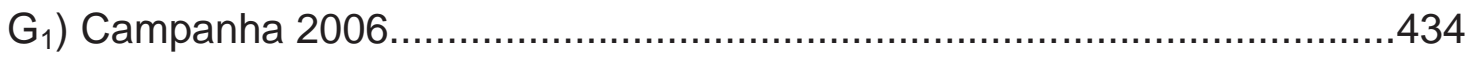

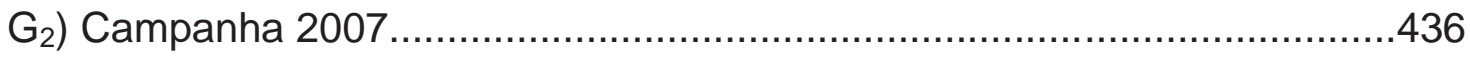

$\left.G_{3}\right)$ Cálculo da Taxa de Emissão Média $\left(T_{x} E_{m}\right)$ pelos dissipadores.............437

$\mathrm{G}_{4}$ ) Cálculo da Taxa média total do aterro $\left(\mathrm{T}_{x} \mathrm{E}_{\mathrm{m}(\mathrm{At})}\right)$ pelos dissipadores.......437

6.6.6. Aterro Bandeirantes - Campanha Única $2007 \ldots \ldots \ldots \ldots \ldots \ldots \ldots \ldots \ldots \ldots . \ldots . \ldots \ldots 38$

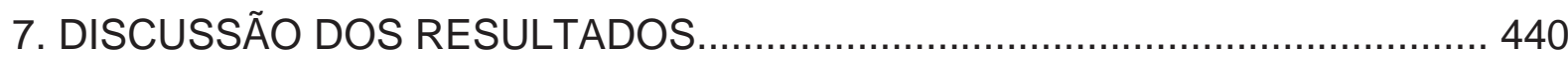

7.1. Concentrações de metano $\left(\mathrm{CH}_{4}\right)$ e de dióxido de carbono $\left(\mathrm{CO}_{2}\right)$ no

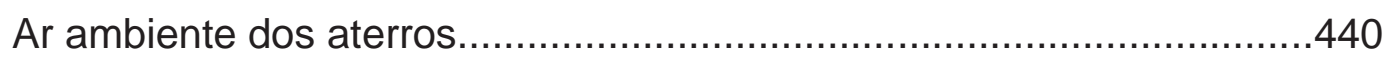

7.2. Emissão solo-ar de metano $\left(\mathrm{CH}_{4}\right)$ e dióxido de carbono $\left(\mathrm{CO}_{2}\right)$ pelos aterros 
7.3. Estimativa de emissão a partir dos dissipadores verticais nos aterros que apresentaram estes equipamentos

7.4. Emissão estimativa total por aterros. .481

8. CONCLUSÕES 486

9. SUGESTÕES PARA TRABALHOS FUTUROS. .490

10. REFERÊNCIAS 492

ANEXOS 520

Anexo A - Sítios consultados na internet e de importância para a Questão Ambiental. 520

Anexo B - Documentos Importantes da legislação Brasileira, com foco ambiental, em ordem cronológica. .523

Anexo C - Curavas de calibração do cromatógrafo $\left(\mathrm{CO}_{2}\right.$ e $\left.\mathrm{CH}_{4}\right)$. 528 



\section{INTRODUÇÃO}

“A NATUREZA NÃo PRODUZ DE UM LADO, PROPRIETÁRIOS DO DINHEIRO OU DE MERCADORIAS,
E DO OUTRO, HOMENS QUE NÃo POSSUEM NADA, SENÃo A PRÓPRIA FORÇA DE TRABALHo”.
MARX, K.

\section{1 - Desenvolvimento Econômico versus Ambiente Natural}

A partir da segunda metade do século passado até o seu ocaso, o debate que se desenvolvia centrado sobre a melhor maneira de se organizar a economia mundial - se o capitalismo ou o socialismo - parece ter chegado ao fim a partir das décadas de setenta e oitenta, em diante, sendo substituído pela premissa básica sobre como desenhar uma economia mundialmente dinâmica, baseada na sustentabilidade, sem destruir, irreversivelmente, os recursos dos ecossistemas ambientais naturais dos quais a própria economia depende.

O entusiasmo de todos com a rapidez e os avanços do sistema produtivo nos países do chamado primeiro mundo, a força da globalização minimizando os tempos de comunicação "na nossa aldeia global", o desenvolvimento da ciência e, a cada dia, as "novidades tecnológicas" - que exigem empregar e gastar mal, quantidades cada vez maiores de recursos naturais para o atendimento das suas necessidades - fizeram o ser humano esquecer que a natureza impunha limites à sua exploração e, como preconiza a ecologia profunda uma visão holística do mundo -, é condição sine qua non, para a sustentabilidade do planeta, uma aliança nova e saudável do homem com a natureza (NAESS, 1973; CAPRA, 1997; LENCASTRE, 2006). 
$\mathrm{Na}$ visão de Capra (1997) a chamada ecologia rasa, que é antropocêntrica, ou seja, centralizada no ser humano, não mais faz sentido nas discussões e análises das questões homem/natureza. A ecologia rasa "vê os seres humanos situados acima ou fora da natureza, como a fonte de todos os valores, e atribui apenas um valor instrumental, ou de uso à natureza". Assim, o homem era visto como o centro de tudo, autorizado a dispor como bem entendesse da natureza. Já a ecologia profunda não separa seres humanos - ou qualquer outro (a) ser/coisa - do ambiente natural. "Esta vê o mundo, não como uma coleção de objetos isolados, mas como uma rede de fenômenos que estão fundamentalmente interconectados e interdependentes". A ecologia profunda "reconhece o valor intrínseco de todos os seres vivos e concebe os seres humanos apenas como um fio particular na teia da vida". O homem é um ser vivo como qualquer outro, como dito por Lutzenberger (MENDES, 2002).

A visão da ecologia profunda está alicerçada em valores ecocêntricos - centralizados na Terra. É uma visão de mundo que reconhece o valor inerente da vida, inclusive, não-humana. Todos os seres vivos são membros de comunidades ecológicas, ligadas umas às outras numa rede de interdependência. A percepção ecológica profunda reconhece a interdependência fundamental de todos os fenômenos, e o fato de que, enquanto indivíduos e sociedade, estamos todos encaixados nos processos cíclicos da natureza e, em última análise, somos dependentes desses processos.

Quando essa percepção ecológica profunda torna-se parte de nossa consciência cotidiana, emerge um sistema ético radicalmente novo, capaz de minimizar a ação predatória do ser humano sobre a natureza, com vistas à tão buscada e necessária sustentabilidade. 
Cabe lembrar que Marx, citado por Casseti (1991), já discutia o conceito de "natureza unificada" ou "natureza não externalizada", em que procurava mostrar através do materialismo dialético a unidade interdependente entre natureza e sociedade, com base nos princípios do desenvolvimento social e da unidade do mundo material. Para isto já conceituava a natureza em dois momentos históricos:

a) [...] uma primeira natureza na qual o homem está presente, embora utilize a mesma como valor-de-uso, ou seja, o trabalho humano se constitui no elemento mediador da relação homemnatureza com a finalidade exclusiva de proporcionar as bases indispensáveis à própria sobrevivência. Neste momento a natureza é tida como meio de produção sem qualquer preocupação com a formação de excedentes;

b) [...] a segunda natureza caracteriza uma situação de valor-detroca, que surge com a formação do excedente, momento em que este se converte em mercadoria negociável e gradativamente se transforma em fator de acumulo do capital. A partir de então, acelera-se o processo de desenvolvimento das forças produtivas com o apóio da própria ciência, responsável pela evolução dos instrumentos de trabalho, alterando de forma substancial a produção da natureza.

Portanto, ainda segundo o mesmo autor, o "conceito de natureza de Marx contesta a idéia de natureza como substrato material preconizado pelos defensores da natureza externalizada, e passa a entendê-la como produto social”. 


\section{2 - A Revolução Industrial: Impactos populacional e de consumo; crescimento econômico; degradação ambiental; efeito estufa.}

Após o advento da Revolução Industrial, a partir de 1750 (RIOUX, 1975; IANNONE, 1992), houve um crescimento econômico e populacional muito significativo e impactante, que fomentou a chamada revolução tecnológica e um consumismo exacerbado, que se intensificou em maior extensão no pós segunda grande guerra. O homem acabou por assumir um papel extremamente egoísta e alienante mediante sua relação com o ambiente natural que o cerca. E uma das consequências mais desastrosas disso, tem sido a poluição do planeta - solos e corpos hídricos - e da sua atmosfera.

Especialmente, sobre a atmosfera terrestre, por ser receptora dos gases resultantes das atividades naturais e antropogênicas - atividades humanas tem acarretado um aumento indevido na temperatura terrestre, pelo efeito estufa intensificado (BAIRD, 2002), que se distingue daquele efeito estufa que vem atuando naturalmente durante milênios, levando ao aquecimento global.

As tendências do uso dos recursos naturais e da saúde dos ecossistemas planetários indicam que as áreas naturais estão sob o estresse das pressões crescentes do consumo e da sua exploração desastrosa. Segundo estudo recomendado pelo WRF (EM, 2004), a tabela 1.2.1, a seguir, mostra estas tendências de forma patente. 
Tabela 1.2.1 - Tendências Globais dos Recursos e do Ambiente Naturais.

\begin{tabular}{ll}
\hline Indicador Ambiental & Tendência \\
\hline Combustíveis & O consumo global de carvão, petróleo e gás natural foi 4,9 vezes \\
fósseis & maior em 2002 do que em 1950. Os níveis de dióxido de carbono em \\
e a atmosfera & 2002 foram $18 \%$ maiores do que em 1960, e estão estimados em \\
& $31 \%$ a mais do que na revolução industrial, em 1750. Os cientistas \\
& atribuíram a tendência de aquecimento global durante o século XX ao \\
& acúmulo de dióxido de carbono e outros gases retentores de calor na \\
& atmosfera terrestre. \\
\hline Degradação de & Mais da metade das terras alagadas do planeta, desde pântanos \\
Ecossistemas & costeiros a baixios interioranos, foi perdido devido, em grande parte, à \\
& drenagem ou aterros para loteamentos ou agricultura. Cerca da \\
& metade da cobertura florestal original do mundo também já deixou de \\
& existir, enquanto outros $30 \%$ estão degradados ou fragmentados. Em \\
& 1999, o consumo global de madeira para combustível, madeireiras, \\
& papel e outros produtos foi mais que o dobro do consumo de 1950. \\
\hline Nível do mar & O nível do mar subiu 10-20 centímetros no século XX, uma média de \\
& 1-2 milímetros ao ano, como consequência do degelo da massa \\
& continental polar e da expansão dos oceanos devido à mudança \\
& climática. Pequenas ilhas-nações, embora responsáveis por menos \\
& de $1 \%$ das emissões globais de gases estufa, correm o risco de \\
& serem inundadas pelo aumento do nível do mar. \\
\hline Cerca de $10-20 \%$ das terras cultivadas mundiais sofrem algum tipo de \\
Água \\
degradação, enquanto mais de $70 \%$ dos pastos globais estão \\
degradados. Ao longo do último meio século, a degradação do solo \\
reduziu a produção de alimentos em cerca de 13\% nas terras \\
cultivadas e 4\% nos pastos.
\end{tabular}

Fonte: WRF, 2004.

Também verificações constantes do declínio ambiental global podem

ser constatadas no Índice Planeta Vivo (IPV), instrumento desenvolvido pelo WWF

Internacional para medir a saúde das florestas, oceanos, rios e outros sistemas

naturais. Este índice mostra um declínio de 35\% na saúde ecológica do planeta

BERTO NETO, J. (2009). - Medidas da Emissão de Gases de oito aterros de resíduos sólidos urbanos do Estado de São Paulo - Brasil. Tese apresentada ao PPG-SEA/CRHEA - EESC/USP. São Carlos-SP, Dez. 2009. 
desde 1970 (WWF, PNUMA, RP, 2002), conforme quadro 1. 2.1, a seguir, citados em Estado do Mundo(2004).

Quadro 1.2.1 - Evolução do PMB versus Saúde dos ecossistemas naturais.

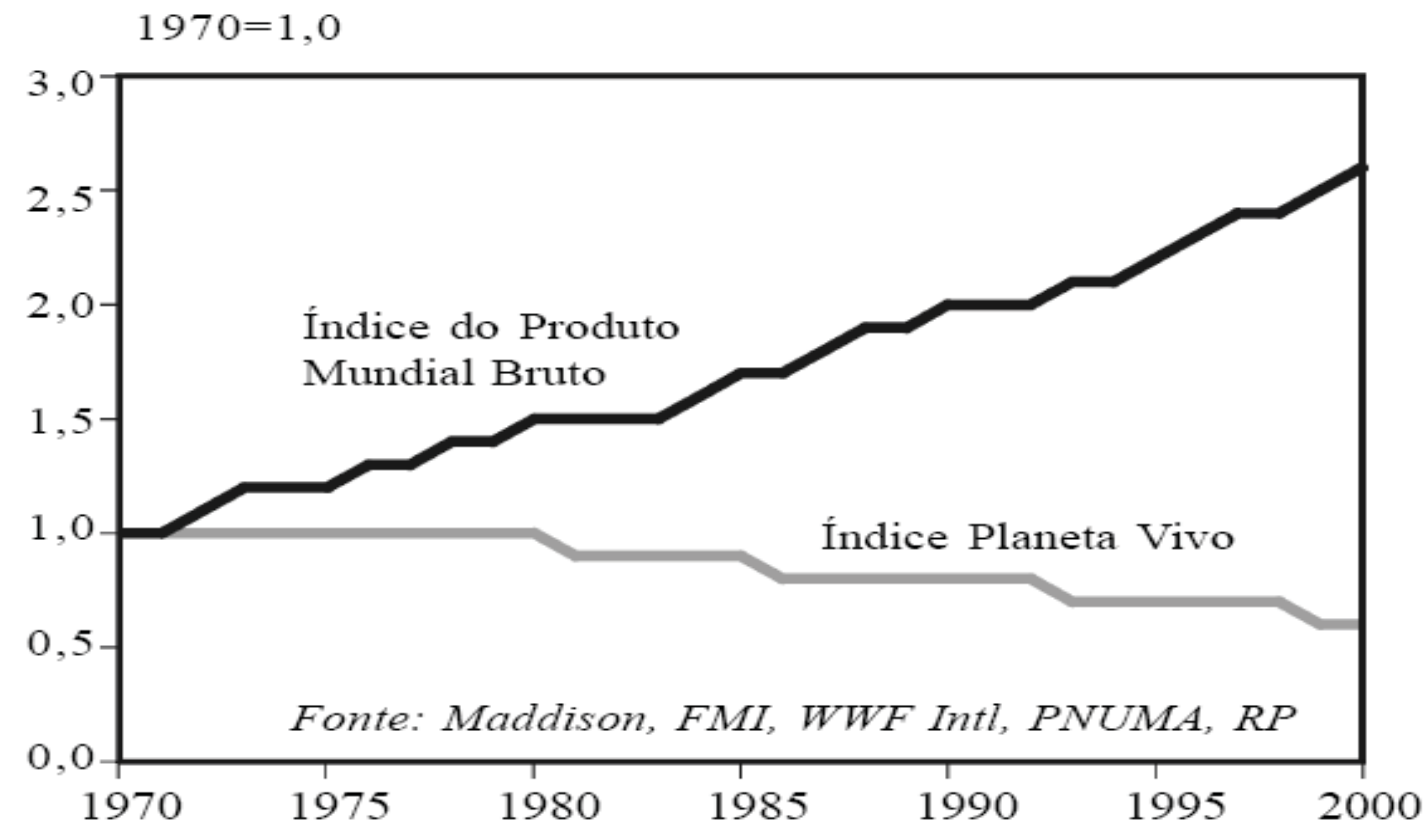

Fonte: Estado do Mundo (2004)

Nota-se uma quase simetria, preocupante, entre o Produto Mundial Bruto (PMB) - sempre crescente - e o impacto na saúde dos ecossistemas naturais (IPV) - sempre decrescente - mostrando que o desenvolvimento econômico e suas demandas por matérias-prima e aumentos na geração de resíduos, têm pressionado, degradativamente, os sistemas ecológicos do planeta, com tendências de continuidade, mantidos os atuais padrões de consumo e pressão sobre a natureza.

Uma equipe internacional de ecólogos, economistas e biólogos conservacionistas publicou um estudo na Science (BALMFORD et al, 2002) 
indicando que quase todos os ecossistemas mundiais estão perdendo lugar para residências, fazendas, shoppings e fábricas, especialmente, em se tratando do crescimento econômico nos países do primeiro mundo. Como revela o estudo, a relva marinha e leitos de algas estão declinando $0,01-0,02 \%$ ao ano; florestas tropicais $0,8 \%$; pesqueiros marítimos 1,5\%; ecossistemas de águas doce (pântanos, baixios, lagos e rios) $2,4 \%$ e manguezais em assustadores $2,5 \%$. Também se mencionaram grandes perdas anuais, difíceis de quantificar, de recifes de coral, pradarias e terras cultivadas e cultiváveis. Apenas as florestas temperadas e boreais mostraram revitalização tímida, aumentando 0,1\% ao ano após décadas de declínio (GARDNER, ASSADOURIAN et SARIN, 2004).

Ainda uma publicação do WWF (2007) indica que precisamos limitar o aquecimento global a menos de $2^{\circ} \mathrm{C}$ acima do nível pré-Revolução Industrial para evitar impactos perigosos sobre a natureza, a humanidade e a economia global. Também mostra aspectos da vida humana e do planeta que seriam muito afetados a partir de um aumento de até $2^{\circ} \mathrm{C}$ ou $3^{\circ} \mathrm{C}$, na temperatura média terrestre. Vide tabela 1.2.2: 
Tabela 1.2.2 - Mudanças climáticas: Consequências desastrosas

\begin{tabular}{|c|c|c|}
\hline Parâmetro & Impactos a $2^{\circ} \mathrm{C}$ & Impactos a $3^{\circ} \mathrm{C}$ \\
\hline $\begin{array}{l}\text { Saúde } \\
\text { Humana }\end{array}$ & $\begin{array}{l}\text {-90-200 milhões de pessoas correrão } \\
\text { o risco de serem contaminadas por } \\
\text { malária e outras doenças } \\
\text { transmissíveis por insetos ou pela } \\
\text { água. Aumentos nas taxas de diarréia } \\
\text { e subnutrição em países de baixa } \\
\text { renda. }\end{array}$ & $\begin{array}{l}\text { - Mais de } 300 \text { milhões de pessoas } \\
\text { correrão o risco de serem } \\
\text { contaminas por malaria no mundo. } \\
\text {-5-6 bilhões de pessoas correrão o } \\
\text { risco de serem contaminadas por } \\
\text { dengue. }\end{array}$ \\
\hline Agricultura & $\begin{array}{l}\text {-A agricultura brasileira será } \\
\text { negativamente afetada, sobretudo no } \\
\text { Centro-Oeste e no Nordeste. A } \\
\text { produção de cereais poderá diminuir } \\
\text { em } 50 \% \text {, a de milho em } 25 \% \text { e a de } \\
\text { soja em } 10 \% \text {. } \\
\text {-Aumentos das desigualdades e dos } \\
\text { conflitos devido ao efeito da escassez } \\
\text { da água e da pouca previsibilidade } \\
\text { das colheitas. }\end{array}$ & $\begin{array}{l}\cdot 50-120 \text { milhões de pessoas em } \\
\text { áreas de risco de fome. A agricultura } \\
\text { será duramente atingida e os preços } \\
\text { mundiais dos alimentos aumentarão. } \\
\text { • } O \text { Nordeste do Brasil será uma das } \\
\text { regiões mais afetadas do } \\
\text { Mundo }\end{array}$ \\
\hline Água & $\begin{array}{l}\text { •De } 662 \text { milhões a } 3 \text { bilhões de } \\
\text { pessoas ameaçadas pela } \\
\text { escassez de água. } \\
\text { •Escassez global de água. }\end{array}$ & $\begin{array}{l}\text { - Entre 3,1 a 3,5 bilhões adicionais de } \\
\text { pessoas sofrendo risco de escassez } \\
\text { de água com possíveis migrações } \\
\text { por causa da seca. O resultado será } \\
\text { instabilidade socioeconômica e } \\
\text { política. } \\
\text {-Riscos altos de seca no sul da } \\
\text { Europa, no oeste da África, na } \\
\text { América Central e em partes da } \\
\text { América do Norte, da Amazônia e da } \\
\text { China. } \\
\text {-A Caatinga se tornará bem mais } \\
\text { árida e a Amazônia sofrerá períodos } \\
\text { intensos de seca. }\end{array}$ \\
\hline $\begin{array}{l}\text { Gelo e } \\
\text { geleiras }\end{array}$ & $\begin{array}{l}\text { - } 60 \% \text { de perda do gelo no Ártico } \\
\text { durante o verão. } \\
\text {-Derretimento completo e irreversível } \\
\text { do gelo da Groenlândia com um } \\
\text { aquecimento de } 1.5^{\circ} \mathrm{C} \text {. } \\
\text {-Diminuição de } 25 \% \text { ou mais do } \\
\text { volume de gelo oceânico. O gelo } \\
\text { continua a retroceder por cerca de } 2 \\
\text { graus de latitude. }\end{array}$ & $\begin{array}{l}\text {-Perda completa do gelo oceânico } \\
\text { durante o inverno no Ártico. } \\
\text {-Perda completa da camada de gelo } \\
\text { a Groenlândia e das geleiras da } \\
\text { Antártida com um aquecimento de } 3^{\circ} \\
\text { C durante vários séculos. }\end{array}$ \\
\hline
\end{tabular}

(continua...) 
Tabela 1.2.2 - Mudanças climáticas: Consequências desastrosas

(continuação)

\begin{tabular}{|c|c|c|}
\hline & 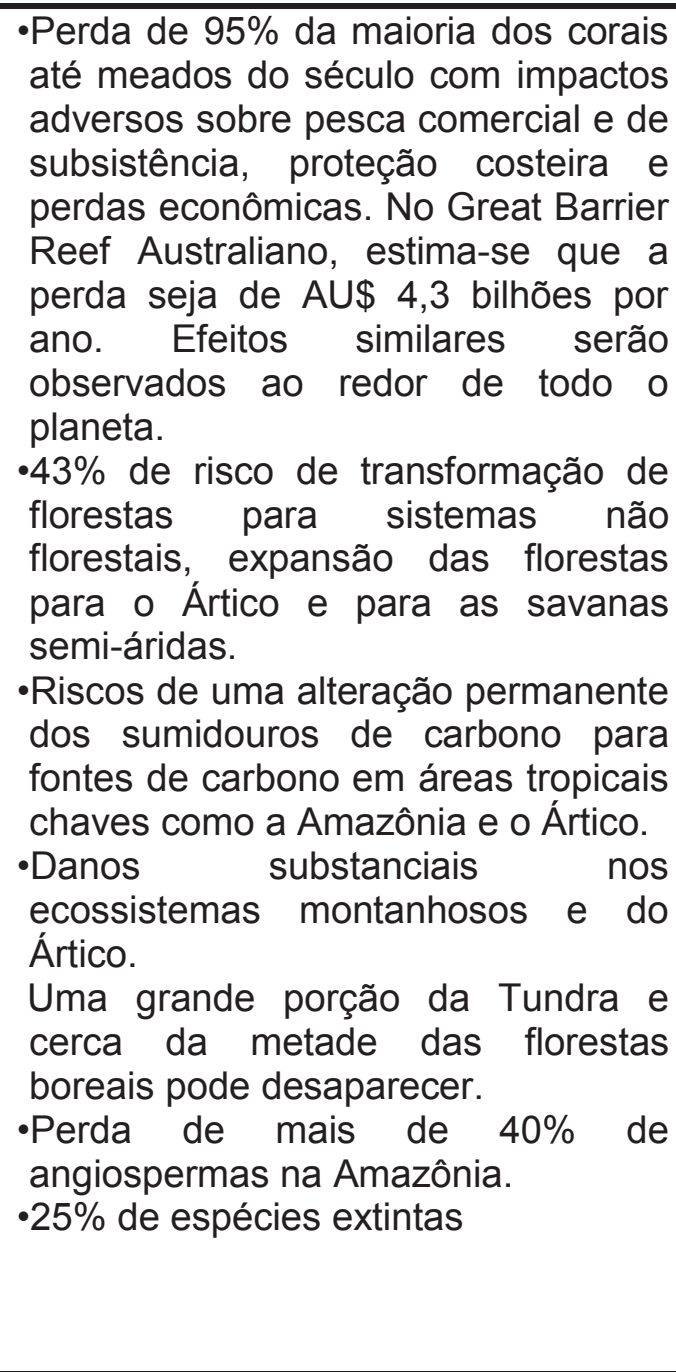 & $\begin{array}{l}\text {-Pouca chance de recuperação do } \\
\text { corais danificados } \\
\text { branqueamento dos corai } \\
\text { restantes. } \\
\text { - Risco de } 88 \% \text { de transformação d } \\
\text { florestas para sistemas não } \\
\text { florestais. Riscos de perda } \\
\text { florestais na Eurásia, Amazônia } \\
\text { no Canadá. Perda potencial d } \\
\text { florestas na zona boreal sul, n } \\
\text { leste chinês, na América Centra } \\
\text { na Amazônia e nas Costa do Golf } \\
\text { dos Estados Unidos. } \\
\text {-Risco bem maior de uma alteraçã } \\
\text { permanente dos sumidouro } \\
\text { terrestres de carbono para fonte } \\
\text { de carbono. ireversíveis para } \\
\text { Danos irres } \\
\text { Amazônia, resultando em se } \\
\text { colapso. Pe. de } 50 \% \text { dos pântanos n } \\
\text {-Perda de } \\
\text { Mediterrâneo, nos Bálticos. } \\
\text { Perda de vários habitats d } \\
\text { pássaros migratórios. } \\
\text {-Perda maciça e possível extinçã } \\
\text { de espécies dependentes de gel } \\
\text { como ursos polares e vária } \\
\text { espécies no México e África do Sul } \\
\text {-Mais de } 40 \% \text { da Amazônia s } \\
\text { transformará em Cerrado } \\
\text {-33\% de espécies extintas }\end{array}$ \\
\hline
\end{tabular}

Aumento do $\cdot 25-50$ milhões em risco devido ao $\bullet 180$ milhões de pessoas em risco Nível do mar aumento dos níveis dos mares e às inundações costeiras. Os custos às nações serão de centenas de bilhões de dólares.

devido às inundações costeiras, stress hídrico e aumento dos níveis dos mares.

- O Norte e o Nordeste do Brasil serão terão que migrar para outras as regiões mais afetadas regiões ou mesmo países.

Eventos •Aumentos na freqüência e •Aumento maciço na freqüência $\mathrm{e}$ climáticos intensidade de inundações, secas, intensidade de incêndios, secas, extremos tempestades, ondas de calor, tempestades e ondas de calor. ciclones tropicais e outros eventos •Perdas sócio-econômicas climáticos extremos. decorrentes dos danos globais: de - O Sul e o Sudeste do Brasil sofrerão $3 \%$ a $5 \%$ para os países em mais episódios de eventos climáticos desenvolvimento e uma média extremos. mundial de $1 \%$ a $2 \%$ para um aquecimento de $2,5^{\circ} \mathrm{C}$ a $3^{\circ} \mathrm{C}$.

Fonte: WWF (2007) 
Desde meados do século 20, diferentemente das vezes anteriores, o aumento da temperatura média global do planeta é seguramente uma consequência do crescimento da concentração dos chamados gases de efeito estufa (GHG Greenhouse Gases, na sigla em inglês) na atmosfera terrestre, de origem antropogênica (HOLMES, 1999; CGEE, 2008), que, em conjunto, impedem que a radiação infravermelha seja totalmente retransmitida da Terra para o espaço. Embora esse processo seja vital para a manutenção da temperatura no planeta, o aumento na concentração dos GEE's pode alterar os padrões de absorção e reflexão da radiação infravermelha (Infravermelho térmico) e, conseqüentemente, resultar na elevação da temperatura média da superfície terrestre, com possível derretimento das calotas polares e o aumento do nível dos oceanos (USEPA, 2006). 


\section{3 - O despertar da questão ambiental: desenvolvimento sustentável}

A partir das últimas décadas, a questão ambiental tornou-se uma preocupação mundial (PNEA, 2007). A partir da reunião do Clube de Roma em 1968 - que reuniu cientistas de países desenvolvidos, com objetivo de colocar o problema ambiental em nível mundial, através de discussões pertinentes sobre consumo e reservas de recursos naturais não-renováveis, assim como o crescimento demográfico da população mundial até meados do século XXI (GRABBE, 2008; SOUZA, 2000) -; do Relatório da Comissão Brundtland de 1987(Nosso Futuro Comum) (AZEVEDO, 1988; FGV, 1992); da Conferência de Estocolmo - Conferência das Nações Unidas sobre Meio Ambiente Humano em 1972, e, da Cúpula da Terra em 1992 ou Rio-92 (BRASIL, CONUMAD 1992); a problemática ambiental passou a ser analisada e entendida em sua dimensão planetária.

A grande maioria das nações do planeta reconhece a emergência de soluções, permanentes ou minimizadoras e imediatas, para os problemas ambientais. Assuntos como: destruição da camada de ozônio, acidentes nucleares, alterações climáticas, desflorestamento e queimadas, desertificação, aumento na produção de resíduos sólidos de uma forma geral, armazenamento e transporte de resíduos perigosos, poluição hídrica, poluição atmosférica, pressão populacional sobre os recursos naturais, perda de biodiversidade e a exploração sem limites dos recursos naturais, etc.; são algumas das questões a serem resolvidas por cada uma das nações do mundo, segundo suas respectivas especificidades, e por todas as nações, num movimento em que ninguém pode ou deve ficar de fora. Como prevê Ministério do Meio Ambiente, tendo por base a tomada de medidas de políticas 
públicas que preconizem: o uso racional dos recursos naturais, a proteção do ambiente natural, a prevenção da degradação ambiental e, acima de tudo, a promoção dos princípios e das práticas que levem ao desenvolvimento sustentável (BRASIL/MMA, 2002).

Segundo Iglesias (2004),

[...] o desenvolvimento sustentável adota uma perspectiva de longo prazo do processo econômico e social que compreende a salvaguarda e o incremento do capital ambiental e social e a redução da iniquidade. Este conceito ganhou relevância no relatório da Comissão Brundtland de 1987 e consolidou o seu lugar como âncora para as políticas de desenvolvimento durante a Cúpula da Terra de 1992 no Rio de Janeiro. [...] resta a questão: Como intensificar a sustentabilidade do desenvolvimento? (ou, como reduzir o impacto do consumo sobre o ambiente natural?!,Grifo nosso). Um dos resultados da Cúpula de Johannesburgo de 2002 foi colocar o desenvolvimento sustentável como um dos objetivos integral entre as Metas de Desenvolvimento do Milênio compartilhadas pela comunidade global.

[...] é imperativo melhorar a gestão e a direção dos recursos naturais e ambientais... e aumentar a eficiência no uso de recursos essenciais, como a água e a energia. Igualmente importante é reconhecer que a redução da degradação ambiental protege a saúde humana, torna a terra mais produtiva e melhora diversos outros elementos do processo econômico e social. A proteção e a gestão aperfeiçoada dos recursos naturais ajustam-se a uma abordagem totalmente integrada do desenvolvimento sustentável, 
como determinam as Metas de Desenvolvimento do Milênio. Essas metas vão além da sustentabilidade ambiental e abrangem objetivos como a erradicação da fome e a melhora da saúde, da educação, da equidade social e da cooperação internacional. 


\section{4 - Homem e Natureza: interdependência e novo paradigma}

O Homem somente sobrevive daquilo que extrai da natureza. Tudo o que possui matéria é extraído da natureza. Homem e natureza são um só. A novidade do tema ambiental emergente e que se torna preocupação constante na atualidade, tornando-se ponto de convergência na agenda internacional, explica o estágio embrionário em que nos encontramos, tanto em termos de conscientização social, crenças e valores, quanto em termos de regulação e aplicação. Os gestores ambientais das organizações enfrentam um alto risco jurídico de interpretações equivocadas que podem comprometer a sustentabilidade de suas empresas. Segundo Fenker (2007), o mundo jurídico, por sua vez, tão autônomo na aplicação das Leis, deveria tomar consciência de que o tema ambiental não pode ser tratado senão de forma holística, sistêmica, o que implica na indispensável atuação multidisciplinar para qualquer tomada de decisão, sob pena de parcialidade. A consideração de dano não pode ser dissociada de impacto, em suas dimensões positiva ou negativa. O impacto ambiental, por outro lado, não pode ser analisado dissociado de impacto econômico e social.

Para este autor, a sustentabilidade que se busca neste planeta é a do Ser Humano Integral, e, o equilíbrio exige consideração sistêmica de todos os aspectos envolvidos: sustentabilidade que permite a vida das atuais e das futuras gerações. Cabe aos gestores incorporarem na área econômica as considerações, crenças e valores éticos, sociais e ambientais emergentes, como estratégia de competitividade e de sustentabilidade em longo prazo.

Alterações no sistema de crenças e valores da sociedade precisam 
gerar um novo paradigma que, na visão de Capra (1997), "transcende as atuais fronteiras disciplinares e conceituais, e demanda uma estrutura sistêmica, que está sendo formulada por indivíduos, comunidades e organizações, de acordo com novos princípios".

Entretanto, a complexidade destas questões e demandas ambientais exige mais do que medidas pontuais que busquem resolver os problemas a partir de seus efeitos, ignorando ou desconhecendo suas causas.

O modo como se dá o sempre buscado crescimento econômico e o consumismo insustentável, comprometem o ambiente natural, pois aumentam a pressão sobre o mesmo, tanto na extração de recursos da natureza para garantir a produção, tanto quanto dos refugos decorrentes do processo, que exercem impactos sobre a natureza, seguramente prejudicando o próprio crescimento, pois inviabiliza um dos fatores da produção, o capital natural.

Natureza, terra, espaço e bem estar social devem compor o processo de desenvolvimento como elementos de sustentação e preservação dos ecossistemas. A degradação ou destruição de um ecossistema interfere no equilíbrio de outros ecossistemas, comprometendo a qualidade de vida da sociedade, uma vez que reduz os fluxos de bens e serviços (retroalimentação positiva) que a natureza pode oferecer à humanidade.

Logo, um desenvolvimento centrado no crescimento somente econômico, que relegue para segundo plano as questões sociais e ignore os aspectos ambientais, não pode ser denominado de desenvolvimento, pois de fato, trata-se de mero crescimento econômico, comumente realimentando a iniquidade social, sem contemplar a sustentabilidade. 
O sucesso das ações que devem conduzir ao desenvolvimento sustentável - um paradigma que tenha como objetivos conciliar o desenvolvimento econômico às qualidades ambiental e de vida - segundo Souza (2000) dependerá, em grande parte, da influência da opinião pública, do comportamento das pessoas e de suas decisões individuais. Sem podermos esquecer "a equidade nas negociações internacionais entre países desenvolvidos e em desenvolvimento, pois, apesar da importância do argumento de que os países desenvolvidos foram os principais responsáveis, p.ex., pela maior parte das emissões passadas de gases estufa, esse critério não deveria ser utilizado para isentar os países em desenvolvimento de contribuir, a médio e longo prazo, em um programa de redução dos gases estufa, uma vez que o alcance de objetivos ambientais poderia se ver comprometido, caso isso não viesse a acorrer (GUTIERREZ, 1998; WWF, 1992)".

Mesmo considerando que já existe certo interesse pelas questões ambientais, há que se reconhecer a falta de informações e conhecimento dos problemas ambientais. 


\section{5 - A Questão ambiental e a iniquidade}

$\mathrm{Na}$ atualidade, o crescimento populacional na terra põe em risco uma convivência sadia homem-natureza. Segundo a publicação Estado do Mundo (GARDNER, ASSADOURIAN and SARIN, 2004) e IBGE (2005e \& 2007f), com atualização estimativa, somos mais de 6,8 bilhões de pessoas e nos mostramos, ostensivamente incapazes de alimentar, alojar, educar e empregar, em condições minimamente aceitáveis, quase dois terços desta população.

O problema não se circunscreve somente à explosão populacional. O que mais importa ainda é a explosão de consumo que ela acarreta, mesmo que os bens de consumo que demandam maiores impactos sobre a natureza estejam acessíveis apenas a uma parcela muito pequena da população mundial.

Estima-se que 20\% - em torno de 1,4 bilhão de indivíduos - da humanidade sejam de pessoas afortunadas, pertencentes à chamada "classe consumista ou privilegiada" que desfrutam de um estilo de vida de alto consumo, em que prepondera a descartabilidade e mesmo o supérfluo, que impõe uma pressão depreciativa muito grande, desproporcional, sobre o ecossistema planetário. Esta porção da população mundial é usuária de "uma cultura e estilo de vida que se tornaram comuns na Europa, América do Norte, Japão e em alguns outros pontos do planeta onde isto se tornou possível (GARDNER, ASSADOURIAN and SARIN, 2004)".

Outros $20 \%$ tem um nível de vida de estilo moderado, sem consumo supérfluo, demandando o suficiente para o atendimento de suas necessidades básicas, embora uma grande parte deste grupo aspire atingir o nível de consumo 
suntuário daquele quinto afortunado.

O restante - da ordem de 4,0 bilhões de seres humanos - no entanto, não consegue atender sequer suas necessidades materiais mínimas, vivendo na miséria, embora tenha como referência, o nível de consumo predatório da minoria privilegiada, especialmente, pela força globalizada da comunicação de massas.

Conforme Laszlo (2001), "enquanto comunidade global estamos à beira de uma flutuação crítica que tem a ver com o clima, a poluição do ar, a água, a terra e a maneira como as culturas, sociedades e sistemas econômicos se relacionam". Suas manifestações são várias. Por exemplo, "a concentração de desejos e poder, onde quinhentos superbilionários, alguns aqui mesmo no Brasil, concentram a mesma riqueza que a metade da humanidade - mais de três bilhões de pessoas - ou as quinhentas corporações, citadas na Fortune Five Hundred, cuja riqueza é maior que a de muitas nações somadas". Do outro lado, "temos $20 \%$ da humanidade cada vez mais pobre. São cerca de um bilhão e quinhentos milhões de pessoas sobrevivendo com o equivalente a US\$ 1 ou menos por dia e $40 \%$ sem acesso a água potável”.

Deve ser ressaltado, só para citar um exemplo, que as projeções da FAO em relação a uma distribuição 'mais eqüitativa de alimentos' em nosso planeta são bem pessimistas e acredita-se que o total de quase 900 milhões de indivíduos subnutridos ou famintos será ampliado nas próximas décadas. Apesar de criado há um século, o processo de fixação de nitrogênio por Haber-Bosch ainda não foi capaz de estender seus benefícios a uma parte significativa da humanidade, que permanece faminta e distante das condições mínimas para seu desenvolvimento. Contudo, os impactos ambientais negativos do desenvolvimento daquela porção privilegiada da humanidade, já há algum tempo, se distribuem de forma igualitária 
para todos os habitantes do planeta (BORGES \& HIPÓLITO, 2008).

Ainda segundo Gardner, Assadourian and Sarin (2004) a sociedade de consumo tem, claramente, um forte encanto e traz consigo muitos benefícios e confortos da vida moderna. Mas, também seria injusto argumentar que as vantagens obtidas por uma geração anterior de consumidores não deveriam ser compartilhadas pela geração seguinte.

Viera (2008) até apela para que não se

"[...] pode afirmar que a adoção da prática do consumo em demasia, onde o desperdício é marca proeminente, seja um comportamento com aspectos tão somente negativos. Numa rápida reflexão é possível aquilatar o quanto a geração de novidades tecnológicas gerou necessidades e, desta forma, ampliou o volume de empregos no mercado de trabalho, colocando em ação uma quantidade enorme de pessoas que, sem o frenesi da ação mercadológica do marketing, e por conseqüência o consumo, ficaria desempregada".

Na realidade, a premissa básica da economia de consumo em massa - ou seja, que o consumo ilimitado é aceitável e até desejável - choca-se fundamentalmente com os padrões de vida do mundo natural e com os ensinamentos sobre moderação, respeito ao outrem e à natureza, comuns a filósofos e líderes religiosos em todas as culturas e através de grande parte da história da humanidade (GARDNER, ASSADOURIAN and SARIN, 2004).

Thomas (2007) afirma que o desenvolvimento dos países está condicionado à mudança de atitude por parte das nações, e que, se nada for feito para que as mudanças climáticas e a destruição do ambiente natural sejam 
revertidas, o crescimento econômico ficará comprometido. Não basta ter vontade, é preciso agir rapidamente antes que seja tarde.

Existem injustiças que envolvem a questão climática do planeta no que respeita ao aquecimento global, pois nas suas consequências as populações que serão mais afetadas pelas mudanças climáticas estão localizadas nas regiões mais pobres que, por sinal, são as menos responsáveis por causar este fenômeno.

Diz Ricupero (2007) que,

“[...] Os Estados Unidos e a Europa respondem por dois terços dos gases causadores da mudança climática, enquanto que os 840 milhões de africanos não atingem 3\% na contribuição do mesmo. Em compensação, as secas e as inundações, decorrentes do aumento de temperatura, castigarão muito mais os africanos, inocentes de culpa, do que os ocidentais, vilões históricos do aquecimento global, desde a Revolução Industrial".

Todavia, o aumento disparado do consumo dos últimos tempos - e as projeções alucinantes que logicamente dele derivam - indica que o mundo como um todo - e aí está a injustiça, pois o bônus é de poucos, mas o ônus de todos - se verá, em breve, frente a um grande dilema. Caso os níveis de consumo que as várias centenas de milhões de pessoas mais afluentes gozam hoje se repliquem por, pelo menos, metade dos cerca de 9 bilhões de pessoas previstas para o ano de 2050 (ONU, 2004) o impacto em nossa oferta de água, alimentos, qualidade do ar, florestas, clima, diversidade biológica e saúde humana e ambiental será extremamente grave.

E, facilmente podemos supor que, se as aspirações consumistas daquele quinto mais rico do mundo não podem ser saciadas, as perspectivas de 
controle do consumo dos mais pobres - especialmente, nos países em desenvolvimento e/ou naqueles que a este grupo desejam chegar - antes do desnudamento e degradação por completo do nosso planeta, são muito desanimadoras.

Nas décadas finais do século passado, intensificou-se em todo o mundo a preocupação com os impactos ambientais decorrentes das atividades antrópicas - desenvolvidas pelo homem - e seus efeitos para o nosso planeta. Especialmente, os impactos destas atividades nos diferentes ecossistemas locais e mundiais; buscando-se evitar ou mitigar os desequilíbrios ecológicos e o esgotamento dos recursos naturais que fornecem matérias-prima para o modus operandi do processo de desenvolvimento.

Os impactos ambientais em diferentes níveis, as mudanças climáticas já observadas nas diferentes regiões do planeta e as suas relações com as emissões dos chamados gases do efeito estufa (Greenhouse Gas - GHG, na sigla em inglês) impuseram às nações a soma de esforços necessários para se controlar estas emissões, com a busca de tecnologias "mais limpas" e a aplicação das opções já disponíveis, para alcançar a diminuição ou a estabilização destes gases no ambiente natural.

Em especial, no que diz respeito à poluição da atmosfera terrestre pelas emissões dos gases do efeito estufa (GEE), as preocupações têm levado os governos nacionais e os organismos internacionais - veja-se o caso do Protocolo de Quioto - a envidarem esforços e concentrarem muitas das suas atenções no potencial de aquecimento global (Global Warming Potential, GWP, na sigla em inglês) que estes gases exercem, uma vez lançados para a atmosfera terrestre. 
Segundo o WRI (2002), substâncias gasosas como dióxido de carbono $\left(\mathrm{CO}_{2}\right)$, metano $\left(\mathrm{CH}_{4}\right)$, óxido nitroso $\left(\mathrm{N}_{2} \mathrm{O}\right)$, hidroclorofluorocarbonos (HCFC's), ozônio $\left(\mathrm{O}_{3}\right)$, hidrofluorocarbonos (HFC's), perfluorocarbonos (PFC's), enxofre hexafluorado $\left(\mathrm{SF}_{6}\right)$ e, descoberto mais recentemente (STURGES, et. al. 2000), o trifluorometil pentafluoreto de enxofre $\left(\mathrm{SF}_{5} \mathrm{CF}_{3}\right)$, cada um com suas características específicas - destacando-se como fatores de relevância para o potencial de aquecimento global, as quantidades de cada um e o seu tempo de vida na atmosfera - devem ter suas emissões constantemente monitoradas para que se possa mitigar suas contribuições para o aquecimento global.

O protocolo de Quioto (2005) ressalta a necessidade de avaliarmos, constantemente, os poluentes gasosos já patentemente conhecidos, mas também monitorarmos o surgimento de novos poluentes, as suas concentrações e as variações destas, como evoluem no tempo, bem como as contribuições potenciais de cada um para o aquecimento global.

As principais atividades antropogênicas que geram emissões de GEE para a atmosfera terrestre (IPCC, 2001 apud WRI, 2002); (BAIRD, 2002) e (FURTADO, 2005), são:

- A geração de energia pela queima de combustíveis fósseis com contribuição de cerca de três quartos das emissões (p.ex.: carvão mineral, petróleo e gás natural);

- As devastações florestais, especialmente, com o fito da expansão da fronteira agropecuário-industrial. Esta atividade aconteceu em grande escala em zonas de clima temperado no último século. É o caso do desflorestamento que acompanhou o progresso dos Estados Unidos e do sul do Canadá, mas que na atualidade tem se deslocado fortemente para as regiões 
tropicais; com destaques para países como o Brasil, que devasta tanto a floresta tropical quanto a decídua; no entanto, a taxa anual de desflorestamento em base percentual é maior na Ásia $(1,6 \%)$ e na América Central $(1,5 \%)$ do que na América do Sul $(0,6 \%)$. Em resumo, o desflorestamento contribui com cerca de um quarto das emissões de $\mathrm{CO}_{2}$ de origem antropogênica.

- A produção de cimento, que produz emissões de dióxido de carbono;

- A decomposição anaeróbica de matéria orgânica, que produz emissões de metano em aterros sanitários e na agropecuária;

- O uso de fertilizantes nitrogenados na agricultura intensiva, que produz emissões de óxidos nitrosos (NOx’s);

e,

- Processos industriais que produzem emissões de perfluorocarbonos, hidrofluorocarbonos e fluoretos de enxofre (CGEE, 2008).

Ressalte-se que o potencial de aquecimento global (GWP) atribuído a uma substância gasosa contribuinte do efeito estufa é decorrente de um conjunto de propriedades físico-químicas próprias, muito específicas para cada uma delas e de condições fisico-ambientais da própria atmosfera. O protocolo de Quioto chama a atenção (STURGES et al., 2000) para o fato de que enquanto uma maior atenção tem sido dada aos principais e mais tradicionais gases contribuintes do efeito estufa - $\mathrm{CO}_{2}, \mathrm{CH}_{4}$ e $\mathrm{N}_{2} \mathrm{O}$, por exemplo - está claro que vários outros gases estão presentes e, mesmo em suas pequenas concentrações, podem contribuir para o aquecimento global de forma muito significativa, com potencialidades muitas vezes 
superiores àqueles tradicionais, por suas excepcionais capacidades de absorção de energia calorífica na faixa do infravermelho(IV), ou seja, as suas capacidades de "retenção da irradiação de calor da terra" na atmosfera, resultando daí maior quantidade de calor retido e aumentos indesejáveis na temperatura da atmosfera terrestre.

A tabela 1.5.1, a seguir, mostra dados importantes - abundância atual, taxa de aumento anual na atmosfera, tempo de residência e a eficiência (GWP) - de alguns destes gases para o aquecimento global.

Tabela 1.5.1 - Características de Gases indutores do Efeito Estufa. (STURGES et al., 2000); (IPCC, 2001 apud WRI, 2002) e (BAIRD, 2002).

\begin{tabular}{|c|c|c|c|c|c|}
\hline \multirow{2}{*}{ Gás } & \multirow{2}{*}{$\begin{array}{c}\text { Abundância } \\
\text { Atual }\end{array}$} & \multirow{2}{*}{$\begin{array}{l}\text { Taxa de } \\
\text { aumento }\end{array}$} & \multirow{2}{*}{$\begin{array}{c}\text { Tempo de } \\
\text { Residência } \\
\text { (anos) }\end{array}$} & \multicolumn{2}{|c|}{ GWP $\mathbf{P}^{* * *}$} \\
\hline & & & & Atual & 100 anos \\
\hline $\mathrm{CO}_{2}$ & 365 ppm & $0,4 \%$ & $50-200^{* *}$ & 1 & 1 \\
\hline $\mathrm{CH}_{4}$ & 1,72 ppm & $0,5 \%$ & 12 & 23 & 21 \\
\hline $\mathrm{N}_{2} \mathrm{O}$ & 312 ppb & $0,3 \%$ & 120 & 296 & 320 \\
\hline $\mathrm{SF}_{6}$ & $n / d$ & $n / d$ & 3.200 & 22.200 & 22.200 \\
\hline $\mathrm{SF}_{5} \mathrm{CF}_{3}{ }^{*}$ & $n / d$ & $n / d$ & 1.000 & 22.200 & 22.200 \\
\hline CFC-11 & 0,27 ppb & $0,0 \%$ & 50 & 12.400 & 12.500 \\
\hline Halon-1301 & 0, 002 ppb & $7,0 \%$ & 65 & 16.000 & 19.000 \\
\hline HCFC-22 & $0,11 \mathrm{ppb}$ & $5,0 \%$ & 12 & 11.000 & 3.300 \\
\hline HFC-134 ${ }^{a}$ & $2 \mathrm{ppt}$ & $n / d$ & 15 & 9.400 & 3.000 \\
\hline
\end{tabular}

* (STURGES, W.T. et al., 2000; BALL, D. W., 2002, IBUKI, 2005).

** Este tempo de vida refere-se ao componente que não é absorvido rapidamente pelos oceanos ou biomassa.

*** Por molécula. 


\section{6 - Resíduos sólidos e a questão ambiental}

A geração de resíduos apresenta-se como uma característica inerente à condição e atividades humanas, seja por meio de seus processos fisiológicos, seja por meio do manejo de materiais existentes ou do usufruto dos bens que lhe são disponibilizados, o homem está sempre a produzir resíduos.

Nas palavras de Leite (2003),

[...] principalmente após a segunda grande guerra, o acelerado desenvolvimento tecnológico experimentado pela humanidade permitiu a introdução constante, e com velocidade crescente, de novas tecnologias e de novos materiais que contribuem para a melhoria da performance técnica, para a redução de preços e do ciclo de vida útil de grande parcela dos bens de consumo duráveis e semiduráveis. Esses materiais, essas tecnologias e a obsolescência mercadológica planejada permitem a satisfação dos conceitos de diferenciação entre as empresas no mercado. O acelerado ímpeto de lançamento de inovações no mercado cria um alto nível de obsolescência desses produtos e reduz seu ciclo de vida, com clara tendência à descartabilidade.

Já Halweil e Nierenberg (2004) mostram que em 1895, o caixeiro viajante King Camp Gillette teve a idéia de vender lâminas de barbear descartáveis - um produto que os consumidores teriam que comprar constantemente. Já em 1915, as vendas dispararam para 70 milhões de unidades e hoje a Gillette é uma empresa com faturamento anual de US\$10 bilhões. O que começou como um veículo de alto lucro para um comerciante assegurar um fluxo inesgotável de 
vendas transformou-se num conceito amplamente adotado - a obsolescência programada.

Estes autores informam, citando Taub (2003), que em meados de 2003 a Disney anunciou que iria testar no mercado um novo DVD, destinado a substituir os videodiscos e cassetes de locadoras e que deixam de funcionar após um tempo predeterminado. A Abertura da embalagem hermeticamente fechada dispara uma contagem regressiva química que torna o disco inútil após 48 horas. As sofisticadas tecnologias envolvidas nesta proposta podem ser estritamente do século XXI, mas a filosofia subjacente vem do tempo daquele conceito introduzido por Gillette e seus contemporâneos.

Estes avanços tecnológicos do final do último século tornaram possível "produzir mais que a demanda e oferecer mais que o necessário". Crescimento econômico infindável, motivado pelo consumo descontrolado, tem sido elevado ao status de religião moderna. Isto é tanto um objetivo de executivos corporativos, desejosos de manter acionistas felizes, como é uma meta de líderes políticos, geralmente a postos para tirar proveito de tudo que Ihes seja possível, com um olho na vitória nas próximas eleições (ROTHSTEIN, 2003; HALWEIL e NIERENBERG, 2004).

A forma despreocupada com que o homem trata os recursos naturais disponíveis, e que são finitos, em futuro diminuto cobrará dividendos das futuras gerações. Pode-se dizer que esta cobrança já está em andamento, haja vista as conseqüências observadas com maior evidência nas oscilações climáticas do planeta, e que demonstram a necessidade iminente de uma mudança de nossos comportamentos. O atual paradigma do crescimento constante e do consumo indiscriminado de supérfluos e descartáveis, por certo, não se coaduna com a 
conservação de um ambiente natural onde seja possível as condições adequadas para a sobrevivência humana. Na concepção de James Lovelock, "Gaia" (Terra) continuará sua jornada independente das agressões sofridas em função da inabilidade do homem no tratamento do planeta (VIEIRA, 2008).

Neste início de século a sociedade atual precisa, com a urgência necessária e através das agências de políticas mundiais, endossadas pelos governos nacionais, implantar e fazer cumprir um novo paradigma para o trato dos seus resíduos, de forma universalizada. Este fato torna-se a cada dia mais necessário e urgente devido ao desperdício, ao consumo indiscriminado e também pelas contradições existentes no próprio crescimento econômico das nações, no desenvolvimento industrial e tecnológico.

Ao mesmo tempo em que os recursos da biosfera são utilizados como se fossem inexauríveis, a natureza é desafiada a "assimilar" os resíduos de novos produtos artificiais, desconhecidos dos agentes naturais, ultrapassando os limites da capacidade dos ciclos naturais e dos fluxos de energia.

Segundo Baird (2002),

[...] historicamente, foi considerado implícita ou explicitamente que os produtos químicos ou quaisquer resíduos emitidos para o ambiente natural seriam assimilados pela natureza: ou o sistema natural os transformaria em substâncias de ocorrência natural, não-prejudiciais, ou os produtos químicos residuais seriam diluídos em tal extensão que não poderiam ser atribuídos aos mesmos quaisquer riscos para a vida. A estratégia de que "a solução para a poluição é a diluição" é, de fato, bem-sucedida com muitos poluentes. Porém, nas décadas de 60 e 70 em diante, 
ficou bem claro que muitos dos produtos químicos sintéticos não são assimilados porque são persistentes, isto é, não são alterados pela ação da luz, água, ar ou microorganismos (que atuam com frequência na degradação de muitos poluentes) durante períodos muito longos de tempo. Exemplos destas substâncias persistentes incluem pesticidas, como o DDT, os gases de refrigeração chamados CFC's, o gás dióxido de carbono e as formas tóxicas do elemento mercúrio. Devido a sua persistência e a sua contínua liberação, as concentrações ambientais de tais substâncias aumentaram no passado em níveis inquietantes. Devido à quantidade de problemas que provocaram, foi descoberto que muitas das substâncias persistentes não se tornam uniformemente dispersa no meio ambiente. Em vez disso, concentram-se em organismos vivos, podendo atingir, em seres humanos e outros animais, níveis que, em alguns casos, afetam sua saúde e até levam à morte prematura.

Está cada vez mais claro e patente que o modelo de iniquidade do desenvolvimento baseado no extrativismo à exaustão dos recursos naturais, os seus impactos nos ecossistemas naturais e a ausência de distribuição equitativa dos benefícios auferidos com esta exploração à comunidade mundial como um todo, ou seja, o chamado desenvolvimento explorador (CABRAL, 2007), não mais pode perdurar. Propugna-se então por um desenvolvimento sustentável.

Ainda segundo este autor, o desenvolvimento sustentável deve ter por base a conservação ambiental, ou seja, admite-se o aproveitamento controlado dos recursos naturais, com usufruto dos ecossistemas para necessidades humanas da 
presente geração, em ritmo e extensão tais que permitam sua recomposição, natural ou induzida. Isto difere da visão da preservação ambiental que adota o critério da intocabilidade dos sistemas naturais pelo homem, acreditando-se que, uma vez rompido o equilíbrio pré-existente, este não mais se recomporá. Nas palavras de Boeira (2002), “... o preservacionismo caracteriza-se pela preservação da natureza com forte desconfiança em relação à ação humana (biocentrismo), enquanto o conservacionismo representa a defesa de princípios racionais no uso dos recursos naturais, a prevenção do desperdício e o desenvolvimento dos ecossistemas para a maioria dos cidadãos (relativo antropocentrismo)", citando Leis (1999) e McCormick (1992).

Como nos ensina Valle (2004), o desenvolvimento sustentável propõe-se a atender às necessidades da atual geração sem o comprometimento do direto das gerações vindouras.

O crescimento constante das populações urbanas (p.ex., $81 \%$ da população brasileira reside atualmente em centros urbanos - IBGE, Censo 2000), aliado à intensa industrialização, à melhoria do poder aquisitivo e qualidade de vida nos países industrializados ou em desenvolvimento, vem causando a acelerada geração de grandes massas e volumes de resíduos sólidos, com destaque visível e de consequencias imprevisíveis nas grandes metrópoles (MARQUES, 2001; PUGLIESI, 2006).

Entre as muitas atividades praticadas pelo homem e que resultam incrementos significativos na problemática ambiental, estão aquelas que dizem respeito ao tratamento e à disposição finais dados aos resíduos sólidos urbanos (RSU's). Até porque ainda não dispomos e acreditamos, não existirá, processo de disposição que não resulte em "novos resíduos a serem tratados e dispostos". 
Este problema tem sido objeto de grande preocupação de vários países e de organismos internacionais, principalmente, pela quantidade cada vez maior na geração destes resíduos, registrada a cada dia, com o desenvolvimento, inovação e a oferta crescentes de vários produtos, com destaque especial para os manufaturados, com diminuição acentuada, inclusive, do ciclo de usufruto destes bens.

Esta dinâmica da produção e do consumo acarreta cada vez mais, maiores quantidades de resíduos e, conseqüentemente, o aumento de aportes tecnológicos e financeiros. Inclusive e necessariamente, na qualificação de recursos humanos para atuar nesta área; para que os RSU's tenham o seu tratamento e a sua destinação finais, os mais adequados possíveis, evitando-se que resultem a céu aberto, transformando-se em fonte de proliferação e irradiação de vetores de diversas doenças.

O lixo tem grande importância na transmissão de doenças através de vetores como moscas, mosquitos, baratas e roedores, que encontram na disposição inadequada do lixo, alimento, abrigo e condições adequadas para proliferação. Os organismos patogênicos, em geral, são pouco resistentes às condições do meio exterior.

Além da poluição visual - resíduos espalhados 'ao vento' tiram a estética de qualquer área - que sempre acarreta às áreas de destinação e seu entorno, a consequente desvalorização imobiliária e da poluição do solo, águas superficiais e subterrâneas e do ar, pelo não tratamento adequado dos líquidos percolados e dos gases emitidos. 


\section{7 - Os aterros sanitários}

Um dos equipamentos mais recomendados para a disposição final de resíduos sólidos urbanos são os aterros sanitários (AS). Embora sejam cada vez mais difícil a disponibilidade de áreas e a escolha de locais para tais equipamentos, na maioria das cidades, notadamente, grandes metrópoles, como p.ex. a cidade de São Paulo, como denunciado por Morelli (2007). Ou ainda, como dito por Fecuri (2004) quando mostra que a maior metrópole do Brasil "não dispõe mais de locais adequados para a disposição final dos seus RSU's. Os aterros sanitários existentes, de Santo Amaro (Interlagos) e Vila Albertina (Cantareira), foram simplesmente desativados, dada à extrapolação dos limites técnicos impostos e a possibilidade de desmoronamentos, restando tão-somente os aterros Bandeirantes (Perus), reaberto recentemente, e o São João, os quais, em conjunto, terão vida útil curtíssima".

Estes equipamentos devem ser construídos seguindo técnicas já normalizadas e bastante maduras, usando princípios de engenharia para sua construção e operação (ABNT 8419: 1992). Deve também ser observada a legislação correspondente - p.ex., Portaria do Ministério do Interior $n^{0}$. 53/79; Resolução CONAMA n. 237/97; Portaria n . 961/98; Lei n . 13.103/2001(Estado do Ceará); Resolução CONAMA n . 308/2002; Lei $n^{0}$. 12.300/2006(Estado de São Paulo) -, com os devidos Estudos de Impactos Ambientais e os Relatórios de Impactos Ambientais (EIA/RIMA), as devidas análises físico-geológicas do solo a que se destina e todo o processo do projeto com as devidas: Licença Prévia (LP), Licença de Instalação (LI) e a Licença de operação (LO), (FUNASA, 2006).

Nos aterros sanitários os resíduos sólidos urbanos (RSU's) são 
dispostos no solo impermeabilizado (manta PEAD, $2 \mathrm{~mm}$ ); em unidades espaçooperacionais definidas para simplificar e ordenar a operação - células de trabalho geralmente em depressões naturais ou em escavações específicas para tal; com compactação para a redução de volume e diminuição da área ocupada, recobrimento com materiais argilosos ao fim de cada jornada de trabalho, ou em intervalos menores se necessário.

Estes aterros sanitários devem dispor de sistemas de drenagem das águas fluviais, evitando-se total penetração do aterro; sistema de coleta dos líquidos percolados - chorume - para o devido tratamento, antes do seu lançamento no solo ou em corpos hídricos e um sistema de coleta dos gases emitidos para tratamentos (dissipadores de GAS - queimadores; Coleta Vertical), evitando-se os seus lançamentos na atmosfera, em prevenção à poluição do ar de entorno e ao efeito estufa (Figura 1.7.1), a seguir.

O tratamento do chorume pode ser através de lagoas de estabilização que operam num sistema físico-químico de recuperação dos líquidos, objeto do processamento.

Nos aterros sanitários, o sistema de captação vertical para os gases, se destina principalmente a eliminar o gás carbônico, o gás metano e o gás sulfídrico para que o terreno não fique sujeito a explosões, deslizamentos e combustão.

Ao final de sua vida útil, o aterro sanitário pode ser reutilizado mediante abertura das células, para retirada do material bioestabilizado ou utilização do mesmo em outras situações tais como: áreas de lazer e praças (BIDONE e POVINELLI, 1999; FALCÃO e ARAUJO, 2005). 
No entanto, por melhor que sejam o projeto de construção e a operação dispensada a um aterro sanitário, especialmente na sua compactação e recobrimento, os gases produzidos pela degradação anaeróbia da matéria orgânica presente nos resíduos sólidos urbanos migram através do maciço de lixo, efluindo na superfície do aterro - emissões fugitivas - fora do alcance do sistema de captação vertical (Dissipadores/queimadores), sendo lançados diretamente para a atmosfera, numa emissão solo-ar, destaque, em vermelho na figura 1.7.1; a seguir:

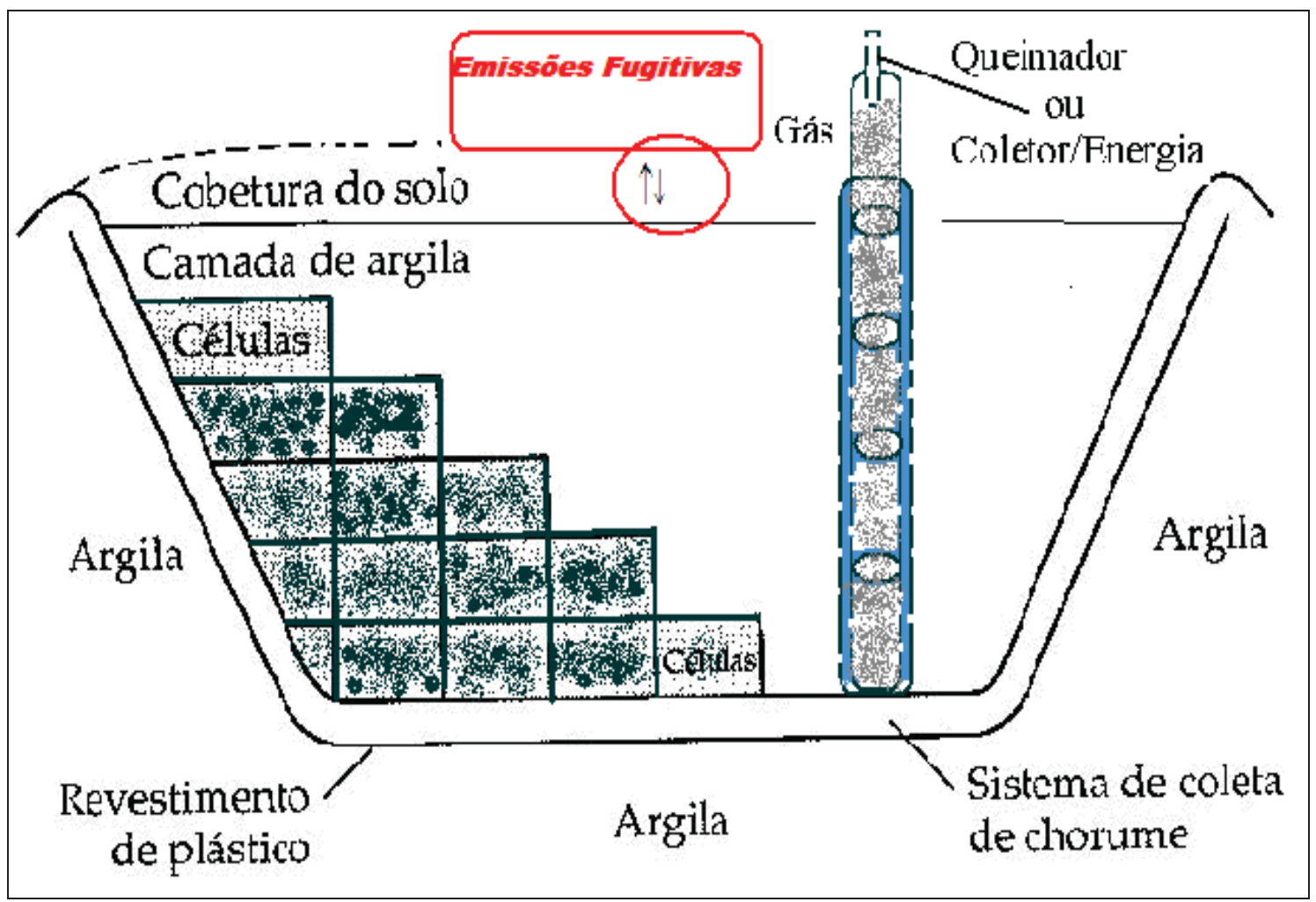

Figura 1.7.1 - Elementos construtivos de um Aterro Sanitário, em processo de preenchimento. Corte em perfil, com destaque para a cobertura, sítio de emissões fugitivas.

Fonte: Adaptado de Baird (2002)

A relevância e o impacto do lançamento das emissões gasosas de aterros sanitários na atmosfera são devidos: ser um gás tóxico, de odor repulsivo 
pelo seu conteúdo de gás sulfídrico $\left(\mathrm{H}_{2} \mathrm{~S}\right)$, várias mercaptanas, ácidos graxos e compostos orgânicos voláteis (VOC's), perfazendo mais de 200 compostos; embora com contrações abaixo de 100 ppm (JAFFRIN et al., 2003). Além do seu elevado conteúdo de, aproximadamente, 55 a $60 \%$, ou mais, de metano $\left(\mathrm{CH}_{4}\right)$ e 45 a $50 \%$ de dióxido de carbono $\left(\mathrm{CO}_{2}\right)$, que são considerados gases de efeito estufa, por absorverem a radiação infravermelha (IV, ou IR, na sigla em inglês) e poderem também influenciar na depreciação da camada de ozônio, potencializando o aumento do aquecimento global (KUMAR et al., 2004).

O gás metano $\left(\mathrm{CH}_{4}\right)$, um dos principais produtos da degradação anaeróbia dos resíduos orgânicos em aterros sanitários, apresenta características energéticas que não podem e não devem ser desperdiçadas. Especialmente porque se coletado e recuperado o seu potencial energético, estará se constituindo em uma prática, ambientalmente correta, de elevado valor ecológico e econômico, evitando-se a sua emissão para a atmosfera e reduzindo-se o uso de combustíveis fósseis naturais, pela suas finitude e altos preços, especialmente os derivados do petróleo, cada vez mais escassos e onerosos. Segundo Kumar et al (2004) citando o IPCC, além de o metano ser um dos GEE mais importante, as suas concentrações atmosféricas têm aumentado a uma taxa da ordem de $1-2 \%$ ao ano.

O metano $\left(\mathrm{CH}_{4}\right)$ tem um potencial de aquecimento global (GWP, na sigla em inglês) da ordem de vinte e três vezes maior do que o dióxido de carbono $\left(\mathrm{CO}_{2}\right)$ e permanece ativo na atmosfera por até doze anos (ROSA, et al. 2001; WRI, 2002). Isto significa, para ilustração, que uma tonelada de gás metano emitida para a atmosfera terrestre equivaleria à emissão de vinte e três toneladas de dióxido de carbono. 
Assim, pode-se afirmar que as emissões de metano na atmosfera são 23 vezes mais agressivas que para as mesmas quantidades de dióxido de carbono, em termos de potencial de contribuição para o efeito estufa. Portanto, se torna necessária e imprescindível, uma prática ambiental em que se procure, cada vez mais, identificar e dimensionar as fontes de emissão deste gás para a mitigação do aquecimento da atmosfera terrestre e a devida compreensão do fluxo de carbono na atmosfera.

Diversos outros aspectos estão relacionados aos potenciais impactos ambientais que os aterros podem produzir, principalmente, no que tange à migração e emissão dos gases produzidos. A falta de seu monitoramento e coleta efetiva pode afetar a qualidade do ambiente de entorno e, diversos aspectos devem ser atentados, como os de saúde pública, odores desagradáveis, danos causados à vegetação, às águas subterrâneas, riscos de explosão pela flamabilidade do gás em circunstâncias especiais, etc... Tais efeitos estão relacionados a diferentes escalas de abordagem e às concentrações dos gases no ambiente do aterro e de entorno.

O presente trabalho teve como objetivo medir, estimativamente, e contribuir para a determinação do quantum da "emissão fugitiva" de gases de aterros sanitários(GAS) para a atmosfera terrestre e para uma melhor compreensão do fluxo de carbono na natureza, a partir destes sistemas de disposição final de resíduos sólidos urbanos. Até porque não foram encontrados trabalhos com estes objetivos.

Muitas pesquisas tentam quantificar a geração do gás de aterros via seu potencial de produção, a partir de modelagens variadas, levando em conta parâmetros como: quantidades de RSU depositadas em aterros; quantidades de 
material orgânico (degradável) contido nestes resíduos e suas diferentes taxas de degradação; massa de carbono nos resíduos; tempos de deposição e de atividade do aterro; fatores como operação do aterro, influências climáticas, aspectos físicoquímicos e biológicos... etc (HAM, 1979; BOGNER, 1986; KUMAR et al., 2004; SPOKAS et al., 2006) e outras aliam o potencial de geração ao potencial energético (PECORA, 2006; FIGUEIREDO, 2006; ZAMORANO et al., 2007).

Tendo por base os dados obtidos em trabalho de campo desenvolvido em aterros ou lixões de municípios do estado de São Paulo, Brasil, a saber: Araraquara, Brotas, Campinas, Jaú, Ribeirão Bonito, Ribeirão Preto, São Carlos e do Aterro Bandeirantes, na Capital; pôde-se fazer uma estimativa de quanto estes equipamentos de disposição de resíduos sólidos urbanos emitem de gases de efeito estufa (GEE) para o ambiente natural, independentemente, da operação que se aplique a cada um deles, tendo em vista a melhor técnica e disponibilidade políticofinanceira do município. São feitas recomendações direcionadas às potenciais pesquisas a serem desenvolvidas na área, no intuito de cada vez mais diminuirmos estas emissões, com efetiva contribuição para a prevenção e mitigação do efeito estufa, de reduções no uso de combustíveis fósseis e os demais impactos já mencionados; tornando os aterros sanitários cada vez mais recomendáveis como equipamentos de destinação e tratamento finais do lixo urbano. 


\title{
2. OBJETIVOS
}

\author{
“A MAIOR TRAGÉDIA DESTE PERÍODO DE TRANSIÇÃO SOCIAL NÃO FOI O ESTRIDENTE CLAMOR \\ DOS MAUS, MAS O TERRÍVEL SILÊNCIO DOS BONS." \\ MARTIN LUTHER KING
}

\subsection{Geral}

Estudar as emissões fugitivas de metano $\left(\mathrm{CH}_{4}\right)$ e dióxido de carbono $\left(\mathrm{CO}_{2}\right)$ (GEE), que efluem na superfície de aterros de resíduos urbanos (solo-ar), escapando do sistema de dissipação vertical, bem como a concentração destes gases no ar ambiente dos aterros e a emissão dos dissipadores/queimadores.

\subsection{Específicos}

1. Medir as emissões fugitivas de $\mathrm{CH}_{4}$ e $\mathrm{CO}_{2}$ em aterros sanitários, aterros controlados e em valas nos municípios de Araraquara, Brotas, Campinas, Jaú, Ribeirão Bonito, Ribeirão Preto, São Carlos e no aterro Bandeirantes, São Paulo - Capital; Estado de São Paulo, Brasil.

2. Implementar uma metodologia experimental para a coleta de amostras de GAS (Gás de Aterros Sanitários) nas emissões solo-ar (Construmaq, 2006).

3. Analisar amostras do GAS, para qualificar e quantificar as frações de metano $\left(\mathrm{CH}_{4}\right)$ e de dióxido de carbono $\left(\mathrm{CO}_{2}\right)$.

4. Comparar as emissões em aterros diferentes em: montante de resíduos, tempo de disposição e IQR, buscando possíveis correlações entre estas emissões e os aterros, para que se possa estabelecer ou não tendências gerais. 


\section{REVISÃO BIBLIOGRÁFICA}

“... A VERDADEIRA, A MAIS PROFUNDA ESPIRITUALIDADE CONSISTE EM SENTIR-NOS PARTE INTEGRANTE DESTE MARAVILHOSO E MISTERIOSO PROCESSO QUE CARACTERIZA GAIA, NOSSO PLANETA VIVO: A FANTÁSTICA SINFONIA DA EVOLUÇÃO ORGÂNICA QUE NOS DEU ORIGEM JUNTO COM MILHÕES DE OUTRAS ESPÉCIES. É SENTIR-NOS RESPONSÁVEIS PELA SUA CONTINUAÇÃO E DESDOBRAMENTOS".

LUTZENBERGER, J.A.

\subsection{Os resíduos sólidos urbanos: problemática, definições e classificações.}

Os problemas gerados pelo atual manejo dos resíduos sólidos urbanos (RSU's); resultantes dos diferentes processos de transformação manufatura - em busca da satisfação da sociedade humana e manifestados com maior intensidade no meio urbano; especialmente nas grandes metrópoles; são diversos, tanto na sua variedade como na magnitude de suas implicações.

A Revolução Industrial, no século XVIII, permitiu o desenvolvimento de indústrias diversas. Então surgiram novos artefatos e utensílios com o consequente aumento na geração de novos tipos de resíduos, com destaque para os industriais ou sintéticos; produtos comprados, usados e descartados; demandando quantidades crescentes de matérias primas, subtraídas da natureza; muitas delas não-renováveis; e o grande incremento de suas composições químicas, que na atualidade são muito diversas, dificultando a sua degradação e reabsorção naturais. Muitos têm pouco tempo de uso, como o caso das baterias, eletro-eletrônicos e embalagens as mais variadas, notadamente, as poliméricas, como as plásticas e plástico-celulósicas. 
Muitos produtos manufaturados requerem imensos insumos de água, madeira, energia, metais e outros recursos, todos esgotáveis. E, frequentemente, também contêm insumos químicos tóxicos que, quando liberados no ambiente natural, ameaçam a saúde dos seres humanos e de sistemas ecológicos dos quais dependemos. Estes impactos podem ocorrer em qualquer etapa do ciclo de vida de um produto: na obtenção da matéria-prima, industrialização, embalagem, transporte, uso e até mesmo após o descarte (DUMNING, 1992 apud MASTNY, 2004)

Segundo Sonnemann (2003):

[...] uma abordagem de ciclo de vida nos permite verificar as consequências involuntárias de nossas ações durante toda a vida dos produtos - desde a extração da matéria-prima até a disposição final. Oferecendo informações mais completas sobre tudo, desde nossos sistemas de transportes até nossas fontes energéticas, pode nos ajudar a reorientar o consumo numa direção mais sustentável. "Os consumidores estão cada vez mais interessados no mundo por trás dos produtos que adquirem", observa Klaus Töpfer, diretor executivo do PNUMA. "O conceito de ciclo de vida significa que cada um de nós, por toda a cadeia do ciclo de vida de um produto, do berço ao túmulo, temos responsabilidades e um papel a desempenhar".

Em 2001, em resposta a uma convocação de governos por uma economia de ciclo de vida, o PNUMA e a Sociedade de Toxicologia e Química Ambiental iniciaram, conjuntamente, uma Iniciativa de Ciclo de Vida. Através de seus três programas principais - Gestão de Ciclo de Vida, Inventário de Ciclo de Vida 
e Avaliação do Impacto do Ciclo de Vida -, a iniciativa busca desenvolver e disseminar ferramentas práticas para avaliar oportunidades, riscos e compensações associados a produtos e serviços ao longo do seu ciclo de vida. A iniciativa é regida por um Painel Internacional de Ciclo de Vida, que também age como principal fórum global para especialistas e interessados em ciclo de vida em todo o mundo.

É uma iniciativa que também contribuiu para um arcabouço de programas decenais mais amplos, que promovem as normas de consumo e produção sustentáveis solicitados na Cúpula Mundial sobre Desenvolvimento Sustentável de 2002, em Johanesburgo. O Plano de Ação de Johanesburgo enfatizou a necessidade de "políticas que melhorem os produtos e serviços, reduzindo ao mesmo tempo, impactos ambientais e à saúde e utilizando, onde sejam indicadas, abordagens científicas, como a análise de ciclo de vida".

Para Mastny (2004), felizmente, estão sendo desenvolvidas ferramentas sofisticadas para ajudar tanto fabricantes quanto compradores a avaliarem o desempenho ambiental dos produtos. Esta técnica particularmente promissora, a avaliação do ciclo de vida, oferece uma metodologia para identificar e quantificar os insumos, produtos e impactos ambientais potenciais de um determinado produto ou serviço por toda sua vida. Instituições públicas e privadas, universidades, igrejas e governos, de modo geral, já aplicam princípios deste parâmetro nas suas aquisições. Grandes empresas, nacionais e multinacionais, já aplicam considerações do ciclo de vida, a fim de prestar informações detalhadas 
sobre vários impactos ambientais que surjam durante a fabricação e uso de seus produtos ao consumidor final.

O Departamento de Comércio dos Estados Unidos utiliza um software BEES 3.0 (sigla em inglês para Construir para a Sustentabilidade Ambiental e Econômica) (NIST, 2009), com dados do ciclo de vida de produtos e serviços, para assessorar compras do Estado e compradores na comparação e classificação do desempenho ambiental e econômico de materiais de construção, com base em seus impactos relativos em áreas como, aquecimento global, qualidade do ar interno, exaustão de recursos e resíduos sólidos.

Mesmo com toda esta problemática e consequencias maléficas, os resíduos sólidos urbanos tornaram-se um indicador curioso de desenvolvimento de uma localidade, cidade, estado ou nação. Segundo um levantamento feito pela (ABRELPE, 2007) os brasileiros passaram a produzir muito mais lixo depois do plano real. Em algumas capitais brasileiras o aumento variou de $13 \%$ a $40 \%$. Calcula-se que por dia cada brasileiro, em média, produza em torno de $1 \mathrm{~kg}$ de lixo domiciliar. Levando em conta uma média de vida de 70 a 75 anos, uma criança que nasça hoje se mantiver essa média até sua morte irá produzir de 25 a 27 toneladas de lixo, durante sua vida.

Já Rosa et al (2003) dizem que a média de geração diária de resíduos sólidos domésticos, dos países do primeiro mundo, é da ordem de 1,77 kg per capita. Esta realidade, agregada aos custos de manejo e tratamento dos resíduos, decorrentes de aperfeiçoamentos e revisões das normas sanitárias e ambientais, tem sido motivo de altos investimentos, desde a década de 80 , na coleta seletiva do lixo e na reciclagem dos resíduos gerados, com vistas à minimização no destino final. Igualmente, lembram estes autores esta geração de RSU's ainda está muito 
longe dos norte-americanos que já atingiram a marca 3,2 kg por pessoa ao dia.

Estes números são corroborados em trabalho de Freudenrich (2007) que estima uma quantidade bem acima de 650.000 toneladas por dia o que eleva a geração em torno de duzentas e trinta milhões de toneladas por ano na década passada (REAMS \& TEMPLET, 1996), a geração de RSU naquela nação. Isso é quase o dobro do lixo produzido por pessoa na maioria dos outros países de grandes economias ou do primeiro mundo.

A nação norte americana é a grande campeã em geração de resíduos, mesmo tendo a sua agência de proteção ambiental mostrado que a não geração de resíduos é menos dispendiosa, tanto do ponto de vista econômico quanto ambiental, com proposição dos princípios da Prevenção à Poluição (P2); indicando que todas as formas de poluição devem ser evitadas; quando isto não for possível a geração na fonte deve ser reduzida e, nos casos em que a redução não seja factível recomenda a reciclagem ou tratamento final (EPA, 1990).

A saúde pública e a conservação do ambiente natural são os dois pontos fundamentais da geração acelerada e da problemática resultante dos RSU's que justificam a busca de soluções adequadas e permanentes. Segundo Fecuri (2004), como principais poluentes do solo, subsolo e corpos de águas; superficiais ou subterrâneos; bem como da atmosfera terrestre, os RSU's sempre foram negligenciados pelo poder público, em decorrência, provavelmente, da ausência de informações e divulgação de sua nocividade. Até bem pouco tempo atrás o tema "lixo" sequer fazia parte da agenda das lideranças político-administrativas. Por esta razão, não existia um conjunto de políticas públicas de gestão, gerenciamento e tratamento desses resíduos sólidos urbanos. 
Esta autora, citando Fiorillo (2003), chama a atenção para que...

"[...] o lixo atinge de forma mediata e imediata os valores relacionados com saúde, habitação, lazer, segurança, direito ao trabalho e tantos outros componentes de uma vida saudável e com qualidade. Além de atingir, mais intensamente, o espaço urbano, verificamos que o lixo é um fenômeno que agride também o próprio ambiente natural, como um todo, e acarreta perdas significativas aos espaços culturais, desconfigurando valores estéticos do ambiente urbano".

Todas as atividades do homem - antrópicas - produzem resíduos que induzem enormes dificuldades na hora de seu tratamento e disposição finais. A produção e deposição final do lixo são um problema mundial, sobretudo, nas grandes cidades. Segundo o AmbienteBrasil (2007), estima-se que no mundo inteiro são produzidos, aproximadamente, 400 milhões de toneladas de lixo por ano. Como a população na Terra deverá passar dos atuais mais de 6,5 bilhões de habitantes para, aproximadamente, 9 bilhões até 2050 (ONU/FAO, 2004; IBGE, 2005), tem-se aí, em traços grossos, o desenho do cenário da catástrofe global que vem se anunciando, desde os fins dos anos 1960, e que deu origem à consciência, cada vez mais geral, de que é preciso replanejar, com clareza, e praticar, com urgência, novas formas culturais de relacionamento produtivo do homem em sociedade e da sociedade com a natureza (VOGT, 2002).

Estudos feitos em outros países como Demajorovic (1995); Chung \& Poon (1998); Read (1999); têm demonstrado que os problemas relacionados com os resíduos sólidos são de espectro mundial. Tanto nações desenvolvidas quanto países do terceiro mundo sofrem suas consequências, e, muitas vezes estes em 
consequência do lixo daqueles. Esta situação se agrava muito mais em países onde não existe uma atenção maior para o caso, seja ele de primeiro ou de terceiro mundo, quando descuidam das fontes geradoras, dos serviços de coleta, do tratamento e da disposição finais adequados a esses resíduos.

Na Europa se produziram na década de 90, de $300 \mathrm{~kg}$ a $400 \mathrm{~kg}$ de resíduos domésticos por habitante por ano, segundo Hartenstein \& Horvay (1996). Nos Estados Unidos, neste período, geravam-se 25\% a mais de resíduos sólidos municipais que na década anterior (REAMS \& TEMPLET, 1996), aproximadamente, 230 milhões de toneladas por dia.

Segundo Gardner et al (2004) os refugos do consumo é algo sombrio, especialmente nos países ricos, embora tal problemática não Ihes seja exclusiva. Um habitante comum de um país da Organização para Cooperação e Desenvolvimento Econômico (OCDE) gera 560 quilos de lixo urbano por ano, numa média de $1,55 \mathrm{Kg} /$ dia e, com exceção de três, todos os 27 países geraram mais, per capta, em 2000 do que em 1995. E então mostra que os valores gastos no consumo extremo contestam a visão de que muitas das necessidades básicas dos pobres mundiais não atendidas sejam muito dispendiosas para se atender. A provisão de alimentação adequada, água potável e educação básica para os mais pobres podem ser realizadas gastando-se menos do que se gasta anualmente, com artigos de luxo, como cosméticos, sorvetes e ração de animais de estimação, em países ricos, conforme demonstrado na tabela 3.1.1: 
Tabela 3.1.1 - Gastos Anuais em Itens de Luxo versus Recursos Necessários para o atendimento de necessidades básicas selecionadas. Ano base: 2003.

\begin{tabular}{|c|c|c|c|}
\hline Itens Selecionados & $\begin{array}{l}\text { Gasto Anual } \\
\text { (US\$) }\end{array}$ & $\begin{array}{l}\text { Objetivo Social ou } \\
\text { Econômico }\end{array}$ & $\begin{array}{l}\text { Investimento } \\
\text { extra anual } \\
\text { para atingir o } \\
\text { Objetivo (US\$) }\end{array}$ \\
\hline Cosméticos & 18 bilhões & $\begin{array}{l}\text { Saúde reprodutiva para } \\
\text { todas as mulheres }\end{array}$ & 12 bilhões \\
\hline $\begin{array}{l}\text { Ração c/animais de } \\
\text { Estimação (USA/EU) }\end{array}$ & 17 bilhões & $\begin{array}{l}\text { Erradicação da fome e } \\
\text { má-nutrição }\end{array}$ & 19 bilhões \\
\hline Perfumes & 15 bilhões & $\begin{array}{l}\text { Alfabetização } \\
\text { Universal }\end{array}$ & 5 bilhões \\
\hline Cruzeiros marítimos & 14 bilhões & $\begin{array}{l}\text { Água Potável para } \\
\text { Todos }\end{array}$ & 10 bilhões \\
\hline Sorvetes na Europa & 11 bilhões & $\begin{array}{l}\text { Vacinação de todas as } \\
\text { crianças }\end{array}$ & 1,3 bilhão \\
\hline Totais & 75 bilhões & - & 47,3 bilhões \\
\hline
\end{tabular}

Fonte: (PNUD, 1998; MASTNY, 2002; GARDNER e SAMPAT, 2003). Com adaptações.

Como se pode observar a partir dos dados da tabela 3.1.1, para "o mundo pobre do planeta", sobraria uma ajuda de US\$27,7 bilhões, caso houvesse real interesse sócio-econômico e político de se resolver àquelas suas necessidades básicas; com o "mundo privilegiado" do planeta abrindo mão apenas daquilo que lhe é luxuoso e supérfluo. Isto sem que fosse necessário alterar, minimamente, o padrão de vida desta porção rica da comunidade mundial.

O mesmo autor mostra que mesmo em países considerados líderes em política ambiental, como a Noruega, a redução da produção de lixo é um desafio constante. Em 2000, o norueguês, em média, gerou $354 \mathrm{~kg}$ de lixo, $7 \%$ a mais do que no ano anterior. Naquele país a proporção do lixo reciclado também cresceu, porém estancou em menos da metade do total gerado. Enquanto isso, nos Estados Unidos seus habitantes continuam sendo os campeões mundiais do lixo, 
produzindo, per capta, $51 \%$ mais lixo urbano do que o habitante comum de qualquer outro país da OCDE. E, mesmo havendo indícios de que o índice per capta tenha aparentemente estabilizado no final da década de 90 e início desta década, somando-se os altos níveis de lixo produzido por um cidadão americano ao crescimento contínuo da população dos EUA, chega-se a um montante de entulho descomunal (OCDE, 2002).

Para Gardner (2004) a crescente febre de consumo que se iniciou e manteve-se durante o século $X X$, levou ao maior uso de matérias-primas, o que aumentou os gastos familiares e o número de consumidores. Entre 1960 e 1995 o consumo mundial de minérios aumentou 2,5 vezes, metais 2,1 vezes, produtos madeireiros 2,3 e produtos sintéticos, como plásticos, 5,6 vezes. Este crescimento superou o aumento da população mundial, tendo ocorrido mesmo quando a economia global mudou para abranger mais indústrias de serviços, como telecomunicações e finanças, que não são intensivas em materiais como indústria, transportes e outros setores outrora dominantes (ONU, 2004).

O consumo de combustíveis e materiais reflete o mesmo padrão de desigualdades encontrado no consumo de produtos finais. Só os Estados Unidos, com menos de $5 \%$ da população global, consomem aproximadamente um quarto dos recursos mundiais de combustíveis fósseis, queimando quase $25 \%$ do carvão, $26 \%$ do petróleo e $27 \%$ do gás natural. Em termos do consumo de metais os Estados Unidos, Canadá, Austrália, Japão e Europa Ocidental - que detêm 15\% da população mundial - consomem $61 \%$ do alumínio produzido a cada ano, $60,5 \%$ do chumbo, $59 \%$ do cobre e $49 \%$ do aço. O consumo per capta também é alto, principalmente se considerado o que é verificado nas nações mais pobres. O americano comum consome 22 quilogramas de alumínio por ano, enquanto o 
indiano consome 2 e o africano menos de 1 quilograma (EM, 2004).

O tratamento último e a disposição final dos resíduos sólidos têm gerado problemas por falta de espaços adequados para a construção de aterros sanitários na Europa, Japão, Estados Unidos, etc., elevando bastante os custos dos locais de implantação destes equipamentos. Por exemplo, em Flandes, na Bélgica, o custo de implantação foi duplicado, levando a um aumento de 2,5 vezes nos impostos cobrados pelo estado para estas instalações no período 1989-2000 (van GERVEN, 2005). Nas últimas décadas a formulação de estratégias dos países europeus para eliminar os problemas dos seus resíduos tem levado ao uso da incineração como opção de manejo e se discute e acredita que uma estratégia de manejo integrado dos resíduos, ainda é a melhor proposta para tal.

Para Passinato (2008) o lixo produzido pelas atividades do homem é hoje uma das mais graves ameaças à sua própria qualidade de vida. Isso tem determinado a tendência mundial pela minimização da geração, entendendo-se como tal a produção/venda de produtos dos quais restem o mínimo possível de resíduos, o reuso de embalagens e a reciclagem. Como a gestão e o gerenciamento dos resíduos sólidos urbanos é uma responsabilidade direta das municipalidades, a reprogramação conceitual de processos produtivos e de produtos em geral, com atenção especial para suas embalagens, é algo que foge completamente ao controle dos Municípios. Já a reciclagem pode e deve ser incentivada por estes entes federados, conscientizando a população e estruturando programas de coleta seletiva e mantendo núcleos de triagem de recicláveis. No entanto, mesmo que se obtenha o maior sucesso nestes programas, a maior parcela dos resíduos gerados, mais de $65 \%$, necessitará de uma destinação final adequada, e aí que se adeque, preferencialmente, uma rota que privilegie o 
aproveitamento da energia contida no lixo. Isso é demonstrado no quadro 3.1.1, a seguir:

Quadro 3.1.1 - Gestão Integrada de RSU's - com vistas à minimização para AS.

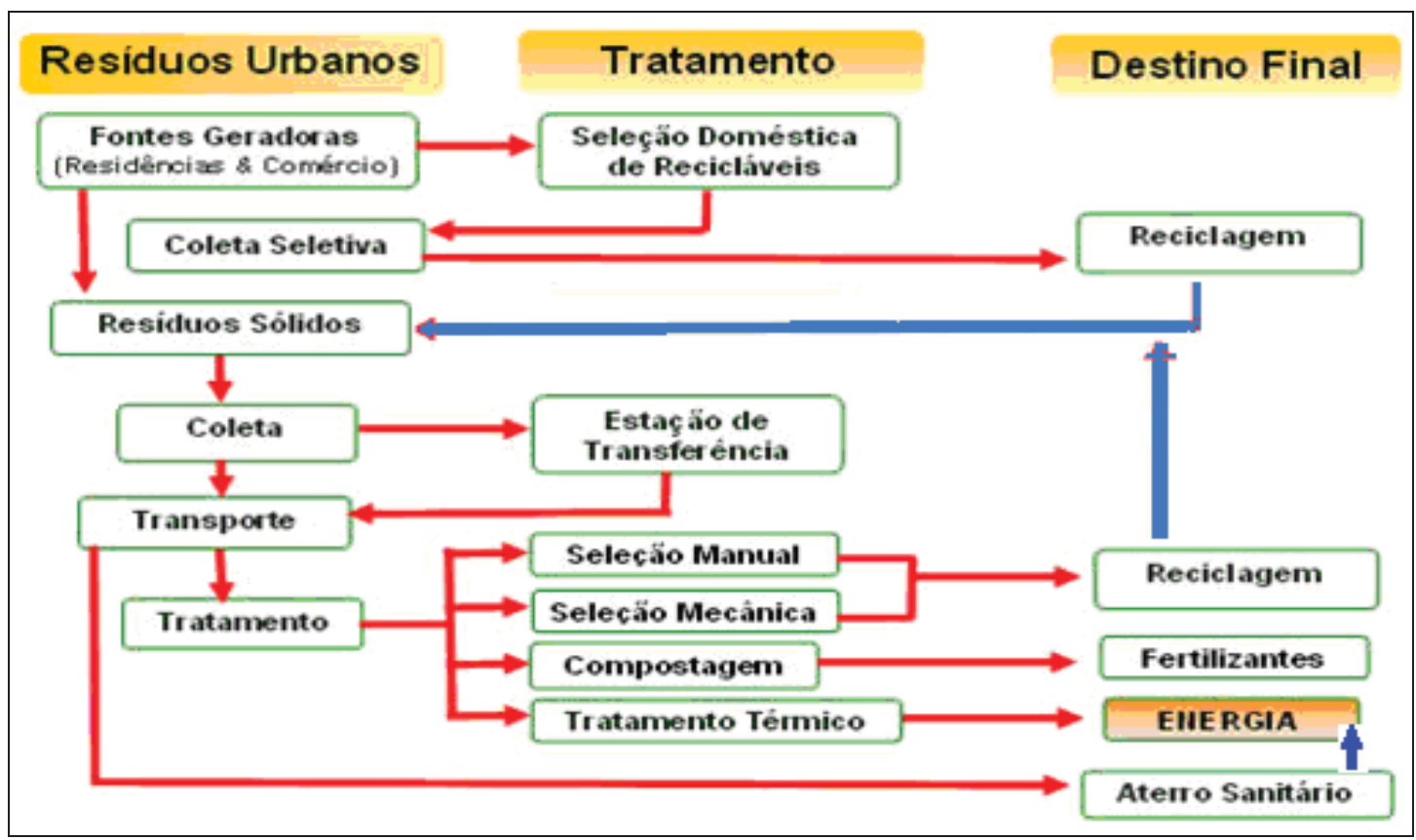

Fonte: Adaptado (destaques em azul) de Passinato (2008), citando um "Technical Guidance Report". BM.

Como se pode depreender do quadro 3.1.1, anterior, tudo deve ser feito para que o descarte em aterros seja da menor quantidade possível de resíduos urbanos, como já se pratica em vários países europeus (KORHONEN e DAHLBO, 2007). Pelas tecnologias disponíveis, uma vez gerado o resíduo, teríamos uma segregação consequente na fonte (residências e comércio), o que realocaria no ciclo econômico uma grande parte dos recicláveis e também acarretaria maior vida útil a estes equipamentos de disposição final, minimizando a demanda por áreas para tais, cada vez mais difíceis.

Veja-se ainda no quadro 3.1.1, que infelizmente ainda não dispomos 
de tecnologia para "um ciclo fechado". Por mais correto e completo que seja um programa de coleta seletiva, a própria reciclagem gerará resíduos, os quais demandam disposição adequada. E que, depois que se desse tratamento correto a todo o resíduo, mesmo da quantidade mínima destinada aos aterros - que via de regra, em especial nas grandes cidades, não seriam quantias nada desprezíveis temos a possibilidade do aproveitamento do gás de aterro, com fins energéticos; aqui sim; com tecnologia já bem sedimentada e praticada, como é exemplo o aterro bandeirantes, em São Paulo, Capital, um dos aterros objeto deste estudo.

Na União Européia; dado às dificuldades de disponibilidade de áreas para disposição final; a reciclagem de resíduos tem ganhado incrementos significativos, com obrigações a ser cumpridas pelos seus membros, no sentido de destinarem um mínimo possível para os aterros (EC, 2005).

Segundo Korhonen e Dahlbo (2007), a taxa média de reciclagem em quinze países do bloco para o ano de 2002, foi de $19 \%$, como mostra o quadro 3.1.2, a seguir, excluídos a Áustria e Luxemburgo. Mas sete países apresentaram taxas acima da média, com destaque para a Alemanha (33\%), além de Dinamarca, Holanda, Finlândia, Bélgica, Noruega e Suécia. Outros quatro países: Bulgária, Chipre, Lituânia e Malta; lançam seus RSU quase que totalmente em aterros, sem privilegiar a reciclagem. 
Quadro 3.1.2 - Taxas de reciclagem de RSU's em países da EU em 2002.

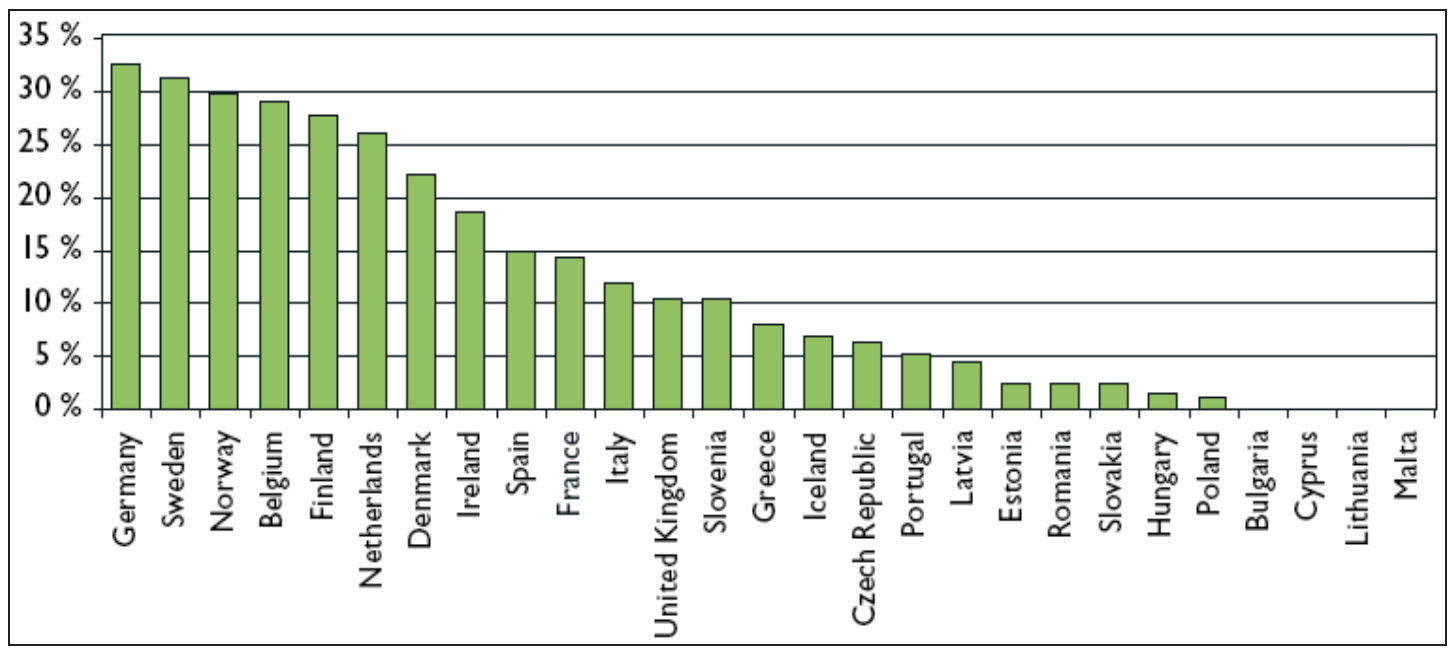

Fonte: Korhonen e Dahlbo (2007).

Para a América Latina e Caribe, segundo Calderoni (2001), são conhecidos estudos e proposições de instrumentos de políticas para a gestão dos RSU's, com vistas a que se alcance a promoção dos objetivos que dizem respeito ao desenvolvimento sustentável, como a seguir:

- Maximização da reciclagem;

- Maximização na divulgação de informações e ações para educação ambiental;

- Minimização na geração dos RSU;

- Minimização nos processos de incineração;

- Minimização nas quantidades de RSU para os aterros... etc.

No esforço para livrar-se do "lixo" ou "resíduos indesejáveis", o homem tem utilizado desde a antiguidade várias técnicas, algumas praticadas até hoje, como a disposição em lixões a céu aberto, o despejo em corpos de água, as "valas" 
de lixo e a incineração sem controle.

A incineração é, provavelmente, a segunda mais antiga forma de disposição do lixo. A primeira seria simplesmente abandonar em qualquer lugar as coisas "inservíveis". A técnica da incineração, possivelmente, teve início quando o homem percebeu que podia aquecer-se queimando coisas "não úteis" na sua caverna e assim podê-la habitar por mais tempo, antes que o acúmulo de resíduos tornasse sua estada ali impossível (COREY, 1980).

Já na década de 90, Petts (1994); Hartenstein \& Horvay (1996) e Reams \& Templet (1996); e no início desta década Zhang et al. (2002) e Forteza et al (2004); chamavam a atenção para que ao se lançar mão da incineração como opção prática sustentável e ambientalmente correta e de domínio público, no tratamento de resíduos sólidos urbanos, torna-se necessário:

- manter um sistema de coleta seletiva que contemple a segregação de todos os materiais reutilizáveis e recuperáveis, otimizando o potencial energético daqueles a serem queimados;

- dispor-se de sistema de recuperação de energia em todas as plantas de incineração, o que torna a prática uma atividade econômica recomendável;

- dispor-se de sistemas de filtração, captação e tratamento de todos os gasosos resultantes do processo, garantindose a não eliminação dos mesmos para atmosfera. Assim como a disposição correta das escórias sólidas - cinzas ricas em metais pesados, destinadas a aterros sanitários resultantes, tornando a atividade ecologicamente correta. 
A incineração tem sido muito utilizada, principalmente na Europa, para o manejo e gerenciamento dos RSU's, pela capacidade de redução entre $75 \%$ a 90\% da massa de resíduos incinerada (IBAÑEZ, 2000) dependendo do tipo e segregação dos resíduos; pela possibilidade de recuperação da energia calorífica e transformação em energia elétrica; e, pelo fato de neste processo poder ser eliminados todos os elementos patogênicos presentes nos resíduos, inclusive, nos resíduos de serviços de saúde (RSS's) (FORTEZA et al., 2004).

As dificuldades encontradas na hora da instalação de quaisquer equipamentos para tratamento de lixo, quer sejam aterros ou incineradores, decorrem do fato de que a população é "muito sensível" aos riscos associados "às invenções humanas" que Ihe são desconhecidas, levando-a, muitas vezes, à maximização daqueles riscos, gerando recusas às vezes intransponíveis, se não bem discutidas, com muita informação e diálogo. Ambas as técnicas resultam, via de regra, em imagem negativa para opinião pública. Os incineradores produzem grandes volumes de gases tóxicos, cinzas com metais pesados e dioxinas. Os aterros são potenciais poluidores pela emissão do gás de aterros, do chorume que atinge águas superficiais e subterrâneas, além de inviabilizar áreas do entorno para outras atividades (JAFFRIN et al, 2003). Outro aspecto que também influencia determinadas rejeições pela comunidade, são informações que decorrem de experiências mal planejadas e mal sucedidas, anteriormente. Seja devido ao uso de equipamentos já obsoletos para o que se destinavam ou a operações e manutenções inadequadas. Daí, por exemplo, a pecha do processo de incineração de poluidor, nocivo à saúde humana e ao ambiente natural (REAM \& TEMPLET, 1996). 
Tabela 3.1.2 - Uso da incineração de RSU's em países desenvolvidos.

\begin{tabular}{lcccc}
\hline País & $\begin{array}{l}\text { \% de } \\
\text { incineradores } \\
\text { de RSU's }\end{array}$ & $\begin{array}{l}\mathbf{N}^{\mathbf{0}} \text {. de } \\
\text { Incineradores }\end{array}$ & $\begin{array}{l}\text { \% de incineradores } \\
\text { com recuperação } \\
\text { de energia }\end{array}$ & $\begin{array}{l}\text { \% de lodos } \\
\text { tratados em } \\
\text { incineradores }\end{array}$ \\
\hline Canadá & 9 & 17 & 7 & N/a \\
\hline Estados Unidos & 16 & 168 & $*$ & $\mathrm{~N} / \mathrm{a}$ \\
\hline Japão & 75 & 1900 & 86 & 0 \\
\hline Suécia & 55 & 23 & $*$ & 19 \\
\hline Dinamarca & 65 & 38 & 67 & 20 \\
\hline França & 42 & 170 & 72 & 10 \\
\hline Holanda & 40 & 12 & $\mathrm{~N} / \mathrm{a}$ & 11 \\
\hline Alemanha & 35 & 47 & 21 & $\mathrm{~N} / \mathrm{a}$ \\
\hline Itália & 18 & 94 & 61 & 7 \\
\hline Espanha & 6 & 22 & 33 & \\
\hline Reino Unido & 7 & 30 & & \\
\hline
\end{tabular}

* Não disponível

N/a - não anotado

Fonte: PETTS, 1994.

Segundo Petts (1994) o primeiro incinerador de RSU's surgiu na Inglaterra, Nottingham, em 1874, sendo que no início do século XX existiam mais de 300, alguns deles já com recuperação de energia. Este autor mostrou o uso da incineração como tratamento de resíduos em alguns países desenvolvidos, indicando que alguns daqueles tem até mais de $60 \%$ das suas plantas com recuperação de energia, vide tabela 3.1.2.

Hjelmer (1996) indica que países como Suíça, Japão, França e Alemanha incineravam $50 \%$ dos seus resíduos sólidos municipais. Nos Estados Unidos da América existiam em 1995, 128 plantas de incineração, operando 307 incineradores com capacidade instalada de 94.000 toneladas $\cdot$ dia $^{-1}$ (EPA, 1995). Conforme Zhang et al (2002) no início deste século 15\% dos RSU's, no mundo, 
eram incinerados, sendo que destes, $30 \%$ nos países desenvolvidos. No Japão 75\% dos RSU's são incinerados e esta percentagem tende a aumentar pelas políticas de gestão e gerenciamento promovidas pelo governo daquele país. Os mesmos autores informam que na atualidade 100 milhões de toneladas de cinzas são depositados em aterros sanitários, provindas da incineração de RSU's, embora o grande destaque das pesquisas seja "um uso mais nobre" para estes resíduos resultantes dos processos de incineração, como, por exemplo, destiná-las a cimenteiras, misturas asfálticas, e, pavimentações de modo geral.

A União Européia tem legislação mais antiga e melhor praticada sobre os controles que devem ser dispensados para os resíduos sólidos urbanos desde 1975, com modificações para adaptar-se às novas demandas tecnológicas em 1989 e 1994, especialmente, nos padrões de emissão de incineradores ou aterros sanitários (UE, 2005). A Diretiva 2000/76/CE aprovou um conjunto de normativas para instalações de quaisquer novos equipamentos a partir do ano 2000 e adequações até o ano de 2005 naqueles já existentes. A própria Diretiva já estabelecia que até dezembro do ano de 2008 na Comunidade Econômica Européia (CEE), teriam que ser apresentados relatórios ao Parlamento Europeu da aplicação das normativas, dos avanços no controle de emissões e quaisquer experiências de contaminações locais e/ou transfronteiras de grandes e pequenas distâncias, inclusive com conhecimento às Nações Unidas.

No Brasil, especialmente nas grandes cidades, segundo Rosa et al. (2003) o lixo doméstico produzido já estava em torno de 0,8 kg a 1 kg per capta. Isso indica a crescente necessidade, no país, de programas que tratem os resíduos gerados de forma adequada, e que possam, além de combater a poluição, gerar riquezas e empregos. 
Uma das grandes preocupações que também deve fazer parte da nossa agenda político-administrativa no Brasil de hoje é o crescimento da quantidade de lixo produzida no país - estamos próximo das 180 mil toneladas por dia - média de quase 1 quilo de lixo por habitante. Logo, para que o país se enquadre no novo paradigma do desenvolvimento sustentável, a despeito das grandes e graves questões sócio-humanitárias, seria de bom alvitre soluções que pudessem p.ex, acabar com os chamados lixões; reforçar via políticas públicas consequentes, a reciclagem, diminuindo as quantidades de resíduos a ser disposta; reforçar políticas de incentivos aos municípios para a construção de aterros sanitários; especialmente, para os pequenos, a adoção de consórcios; e, estimular o usufruto de forma econômico-ambiental correta do gás produzidos nestes aterros.

Segundo Freudenrich (2007) alguns programas de resíduos sólidos então sendo elaborados pelo Ministério do Meio Ambiente juntamente com a FUNASA (Ação Resíduos Sólidos da Fundação Nacional de Saúde) e outros órgãos. O objetivo é acabar com os lixões e melhorar a qualidade ambiental. De acordo com o MMA, o projeto prevê a implantação, ampliação ou melhoria do sistema de coleta de RSU em cidades de todos os Estados brasileiros (BRASIL, 2006).

Algumas cidades, especialmente nas regiões Sul e Sudeste (São Paulo, Rio de Janeiro e Curitiba), têm alcançado altos índices de produção de lixo, podendo chegar a 1,3 $\mathrm{Kg}$ por habitante por dia, em média, isso incluindo todos os resíduos manipulados pelo sistema de serviço de limpeza urbana (domiciliares, comerciais, de limpeza de logradouros, de serviços de saúde e entulhos). Outro fator relevante no Brasil é a participação de catadores na segregação informal do lixo. 
A história do lixo se confunde com a história da humanidade. Enquanto era nômade, o lixo gerado pelo homem provinha das suas atividades biofisiológicas e dos restos de alimentos que eram deixados espalhados por grandes áreas. Sendo essencialmente orgânico, este lixo era fácil e rapidamente degradado no ambiente, servindo inclusive de nutriente para o solo. Com o domínio do fogo o homem aprendeu a modificar os materiais naturais, primeiro com as cerâmicas, depois com os metais e o vidro, iniciando desta forma a produção do que muitas vezes chamamos de "lixo químico". Continuando em sua evolução cada vez mais rápida, dominou a fabricação de pigmentos para a tecelagem, a produção de papel, as ligas metálicas especiais, os plásticos, chegando até aos praguicidas específicos, aos medicamentos sofisticados e aos alimentos transgênicos (organismos geneticamente modificados - OGM's). Esta evolução, agregada ao contínuo crescimento populacional, em parte sustentado pela própria evolução da "indústria química", para sua manutenção requer cada vez mais, maiores quantidades de energia e maiores demandas de recursos naturais (COREY, 1980; AQUINO, 2008).

O homem - ao contrário das outras espécies que se adaptam ao ambiente natural para sobreviverem - modifica o ambiente para se perpetuar. É muito importante saber que todos os refugos existentes são materiais vindos da natureza, passaram pela manipulação e usufruto pelo homem e que são descartados em outro local, quando não no mesmo, mas já com "outras formulações" ou após este local ter sido modificado, o que influencia os ciclos naturais. Então o lixo é a coisa certa no lugar errado. O espaço se confunde com o tempo e o lixo também pode ser a coisa certa na hora errada. A evolução da humanidade acarretou a formação de grandes cidades onde são descartadas 
quantidades cada vez maiores de lixo. São nas megalópoles onde ficam mais acentuadas as contradições de se fabricarem produtos com validade cada vez menor, construídos com materiais de durabilidade cada vez maior. O material orgânico facilmente degradável gerado pelo homem primitivo foi substituído por superpolímeros de alta resistência e durabilidade, e os metais simples por superligas. A sociedade do consumo e do desperdício enche as lixeiras de produtos industrializados. No campo também é possível notar a influência dos tempos modernos. Os vegetais abatidos para o consumo humano deram lugar aos transgênicos (OGM's), capazes de eliminar espécies que, apesar de o parasitarem, podem ser fundamentais para a sobrevivência de outras culturas, além de poderem modificar o solo ao seu redor, e os agrotóxicos que por serem cada vez mais específicos contribuíram para a criação de pragas super-resistentes. Todo esse crescimento implica em novas definições do que é ou deixa de ser lixo (Idem).

Quando a população humana adensou-se, grupos nômades como beduínos ainda podiam ignorar as "valas" para a disposição do lixo, mas as comunidades fixas já não podiam fazê-lo.

Ainda hoje é possível encontrar-se montanhas de lixo - os chamados "lixões" - mesmo em comunidades altamente desenvolvidas (COREY, 1980), que ainda ignoram uma política de gestão e gerenciamento dos resíduos sólidos urbanos.

A prática de lançamento dos resíduos sólidos urbanos a céu aberto não acarreta apenas desperdício de matérias-prima, inclusive com o seu potencial energético agregado, mas proporciona perniciosa degradação ambiental, que se agrava ainda mais com a falta de planejamento por parte dos geradores de tais resíduos e do poder público. 
A disposição final deve ser uma etapa no ciclo de vida útil do material a ser descartado que tem como objetivo retirar de circulação "aquilo que não mais se presta" a nenhum uso, embora o que deveria preponderar fosse sempre a possibilidade do seu retorno a algum ciclo econômico. Também tem como objetivo assegurar que os resíduos não gerem nenhum prejuízo para a saúde humana e ao ambiente natural, em curto ou longo prazo (HJELMAR, 1996). A recomendação é que o descarte final - depois de esgotadas todas as possibilidades tecnológicas disponíveis (PASSINATO, 2008) - seja feito em aterros sanitários, de forma sustentável, sem custos excessivos ou prolongados, de manutenção ou operação, assegurando-se que cada geração seja responsável pelo resíduo que ela gere.

Para que não venha tornar-se um problema sanitário, ambiental e social de maior monta, necessário se faz o conhecimento detalhado dos tipos de RSU's, composição, taxa de geração e aspectos sazonais como instrumentos para um gerenciamento adequado dos mesmos (KGATHI e BOLAANE, 2001).

Neste contexto, são várias as ações a serem planejadas e executadas para a atenuação dos impactos destes resíduos no ambiente natural, destacandose, no tocante à defesa e conservação do meio natural, a Gestão e o Gerenciamento destes resíduos.

Por Gestão de Resíduos entende-se um conjunto de ações (procedimentos e controles) e recursos (humanos, financeiros, materiais) organizados e inter-relacionados, de forma integrada, cuja finalidade é prevenir e controlar os impactos causados pelos resíduos sólidos urbanos no ambiente natural. Dessa forma, a gestão de resíduos sólidos está ancorada nos seguintes princípios; adaptados de Pugliesi (2006): 
i) Proteção do ambiente natural para as gerações futuras;

ii) Usufruto racional dos recursos naturais;

iii) Redução de desperdícios (de matérias-prima, energia, água, combustíveis), reaproveitamento e reciclagem;

iv) Melhoria na qualidade de vida de todos, por meio de:

(a) uma maior conscientização da necessidade de conservação e proteção ambiental;

(b) de um ambiente natural conservado limpo, sem aqueles impactos mais absurdos decorrentes da disposição não apropriada; e da

(c) redução da quantidade de resíduos no meio ambiente, onde as práticas dos 4 R's esteja sempre presente.

v) Melhoria visual dos perímetros urbanos, com ganhos na imagem das cidades, tanto para seus munícipes como para quem as visita.

$\mathrm{Na}$ questão relativa à prevenção da poluição, considerando algumas maneiras de ajudar ao ambiente natural, o que se recomenda é a utilização do princípio dos 4 R's (BAIRD, 2002).

- REDUZIR - para isto, é necessário planejar e trocar o consumo desenfreado pelo consumo necessário, repensando alguns hábitos e diminuindo a produção do lixo na fonte geradora.

- REUTILIZAR - o que é lixo para uma pessoa pode não ser para outra, uma vez que muitos objetos podem ser reutilizados. A reutilização de muito do que muitas vezes, egoisticamente, se lança fora, poderia ter usufruto por gente que às vezes está ao nosso lado. Devemos, pois, pensar nisso antes de jogarmos alguma 
coisa no lixo.

- $\underline{R E C I C L A R}$ - é muito antiga a prática da reciclagem de resíduos sólidos. Os utensílios metálicos são fundidos e remodelados desde os tempos pré-históricos. Já é de largo conhecimento e utilização a tecnologia de transformação de artefatos plásticos e similares para remodelagem e produção de outras utilidades. Hoje a coleta seletiva e a reciclagem estão disseminadas por todo o mundo e reciclar significa recuperação da parte reutilizável dos refugos e dejetos do sistema de produção ou de consumo, para reintroduzí-la no ciclo de produção de que provêm ou outros quaisquer. Segundo Valle (1995), o ato de reciclar significa refazer o ciclo, permite trazer de volta, à origem, sob a forma de matéria-prima, aqueles materiais que não se degradam facilmente e que podem ser reprocessados, mantendo suas características básicas. Essa prática, não apenas reduz a quantidade de resíduos, destinada a aterros sanitários, por exemplo, como também recupera produtos já processados, economizando matéria-prima - recursos naturais esgotáveis, energia - e desperta nas pessoas hábitos conservacionistas, além de reduzir a degradação ambiental. Só para citar um exemplo, em Madri, capital da Espanha, 50.000 habitantes recebem energia elétrica gerada a partir da reciclagem de lixo. O sistema que custou 15 milhões de dólares consome 250 toneladas de lixo por dia e transforma os detritos em gás metano. Este gás vai para uma minitermoelétrica que faz a conversão para eletricidade (AQUINO, 2007).

- REEDUCAR - muitas vezes jogamos materiais que ainda podem ser aproveitados e não paramos para pensar, de forma ecologicamente consciente, que poderia ter utilidade para uma outra pessoa. Não fazemos por mal, apenas não estamos acostumados a pensar antes de jogarmos objetos no lixo. Temos hábitos adquiridos que precisam ser repensados e mudados para ajudarmos à natureza e 
melhorarmos a nossa qualidade de vida. A reeducação consiste na aquisição de novos hábitos como, por exemplo, procurar conhecer para melhor conservar.

Silva (2004) afirma que a falta de gerenciamento dos resíduos sólidos constitui um dos principais fatores que contribuem para a perturbação dos ecossistemas, excedendo, assim, a capacidade de suporte. Isto implica em destruir totalmente os recursos ambientais ou reduzir irreversivelmente esta capacidade. Para amenizar a problemática dos resíduos sólidos é preciso sensibilizar os seres humanos, no sentido de reduzir o consumo, reutilizar e/ou reciclar os resíduos gerados e repensar as atitudes que degradam o ambiente natural. Educação ambiental é um instrumento indispensável. No entanto, deve ser realizada de forma contínua, em permanente construção e inserida no currículo das escolas. Talvez não enquanto disciplina, mas permeando todas as áreas do conhecimento, de modo interdisciplinar, conforme estabelece a Política Nacional de Educação Ambiental, Lei 9795/99. Já a SECAD/MEC (BRASIL, 2007), estabeleceu princípios fundamentais da educação para sociedades sustentáveis, destacando a necessidade de formação de um pensamento crítico, coletivo e solidário, de interdisciplinaridade, de multiplicidade e diversidade.

Já o Gerenciamento de Resíduos compreende o conjunto de todas as atividades desenvolvidas desde a geração dos resíduos até o seu tratamento e disposição finais. Estas atividades envolvem as etapas de conhecimento da geração - onde a minimização/redução devem ser práticas de conscientização permanente -, segregação, identificação, acondicionamento, armazenamento, coleta, transporte, tratamento e disposição final dos resíduos.

Ou seja, além das decisões políticas, elaboração de legislações e estratégias, aspectos técnicos e econômicos relacionados à gestão dos resíduos 
sólidos; existem aspectos operacionais relacionados ao gerenciamento dos mesmos, como geração, armazenamento, coleta, transbordo, transporte, tratamento e disposição finais, que devem ser analisados, bem como os aspectos sociais envolvidos. Estas questões são peculiares a cada localidade, que se distinguem conforme a densidade populacional, cultura, administração política, situação econômica, características ambientais da região, entre outros fatores (LOPES, 2007).

Embora nas várias definições encontradas sobre Gestão e Gerenciamento, muitas vezes estas expressões sejam tratadas como sinônimas, entendemos as mesmas como distintas, de forma que Gestão está relacionada à condução, coordenação e elaboração de estratégias. Portanto, a gestão associa-se ao planejamento e dotação de diretrizes dos sistemas integrados de resíduos sólidos (MASSUKADO, 2004; PUGLIESI, 2006), enquanto o Gerenciamento está relacionado à implementação e operacionalização das estratégias propostas na gestão.

O quadro 3.1.3, enfoca características para a diferenciação mais compreensível dos termos Gestão e Gerenciamento, no trato com RSU's. 
Quadro 3.1.3 - Características que distinguem a gestão do gerenciamento de RSU.

\begin{tabular}{|lc|}
\hline & GESTÃO \\
\hline $1 \bullet$ O que fazer? & $1 \bullet$ Como fazer? \\
$2 \bullet$ Visão ampla & $2 \bullet$ Implementação desta visão \\
$3 \bullet$ Decisões estratégicas & $3 \bullet$ Aspectos operacionais \\
$4 \bullet$ Planejamento, definição de diretrizes & $4 \bullet$ Ações que visam programar e \\
e estabelecimento de metas & operacionalizar as diretrizes \\
& estabelecidas pela gestão \\
$5 \bullet$ Conceber, planejar, definir e & $5 \bullet$ Programar, orientar, coordenar, \\
organizar. & controlar e fiscalizar. \\
\hline
\end{tabular}

Fonte: Massukado (2004), com adaptações.

Lixo gerado das mais variadas fontes: doméstico, industrial ou hospitalar; freqüentemente têm a mesma destinação, sendo enviado a locais de despejo sem separação ou tratamento prévios, com enormes perdas de matériasprima e de energia. Estes locais, na maioria das vezes, mal instalados e localizados, necessitam de áreas cada vez maiores, que se tornam cada vez mais difíceis de se obter. E vale lembrar que existe um gradiente de percepção do risco, vinculado com a distância na qual a população quer morar de um lixão, aterro, incinerador ou qualquer outro equipamento de destinação-tratamento relacionado com lixo (REAMS \& TEMPLET, 1996).

Cabe também lembrar a assertiva "não ensinada", mas por todos conhecida, de que "embora o lixo seja produzido pelas comunidades como um todo, ninguém quer tê-lo como vizinho", ou ainda, como é conhecida na literatura inglesa a síndrome de NIMBY (no in my back yard); ou seja; não no meu jardim. 
Com a evolução do conhecimento e da tecnologia, se passou a perceber que a atitude de despejar o lixo de qualquer maneira era causadora de efeitos desfavoráveis ou crônicos à saúde do próprio homem e/ou ao ambiente natural, pelo descarte não apropriadamente controlado.

Técnicas mais modernas têm sido praticadas, mundialmente, como a construção de aterros sanitários; depósitos especiais e encapsulamento para resíduos radioativos, tóxicos, agrotóxicos e químicos; processos de incineração com controle da combustão e das emissões gasosas - por vezes realizadas com recuperação e aproveitamento da energia térmica do resíduo incinerado - e, mais recentemente, a técnica do plasma térmico (MENEZES et al., 1999), especialmente, para resíduos industriais perigosos. Esta última é uma tecnologia de destruição térmica dos componentes ativos dos resíduos, a elevadas temperaturas, que promove grande redução do volume, inertização e vitrificação do resíduo último. Este então, pode ser disposto sem causar problemas em aterros ou mesmo se presta para o uso em outros processos que os possa demandar como, por exemplo, em cimenteiras, na construção civil e em pavimentação.

Para uma melhor compreensão deste trabalho, outras definições fazem-se necessárias, além da gestão e gerenciamento, todas básicas na área de resíduos, como a seguir.

Nos dicionários (AULETE, 2004; AMORA, 1997), e segundo Rodrigues e Gravinato (2004), a palavra lixo é definida simplesmente como sujeira, imundície, coisa ou coisas inúteis, velhas, sem valor. Aquilo que se "joga fora" depois de uma limpeza. Entulho. Tudo aquilo que não tem mais valor, é varrido de uma casa e pode ser jogado fora. 
Lixo, na linguagem técnica, é sinônimo de resíduos sólidos e é representado por materiais descartados pelas atividades humanas. É qualquer material que seu proprietário ou produtor não o considera mais com o valor suficiente para conservá-lo; por outro lado, o lixo resulta da atividade humana e por isso é considerado inesgotável, é diretamente proporcional à intensidade industrial e ao aumento populacional. Há aproximadamente um século é que surgiram soluções consideradas racionais para se amenizar os problemas decorrentes dos resíduos sólidos (James, 1997). Para Fadini (2001), a taxa de geração de RSU está relacionada aos hábitos de consumo de cada cultura.

Desde os tempos mais remotos até meados do século XVIII, quando surgiram as primeiras indústrias na Europa, o lixo era produzido em pequenas quantidades e constituído essencialmente de sobras de alimentos. A partir da revolução industrial; e acentuadamente, após a segunda guerra mundial; as fábricas começaram a produzir objetos de consumo em larga escala e a introduzir novas embalagens no mercado, aumentando consideravelmente o volume e a diversidade dos resíduos gerados. A humanidade passou a viver a era dos descartáveis em que a maior parte dos produtos - desde guardanapos de papel e latas de refrigerante, até computadores - é usada, inutilizada e jogada fora com enorme rapidez.

Ao mesmo tempo, o crescimento acelerado das metrópoles fez com que as áreas disponíveis para colocar o lixo se tornassem escassas. A sujeira acumulada no ambiente aumentou a poluição do solo, das águas e piorou as condições de saúde das populações em todo o mundo, especialmente nas regiões menos desenvolvidas. Até hoje, no Brasil, a maior parte dos resíduos recolhidos nos centros urbanos é simplesmente jogada sem quaisquer cuidados em vazadouros existentes nas periferias das cidades. O ideal seria que evitássemos o 
acúmulo de detritos, diminuindo o desperdício de materiais e o consumo excessivo de embalagens. Nos últimos anos, nota-se uma tendência mundial em reaproveitar cada vez mais os produtos jogados no lixo para fabricação de novos objetos, através dos processos de reciclagem, o que representa economia de matéria prima e de energia fornecidas pela natureza. Assim, o conceito de lixo tende a ser modificado, podendo ser entendido como "coisas que podem e devem ser úteis e aproveitadas pelo homem".

Schalch (1992), citando Oliveira (1969), informa que a palavra lixo, em português, provém do latim "Lix", que significa cinzas. Seu equivalente em espanhol é "Basura", ou então, no sentido mais moderno, é "Resíduo Sólido". Em inglês, de uma maneira geral é denominado "Refuse" ou "Garbage" e, mais atual ainda, "Solid Waste".

O Código de Regulamentos Federais (CFR) dos Estados Unidos da América, em seu título 40 - "Proteção do Meio Ambiente" - item 257 (40 CFR 257, 1992), apresenta as definições a seguir, citadas por Marques (2001):

- Resíduos sólidos ("solid waste"): "any garbage, refuse, sludge and other discarded material, including solid, liquid, semisolid or contained gaseous material resulting from industrial, commercial, mining and agricultural operations. This does not include solid or dissolved materials in domestic sewage, in irrigation return flows or industrial discharges that are point sources".

- Aterro de resíduos ("landfill): "an area of land or an excavation in which wastes are placed for permanent disposal'.

- Aterro de resíduos sólidos urbanos ("municipal solid waste landfill - MSWLF"): "a discrete area of land or an excavation that 
receives household waste".

- Aterro sanitário ("sanitary landfill"): "a facility for the disposal of solid waste which complies with Code of Federal Regulations $(C F R)^{\prime \prime}$.

A Associação Brasileira de Normas Técnicas (ABNT) pela norma NBR 10.004/2004 ("Resíduos Sólidos - Classificação") define que resíduos sólidos são aqueles...

“[...] resíduos nos estados sólido e semi-sólido, que resultam de atividades de origem industrial, doméstica, hospitalar, comercial, agrícola, de serviços e de varrição. Ficam incluídos nesta definição os lodos de sistemas de tratamento de água (ETA's), aqueles gerados em equipamentos e instalações de controle da poluição, bem como determinados líquidos cujas particularidades tornem inviável o seu lançamento na rede pública de esgotos ou corpos de água, ou exijam para isso soluções técnicas e economicamente inviáveis em face à melhor tecnologia disponível".

Para determinar a melhor tecnologia para tratamento, aproveitamento ou destinação final dos resíduos sólidos é necessário conhecer a sua classificação. Diversas propostas têm sido apresentadas para a classificação dos resíduos sólidos, que evoluem ao longo do tempo, de forma a melhor enquadrar e cobrir a elevada variabilidade dos mesmos e que convergem às unidades de disposição final, que para efeito deste trabalho, tem como foco os aterros sanitários.

A Associação Brasileira de Normas Técnicas (ABNT, 2004) por sua norma NBR 10.004/2004, já citada, em consonância com as NBR's 10.005, 10.006 
e 10.007, todas revisadas e atualizadas em 2004, classifica os resíduos em duas classes; considerando o risco que estes podem causar à saúde pública e ao ambiente natural:

\section{- Classe I- Perigosos}

Aqueles resíduos que apresentam periculosidade por inflamabilidade, corrosividade, reatividade, toxidade e/ou patogenicidade.

\section{- Classe II - Não perigosos}

Estes, subdivididos em:

- Resíduos classe IIA - Não inertes

Abrangem aqueles resíduos que não se enquadram nas classificações de resíduos classe I - Perigosos ou resíduos classe IIB - inertes.

Podem apresentar propriedades tais como: biodegradabilidade, combustibilidade ou solubilidade em água.

- Resíduos classe IIB - Inertes

Abrangem quaisquer resíduos que, quando amostrados de uma forma representativa (ABNT NBR 10.007/2004) e submetidos a um contato dinâmico e estático com água destilada ou deionizada, à temperatura ambiente (ABNT NBR 10.006/2004) não tiverem nenhum de seus constituintes solubilizados a concentrações superiores aos padrões de potabilidade da água, excetuando-se aspecto, cor, turbidez, dureza e sabor.

Em decorrência destas definições pode-se ainda classificar os resíduos sólidos, considerando a fonte geradora, como proposto por Schalch 
(1992); Menin (2000), IPT (2000) e, Tenório e Espinosa (2004) em:

1 - URBANOS: resíduos sólidos das áreas urbanas, que incluem o resíduo doméstico ou domiciliar, produzido nas residências (contêm muita matéria orgânica, plásticos, papéis, latas, vidros); os efluentes industriais domiciliares (pequenas indústrias de fundo de quintal); o comercial proveniente de estabelecimentos como escritórios, lojas e hotéis (contêm matéria orgânica, papéis, papelão, plásticos de vários grupos); de varrição e os resíduos de serviços, como por exemplo, feiras livres, capinação e poda;

2 - INDUSTRIAIS (TóxICOS E PERIgosos): constituídos pelos resíduos gerados pelos mais diversos tipos de indústrias de processamento. Pertencem a uma área altamente complexa, pois devem ser estudados, caso a caso, para que se possa obter uma solução técnica e economicamente adequada. Podemos ter neste grupo, pilhas, baterias, etc...

3 - De Serviços de SAÚde: que são aqueles resíduos produzidos por prestadores de assistência médico-hospitalar-odontológica; laboratorial-farmacêutica; veterinária e de centros de saúde em geral. Temos neste grupo os mais variados tipos de resíduos sépticos, resultados de curativos e aplicação de medicamentos que, em contato com o ambiente ou misturados ao lixo doméstico, poderão ser patógenos ou vetores de doenças. Devem ser destinados, especialmente, para a incineração.

4 - RAdioAtivos (LIXO ATÔMICO): resíduos provenientes do aproveitamento dos combustíveis nucleares. Seu gerenciamento é de competência exclusiva da Comissão Nacional de Energia Nuclear - CNEN.

5 - AGRícolAs: correspondem, principalmente, aos vasilhames descartados pelo 
uso de agrotóxicos na agricultura.

Uma outra classificação é indicada por Leite (1997), levando em conta outros fatores, como:

- Pela natureza física: seco ou molhado.

- Composição química: matéria orgânica ou inorgânica.

- Pelo grau de biodegradabilidade: facilmente, moderadamente, dificilmente e nãodegradáveis.

- Segundo a origem: urbanos; industriais; resíduos de serviços de saúde; resíduos de portos e aeroportos, terminais rodoviários e ferroviários; resíduos agrícolas; resíduos da construção civil e demolição e resíduos radioativos.

Podemos ainda classificá-los, segundo a capacidade de incineração em:

- Materiais não combustíveis (vidros, metais)

- Materiais combustíveis (plásticos, papeis, trapos)

A figura 3.1.2, mostra uma das classificações correntes e a responsabilidade sobre os resíduos gerados na disposição final. 


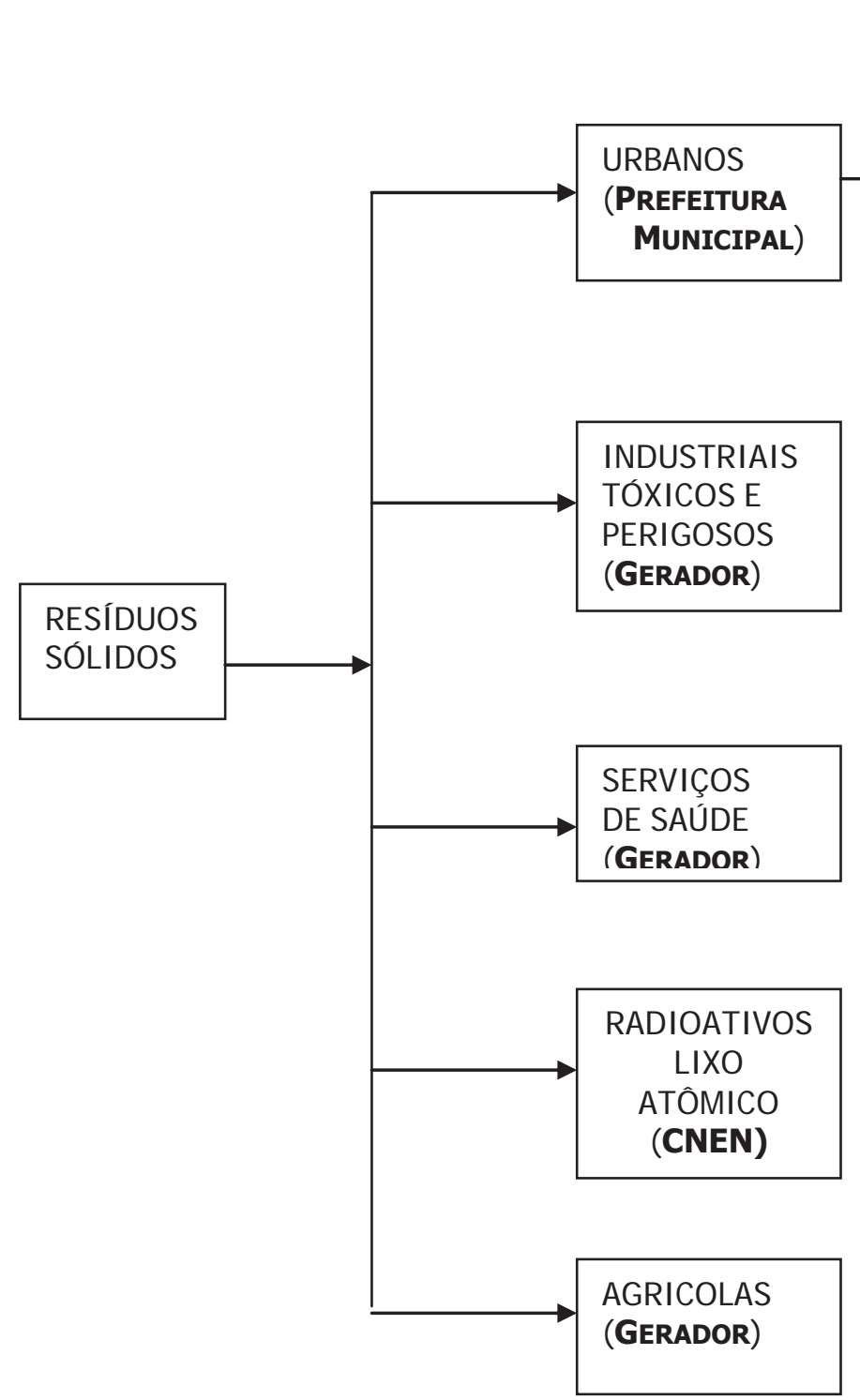

Figura 3.1.1 - Classificação dos RS's e Responsabilidade pela disposição final Fonte: Schalch (1992), com adaptação. 


\subsection{A biodegradabilidade dos resíduos sólidos urbanos}

Segundo Marques (2001), citando inúmeras fontes da literatura nesta área, "um aterro sanitário pode ser entendido como um verdadeiro e heterogêneo reator biológico, tendo como principais componentes de entrada e alimentação os resíduos sólidos e a água, e como principais elementos de saída os líquidos percolados - chorume - e os gases de aterro". Já Wise (1987, apud SCHALCH, 1992), diz que "o ambiente criado a partir de um aterro sanitário pode ser considerado um "ecossistema" especial, pois, uma vez que se forneçam condições ambientais propícias para o estabelecimento de populações bacterianas características, estas evoluem e se multiplicam no aterro, caracterizando um ecossistema, no sentido ecológico da palavra".

A decomposição dos resíduos sólidos urbanos, em um aterro sanitário, dá-se tanto por processos aeróbios quanto por processos anaeróbios de digestão da matéria orgânica, presente em aproximadamente $60 \%$ dos rejeitos destinados a aterros, sendo a diferença básica entre os dois processos, a presença e ausência de oxigênio, respectivamente.

Os principais fatores que influenciam a cinética destes processos de biodegradação são segundo Parker (1983): a granulometria do resíduo; a composição e idade do resíduo; a umidade contida no resíduo; a temperatura no aterro; aspectos quantitativos e qualitativos dos nutrientes; $\mathrm{pH}$ dos líquidos presentes no aterro; densidade e grau de compactação dos resíduos.

Ainda segundo Schalch (1992), as interações existentes internamente e as variáveis que interferem externamente em um aterro sanitário, são de extrema 
complexidade, o que torna muito difícil o seu estudo de forma global. Como influências externas podemos destacar - devido à própria geração dos resíduos sólidos urbanos - a sua composição física, que difere de região para região, sendo constituídos por uma mistura altamente variada e variável de rejeitos. Esta variabilidade na geração dos resíduos sólidos urbanos está relacionada a influências como o nível sócio-economico-cultural, hábitos de consumo, fatores climáticos, características de sexo e idade da população que habita uma determinada região, além de fatores sazonais.

Consequentemente, não é possível generalizar a priori a composição física da massa de resíduos sólidos que compõe um aterro e se pode concluir que cada aterro conduzirá a um "ecossistema" particular, com características próprias concernentes às interações internas e externas.

Nos processos de degradação do material orgânico presente no maciço de lixo em um aterro sanitário, variáveis como: gradiente de temperatura, migrações gasosas e dos líquidos percolados, potencial de oxido-redução $\left(E_{r}\right)$, potencial hidrogeniônico $(\mathrm{pH})$, atividade enzimática, além de processos nas interfaces sólido-líquido, líquido-gás, líquido-líquido e sólido-gás, são de extrema importância no conjunto de reações físico-bioquímicas que estão relacionados ao substrato orgânico. 


\subsection{Geração e características do gás de aterros sanitários (GAS)}

As pesquisas sobre a biodegradabilidade dos resíduos sólidos urbanos em aterros sanitários dizem respeito ao conteúdo da porção orgânica destes rejeitos, com potencial à degradabilidade e têm sido direcionadas, preferencialmente, para a produção e caracterização, qualitativa e quantitativamente, dos seus líquidos percolados e dos gases gerados.

Os líquidos ou chorume, pela carga orgânica e inorgânica que comportam, com risco de contaminação do solo, das águas superficiais e subterrâneas - especialmente, por metais pesados - quando não apropriadamente tratados (LOPES, 2007).

O gás de aterros (Landfill gas - LFG, na sigla em inglês), por constituirse importante fonte de energia, contando, portanto, com elevado interesse econômico; apresenta grande interesse pelo seu potencial impacto na atmosfera terrestre, como um dos principais contribuintes do aquecimento global. É uma mistura inflamável, consistindo principalmente de metano $\left(\mathrm{CH}_{4}\right)$ e dióxido de carbono $\left(\mathrm{CO}_{2}\right)$, junto com gases traço chamados de compostos orgânicos voláteis (VOC) (QIN et al, 2001). As emissões em aterros são afetadas por numerosos fatores, como temperatura, mistura dos resíduos com o solo, quantidade e idade do lixo e a espessura da camada de cobertura (PEER et al, 1993).

A degradação dos resíduos sólidos urbanos em aterro sanitário é um processo demorado, por estar relacionado à velocidade de degradação dos diferentes tipos de substratos presentes na massa de lixo e, sequencial, em razão dos metabolismos distintos que se sucedem ou se superpõem. 
Conforme Brito Filho (2005), após contribuições de vários cientistas, a partir de 1850 e por todo o século passado, muito se pôde aperfeiçoar no entendimento dos processos de degradação dos RSU's. Louis Pasteur em 1856 descobriu a utilização de microorganismos em benefício da humanidade, de forma que fossem aplicados no tratamento de doenças e na produção de alimentos e bens de consumo. O próprio Pasteur não pode prever que esta descoberta poderia ser utilizada em outras áreas, podendo solucionar problemas como, por exemplo, a questão do tratamento e destinação final dos resíduos sólidos urbanos e no emprego de remediação de lixões e vazadouros. Gayon em 1883, aluno de Pasteur, realizou a primeira fermentação anaeróbia conseguindo produzir $100 \ell$ de gás por metro cúbico de substrato, a partir de uma mistura de esterco e água, a $35^{\circ} \mathrm{C}$.

Ainda conforme Brito Filho (2005), uma das primeiras unidades de produção semi-industriais de gás usando a técnica, data de 1895, no Reino Unido, onde foi construído um digestor de lodos obtidos por decantação de esgotos domésticos da cidade de Exeter. O gás produzido era usado para a iluminação das ruas da cidade. Em 1884, quando Pasteur apresentou à Academia das Ciências os resultados do trabalho do seu aluno, considerou que esta fermentação poderia constituir uma fonte de energia para aquecimento e iluminação.

Alguns modelos globais de degradação foram desenvolvidos na perspectiva de demonstrar as diferentes etapas que conduzem à estabilização dos resíduos. Um primeiro modelo foi proposto por Farquhar e Rovers (1973), identificando quatro fases para a produção dos gases.

O dióxido de carbono gerado em aterros sanitários não é considerado em termos do efeito estufa (IMBELLONI, 2004), visto que a biomassa recente continha carbono e o mesmo $\mathrm{CO}_{2}$ seria emitido como resultado do processo natural 
de decomposição. O dióxido de carbono que contribui para o aquecimento global com maior relevância é aquele que provêm da queima de combustíveis fósseis, principalmente, carvão, petróleo bruto e seus derivados e gás natural, os quais se formaram (BAIRD, 2002) eras atrás, quando a matéria derivada de plantas e animais foi coberta em depósitos geológicos antes que pudesse ser integralmente decompostos pela oxidação do ar e que não seria emitido caso estes combustíveis não fossem queimados.

Ainda segundo Baird (2002), de fato, o vapor d'água é o gás estufa mais importante da atmosfera terrestre, no sentido de que a água produz mais aquecimento por efeito estufa do que qualquer outro gás, muito embora seja menos eficiente que $\mathrm{o} \mathrm{CO}_{2}$ quando considera-se como base uma unidade molecular. A pressão de vapor de equilíbrio da água líquida, e consequentemente a máxima concentração do vapor de água no ar, aumenta de maneira exponencial com a temperatura. Assim, a quantidade de IR térmico redirecionado pelo vapor d'água no ar aumentará como resultado de qualquer aquecimento global provocado por outros gases indutores do efeito estufa e amplificará o aumento de temperatura. Uma vez que isto ocorre como efeito indireto do aumento dos níveis de outros gases, e considerando que não seja controlável, o aumento no aquecimento pela ação do vapor de água é usualmente incorporado sem maiores comentários com o efeito de aquecimento direto produzido pelos outros gases. Por isso a água não é habitualmente incluída explicitamente na lista dos gases cujo aumento nas concentrações está intensificando o efeito estufa.

Com esta especificidade do vapor de água, o dióxido de carbono $\left(\mathrm{CO}_{2}\right)$ ou gás carbônico é o gás estufa mais importante no sentido de regulação do efeito estufa na atmosfera terrestre, além de ser o gás mais liberado dentre as 
emissões de origem antrópica (ROSA et al., 2001; BAIRD, 2002). Segundo a CQNUMC (2001) os volumes de dióxido de carbono despejados na atmosfera terrestre por atividades antrópicas nos anos 90 foram de 6 e 12 vezes maiores aos volumes emitidos de metano $\left(\mathrm{CH}_{4}\right)$ e óxido nitroso $\left(\mathrm{N}_{2} \mathrm{O}\right)$, respectivamente, embora seja o gás de menor potencial entre os três.

Depois do vapor de água e do dióxido de carbono, o metano $\left(\mathrm{CH}_{4}\right)$ é o gás indutor do efeito estufa de maior importância. É um dos GEE's priorizados em 1997 pelo Protocolo de Kyoto (2004). Segundo Holmes (1999), nos últimos 300 anos as emissões do gás metano aumentaram aproximadamente $1 \%$ ao ano, sendo o potencial de absorção de radiação infravermelha pelo metano estimado em 21 equivalentes de $\mathrm{CO}_{2}$ (KIGHTLEY et al., 1995; HANSON \& HANSON, 1996; BOECKX \& CLEEMPUT, 2000), ou seja, ele é ao menos vinte e três vezes mais potente que o dióxido de carbono $\left(\mathrm{CO}_{2}\right)$, o gás mais conhecido do efeito estufa.

O metano $\left(\mathrm{CH}_{4}\right)$ é um dos principais gases entre os denominados gases do efeito estufa por suas influências diretas e indiretas sobre o forçante radiativo atmosférico. Ele apresenta uma forte banda de absorção em torno de 7,66 $\mu \mathrm{m}$ (infravermelho térmico) que é uma região espectral onde o gás carbônico e a água absorvem fracamente. Isso faz com que sua participação no balanço radiativo da troposfera e da estratosfera seja significativa (RAMANATHAN et al., 1985; DICKINSON and CICERONE, 1986). Devido ao aumento do seu conteúdo na atmosfera, sua contribuição para o forçante climático aumentou, aproximadamente, $30 \%$ desde 1860 (MITCHELL, 1989) correspondendo a cerca de $20 \%$ do efeito total observado (WUEBBLES and HAYHOE, 2002).

A concentração atual de metano na atmosfera terrestre está em torno de 1770 ppbv (SIMPSON et al., 2006), correspondendo a um reservatório 
atmosférico de mais de $4900 \mathrm{Tg}\left(10^{12} \mathrm{~g}\right)$ de metano $\left(\mathrm{TgCH}_{4}\right)$. As estimativas para o balanço global de metano indicam uma emissão anual total de 503 ( \pm 125$)$ $\mathrm{TgCH}_{4} / \mathrm{ano}$, com uma faixa de estimativa entre 410 e $660 \mathrm{TgCH}_{4} / \mathrm{ano}$ e um sumidouro de 515 ( \pm 85) $\mathrm{TgCH}_{4} / \mathrm{ano}$, com uma faixa de estimativa entre 430-600 $\mathrm{TgCH}_{4}$ /ano (WUEBBLES and HAYHOE, 2002).

Uma molécula de metano contém quatro ligações simples $\mathrm{C}-\mathrm{H}$. Embora as vibrações de estiramento da ligação carbono-hidrogênio ocorram bastante fora da região do IR térmico, as vibrações de deformação angular da ligação $\mathrm{H}-\mathrm{C}-\mathrm{H}$ absorvem a 7,7 $\mu \mathrm{m}$, próximo do limite da janela do IR térmico, consequentemente o metano absorve IR nesta região. Por molécula, um aumento da quantidade de metano no ar causa um efeito de aquecimento da ordem de 21 a 25 vezes maior que a adição de dióxido de carbono, porque as moléculas de $\mathrm{CH}_{4}$ absorvem uma maior fração dos fótons do IR térmico que a atravessam do que as moléculas de $\mathrm{CO}_{2}$. Contudo, o aumento atual de 80 vezes no número de moléculas de $\mathrm{CO}_{2}$ significa que, no momento, $\mathrm{o} \mathrm{CH}_{4}$ é menos impactante para o aquecimento global. Até agora, estima-se que o metano seja responsável por cerca de um terço de todo o aquecimento global produzido pelo $\mathrm{CO}_{2}$ (BAIRD, 2002; STERN and KAUFMANN, 1996).

Os benefícios da redução de gases que provocam o efeito estufa em um projeto de recuperação da energia, em um aterro típico, gerando, por exemplo, cinco megawatts (MW) de eletricidade seriam equivalentes à plantação de 80.000 acres de bosque por ano ou eliminar as emissões anuais de mais de 60.000 carros (IMBELLONI, 2004).

Portanto, o uso do metano presente no gás de aterros para gerar 
energia reduz, diretamente, a poluição do ar evitando maus cheiros à comunidade de entorno e ao compensar o uso de recursos não renováveis com carvão, petróleo e outros, para produzir a mesma quantidade de força.

Isto também pode evitar emissões de $\mathrm{CO}_{2}$ de usinas de energia a partir de outros combustíveis mais poluentes, que podem emitir outros poluentes como, por exemplo, óxidos de enxofre ( $\mathrm{SO}_{x}$ 's) - que contribuem em grande medidas para a chuva ácida - entre outros; particulados emitidos pelos veículos automotores - responsáveis por problemas de saúde de humanos como disfunções da vias respiratórias -; os óxidos de nitrogênio( $\mathrm{NO}_{x}$ 's); e pequenas quantidades de outros poluentes perigosos do ar. Desta forma, várias formulações foram propostas, visando à compreensão e à determinação da produção dos gases em aterros sanitários (FARQUHAR \& HOVERS, 1973; REES, 1980; POHLAND et al., 1983; BARLAZ et al., 1990; MCBEAN et al., 1995 apud MARQUES, 2001).

A decomposição do material orgânico presente na massa de lixo em um aterro sanitário pode ser representada pela seguinte reação química geral, conforme equação 3.3.1, segundo Tchobanoglous et al (1994):

Equação 3.3. 1 - Decomposição Orgânica em Aterros Sanitários

Matéria orgânica $+\mathrm{H}_{2} \mathrm{O} \stackrel{\text { Badéria }}{\rightarrow}$ Matéria orgânica $+\mathrm{CH}_{4}+\mathrm{CO}_{2}+$ Outros gases
(resíduos sólidos)
biodeg radável

Ressalta-se que a reação necessita da presença de água. Existem aterros que carecem de umidade, levando a uma condição de paralisação da decomposição. Nestas condições de baixa umidade, estudos mostraram que até mesmo um jornal pode ser encontrado em condições legíveis, muito tempo após o 


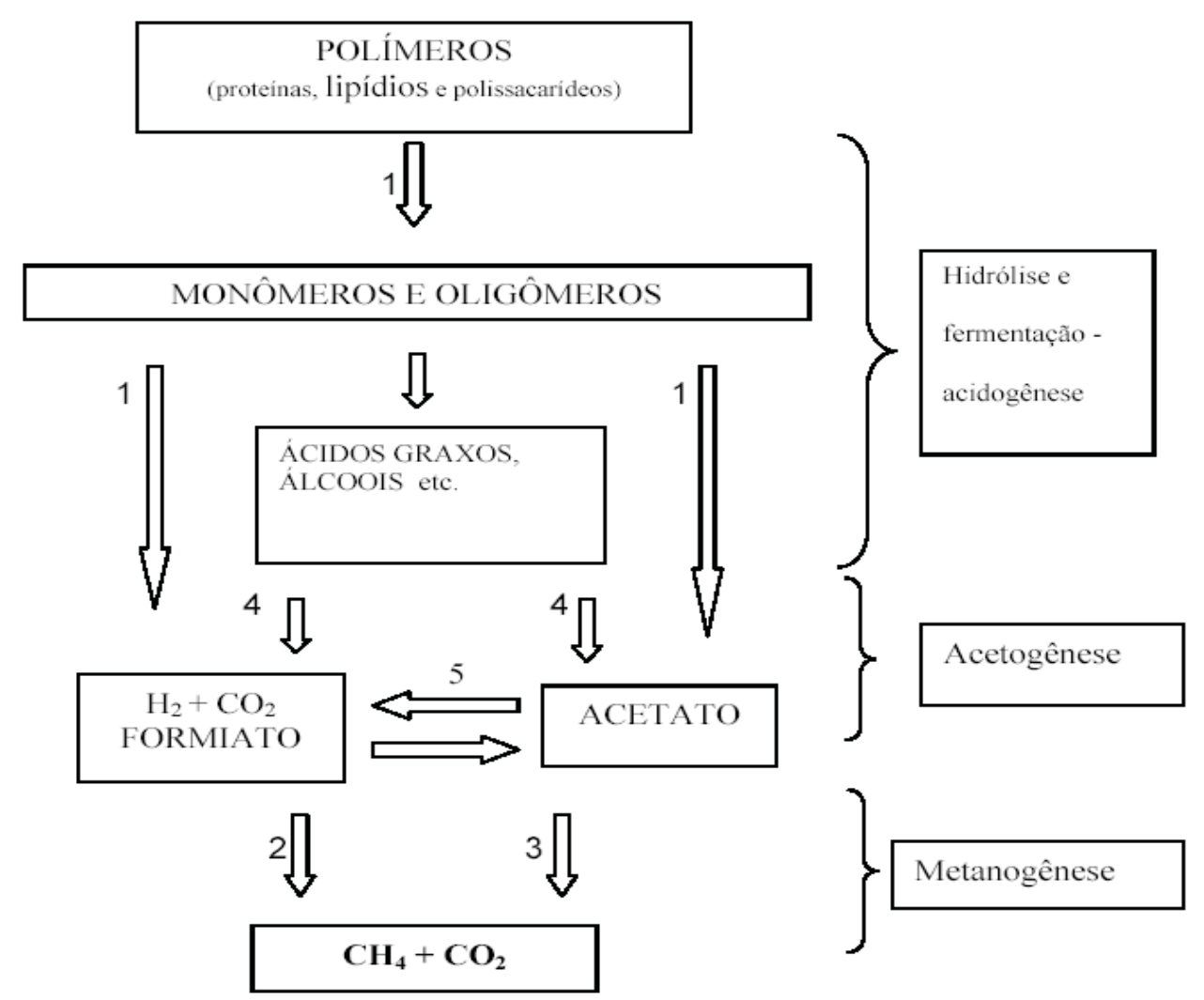

Figura 3.3.1 - Fluxo da degradação anaeróbica dos constituintes orgânicos em aterros.

Fonte: Tchobanoglous et al 1994.

Ainda segundo Marques (2001), a definição de um modelo geral para a produção de gases em aterros foi proposta inicialmente por Farquhar \& Rovers (1973). Estes autores propuseram quatro fases para o processo de degradação biológica e produção dos gases, no tempo, que são: fase1 (aeróbia); fase 2 (anaeróbia não metânica); fase 3 (anaeróbia, metanogênica não estabilizada), e, fase 4 (anaeróbia, metanogênica, estabilizada). Tchobanoglous et al (1994), propôs uma quinta fase, em continuidade àquelas já citadas. As características e aspectos gerais de cada uma destas fases podem ser descritos como seguem, com complementações: 


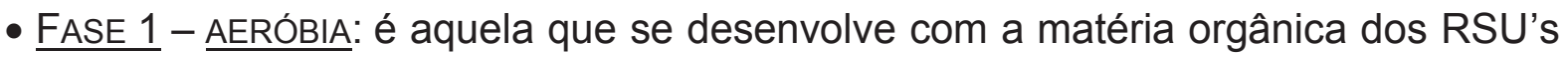
recém dispostos no aterro, na presença de oxigênio do ar e daquele presente internamente nos resíduos, que é consumido, para a produção de dióxido de carbono $\left(\mathrm{CO}_{2}\right)$. Nota-se nesta fase a produção do dióxido e consumo sensível de nitrogênio $\left(\mathrm{N}_{2}\right)$ e oxigênio $\left(\mathrm{O}_{2}\right)$, sem geração de metano $\left(\mathrm{CH}_{4}\right)$, no entanto. Estimase que nesta fase é degradada de 5 a $10 \%$ da matéria sólida passível de transformação em gases, embora este processo tenda a uma grande variabilidade percentual, em função, principalmente, da operação do aterro. Ou seja, a extensão da degradação desta fase, provavelmente será maior, quanto maior for o tempo de exposição dos resíduos sólidos ao ar, antes do seu aterramento.

- $\underline{\text { FASE } 2}$ - ANAERÓBIA ÁCIDA: é uma fase, inicialmente, de transição. Com o aterramento ou cobertura dos RSU's por material argiloso e a extinção do oxigênio presente no ar, a quantidade de oxigênio decai rapidamente, considerando-se a primeira fase. Estabelecem-se condições idéias para a decomposição anaeróbia do material orgânico constituído de grandes moléculas, poliméricas, em ácidos orgânicos, de menores cadeias e outros produtos intermediários, característicos desta fase. Nota-se também um aumento considerável da produção de $\mathrm{CO}_{2}$. Nesta fase os líquidos percolados apresentam um $\mathrm{pH}$ não superior a 5 , pela presença dos ácidos orgânicos e $\mathrm{CO}_{2}$ no aterro. Nitratos e sulfatos podem servir de receptores de elétrons nas reações bioquímicas da conversão. É bem característico ainda desta fase, elevados valores de DBO e DQO nos líquidos percolados, pela alta solubilidade dos ácidos orgânicos presentes. Estima-se a decomposição de 15 a 20 \% da matéria sólida com potencial de conversão a gás.

- $\underline{\text { FASE } 3}$ - METANOGÊNICA ACELERADA: nesta fase as reações iniciadas na anterior são aceleradas, com a produção de quantidades significativas de ácidos orgânicos 
e quantidades menores de hidrogênio. A produção de metano e de ácidos ocorre simultaneamente, com a taxa dos ácidos sendo, significativamente, menor. Aumenta a conversão dos ácidos e do hidrogênio $\left(\mathrm{H}_{2}\right)$ em termos de $\mathrm{CH}_{4}$ e $\mathrm{CO}_{2}$, o $\mathrm{pH}$ do aterro aumenta, podendo variar de 6,8 a 8 , enquanto que os valores da DBO e da DQO sofrem significativas reduções. Observa-se ainda uma redução da solubilidade de compostos inorgânicos, implicando uma menor quantidade de metais pesados contidos nos líquidos percolados. Uma parcela adicional da matéria orgânica sólida é degradada e convertida nesta fase.

- FASE 4 - METANOGÊNICA DESACELERADA: ocorre após a conversão de toda matéria orgânica disponível em $\mathrm{CH}_{4}$ e $\mathrm{CO}_{2}$. A taxa de produção de gases diminui, significativamente, uma vez que a maioria dos nutrientes já foi removida pelos líquidos percolados nas fases anteriores e os remanescentes apresentam lento processo de biodegradação. Ainda se gera, principalmente, $\mathrm{CH}_{4}$ e $\mathrm{CO}_{2}$ e pequenas quantidade de $\mathrm{N}_{2}$ e $\mathrm{O}_{2}$. Nesta fase a decomposição da matéria sólida atinge valores de 50 a $70 \%$, dependendo da produção de metano e das práticas operacionais empregadas no aterro.

- FASE 5 - METANOGÊNICA ESTÁVEL OU DE MATURAÇÃO: a estabilidade ocorre após grandes quantidades de material orgânico ter sido biodegradado e convertido a metano e dióxido de carbono. A presença de muita umidade na massa de lixo faz com que porções de material biodegradável ainda não convertido continuem reagindo. A taxa de geração de gases diminui, consideravelmente, pois a maioria dos nutrientes disponíveis foi consumida nas fases anteriores e o que resta no aterro, são substâncias de degradação lenta. Dependendo das medidas e operação do 'fechamento' do aterro, pequenas quantidades de nitrogênio e oxigênio podem ser ainda produzidas. Os processos se estabilizam e continuam 
por longo tempo, mesmo podendo haver diminuição nas quantidades de gases produzidas e da temperatura do aterro.

A duração de cada uma das fases varia em função de uma série de características peculiares do aterro, destacando-se: presença e distribuição da matéria orgânica, disponibilidade dos nutrientes, umidade presente no resíduo e no interior do aterro, grau de compactação inicial,... etc. Densidades mais elevadas e/ou umidades reduzidas implicam, por exemplo, menores taxas de produção de gases (TCHOBANOGLOUS et al., (1994); MCBEAN et al., 1995).

A velocidade de produção dos gases é função da decomposição anaeróbia da matéria orgânica biodegradável presente no aterro. Segundo Parker (1983) cerca de 50 \% do potencial de geração de gás em um aterro sanitário será desenvolvido no período de 5 a 15 anos após o aterramento do resíduo, podendo traços de gases serem detectados após várias décadas.

O teor de umidade no interior de um aterro sanitário representa importante papel no processo de decomposição e, consequentemente, da geração dos gases. Valores de umidade entre 50 e $60 \%$ concorrem para acelerar, sobremaneira, o processo de biodegradação do material orgânico presente nos resíduos sólidos urbanos. No entanto, baixos valores de umidade implicam menores quantidades e prolongamento nesta geração (TCHOBANNOGLOUS et al., 1994; MCBEAN et al., 1995).

Os modelos teóricos propostos para determinação das taxas de produção de gases geralmente assumem que a degradação dos resíduos orgânicos está relacionada a uma reação de primeira ordem, gerando como produtos, essencialmente, metano $\left(\mathrm{CH}_{4}\right)$ e dióxido de carbono $\left(\mathrm{CO}_{2}\right)(B A R L A Z \& H A M, 1993)$. 
Neste sentido HOEKS (1983) propôs a seguinte formulação para a produção específica dos gases $(\alpha)$, em $\mathrm{m}^{3} \cdot \operatorname{ton}^{-1}(\mathrm{RSU}) \cdot$ ano $^{-1}$; equação 3.3.2:

Equação 3.3.2 - Produção de gases em aterros sanitários.

$$
\alpha=0,8 P_{0} E^{-\kappa T}
$$

Em que:

$\boldsymbol{P}_{\mathrm{o}}=$ concentração de matéria orgânica degradável no instante $t=0$ (em kg por tonelada de resíduo);

$K=$ coeficiente de degradação $\left(\mathrm{ano}^{-1}\right)$, sendo dependente de vários parâmetros, como o tipo de matéria a ser decomposta, umidade na massa de resíduos, temperatura e da própria população bacteriana;

$T=$ tempo $($ ano $)$

Ainda segundo Marques (2001), valores de $K$ e $P_{o}$ são diretamente dependentes da natureza da matéria orgânica constituinte do resíduo, enquanto o coeficiente 0,8 corresponde ao fator de produção do gás a partir da matéria orgânica degradável, em $\mathrm{m}^{3}(\mathrm{gás}) \cdot \mathrm{Kg}^{-1}(\mathrm{RSU})$. A literatura reporta poucos valores para estes parâmetros, sendo os mesmo resultantes de experimentos em lisímetros ou testes com extração de gases in situ. Relata que em experimentos com lisímetros, por exemplo, Farquhar \& Rovers (1973) obtiveram um valor para o coeficiente de degradação(K) igual a 0,0365 ano-1. Já Hoeks (1983), por sua vez, apresenta valores para $K$ iguais a 0,$693 ; 0,139$ e $0,046 \mathrm{ano}^{-1}$, respectivamente, para materiais prontamente degradáveis (resíduos alimentícios, p. ex.), moderadamente 
degradáveis (podas, vegetação, capina, p. ex.) e lentamente degradáveis (papel, tecidos e madeira, p. ex.).

Quanto à composição, o gás de aterro é constituído por uma série de gases que se apresentam em maior ou menor proporção, que depende tanto da operação do aterro, do sem tempo de atividades, como de condições intra composição da massa de lixo, especialmente, quantidade de orgânicos biodegradáveis, população bacteriana e quantidade de nutrientes, catalisadores ou inibidores dos processos físico-químicos e biológicos, etc... - e extra aterro - como condições de clima e variações das mesmas na região em que está o aterro.

O metano $\left(\mathrm{CH}_{4}\right)$ e o dióxido de carbono $\left(\mathrm{CO}_{2}\right)$ são os gases de maior representação em termos do volume gerado durante a vida de um aterro. O WRI (2002) informa que o gás de aterro é constituído por, aproximadamente, $55 \%$ de metano e $45 \%$ de dióxido de carbono, além de poder apresentar nitrogênio, oxigênio, hidrogênio e traços de compostos orgânicos voláteis não-metânicos (COVNM's) e de inorgânicos. Já van Elk (2004) citando Tchobanoglous et al. (1994) opta pelas faixas de $45-60 \%$ de $\mathrm{CH}_{4}$ e $40-60 \%$ de $\mathrm{CO}_{2}$. Parker (1983) foi mais conservador e propôs participações menores para os dois principais componentes. O que se depreende da literatura é uma variação muito significativa destas proporções. A tabela 3.3.1, a seguir, mostra a composição percentual típica dos gases gerados em um aterro sanitário, segundo estes autores, onde se pode observar que cerca de 90 a $99 \%$ dos gases gerados são representados por $\mathrm{CH}_{4} \mathrm{e}$ $\mathrm{CO}_{2}$, sendo o restante uma composição de outros gases, geralmente, denominados traços ou gases secundários. 
Tabela 3.3.1 - Constituição volumétrica típica do gás de aterros sanitários.

\begin{tabular}{l|c|c|c}
\hline \multirow{2}{*}{ COMPONENTE } & \multicolumn{3}{|c}{ VOLUME (\%) } \\
\cline { 2 - 4 } & $($ Parker 1983) & $($ WRI 2002) & (van Elk 2004) \\
\hline Metano $\left(\mathrm{CH}_{4}\right)$ & 47,5 & 55,0 & $45-60$ \\
\hline Dióxido de Carbono $\left(\mathrm{CO}_{2}\right)$ & 47,0 & 45,0 & $40-60$ \\
\hline Nitrogênio $\left(\mathrm{N}_{2}\right)$ & 3,7 & 2,0 & $2-5$ \\
\hline Oxigênio $\left(\mathrm{O}_{2}\right)$ & 0,8 & 1,0 & $0,1-1,0$ \\
\hline Hidrocarbonetos $(\mathrm{HC}$ 's) & 0,3 & 0,4 & $\mathrm{n} / \mathrm{d}$ \\
\hline Hidrogênio $\left(\mathrm{H}_{2}\right)$ & 0,1 & 0,2 & $0-0,2$ \\
\hline Monóxido de Carbono $(\mathrm{CO})$ & 0,1 & 0,1 & $0-0,2$ \\
\hline Outros & 0,5 & $\mathrm{n} / \mathrm{d}$ & $\mathrm{n} / \mathrm{d}$ \\
\hline
\end{tabular}

Segundo Imbelloni (2004) a captura do gás de aterros sanitários e a geração de energia a partir dele cria vários benefícios ambientais. A disposição definitiva dos resíduos sólidos é, na atualidade, um dos problemas mais importantes que afetam, especialmente, países pobres como os da América Latina e do terceiro mundo em geral. Surgem então possibilidades de se auferir lucros provenientes da comercialização da energia e/ou dos créditos de carbono, via MDL's/Protocolo de Quioto, que entre outras poderiam aperfeiçoar a construção e operação adequadas de instalações de disposição definitiva.

Diretamente, reduz as emissões de gases do efeito estufa. O mesmo autor ainda informa que os aterros sanitários são uma das maiores fontes de emissões de metano criadas por seres humanos. Nos Estados Unidos da América, foram liberadas aproximadamente 58 MMTCE na atmosfera só no ano de 1999. Segundo Sikar e La Scala Jr (2004), em trabalho conduzido no aterro sanitário municipal de São Carlos-SP, este aterro contribuiria com 4,9 \% da concentração de 
metano $\left(\mathrm{CH}_{4}\right)$ e gás carbônico $\left(\mathrm{CO}_{2}\right)$ ambiental local urbana, comparada com a concentração de áreas remotas do globo terrestre ou concentrações "background". Dado que todos os aterros sanitários geram metano, é lógico utilizar o gás para um fim útil, como gerar energia, sempre que for possível em termos econômicos. 


\subsection{Líquidos Percolados: Geração e características}

Segundo Schalch (1992) e Tchobanoglous et al (1993) os líquidos percolados são aqueles que de fato compõe a fase líquida do aterro sanitário. Juntamente com os gases produzidos, ocupam os interstícios existentes no maciço de lixo e são resultantes de uma complexa gama de interações entre fatores relacionados com o local de disposição dos resíduos, como geológicos, hidrológicos, hidrometeorológicos e topográficos; além da composição do rejeito em si, incluindo teor de umidade e inoculação microbiana, compactação das células do aterro, impermeabilização e cobertura vegetal. Esses fatores fazem com que haja, com o passar do tempo, interações de variáveis como o potencial hidrogeniônico $(\mathrm{pH}), \quad$ o potencial de oxido-redução (Eh) e temperatura, que atuam como intermediários na seleção microbiana, permitindo a realização de reações físicoquímicas com acidificação, volatilização, precipitação e troca iônica, as quais conferirão características próprias para os líquidos percolados de cada aterro. Apresentam carga orgânica e inorgânica, bastante significativas, com destaque especial para a presença de elementos químicos metálicos e radicais inorgânicos. Ressalte-se que as composições destes líquidos variam muito para um mesmo aterro e de aterro para aterro, dependendo das variáveis já citadas. Para o monitoramento de aterros, parâmetros como condutividade, alcalinidade, potencial de oxido-redução, nutrientes como nitrogênio e fósforo, presença e quantificação de ácidos voláteis, sólidos totais e demanda química de oxigênio (DQO) e demanda bioquímica de oxigênio (DBO), metais pesados e substancias tóxicas(inibidoras), entre outros, com as suas variações e/ou estabilizações, são de elevadas significâncias na condução adequada do aterro e previsão mais segura dos 
impactos que possa causar ao ambiente natural. Todos estes parâmetros, num determinado instante, são indicadores para uma maior compreensão do estado de degradação em que se encontra a matéria orgânica confinada em um aterro sanitário.

\section{5 - Aterros Sanitários e a situação brasileira}

Pela resolução número 001 do CONAMA (1986), mesmo que bem projetado e operado, o aterro sanitário causa impacto negativo ao ambiente circunvizinho e, portanto, para sua implantação faz-se necessária a apresentação do devido Estudo de Impacto Ambiental (EIA) e do Relatório de Impacto Ambiental (RIMA).

Dados da Pesquisa Nacional de Saneamento Básico (PNSB) feita pelo IBGE (2000) já indicavam que $47,1 \%$ do lixo gerado no país tinham como destino final os aterros sanitários. Este dado mostra uma tendência da melhora da situação da disposição final do lixo no Brasil nos últimos anos - pois em 1989, a mesma PNSB mostrava que o percentual de resíduos dispostos de forma adequada era de apenas $11,0 \%$ - e um uso bastante razoável destes equipamentos como destino final dos resíduos sólidos urbanos.

Ainda segundo o IBGE, em 2000, o lixo produzido no Brasil chegava a, aproximadamente, 126.000 toneladas por dia, sendo que $47,1 \%$ eram destinados a aterros sanitários, $22,5 \%$ a aterros controlados e apenas 30,5 \% a lixões. Ou seja, mais de $69 \%$ de todo o lixo coletado no país estaria tendo um destino final 
adequado, em aterros sanitários e/ou controlados. Todavia, em termos do número de municípios que dariam destino adequado a seus resíduos, o resultado não é tão favorável: aproximadamente, $64,0 \%$ destes utilizavam lixões e 32,0\%, aterros adequados (14,0\% aterros sanitários, $18,0 \%$ aterros controlados), sendo que $5 \%$ não informaram para onde encaminhavam seus resíduos.

Dos 5.507 municípios brasileiros, 4.026, ou seja, $73,0 \%$ têm população de até 20.000 habitantes. Nestes municípios, 68,5\% dos resíduos gerados são vazados em lixões e em alagados. Se tomarmos, entretanto, como referência, a quantidade de lixo por eles gerada, em relação ao total da produção nacional, a situação é menos grave, pois em conjunto coletam somente da ordem de $13,0 \%$ do total brasileiro (20.658 t/dia). Isto é menos do que o gerado pelas treze maiores cidades brasileiras, com população acima de um milhão de habitantes. Só estas, coletam 32,0\% (51.635 t/dia) de todo o lixo urbano brasileiro e têm seus locais de disposição final em melhor situação; apenas em torno de 2,0\% (832 t/dia) são destinados a lixões, com o restante sendo depositado em aterros controlados ou sanitários.

Dados do Panorama dos Resíduos Sólidos no Brasil 2004, em Resíduos Sólidos no Brasil; publicação da Associação Brasileira de Empresas de Limpeza Pública e Resíduos Especiais - ABRELPE; mostram a evolução da coleta de resíduos sólidos urbanos (Tabela 3.5.1), abrangendo o período 2000-2004, a partir dos indicadores da revisão da Política Nacional de Saneamento Básico (PNSB, 2000), por região e das estimativas populacionais do IBGE (2001 a 2004), segundo as macrorregiões. 
Tabela 3.5.1 - Quantidade Coletada de RSU's por região no Brasil

\begin{tabular}{lrrrrr}
\hline \multirow{2}{*}{ Macrorregião } & \multicolumn{5}{c}{ Quantidade Coletada (t/dia) } \\
\cline { 2 - 6 } & Ano - 2000 & Ano - 2001 & Ano - 2002 & Ano - 2003 & Ano - 2004 \\
\hline Norte & $11.036,85$ & $11.313,23$ & $11.521,00$ & $11.755,96$ & $12.208,95$ \\
\hline Nordeste & $38.454,60$ & $39.042,41$ & $39.497,59$ & $40.139,45$ & $41.135,71$ \\
\hline Sudeste & $73.927,63$ & $75.216,36$ & $76.254,74$ & $77.828,45$ & $79.949,96$ \\
\hline Sul & $18.008,54$ & $18.298,96$ & $18.530,32$ & $18.831,35$ & $19.380,88$ \\
\hline Centro-Oeste & $8.476,64$ & $8.671,15$ & $9.058,45$ & $9.220,71$ & $9.556,53$ \\
\hline Brasil & $149.904,27$ & $152.542,11$ & $154.862,10$ & $157.775,92$ & $162.232,03$ \\
\hline
\end{tabular}

Fonte: ABRELPE (2004)

A partir destes dados ver-se que para o ano de 2004, a região Sudeste é a região responsável pela maior parcela da geração e coletada de resíduos sólidos urbanos com, aproximadamente, 49,28 \%, enquanto as regiões Norte e Centro-Oeste seriam as menores geradoras/coletoras, com 7,53 \% e 5,89 $\%$, respectivamente. As regiões Nordeste, com 25,36 \% do total gerado no país, e Sul, com $11,95 \%$, estariam em posição intermediária.

Em vista do exposto, pode-se inferir que no Brasil não existem dados precisos sobre a quantidade de lixo gerada nos municípios. Na tabela 3.5.2, são apresentados dados da CETESB sobre a geração diária per capita de Resíduos Sólidos Urbanos (RSU) por municípios classificados de acordo com o número de habitantes. 
Tabela 3.5.2 - Características dos RSU's nos municípios brasileiros.

\begin{tabular}{lcccc}
\hline $\begin{array}{l}\text { Classificação do } \\
\text { Município }\end{array}$ & $\begin{array}{l}\text { População } \\
\text { (habitantes) }\end{array}$ & $\begin{array}{c}\mathrm{kg} / \mathrm{habitante} \\
\left(\mathrm{dia}^{-1}\right)\end{array}$ & $\begin{array}{c}\text { Toneladas } \\
\left(\mathrm{dia}^{-1}\right)\end{array}$ & $\%$ \\
\hline Até 100 mil habitantes & 84.433 .133 & 0,4 & 33.773 .253 & 39 \\
\hline 100 a 200 mil habitantes & 16.615 .355 & 0,5 & 8.307 .677 & 10 \\
\hline 200 a 500 mil habitantes & 22.040 .778 & 0,6 & 13.224 .466 & 14 \\
\hline Acima 500 mil habitantes & 45.777 .000 & 0,7 & 32.043 .900 & 37 \\
\hline Total & $\mathbf{1 6 9 . 5 4 4 . 4 4 3}$ & $\mathbf{0 , 5 2}$ & $\mathbf{8 7 . 3 4 9 . 2 9 6}$ & $\mathbf{1 0 0}$ \\
\hline
\end{tabular}

Fonte: CETESB (2001) e Censo IBGE (2001)

Como se pode constatar, a geração diária de resíduos sólidos per capita no Brasil em 2001 já registrava variação de 0,4 a 0,7 kg, com média de 0,52 $\mathrm{kg} / \mathrm{habitante} / \mathrm{dia}$. Cabe ressaltar a tendência de elevação da geração de lixo no país, ano após ano, caso os padrões de consumo e produção não sejam modificados, como já mostraram dados de Rosa et al. (2003). 


\subsection{Efeito Estufa e o Aquecimento Global}

Segundo Baird (2002) e Buckeridge \& Aidar (2005) ao ouvirmos a expressão efeito estufa temos logo a impressão de que se trata de fenômeno totalmente nefasto e que nos conduzirá à hecatombe planetária, pois é usado sempre com uma conotação negativa, indicando que algo de errado está acontecendo com a atmosfera terrestre. Faz sentido, mas, o efeito estufa não é de todo maléfico e é exato por ele que conhecemos a vida na terra tal como ela é. Para se ter uma idéia da importância do efeito estufa, pode-se comparar a Terra e a Lua.

Enquanto a camada de ar (gases) que envolve o nosso planeta se mantém entre extremos aproximados de $-10^{\circ} \mathrm{C}$ e $+50^{\circ} \mathrm{C}$, a Lua, que até onde sabemos não possui seres vivos, apresenta extremos de $-150^{\circ} \mathrm{C}$ a $+100^{\circ} \mathrm{C}$ na superfície exposta ao sol. Essas diferenças existem a despeito do fato de que ambos os corpos celestes se encontrem à mesma distancia do sol. Tais diferenças existem porque a Terra possui uma camada de gases capazes, em diferentes níveis, de absorverem parte da radiação emitida pelo sol.

A expressão efeito estufa, já de uso corrente, indica que a temperatura média global do ar aumentará de vários graus como resultado do aumento da quantidade de gás carbônico e outros gases indutores do fenômeno na atmosfera terrestre. De fato, muitos cientistas (IPCC, 1996; 2001; 2002) acreditam que este aquecimento global já esteja atuando há algum tempo e seja largamente responsável pelo aumento da temperatura em aproximadamente dois terços de grau Celcius $\left({ }^{\circ} \mathrm{C}\right)$ que ocorre desde 1860.

O aquecimento global, mesmo que com aumentos mínimos da 
atmosfera terrestre, induz às alterações climáticas que se prenunciam e já se fazem sentir.

O aumento da temperatura média da Terra acarreta o aquecimento dos oceanos (aumentando o nível dos oceanos pela expansão da água e afetando ecossistemas marinhos e, possivelmente, até as correntes marítimas), a redução da cobertura de gelo em várias regiões (afetando a disponibilidade de água doce naqueles locais), a alteração na dinâmica nos ecossistemas terrestres (alterando períodos de migração, acasalamentos e hibernação, eliminando espécies sensíveis ao aumento da temperatura ou introduzindo novas espécies) e até mesmo o aumento da periodicidade e intensidade de chuvas, secas e furacões. Cada uma destas consequências ambientais tem desdobramentos socioeconômicos diversos (PINHEIRO, 2005).

Podem existir tanto "efeitos" positivos quanto negativos associados com qualquer variação significativa na temperatura global média. De toda a radiação que chega à Terra, apenas a luz visível e parte das ondas de rádio são capazes de atingir a superfície da Terra sem interferência, enquanto a luz ultravioleta é absorvida na estratosfera, provocando seu aquecimento ( BAIRD, 2002). A energia absorvida faz com que as moléculas de certos gases vibrem, promovendo produção de energia calorífica, a qual em parte acaba sendo reemitida para o espaço e em parte é responsável pela manutenção dos sistemas vivos na superfície terrestre. É fácil ver que este é o efeito estufa benéfico, sem o qual a vida na Terra seria impossível.

Por outro lado, quando se fala do "aspecto ruim" do efeito estufa, querse dizer que a contribuição antrópica, e proporcionalmente rápida na concentração de certos gases que provocam este efeito $\left(\mathrm{CO}_{2}, \mathrm{CH}_{4}, \mathrm{~N}_{2} \mathrm{O}, \mathrm{CFC}\right.$ 's, $\mathrm{O}_{3}$, p.ex. $)$ vem 
provocando um aumento de temperatura da atmosfera. Na realidade, o rápido fenômeno de aquecimento global - com sua demanda de adaptações em grande escala - já é considerado um dos nossos maiores problemas ambientais mundial. Ao contrário da depleção da camada de ozônio estratosférico, manifestado de modo espetacular na forma de um "buraco no ozônio", o fenômeno do aquecimento global devido ao efeito estufa ainda não foi observado de maneira a convencer a todos de sua existência. Devido à complexidade dos fatores que implicam o aquecimento global, não há ainda uma segurança da extensão ou do ritmo em que a temperatura aumentará no futuro, tampouco é provável que se façam previsões confiáveis para regiões específicas antes que ocorram os fatos em questão. Contudo, se os modelos atuais da atmosfera são corretos, um aquecimento global significativo ocorrerá nas próximas décadas. Assim, é importante que compreendamos os fatores que influenciam o aumento global das temperaturas, de modo que possamos tomar medidas imediatas para evitarmos ou mitigarmos as catástofres previstas por rápidas mudanças climáticas no futuro.

As ações para evitar ou amenizar alterações globais do clima abrangem quase todos os setores socioeconômicos e todas as regiões geográficas do planeta. Talvez por isso as negociações internacionais sejam frequentemente tensas e demorem a produzir resultados concretos. Já na década de 1970 a Organização Meteorológica Mundial (WMO, na sigla inglesa) alertava para as possíveis alterações do clima planetário como consequência das atividades antrópicas.

No final da década de 1980 a WMO e o Programa das Nações Unidas para o Meio Ambiente (PNUMA) uniram forças para criar o Painel Intergovernamental sobre Mudança do Clima (IPCC, na sigla inglesa) para compilar 
o conhecimento científico sobre o tema com o objetivo de orientar a atividade científica para as áreas menos exploradas e estudar as possíveis implicações da Mudança do Clima sobre a sociedade, a economia e o ambiente natural (PINHEIRO, 2005).

O IPCC publicou o seu primeiro relatório de avaliação em 1990 Climate Change: The IPCC Scientific Assessement in 1990 - onde concluía que o acúmulo de gases de efeito estufa na atmosfera terrestre decorrente de atividades humanas levaria a uma mudança global do clima que por sua vez afetaria de forma significativa o ambiente natural e a sociedade. Estas conclusões do IPCC motivaram a criação da Convenção-Quadro das Nações Unidas sobre Mudanças do Clima (UNFCCC, na sigla inglesa) durante a Conferencia das Nações Unidas sobre meio ambiente e Desenvolvimento; no rio de Janeiro em 1992; conhecida como ECO-92 ou Rio-92.

O IPCC e a UNFCCC funcionam de forma coordenada. De um lado, o IPCC compila informações científicas, colhidas do mundo todo, faz estudos de vulnerabilidades socioeconômicas e ambientais e de adaptações a mudanças climáticas, analisa opções políticas e tecnológicas para redução de emissões e desenvolve metodologias para elaboração de inventários nacionais de emissões de gases estufa. De outro lado, a UNFCCC funciona principalmente como órgão político, responsável por promover negociações multilaterais e induzir ações para implementação internacional. A UNFCCC congrega quase 190 países, inclusive o Brasil. Entre outros compromissos estes países signatários propuseram-se:

I) elaborar, atualizar periodicamente e publicar seus inventários de emissões;

II) promover e implementar medidas para a redução de suas emissões e de 
adaptação às mudanças climáticas;

III) transferir tecnologias limpas, e,

IV) promover e cooperar em pesquisas, divulgação de informações e educação ambiental.

Para os países desenvolvidos signatários, inclusive os Estados Unidos, há compromissos adicionais, como por exemplo, a redução de suas emissões combinadas de gases de efeito estufa em pelo menos $5 \%$ em relação aos níveis de 1990, até o período entre 2008 e 2012 e ajuda financeira a países em desenvolvimento para que os mesmos possam alcançar seus compromissos junta à UNFCCC, sem que prejudiquem as suas possibilidades de desenvolvimento, procurando um desenvolvimento limpo (PINHEIRO, 2005; MCT, 2002).

Para garantir a manutenção dos compromissos assumidos e reavaliar estratégias e objetivos, a UNFCCC promove uma Conferência da Partes (COP) a cada ano desde 1995, com representações de governos, empresas, instituições multilaterais e organizações não-governamentais para tratarem da Mudança Global do Clima. O Protocolo de Quioto foi resultado da terceira COP em dezembro de 1997, em Quioto, no Japão. O Protocolo de Quioto é o primeiro documento, com vinculação legal, em que países estabelecem metas claras de redução de emissões de gases de efeito estufa, prometendo produzir uma reversão da tendência histórica de crescimento das emissões iniciadas nesses países há cerca de 150 anos (MCT, 2002).

O que se espera é que as já iniciadas negociações que seguirão ao Protocolo de Quioto possam sedimentar as convicções e conhecimentos já compilados nas rodadas efetivadas até aqui e que venham proposições de ações 
bem mais consequentes, inclusive com metas e compromissos mais claros e bem determinados para os países em desenvolvimento. Só assim, com todos envolvidos e contribuindo, conforme suas especificidades, mas de forma consequente e transparente, poderemos evitar as previsões que se anunciam. Caso contrário, poderemos não deixar às gerações futuras um planeta habitável e que tivemos as condições concretas, pelo menos em muitos aspectos científicos, de otimizá-lo aos nossos próximos, mas não o fizemos como bem já frisado por Thomas (2007) em citação antecedente. 


\subsubsection{O mecanismo do Efeito Estufa}

A superfície e a atmosfera da Terra são mantidas aquecidas principalmente pela energia proveniente do sol. A quantidade máxima de energia que incide na Terra - parte tracejada da figura 3.6.1.1 - situa-se na região da luz visível do espectro de energia - com comprimentos de onda entre 0,40 e $0,75 \mu \mathrm{m}$, ou seja, de 400 a $750 \mathrm{~nm}$. O espectro da luz visível solar situa-se entre a luz violeta (400 nm) e a vermelha (750 nm). Além do "limite vermelho", ou seja, o comprimento máximo da luz visível recebemos luz solar na região do infravermelho (IR, na sigla em inglês) situada entre 0,8 a $3,0 \mu \mathrm{m}$. De toda a energia recebida do sol pelas camadas superiores da atmosfera, cerca de pouco mais que a metade é IR, e o restante é luz visível. Grande parte da luz ultravioleta (UV) solar - comprimento de onda $<0,4 \mu \mathrm{m}$ - é removida na estratosfera e aquece o ar naquele local em vez de aquecer a superfície da Terra. Da luz incidente total envolvendo todos os comprimentos de onda que chegam até a Terra, cerca de $50 \%$ alcança a superfície, onde é absorvida. Outros $20 \%$ da luz incidente são absorvidas por gases - UV pelo ozônio estratosférico e IR pelo $\mathrm{CO}_{2}$ e $\mathrm{H}_{2} \mathrm{O}_{(\mathrm{v})}$-, os restantes $30 \%$ são refletidas de volta ao espaço pelas nuvens, pelo gelo, pela neve, pela areia e por outros corpos refletores, sem que ocorra qualquer absorção (BAIRD, 2002). 


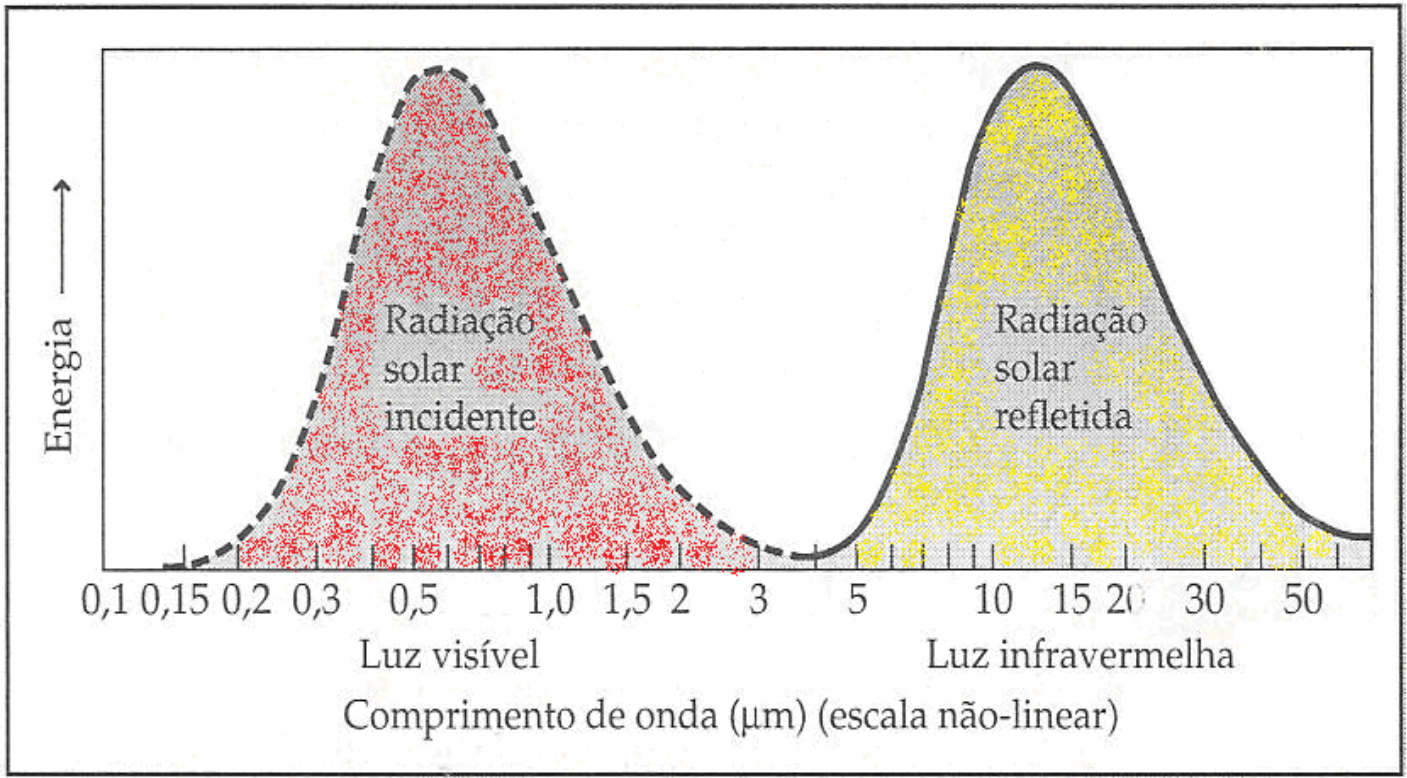

Figura 3.6.1.1 - Distribuição de comprimentos de onda ( $\lambda$, escalas diferentes) da luz emitida pelo sol (- - - -) e da luz refletida pela superfície terrestre (-).

Fonte: Adaptado de Gribbin (1988) citado por Baird (2002).

Uma parte do aumento de temperatura observado de 1860 até os nossos dias - Figura 3.6.1.2 —pode ser atribuída diretamente ao aumento (cerca de 24\%) no fluxo de energia emitida pelo sol, especialmente na região do UV - que pode ter provocado alterações nos níveis de ozônio troposférico. O aquecimento resultante do aumento da radiação solar, que poderia ser responsável por até um terço do aumento da temperatura do ar observado desde 1970 (Figura 3.6.1.2), deve continuar nos próximos 50 anos, segundo extrapolações das tendências atuais. 


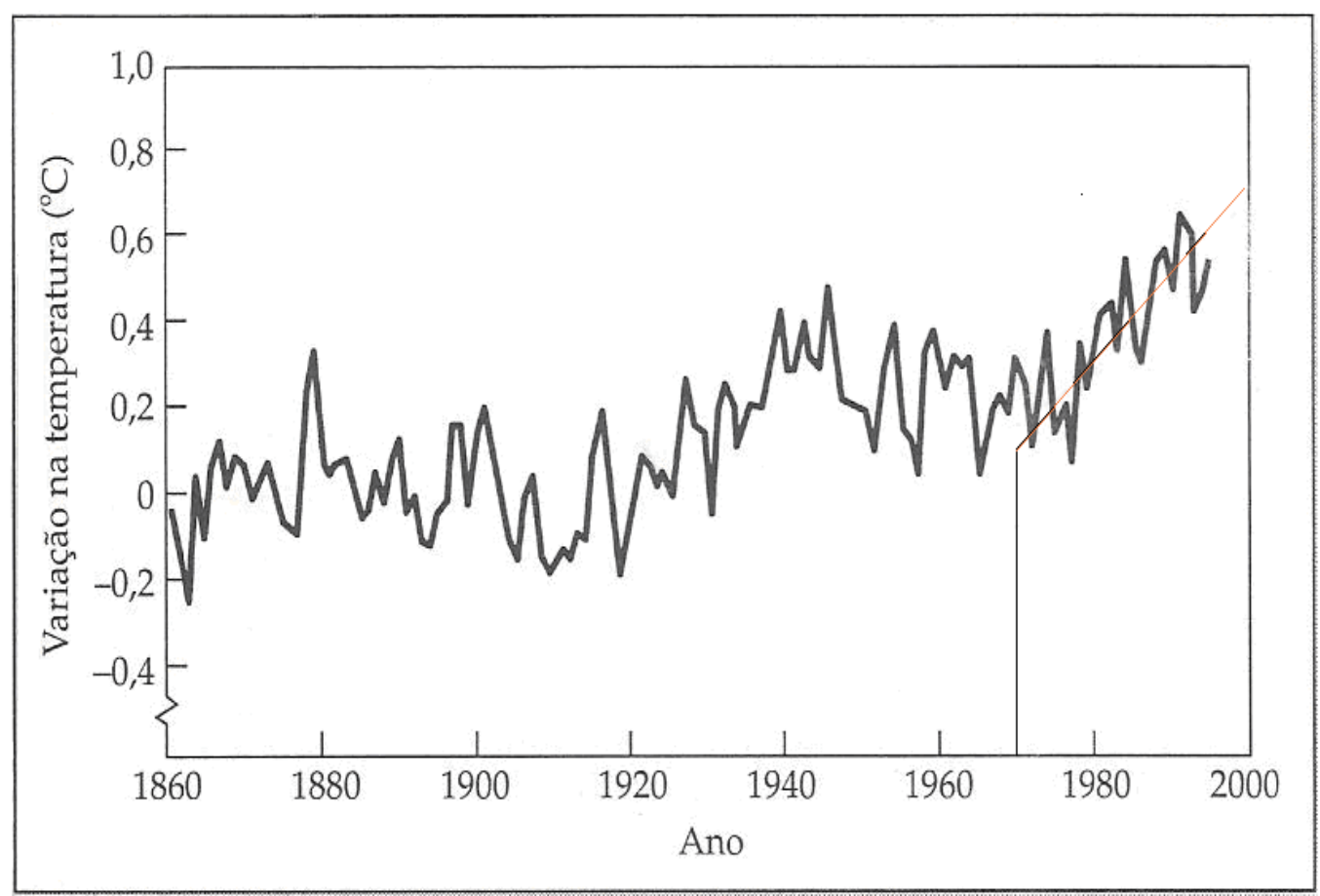

Figura 3.6.1.2 - Variação da temperatura global média. Destaque a partir de 1970.

Fonte: Baird (2002) citando Canadian Climate Center (1997), modificado.

Como qualquer outro corpo aquecido, a Terra emite energia. De fato, a quantidade de energia que o planeta absorve e aquela liberada, devem ser iguais para que a temperatura se mantenha constante (balanço energético). A energia emitida (parte contínua da Figura 3.6.1.1) não se situa na região do visível, ou UV, mas na região do IR, apresentando comprimentos de onda que variam de 4 a 50 $\mu \mathrm{m}$. Essa região é chamada de infravermelho térmico porque é energia na forma de calor, o mesmo tipo de energia que é irradiado por uma panela de ferro, quando aquecida.

Alguns gases presentes no ar podem absorver temporariamente luz IR térmica de comprimentos de onda específicos, sendo assim, nem todo IR emitido pela superfície da Terra e pela atmosfera escapa diretamente para o espaço. Logo 
após sua absorção pelas moléculas presentes no ar, como $0 \mathrm{CO}_{2}$, a luz infravermelha é reemitida em todas as direções, de modo completamente aleatório. Assim, parte do IR térmico é direcionada de volta em direção à superfície, sendo reabsorvida, e consequentemente, provocando o aquecimento adicional tanto da superfície como do ar. Esse fenômeno, o redirecionamento ou desvio do IR térmico em direção a Terra, como mostra a Figura 3.6, é chamado de efeito estufa e é responsável pelo fato de a temperatura média da superfície da Terra ser de aproximadamente $+15^{\circ} \mathrm{C}$, em vez de $-15^{\circ} \mathrm{C}$, temperatura que predominaria se gases que absorvem IR não estivessem presentes na atmosfera. Não somos um planeta coberto de gelo pela atividade natural do efeito estufa. A atmosfera funciona como "um cobertor" que retém na região em sua proximidade uma parte do calor liberado por um corpo, aumentando assim a temperatura local.

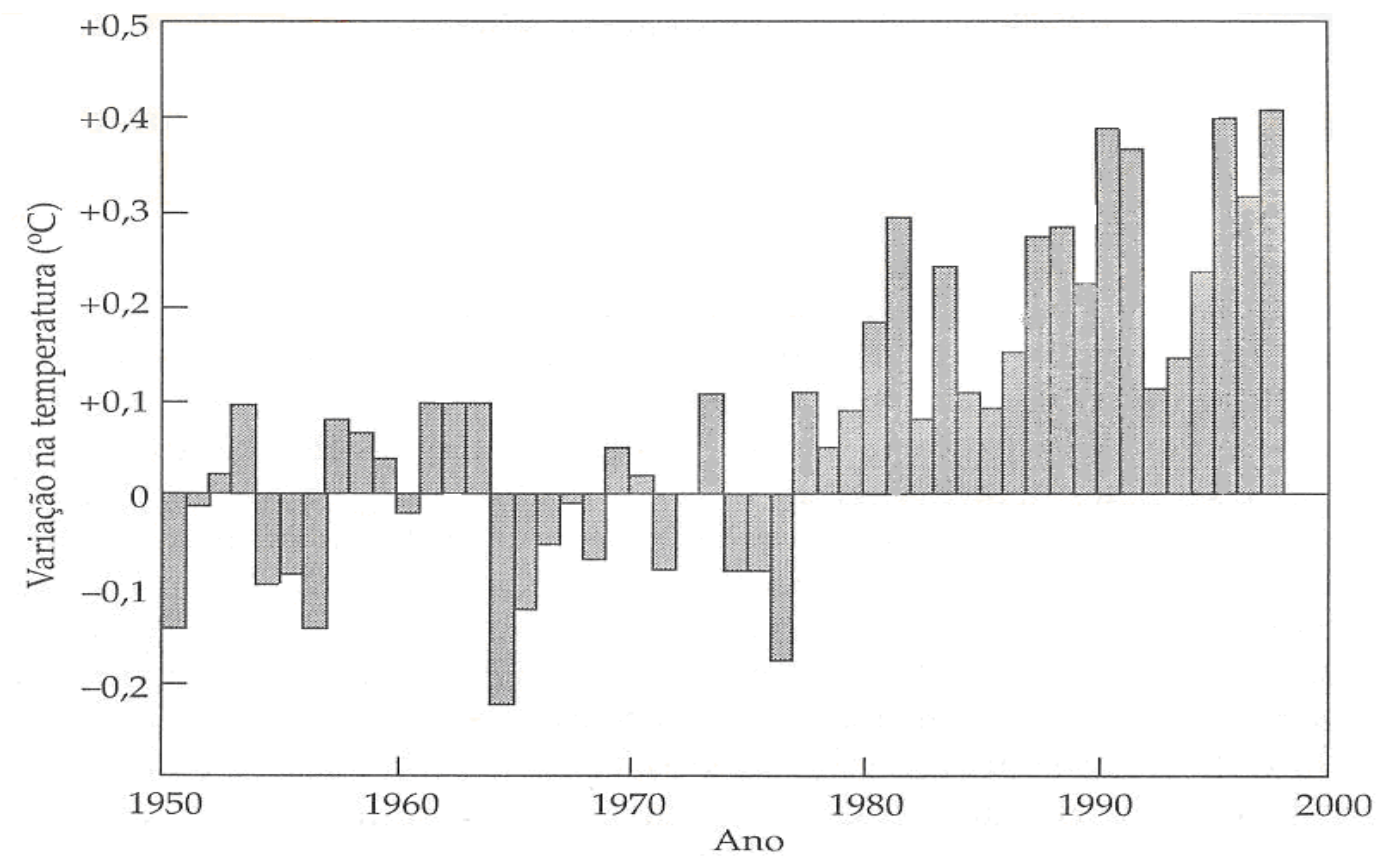

Figura 3.6.1.3 - Variações nas temperaturas médias superficiais de 1950 a 1997.

Fonte: Baird (2002) citando Goddard institute, NASA. 
O fenômeno que tem preocupado os cientistas ambientais é que o aumento das concentrações de gases traços no ar, que absorvem luz IR térmica colocando mais "cobertores" sobrepostos - resultaria no redirecionamento de uma maior quantidade de energia infravermelha refletida, o que poderia aumentar a temperatura média da superfície além dos $15^{\circ} \mathrm{C}$. Este fenômeno é denominado efeito estufa intensificado, para distinguir seus efeitos daquele que vem ocorrendo naturalmente durante milênios (BAIRD, 2002).

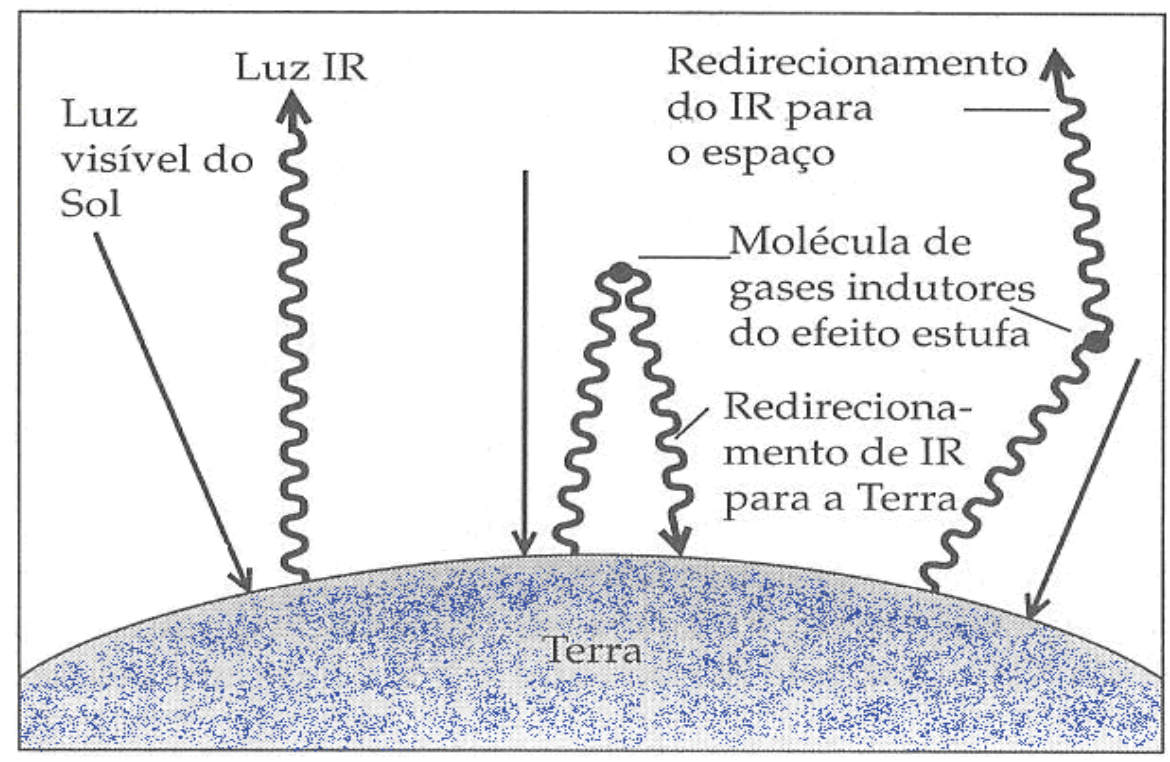

Figura 3.6.1.4 - Fluxo de luz na troposfera terrestre - Efeito estufa. Fonte: Baird (2002), com modificações.

Os principais constituintes da atmosfera, $\mathrm{N}_{2}, \mathrm{O}_{2}$ e $\mathrm{Ar}$, são incapazes de absorver luz infravermelha. Os gases atmosféricos que no passado produziram grande parte do efeito estufa foram a água (responsável por dois terços do efeito) e o dióxido de carbono (responsável por cerca de um quarto do efeito). De fato a ausência de água nas zonas secas do deserto conduz a baixas temperaturas 
noturnas, muito embora as temperaturas durante o dia sejam bastante altas em razão da absorção direta de energia solar. É familiar àqueles que vivem em climas temperados, o resfriamento súbito do ar de inverno nos dias e noites em que não há nuvens no céu. 


\subsubsection{Vibrações Moleculares: Absorção de Energia pelos Gases indutores do Efeito Estufa}

A luz é absorvida praticamente de forma total quando sua frequência quase se iguala à frequência do movimento interno de uma molécula que venha a encontrar. Para as frequências da região do infravermelho, os movimentos relevantes são as vibrações dos átomos que constituem uma molécula, relativamente uns aos outros.

O movimento de vibração mais simples em uma molécula é o movimento oscilatório relativo a dois átomos ligados entre si, A - B. Nesse movimento, chamado de estiramento da ligação, a distância R entre A e B aumenta para um valor maior que $R$ médio, retornando em seguida a $R$, e então se contrai para um valor menor, para finalmente retornar a R, como ilustrado no Quadro 3.6.2.1. Tal movimento oscilatório acorre em todas as ligações e em todas as moléculas sob todas as condições de temperatura, mesmo no zero absoluto. Um número enorme (cerca de $10^{13}$ ) de ciclos vibracionais ocorre a cada segundo. A frequência exata do movimento oscilatório depende principalmente do tipo de ligação, ou seja, se estão envolvidas ligações simples, dupla ou tripla, e da identidade dos dois átomos envolvidos. Para muitos tipos de ligação, por exemplo, a ligação $\mathrm{C}-\mathrm{H}$ no metano e a $\mathrm{O}-\mathrm{H}$ na água, a frequência de estiramento não se encontra na região do $I R$ térmico. A frequência de estiramento das ligações carbono-flour $\mathrm{C}-\mathrm{F}$, contudo, corresponde a um comprimento de onda que se situa na faixa do IR térmico, de 4 a $50 \mu \mathrm{m}$, e assim quaisquer moléculas na atmosfera que possuam ligações $\mathrm{C}-\mathrm{F}$ absorverão luz $\mathrm{IR}$ térmica refletida e intensificarão o 
efeito estufa (BAIRD, 2002).

Quadro 3.6.2.1. - Vibração de estiramento de ligação.

$\mathrm{H}-\mathrm{B} \rightarrow \mathrm{A}+\mathrm{R} \rightarrow \mathrm{B}-\mathrm{R} \rightarrow \mathrm{A}-\mathrm{B} \rightarrow \mathrm{A}-\mathrm{R}$

Um outro tipo relevante de vibração é uma oscilação na distância entre dois átomos $\mathrm{A}$ e $\mathrm{B}$ ligados a um átomo comum $\mathrm{C}$, mas não ligados um ao outro. Esse movimento altera o ângulo de ligação $A C B$ do seu valor médio $\theta$, e é chamado de vibração de deformação angular. Todas as moléculas contendo três átomos ou mais apresentam vibrações de deformação angular. O ciclo oscilatório, no qual um ângulo de ligação aumenta, depois diminui, para então sofrer outro aumento, e assim por diante, é ilustrado no Quadro 3.6.2.2. As frequências de muitos tipos de deformação angular encontram-se na região do infravermelho térmico.

Quadro 3.6.2.2. - Vibração de deformação angular.

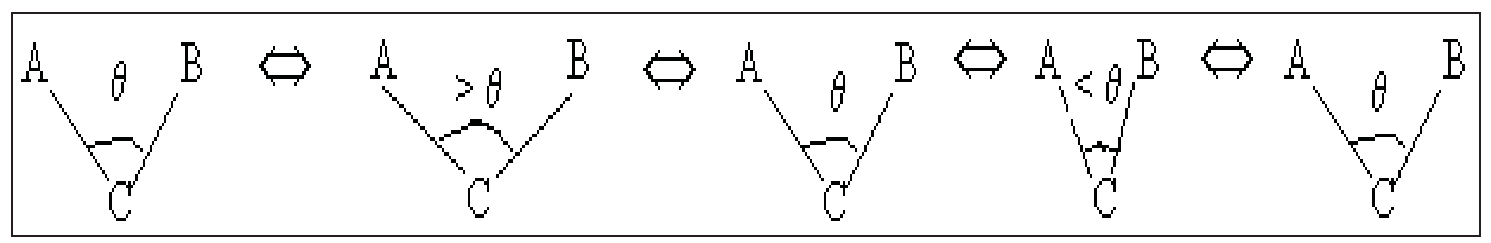


Se luz infravermelha é absorvida por uma molécula durante uma vibração, deve existir uma diferença na posição na molécula entre seu centro de carga positiva - ou seu núcleo - e o centro de carga negativa - de sua "nuvem" eletrônica - em algum ponto durante o movimento. Resumindo, para absorver luz $\mathrm{IR}$, a molécula deve apresentar um momento dipolar durante algum estágio da vibração (tecnicamente deve existir uma mudança na magnitude do momento dipolar durante a vibração). Estes centros de carga coincidem nos átomos livres e (por definição) em moléculas diatômicas homonucleares, como o $\mathrm{O}_{2}$ e $\mathrm{N}_{2}$, e assim, estas espécies moleculares têm momentos dipolares igual a zero durante todo o tempo em sua vibração de estiramento. Assim gás argônio, Ar, nitrogênio gasoso $\left(\mathrm{N}_{2}\right)$ e oxigênio diatômico $\left(\mathrm{O}_{2}\right)$ não absorvem radiação IR. Para o dióxido de carbono, durante o movimento vibratório no qual tanto as distâncias $\mathrm{C}-\mathrm{O}$ estendem-se e encurtam-se de maneira sincronizada (simultaneamente), não ocorre em momento algum qualquer diferença na posição entre os centros de cargas positivas e negativas, dado que ambas situam-se precisamente no núcleo central. Consequentemente, durante esta vibração, chamada de estiramento simétrico ou deformação axial simétrica, a molécula não pode absorver luz IR. Contudo, na vibração de estiramento assimétrico no $\mathrm{CO}_{2}$, a contração de uma das ligações C_-O ocorre quando a outra está se expandindo, ou vice-versa, de modo que durante o movimento os centros de carga não coincidem, necessariamente (Quadro 3.5.2.3). 
Quadro 3.6.2.3 - Estiramento Simétrico e Assimétrico.

\begin{tabular}{|c|c|}
\hline$\overleftarrow{\mathrm{O}} \underset{\begin{array}{c}\text { Estiramento } \\
\text { Simétrico }\end{array}}{\overline{\mathrm{C}}}=\overrightarrow{\mathrm{O}}$ & $\overrightarrow{\mathrm{O}}=\mathrm{C}=\overrightarrow{\mathrm{O}}$ \\
\hline
\end{tabular}

Portanto, a luz IR pode ser absorvida, nesta frequência dado que, em alguns pontos durante a vibração, a molécula possui um momento dipolar. De modo semelhante, a vibração de deformação angular na molécula de $\mathrm{CO}_{2}$, na qual os três átomos se afastam a partir de uma geometria colinear, é um modo de vibração que pode absorver luz IR nesta frequência, já que os outros centros não coincidem quando molécula não é linear. 


\subsubsection{Os principais gases indutores do Efeito Estufa}

Como dito anteriormente, uma molécula absorve energia luminosa, efetivamente, quando as frequências da luz e de uma das suas vibrações coincidem, quase exatamente. Entretanto, luz de frequência um pouco maior ou um pouco menor que as frequências da vibração é absorvida, parcialmente, por um grupo de moléculas. Esta capacidade de absorver IR sobre uma curta faixa de frequências, ocorre porque não é apenas a energia associada à vibração que é alterada quando um fóton IR é absorvido; ocorre também uma variação na energia rotacional, ou 'de giro', da molécula em torno do seu próprio eixo. Esta energia pode ser tanto ligeiramente aumentada tanto quanto diminuída, quando a luz IR é absorvida para aumentar sua energia vibracional.

Assim, ocorre absorção de fótons em frequências ligeiramente maiores ou menores que aquelas que correspondem à da vibração. Geralmente, a tendência à absorção de um gás diminui à medida que a frequência da luz afastase, em qualquer direção, da frequência vibracional. A seguir discutiremos os principais aspectos dos gases indutores do efeito estufa, citados na tabela 1.5.1.

Dióxido de carbono

O espectro de absorção do dióxido de carbono em uma parte da região do IR é mostrado na figura 3.6.3.1. A absorção máxima de luz deste gás na região do infravermelho térmico ocorre no comprimento de onda $(\lambda)$ de $15 \mu m$, que 
corresponde à frequência de $2,0 \times 10^{13}$ ciclos por segundo (Hertz). A absorção acontece nesta frequência particular pelo fato de igualar-se àquela das vibrações das moléculas do $\mathrm{CO}_{2}$, ou seja, à vibração de deformação angular da ligação $\mathrm{O}=\mathrm{C}=\mathrm{O} . \quad \mathrm{O} \mathrm{CO}_{2}$ também absorve fortemente IR com $\lambda$ igual a 4,26 $\mu$, correspondente a uma frequência de $7 \times 10^{13}$ ciclos. $^{-1}$ da vibração de estiramento assimétrico.

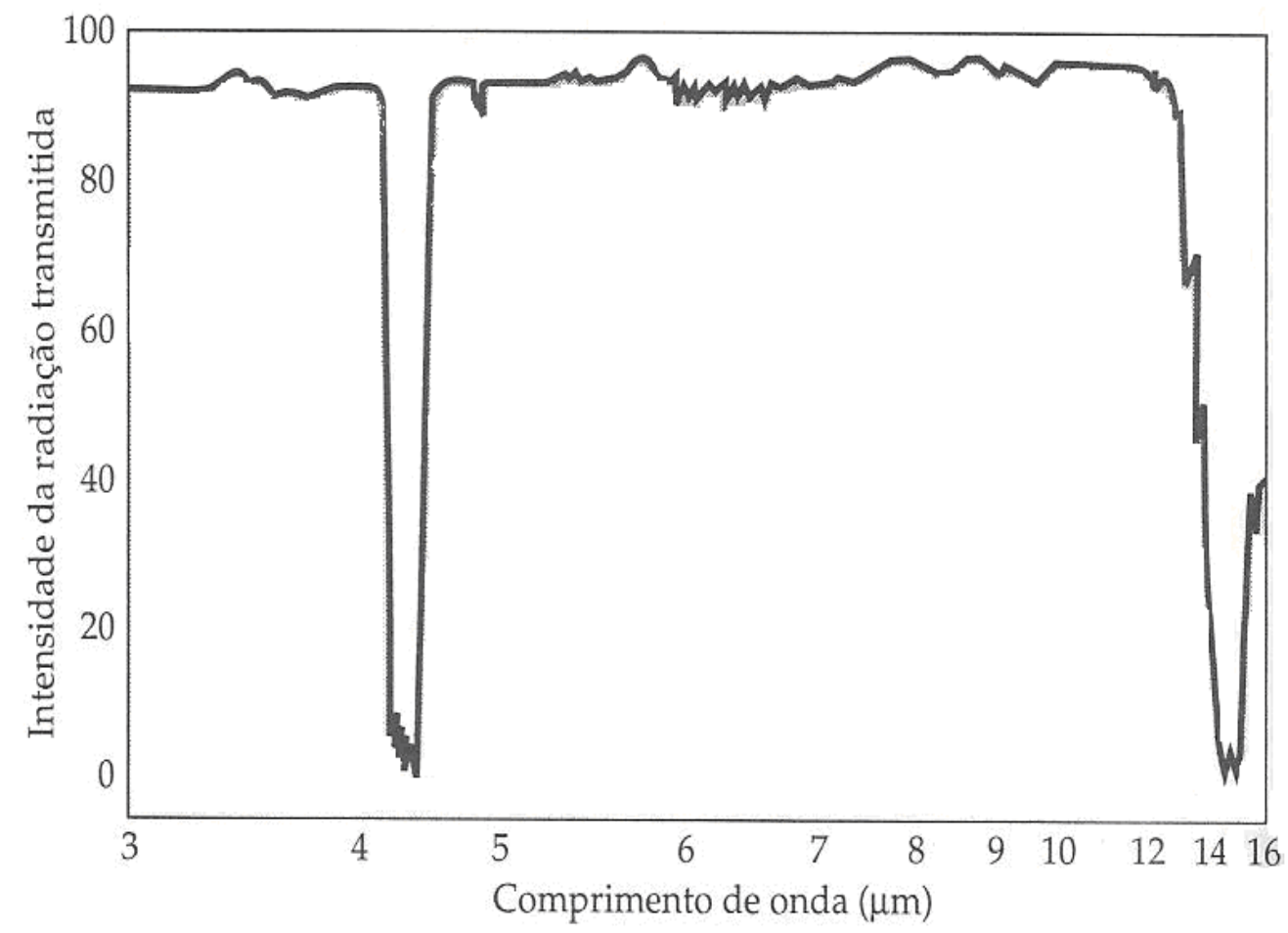

Figura 3.6.3.1 - Espectro de absorção do $\mathrm{CO}_{2}$ na região do IR térmico.

Fonte: Baird, 2002, com modificação.

Segundo Baird (2002) o $\mathrm{CO}_{2}$ presente atualmente na atmosfera absorve, coletivamente, metade da luz IR térmica refletida $\operatorname{com} \lambda$ na região compreendida entre 14-16 $\mu m$, juntamente com a porção relativamente considerável daquela nas regiões compreendidas entre 12-14 $\mu \mathrm{m}$ e 16-18 $\mu \mathrm{m}$, originárias das 
variações de energia dos movimentos rotacionais quando a energia vibracional é alterada. Isto mostra porque na figura 3.6.3.2, a linha contínua, que representa a quantidade de radiação infravermelha que realmente escapa de nossa atmosfera, cai abruptamente em $15 \mu \mathrm{m}$. A separação vertical entre as linhas pontilhada e contínua é proporcional à quantidade de IR de um dado $\lambda$ que está sendo absorvida em vez de escapar. O aumento da concentração de $\mathrm{CO}_{2}$ na atmosfera terrestre impedirá cada vez mais, que mais radiação IR refletida escape, especialmente, nas regiões "de ombro", e deverá produzir maior efeito no aquecimento do ar. Embora o $\mathrm{CO}_{2}$ também absorva irradiação IR na região de $4,3 \mu \mathrm{m}$, devido à vibração e estiramento assimétrico, existe pouca energia emitida pela Terra neste comprimento de onda, assim, esta absorção potencial não é significativa.

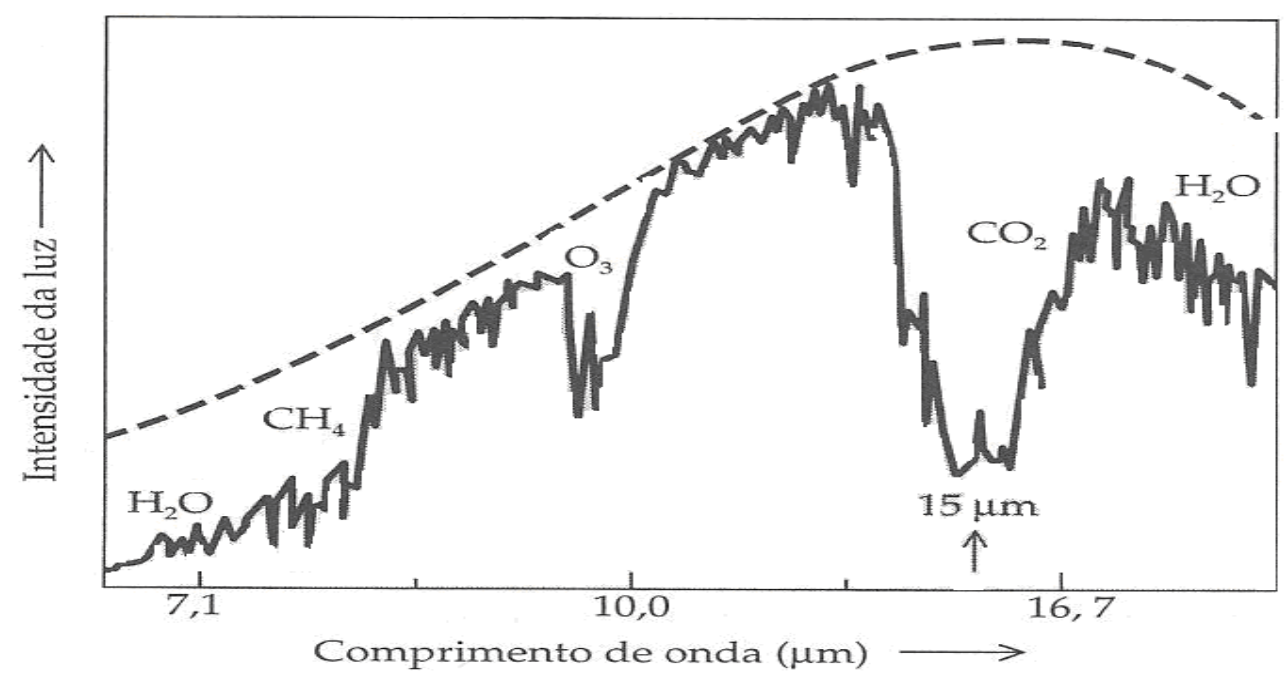

Figura 3.6.3.2 - Intensidade da luz IR térmica que escapa da superfície da Terra(I contínua) e aquela que é absorvida(I pontilhada).

Fonte: Baird, 2002. 
Vapor de água

As moléculas de água, na forma de vapor, abundantes no ar, absorvem luz IR térmica, devido à vibração de deformação angular da ligação H-O$\mathrm{H}$; cujo pico de absorção ocorre a cerca de 6,3 $\mu$ m. Assim, quase toda a relativamente pequena quantidade de IR refletida na região de $5,5 \mu \mathrm{m}$ a $7,5 \mu \mathrm{m}$ é interceptada pelo vapor de água(Figura 3.6.3.2). A vibração de estiramento assimétrico na água ocorre em 2,7 $\mu \mathrm{m}$, fora da região do IR térmico. O aumenta da energia rotacional das moléculas de água, sem qualquer variação na energia vibracional, remove a luz infravermelha térmica de $\lambda$ igual e mais longo que $18 \mu m$. De fato o vapor de água é o mais importante gás estufa na atmosfera terrestre, no sentido de que ele produz mais aquecimento por efeito estufa do que qualquer outro gás, muito embora seja menos eficiente que o dióxido de carbono quando se considera como base uma unidade molecular.

Os gases traço que contribuem com o efeito estufa; isto é, aqueles cuja concentração é pequena em termos absolutos, mas cuja capacidade, mesmo nesses níveis, de provocar o aquecimento do ar é substancial; já citados na tabela os seguintes, como já indicados na tabela 1.5.1:

O Metano

Depois do $\mathrm{CO}_{2}$ e do vapor de água, o metano é o gás indutor do efeito estufa de origem antropogênica de maior importância, tornando-se um dos 
gases importantes no estudo das alterações climáticas induzidas pelo homem.

É o hidrocarboneto mais abundante na atmosfera terrestre, com uma concentração média global de 1,72 ppmv (partes por milhão por volume) em 1994. Medidas sistemáticas da sua concentração na atmosfera tiveram início na metade da década de 70, quando foram identificadas atuações importantes desse gás na química atmosférica e no clima. A partir dessas observações, determinaram-se várias de suas características na atmosfera, como um acentuado gradiente de concentração em função da latitude, com os maiores valores ocorrendo no Hemisfério Norte, uma variação sazonal nos dois hemisférios e uma taxa de crescimento global anual da ordem de $0,6 \%$. Análises de bolhas de ar aprisionadas em geleiras permanentes revelaram que a concentração média de metano era de 0,8 ppmv entre 200 e 2.000 anos atrás e que um crescimento mais rápido teve início há cerca de 150 anos até dobrar esse valor na atmosfera atual (KHALIL and RASMUSSEN, 1987; ALVALA, KIRCHHOFF e PAVÃO, 1999).

Essa tendência de aumento é atribuída ao crescimento da população humana, que, por sua vez, acarreta uma maior demanda de alimentos, levando ao incremento, por exemplo, da criação de gado, de plantações de arroz e de utilização de combustíveis fósseis, principalmente gás natural e carvão, atividades significativas na geração de metano.

A molécula de metano contém quatro ligações $\mathrm{C}-\mathrm{H}$. Suas vibrações de estiramento da ligação ocorrem fora da região do IR térmico. As vibrações de deformação angular da ligação $\mathrm{H}-\mathrm{C}-\mathrm{H}$ absorvem a $7,7 \mu m$, próximo do limite da janela do IR térmico, consequentemente, o metano absorve IR nesta região. Considerando a unidade molecular, um aumento da concentração de metano no ar causa um efeito de aquecimento 21 vezes maior que a adição de dióxido de 
carbono, porque as moléculas de metano absorvem uma maior fração dos fótons de IR térmico que as atravessam do que as moléculas de $\mathrm{CO}_{2}$.

A figura 3.6.3.3, a seguir, mostra que a concentração atmosférica de metano mais que dobrou em relação à época pré-industrial (1750); quando a concentração era de, aproximadamente, $0,75 \mathrm{ppm}$, tendo aumentado para 1,80 ppm em 1994( SIKAR and LA SCALA JR., 2004; BAIRD, 2002; KHALIL and RASMUSSEN, 1987). Presume-se que o aumento da concentração de metano na atmosfera terrestre seja em grande parte antropogênico, por atividades como o aumento da produção de alimentos, o uso intenso de combustíveis fósseis e o desflorestamento.

O metano é produzido a partir de complexas reações bioquímicas da decomposição anaeróbia de materiais orgânicos. Este processo ocorre em larga escala onde acontece a decomposição de plantas submersas em água, p.ex. em pântanos e brejos, e em terras úmidas destinada à rizicultura. Terras alagadas são a maior fonte natural das emissões de metano, bem como grandes lagos de hidrelétricas, especialmente, quando a madeira não é previamente removida da área a ser inundada. Isto demonstra que a energia hidrelétrica não é de todo isenta de emissões quando grandes áreas são inundadas para a sua geração (ALVALA, KIRCHHOFF e PAVÃO, 1999). 


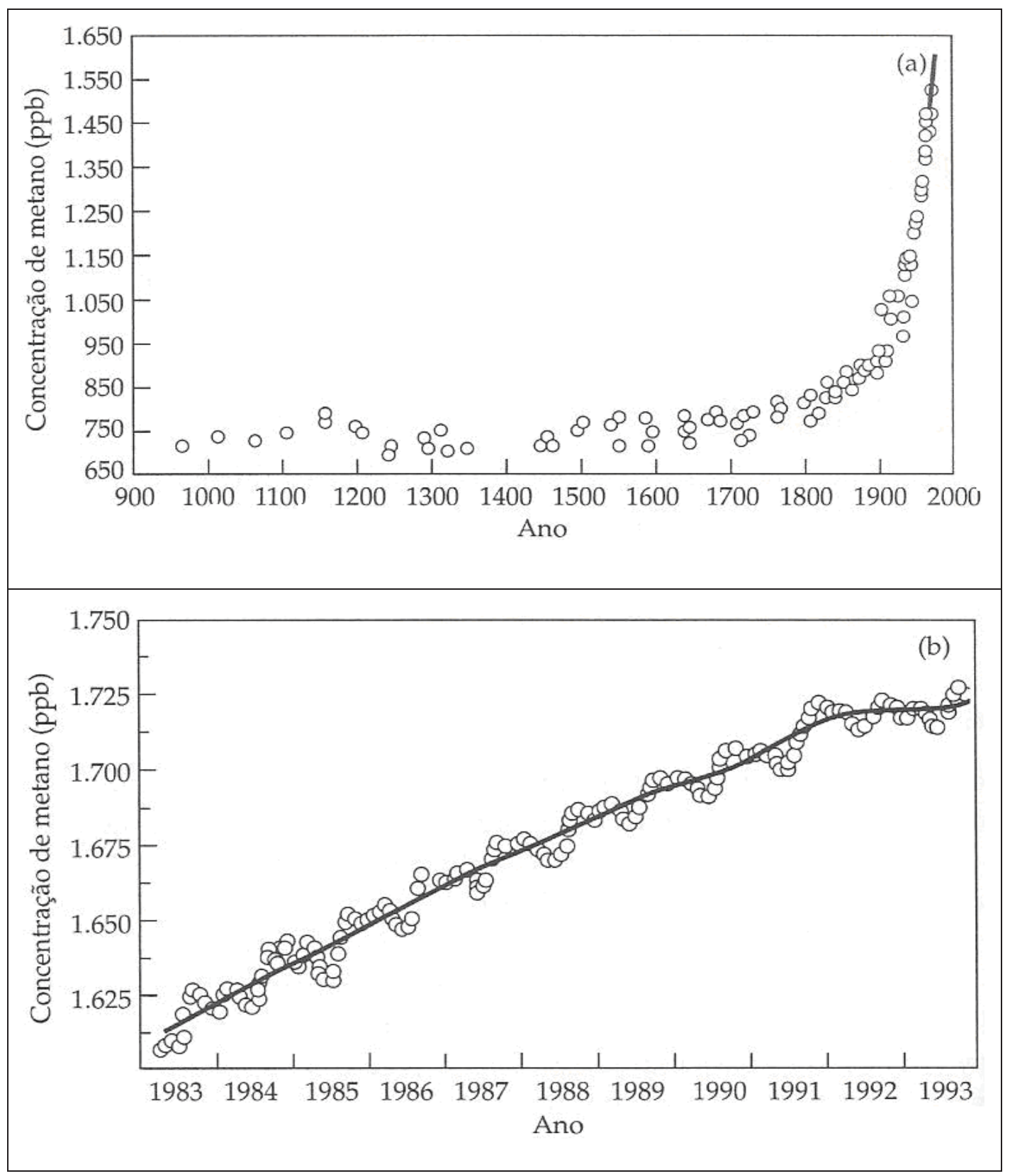

Figura 3.6.3.3 - Crescimento da concentração de metano atmosférico no último milênio (a) e nas décadas de 80 e 90 (b).

Fonte: Baird, 2002 citando Houghton et al, 1995.

Animais ruminantes; bovinos, caprinos, bufalinos e certos animais selvagens, produzem quantidades significativas de metano com subproduto da digestão da celulose de que se alimentam. Portanto o sistema agropecuário é emissor considerável. 
Outra importante fonte de emissão deste gás são os depósitos de lixo ou resíduos sólidos, ao redor do mundo, desde aqueles depósitos a céu aberto até os aterros sanitários melhores operados.

Resumindo, são consideradas (STERN AND KAUFMANN, 1996; KHALIL and RASMUSSEN, 1987) diferentes fontes significativas para o metano atmosférico: emanações vulcânicas, zonas alagadas naturais, combustíveis fósseis - desde a sua extração, transporte e uso -, aterros sanitários e/ou similares, animais ruminantes, áreas de cultivo de arroz e queima de biomassa. A magnitude de cada contribuição é objeto de tamanha incerteza que mesmo sua ordem relativa é constante motivo de revisão.

Óxido nitroso

Outro gás traço importante é o óxido nitroso $\left(\mathrm{N}_{2} \mathrm{O}\right)$, o chamado "gás hilariante", cuja vibração de deformação angular absorve IR a 8,6 $\mu m$, ou seja, na região da janela; e suas vibrações de estiramento de ligação absorvem em 7,8 $\mu$, no "ombro" da janela. Por unidade molecular, o $\mathrm{N}_{2} \mathrm{O}$ é 206 vezes mais efetivo que o $\mathrm{CO}_{2}$ em causar aquecimento global. Sua concentração atmosférica variou de 275 ppb, na era pré-industrial, para 312 ppb, na década passada (BAIRD, 2002). 
Os CFC's

Um grupo de compostos importante na questão do aquecimento global são os Clorofluorcarbonetos (CFC's) e seus substitutos, compostos gasosos cujas moléculas constituídas por átomos de carbono ligados a átomos de flúor e/ou cloro representam talvez o maior potencial entre os gases traço na indução do efeito estufa, por suas grandes persistências e absorverem fortemente na região da janela. O estiramento de ligação $\mathrm{C}-\mathrm{F}$ absorve em $9 \mu \mathrm{m}$, e o estiramento da ligação $\mathrm{C}-\mathrm{Cl}$ e as várias vibrações de deformação angular envolvendo átomos de carbono ligados a halogênios também ocorrem em frequências que se situam dentro da região da janela. Os vários clorofluorcarbonos, como p.ex., $\mathrm{CFCl}_{3} \mathrm{e}$ $\mathrm{CF}_{2} \mathrm{Cl}_{2}$, já foram emitidos para a atmosfera em grandes quantidades e apresentam longos tempos de residência. Devido a essa persistência e à sua alta eficiência na absorção de IR térmico na região da janela, cada molécula de CFC tem o potencial de causar a mesma quantidade de aquecimento global que dez mil moléculas de $\mathrm{CO}_{2}$. Os substitutos destes compostos; os $\mathrm{HCFC}$ e HFC têm tempos de vida atmosféricos mais curtos e absorvem com menos eficiência, representando uma ameaça menor na indução do efeito estufa (BAIRD, 2002).

Ozônio troposférico

Como o metano e o óxido nitroso, também o ozônio $\left(\mathrm{O}_{3}\right)$ troposférico é um gás indutor de efeito estufa "natural", embora apresente um curto tempo de residência no ar. Suas vibrações de estiramento assimétrico ocorrem entre $9 \mu \mathrm{m}$ e 
$11 \mu \mathrm{m}$, dentro da região da janela (Figura3.6.3.2). A vibração de flexão que ocorre em 14,2 $\mu \mathrm{m}$ coincide com a do $\mathrm{CO}_{2}$, e assim não contribui muito para a intensificação do efeito estufa. 


\section{METODOLOGIA}

"NÃo SEI SE O CAOS É ESTE A QUE SE REFEREM NOSSOS ARTICULISTAS POLÍTICOS, E QUE, SEGUNDO ELES, JÁ SE APROXIMA. ENGANO: HÁ MUITO ESTAMOS NELE."

LÚCIO CARDOSO

Para a execução do presente trabalho e atingir os objetivos propostos foram utilizados os equipamentos e ferramentas listados a seguir( item 4.1) e a metodologia descrita no item 4.2.

\subsection{Materiais e equipamentos}

\section{A) Em campo:}

1) Câmaras de difusão de gases.

Para a coleta de amostra gasosas da emissão solo-ar foram utilizadas duas (2) câmaras de difusão de gases: uma grande (retangular; de chapa galvanizada) com volume de 33,2 L e área da base de 0,664 m²; (com comprimento de $83 \mathrm{~cm}$ X largura de $80 \mathrm{~cm} \mathrm{X}$ altura de $5 \mathrm{~cm}$ ) e uma pequena (redonda; PVC) com volume de $1.200 \mathrm{~mL}$ e área da base de $0,01815 \mathrm{~m}^{2}$. Concebidas e construídas pela Construmaq São Carlos Ind. e Com Ltda ME, Figura 4.1.1. 


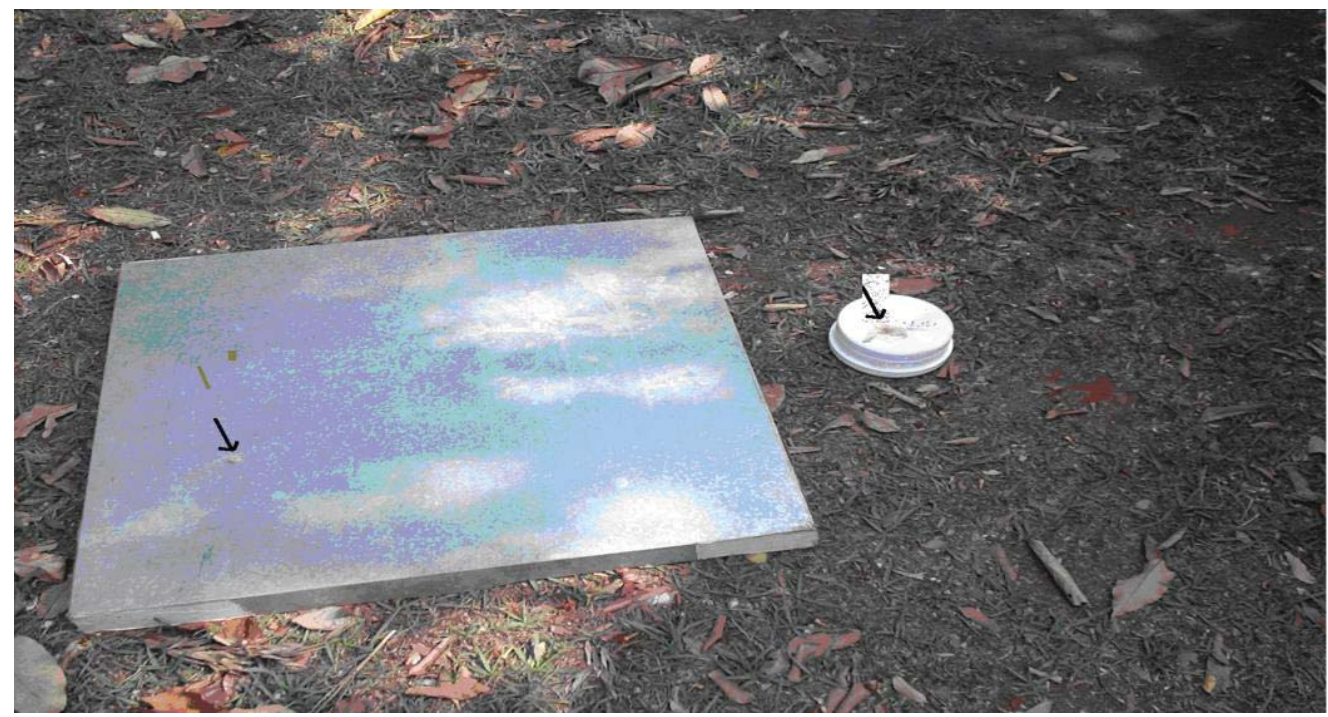

Figura 4.1.1 - Câmaras de difusão de gases (Grande e Pequena). As setas indicam dispositivos de coleta das amostras.

2) Sacos de plásticos de 60 litros.

Para os aterros sanitários (com dissipadores de gases) foram usados sacos de plástico preto de $60 \mathrm{~L}$, para coleta e estimativa do fluxo.

3) Ampolas gasométricas (Construmaq São Carlos).

(a) Primeira Campanha 2006: Foram utilizadas vinte e quatro (24) ampolas gasométricas, com capacidade de $30 \mathrm{~mL}$ cada.

(b) Segunda Campanha 2007: Foram utilizadas quarenta e oito (48) ampolas gasométricas, com capacidade de $30 \mathrm{~mL}$ cada. Figuras 4.1.2a e b. 


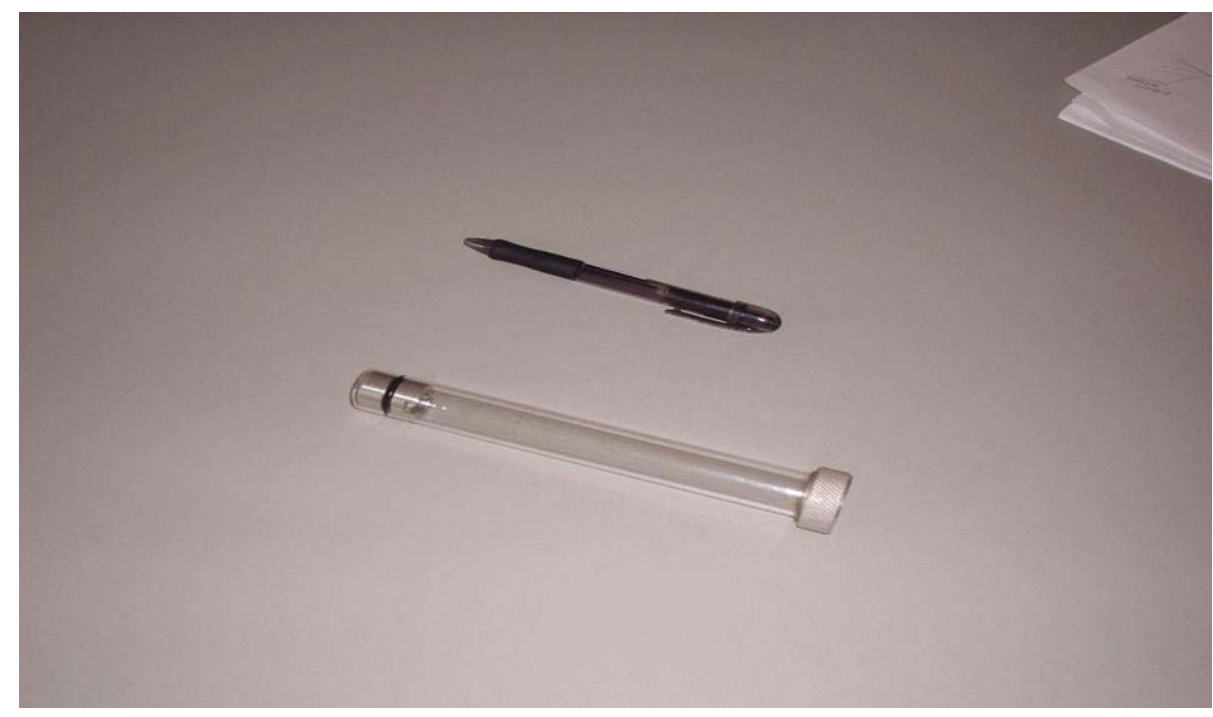

Figura 4.1.2a - Ampola gasométrica de $30 \mathrm{~mL}$.

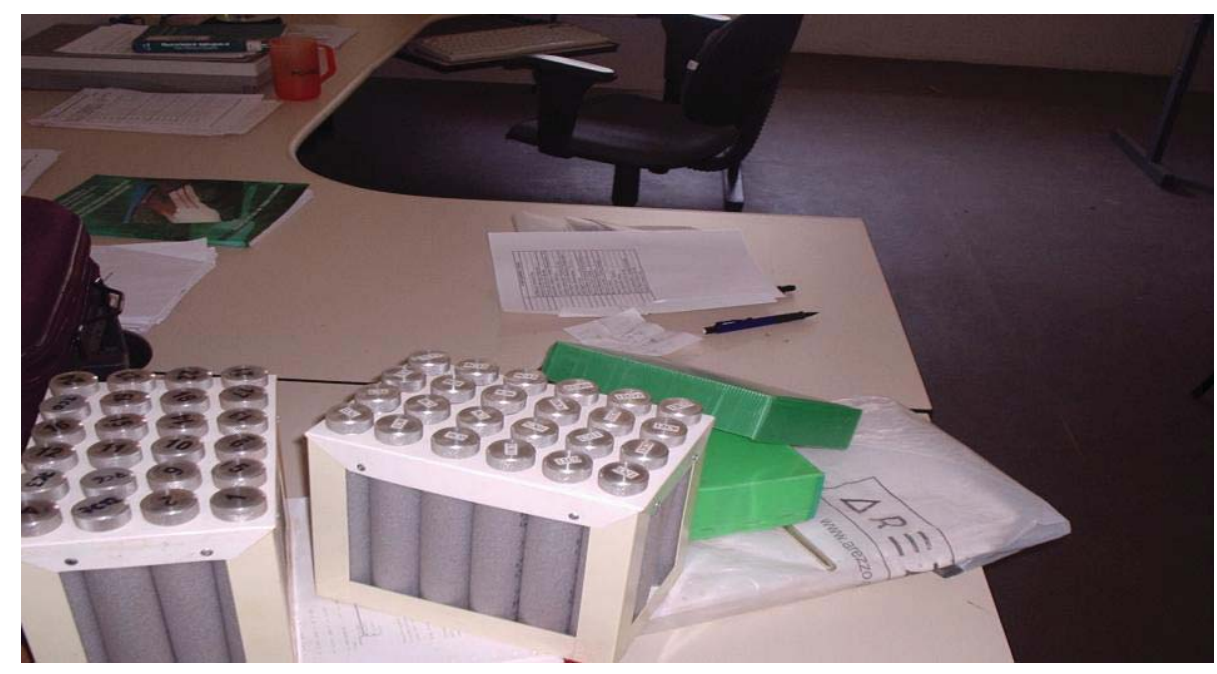

Figura 4.1.2b - Caixas de ampolas gasométricas com 24 unidades cada.

As ampolas gasométricas desenvolvidas e fabricadas pela Construmaq São Carlos Ind. e Com - usadas para coletas in situ, a partir das câmaras de difusão no solo ou dos sacos plásticos nos drenos -, são feitas de vidro com tampas rosqueadas de alumínio. Apresentam válvula e acessórios que simplificam e garantem a coleta e armazenagem/confinamento das amostras de gás de aterros, transporte seguro e injeção cromatográfica, em laboratório. 
As três ferramentas ilustradas abaixo (Figuras 4.1.3), são coletivamente denominadas "kit de transferência". Acompanham as ampolas gasométricas e são necessárias durante o uso das mesmas.

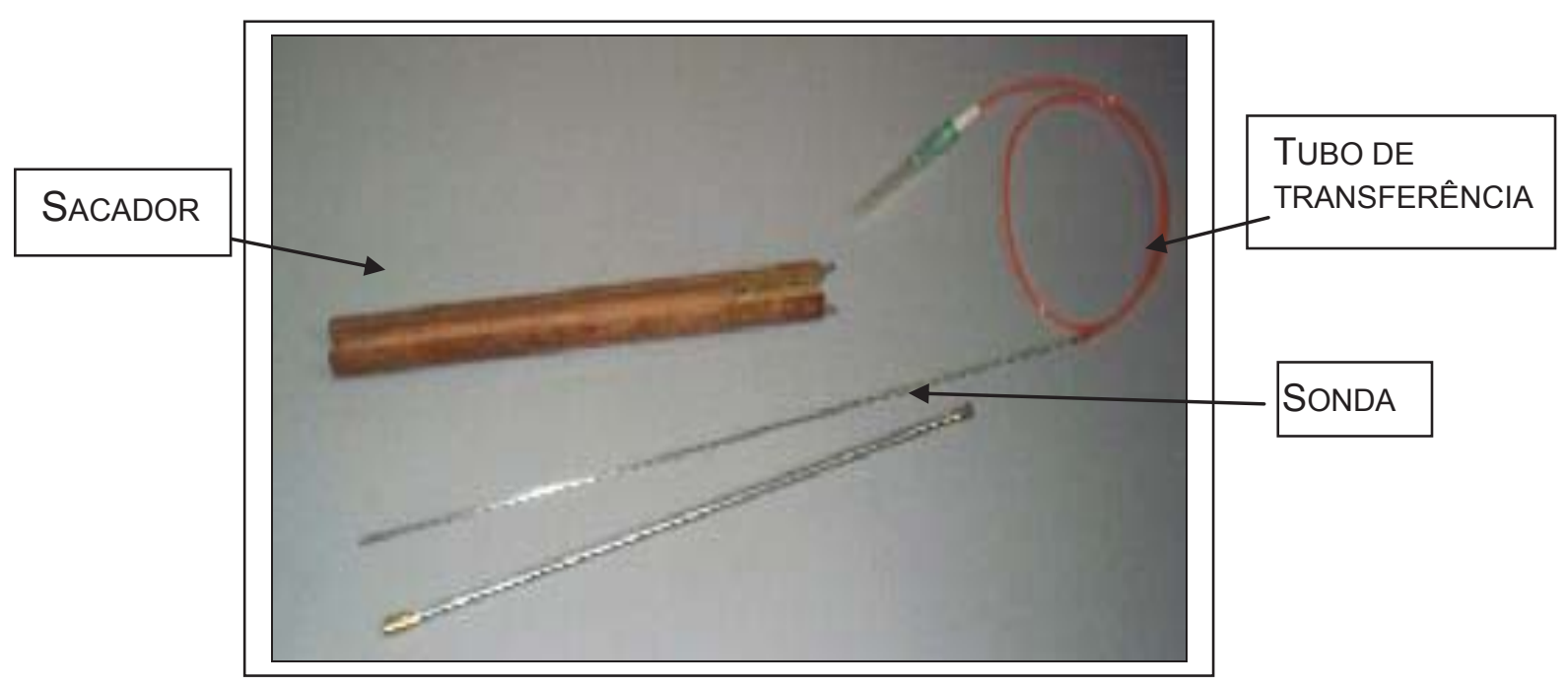

Figura 4.1.3 - O "kit de transferência" usado para armazenar e retirar amostras gasosas das ampolas.

Fonte: Manual de uso das ampolas gasométricas, Construmaq São Carlos, 2006.

Uma válvula localizada no miolo de um pistão e dentro de cada ampola permite a captação controlada das amostras; estando aberta quando se encontra empurrada no sentido do fundo da ampola (Figura 4.1.4a) e fechada na posição em que fica faceada ou alinhada com o pistão (Figura 4.1.4b): 


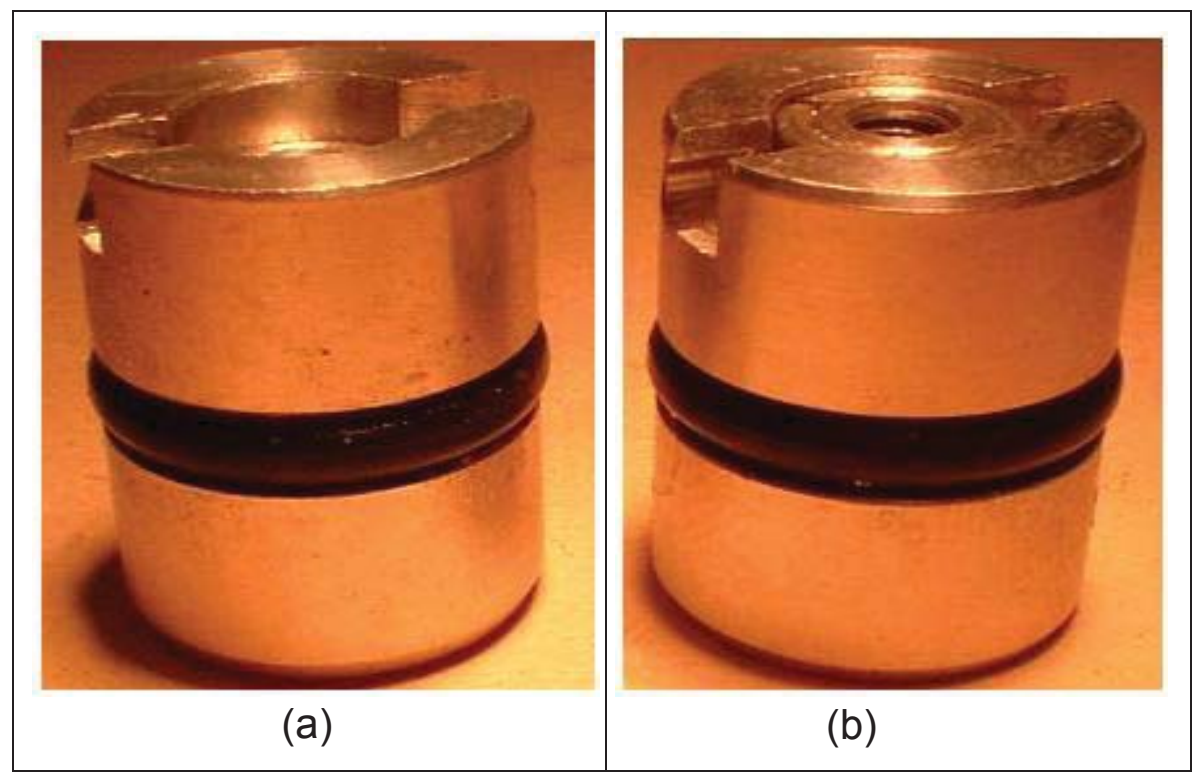

Figura 4.1.4 - Válvula aberta (a) e fechada (b). Fonte: Construmaq São Carlos, 2006.

A figura 4.1.5, mostra detalhes da operação com as ampolas; como rosqueamento/desrosqueamento da tampa (a), inserção do sacador na sonda (b), conjunto ampola/sacador/sonda montado (c) e o conjunto ampola/sacador/tubo de transferência montado, pronto para coleta. 


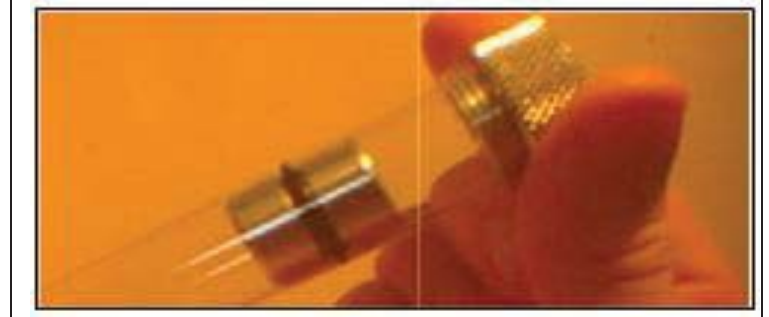

(a)

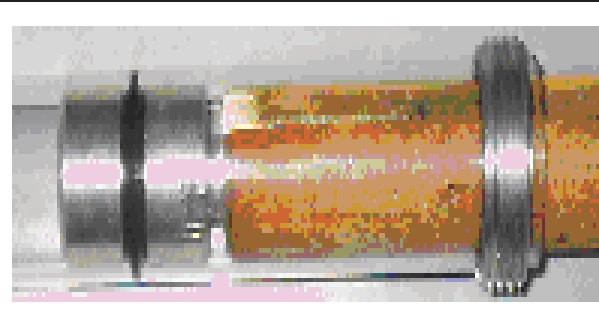

(b)

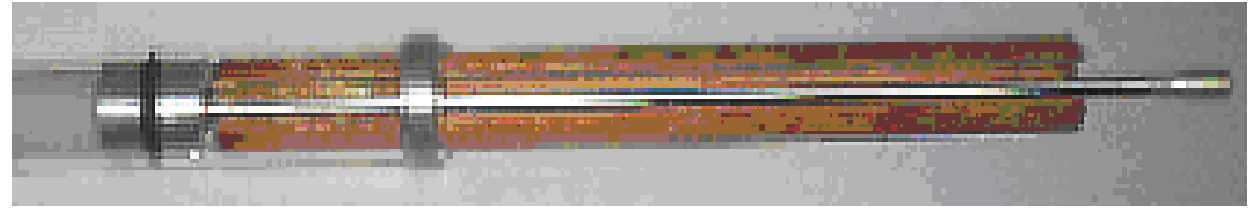

(c)

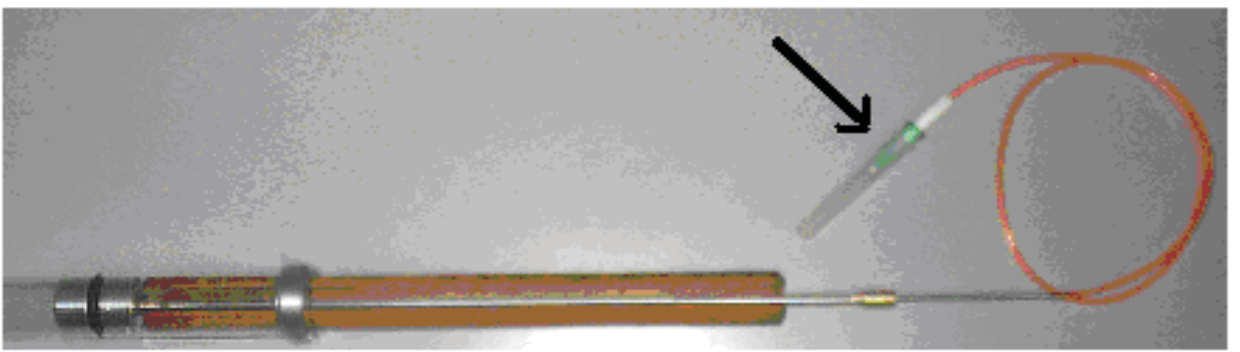

(d)

Figura 4.1.5 - Rosqueamento da tampa da ampola (a), inserção do sacador/sonda (b), conjunto ampola/sacador/sonda (c) e o conjunto ampola/sacador/tubo de transferência, montado(d). Destaque $(\rightarrow)$ (d) para agulha de transferência (insere-se no dispositivo de silicone nas câmaras).

Fonte: Construmaq São Carlos, 2006.

4) 01 pá de jardinagem;

5) Termômetro (espeto; termopar) - medidas de temperatura do solo e ambiente;

6) Anemômetro e cronômetro;

7) Aparelho GPS;

8) câmara fotográfica. 
B) No laboratório:

1) Equipamento: Gas Cromatograph - GOW MAC Instruments Co.; Detector por Condutividade Térmica(DCT); $50^{\circ} \mathrm{C}$; Fluxo de $\mathrm{H}_{2}$ de $60 \mathrm{~mL} \cdot \mathrm{min}^{-1}$, com Coluna Porapak Q, aço inoxidável. Registrador em papel (cromatogramas) contínuo.

2) Microseringas hipodérmicas para injeção da amostra retirada da ampola, no cromatógrafo.

As análises cromatográficas foram desenvolvidas no Laboratório de Produtos Biológicos (LPB) - SHS/EESC-USP, sempre em horário seguinte às coletas nos aterros.

O cromatógrafo foi calibrado para as análises de metano $\left(\mathrm{CH}_{4}\right)$ e dióxido de carbono $\left(\mathrm{CO}_{2}\right)$, segundo curvas de calibração constantes do anexo C. 


\subsection{Metodologia de trabalho}

Nos aterros sanitários, com sistema vertical de coleta do GAS (dissipadores), as amostras eram colhidas a partir de um saco plástico preto $(60 L)$ colocado vazio na extremidade superior do dissipador (ajustadas, boca do dissipador/boca do saco). Iniciava-se, a coleta disparando um cronômetro para medir o tempo de preenchimento do saco pelo GAS, o que se permite estimar a vazão.

Com o saco completo, era retirada uma amostra $(30 \mathrm{~mL})$ do GAS em uma ampola gasométrica para análise quali-quantitativa por cromatografia gasosa (CG).

Os aterros dos municípios selecionados foram 'trans-sectados', vertical e horizontalmente, em toda a sua extensão, de modo que cada cruzamento de linhas determinasse um ponto de amostragem dos gases emanados do aterro para a amostragem de emissão solo-ar. O número de pontos de coleta variou de 4 a 12, dependendo do tamanho do aterro e do número de ampolas gasométricas em cada campanha, 24 na primeira (2006) e 48 na segunda (2007).

As amostras da emissão solo-ar foram coletadas em ampolas gasométricas com capacidade para $30 \mathrm{~mL}$ cada (Figura 4.1.2a e b, anterior), a partir de câmaras de difusão de gases - uma grande e uma pequena (Figura 4.1.1, anterior) - com áreas das bases e volumes definidos, em quatro tomadas, com intervalos de três (3), seis (6) e doze (12) minutos, a partir da tomada de tempo zero (0). Estas eram coletadas em local da área do aterro correspondente à área de base das câmaras, procurando-se não produzir "qualquer perturbação prévia", após 
"purga ambiental de cada câmara", ou seja, "lavagem" da câmara com o ar ambiente e selagem da mesma com terra do próprio local, no solo.

As amostras eram colhidas (Figura 4.2.1) a partir de um dispositivo de silicone na parte superior das câmaras, onde se insere uma agulha hipodérmica localizada na extremidade do tubo transferidor, oposta ao fundo da ampola gasométrica (Figura 4.1.5d, anterior, destaque) e eram levadas ao laboratório para análises quali-quantitativas dos gases captados, por cromatografia gasosa.

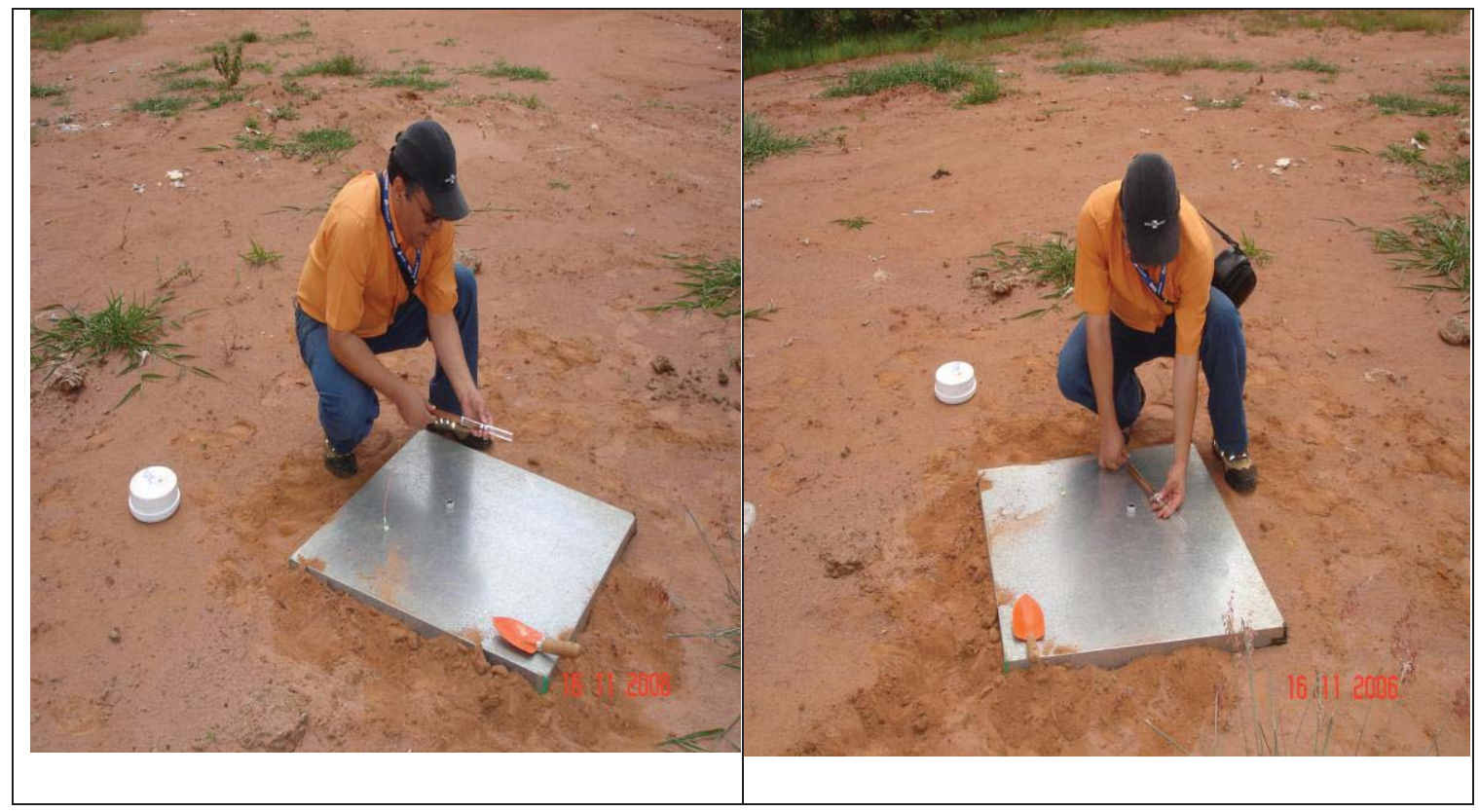

Figura 4.2.1 - Detalhe da coleta de amostras do GAS (solo-ar).

Como as viagens de campo - coletas nos aterros - foram feitas/iniciadas, sempre a partir do inicio do dia, e, muitas vezes, em dias sequentes, as análises cromatográficas eram feitas sempre ao final da tarde e início da noite, com um intervalo mínimo de 6 a 10 horas após a coleta. 
Imediatamente, após as análises, cada ampola era esvaziada, 'purgada com ar atmosférico' fora do ambiente do laboratório e deixada aberta em ambiente arejado até o reinício da amostragem do dia seguinte. Com este procedimento garantia-se a não 'contaminação' das ampolas com o gás do aterro do dia anterior.

A determinação da taxa de emissão fugitiva do $\mathrm{CH}_{4}$ e do $\mathrm{CO}_{2}$, na área amostrada era feita a partir das áreas dos cromatogramas correspondentes e das equações resultantes das curvas de calibração do cromatógrafo (vide Anexo C); comparando-se o volume do gás de aterro injetado na cromatografia, o volume coletado em cada ampola, o volume e a área da base das câmaras.

O resultado encontrado para taxa de emissão média calculada nos $\boldsymbol{n}$ sítios $\left(P_{n}\right)$ amostrados, multiplicado pela área do aterro, resulta uma estimativa da taxa média de emissão de cada aterro.

Estes resultados foram discutidos, levando-se em consideração fatores como a idade de aterro, a quantidade de resíduos nele confinada, entre outras variáveis que possam influenciar nas taxas de emissões. 


\subsection{1 - Determinação instrumental do metano e do dióxido de carbono - Cromatografia Gasosa (CG).}

Tomando como referências textos tradicionais em Química Ambiental e Cromatografia Gasosa (BAIRD, 2002; STERN, KAUFMANN, 1996; LANÇAS, 1993; CIOLA, 1985; LAUB, PECSOK, 1945), além de sítios na internet como (CHEMKEYS, 2007; AGA, 2006), relatamos neste item alguns fundamentos desta poderosa técnica na determinação qualiquantitativa de misturas com constituintes gasosos, caso deste trabalho.

A determinação qualiquantitativa de gases em uma mistura; como é o caso do gás de aterros sanitários (GAS), pode ser realizada pela análise de amostras da mistura, usando a técnica da cromatografia gasosa (CG). É uma técnica muito precisa e um meio de separar uma mistura gasosa em seus componentes individuais, através de um instrumento muito sensível, o Detector por Condutividade Térmica (DCT) para, efetivamente, medir qualitativa e quantitativamente os componentes ou analitos separados.

Na Cromatografia Gasosa (CG) a amostra é introduzida e vaporizada em um fluxo de um gás adequado, denominado de fase móvel (FM) ou gás de arraste (Figura 4.2.1.1, 01).

A fase móvel é um gás inerte - normalmente nitrogênio ou hélio - ou hidrogênio. Se a fase estacionária é um líquido temos a cromatografia gás-líquido ou cromatografia de partição, se a fase estacionária é um sólido temos a cromatografia gás-sólido ou cromatografia de adsorção. Em qualquer dos casos a coluna pode ser de empacotamento ou capilar aberta de sílica fundida. Deve-se 
conhecer a resolução - definida como a capacidade que tem uma coluna cromatográfica, de separar satisfatoriamente dois picos adjacentes - e a eficiência definida como sua capacidade de produzir picos estreitos e agudos - da coluna para a amostra a ser analisada.

O fluxo de gás da fase móvel com a amostra vaporizada passa por um tubo contendo a fase estacionária FE (coluna cromatográfica), onde ocorre a separação da mistura. A FE pode ser um sólido adsorvente (Cromatografia GásSólido) ou, mais comumente, um filme de um líquido pouco volátil, suportado sobre um sólido inerte (Cromatografia Gás-Líquido com Coluna Empacotada ou Recheada) ou sobre a própria parede do tubo (Cromatografia Gasosa de Alta Resolução).

$\mathrm{Na}$ cromatografia gasosa, os dois fatores que governam a separação dos constituintes de uma amostra são:

a solubilidade na FE: quanto maior a solubilidade de um constituinte da mistura gasosa na FE, mais lentamente ele caminha pela coluna;

a volatilidade: quanto mais volátil a substância (ou, em outros termos, quanto maior a pressão de vapor), maior a sua tendência de permanecer vaporizada e mais rapidamente caminha pelo sistema.

As substâncias separadas saem da coluna dissolvidas no gás de arraste e passam por um detector; dispositivo que gera um sinal elétrico proporcional à quantidade de cada componente eluído.

O registro deste sinal em função do tempo é o cromatograma, sendo que, as substâncias aparecem nele como picos com área proporcional à sua massa, o que possibilita a análise quantitativa (Figura 4.2.1.1, 04). 
O poder de análise da cromatografia gasosa se baseia em sua capacidade de separar os componentes individuais de uma mistura injetada em uma coluna cromatográfica, e identificar cada componente, à medida que saem da coluna, um após outro.

O processo de separação por CG ocorre quando os componentes gasosos de uma mistura, sob influência da temperatura da coluna, da superfície cromatográfica e de um gás de arraste, em fluxo constante, sofrem uma série de interações não-destrutivas com a superfície cromatográfica conforme atravessam a coluna. Dado que cada composto ou componente individual a ser separado, interage de maneira diferenciada com a superfície da coluna cromatográfica, o resultado é um tempo de percurso diferente para cada composto e, portanto, um tempo de saída ou tempo de retenção individual.

Colunas capilares de CG de alta-resolução, projetadas para separar literalmente centenas de compostos presentes em uma mistura, apresentam um diâmetro interno reduzido, menor que 0,53 mm. Muitas superfícies cromatográficas diferentes encontram-se disponíveis; cada uma é projetada para separar famílias de analitos distintas. Para a família da parafinas, p.ex., superfícies cromatográficas ou fases apolares são utilizadas.

O sistema CG apresenta três elementos básicos: o injetor, a coluna cromatográfica e o detector. A coluna cromatográfica é conectada ao injetor CG, no qual uma amostra mínima da mistura gasosa é inicialmente introduzida na coluna. Esta coluna - cuja temperatura é controlada por um pequeno forno - termina na base do DCT, no qual cada analito de saída é detectado.

O resultado dos analitos no método cromatográfico é registrado em gráficos chamados cromatogramas, que em geral registram o tempo de retenção 
versus o sinal do detector. A análise cuidadosa do cromatograma nos fornece dados como a identidade, baseada em padrões conhecidos, e a quantidade de cada um dos componentes presentes na amostra analisada.

A figura 4.2.1.1, mostra um esquema de um sistema de cromatografia gasosa, com indicação dos seus principais componentes e o registro de um cromatograma em andamento. 


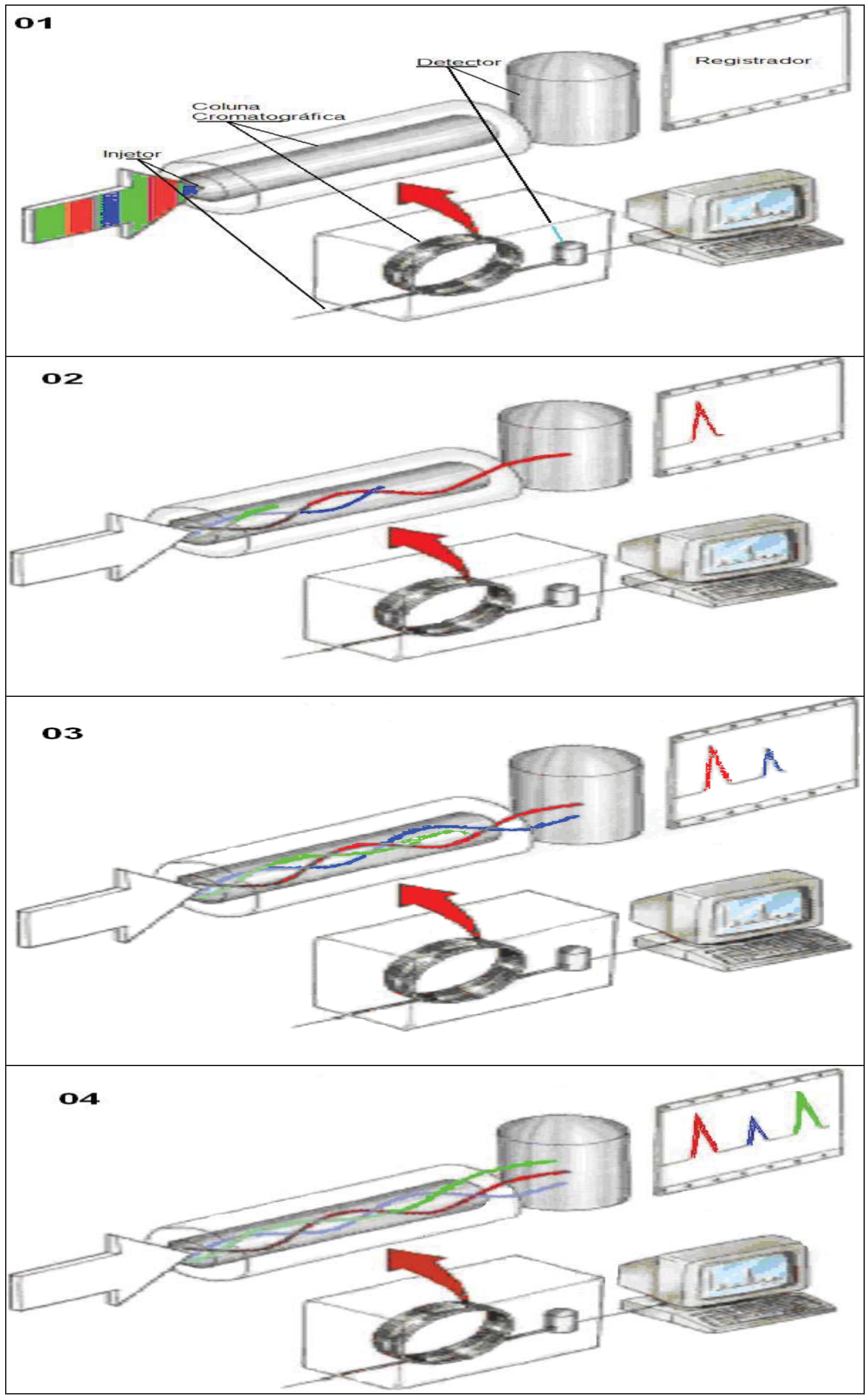

Figura 4.2.1.1 - Sistema CG. Componentes (01) e evolução de cromatogramas (02 a 04)

Fonte: Adaptado de CHEMKEYS, 2007. 


\title{
5. CARACTERIZAÇÃO DAS ÁREAS DE ESTUDO
}

\author{
“Que Saberá a Mata? Que PEDirá a Mata? Pedirá ÁGua."
}

MANUEL BANDEI RA

A figura 5.1, mostra a localização geográfica - em relação à América do Sul, ao Brasil, ao Estado de São Paulo e sua Unidades de Gerenciamento de Recursos hídricos - dos municípios em cujos aterros este trabalho foi desenvolvido.

A Companhia Ambiental do Estado de São Paulo, CETESB (2006), desenvolve diversos trabalhos de levantamento e avaliações sobre as condições ambientais e sanitárias dos locais de destinação final dos resíduos sólidos urbanos nos municípios paulistas. Com a organização e sistematização das informações que obtém, a partir de 1997, compõe o Inventário Estadual de Resíduos Sólidos Domiciliares do Estado (IERSD).

Toda a política pública projetada para o Estado, na área ambiental, tem como referência as Unidades de Gerenciamento de Recursos Hídricos (UGRHI's), nas quais cada município está inserido, como mostrado nas figuras 5.1 e 5.2; mapas do estado de São Paulo e suas UGRHI's; com destaque - na figura 5.2, em branco - para aquelas cujos municípios, foram objetos deste trabalho, pertencem. 


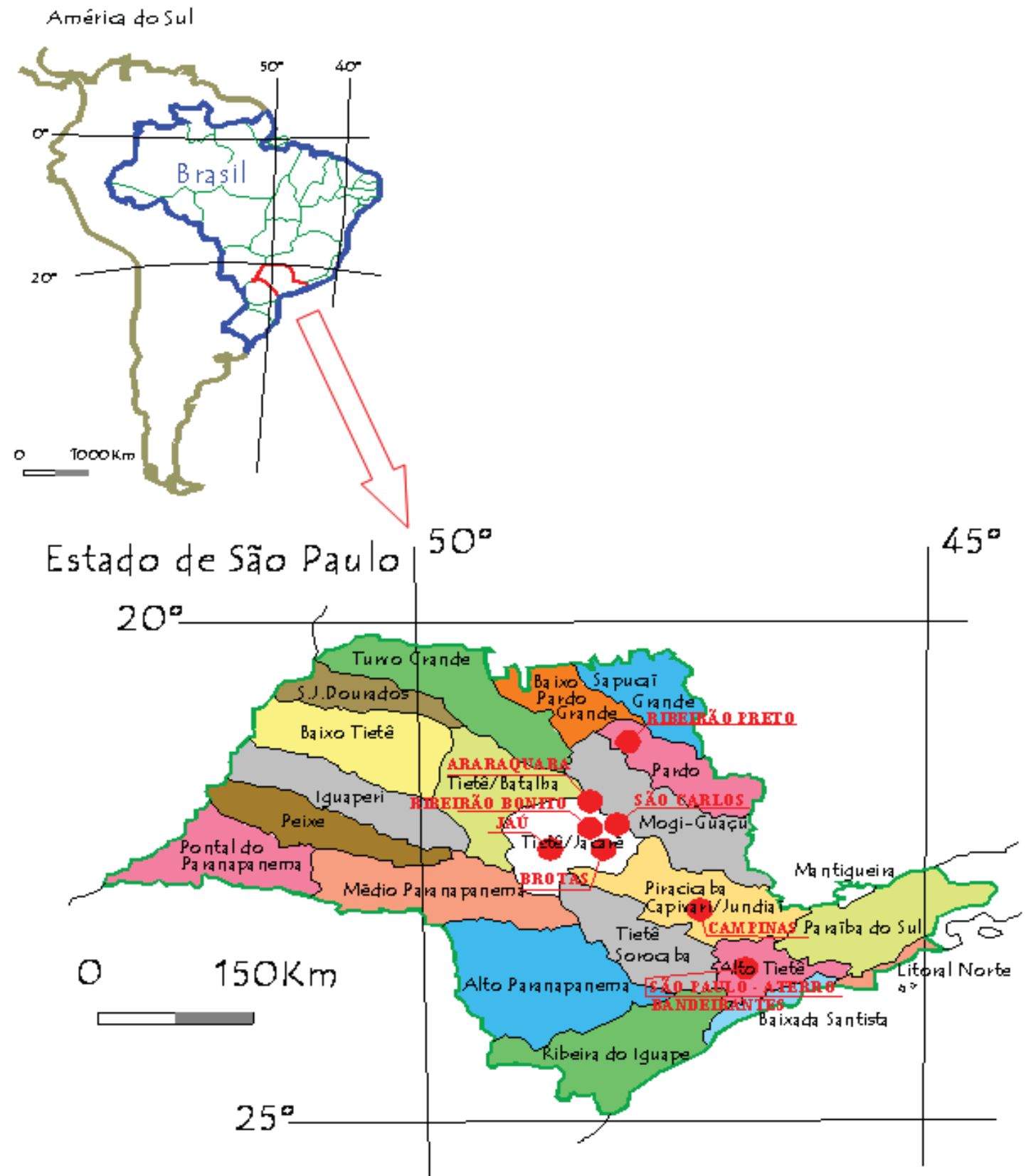

Figura 5.1 - Localização geográfica dos municípios/aterros estudados em relação à América do Sul, Brasil, Estado de São Paulo e suas UGRHI's.

Fonte: Adaptado de Matos (2006).

O IERSD/CETESB/2005 mostra as condições em que se encontram os sistemas de disposição e tratamento finais, em operação, a partir de dados e 
informações coletadas e consolidadas em 2005 nos 645 municípios do Estado.

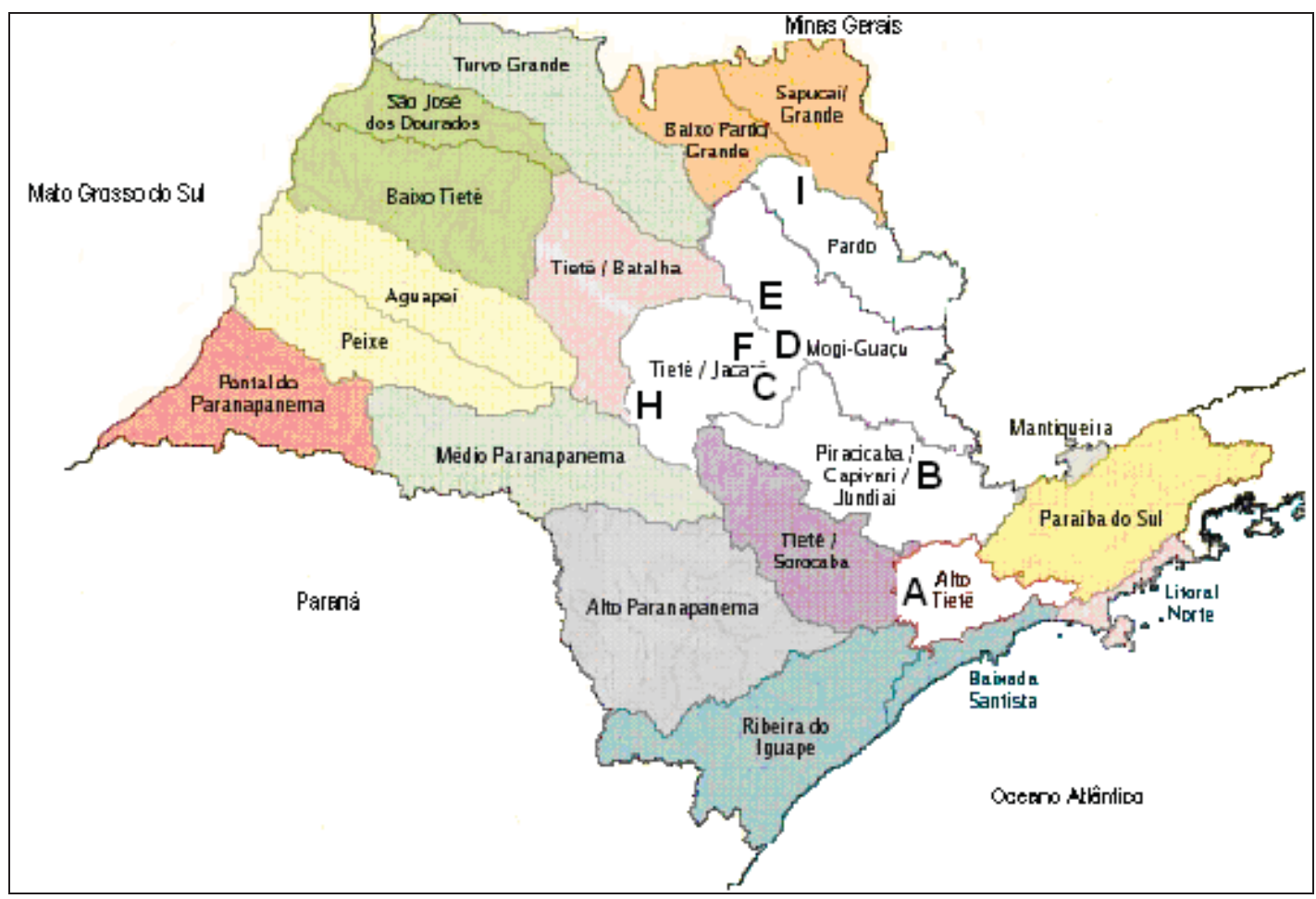

Figura 5.2. Mapa do Estado de São Paulo, Brasil, seus limites e as UGRHI dos

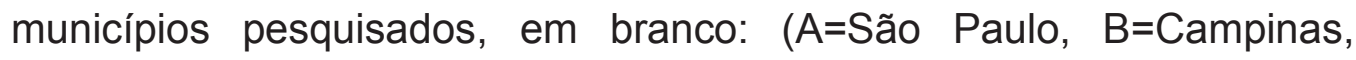
$\mathrm{C}=$ Ribeirão Bonito, $\mathrm{D}=\mathrm{São}$ Carlos, E=Araraquara, $\mathrm{F}=$ Brotas, $\mathrm{H}=\mathrm{Jaú} \mathrm{e}$ I=Ribeirão Preto).

Fonte: <http://www.rededasaguas.org.br> Com adaptações. Acesso em: 26 jul. 2006.

No IERSD são levantadas as condições relativas às características locacionais, estruturais e operacionais, de cada local e instalações de tratamento e de disposição, que são expressas pelos: Índice de Qualidade de Aterro de Resíduos

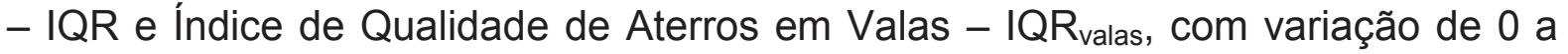
10, e os classifica em três faixas de enquadramento: Inadequada (I), Controlada(C) e Adequada (A). Tabela 5.1, a seguir. 
Tabela 5.1 - Enquadramento das condições das instalações de tratamento e/ou disposição final dos RSD em função dos indicadores IQR e IQR valas dos municípios Paulistas.

\begin{tabular}{c|c}
\hline$I Q R / I Q R_{v}$ & \multicolumn{1}{|c}{ Enquadramento } \\
\hline 0,0 a 6,0 & Condição Inadequada $(\mathrm{I})$ \\
6.1 a 8,0 & Condição Controlada $(\boldsymbol{C})$ \\
8,1 a 10,0 & Condição Adequada $(\boldsymbol{A})$ \\
\hline
\end{tabular}

Fonte: CETESB (2007).

A tabela 5.2, seguinte, retrata os dados resultantes deste levantamento, no IERSD/2005, acrescida de dados da: UGRHI, populacionais, massa de RS disposta por dia, IQR e enquadramento (2005).

Tabela 5.2 - UGRHI's, população coberta pela coleta e geração de RSU's, IQR e enquadramento dos municípios.

\begin{tabular}{|c|c|c|c|c|c|}
\hline Município & $\mathrm{UGRHI}^{\mathrm{b}}$ & $\begin{array}{c}\text { Número } \\
\text { de habitantes }^{a}\end{array}$ & $\begin{array}{c}\text { RSU's }^{b} \\
\text { (t/dia }-2005)\end{array}$ & $\begin{array}{l}R^{b} \\
(2005)\end{array}$ & $\begin{array}{c}\text { Enquadramento } \\
\text { do aterro }\end{array}$ \\
\hline Araraquara & 13 & 197034 & 110,0 & 9,1 & $A$ \\
\hline Brotas & 13 & 21695 & 7,5 & 9,8 & $A$ \\
\hline Campinas & 05 & 1045706 & 718,4 & 8,8 & $A$ \\
\hline Jaú & 13 & 123374 & 59,0 & 5,2 & I \\
\hline R. Bonito & 13 & 11821 & 4,2 & 9,5 & A \\
\hline R. Preto & 04 & 551312 & 384,3 & 8,7 & $A$ \\
\hline São Carlos & 13 & 214760 & 123,0 & 9,1 & A \\
\hline $\begin{array}{l}\text { São Paulo } \\
\text { (Capital) }^{\text {d }}\end{array}$ & 06 & 4200000 & 7500,0 & 9,1 & A \\
\hline Totais & - & 6365702 & 8961,9 & - & - \\
\hline
\end{tabular}

Fontes: a - IBGE, 2005. Estimativa de 01/07/2005. Pressupõe-se cobertura total pela coleta regular de RSU's.

b - CETESB, 2005.

c - O aterro de Araraquara também recebe os RSU's dos municípios de Américo Brasiliense (13,4 t/dia) e Santa Lúcia (3,2 t/dia).

d - População coberta pela coleta que se destinava ao aterro Bandeirantes, quando foi desativado (ARAUJO, 2009). 
Ainda segundo o IERSD/CETESB (2005), o acompanhamento e a evolução destes índices permitem aferir os resultados das ações de controle da poluição ambiental desenvolvidas no Estado, monitorar a eficácia dos programas alinhados com as políticas públicas estabelecidas para o setor, além de aprimorar os mecanismos de controle, especialmente, no que respeita ao tratamento e à disposição final, dados aos resíduos sólidos urbanos.

A tabela 5.3, apresenta a evolução anual do IQR, nos municípios pesquisados, tomando por base o IERSD/CETESB (2007), e considerando os anos de 2000 a 2007. Acrescentou-se a quantidade de resíduos dispostos nos aterros, desde o início de suas operações, até a nos de 2007, com informações das respectivas administrações municipais.

Tabela 5.3 - Evolução anual do IQR dos municípios estudados, de 2002 a 2007; enquadramento 2007 e a quantidade de resíduos dispostos em cada aterro até setembro de 2007.

\begin{tabular}{|c|c|c|c|c|c|c|c|c|c|c|}
\hline \multirow[b]{2}{*}{ Município } & \multicolumn{8}{|c|}{ Ano } & \multirow[t]{2}{*}{$E *$} & \multirow{2}{*}{$\mathrm{Q} * * \mathrm{X} 10^{3}(\mathrm{t})$} \\
\hline & 2000 & 2001 & 2002 & 2003 & 2004 & 2005 & 2006 & 2007 & & \\
\hline Araraquara & 6,2 & 6,5 & 6,9 & 6,8 & 7,1 & 9,1 & 8,5 & 5,6 & (I) & $2.378,00$ \\
\hline Brotas & 8,8 & 6,8 & 6,3 & 8,6 & 8,8 & 9,8 & 7,5 & 7,0 & (C) & 25,00 \\
\hline Campinas & 6,5 & 6,6 & 8,2 & 8,5 & 8,7 & 8,8 & 8,6 & 8,6 & (A) & $4.334,71$ \\
\hline Jaú & 4,0 & 6,1 & 6,4 & 6,6 & 5,5 & 5,2 & 5,5 & 4,5 & (I) & 670,00 \\
\hline Ribeirão Bonito & 5,5 & 4,5 & 9,6 & 9,5 & 9,1 & 9,3 & 7,6 & 7,2 & (C) & 32,60 \\
\hline Ribeirão Preto & 7,6 & 8,5 & 9,6 & 9,8 & 9,8 & 8,7 & 6,8 & 6,3 & (C) & $2.342,26$ \\
\hline São Carlos & 8,3 & 8,7 & 8,0 & 6,8 & 6,8 & 9,1 & 9,0 & 10,0 & (A) & 608,90 \\
\hline $\begin{array}{l}\text { São Paulo } \\
\text { (Bandeirantes) }\end{array}$ & 8,6 & 9,0 & 9,0 & 8,8 & 8,0 & 9,1 & 9,1 & - & (A) & $35.000,00$ \\
\hline
\end{tabular}

E* = Enquadramento IERSD (2007)

Q** = Quantidade de Resíduos dispostos até setembro de 2007(Toneladas).

Fonte: IERSD-IQR/Enquadramento (CETESB, 2007); Q** (Admin. Mun./Aterros). 
Como objeto deste trabalho, pode ser observado a partir na tabela 5.2, uma cobertura que abrangeu $16,1 \%$ - correspondendo a 6,4 milhões de habitantes do total de 39,6 milhões - da população do Estado de São Paulo. No que diz respeito à Capital do Estado, o levantamento abrangeu $38,8 \%$ da população - 4,2 milhões de habitantes de um total de 10,8 milhões (ARAÚLO, 2008; IBGE, 2007f).

Os municípios selecionados estão geograficamente dispostos, no sentido leste-centro no Estado de São Paulo, conforme se pode ver na figura 5.3, e suas áreas têm assento nas seguintes Unidades de Gerenciamento de Recursos Hídricos (UGRHI):

- Araraquara, Brotas, Jaú, Ribeirão Bonito e São Carlos na UGRHI-13 Tietê/Jacaré;

- Campinas na UGRHI-05 - Piracicaba/Capivari/Jundiaí;

- Ribeirão Preto na UGRHI-04 - Pardo, e

- São Paulo na UGRHI-06 - Alto Tietê.

Ou seja, cinco municípios a UGRHI 13, um município na UGRHI 05, um na UGRHI 04 e um aterro (Bandeirantes, Capital) na UGRHI 06. 


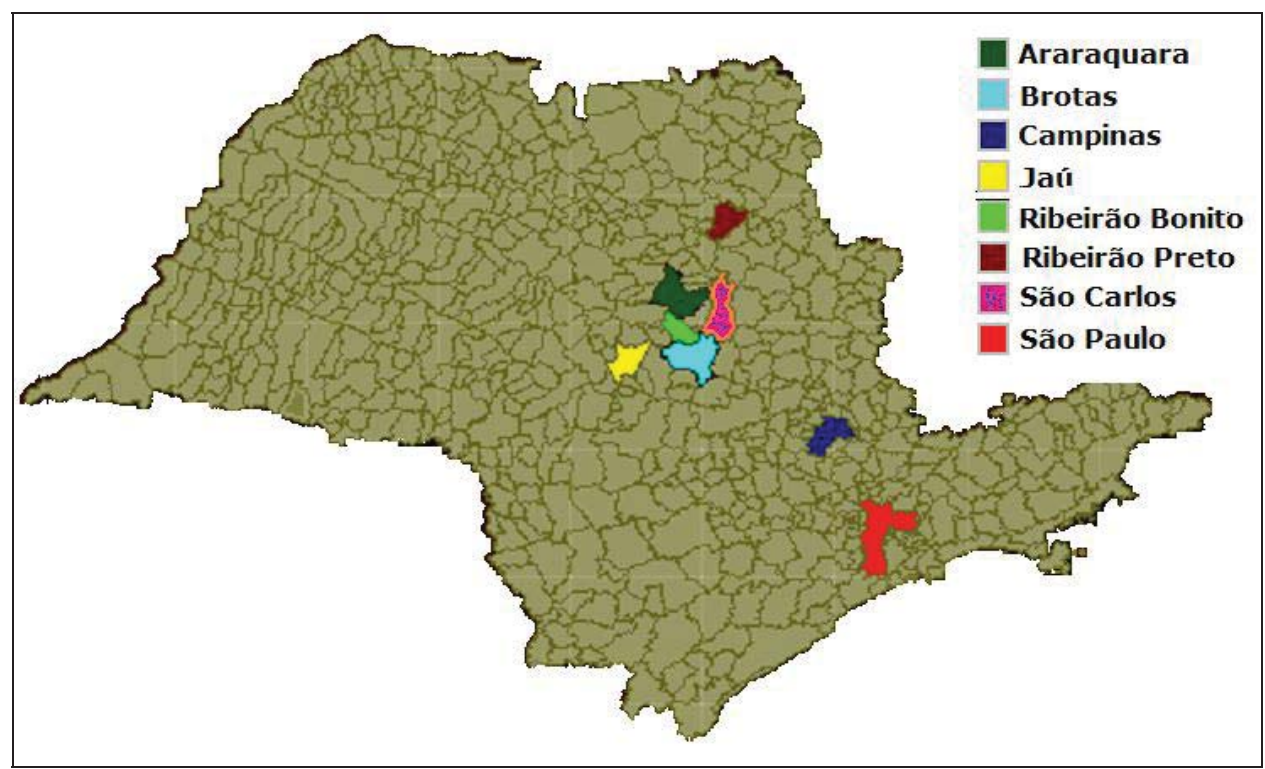

Figura 5.3 - Mapa do Estado de São Paulo com destaque dos Municípios estudados.

Fonte: <http://www.rededasaguas.org.br> Com adaptações. Acesso em: 26 jul. 2006.

Mostra-se, a seguir, informações sobre o PIB e a renda per capta dos municípios nos quais foram feitas as pesquisas, entre os anos 2000 a 2003, tabela 5.4 . 
Tabela 5.4 Evolução do Produto Interno Bruto (PIB) a preços correntes e Produto Interno Bruto per capta dos municípios pesquisados, 2000-2003.

\begin{tabular}{|c|c|c|c|c|c|c|c|c|}
\hline \multirow[b]{3}{*}{ Município } & \multicolumn{8}{|c|}{ Produto Interno Bruto } \\
\hline & \multicolumn{2}{|c|}{2000} & \multicolumn{2}{|c|}{2001} & \multicolumn{2}{|c|}{2002} & \multicolumn{2}{|c|}{2003} \\
\hline & $\begin{array}{c}\text { PIB } \\
(1000 \mathrm{R} \$)\end{array}$ & $\begin{array}{l}\text { Per } \\
\text { capta } \\
\text { (R\$) }\end{array}$ & $\begin{array}{c}\text { PIB } \\
(1000 \mathrm{R} \$)\end{array}$ & $\begin{array}{l}\text { Per } \\
\text { capta } \\
\text { (R\$) }\end{array}$ & $\begin{array}{c}\text { PIB } \\
(1000 \mathrm{R} \$)\end{array}$ & $\begin{array}{l}\text { Per } \\
\text { capta } \\
(\mathrm{R} \$)\end{array}$ & $\begin{array}{c}\text { PIB } \\
(1000 \mathrm{R} \$)\end{array}$ & $\begin{array}{l}\text { Per capta } \\
\text { (R\$) }\end{array}$ \\
\hline Araraquara & 1.534 .934 & 8.343 & 1.658 .281 & 8.889 & 1.777 .772 & 9399 & 2.266 .687 & 11.819 \\
\hline Brotas & 171.269 & 8.931 & 296.372 & 15.066 & 387.141 & 19190 & 386.675 & 18.698 \\
\hline Campinas & 10.010 .892 & 10.244 & 10.616 .569 & 10.716 & 10.820 .585 & 10773 & 13.005 .591 & 12.774 \\
\hline Jaú & 644.616 & 5.691 & 675.329 & 5.859 & 738.231 & 6295 & 824.588 & 7.063 \\
\hline R. Bonito & 78.858 & 6.976 & 119.922 & 10.513 & 142.406 & 12373 & 179.518 & 15.458 \\
\hline R. Preto & 3.907 .340 & 7.666 & 3.868 .267 & 7.469 & 4.062 .181 & 7720 & 5.020 .808 & 9.393 \\
\hline São Carlos & 2.031 .373 & 10.404 & 2.115 .162 & 10.624 & 2.313 .959 & 11400 & 2.472 .750 & 11.951 \\
\hline São Paulo & 127.437 .119 & 12.154 & 134.306 .169 & 12.703 & 140.066 .059 & 13139 & 146.855 .265 & 13.661 \\
\hline
\end{tabular}

Fonte: IBGE, 2005b. 


\subsection{Aterro controlado do município de Araraquara, São Paulo.}

Segundo informações da GORES/DAAE - Araraquara $(2007)^{1}$, o aterro controlado do município tem 32 (trinta e dois) anos de atividades. Começou como lixão a céu aberto em 1975 e assim foi operado até 1990, passando a partir daí a receber constantes melhorias como compactação e cobertura do lixo, execução de drenagem do chorume, dissipadores/queimadores de gases, etc... Em 2003 a Prefeitura Municipal de Araraquara passou ao Departamento Autônomo de Águas e Esgotos (DAAE) a gestão dos Resíduos Sólidos Urbanos (RSU) e o DAAE criou a Gerência de Operação do Sistema de Resíduos Sólidos (GORES), que administra um complexo denominado Estação de Tratamento de Resíduos Sólidos (ETRS). Este sistema atende a uma população de 195.815 munícipes, que produzem 165 toneladas de RS por dia.

A ETRS de Araraquara é, na verdade, um complexo constituído por:

- Uma Central de Triagem e Recicláveis;

- Uma Unidade de Tratamento de Resíduos de Serviços de Saúde (Incinerador); e,

- Aterro Controlado (Disposição final).

O aterro controlado de Araraquara está localizado nas coordenadas $21^{\circ} 45^{\prime} \mathrm{S}$ e $48^{\circ} 07^{\prime} \mathrm{W}$. Ainda segundo a GORES/DAAE (2007) é impossível calcular a massa ou volume de resíduos depositados até hoje no aterro, pois nos seus primórdios era constituído por um grande "buraco" deixado pela extração de terra para execução de obras no município. Este buraco, do qual não se conhece as

\footnotetext{
${ }^{1}$ Comunicação Pessoal de Agamemnon Brunetti Junior - GORES/DAAE-Araraquara/SP BERTO NETO, J. (2009). - Medidas da Emissão de Gases de oito aterros de resíduos sólidos urbanos do Estado de São Paulo - Brasil. Tese apresentada ao PPG-SEA/CRHEA - EESC/USP. São Carlos-SP, Dez. 2009.
} 
exatas dimensões de profundidade, largura e comprimento, foi sendo preenchido com lixo até chegar ao nível natural do terreno.

Hoje a célula do aterro, em seu ponto mais alto, em relação ao terreno primitivo, está com, aproximadamente, 22 metros de altura.

O volume da célula existente, na sua porção "não enterrada" é de, aproximadamente, 2.378.000 toneladas. A área total do aterro é de $80.000 \mathrm{~m}^{2}$.

Estima-se (GORES/DAAE,2007) em 60\% (massa) a porção orgânica dos resíduos depositados no aterro.

O aterro de Araraquara conta com uma usina de reciclagem que opera com, aproximadamente, $60 \%$ do total dos resíduos coletados no município - da ordem de 150 t/d - e na triagem são separadas 3 t/d de recicláveis. Os outros 40\% vão diretamente para o aterro.

No município a coleta seletiva, que desde 2005 atendia a aproximadamente $20 \%$ da população, foi estendida a partir de 24 de setembro de 2007 a $100 \%$ da população, num total de 205.000 habitantes. A previsão é que a quantidade de material reciclável, coletado, ultrapasse as 100 toneladas por mês, ou seja, $3,86 \mathrm{t} / \mathrm{d}$, excetos aos domingos. Portanto, somadas a quantidade retirada do lixo bruto na usina de triagem, mais a quantidade arrecadada com a coleta seletiva, deixarão de ir para o aterro 6,86 t/d de materiais recicláveis, traduzindo-se em sensível redução no volume de resíduos enviados para o aterro, significando um aumento em sua vida útil.

O aterro controlado de Araraquara também recebe em torno de 450 t/mês (15,0 t/dia) de resíduos domiciliares do município de Américo Brasiliense e 120 t/mês (4,0 t/d) do município de Santa Lúcia, que vão diretamente para o aterro 
não passando pela triagem da usina de reciclagem.

Ainda, segundo a GORES/DAAE, no aterro de Araraquara são tratados, aproximadamente, 32 toneladas por mês de Resíduos de Serviços de Saúde (RSS) do próprio município, mais aqueles oriundo dos municípios vizinhos de Motuca, Gavião Peixoto, Américo Brasiliense, Santa Lúcia e Rincão. Estes municípios vizinhos somam juntos, aproximadamente, 1,2 toneladas por mês do total dos RSS's tratados na ETRS.

O chorume do aterro, em média $18 \mathrm{~m}^{3} /$ dia, é coletado em um tanque e bombeado para a rede de esgotos que leva à Estação de Tratamentos de Esgotos (ETE) de Araraquara. O mesmo tratamento é dispensado ao chorume que, eventualmente, o município tem recebido da cidade de São Carlos.

A GORES faz monitoramento do lençol freático na área do aterro, através de 4 poços, sendo 1 a montante e 3 a jusante. Também é monitorado, em 4 pontos, o córrego Pinheirinho que dista 300 metros no seu ponto mais próximo do aterro.

O município elaborou um Plano de Gestão de Resíduos Sólidos da Construção, Demolição e Volumosos, com amparo em lei municipal elaborada especificamente para tal, com a designação de um Grupo Gestor, para o acompanhamento do desenvolvimento do plano. Foi incentivada a instalação de uma usina de tratamento e reciclagem destes RSCD e V's, pela iniciativa privada, já em funcionamento, com a Prefeitura se responsabilizando pela criação de Pontos de Entrega Voluntários (PEV's) para volumes pequenos (até $1 \mathrm{~m}^{3}$ ). Estes PEV's estão em plena expansão e em breve serão treze pontos.

Em convênio com a Associação Nacional da Indústria de Pneumáticos 
(ANIP) o município recolhe cerca de 30 toneladas/mês de pneus inservíveis que são destinados à recicladora CBL.

Também foi adquirido um equipamento triturador e descontaminador de lâmpadas fluorescentes e de outras à base de mercúrio, que estão em processo de licenciamento pela CETESB.

O DAAE, através da Gerência de meio Ambiente, também realiza ações educacionais e de prevenção de mananciais, entre outras.

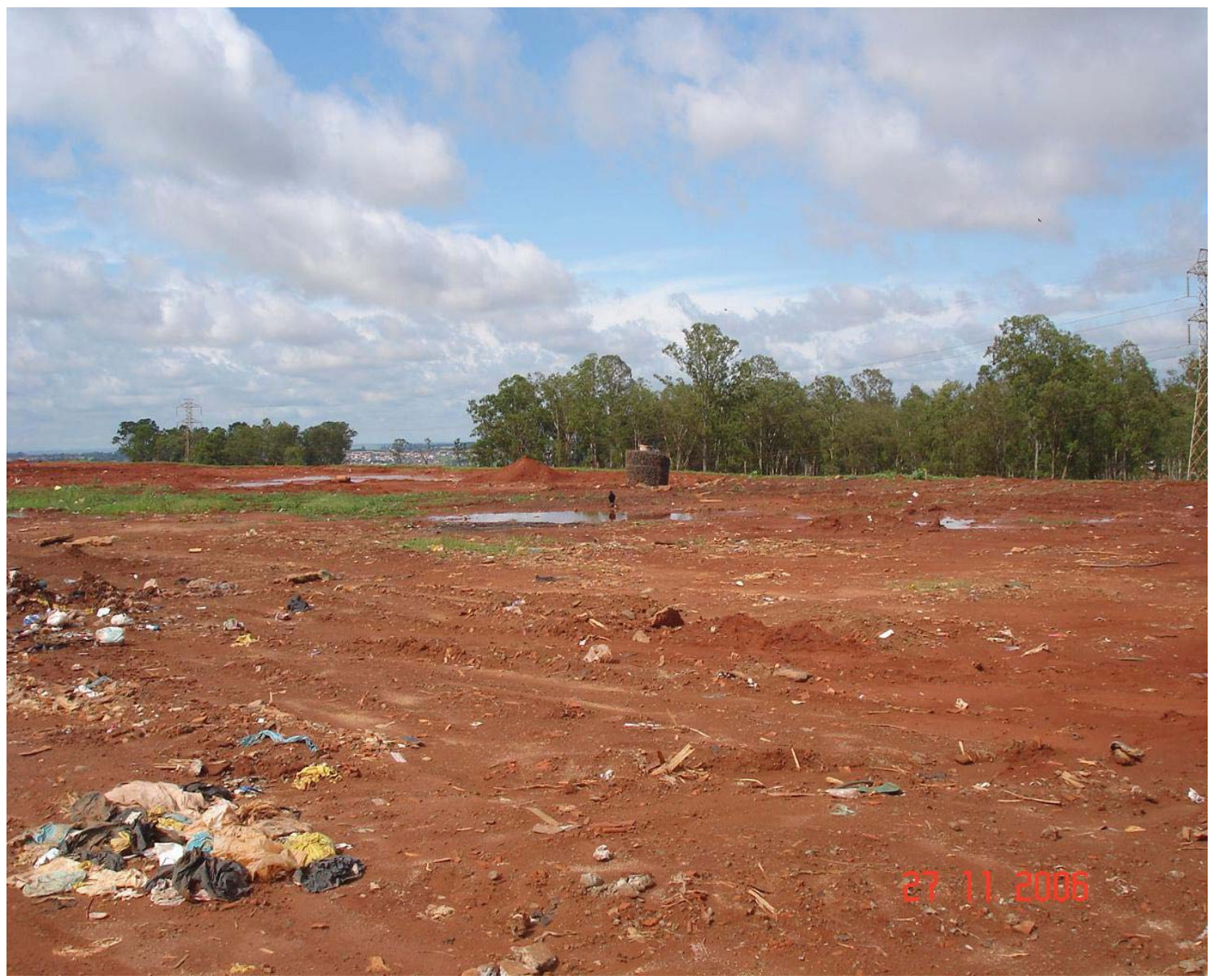

Foto 5.1.1 - Aterro controlado de Araraquara. 2006 


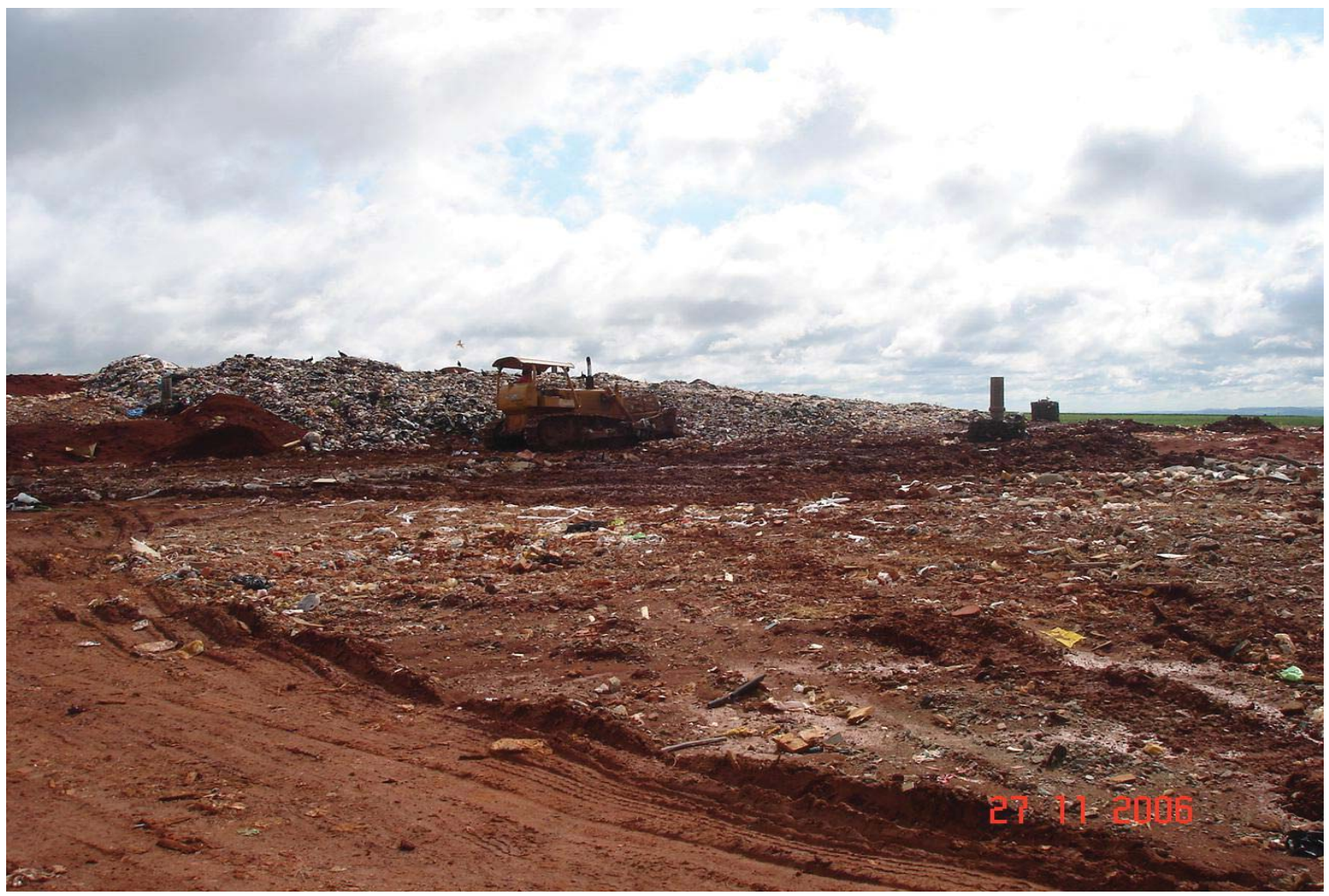

Foto 5.1.2 - Aterro controlado de Araraquara. 2006

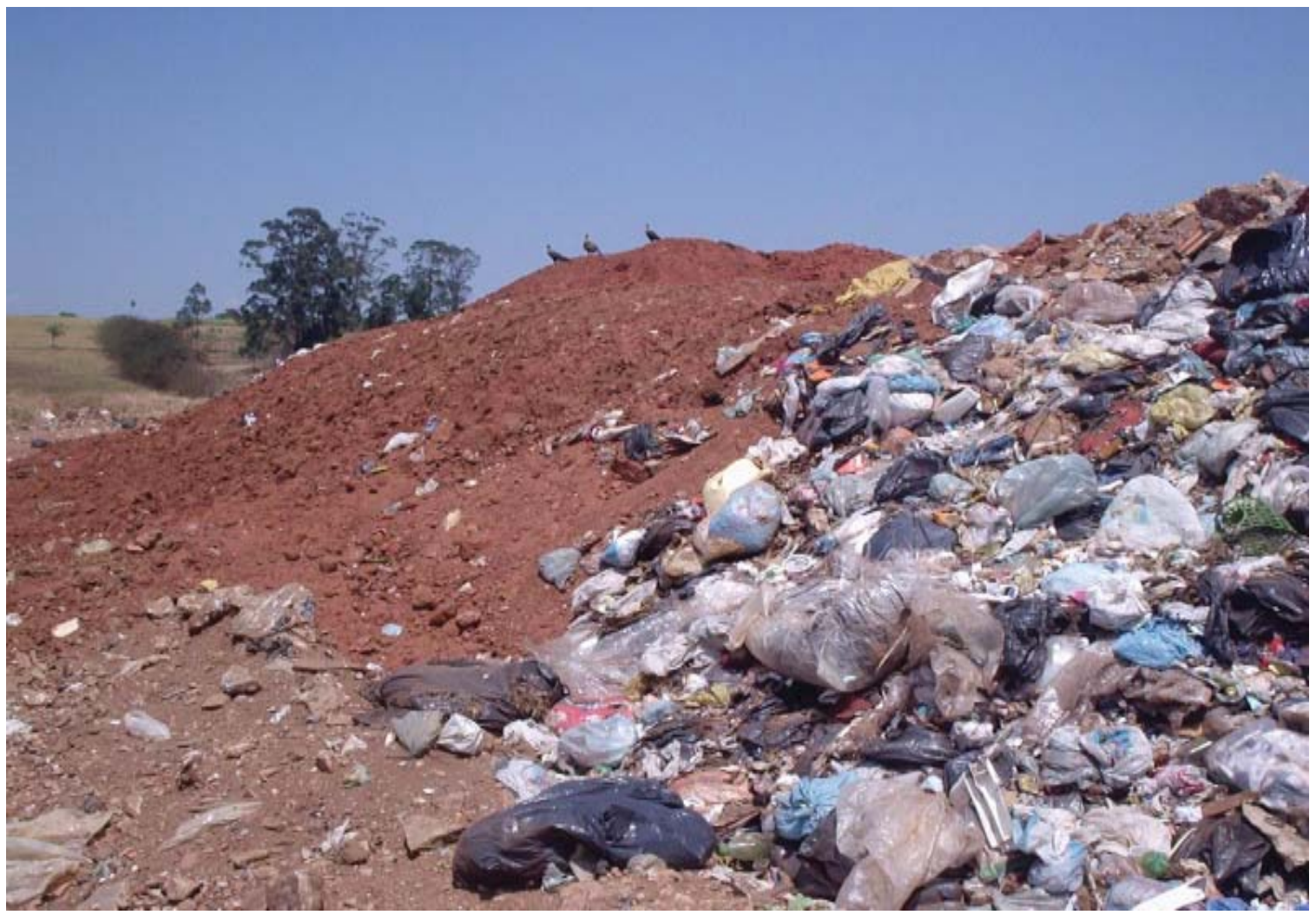

Foto 5.1.3 - Aterro controlado de Araraquara. 2007 


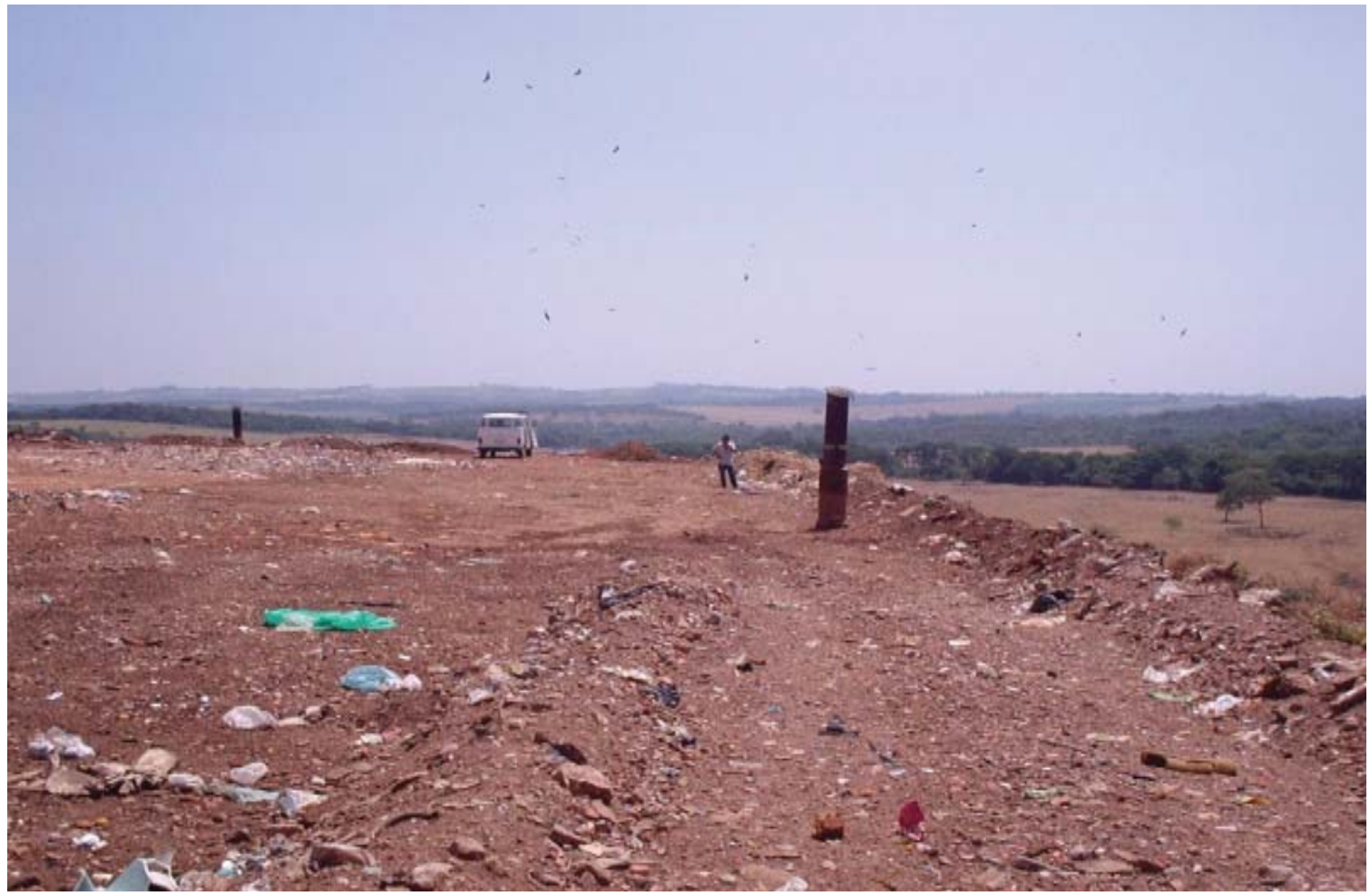

Foto 5.1.4 - Aterro controlado de Araraquara /2007

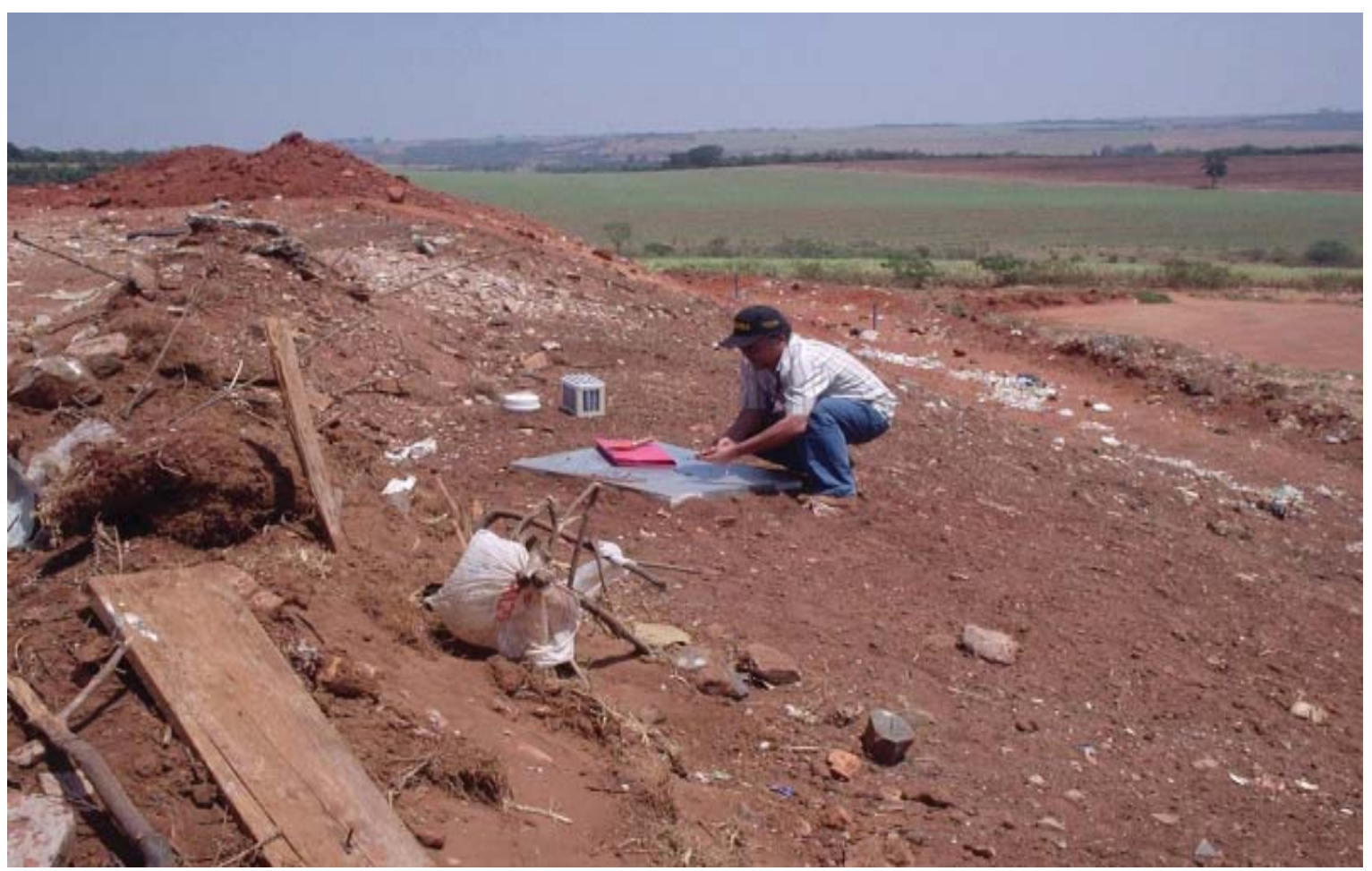

Foto 5.1.5 - Aterro controlado de Araraquara /2007 


\subsection{Aterro em valas do município de Brotas, São Paulo.}

Segundo informações da Prefeitura Municipal (SCARABEL, LAZARI Jr; 2006) $)^{2}$ e Brotas (2007) o aterro em valas de Brotas dispunha de uma área de $45.000 m^{2}$ e recebia em média 9,44 toneladas de resíduos por dia, gerados por uma população de 20.996 habitantes (IBGE, 2007f). O aterro está situado na zona rural do município nas coordenadas $22^{\circ} 13^{\prime} \mathrm{S}$ e $48^{\circ} 05^{\prime} \mathrm{W}$, é cercado por um canavial e tinha vida útil prevista para se esgotar em 2008. A Prefeitura já planejava construir um aterro sanitário em área contígua e implantar um programa de coleta seletiva, que o município ainda não desenvolve.

Os resíduos depositados nas valas eram compactados semanalmente e seu IQR foi de 7,5 (CETESBE, 2006), indicando ser um aterro controlado e adequado.

Ainda por informações dos Administradores acima citados, o aterro iniciou sua operação em 2001 e acumularia, até o seu fechamento, cerca de 23,78 mil toneladas de lixo urbano.

\footnotetext{
${ }^{2}$ Comunicação/informações pessoal. Srs. Marcos Antonio SCARABEL e Ângelo Roberto LAZARI Jr.; Diretor do Departamento de Meio Ambiente/Diretor de Gestão Ambiental. Prefeitura Municipal de Brotas. 2006. 


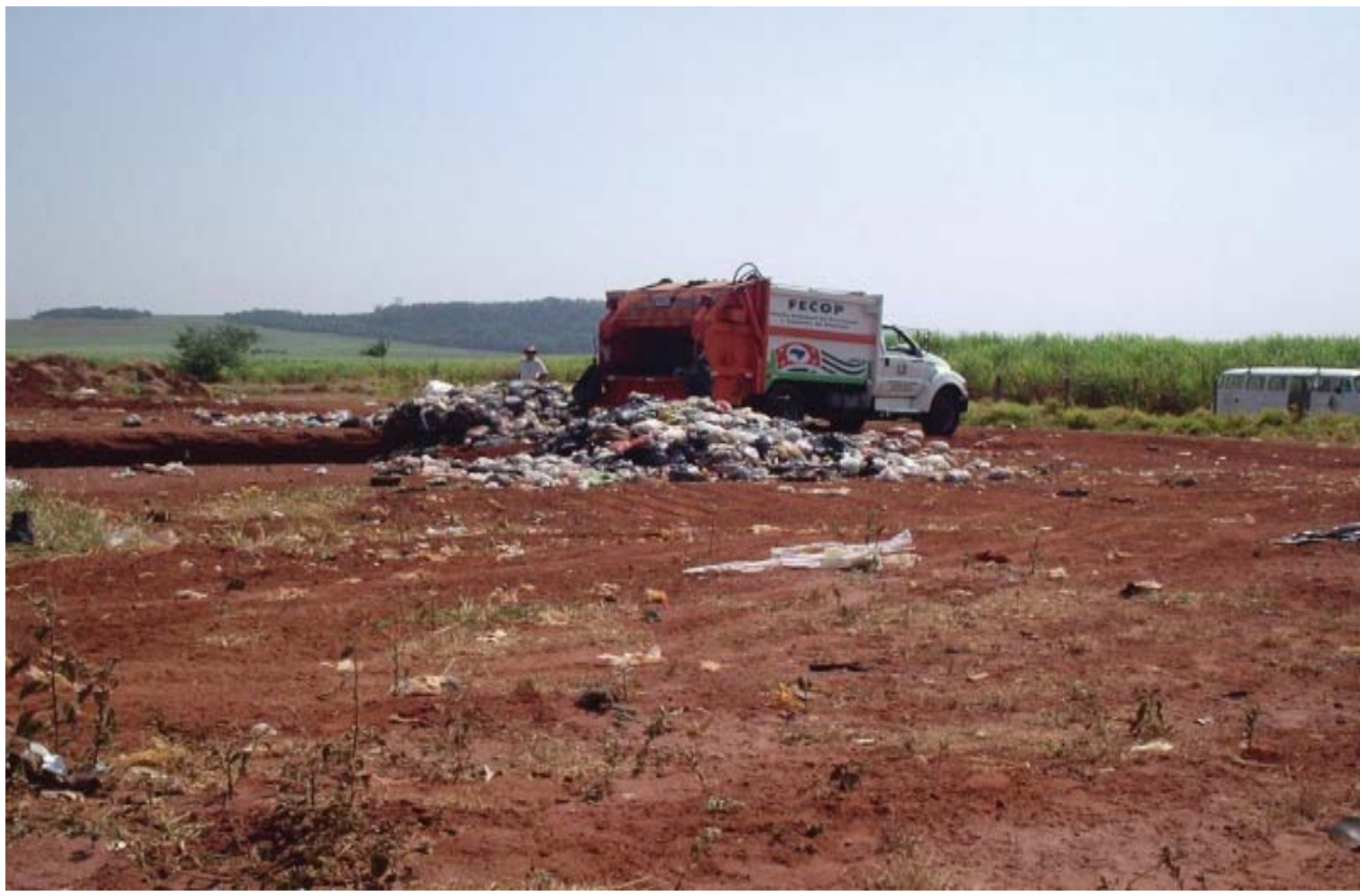

Foto 5.2.1 - Aterro em valas de Brotas. 2006

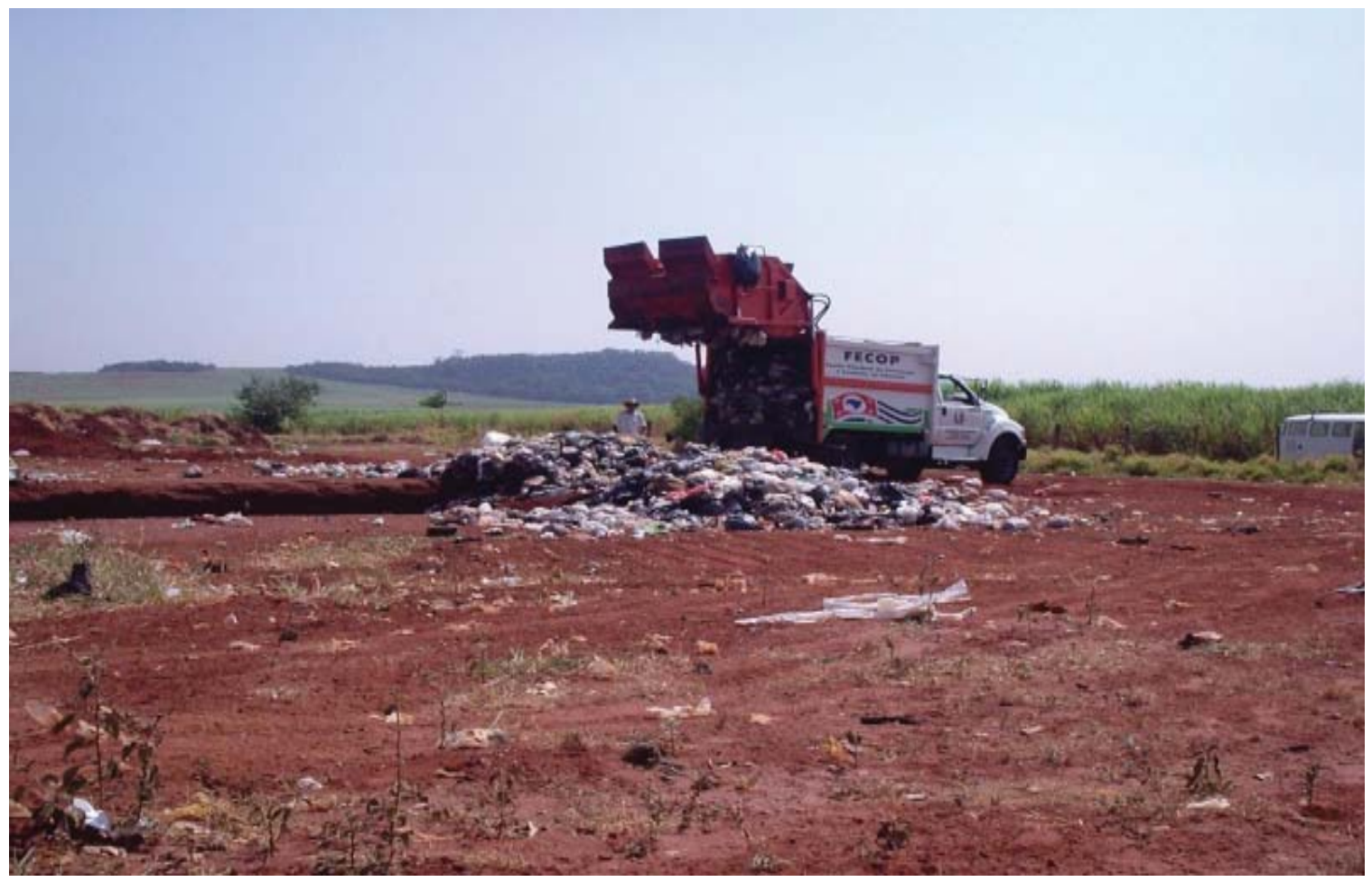

Foto 5.2.2 - Aterro em valas de Brotas. 2006 


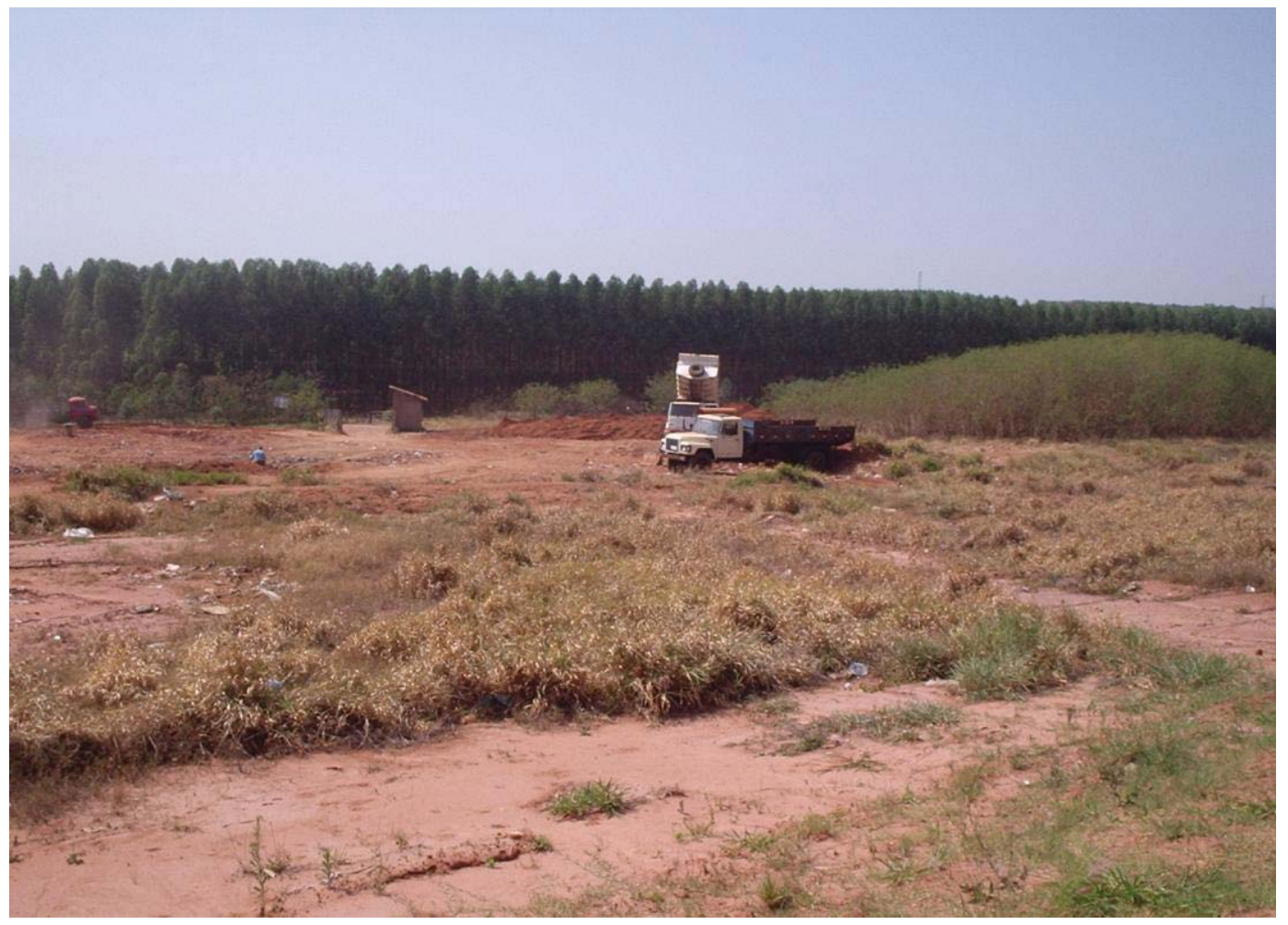

Foto 5.2.3 - Aterro em valas de Brotas. 2007 


\subsection{Aterro sanitário do município de Campinas, São Paulo.}

Segundo informações de Pires $(2009)^{3}$ o aterro sanitário de Campinas iniciou sua operação em 1992, dispondo de área total de $520.000 \mathrm{~m}^{2}$ e uma área de disposição de, aproximadamente, $260.000 \mathrm{~m}^{2}$, na qual recebia em 2007 uma média de 820 toneladas de resíduos por dia, tendo recebido e enterrado um montante de RSU`s da ordem de 4.334.717,21 toneladas até outubro de 2007.

A montanha de resíduos perfaz uma altura de 45 metros e a Prefeitura Municipal já providencia construção de novo aterro, tendo conseguido autorização para aumentar a cota do atual, enquanto decide por um novo.

No aterro de Campinas opera uma estrutura de compostagem com grande produção de composto.

O aterro dispõe de drenagem, lagoa de chorume e sistema de captação de gases de aterro com 110 drenos que nas duas campanhas observamos quase todos mantidos acesos e, aqueles assim encontrados, com muita chama.

${ }^{3}$ Comunicação pessoal por e-mail de Tânia Maria Pires do DLU de Campinas. 


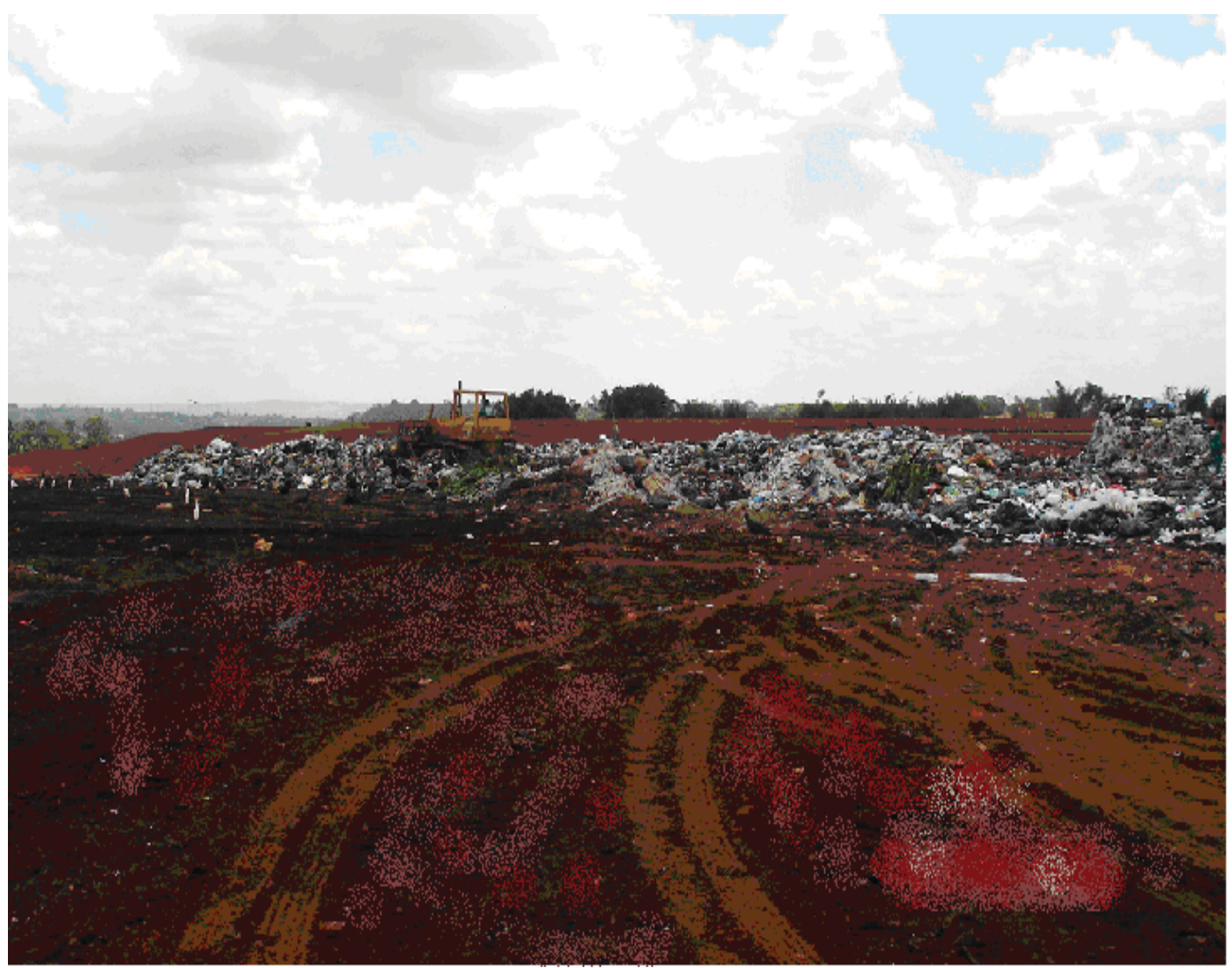

Foto 5.3.1. - Aterro de Campinas. 2006. Área em operação. 


\subsection{Aterro controlado do Município de Jaú, São Paulo.}

Em agosto de 2006 o município obteve a Licença Prévia (LP) para instalação de um aterro de resíduos, conforme comunicação do Departamento de Avaliação de Impacto Ambiental (DAIA). O aterro controlado, cujo projeto foi elaborado pela Fundação para o Incremento da Pesquisa e do Aperfeiçoamento Industrial (FIPAI) de São Carlos, atendeu todas as exigências técnicas, com impermeabilização e tratamento de chorume, compactação e cobertura diária do lixo, terá capacidade para receber RSU por duas décadas, levando-se em conta a geração atual de 90 toneladas por dia (SC/Jaú-2006).

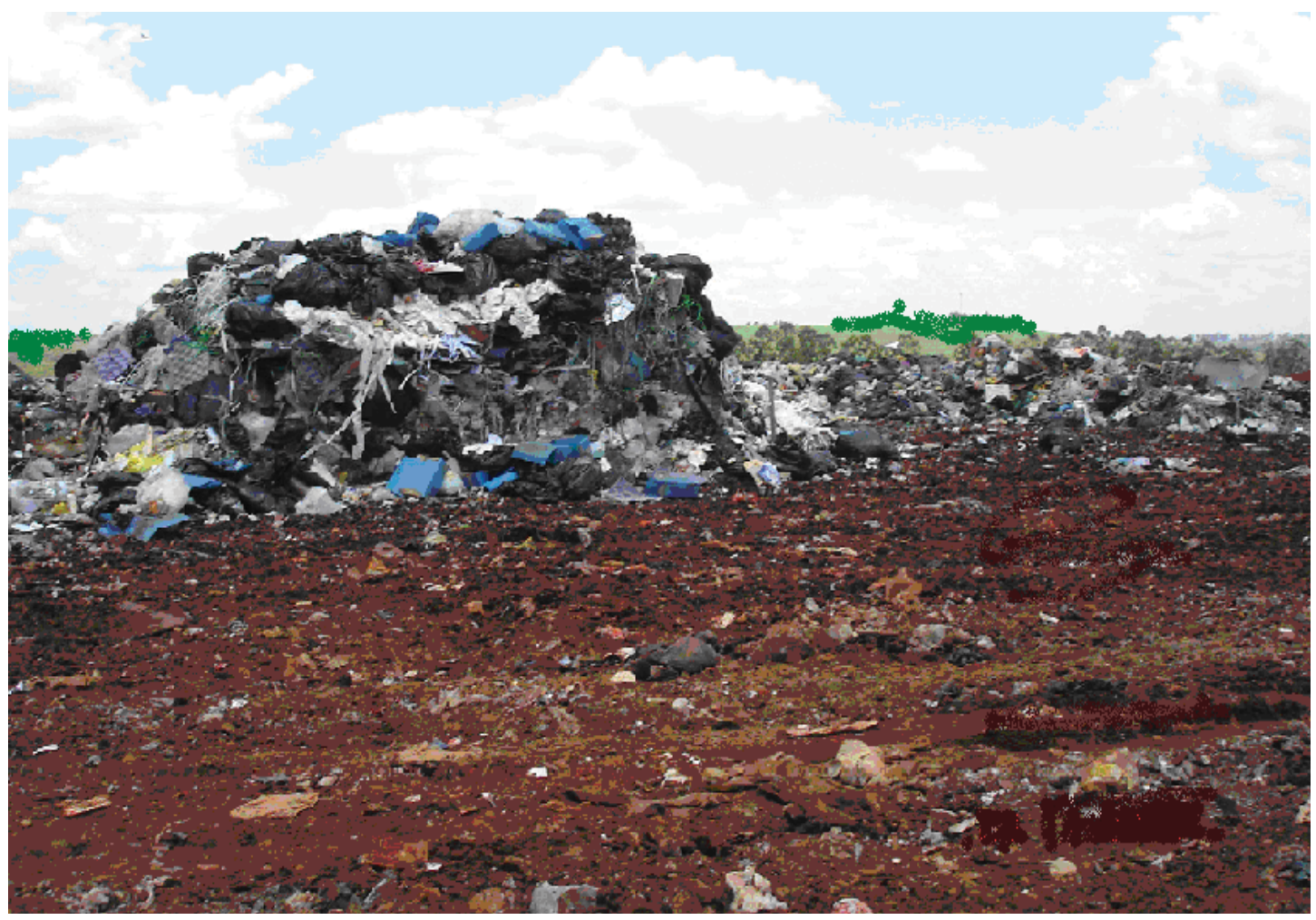

Foto 5.4.1 - Aterro controlado de Jaú. 2006 


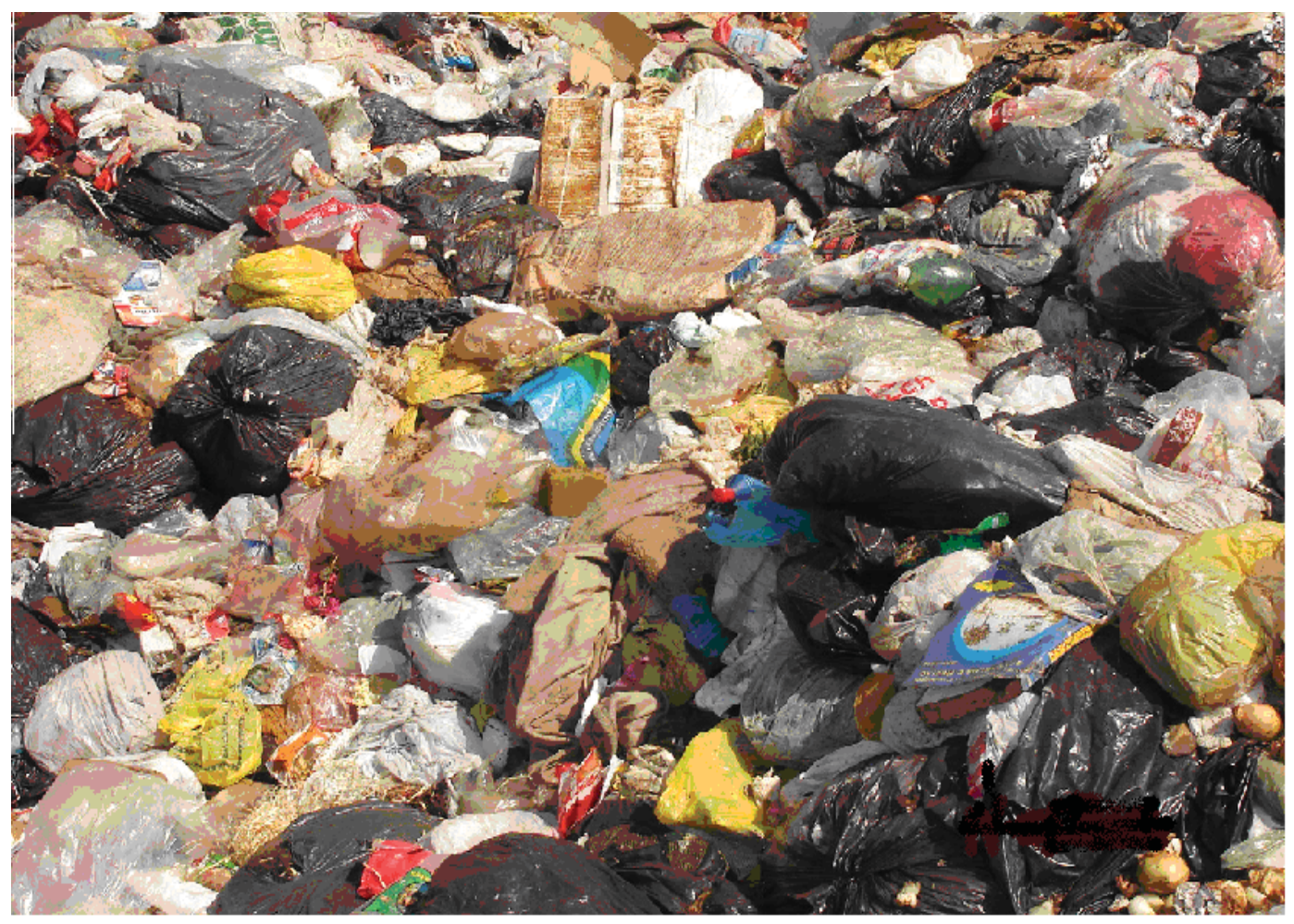

Foto 5.4.2 - Aterro controlado de Jaú. 2006

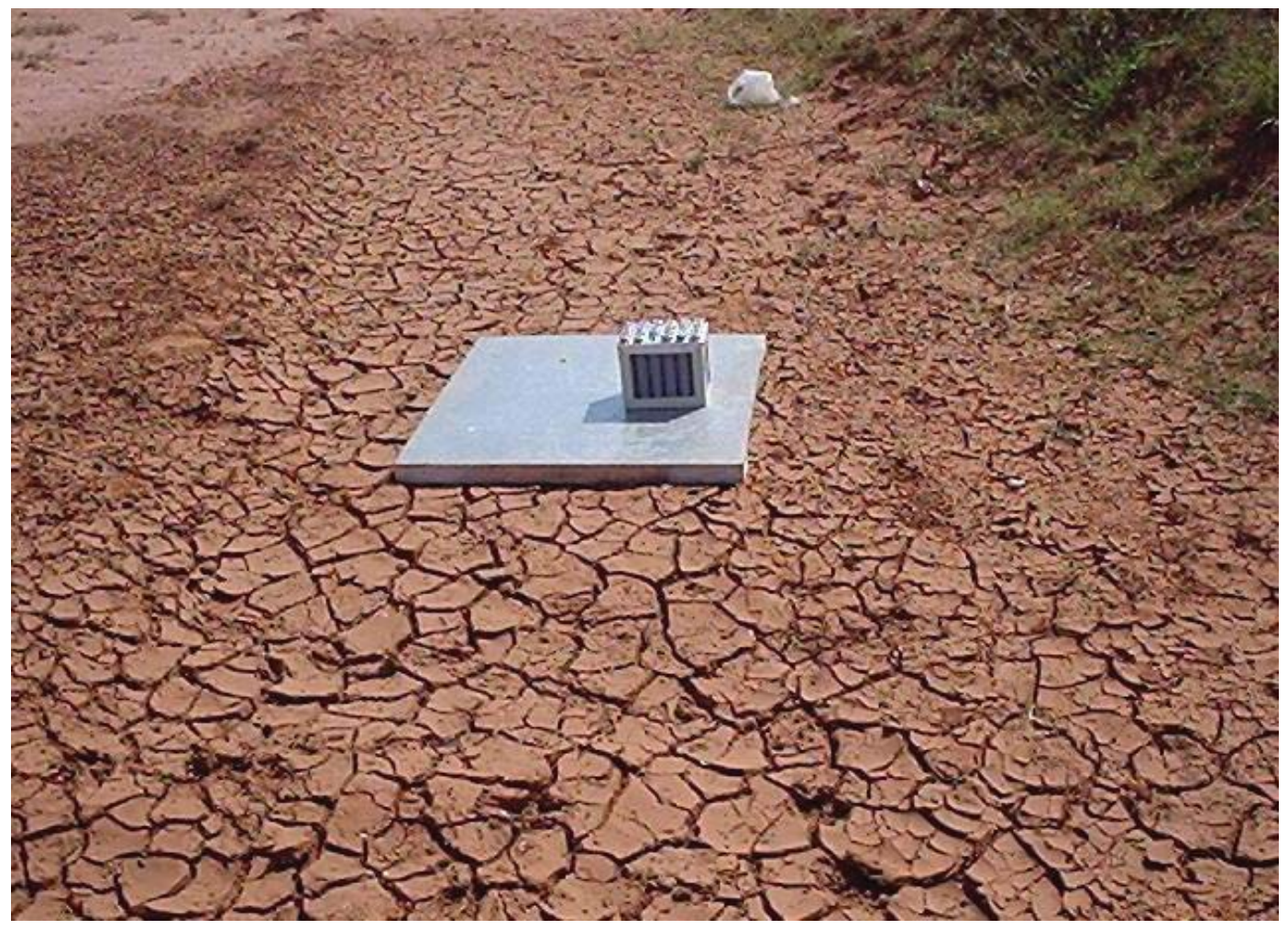

Foto 5.4.3 - Aterro controlado de Jaú. 2007 


\subsection{Aterro em valas do Município de Ribeirão Bonito, São Paulo.}

Segundo informações da Prefeitura Municipal, Secretaria de Governo $(\mathrm{AMARAL}, 2006)^{4}$ o aterro em valas de Ribeirão Bonito dispunha de uma área de $40.000 \mathrm{~m}^{2}$ e recebia em média 10 toneladas de resíduos por dia, gerados por uma população de 11.821 habitantes (IBGE, 2007f). Situado na zona rural do município nas coordenadas $22^{\circ} 05^{\prime} 14^{\prime \prime S}$ e $48^{\circ} 08^{\prime} 15^{\prime \prime} \mathrm{W}$, apresentou cerca de proteção em arame farpado.

Nas duas campanhas empreendidas não se presenciou vigilância no local, que apresentou na sua vizinhança um bosque de vegetação de cerrado e canavial. O aterro operava desde 2003 e já estava com vida útil prevista para se esgotasse em 2008. Apresentou muito lixo a descoberto, nas valas em operação, que são cobertas semanalmente.

A CETESB (2008) enquadrou o aterro como controlado com IQR de 7,6 e 7,2, respectivamente.

O Município tem programa de coleta seletiva, apenas por iniciativa de uma Associação Comunitária que recolhe recicláveis.

Ainda por informações da Administração Municipal, o aterro já acumulava, em 2006, aproximadamente, 32.000 toneladas de resíduos enterradas.

\footnotetext{
${ }^{4}$ Comunicação/informações pessoal. Sr. Mariano Monteiro do AMARAL; Secretaria de Governo/Prefeitura Municipal de Ribeirão Bonito, 2006. 


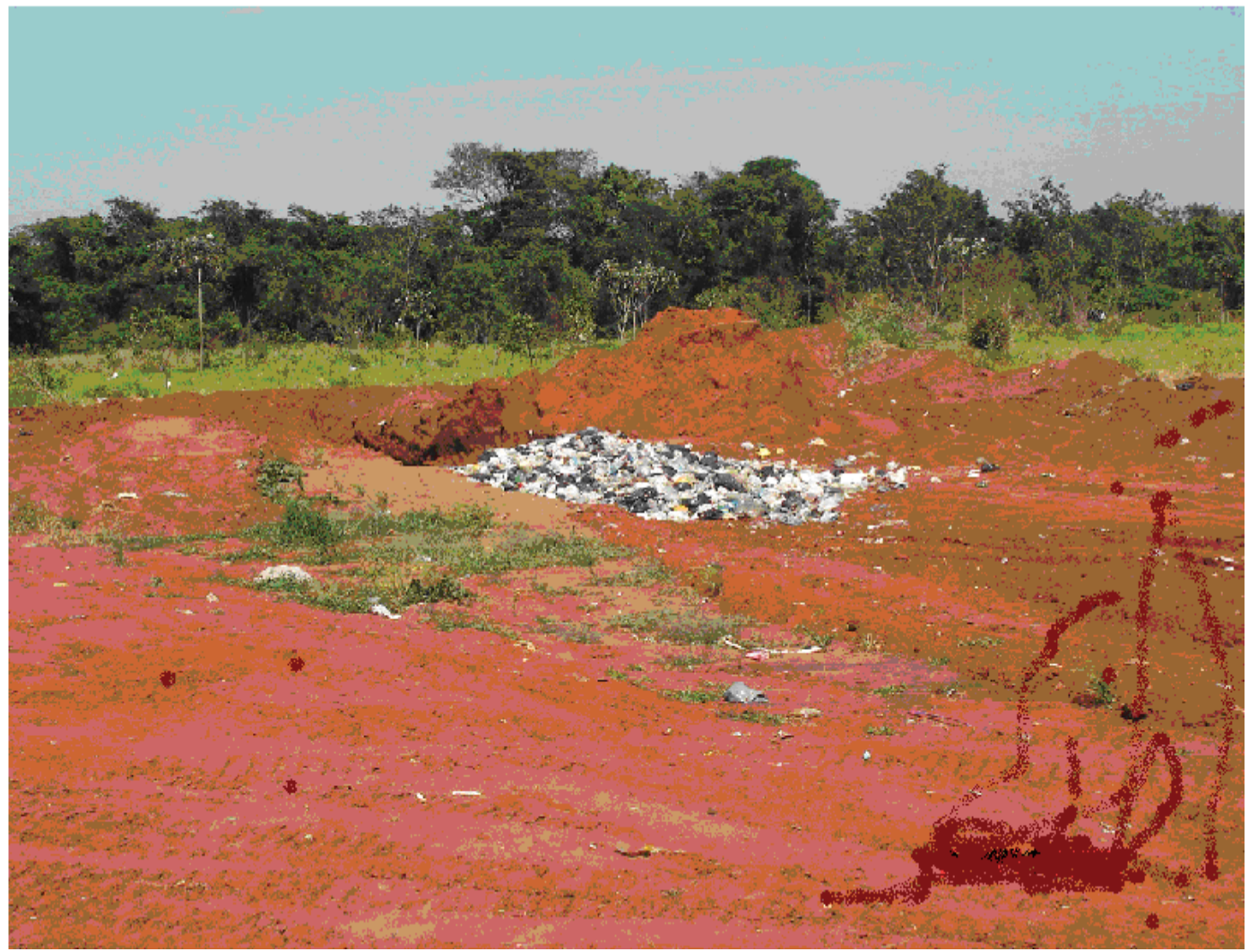

Foto 5.5.1 - Aterro em valas de Ribeirão Bonito. 2006

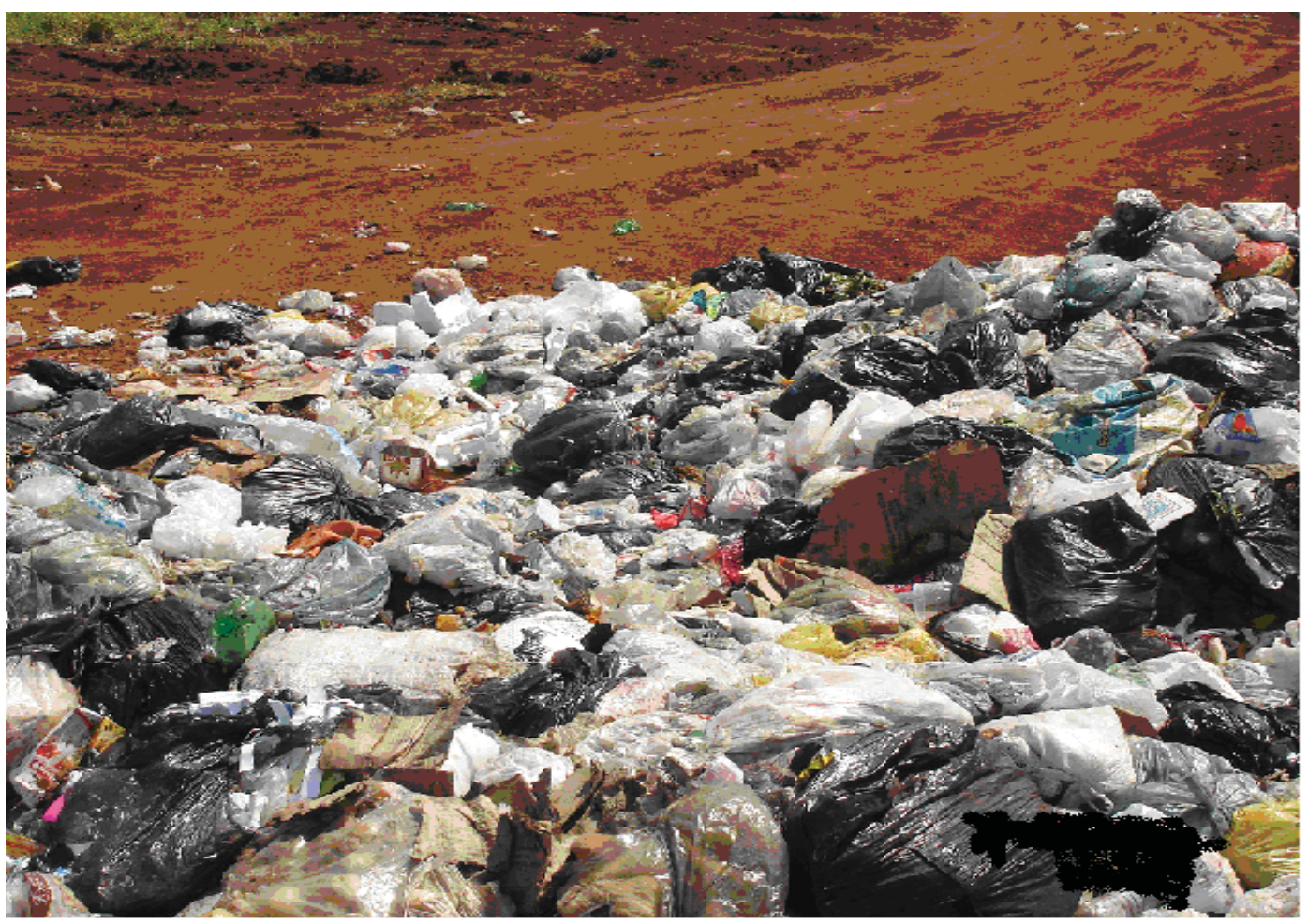

Foto 5.5.2- Aterro em valas de Ribeirão Bonito. 2007 


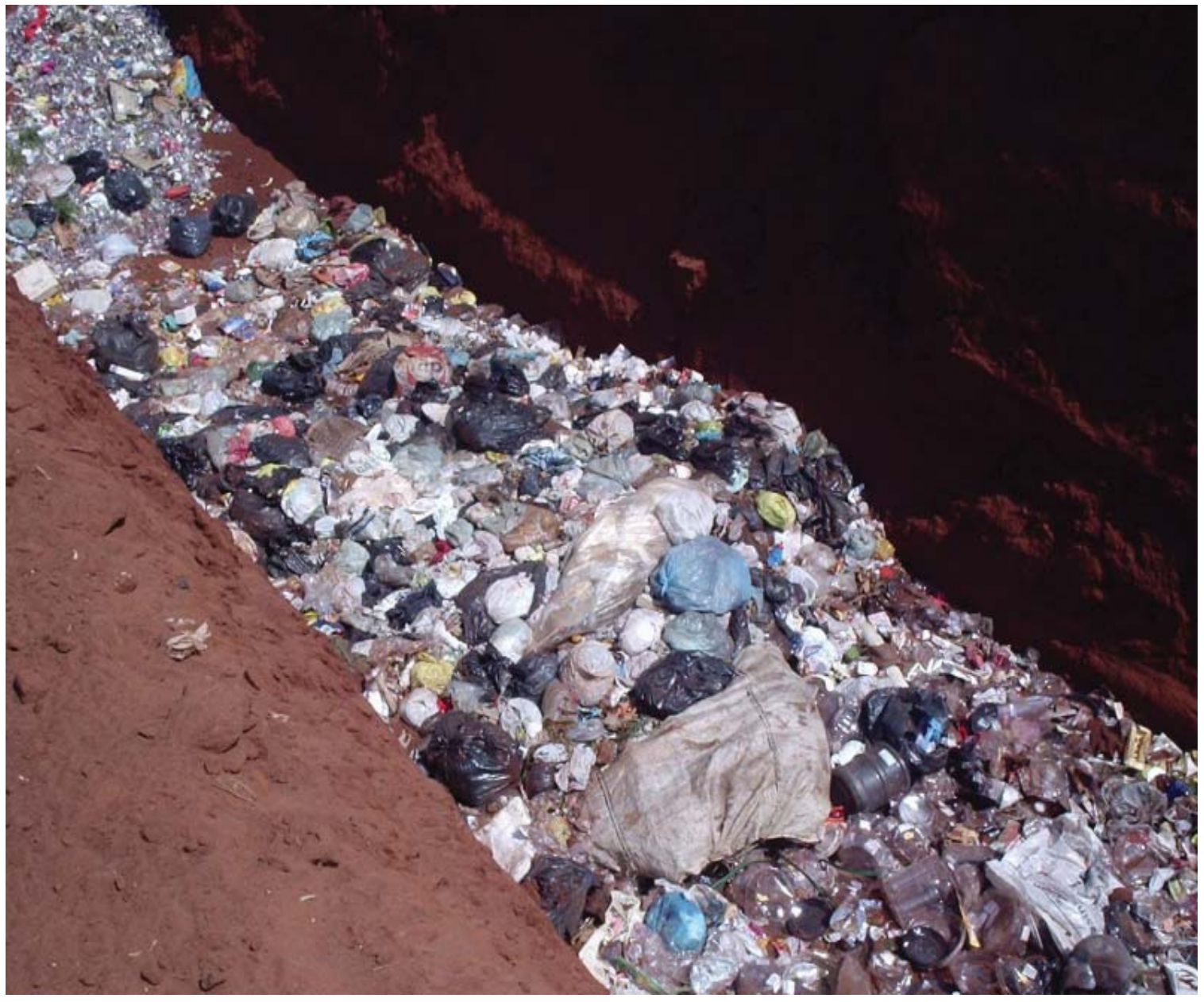

Foto 5.5.3- Aterro em valas de Ribeirão Bonito. 2007 


\subsection{Aterro controlado do Município de Ribeirão Preto, São Paulo.}

Segundo informações de Falsarella $(2007)^{5}$, Departamento de Águas e Esgotos de Ribeirão Preto (DAERP), Prefeitura Municipal de Ribeirão Preto, o aterro de resíduos de Ribeirão Preto iniciou suas atividades em 1990. Dispõe de uma área total de $218.000 \mathrm{~m}^{2}$, com uma disposição média de 500 toneladas/dia de resíduos e do início da sua operação até agosto de 2007. Segundo o informante o aterro já contava com 2.342.266,65 toneladas de resíduos nele dispostas, em seis camadas com altura média de $4 \mathrm{~m}$ cada, totalizando uma altura média da montanha de lixo de $24 \mathrm{~m}$.

O aterro está situado na zona rural do município, em meio a canaviais, nas proximidades das coordenadas $21^{0} 12^{\prime} 17^{\prime \prime}$, apresentou-se cercado, inclusive com árvores de delimitação do espaço e controle de entrada.

Ainda segunda dados do DAERP, a cidade de Ribeirão Preto tem implementado programas de incentivo à coleta seletiva de recicláveis, más esta retira do destino do aterro apenas em torno de 4 toneladas.dia $^{-1}$ e que este programa abrangeria apenas $15 \%$ da área urbana.

Foi observado, nas duas campanhas, que o aterro não estava queimando o GAS, apresentava muitos drenos danificados e, ainda, muito material orgânico - principalmente, 'camas-de-frango' - dispostos em locais que já se achavam encerrados. Nas áreas encerradas, apresentou rala vegetação de recobrimento, com muitos locais a descoberto.

\footnotetext{
${ }^{5}$ Informação por e-mail, prestada pela Sra. Marilene Falsarella, em 21 out 2007, a partir de Resíduos Sólidos. Daerp < residousolido@daerp.pmrp.com.br >. 
Segundo a CETESB(2008), nos seus inventários de 2000 a 2007, o aterro de Ribeirão Preto tem apresentado quebra no seu IQR, tendo, nos anos 2006 e 2007, recebido avaliação de 6,8 e 6,3,respectivamente, o que the confere enquadramento de controlado.

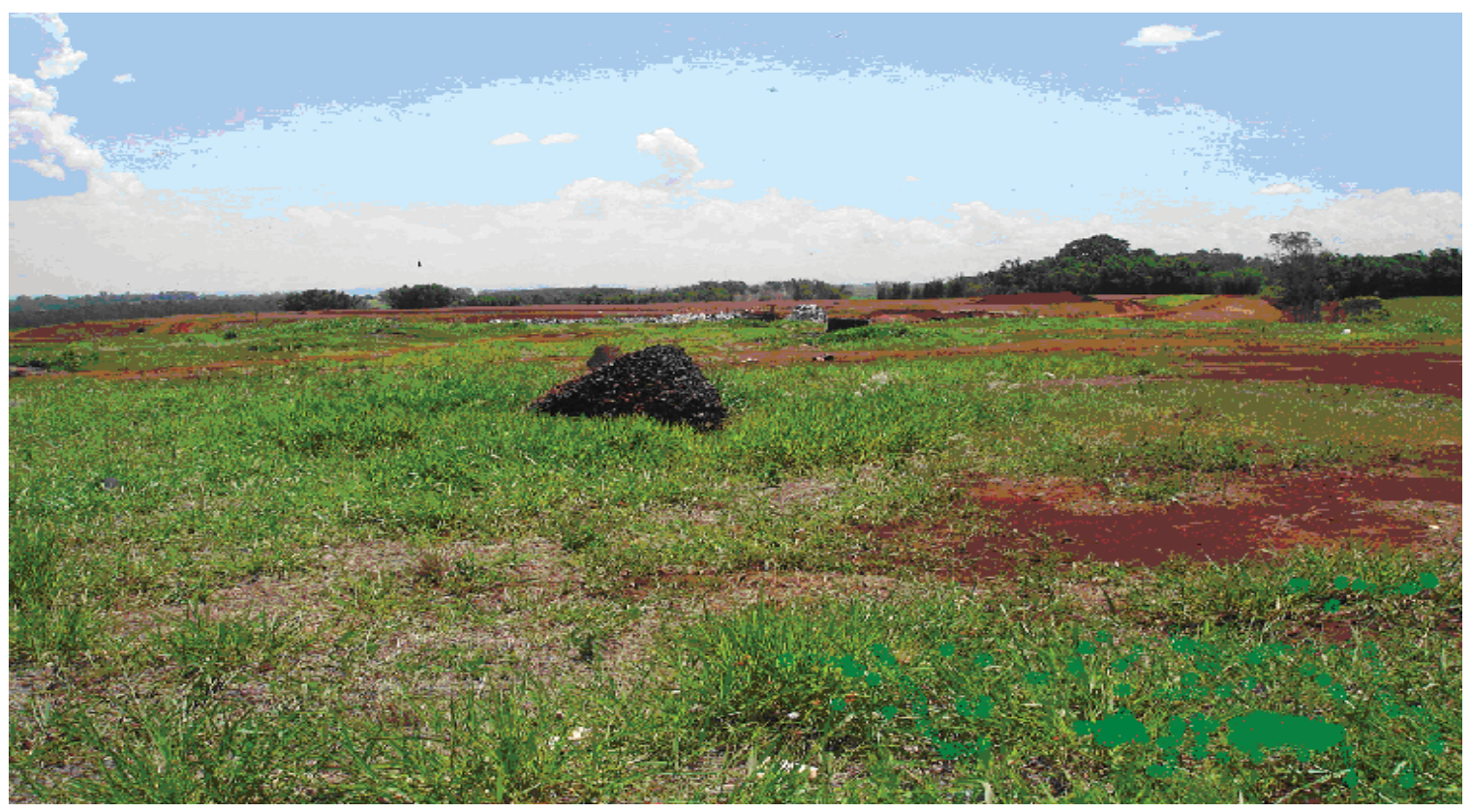

Foto 5.6.1 - Aterro controlado de Ribeirão Preto. 2006

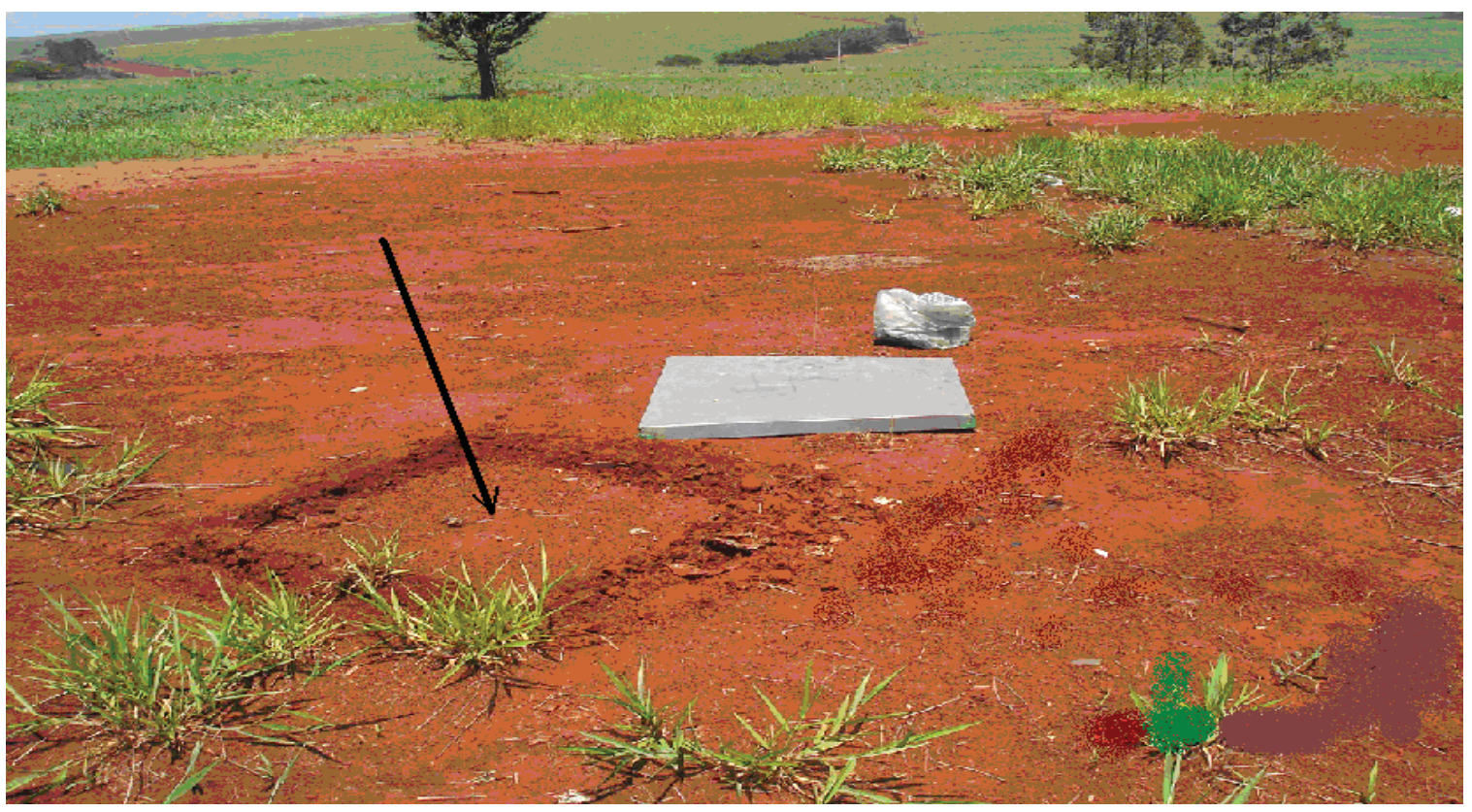

Foto 5.6.2 - Aterro controlado de Ribeirão Preto. 2006

Detalhe de sítio onde recém-terminou a coleta. 


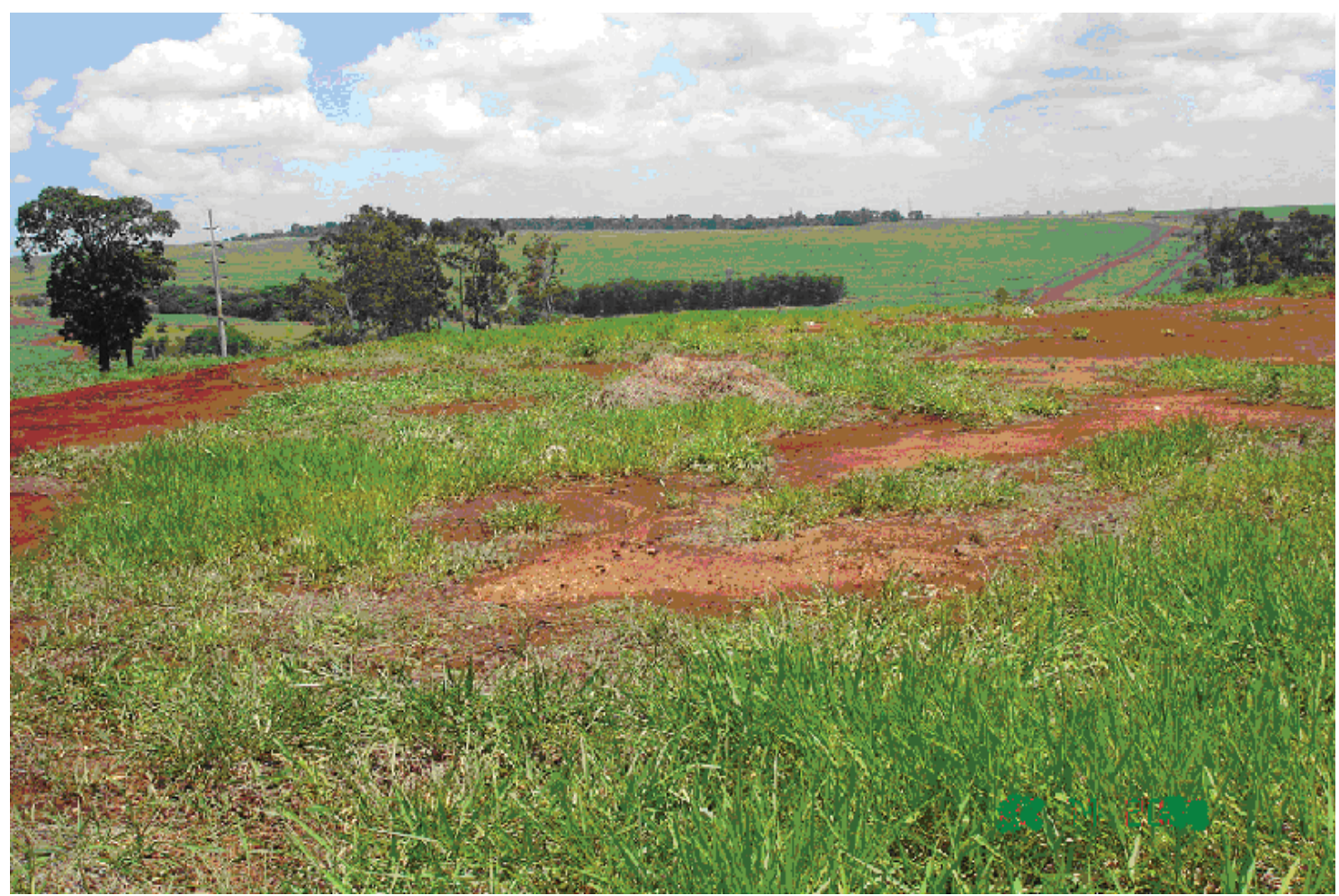

Foto 5.6.3 - Aterro controlado de Ribeirão Preto. 2007

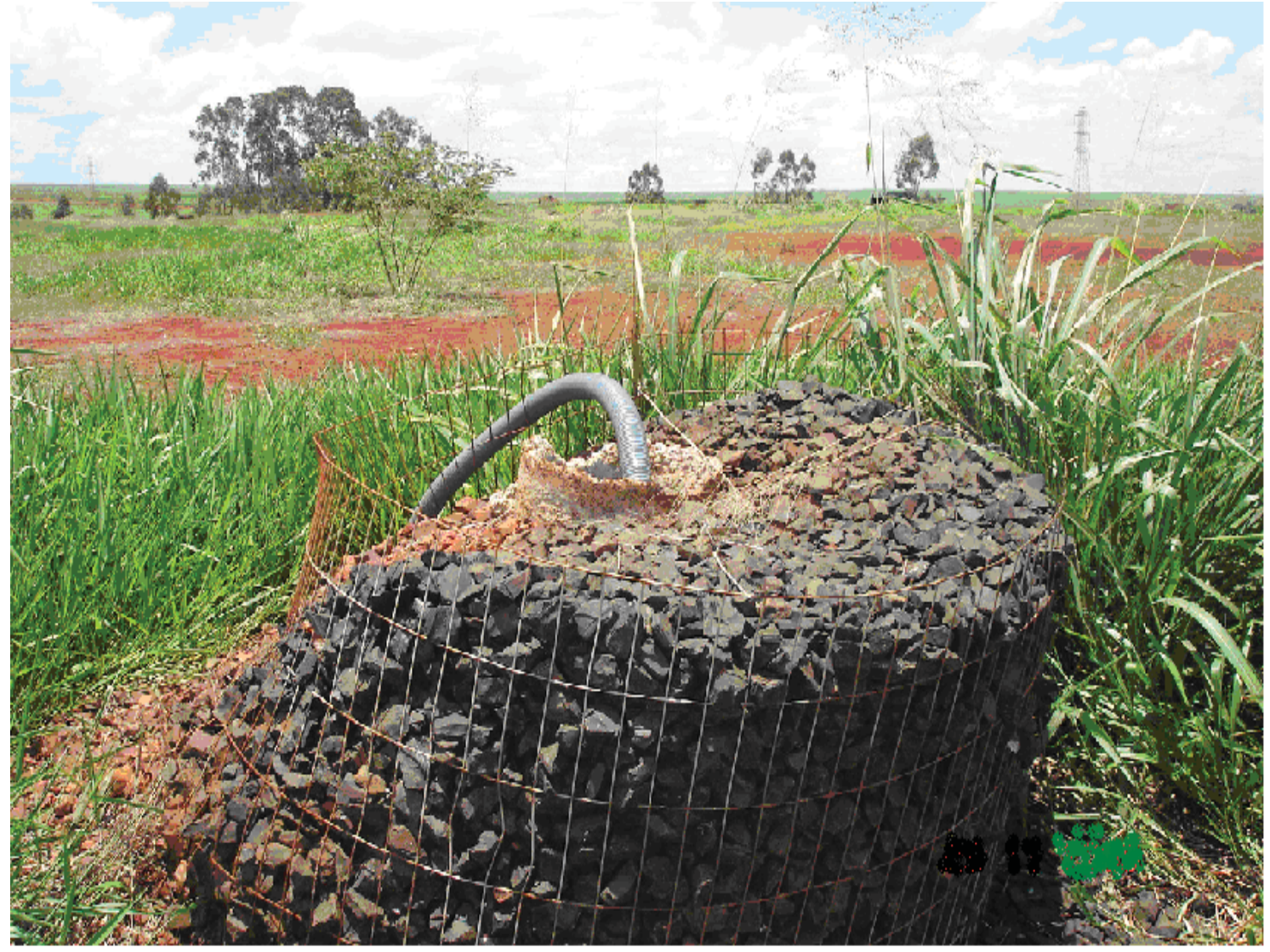

Foto 5.6.4 - Aterro controlado de Ribeirão Preto. 2007 


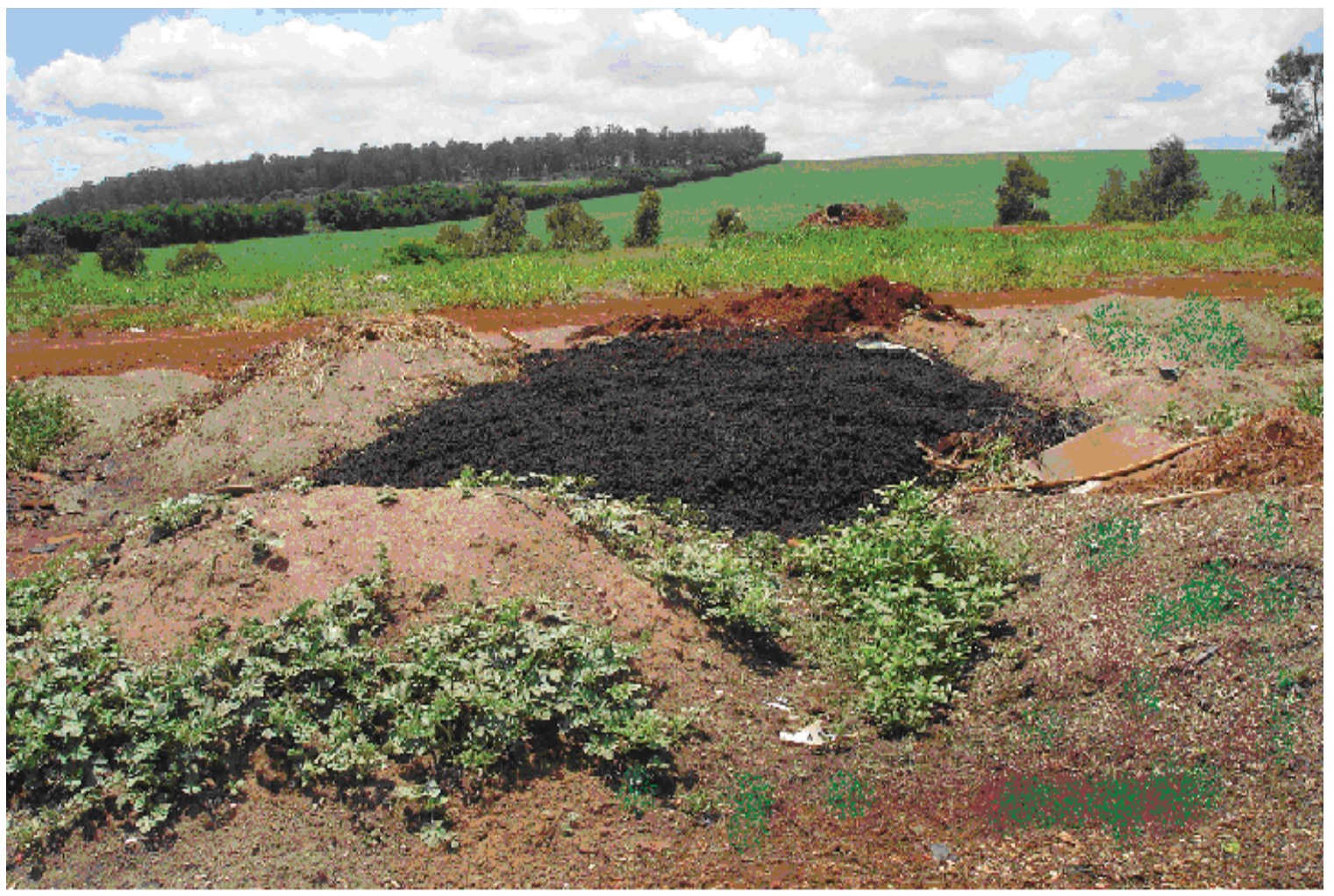

Foto 5.6.5 - Aterro controlado de Ribeirão Preto. 2007

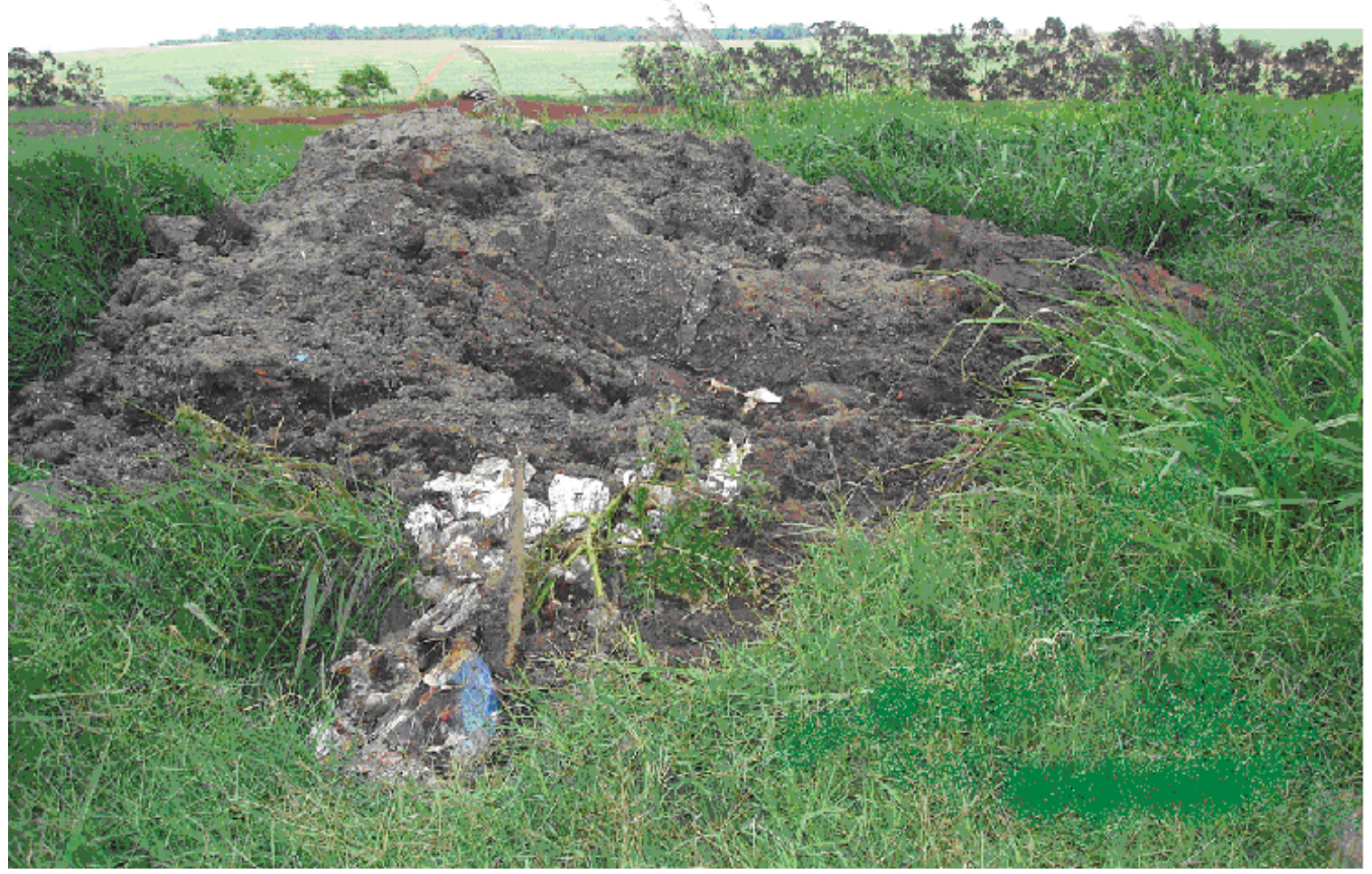

Foto 5.6.6 - Aterro controlado de Ribeirão Preto. 2007 


\subsection{Aterro sanitário do Município de São Carlos, São Paulo.}

O município de São Carlos está situado na região central do Estado de São Paulo. Apresenta uma área de $1.140,92 \mathrm{Km}^{2}$ e população de 192.998 habitantes. Destes, 183.433 estão na área urbana - 68,45 $\mathrm{Km}^{2}$ - e 9.565 na área rural - 1.072,47 Km² (IBGE, Censo 2000). Sua extensão territorial faz parte de duas Unidades de Gerenciamento de Recursos Hídricos, ou seja, a UGRHI-09 da bacia Mogi-Guaçu e a UGRHI-13 da bacia Tietê/Jacaré. Situa-se ainda em um planalto com altitude média de $856 \mathrm{~m}$, com clima subseqüente úmido, com três meses de baixa umidade por ano e temperatura média máxima de $+27^{\circ} \mathrm{C}$ e média mínima de $+14^{\circ} \mathrm{C}$.

Segundo Matos (2006), aproximadamente $70 \%$ da população tem idade abaixo dos 40 anos, o que indica a tendência de jovialidade; 65 \% estão compreendidas na faixa dos 18 aos 70 anos de idade - idade economicamente ativa - indicando disponibilidade de mão-de-obra e $95 \%$ da população reside na área urbana, confirmando a tendência dos municípios brasileiros de alta concentração no meio urbano.

O aterro de RSU's de São Carlos está localizado na fazenda Guaporé distante, aproximadamente, $15 \mathrm{Km}$ do centro da cidade com acesso pela Rodovia Washington Luiz ( SP - 310 ).

Está implantado em escavações resultantes de erosões em áreas das fazendas Guaporé e Embaré, sendo construído, portanto, abaixo do nível original do terreno. São duas escavações que foram aproveitadas, distando, aproximadamente, 200 metros entre si, o que resultou na realidade em dois aterros, constituídos pelas 
células AS-1 e AS-2, com concepções idênticas.

As duas áreas juntas perfazem $180.000 \mathrm{~m}^{2}$; com área para disposição dos resíduos sólidos, totalizando $110.000 \mathrm{~m}^{2}$ com operação iniciada em 1996 e encerrada para 2008.

Segundo informações de Minamisako $(2009)^{6}$ o aterro tem acumulado o equivalente a, aproximadamente, $608.907,19$ toneladas de lixo, enterrados desde o início da sua operação em 1996 até setembro de 2007.

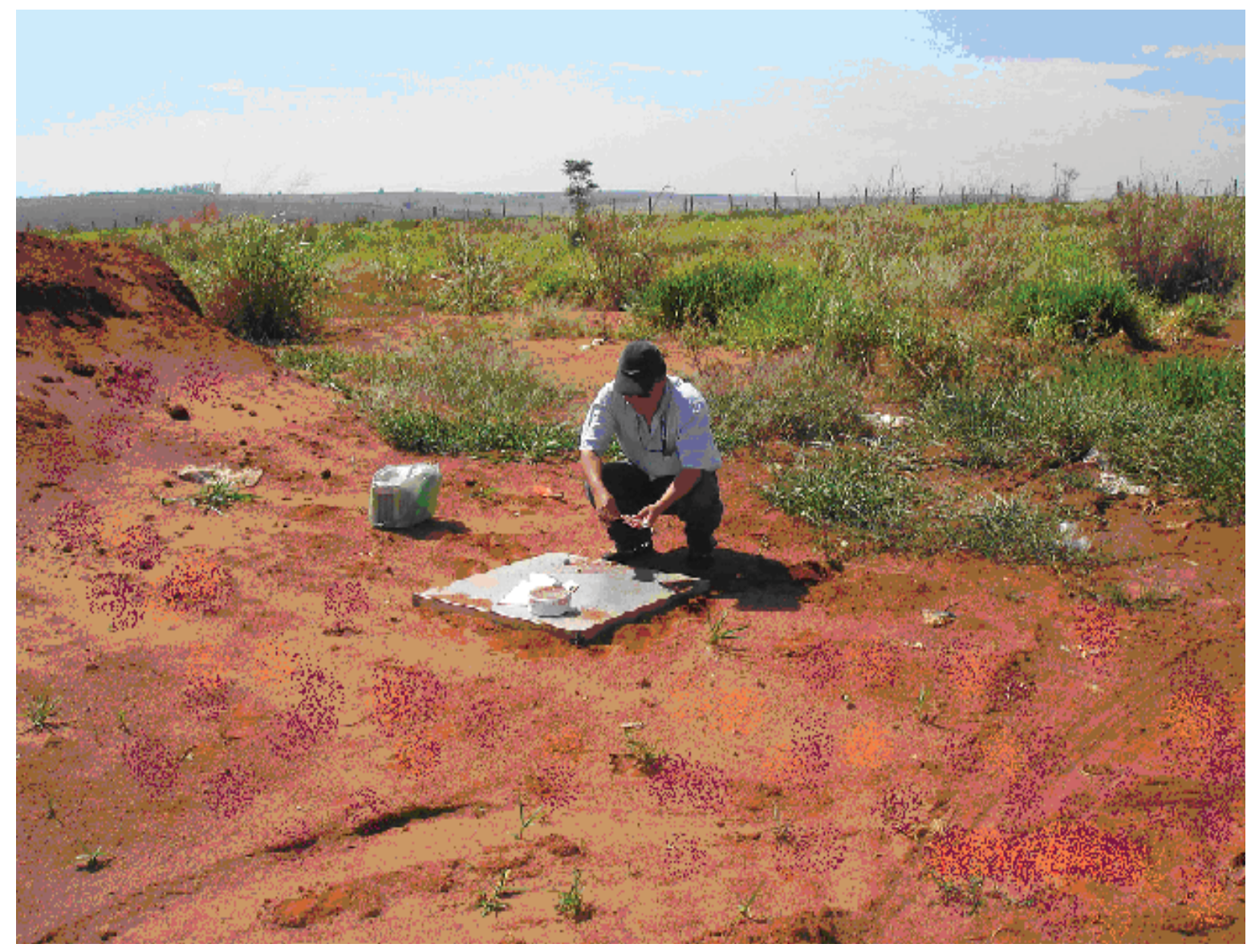

Foto 5.7.1 - Aterro sanitário de São Carlos. 2006

6 Informações por e-mail, prestadas pelo Engenheiro Douglas Comparotto Minamisako, Chefe da Divisão de Gestão de Resíduos Sólidos, Prefeitura Municipal de São Carlos, 2009.

BERTO NETO, J. (2009). - Medidas da Emissão de Gases de oito aterros de resíduos sólidos urbanos do Estado de São Paulo - Brasil. Tese apresentada ao PPG-SEA/CRHEA - EESC/USP. São Carlos-SP, Dez. 2009. 


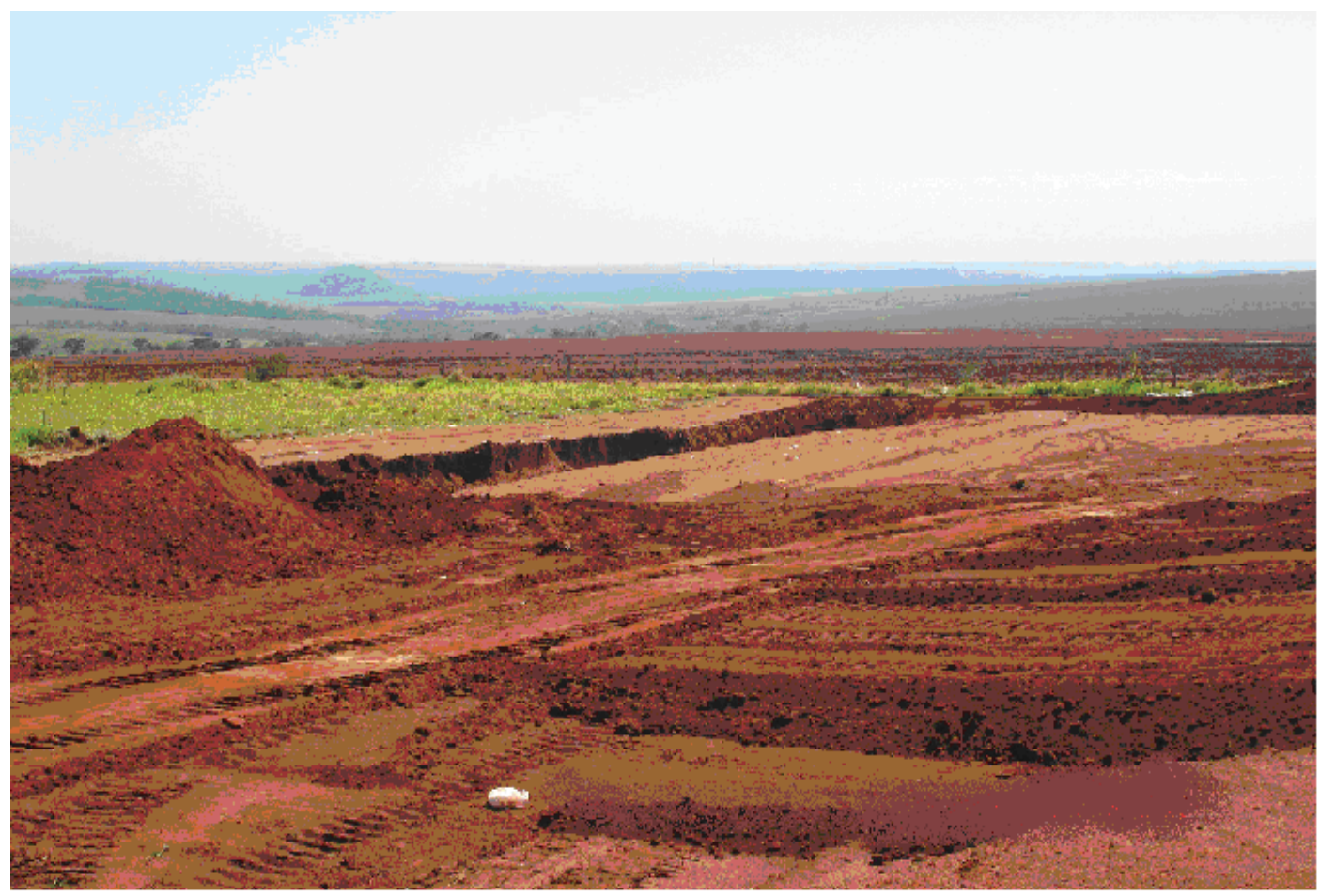

Foto 5.7.2 - Aterro sanitário de São Carlos. 2006. Área em operação

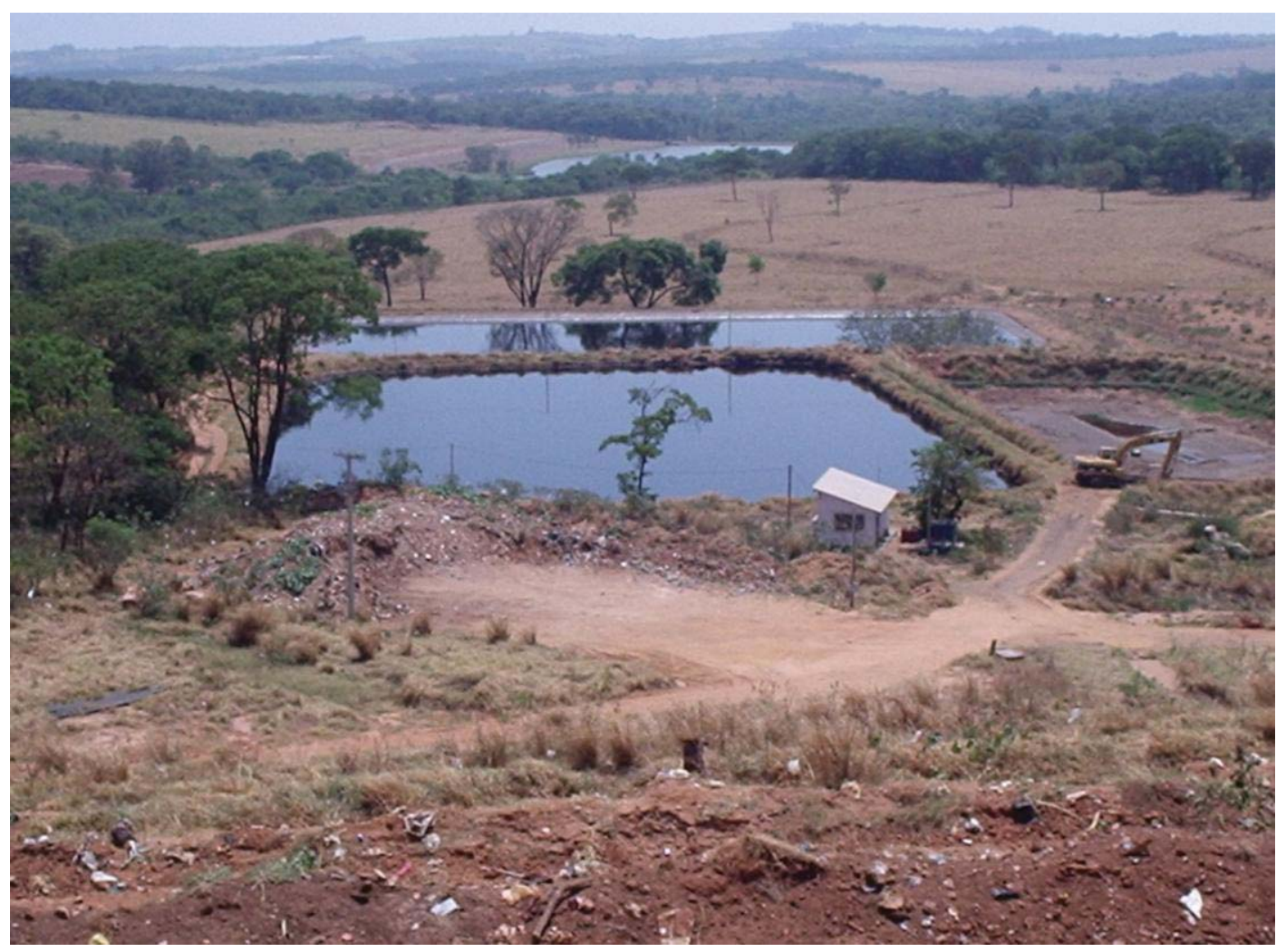

Foto 5.7.3 - Aterro sanitário de São Carlos. 2007.

Lagoas de estabilização de chorume. 


\subsection{Aterro Sanitário Bandeirantes - São Paulo/Capital.}

O Aterro Bandeirantes, Figuras 5.4a, 5.4b e 5.4c, no Bairro de Perus, em São Paulo/Capital, é considerado um dos maiores do mundo e as fotos aéreas mostram que não poderia mais se expandir, pois está cercado de rodovias importantes de um lado e a cidade do outro. Por isto o seu fechamento em 2006.

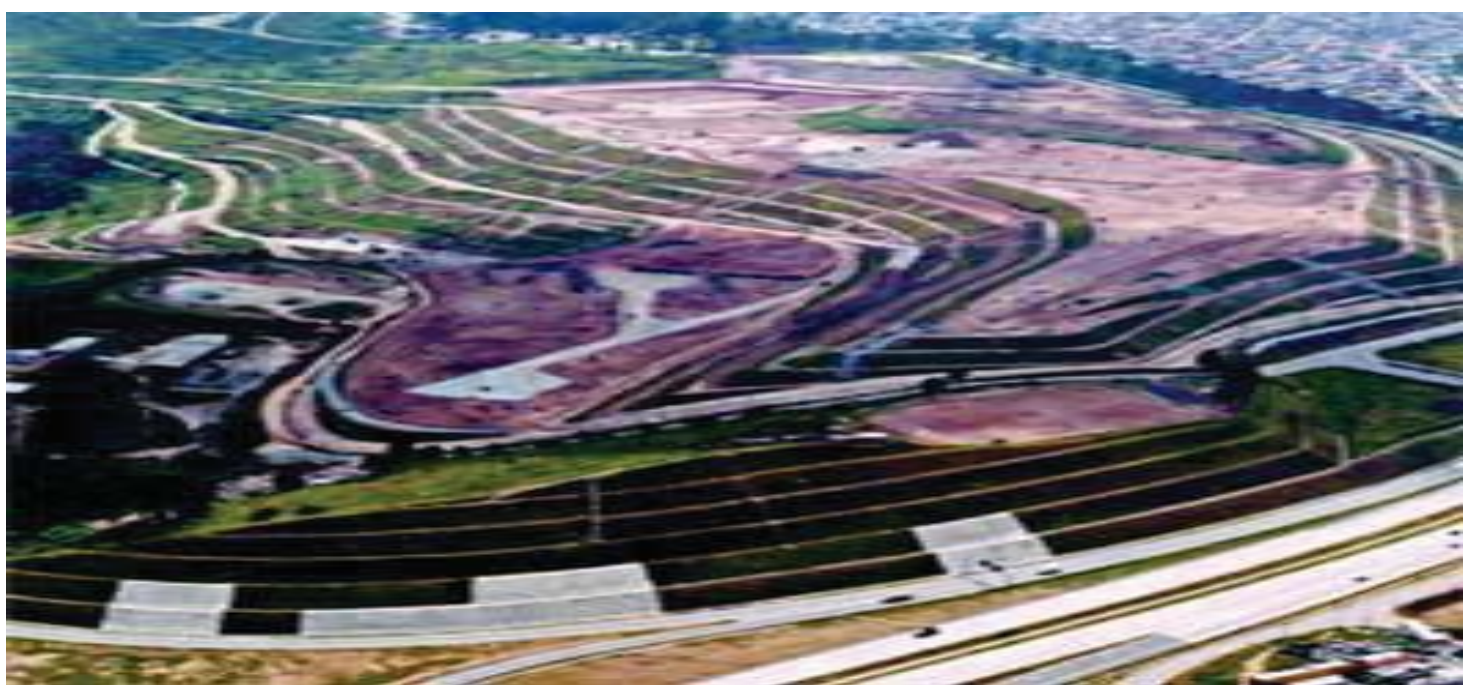

Figura 5.8.1a - Foto aérea do Aterro Bandeirantes/São Paulo - Capital Fonte: < http://www.logosenergia.com.br/alen/pt/projetos/UTE-Bandeirantes > Acesso em 23 dez.2008.

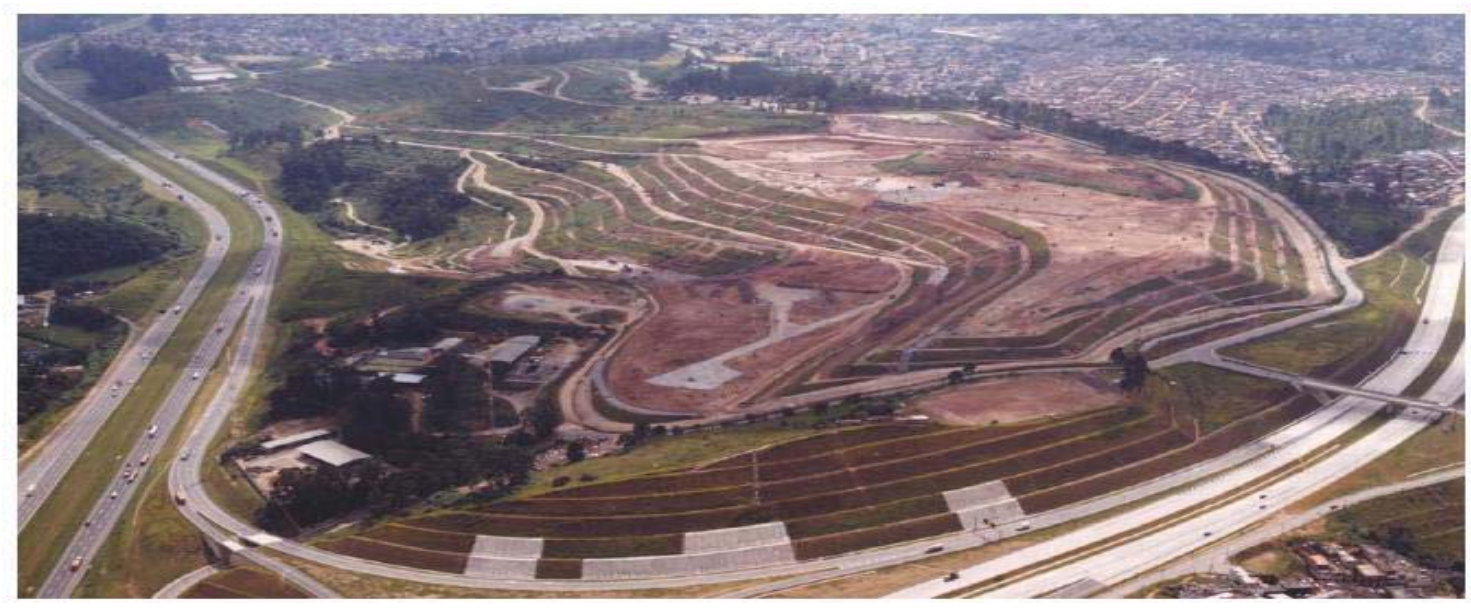

Figura 5.8.1b - Foto aérea Aterro Bandeirantes/São Paulo - Capital

Fonte: <http://www.logosenergia.com.br/alen/pt/projetos/UTE-Bandeirantes> Acesso em 23 dez.2008. 


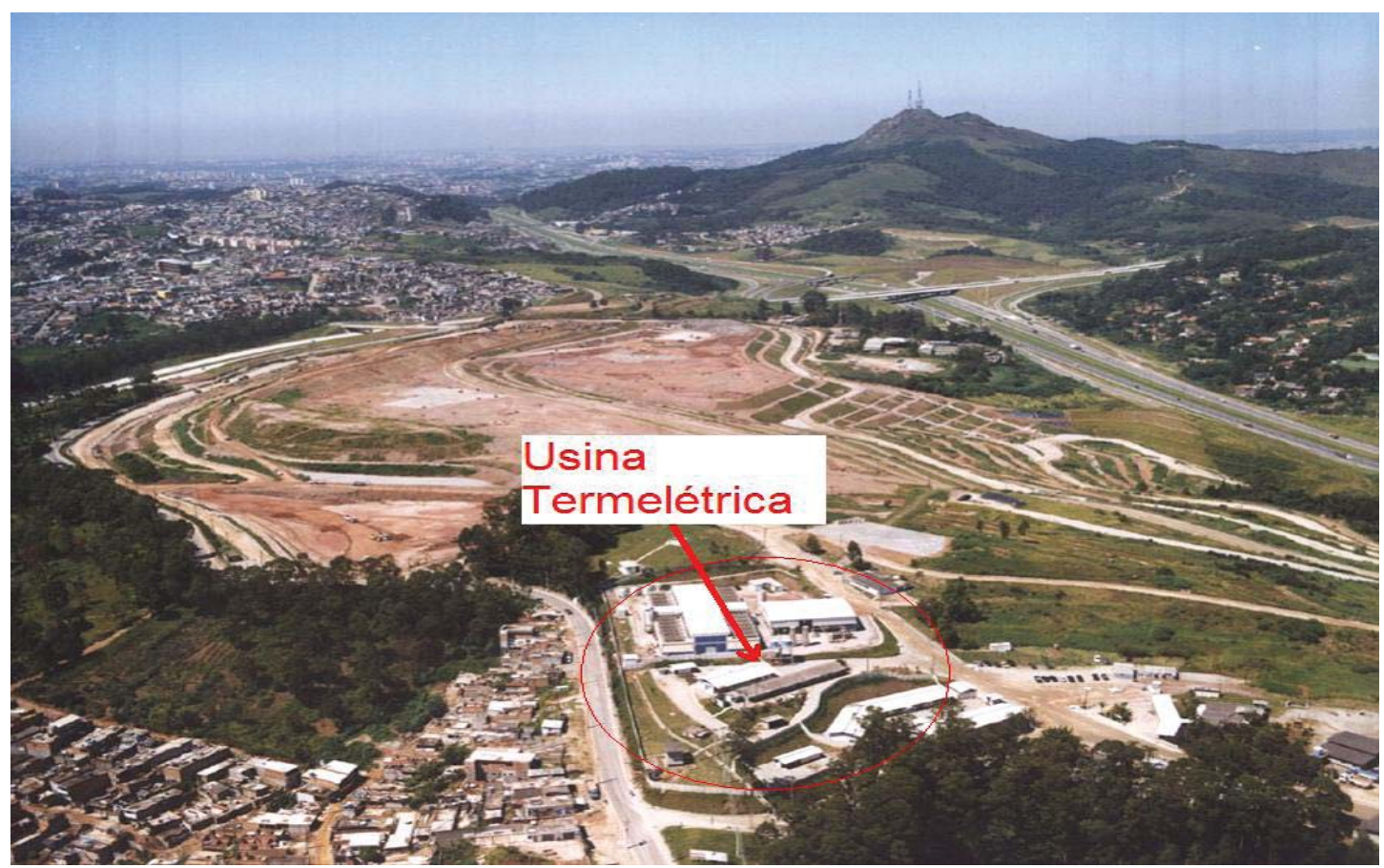

Figura 5.8.1c - Foto aérea Aterro Bandeirantes/São Paulo/Capital - Destaque UTEB.

Fonte: < http://www.logosenergia.com.br/alen/pt/projetos/UTE-Bandeirantes > Acesso em 23 dez.2008.

Segundo Senaga (2004) e Araújo (2008), o aterro bandeirantes recebeu, durante sua vida útil, cerca de 7.000 a 7.500 toneladas diárias de resíduos sólidos da cidade de São Paulo (Capital), correspondendo a 50\% do total produzido pela metrópole, cerca de 15.000 toneladas.dia ${ }^{-1}$. Sua operação foi iniciada em 1974 e esteve ativo por 32 anos. O bandeirantes recebeu os resíduos sólidos de uma área de, aproximadamente, 500 quilômetros quadrados $\left(\mathrm{Km}^{2}\right)$, correspondendo a treze subprefeituras da capital paulista, a saber: Perus, Pirituba/Jaraguá, Lapa, Butantã, Pinheiros, Sé, Mooca, Penha, Vila Maria/Vila Guilherme, Santana/Tucuruvi, Casa Verde, Freguesia do Ó/Brasilândia e Tremembé/Jaçanã.

Isto correspondia à cobertura de coleta a uma população de, aproximadamente, 4,2 milhões de habitantes e 1,4 milhões de domicílios (ARAÚJO, 
2008).

Quando foi encerrado, em 2006, os cálculos indicam um montante de RSU naquele ano de mais de 35 milhões de toneladas, quando foi considerada esgotada a sua capacidade de recepção, tendo formado 'uma verdadeira montanha de lixo', com área de aproximadamente $1.400 .000 \mathrm{~m}^{2}$ e uma altura de 140 metros (LIXO, 2006). O aterro situa-se no km 26 da Rodovia dos Bandeirantes, uma das principais artérias de saída da capital no rumo norte do interior do estado.

Os gases produzidos neste aterro eram queimados em flares verticais, de maneira incipiente, como é prática na grande maioria dos aterros sanitários, lançando milhões de toneladas de poluentes(GEE) na atmosfera. Em janeiro de 2004 foi inaugurada a Usina Termelétrica a Gás do Aterro Sanitário Bandeirantes. A utilização correta que passou a ser dada aos gases ali produzidos, reduziu a emissão equivalente a 8 milhões de toneladas de gás carbônico $\left(\mathrm{tCO}_{2} \mathrm{e}\right)$, considerado um período de 15 anos (LOGOS ENGENHARIA, 2006).

A UTEB tem capacidade instalada para 18 mil metros cúbicos de gás de aterro por hora. Destes, 12 mil metros cúbicos por hora são consumidos para gerar energia e atender ao contrato de fornecimento fechado como Unibanco. Quando atingir sua capacidade plena de captura do gás, a usina terá o equivalente a um milhão de créditos de carbono ao ano (ELO 27, 2005).

A exploração do gás proveniente do lixo acondicionado no aterro é uma iniciativa conjunta da Biogás Energia Ambiental, que coleta e beneficia o gás, e do Unibanco, financiador da Central Termelétrica, que utiliza o gás como fonte de energia elétrica.

A Arcadis Logos Energia, empresa subsidiária da Logos, foi a 
responsável pela estruturação e desenvolvimento do negócio em torno do aproveitamento da energia disponível e integra a Biogás Energia Ambiental, empresa detentora da concessão outorgada pela Prefeitura de São Paulo para a exploração do gás do aterro.

A utilização correta dos gases prevê uma redução significativa de gás metano, obedecendo-se, na prática, o que está determinado no Protocolo de Kyoto sobre a redução da emissão de gases de efeito estufa.

A captação do gás do aterro se dá por meio de tubos conectados aos dissipadores colocados estrategicamente no aterro, juntamente com equipamentos de sucção, secagem e queima do gás excedente, figuras 5.8.2(a e b).

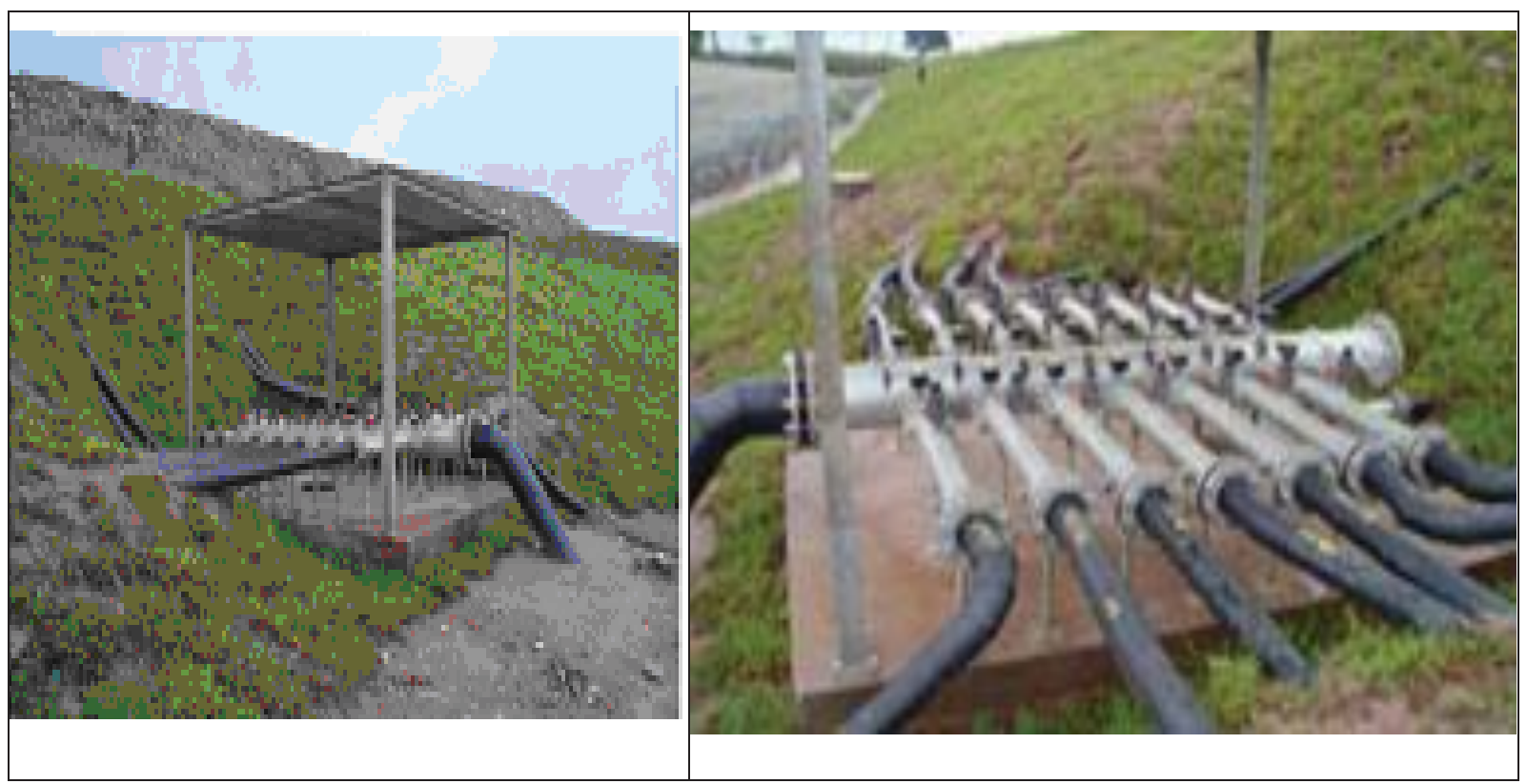

Figuras 5.8.2(a e b). Entroncamentos do Sistema de Coletores do GAS Aterro Bandeirantes/SP.

Fonte: < http://www.logosenergia.com.br/alen/pt/projetos/UTE-bandeirantes > Acesso em 23 dez.2008.

O GAS coletado é encaminhado para moto-geradores (Figura 5.8.3, a 
e b), localizados na usina do aterro, com uma concentração mínima em volume de $50 \%$ e uma vazão de até $12.000 \mathrm{~m}^{3} / \mathrm{h}$. Esta quantidade pode gerar energia elétrica para abastecer uma cidade de cerca de 300.000 pessoas. A usina está conectada a quatro alimentadores de energia da Eletropaulo, que a distribui para os pontos da cidade.

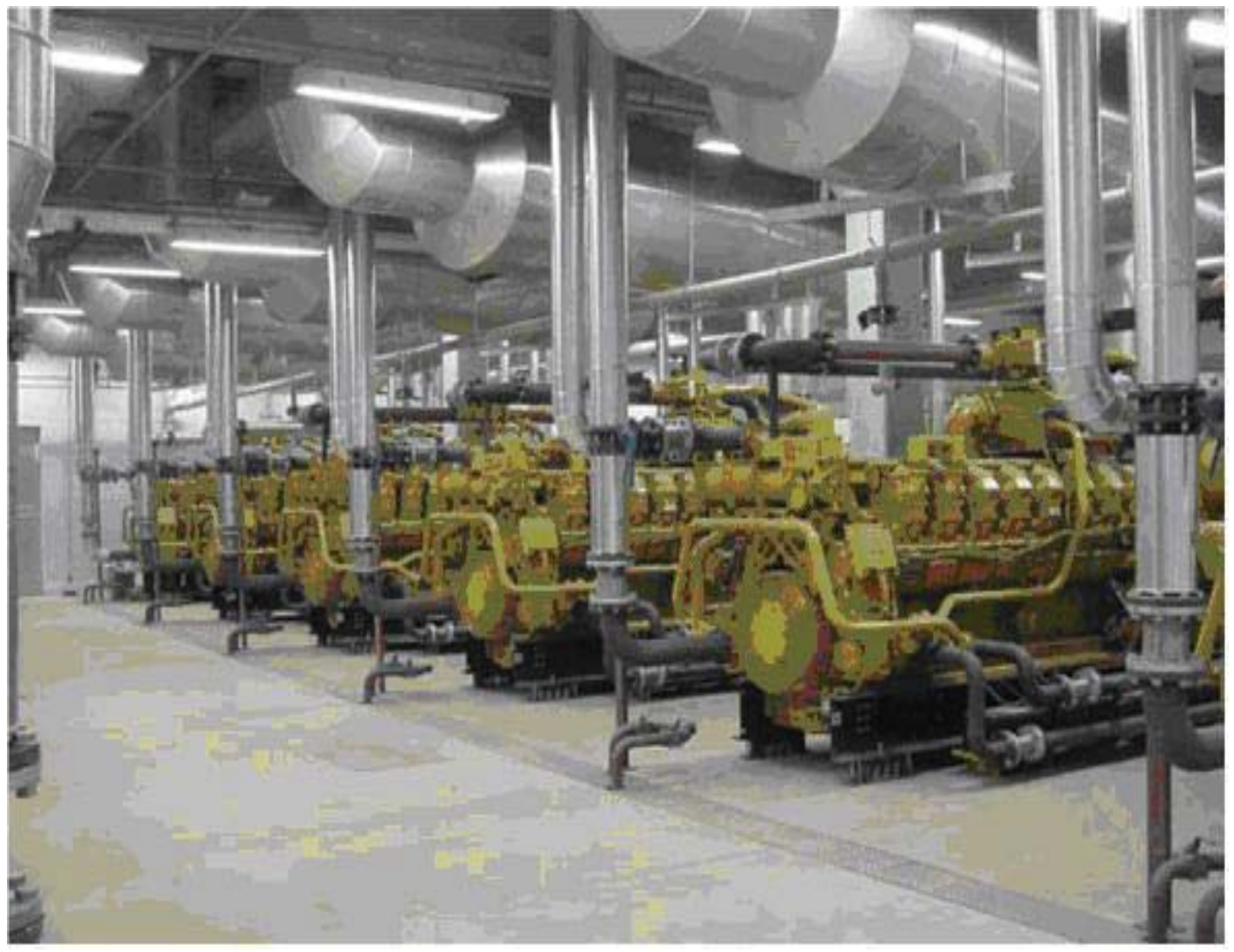

Figura 5.8.3a - Aterro Bandeirantes - Moto-geradores

Fonte: < http://www.logosenergia.com.br/alen/pt/projetos/UTE-Bandeirantes > Acesso em 23 dez 2008. 


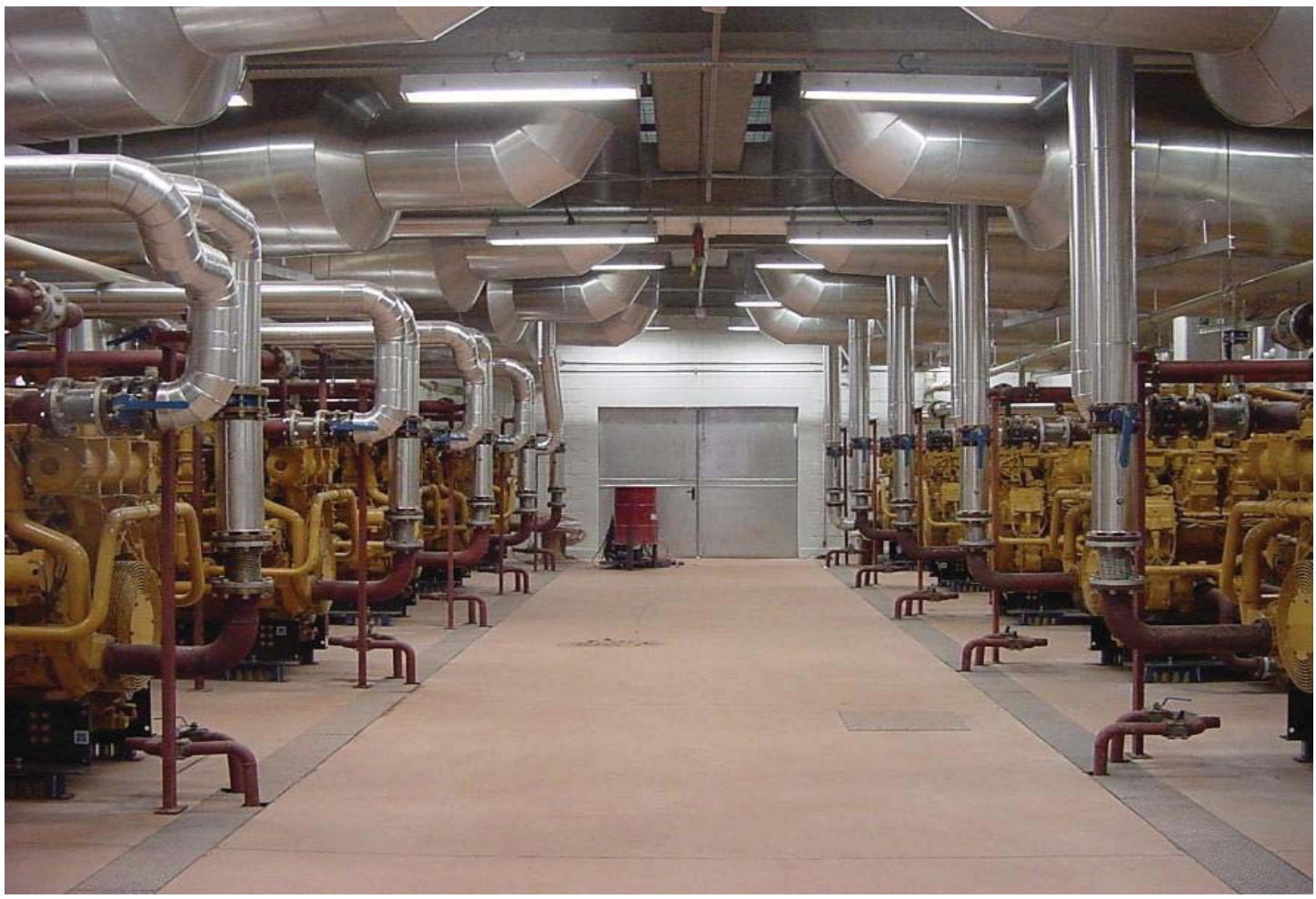

Figura 5.8.3b - Aterro Bandeirantes - Moto-geradores

Fonte: < http://www.logosenergia.com.br/alen/pt/projetos/UTE-Bandeirantes > Acesso em 23 dez 2008.

Segundo Mellis (2004) é o maior projeto mundial de geração de energia elétrica, exclusivamente com gás de aterro, sendo pioneiro no Brasil, com solução eficiente, sócio-econômica e ambientalmente, para o destino do lixo e do metano, com reservas estimadas em 2,4 bilhões de $\mathrm{m}^{3}$ de gás de aterro e uma geração líquida esperada de 170.000 MWh por ano.

Ainda segundo este autor, do ponto de vista sócio-econômico, o empreendimento é muito favorável pois "tem-se a geração de energia elétrica ao lado do consumo - parte da energia elétrica abastece o bairro de Perus - com ganhos elétricos pela redução de perdas”. Foram investidos cerca de $\mathrm{R} \$ 1,5$ milhão em melhorias na rede elétrica do bairro, além do efeito na redução da emissão de $\mathrm{CO}_{2} \mathrm{e}$ (metano é 23 vezes mais potente que o $\mathrm{CO}_{2}$ para o efeito estufa) pela 
queima eficiente. O projeto previu a geração de 8 milhões de créditos de carbono (MDL), sendo $50 \%$ dos créditos destinados à Prefeitura de São Paulo.

\subsection{Situação-resumo dos aterros estudados}

A tabela 5.9.1, a seguir, resume a situação de quantitativos de área, idade, quantidade de resíduos sólidos disposta, tipo de aterro, altura do montante, número de drenos/queimadores e disposição diária dos aterros estudados e que embasam os cálculos da emissão de cada um neste trabalho.

Tabela 5.9.1 - Situação-resumo dos aterros estudados.

\begin{tabular}{l|rcrrrrr}
\hline Aterro & $\begin{array}{c}\text { Área de } \\
\text { disposição } \\
\left(m^{2}\right)\end{array}$ & $\begin{array}{l}\text { Início da } \\
\text { Operação }\end{array}$ & $\begin{array}{r}\text { Quant. de RS } \\
\text { disposta(Ton) }\end{array}$ & $\begin{array}{c}\text { Tipo* } \\
\text { de } \\
\text { Aterro }\end{array}$ & $\begin{array}{c}\text { Altura } \\
(m)\end{array}$ & $\begin{array}{c}\text { Número } \\
\text { queimadores }\end{array}$ & $\begin{array}{r}\text { Demanda } \\
\text { (Ton/d) }\end{array}$ \\
\hline Araraquara & 80.000 & 1975 & 2.378 .000 & AC & 22 & 81 & 150 \\
Brotas & 54.000 & 2004 & 25.280 & $\mathrm{~V}$ & - & - & 9,50 \\
Campinas & 260.000 & 1992 & 4.334 .717 & AS & 45 & 110 & 820,00 \\
Jaú & 48.400 & 1999 & 679.000 & AC & 20 & $* *$ & 115,00 \\
R Bonito & 40.000 & 2003 & 32.000 & V & - & - & 10,00 \\
R Preto & 218.000 & 1990 & 2.342 .266 & AC & 25 & 85 & 500,00 \\
São Carlos & 180.000 & 1996 & 608.907 & AS & 28 & 17 & 130,00 \\
Bandeirantes & 1.400 .000 & 1974 & 35.000 .000 .000 & AS & 140 & - & $7.500,00$ \\
\hline
\end{tabular}

* AC(Aterro Controlado), V(Aterro em Valas), AS(Aterro Sanitário)

** Um cano( PVC)( LOPES, 2007). (Não é um queimador) 


\section{RESULTADOS}

"Os EXCESSOS SÃO, POR SI SÓS, CONTRÁRIOS AO APROVEITAMENTO PACÍFICO DE QUALQUER BEM." GIUSEPPE BERTO (ITALIANO)

\subsection{Resultados das amostras por aterro, data e tempos de coleta; cálculo do} número de moles $(n)$ e massa $(m, \mu g)$ para $\circ \mathrm{CH}_{4}$ e o $\mathrm{CO}_{2}$.

Os cálculos do número de moles de metano $\left[\eta_{1}\left(\mathrm{CH}_{4}\right)\right]$ e de dióxido de carbono $\left[\eta_{2}\left(\mathrm{CO}_{2}\right)\right]$ foram feitos a partir das áreas cromatográficas medidas $(A)$ e das equações [6.1.1.1(a e b) e 6.1.1.2(c e d)], resultantes das curvas de calibração do cromatógrafo (Apêndice C).

Com o número de moles $(n)$ de cada gás calculou-se as massas correspondestes, conforme mostrado a seguir:

\subsection{1 - Equações para o cálculo do número de moles $\left(\eta_{1}\right)$ e da massa $\left(m_{1} ; \mu g\right)$ para o metano:}

$$
n_{1}\left(\mathrm{CH}_{4}\right)=\frac{11160,36+A_{1}}{17579209812,27}
$$

Equação 6.1.1.1a

Na equação 6.1.1.1a, resultante da curva de calibração para o metano, temos que: $\eta_{1}$ é o número de moles de metano a ser calculado e $A_{1}$ é a área cromatográfica medida para metano $\left(\mathrm{CH}_{4}\right)$, numa injeção cromatográfica de 1 $\mathrm{mL}$, de cada amostra de $30 \mathrm{~mL}$ do ar ambiente dos aterros, das amostras do GAS 
nos tempos 0', 3', 6' e 12', em cada sítio amostrado $\left(P_{n}\right)$ para a emissão solo-ar e dos dissipadores verticais - estes quando presentes.

$$
m_{1}\left(\mathrm{CH}_{4}\right)=n_{1}\left(\mathrm{CH}_{4}\right) \times 16,04 \times 10^{6}
$$

Equação 6.1.2.1b

A equação $6.1 .1 .1 \mathrm{~b}$, foi utilizada para o cálculo da massa de metano $\left(m_{1}\right)$, correspondente a cada amostra, a partir do número de moles de metano $\left(\eta_{1}\right)$ calculado a partir da equação 6.1.1.1a e da massa molar do metano $(16,04 \mathrm{~g})$; multiplicados por $10^{6}$, resultando a massa de metano presente em cada $1 \mathrm{~mL}$ da amostra, injetado no cromatógrafo, em microgramas $(\mu g)$.

\subsection{2 - Equações para o cálculo do número de moles $\left(\eta_{2}\right)$ e da massa $\left(m_{2} ; \mu g\right)$ para o dióxido de carbono:}

$$
n_{2}\left(C O_{2}\right)=\frac{3433,10+A_{2}}{20506760039,50}
$$

$\mathrm{Na}$ equação 6.1.1.2a, resultante da curva de calibração para o dióxido de carbono, temos que: $\eta_{2}$ é o número de moles a ser calculado para o dióxido de carbono e $A_{2}$ é a área cromatográfica medida para dióxido de carbono $\left(\mathrm{CO}_{2}\right)$ para cada $1 \mathrm{~mL}$ da amostra de $30 \mathrm{~mL}$, colhida do ar ambiente dos aterros, das amostras do GAS nos tempos 0', 3', 6' e 12', em cada sítio amostrado $\left(P_{n}\right)$ para a emissão solo-ar e dos dissipadores verticais - estes quando presentes. 


$$
m_{2}\left(\mathrm{CO}_{2}\right)=x_{2}\left(\mathrm{CO}_{2}\right) \times 44,00 \times 10^{6} \quad \text { Equação } 6.1 .2 .1 \mathrm{~b}
$$

A equação 6.1.1.2b, foi utilizada para o cálculo da massa de dióxido de carbono $\left(m_{2}\right)$, correspondente a cada amostra, a partir do número de moles de dióxido de carbono $\left(\eta_{2}\right)$ calculado a partir da equação $6.1 .1 .2^{\mathrm{a}}$ e da massa molar do dióxido de carbono $(44,00 \mathrm{~g})$; multiplicados por $10^{6}$, resultando a massa de dióxido de carbono presente em cada $1 \mathrm{~mL}$ da amostra, injetado no cromatógrafo, em microgramas $(\mu g)$.

Nos cromatogramas representativos de algumas amostras - do ar ambiente dos aterros e do GAS( solo-ar e dissipadores) - mostrados na sessão a seguir, estão indicados os picos e áreas correspondentes a metano $\left(\mathrm{CH}_{4}\right)$ e dióxido de carbono $\left(\mathrm{CO}_{2}\right)$. 


\section{2 - Cromatogramas representativos.}

Nesta sessão estão mostrados os cromatogramas representativos de algumas amostras do ar ambiente dos aterros e do GAS (emissão solo-ar e dissipadores), com destaque para os picos e áreas cromatográficos de $\mathrm{CH}_{4}$ e $\mathrm{CO}_{2}$.

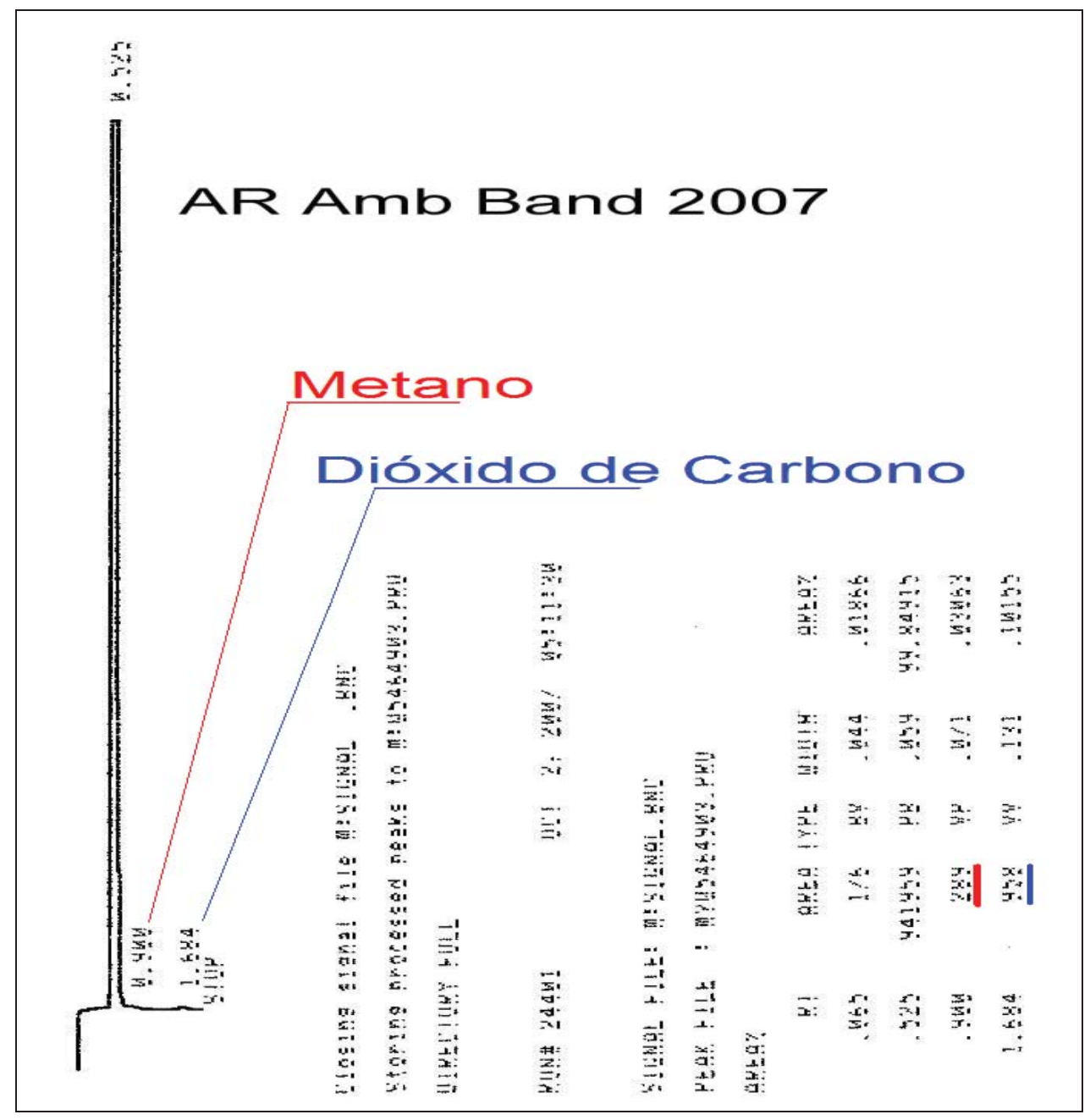

Quadro 6.2.1 - Cromatograma de amostra de Ar Ambiente do Aterro Bandeirantes (2007), colhida a, aproximadamente, 1,5 $\mathrm{m}$ de altura do solo. Destaque para os picos de metano (vermelho) e dióxido de carbono (azul) com respectivas áreas cromatográficas. 


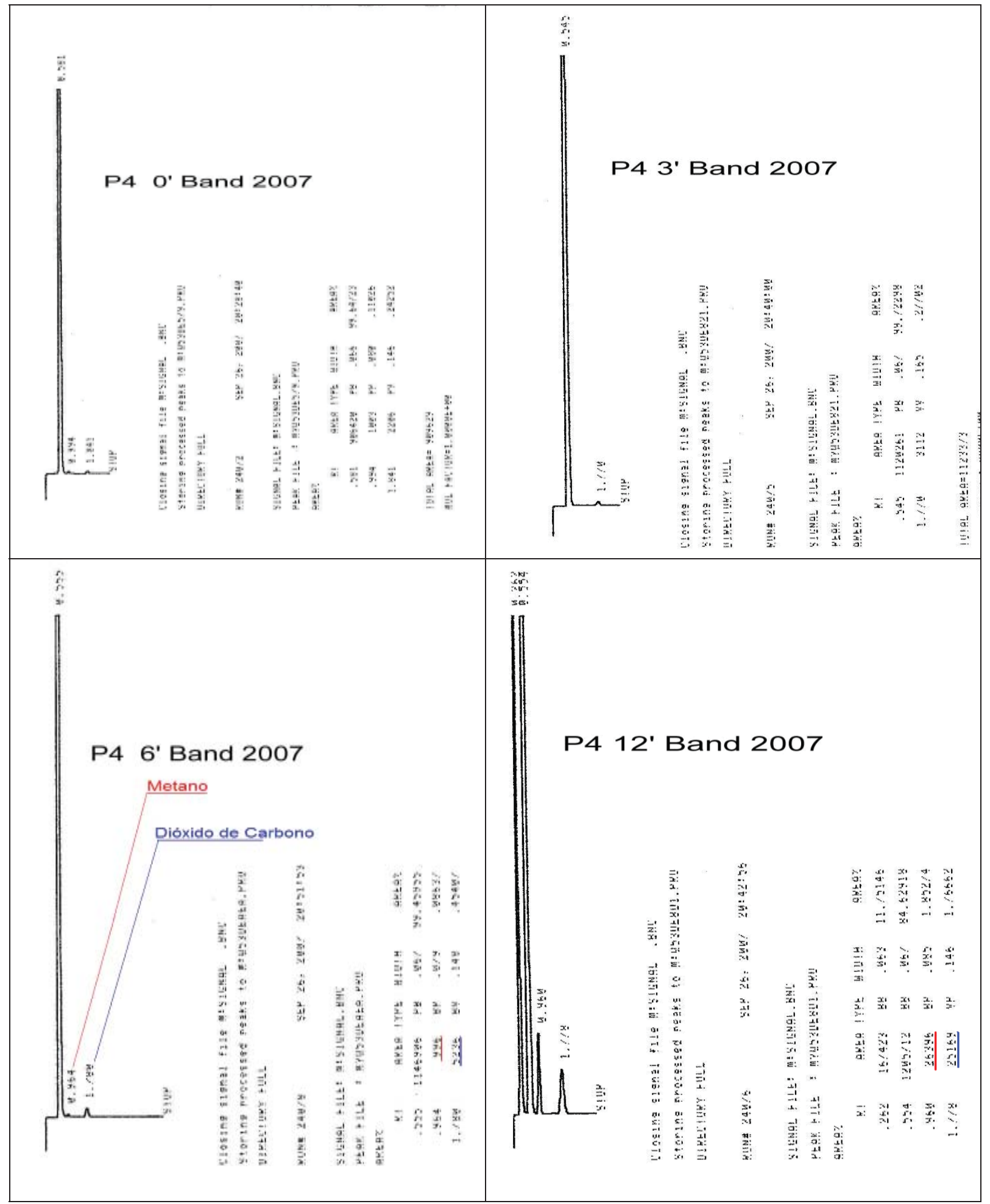

Quadro 6.2.2 - Cromatogramas das amostras do sítio de coleta $\mathrm{P}_{4}$ (emissão solo-ar) do aterro bandeirantes/Capital - SP 2007, nos tempos 0', 3', 6' e 12'. Destaque ( $\mathrm{t}=6$ ') para picos de $\mathrm{CH}_{4}$ (vermelho) e $\mathrm{CO}_{2}$ (azul) e respectivas áreas cromatográficas. 


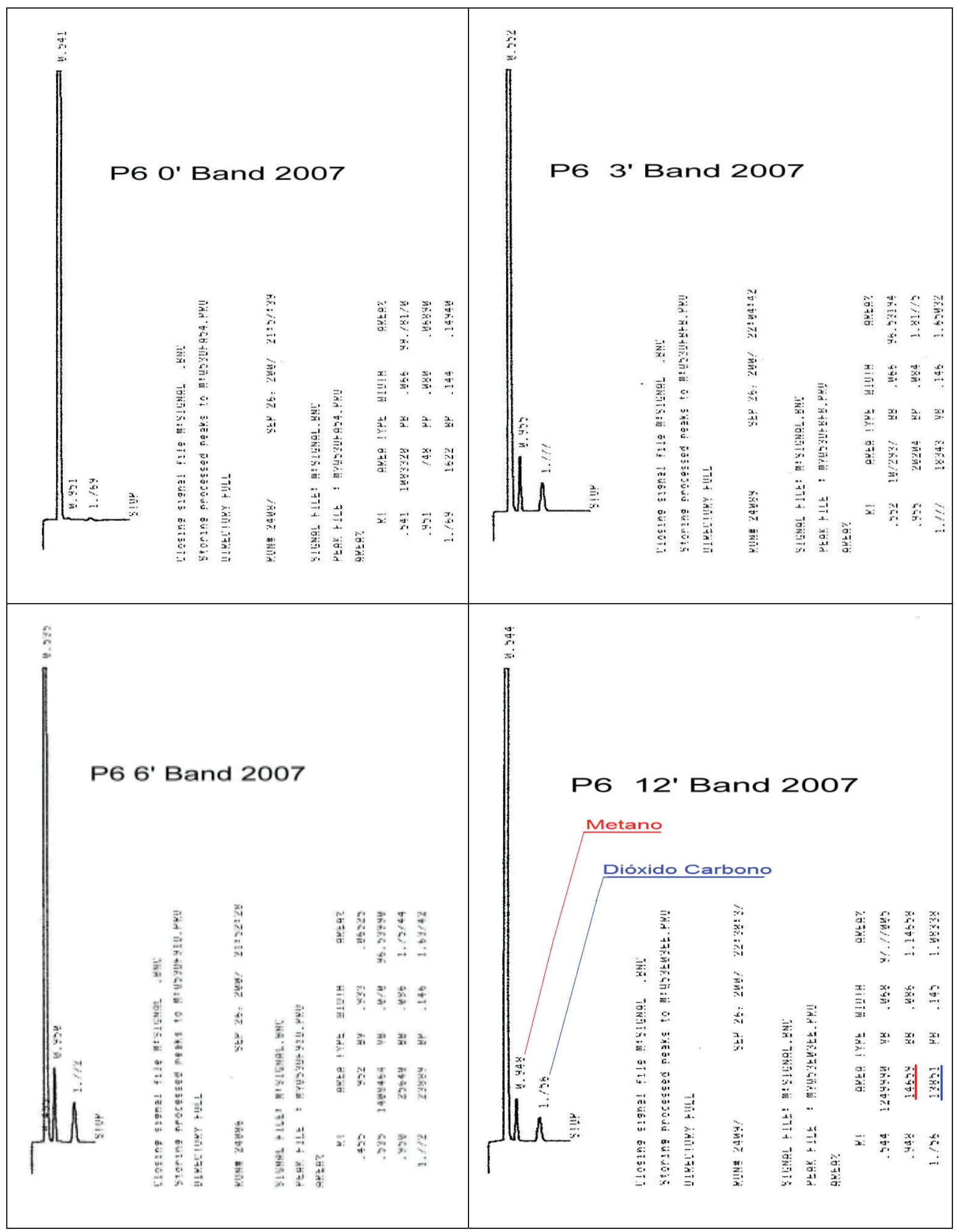

Quadro 6.2.3 - Cromatogramas das amostras do sítio de coleta $\mathrm{P}_{6}$ do aterro bandeirantes/Capital - SP 2007, nos tempos 0', 3', 6' e 12'. Destaque ( $\mathrm{t}=12$ ') para picos de $\mathrm{CH}_{4}$ (vermelho) e $\mathrm{CO}_{2}($ azul) e respectivas áreas cromatográficas. 


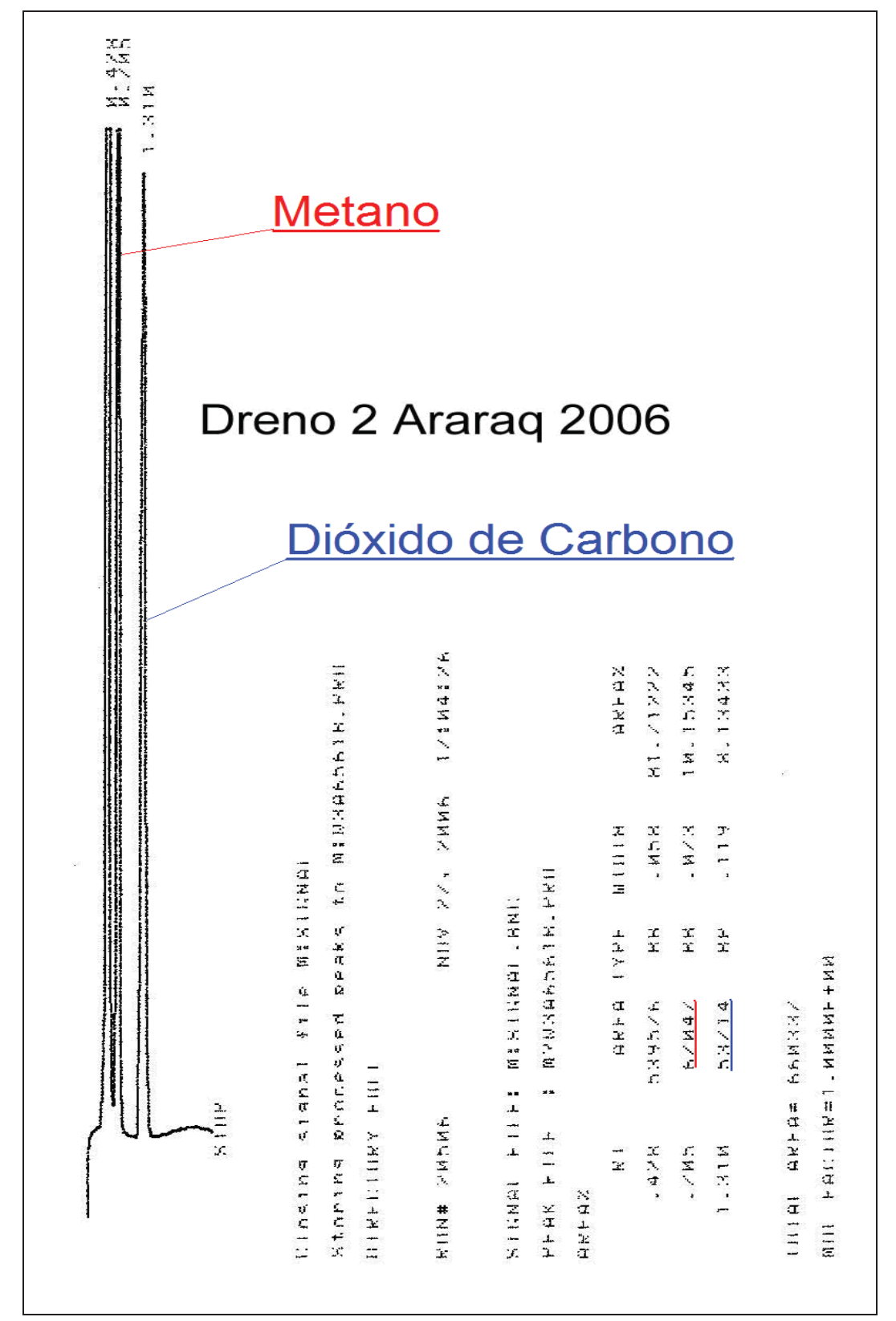

Quadro 6.2.4 - Cromatograma de amostra do dissipador (2) do aterro de Araraquara 2006. Destaque para os picos de $\mathrm{CH}_{4}$ (vermelho) e $\mathrm{CO}_{2}$ (azul) com respectivas áreas cromatográficas. 


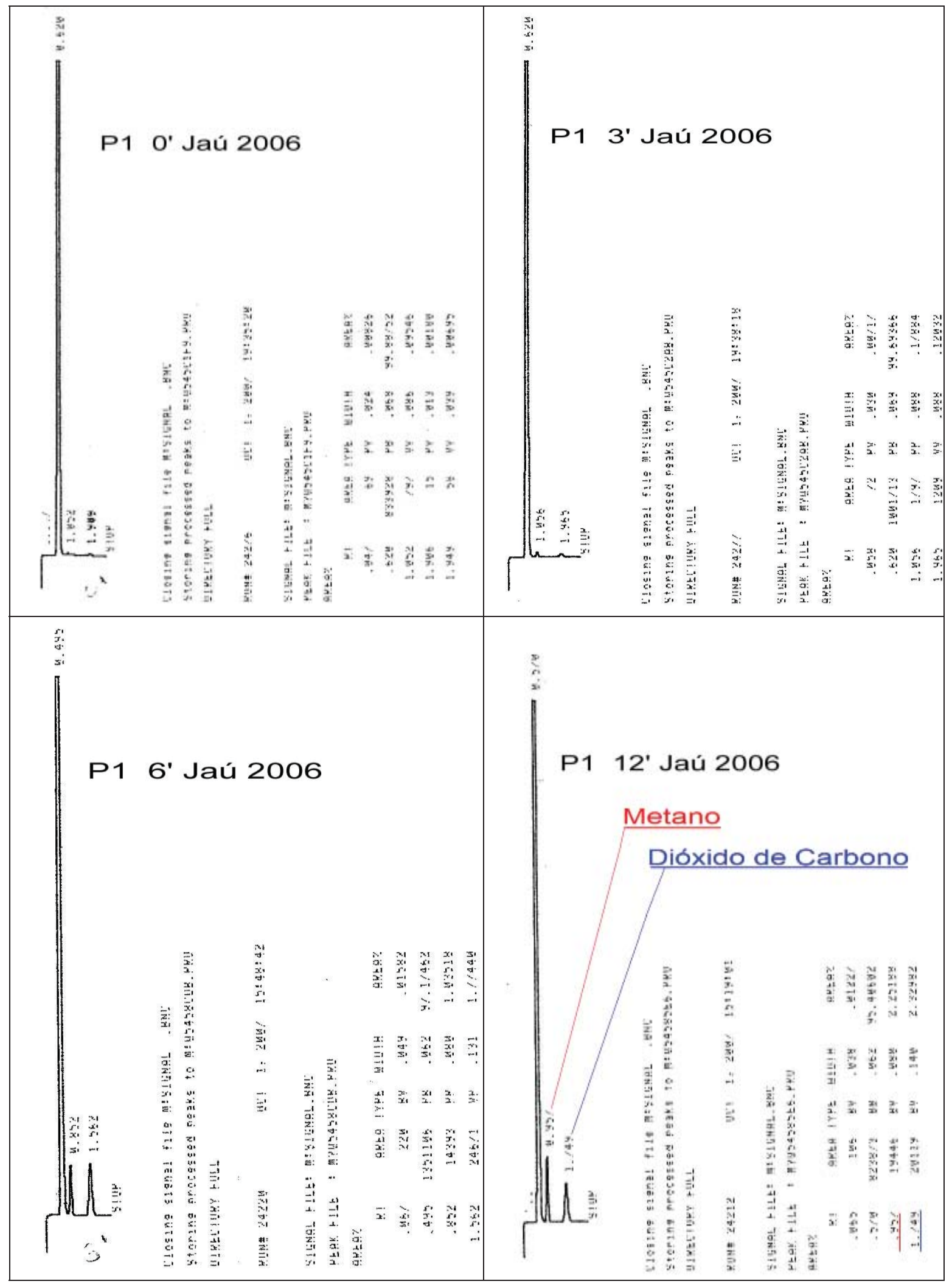

Quadro 6.2.5 - Cromatogramas das amostras do sítio de coleta $\mathrm{P}_{1}$ do aterro de Jaú - SP 2006, nos tempos 0', 3', 6' e 12'. Destaque (t=12') para picos de $\mathrm{CH}_{4}$ (vermelho) e $\mathrm{CO}_{2}$ (azul) com respectivas áreas cromatográficas. 


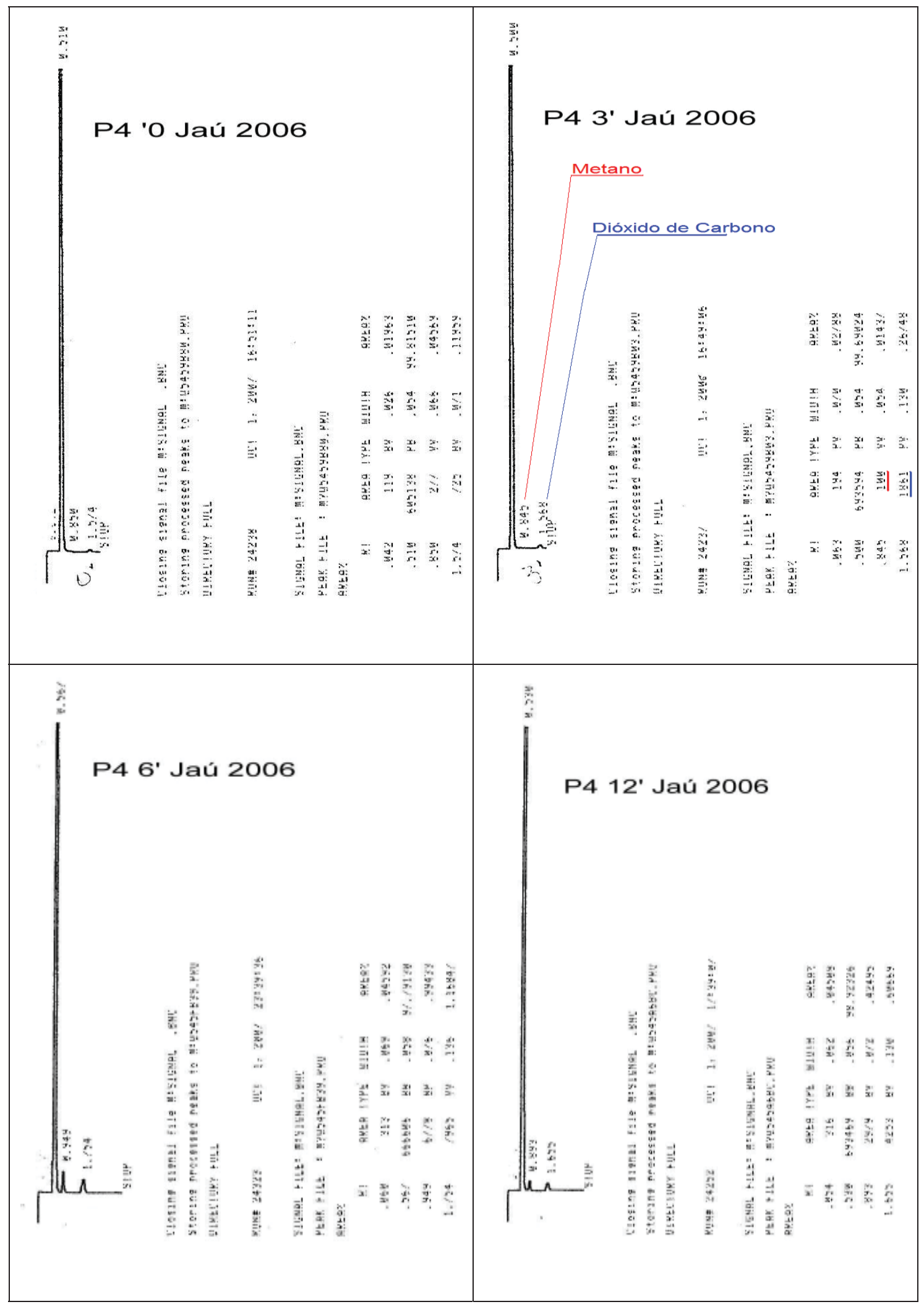

Quadro 6.2.6 - Cromatogramas das amostras do sítio de coleta $\mathrm{P}_{4}$ do aterro de Jaú - SP 2006, nos tempos 0', 3', 6' e 12'. Destaque ( $\left.t=3^{\prime}\right)$ para picos de $\mathrm{CH}_{4}($ vermelho $)$ e $\quad \mathrm{CO}_{2}$ (azul) e respectivas áreas cromatográficas. 


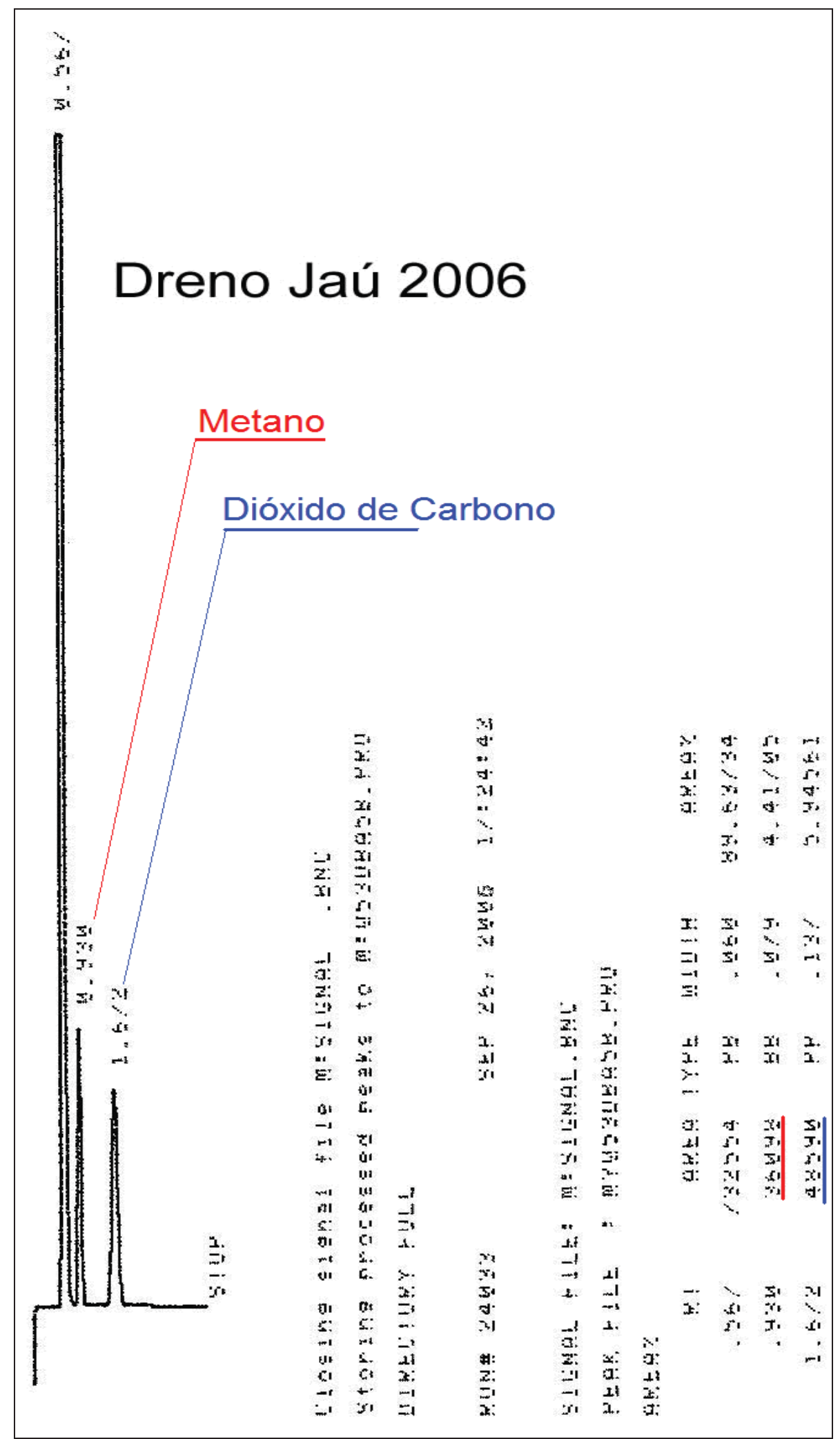

Quadro 6.2.7 - Cromatograma da amostra de dissipador do aterro de Jaú - SP 2006. Destaque para os picos de $\mathrm{CH}_{4}$ (vermelho) e $\mathrm{CO}_{2}$ (azul) e respectivas áreas cromatográficas. 


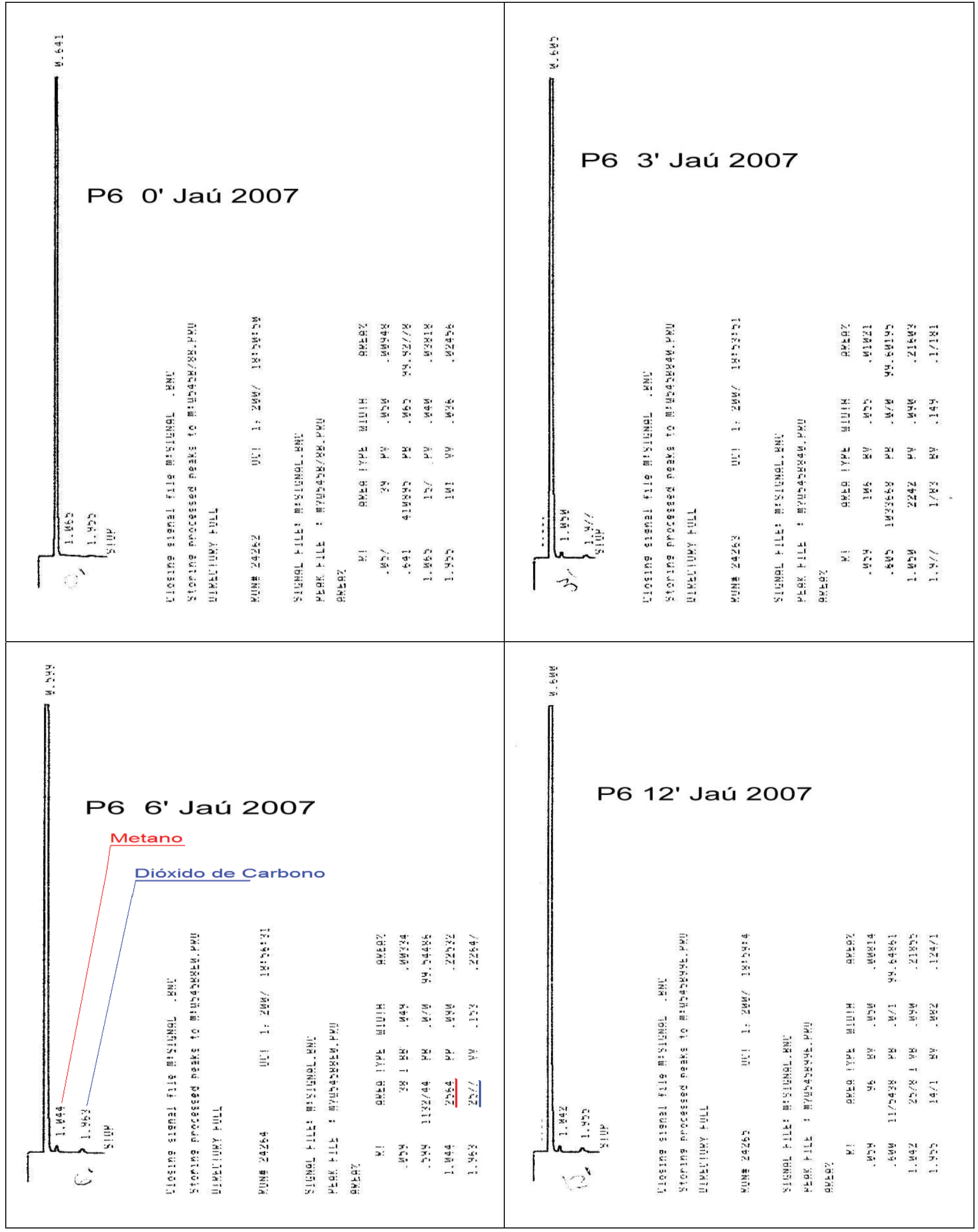

Quadro 6.2.8 - Cromatogramas das amostras do sítio de coleta $\mathrm{P}_{6}$ do aterro de Jaú - SP 2007, nos tempos 0', 3', 6' e 12'. Destaque ( $\mathrm{t}=6$ ') para picos de $\mathrm{CH}_{4}$ (vermelho) e $\mathrm{CO}_{2}$ (azul) e respectivas áreas cromatográficas. 


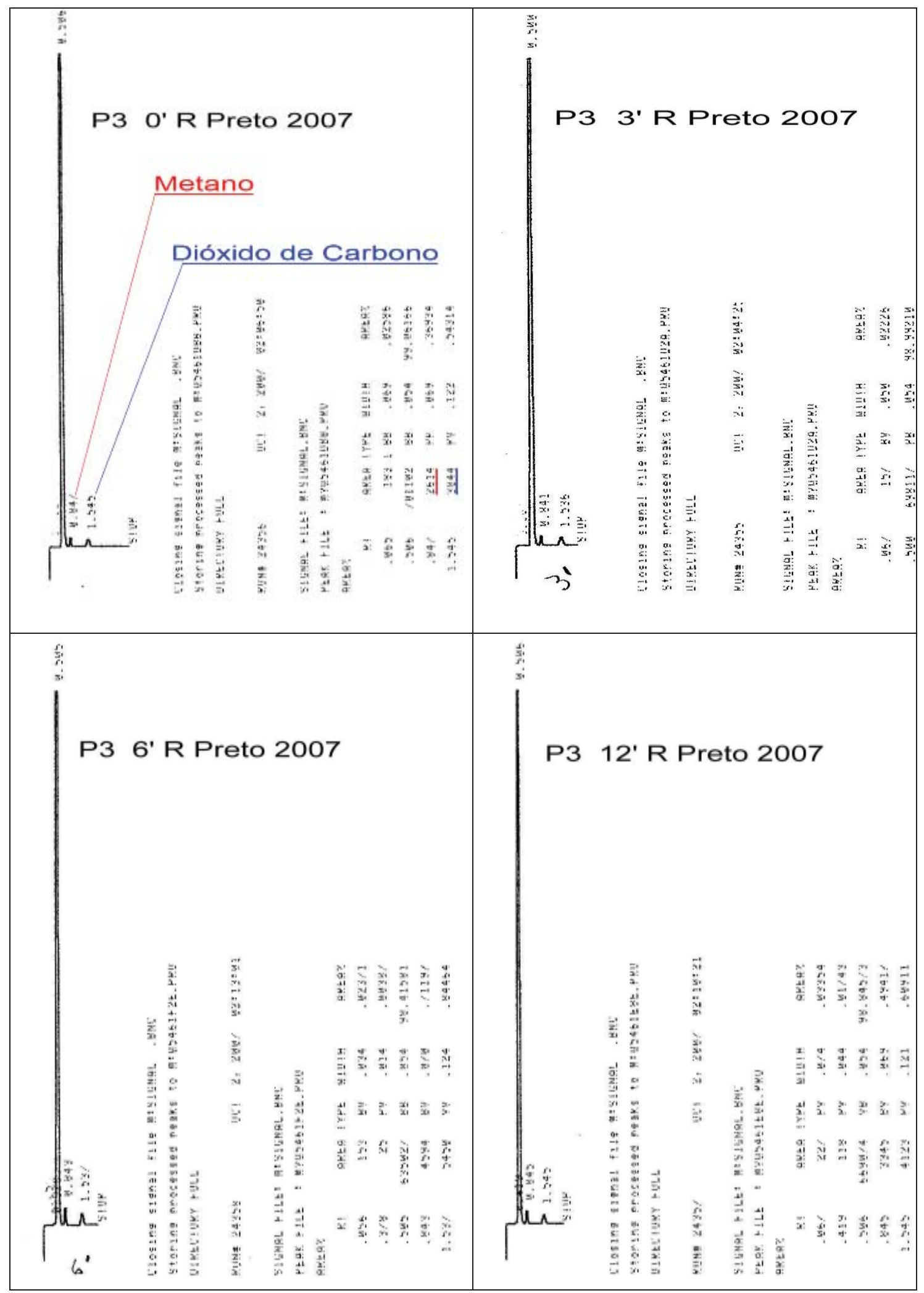

Quadro 6.2.9 - Cromatogramas das amostras do sítio de coleta $\mathrm{P}_{3}$ do aterro de Ribeirão Preto-SP 2007, nos tempos 0', 3', 6' e 12'. Destaque ( $\mathrm{t}=0$ ') para picos de $\mathrm{CH}_{4}$ (vermelho) e $\mathrm{CO}_{2}($ azul) e respectivas áreas cromatográficas. 


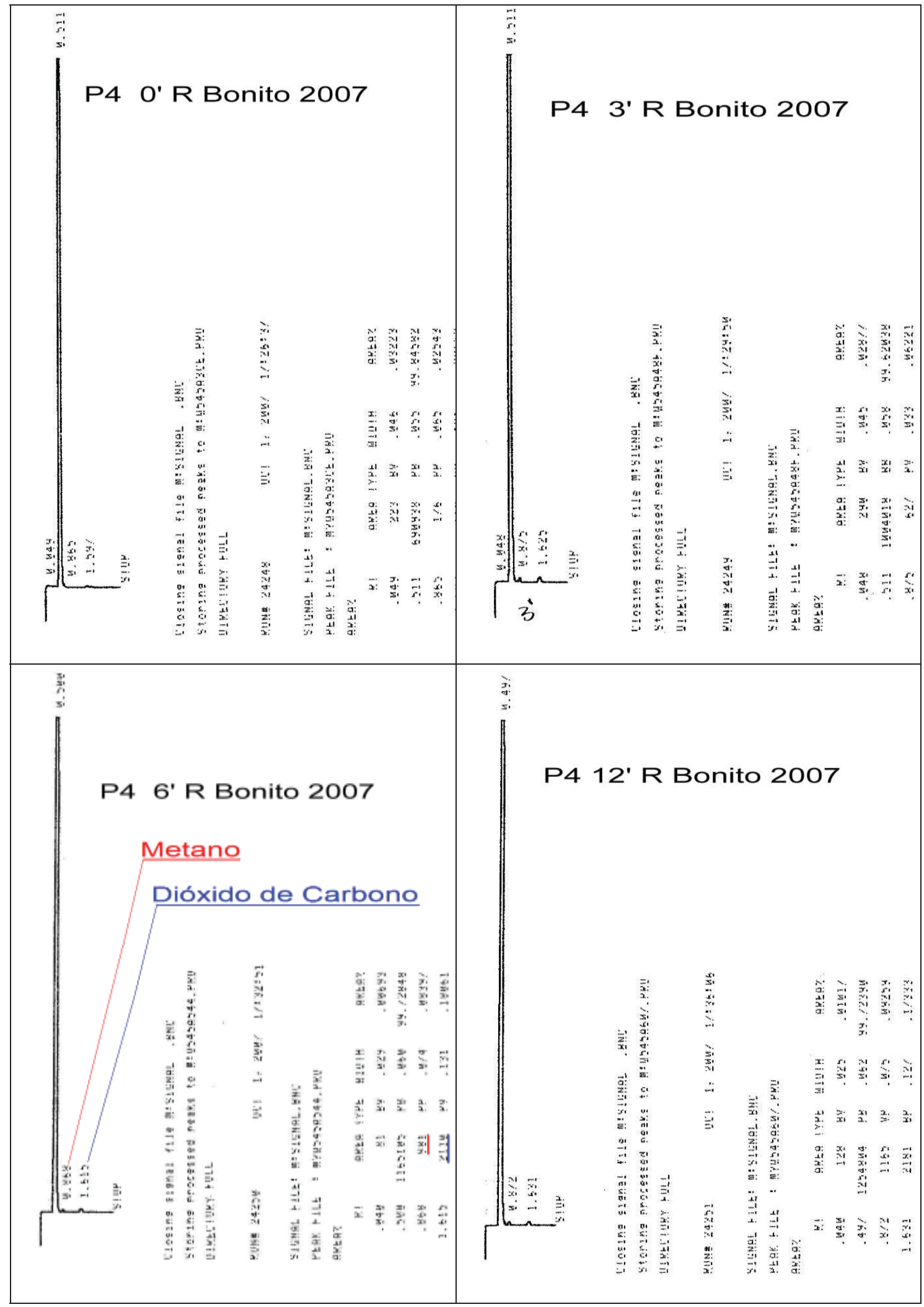

Quadro 6.2.10 - Cromatogramas das amostras do sítio de coleta $\mathrm{P}_{4}$ do aterro de Ribeirão Bonito - SP 2007, nos tempos 0', 3', 6' e 12'. Destaque ( $\mathrm{t}=6$ ') para picos de $\mathrm{CH}_{4}$ (vermelho) e $\mathrm{CO}_{2}($ azul) e respectivas áreas cromatográficas. 


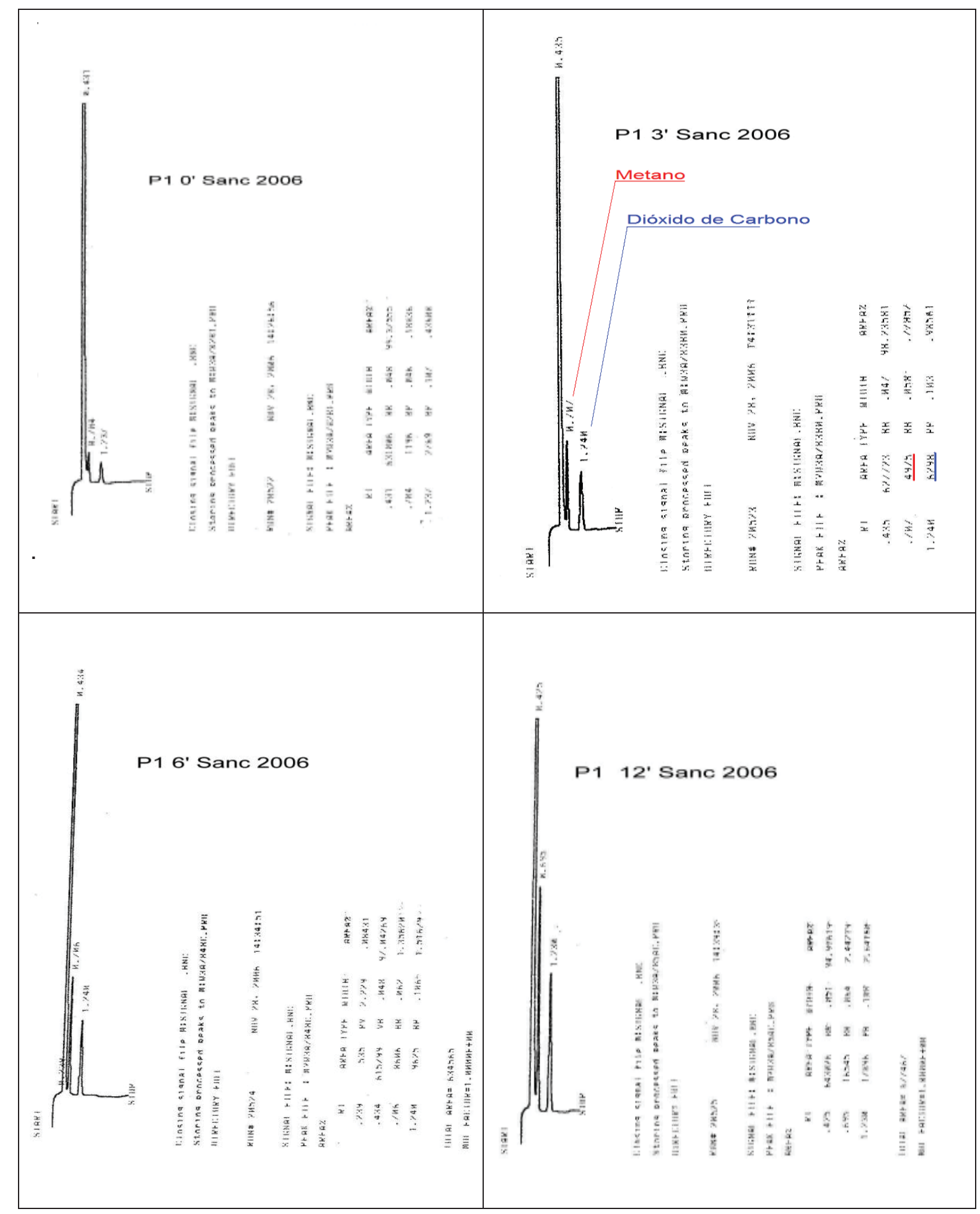

Quadro 6.2.11 - Cromatogramas das amostras do sítio de coleta $\mathrm{P}_{1}$ do aterro de São Carlos - SP 2006, nos tempos 0', 3', 6' e 12'. Destaque ( $t=3$ ') para picos de $\mathrm{CH}_{4}$ (vermelho) e $\mathrm{CO}_{2}($ azul) e respectivas áreas cromatográficas. 


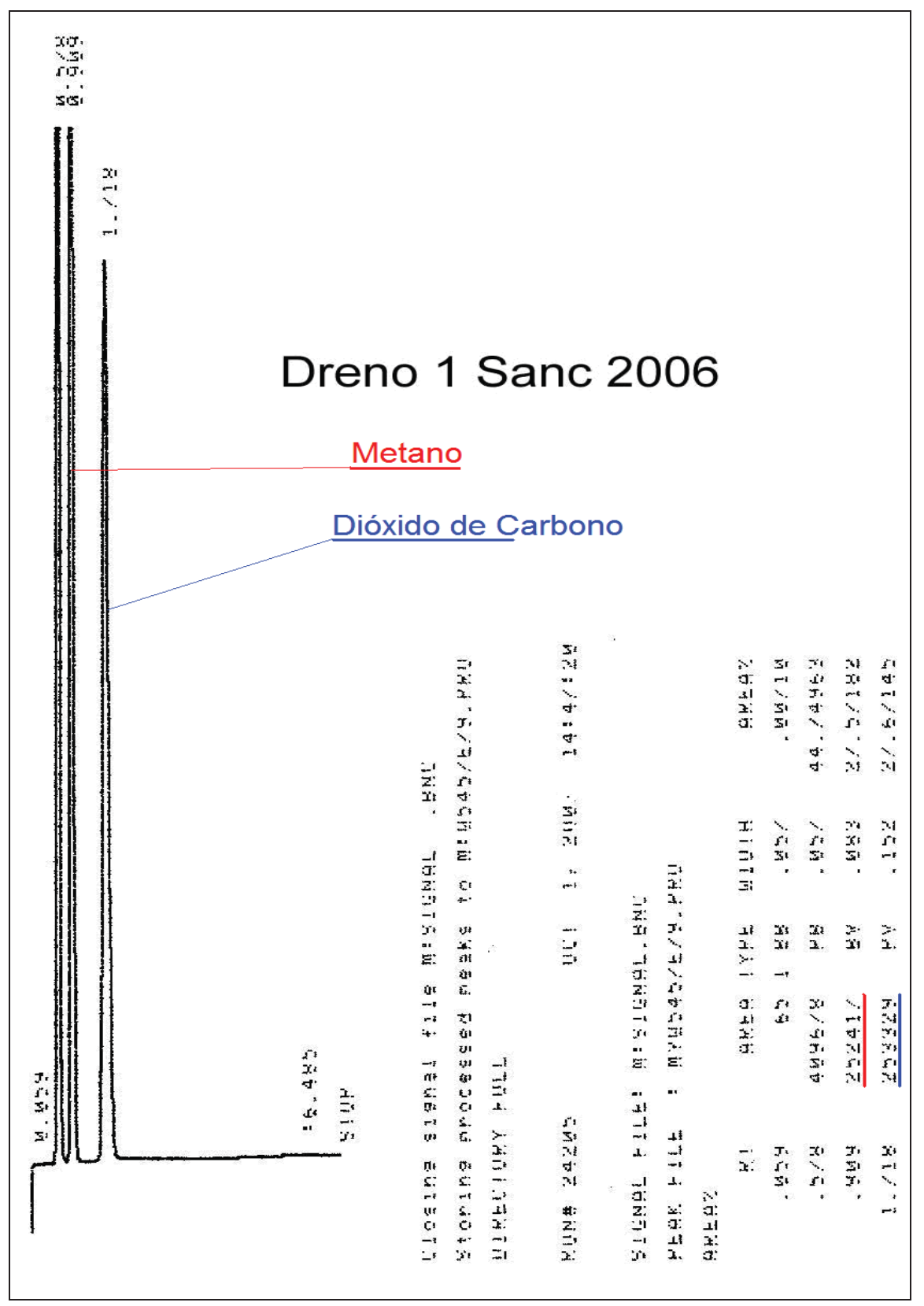

Quadro 6.2.12 - Cromatograma da amostra do dreno (1) do aterro de São Carlos SP 2006. Destaque para picos de $\mathrm{CH}_{4}$ (vermelho) e $\mathrm{CO}_{2}($ azul) e respectivas áreas cromatográficas. 


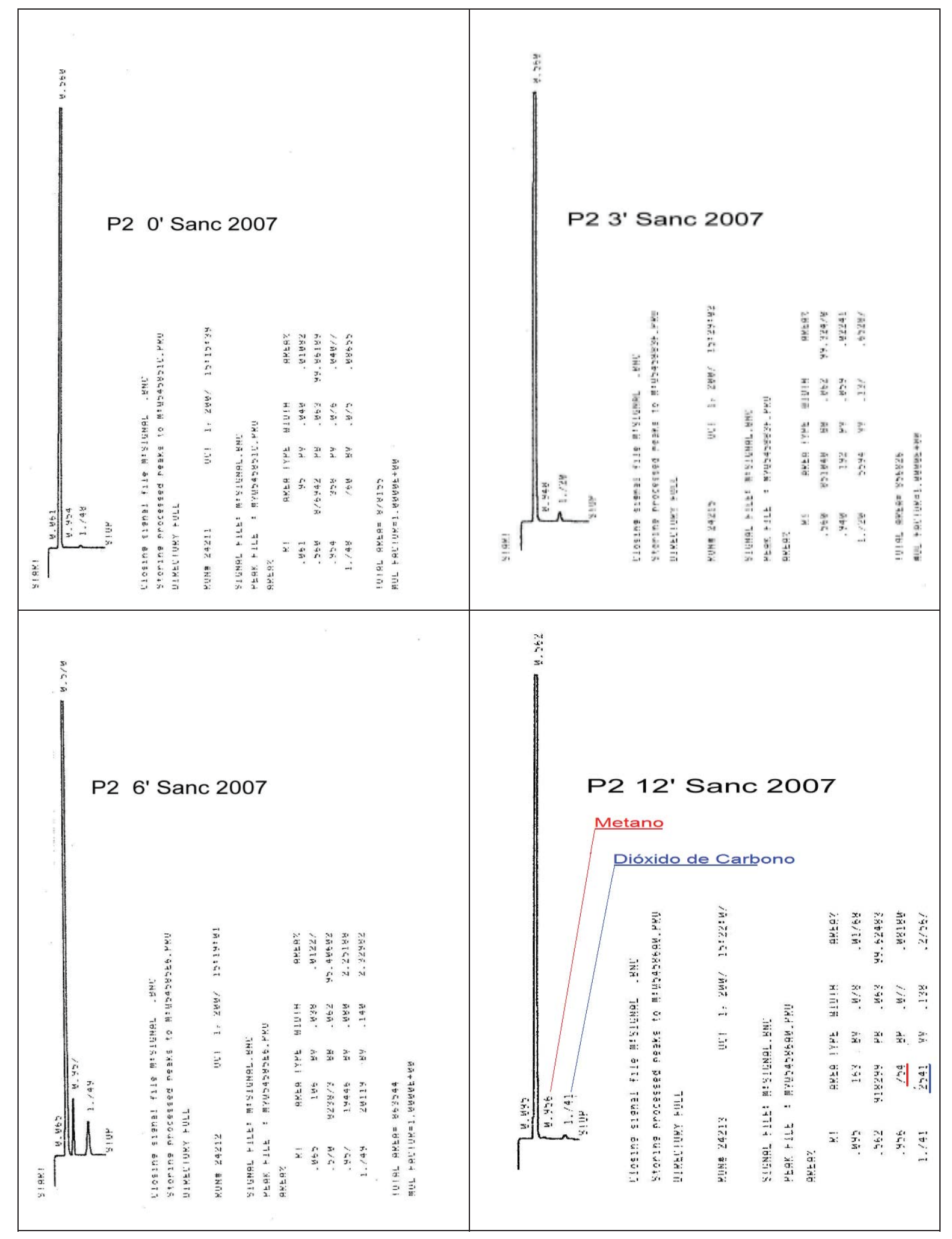

Quadro 6.2.13 - Cromatogramas das amostras do sítio de coleta $\mathrm{P}_{2}$ do aterro de São Carlos - SP 2007, nos tempos 0', 3', 6' e 12'. Destaque ( $\mathrm{t}=12$ ') para picos de $\mathrm{CH}_{4}$ (vermelho) e $\mathrm{CO}_{2}$ (azul) e respectivas áreas cromatográficas. 


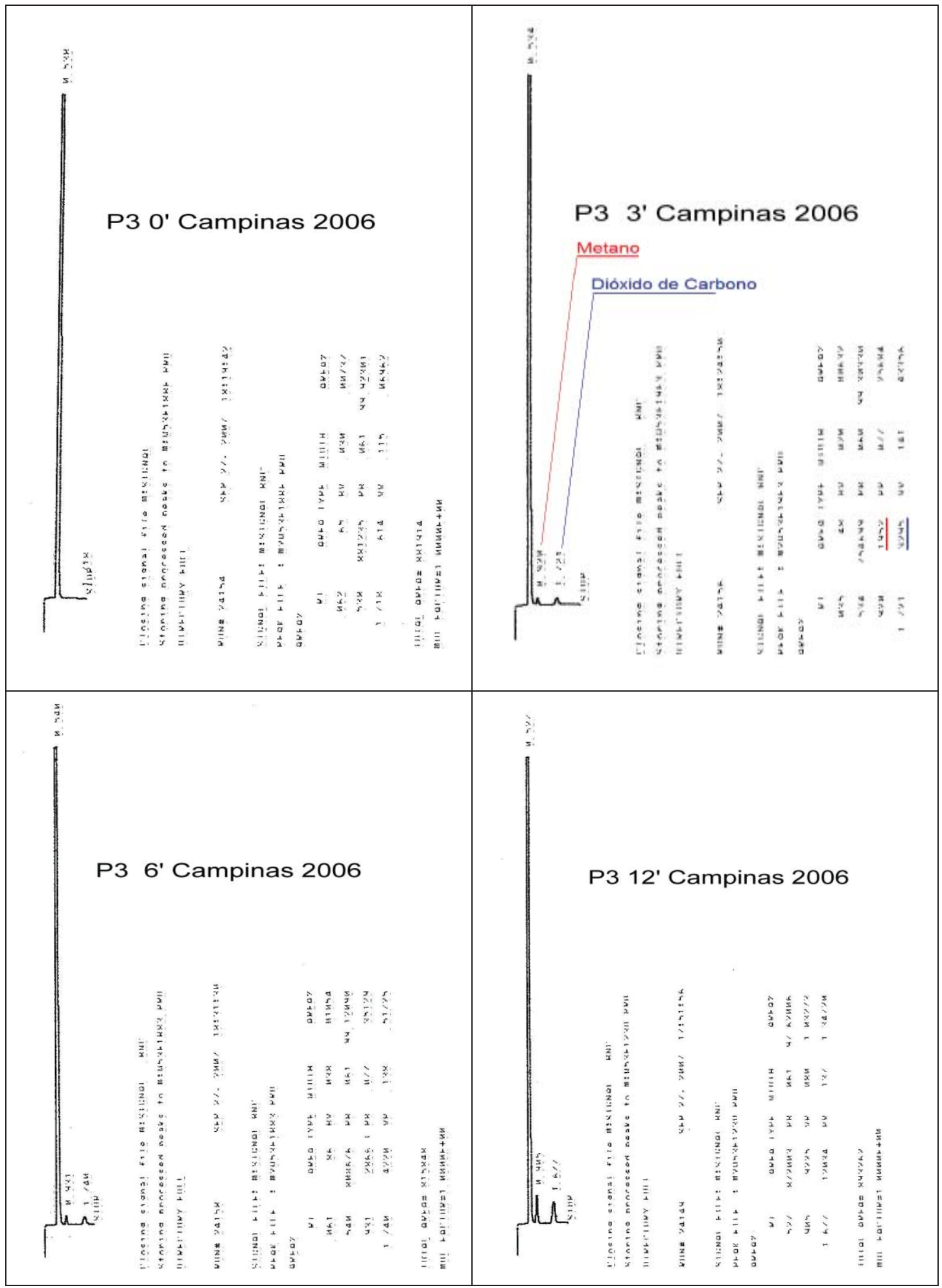

Quadro 6.2.14 - Cromatogramas das amostras do sítio de coleta $\mathrm{P}_{3}$ do aterro de Campinas - SP 2006, nos tempos 0', 3', 6' e 12'. Destaque ( $\left.\mathrm{t}=3^{\prime}\right)$ para picos de $\mathrm{CH}_{4}$ (vermelho) e $\mathrm{CO}_{2}$ (azul) e respectivas áreas cromatográficas. 
6.3 - Tabelas com o cálculo do número de moles $(n)$ e da massa $(m, \mu g)$ de $\mathrm{CH}_{4}$ e $\mathrm{CO}_{2}$, para cada amostra, por aterro e tempos de coleta.

Nesta sessão são apresentadas tabelas em que aparecem os valores calculados para o $\boldsymbol{n}$ e para a $\boldsymbol{m}(\mu \mathrm{g})$ do ar ambiente, da emissão solo-ar e dos dissipadores, para os dois gases, por aterro.

6.3.1- $\mathrm{A}_{1}$ ) Aterro de Araraquara - Primeira Campanha - 27/11/2006

Tabela 6.3.1 - AR Ambiente - Áreas cromatográficas medidas $(A)$, número de moles $(n)$ e massa $(m, \mu \mathrm{g})$ de cada gás, correspondentes:

\begin{tabular}{|c|c|c|c|c|}
\hline Tomada & Gás & $A$ & $n$ & $m(\mu g)$ \\
\hline \multirow{2}{*}{1} & $\mathrm{CH}_{4}$ & 786 & $6,7958 \times 10^{-1}$ & 10,9005 \\
\hline & $\mathrm{CO}_{2}$ & 1487 & $2,3992 \times 10^{-1}$ & 10,5567 \\
\hline
\end{tabular}

Tabela 6.3.2 - $\mathrm{P}_{1}(\mathrm{G})$ - Áreas cromatográficas medidas $(A)$, número de moles $(n)$ e massa $(m, \mu g)$ de cada gás, correspondentes:

\begin{tabular}{crrcr}
\hline Tempo & Gás & \multicolumn{1}{c}{$\boldsymbol{A}$} & $\boldsymbol{n}$ & $\boldsymbol{m}(\boldsymbol{\mu g})$ \\
\hline \multirow{2}{*}{$0^{\prime}$} & $\mathrm{CH}_{4}$ & 302 & $6,5204 \times 10^{-7}$ & 10,4588 \\
& $\mathrm{CO}_{2}$ & 650 & $1,9911 \times 10^{-7}$ & 8,7608 \\
\multirow{2}{*}{$3^{\prime}$} & $\mathrm{CH}_{4}$ & 928 & $6,8765 \times 10^{-7}$ & 11,0299 \\
& $\mathrm{CO}_{2}$ & 1043 & $2,1827 \times 10^{-7}$ & 9,6041 \\
\multirow{2}{*}{$6^{\prime}$} & $\mathrm{CH}_{4}$ & 959 & $6,8941 \times 10^{-7}$ & 11,0582 \\
& $\mathrm{CO}_{2}$ & 1208 & $2,2632 \times 10^{-7}$ & 9,9581 \\
\multirow{2}{*}{$12^{\prime}$} & $\mathrm{CH}_{4}$ & 1817 & $7,3822 \times 10^{-7}$ & 11,8411 \\
& $\mathrm{CO}_{2}$ & 1014 & $2,1686 \times 10^{-7}$ & 9,5418 \\
\hline
\end{tabular}


Tabela 6.3.3 - $\mathrm{P}_{2}(\mathrm{p})$ - Áreas cromatográficas medidas $(A)$, número de moles $(n)$ e massa $(m, \mu \mathrm{g})$ de cada gás, correspondentes:

\begin{tabular}{crrrr}
\hline Tempo & Gás & \multicolumn{1}{c}{$\boldsymbol{A}$} & $\boldsymbol{n}$ & $\boldsymbol{m}(\boldsymbol{\mu g})$ \\
\hline \multirow{2}{*}{$0^{\prime}$} & $\mathrm{CH}_{4}$ & 783 & $6,7940 \times 10^{-7}$ & 10,8976 \\
& $\mathrm{CO}_{2}$ & 1425 & $2,3690 \times 10^{-7}$ & 10,4237 \\
\multirow{2}{*}{$3^{\prime}$} & $\mathrm{CH}_{4}$ & 1457 & $7,1774 \times 10^{-7}$ & 11,5126 \\
& $\mathrm{CO}_{2}$ & 1561 & $2,4353 \times 10^{-7}$ & 10,7155 \\
\multirow{2}{*}{$6^{\prime}$} & $\mathrm{CH}_{4}$ & 1389 & $7,1387 \times 10^{-4}$ & 11,5865 \\
& $\mathrm{CO}_{2}$ & 2488 & $2,8873 \times 10^{-7}$ & 12,7045 \\
\multirow{2}{*}{$12^{\prime}$} & $\mathrm{CH}_{4}$ & 541 & $6,6563 \times 10^{-7}$ & 11,6768 \\
& $\mathrm{CO}_{2}$ & $14792,3953 \times 10^{-7}$ & 10,5395 \\
\hline
\end{tabular}

Tabela 6.3.4 - $\mathrm{P}_{3}(\mathrm{G})$ - Áreas cromatográficas medidas $(A)$, número de moles $(n)$ e massa $(m, \mu \mathrm{g})$ de cada gás, correspondentes:

\begin{tabular}{c|c|rcc}
\hline Tempo & Gás & \multicolumn{1}{c}{$\boldsymbol{A}$} & $\boldsymbol{n}$ & $\boldsymbol{m}(\boldsymbol{\mu g})$ \\
\hline \multirow{2}{*}{$0^{\prime}$} & $\mathrm{CH}_{4}$ & 773 & $6,7883 \times 10^{-1}$ & 10,8885 \\
& $\mathrm{CO}_{2}$ & 1424 & $2,3685 \times 10^{-7}$ & 10,4215 \\
\multirow{2}{*}{$3^{\prime}$} & $\mathrm{CH}_{4}$ & 831 & $6,8213 \times 10^{-1}$ & 10.9441 \\
& $\mathrm{CO}_{2}$ & 1653 & $2,4802 \times 10^{-7}$ & 10,9130 \\
\multirow{2}{*}{$6^{\prime}$} & $\mathrm{CH}_{4}$ & 894 & $6,8571 \times 10^{-7}$ & 10,9989 \\
& $\mathrm{CO}_{2}$ & 2886 & $3,0815 \times 10^{-7}$ & 13,5585 \\
\hline \multirow{2}{*}{$2^{\prime}$} & $\mathrm{CH}_{4}$ & 4481 & $8,8976 \times 10^{-1}$ & 14,2718 \\
& $\mathrm{CO}_{2}$ & 5683 & $4,4454 \times 10^{-7}$ & 19,5598 \\
\hline
\end{tabular}

Tabela 6.3.5 - $\mathrm{P}_{4}(\mathrm{G})$ - Áreas cromatográficas medidas $(A)$, número de moles $(n)$ e massa $(m, \mu \mathrm{g})$ de cada gás, correspondentes:

\begin{tabular}{crrcc}
\hline Tempo & Gás & \multicolumn{1}{c}{$\boldsymbol{A}$} & $\boldsymbol{n}$ & $\boldsymbol{m}(\boldsymbol{\mu} \mathbf{g})$ \\
\hline \multirow{2}{*}{$0^{\prime}$} & $\mathrm{CH}_{4}$ & 795 & $6,8008 \times 10^{-7}$ & 10,9085 \\
& $\mathrm{CO}_{2}$ & 1471 & $2,3914 \times 10^{-7}$ & 10,5224 \\
\multirow{2}{*}{$\mathbf{C}^{\prime}$} & $\mathrm{CH}_{4}$ & 1197 & $7,0295 \times 10^{-7}$ & 11,2754 \\
& $\mathrm{CO}_{2}$ & 2524 & $2,9050 \times 10^{-7}$ & 12,7817 \\
\multirow{2}{*}{6,} & $\mathrm{CH}_{4}$ & 17625 & $1,6375 \times 10^{-7}$ & 26,2650 \\
& $\mathrm{CO}_{2}$ & 16760 & $9,8470 \times 10^{-7}$ & 43,3270 \\
\multirow{2}{*}{$12^{\prime}$} & $\mathrm{CH}_{4}$ & 2914 & $8,0062 \times 10^{-7}$ & 12,8420 \\
& $\mathrm{CO}_{2}$ & 4143 & $3,6944 \times 10^{-7}$ & 16,2555 \\
\hline
\end{tabular}


Tabela 6.3.6 - Dissipadores 1, 2 e 3 - Áreas cromatográficas medidas $(A)$, número de moles $(n)$ e massa $(m, \mu g)$ de cada gás, correspondentes:

\begin{tabular}{ccccc}
\hline Dissipador & Gás & \multicolumn{1}{c}{$\boldsymbol{A}$} & $\boldsymbol{n}$ & $\boldsymbol{m}(\boldsymbol{\mu g})$ \\
\hline \multirow{2}{*}{1} & $\mathrm{CH}_{4}$ & 52491 & $3,6209 \times 10^{-6}$ & 58,0781 \\
& $\mathrm{CO}_{2}$ & 48194 & $2,5175 \times 19^{-6}$ & 110,7730 \\
\multirow{2}{*}{2} & $\mathrm{CH}_{4}$ & 67497 & $4,4845 \times 10^{-6}$ & 71,7702 \\
& $\mathrm{CO}_{2}$ & 53714 & $2,7867 \times 10^{-6}$ & 122,6167 \\
\multirow{2}{*}{3} & $\mathrm{CH}_{4}$ & 148454 & $9,0797 \times 10^{-6}$ & 145,6390 \\
& $\mathrm{CO}_{2}$ & 141281 & $7,0569 \times 10^{-6}$ & 310,5035 \\
\hline
\end{tabular}

6.3.1- $\mathrm{A}_{2}$ ) Aterro de Araraquara - Segunda Campanha - Data: 04/10/2007.

Tabela 6.3.7 - AR Ambiente - Áreas cromatográficas medidas $(A)$, número de moles $(n)$ e massa $(m, \mu g)$ de cada gás, correspondentes:

\begin{tabular}{ccccc}
\hline Tomada & Gás & $\boldsymbol{A}$ & $\boldsymbol{n}$ & $\boldsymbol{m}(\boldsymbol{\mu} \mathbf{g})$ \\
\hline \multirow{2}{*}{1} & $\mathrm{CH}_{4}$ & 359 & $6,5529 \times 10^{-7}$ & 10,5107 \\
& $\mathrm{CO}_{2}$ & 421 & $1,8795 \times 10^{-7}$ & 8,2695 \\
\hline
\end{tabular}

Tabela 6.3.8 - $\mathrm{P}_{1}(\mathrm{G})$ - Áreas cromatográficas medidas $(A)$, número de moles $(n)$ e massa $(m, \mu g)$ de cada gás, correspondentes:

\begin{tabular}{|c|c|c|c|c|}
\hline Tempo & Gás & $A$ & $n$ & $m(\mu \mathrm{g})$ \\
\hline \multirow{2}{*}{$0^{\prime}$} & $\mathrm{CH}_{4}$ & 32 & $6,3668 \times 10^{-1}$ & 10,2124 \\
\hline & $\mathrm{CO}_{2}$ & 44 & $1,6955 \times 10^{-7}$ & 7,4606 \\
\hline \multirow{2}{*}{ 3' } & $\mathrm{CH}_{4}$ & 3689 & $8,4472 \times 10^{-7}$ & 13,5492 \\
\hline & $\mathrm{CO}_{2}$ & 4481 & $3,8593 \times 10^{-1}$ & 16,9807 \\
\hline \multirow{2}{*}{$6^{\prime}$} & $\mathrm{CH}_{4}$ & 6339 & $9,9546 \times 10^{-7}$ & 15,9671 \\
\hline & $\mathrm{CO}_{2}$ & 7293 & $5,2305 \times 10^{-7}$ & 23,0143 \\
\hline \multirow{2}{*}{$12^{\prime}$} & $\mathrm{CH}_{4}$ & 4389 & $8,8453 \times 10^{-7}$ & 14,1879 \\
\hline & $\mathrm{CO}_{2}$ & 5190 & $4,2050 \times 10^{-1}$ & 18,5020 \\
\hline
\end{tabular}


Tabela 6.3.9 - $\mathrm{P}_{2}(\mathrm{p})$ - Áreas cromatográficas medidas $(A)$, número de moles $(n)$ e massa $(m, \mu \mathrm{g})$ de cada gás, correspondentes:

\begin{tabular}{|c|c|c|c|c|}
\hline Tempo & Gás & $A$ & $n$ & $m(\mu \mathrm{g})$ \\
\hline \multirow{2}{*}{$0^{\prime}$} & $\mathrm{CH}_{4}$ & 0 & & 0 \\
\hline & $\mathrm{CO}_{2}$ & 14 & $1,6809 \times 10^{-7}$ & 7,3962 \\
\hline \multirow{2}{*}{$3^{\prime}$} & $\mathrm{CH}_{4}$ & 506 & $6,6364 \times 10^{-7}$ & 10,6449 \\
\hline & $\mathrm{CO}_{2}$ & 526 & $1,9306 \times 10^{-7}$ & 8,4948 \\
\hline \multirow{2}{*}{$6^{\prime}$} & $\mathrm{CH}_{4}$ & 673 & $6,7314 \times 10^{-7}$ & 10,7972 \\
\hline & $\mathrm{CO}_{2}$ & 1539 & $2,4246 \times 10^{-7}$ & 10,6683 \\
\hline \multirow{2}{*}{$12^{\prime}$} & $\mathrm{CH}_{4}$ & 4675 & $9,0080 \times 10^{-7}$ & 14,4488 \\
\hline & $\mathrm{CO}_{2}$ & 7771 & $5,4636 \times 10^{-7}$ & 24,0399 \\
\hline
\end{tabular}

Tabela 6.3.10 - $\mathrm{P}_{3}(\mathrm{G})$ - Áreas cromatográficas medidas $(A)$, número de moles $(n)$ e massa $(m, \mu \mathrm{g})$ de cada gás, correspondentes:

\begin{tabular}{|c|c|c|c|c|}
\hline Tempo & Gás & $A$ & $n$ & $m(\mu \mathrm{g})$ \\
\hline \multirow{2}{*}{$0^{\prime}$} & $\overline{\mathrm{CH}_{4}}$ & $\overline{348}$ & $6,5466 \times 10^{-7}$ & 10,5007 \\
\hline & $\mathrm{CO}_{2}$ & 447 & $1,8922 \times 10^{-7}$ & 8,3253 \\
\hline \multirow{2}{*}{$3^{\prime}$} & $\mathrm{CH}_{4}$ & 2650 & $7,8561 \times 10^{-1}$ & 12,6012 \\
\hline & $\mathrm{CO}_{2}$ & 3566 & $3,4131 \times 10^{-7}$ & 15,0175 \\
\hline \multirow{2}{*}{$6^{\prime}$} & $\mathrm{CH}_{4}$ & 20696 & $1,8122 \times 10^{-6}$ & 29,0671 \\
\hline & $\mathrm{CO}_{2}$ & 35999 & $1,9229 \times 10^{-6}$ & 84,6068 \\
\hline \multirow{2}{*}{$12^{\prime}$} & $\mathrm{CH}_{4}$ & 3043 & $8,0796 \times 10^{-7}$ & 12,9597 \\
\hline & $\mathrm{CO}_{2}$ & 5792 & $4,4986 \times 10^{-7}$ & 19,7937 \\
\hline
\end{tabular}

Tabela 6.3.11 - $\mathrm{P}_{4}(\mathrm{G})$ - Áreas cromatográficas medidas $(A)$, número de moles $(n)$ e massa $(m, \mu \mathrm{g})$ de cada gás, correspondentes:

\begin{tabular}{|c|c|c|c|c|}
\hline Tempo & Gás & $A$ & $n$ & $m(\mu \mathrm{g})$ \\
\hline \multirow{2}{*}{$0^{\prime}$} & $\mathrm{CH}_{4}$ & 0 & 0 & 0 \\
\hline & $\mathrm{CO}_{2}$ & 20 & $1,6839 \times 10^{-7}$ & 7,4091 \\
\hline \multirow{2}{*}{$3^{\prime}$} & $\mathrm{CH}_{4}$ & 329 & $6,5357 \times 10^{-7}$ & 10,4834 \\
\hline & $\mathrm{CO}_{2}$ & 391 & $1,8648 \times 10^{-7}$ & 8,2051 \\
\hline \multirow{2}{*}{$6^{\prime}$} & $\mathrm{CH}_{4}$ & 3669 & $8,4358 \times 19^{-7}$ & 13,5310 \\
\hline & $\mathrm{CO}_{2}$ & 6103 & $4,6502 \times 19^{-7}$ & 20,4610 \\
\hline \multirow{2}{*}{$12^{\prime}$} & $\mathrm{CH}_{4}$ & 3199 & $8,1683 \times 19^{-7}$ & 13,1021 \\
\hline & $\mathrm{CO}_{2}$ & 4950 & $4,0880 \times 19^{-7}$ & 17,9870 \\
\hline
\end{tabular}


Tabela 6.3.12 - $\mathrm{P}_{5}(\mathrm{p})$ - Áreas cromatográficas medidas $(A)$, número de moles $(n)$ e massa $(m, \mu \mathrm{g})$ de cada gás, correspondentes:

\begin{tabular}{cc|ccc}
\hline Tempo & Gás & $\boldsymbol{A}$ & $\boldsymbol{n}$ & $\boldsymbol{m}(\boldsymbol{\mu g})$ \\
\hline \multirow{2}{*}{$\mathbf{0}^{\prime}$} & $\mathrm{CH}_{4}$ & 1797 & $7,3708 \times 10^{-7}$ & 11,8228 \\
& $\mathrm{CO}_{2}$ & 2389 & $2,8391 \times 10^{-7}$ & 12,4921 \\
\multirow{2}{*}{$3^{\prime}$} & $\mathrm{CH}_{4}$ & 2381 & $7,7030 \times 10^{-7}$ & 12,3557 \\
& $\mathrm{CO}_{2}$ & 3014 & $3,1439 \times 10^{-7}$ & 13,8331 \\
\multirow{2}{*}{$6^{\prime}$} & $\mathrm{CH}_{4}$ & 4238 & $8,7594 \times 10^{-7}$ & 14,0501 \\
& $\mathrm{CO}_{2}$ & 4998 & $4,1114 \times 19^{-7}$ & 18,0900 \\
\multirow{2}{*}{$12^{\prime}$} & $\mathrm{CH}_{4}$ & 4905 & $9,1388 \times 10^{-7}$ & 14,6587 \\
& $\mathrm{CO}_{2}$ & 5761 & $4,4834 \times 10^{-7}$ & 19,7272 \\
\hline
\end{tabular}

Tabela 6.3.13 - $\mathrm{P}_{6}(\mathrm{G})$ - Áreas cromatográficas medidas $(A)$, número de moles $(n)$ e massa $(m, \mu \mathrm{g})$ de cada gás, correspondentes:

\begin{tabular}{c|c|rcr}
\hline Tempo & Gás & \multicolumn{1}{c}{$\boldsymbol{A}$} & $\boldsymbol{n}$ & $\boldsymbol{m}(\boldsymbol{\mu} \mathbf{g})$ \\
\hline \multirow{2}{*}{$\mathbf{0}^{\prime}$} & $\mathrm{CH}_{4}$ & 31 & $6,3662 \times 10^{-7}$ & 10,2114 \\
& $\mathrm{CO}_{2}$ & 45 & $1,6892 \times 10^{-7}$ & 7,4327 \\
\multirow{2}{*}{$3^{\prime}$} & $\mathrm{CH}_{4}$ & 1950 & $7,4579 \times 10^{-1}$ & 11,9624 \\
& $\mathrm{CO}_{2}$ & 3269 & $3,2682 \times 10^{-7}$ & 14,3802 \\
\multirow{2}{*}{$6^{\prime}$} & $\mathrm{CH}_{4}$ & 17689 & $1,6411 \times 10^{-6}$ & 26,3233 \\
& $\mathrm{CO}_{2}$ & 19961 & $1,1408 \times 10^{-6}$ & 50,1952 \\
\multirow{2}{*}{$2^{\prime}$} & $\mathrm{CH}_{4}$ & 3821 & $8,5223 \times 10^{-1}$ & 16,0400 \\
& $\mathrm{CO}_{2}$ & 4661 & $3,9470 \times 10^{-7}$ & 17,3670 \\
\hline
\end{tabular}

Tabela 6.3.14 - $P_{7}(G)$ - Áreas cromatográficas medidas $(A)$, número de moles $(n)$ e massa $(m, \mu \mathrm{g})$ de cada gás, correspondentes:

\begin{tabular}{ccrcc}
\hline Tempo & Gás & \multicolumn{1}{c}{$\boldsymbol{A}$} & $\boldsymbol{n}$ & $\boldsymbol{m}(\boldsymbol{\mu} \mathbf{g})$ \\
\hline \multirow{2}{*}{$0^{\prime}$} & $\mathrm{CH}_{4}$ & 913 & $6,8680 \times 10^{-7}$ & 11,0162 \\
& $\mathrm{CO}_{2}$ & 1305 & $2,3105 \times 10^{-7}$ & 10,1662 \\
\multirow{2}{*}{$3^{\prime}$} & $\mathrm{CH}_{4}$ & 1831 & $7,0909 \times 10^{-7}$ & 11,3740 \\
& $\mathrm{CO}_{2}$ & 5091 & $4,1567 \times 10^{-7}$ & 18,2896 \\
\multirow{2}{*}{$6^{\prime}$} & $\mathrm{CH}_{4}$ & 12694 & $1,3570 \times 10^{-6}$ & 21,7657 \\
& $\mathrm{CO}_{2}$ & 12179 & $7,6131 \times 10^{-7}$ & 33,5000 \\
\multirow{2}{*}{${ }^{\prime}$} & $\mathrm{CH}_{4}$ & 13764 & $1,4179 \times 10^{-6}$ & 22,7420 \\
& $\mathrm{CO}_{2}$ & 13813 & $8,4099 \times 10^{-7}$ & 37,0038 \\
\hline
\end{tabular}


Tabela 6.3.15 - $\mathrm{P}_{8}(\mathrm{p})$ - Áreas cromatográficas medidas $(A)$, número de moles $(n)$ e massa $(m, \mu \mathrm{g})$ de cada gás, correspondentes:

\begin{tabular}{crrcr}
\hline Tempo & Gás & \multicolumn{1}{c}{$\boldsymbol{A}$} & $\boldsymbol{n}$ & $\boldsymbol{m}(\boldsymbol{\mu g})$ \\
\hline \multirow{2}{*}{$\mathbf{y}^{\prime}$} & $\mathrm{CH}_{4}$ & 97 & $6,4038 \times 10^{-7}$ & 10,2717 \\
& $\mathrm{CO}_{2}$ & 177 & $1,7604 \times 10^{-7}$ & 7,7460 \\
\multirow{2}{*}{$\mathbf{3}^{\prime}$} & $\mathrm{CH}_{4}$ & 9203 & $1,1583 \times 10^{-6}$ & 18,5804 \\
& $\mathrm{CO}_{2}$ & 10252 & $6,6734 \times 10^{-7}$ & 29,3632 \\
\multirow{2}{*}{$6^{\prime}$} & $\mathrm{CH}_{4}$ & 9515 & $1,1761 \times 10^{-6}$ & 18,8650 \\
& $\mathrm{CO}_{2}$ & 10116 & $6,6071 \times 10^{-7}$ & 29,0714 \\
\multirow{2}{*}{$2^{\prime}$} & $\mathrm{CH}_{4}$ & 9050 & $1,1497 \times 10^{-6}$ & 18,4408 \\
& $\mathrm{CO}_{2}$ & 10172 & $6,6344 \times 10^{-7}$ & 29,1915 \\
\hline
\end{tabular}

Tabela 6.3.16 - Dissipadores 1, 2 e 3 - Áreas cromatográficas medidas $(A)$, número de moles $(n)$ e massa $(m, \mu \mathrm{g})$ de cada gás, correspondentes:

\begin{tabular}{crrrr}
\hline Drenos & Gás & \multicolumn{1}{c}{$\boldsymbol{A}$} & \multicolumn{1}{c}{$\boldsymbol{n}$} & \multicolumn{1}{c}{$\boldsymbol{m}(\boldsymbol{\mu g})$} \\
\hline \multirow{2}{*}{1} & $\mathrm{CH}_{4}$ & 172822 & $1,0465 \times 10^{-5}$ & 167,8731 \\
& $\mathrm{CO}_{2}$ & 167175 & $8,3196 \times 10^{-6}$ & 366,0625 \\
\multirow{2}{*}{2} & $\mathrm{CH}_{4}$ & 21575 & $1,8622 \times 10^{-6}$ & 29,8691 \\
& $\mathrm{CO}_{2}$ & 26053 & $1,4379 \times 10^{-6}$ & 63,2664 \\
\multirow{2}{*}{3} & $\mathrm{CH}_{4}$ & 14545 & $1,4622 \times 10^{-6}$ & 23,4546 \\
& $\mathrm{CO}_{2}$ & 19391 & $1,1373 \times 10^{-6}$ & 50,0450 \\
\hline
\end{tabular}


6.3.2-B ${ }_{1}$ ) Aterro de Brotas - Primeira Campanha - Data: 14/11/2006.

Tabela 6.3.17 - AR ambiente - Áreas cromatográficas medidas $(A)$, número de moles $(n)$ e massa $(m, \mu \mathrm{g})$ de cada gás, correspondentes:

\begin{tabular}{ccccc}
\hline Tomada & Gás & $\boldsymbol{A}$ & $\boldsymbol{n}$ & $\boldsymbol{m}(\boldsymbol{\mu} \mathbf{g})$ \\
\hline \multirow{2}{*}{1} & $\mathrm{CH}_{4}$ & 329 & $6,5358 \times 10^{-7}$ & 10,4833 \\
& $\mathrm{CO}_{2}$ & 458 & $1,8975 \times 10^{-7}$ & 8,3489 \\
\hline
\end{tabular}

Tabela 6.3.18 - $\mathrm{P}_{1}(\mathrm{G})$ - Áreas cromatográficas medidas $(A)$, número de moles $(n)$ e massa $(m, \mu \mathrm{g})$ de cada gás, correspondentes:

\begin{tabular}{|c|c|c|c|c|}
\hline Tempo & Gás & $A$ & $n$ & $m(\mu g)$ \\
\hline \multirow{2}{*}{$0^{\prime}$} & $\mathrm{CH}_{4}$ & 502 & $6,6341 \times 10^{-7}$ & 10,6412 \\
\hline & $\mathrm{CO}_{2}$ & 621 & $1,9769 \times 10^{-7}$ & 8,6986 \\
\hline \multirow{2}{*}{ 3' } & $\mathrm{CH}_{4}$ & 781 & $6,7928 \times 10^{-7}$ & 10,8958 \\
\hline & $\mathrm{CO}_{2}$ & 920 & $2,1227 \times 10^{-7}$ & 9,3401 \\
\hline \multirow{2}{*}{$6^{\prime}$} & $\mathrm{CH}_{4}$ & 1085 & $6,9658 \times 10^{-7}$ & 11,1732 \\
\hline & $\mathrm{CO}_{2}$ & 1827 & $2,5650 \times 10^{-7}$ & 11,2863 \\
\hline \multirow{2}{*}{$12^{\prime}$} & $\mathrm{CH}_{4}$ & 1293 & $7,0841 \times 10^{-7}$ & 11,3630 \\
\hline & $\mathrm{CO}_{2}$ & 2097 & $2,6967 \times 10^{-7}$ & 11,8656 \\
\hline
\end{tabular}

Tabela 6.3.19 - $\mathrm{P}_{2}(\mathrm{p})$ - Áreas cromatográficas medidas $(A)$, número de moles $(n)$ e massa $(m, \mu g)$ de cada gás, correspondentes:

\begin{tabular}{ccrcr}
\hline Tempo & Gás & \multicolumn{1}{c}{$\boldsymbol{A}$} & $\boldsymbol{n}$ & $\boldsymbol{m}(\boldsymbol{\mu} \mathbf{g})$ \\
\hline \multirow{2}{*}{$0^{\prime}$} & $\mathrm{CH}_{4}$ & 601 & $6,6904 \times 10^{-7}$ & 10,7315 \\
& $\mathrm{CO}_{2}$ & 760 & $2,0447 \times 10^{-7}$ & 8,9968 \\
\multirow{2}{*}{$3^{\prime}$} & $\mathrm{CH}_{4}$ & 892 & $6,8560 \times 10^{-7}$ & 10,9970 \\
& $\mathrm{CO}_{2}$ & 948 & $2,1364 \times 10^{-7}$ & 9,4002 \\
\multirow{2}{*}{$6^{\prime}$} & $\mathrm{CH}_{4}$ & 2007 & $7,4903 \times 10^{-7}$ & 12,0144 \\
& $\mathrm{CO}_{2}$ & 2937 & $3,1063 \times 10^{-7}$ & 13,6680 \\
\multirow{2}{*}{$2^{\prime}$} & $\mathrm{CH}_{4}$ & 2109 & $7,5483 \times 10^{-7}$ & 12,1075 \\
& $\mathrm{CO}_{2}$ & 2045 & $2,6713 \times 10^{-7}$ & 11,7540 \\
\hline
\end{tabular}


Tabela 6.3.20 - $P_{3}(G)$ - Áreas cromatográficas medidas $(A)$, número de moles $(n)$ e massa $(m, \mu \mathrm{g})$ de cada gás, correspondentes:

\begin{tabular}{|c|c|c|c|c|}
\hline Tempo & Gás & $A$ & $n$ & $m(\mu \mathrm{g})$ \\
\hline \multirow{2}{*}{0 ' } & $\mathrm{CH}_{4}$ & 287 & $6,5118 \times 10^{-1}$ & 10,4450 \\
\hline & $\mathrm{CO}_{2}$ & 393 & $1,8657 \times 10^{-7}$ & 8,2094 \\
\hline \multirow{2}{*}{ 3' } & $\mathrm{CH}_{4}$ & 409 & $6,5812 \times 10^{-7}$ & 10,5563 \\
\hline & $\mathrm{CO}_{2}$ & 651 & $1,9915 \times 10^{-1}$ & 8,7630 \\
\hline \multirow{2}{*}{6} & $\mathrm{CH}_{4}$ & 984 & $6,9083 \times 10^{-7}$ & 11,0810 \\
\hline & $\mathrm{CO}_{2}$ & 1209 & $2,2636 \times 10^{-7}$ & 9,9603 \\
\hline \multirow{2}{*}{$12^{\prime}$} & $\mathrm{CH}_{4}$ & 1095 & $6,9715 \times 10^{-7}$ & 11,1823 \\
\hline & $\mathrm{CO}_{2}$ & 1430 & $2.3714 \times 10^{-7}$ & 10,4344 \\
\hline
\end{tabular}

Tabela 6.3.21 - $\mathrm{P}_{4}(\mathrm{G})$ - Áreas cromatográficas medidas $(A)$, número de moles $(n)$ e massa $(m, \mu \mathrm{g})$ de cada gás, correspondentes:

\begin{tabular}{c|c|r|r|r}
\hline Tempo & Gás & \multicolumn{1}{c}{$\boldsymbol{A}$} & $\boldsymbol{n}$ & $\boldsymbol{m}(\boldsymbol{\mu g})$ \\
\hline \multirow{2}{*}{${ }^{\prime}$} & $\mathrm{CH}_{4}$ & 128 & $6,4214 \times 10^{-1}$ & 10,3000 \\
& $\mathrm{CO}_{2}$ & 302 & $1,8214 \times 10^{-7}$ & 8,0141 \\
\hline \multirow{2}{*}{$\mathbf{3}^{\prime}$} & $\mathrm{CH}_{4}$ & 437 & $6,5972 \times 10^{-1}$ & 10,5820 \\
& $\mathrm{CO}_{2}$ & 658 & $1,9950 \times 10^{-7}$ & 8,7780 \\
\hline \multirow{2}{*}{$6^{\prime}$} & $\mathrm{CH}_{4}$ & 867 & $6,8418 \times 10^{-7}$ & 10,9743 \\
& $\mathrm{CO}_{2}$ & 1089 & $2,2051 \times 10^{-7}$ & 9,7027 \\
\hline \multirow{2}{*}{$2^{\prime}$} & $\mathrm{CH}_{4}$ & 982 & $6,9072 \times 10^{-1}$ & 11,0792 \\
& $\mathrm{CO}_{2}$ & 1234 & $2,2758 \times 10^{-7}$ & 10,0139 \\
\hline
\end{tabular}

Tabela 6.3.22 - $\mathrm{P}_{5}(\mathrm{p})$ - Áreas cromatográficas medidas $(A)$, número de moles $(n)$ e massa $(m, \mu \mathrm{g})$ de cada gás, correspondentes:

\begin{tabular}{c|c|r|r|r}
\hline Tempo & Gás & \multicolumn{1}{c}{$\boldsymbol{A}$} & $\boldsymbol{n}$ & $\boldsymbol{m}(\boldsymbol{\mu g})$ \\
\hline $0^{\prime}$ & $\mathrm{CH}_{4}$ & 184 & $6,4532 \times 10^{-1}$ & 10,3510 \\
& $\mathrm{CO}_{2}$ & 207 & $1,7750 \times 10^{-7}$ & 7,8103 \\
\hline \multirow{2}{*}{$3^{\prime}$} & $\mathrm{CH}_{4}$ & 382 & $6,5659 \times 10^{-7}$ & 10,5317 \\
& $\mathrm{CO}_{2}$ & 493 & $1,9145 \times 10^{-7}$ & 8,4240 \\
\hline \multirow{2}{*}{$6^{\prime}$} & $\mathrm{CH}_{4}$ & 789 & $6,7974 \times 10^{-7}$ & 10,9031 \\
& $\mathrm{CO}_{2}$ & 1079 & $2,2003 \times 10^{-7}$ & 9,6813 \\
\hline \multirow{2}{*}{$2^{\prime}$} & $\mathrm{CH}_{4}$ & 907 & $6,8645 \times 10^{-7}$ & 11,0107 \\
& $\mathrm{CO}_{2}$ & 1206 & $2,2622 \times 10^{-7}$ & 9,9538 \\
\hline
\end{tabular}


6.3.2-B $\mathrm{B}_{2}$ ) Aterro de Brotas - Segunda Campanha - Data: 02/10/2007

Tabela 6.3.23 - Ar ambiente - Áreas cromatográficas medidas $(A)$, número de moles $(n)$ e massa $(m, \mu \mathrm{g})$ de cada gás, correspondentes:

\begin{tabular}{rrrrr}
\hline Tomada & Gás & \multicolumn{1}{c}{$\boldsymbol{A}$} & $\boldsymbol{n}$ & \multicolumn{1}{c}{$\boldsymbol{m}(\boldsymbol{\mu} \mathbf{g})$} \\
\hline \multirow{2}{*}{1} & $\mathrm{CH}_{4}$ & 98 & $6,4044 \times 10^{-7}$ & 10,2726 \\
& $\mathrm{CO}_{2}$ & 132 & $1,7385 \times 10^{-7}$ & 7,6494 \\
\hline
\end{tabular}

Tabela 6.3.24 - $\mathrm{P}_{1}(\mathrm{G})$ - Áreas cromatográficas medidas $(A)$, número de moles $(n)$ e massa $(m, \mu \mathrm{g})$ de cada gás, correspondentes:

\begin{tabular}{ccrrr}
\hline Tempo & Gás & $\boldsymbol{A}$ & $\boldsymbol{n}$ & $\boldsymbol{m}(\boldsymbol{\mu g})$ \\
\hline \multirow{2}{*}{$\mathbf{0}^{\prime}$} & $\mathrm{CH}_{4}$ & 0 & 0 & 0 \\
& $\mathrm{CO}_{2}$ & 364 & $1,851633 \times 10^{-7}$ & 8,1472 \\
\multirow{2}{*}{$3^{\prime}$} & $\mathrm{CH}_{4} 3672$ & $8,437445 \times 10^{-7}$ & 13,5336 \\
& $\mathrm{CO}_{2} 5210$ & $4,214756 \times 10^{-7}$ & 18,5450 \\
\multirow{2}{*}{$6^{\prime}$} & $\mathrm{CH}_{4} 7967$ & $1,088067 \times 10^{-6}$ & 17,5426 \\
& $\mathrm{CO}_{2} 8215$ & $5,680127 \times 10^{-7}$ & 24,9925 \\
\multirow{2}{*}{$2^{\prime}$} & $\mathrm{CH}_{4} 559$ & $6,666602 \times 10^{-7}$ & 10,7000 \\
& $\mathrm{CO}_{2} 2975$ & $3,124872 \times 10^{-7}$ & 13,7500 \\
\hline
\end{tabular}

Tabela 6.3.25 - $\mathrm{P}_{2}(\mathrm{p})$ - Áreas cromatográficas medidas $(A)$, número de moles $(n)$ e massa $(m, \mu \mathrm{g})$ de cada gás, correspondentes:

\begin{tabular}{ccrcr}
\hline Tempo & Gás & \multicolumn{1}{c}{$\boldsymbol{A}$} & $\boldsymbol{n}$ & $\boldsymbol{m}(\boldsymbol{\mu g})$ \\
\hline \multirow{2}{*}{$\mathbf{0}^{\prime}$} & $\mathrm{CH}_{4}$ & 283 & $6,5096 \times 10^{-7}$ & 10,4414 \\
& $\mathrm{CO}_{2}$ & 219 & $1,7809 \times 10^{-7}$ & 7,8360 \\
\multirow{2}{*}{$3^{\prime}$} & $\mathrm{CH}_{4}$ & 1309 & $7,0932 \times 10^{-7}$ & 11,3776 \\
& $\mathrm{CO}_{2}$ & 1421 & $2,3670 \times 10^{-7}$ & 10,4151 \\
\multirow{2}{*}{$6^{\prime}$} & $\mathrm{CH}_{4}$ & 2787 & $7,9340 \times 10^{-7}$ & 12,7262 \\
& $\mathrm{CO}_{2}$ & 3290 & $3,2784 \times 10^{-7}$ & 14,4253 \\
\multirow{2}{*}{$2^{\prime}$} & $\mathrm{CH}_{4}$ & 2489 & $7,7644 \times 10^{-7}$ & 12,4542 \\
& $\mathrm{CO}_{2}$ & 3121 & $3,1960 \times 10^{-7}$ & 14,0627 \\
\hline
\end{tabular}


Tabela 6.3.26 - $P_{3}(G)$ - Áreas cromatográficas medidas $(A)$, número de moles $(n)$ e massa $(m, \mu \mathrm{g})$ de cada gás, correspondentes:

\begin{tabular}{ccccr}
\hline Tempo Gás & \multicolumn{1}{c}{$\boldsymbol{A}$} & $\boldsymbol{n}$ & $\boldsymbol{m}(\boldsymbol{\mu g})$ \\
\hline \multirow{2}{*}{0} & $\mathrm{CH}_{4}$ & 152 & $6,4350 \times 10^{-7}$ & 10,3220 \\
& $\mathrm{CO}_{2}$ & 128 & $1,7365 \times 10^{-7}$ & 7,6408 \\
& $\mathrm{CH}_{4}$ & 384 & $6,5670 \times 10^{-7}$ & 10,5335 \\
3 & $\mathrm{CO}_{2}$ & 431 & $1,8843 \times 10^{-7}$ & 8,3000 \\
& $\mathrm{CH}_{4}$ & 994 & $6,9140 \times 10^{-7}$ & 11,0902 \\
6 & $\mathrm{CO}_{2}$ & 1048 & $2,1851 \times 10^{-7}$ & 9,6148 \\
& $\mathrm{CH}_{4}$ & 2013 & $7,4937 \times 10^{-7}$ & 12,0200 \\
12 & $\mathrm{CO}_{2}$ & 1937 & $2,6186 \times 10^{-7}$ & 11,5222 \\
\hline
\end{tabular}

Tabela 6.3.27 - $\mathrm{P}_{4}(\mathrm{G})$ - Áreas cromatográficas medidas $(A)$, número de moles $(n)$ e massa $(m, \mu \mathrm{g})$ de cada gás, correspondentes:

\begin{tabular}{|c|c|c|c|c|}
\hline Tempo & Gás & $A$ & $n$ & $m(\mu g)$ \\
\hline \multirow{2}{*}{$0^{\prime}$} & $\overline{\mathrm{CH}_{4}}$ & 31 & $6,3662 \times 10^{-1}$ & 10,2114 \\
\hline & $\mathrm{CO}_{2}$ & & $1,6848 \times 10^{-7}$ & 7,4134 \\
\hline \multirow{2}{*}{$3^{\prime}$} & $\mathrm{CH}_{4}$ & 39 & $6,3707 \times 10^{-1}$ & 10,2187 \\
\hline & $\mathrm{CO}_{2}$ & & $1,6980 \times 10^{-7}$ & 7,4713 \\
\hline \multirow{2}{*}{$6^{\prime}$} & $\mathrm{CH}_{4}$ & & $6,3935 \times 10^{-7}$ & 10,2552 \\
\hline & $\mathrm{CO}_{2}$ & 119 & $1,7322 \times 10^{-7}$ & 7,6250 \\
\hline \multirow{2}{*}{$12^{\prime}$} & $\mathrm{CH}_{4}$ & 239 & $6,4845 \times 10^{-1}$ & 10,4013 \\
\hline & $\mathrm{CO}_{2}$ & 903 & $2,1145 \times 10^{-7}$ & 9,3037 \\
\hline
\end{tabular}

Tabela 6.3.28 - $\mathrm{P}_{5}(\mathrm{G})$ - Áreas cromatográficas medidas $(A)$, número de moles $(n)$ e massa $(m, \mu \mathrm{g})$ de cada gás, correspondentes:

\begin{tabular}{crrrr}
\hline Tempo & Gás & \multicolumn{1}{c}{$\boldsymbol{A}$} & $\boldsymbol{n}$ & $\boldsymbol{m}(\boldsymbol{\mu} \mathbf{g})$ \\
\hline \multirow{2}{*}{$\mathbf{r}^{\prime}$} & $\mathrm{CH}_{4}$ & 0 & 0 & 0 \\
& $\mathrm{CO}_{2}$ & 43 & $1,6951 \times 10^{-7}$ & 7,4584 \\
& $\mathrm{CH}_{4}$ & 124 & $6,4191 \times 10^{-7}$ & 10,2963 \\
3' & $\mathrm{CO}_{2}$ & 164 & $1,7541 \times 10^{-7}$ & 7,7180 \\
& $\mathrm{CH}_{4}$ & 301 & $6,5198 \times 10^{-7}$ & 10,4578 \\
6, & $\mathrm{CO}_{2}$ & 396 & $1,8672 \times 10^{-7}$ & 8,2158 \\
& $\mathrm{CH}_{4}$ & 674 & $6,7320 \times 10^{-7}$ & 10,7981 \\
\multirow{2}{*}{$2^{\prime}$} & $\mathrm{CO}_{2}$ & 736 & $2,0330 \times 10^{-7}$ & 8,9453 \\
\hline
\end{tabular}


Tabela 6.3.29 - $\mathrm{P}_{6}(\mathrm{p})$ - Áreas cromatográficas medidas $(A)$, número de moles $(n)$ e massa $(m, \mu \mathrm{g})$ de cada gás, correspondentes:

\begin{tabular}{crrrr}
\hline Tempo & Gás & \multicolumn{1}{c}{$\boldsymbol{A}$} & \multicolumn{1}{c}{$\boldsymbol{n}$} & $\boldsymbol{m}(\boldsymbol{\mu} \mathbf{g})$ \\
\hline \multirow{2}{*}{${ }^{\prime}$} & $\mathrm{CH}_{4}$ & 348 & $6,5465 \times 10^{-1}$ & 10,5007 \\
& $\mathrm{CO}_{2}$ & 395 & $1,8667 \times 10^{-7}$ & 8,2137 \\
\multirow{2}{*}{${ }^{\prime}$} & $\mathrm{CH}_{4}$ & 781 & $6,8000 \times 10^{-7}$ & 10,8958 \\
& $\mathrm{CO}_{2}$ & 1038 & $2,1792 \times 10^{-7}$ & 9,5887 \\
\multirow{2}{*}{ 6, } & $\mathrm{CH}_{4}$ & 2802 & $7,9425 \times 10^{-7}$ & 12,7400 \\
& $\mathrm{CO}_{2}$ & 3941 & $3,5960 \times 10^{-7}$ & 15,8222 \\
\multirow{2}{*}{12} & $\mathrm{CH}_{4}$ & 2968 & $8,0370 \times 10^{-7}$ & 12,8913 \\
& $\mathrm{CO}_{2}$ & 4073 & $3,6603 \times 10^{-7}$ & 16,1054 \\
\hline
\end{tabular}


6.3.3- $\mathrm{C}_{1}$ ) Aterro de Campinas - Primeira Campanha - Data: 24/10/2006.

Tabela 6.3.30 - AR ambiente - Áreas cromatográficas medidas $(A)$, número de $\operatorname{moles}(n)$ e massa $(m, \mu \mathrm{g})$ de cada gás, correspondentes:

\begin{tabular}{rrlcr}
\hline \multicolumn{2}{r}{ Tomada Gás } & $\boldsymbol{A}$ & $\boldsymbol{n}$ & $\boldsymbol{m}(\boldsymbol{\mu} \mathbf{g})$ \\
\hline \multirow{2}{*}{1} & $\mathrm{CH}_{4}$ & 68 & $6,3873 \times 10^{-1}$ & 10,2452 \\
& $\mathrm{CO}_{2}$ & 97 & $1,7214 \times 10^{-1}$ & 7,5743 \\
\hline
\end{tabular}

Tabela 6.3.31 - $\mathrm{P}_{1}(\mathrm{G})$ - Áreas cromatográficas medidas $(A)$, número de moles $(n)$ e massa $(m, \mu \mathrm{g})$ de cada gás, correspondentes:

\begin{tabular}{|c|c|c|c|c|}
\hline Tempo & Gás & $A$ & $n$ & $m(\mu \mathrm{g})$ \\
\hline \multirow{2}{*}{0 ' } & $\mathrm{CH}_{4}$ & 0 & 0 & 0 \\
\hline & $\mathrm{CO}_{2}$ & 246 & $1,7941 \times 10^{-7}$ & 7,8940 \\
\hline \multirow{2}{*}{$3^{\prime}$} & $\mathrm{CH}_{4}$ & 187 & $6,4550 \times 10^{-1}$ & 10,3538 \\
\hline & $\mathrm{CO}_{2}$ & 321 & $1,8306 \times 10^{-7}$ & 8,0550 \\
\hline \multirow{2}{*}{$6^{\prime}$} & $\mathrm{CH}_{4}$ & 993 & $6,9135 \times 10^{-7}$ & 11,0892 \\
\hline & $\mathrm{CO}_{2}$ & 2975 & $3,1249 \times 10^{-7}$ & 13,7494 \\
\hline \multirow{2}{*}{$12^{\prime}$} & $\mathrm{CH}_{4}$ & 6149 & $9,8465 \times 10^{-7}$ & 15,7938 \\
\hline & $\mathrm{CO}_{2}$ & 4788 & $4,0090 \times 10^{-7}$ & 17,6395 \\
\hline
\end{tabular}

Tabela 6.3.32 - $\mathrm{P}_{2}(\mathrm{p})$ - Áreas cromatográficas medidas $(A)$, número de moles $(n)$ e massa $(m, \mu \mathrm{g})$ de cada gás, correspondentes:

\begin{tabular}{ccrrr}
\hline Tempo & Gás & \multicolumn{1}{c}{$\boldsymbol{A}$} & $\boldsymbol{n}$ & $\boldsymbol{m}(\boldsymbol{\mu} \mathbf{g})$ \\
\hline \multirow{2}{*}{, } & $\mathrm{CH}_{4}$ & 0 & 0 & 0 \\
& $\mathrm{CO}_{2}$ & $781,7121 \times 10^{-7}$ & 7,5335 \\
\multirow{2}{*}{ 3' } & $\mathrm{CH}_{4}$ & $476,3753 \times 10^{-7}$ & 10,2260 \\
& $\mathrm{CO}_{2}$ & $961,7209 \times 10^{-1}$ & 7,5721 \\
\multirow{2}{*}{ 6' } & $\mathrm{CH}_{4}$ & $1096,4106 \times 10^{-7}$ & 10,2826 \\
& $\mathrm{CO}_{2}$ & $1161,7307 \times 10^{-7}$ & 7,6150 \\
\multirow{2}{*}{12} & $\mathrm{CH}_{4}$ & 7162 & $1,0423 \times 10^{-6}$ & 16,7181 \\
& $\mathrm{CO}_{2}$ & $95496,3306 \times 10^{-7}$ & 27,8548 \\
\hline
\end{tabular}


Tabela 6.3.33 - $P_{3}(G)$ - Áreas cromatográficas medidas $(A)$, número de moles $(n)$ e massa $(m, \mu \mathrm{g})$ de cada gás, correspondentes:

\begin{tabular}{ccrcr}
\hline Tempo & Gás & \multicolumn{1}{c}{$\boldsymbol{A}$} & $\boldsymbol{n}$ & \multicolumn{1}{c}{$\boldsymbol{m}(\boldsymbol{\mu} \mathbf{g})$} \\
\hline \multirow{2}{*}{$0^{\prime}$} & $\mathrm{CH}_{4}$ & 439 & $6,5983 \times 10^{-7}$ & 10,5837 \\
& $\mathrm{CO}_{2}$ & 614 & $1,9735 \times 10^{-7}$ & 8,6834 \\
\multirow{2}{*}{ 3 $^{\prime}$} & $\mathrm{CH}_{4}$ & 1449 & $7,1729 \times 10^{-7}$ & 11,5053 \\
& $\mathrm{CO}_{2}$ & 4795 & $4,0123 \times 10^{-7}$ & 17,6545 \\
\multirow{2}{*}{$6^{\prime}$} & $\mathrm{CH}_{4}$ & 2865 & $7,9784 \times 10^{-7}$ & 12,7973 \\
& $\mathrm{CO}_{2}$ & 4280 & $3,7612 \times 10^{-7}$ & 16,5495 \\
\multirow{2}{*}{$2^{\prime}$} & $\mathrm{CH}_{4}$ & 4224 & $8,7814 \times 10^{-7}$ & 14,0854 \\
& $\mathrm{CO}_{2}$ & 19434 & $1,1151 \times 10^{-6}$ & 49,0642 \\
\hline
\end{tabular}

Tabela 6.3.34 - $\mathrm{P}_{4}(\mathrm{p})$ - Áreas cromatográficas medidas $(A)$, número de moles $(n)$ e massa $(m, \mu \mathrm{g})$ de cada gás, correspondentes:

\begin{tabular}{ccccc}
\hline Tempo & Gás & $\boldsymbol{A}$ & $\boldsymbol{n}$ & $\boldsymbol{m}(\boldsymbol{\mu g})$ \\
\hline \multirow{2}{*}{$0^{\prime}$} & $\mathrm{CH}_{4}$ & 3312 & $8,2326 \times 10^{-7}$ & 13,2052 \\
& $\mathrm{CO}_{2}$ & 4183 & $3,7140 \times 10^{-7}$ & 16,3413 \\
\multirow{2}{*}{$3^{\prime}$} & $\mathrm{CH}_{4}$ & 12165 & $1,3269 \times 10^{-6}$ & 21,2830 \\
& $\mathrm{CO}_{2}$ & 14040 & $8,5206 \times 10^{-7}$ & 37,5000 \\
\multirow{2}{*}{$6^{\prime}$} & $\mathrm{CH}_{4}$ & 37673 & $2,7780 \times 10^{-6}$ & 45,5576 \\
& $\mathrm{CO}_{2}$ & 36287 & $1,9370 \times 10^{-6}$ & 85,2250 \\
\multirow{2}{*}{${ }^{\prime}}$, & $\mathrm{CH}_{4}$ & 25941 & $2,1105 \times 10^{-6}$ & 33,8528 \\
& $\mathrm{CO}_{2}$ & 28195 & $1,5423 \times 10^{-6}$ & 67,8623 \\
\hline
\end{tabular}

Tabela 6.3.35 - Dissipadores 1 e 2 - Áreas cromatográficas medidas $(A)$, número de moles $(n)$ e massa $(m, \mu \mathrm{g})$ de cada gás, correspondentes:

\begin{tabular}{ccccc}
\hline Dreno & Gás & $\boldsymbol{A}$ & $\boldsymbol{n}$ & $\boldsymbol{m}(\boldsymbol{\mu} \mathbf{g})$ \\
\hline \multirow{2}{*}{1} & $\mathrm{CH}_{4}$ & $295212,3141 \times 10^{-6}$ & 37,1194 \\
& $\mathrm{CO}_{2}$ & $312321,6904 \times 10^{-6}$ & 74,3786 \\
\multirow{2}{*}{2} & $\mathrm{CH}_{4}$ & $1279547,9135 \times 10^{-6}$ & 126,9337 \\
& $\mathrm{CO}_{2}$ & $1383536,9141 \times 10^{-6}$ & 304,2211 \\
\hline
\end{tabular}




\subsection{3- $\mathrm{C}_{2}$ ) Aterro de Campinas - Segunda Campanha - Data 27/09/2007.}

Tabela 6.3.36 - AR Ambiente - Áreas cromatográficas medidas $(A)$, número de moles $(n)$ e massa $(m, \mu g)$ de cada gás, correspondentes:

\begin{tabular}{ccccr}
\hline Tomada & Gás & $\boldsymbol{A}$ & $\boldsymbol{n}$ & $\boldsymbol{m}(\boldsymbol{\mu} \mathbf{g})$ \\
\hline \multirow{2}{*}{1} & $\mathrm{CH}_{4}$ & $316,366247 \times 10^{-1}$ & 10,2115 \\
& $\mathrm{CO}_{2}$ & $431,695100 \times 10^{-7}$ & 7,4584 \\
\hline
\end{tabular}

Tabela 6.3.37 - $\mathrm{P}_{1}(\mathrm{G})$ - Áreas cromatográficas medidas $(A)$, número de moles $(n)$ e massa $(m, \mu \mathrm{g})$ de cada gás, correspondentes:

\begin{tabular}{crrcr}
\hline Tempo & Gás & \multicolumn{1}{c}{$\boldsymbol{A}$} & $\boldsymbol{n}$ & $\boldsymbol{m}(\boldsymbol{\mu} \mathbf{g})$ \\
\hline \multirow{2}{*}{$0^{\prime}$} & $\mathrm{CH}_{4}$ & 36 & $6,3691 \times 10^{-1}$ & 10,2160 \\
& $\mathrm{CO}_{2}$ & 21 & $1,6844 \times 10^{-7}$ & 7,4112 \\
\multirow{2}{*}{${ }^{\prime}$} & $\mathrm{CH}_{4}$ & 4289 & $8,7884 \times 10^{-1}$ & 14,0966 \\
& $\mathrm{CO}_{2}$ & 4951 & $4,0885 \times 10^{-7}$ & 17,9892 \\
\multirow{2}{*}{ 6, } & $\mathrm{CH}_{4}$ & 4195 & $8,7350 \times 10^{-7}$ & 14,0108 \\
& $\mathrm{CO}_{2}$ & 30739 & $1,6663 \times 10^{-6}$ & 73,3208 \\
\multirow{2}{*}{12,} & $\mathrm{CH}_{4}$ & 11067 & $1,2644 \times 10^{-6}$ & 20,2817 \\
& $\mathrm{CO}_{2}$ & 11111 & $7,0923 \times 10^{-7}$ & 31,2063 \\
\hline
\end{tabular}

Tabela 6.3.38 - $\mathrm{P}_{2}(\mathrm{p})$ - Áreas cromatográficas medidas $(A)$, número de moles $(n)$ e massa $(m, \mu \mathrm{g})$ de cada gás, correspondentes:

\begin{tabular}{ccccc}
\hline Tempo & Gás & $\boldsymbol{A}$ & $\boldsymbol{n}$ & $\boldsymbol{m}(\boldsymbol{\mu g})$ \\
\hline \multirow{2}{*}{$0^{\prime}$} & $\mathrm{CH}_{4}$ & 3693 & $8,4494 \times 10^{-7}$ & 13,5528 \\
& $\mathrm{CO}_{2}$ & 4965 & $4,0953 \times 10^{-7}$ & 18,0192 \\
\multirow{2}{*}{$3^{\prime}$} & $\mathrm{CH}_{4}$ & 3985 & $8,6155 \times 10^{-7}$ & 13,8192 \\
& $\mathrm{CO}_{2}$ & 4762 & $3,9963 \times 10^{-7}$ & 17,5837 \\
\multirow{2}{*}{ 6' } & $\mathrm{CH}_{4}$ & 8136 & $1,0977 \times 10^{-6}$ & 17,6068 \\
& $\mathrm{CO}_{2}$ & 8714 & $5,9235 \times 10^{-7}$ & 26,0632 \\
\multirow{2}{*}{ 12 $^{\prime}$} & $\mathrm{CH}_{4}$ & 12767 & $1,3611 \times 10^{-6}$ & 21,8323 \\
& $\mathrm{CO}_{2}$ & 13586 & $8,2993 \times 10^{-7}$ & 36,5167 \\
\hline
\end{tabular}


Tabela 6.3.39 - $\mathrm{P}_{3}(\mathrm{G})$ - Áreas cromatográficas medidas $(A)$, número de moles $(n)$ e massa $(m, \mu \mathrm{g})$ de cada gás, correspondentes:

\begin{tabular}{crrcr}
\hline Tempo & Gás & \multicolumn{1}{c}{$\boldsymbol{A}$} & $\boldsymbol{n}$ & \multicolumn{1}{c}{$\boldsymbol{m}(\boldsymbol{\mu} \mathbf{g})$} \\
\hline \multirow{2}{*}{$\mathbf{C}^{\prime}$} & $\mathrm{CH}_{4}$ & 0 & 0 & 0 \\
& $\mathrm{CO}_{2}$ & 489 & $1,9126 \times 10^{-7}$ & 8,4154 \\
\multirow{2}{*}{$\mathrm{CH}^{\prime}$} & $\mathrm{CH}_{4}$ & 651 & $6,7190 \times 10^{-7}$ & 10,7772 \\
& $\mathrm{CO}_{2}$ & 1952 & $2,6260 \times 10^{-7}$ & 11,5545 \\
\multirow{2}{*}{6,} & $\mathrm{CH}_{4}$ & 789 & $6,7974 \times 10^{-7}$ & 10,9031 \\
& $\mathrm{CO}_{2}$ & 1122 & $2,2212 \times 10^{-7}$ & 9,7736 \\
\multirow{2}{*}{$12^{\prime}$} & $\mathrm{CH}_{4}$ & 1082 & $6,9641 \times 10^{-7}$ & 11,1704 \\
& $\mathrm{CO}_{2}$ & 1734 & $2,5197 \times 10^{-7}$ & 11,0867 \\
\hline
\end{tabular}

Tabela 6.3.40 - $\mathrm{P}_{4}(\mathrm{p})$ - Áreas cromatográficas medidas $(A)$, número de moles $(n)$ e massa $(m, \mu \mathrm{g})$ de cada gás, correspondentes:

\begin{tabular}{ccrcc}
\hline Tempo & Gás & \multicolumn{1}{c}{$\boldsymbol{A}$} & $\boldsymbol{n}$ & $\boldsymbol{m}(\boldsymbol{\mu g})$ \\
\hline \multirow{2}{*}{$0^{\prime}$} & $\mathrm{CH}_{4}$ & 214 & $6,4703 \times 10^{-7}$ & 10,3784 \\
& $\mathrm{CO}_{2}$ & 462 & $1,8994 \times 10^{-7}$ & 8,3574 \\
\multirow{2}{*}{$3^{\prime}$} & $\mathrm{CH}_{4}$ & 358 & $6,5676 \times 10^{-1}$ & 10,5345 \\
& $\mathrm{CO}_{2}$ & 1441 & $2,3768 \times 10^{-7}$ & 10,4580 \\
\multirow{2}{*}{6} & $\mathrm{CH}_{4}$ & 874 & $6,8458 \times 10^{-7}$ & 10,9806 \\
& $\mathrm{CO}_{2}$ & 1885 & $2,5933 \times 10^{-7}$ & 11,4107 \\
\multirow{2}{*}{$12^{\prime}$} & $\mathrm{CH}_{4}$ & 958 & $6,8936 \times 10^{-1}$ & 11,0573 \\
& $\mathrm{CO}_{2}$ & 1648 & $2,4778 \times 10^{-7}$ & 10,9022 \\
\hline
\end{tabular}

Tabela 6.3.41 - $\mathrm{P}_{5}(\mathrm{G})$ - Áreas cromatográficas medidas $(A)$, número de moles $(n)$ e massa $(m, \mu \mathrm{g})$ de cada gás, correspondentes:

\begin{tabular}{crrcr}
\hline Tempo & Gás & \multicolumn{1}{c}{$\boldsymbol{A}$} & $\boldsymbol{n}$ & $\boldsymbol{m}(\boldsymbol{\mu} \mathbf{g})$ \\
\hline \multirow{2}{*}{, } & $\mathrm{CH}_{4}$ & 394 & $6,5727 \times 10^{-7}$ & 10,5427 \\
& $\mathrm{CO}_{2}$ & 391 & $1,8648 \times 10^{-7}$ & 8,2051 \\
\multirow{2}{*}{${ }^{\prime}$} & $\mathrm{CH}_{4}$ & 9765 & $1,1903 \times 10^{-6}$ & 19,0932 \\
& $\mathrm{CO}_{2}$ & 9486 & $6,3000 \times 10^{-7}$ & 27,7196 \\
\multirow{2}{*}{ 6' } & $\mathrm{CH}_{4}$ & 25778 & $2,1012 \times 10^{-6}$ & 33,7041 \\
& $\mathrm{CO}_{2}$ & 27049 & $1,4913 \times 10^{-6}$ & 65,6180 \\
\multirow{2}{*}{ 12' } & $\mathrm{CH}_{4}$ & 18927 & $1,7115 \times 10^{-6}$ & 27,4530 \\
& $\mathrm{CO}_{2}$ & 19097 & $1,0986 \times 10^{-6}$ & 48,3413 \\
\hline
\end{tabular}


Tabela 6.3.42 - $\mathrm{P}_{6}(p)$ - Áreas cromatográficas medidas $(A)$, número de moles $(n)$ e massa $(m, \mu \mathrm{g})$ de cada gás, correspondentes:

\begin{tabular}{|c|c|c|c|c|}
\hline Tempo & Gás & $A$ & $N$ & $m(\mu \mathrm{g})$ \\
\hline \multirow{2}{*}{0 ' } & $\overline{\mathrm{CH}_{4}}$ & 48 & $6,3760 \times 10^{-1}$ & 10,2270 \\
\hline & $\mathrm{CO}_{2}$ & 378 & $1,8584 \times 10^{-7}$ & 8,1772 \\
\hline \multirow{2}{*}{ 3' } & $\mathrm{CH}_{4}$ & 5452 & $9,4500 \times 10^{-7}$ & 15,1578 \\
\hline & $\mathrm{CO}_{2}$ & 6909 & $5,0433 \times 10^{-7}$ & 22,2000 \\
\hline \multirow{2}{*}{ 6' } & $\mathrm{CH}_{4}$ & 9683 & $1,1857 \times 10^{-6}$ & 19,0183 \\
\hline & $\mathrm{CO}_{2}$ & 9996 & $6,5486 \times 10^{-7}$ & 28,8140 \\
\hline \multirow[b]{2}{*}{$12^{\prime}$} & $\mathrm{CH}_{4}$ & 3502 & $8,3407 \times 10^{-7}$ & 13,3785 \\
\hline & $\mathrm{CO}_{2}$ & 4685 & $3,9587 \times 10^{-7}$ & 17,4185 \\
\hline
\end{tabular}

Tabela 6.3.43 - $\mathrm{P}_{7}(\mathrm{G})$ - Áreas cromatográficas medidas $(A)$, número de moles $(n)$ e massa $(m, \mu \mathrm{g})$ de cada gás, correspondentes:

\begin{tabular}{crrrr}
\hline Tempo & Gás & \multicolumn{1}{c}{$\boldsymbol{A}$} & $\boldsymbol{n}$ & $\boldsymbol{m}(\boldsymbol{\mu} \boldsymbol{g})$ \\
\hline \multirow{2}{*}{0} & $\mathrm{CH}_{4}$ & $3486,5466 \times 10^{-7}$ & 10,5007 \\
& $\mathrm{CO}_{2}$ & $9122,1188 \times 10^{-7}$ & 9,3230 \\
\multirow{2}{*}{3} & $\mathrm{CH}_{4}$ & 16414 & $1,5686 \times 10^{-6}$ & 25,1600 \\
& $\mathrm{CO}_{2}$ & 19528 & $1,1197 \times 10^{-6}$ & 49,2661 \\
\multirow{2}{*}{6,} & $\mathrm{CH}_{4}$ & 18766 & $1,7024 \times 10^{-6}$ & 27,3060 \\
& $\mathrm{CO}_{2}$ & 25334 & $1,4028 \times 19^{-6}$ & 61,7236 \\
\multirow{2}{*}{$12^{\prime}$} & $\mathrm{CH}_{4}$ & $210591,8328 \times 10^{-6}$ & 29,3983 \\
& $\mathrm{CO}_{2}$ & $213711,2095 \times 10^{-6}$ & 53,2205 \\
\hline
\end{tabular}

Tabela 6.3.44 - $\mathrm{P}_{8}(\mathrm{G})$ - Áreas cromatográficas medidas $(A)$, número de moles $(n)$ e massa $(m, \mu \mathrm{g})$ de cada gás, correspondentes:

\begin{tabular}{crrrr}
\hline Tempo & Gás & $\boldsymbol{A}$ & $\boldsymbol{n}$ & $\boldsymbol{m}(\boldsymbol{\mu g})$ \\
\hline \multirow{2}{*}{${ }^{\prime}$} & $\mathrm{CH}_{4}$ & 0 & 0 & 0 \\
& $\mathrm{CO}_{2}$ & 145 & $1,7448 \times 10^{-7}$ & 7,6773 \\
\multirow{2}{*}{ 3' } & $\mathrm{CH}_{4}$ & 203 & $6,4641 \times 10^{-7}$ & 10,3684 \\
& $\mathrm{CO}_{2}$ & 217 & $1,7799 \times 10^{-7}$ & 7,8318 \\
& $\mathrm{CH}_{4}$ & 275 & $6,5050 \times 10^{7}$ & 10,4341 \\
6 & $\mathrm{CO}_{2}$ & 315 & $1,8277 \times 10^{-7}$ & 8,0420 \\
& $\mathrm{CH}_{4}$ & 1454 & $7,1757 \times 10^{-7}$ & 11,5100 \\
\multirow{2}{*}{12} & $\mathrm{CO}_{2}$ & 3463 & $3,3628 \times 10^{-7}$ & 14,8000 \\
\hline
\end{tabular}


Tabela 6.3.45 - $P_{9}(G)$ - Áreas cromatográficas medidas $(A)$, número de moles $(n)$ e massa $(m, \mu \mathrm{g})$ de cada gás, correspondentes:

\begin{tabular}{|c|c|c|c|c|}
\hline Tempo & Gás & $A$ & $n$ & $m(\mu g)$ \\
\hline \multirow{2}{*}{$0^{\prime}$} & $\mathrm{CH}_{4}$ & 0 & 0 & \\
\hline & $\mathrm{CO}_{2}$ & 115 & $1,7302 \times 10^{-2}$ & 7,6130 \\
\hline \multirow{2}{*}{$3^{\prime}$} & $\mathrm{CH}_{4}$ & 137 & $6,4265 \times 10^{-1}$ & 10,3082 \\
\hline & $\mathrm{CO}_{2}$ & 536 & $1,9355 \times 10^{-}$ & 8,5162 \\
\hline \multirow{2}{*}{$6^{\prime}$} & $\mathrm{CH}_{4}$ & 2991 & $8,0500 \times 10^{-1}$ & 12,9123 \\
\hline & $\mathrm{CO}_{2}$ & 5162 & $4,1913 \times 10^{-}$ & 18,4420 \\
\hline \multirow{2}{*}{$12^{\prime}$} & $\mathrm{CH}_{4}$ & 3416 & $8,2918 \times 10^{-}$ & 13,3001 \\
\hline & $\mathrm{CO}_{2}$ & 6714 & $4,9482 \times 10^{-2}$ & 21,7720 \\
\hline
\end{tabular}

Tabela 6.3.46 - $\mathrm{P}_{10}(\mathrm{G})$ - Áreas cromatográficas medidas $(A)$, número de moles $(n)$ e massa $(m, \mu \mathrm{g})$ de cada gás, correspondentes:

\begin{tabular}{crrrr}
\hline Tempo & Gás & \multicolumn{1}{c}{$\boldsymbol{A}$} & $\boldsymbol{n}$ & $\boldsymbol{m}(\boldsymbol{\mu} \mathbf{g})$ \\
\hline \multirow{2}{*}{${ }^{\prime}$} & $\mathrm{CH}_{4}$ & 0 & 0 & 0 \\
& $\mathrm{CO}_{2}$ & 323 & $1,8316 \times 10^{-7}$ & 8,0592 \\
\multirow{2}{*}{${ }^{\prime}$} & $\mathrm{CH}_{4}$ & 179 & $6,4504 \times 10^{-1}$ & 10,3465 \\
& $\mathrm{CO}_{2}$ & 349 & $1,8443 \times 10^{-7}$ & 8,1150 \\
\multirow{2}{*}{6} & $\mathrm{CH}_{4}$ & 5447 & $9,4471 \times 10^{-7}$ & 15,1532 \\
& $\mathrm{CO}_{2}$ & 4184 & $3,7144 \times 10^{-7}$ & 16,3435 \\
\multirow{2}{*}{$12^{\prime}$} & $\mathrm{CH}_{4}$ & 5979 & $9,7498 \times 10^{-1}$ & 15,6386 \\
& $\mathrm{CO}_{2}$ & 6951 & $5,0637 \times 10^{-7}$ & 22,2805 \\
\hline
\end{tabular}

Tabela 6.3.47 - Dissipadores 1, 2, 3 e 4 - Áreas cromatográficas medidas $(A)$, número de moles $(n)$ e massa $(m, \mu g)$ de cada gás, correspondentes:

\begin{tabular}{ccccr}
\hline Dreno & Gás & $\boldsymbol{A}$ & $\boldsymbol{n}$ & $\boldsymbol{m}(\boldsymbol{\mu g})$ \\
\hline 1 & $\mathrm{CH}_{4}$ & 29992 & $2,3410 \times 10^{-6}$ & 37,5491 \\
& $\mathrm{CO}_{2}$ & 31911 & $1,7235 \times 10^{-6}$ & 75,8355 \\
2 & $\mathrm{CH}_{4}$ & 56841 & $3,8682 \times 10^{-6}$ & 62,0472 \\
& $\mathrm{CO}_{2}$ & 63912 & $3,2840 \times 10^{-6}$ & 144,5000 \\
3 & $\mathrm{CH}_{4}$ & 34642 & $2,6054 \times 10^{-6}$ & 41,7920 \\
& $\mathrm{CO}_{2}$ & 39674 & $2,1020 \times 10^{-6}$ & 92,5000 \\
4 & $\mathrm{CH}_{4}$ & 33987 & $2,5682 \times 10^{-6}$ & 41,2000 \\
& $\mathrm{CO}_{2}$ & 39963 & $2,1162 \times 10^{-6}$ & 93,1121 \\
\hline
\end{tabular}


6.3.4- $D_{1}$ ) Aterro de Jaú - Primeira Campanha - Data: 20/11/2006.

Tabela 6.3.48 - AR Ambiente - Áreas cromatográficas medidas $(A)$, número de moles $(n)$ e massa $(m, \mu g)$ de cada gás, correspondentes:

\begin{tabular}{cllcr}
\hline Tomada & Gás & $\boldsymbol{A}$ & $\boldsymbol{n}$ & $\boldsymbol{m}(\boldsymbol{\mu g})$ \\
\hline \multirow{2}{*}{1} & $\mathrm{CH}_{4}$ & 127 & $6,4208 \times 10^{-1}$ & 10,3000 \\
& $\mathrm{CO}_{2}$ & 187 & $1,7653 \times 10^{-1}$ & 7,7674 \\
\hline
\end{tabular}

Tabela 6.3.49 - $\mathrm{P}_{1}(\mathrm{G})$ - Áreas cromatográficas medidas $(A)$, número de moles $(n)$ e massa $(m, \mu g)$ de cada gás, correspondentes:

\begin{tabular}{rrrcr}
\hline Tempo & Gás & \multicolumn{1}{c}{$\boldsymbol{A}$} & $\boldsymbol{n}$ & $\boldsymbol{m}(\boldsymbol{\mu g})$ \\
\hline \multirow{2}{*}{, } & $\mathrm{CH}_{4}$ & 797 & $6,8020 \times 10^{-1}$ & 10,9104 \\
& $\mathrm{CO}_{2}$ & 328 & $1,8341 \times 10^{-7}$ & 8,0700 \\
\multirow{2}{*}{ 3' } & $\mathrm{CH}_{4}$ & 1787 & $7,3651 \times 10^{-1}$ & 11,8137 \\
& $\mathrm{CO}_{2}$ & 1209 & $2,2637 \times 10^{-7}$ & 9,9602 \\
\multirow{2}{*}{ 6' } & $\mathrm{CH}_{4}$ & 14393 & $1,4536 \times 10^{-6}$ & 23,3160 \\
& $\mathrm{CO}_{2}$ & 24671 & $1,3705 \times 10^{-6}$ & 60,3011 \\
\multirow{2}{*}{ 12' } & $\mathrm{CH}_{4}$ & 19446 & $1,7410 \times 10^{-6}$ & 27,9265 \\
& $\mathrm{CO}_{2}$ & 20119 & $1,1485 \times 10^{-6}$ & 50,5342
\end{tabular}

Tabela 6.3.50 - $\mathrm{P}_{2}(\mathrm{p})$ - Áreas cromatográficas medidas $(A)$, número de moles $(n)$ e massa $(m, \mu g)$ de cada gás, correspondentes:

\begin{tabular}{rrrrr}
\hline Tempo & Gás & \multicolumn{1}{c}{$\boldsymbol{A}$} & $\boldsymbol{n}$ & $\boldsymbol{m}(\boldsymbol{\mu g})$ \\
\hline \multirow{2}{*}{, } & $\mathrm{CH}_{4}$ & 0 & 0 & 0 \\
& $\mathrm{CO}_{2}$ & 1868 & $2,5850 \times 10^{-7}$ & 11,3742 \\
\multirow{2}{*}{ 3, } & $\mathrm{CH}_{4}$ & 4031 & $8,6416 \times 10^{-7}$ & 13,8613 \\
& $\mathrm{CO}_{2}$ & 2141 & $2,7182 \times 10^{-7}$ & 11,9600 \\
\multirow{2}{*}{ 6, } & $\mathrm{CH}_{4}$ & 8187 & $1,1006 \times 10^{-6}$ & 17,6533 \\
& $\mathrm{CO}_{2}$ & 5893 & $4,5478 \times 10^{-1}$ & 20,0104 \\
\multirow{2}{*}{12,} & $\mathrm{CH}_{4}$ & 9135 & $1,1545 \times 10^{-6}$ & 18,5183 \\
& $\mathrm{CO}_{2}$ & 9113 & $6,1180 \times 10^{-7}$ & 26,9200 \\
\hline
\end{tabular}


Tabela 6.3.51 - $\mathrm{P}_{3}(\mathrm{G})$ - Áreas cromatográficas medidas $(A)$, número de moles $(n)$ e massa $(m, \mu \mathrm{g})$ de cada gás, correspondentes:

\begin{tabular}{crrrr}
\hline Tempo & Gás & \multicolumn{1}{c}{$\boldsymbol{A}$} & $\boldsymbol{n}$ & $\boldsymbol{m}(\boldsymbol{\mu g})$ \\
\hline $0^{\prime}$ & $\mathrm{CH}_{4}$ & 0 & 0 & 0 \\
& $\mathrm{CO}_{2}$ & 1109 & $2,2150 \times 10^{-7}$ & 9,7457 \\
\multirow{2}{*}{ 3 $^{\prime}$} & $\mathrm{CH}_{4}$ & 983 & $6,9078 \times 10^{-7}$ & 11,0801 \\
& $\mathrm{CO}_{2}$ & 1179 & $2,2491 \times 10^{-7}$ & 9,8959 \\
\multirow{2}{*}{$6^{\prime}$} & $\mathrm{CH}_{4}$ & 1225 & $7,0454 \times 10^{-7}$ & 11,3009 \\
& $\mathrm{CO}_{2}$ & 1891 & $2,5962 \times 10^{-7}$ & 11,4235 \\
\multirow{2}{*}{ 12' $^{\prime}$} & $\mathrm{CH}_{4}$ & 9018 & $1,1478 \times 10^{-6}$ & 18,4116 \\
& $\mathrm{CO}_{2}$ & 11564 & $7,3133 \times 10^{-7}$ & 32,1783 \\
\hline
\end{tabular}

Tabela 6.3.52 - $\mathrm{P}_{4}(\mathrm{G})$ - Áreas cromatográficas medidas $(A)$, número de moles $(n)$ e massa $(m, \mu \mathrm{g})$ de cada gás, correspondentes:

\begin{tabular}{ccrcr}
\hline Tempo & Gás & \multicolumn{1}{c}{$\boldsymbol{A}$} & $\boldsymbol{n}$ & $\boldsymbol{m}(\boldsymbol{\mu g})$ \\
\hline \multirow{2}{*}{$\mathbf{y}^{\prime}$} & $\mathrm{CH}_{4}$ & 277 & $6,4493 \times 10^{-7}$ & 10,3447 \\
& $\mathrm{CO}_{2}$ & 725 & $2,0277 \times 10^{-7}$ & 8,9218 \\
\multirow{2}{*}{ 3 $^{\prime}$} & $\mathrm{CH}_{4}$ & 199 & $6,4618 \times 10^{-7}$ & 10,3647 \\
& $\mathrm{CO}_{2}$ & 1861 & $2,5816 \times 10^{-7}$ & 11,3592 \\
\multirow{2}{*}{ 6 $^{\prime}$} & $\mathrm{CH}_{4}$ & 6778 & $1,0204 \times 10^{-6}$ & 16,3677 \\
& $\mathrm{CO}_{2}$ & 7965 & $5,5582 \times 10^{-7}$ & 24,4561 \\
\multirow{2}{*}{ 12' } & $\mathrm{CH}_{4}$ & 2979 & $8,0432 \times 10^{-7}$ & 12,9013 \\
& $\mathrm{CO}_{2}$ & 4253 & $3,7481 \times 10^{-7}$ & 16,5000 \\
\hline
\end{tabular}

Tabela 6.3.53 - $\mathrm{P}_{5}(\mathrm{p})$ - Áreas cromatográficas medidas $(\boldsymbol{A})$, número de moles $(n)$ e massa $(m, \mu \mathrm{g})$ de cada gás, correspondentes:

\begin{tabular}{cc|rcr|}
\hline Tempo & Gás & \multicolumn{1}{c}{$\boldsymbol{A}$} & $\boldsymbol{n}$ & $\boldsymbol{m}(\boldsymbol{\mu g})$ \\
\hline \multirow{2}{*}{$\mathbf{y}^{\prime}$} & $\mathrm{CH}_{4}$ & 0 & 0 & 0 \\
& $\mathrm{CO}_{2}$ & 1202 & $2,2603 \times 10^{-7}$ & 9,9452 \\
\multirow{2}{*}{$3^{\prime}$} & $\mathrm{CH}_{4}$ & 984 & $6,9084 \times 10^{-7}$ & 11,0810 \\
& $\mathrm{CO}_{2}$ & 1645 & $2,4763 \times 10^{-1}$ & 10,8957 \\
\multirow{2}{*}{$6^{\prime}$} & $\mathrm{CH}_{4}$ & 1018 & $6,9277 \times 10^{-7}$ & 11,0912 \\
& $\mathrm{CO}_{2}$ & 1665 & $2,4861 \times 10^{-7}$ & 10,9386 \\
\multirow{2}{*}{$12^{\prime}$} & $\mathrm{CH}_{4}$ & 1212 & $7,0381 \times 10^{-7}$ & 11,2900 \\
& $\mathrm{CO}_{2}$ & 1795 & $2,5495 \times 19^{-1}$ & 11,2176 \\
\hline
\end{tabular}


Tabela 6.3.54 - Dissipador - Áreas cromatográficas medidas $(\boldsymbol{A})$, número de $\operatorname{moles}(\boldsymbol{n})$ e massa $(\boldsymbol{m}, \mu \mathrm{g})$ de cada gás, correspondentes:

\begin{tabular}{ccccc}
\hline Dreno & Gás & $\boldsymbol{A}$ & $\boldsymbol{n}$ & $\boldsymbol{m}(\boldsymbol{\mu} \mathbf{g})$ \\
\hline \multirow{2}{*}{1} & $\mathrm{CH}_{4}$ & 36998 & $2,7395 \times 19^{-6}$ & 43,9417 \\
& $\mathrm{CO}_{2}$ & 48590 & $2,5369 \times 10^{-6}$ & 111,6225 \\
\hline
\end{tabular}




\subsection{4- $D_{2}$ ) Aterro de Jaú - Segunda Campanha - Data: $\underline{02 / 10 / 2007}$.}

Tabela 6.3.55 - AR Ambiente - Áreas cromatográficas medidas $(A)$, número de $\operatorname{moles}(n)$ e massa $(m, \mu \mathrm{g})$ de cada gás, correspondentes:

\begin{tabular}{ccrcr}
\hline Tomadas & Gás & \multicolumn{1}{c}{$\boldsymbol{A}$} & $\boldsymbol{n}$ & $\boldsymbol{m}(\boldsymbol{\mu} \mathbf{g})$ \\
\hline \multirow{2}{*}{1} & $\mathrm{CH}_{4}$ & 576 & $6,6763 \times 10^{-7}$ & 10,7087 \\
& $\mathrm{CO}_{2}$ & 1995 & $2,6470 \times 10^{-7}$ & 11,6467 \\
\multirow{2}{*}{2} & $\mathrm{CH}_{4}$ & 769 & $6,7861 \times 10^{-7}$ & 10,8848 \\
& $\mathrm{CO}_{2}$ & 1076 & $2,1988 \times 10^{-7}$ & 9,6749 \\
\hline
\end{tabular}

Tabela 6.3.56 - $\mathrm{P}_{1}(\mathrm{G})$ - Áreas cromatográficas medidas $(A)$, número de moles $(n)$ e massa $(m, \mu \mathrm{g})$ de cada gás, correspondentes:

\begin{tabular}{ccrcr}
\hline Tempo & Gás & \multicolumn{1}{c}{$\boldsymbol{A}$} & $\boldsymbol{n}$ & $\boldsymbol{m}(\boldsymbol{\mu g})$ \\
\hline \multirow{2}{*}{$0^{\prime}$} & $\mathrm{CH}_{4}$ & 0 & 0 & 0 \\
& $\mathrm{CO}_{2}$ & 297 & $1,8190 \times 10^{-7}$ & 8,0034 \\
\multirow{2}{*}{ 3' $^{\prime}$} & $\mathrm{CH}_{4}$ & 69 & $6,5175 \times 10^{-7}$ & 10,4542 \\
& $\mathrm{CO}_{2}$ & 344 & $1,8419 \times 10^{-7}$ & 8,1043 \\
\multirow{2}{*}{$\mathbf{C}^{\prime}$} & $\mathrm{CH}_{4}$ & 987 & $6,9101 \times 10^{-7}$ & 11,0837 \\
& $\mathrm{CO}_{2}$ & 551 & $1,9428 \times 10^{-7}$ & 8,5484 \\
\multirow{2}{*}{$2^{\prime}$} & $\mathrm{CH}_{4}$ & 793 & $6,7997 \times 10^{-7}$ & 10,9067 \\
& $\mathrm{CO}_{2}$ & 1596 & $2,4524 \times 10^{-7}$ & 10,8000 \\
\hline
\end{tabular}

Tabela 6.3.57 - $\mathrm{P}_{2}(\mathrm{p})$ - Áreas cromatográficas medidas $(A)$, número de moles $(n)$ e massa $(m, \mu \mathrm{g})$ de cada gás, correspondentes:

\begin{tabular}{ccrcr}
\hline Tempo & Gás & \multicolumn{1}{c}{$\boldsymbol{A}$} & $\boldsymbol{n}$ & $\boldsymbol{m}(\boldsymbol{\mu g})$ \\
\hline \multirow{2}{*}{$0^{\prime}$} & $\mathrm{CH}_{4}$ & 771 & $6,7872 \times 10^{-7}$ & 10,8866 \\
& $\mathrm{CO}_{2}$ & 566 & $1,9501 \times 10^{-7}$ & 8,5806 \\
\multirow{2}{*}{${ }^{\prime}$} & $\mathrm{CH}_{4}$ & 295 & $6,5164 \times 10^{-7}$ & 10,4523 \\
& $\mathrm{CO}_{2}$ & 1245 & $2,2812 \times 10^{-7}$ & 10,0375 \\
\multirow{2}{*}{6,} & $\mathrm{CH}_{4}$ & 2664 & $7,8640 \times 10^{-7}$ & 12,6140 \\
& $\mathrm{CO}_{2}$ & 2643 & $2,9630 \times 10^{-7}$ & 13,0371 \\
\multirow{2}{*}{$12^{\prime}$} & $\mathrm{CH}_{4}$ & 1565 & $7,2389 \times 10^{-7}$ & 11,6111 \\
& $\mathrm{CO}_{2}$ & 1122 & $2,2211 \times 10^{-7}$ & 9,7736 \\
\hline
\end{tabular}


Tabela 6.3.58 - $\mathrm{P}_{3}(G)$ - Áreas cromatográficas medidas $(A)$, número de moles $(n)$ e massa $(m, \mu \mathrm{g})$ de cada gás, correspondentes:

\begin{tabular}{crrrr}
\hline Tempo & Gás & \multicolumn{1}{c}{$\boldsymbol{A}$} & $\boldsymbol{n}$ & $\boldsymbol{m}(\boldsymbol{\mu} \mathbf{g})$ \\
\hline \multirow{2}{*}{$0^{\prime}$} & $\mathrm{CH}_{4}$ & 0 & 0 & 0 \\
& $\mathrm{CO}_{2}$ & 123 & $1,7342 \times 10^{-7}$ & 7,6301 \\
\multirow{2}{*}{$3^{\prime}$} & $\mathrm{CH}_{4}$ & 572 & $6,6740 \times 10^{-7}$ & 10,7051 \\
& $\mathrm{CO}_{2}$ & 619 & $1,9760 \times 10^{-7}$ & 8,7000 \\
\multirow{2}{*}{6,} & $\mathrm{CH}_{4}$ & 2930 & $8,0153 \times 10^{-7}$ & 12,8566 \\
& $\mathrm{CO}_{2}$ & 2258 & $2,7752 \times 10^{-7}$ & 12,2110 \\
\multirow{2}{*}{$12^{\prime}$} & $\mathrm{CH}_{4}$ & 2516 & $7,7798 \times 10^{-7}$ & 12,4789 \\
& $\mathrm{CO}_{2}$ & 1459 & $2,3856 \times 10^{-7}$ & 10,5000 \\
\hline
\end{tabular}

Tabela 6.1.3.59 - $\mathrm{P}_{4}(\mathrm{p})$ - Áreas cromatográficas medidas $(A)$, número de moles $(n)$ e massa $(m, \mu \mathrm{g})$ de cada gás, correspondentes:

\begin{tabular}{ccccr}
\hline Tempo & Gás & $\boldsymbol{A}$ & $\boldsymbol{n}$ & $\boldsymbol{m}(\boldsymbol{\mu g})$ \\
\hline \multirow{2}{*}{$\mathbf{0}^{\prime}$} & $\mathrm{CH}_{4}$ & 109 & $6,4106 \times 10^{-7}$ & 10,2826 \\
& $\mathrm{CO}_{2}$ & 162 & $1,7531 \times 10^{-7}$ & 7,7138 \\
\multirow{2}{*}{$3^{\prime}$} & $\mathrm{CH}_{4}$ & 347 & $6,5460 \times 10^{-7}$ & 10,5000 \\
& $\mathrm{CO}_{2}$ & 294 & $1,8175 \times 19^{-7}$ & 7,9970 \\
\multirow{2}{*}{ 6' } & $\mathrm{CH}_{4}$ & 1195 & $7,0284 \times 10^{-7}$ & 11,2735 \\
& $\mathrm{CO}_{2}$ & 1769 & $2,5368 \times 10^{-7}$ & 11,1618 \\
\multirow{2}{*}{${ }^{\prime}}$, & $\mathrm{CH}_{4}$ & 2702 & $7,8856 \times 10^{-7}$ & 12,6486 \\
& $\mathrm{CO}_{2}$ & 2719 & $3,0000 \times 10^{-7}$ & 13,2001 \\
\hline
\end{tabular}

Tabela 6.3.60 - $\mathrm{P}_{5}(\mathrm{G})$ - Áreas cromatográficas medidas $(A)$, número de moles $(n)$ e massa $(m, \mu \mathrm{g})$ de cada gás, correspondentes:

\begin{tabular}{rrrcr}
\hline \multicolumn{2}{r}{ Tempo Gás } & \multicolumn{1}{c}{$\boldsymbol{A}$} & $\boldsymbol{n}$ & $\boldsymbol{m}(\boldsymbol{\mu} \mathbf{g})$ \\
\hline \multirow{2}{*}{$\mathbf{r}^{\prime}$} & $\mathrm{CH}_{4}$ & 0 & 0 & 0 \\
& $\mathrm{CO}_{2}$ & 22 & $1,6848 \times 10^{-7}$ & 7,4134 \\
& $\mathrm{CH}_{4}$ & 804 & $6,8060 \times 10^{-7}$ & 10,9168 \\
3 & $\mathrm{CO}_{2}$ & 453 & $1,8950 \times 10^{-7}$ & 8,3382 \\
& $\mathrm{CH}_{4}$ & 1505 & $7,2048 \times 10^{-7}$ & 11,5564 \\
6 & $\mathrm{CO}_{2}$ & 2294 & $2,7928 \times 19^{-7}$ & 12,2883 \\
& $\mathrm{CH}_{4}$ & 479 & $6,6211 \times 10^{-7}$ & 10,6202 \\
\multirow{2}{*}{12} & $\mathrm{CO}_{2}$ & 1349 & $2,3320 \times 10^{-7}$ & 10,2606 \\
\hline
\end{tabular}


Tabela 6.3.61 - $\mathrm{P}_{6}(\mathrm{G})$ - Áreas cromatográficas medidas $(A)$, número de moles $(n)$ e massa $(m, \mu \mathrm{g})$ de cada gás, correspondentes:

\begin{tabular}{|c|c|c|c|c|}
\hline Tempo & Gás & $A$ & $n$ & $m(\mu \mathrm{g})$ \\
\hline \multirow{2}{*}{$0^{\prime}$} & $\mathrm{CH}_{4}$ & 157 & $6,4380 \times 10^{-7}$ & 10,3264 \\
\hline & $\mathrm{CO}_{2}$ & 191 & $1,7673 \times 10^{-7}$ & 7,7760 \\
\hline \multirow{2}{*}{3} & $\mathrm{CH}_{4}$ & 2242 & $7,6240 \times 19^{-7}$ & 12,2289 \\
\hline & $\mathrm{CO}_{2}$ & 1783 & $2,5436 \times 10^{-7}$ & 11,1918 \\
\hline \multirow{2}{*}{$6{ }^{\prime}$} & $\mathrm{CH}_{4}$ & 2564 & $7,8072 \times 10^{-7}$ & 12,5227 \\
\hline & $\mathrm{CO}_{2}$ & 2577 & $2,9308 \times 10^{-7}$ & 12,8955 \\
\hline \multirow{2}{*}{$12^{\prime}$} & $\mathrm{CH}_{4}$ & 2579 & $7,8157 \times 10^{-7}$ & 12,5363 \\
\hline & $\mathrm{CO}_{2}$ & 1471 & $2,3915 \times 10^{-7}$ & 10,5224 \\
\hline
\end{tabular}

Tabela 6.3.62 - Dissipador - Áreas cromatográficas medidas $(A)$, número de moles $(n)$ e massa $(m, \mu g)$ de cada gás, correspondentes:

\begin{tabular}{ccccc}
\hline Dreno & Gás & $\boldsymbol{A}$ & $\boldsymbol{n}$ & $\boldsymbol{m}(\boldsymbol{\mu g})$ \\
\hline \multirow{2}{*}{1} & $\mathrm{CH}_{4}$ & 15831 & $1,5354 \times 10^{-6}$ & 24,6280 \\
& $\mathrm{CO}_{2}$ & 17911 & $1,0408 \times 10^{-6}$ & 45,8000 \\
\hline
\end{tabular}


6.3.5- $\mathrm{E}_{1}$ ) Aterro de Ribeirão Bonito - Primeira Campanha - Data: 16/11/2006.

Tabela 6.3.63 - AR ambiente - Áreas cromatográficas medidas $(A)$, número de moles $(n)$ e massa $(m, \mu \mathrm{g})$ de cada gás, correspondentes:

\begin{tabular}{|c|c|c|c|c|}
\hline Tomada & Gás & $A$ & $n$ & $m(\mu \mathrm{g})$ \\
\hline & $\mathrm{CH}_{4}$ & 783 & $6,7940 \times 10^{-1}$ & 10,9000 \\
\hline & $\mathrm{CO}_{2}$ & 891 & $2,1086 \times 10^{-7}$ & 9,2780 \\
\hline
\end{tabular}

Tabela 6.3.64 - $\mathrm{P}_{1}(\mathrm{G})$ - Áreas cromatográficas medidas $(A)$, número de moles $(n)$ e massa $(m, \mu \mathrm{g})$ de cada gás, correspondentes:

\begin{tabular}{|c|c|c|c|c|}
\hline Tempo & Gás & $A$ & $n$ & $m(\mu \mathrm{g})$ \\
\hline \multirow{2}{*}{$0^{\prime}$} & $\mathrm{CH}_{4}$ & $\overline{1424}$ & $7,1586 \times 10^{-1}$ & 11,4825 \\
\hline & $\mathrm{CO}_{2}$ & 984 & $2,1540 \times 10^{-7}$ & 9,4800 \\
\hline \multirow{2}{*}{$3^{\prime}$} & $\mathrm{CH}_{4}$ & 1442 & $7,1690 \times 10^{-7}$ & 11,4990 \\
\hline & $\mathrm{CO}_{2}$ & 1389 & $2,3515 \times 10^{-7}$ & 10,3465 \\
\hline \multirow{2}{*}{$6^{\prime}$} & $\mathrm{CH}_{4}$ & 1438 & $7,1666 \times 10^{-7}$ & 11,5000 \\
\hline & $\mathrm{CO}_{2}$ & 1570 & $2,4398 \times 10^{-7}$ & 10,7349 \\
\hline \multirow{2}{*}{$12^{\prime}$} & $\mathrm{CH}_{4}$ & 1156 & $7,0062 \times 10^{-7}$ & 11,2380 \\
\hline & $\mathrm{CO}_{2}$ & 1539 & $2,4246 \times 10^{-7}$ & 10,6683 \\
\hline
\end{tabular}

Tabela 6.3.65 - $\mathrm{P}_{2}(\mathrm{p})$ - Áreas cromatográficas medidas $(A)$, número de moles $(n)$ e massa $(m, \mu \mathrm{g})$ de cada gás, correspondentes:

\begin{tabular}{ccccr}
\hline Tempo & Gás & $\boldsymbol{A}$ & $\boldsymbol{n}$ & $\boldsymbol{m}(\boldsymbol{\mu g})$ \\
\hline \multirow{2}{*}{$0^{\prime}$} & $\mathrm{CH}_{4}$ & 131 & $6,4231 \times 10^{-7}$ & 10,3030 \\
& $\mathrm{CO}_{2}$ & 120 & $1,7326 \times 10^{-7}$ & 7,6236 \\
\multirow{2}{*}{${ }^{\prime}$} & $\mathrm{CH}_{4}$ & 328 & $6,5351 \times 10^{-7}$ & 10,4824 \\
& $\mathrm{CO}_{2}$ & 421 & $1,8794 \times 10^{-7}$ & 8,2695 \\
\multirow{2}{*}{6} & $\mathrm{CH}_{4}$ & 794 & $6,8002 \times 10^{-7}$ & 10,9076 \\
& $\mathrm{CO}_{2}$ & 983 & $2,1534 \times 10^{-7}$ & 9,4754 \\
\multirow{2}{*}{$12^{\prime}$} & $\mathrm{CH}_{4}$ & 975 & $6,9032 \times 10^{-7}$ & 11,0728 \\
& $\mathrm{CO}_{2}$ & 1008 & $2,1656 \times 10^{-7}$ & 9,5290 \\
\hline
\end{tabular}


Tabela 6.3.66 - $\mathrm{P}_{3}(\mathrm{G})$ - Áreas cromatográficas medidas $(A)$, número de moles $(n)$ e massa $(m, \mu \mathrm{g})$ de cada gás, correspondentes:

\begin{tabular}{|c|c|c|c|}
\hline Tempo & Gás & $A$ & $m(\mu \mathrm{g})$ \\
\hline \multirow{2}{*}{$0^{\prime}$} & $\mathrm{CH}_{4}$ & $13167,0972 \times 10^{-7}$ & 11,3840 \\
\hline & $\mathrm{CO}_{2}$ & $7492,0394 \times 10^{-7}$ & 8,9732 \\
\hline \multirow{2}{*}{ 3' } & $\mathrm{CH}_{4}$ & $18367,3930 \times 10^{-7}$ & 11,8584 \\
\hline & $\mathrm{CO}_{2}$ & $12902,3032 \times 10^{-7}$ & 10,1340 \\
\hline \multirow[t]{2}{*}{$6^{\prime}$} & $\mathrm{CH}_{4}$ & $11667,0119 \times 10^{-7}$ & 11,2471 \\
\hline & $\mathrm{CO}_{2}$ & $14982,4046 \times 10^{-7}$ & 10,5803 \\
\hline \multirow{2}{*}{$12 '$} & $\mathrm{CH}_{4}$ & $14367,1655 \times 10^{-7}$ & 11,5000 \\
\hline & $\mathrm{CO}_{2}$ & $11742,2466 \times 10^{-7}$ & 9,8851 \\
\hline
\end{tabular}

Tabela 6.3.67 - $\mathrm{P}_{4}(\mathrm{p})$ - Áreas cromatográficas medidas $(A)$, número de moles $(n)$ e massa $(m, \mu \mathrm{g})$ de cada gás, correspondentes:

\begin{tabular}{rrrcr}
\hline Tempo & Gás & \multicolumn{1}{c}{$\boldsymbol{A}$} & $\boldsymbol{n}$ & \multicolumn{1}{c}{$\boldsymbol{m}(\boldsymbol{\mu} \mathbf{g})$} \\
\hline \multirow{2}{*}{$0^{\prime}$} & $\mathrm{CH}_{4}$ & 97 & $6,4037 \times 10^{-7}$ & 10,2717 \\
& $\mathrm{CO}_{2}$ & 132 & $1,7385 \times 10^{-7}$ & 7,6494 \\
\multirow{2}{*}{$3^{\prime}$} & $\mathrm{CH}_{4}$ & 231 & $6,4800 \times 10^{-1}$ & 10,3940 \\
& $\mathrm{CO}_{2}$ & 496 & $1,9160 \times 10^{-7}$ & 8,4304 \\
\multirow{2}{*}{6} & $\mathrm{CH}_{4}$ & 798 & $6,8025 \times 10^{-7}$ & 10,9113 \\
& $\mathrm{CO}_{2}$ & 1028 & $2,1754 \times 10^{-7}$ & 9,5719 \\
\multirow{2}{*}{12} & $\mathrm{CH}_{4}$ & 1282 & $7,0778 \times 10^{-1}$ & 11,3530 \\
& $\mathrm{CO}_{2}$ & 1673 & $2,4899 \times 10^{-7}$ & 10,9558 \\
\hline
\end{tabular}

Tabela 6.3.68 - $\mathrm{P}_{5}(\mathrm{G})$ - Áreas cromatográficas medidas $(A)$, número de moles $(n)$ e massa $(m, \mu \mathrm{g})$ de cada gás, correspondentes:

\begin{tabular}{|c|c|c|c|c|}
\hline Tempo & Gás & $A$ & $n$ & $m(\mu \mathrm{g})$ \\
\hline \multirow{2}{*}{$0^{\prime}$} & $\mathrm{CH}_{4}$ & 714 & $6,7547 \times 10^{-1}$ & 10,8346 \\
\hline & $\mathrm{CO}_{2}$ & 895 & $2,1105 \times 10^{-7}$ & 9,2865 \\
\hline \multirow[b]{2}{*}{ 3' } & $\mathrm{CH}_{4}$ & 1085 & $6,9658 \times 10^{-7}$ & 11,1732 \\
\hline & $\mathrm{CO}_{2}$ & 1294 & $2,3051 \times 10^{-7}$ & 10,1426 \\
\hline \multirow{2}{*}{6} & $\mathrm{CH}_{4}$ & 2196 & $7,5978 \times 10^{-7}$ & 12,1869 \\
\hline & $\mathrm{CO}_{2}$ & 3048 & $3,1604 \times 10^{-7}$ & 13,9060 \\
\hline \multirow{2}{*}{$12^{\prime}$} & $\mathrm{CH}_{4}$ & 2365 & $7,6939 \times 10^{-7}$ & 12,3411 \\
\hline & $\mathrm{CO}_{2}$ & 3119 & $3,1950 \times 10^{-7}$ & 14,0584 \\
\hline
\end{tabular}


6.3.5- $\mathrm{E}_{2}$ ) Aterro de Ribeirão Bonito - Segunda Campanha - Data: 01/10/2007.

Tabela 6.3.69 - AR ambiente - Áreas cromatográficas medidas $(A)$, número de moles $(n)$ e massa $(m, \mu \mathrm{g})$ de cada gás, correspondentes:

\begin{tabular}{rrrrr}
\hline Tomada & Gás & \multicolumn{1}{c}{$\boldsymbol{A}$} & $\boldsymbol{n}$ & $\boldsymbol{m}(\boldsymbol{\mu} \mathbf{g})$ \\
\hline \multirow{2}{*}{1} & $\mathrm{CH}_{4}$ & 151 & $6,4345 \times 10^{-7}$ & 10,3210 \\
& $\mathrm{CO}_{2}$ & 1613 & $2,4607 \times 10^{-7}$ & 10,8271 \\
\hline
\end{tabular}

Tabela 6.3.70 - $\mathrm{P}_{1}(\mathrm{G})$ - Áreas cromatográficas medidas $(A)$, número de moles $(n)$ e massa $(m, \mu \mathrm{g})$ de cada gás, correspondentes:

\begin{tabular}{ccrcr}
\hline Tempo & Gás & \multicolumn{1}{c}{$\boldsymbol{A}$} & $\boldsymbol{n}$ & $\boldsymbol{m}(\boldsymbol{\mu} \mathbf{g})$ \\
\hline \multirow{2}{*}{$\mathbf{0}^{\prime}$} & $\mathrm{CH}_{4}$ & 187 & $6,4550 \times 10^{-7}$ & 10,3538 \\
& $\mathrm{CO}_{2}$ & 1049 & $2,1842 \times 10^{-7}$ & 9,6151 \\
\multirow{2}{*}{$3^{\prime}$} & $\mathrm{CH}_{4}$ & 239 & $6,4845 \times 10^{-7}$ & 10,4012 \\
& $\mathrm{CO}_{2}$ & 1377 & $2,3456 \times 10^{-7}$ & 10,3207 \\
\multirow{2}{*}{6} & $\mathrm{CH}_{4}$ & 296 & $6,5170 \times 10^{-7}$ & 10,4532 \\
& $\mathrm{CO}_{2}$ & 3057 & $3,1648 \times 10^{-7}$ & 13,9254 \\
\multirow{2}{*}{12,} & $\mathrm{CH}_{4}$ & 874 & $6,8452 \times 10^{-7}$ & 10,9797 \\
& $\mathrm{CO}_{2} 3311$ & $3,2887 \times 10^{-7}$ & 14,4704 \\
\hline
\end{tabular}

Tabela 6.3.71 - $\mathrm{P}_{2}(\mathrm{p})$ - Áreas cromatográficas medidas $(A)$, número de moles $(n)$ e massa $(m, \mu \mathrm{g})$ de cada gás, correspondentes:

\begin{tabular}{ccrcr}
\hline $\begin{array}{c}\text { Tem } \\
\text { po }\end{array}$ & Gás & $\boldsymbol{A}$ & $\boldsymbol{n}$ & $\boldsymbol{m}(\boldsymbol{\mu g})$ \\
\hline $0^{\prime}$ & $\mathrm{CH}_{4}$ & 150 & $6,4340 \times 10^{-7}$ & 10,3200 \\
& $\mathrm{CO}_{2}$ & 1089 & $2,2052 \times 10^{-7}$ & 9,7028 \\
3 & $\mathrm{CH}_{4}$ & 282 & $6,5090 \times 10^{-7}$ & 10,4405 \\
& $\mathrm{CO}_{2}$ & 1021 & $2,1720 \times 10^{-7}$ & 9,5569 \\
$6^{\prime}$ & $\mathrm{CH}_{4}$ & 235 & $6,4823 \times 10^{-7}$ & 10,4000 \\
& $\mathrm{CO}_{2}$ & 967 & $2,1457 \times 10^{-7}$ & 9,4410 \\
12 & $\mathrm{CH}_{4}$ & 114 & $6,4134 \times 10^{-7}$ & 10,2872 \\
& $\mathrm{CO}_{2}$ & 2505 & $2,8957 \times 10^{-7}$ & 12,7410 \\
\hline
\end{tabular}


Tabela 6.3.72 - $\mathrm{P}_{3}(\mathrm{G})$ - Áreas cromatográficas medidas $(A)$, número de moles $(n)$ e massa $(m, \mu \mathrm{g})$ de cada gás, correspondentes:

\begin{tabular}{|c|c|c|c|c|}
\hline Tempo & Gás & $A$ & $n$ & $M(\mu \mathrm{g})$ \\
\hline \multirow{2}{*}{$0^{\prime}$} & $\mathrm{CH}_{4}$ & 509 & $6,6381 \times 10^{-1}$ & 10,6478 \\
\hline & $\mathrm{CO}_{2}$ & 972 & $2,1481 \times 10^{-7}$ & 9,4517 \\
\hline \multirow{2}{*}{$3^{\prime}$} & $\mathrm{CH}_{4}$ & 4112 & $8,6878 \times 10^{-7}$ & 13,9351 \\
\hline & $\mathrm{CO}_{2}$ & 2092 & $2,6942 \times 10^{-7}$ & 11,8548 \\
\hline \multirow{2}{*}{$6^{\prime}$} & $\mathrm{CH}_{4}$ & 16231 & $1,5581 \times 10^{-6}$ & 24,9930 \\
\hline & $\mathrm{CO}_{2}$ & 14783 & $8,8830 \times 10^{-7}$ & 39,0851 \\
\hline \multirow{2}{*}{$12^{\prime}$} & $\mathrm{CH}_{4}$ & 9339 & $1,1661 \times 10^{-6}$ & 18,7045 \\
\hline & $\mathrm{CO}_{2}$ & 7671 & $5,4148 \times 10^{-7}$ & 23,8253 \\
\hline
\end{tabular}

Tabela 6.3.73 - $\mathrm{P}_{4}(\mathrm{G})$ - Áreas cromatográficas medidas $(A)$, número de moles $(n)$ e massa $(m, \mu \mathrm{g})$ de cada gás, correspondentes:

\begin{tabular}{crrrr}
\hline Tempo & Gás & \multicolumn{1}{c}{$\boldsymbol{A}$} & $\boldsymbol{n}$ & $\boldsymbol{m}(\boldsymbol{\mu g})$ \\
\hline \multirow{2}{*}{$0^{\prime}$} & $\mathrm{CH}_{4}$ & 176 & $6,4487 \times 10^{-7}$ & 10,3438 \\
& $\mathrm{CO}_{2}$ & 668 & $2,0000 \times 10^{-7}$ & 8,7995 \\
\multirow{2}{*}{$3^{\prime}$} & $\mathrm{CH}_{4}$ & 627 & $6,7053 \times 10^{-7}$ & 10,7553 \\
& $\mathrm{CO}_{2}$ & 2909 & $3,0927 \times 10^{-7}$ & 13,6078 \\
\multirow{2}{*}{$6^{\prime}$} & $\mathrm{CH}_{4}$ & 981 & $6,9066 \times 10^{-7}$ & 11,0783 \\
& $\mathrm{CO}_{2}$ & 2110 & $2,7030 \times 10^{-7}$ & 11,8935 \\
\multirow{2}{*}{$12^{\prime}$} & $\mathrm{CH}_{4}$ & 1165 & $7,0113 \times 10^{-7}$ & 11,2462 \\
& $\mathrm{CO}_{2}$ & 2181 & $2,7377 \times 10^{-7}$ & 12,0458 \\
\hline
\end{tabular}

Tabela 6.3.74 - $\mathrm{P}_{5}(\mathrm{G})$ - Áreas cromatográficas medidas $(A)$, número de moles $(n)$ e massa $(m, \mu \mathrm{g})$ de cada gás, correspondentes:

\begin{tabular}{crrrr}
\hline Tempo & Gás & \multicolumn{1}{c}{$\boldsymbol{A}$} & $\boldsymbol{n}$ & $\boldsymbol{m}(\boldsymbol{\mu g})$ \\
\hline \multirow{2}{*}{$\mathbf{y}^{\prime}$} & $\mathrm{CH}_{4}$ & 0 & 0 & 0 \\
& $\mathrm{CO}_{2}$ & 979 & $2,1515 \times 10^{-7}$ & 9,4668 \\
\multirow{2}{*}{$3^{\prime}$} & $\mathrm{CH}_{4}$ & 950 & $6,9000 \times 10^{-7}$ & 11,0515 \\
& $\mathrm{CO}_{2}$ & 1471 & $2,4000 \times 10^{-7}$ & 10,5224 \\
& $\mathrm{CH}_{4}$ & 2282 & $7,6467 \times 10^{-7}$ & 12,2654 \\
6 & $\mathrm{CO}_{2}$ & 172 & $1,7580 \times 10^{-7}$ & 7,7352 \\
& $\mathrm{CH}_{4}$ & 1741 & $7,3390 \times 10^{-7}$ & 11,7718 \\
\multirow{2}{*}{${ }^{\prime}$} & $\mathrm{CO}_{2}$ & 152 & $1,7482 \times 10^{-7}$ & 7,7000 \\
\hline
\end{tabular}


Tabela 6.3.75 - $\mathrm{P}_{6}(\mathrm{p})$ - Áreas cromatográficas medidas $(A)$, número de moles ( $n)$ e massa $(m, \mu \mathrm{g})$ de cada gás, correspondentes:

\begin{tabular}{crrrr}
\hline Tempo & Gás & \multicolumn{1}{c}{$\boldsymbol{A}$} & $\boldsymbol{n}$ & $\boldsymbol{m}(\boldsymbol{\mu} \mathbf{g})$ \\
\hline \multirow{2}{*}{$0^{\prime}$} & $\mathrm{CH}_{4}$ & - & - & - \\
& $\mathrm{CO}_{2}$ & - & - & - \\
\multirow{2}{*}{$3^{\prime}$} & $\mathrm{CH}_{4}$ & 115 & $6,4140 \times 10^{-7}$ & 10,2881 \\
& $\mathrm{CO}_{2}$ & 320 & $1,8302 \times 10^{-7}$ & 8,0528 \\
\multirow{2}{*}{6,} & $\mathrm{CH}_{4}$ & 679 & $6,7348 \times 10^{-7}$ & 10,8003 \\
& $\mathrm{CO}_{2}$ & 2821 & $3,0498 \times 10^{-7}$ & 13,4190 \\
\multirow{2}{*}{${ }^{\prime}}$, & $\mathrm{CH}_{4}$ & 2201 & $7,6006 \times 10^{-7}$ & 12,1915 \\
& $\mathrm{CO}_{2}$ & 6715 & $4,9486 \times 10^{-7}$ & 21,7741 \\
\hline
\end{tabular}


6.3.6- $\mathrm{F}_{1}$ ) Aterro de Ribeirão Preto - Primeira Campanha - Data: 23/11/2006.

Tabela 6.3.76 - AR ambiente - Áreas cromatográficas medidas $(A)$, número de moles $(n)$ e massa $(m, \mu \mathrm{g})$ de cada gás, correspondentes:

\begin{tabular}{ccccr}
\hline Tomada & Gás & $\boldsymbol{A}$ & $\boldsymbol{n}$ & $\boldsymbol{m}(\boldsymbol{\mu} \mathbf{g})$ \\
\hline \multirow{2}{*}{1} & $\mathrm{CH}_{4}$ & 674 & $6,7320 \times 10^{-7}$ & 10,8000 \\
& $\mathrm{CO}_{2}$ & 969 & $2,1466 \times 10^{-7}$ & 9,4453 \\
\hline
\end{tabular}

Tabela 6.3.77 - $\mathrm{P}_{1}(\mathrm{G})$ - Áreas cromatográficas medidas $(A)$, número de moles $(n)$ e massa $(m, \mu \mathrm{g})$ de cada gás, correspondentes:

\begin{tabular}{|c|c|c|c|c|}
\hline Tempo & Gás & $A$ & $n$ & $m(\mu g)$ \\
\hline \multirow{2}{*}{ 0' } & $\mathrm{CH}_{4}$ & 0 & 0 & 0 \\
\hline & $\mathrm{CO}_{2}$ & 195 & $1,7692 \times 10^{-7}$ & 7,7846 \\
\hline \multirow{2}{*}{ 3' } & $\mathrm{CH}_{4}$ & 806 & $6,4596 \times 10^{-7}$ & 10,3611 \\
\hline & $\mathrm{CO}_{2}$ & 389 & $1,8638 \times 10^{-7}$ & 8,2008 \\
\hline \multirow{2}{*}{$6^{\prime}$} & $\mathrm{CH}_{4}$ & 7947 & $1,0870 \times 10^{-6}$ & 17,4343 \\
\hline & $\mathrm{CO}_{2}$ & 4189 & $3,7169 \times 10^{-7}$ & 16,3542 \\
\hline \multirow{2}{*}{$12^{\prime}$} & $\mathrm{CH}_{4}$ & 2972 & $8,0392 \times 10^{-7}$ & 12,9000 \\
\hline & $\mathrm{CO}_{2}$ & 6951 & $5,0637 \times 10^{-7}$ & 22,2805 \\
\hline
\end{tabular}

Tabela 6.3.78 - $\mathrm{P}_{2}(\mathrm{p})$ - Áreas cromatográficas medidas $(A)$, número de moles $(n)$ e massa $(m, \mu \mathrm{g})$ de cada gás, correspondentes:

\begin{tabular}{ccrcr}
\hline Tempo & Gás & \multicolumn{1}{c}{$\boldsymbol{A}$} & $\boldsymbol{n}$ & $\boldsymbol{m}(\boldsymbol{\mu g})$ \\
\hline \multirow{2}{*}{$\mathbf{r}^{\prime}$} & $\mathrm{CH}_{4}$ & 403 & $6,5778 \times 10^{-7}$ & 10,5509 \\
& $\mathrm{CO}_{2}$ & 887 & $2,1067 \times 10^{-7}$ & 9,2693 \\
\multirow{2}{*}{${ }^{\prime}$} & $\mathrm{CH}_{4}$ & 904 & $6,8631 \times 10^{-7}$ & 10,9925 \\
& $\mathrm{CO}_{2}$ & 1559 & $2,4343 \times 10^{-7}$ & 10,7112 \\
\multirow{2}{*}{${ }^{\prime}$} & $\mathrm{CH}_{4}$ & 1287 & $7,0807 \times 10^{-7}$ & 11,3575 \\
& $\mathrm{CO}_{2}$ & 1363 & $2,3388 \times 10^{-7}$ & 10,3000 \\
\multirow{2}{*}{ 12' } & $\mathrm{CH}_{4}$ & 1578 & $7,2462 \times 10^{-7}$ & 11,6230 \\
& $\mathrm{CO}_{2}$ & 3459 & $3,3609 \times 10^{-7}$ & 14,7880 \\
\hline
\end{tabular}


Tabela 6.3.79 - $\mathrm{P}_{3}(\mathrm{G})$ - Áreas cromatográficas medidas $(A)$, número de moles $(n)$ e massa $(m, \mu g)$ de cada gás, correspondentes:

\begin{tabular}{ccrcc}
\hline Tempo & Gás & \multicolumn{1}{c}{$\boldsymbol{A}$} & $\boldsymbol{n}$ & $\boldsymbol{m}(\boldsymbol{\mu g})$ \\
\hline \multirow{2}{*}{$\mathbf{0}^{\prime}$} & $\mathrm{CH}_{4}$ & 1439 & $7,1671 \times 10^{-7}$ & 11,4962 \\
& $\mathrm{CO}_{2}$ & 2418 & $2,8532 \times 10^{-7}$ & 12,5543 \\
\multirow{2}{*}{$\mathbf{3}^{\prime}$} & $\mathrm{CH}_{4}$ & 1116 & $6,9834 \times 10^{-7}$ & 11,2015 \\
& $\mathrm{CO}_{2}$ & 3928 & $3,5896 \times 10^{-7}$ & 15,8000 \\
\multirow{2}{*}{$6^{\prime}$} & $\mathrm{CH}_{4}$ & 659 & $6,7235 \times 10^{-7}$ & 10,7845 \\
& $\mathrm{CO}_{2}$ & 4145 & $3,6954 \times 10^{-7}$ & 16,2600 \\
\multirow{2}{*}{$2^{\prime}$} & $\mathrm{CH}_{4}$ & 608 & $6,6945 \times 10^{-7}$ & 10,7380 \\
& $\mathrm{CO}_{2}$ & 2187 & $2,7406 \times 10^{-7}$ & 12,0600 \\
\hline
\end{tabular}

Tabela 6.3.80 - $\mathrm{P}_{4}(\mathrm{G})$ - Áreas cromatográficas medidas $(A)$, número de moles $(n)$ e massa $(m, \mu g)$ de cada gás, correspondentes:

\begin{tabular}{ccccr}
\hline Tempo & Gás & $\boldsymbol{A}$ & $\boldsymbol{n}$ & $\boldsymbol{m}(\boldsymbol{\mu} \mathbf{g})$ \\
\hline \multirow{2}{*}{$0^{\prime}$} & $\mathrm{CH}_{4}$ & 793 & $6,7997 \times 10^{-7}$ & 10,9067 \\
& $\mathrm{CO}_{2}$ & 893 & $2,1096 \times 10^{-7}$ & 9,2822 \\
\multirow{2}{*}{$3^{\prime}$} & $\mathrm{CH}_{4}$ & 209 & $6,4675 \times 10^{-7}$ & 10,3739 \\
& $\mathrm{CO}_{2}$ & 1312 & $2,3140 \times 10^{-7}$ & 10,1812 \\
\multirow{2}{*}{ 6, } & $\mathrm{CH}_{4}$ & 5349 & $9,3743 \times 10^{-7}$ & 15,0364 \\
& $\mathrm{CO}_{2}$ & 6419 & $4,8043 \times 10^{-7}$ & 21.1390 \\
\multirow{2}{*}{ 12, $^{\prime}$} & $\mathrm{CH}_{4}$ & 4131 & $8,6985 \times 10^{-7}$ & 13,9525 \\
& $\mathrm{CO}_{2}$ & 6893 & $5,0354 \times 10^{-7}$ & 22,1560 \\
\hline
\end{tabular}

Tabela 6.3.81 - $\mathrm{P}_{5}(\mathrm{p})$ - Áreas cromatográficas medidas $(A)$, número de moles $(n)$ e massa $(m, \mu g)$ de cada gás, correspondentes:

\begin{tabular}{crrrr}
\hline Tempo & Gás & \multicolumn{1}{c}{$\boldsymbol{A}$} & $\boldsymbol{n}$ & $\boldsymbol{m}(\boldsymbol{\mu} \mathbf{g})$ \\
\hline \multirow{2}{*}{0} & $\mathrm{CH}_{4}$ & 0 & 0 & 0 \\
& $\mathrm{CO}_{2}$ & 394 & $1,8662 \times 10^{-7}$ & 8,2115 \\
\multirow{2}{*}{${ }^{\prime}$} & $\mathrm{CH}_{4}$ & 7719 & $1,0740 \times 10^{-6}$ & 17,2245 \\
& $\mathrm{CO}_{2}$ & 8418 & $5,7791 \times 19^{-7}$ & 25,4281 \\
\multirow{2}{*}{6} & $\mathrm{CH}_{4}$ & 8489 & $1,1177 \times 10^{-6}$ & 17,9289 \\
& $\mathrm{CO}_{2}$ & 9656 & $6,3828 \times 19^{-7}$ & 28,0844 \\
\multirow{2}{*}{12} & $\mathrm{CH}_{4}$ & 8995 & $1,1465 \times 19^{-6}$ & 18,4000 \\
& $\mathrm{CO}_{2}$ & 9945 & $6,5237 \times 10^{-7}$ & 28,7045 \\
\hline
\end{tabular}


Tabela 6.3.82 - Dissipadores 1, 2 e 3. - Áreas cromatográficas medidas $(A)$, número de moles $(n)$ e massa $(m, \mu \mathrm{g})$ de cada gás, correspondentes:

\begin{tabular}{ccccc}
\hline Drenos & Gás & $\boldsymbol{A}$ & $\boldsymbol{n}$ & $\boldsymbol{m}(\boldsymbol{\mu} \mathbf{g})$ \\
\hline \multirow{2}{*}{1} & $\mathrm{CH}_{4}$ & 135448 & $8,3399 \times 10^{-6}$ & 133,7715 \\
& $\mathrm{CO}_{2}$ & 141624 & $7,0736 \times 10^{-6}$ & 311,2400 \\
\multirow{2}{*}{2} & $\mathrm{CH}_{4}$ & 131474 & $8,1138 \times 10^{-6}$ & 130,1455 \\
& $\mathrm{CO}_{2}$ & 141393 & $7,0623 \times 10^{-6}$ & 310,7438 \\
\multirow{2}{*}{3} & $\mathrm{CH}_{4}$ & 243481 & $1,4485 \times 10^{-5}$ & 232,3453 \\
& $\mathrm{CO}_{2}$ & 243296 & $1,2031 \times 10^{-5}$ & 529,3903 \\
\hline
\end{tabular}


6.3.6- $\mathrm{F}_{2}$ ) Aterro de Ribeirão Preto - Segunda Campanha - data: 03/10/2007.

Tabela 6.3.83 - AR ambiente - Áreas cromatográficas medidas $(A)$, número de moles $(n)$ e massa $(m, \mu g)$ de cada gás, correspondentes:

\begin{tabular}{|c|c|c|c|c|}
\hline Tomada & Gás & $A$ & $n$ & $m(\mu \mathrm{g})$ \\
\hline \multirow{2}{*}{1} & $\mathrm{CH}_{4}$ & 105 & $6,4083 \times 10^{-1}$ & 10,2790 \\
\hline & $\mathrm{CO}_{2}$ & 287 & $1,8141 \times 10^{-1}$ & 7,9820 \\
\hline \multirow{2}{*}{2} & $\mathrm{CH}_{4}$ & 85 & $6,3970 \times 10^{-1}$ & 10,2607 \\
\hline & $\mathrm{CO}_{2}$ & 99 & $1,7224 \times 10^{-6}$ & 7,5786 \\
\hline
\end{tabular}

Tabela 6.3.84 - $\mathrm{P}_{1}(\mathrm{G})$ - Áreas cromatográficas medidas $(A)$, número de moles $(n)$ e massa $(m, \mu \mathrm{g})$ de cada gás, correspondentes:

\begin{tabular}{crrcr}
\hline Tempo & Gás & \multicolumn{1}{c}{$\boldsymbol{A}$} & $\boldsymbol{n}$ & $\boldsymbol{m}(\boldsymbol{\mu g})$ \\
\hline \multirow{2}{*}{$\mathbf{r}^{\prime}$} & $\mathrm{CH}_{4}$ & 54 & $6,3793 \times 10^{-7}$ & 6,3793 \\
& $\mathrm{CO}_{2}$ & 714 & $2,0223 \times 10^{-7}$ & 8,9000 \\
\multirow{2}{*}{$3^{\prime}$} & $\mathrm{CH}_{4}$ & 206 & $6,4658 \times 10^{-7}$ & 10,3711 \\
& $\mathrm{CO}_{2}$ & 365 & $1,8521 \times 10^{-7}$ & 8,1500 \\
\multirow{2}{*}{6} & $\mathrm{CH}_{4}$ & 2456 & $7,7457 \times 10^{-7}$ & 12,4241 \\
& $\mathrm{CO}_{2}$ & 4193 & $3,7188 \times 10^{-7}$ & 16,3628 \\
\multirow{2}{*}{$12^{\prime}$} & $\mathrm{CH}_{4}$ & 2941 & $8,0216 \times 10^{-7}$ & 12,8666 \\
& $\mathrm{CO}_{2}$ & 4386 & $3,8130 \times 10^{-7}$ & 16,7770 \\
\hline
\end{tabular}

Tabela 6.3.85 - $\mathrm{P}_{2}(\mathrm{p})$ - Áreas cromatográficas medidas $(A)$, número de moles $(n)$ e massa $(m, \mu \mathrm{g})$ de cada gás, correspondentes:

\begin{tabular}{|c|c|c|c|}
\hline Tempo & Gás & $A$ & $m(\mu \mathrm{g})$ \\
\hline \multirow{2}{*}{0 ' } & $\mathrm{CH}_{4}$ & $1966,4601 \times 10^{-1}$ & 10,3620 \\
\hline & $\mathrm{CO}_{2}$ & $2481,7950 \times 10^{-7}$ & 7,9000 \\
\hline \multirow{2}{*}{ 3' } & $\mathrm{CH}_{4}$ & $2946,5158 \times 10^{-7}$ & 10,4514 \\
\hline & $\mathrm{CO}_{2}$ & $3471,8433 \times 10^{-1}$ & 8,1107 \\
\hline \multirow{2}{*}{$6^{\prime}$} & $\mathrm{CH}_{4}$ & $26377,8486 \times 10^{-7}$ & 12,5893 \\
\hline & $\mathrm{CO}_{2}$ & $38893,5706 \times 10^{-7}$ & 15,7105 \\
\hline \multirow{2}{*}{$12^{\prime}$} & $\mathrm{CH}_{4}$ & $75111,0621 \times 10^{-6}$ & 17,0365 \\
\hline & $\mathrm{CO}_{2}$ & $80845,6162 \times 10^{-7}$ & 24,7115 \\
\hline
\end{tabular}


Tabela 6.3.86 - $\mathrm{P}_{3}(\mathrm{G})$ - Áreas cromatográficas medidas $(A)$, número de moles $(n)$ e massa $(m, \mu \mathrm{g})$ de cada gás, correspondentes:

\begin{tabular}{ccccc}
\hline Tempo & Gás & $\boldsymbol{A}$ & $\boldsymbol{n}$ & $\boldsymbol{m}(\boldsymbol{\mu g})$ \\
\hline \multirow{2}{*}{${ }^{\prime}$} & $\mathrm{CH}_{4}$ & 2614 & $7,8356 \times 10^{-7}$ & 12,5683 \\
& $\mathrm{CO}_{2}$ & 3844 & $3,5483 \times 10^{-7}$ & 15,6140 \\
\multirow{2}{*}{${ }^{\prime}$} & $\mathrm{CH}_{4}$ & 2618 & $7,8379 \times 10^{-7}$ & 12,5720 \\
& $\mathrm{CO}_{2}$ & 4338 & $3,7895 \times 10^{-7}$ & 16,6740 \\
\multirow{2}{*}{6} & $\mathrm{CH}_{4}$ & 4594 & $8,9620 \times 10^{-7}$ & 14,3750 \\
& $\mathrm{CO}_{2}$ & 5450 & $4,3318 \times 10^{-7}$ & 19,0600 \\
\multirow{2}{*}{$12^{\prime}$} & $\mathrm{CH}_{4}$ & 3345 & $8,2514 \times 10^{-7}$ & 13,2353 \\
& $\mathrm{CO}_{2}$ & 4123 & $3,6847 \times 10^{-7}$ & 16,2126 \\
\hline
\end{tabular}

Tabela 6.3.87 - $\mathrm{P}_{4}(\mathrm{p})$ - Áreas cromatográficas medidas $(A)$, número de moles $(n)$ e massa $(m, \mu \mathrm{g})$ de cada gás, correspondentes:

\begin{tabular}{ccrcc}
\hline Tempo & Gás & \multicolumn{1}{c}{$\boldsymbol{A}$} & $\boldsymbol{n}$ & $\boldsymbol{m}(\boldsymbol{\mu} \mathbf{g})$ \\
\hline \multirow{2}{*}{${ }^{\prime}$} & $\mathrm{CH}_{4}$ & 624 & $6,7036 \times 10^{-7}$ & 10,7526 \\
& $\mathrm{CO}_{2}$ & 1479 & $2,3953 \times 10^{-7}$ & 10,5396 \\
\multirow{2}{*}{${ }^{\prime}$} & $\mathrm{CH}_{4}$ & 485 & $6,6245 \times 10^{-1}$ & 10,6258 \\
& $\mathrm{CO}_{2}$ & 1422 & $2,3675 \times 10^{-7}$ & 10,4173 \\
\multirow{2}{*}{6} & $\mathrm{CH}_{4}$ & 18426 & $1,6830 \times 10^{-6}$ & 27,0000 \\
& $\mathrm{CO}_{2}$ & 19881 & $1,1369 \times 10^{-6}$ & 50,0235 \\
\multirow{2}{*}{$12^{\prime}$} & $\mathrm{CH}_{4}$ & 15845 & $1,5362 \times 10^{-6}$ & 24,6408 \\
& $\mathrm{CO}_{2}$ & 16699 & $9,8173 \times 10^{-7}$ & 43,2000 \\
\hline
\end{tabular}

Tabela 6.3.88 - $P_{5}(G)$ - Áreas cromatográficas medidas $(A)$, número de moles $(n)$ e massa $(m, \mu \mathrm{g})$ de cada gás, correspondentes:

\begin{tabular}{|c|c|c|c|c|}
\hline Tempo & Gás & $A$ & $n$ & $m(\mu \mathrm{g})$ \\
\hline \multirow{2}{*}{$0^{\prime}$} & $\mathrm{CH}_{4}$ & 307 & $6,5232 \times 10^{-1}$ & 10,4633 \\
\hline & $\mathrm{CO}_{2}$ & 281 & $1,8111 \times 10^{-7}$ & 7,0691 \\
\hline \multirow{2}{*}{$3^{\prime}$} & $\mathrm{CH}_{4}$ & 524 & $6,6467 \times 10^{-7}$ & 10,6613 \\
\hline & $\mathrm{CO}_{2}$ & 1545 & $2,4275 \times 10^{-7}$ & 10,6812 \\
\hline \multirow{2}{*}{$6^{\prime}$} & $\mathrm{CH}_{4}$ & 16806 & $1,5909 \times 10^{-6}$ & 25,5200 \\
\hline & $\mathrm{CO}_{2}$ & 18948 & $1,0914 \times 10^{-6}$ & 48,0216 \\
\hline \multirow{2}{*}{$12^{\prime}$} & $\mathrm{CH}_{4}$ & 15513 & $1,5173 \times 10^{-6}$ & 24,3400 \\
\hline & $\mathrm{CO}_{2}$ & 16629 & $9,7836 \times 10^{-7}$ & 43,0460 \\
\hline
\end{tabular}


Tabela 6.3.89 - $\mathrm{P}_{6}(\mathrm{G})$ - Áreas cromatográficas medidas $(A)$, número de moles $(n)$ e massa $(m, \mu \mathrm{g})$ de cada gás, correspondentes:

\begin{tabular}{ccrcr}
\hline Tempo & Gás & \multicolumn{1}{c}{$\boldsymbol{A}$} & $\boldsymbol{n}$ & $\boldsymbol{m}(\boldsymbol{\mu g})$ \\
\hline \multirow{2}{*}{ 0, } & $\mathrm{CH}_{4}$ & 270 & $6,5022 \times 10^{-1}$ & 10,4295 \\
& $\mathrm{CO}_{2}$ & 393 & $1,8658 \times 10^{-7}$ & 8,2095 \\
\multirow{2}{*}{3} & $\mathrm{CH}_{4}$ & 3617 & $8,4061 \times 10^{-7}$ & 13,4835 \\
& $\mathrm{CO}_{2}$ & 4698 & $3,9651 \times 10^{-7}$ & 17,4464 \\
\multirow{2}{*}{6,} & $\mathrm{CH}_{4}$ & 8668 & $1,1280 \times 10^{-6}$ & 18,1000 \\
& $\mathrm{CO}_{2}$ & 9327 & $6,2224 \times 10^{-7}$ & 27,3785 \\
\multirow{2}{*}{$12^{\prime}$} & $\mathrm{CH}_{4}$ & 581 & $6,6791 \times 10^{-7}$ & 10,7133 \\
& $\mathrm{CO}_{2}$ & 1451 & $2,3817 \times 10^{-7}$ & 10,4800 \\
\hline
\end{tabular}

Tabela 6.3.90 - $P_{7}(G)$ - Áreas cromatográficas medidas $(A)$, número de moles $(n)$ e massa $(m, \mu \mathrm{g})$ de cada gás, correspondentes:

\begin{tabular}{ccccc}
\hline Tempo & Gás & $\boldsymbol{A}$ & $\boldsymbol{n}$ & $\boldsymbol{m}(\boldsymbol{\mu g})$ \\
\hline \multirow{2}{*}{$\mathbf{c}^{\prime}$} & $\mathrm{CH}_{4}$ & 922 & $6,8731 \times 10^{-7}$ & 11,0244 \\
& $\mathrm{CO}_{2}$ & 1918 & $2,6094 \times 10^{-7}$ & 11,4815 \\
\multirow{2}{*}{$3^{\prime}$} & $\mathrm{CH}_{4}$ & 2433 & $7,7326 \times 10^{-1}$ & 12,4031 \\
& $\mathrm{CO}_{2}$ & 4119 & $3,6827 \times 10^{-7}$ & 16,2040 \\
\multirow{2}{*}{6} & $\mathrm{CH}_{4}$ & 5349 & $9,3914 \times 10^{-7}$ & 15,0638 \\
& $\mathrm{CO}_{2}$ & 6419 & $4,8043 \times 10^{-7}$ & 21,1400 \\
\multirow{2}{*}{$1{ }^{\prime}$} & $\mathrm{CH}_{4}$ & 4990 & $9,1872 \times 10^{-1}$ & 14,7363 \\
& $\mathrm{CO}_{2}$ & 4934 & $4,0801 \times 10^{-7}$ & 17,9527 \\
\hline
\end{tabular}

Tabela 6.3.91 - $P_{8}(G)$ - Áreas cromatográficas medidas $(A)$, número de moles $(n)$ e massa $(m, \mu \mathrm{g})$ de cada gás, correspondentes:

\begin{tabular}{|c|c|c|c|c|}
\hline Tempo & Gás & $A$ & $n$ & $m(\mu \mathrm{g})$ \\
\hline \multirow{2}{*}{$0^{\prime}$} & $\mathrm{CH}_{4}$ & 185 & $6,4538 \times 10^{-1}$ & 10,3520 \\
\hline & $\mathrm{CO}_{2}$ & 442 & $1,8897 \times 10^{-7}$ & 8,3146 \\
\hline \multirow{2}{*}{ 3' } & $\mathrm{CH}_{4}$ & 261 & $6,4971 \times 10^{-7}$ & 10,4213 \\
\hline & $\mathrm{CO}_{2}$ & 549 & $1,9418 \times 10^{-7}$ & 8,5442 \\
\hline \multirow{2}{*}{6} & $\mathrm{CH}_{4}$ & 177 & $6,4493 \times 10^{-7}$ & 10,3446 \\
\hline & $\mathrm{CO}_{2}$ & 1265 & $2,2910 \times 10^{-7}$ & 10,0804 \\
\hline \multirow{2}{*}{$12^{\prime}$} & $\mathrm{CH}_{4}$ & 2345 & $7,6826 \times 10^{-7}$ & 12,3230 \\
\hline & $\mathrm{CO}_{2}$ & 1938 & $2,6192 \times 19^{-7}$ & 11,5244 \\
\hline
\end{tabular}


Tabela 6.3.92 - Dissipadores 1, 2, 3 e 4 - Áreas cromatográficas medidas $(A)$, número de moles $(n)$ e massa $(m, \mu \mathrm{g})$ de cada gás, correspondentes:

\begin{tabular}{ccccr}
\hline Dreno & Gás & $\boldsymbol{A}$ & $\boldsymbol{n}$ & \multicolumn{1}{c}{$\boldsymbol{m}(\boldsymbol{\mu} \mathbf{g})$} \\
\hline \multirow{2}{*}{1} & $\mathrm{CH}_{4}$ & 133861 & $8,2496 \times 10^{-6}$ & 132,3235 \\
& $\mathrm{CO}_{2}$ & 127517 & $6,3857 \times 10^{-6}$ & 280,9800 \\
\multirow{2}{*}{2} & $\mathrm{CH}_{4}$ & 166912 & $1,0130 \times 10^{-5}$ & 162,4806 \\
& $\mathrm{CO}_{2}$ & 159338 & $7,9374 \times 10^{-6}$ & 349,2472 \\
& $\mathrm{CH}_{4}$ & 168797 & $1,0237 \times 10^{-5}$ & 164,2006 \\
\multirow{2}{*}{3} & $\mathrm{CO}_{2}$ & 164650 & $8,1965 \times 10^{-6}$ & 360,6449 \\
& $\mathrm{CH}_{4}$ & 57766 & $3,9210 \times 10^{-6}$ & 62,9000 \\
\multirow{2}{*}{4} & $\mathrm{CO}_{2}$ & 58528 & $3,0215 \times 10^{-6}$ & 132,9459 \\
\hline
\end{tabular}


6.3.7- $\mathrm{G}_{1}$ ) Aterro de São Carlos - Primeira Campanha - Data 13/11/2006.

Tabela 6.3.93 - AR ambiente - Áreas cromatográficas medidas $(A)$, número de moles $(n)$ e massa $(m, \mu \mathrm{g})$ de cada gás, correspondentes:

\begin{tabular}{ccccc}
\hline Tomada & Gás & $\boldsymbol{A}$ & $\boldsymbol{n}$ & $\mathbf{m}(\boldsymbol{\mu} \mathbf{g})$ \\
\hline \multirow{2}{*}{1} & $\mathrm{CH}_{4}$ & 606 & $6,6933 \times 10^{-7}$ & 10,7361 \\
& $\mathrm{CO}_{2}$ & 997 & $2,1603 \times 10^{-7}$ & 9,5054 \\
\hline
\end{tabular}

Tabela 6.3.94 - $\mathrm{P}_{1}(\mathrm{G})$ - Áreas cromatográficas medidas $(A)$, número de moles $(n)$ e massa $(m, \mu \mathrm{g})$ de cada gás, correspondentes:

\begin{tabular}{ccccc}
\hline Tempo & Gás & $\boldsymbol{A}$ & $\boldsymbol{n}$ & $\boldsymbol{m}(\boldsymbol{\mu g})$ \\
\hline \multirow{2}{*}{${ }^{\prime}$} & $\mathrm{CH}_{4}$ & 1196 & $7,0290 \times 10^{-1}$ & 11,2744 \\
& $\mathrm{CO}_{2}$ & 2769 & $3,0244 \times 10^{-7}$ & 13,3074 \\
\multirow{2}{*}{${ }^{\prime}$} & $\mathrm{CH}_{4}$ & 4975 & $9,1786 \times 10^{-7}$ & 14,7226 \\
& $\mathrm{CO}_{2}$ & 6298 & $4,7453 \times 10^{-7}$ & 20,8800 \\
\multirow{2}{*}{6} & $\mathrm{CH}_{4}$ & 9625 & $1,1824 \times 10^{-6}$ & 18,9654 \\
& $\mathrm{CO}_{2}$ & 8646 & $5,8903 \times 10^{-7}$ & 25,9173 \\
\multirow{2}{*}{12} & $\mathrm{CH}_{4}$ & 16545 & $1,5760 \times 10^{-6}$ & 25,2800 \\
& $\mathrm{CO}_{2}$ & 17896 & $1,0400 \times 10^{-6}$ & 45,7644 \\
\hline
\end{tabular}

Tabela 6.3.95 $-\mathrm{P}_{2}(\mathrm{p})$ - Áreas cromatográficas medidas $(A)$, número de moles $(n)$ e massa $(m, \mu \mathrm{g})$ de cada gás, correspondentes:

\begin{tabular}{ccccc}
\hline Tempo & Gás & $\boldsymbol{A}$ & $\boldsymbol{n}$ & $\boldsymbol{m}(\boldsymbol{\mu} \mathbf{g})$ \\
\hline \multirow{2}{*}{ 3, } & $\mathrm{CH}_{4}$ & 974 & $6,9027 \times 10^{-7}$ & 11,0719 \\
& $\mathrm{CO}_{2}$ & 1842 & $2,5724 \times 10^{-7}$ & 11,3184 \\
\multirow{2}{*}{ 6, } & $\mathrm{CH}_{4}$ & 1020 & $6,9288 \times 10^{-7}$ & 11,1138 \\
& $\mathrm{CO}_{2}$ & 1834 & $2,5684 \times 10^{-7}$ & 11,3513 \\
\multirow{2}{*}{ 12, } & $\mathrm{CH}_{4}$ & 3961 & $8,6018 \times 10^{-7}$ & 13,7974 \\
& $\mathrm{CO}_{2}$ & 5840 & $4,5220 \times 10^{-7}$ & 19,8967 \\
\hline
\end{tabular}


Tabela 6.3.96 - $\mathrm{P}_{3}(\mathrm{G})$ - Áreas cromatográficas medidas $(A)$, número de moles $(n)$ e massa $(m, \mu \mathrm{g})$ de cada gás, correspondentes:

\begin{tabular}{crrcr}
\hline Tempo & Gás & \multicolumn{1}{c}{$\boldsymbol{A}$} & $\boldsymbol{n}$ & $\boldsymbol{m}(\boldsymbol{\mu} \mathbf{g})$ \\
\hline \multirow{2}{*}{$0^{\prime}$} & $\mathrm{CH}_{4}$ & 508 & $6,6376 \times 10^{-7}$ & 10,6467 \\
& $\mathrm{CO}_{2}$ & 1461 & $2,3865 \times 10^{-7}$ & 10,5010 \\
3' & $\mathrm{CH}_{4}$ & 871 & $6,8441 \times 10^{-7}$ & 10,9780 \\
& $\mathrm{CO}_{2}$ & 986 & $2,1549 \times 10^{-7}$ & 9,4818 \\
\multirow{2}{*}{6,} & $\mathrm{CH}_{4}$ & 980 & $6,9061 \times 10^{-7}$ & 11,0774 \\
& $\mathrm{CO}_{2}$ & 1965 & $2,6323 \times 10^{-7}$ & 11,5824 \\
\multirow{2}{*}{${ }^{\prime}$} & $\mathrm{CH}_{4}$ & 11454 & $1,2864 \times 10^{-6}$ & 20,6343 \\
& $\mathrm{CO}_{2}$ & 14373 & $8,6830 \times 10^{-7}$ & 38,2054 \\
\hline
\end{tabular}

Tabela 6.3.97 - $\mathrm{P}_{4}(\mathrm{G})$ - Áreas cromatográficas medidas $(A)$, número de moles $(n)$ e massa $(m, \mu \mathrm{g})$ de cada gás, correspondentes:

\begin{tabular}{rrrrr}
\hline Tempo & Gás & \multicolumn{1}{c}{$\boldsymbol{A}$} & $\boldsymbol{n}$ & $\boldsymbol{m}(\boldsymbol{\mu g})$ \\
\hline \multirow{2}{*}{${ }^{\prime}$} & $\mathrm{CH}_{4}$ & 0 & 0 & 0 \\
& $\mathrm{CO}_{2}$ & 0 & 0 & 0 \\
\multirow{2}{*}{${ }^{\prime}$} & $\mathrm{CH}_{4}$ & 762 & $6,7821 \times 10^{-1}$ & 10,8785 \\
& $\mathrm{CO}_{2}$ & 1415 & $2,3641 \times 10^{-7}$ & 10,4022 \\
\multirow{2}{*}{6} & $\mathrm{CH}_{4}$ & 1086 & $6,9664 \times 10^{-7}$ & 11,1741 \\
& $\mathrm{CO}_{2}$ & 1278 & $2,2973 \times 10^{-7}$ & 10,7183 \\
\multirow{2}{*}{12} & $\mathrm{CH}_{4}$ & 986 & $6,4043 \times 10^{-1}$ & 11,2726 \\
& $\mathrm{CO}_{2}$ & 1588 & $2,4485 \times 10^{-7}$ & 10,7735 \\
\hline
\end{tabular}

Tabela 6.3.98 - Dissipadores 1, 2 e 3 - Áreas cromatográficas medidas $(A)$, número de moles $(n)$ e massa $(m, \mu g)$ de cada gás, correspondentes:

\begin{tabular}{ccccc}
\hline Dreno & Gás & $\boldsymbol{A}$ & $\boldsymbol{n}$ & $\boldsymbol{m}(\boldsymbol{\mu} \mathbf{g})$ \\
\hline \multirow{2}{*}{1} & $\mathrm{CH}_{4}$ & 252417 & $1,4994 \times 10^{-5}$ & 240,5000 \\
& $\mathrm{CO}_{2}$ & 253329 & $1,2521 \times 10^{-5}$ & 550,9175 \\
\multirow{2}{*}{2} & $\mathrm{CH}_{4}$ & 228347 & $1,3625 \times 10^{-5}$ & 218,5364 \\
& $\mathrm{CO}_{2}$ & 287638 & $1,4194 \times 10^{-5}$ & 624,5320 \\
\multirow{2}{*}{3} & $\mathrm{CH}_{4}$ & 25267 & $2,0722 \times 10^{-6}$ & 33,2379 \\
& $\mathrm{CO}_{2}$ & 27979 & $1,5318 \times 10^{-6}$ & 67,4000 \\
\hline
\end{tabular}


6.3.7- $\mathrm{G}_{2}$ ) Aterro de São Carlos - Segunda Campanha - Data 01/10/2007

Tabela 6.3.99 - AR ambiente - Áreas cromatográficas medidas $(A)$, número de moles $(n)$ e massa $(m, \mu \mathrm{g})$ de cada gás, correspondentes:

\begin{tabular}{ccccr}
\hline Tomada & Gás & $\boldsymbol{A}$ & $\boldsymbol{n}$ & $\boldsymbol{m}(\boldsymbol{\mu} \mathbf{g})$ \\
\hline \multirow{2}{*}{1} & $\mathrm{CH}_{4}$ & 859 & $6,8372 \times 10^{-7}$ & 10,9670 \\
& $\mathrm{CO}_{2}$ & 1200 & $2,2594 \times 10^{-1}$ & 9,9410 \\
\hline
\end{tabular}

Tabela 6.3.100 - $\mathrm{P}_{1}(\mathrm{G})$ - Áreas cromatográficas medidas $(A)$, número de moles ( $n)$ e massa $(m, \mu \mathrm{g})$ de cada gás, correspondentes:

\begin{tabular}{|c|c|c|c|c|}
\hline Tempo & Gás & $A$ & $n$ & $m(\mu \mathrm{g})$ \\
\hline \multirow{2}{*}{$0^{\prime}$} & $\mathrm{CH}_{4}$ & 34 & $6,3680 \times 10^{-1}$ & 10,2142 \\
\hline & $\mathrm{CO}_{2}$ & 1523 & $2,4168 \times 10^{-7}$ & 10,6340 \\
\hline \multirow{2}{*}{$3^{\prime}$} & $\mathrm{CH}_{4}$ & 1701 & $7,3162 \times 10^{-7}$ & 11,7352 \\
\hline & $\mathrm{CO}_{2}$ & 3764 & $3,5096 \times 10^{-7}$ & 15,4423 \\
\hline \multirow{2}{*}{$6^{\prime}$} & $\mathrm{CH}_{4}$ & 13175 & $1,3843 \times 10^{-6}$ & 22,2046 \\
\hline & $\mathrm{CO}_{2}$ & 14518 & $8,7537 \times 10^{-7}$ & 38,5165 \\
\hline \multirow{2}{*}{$12^{\prime}$} & $\mathrm{CH}_{4}$ & 3532 & $8,3578 \times 10^{-7}$ & 13,4060 \\
\hline & $\mathrm{CO}_{2}$ & 5895 & $4,5488 \times 10^{-7}$ & 20,0147 \\
\hline
\end{tabular}

Tabela 6.3.101 - $\mathrm{P}_{2}(\mathrm{p})$ - Áreas cromatográficas medidas $(A)$, número de moles $(n)$ e massa $(m, \mu \mathrm{g})$ de cada gás, correspondentes:

\begin{tabular}{crrcr}
\hline Tempo Gás & \multicolumn{1}{c}{$\boldsymbol{A}$} & $\boldsymbol{n}$ & $\boldsymbol{m}(\boldsymbol{\mu} \mathbf{g})$ \\
\hline \multirow{2}{*}{0,} & $\mathrm{CH}_{4}$ & 358 & $6,5522 \times 10^{-1}$ & 10,5100 \\
& $\mathrm{CO}_{2}$ & 769 & $2,0491 \times 10^{-7}$ & 9,0162 \\
\multirow{2}{*}{3} & $\mathrm{CH}_{4}$ & 192 & $6,4578 \times 10^{-7}$ & 10,3584 \\
& $\mathrm{CO}_{2}$ & 5594 & $4,4020 \times 10^{-1}$ & 19,3690 \\
\multirow{2}{*}{6} & $\mathrm{CH}_{4}$ & 19446 & $1,7410 \times 10^{-6}$ & 27,9265 \\
& $\mathrm{CO}_{2}$ & 20119 & $1,1485 \times 10^{-6}$ & 50,5342 \\
\multirow{2}{*}{12} & $\mathrm{CH}_{4}$ & 754 & $6,7775 \times 10^{-7}$ & 10,8711 \\
& $\mathrm{CO}_{2}$ & 2641 & $2,9620 \times 10^{-1}$ & 13,0330 \\
\hline
\end{tabular}


Tabela 6.3.102 - $\mathrm{P}_{3}(\mathrm{G})$ - Áreas cromatográficas medidas $(A)$, número de moles ( $n)$ e massa $(m, \mu g)$ de cada gás, correspondentes:

\begin{tabular}{ccccc}
\hline Tempo & Gás & $\boldsymbol{A}$ & $\boldsymbol{n}$ & $\boldsymbol{m}(\boldsymbol{\mu g})$ \\
\hline \multirow{2}{*}{0,} & $\mathrm{CH}_{4}$ & 1089 & $6,9680 \times 10^{-1}$ & 11,1800 \\
& $\mathrm{CO}_{2}$ & 6217 & $4,7058 \times 10^{-7}$ & 20,7056 \\
\multirow{2}{*}{3,} & $\mathrm{CH}_{4}$ & 1369 & $7,1273 \times 10^{-7}$ & 11,4323 \\
& $\mathrm{CO}_{2}$ & 3349 & $3,3072 \times 10^{-1}$ & 14,5520 \\
\multirow{2}{*}{6,} & $\mathrm{CH}_{4}$ & 5945 & $9,7304 \times 10^{-7}$ & 15,6076 \\
& $\mathrm{CO}_{2}$ & 8997 & $6,0614 \times 10^{-7}$ & 26,6704 \\
\multirow{2}{*}{12,} & $\mathrm{CH}_{4}$ & 16244 & $1,5590 \times 10^{-6}$ & 25,0049 \\
& $\mathrm{CO}_{2}$ & 18935 & $1,0907 \times 10^{-6}$ & 47,9937 \\
\hline
\end{tabular}

Tabela 6.3.103 - $\mathrm{P}_{4}(\mathrm{G})$ - Áreas cromatográficas medidas $(A)$, número de moles $(n)$ e massa $(m, \mu \mathrm{g})$ de cada gás, correspondentes:

\begin{tabular}{crrcc}
\hline Tempo & Gás & \multicolumn{1}{c}{$\boldsymbol{A}$} & $\boldsymbol{n}$ & $\boldsymbol{m}(\boldsymbol{\mu} \mathbf{g})$ \\
\hline \multirow{2}{*}{0,} & $\mathrm{CH}_{4}$ & 121 & $6,4174 \times 10^{-7}$ & 10,3000 \\
& $\mathrm{CO}_{2}$ & 1755 & $2,5300 \times 10^{-7}$ & 11,1318 \\
\multirow{2}{*}{${ }^{\prime}$} & $\mathrm{CH}_{4}$ & 2007 & $7,4903 \times 10^{-7}$ & 12,0144 \\
& $\mathrm{CO}_{2}$ & 3559 & $3,4096 \times 10^{-7}$ & 15,0025 \\
& $\mathrm{CH}_{4}$ & 7095 & $1,0384 \times 10^{-6}$ & 16,6570 \\
6 & $\mathrm{CO}_{2}$ & 12213 & $7,6297 \times 10^{-7}$ & 33,5708 \\
& $\mathrm{CH}_{4}$ & 696 & $6,7445 \times 10^{-7}$ & 10,8182 \\
12 & $\mathrm{CO}_{2}$ & 3848 & $3,5506 \times 10^{-7}$ & 15,6226 \\
\hline
\end{tabular}

Tabela 6.3.104 - $\mathrm{P}_{5}(\mathrm{G})$ - Áreas cromatográficas medidas $(A)$, número de moles $(n)$ e massa $(m, \mu \mathrm{g})$ de cada gás, correspondentes:

\begin{tabular}{|c|c|c|c|c|}
\hline Tempo & Gás & $A$ & $n$ & $\boldsymbol{m}(\mu \mathrm{g})$ \\
\hline \multirow{2}{*}{$0^{\prime}$} & $\mathrm{CH}_{4}$ & 8 & $6,3531 \times 10^{-2}$ & 10,1905 \\
\hline & $\mathrm{CO}_{2}$ & 29 & $1,6882 \times 10^{-7}$ & 7,4284 \\
\hline \multirow{2}{*}{$3^{\prime}$} & $\mathrm{CH}_{4}$ & 1037 & $6,9385 \times 10^{-7}$ & 11,1294 \\
\hline & $\mathrm{CO}_{2}$ & 2467 & $2,8771 \times 10^{-7}$ & 12,6595 \\
\hline \multirow{2}{*}{$6^{\prime}$} & $\mathrm{CH}_{4}$ & 2259 & $7,6336 \times 10^{-7}$ & 12,2444 \\
\hline & $\mathrm{CO}_{2}$ & 2849 & $3,0634 \times 10^{-7}$ & 13,4800 \\
\hline \multirow{2}{*}{$12^{\prime}$} & $\mathrm{CH}_{4}$ & 2017 & $7,4960 \times 10^{-1}$ & 12,3236 \\
\hline & $\mathrm{CO}_{2}$ & 3244 & $3,2560 \times 10^{-7}$ & 14,3266 \\
\hline
\end{tabular}


Tabela 6.3.105 - Dissipadores 1, 2 e 3. - Áreas cromatográficas medidas $(A)$, número de moles $(n)$ e massa $(m, \mu \mathrm{g})$ de cada gás, correspondentes:

\begin{tabular}{ccccc}
\hline Dreno & Gás & $\boldsymbol{A}$ & $\boldsymbol{n}$ & $\boldsymbol{m}(\boldsymbol{\mu} \mathbf{g})$ \\
\hline \multirow{2}{*}{1} & $\mathrm{CH}_{4}$ & 262895 & $1,5590 \times 10^{-5}$ & 250,0600 \\
& $\mathrm{CO}_{2}$ & 261196 & $1,2904 \times 10^{-5}$ & 567,8000 \\
\multirow{2}{*}{2} & $\mathrm{CH}_{4}$ & 187183 & $1,1282 \times 10^{-5}$ & 180,9767 \\
& $\mathrm{CO}_{2}$ & 192876 & $9,5728 \times 10^{-6}$ & 421,2075 \\
\multirow{2}{*}{3} & $\mathrm{CH}_{4}$ & 109977 & $6,8910 \times 10^{-6}$ & 110,5307 \\
& $\mathrm{CO}_{2}$ & 117673 & $5,9056 \times 10^{-6}$ & 259,8494 \\
\hline
\end{tabular}


6.3.8-H) Aterro Bandeirantes (Capital) - Campanha Única - Data: 26/09/2007.

Tabela 6.3.106 - AR ambiente - Áreas cromatográficas medidas $(A)$, número de moles $(n)$ e massa $(m, \mu \mathrm{g})$ de cada gás, correspondentes:

\begin{tabular}{|c|c|c|c|c|}
\hline Tomada & Gás & $A$ & $n$ & $m(\mu \mathrm{g})$ \\
\hline \multirow{2}{*}{1} & $\mathrm{CH}_{4}$ & 387 & $6,5687 \times 10^{-7}$ & 10,5363 \\
\hline & $\mathrm{CO}_{2}$ & 2494 & $2,8903 \times 10^{-1}$ & 12,7174 \\
\hline \multirow{2}{*}{2} & $\mathrm{CH}_{4}$ & 289 & $5,5130 \times 10^{-7}$ & 10,4469 \\
\hline & $\mathrm{CO}_{2}$ & 958 & $2,1413 \times 10^{-7}$ & 9,4217 \\
\hline
\end{tabular}

Tabela 6.3.107 - $\mathrm{P}_{1}(\mathrm{G})$ - Áreas cromatográficas medidas $(A)$, número de moles $(n)$ e massa $(m, \mu \mathrm{g})$ de cada gás, correspondentes:

\begin{tabular}{rrrrr}
\hline Tempo & Gás & \multicolumn{1}{c}{$\boldsymbol{A}$} & $\boldsymbol{n}$ & $\boldsymbol{m}(\mathbf{m g})$ \\
\hline \multirow{2}{*}{,' } & $\mathrm{CH}_{4}$ & 605 & $6,6927 \times 10^{-7}$ & 10,7352 \\
& $\mathrm{CO}_{2}$ & 873 & $2,0998 \times 10^{-7}$ & 9,2393 \\
\multirow{2}{*}{ 3 $^{\prime}$} & $\mathrm{CH}_{4}$ & 751 & $6,7758 \times 10^{-7}$ & 10,8684 \\
& $\mathrm{CO}_{2}$ & 1371 & $2,3426 \times 10^{-7}$ & 10,3078 \\
\multirow{2}{*}{ 6' } & $\mathrm{CH}_{4}$ & 4823 & $9,0922 \times 10^{-7}$ & 14,5839 \\
& $\mathrm{CO}_{2}$ & 8759 & $5,9454 \times 10^{-7}$ & 26,1600 \\
\multirow{2}{*}{ 12' } & $\mathrm{CH}_{4}$ & 14597 & $1,4652 \times 10^{-6}$ & 23,5021 \\
& $\mathrm{CO}_{2}$ & 17978 & $1,0441 \times 10^{-6}$ & 45,9404 \\
\hline
\end{tabular}

Tabela 6.3.108 $-\mathrm{P}_{2}(\mathrm{p})$ - Áreas cromatográficas medidas $(A)$, número de moles $(n)$ e massa $(m, \mu g)$ de cada gás, correspondentes:

\begin{tabular}{rrrcr}
\hline Tempo & Gás & $\boldsymbol{A}$ & $\boldsymbol{n}$ & $\boldsymbol{m}(\boldsymbol{\mu} \mathbf{g})$ \\
\hline \multirow{2}{*}{ 0' } & $\mathrm{CH}_{4}$ & 1013 & $6,9249 \times 10^{-7}$ & 11,1075 \\
& $\mathrm{CO}_{2}$ & 1554 & $2,4319 \times 10^{-1}$ & 10,7005 \\
\multirow{2}{*}{${ }^{\prime}$} & $\mathrm{CH}_{4}$ & 1481 & $7,1911 \times 10^{-7}$ & 11,5345 \\
& $\mathrm{CO}_{2}$ & 1387 & $2,3505 \times 10^{-7}$ & 10,3422 \\
\multirow{2}{*}{ 6' } & $\mathrm{CH}_{4}$ & 15399 & $1,5108 \times 10^{-6}$ & 24,2339 \\
& $\mathrm{CO}_{2}$ & 13209 & $8,1154 \times 10^{-1}$ & 35,7078 \\
\multirow{2}{*}{ 12' } & $\mathrm{CH}_{4} 33369$ & $2,5331 \times 10^{-6}$ & 40,6304 \\
& $\mathrm{CO}_{2}$ & 28614 & $1,5627 \times 10^{-6}$ & 68,7613 \\
\hline
\end{tabular}


Tabela 6.3.109 - $P_{3}(G)$ - Áreas cromatográficas medidas $(A)$, número de moles $(n)$ e massa $(m, \mu \mathrm{g})$ de cada gás, correspondentes:

\begin{tabular}{crrcr}
\hline Tempo & Gás & \multicolumn{1}{c}{$\boldsymbol{A}$} & $\boldsymbol{n}$ & $\boldsymbol{m}(\boldsymbol{\mu g})$ \\
\hline \multirow{2}{*}{ 0, } & $\mathrm{CH}_{4}$ & - & - & - \\
& $\mathrm{CO}_{2}$ & - & - & - \\
\multirow{2}{*}{ 3, } & $\mathrm{CH}_{4}$ & 5444 & $9,4454 \times 10^{-7}$ & 15,1505 \\
& $\mathrm{CO}_{2}$ & 11329 & $7,1986 \times 10^{-7}$ & 31,6741 \\
\multirow{2}{*}{ 6, } & $\mathrm{CH}_{4}$ & 82464 & $5,3258 \times 10^{-6}$ & 85,4267 \\
& $\mathrm{CO}_{2}$ & 74990 & $3,8243 \times 10^{-6}$ & 168,2673 \\
\multirow{2}{*}{ 12, } & $\mathrm{CH}_{4}$ & 27771 & $2,2146 \times 10^{-6}$ & 45,1467 \\
& $\mathrm{CO}_{2}$ & 24904 & $1,3751 \times 10^{-6}$ & 60,5098 \\
\hline
\end{tabular}

Tabela 6.3.110 - $\mathrm{P}_{4}(\mathrm{p})$ - Áreas cromatográficas medidas $(A)$, número de moles $(n)$ e massa $(m, \mu \mathrm{g})$ de cada gás, correspondentes:

\begin{tabular}{ccrcc}
\hline Tempo & Gás & \multicolumn{1}{c}{$\boldsymbol{A}$} & $\boldsymbol{n}$ & $\boldsymbol{m}(\boldsymbol{\mu} \mathbf{g})$ \\
\hline \multirow{2}{*}{$0^{\prime}$} & $\mathrm{CH}_{4}$ & 1003 & $6,9191 \times 10^{-1}$ & 11,0983 \\
& $\mathrm{CO}_{2}$ & 2206 & $2,7498 \times 10^{-7}$ & 12,0994 \\
\multirow{2}{*}{${ }^{\prime}$} & $\mathrm{CH}_{4}$ & 2261 & $7,6348 \times 10^{-1}$ & 12,2462 \\
& $\mathrm{CO}_{2}$ & 3112 & $3,1916 \times 10^{-7}$ & 14,0434 \\
\multirow{2}{*}{ 6, } & $\mathrm{CH}_{4}$ & 996 & $6,9152 \times 10^{-7}$ & 11,0920 \\
& $\mathrm{CO}_{2}$ & 5236 & $4,2274 \times 10^{-7}$ & 18,6007 \\
\multirow{2}{*}{${ }^{\prime}}$, & $\mathrm{CH}_{4}$ & 26396 & $2,1364 \times 10^{-6}$ & 34,2680 \\
& $\mathrm{CO}_{2}$ & 25169 & $1,3947 \times 10^{-6}$ & 61,3696 \\
\hline
\end{tabular}

Tabela 6.3.111 - $P_{5}(G)$ - Áreas cromatográficas medidas $(A)$, número de moles $(n)$ e massa $(m, \mu \mathrm{g})$ de cada gás, correspondentes:

\begin{tabular}{crrcr}
\hline Tempo & Gás & \multicolumn{1}{c}{$\boldsymbol{A}$} & $\boldsymbol{n}$ & $\boldsymbol{m}(\boldsymbol{\mu} \mathbf{g})$ \\
\hline \multirow{2}{*}{0,} & $\mathrm{CH}_{4}$ & 902 & $6,8617 \times 10^{-7}$ & 11,0062 \\
& $\mathrm{CO}_{2}$ & 2993 & $3,1336 \times 10^{-7}$ & 13,7900 \\
\multirow{2}{*}{3} & $\mathrm{CH}_{4}$ & 1017 & $6,9271 \times 10^{-7}$ & 11,1111 \\
& $\mathrm{CO}_{2}$ & 2166 & $2,7303 \times 10^{-7}$ & 12,0136 \\
\multirow{2}{*}{6,} & $\mathrm{CH}_{4}$ & 29988 & $2,3407 \times 10^{-6}$ & 37,5455 \\
& $\mathrm{CO}_{2}$ & 27965 & $1,5311 \times 10^{-6}$ & 67,3688 \\
\multirow{2}{*}{12,} & $\mathrm{CH}_{4}$ & 26827 & $2,1609 \times 10^{-6}$ & 34,6612 \\
& $\mathrm{CO}_{2}$ & 24850 & $1,3792 \times 10^{-6}$ & 60,6852 \\
\hline
\end{tabular}


Tabela 6.3.112 - $\mathrm{P}_{6}(\mathrm{G})$ - Áreas cromatográficas medidas $(A)$, número de moles $(n)$ e massa $(m, \mu \mathrm{g})$ de cada gás, correspondentes:

\begin{tabular}{cc|rcc}
\hline Tempo & Gás & \multicolumn{1}{c}{$\boldsymbol{A}$} & $\boldsymbol{n}$ & $\boldsymbol{m}(\boldsymbol{\mu g})$ \\
\hline \multirow{2}{*}{ 0' } & $\mathrm{CH}_{4}$ & 748 & $6,7741 \times 10^{-7}$ & 10,8657 \\
& $\mathrm{CO}_{2}$ & 1622 & $2,4651 \times 10^{-7}$ & 10,8464 \\
\multirow{2}{*}{ 3 $^{\prime}$} & $\mathrm{CH}_{4}$ & 20204 & $1,7841 \times 10^{-6}$ & 28,6181 \\
& $\mathrm{CO}_{2}$ & 18343 & $1,0619 \times 10^{-6}$ & 46,7235 \\
\multirow{2}{*}{ 6 $^{\prime}$} & $\mathrm{CH}_{4}$ & 25649 & $2.0940 \times 10^{-6}$ & 33,5864 \\
& $\mathrm{CO}_{2}$ & 29889 & $1,6250 \times 10^{-6}$ & 71,4970 \\
\multirow{2}{*}{ 12' } & $\mathrm{CH}_{4}$ & 14659 & $1,4687 \times 10^{-6}$ & 23,5586 \\
& $\mathrm{CO}_{2}$ & 13851 & $8,4285 \times 10^{-7}$ & 37,0853 \\
\hline
\end{tabular}

Tabela 6.3.113 - $\mathrm{P}_{7}(\mathrm{G})$ - Áreas cromatográficas medidas $(A)$, número de moles $(n)$ e massa $(m, \mu g)$ de cada gás, correspondentes:

\begin{tabular}{ccrcc}
\hline Tempo & Gás & \multicolumn{1}{c}{$\boldsymbol{A}$} & $\boldsymbol{n}$ & $\boldsymbol{m}(\boldsymbol{\mu g})$ \\
\hline \multirow{2}{*}{$\mathbf{0}^{\prime}$} & $\mathrm{CH}_{4}$ & 800 & $6,8037 \times 10^{-1}$ & 10,9131 \\
& $\mathrm{CO}_{2}$ & 1267 & $2,2920 \times 10^{-7}$ & 10,0847 \\
\multirow{2}{*}{${ }^{\prime}$} & $\mathrm{CH}_{4}$ & 19639 & $1,7520 \times 10^{-6}$ & 28,1026 \\
& $\mathrm{CO}_{2}$ & 17844 & $1,0375 \times 10^{-6}$ & 45,2130 \\
\multirow{2}{*}{ 6' } & $\mathrm{CH}_{4}$ & 37491 & $2,7675 \times 10^{-6}$ & 44,3915 \\
& $\mathrm{CO}_{2}$ & 33450 & $1,7985 \times 10^{-6}$ & 79,1376 \\
\multirow{2}{*}{ 12' } & $\mathrm{CH}_{4}$ & 1198 & $7,0301 \times 10^{-1}$ & 11,2763 \\
& $\mathrm{CO}_{2}$ & 1917 & $2,6089 \times 10^{-7}$ & 11,4793 \\
\hline
\end{tabular}

Tabela 6.3.114 - $\mathrm{P}_{8}(\mathrm{p})$ - Áreas cromatográficas medidas $(A)$, número de moles $(n)$ e massa $(m, \mu g)$ de cada gás, correspondentes:

\begin{tabular}{rrrrr}
\hline Tempo & Gás & \multicolumn{1}{c}{$\boldsymbol{A}$} & $\boldsymbol{n}$ & $\boldsymbol{m}(\boldsymbol{\mu g})$ \\
\hline \multirow{2}{*}{ 0 $^{\prime}$} & $\mathrm{CH}_{4}$ & 507 & $6,6370 \times 10^{-7}$ & 10,6458 \\
& $\mathrm{CO}_{2}$ & 1130 & $2,2251 \times 10^{-7}$ & 9,7907 \\
\multirow{2}{*}{ 3 $^{\prime}$} & $\mathrm{CH}_{4}$ & 674 & $6,7320 \times 10^{-7}$ & 10,7982 \\
& $\mathrm{CO}_{2}$ & 1693 & $2,4997 \times 10^{-7}$ & 10,9987 \\
\multirow{2}{*}{ 6' } & $\mathrm{CH}_{4}$ & 15846 & $1,5362 \times 10^{-6}$ & 24,6417 \\
& $\mathrm{CO}_{2}$ & 15385 & $9,1765 \times 10^{-7}$ & 40,3767 \\
\multirow{2}{*}{ 12' } & $\mathrm{CH}_{4}$ & 2014 & $7,4943 \times 10^{-7}$ & 12,0208 \\
& $\mathrm{CO}_{2}$ & 1485 & $2,3983 \times 10^{-7}$ & 10,5524 \\
\hline
\end{tabular}


Tabela 6.3.115 - $\mathrm{P}_{9}(\mathrm{p})$ - Áreas cromatográficas medidas $(A)$, número de moles $(n)$ e massa $(m, \mu \mathrm{g})$ de cada gás, correspondentes:

\begin{tabular}{ccccc}
\hline Tempo & Gás & \multicolumn{1}{c}{$\boldsymbol{A}$} & $\boldsymbol{n}$ & $\boldsymbol{m}(\boldsymbol{\mu} \mathbf{g})$ \\
\hline \multirow{2}{*}{$0^{\prime}$} & $\mathrm{CH}_{4}$ & 904 & $6,8628 \times 10^{-1}$ & 11,0080 \\
& $\mathrm{CO}_{2}$ & 1406 & $2,3597 \times 10^{-7}$ & 10,3830 \\
\multirow{2}{*}{$3^{\prime}$} & $\mathrm{CH}_{4}$ & 8656 & $1,1272 \times 10^{-6}$ & 18,0813 \\
& $\mathrm{CO}_{2}$ & 8890 & $6,0093 \times 10^{-7}$ & 26,4408 \\
& $\mathrm{CH}_{4}$ & 9502 & $1.1754 \times 10^{-6}$ & 18,8532 \\
6, & $\mathrm{CO}_{2}$ & 9268 & $6,1936 \times 10^{-7}$ & 27,2519 \\
& $\mathrm{CH}_{4} 15293$ & $1,5048 \times 10^{-6}$ & 24,1371 \\
12 & $\mathrm{CO}_{2} 14855$ & $8,9181 \times 10^{-7}$ & 39,2395 \\
\hline
\end{tabular}

Tabela 6.3.116 - $\mathrm{P}_{10}(\mathrm{G})$ - Áreas cromatográficas medidas $(A)$, número de moles $(n)$ e massa $(m, \mu \mathrm{g})$ de cada gás, correspondentes:

\begin{tabular}{crrcr}
\hline Tempo & Gás & \multicolumn{1}{c}{$\boldsymbol{A}$} & $\boldsymbol{n}$ & $\boldsymbol{m}(\boldsymbol{\mu g})$ \\
\hline \multirow{2}{*}{$0^{\prime}$} & $\mathrm{CH}_{4}$ & 1056 & $6,9493 \times 10^{-7}$ & 11,1467 \\
& $\mathrm{CO}_{2}$ & 1697 & $2,5016 \times 10^{-7}$ & 11,0073 \\
\multirow{2}{*}{${ }^{\prime}$} & $\mathrm{CH}_{4}$ & 3151 & $8,1410 \times 10^{-1}$ & 13,0583 \\
& $\mathrm{CO}_{2}$ & 3253 & $3,2604 \times 10^{-7}$ & 14,3460 \\
\multirow{2}{*}{ 6' } & $\mathrm{CH}_{4}$ & 33282 & $2,5282 \times 19^{-6}$ & 40,5510 \\
& $\mathrm{CO}_{2}$ & 31066 & $1,6823 \times 10^{-6}$ & 74,0224 \\
\multirow{2}{*}{${ }^{\prime} 2^{\prime}$} & $\mathrm{CH}_{4}$ & 8656 & $1,1273 \times 19^{-6}$ & 18,0813 \\
& $\mathrm{CO}_{2}$ & 8669 & $5,9015 \times 10^{-7}$ & 25,9666 \\
\hline
\end{tabular}

Tabela 6.3.117 - $\mathrm{P}_{11}(\mathrm{G})$ - Áreas cromatográficas medidas $(A)$, número de moles $(n)$ e massa $(m, \mu \mathrm{g})$ de cada gás, correspondentes:

\begin{tabular}{crrcc}
\hline Tempo & Gás & \multicolumn{1}{c}{$\boldsymbol{A}$} & $\boldsymbol{n}$ & $\boldsymbol{m}(\boldsymbol{\mu} \mathbf{g})$ \\
\hline \multirow{2}{*}{$0^{\prime}$} & $\mathrm{CH}_{4}$ & 708 & $6,7513 \times 10^{-1}$ & 10,8292 \\
& $\mathrm{CO}_{2}$ & 1569 & $2,4392 \times 10^{-7}$ & 10,7326 \\
\multirow{2}{*}{${ }^{\prime}$} & $\mathrm{CH}_{4}$ & 873 & $6,8452 \times 10^{-7}$ & 10,9797 \\
& $\mathrm{CO}_{2}$ & 2824 & $3,0512 \times 10^{-1}$ & 13,4254 \\
& $\mathrm{CH}_{4}$ & 665 & $6,7270 \times 10^{-7}$ & 10,7900 \\
6 & $\mathrm{CO}_{2}$ & 3323 & $3,2945 \times 10^{-7}$ & 14,4961 \\
& $\mathrm{CH}_{4}$ & 6491 & $1,0041 \times 10^{-6}$ & 16,1058 \\
12 & $\mathrm{CO}_{2}$ & 13732 & $8,3704 \times 10^{-1}$ & 36,8300 \\
\hline
\end{tabular}


Tabela 6.3.118 - Dissipadores 1, 2, 3 e 4 - Áreas cromatográficas medidas $(A)$, número de moles $(n)$ e massa $(m, \mu \mathrm{g})$ de cada gás, correspondentes:

\begin{tabular}{ccccc}
\hline Dreno & Gás & $\boldsymbol{A}$ & $\boldsymbol{n}$ & $\boldsymbol{m}(\boldsymbol{\mu g})$ \\
\hline \multirow{2}{*}{1} & $\mathrm{CH}_{4}$ & 165632 & $1,0056 \times 10^{-5}$ & 161,3127 \\
& $\mathrm{CO}_{2}$ & 153157 & $7,6360 \times 10^{-6}$ & 335,9850 \\
\multirow{2}{*}{2} & $\mathrm{CH}_{4}$ & 170184 & $1,0315 \times 10^{-5}$ & 165,4662 \\
& $\mathrm{CO}_{2}$ & 155354 & $7,7432 \times 10^{-6}$ & 340,7000 \\
\multirow{2}{*}{3} & $\mathrm{CH}_{4}$ & 207529 & $1,2440 \times 10^{-5}$ & 199,5412 \\
& $\mathrm{CO}_{2}$ & 189889 & $9,4272 \times 10^{-6}$ & 414,8000 \\
\multirow{2}{*}{4} & $\mathrm{CH}_{4}$ & 173983 & $1,0531 \times 10^{-5}$ & 168,9325 \\
& $\mathrm{CO}_{2}$ & 159199 & $7,9306 \times 10^{-6}$ & 348,9500 \\
\hline
\end{tabular}




\subsection{Cálculos da concentração de metano $\left(\mathrm{CH}_{4}\right)$ e dióxido de carbono $\left(\mathrm{CO}_{2}\right)$ no ambiente dos aterros.}

Os cálculos para a concentração do metano e do dióxido de carbono, medida em ppm, no ambiente dos aterros, foram feitos a partir de amostras de $30 \mathrm{~mL}$ coletadas do ar ambiente do aterro, geralmente, em ponto centralizado da área total do aterro, a aproximadamente, 1,5 metro de altura do solo, com anotação da condições ambientais do aterro (temperatura ambiente e do solo e pressão atmosférica).

Nos itens 6.4.1A a $\mathbf{H}$, desta sessão, foram mostrados os procedimentos dos cálculos para medição das concentrações de $\mathrm{CH}_{4}$ e $\mathrm{CO}_{2}$, tomando por base os parâmetros: temperatura ambiente média do aterro $\left[\mathrm{T}_{\mathrm{amb}}(\mathrm{M})(\mathrm{At})\right]$, no dia da coleta, a partir de várias tomadas durante o decorrer da coleta; pressão atmosférica do ambiente do aterro $\left[\mathrm{P}_{\mathrm{atm}}(\mathrm{Amb})\right]$ e o número de moles obtido da análise cromatográfica para metano $\left(n_{1}\right)$ e dióxido de carbono $\left(n_{2}\right)$, sessão 6.3.

Foi aplicada a equação de estado dos gases ideais (Equação 6.4.1), para a determinação do volume $(\mathrm{mL})$ de um milimol do ar ambiente do aterro, nas condições de temperatura $(\mathrm{K})$ e pressão $(\mathrm{mmHg})$ ambientes. Com este dado, calculou-se o número de milimoles em um $\mathrm{mL}$ - volume utilizado na injeção cromatográfica - do ar ambiente do aterro.

A concentração $(p p m)$ de cada um dos dois gases na atmosfera dos aterros foi calculada dividindo-se o número de moles de cada gás obtido na cromatografia, pelo número de moles de ar em um mililitro do ar ambiente do aterro, 
em cada campanha. A concentração média $(p p m)$ estimada para $\mathrm{CH}_{4}$ e $\mathrm{CO}_{2}$ no ambiente de cada aterro foi calculada como a média das duas campanhas $\left(\mathrm{C}_{1}\right.$ e $\mathrm{C}_{1}$ ' - para metano e $\mathrm{C}_{2}$ e $\mathrm{C}_{2}$ '- para dióxido de carbono).

\subsection{1-A) Aterro de Araraquara}

\section{$\left.A_{1}\right)$ Campanha 2006}

1) $\left(T_{\mathrm{amb}}(\mathrm{M})=25,8^{0} \mathrm{C}\right.$ ou $299 \mathrm{~K} ; \mathrm{P}_{\mathrm{atm}}(\mathrm{Amb})=698,8 \mathrm{mmHg} ; \mathrm{n}_{1}=6,7958 \times 10^{-7} \mathrm{e}$ $\left.\mathrm{n}_{2}=2,3992 \times 10^{-7}\right)$

2) Da equação de estado dos gases ideais:

$$
\begin{array}{cc}
P V=n R T \Rightarrow V=\frac{n R T}{P} & \text { Equação 6.4.1 } \\
\Rightarrow V=\frac{1 m m o l \times 62,3637 \mathrm{~L} \times \mathrm{mmHg} \times 299 \mathrm{~K}}{698,8 \mathrm{mmHg} \times \mathrm{mol} \times \mathrm{K}} & \\
\Rightarrow \mathrm{V}(1 \mathrm{mmol} \mathrm{AR})=\underline{\mathbf{2 6 , 6 8}} \mathrm{mL} &
\end{array}
$$

3) Cálculo do número de moles de ar em $1 \mathrm{~mL}$ de Ar ambiente do aterro.

Se $26,68 m L(A r) \rightarrow 1 m m o l(A r)$

$$
\begin{aligned}
& 1,00 m L\left[\operatorname{Ar}_{\mathrm{amb}}(\mathrm{At})\right] \rightarrow \mathbf{n}(\mathrm{mmol})(\text { Volume de GAS injetado na cromatografia) } \\
& \Rightarrow \mathbf{n}=\underline{\mathbf{0 , 0 3 7 4}} \mathrm{mmol}
\end{aligned}
$$

4) Cálculo para concentração $\left(\mathrm{C}_{1}, \mathrm{ppm}\right)$ de metano no ar ambiente do aterro:

$$
C_{1}=\frac{n_{1}\left(\mathrm{CH}_{4}\right) \text { moles } \times 10^{3} \text { mmoles } \times 10^{6}}{n(\text { Ar }) \text { mmoles } . \mathrm{ml}^{-1}}
$$




$$
\begin{aligned}
& \Rightarrow C_{1}=\frac{6,7958 \times 10^{-7} \text { moles }\left(\mathrm{CH}_{4}\right) \times 10^{3} \text { mmoles } \times 10^{6}}{0,0374{\text { mmoles } . l^{-1}}^{-1}} \\
& \Rightarrow \quad \mathrm{C}_{1}\left(\mathrm{CH}_{4}\right)_{\mathrm{amb}}(\mathrm{At})=\mathbf{1 8 . 1 7 0 ~ \mathbf { ~ p m }}
\end{aligned}
$$

Em que: $n_{1}\left(\mathrm{CH}_{4}\right)$ é o número de moles de $\mathrm{CH}_{4}$ da determinação cromatográfica $\mathrm{T}_{\text {amb }}(\mathrm{M})(\mathrm{At})$ é a temperatura ambiente média do aterro

$P_{\text {atm }}$ é a pressão atmosférica no aterro

V é volume

$n$ é número de moles

$\mathrm{R}$ é a constante dos gases ideiais $=62,3637 \mathrm{mmHg} \cdot \mathrm{L} \cdot \mathrm{mol}^{-1} \cdot \mathrm{K}^{-1}$

T é a temperatura absoluta (em graus Kelvin)

$\mathrm{C}_{1}\left[\left(\mathrm{CH}_{4}\right)_{\text {amb }}(\mathrm{At})\right]$ é a concentração de metano no ambiente do aterro $(p p m)$ na primeira campanha.

5) Idem para cálculos do dióxido de carbono $\left(\mathrm{CO}_{2}\right)$ :

$$
\begin{gathered}
C_{2}=\frac{n_{2}\left(\mathrm{CO}_{2}\right) \text { moles } \times 10^{3} \mathrm{mmoles} \times 10^{6}}{n(\mathrm{Ar}) \text { mmoles } . \mathrm{ml}^{-1}} \\
\Rightarrow \quad \mathrm{C}_{2}\left(\mathrm{CO}_{2}\right) \mathrm{amb}(\mathrm{At})=\mathbf{6 . 4 1 5 \mathrm { ppm }}
\end{gathered}
$$

Em que: $\mathrm{C}_{2}\left[\left(\mathrm{CO}_{2}\right)\right.$ amb $\left.(\mathrm{At})\right]$ é a concentração de dióxido de carbono no ambiente do aterro $(p p m)$ na primeira campanha.

$n_{2}$ é o número de moles de $\mathrm{CO}_{2}$ da determinação cromatográfica 


\section{$\mathrm{A}_{2}$ ) Campanha 2007}

1) $\left(T_{\mathrm{amb}}(M)=27,3^{0} \mathrm{C}\right.$ ou 300,$5 ; P_{\mathrm{atm}}(\mathrm{Amb})=698,8 \mathrm{mmHg} ; \mathrm{n}_{1}=6,5529 \times 10^{-7} \mathrm{e}$ $\left.\mathrm{n}_{2}=1,8795 \times 10^{-7}\right)$

2) Da equação de estado dos gases ideais:

$$
\begin{aligned}
& \Rightarrow \quad V=\frac{1 \mathrm{~mol} \times 62,3637 \mathrm{~L} \times \mathrm{mmHg} \times 300,5 \mathrm{~K}}{698,8 \mathrm{mmHg} \times \mathrm{mol} \times \mathrm{K}} \\
& \Rightarrow \mathrm{V}(1 \mathrm{mmol} \mathrm{AR})=\underline{\mathbf{2 6 , 8 2}} \mathrm{mL}
\end{aligned}
$$

3) Cálculo do número de moles de ar em $1 \mathrm{~mL}$ de Ar ambiente do aterro.

Então: Se 26,82 $m L(\operatorname{Ar}) \rightarrow 1 m m o /(A r)$

$$
\begin{aligned}
& 1,00 m L\left[\operatorname{Ar}_{\mathrm{amb}}(\mathrm{At})\right] \rightarrow n(\mathrm{mmol}) \\
& \Rightarrow n=\underline{\mathbf{0 , 0 3 7 2}} \mathrm{mmol}
\end{aligned}
$$

4) Cálculo para concentração $\left(C_{1}\right)$ de metano no ar ambiente do aterro:

$$
\begin{aligned}
\Rightarrow & C_{1}^{\prime}=\frac{6,5529 \times 10^{-7} \text { moles }\left(\mathrm{CH}_{4}\right) \times 10^{3} \text { mmoles } \times 10^{6}}{0,0372{\text { mmoles } . \mathrm{ml}^{-1}}^{6}} \\
\Rightarrow \quad & \mathrm{C}_{1}{ }^{\prime}\left(\mathrm{CH}_{4}\right)_{\mathrm{amb}}(\mathrm{At})=\mathbf{1 7 . 6 1 5} \mathrm{ppm}
\end{aligned}
$$

5) Idem para cálculos do dióxido de carbono $\left(\mathrm{CO}_{2}\right)$ :

$$
\begin{gathered}
C_{2}{ }^{\prime}=\frac{n_{2}\left(\mathrm{CO}_{2}\right) \text { moles } \times 10^{3} \text { mmoles } \times 10^{6}}{n(\text { Ar }) \text { mmoles.ml } l^{-1}} \\
\Rightarrow \frac{\mathrm{C}_{2}{ }^{\prime}\left(\mathrm{CO}_{2}\right) \mathrm{amb}(\mathrm{At})=\mathbf{5 . 0 5 2 \mathrm { ppm }}}{\mathrm{C}_{2}{ }^{\prime}\left[\left(\mathrm{CO}_{2}\right)_{\mathrm{amb}}(\mathrm{At})\right] \text { é a concentração de dióxido de carbono no }} \\
\text { ambiente do aterro(ppm) na segunda campanha. }
\end{gathered}
$$


6) Concentração média $\left(C_{m}\right)$ do ambiente do aterro de Araraquara:

6.1) $\mathrm{C}_{\mathrm{m}}\left(\mathrm{CH}_{4}\right)=\left[\mathrm{C}_{1}+\mathrm{C}_{1}\right] / 2 \Rightarrow \underline{17.892 p p m}$; para Metano.

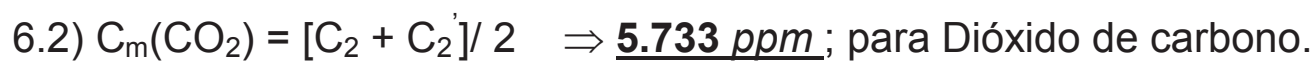




\subsection{1-B) Aterro de Brotas}

\section{$\left.B_{1}\right)$ Campanha 2006}

1) $\left(T_{a m b}(M)=25,8^{0} \mathrm{C}\right.$ ou 299,$0 ; P_{a t m}(A m b)=697,3 \mathrm{mmHg} ; n_{1}=6,5358 \times 10^{-7} \mathrm{e}$ $\left.\mathrm{n}_{2}=1,8975 \times 10^{-7}\right)$

2) Da equação de estado dos gases ideais:

$$
\begin{aligned}
& \Rightarrow \quad V=\frac{1 \mathrm{~mol} \times 62,3637 \mathrm{~L} \times \mathrm{mmHg} \times 299,0 \mathrm{~K}}{697,3 \mathrm{mmHg} \times \mathrm{mol} \times \mathrm{K}} \\
& \Rightarrow \mathrm{V}(1 \mathrm{mmol} \mathrm{AR})=\underline{\mathbf{2 6 , 7 4}} \mathrm{mL}
\end{aligned}
$$

3) Cálculo do número de moles de ar em $1 \mathrm{ml}$ de Ar ambiente do aterro.

Então: Se $26,74 m L(A r) \rightarrow 1 m m o /(A r)$

$$
\begin{aligned}
& 1,00 \mathrm{~mL}\left[\mathrm{Ar}_{\mathrm{amb}}(\mathrm{At})\right] \rightarrow \mathrm{n}(\mathrm{mmol})(\text { Volume de GAS injetado }) \\
& \Rightarrow n=\underline{\mathbf{0 , 0 3 7 3}} \mathrm{mmol}
\end{aligned}
$$

4) Cálculo para concentração(C) de metano no ar ambiente do aterro:

$$
\begin{aligned}
& \Rightarrow C=\frac{6,5358 \times 10^{-7} \text { moles }\left(\mathrm{CH}_{4}\right) \times 10^{3} \text { mmoles } \times 10^{6}}{0,0373 \text { mmoles } . \mathrm{ml}^{-1}} \\
& \Rightarrow \quad \mathrm{C}_{1}\left(\mathrm{CH}_{4}\right)_{\mathrm{amb}}(\mathrm{At})=\underline{\mathbf{1 7 . 5 2 2} \mathrm{ppm}}
\end{aligned}
$$

5) Idem para cálculos do dióxido de carbono $\left(\mathrm{CO}_{2}\right)$ :

$$
C_{2}^{\prime}=\frac{n_{2}\left(\mathrm{CO}_{2}\right) \text { moles } \times 10^{3} \text { mmoles } \times 10^{6}}{n(\text { Ar }) \text { mmoles } . \mathrm{ml}^{-1}}
$$




$$
\begin{gathered}
C_{2}{ }^{\prime}=\frac{1,8795 \times 10^{-7} \text { moles }\left(\mathrm{CO}_{2}\right) \times 10^{3} \text { mmoles } \times 10^{6}}{0,0373 \text { mmoles } . \mathrm{ml}^{-1}} \\
\Rightarrow \quad \mathrm{C}_{2}{ }^{\prime}\left(\mathrm{CO}_{2}\right)_{\mathrm{amb}}(\mathrm{At})=\underline{5.039 \mathrm{ppm}}
\end{gathered}
$$

$\mathrm{C}_{2}{ }^{\prime}\left[\left(\mathrm{CO}_{2}\right)\right.$ amb $\left.(\mathrm{At})\right]$ é a concentração de dióxido de carbono no ambiente do aterro(ppm) na segunda campanha.

\section{$B_{2}$ ) Campanha 2007}

1) $\left(\mathrm{T}_{\mathrm{amb}}(\mathrm{M})=26,9^{0} \mathrm{C}\right.$ ou 300,$1 ; \mathrm{P}_{\mathrm{atm}}(\mathrm{Amb})=697,3 \mathrm{mmHg} ; n_{1}=6,4044 \times 10^{-7} \mathrm{e}$ $n_{2}=1,7385 \times 10^{-7}$ )

2) Da equação de estado dos gases ideais:

$$
\begin{aligned}
& \Rightarrow \quad V=\frac{1 \mathrm{~mol} \times 62,3637 \mathrm{~L} \times \mathrm{mmHg} \times 300,1 \mathrm{~K}}{697,3 \mathrm{mmHg} \times \mathrm{mol} \times \mathrm{K}} \\
& \Rightarrow \mathrm{V}(1 \mathrm{mmol} \mathrm{AR})=\underline{\mathbf{2 6 , 8 4}} \mathrm{mL}
\end{aligned}
$$

3) Cálculo do número de moles de ar em $1 \mathrm{ml}$ de Ar ambiente do aterro.

Então: Se 26,84 $m L(\operatorname{Ar}) \rightarrow 1 m m o l(A r)$

$$
\begin{aligned}
& 1,00 m L\left[\operatorname{Ar}_{\mathrm{amb}}(\mathrm{At})\right] \rightarrow \mathrm{n}(\mathrm{mmol}) \\
& \Rightarrow n=\underline{\mathbf{0 , 0 3 7 2}} \mathrm{mmol}
\end{aligned}
$$

4) Cálculo para concentração(C) de metano no ar ambiente do aterro:

$$
\begin{aligned}
& \Rightarrow C=\frac{6,4044 \times 10^{-7} \text { moles }\left(\mathrm{CH}_{4}\right) \times 10^{3} \text { mmoles } \times 10^{6}}{0,0372 \text { mmoles }^{6} \mathrm{ml}^{-1}} \\
& \Rightarrow \quad \mathrm{C}_{2}\left(\mathrm{CH}_{4}\right)_{\mathrm{amb}}(\mathrm{At})=\underline{17.216 \mathrm{ppm}}
\end{aligned}
$$


5) Idem para cálculos do dióxido de carbono $\left(\mathrm{CO}_{2}\right)$ :

$$
\begin{aligned}
C_{2}{ }^{\prime} & =\frac{n_{2}\left(\mathrm{CO}_{2}\right) \text { moles } \times 10^{3} \mathrm{mmoles} \times 10^{6}}{n(\mathrm{Ar}) \mathrm{mmoles} . \mathrm{ml}^{-1}} \\
C_{2}{ }^{\prime} & =\frac{1,7385 \times 10^{-7} \text { moles }\left(\mathrm{CO}_{2}\right) \times 10^{3} \mathrm{mmoles} \times 10^{6}}{0,0372 \mathrm{mmoles}^{6} \mathrm{ml}^{-1}} \\
& \Rightarrow \mathrm{C}_{2}{ }^{\prime}\left(\mathrm{CO}_{2}\right)_{\mathrm{amb}}(\mathrm{At})=\underline{\mathbf{4 . 6 7 3} \mathrm{ppm}}
\end{aligned}
$$

$\mathrm{C}_{2}{ }^{\prime}\left[\left(\mathrm{CO}_{2}\right)\right.$ amb $\left.(\mathrm{At})\right]$ é a concentração de dióxido de carbono no ambiente do aterro $(p p m)$ na segunda campanha.

6) Concentração média do ambiente do aterro de Brotas:

6.1) $\mathrm{C}_{\mathrm{m}}\left(\mathrm{CH}_{4}\right)=\left[\mathrm{C}_{1}+\mathrm{C}_{1}{ }^{\prime}\right] / 2 \Rightarrow \underline{17.369 p p m}$; para Metano.

6.2) $\mathrm{C}_{\mathrm{m}}\left(\mathrm{CO}_{2}\right)=\left[\mathrm{C}_{2}+\mathrm{C}_{2}\right] / 2 \Rightarrow \underline{\mathbf{4}} \mathrm{s56} \mathrm{ppm}$; para Dióxido de carbono. 


\subsection{1-C) Aterro de Campinas}

\section{$\left.\mathrm{C}_{1}\right)$ Campanha 2006}

1) $\left(\mathrm{T}_{\mathrm{amb}}(\mathrm{M})=29,2^{0} \mathrm{C}\right.$ ou $302,4 \mathrm{~K} ; \mathrm{P}_{\mathrm{atm}}(\mathrm{Amb})=707,7 \mathrm{mmHg} ; n_{1}=6,3873 \times 10^{-7} \mathrm{e}$ $\left.n_{2}=1,7214 \times 10^{-7}\right)$

2) Da equação de estado dos gases ideais:

$$
\begin{aligned}
& \Rightarrow \quad V=\frac{1 \mathrm{~mol} \times 62,3637 \mathrm{~L} \times \mathrm{mmHg} \times 302,4 \mathrm{~K}}{707,7 \mathrm{mmHg} \times \mathrm{mol} \times \mathrm{K}} \\
& \Rightarrow \mathrm{V}(1 \mathrm{mmol} \mathrm{AR})=\underline{\mathbf{2 6 , 6 4}} \mathrm{mL}
\end{aligned}
$$

3) Cálculo do número de moles de ar em $1 \mathrm{ml}$ de Ar ambiente do aterro.

$$
\begin{aligned}
& \text { Se } 26,64 m L(A r) \rightarrow 1 m m o l(A r) \\
& \begin{array}{l}
1,00 m L\left[\operatorname{Ar}_{\mathrm{amb}}(\mathrm{At})\right] \rightarrow \mathrm{n}(\mathrm{mmol})(\text { Volume de GAS injetado) } \\
\Rightarrow \mathrm{n}=\underline{\mathbf{0 , 0 3 7 5}} \mathrm{mmol}
\end{array}
\end{aligned}
$$

4) Cálculo para concentração $\left(\mathrm{C}_{1}\right)$ de metano no ar ambiente do aterro:

$$
\begin{aligned}
& \Rightarrow C_{1}=\frac{6,3873 \times 10^{-7} \text { moles }\left(\mathrm{CH}_{4}\right) \times 10^{3} \text { mmoles } \times 10^{6}}{0,0375 \text { mmoles } . \mathrm{ml}^{-1}} \\
& \Rightarrow \quad \mathrm{C}_{1}\left(\mathrm{CH}_{4}\right)_{\mathrm{amb}}(\mathrm{At})=\underline{\mathbf{1 7 . 0 3 2} \mathrm{ppm}}
\end{aligned}
$$

5) Idem para cálculos do dióxido de carbono $\left(\mathrm{CO}_{2}\right)$ :

$$
C_{2}=\frac{n_{2}\left(\mathrm{CO}_{2}\right) \text { moles } \times 10^{3} \text { mmoles } \times 10^{6}}{n(A r) \text { mmoles } . \mathrm{ml}^{-1}}
$$




$$
\begin{aligned}
C_{2} & =\frac{1,7214 \times 10^{-7} \text { moles }\left(\mathrm{CO}_{2}\right) \times 10^{3} \text { mmoles } \times 10^{6}}{0,0375 \text { mmoles } . \mathrm{ml}^{-1}} \\
& \Rightarrow \mathrm{C}_{2}\left(\mathrm{CO}_{2}\right)_{\mathrm{amb}}(\mathrm{At})=\underline{4.590 \mathrm{ppm}}
\end{aligned}
$$

$\mathrm{C}_{2}{ }^{\prime}\left[\left(\mathrm{CO}_{2}\right) \mathrm{amb}(\mathrm{At})\right]$ é a concentração de dióxido de carbono no ambiente do aterro $(p p m)$ na segunda campanha.

\section{$\mathrm{C}_{2}$ ) Campanha 2007}

1) $\left(\mathrm{T}_{\mathrm{amb}}(\mathrm{M})=28,4^{0} \mathrm{C}\right.$ ou $301,6 \mathrm{~K} ; \mathrm{P}_{\mathrm{atm}}(\mathrm{Amb})=707,7 \mathrm{mmHg} ; n_{1}=6,3662 \times 10^{-7} \mathrm{e}$ $\left.n_{2}=1,6951 \times 10^{-7}\right)$

2) Da equação de estado dos gases ideais:

$$
\begin{aligned}
& \Rightarrow \quad V=\frac{1 \mathrm{~mol} \times 62,3637 \mathrm{~L} \times \mathrm{mmHg} \times 301,6 \mathrm{~K}}{707,7 \mathrm{mmHg} \times \mathrm{mol} \times \mathrm{K}} \\
& \Rightarrow \mathrm{V}(1 \mathrm{mmol} \mathrm{AR})=\underline{\mathbf{2 6 , 5 7}} \mathrm{mL}
\end{aligned}
$$

3) Cálculo do número de moles de ar em $1 \mathrm{ml}$ de Ar ambiente do aterro.

$$
\begin{aligned}
& \text { Então: Se } \begin{aligned}
& 26,57 m L(\operatorname{Ar}) \rightarrow 1 \mathrm{mmo}(\mathrm{Ar}) \\
& 1,00 \mathrm{~mL}\left[\operatorname{Ar}_{\mathrm{amb}}(\mathrm{At})\right] \rightarrow \mathrm{n}(\mathrm{mmol}) \\
& \Rightarrow \underline{n=0,0376} \mathrm{mmol}
\end{aligned}
\end{aligned}
$$

4) Cálculo para concentração $\left(\mathrm{C}_{1}{ }^{\prime}\right)$ de metano no ar ambiente do aterro:

$$
\begin{aligned}
& \Rightarrow C=\frac{6,3662 \times 10^{-7} \text { moles }\left(\mathrm{CH}_{4}\right) \times 10^{3} \text { mmoles } \times 10^{6}}{0,0376 \text { mmoles } . \mathrm{ml}^{-1}} \\
& \Rightarrow \quad \mathrm{C}_{1}{ }^{\prime}\left(\mathrm{CH}_{4}\right)_{\mathrm{amb}}(\mathrm{At})=\underline{16.931 p p m}
\end{aligned}
$$


5) Idem para cálculos do dióxido de carbono $\left(\mathrm{CO}_{2}\right)$ :

$$
\begin{aligned}
C_{2}{ }^{\prime} & =\frac{n_{2}\left(\mathrm{CO}_{2}\right) \text { moles } \times 10^{3} \mathrm{mmoles} \times 10^{6}}{n(\mathrm{Ar}) \mathrm{mmoles} . \mathrm{ml}^{-1}} \\
C_{2}{ }^{\prime} & =\frac{1,6951 \times 10^{-7} \text { moles }\left(\mathrm{CO}_{2}\right) \times 10^{3} \mathrm{mmoles} \times 10^{6}}{0,0376 \mathrm{mmoles}^{6} \mathrm{ml}^{-1}} \\
& \Rightarrow \mathrm{C}_{2}{ }^{\prime}\left(\mathrm{CO}_{2}\right)_{\mathrm{amb}}(\mathrm{At})=\underline{\mathbf{4 . 5 0 8} \mathrm{ppm}}
\end{aligned}
$$

$\mathrm{C}_{2}{ }^{\prime}\left[\left(\mathrm{CO}_{2}\right)\right.$ amb $\left.(\mathrm{At})\right]$ é a concentração de dióxido de carbono no ambiente do aterro $(p p m)$ na segunda campanha.

6) Concentração média do ambiente do aterro de Campinas:

6.1) $\mathrm{C}_{\mathrm{m}}\left(\mathrm{CH}_{4}\right)=\left[\mathrm{C}_{1}+\mathrm{C}_{1}{ }^{\prime}\right] / 2 \Rightarrow \underline{16.981 p p m}$; para Metano.

6.2) $\mathrm{C}_{\mathrm{m}}\left(\mathrm{CO}_{2}\right)=\left[\mathrm{C}_{2}+\mathrm{C}_{2}\right] / 2 \Rightarrow \underline{\mathbf{4 . 5 4 9} p p m}$; para Dióxido de carbono. 


\subsection{1-D) Aterro de Jaú}

$\left.D_{1}\right)$ Campanha 2006

1) $\left(\mathrm{T}_{\mathrm{amb}}(\mathrm{M})=26,1^{0} \mathrm{C}\right.$ ou $299,3 \mathrm{~K} ; \mathrm{P}_{\mathrm{atm}}(\mathrm{Amb})=712,5 \mathrm{mmHg} ; n_{1}=6,4208 \times 10^{-7} \mathrm{e}$ $\left.n_{2}=1,7653 \times 10^{-7}\right)$

2) Da equação de estado dos gases ideais:

$$
\begin{aligned}
& \Rightarrow \quad V=\frac{1 \mathrm{~mol} \times 62,3637 \mathrm{~L} \times \mathrm{mmHg} \times 299,3 \mathrm{~K}}{712,5 \mathrm{mmHg} \times \mathrm{mol} \times \mathrm{K}} \\
& \Rightarrow \mathrm{V}(1 \mathrm{mmol} \mathrm{AR})=\underline{\mathbf{2 6 , 1 9}} \mathrm{mL}
\end{aligned}
$$

3) Cálculo do número de moles de ar em $1 \mathrm{ml}$ de Ar ambiente do aterro.

$$
\begin{aligned}
& \text { Se } 26,19 m L(A r) \rightarrow 1 m m o l(A r) \\
& \begin{array}{l}
1,00 m L\left[\operatorname{Ar}_{\mathrm{amb}}(\mathrm{At})\right] \rightarrow \mathrm{n}(\mathrm{mmol})(\text { Volume de GAS injetado) } \\
\Rightarrow n=\underline{\mathbf{0 , 0 3 8 1} \mathrm{mmol}}
\end{array}
\end{aligned}
$$

4) Cálculo para concentração $\left(C_{1}\right)$ de metano no ar ambiente do aterro:

$$
\Rightarrow C_{1}=\frac{6,4208 \times 10^{-7} \text { moles }\left(\mathrm{CH}_{4}\right) \times 10^{3} \text { mmoles } \times 10^{6}}{0,0381 \text { mmoles } . \mathrm{ml}^{-1}}
$$

\section{$\Rightarrow \quad \mathrm{C}_{1}\left(\mathrm{CH}_{4}\right)_{\mathrm{amb}}(\mathrm{At})=\underline{\mathbf{1 6 . 8 5 2} \mathrm{ppm}}$}

5) Idem para cálculos do dióxido de carbono $\left(\mathrm{CO}_{2}\right)$ :

$$
C_{2}=\frac{n_{2}\left(\mathrm{CO}_{2}\right) \text { moles } \times 10^{3} \mathrm{mmoles} \times 10^{6}}{n(\mathrm{Ar}) \text { mmoles } \cdot \mathrm{ml}^{-1}}
$$




$$
\begin{gathered}
C_{2}=\frac{2,4229 \times 10^{-7} \text { moles }\left(\mathrm{CO}_{2}\right) \times 10^{3} \text { mmoles } \times 10^{6}}{0,0381 \text { mmoles } \cdot \mathrm{ml}^{-1}} \\
\Rightarrow \quad \mathrm{C}_{2}\left(\mathrm{CO}_{2}\right)_{\mathrm{amb}}(\mathrm{At})=\underline{\mathbf{6 . 3 5 9} \mathrm{ppm}} \\
\mathrm{C}_{2}\left[\left(\mathrm{CO}_{2}\right) \mathrm{amb}(\mathrm{At})\right] \text { é a concentração de dióxido de carbono no ambiente do } \\
\text { aterro(ppm) na segunda campanha. }
\end{gathered}
$$

\section{$\left.D_{2}\right)$ Campanha 2007}

1) $\left(\mathrm{T}_{\mathrm{amb}}(\mathrm{M})=23,8^{0} \mathrm{C}\right.$ ou $307,0 \mathrm{~K} ; \mathrm{P}_{\mathrm{atm}}(\mathrm{Amb})=712,5 \mathrm{mmHg} ; n_{1}=6,7312 \times 10^{-7} \mathrm{e}$

$$
n_{2}=2,4229 \times 10^{-7} \text { ) }
$$

Obs. Duas tomadas do ar ambiente do aterro:

1.1) Metano: $\left[n_{1}\left(\mathrm{CH}_{4}\right)+n_{1}{ }^{\prime}\left(\mathrm{CH}_{4}\right)\right] / 2=\underline{6,7312 \times 10^{-7}}$

1.2) Dióxido de carbono: $\left[\mathrm{n}_{2}\left(\mathrm{CO}_{2}\right)+\mathrm{n}_{2}{ }^{\prime}\left(\mathrm{CO}_{2}\right)\right] / 2=\underline{2,4229 \times 10^{-7}}$

2) Da equação de estado dos gases ideais:

$$
\begin{aligned}
& \Rightarrow \quad V=\frac{1 \mathrm{~mol} \times 62,3637 \mathrm{~L} \times \mathrm{mmHg} \times 307 \mathrm{~K}}{712,5 \mathrm{mmHg} \times \mathrm{mol} \times \mathrm{K}} \\
& \Rightarrow \mathrm{V}(1 \mathrm{mmol} \mathrm{AR})=\underline{\mathbf{2 6 , 8 7}} \mathrm{mL}
\end{aligned}
$$

3) Cálculo do número de moles de ar em $1 \mathrm{ml}$ de Ar ambiente do aterro.

$$
\begin{aligned}
& \text { Então: Se } \begin{aligned}
& 26,87 m L(A r) \rightarrow 1 m m o l(A r) \\
& 1,00 m L\left[\operatorname{Ar}_{\mathrm{amb}}(\mathrm{At})\right] \rightarrow \mathrm{n}(\mathrm{mmol}) \\
& \Rightarrow n=\underline{\mathbf{0 , 0 3 7 2}} \mathrm{mmol}
\end{aligned}
\end{aligned}
$$


4) Cálculo para concentração $\left(C_{1}{ }^{\prime}\right)$ de metano no ar ambiente do aterro:

$$
\begin{aligned}
\Rightarrow & C_{1}{ }^{\prime}=\frac{6,7312 \times 10^{-7} \text { moles }\left(\mathrm{CH}_{4}\right) \times 10^{3} \mathrm{mmoles} \times 10^{6}}{0,0372 \mathrm{mmoles}_{\mathrm{ml}}{ }^{-1}} \\
\Rightarrow \quad & \mathrm{C}_{1}{ }^{\prime}\left(\mathrm{CH}_{4}\right)_{\mathrm{amb}}(\mathrm{At})=\underline{\mathbf{1 8 . 0 9 4} \mathrm{ppm}}
\end{aligned}
$$

5) Idem para cálculos do dióxido de carbono $\left(\mathrm{CO}_{2}\right)$ :

$$
\begin{aligned}
C_{2}{ }^{\prime} & =\frac{n_{2}\left(\mathrm{CO}_{2}\right) \text { moles } \times 10^{3} \mathrm{mmoles} \times 10^{6}}{n(\text { Ar }) \text { mmoles. } \mathrm{ml}^{-1}} \\
C_{2}{ }^{\prime} & =\frac{2,4229 \times 10^{-7} \text { moles }\left(\mathrm{CO}_{2}\right) \times 10^{3} \text { mmoles } \times 10^{6}}{0,0372 \mathrm{mmoles}_{\mathrm{ml}}{ }^{-1}} \\
& \Rightarrow \mathrm{C}_{2}{ }^{\prime}\left(\mathrm{CO}_{2}\right)_{\mathrm{amb}}(\mathrm{At})=\underline{\mathbf{6 . 5 1 3} \mathrm{ppm}}
\end{aligned}
$$

$\mathrm{C}_{2}{ }^{\prime}\left[\left(\mathrm{CO}_{2}\right)\right.$ amb $\left.(\mathrm{At})\right]$ é a concentração de dióxido de carbono no ambiente do aterro(ppm) na segunda campanha.

6) Concentração média do ambiente do aterro de Jaú:

6.1) $\mathrm{C}_{\mathrm{m}}\left(\mathrm{CH}_{4}\right)=\left[\mathrm{C}_{1}+\mathrm{C}_{1}\right] / 2 \Rightarrow \underline{\mathbf{1 7 . 4 7 3} \mathrm{ppm}}$; para Metano.

6.2) $\mathrm{C}_{\mathrm{m}}\left(\mathrm{CO}_{2}\right)=\left[\mathrm{C}_{2}+\mathrm{C}_{2}^{\prime}\right] / 2 \Rightarrow \underline{\mathbf{6 . 4 3 6} p p m}$; para Dióxido de carbono. 


\subsection{1-E) Aterro de Ribeirão Bonito}

\section{$\left.E_{1}\right)$ Campanha 2006}

1) $\left(\mathrm{T}_{\mathrm{amb}}(\mathrm{M})=26,7^{0} \mathrm{C}\right.$ ou $299,9 \mathrm{~K} ; \mathrm{P}_{\mathrm{atm}}(\mathrm{Amb})=699,2 \mathrm{mmHg} ; n_{1}=6,7940 \times 10^{-7} \mathrm{e}$ $n_{2}=2,1086 \times 10^{-7}$ )

2) Da equação de estado dos gases ideais:

$$
\begin{aligned}
& \Rightarrow \quad V=\frac{1 \mathrm{~mol} \times 62,3637 \mathrm{~L} \times \mathrm{mmHg} \times 299,9 \mathrm{~K}}{699,2 \mathrm{mmHg} \times \mathrm{mol} \times \mathrm{K}} \\
& \Rightarrow \mathrm{V}(1 \mathrm{mmol} \mathrm{AR})=\underline{\mathbf{2 6 , 7 5}} \mathrm{mL}
\end{aligned}
$$

3) Cálculo do número de moles de ar em $1 \mathrm{ml}$ de Ar ambiente do aterro.

$$
\begin{aligned}
& \text { Se } 26,75 m L(A r) \rightarrow 1 m m o l(A r) \\
& \begin{array}{l}
1,00 m L\left[\mathrm{Ar}_{\mathrm{amb}}(\mathrm{At})\right] \rightarrow \mathrm{n}(\mathrm{mmol})(\text { Volume de GAS injetado) } \\
\Rightarrow \mathrm{n}=\underline{\mathbf{0 , 0 3 7 4}} \mathrm{mmol}
\end{array}
\end{aligned}
$$

4) Cálculo para concentração $\left(C_{1}\right)$ de metano no ar ambiente do aterro:

$$
\begin{aligned}
& \Rightarrow C_{1}=\frac{6,7940 \times 10^{-7} \text { moles }\left(\mathrm{CH}_{4}\right) \times 10^{3} \text { mmoles } \times 10^{6}}{0,0374 \text { mmoles } . \mathrm{ml}^{-1}} \\
& \Rightarrow \mathrm{C}_{1}\left(\mathrm{CH}_{4}\right)_{\mathrm{amb}}(\mathrm{At})=\underline{\mathbf{1 8 . 1 6 6} \mathrm{ppm}}
\end{aligned}
$$

5) Idem para cálculos do dióxido de carbono $\left(\mathrm{CO}_{2}\right)$ :

$$
C_{2}=\frac{n_{2}\left(\mathrm{CO}_{2}\right) \text { moles } \times 10^{3} \text { mmoles } \times 10^{6}}{n(\text { Ar }) \text { mmoles } . \mathrm{ml}^{-1}}
$$




$$
\begin{gathered}
C_{2}^{\prime}=\frac{2,1086 \times 10^{-7} \text { moles }\left(\mathrm{CO}_{2}\right) \times 10^{3} \text { mmoles } \times 10^{6}}{0,0374 \text { mmoles } \cdot \mathrm{ml}^{-1}} \\
\Rightarrow \frac{\mathrm{C}_{2}\left(\mathrm{CO}_{2}\right)_{\mathrm{amb}}(\mathrm{At})=\underline{\mathbf{5 . 6 3 8} \mathrm{ppm}}}{\mathrm{C}_{2}{ }^{\prime}\left[\left(\mathrm{CO}_{2}\right)_{\mathrm{amb}}(\mathrm{At})\right] \text { é a concentração de dióxido de carbono no ambiente do }} \\
\text { aterro }(p p m) \text { na primeira campanha. }
\end{gathered}
$$

\section{$\left.E_{2}\right)$ Campanha 2007}

1) $\left(\mathrm{T}_{\mathrm{amb}}(\mathrm{M})=28,3^{0} \mathrm{C}\right.$ ou $301,5 \mathrm{~K} ; \mathrm{P}_{\mathrm{atm}}(\mathrm{Amb})=699,2 \mathrm{mmHg} ; n_{1}=6,4345 \times 10^{-7} \mathrm{e}$ $n_{2}=2,4607 \times 10^{-7}$ )

2) Da equação de estado dos gases ideais:

$$
\begin{aligned}
& \Rightarrow \quad V=\frac{1 \mathrm{~mol} \times 62,3637 \mathrm{~L} \times \mathrm{mmHg} \times 301,5 \mathrm{~K}}{699,2 \mathrm{mmHg} \times \mathrm{mol} \times \mathrm{K}} \\
& \Rightarrow \mathrm{V}(1 \mathrm{mmol} \mathrm{AR})=\underline{\mathbf{2 6 , 8 9}} \mathrm{mL}
\end{aligned}
$$

3) Cálculo do número de moles de ar em $1 \mathrm{ml}$ de Ar ambiente do aterro.

$$
\begin{array}{ll}
\text { Se } & 26,89 \mathrm{~mL}(\mathrm{Ar}) \rightarrow 1 \mathrm{mmo} /(\mathrm{Ar}) \\
& 1,00 \mathrm{~mL}\left[\operatorname{Ar}_{\mathrm{amb}}(\mathrm{At})\right] \rightarrow \mathrm{n}(\mathrm{mmol}) \\
\Rightarrow \mathrm{n}=\underline{\mathbf{0 , 0 3 7 2}} \mathrm{mmol}
\end{array}
$$

4) Cálculo para concentração $\left(\mathrm{C}_{1}{ }^{\prime}\right)$ de metano no ar ambiente do aterro:

$$
\begin{aligned}
& \Rightarrow C_{1}{ }^{\prime}=\frac{6,4345 \times 10^{-7} \text { moles }\left(\mathrm{CH}_{4}\right) \times 10^{3} \text { mmoles } \times 10^{6}}{0,0372{\text { mmoles } . \mathrm{ml}^{-1}}^{-1}} \\
& \Rightarrow \quad \mathrm{C}_{1}{ }^{\prime}\left(\mathrm{CH}_{4}\right)_{\mathrm{amb}}(\mathrm{At})=\underline{\mathbf{1 7 . 2 9 7} \mathrm{ppm}}
\end{aligned}
$$


5) Idem para cálculos do dióxido de carbono $\left(\mathrm{CO}_{2}\right)$ :

$$
\begin{aligned}
& C_{2}{ }^{\prime}=\frac{n_{2}\left(C_{2}\right) \text { moles } \times 10^{3} \text { mmoles } \times 10^{6}}{n(\text { Ar }) \text { mmoles } . \mathrm{ml}^{-1}} \\
& C_{2}{ }^{\prime}=\frac{2,4607 \times 10^{-7} \text { moles }\left(\mathrm{CO}_{2}\right) \times 10^{3} \text { mmoles } \times 10^{6}}{0,0372 \text { mmoles } . \mathrm{ml}^{-1}} \\
& \Rightarrow \quad \mathrm{C}_{2}^{\prime}\left(\mathrm{CO}_{2}\right)_{\mathrm{amb}}(\mathrm{At})=\underline{\mathbf{6 . 6 1 5} p p m}
\end{aligned}
$$

$\mathrm{C}_{2}{ }^{\prime}\left[\left(\mathrm{CO}_{2}\right)\right.$ amb $\left.(\mathrm{At})\right]$ é a concentração de dióxido de carbono no ambiente do aterro(ppm) na segunda campanha.

6) Concentração média do ambiente do aterro de Jaú:

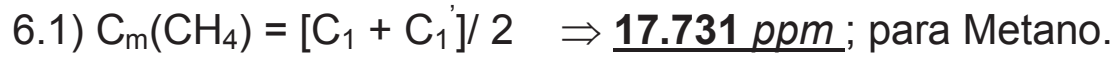

6.2) $\mathrm{C}_{\mathrm{m}}\left(\mathrm{CO}_{2}\right)=\left[\mathrm{C}_{2}+\mathrm{C}_{2}{ }^{\prime}\right] / 2 \Rightarrow \underline{\mathbf{6 . 1 2 6} p p m}$; para Dióxido de carbono. 


\subsection{1-F) Aterro de Ribeirão Preto}

$\left.F_{1}\right)$ Campanha 2006

1) $\left(\mathrm{T}_{\mathrm{amb}}(\mathrm{M})=29,6^{0} \mathrm{C}\right.$ ou $302,8 \mathrm{~K} ; \mathrm{P}_{\mathrm{atm}}(\mathrm{Amb})=705,3 \mathrm{mmHg} ; n_{1}=6,7320 \times 10^{-7} \mathrm{e}$ $\left.n_{2}=2,1466 \times 10^{-7}\right)$

2) Da equação de estado dos gases ideais:

$$
\begin{aligned}
& \Rightarrow \quad V=\frac{1 \mathrm{~mol} \times 62,3637 \mathrm{~L} \times \mathrm{mmHg} \times 302,8 \mathrm{~K}}{705,3 \mathrm{mmHg} \times \mathrm{mol} \times \mathrm{K}} \\
& \Rightarrow \mathrm{V}(1 \mathrm{mmol} \mathrm{AR})=\underline{\mathbf{2 6 , 7 7}} \mathrm{mL}
\end{aligned}
$$

3) Cálculo do número de moles de ar em $1 \mathrm{ml}$ de Ar ambiente do aterro.

Então: Se 26,77mL(Ar) $\rightarrow 1 \mathrm{mmol}(\mathrm{Ar})$

$$
\begin{aligned}
& 1,00 \mathrm{~mL}\left[\mathrm{Ar}_{\mathrm{amb}}(\mathrm{At})\right] \rightarrow \mathrm{n}(\mathrm{mmol})(\text { Volume de GAS injetado }) \\
& \Rightarrow \mathrm{n}=\underline{\mathbf{0 , 0 3 7 3}} \mathrm{mmol}
\end{aligned}
$$

4) Cálculo para concentração $\left(C_{1}\right)$ de metano no ar ambiente do aterro:

$$
\Rightarrow C_{1}=\frac{6,7320 \times 10^{-7} \text { moles }\left(\mathrm{CH}_{4}\right) \times 10^{3} \text { mmoles } \times 10^{6}}{0,0373 \text { mmoles } . \mathrm{ml}^{-1}}
$$

\section{$\Rightarrow \quad \mathrm{C}_{1}\left(\mathrm{CH}_{4}\right)_{\mathrm{amb}}(\mathrm{At})=\underline{\mathbf{1 8 . 0 4 8} \mathrm{ppm}}$}

5) Idem para cálculos do dióxido de carbono $\left(\mathrm{CO}_{2}\right)$ :

$$
C_{2}=\frac{n_{2}\left(\mathrm{CO}_{2}\right) \text { moles } \times 10^{3} \text { mmoles } \times 10^{6}}{n(\text { Ar }) \text { mmoles } . \mathrm{ml}^{-1}}
$$




$$
\begin{gathered}
C_{2}=\frac{2,1466 \times 10^{-7} \text { moles }\left(\mathrm{CO}_{2}\right) \times 10^{3} \text { mmoles } \times 10^{6}}{0,0373 \text { mmoles } \cdot \mathrm{ml}^{-1}} \\
\Rightarrow \quad \mathrm{C}_{2}\left(\mathrm{CO}_{2}\right)_{\mathrm{amb}}(\mathrm{At})=\underline{\mathbf{5 . 7 5 5} \mathrm{ppm}} \\
\mathrm{C}_{2}\left[\left(\mathrm{CO}_{2}\right) \text { amb }(\mathrm{At})\right] \text { é a concentração de dióxido de carbono no ambiente do } \\
\text { aterro(ppm) na primeira campanha. }
\end{gathered}
$$

\section{$F_{2}$ ) Campanha 2007}

1) $\left(\mathrm{T}_{\mathrm{amb}}(\mathrm{M})=27,2^{0} \mathrm{C}\right.$ ou $300,4 \mathrm{~K} ; \mathrm{P}_{\mathrm{atm}}(\mathrm{Amb})=705,3 \mathrm{mmHg} ; n_{1}=6,4026 \times 10^{-7} \mathrm{e}$ $\left.n_{2}=1,7682 \times 10^{-7}\right)$

Obs. Duas tomadas do ar ambiente do aterro:

1.1) Metano: $\left[n_{1}\left(\mathrm{CH}_{4}\right)+n_{1}{ }^{\prime}\left(\mathrm{CH}_{4}\right)\right] / 2=\underline{6,4026 \times 10^{-7}}$

1.2) Dióxido de carbono: $\left[\mathrm{n}_{2}\left(\mathrm{CO}_{2}\right)+\mathrm{n}_{2}{ }^{\prime}\left(\mathrm{CO}_{2}\right)\right] / 2=\underline{1,7682 \times 10^{-7}}$

2) Da equação de estado dos gases ideais:

$$
\begin{aligned}
& \Rightarrow \quad V=\frac{1 \mathrm{~mol} \times 62,3637 \mathrm{~L} \times \mathrm{mmHg} \times 300,4 \mathrm{~K}}{705,3 \mathrm{mmHg} \times \mathrm{mol} \times \mathrm{K}} \\
& \Rightarrow \mathrm{V}(1 \mathrm{mmol} \mathrm{AR})=\underline{\mathbf{2 6 , 5 6}} \mathrm{mL}
\end{aligned}
$$

3) Cálculo do número de moles de ar em $1 \mathrm{ml}$ de Ar ambiente do aterro.

$$
\begin{aligned}
& \text { Então: Se } \begin{aligned}
& 26,56 m L(A r) \rightarrow 1 m m o l(A r) \\
& 1,00 m L\left[\operatorname{Ar}_{\mathrm{amb}}(\mathrm{At})\right] \rightarrow \mathrm{n}(\mathrm{mmol}) \\
& \Rightarrow n=\underline{0,0376} \mathrm{mmol}
\end{aligned}
\end{aligned}
$$


4) Cálculo para concentração $\left(C_{1}{ }^{\prime}\right)$ de metano no ar ambiente do aterro:

$$
\begin{aligned}
& \Rightarrow C_{1}{ }^{\prime}=\frac{6,4026 \times 10^{-7} \text { moles }\left(\mathrm{CH}_{4}\right) \times 10^{3} \text { mmoles } \times 10^{6}}{0,0376{\text { mmoles } . \mathrm{ml}^{-1}}^{-1}} \\
& \Rightarrow \quad \mathrm{C}_{1}{ }^{\prime}\left(\mathrm{CH}_{4}\right)_{\mathrm{amb}}(\mathrm{At})=\mathbf{1 7 . 0 2 8 p p m}
\end{aligned}
$$

5) Idem para cálculos do dióxido de carbono $\left(\mathrm{CO}_{2}\right)$ :

$$
\begin{aligned}
C_{2}^{\prime} & =\frac{n_{2}\left(\mathrm{CO}_{2}\right) \text { moles } \times 10^{3} \mathrm{mmoles} \times 10^{6}}{n(\mathrm{Ar}) \mathrm{mmoles} . \mathrm{ml}^{-1}} \\
C_{2}{ }^{\prime} & =\frac{1,7682 \times 10^{-7} \text { moles }\left(\mathrm{CO}_{2}\right) \times 10^{3} \mathrm{mmoles} \times 10^{6}}{0,0376 \mathrm{mmoles}_{\mathrm{ml}}{ }^{-1}} \\
& \Rightarrow \mathrm{C}_{2}{ }^{\prime}\left(\mathrm{CO}_{2}\right)_{\mathrm{amb}}(\mathrm{At})=\underline{\mathbf{4 . 7 0 2} \mathrm{ppm}}
\end{aligned}
$$

$\mathrm{C}_{2}{ }^{\prime}\left[\left(\mathrm{CO}_{2}\right)\right.$ amb $\left.(\mathrm{At})\right]$ é a concentração de dióxido de carbono no ambiente do aterro $(p p m)$ na segunda campanha.

6) Concentração média do ambiente do aterro de Ribeirão Preto:

6.1) $\mathrm{C}_{\mathrm{m}}\left(\mathrm{CH}_{4}\right)=\left[\mathrm{C}_{1}+\mathrm{C}_{1}\right] / 2 \Rightarrow \underline{\mathbf{1 7}} \mathbf{2} \mathbf{5 3 8 \mathrm { ppm }}$; para Metano.

6.2) $\mathrm{C}_{\mathrm{m}}\left(\mathrm{CO}_{2}\right)=\left[\mathrm{C}_{2}+\mathrm{C}_{2}^{\prime}\right] / 2 \Rightarrow \underline{\mathbf{5 . 2 2 8} p p m}$; para Dióxido de carbono. 


\subsection{1-G) Aterro de São Carlos}

\section{$\mathrm{G}_{1}$ ) Campanha 2006}

1) $\left(\mathrm{T}_{\mathrm{amb}}(\mathrm{M})=26,9^{0} \mathrm{C}\right.$ ou $300,1 \mathrm{~K} ; \mathrm{P}_{\mathrm{atm}}(\mathrm{Amb})=691,8 \mathrm{mmHg} ; n_{1}=6,6933 \times 10^{-7} \mathrm{e}$ $\left.n_{2}=2,1603 \times 10^{-7}\right)$

2) Da equação de estado dos gases ideais:

$$
\begin{aligned}
& \Rightarrow \quad V=\frac{1 \mathrm{~mol} \times 62,3637 \mathrm{~L} \times \mathrm{mmHg} \times 300,1 \mathrm{~K}}{691,8 \mathrm{mmHg} \times \mathrm{mol} \times \mathrm{K}} \\
& \Rightarrow \mathrm{V}(1 \mathrm{mmol} \mathrm{AR})=\underline{\mathbf{2 7 , 0 5}} \mathrm{mL}
\end{aligned}
$$

3) Cálculo do número de moles de ar em $1 \mathrm{ml}$ de Ar ambiente do aterro.

$$
\begin{aligned}
& \text { Se } 27,05 m L(A r) \rightarrow 1 m m o l(A r) \\
& 1,00 m L\left[\operatorname{Ar}_{\text {amb }}(A t)\right] \rightarrow n(m m o l)(\text { Volume de GAS injetado) } \\
& \Rightarrow \mathrm{n}=\underline{0,0369} \mathrm{mmol}
\end{aligned}
$$

4) Cálculo para concentração $\left(C_{1}\right)$ de metano no ar ambiente do aterro:

$$
\begin{aligned}
& \Rightarrow C_{1}=\frac{6,6933 \times 10^{-7} \text { moles }\left(\mathrm{CH}_{4}\right) \times 10^{3} \text { mmoles } \times 10^{6}}{0,0369 \text { mmoles } . \mathrm{ml}^{-1}} \\
& \Leftrightarrow \mathrm{C}_{1}\left(\mathrm{CH}_{4}\right)_{\mathrm{amb}}(\mathrm{At})=\underline{\mathbf{1 8 . 1 3 9} \mathrm{ppm}}
\end{aligned}
$$

5) Idem para cálculos do dióxido de carbono $\left(\mathrm{CO}_{2}\right)$ :

$$
C_{2}=\frac{n_{2}\left(\mathrm{CO}_{2}\right) \text { moles } \times 10^{3} \mathrm{mmoles} \times 10^{6}}{n\left(\text { Ar)mmoles } . \mathrm{ml}^{-1}\right.}
$$




$$
\begin{gathered}
C_{2}=\frac{2,1603 \times 10^{-7} \text { moles }\left(\mathrm{CO}_{2}\right) \times 10^{3} \text { mmoles } \times 10^{6}}{0,0369 \text { mmoles } . \mathrm{ml}^{-1}} \\
\Rightarrow \frac{\mathrm{C}_{2}\left(\mathrm{CO}_{2}\right)_{\mathrm{amb}}(\mathrm{At})=\underline{\mathbf{5 . 8 5 4} \mathrm{ppm}}}{\mathrm{C}_{2}\left[\left(\mathrm{CO}_{2}\right)_{\mathrm{amb}}(\mathrm{At})\right] \text { é a concentração de dióxido de carbono no ambiente do }} \\
\text { aterro }(p p m) \text { na primeira campanha. }
\end{gathered}
$$

\section{$\mathrm{G}_{2}$ ) Campanha 2007}

1) $\left(\mathrm{T}_{\mathrm{amb}}(\mathrm{M})=22,5^{0} \mathrm{C}\right.$ ou $295,7 \mathrm{~K} ; \mathrm{P}_{\mathrm{atm}}(\mathrm{Amb})=691,8 \mathrm{mmHg} ; n_{1}=6,8372 \times 10^{-7} \mathrm{e}$ $n_{2}=2,2594 \times 10^{-7}$ )

2) Da equação de estado dos gases ideais:

$$
\begin{aligned}
& \Rightarrow \quad V=\frac{1 \mathrm{~mol} \times 62,3637 \mathrm{~L} \times \mathrm{mmHg} \times 295,7 \mathrm{~K}}{691,8 \mathrm{mmHg} \times \mathrm{mol} \times \mathrm{K}} \\
& \Rightarrow \mathrm{V}(1 \mathrm{mmol} \mathrm{AR})=\underline{\mathbf{2 6 , 6 5}} \mathrm{mL}
\end{aligned}
$$

3) Cálculo do número de moles de ar em $1 \mathrm{ml}$ de Ar ambiente do aterro.

$$
\begin{array}{ll}
\text { Se } & 26,65 m L(A r) \rightarrow 1 m m o l(A r) \\
& 1,00 m L\left[\operatorname{Ar}_{\mathrm{amb}}(\mathrm{At})\right] \rightarrow \mathrm{n}(\mathrm{mmol}) \\
\Rightarrow \mathrm{n}=\underline{\mathbf{0 , 0 3 7 5}} \mathrm{mmol}
\end{array}
$$

4) Cálculo para concentração $\left(C_{1}{ }^{\prime}\right)$ de metano no ar ambiente do aterro:

$$
\begin{aligned}
& \Rightarrow C_{1}{ }^{\prime}=\frac{6,8372 \times 10^{-7} \text { moles }\left(\mathrm{CH}_{4}\right) \times 10^{3} \text { mmoles } \times 10^{6}}{0,0375{\text { mmoles } . m l^{-1}}^{6}} \\
& \Rightarrow \quad \mathrm{C}_{1}{ }^{\prime}\left(\mathrm{CH}_{4}\right)_{\mathrm{amb}}(\mathrm{At})=\underline{\mathbf{1 8 . 2 3 2} \mathrm{ppm}}
\end{aligned}
$$


5) Idem para cálculos do dióxido de carbono $\left(\mathrm{CO}_{2}\right)$ :

$$
\begin{aligned}
C_{2}^{\prime} & =\frac{n_{2}\left(\mathrm{CO}_{2}\right) \text { moles } \times 10^{3} \mathrm{mmoles} \times 10^{6}}{n(\text { Ar }) \text { mmoles } . \mathrm{ml}^{-1}} \\
C_{2}{ }^{\prime} & =\frac{2,2594 \times 10^{-7} \text { moles }\left(\mathrm{CO}_{2}\right) \times 10^{3} \text { mmoles } \times 10^{6}}{0,0375 \mathrm{mmoles}^{6} \mathrm{ml}^{-1}} \\
& \Rightarrow \mathrm{C}_{2}{ }^{\prime}\left(\mathrm{CO}_{2}\right)_{\mathrm{amb}}(\mathrm{At})=\underline{\mathbf{6 . 0 2 5} \mathrm{ppm}}
\end{aligned}
$$

$\mathrm{C}_{2}{ }^{\prime}\left[\left(\mathrm{CO}_{2}\right)\right.$ amb $\left.(\mathrm{At})\right]$ é a concentração de dióxido de carbono no ambiente do aterro $(p p m)$ na segunda campanha.

6) Concentração média do ambiente do aterro de São Carlos:

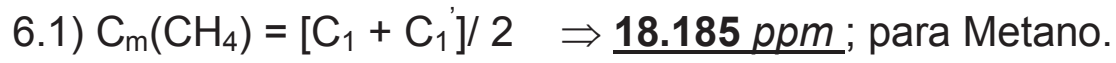

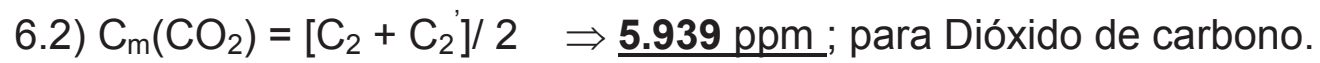




\subsection{1-H) Aterro Bandeirantes}

\section{H1) Campanha Única 2007}

1) $\left(\mathrm{T}_{\mathrm{amb}}(\mathrm{M})=30,0^{\circ} \mathrm{C}\right.$ ou $303,2 \mathrm{~K} ; \mathrm{P}_{\mathrm{atm}}(\mathrm{Amb})=693,9 \mathrm{mmHg} ; n_{1}=6,0408 \times 10^{-7} \mathrm{e}$ $\left.n_{2}=2,5158 \times 10^{-7}\right)$

Obs. Duas tomadas do ar ambiente do aterro:

1.1) Metano: $\left[\mathrm{n}_{\mathrm{a}}\left(\mathrm{CH}_{4}\right)+\mathrm{n}_{\mathrm{b}}\left(\mathrm{CH}_{4}\right)\right] / 2=\underline{6,0408 \times 10^{-7}}$

1.2) Dióxido de carbono: $\left[\mathrm{n}_{\mathrm{c}}\left(\mathrm{CO}_{2}\right)+\mathrm{n}_{\mathrm{d}}\left(\mathrm{CO}_{2}\right)\right] / 2=\underline{2,5158 \times 10^{-7}}$

2) Da equação de estado dos gases ideais:

$$
\begin{aligned}
& \Rightarrow \quad V=\frac{1 \mathrm{~mol} \times 62,3637 \mathrm{~L} \times \mathrm{mmHg} \times 303,2 \mathrm{~K}}{693,9 \mathrm{mmHg} \times \mathrm{mol} \times \mathrm{K}} \\
& \Rightarrow \mathrm{V}(1 \mathrm{mmol} \mathrm{AR})=\underline{\mathbf{2 7 , 2 5}} \mathrm{mL}
\end{aligned}
$$

3) Cálculo do número de moles de ar em $1 \mathrm{~m} /$ de Ar ambiente do aterro.

$$
\begin{array}{ll}
\text { Se } & 27,25 \mathrm{~mL}(\mathrm{Ar}) \rightarrow 1 \mathrm{mmo}(\mathrm{Ar}) \\
& 1,00 \mathrm{~mL}\left[\mathrm{Ar}_{\mathrm{amb}}(\mathrm{At})\right] \rightarrow \mathrm{n}(\mathrm{mmol}) \\
\Rightarrow n=\underline{\mathbf{0 , 0 3 6 7}} \mathrm{mmol}
\end{array}
$$

4) Cálculo para concentração $\left(C_{1}\right)$ de metano no ar ambiente do aterro:

$$
\begin{aligned}
\Rightarrow & \mathrm{C}_{1}=\frac{6,0408 \times 10^{-7} \text { moles }\left(\mathrm{CH}_{4}\right) \times 10^{3} \mathrm{mmoles} \times 10^{6}}{0,0367 \mathrm{mmoles}_{\mathrm{ml}}{ }^{-1}} \\
\Rightarrow \quad & \mathrm{C}_{1}\left(\mathrm{CH}_{4}\right)_{\mathrm{amb}}(\mathrm{At})=\underline{\mathbf{1 6 . 4 6 0} \mathrm{ppm}}
\end{aligned}
$$


5) Idem para cálculos do dióxido de carbono $\left(\mathrm{CO}_{2}\right)$ :

$$
\begin{aligned}
C & =\frac{n_{2}\left(\mathrm{CO}_{2}\right) \text { moles } \times 10^{3} \mathrm{mmoles} \times 10^{6}}{n(\mathrm{Ar}) \text { mmoles } . \mathrm{ml}^{-1}} \\
C & =\frac{2,5158 \times 10^{-7} \text { moles }\left(\mathrm{CO}_{2}\right) \times 10^{3}{\text { mmoles } \times 10^{6}}^{-1}}{0,0367 \mathrm{mmoles}_{\mathrm{ml}}{ }^{-1}} \\
& \Rightarrow \mathrm{C}_{2}\left(\mathrm{CO}_{2}\right) \mathrm{amb}(\mathrm{At})=\underline{\mathbf{6 . 8 5 5} \mathrm{ppm}}
\end{aligned}
$$

$\mathrm{C}_{2}{ }^{\prime}\left[\left(\mathrm{CO}_{2}\right)_{\mathrm{amb}}(\mathrm{At})\right]$ é a concentração de dióxido de carbono no ambiente do aterro.

6) Concentração do ambiente do aterro Bandeirantes:

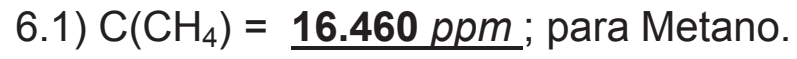

6.2) $\mathrm{C}\left(\mathrm{CO}_{2}\right)=\underline{\mathbf{6 . 8 5 5} p p m}$; para Dióxido de carbono. 


\subsection{Cálculos da emissão solo-ar para $\mathrm{CH}_{4}$ e $\mathrm{CO}_{2}$ de cada sítio de coleta $\left(\mathrm{P}_{\mathrm{n}}\right)$ dos aterros estudados.}

Nesta sessão foram desenvolvidos os cálculos da taxa de emissão solo-ar( $\left.\mathrm{T}_{\mathrm{x}} \mathrm{E}\right)$, para $\mathrm{CH}_{4}$ e $\mathrm{CO}_{2}$, em cada sítio de coleta $\left(\mathrm{P}_{\mathrm{n}}\right)$, por aterro e campanha.

Para a determinação da $T_{x} E$, foram considerados: o tamanho das câmaras de difusão/coleta de gases - se grande(G) ou pequena(p) - seus volumes $\left(V_{G}=33.200 \mathrm{~mL}\right.$ e $\left.V_{p}=1200 \mathrm{~mL}\right)$ e as áreas das suas bases $\left(A_{G}=0,664 \mathrm{~m}^{2}\right.$ e $\left.A_{p}=0.01815 \mathrm{~m}^{2}\right)$, respectivamente.

Os resultados das massas $(\mu \mathrm{g})$ para $\mathrm{CH}_{4}$ e $\mathrm{CO}_{2}$, obtidos da análise cromatográfica (Sessão 6.3), foram lançados numa planilha Excel e plotados, para cada sítio de coleta $\left(P_{n}\right)$, considerando a variação da massa de cada um dos gases, acumuladas nas câmaras versus o tempo de coleta ( 0, 3, 6 e 12 minutos).

Os gráficos resultantes forneceram equações $-y_{1}$ e $y_{2}$, para metano e dióxido de carbono, respectivamente - com a inclinação da reta para cada conjunto de dados lançado ( quatro valores de massa).

A taxa de emissão $\left(T_{x} E\right)$ para cada gás, em cada sítio de coleta de cada aterro, foi calculada pela aplicação da equação:

$$
\text { TxE }(\text { Gás })=\frac{\omega\left(\mu g . \mathrm{min}^{-1} \cdot m L^{-1}\right) \times V(m L) \times t\left(\min . d^{-1}\right) \times g}{m L \times \min \times A\left(m^{2}\right) \times \operatorname{dia} \times 10^{6} \mu g}
$$

Em que: $T_{x} E$ = Taxa de emissão do gás no sítio $\left(g \cdot m^{-2} \cdot d^{-1}\right)$

$\omega=$ Inclinação da reta para um gás específico (termo em $x$ nas equações da reta, $\mu \mathrm{g} \cdot \mathrm{min}^{-1} \cdot m L^{-1}$ ) 


$$
\begin{aligned}
& \mathrm{V}=\text { Volume da câmara de coleta }\left(m L, V_{\mathrm{G}}=\text { Grande e } \mathrm{V}_{\mathrm{p}}=\right.\text { pequena) } \\
& \mathrm{t}=\text { tempo( com fator de conversão, } \min \cdot d^{-1} \text { ) } \\
& 10^{6}=\text { fator de conversão, } \mu g \text { para } g ; \text { e, } \\
& A=\text { Área da base da câmara de coleta }\left(m^{2}, A_{G}=G \text { rande e } A_{p}=\text { pequena }\right) \\
& \text { Obtida a taxa de emissão }\left(T_{x} E\right) \text { de cada sítio } P_{n} \text {, foi determinada a }
\end{aligned}
$$
taxa de emissão média $\left(T_{x} E_{m}\right)$ para cada aterro; multiplicando-se $T_{x} E$ pela área total do aterro $\left(A_{a t}, m^{2}\right)$; medida em toneladas por ano $\left(t . a^{-1}\right)$, em cada campanha.

A Emissão Total Média $\left(E_{t} M, t . a^{-1}\right)$ solo-ar, para cada aterro, foi calculada como a média das duas campanhas, 2006 e 2007.

\subsection{1-A) Aterro de Araraquara}

\section{A ${ }_{1}$ Campanha 2006}

$\mathbf{P}_{1}\left(\mathrm{G} ; \mathrm{V}_{\mathrm{G}}=33.200 \mathrm{~mL}\right.$ e $\left.\mathrm{A}_{\mathrm{G}}=0,664 \mathrm{~m}^{2}\right)$

a) Tabela com tempos de coleta e massas correspondentes, gráfico com equações de retas e inclinações:

Tabela 6.5.1 - Sítio de coleta $\mathbf{P}_{\mathbf{1}}$ - Araraquara 2006: tempos de coleta e massas $(\mu \mathrm{g})$ de $\mathrm{CH}_{4}$ e $\mathrm{CO}_{2}$.

\begin{tabular}{ccc}
\hline Tempo $(\min )$ & Massa do $\mathrm{CH}_{4}(\mu g)$ & Massa do $\mathrm{CO}_{2}(\mu g)$ \\
\hline 0 & 10,4588 & 8,7608 \\
3 & 11,0299 & 9,6741 \\
6 & 11,0582 & 9,9581 \\
12 & 11,8411 & 9,5418 \\
\hline
\end{tabular}




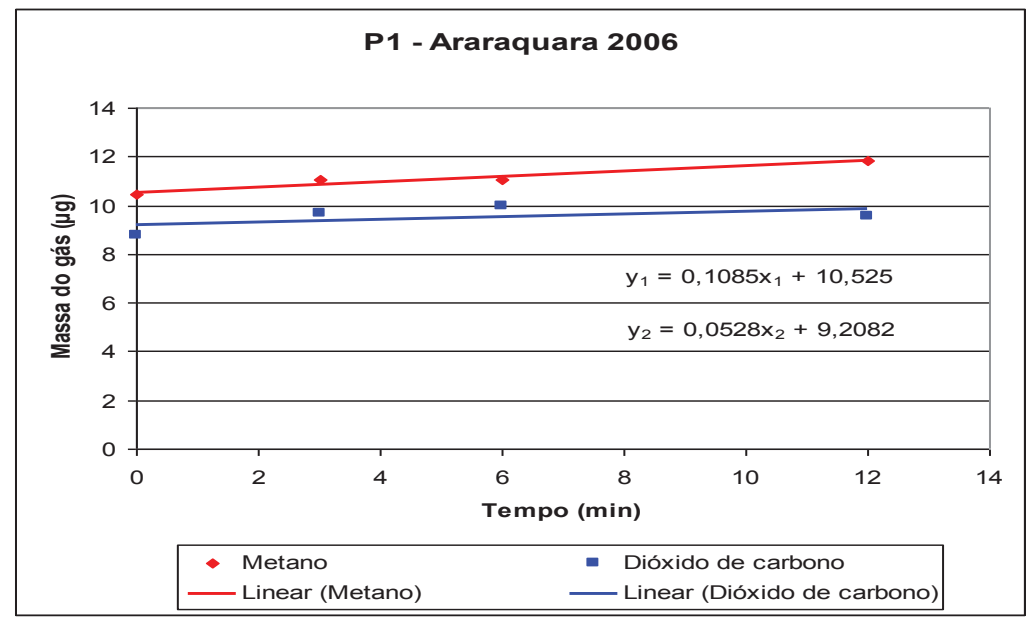

Gráfico 6.5.1 - Sítio $\mathbf{P}_{\mathbf{1}}$ - Araraquara 2006. Equações de retas e inclinações para $\mathrm{CH}_{4}$ e $\mathrm{CO}_{2}$.

Equações das retas:

$$
\begin{aligned}
& y_{1}=0,1085 x_{1}+10,525 \quad \text { Equação do metano } \\
& y_{2}=0,0528 x_{2}+9,2082 \quad \text { Equação do dióxido }
\end{aligned}
$$

\section{b) Cálculo da taxa de emissão:}

b1) Metano: $\operatorname{Tx} E\left(\mathrm{CH}_{4}\right)=\frac{0,1085 \mu g\left(\mathrm{CH}_{4}\right) \times 33.200 \mathrm{~mL} \times 1440 \mathrm{~min} \times g}{m L \times \min \times 0,664 \mathrm{~m}^{2} \times \operatorname{dia} \times 10^{6} \mu \mathrm{g}}$

$$
=7,82 \mathrm{~g} \times \mathrm{m}^{-2} \cdot \mathrm{d}^{-1}\left(\mathrm{CH}_{4}\right) \quad \text { No sítio de coleta } \mathrm{P}_{1} \text {. }
$$

Em que: $\quad T_{x} E\left(\mathrm{CH}_{4}\right)=$ Taxa de emissão de metano no sítio;

$0,0984 \mu \mathrm{g} \cdot \mathrm{min}^{-1} \cdot \mathrm{mL}^{-1}=$ Inclinação da reta do gráfico de metano;

33.200 $m L=$ Volume da câmara de coleta (grande);

$1440 \min =$ número de $\operatorname{minutos} \cdot \mathrm{dia}^{-1}$;

$10^{6}=$ fator de conversão de $\mu g$ para $g ;$ e,

0,664 $\mathrm{m}^{2}=$ Área da base da câmara de coleta (grande). 
$\mathrm{b}_{2}$ ) Dióxido de carbono: $\operatorname{Tx} E\left(\mathrm{CO}_{2}\right)=\frac{0,0528 \mu \mathrm{g}\left(\mathrm{CO}_{2}\right) \times 33.200 \mathrm{~mL} \times 1440 \mathrm{~min} \times g}{\mathrm{~mL} \times \min \times 0,664 \mathrm{~m}^{2} \times \operatorname{dia} \times 10^{6} \mu \mathrm{g}}$

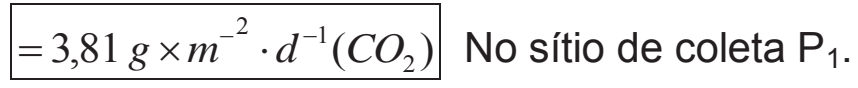

Em que: $\quad \mathrm{T}_{\mathrm{x}} \mathrm{E}\left(\mathrm{CO}_{2}\right)=$ Taxa de emissão de dióxido de carbono no sítio;

0,0543 $\mu \mathrm{g} \cdot \mathrm{min}^{-1} \cdot \mathrm{mL}^{-1}=$ Inclinação da reta do gráfico de dióxido de carbono;

$1.200 m L=$ Volume da câmara de coleta (grande);

$1440 \min =$ número de minutos $\cdot$ dia $^{-1}$

$10^{6}=$ fator de conversão de $\mu \mathrm{g}$ para g; e,

0,664 $m^{2}$ = Área da base da câmara de coleta (grande).

$\mathbf{P}_{2}\left(p ; V_{p}=1.200 m L\right.$ e $\left.A_{p}=0,01815 m^{2}\right)$

a) Tabela com tempos de coleta e massas correspondentes, gráfico com equações de retas e inclinações:

Tabela 6.5.2 - Sítio de coleta $\mathbf{P}_{\mathbf{2}}$ - Araraquara 2006: tempos de coleta e massas $(\mu g)$ para $\mathrm{CH}_{4}$ e $\mathrm{CO}_{2}$.

\begin{tabular}{ccc}
\hline Tempo $($ min $)$ & Massa do $\mathrm{CH}_{4}(\mu g)$ & Massa do $\mathrm{CO}_{2}(\mu g)$ \\
\hline 0 & 10,8976 & 10,4237 \\
3 & 11,5126 & 10,7155 \\
6 & 11,5865 & 12,7045 \\
12 & 11,6768 & 10,5395 \\
\hline
\end{tabular}




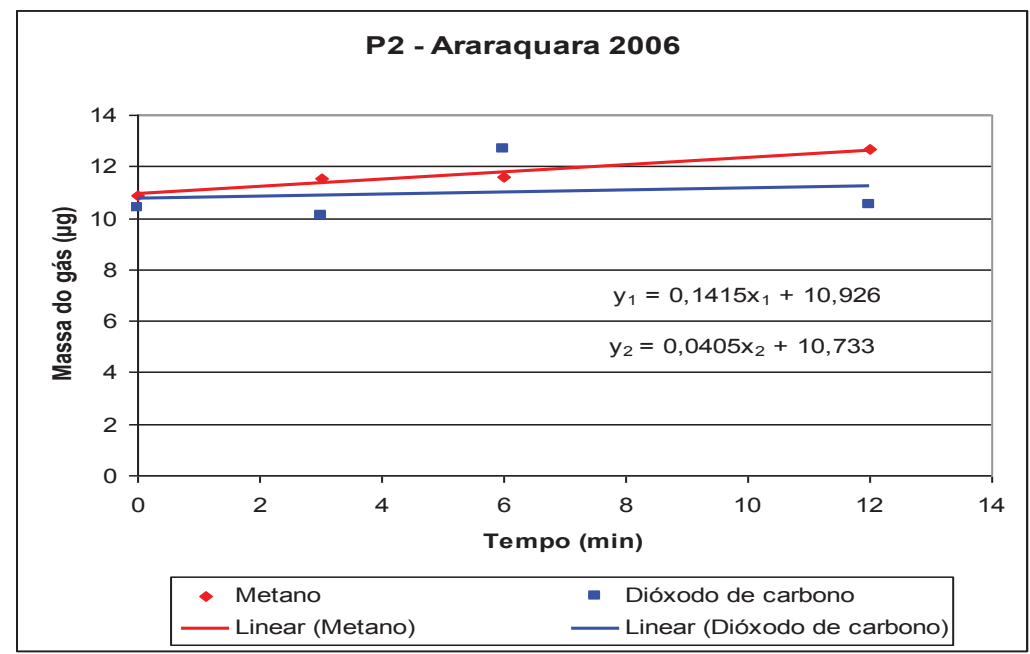

Gráfico 6.5.2 - Sítio $\mathrm{P}_{2}$ - Araraquara 2006. Equações de retas e inclinações para $\mathrm{CH}_{4}$ e $\mathrm{CO}_{2}$.

Equações das retas:

$$
\begin{aligned}
& y_{1}=0,0415 x_{1}+10,928 \text { Equação do metano } \\
& y_{2}=0,0405 x_{2}+10,733 \text { Equação do dióxido }
\end{aligned}
$$

b) Cálculo da taxa de emissão:

b) Metano:

$$
\begin{aligned}
& \operatorname{TxE}\left(\mathrm{CH}_{4}\right)=\frac{0,0415 \mu \mathrm{g}\left(\mathrm{CO}_{2}\right) \times 1.200 \mathrm{~mL} \times 1440 \mathrm{~min} \times \mathrm{g}}{\mathrm{mL} \times \min \times 0,01815 \mathrm{~m}^{2} \times \operatorname{dia} \times 10^{6} \mu \mathrm{g}} \\
& \operatorname{TxE}\left(\mathrm{CH}_{4}\right)=3,95 \mathrm{~g} \times \mathrm{m}^{-2} \cdot \mathrm{d}^{-1}\left(\mathrm{CH}_{4}\right) \text { No sítio de coleta } \mathrm{P}_{2} .
\end{aligned}
$$

$\mathrm{b}_{2}$ ) Dióxido de carbono: $\operatorname{Tx} E\left(\mathrm{CO}_{2}\right)=\frac{0,0405 \mu \mathrm{g}\left(\mathrm{CO}_{2}\right) \times 1.200 \mathrm{~mL} \times 1440 \mathrm{~min} \times \mathrm{g}}{\mathrm{mL} \times \min \times 0,01815 \mathrm{~m}^{2} \times \operatorname{dia} \times 10^{6} \mu \mathrm{g}}$

$$
\operatorname{Tx} E\left(C_{2}\right)=3,85 \mathrm{~g} \times \mathrm{m}^{-2} \cdot d^{-1}\left(C_{2}\right) \quad \text { No sítio de coleta } \mathrm{P}_{2} \text {. }
$$


$\mathbf{P}_{3}\left(\mathrm{G} ; \mathrm{V}_{\mathrm{G}}=33.200 \mathrm{~mL}\right.$ e $\left.\mathrm{A}_{\mathrm{G}}=0,664 \mathrm{~m}^{2}\right)$

a) Tabela com tempos de coleta e massas correspondentes, gráfico com equações de retas e inclinações:

Tabela 6.5.3 - Sítio de coleta $\mathbf{P}_{\mathbf{3}}$ - Araraquara 2006: tempos de coleta e massas $(\mu \mathrm{g})$ para $\mathrm{CH}_{4}$ e $\mathrm{CO}_{2}$.

\begin{tabular}{rcc}
\hline Tempo $(\mathrm{min})$ & Massa do $\mathrm{CH}_{4}(\mu \mathrm{g})$ & Massa do $\mathrm{CO}_{2}(\mu \mathrm{g})$ \\
\hline 0 & 10,8885 & 10,4215 \\
3 & 10,9441 & 10,9130 \\
6 & 10,9989 & 13,5585 \\
12 & 14,2718 & 19,5598 \\
\hline
\end{tabular}

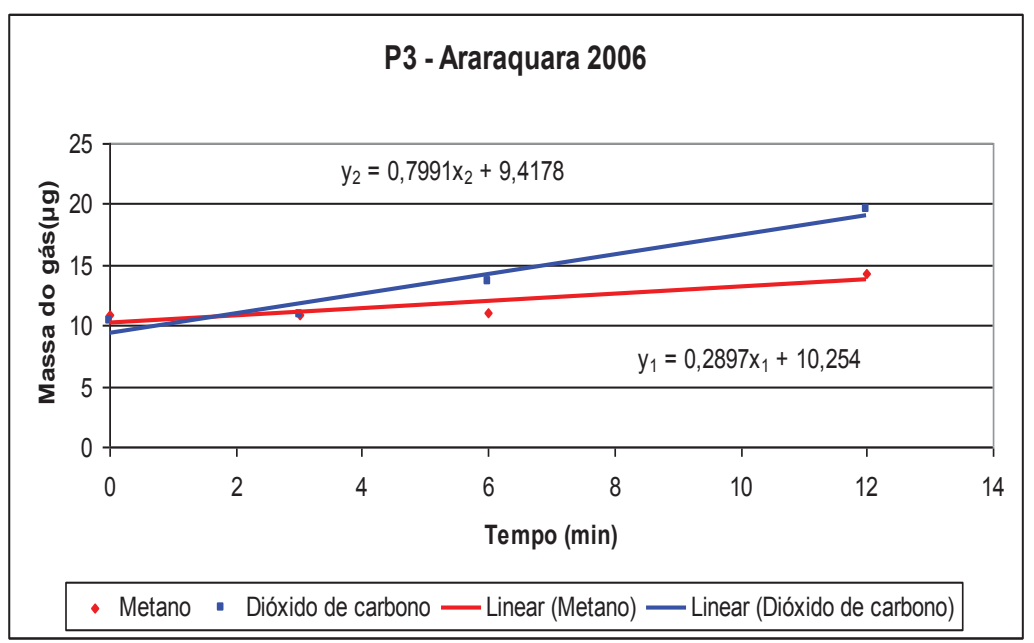

Gráfico 6.5.3 - Sítio $\mathbf{P}_{3}$ - Araraquara 2006. Equações de retas e inclinações para $\mathrm{CH}_{4}$ e $\mathrm{CO}_{2}$.

Equações das retas:

$$
\begin{aligned}
& y_{1}=0,2897 x_{1}+10,254 \text { Equação do metano } \\
& y_{2}=0,7991 x_{2}+9,4178 \text { Equação do dióxido }
\end{aligned}
$$

b) Cálculo da taxa de emissão: 
$\left.b_{1}\right)$ Metano:

$$
\begin{aligned}
& \mathrm{T}_{\mathrm{x}} \mathrm{E}\left(\mathrm{CH}_{4}\right)=\frac{0,2897 \mu \mathrm{g}\left(\mathrm{CH}_{4}\right) \times 33.200 \mathrm{~mL} \times 1440 \mathrm{~min} \times g}{m L \times \min \times 0664 \mathrm{~m}^{2} \times \operatorname{dia} \times 10^{6} \mu g} \\
& \operatorname{TxE}\left(\mathrm{CH}_{4}\right)=20,86 \mathrm{~g} \times \mathrm{m}^{-2} \cdot d^{-1}\left(\mathrm{CH}_{4}\right) \text { No sítio de coleta } \mathrm{P}_{3} .
\end{aligned}
$$

$\mathrm{b}_{2}$ ) Dióxido de carbono: $\operatorname{Tx} E\left(\mathrm{CO}_{2}\right)=\frac{0,7991 \mu \mathrm{g}\left(\mathrm{CO}_{2}\right) \times 33.200 \mathrm{~mL} \times 1440 \mathrm{~min} \times \mathrm{g}}{\mathrm{mL} \times \min \times 0,664 \mathrm{~m}^{2} \times \operatorname{dia} \times 10^{6} \mu \mathrm{g}}$

$$
\operatorname{Tx} E\left(\mathrm{CO}_{2}\right)=57,53 \mathrm{~g} \times \mathrm{m}^{-2} \cdot \mathrm{d}^{-1}\left(\mathrm{CO}_{2}\right) \text { No sítio de coleta } \mathrm{P}_{3} .
$$

$\mathbf{P}_{4}\left(\mathrm{G} ; \mathrm{V}_{\mathrm{G}}=33.200 \mathrm{~mL}\right.$ e $\left.A_{G}=0,664 \mathrm{~m}^{2}\right)$

a) Tabela com tempos de coleta e massas correspondentes, gráfico com equações de retas e inclinações:

Tabela 6.5.4 - Sítio de coleta $\mathbf{P}_{\mathbf{4}}$ - Araraquara 2006: tempos de coleta e massas $(\mu \mathrm{g})$ para $\mathrm{CH}_{4}$ e $\mathrm{CO}_{2}$.

\begin{tabular}{ccc}
\hline Tempo $(\mathrm{min})$ & Massa do $\mathrm{CH}_{4}(\mu \mathrm{g})$ & Massa do $\mathrm{CO}_{2}(\mu \mathrm{g})$ \\
\hline 0 & 10,9085 & 10,5224 \\
3 & 11,2754 & 12,7817 \\
6 & 26,2650 & 43,3270 \\
12 & 12,8429 & 16,2555 \\
\hline
\end{tabular}

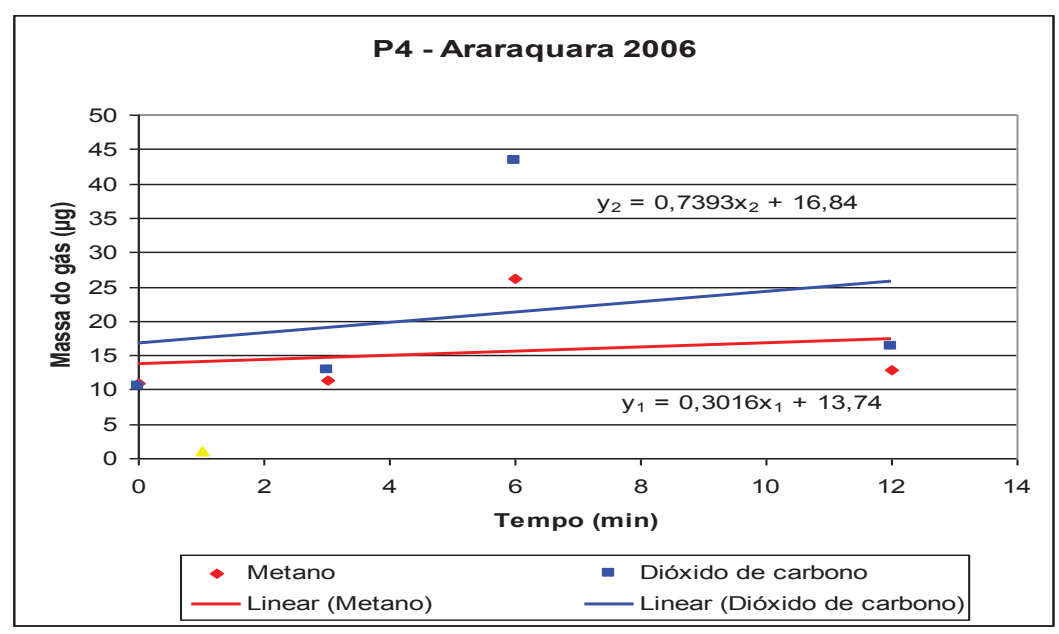

Gráfico 6.5.4 - Sítio $\mathrm{P}_{4}$ - Araraquara 2006. Equações de retas e inclinações para $\mathrm{CH}_{4}$ e $\mathrm{CO}_{2}$. 
Equações das retas:

$$
\begin{aligned}
& y_{1}=0,3016 x_{1}+13,74 \text { Equação do metano } \\
& y_{2}=0,7393 x_{2}+16,84 \text { Equação do dióxido }
\end{aligned}
$$

b) Cálculo da taxa de emissão:

$\left.b_{1}\right)$ Metano:

$$
\operatorname{TxE}\left(\mathrm{CH}_{4}\right)=\frac{0,3017 \mu g\left(\mathrm{CO}_{2}\right) \times 33.200 \mathrm{~mL} \times 1440 \mathrm{~min} \times g}{m L \times \min \times 0,664 \mathrm{~m}^{2} \times \operatorname{dia} \times 10^{6} \mu \mathrm{g}}
$$

$$
\operatorname{TxE}\left(\mathrm{CH}_{4}\right)=21,72 \mathrm{~g} \times \mathrm{m}^{-2} \cdot \mathrm{d}^{-1}\left(\mathrm{CH}_{4}\right) \text { No sítio de coleta } \mathrm{P}_{4} \text {. }
$$

$\mathrm{b}_{2}$ ) Dióxido de carbono: $\operatorname{Tx} E\left(C \mathrm{CO}_{2}\right)=\frac{0,7393 \mu \mathrm{g}\left(\mathrm{CO}_{2}\right) \times 33.200 \mathrm{~mL} \times 1440 \mathrm{~min} \times \mathrm{g}}{\mathrm{mL} \times \min \times 0,664 \mathrm{~m}^{2} \times \operatorname{dia} \times 10^{6} \mu \mathrm{g}}$

$$
\operatorname{Tx} E\left(\mathrm{CO}_{2}\right)=53,23 \mathrm{~g} \times \mathrm{m}^{-2} \cdot \mathrm{d}^{-1}\left(\mathrm{CO}_{2}\right) \quad \text { No sítio de coleta } \mathrm{P}_{4} \text {. }
$$

\section{Emissão solo-ar - campanha 2006:}

A tabela 6.5.5, resume as taxas de emissão solo-ar, medidas para $\mathrm{CH}_{4}$ e $\mathrm{CO}_{2}$, em cada sítio $\mathbf{P}_{\mathbf{n}}$ do aterro de Araraquara, na campanha de 2006.

Tabela 6.5.5 - Resumo da taxa de emissão solo-ar - Araraquara 2006

\begin{tabular}{ccc}
\hline Sítio amostrado & Gás & $\mathrm{T}_{\mathrm{x}} \mathrm{E}\left(\mathrm{g} \cdot \mathrm{m}^{-2} \cdot \mathrm{d}^{-1}\right)$ \\
\hline $\mathrm{P}_{1}$ & $\mathrm{CH}_{4}$ & 7,82 \\
& $\mathrm{CO}_{2}$ & 3,81 \\
& $\mathrm{CH}_{4}$ & 3,95 \\
$\mathrm{P}_{2}$ & $\mathrm{CO}_{2}$ & 3,85 \\
& $\mathrm{CH}_{4}$ & 20,86 \\
$\mathrm{P}_{3}$ & $\mathrm{CO}_{2}$ & 57,53 \\
& $\mathrm{CH}_{4}$ & 21,72 \\
\hline $\mathrm{P}_{4}$ & $\mathrm{CO}_{2}$ & 53,25 \\
\hline
\end{tabular}


1) Cálculo da taxa de emissão média do Metano $\left(T_{x} E_{m}\left({ }_{(C H 4)}\right)\right.$ nos sítios $\left(P_{n}\right)$ :

$$
T_{x} E_{m(C H 4)}=\left(P_{1}+\ldots+P_{4}\right) / 4=13,59 \mathrm{~g} \cdot \mathrm{m}^{-2} \cdot \mathrm{d}^{-1}
$$

2) Taxa de emissão média total do metano $\left(\mathrm{TxE}_{\mathrm{m}(\mathrm{t})(\mathrm{CH} 4)}\right)$ no aterro :

$$
\begin{aligned}
\Rightarrow \operatorname{TxE}_{m(t)}= & T_{x} E_{m}\left(13,59 \mathrm{~g} \cdot \mathrm{m}^{-2} \cdot \mathrm{d}^{-1}\right) \cdot A_{a t}\left(80.000 \mathrm{~m}^{2}\right) \cdot 365 \mathrm{~d} \cdot 10^{-6}=396,83 \mathrm{t} \cdot \mathrm{a}^{-1} \\
& \Rightarrow T_{x} E_{m(t)}\left(\mathrm{CH}_{4}\right)=\mathbf{3 9 6 , 8 3} \mathbf{t} \cdot \mathbf{a}^{-1}
\end{aligned}
$$

Em que: $T_{x} E_{m}=$ Taxa de Emissão média $\left(\mathrm{g} \cdot \mathrm{m}^{-2} \cdot \mathrm{d}^{-1}\right)$

$$
\begin{aligned}
\mathrm{A}_{\mathrm{at}} & =\text { Área do aterro }\left(\mathrm{m}^{2}\right) \\
\mathrm{T}_{\mathrm{x}} \mathrm{E}_{\mathrm{m}(\mathrm{t})} & =\text { Taxa de Emissão média total para } 2006\left({\text { Toneladas } \left.\cdot a n o^{-1}\right)}\right. \\
365 & =\text { fator de conversão de dias para ano } \\
10^{-6} & =\text { fator de conversão de } g \text { para Tonelada }
\end{aligned}
$$

3) Cálculo da taxa de emissão média do dióxido de carbono ( $\left.T_{x} E_{m}\left(C_{2}\right)\right)$ nos sítios $\left(P_{n}\right)$ :

$$
T_{x} E_{m}\left(C O_{2}\right)=\left(P_{1}+\ldots+P_{4}\right) / 4=29,60 g \cdot m^{-2} \cdot d^{-1}
$$

4) Cálculo da taxa de emissão média total do dióxido de carbono $\left(\operatorname{TxE}_{\mathrm{m}(\mathrm{t})(\mathrm{CO} 2)}\right)$ no aterro :

$$
\Rightarrow T_{x} E_{m(t)}=T_{x} E_{m} \cdot A_{a t} \cdot 365 \cdot 10^{-6}=\mathbf{8 6 4 , 6 1} \mathbf{t} \cdot \mathbf{a}^{-1}
$$




\section{A 2 ) Campanha 2007}

$\mathbf{P}_{1}\left(\mathrm{G} ; \mathrm{V}_{\mathrm{G}}=33.200 \mathrm{~mL} ; \mathrm{A}_{\mathrm{G}}=0,664 \mathrm{~m}^{2}\right)$

a) Tabela com tempos de coleta e massas correspondentes, gráfico com equações de retas e inclinações:

Tabela 6.5.6 - Sítio de coleta $\mathbf{P}_{\mathbf{1}}$ - Araraquara 2007: tempos de coleta e massas $(\mu g)$ para $\mathrm{CH}_{4}$ e $\mathrm{CO}_{2}$.

\begin{tabular}{ccc}
\hline Tempo $(\mathrm{min})$ & Massa do $\mathrm{CH}_{4}(\mu \mathrm{g})$ & Massa do $\mathrm{CO}_{2}(\mu \mathrm{g})$ \\
\hline 0 & 10,2124 & 7,4606 \\
3 & 13,5492 & 16,9807 \\
6 & 15,9671 & 23,0143 \\
12 & 14,1879 & 18,5020 \\
\hline
\end{tabular}

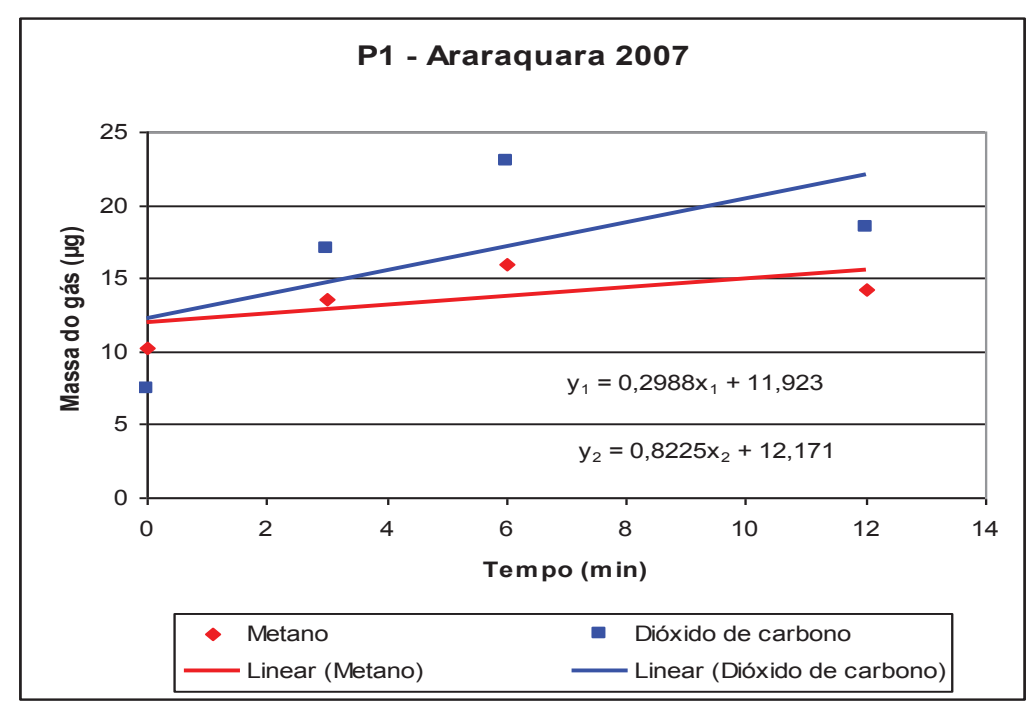

Gráfico 6.5.5 - Sítio $\mathrm{P}_{1}$ - Araraquara 2007. Equações de retas e inclinações para $\mathrm{CH}_{4}$ e $\mathrm{CO}_{2}$.

Equações das retas:

$$
\begin{aligned}
& y_{1}=0,2988 x_{1}+11,923 \text { Equação do metano } \\
& y_{2}=0,8225 x_{2}+12,171 \text { Equação do dióxido }
\end{aligned}
$$


b) Cálculo da taxa de emissão:

$\left.b_{1}\right)$ Metano:

$$
\operatorname{TxE}\left(\mathrm{CH}_{4}\right)=\frac{0,2988 \mu g\left(\mathrm{CO}_{2}\right) \times 33.200 \mathrm{~mL} \times 1440 \mathrm{~min} \times g}{m L \times \min \times 0,664 \mathrm{~m}^{2} \times \operatorname{dia} \times 10^{6} \mu g}
$$

$$
\operatorname{TxE}\left(\mathrm{CH}_{4}\right)=21,51 \mathrm{~g} \times \mathrm{m}^{-2} \cdot \mathrm{d}^{-1}\left(\mathrm{CH}_{4}\right) \text { No sítio de coleta } \mathrm{P}_{1} \text {. }
$$

$\left.\mathrm{b}_{2}\right)$ dióxido de carbono: $\operatorname{Tx} E\left(\mathrm{CO}_{2}\right)=\frac{0,8225 \mu \mathrm{g}\left(\mathrm{CO}_{2}\right) \times 33.200 \mathrm{~mL} \times 1440 \mathrm{~min} \times \mathrm{g}}{\mathrm{mL} \times \min \times 0,664 \mathrm{~m}^{2} \times \operatorname{dia} \times 10^{6} \mu \mathrm{g}}$

$$
\operatorname{TxE}\left(\mathrm{CO}_{2}\right)=59,22 \mathrm{~g} \times \mathrm{m}^{-2} \cdot \mathrm{d}^{-1}\left(\mathrm{CO}_{2}\right) \text { No sítio de coleta } \mathrm{P}_{1} \text {. }
$$

$\mathbf{P}_{\mathbf{2}}\left(\mathrm{p} ; \mathrm{V}_{\mathrm{p}}=1.200 m L\right.$ e $\left.\mathrm{A}_{\mathrm{p}}=0,664 \mathrm{~m}^{2}\right)$

a) Tabela com tempos de coleta e massas correspondentes, gráfico com equações de retas e inclinações:

Tabela 6.5.7 - Sítio de coleta $\mathbf{P}_{\mathbf{2}}$ - Araraquara 2007: tempos de coleta e massas $(\mu g)$ para $\mathrm{CH}_{4}$ e $\mathrm{CO}_{2}$.

\begin{tabular}{ccc}
\hline Tempo $(\mathrm{min})$ & Massa do $\mathrm{CH}_{4}(\mu \mathrm{g})$ & Massa do $\mathrm{CO}_{2}(\mu \mathrm{g})$ \\
\hline 0 & 0 & 7,3962 \\
3 & 10,6449 & 8,4948 \\
6 & 10,7972 & 10,6682 \\
12 & 14,4488 & 24,0300 \\
\hline
\end{tabular}




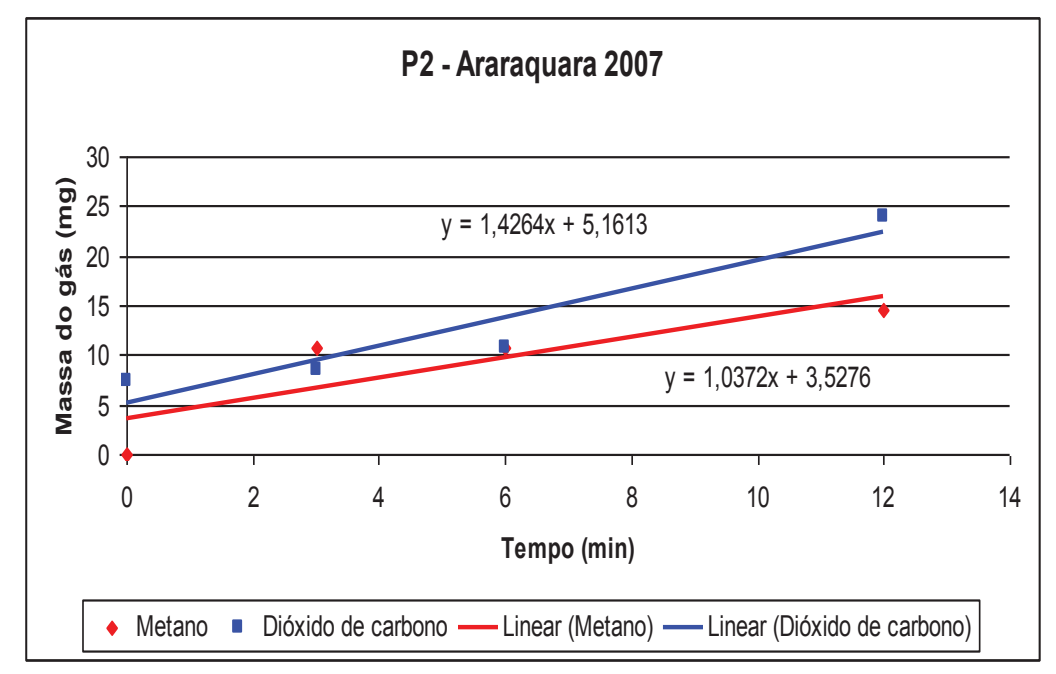

Gráfico 6.5.6 - Sítio $\mathbf{P}_{\mathbf{2}}$ - Araraquara 2007. Equações de retas e inclinações para $\mathrm{CH}_{4}$ e $\mathrm{CO}_{2}$.

Equações das retas:

$$
\begin{aligned}
& y_{1}=1,0372 x_{1}+3,5276 \text { Equação do metano } \\
& y_{2}=1,4226 x_{2}+5,1613 \text { Equação do dióxido }
\end{aligned}
$$

b) Cálculo da taxa de emissão:

$b_{1}$ ) Metano:

$$
\operatorname{Tx} E\left(\mathrm{CH}_{4}\right)=\frac{1,0372 \mu \mathrm{g}\left(\mathrm{CO}_{2}\right) \times 1.200 \mathrm{~mL} \times 1440 \mathrm{~min} \times g}{m L \times \min \times 0,01815 \mathrm{~m}^{2} \times \operatorname{dia} \times 10^{6} \mu \mathrm{g}}
$$

$$
\operatorname{TxE}\left(\mathrm{CH}_{4}\right)=98,75 \mathrm{~g} \times \mathrm{m}^{-2} \cdot \mathrm{d}^{-1}\left(\mathrm{CH}_{4}\right) \text { No sítio de coleta } \mathrm{P}_{2} \text {. }
$$

$\mathrm{b}_{2}$ ) Dióxido de carbono: $\operatorname{Tx} E\left(\mathrm{CO}_{2}\right)=\frac{1,4226 \mu \mathrm{g}\left(\mathrm{CO}_{2}\right) \times 1.200 \mathrm{~mL} \times 1440 \mathrm{~min} \times \mathrm{g}}{\mathrm{mL} \times \min \times 0,01815 \mathrm{~m}^{2} \times \operatorname{dia} \times 10^{6} \mu \mathrm{g}}$

$$
\operatorname{Tx} E\left(\mathrm{CO}_{2}\right)=135,44 \mathrm{~g} \times \mathrm{m}^{-2} \cdot \mathrm{d}^{-1}\left(\mathrm{CO}_{2}\right) \quad \text { No sítio de coleta } \mathrm{P}_{2} \text {. }
$$


$\mathbf{P}_{3}\left(\mathrm{G} ; \mathrm{V}_{\mathrm{G}}=33.200 \mathrm{~mL} ; \mathrm{A}_{\mathrm{G}}=0,664 \mathrm{~m}^{2}\right)$

a) Tabela com tempos de coleta e massas correspondentes, gráfico com equações de retas e inclinações:

Tabela 6.5.8 - Sítio de coleta $\mathbf{P}_{\mathbf{3}}$ - Araraquara 2006: tempos de coleta e massas $(\mu g)$ para $\mathrm{CH}_{4}$ e $\mathrm{CO}_{2}$.

\begin{tabular}{ccc}
\hline Tempo $(\mathrm{min})$ & Massa do $\mathrm{CH}_{4}(\mu \mathrm{g})$ & Massa do $\mathrm{CO}_{2}(\mu \mathrm{g})$ \\
\hline 0 & 10,5007 & 8,3253 \\
3 & 12,6012 & 15,0175 \\
6 & 29,0671 & 84,6068 \\
12 & 12,9597 & 19,7937 \\
\hline
\end{tabular}

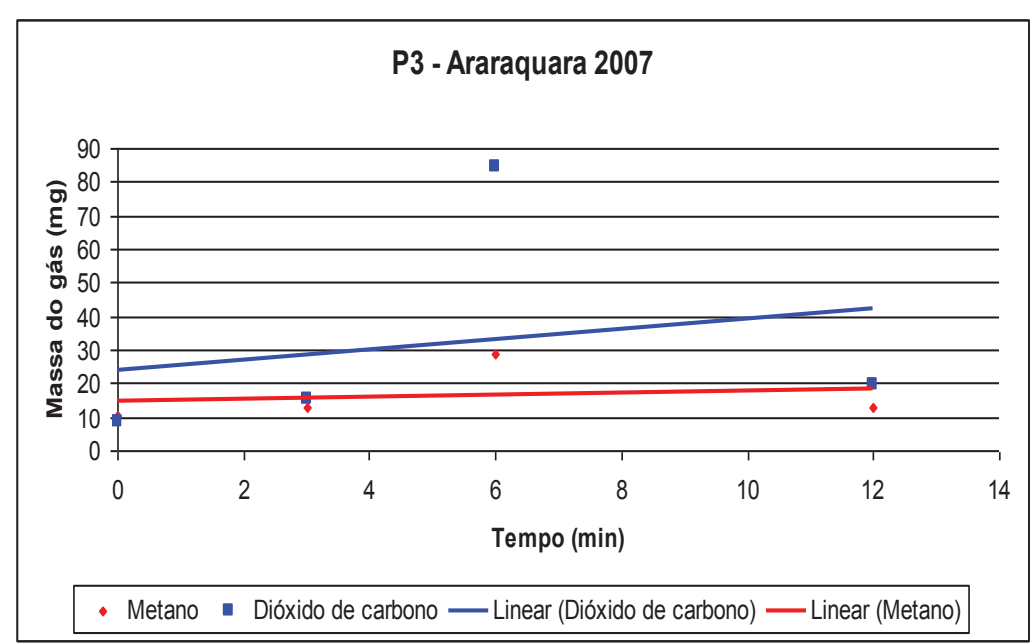

Gráfico 6.5.7 - Sítio $\mathrm{P}_{3^{-}}$-Araraquara 2007. Equações de retas e inclinações para $\mathrm{CH}_{4}$ e $\mathrm{CO}_{2}$.

Equações das retas:

$$
\begin{aligned}
& y_{1}=0,3276 x_{1}+14,562 \text { Equação do metano } \\
& y_{2}=1,5190 x_{2}+23,959 \quad \text { Equação do dióxido }
\end{aligned}
$$

b) Cálculo da taxa de emissão: 
$\left.b_{1}\right)$ Metano:

$$
\operatorname{Tx} E\left(\mathrm{CH}_{4}\right)=\frac{0,3276 \mu g\left(\mathrm{CO}_{2}\right) \times 33.200 \mathrm{~mL} \times 1440 \mathrm{~min} \times g}{m L \times \min \times 0,664 \mathrm{~m}^{2} \times \operatorname{dia} \times 10^{6} \mu g}
$$

$$
\mathrm{Tx}\left(\mathrm{CH}_{4}\right)=23,59 \mathrm{~g} \times \mathrm{m}^{-2} \cdot \mathrm{d}^{-1}\left(\mathrm{CH}_{4}\right) \text { No sítio de coleta } \mathrm{P}_{3} \text {. }
$$

$\mathrm{b}_{2}$ ) Dióxido de carbono: $\operatorname{Tx} E\left(\mathrm{CO}_{2}\right)=\frac{1,5190 \mu \mathrm{g}\left(\mathrm{CO}_{2}\right) \times 33.200 \mathrm{~mL} \times 1440 \mathrm{~min} \times \mathrm{g}}{\mathrm{mL} \times \min \times 0,664 \mathrm{~m}^{2} \times \operatorname{dia} \times 10^{6} \mu \mathrm{g}}$

$$
\operatorname{TxE}\left(\mathrm{CO}_{2}\right)=109,37 \mathrm{~g} \times \mathrm{m}^{-2} \cdot \mathrm{d}^{-1}\left(\mathrm{CO}_{2}\right) \text { No sítio de coleta } \mathrm{P}_{3} \text {. }
$$

$\mathbf{P}_{4}\left(\mathrm{G} ; \mathrm{V}_{\mathrm{G}}=33.200 \mathrm{~mL} ; \mathrm{A}_{\mathrm{G}}=0,664 \mathrm{~m}^{2}\right)$

a) Tabela com tempos de coleta e massas correspondentes, gráfico com equações de retas e inclinações:

Tabela 6.5.9 - Sítio de coleta $\mathbf{P}_{\mathbf{4}}$ - Araraquara 2007: tempos de coleta e massas $(\mu g)$ para $\mathrm{CH}_{4}$ e $\mathrm{CO}_{2}$.

\begin{tabular}{ccc}
\hline Tempo $(\boldsymbol{m i n})$ & Massa do $\mathrm{CH}_{\mathbf{4}}(\mu \mathrm{g})$ & Massa do $\mathrm{CO}_{\mathbf{2}}(\boldsymbol{\mu g})$ \\
\hline 0 & 0 & 7,4091 \\
3 & 10,4834 & 8,2051 \\
6 & 13,5310 & 20,4610 \\
12 & 13,1021 & 17,9870 \\
\hline
\end{tabular}




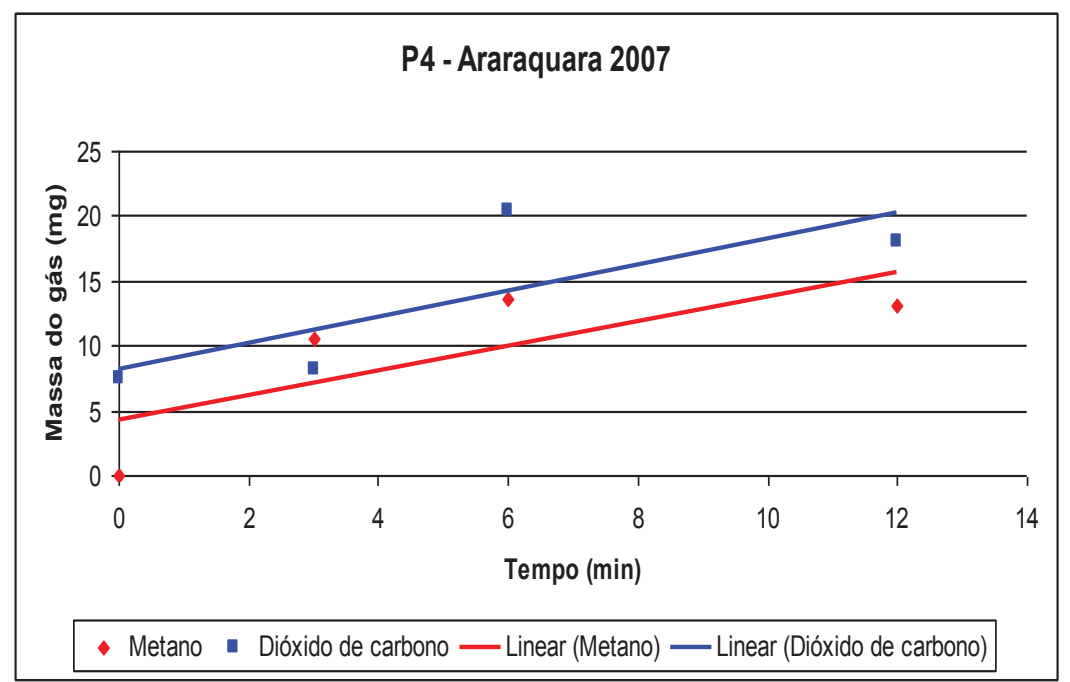

Gráfico 6.5.8 - Sítio $\mathbf{P}_{\mathbf{4}}$ - Araraquara 2007. Equações de retas e inclinações para $\mathrm{CH}_{4}$ e $\mathrm{CO}_{2}$.

Equações das retas:

$$
\begin{aligned}
& y_{1}=0,9524 x_{1}+4,2791 \text { Equação do metano } \\
& y_{2}=1,0082 x_{2}+8,2223 \text { Equação do dióxido }
\end{aligned}
$$

b) Cálculo da taxa de emissão:

b) Metano: $\quad \operatorname{Tx} E\left(\mathrm{CH}_{4}\right)=\frac{0,9524 \mu g\left(\mathrm{CO}_{2}\right) \times 33.200 \mathrm{~mL} \times 1440 \mathrm{~min} \times g}{\mathrm{~mL} \times \min \times 0,664 \mathrm{~m}^{2} \times \operatorname{dia} \times 10^{6} \mu \mathrm{g}}$

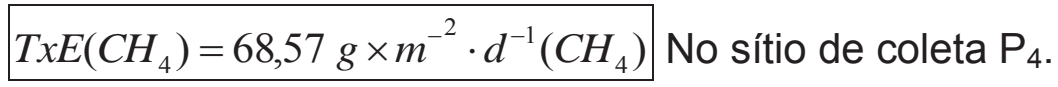

$\mathrm{b}_{2}$ ) Dióxido de carbono: $\operatorname{Tx}\left(\mathrm{CO}_{2}\right)=\frac{1,0082 \mu \mathrm{g}\left(\mathrm{CO}_{2}\right) \times 33.200 \mathrm{~mL} \times 1440 \mathrm{~min} \times \mathrm{g}}{\mathrm{mL} \times \min \times 0,664 \mathrm{~m}^{2} \times \operatorname{dia} \times 10^{6} \mu \mathrm{g}}$

$$
\operatorname{Tx} E\left(\mathrm{CO}_{2}\right)=72,59 \mathrm{~g} \times \mathrm{m}^{-2} \cdot \mathrm{d}^{-1}\left(\mathrm{CO}_{2}\right) \quad \text { No sítio de coleta } \mathrm{P}_{4} \text {. }
$$


$P_{5}\left(p ; V_{P}=1.200 m L\right.$ e $\left.A_{P}=0,01815 m^{2}\right)$

a) Tabela com tempos de coleta e massas correspondentes, gráfico com equações de retas e inclinações:

Tabela 6.5.10 - Sítio de coleta $\mathbf{P}_{\mathbf{5}}$ - Araraquara 2007: tempos de coleta e massas $(\mu g)$ para $\mathrm{CH}_{4}$ e $\mathrm{CO}_{2}$.

\begin{tabular}{ccc}
\hline Tempo $(\boldsymbol{m i n})$ & Massa do $\mathrm{CH}_{4}(\mu \boldsymbol{g})$ & Massa do $\mathrm{CO}_{2}(\mu \mathrm{g})$ \\
\hline 0 & 11,8228 & 12,4921 \\
3 & 12,3557 & 13,8331 \\
6 & 14,0501 & 18,0900 \\
12 & 14,6587 & 19,7272 \\
\hline
\end{tabular}

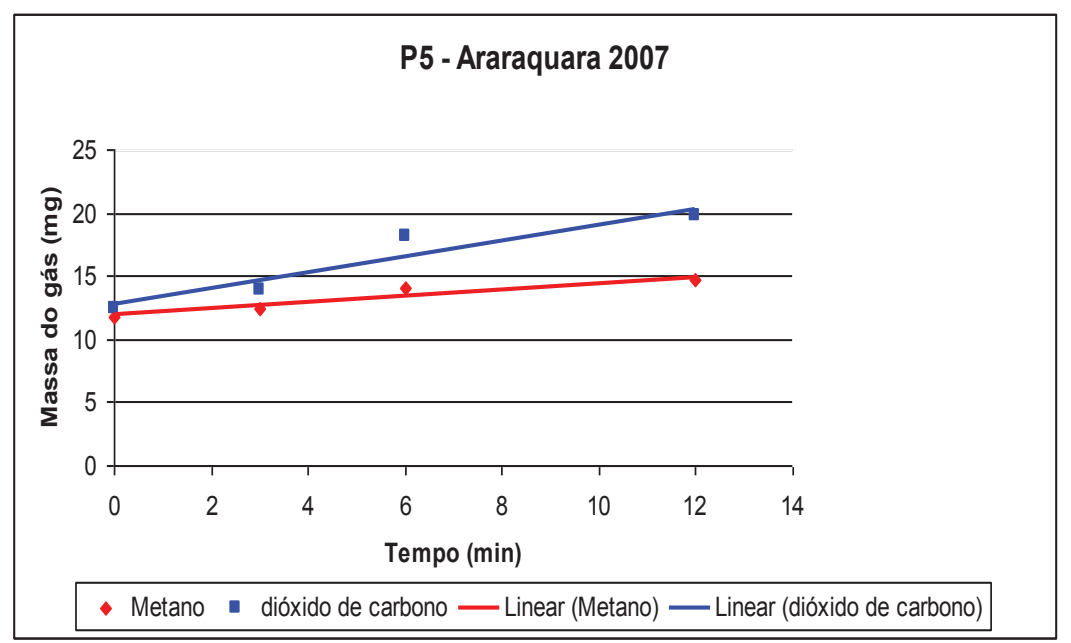

Gráfico 6.5.9 - Sítio $\mathbf{P}_{\mathbf{5}}$ - Araraquara 2007. Equações de retas e inclinações para $\mathrm{CH}_{4}$ e $\mathrm{CO}_{2}$.

Equações das retas:

$$
\begin{aligned}
& y_{1}=0,2491 x_{1}+11,914 \text { Equação do metano } \\
& y_{2}=0,6352 x_{2}+12,701 \text { Equação do dióxido }
\end{aligned}
$$


b) Cálculo da taxa de emissão:

$\left.b_{1}\right)$ Metano:

$$
\operatorname{TxE}\left(\mathrm{CH}_{4}\right)=\frac{0,2491 \mu \mathrm{g}\left(\mathrm{CO}_{2}\right) \times 1.200 \mathrm{~mL} \times 1440 \mathrm{~min} \times g}{m L \times \min \times 0,01815 \mathrm{~m}^{2} \times \operatorname{dia} \times 10^{6} \mu \mathrm{g}}
$$

$$
\operatorname{TxE}\left(\mathrm{CH}_{4}\right)=23,71 \mathrm{~g} \times \mathrm{m}^{-2} \cdot \mathrm{d}^{-1}\left(\mathrm{CH}_{4}\right) \text { No sítio de coleta } \mathrm{P}_{5} \text {. }
$$

$\mathrm{b}_{2}$ ) Dióxido de carbono: $\operatorname{Tx} E\left(\mathrm{CO}_{2}\right)=\frac{0,6352 \mu \mathrm{g}\left(\mathrm{CO}_{2}\right) \times 1.200 \mathrm{~mL} \times 1440 \mathrm{~min} \times \mathrm{g}}{\mathrm{mL} \times \min \times 0,01815 \mathrm{~m}^{2} \times \operatorname{dia} \times 10^{6} \mu \mathrm{g}}$

$$
\operatorname{TxE}\left(\mathrm{CO}_{2}\right)=60,47 \mathrm{~g} \times \mathrm{m}^{-2} \cdot \mathrm{d}^{-1}\left(\mathrm{CO}_{2}\right) \quad \text { No sítio de coleta } \mathrm{P}_{5} \text {. }
$$

$\mathbf{P}_{6}\left(\mathrm{G} ; \mathrm{V}_{\mathrm{G}}=33.200 \mathrm{~mL} ; \mathrm{A}_{\mathrm{G}}=0,664 \mathrm{~m}^{2}\right)$

a) Tabela com tempos de coleta e massas correspondentes, gráfico com equações de retas e inclinações:

Tabela 6.5.11 - Sítio de coleta $\mathbf{P}_{\mathbf{6}}$ - Araraquara 2007: tempos de coleta e massas $(\mu g)$ para $\mathrm{CH}_{4}$ e $\mathrm{CO}_{2}$.

\begin{tabular}{ccc}
\hline Tempo (min) & Massa do $\mathrm{CH}_{4}(\mu g)$ & Massa do $\mathrm{CO}_{2}(\mu g)$ \\
\hline 0 & 10,2114 & 7,4327 \\
3 & 11,9624 & 14,3802 \\
6 & 26,3233 & 50,1952 \\
12 & 16,0400 & 17,3670 \\
\hline
\end{tabular}




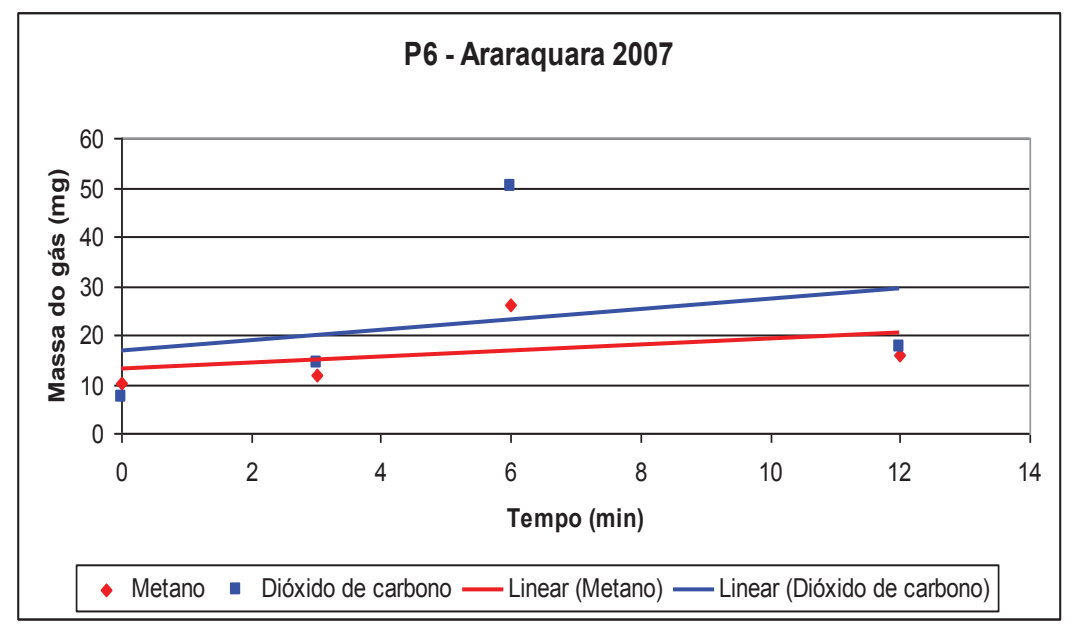

Gráfico 6.5.10 - Sítio $\mathbf{P}_{6}$ - Araraquara 2007. Equações de retas e inclinações para $\mathrm{CH}_{4}$ e $\mathrm{CO}_{2}$.

Equações das retas:

$$
\begin{aligned}
& y_{1}=0,603 x_{1}+12,968 \text { Equação do metano } \\
& y_{2}=1,0603 x_{2}+16,777 \text { Equação do dióxido }
\end{aligned}
$$

b) Cálculo da taxa de emissão:

b) Metano: $\quad \operatorname{Tx} E\left(\mathrm{CH}_{4}\right)=\frac{0,603 \mu g\left(\mathrm{CO}_{2}\right) \times 33.200 \mathrm{~mL} \times 1440 \mathrm{~min} \times g}{m L \times \min \times 0,664 \mathrm{~m}^{2} \times \operatorname{dia} \times 10^{6} \mu g}$

$$
\operatorname{Tx} E\left(\mathrm{CH}_{4}\right)=43,41 \mathrm{~g} \times \mathrm{m}^{-2} \cdot \mathrm{d}^{-1}\left(\mathrm{CH}_{4}\right) \text { No sítio de coleta } \mathrm{P}_{6} \text {. }
$$

$\mathrm{b}_{2}$ ) Dióxido de carbono: $\operatorname{Tx} E\left(\mathrm{CO}_{2}\right)=\frac{1,0603 \mu \mathrm{g}\left(\mathrm{CO}_{2}\right) \times 33.200 \mathrm{~mL} \times 1440 \mathrm{~min} \times g}{\mathrm{~mL} \times \min \times 0,664 \mathrm{~m}^{2} \times \operatorname{dia} \times 10^{6} \mu \mathrm{g}}$

$$
\operatorname{TxE}\left(\mathrm{CO}_{2}\right)=76,34 \mathrm{~g} \times \mathrm{m}^{-2} \cdot \mathrm{d}^{-1}\left(\mathrm{CO}_{2}\right) \text { No sítio de coleta } \mathrm{P}_{6} \text {. }
$$


$\mathbf{P}_{7}\left(\mathrm{G} ; \mathrm{V}_{\mathrm{G}}=33.200 \mathrm{~mL} ; \mathrm{A}_{\mathrm{G}}=0,664 \mathrm{~m}^{2}\right)$

a) Tabela com tempos de coleta e massas correspondentes, gráfico com equações de retas e inclinações:

Tabela 6.5.12 - Sítio de coleta $\mathbf{P}_{\mathbf{7}}$ - Araraquara 2007: tempos de coleta e massas $(\mu \mathrm{g})$ para $\mathrm{CH}_{4}$ e $\mathrm{CO}_{2}$.

\begin{tabular}{ccc}
\hline Tempo (min) & Massa do $\mathrm{CH}_{4}(\mu g)$ & Massa do $\mathrm{CO}_{2}(\mu g)$ \\
\hline 0 & 10,2114 & 7,4327 \\
3 & 11,9624 & 14,3802 \\
6 & 26,3233 & 50,1952 \\
12 & 16,0400 & 17,3670 \\
\hline
\end{tabular}

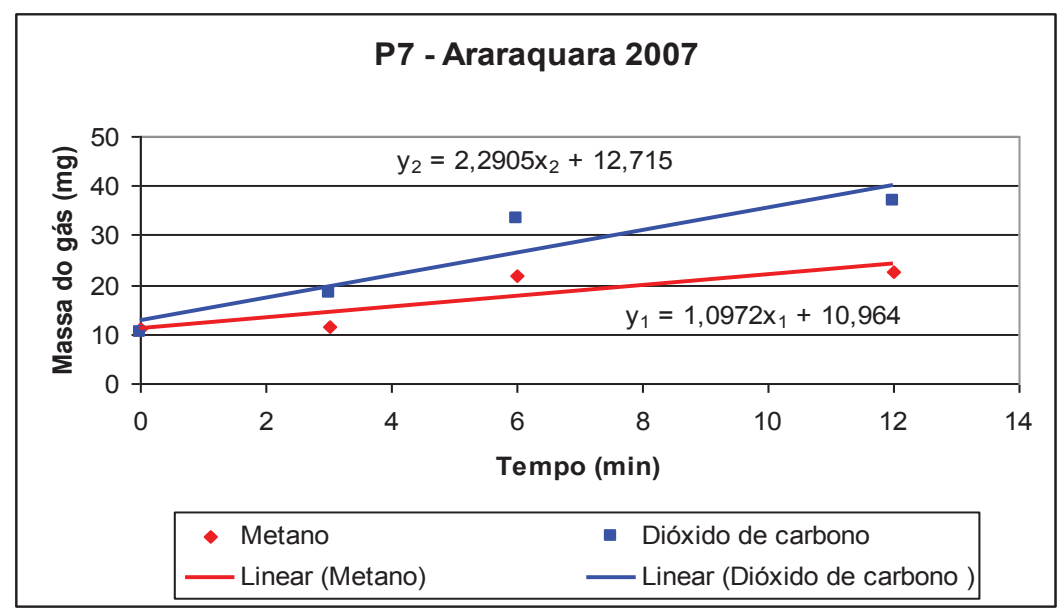

Gráfico 6.5.11 - Sítio $\mathbf{P}_{\mathbf{7}}$ - Araraquara 2007. Equações de retas e inclinações para $\mathrm{CH}_{4}$ e $\mathrm{CO}_{2}$.

Equações das retas:

$$
\begin{aligned}
& y_{1}=1,0972 x_{1}+10,964 \quad \text { Equação do metano } \\
& y_{2}=2,2905 x_{2}+12,715 \quad \text { Equação do dióxido }
\end{aligned}
$$

b) Cálculo da taxa de emissão:

b) Metano: $\quad \operatorname{Tx} E\left(\mathrm{CH}_{4}\right)=\frac{1,0972 \mu g\left(\mathrm{CO}_{2}\right) \times 33.200 \mathrm{~mL} \times 1440 \mathrm{~min} \times g}{m L \times \min \times 0,664 \mathrm{~m}^{2} \times \operatorname{dia} \times 10^{6} \mu \mathrm{g}}$ 


$$
\mathrm{TxE}\left(\mathrm{CH}_{4}\right)=79,00 \mathrm{~g} \times \mathrm{m}^{-2} \cdot \mathrm{d}^{-1}\left(\mathrm{CH}_{4}\right) \text { No sítio de coleta } \mathrm{P}_{7} \text {. }
$$

$\left.\mathrm{b}_{2}\right)$ Dióxido de carbono: $\operatorname{Tx} E\left(\mathrm{CO}_{2}\right)=\frac{2,2905 \mu \mathrm{g}\left(\mathrm{CO}_{2}\right) \times 33.200 \mathrm{~mL} \times 1440 \mathrm{~min} \times \mathrm{g}}{\mathrm{mL} \times \min \times 0,664 \mathrm{~m}^{2} \times \operatorname{dia} \times 10^{6} \mu \mathrm{g}}$

$$
\operatorname{Tx} E\left(\mathrm{CO}_{2}\right)=164,92 \mathrm{~g} \times \mathrm{m}^{-2} \cdot \mathrm{d}^{-1}\left(\mathrm{CO}_{2}\right) \text { No sítio de coleta } \mathrm{P}_{7} \text {. }
$$

$\mathbf{P}_{8}\left(p ; V_{P}=1.200 m L\right.$ e $\left.A_{P}=0,01815 m^{2}\right)$

a) Tabela com tempos de coleta e massas correspondentes, gráfico com equações de retas e inclinações:

Tabela 6.5.13 - Sítio de coleta $\mathbf{P}_{\mathbf{8}}$ - Araraquara 2007: tempos de coleta e massas $(\mu \mathrm{g})$ para $\mathrm{CH}_{4}$ e $\mathrm{CO}_{2}$.

\begin{tabular}{ccc}
\hline Tempo $(\boldsymbol{m i n})$ & Massa do $\mathrm{CH}_{4}(\mu g)$ & Massa do $\mathrm{CO}_{2}(\mu \mathrm{g})$ \\
\hline 0 & 10,2114 & 7,4327 \\
3 & 11,9624 & 14,3802 \\
6 & 26,3233 & 50,1952 \\
12 & 16,0400 & 17,3670 \\
\hline
\end{tabular}

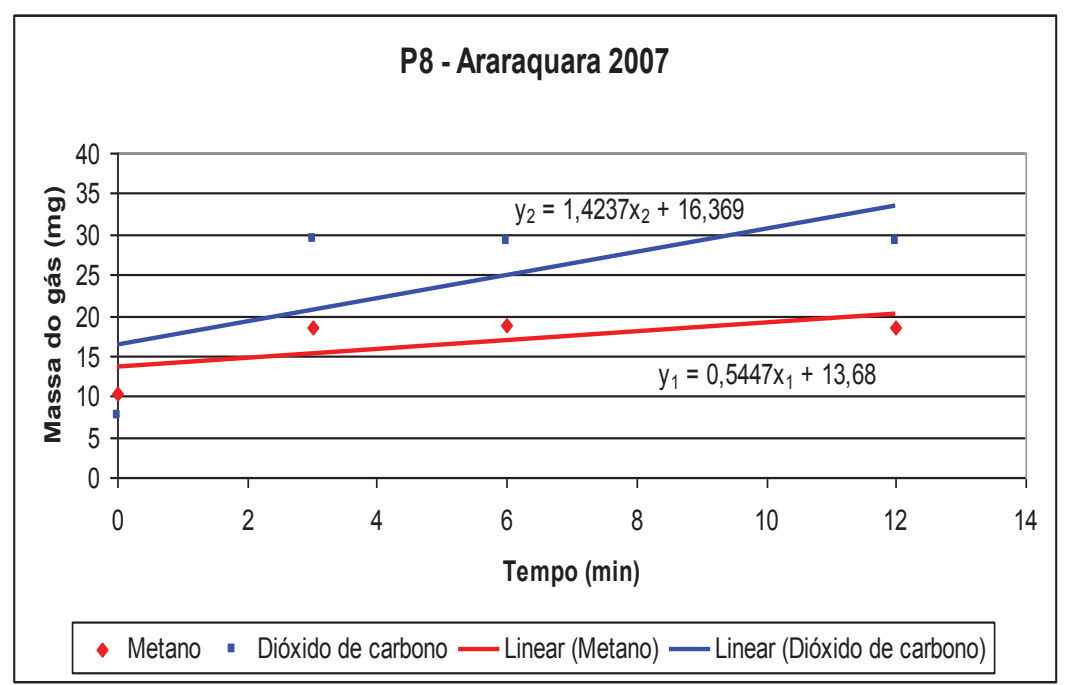

Gráfico 6.5.12 - Sítio $P_{8}$ - Araraquara 2007. Equações de retas e inclinações para $\mathrm{CH}_{4}$ e $\mathrm{CO}_{2}$. 
Equações das retas:

$$
\begin{aligned}
& y_{1}=0,5447 x_{1}+13,68 \quad \text { Equação do metano } \\
& y_{2}=1,4237 x_{2}+16,396 \text { Equação do dióxido }
\end{aligned}
$$

b) Cálculo da taxa de emissão:

$\left.b_{1}\right)$ Metano:

$$
\operatorname{TxE}\left(\mathrm{CH}_{4}\right)=\frac{0,5447 \mu \mathrm{g}\left(\mathrm{CO}_{2}\right) \times 1.200 \mathrm{~mL} \times 1440 \mathrm{~min} \times g}{m L \times \min \times 0,01815 \mathrm{~m}^{2} \times \operatorname{dia} \times 10^{6} \mu \mathrm{g}}
$$

$$
\operatorname{Tx} E\left(\mathrm{CH}_{4}\right)=518,60 \mathrm{~g} \times \mathrm{m}^{-2} \cdot \mathrm{d}^{-1}\left(\mathrm{CH}_{4}\right) \text { No sítio de coleta } \mathrm{P}_{8} \text {. }
$$

$\left.\mathrm{b}_{2}\right)$ Dióxido de carbono: $\operatorname{Tx} E\left(\mathrm{CO}_{2}\right)=\frac{1,4237 \mu \mathrm{g}\left(\mathrm{CO}_{2}\right) \times 1.200 \mathrm{~mL} \times 1440 \mathrm{~min} \times \mathrm{g}}{\mathrm{mL} \times \min \times 0,01815 \mathrm{~m}^{2} \times \operatorname{dia} \times 10^{6} \mu \mathrm{g}}$

$$
\operatorname{TxE}\left(\mathrm{CO}_{2}\right)=135,54 \mathrm{~g} \times \mathrm{m}^{-2} \cdot \mathrm{d}^{-1}\left(\mathrm{CO}_{2}\right) \quad \text { No sítio de coleta } \mathrm{P}_{8} .
$$




\section{Emissão solo-ar campanha 2007:}

A tabela 6.5.14, resume as taxas de emissão solo-ar, medidas para $\mathrm{CH}_{4}$ e $\mathrm{CO}_{2}$, em cada sítio $\mathbf{P}_{\mathbf{n}}$ do aterro de Araraquara, na campanha de 2007 .

Tabela 6.5.14 - Resumo das taxas de emissão solo-ar - Araraquara 2007

\begin{tabular}{ccr}
\hline Sítio amostrado & Gás & $\mathrm{T}_{\mathbf{x}} \mathrm{E}\left(\boldsymbol{g} \cdot \boldsymbol{m}^{-\mathbf{2}} \cdot \boldsymbol{d}^{-\mathbf{1}}\right)$ \\
\hline $\mathrm{P}_{1}$ & $\mathrm{CH}_{4}$ & 21,51 \\
& $\mathrm{CO}_{2}$ & 59,22 \\
\hline $\mathrm{P}_{2}$ & $\mathrm{CH}_{4}$ & 98,75 \\
& $\mathrm{CO}_{2}$ & 135,44 \\
\hline $\mathrm{P}_{3}$ & $\mathrm{CH}_{4}$ & 23,59 \\
& $\mathrm{CO}_{2}$ & 109,37 \\
\hline $\mathrm{P}_{4}$ & $\mathrm{CH}_{4}$ & 68,57 \\
& $\mathrm{CO}_{2}$ & 72,59 \\
& $\mathrm{CH}_{4}$ & 23,71 \\
$\mathrm{P}_{5}$ & $\mathrm{CO}_{2}$ & 60,47 \\
& $\mathrm{CH}_{4}$ & 43,41 \\
\hline $\mathrm{P}_{6}$ & $\mathrm{CO}_{2}$ & 76,34 \\
& $\mathrm{CH}_{4}$ & 79,00 \\
\hline $\mathrm{P}_{7}$ & $\mathrm{CO}_{2}$ & 164,92 \\
& $\mathrm{CH}_{4}$ & 518,60 \\
\hline $\mathrm{P}_{8}$ & $\mathrm{CO}_{2}$ & 135,54 \\
\hline
\end{tabular}

1) Cálculo da taxa de emissão média do Metano $\left(T_{x} E_{m}(C H 4)\right)$ nos sítios $\left(P_{n}\right)$ :

$$
\mathrm{T}_{\mathrm{x}} \mathrm{E}_{\mathrm{m}}\left(\mathrm{CH}_{4}\right)=\left(\mathrm{P}_{1}+\ldots+\mathrm{P}_{8}\right) / 8=109,64 \mathrm{~g} \cdot \mathrm{m}^{-2} \cdot \mathrm{d}^{-1}
$$

2) Taxa da emissão média total do metano $\left(\operatorname{TxE}_{m(t)\left(\mathrm{CH}_{4}\right)}\right)$ no aterro :

$$
\begin{array}{r}
\Rightarrow \operatorname{TxE}_{\mathrm{m}(\mathrm{t})}=\mathrm{T}_{\mathrm{x}} \mathrm{E}_{\mathrm{m}} \cdot \mathrm{A}_{\mathrm{at}} \cdot 365 \mathrm{~d} \cdot 10^{-9}=3.201,49 \text { Ton } \cdot \mathrm{a}^{-1} \\
\Rightarrow \mathbf{T}_{\mathrm{x}} \mathrm{E}_{\mathrm{m}(\mathrm{t})}\left(\mathbf{C H}_{\mathbf{4}}\right)=3.201,49 \mathrm{t} \cdot \mathbf{a}^{-1}
\end{array}
$$


Em que: $T_{x} E_{m}=$ Taxa de Emissão média $\left(g \cdot m^{-2} \cdot d^{-1}\right)$

$$
\mathrm{A}_{\mathrm{at}}=\text { Área do aterro }\left(80.000 \mathrm{~m}^{2}\right)
$$

$T_{x} E_{m(t)}=$ Taxa de Emissão média total para 2007 (Toneladas $\cdot a n o^{-1}$ )

365 = fator de conversão de dias para ano

$$
10^{-6}=\text { fator de conversão de } \mathrm{mg} \text { para Tonelada }
$$

3) Cálculo da taxa de emissão média do dióxido de carbono $\left(T_{x} E_{m((C O 2)}\right)$ nos sítios $\left(P_{n}\right)$ :

$$
\mathrm{T}_{\mathrm{x}} \mathrm{E}_{\mathrm{m}}\left(\mathrm{CO}_{2}\right)=\left(\mathrm{P}_{1}+\ldots+\mathrm{P}_{8}\right) / 8=101,73 \mathrm{~g} \cdot \mathrm{m}^{-2} \cdot \mathrm{d}^{-1}
$$

4) Cálculo da taxa de emissão média total do dióxido de carbono $\left(\operatorname{TxE}_{\mathrm{m}(\mathrm{t})(\mathrm{CO} 2)}\right)$ no aterro :

$$
\Rightarrow \mathrm{T}_{\mathrm{x}} \mathrm{E}_{\mathrm{m}(\mathrm{t})}\left(\mathrm{CO}_{2}\right)=2.970,52 \mathrm{t} \cdot \mathrm{a}^{-1}
$$

Emissão Total Média ( $\left.E_{t} \underline{M}\right)$ solo-ar do aterro de Araraquara: Consideradas as campanhas 2006 e 2007 :

1) Para o Metano: $\quad E_{t} M\left(C_{4}\right)=1.799,16 t \cdot a^{-1}$

2) Para o Dióxido de Carbono: $\mathrm{E}_{\mathrm{t}} \mathrm{M}\left(\mathrm{CO}_{2}\right)=1.917,56 \mathrm{t} \cdot \mathrm{a}^{-1}$ 


\subsection{1-B) Aterro de Brotas}

\section{B 1 ) Campanha 2006}

$\mathbf{P}_{1}\left(\mathrm{G} ; \mathrm{V}_{\mathrm{G}}=33.200 \mathrm{~mL}, \mathrm{~A}_{\mathrm{G}}=0,664 \mathrm{~m}^{2}\right)$

a) Tabela com tempos de coleta e massas correspondentes, gráfico com equações de retas e inclinações:

Tabela 6.5.15 - Sítio de coleta $\mathbf{P}_{\mathbf{1}}$ - Brotas 2006: tempos de coleta e massas $(\mu g)$ para $\mathrm{CH}_{4}$ e $\mathrm{CO}_{2}$.

\begin{tabular}{ccc}
\hline Tempo (min) & Massa do $\mathrm{CH}_{4}(\mu \mathrm{g})$ & Massa do $\mathrm{CO}_{2}(\mu \mathrm{g})$ \\
\hline 0 & 10,6412 & 8,6986 \\
3 & 10,8958 & 9,3401 \\
6 & 11,1732 & 11,2863 \\
12 & 11,3630 & 11,8656 \\
\hline
\end{tabular}

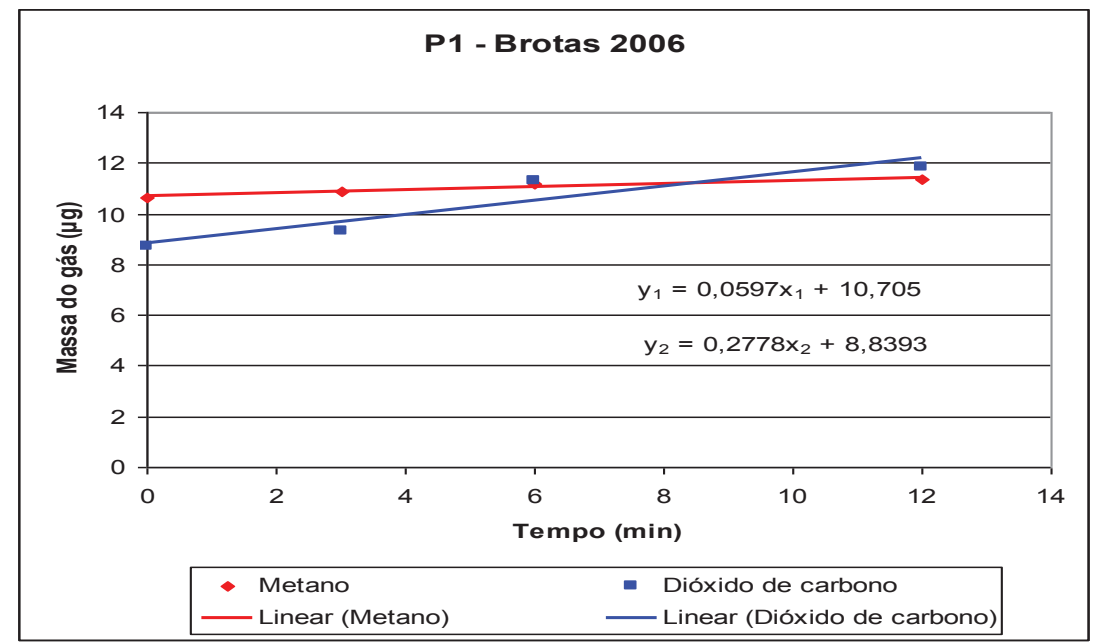

Gráfico 6.5.13 - Sítio $\mathbf{P}_{\mathbf{1}}$ - Brotas 2006. Equações de retas e inclinações para $\mathrm{CH}_{4}$ e $\mathrm{CO}_{2}$.

Equações das retas:

$$
\begin{aligned}
& y_{1}=0,0597 x_{1}+10,705 \text { Equação do metano } \\
& y_{2}=0,2778 x_{2}+8,8393 \text { Equação do dióxido }
\end{aligned}
$$

b) Cálculo da taxa de emissão: 
b) Metano: $\operatorname{Tx} E\left(\mathrm{CH}_{4}\right)=\frac{0,0597 \mu g\left(\mathrm{CH}_{4}\right) \times 33.200 \mathrm{~mL} \times 1440 \mathrm{~min} \times g}{\mathrm{~mL} \times \min \times 0,664 \mathrm{~m}^{2} \times \operatorname{dia} 10^{6} \mu \mathrm{g}}$

$$
\text { TxE }\left(\mathrm{CH}_{4}\right)=4,30 \mathrm{~g} \times \mathrm{m}^{-2} \cdot \mathrm{d}^{-1}\left(\mathrm{CH}_{4}\right) \text { No sítio de coleta } \mathrm{P}_{1} \text {. }
$$

Em que: $\quad T_{x} E\left(\mathrm{CH}_{4}\right)=$ Taxa de emissão de metano no sítio;

0,0597 $\mu \mathrm{g} \cdot \mathrm{min}^{-1} \cdot \mathrm{mL}^{-1}=$ Inclinação da reta do gráfico de metano;

33.200 $\mathrm{mL}=$ Volume da câmara de coleta (grande);

$1440 \min =$ número de $\operatorname{minutos} \cdot \mathrm{dia}^{-1}$;

$10^{6}=$ fator de conversão de $\mu g$ para g; e,

0,664 $m^{2}$ = Área da base da câmara de coleta (grande).

$\mathrm{b}_{2}$ ) Dióxido de carbono: $\operatorname{Tx} E\left(\mathrm{CO}_{2}\right)=\frac{0,2778 \mu \mathrm{g}\left(\mathrm{CO}_{2}\right) \times 33.200 \mathrm{~mL} \times 1440 \mathrm{~min} \times \mathrm{g}}{\mathrm{mL} \times \min \times 0,664 \mathrm{~m}^{2} \times \operatorname{dia} \times 10^{6} \mu \mathrm{g}}$

$$
\operatorname{TxE}\left(\mathrm{CO}_{2}\right)=20,00 \mathrm{~g} \times \mathrm{m}^{-2} \cdot \mathrm{d}^{-1}\left(\mathrm{CO}_{2}\right) \text { No sítio de coleta } \mathrm{P}_{1} \text {. }
$$

Em que: $\quad \mathrm{T}_{\mathrm{x}} \mathrm{E}\left(\mathrm{CO}_{2}\right)=$ Taxa de emissão de dióxido de carbono no sítio;

$0,2778 \mu \mathrm{g} \cdot \mathrm{min}^{-1} \cdot \mathrm{mL}^{-1}=$ Inclinação da reta do gráfico de dióxido de carbono;

33.200 $m \mathrm{~L}=$ Volume da câmara de coleta (grande);

$1440 \min =$ número de $\operatorname{minutos} \cdot \mathrm{dia}^{-1}$;

$10^{6}=$ fator de conversão de $\mu g$ para g; e,

$0,664 m^{2}=$ Área da base da câmara de coleta (grande). 
$P_{2}-\left(p ; V_{P}=1.200 m L, A_{P}=0,01815 m^{2}\right)$

a) Tabela com tempos de coleta e massas correspondentes, gráfico com equações de retas e inclinações:

Tabela 6.5.16 - Sítio de coleta $\mathbf{P}_{\mathbf{2}}$ - Brotas 2006: tempos de coleta e massas $(\mu \mathrm{g})$ para $\mathrm{CH}_{4}$ e $\mathrm{CO}_{2}$.

\begin{tabular}{ccc}
\hline Tempo $(\min )$ & Massa do $\mathrm{CH}_{4}(\mu \mathrm{g})$ & Massa do $\mathrm{CO}_{2}(\mu \mathrm{g})$ \\
\hline 0 & 10,7315 & 8,9968 \\
3 & 10,9970 & 9,4002 \\
6 & 12,0144 & 13,6680 \\
12 & 12,1075 & 11,7540 \\
\hline
\end{tabular}

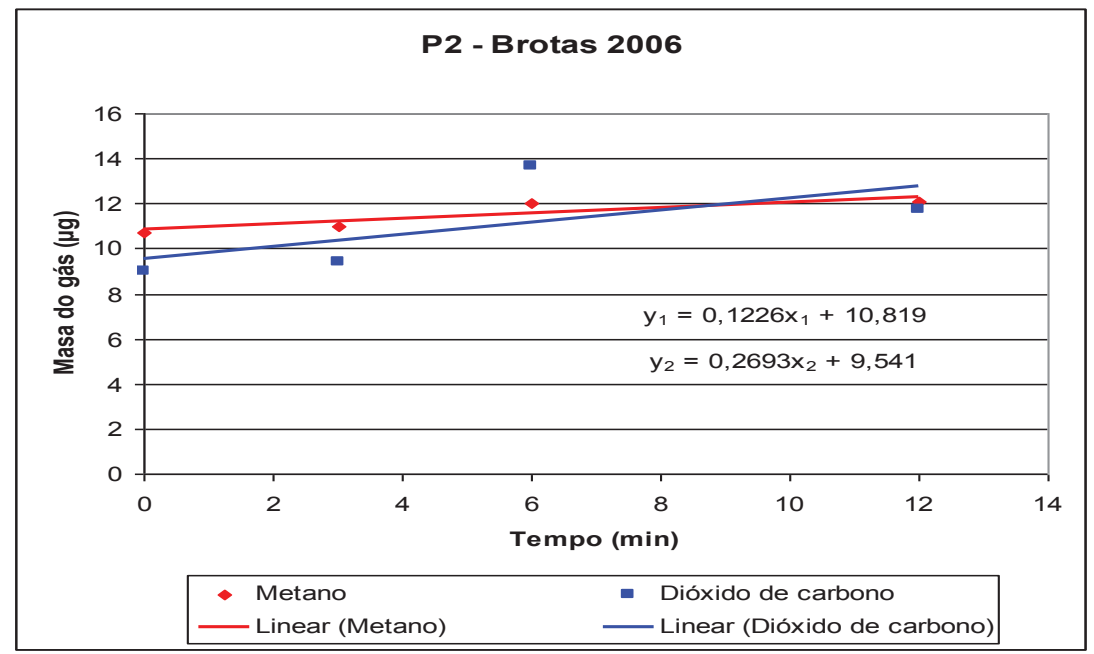

Gráfico 6.5.14 - Sítio $\mathbf{P}_{\mathbf{2}}$ - Brotas 2006. Equações de retas e inclinações para $\mathrm{CH}_{4} \mathrm{e} \mathrm{CO}_{2}$.

Equações das retas:

$$
\begin{aligned}
& y_{1}=0,11226 x_{1}+10,819 \text { Equação do metano } \\
& y_{2}=0,2693 x_{2}+9,541 \text { Equação do dióxido }
\end{aligned}
$$

b) Cálculo da taxa de emissão: 
$\left.b_{1}\right)$ Metano:

$$
\operatorname{TxE}\left(\mathrm{CH}_{4}\right)=\frac{0,1126 \mu g\left(\mathrm{CO}_{2}\right) \times 1.200 \mathrm{~mL} \times 1440 \mathrm{~min} \times g}{m L \times \min \times 0,01815 \mathrm{~m}^{2} \times \operatorname{dia} \times 10^{6} \mu \mathrm{g}}
$$

$$
\operatorname{Tx} E\left(\mathrm{CH}_{4}\right)=10,72 \mathrm{~g} \times \mathrm{m}^{-2} \cdot \mathrm{d}^{-1}\left(\mathrm{CH}_{4}\right) \text { No sítio de coleta } \mathrm{P}_{2} \text {. }
$$

$\mathrm{b}_{2}$ ) Dióxido de carbono: $\operatorname{Tx} E\left(\mathrm{CO}_{2}\right)=\frac{0,2693 \mu \mathrm{g}\left(\mathrm{CO}_{2}\right) \times 1.200 \mathrm{~mL} \times 1440 \mathrm{~min} \times g}{\mathrm{~mL} \times \min \times 0,01815 \mathrm{~m}^{2} \times \operatorname{dia} \times 10^{6} \mu \mathrm{g}}$

$$
\operatorname{Tx} E\left(\mathrm{CO}_{2}\right)=25,67 \mathrm{~g} \times \mathrm{m}^{-2} \cdot \mathrm{d}^{-1}\left(\mathrm{CO}_{2}\right) \text { No sítio de coleta } \mathrm{P}_{2} \text {. }
$$

$\mathbf{P}_{3}-\left(\mathrm{G} ; \mathrm{V}_{\mathrm{G}}=33.200 \mathrm{~mL}, \mathrm{~A}_{\mathrm{G}}=0,664 \mathrm{~m}^{2}\right)$

a) Tabela com tempos de coleta e massas correspondentes, gráfico com equações de retas e inclinações:

Tabela 6.5.17 - Sítio de coleta $\mathbf{P}_{\mathbf{3}}$ - Brotas 2006: tempos de coleta e massas $(\mu \mathrm{g})$ para $\mathrm{CH}_{4}$ e $\mathrm{CO}_{2}$.

\begin{tabular}{ccc}
\hline Tempo (min) & Massa do $\mathrm{CH}_{\mathbf{4}}(\mu \mathrm{g})$ & Massa do $\mathbf{C O}_{2}(\mu \mathrm{g})$ \\
\hline 0 & 10,4450 & 8,2094 \\
3 & 10,5563 & 8,7630 \\
6 & 11,0810 & 9,9603 \\
12 & 11,1823 & 10,3444 \\
\hline
\end{tabular}

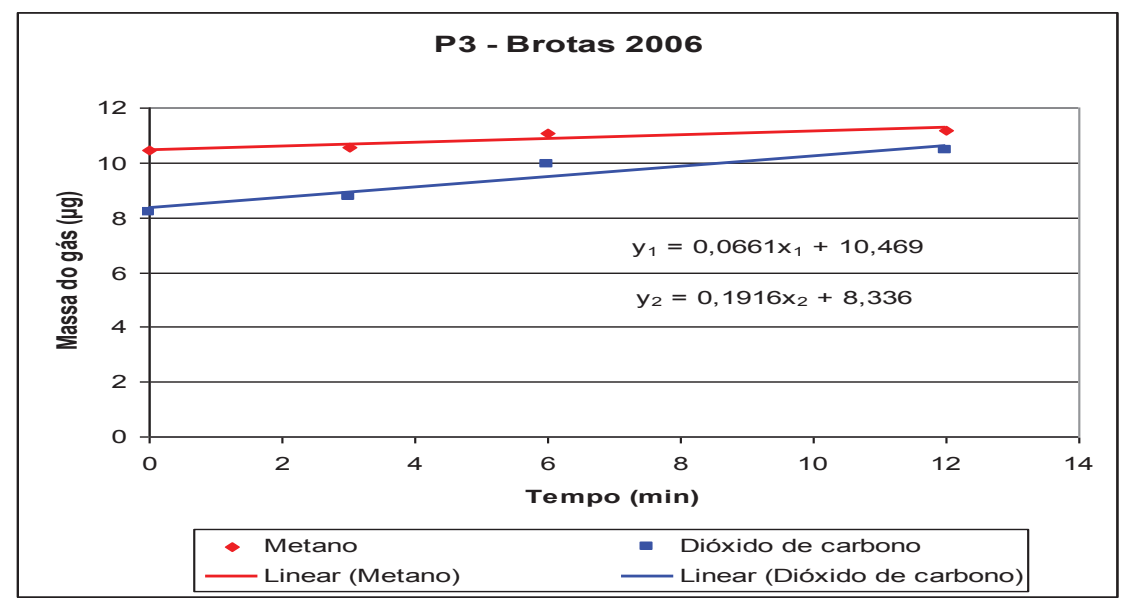

Gráfico 6.5.15 - Sítio $\mathbf{P}_{\mathbf{3}}$ - Brotas 2006. Equações de retas e inclinações para $\mathrm{CH}_{4}$ e $\mathrm{CO}_{2}$. 
Equações das retas:

$$
y_{1}=0,0661 x_{1}+10,469 \text { Equação do metano }
$$$$
y_{2}=0,1916 x_{2}+8,336 \text { Equação do dióxido }
$$

b) Cálculo da taxa de emissão:

b1) Metano: $\quad \mathrm{T}_{\mathrm{x}} \mathrm{E}\left(\mathrm{CH}_{4}\right)=\frac{0,0661 \mu \mathrm{g}\left(\mathrm{CH}_{4}\right) \times 33.200 \mathrm{~mL} \times 1440 \mathrm{~min} \times g}{\mathrm{~mL} \times \min \times 0664 \mathrm{~m}^{2} \times \operatorname{dia} \times 10^{6} \mu \mathrm{g}}$

$$
\operatorname{TxE}\left(\mathrm{CH}_{4}\right)=4,76 \mathrm{~g} \times \mathrm{m}^{-2} \cdot \mathrm{d}^{-1}\left(\mathrm{CH}_{4}\right) \text { No sítio de coleta } \mathrm{P}_{3} \text {. }
$$

$\mathrm{b}_{2}$ ) Dióxido de carbono: $\operatorname{Tx} E\left(\mathrm{CO}_{2}\right)=\frac{0,1916 \mu \mathrm{g}\left(\mathrm{CO}_{2}\right) \times 33.200 \mathrm{~mL} \times 1440 \mathrm{~min} \times \mathrm{g}}{\mathrm{mL} \times \min \times 0,664 \mathrm{~m}^{2} \times \operatorname{dia} \times 10^{6} \mu \mathrm{g}}$

$$
\operatorname{Tx} E\left(C \mathrm{CO}_{2}\right)=13,80 \mathrm{~g} \times \mathrm{m}^{-2} \cdot \mathrm{d}^{-1}\left(\mathrm{CO}_{2}\right) \text { No sítio de coleta } \mathrm{P}_{3} \text {. }
$$

$\mathbf{P}_{4}-\left(\mathrm{G} ; \mathrm{V}_{\mathrm{G}}=33.200 \mathrm{~mL}, \mathrm{~A}_{\mathrm{G}}=0,664 \mathrm{~m}^{2}\right)$

a) Tabela com tempos de coleta e massas correspondentes, gráfico com equações de retas e inclinações:

Tabela 6.5.18 - Sítio de coleta $\mathbf{P}_{\mathbf{4}}$ - Brotas 2006: tempos de coleta e massas $(\mu g)$ para $\mathrm{CH}_{4}$ e $\mathrm{CO}_{2}$.

\begin{tabular}{ccc}
\hline Tempo (min) & Massa do $\mathrm{CH}_{4}(\mu \mathrm{g})$ & Massa do $\mathrm{CO}_{2}(\mu \mathrm{g})$ \\
\hline 0 & 10,3000 & 8,0141 \\
3 & 10,5820 & 8,7780 \\
6 & 10,9743 & 9,7027 \\
12 & 11,0792 & 10,0139 \\
\hline
\end{tabular}




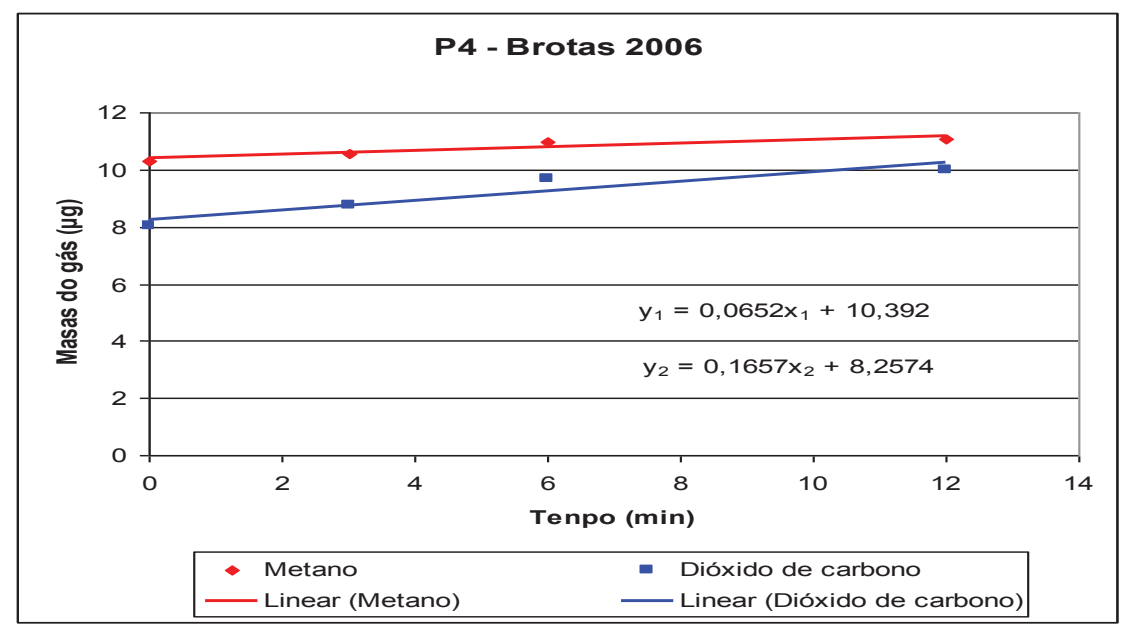

Gráfico 6.5.16 - Sítio $\mathbf{P}_{\mathbf{4}}$ - Brotas 2006. Equações de retas e inclinações para $\mathrm{CH}_{4}$ e $\mathrm{CO}_{2}$.

Equações das retas:

$$
\begin{aligned}
& y_{1}=0,0652 x_{1}+10,392 \text { Equação do metano } \\
& y_{2}=0,1657 x_{2}+8,2574 \text { Equação do dióxido }
\end{aligned}
$$

b) Cálculo da taxa de emissão:

$\left.b_{1}\right)$ Metano:

$$
\mathrm{T}_{\mathrm{x}} \mathrm{E}\left(\mathrm{CH}_{4}\right)=\frac{0,0652 \mu \mathrm{g}\left(\mathrm{CH}_{4}\right) \times 33.200 \mathrm{~mL} \times 1440 \mathrm{~min} \times g}{m L \times \min \times 0664 \mathrm{~m}^{2} \times \operatorname{dia} \times 10^{6} \mu \mathrm{g}}
$$

$$
\text { TxE }\left(\mathrm{CH}_{4}\right)=4,70 \mathrm{~g} \times \mathrm{m}^{-2} \cdot d^{-1}\left(\mathrm{CH}_{4}\right) \text { No sítio de coleta } \mathrm{P}_{4} \text {. }
$$

$\mathrm{b}_{2}$ ) Dióxido de carbono: $\quad \operatorname{Tx} E\left(\mathrm{CO}_{2}\right)=\frac{0,1657 \mu g\left(\mathrm{CO}_{2}\right) \times 33.200 \mathrm{~mL} \times 1440 \mathrm{~min} \times \mathrm{g}}{\mathrm{mL} \times \min \times 0,664 \mathrm{~m}^{2} \times \operatorname{dia} \times 10^{6} \mu \mathrm{g}}$

$$
\operatorname{TxE}\left(\mathrm{CO}_{2}\right)=11,93 \mathrm{~g} \times \mathrm{m}^{-2} \cdot \mathrm{d}^{-1}\left(\mathrm{CO}_{2}\right) \text { No sítio de coleta } \mathrm{P}_{4} \text {. }
$$


$\mathbf{P}_{5}-\left(p ; V_{P}=1.200 m L, A_{P}=0,01815 m^{2}\right)$

a) Tabela com tempos de coleta e massas correspondentes, gráfico com equações de retas e inclinações:

Tabela 6.5.19 - Sítio de coleta $\mathbf{P}_{\mathbf{5}}$ - Brotas 2006: tempos de coleta e massas $(\mu g)$ para $\mathrm{CH}_{4}$ e $\mathrm{CO}_{2}$.

\begin{tabular}{ccc}
\hline Tempo (min) & Massa do $\mathrm{CH}_{\mathbf{4}}(\boldsymbol{\mu g})$ & Massa do $\mathrm{CO}_{\mathbf{2}}(\mu \mathrm{g})$ \\
\hline 0 & 10,3510 & 7,8103 \\
3 & 10,5317 & 8,4240 \\
6 & 10,9031 & 9,6813 \\
12 & 11,0107 & 9,9538 \\
\hline
\end{tabular}

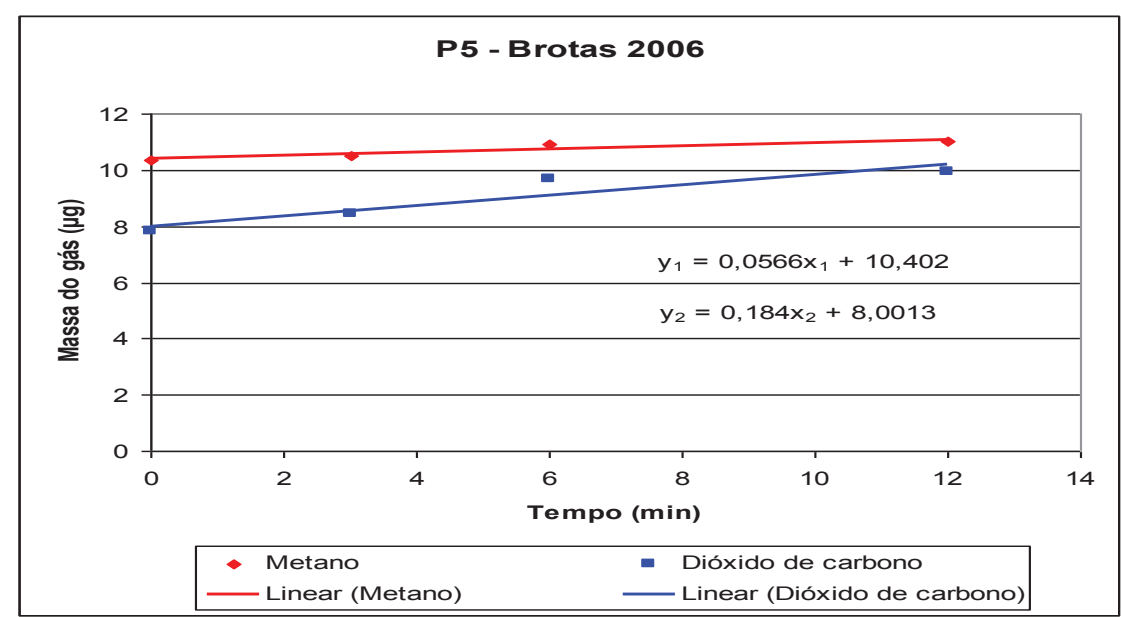

Gráfico 6.5.17 - Sítio $\mathbf{P}_{\mathbf{5}}$ - Brotas 2006. Equações de retas e inclinações para $\mathrm{CH}_{4}$ e $\mathrm{CO}_{2}$.

Equações das retas:

$$
\begin{aligned}
& y_{1}=0,0566 x_{1}+10,402 \text { Equação do metano } \\
& y_{2}=0,184 x_{2}+8,0013 \text { Equação do dióxido }
\end{aligned}
$$

b) Cálculo da taxa de emissão:

b) Metano: $\quad \operatorname{Tx} E\left(\mathrm{CH}_{4}\right)=\frac{0,0566 \mu g\left(\mathrm{CO}_{2}\right) \times 1.200 \mathrm{~mL} \times 1440 \mathrm{~min} \times g}{\mathrm{~mL} \times \min \times 0,01815 \mathrm{~m}^{2} \times \operatorname{dia} \times 10^{6} \mu \mathrm{g}}$ 


$$
\operatorname{TxE}\left(\mathrm{CH}_{4}\right)=5,39 \mathrm{~g} \times \mathrm{m}^{-2} \cdot \mathrm{d}^{-1}\left(\mathrm{CH}_{4}\right) \text { No sítio de coleta } \mathrm{P}_{5} \text {. }
$$

$\mathrm{b}_{2}$ ) Dióxido de carbono: $\operatorname{Tx} E\left(\mathrm{CO}_{2}\right)=\frac{0,184 \mu \mathrm{g}\left(\mathrm{CO}_{2}\right) \times 1.200 \mathrm{~mL} \times 1440 \mathrm{~min} \times \mathrm{g}}{\mathrm{mL} \times \min \times 0,01815 \mathrm{~m}^{2} \times \operatorname{dia} \times 10^{6} \mu \mathrm{g}}$

$$
\operatorname{TxE}\left(\mathrm{CO}_{2}\right)=17,52 \mathrm{~g} \times \mathrm{m}^{-2} \cdot \mathrm{d}^{-1}\left(\mathrm{CO}_{2}\right) \text { No sítio de coleta } \mathrm{P}_{5}
$$

\section{Aterro de Brotas - Emissão solo-ar campanha 2006:}

A tabela 6.5 .20 , resume as taxas de emissão solo-ar, medidas para $\mathrm{CH}_{4}$ e $\mathrm{CO}_{2}$, em cada sítio $\mathbf{P}_{\mathbf{n}}$, do aterro de Brotas, na campanha de 2006.

Tabela 6.5.20 - Resumo das taxas de emissão solo-ar do aterro de Brotas na campanha de 2006.

\begin{tabular}{clr}
\hline Sítio amostrado & Gás & $\mathbf{T}_{\mathbf{x}} \mathbf{E}\left(\boldsymbol{g} \cdot \boldsymbol{m}^{-\mathbf{2}} \cdot \boldsymbol{d}^{-\mathbf{1}}\right)$ \\
\hline $\mathrm{P}_{1}$ & $\mathrm{CH}_{4}$ & 4,30 \\
& $\mathrm{CO}_{2}$ & 20,00 \\
$\mathrm{P}_{2}$ & $\mathrm{CH}_{4}$ & 10,72 \\
& $\mathrm{CO}_{2}$ & 25,67 \\
& $\mathrm{CH}_{4}$ & 4,76 \\
$\mathrm{P}_{3}$ & $\mathrm{CO}_{2}$ & 13,80 \\
& $\mathrm{CH}_{4}$ & 4,70 \\
$\mathrm{P}_{4}$ & $\mathrm{CO}_{2}$ & 11,93 \\
& $\mathrm{CH}_{4}$ & 5,39 \\
& $\mathrm{CO}_{2}$ & 17,52 \\
\hline
\end{tabular}

1) Cálculo da taxa de emissão média do Metano $\left(T_{x} E_{m(C H 4)}\right)$ nos sítios $\left(P_{n}\right)$ :

$$
\mathrm{T}_{\mathrm{x}} \mathrm{E}_{\mathrm{m}}\left(\mathrm{CH}_{4}\right)=\left(\mathrm{P}_{1}+\ldots+\mathrm{P}_{5}\right) / 5=5,97 \mathrm{~g} \cdot \mathrm{m}^{-2} \cdot \mathrm{d}^{-1}
$$


2) Taxa de emissão média total do metano $\left(\mathrm{TxE}_{\mathrm{m}(\mathrm{t})(\mathrm{CH} 4)}\right)$ no aterro :

$$
\begin{aligned}
\Rightarrow \mathrm{Tx}_{\mathrm{m}(\mathrm{t})} & =\mathrm{T}_{\mathrm{x}} \mathrm{E}_{\mathrm{m}} \cdot \mathrm{A}_{\mathrm{at}} \cdot 365 \mathrm{~d} \cdot 10^{-6}=117,67 \mathrm{t} \cdot \mathrm{a}^{-1} \\
& \Rightarrow \mathrm{T}_{\mathbf{x}} \mathrm{E}_{\mathrm{m}(\mathrm{t})}\left(\mathbf{C H}_{\mathbf{4}}\right)=117,67{\mathrm{t} \cdot \mathrm{a}^{-1}}^{-1}
\end{aligned}
$$

Em que: $T_{x} E_{m}=$ Taxa de Emissão média $\left(g \cdot m^{-2} \cdot d^{-1}\right)$

$$
\begin{aligned}
\mathrm{A}_{\mathrm{at}} & =\text { Área do aterro }\left(54.000 \mathrm{~m}^{2}\right) \\
\mathrm{T}_{\mathrm{x}} \mathrm{E}_{\mathrm{m}(\mathrm{t})} & =\text { Taxa de Emissão média total para } 2006\left({\text { Toneladas } \left.\cdot a n o^{-1}\right)}\right. \text { ) } \\
365 & =\text { fator de conversão de dias p ano } \\
10^{-6} & =\text { fator de conversão de mg para Tonelada }
\end{aligned}
$$

3) Cálculo da taxa de emissão média do dióxido de carbono $\left(T_{x} E_{m}\left(C_{2}\right)\right)$ nos sítios $\left(P_{n}\right)$ :

$$
\mathrm{T}_{\mathrm{x}} \mathrm{E}_{\mathrm{m}}\left(\mathrm{CO}_{2}\right)=\left(\mathrm{P}_{1}+\ldots+\mathrm{P}_{5}\right) / 5=17,78 \mathrm{~g} \cdot \mathrm{m}^{-2} \cdot \mathrm{d}^{-1}
$$

4) Cálculo da taxa de emissão média total do dióxido de carbono ( $\left.\operatorname{TxE}_{\mathrm{m}(\mathrm{t})(\mathrm{CO} 2)}\right)$ no aterro :

$$
\Rightarrow T_{x} E_{m(t)}\left(C O_{2}\right)=350,44 t \cdot a^{-1}
$$


B $)$ Campanha - 2007

$\mathbf{P}_{1}-\left(\mathrm{G} ; \mathrm{V}_{\mathrm{G}}=33.200 \mathrm{~mL} ; \mathrm{A}_{\mathrm{G}}=0,664 \mathrm{~m}^{2}\right)$

a) Tabela com tempos de coleta e massas correspondentes, gráfico com equações de retas e inclinações:

Tabela 6.5.21 - Sítio de coleta $\mathbf{P}_{\mathbf{1}}$ - Brotas 2007: tempos e coleta e massas $(\mu g)$ para $\mathrm{CH}_{4}$ e $\mathrm{CO}_{2}$.

\begin{tabular}{ccc}
\hline Tempo $(\boldsymbol{m i n})$ & Massa do $\mathrm{CH}_{4}(\mu \mathrm{g})$ & Massa do $\mathrm{CO}_{2}(\mu \mathrm{g})$ \\
\hline 0 & 0 & 8,1472 \\
3 & 13,5336 & 18,5450 \\
6 & 17,5426 & 24,9925 \\
12 & 10,7000 & 13,7500 \\
\hline
\end{tabular}

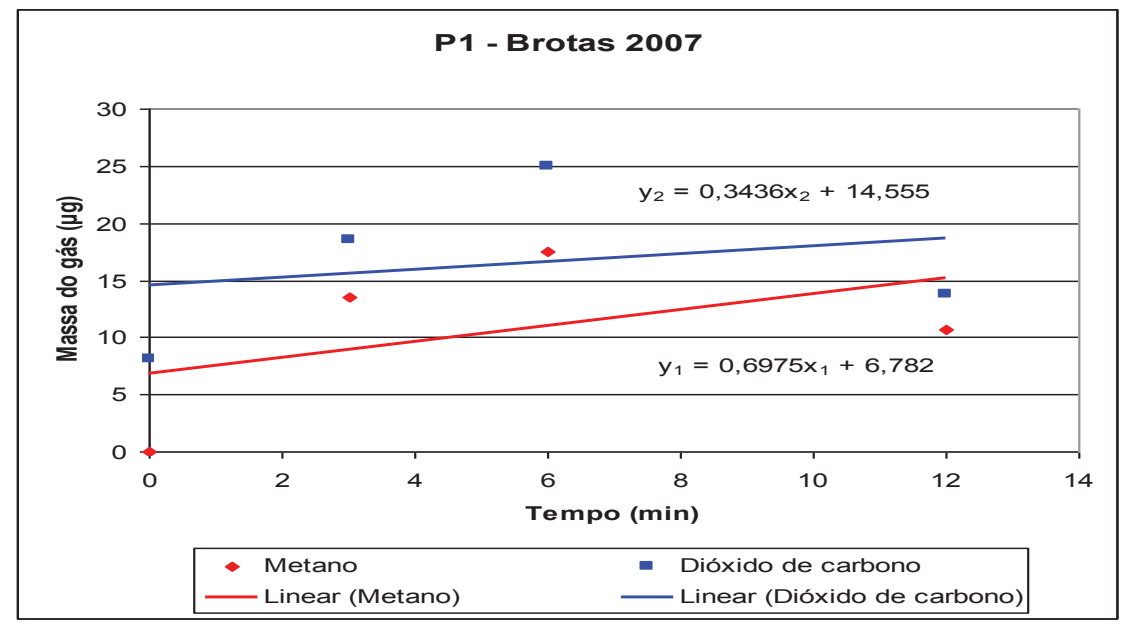

Gráfico 6.5.18 - Sítio $\mathbf{P}_{\mathbf{1}}$ - Brotas 2006. Equações de retas e inclinações para $\mathrm{CH}_{4}$ e $\mathrm{CO}_{2}$.

Equações das retas:

$$
\begin{aligned}
& y_{1}=0,6975 x_{1}+6,782 \text { Equação do metano } \\
& y_{2}=0,3436 x_{2}+14,555 \text { Equação do dióxido }
\end{aligned}
$$

b) Cálculo da taxa de emissão:

b) Metano: $\quad \mathrm{T}_{\mathrm{x}} \mathrm{E}\left(\mathrm{CH}_{4}\right)=\frac{0,6975 \mu \mathrm{g}\left(\mathrm{CH}_{4}\right) \times 33.200 \mathrm{~mL} \times 1440 \mathrm{~min} \times g}{\mathrm{~mL} \times \min \times 0664 \mathrm{~m}^{2} \times \operatorname{dia} \times 10^{6} \mu \mathrm{g}}$ 


$$
\mathrm{TxE}\left(\mathrm{CH}_{4}\right)=50,22 \mathrm{~g} \times \mathrm{m}^{-2} \cdot \mathrm{d}^{-1}\left(\mathrm{CH}_{4}\right) \text { No sítio de coleta } \mathrm{P}_{1} \text {. }
$$

$\mathrm{b}_{2}$ ) Dióxido de carbono: $\operatorname{Tx} E\left(\mathrm{CO}_{2}\right)=\frac{0,3436 \mu \mathrm{g}\left(\mathrm{CO}_{2}\right) \times 33.200 \mathrm{~mL} \times 1440 \mathrm{~min} \times \mathrm{g}}{\mathrm{mL} \times \min \times 0,664 \mathrm{~m}^{2} \times \operatorname{dia} \times 10^{6} \mu \mathrm{g}}$

$$
\operatorname{Tx} E\left(\mathrm{CO}_{2}\right)=24,74 \mathrm{~g} \times \mathrm{m}^{-2} \cdot \mathrm{d}^{-1}\left(\mathrm{CO}_{2}\right) \text { No sítio de coleta } \mathrm{P}_{1} \text {. }
$$

$\mathbf{P}_{2}-\left(p ; V_{P}=1.200 m L, A_{P}=0,01815 m^{2}\right)$

a) Tabela com tempos de coleta e massas correspondentes, gráfico com equações de retas e inclinações:

Tabela 6.5.22 - Sítio de coleta $P_{2}$ - Brotas 2007: tempos de coleta e massas $(\mu \mathrm{g})$ para $\mathrm{CH}_{4}$ e $\mathrm{CO}_{2}$.

\begin{tabular}{rcr}
\hline Tempo (min) & Massa do $\mathrm{CH}_{\mathbf{4}}(\mu \mathrm{g})$ & Massa do $\mathbf{C O}_{\mathbf{2}}(\mu \mathrm{g})$ \\
\hline 0 & 10,4414 & 7,8360 \\
3 & 11,3776 & 10,4151 \\
6 & 12,7262 & 14,4253 \\
12 & 12,4542 & 14,0627 \\
\hline
\end{tabular}

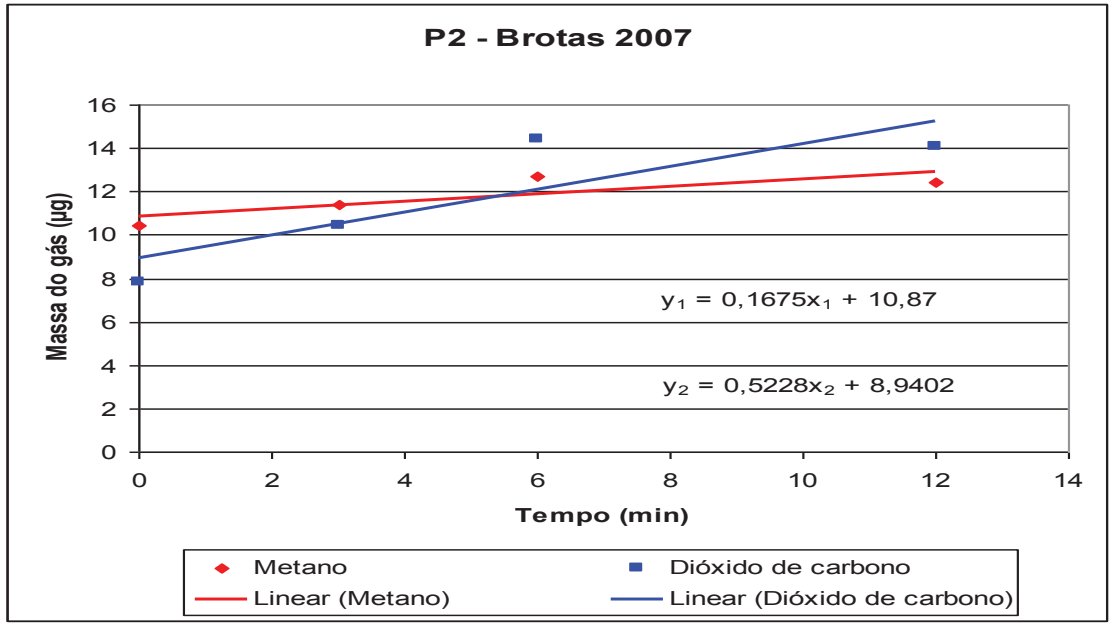

Gráfico 6.5.19 - Sítio $\mathbf{P}_{\mathbf{2}}$ - Brotas 2007. Equações de retas e inclinações para $\mathrm{CH}_{4}$ e $\mathrm{CO}_{2}$. 
Equações das retas:

$$
\begin{aligned}
& y_{1}=0,1675 x_{1}+10,87 \text { Equação do metano } \\
& y_{2}=0,5228 x_{2}+8,9402 \text { Equação do dióxido }
\end{aligned}
$$

b) Cálculo da taxa de emissão:

b) Metano: $\quad \operatorname{Tx} E\left(\mathrm{CH}_{4}\right)=\frac{0,1675 \mu g\left(\mathrm{CO}_{2}\right) \times 1.200 \mathrm{~mL} \times 1440 \mathrm{~min} \times g}{m L \times \min \times 0,01815 \mathrm{~m}^{2} \times \operatorname{dia} \times 10^{6} \mu \mathrm{g}}$

$$
\operatorname{Tx} E\left(\mathrm{CH}_{4}\right)=15,95 \mathrm{~g} \times \mathrm{m}^{-2} \cdot \mathrm{d}^{-1}\left(\mathrm{CH}_{4}\right) \text { No sítio de coleta } \mathrm{P}_{2} \text {. }
$$

$\mathrm{b}_{2}$ ) Dióxido de carbono: $\operatorname{Tx} E\left(\mathrm{CO}_{2}\right)=\frac{0,5228 \mu \mathrm{g}\left(\mathrm{CO}_{2}\right) \times 1.200 \mathrm{~mL} \times 1440 \mathrm{~min} \times \mathrm{g}}{\mathrm{mL} \times \min \times 0,01815 \mathrm{~m}^{2} \times \operatorname{dia} \times 10^{6} \mu \mathrm{g}}$

$$
\operatorname{Tx} E\left(\mathrm{CO}_{2}\right)=49,77 \mathrm{~g} \times \mathrm{m}^{-2} \cdot \mathrm{d}^{-1}\left(\mathrm{CO}_{2}\right) \quad \text { No sítio de coleta } \mathrm{P}_{2} \text {. }
$$

$\mathbf{P}_{3}-\left(\mathrm{G} ; \mathrm{V}_{\mathrm{G}}=33.200 \mathrm{~mL}, \mathrm{~A}_{\mathrm{G}}=0,664 \mathrm{~m}^{2}\right)$

a) Tabela com tempos de coleta e massas correspondentes, gráfico com equações de retas e inclinações:

Tabela 6.5.23 - Sítio de coleta $\mathbf{P}_{\mathbf{3}}$ - Brotas 2007: tempos de coleta e massas $(\mu \mathrm{g})$ para $\mathrm{CH}_{4}$ e $\mathrm{CO}_{2}$.

\begin{tabular}{rcr}
\hline Tempo (min) & Massa do $\mathrm{CH}_{\mathbf{4}}(\mu \mathrm{g})$ & Massa do $\mathrm{CO}_{2}(\mu \mathrm{g})$ \\
\hline 0 & 10,3220 & 7,6408 \\
3 & 10,5335 & 8,3000 \\
6 & 11,0902 & 9,6148 \\
12 & 12,0200 & 11,5222 \\
\hline
\end{tabular}




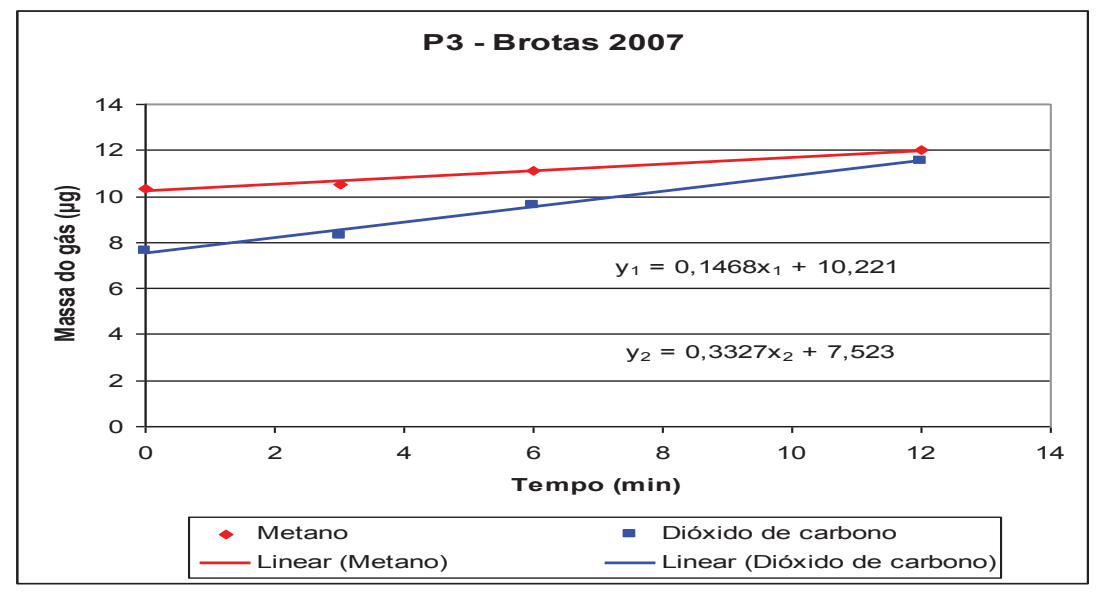

Gráfico 6.5.20 - Sítio $\mathbf{P}_{\mathbf{3}}$ - Brotas 2007. Equações de retas e inclinações para $\mathrm{CH}_{4}$ e $\mathrm{CO}_{2}$.

Equações das retas:

$$
\begin{aligned}
& y_{1}=0,1468 x_{1}+10,221 \text { Equação do metano } \\
& y_{2}=0,3327 x_{2}+7,523 \text { Equação do dióxido }
\end{aligned}
$$

b) Cálculo da taxa de emissão:

$\left.b_{1}\right)$ Metano:

$$
\mathrm{T}_{\mathrm{x}} \mathrm{E}\left(\mathrm{CH}_{4}\right)=\frac{0,1468 \mu \mathrm{g}\left(\mathrm{CH}_{4}\right) \times 33.200 \mathrm{~mL} \times 1440 \mathrm{~min} \times g}{m L \times \min \times 0664 \mathrm{~m}^{2} \times \operatorname{dia} \times 10^{6} \mu \mathrm{g}}
$$

$$
\operatorname{TxE}\left(\mathrm{CH}_{4}\right)=10,57 \mathrm{~g} \times \mathrm{m}^{-2} \cdot \mathrm{d}^{-1}\left(\mathrm{CH}_{4}\right) \text { No sítio de coleta } \mathrm{P}_{3} \text {. }
$$

$\mathrm{b}_{2}$ ) Dióxido de carbono: $\operatorname{Tx} E\left(C \mathrm{CO}_{2}\right)=\frac{0,3327 \mu g\left(C \mathrm{C}_{2}\right) \times 33.200 \mathrm{~mL} \times 1440 \mathrm{~min} \times g}{\mathrm{~mL} \times \min \times 0,664 \mathrm{~m}^{2} \times \operatorname{dia} \times 10^{6} \mu \mathrm{g}}$

$$
\operatorname{TxE}\left(\mathrm{CO}_{2}\right)=23,95 \mathrm{~g} \times \mathrm{m}^{-2} \cdot \mathrm{d}^{-1}\left(\mathrm{CO}_{2}\right) \text { No sítio de coleta } \mathrm{P}_{3} \text {. }
$$

$\mathbf{P}_{4}-\left(\mathrm{G} ; \mathrm{V}_{\mathrm{G}}=33.200 \mathrm{~mL}, \mathrm{~A}_{\mathrm{G}}=0,664 \mathrm{~m}^{2}\right)$

a) Tabela com tempos de coleta e massas correspondentes, gráfico com equações de retas e inclinações: 
Tabela 6.5.24 - Sítio de coleta $\mathbf{P}_{\mathbf{4}}$ - Brotas 2007: tempos de coleta e massas $(\mu g)$ para $\mathrm{CH}_{4}$ e $\mathrm{CO}_{2}$.

\begin{tabular}{rcr}
\hline Tempo (min) & Massa do $\mathrm{CH}_{\mathbf{4}}(\mu \mathrm{g})$ & Massa do $\mathbf{C O}_{\mathbf{2}}(\mu \mathrm{g})$ \\
\hline 0 & 10,2114 & 7,4134 \\
3 & 10,2184 & 7,4713 \\
6 & 10,2552 & 7,6250 \\
12 & 10,4013 & 9,3037 \\
\hline
\end{tabular}

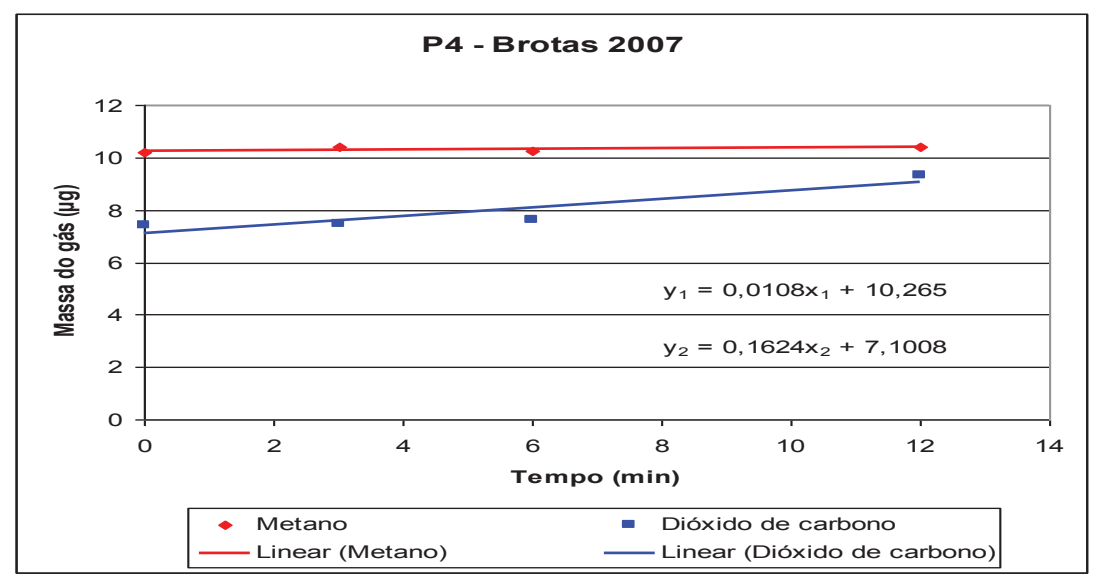

Gráfico 6.5.21 - Sítio $\mathbf{P}_{4}$ - Brotas 2007. Equações de retas e inclinações para $\mathrm{CH}_{4}$ e $\mathrm{CO}_{2}$.

Equações das retas:

$$
\begin{aligned}
& y_{1}=0,0108 x_{1}+10,265 \text { Equação do metano } \\
& y_{2}=0,1624 x_{2}+7,1008 \text { Equação do dióxido }
\end{aligned}
$$

b) Cálculo da taxa de emissão:

$\left.b_{1}\right)$ Metano:

$$
\begin{aligned}
& \mathrm{T}_{\mathrm{x}} \mathrm{E}\left(\mathrm{CH}_{4}\right)=\frac{0,0108 \mu \mathrm{g}\left(\mathrm{CH}_{4}\right) \times 33.200 \mathrm{~mL} \times 1440 \mathrm{~min} \times g}{m L \times \min \times 0664 \mathrm{~m}^{2} \times \operatorname{dia} \times 10^{6} \mu \mathrm{g}} \\
& \operatorname{TxE}\left(\mathrm{CH}_{4}\right)=0,78 \mathrm{~g} \times \mathrm{m}^{-2} \cdot d^{-1}\left(\mathrm{CH}_{4}\right) \text { No sítio de coleta } \mathrm{P}_{4} .
\end{aligned}
$$

$\mathrm{b}_{2}$ ) Dióxido de carbono: $\operatorname{Tx} E\left(\mathrm{CO}_{2}\right)=\frac{0,1624 \mu \mathrm{g}\left(\mathrm{CO}_{2}\right) \times 33.200 \mathrm{~mL} \times 1440 \mathrm{~min} \times \mathrm{g}}{\mathrm{mL} \times \min \times 0,664 \mathrm{~m}^{2} \times \operatorname{dia} \times 10^{6} \mu \mathrm{g}}$

$$
\operatorname{Tx} E\left(\mathrm{CO}_{2}\right)=11,70 \mathrm{~g} \times \mathrm{m}^{-2} \cdot \mathrm{d}^{-1}\left(\mathrm{CO}_{2}\right) \text { No sítio de coleta } \mathrm{P}_{4}
$$


$P_{5}-\left(p ; V_{P}=1.200 m L, A_{P}=0,01815 m^{2}\right)$

a) Tabela com tempos de coleta e massas correspondentes, gráfico com equações de retas e inclinações:

Tabela 6.5.25 - Sítio de coleta $\mathbf{P}_{\mathbf{5}}$ - Brotas 2007: tempos de coleta e massas $(\mu g)$ para $\mathrm{CH}_{4}$ e $\mathrm{CO}_{2}$.

\begin{tabular}{ccc}
\hline Tempo (min) & Massa do $\mathrm{CH}_{\mathbf{4}}(\mu \mathrm{g})$ & Massa do $\mathbf{C O}_{\mathbf{2}}(\mu \mathrm{g})$ \\
\hline 0 & - & 7,4584 \\
3 & 10,2963 & 7,7180 \\
6 & 10,4578 & 8,2158 \\
12 & 10,7981 & 8,9453 \\
\hline
\end{tabular}

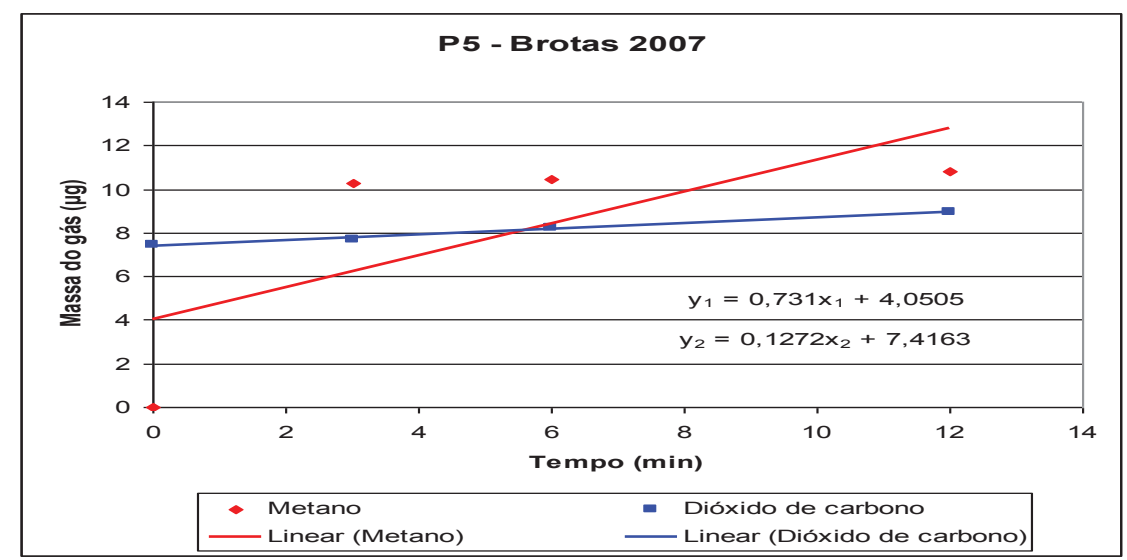

Gráfico 6.5.22 - Sítio $\mathbf{P}_{\mathbf{5}}$ - Brotas 2007. Equações de retas e inclinações para $\mathrm{CH}_{4}$ e $\mathrm{CO}_{2}$.

Equações das retas:

$$
\begin{aligned}
& y_{1}=0,731 x_{1}+4,0505 \text { Equação do metano } \\
& y_{2}=0,2172 x_{2}+7,4163 \text { Equação do dióxido }
\end{aligned}
$$

b) Cálculo da taxa de emissão:

b $)$ Metano: $\quad \operatorname{Tx} E\left(\mathrm{CH}_{4}\right)=\frac{0,731 \mu g\left(\mathrm{CO}_{2}\right) \times 1.200 \mathrm{~mL} \times 1440 \mathrm{~min} \times g}{\mathrm{~mL} \times \min \times 0,01815 \mathrm{~m}^{2} \times \operatorname{dia} \times 10^{6} \mu \mathrm{g}}$

$$
\operatorname{TxE}\left(\mathrm{CH}_{4}\right)=69,60 \mathrm{~g} \times \mathrm{m}^{-2} \cdot \mathrm{d}^{-1}\left(\mathrm{CH}_{4}\right) \text { No sítio de coleta } \mathrm{P}_{5} \text {. }
$$


$\mathrm{b}_{2}$ ) Dióxido de carbono: $\operatorname{Tx} E\left(\mathrm{CO}_{2}\right)=\frac{0,2172 \mu \mathrm{g}\left(\mathrm{CO}_{2}\right) \times 1.200 \mathrm{~mL} \times 1440 \mathrm{~min} \times \mathrm{g}}{\mathrm{mL} \times \min \times 0,01815 \mathrm{~m}^{2} \times \operatorname{dia} \times 10^{6} \mu \mathrm{g}}$

$$
\operatorname{Tx} E\left(\mathrm{CO}_{2}\right)=20,68 \mathrm{~g} \times \mathrm{m}^{-2} \cdot \mathrm{d}^{-1}\left(\mathrm{CO}_{2}\right) \quad \text { No sítio de coleta } \mathrm{P}_{5}
$$

$\mathbf{P}_{6}-\left(p ; V_{P}=1.200 m L, A_{P}=0,01815 m^{2}\right)$

a) Tabela com tempos de coleta e massas correspondentes, gráfico com equações de retas e inclinações:

Tabela 6.5.26 - Sítio de coleta $\mathbf{P}_{\mathbf{6}}$ - Brotas 2007: tempos de coleta e massas $(\mu \mathrm{g})$ para $\mathrm{CH}_{4}$ e $\mathrm{CO}_{2}$.

\begin{tabular}{rcr}
\hline Tempo (min) & Massa do $\mathrm{CH}_{\mathbf{4}}(\mu \mathrm{g})$ & Massa do $\mathbf{C O}_{2}(\mu \mathrm{g})$ \\
\hline 0 & 10,5007 & 8,2137 \\
3 & 10,8958 & 9,5887 \\
6 & 12,7400 & 15,8222 \\
12 & 12,8913 & 16,1054 \\
\hline
\end{tabular}

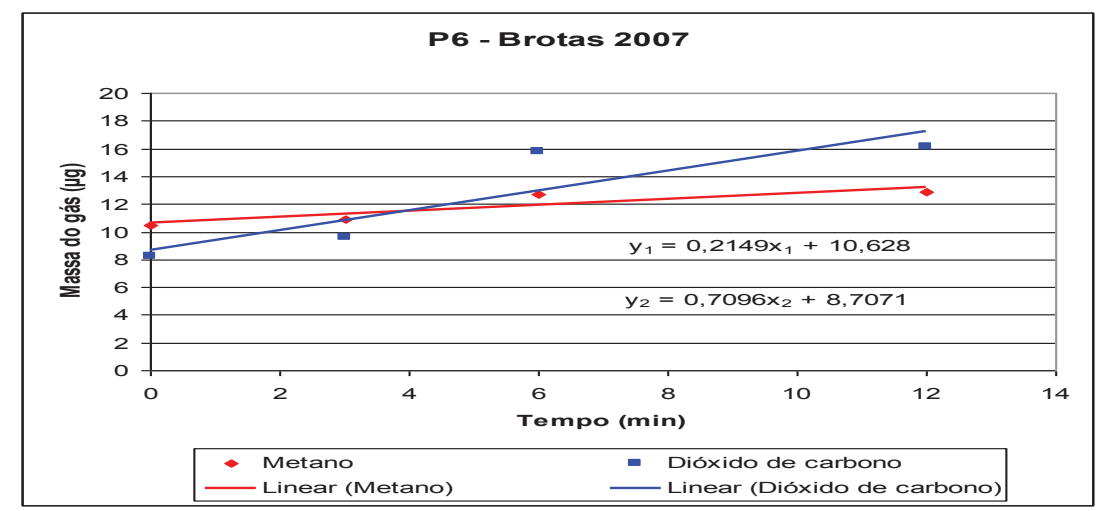

Gráfico 6.5.23 - Sítio $\mathbf{P}_{6}$ - Brotas 2007. Equações de retas e inclinações para $\mathrm{CH}_{4}$ e $\mathrm{CO}_{2}$.

Equações das retas:

$$
\begin{aligned}
& y_{1}=0,2149 x_{1}+10,628 \text { Equação do metano } \\
& y_{2}=0,7096 x_{2}+8,7071 \text { Equação do dióxido }
\end{aligned}
$$


b) Cálculo da taxa de emissão:

$\left.b_{1}\right)$ Metano:

$$
\begin{aligned}
& \operatorname{Tx} E\left(\mathrm{CH}_{4}\right)=\frac{0,2149 \mu g\left(\mathrm{CO}_{2}\right) \times 1.200 \mathrm{~mL} \times 1440 \mathrm{~min} \times g}{m L \times \min \times 0,01815 \mathrm{~m}^{2} \times \operatorname{dia} \times 10^{6} \mu g} \\
& \operatorname{TxE}\left(\mathrm{CH}_{4}\right)=20,46 \mathrm{~g} \times \mathrm{m}^{-2} \cdot d^{-1}\left(\mathrm{CH}_{4}\right) \text { No sítio de coleta } \mathrm{P}_{6} .
\end{aligned}
$$

$\mathrm{b}_{2}$ ) Dióxido de carbono: $\operatorname{Tx} E\left(\mathrm{CO}_{2}\right)=\frac{0,7096 \mu \mathrm{g}\left(\mathrm{CO}_{2}\right) \times 1.200 \mathrm{~mL} \times 1440 \mathrm{~min} \times \mathrm{g}}{\mathrm{mL} \times \min \times 0,01815 \mathrm{~m}^{2} \times \operatorname{dia} \times 10^{6} \mu \mathrm{g}}$

$$
\operatorname{Tx} E\left(\mathrm{CO}_{2}\right)=67,56 \mathrm{~g} \times \mathrm{m}^{-2} \cdot d^{-1}\left(\mathrm{CO}_{2}\right) \quad \text { No sítio de coleta } \mathrm{P}_{6} \text {. }
$$

\section{Aterro de Brotas - Emissão solo-ar campanha 2007:}

A tabela 6.5.27, resume as taxas de emissão solo-ar, medidas para $\mathrm{CH}_{4}$ e $\mathrm{CO}_{2}$, em cada sítio $\mathbf{P}_{\mathbf{n}}$ do aterro de Brotas, na campanha de 2007.

Tabela 6.5.27 - Resumo das taxas de emissão solo-ar - Brotas 2007

\begin{tabular}{cc|c}
\hline Sítio amostrado & Gás & $\mathbf{T}_{\mathbf{x}} \mathbf{E}\left(\boldsymbol{g} \cdot \boldsymbol{m}^{-\mathbf{2}} \cdot \boldsymbol{d}^{\mathbf{- 1}}\right)$ \\
\hline $\mathrm{P}_{1}$ & $\mathrm{CH}_{4}$ & 50,22 \\
& $\mathrm{CO}_{2}$ & 24,74 \\
\hline $\mathrm{P}_{2}$ & $\mathrm{CH}_{4}$ & 15,95 \\
& $\mathrm{CO}_{2}$ & 49,77 \\
\hline $\mathrm{P}_{3}$ & $\mathrm{CH}_{4}$ & 10,57 \\
& $\mathrm{CO}_{2}$ & 23,95 \\
\hline $\mathrm{P}_{4}$ & $\mathrm{CH}_{4}$ & 0,78 \\
& $\mathrm{CO}_{2}$ & 11,70 \\
& $\mathrm{CH}_{4}$ & 69,60 \\
$\mathrm{P}_{5}$ & $\mathrm{CO}_{2}$ & 20,68 \\
& $\mathrm{CH}_{4}$ & 20,46 \\
\hline $\mathrm{P}_{6}$ & $\mathrm{CO}_{2}$ & 67,56 \\
\hline
\end{tabular}


1) Cálculo da taxa de emissão média do Metano $\left(T_{x} E_{m}\left({ }_{(C H 4)}\right)\right.$ nos sítios $\left(P_{n}\right)$ :

$$
\mathrm{T}_{\mathrm{x}} \mathrm{E}_{\mathrm{m}}\left(\mathrm{CH}_{4}\right)=\left(\mathrm{P}_{1}+\ldots+\mathrm{P}_{6}\right) / 6=27,93 \mathrm{~g} \cdot \mathrm{m}^{-2} \cdot \mathrm{d}^{-1}
$$

2) Taxa de emissão média total do metano $\left(\mathrm{TxE}_{\mathrm{m}(\mathrm{t})(\mathrm{CH} 4)}\right)$ no aterro:

$$
\begin{gathered}
\Rightarrow \mathrm{Tx}_{\mathrm{m}(\mathrm{t})}=\mathrm{T}_{\mathrm{x}} \mathrm{E}_{\mathrm{m}} \cdot \mathrm{A}_{\mathrm{at}} \cdot 365 \mathrm{~d} \cdot 10^{-6}=458,75 \text { Ton } \cdot \mathrm{a}^{-1} \\
\Rightarrow \mathbf{T}_{\mathbf{x}} \mathrm{E}_{\mathrm{m} \text { (t) }}\left(\mathbf{C H}_{4}\right)=\mathbf{5 5 0 , 5 0 ~ t \cdot \mathbf { a } ^ { - 1 }}
\end{gathered}
$$

Em que: $\mathrm{T}_{\mathrm{x}} \mathrm{E}_{\mathrm{m}}=$ Taxa de Emissão média $\left(g \cdot m^{-2} \cdot d^{-1}\right)$;

$$
\begin{gathered}
\mathrm{A}_{\mathrm{at}}=\text { Área do aterro }\left(54.000 \mathrm{~m}^{2}\right) \\
\mathrm{T}_{\mathrm{x}} \mathrm{E}_{\mathrm{m}(\mathrm{t})}=\text { Taxa de Emissão média total para } 2006\left({\text { Toneladas } \left.\cdot a n o^{-1}\right)}\right. \\
365=\text { fator de conversão de dias p ano; } \\
10^{-6}=\text { fator de conversão de g para Tonelada }
\end{gathered}
$$

3) Cálculo da taxa de emissão média do dióxido de carbono $\left(T_{x} E_{m(C O 2)}\right)$ nos sítios $\left(P_{n}\right)$ :

$$
T_{x} E_{m}\left(C O_{2}\right)=\left(P_{1}+\ldots+P_{6}\right) / 6=33,06 g \cdot m^{-2} \cdot d^{-1}
$$

1) Cálculo da taxa de emissão média total do dióxido de carbono $\left(\operatorname{TxE}_{\mathrm{m}(\mathrm{t})(\mathrm{CO} 2)}\right)$ no aterro :

$$
\Rightarrow \mathrm{T}_{\mathrm{x}} \mathrm{E}_{\mathrm{m}(\mathrm{t})}\left(\mathrm{CO}_{2}\right)=651,61 \mathrm{t} . \mathrm{a}^{-1}
$$

Emissão Total Média (Et⿳亠口冋) do aterro de Brotas: Consideradas as campanhas 2006 e 2007:

1) Para o Metano: $\quad E_{t} M\left(C_{4}\right)=\mathbf{2 7 8 , 4 0 ~ t . a - 1}$

2) Para o Dióxido de carbono: $\mathbb{E}_{t} M\left(\mathrm{CO}_{2}\right)=417,52 \mathrm{t}^{-a^{-1}}$ 


\subsection{1-C) Aterro de Campinas}

\section{$\left.C_{1}\right)$ Campinas 2006}

$P_{1}\left(G ; V_{G}=33.200 m L\right.$ e $\left.A_{G}=0,664 m^{2}\right)$

a) Tabela com tempos de coleta e massas correspondentes, gráfico com equações de retas e inclinações:

Tabela 6.5.28 - Sítio de coleta $\mathbf{P}_{\mathbf{1}}$ - Campinas 2006: tempos de coleta e massas $(\mu g)$ para $\mathrm{CH}_{4}$ e $\mathrm{CO}_{2}$.

\begin{tabular}{ccc}
\hline Tempo $(\min )$ & Massa do $\mathrm{CH}_{4}(\mu \mathrm{g})$ & Massa do $\mathrm{CO}_{2}(\mu \mathrm{g})$ \\
\hline 0 & 0 & 7,8940 \\
3 & 10,3538 & 8,0550 \\
6 & 11,0892 & 13,7494 \\
12 & 15,7938 & 17,6395 \\
\hline
\end{tabular}

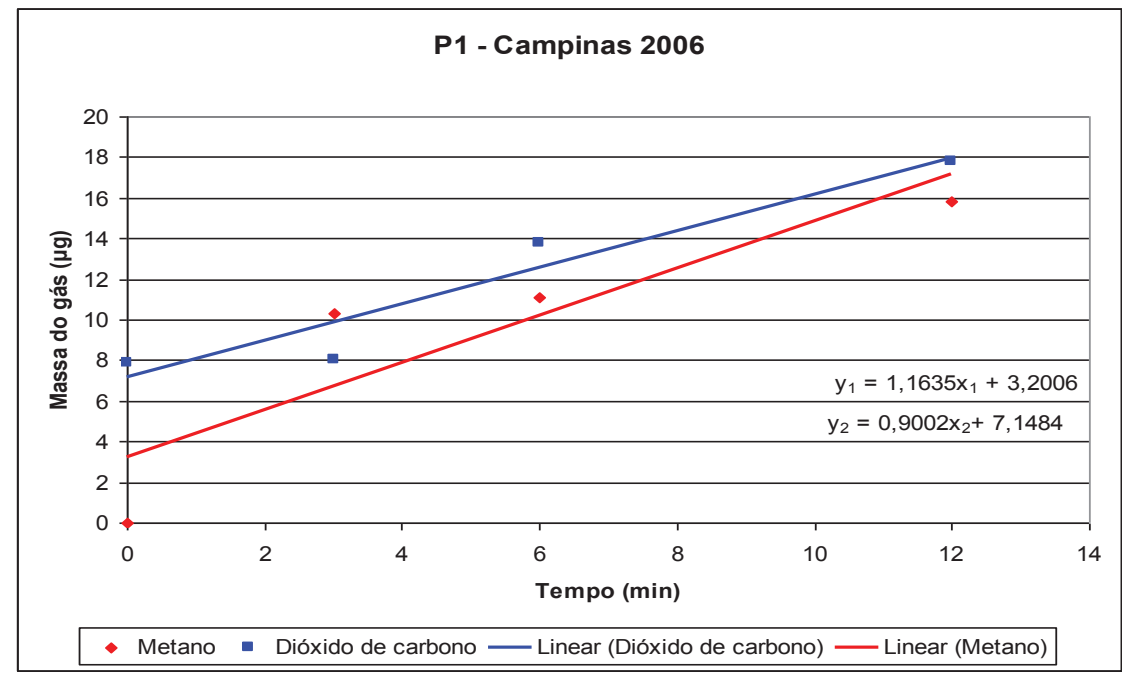

Gráfico 6.5.24 - Sítio $P_{1}$ - Campinas 2006. Equações de retas e inclinações para $\mathrm{CH}_{4}$ e $\mathrm{CO}_{2}$.

Equações das retas:

$$
\begin{aligned}
& y_{1}=1,1635 x_{1}+3,2006 \text { Equação do metano } \\
& y_{2}=0,9002 x_{2}+7,1484 \text { Equação do dióxido }
\end{aligned}
$$


b) Cálculo da taxa de emissão:

$\left.b_{1}\right)$ Metano:

$$
\operatorname{Tx} E\left(\mathrm{CH}_{4}\right)=\frac{1,1635 \mu \mathrm{g}\left(\mathrm{CH}_{4}\right) \times 33.200 \mathrm{~mL} \times 1440 \mathrm{~min} \times g}{m L \times \min \times 0,664 \mathrm{~m}^{2} \times \operatorname{dia} \times 10^{6} \mu \mathrm{g}}
$$

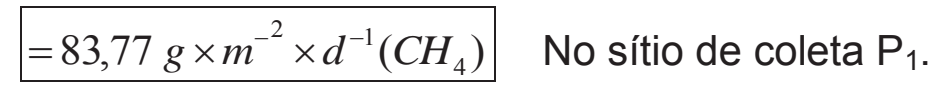

Em que: $\quad \mathrm{T}_{\mathrm{x}} \mathrm{E}\left(\mathrm{CH}_{4}\right)=$ Taxa de emissão de metano no sítio;

$1,1535 \mu \mathrm{g} \cdot \mathrm{min}^{-1} \mathrm{~mL}^{-1}=$ Inclinação da reta do gráfico de metano;

33.200 $\mathrm{mL}=$ Volume da câmara de coleta (grande);

1440 min = número de minutos $\cdot \mathrm{dia}^{-1}$;

$10^{6}=$ fator de conversão de $\mu g$ para $g ;$ e,

0,664 $m^{2}=$ Área da base da câmara de coleta (grande).

$\mathrm{b}_{2}$ ) Dióxido de carbono: $\operatorname{Tx} E\left(C \mathrm{CO}_{2}\right)=\frac{0,9002 \mu \mathrm{g}\left(\mathrm{CO}_{2}\right) \times 33.200 \mathrm{~mL} \times 1440 \mathrm{~min} \times g}{m L \times \min \times 0,664 \mathrm{~m}^{2} \times \operatorname{dia} \times 10^{6} \mu \mathrm{g}}$

$$
=64,81 \mathrm{mg} \times \mathrm{m}^{-2} \cdot \mathrm{d}^{-1}\left(\mathrm{CO}_{2}\right) \quad \text { No sítio de coleta } \mathrm{P}_{1} \text {. }
$$

Em que: $\quad \mathrm{T}_{\mathrm{x}} \mathrm{E}\left(\mathrm{CO}_{2}\right)=$ Taxa de emissão de dióxido de carbono no sítio;

0,9002 $\mu \mathrm{g} \cdot \mathrm{min}^{-1} \cdot \mathrm{mL}^{-1}=$ Inclinação da reta do gráfico de dióxido de carbono;

33.200 $\mathrm{mL}=$ Volume da câmara de coleta (grande);

$1440 \min =$ número de minutos $\cdot \mathrm{dia}^{-1}$;

$10^{6}=$ fator de conversão de $\mu g$ para $g ;$ e,

0,664 $m^{2}=$ Área da base da câmara de coleta (grande). 
$\mathbf{P}_{\mathbf{2}}\left(p ; V_{P}=1200 \mathrm{~mL}\right.$ e $\left.A_{P}=0,01815 \mathrm{~m}^{2}\right)$

a) Tabela com tempos de coleta e massas correspondentes, gráfico com equações de retas e inclinações:

Tabela 6.5.29 - Sítio de coleta $\mathrm{P}_{2}$ - Campinas 2006: tempos de coleta e massas $(\mu g)$ para $\mathrm{CH}_{4}$ e $\mathrm{CO}_{2}$.

\begin{tabular}{ccc}
\hline Tempo (min) & Massa do $\mathrm{CH}_{4}(\mu \mathrm{g})$ & Massa do $\mathrm{CO}_{2}(\mu \mathrm{g})$ \\
\hline 0 & 0 & 7,5335 \\
3 & 10,2260 & 7,5721 \\
6 & 10,2826 & 7,6150 \\
12 & 16,7181 & 27,8548 \\
\hline
\end{tabular}

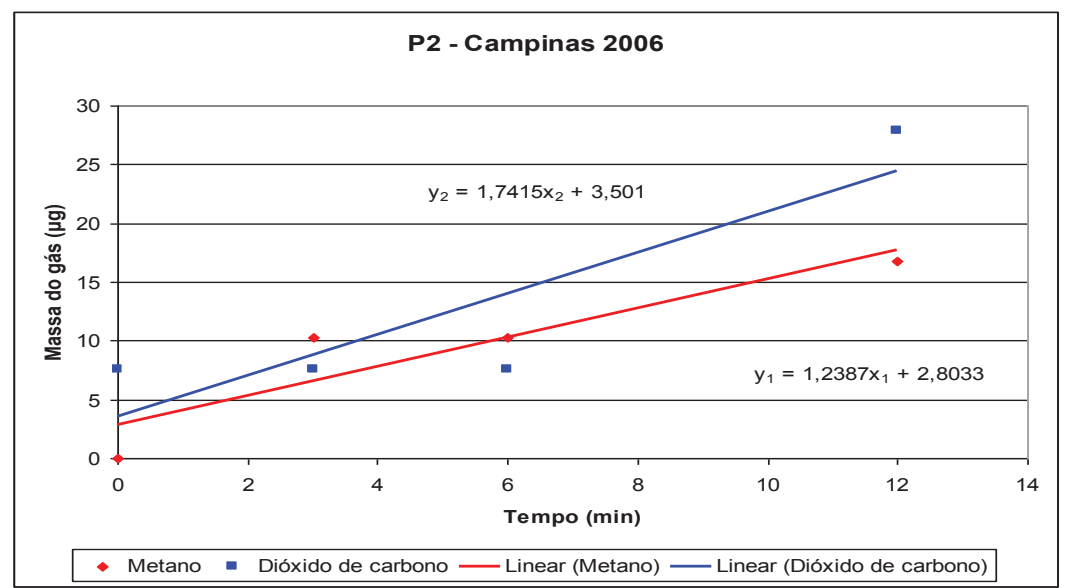

Gráfico 6.5.25 - Sítio $P_{2}$ - Campinas 2006. Equações de retas e inclinações para $\mathrm{CH}_{4}$ e $\mathrm{CO}_{2}$.

Equações das retas:

$$
\begin{aligned}
& y_{1}=1,2387 x_{1}+2,8033 \text { Equação do metano } \\
& y_{2}=1,7415 x_{2}+3,501 \text { Equação do dióxido }
\end{aligned}
$$

b) Cálculo da taxa de emissão:

b) Metano: $\quad \operatorname{Tx} E\left(\mathrm{CH}_{4}\right)=\frac{1,2387 \mu g\left(\mathrm{CO}_{2}\right) \times 1.200 \mathrm{~mL} \times 1440 \mathrm{~min} \times \mathrm{g}}{\mathrm{mL} \times \min \times 0,01815 \mathrm{~m}^{2} \times \operatorname{dia} \times 10^{6} \mathrm{~g}}$ 
$\operatorname{Tx} E\left(\mathrm{CH}_{4}\right)=117,93 \mathrm{~g} \times \mathrm{m}^{-2} \cdot \mathrm{d}^{-1}\left(\mathrm{CH}_{4}\right)$ No sítio de coleta $\mathrm{P}_{2}$.

$\mathrm{b}_{2}$ ) Dióxido de carbono: $\quad \operatorname{Tx} E\left(\mathrm{CO}_{2}\right)=\frac{1,7415 \mu \mathrm{g}\left(\mathrm{CO}_{2}\right) \times 1.200 \mathrm{~mL} \times 1440 \mathrm{~min} \times \mathrm{g}}{\mathrm{mL} \times \min \times 0,01815 \mathrm{~m}^{2} \times \operatorname{dia} \times 10^{6} \mu \mathrm{g}}$

$$
\operatorname{TxE}\left(\mathrm{CO}_{2}\right)=165,86 \mathrm{~g} \times \mathrm{m}^{-2} \cdot \mathrm{d}^{-1}\left(\mathrm{CO}_{2}\right) \text { No sítio de coleta } \mathrm{P}_{2} \text {. }
$$

$\mathbf{P}_{\mathbf{3}}\left(\mathrm{G} ; \mathrm{V}_{\mathrm{G}}=33.200 \mathrm{~mL}\right.$ e $\left.\mathrm{A}_{\mathrm{G}}=0,664 \mathrm{~m}^{2}\right)$

a) Tabela com tempos de coleta e massas correspondentes, gráfico com equações de retas e inclinações:

Tabela 6.5.30 - Sítio de coleta $\mathbf{P}_{\mathbf{3}}$ - Campinas 2006: tempos de coleta e massas $(\mu \mathrm{g})$ para $\mathrm{CH}_{4}$ e $\mathrm{CO}_{2}$.

\begin{tabular}{rcr}
\hline Tempo (min) & Massa do $\mathrm{CH}_{4}(\mu \mathrm{g})$ & Massa do $\mathrm{CO}_{2}(\mu \mathrm{g})$ \\
\hline 0 & 10,5837 & 8,6834 \\
3 & 11,5053 & 17,6545 \\
6 & 12,7973 & 16,5495 \\
12 & 14,0854 & 49,0642 \\
\hline
\end{tabular}

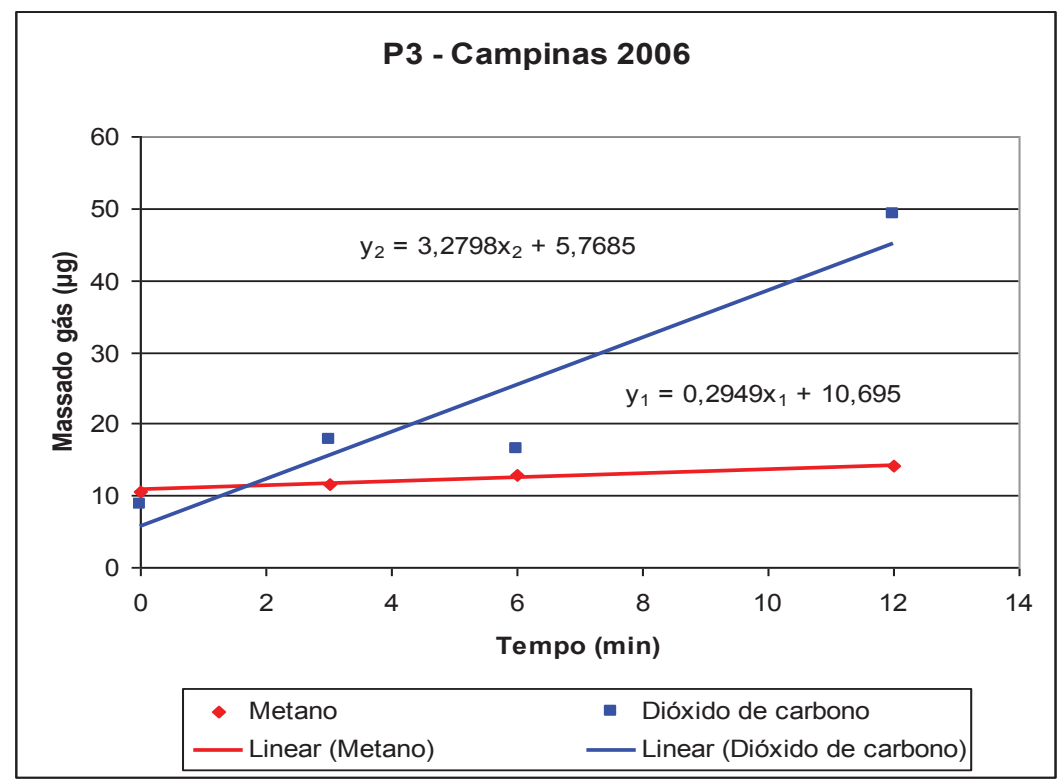

Gráfico 6.5.26 - Sítio $\mathrm{P}_{3}$ - Campinas 2006. Equações de retas e inclinações para $\mathrm{CH}_{4}$ e $\mathrm{CO}_{2}$. 
Equações das retas:

$y_{1}=0,2949 x_{1}+10,695$ Equação do metano

$y_{2}=3,2798 x_{2}+5,7685$ Equação do dióxido

b) Cálculo da taxa de emissão:

$\left.b_{1}\right)$ Metano:

$$
\begin{aligned}
& \operatorname{Tx} E\left(\mathrm{CH}_{4}\right)=\frac{0,2949 \mu g\left(\mathrm{CO}_{2}\right) \times 33.200 \mathrm{~mL} \times 1440 \mathrm{~min} \times \mathrm{g}}{\mathrm{mL} \times \min \times 0,664 \mathrm{~m}^{2} \times \operatorname{dia} \times 10^{6} \mu \mathrm{g}} \\
& \operatorname{TxE}\left(\mathrm{CH}_{4}\right)=21,23 \mathrm{~g} \times \mathrm{m}^{-2} \cdot \mathrm{d}^{-1}\left(\mathrm{CH}_{4}\right) \text { No sítio de coleta } \mathrm{P}_{3} .
\end{aligned}
$$

$\mathrm{b}_{2}$ ) Dióxido de carbono: $\operatorname{Tx} E\left(\mathrm{CO}_{2}\right)=\frac{3,2798 \mu \mathrm{g}\left(\mathrm{CO}_{2}\right) \times 33.200 \mathrm{~mL} \times 1440 \mathrm{~min} \times \mathrm{g}}{\mathrm{mL} \times \min \times 0,664 \mathrm{~m}^{2} \times \operatorname{dia} \times 10^{6} \mu \mathrm{g}}$

$$
\operatorname{TxE}\left(\mathrm{CO}_{2}\right)=236,15 \mathrm{~g} \times \mathrm{m}^{-2} \cdot \mathrm{d}^{-1}\left(\mathrm{CO}_{2}\right) \text { No sítio de coleta } \mathrm{P}_{3} \text {. }
$$

$\mathbf{P}_{4}\left(\mathrm{p} ; \mathrm{V}_{\mathrm{P}}=1.200 \mathrm{~mL}\right.$ e $\left.A_{P}=0,01815 \mathrm{~m}^{2}\right)$

a) Tabela com tempos de coleta e massas correspondentes, gráfico com equações de retas e inclinações:

Tabela 6.5.31 - Sítio de coleta $\mathbf{P}_{\mathbf{4}}$ - Campinas 2006: tempos de coleta e massas $(\mu g)$ para $\mathrm{CH}_{4}$ e $\mathrm{CO}_{2}$.

\begin{tabular}{ccc}
\hline TEMPO (MIN) & MASSA DO $\mathrm{CH}_{\mathbf{4}}(\mu \mathrm{G})$ & MASSA DO $\mathrm{CO}_{2}(\mu \mathrm{G})$ \\
\hline 0 & 13,2052 & 16,3413 \\
3 & 21,2830 & 37,5000 \\
6 & 45,5576 & 85,2250 \\
12 & 33,8528 & 67,8623 \\
\hline
\end{tabular}




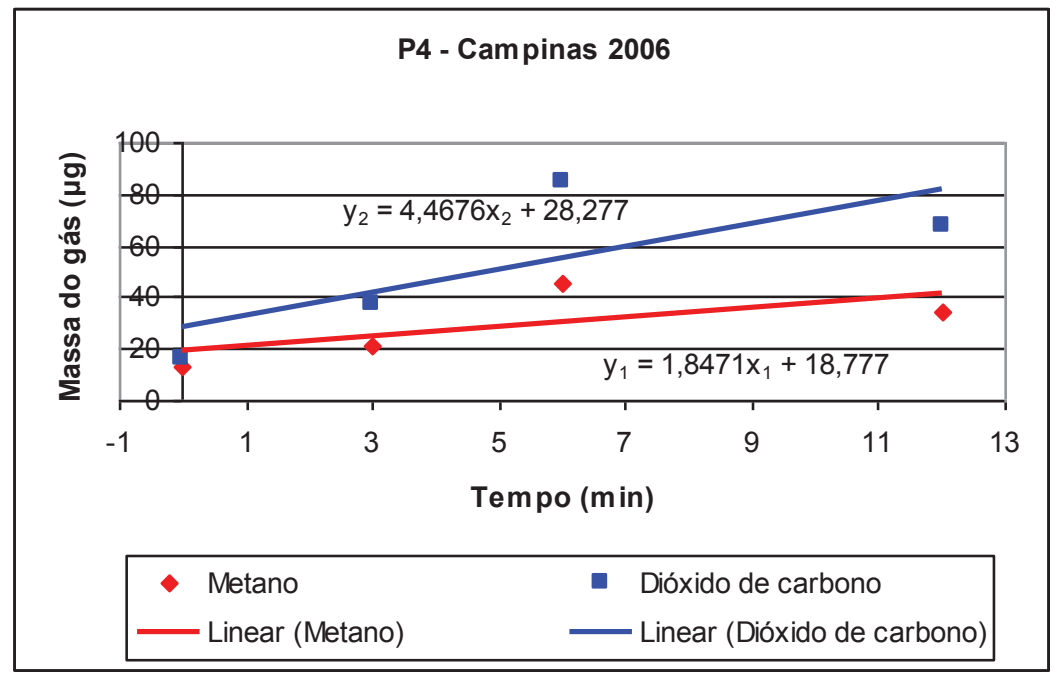

Gráfico 6.5.27 - Sítio $\mathrm{P}_{4}$ - Campinas 2006. Equações de retas e inclinações para $\mathrm{CH}_{4}$ e $\mathrm{CO}_{2}$.

Equações das retas:

$$
\begin{aligned}
& y_{1}=1,8471 x_{1}+18,777 \text { Equação do metano } \\
& y_{2}=4,4676 x_{2}+28,277 \text { Equação do dióxido }
\end{aligned}
$$

b) Cálculo da taxa de emissão:

$\left.b_{1}\right)$ Metano:

$$
\operatorname{TxE}\left(\mathrm{CH}_{4}\right)=\frac{1,8471 \mu \mathrm{g}\left(\mathrm{CO}_{2}\right) \times 1.200 \mathrm{~mL} \times 1440 \mathrm{~min} \times g}{m L \times \min \times 0,01815 \mathrm{~m}^{2} \times \operatorname{dia} \times 10^{6} \mu \mathrm{g}}
$$

$$
\operatorname{TxE}\left(\mathrm{CH}_{4}\right)=175,85 \mathrm{~g} \times \mathrm{m}^{-2} \cdot \mathrm{d}^{-1}\left(\mathrm{CH}_{4}\right) \text { No sítio de coleta } \mathrm{P}_{4} \text {. }
$$

$\mathrm{b}_{2}$ ) Dióxido de carbono: $\operatorname{Tx} E\left(\mathrm{CO}_{2}\right)=\frac{4,4676 \mu \mathrm{g}\left(\mathrm{CO}_{2}\right) \times 1.200 \mathrm{~mL} \times 1440 \mathrm{~min} \times \mathrm{g}}{\mathrm{mL} \times \min \times 0,01815 \mathrm{~m}^{2} \times \operatorname{dia} \times 10^{6} \mathrm{~g}}$

$$
\operatorname{Tx} E\left(\mathrm{CO}_{2}\right)=425,34 \mathrm{~g} \times \mathrm{m}^{-2} \cdot \mathrm{d}^{-1}\left(\mathrm{CO}_{2}\right) \text { No sítio de coleta } \mathrm{P}_{4} \text {. }
$$




\section{Aterro de Campinas - Emissão solo-ar campanha 2006:}

A tabela 6.5.32, resume as taxas de emissão solo-ar, medidas para de $\mathrm{CH}_{4}$ e $\mathrm{CO}_{2}$, em cada sítio $\mathbf{P}_{\mathbf{n}}$ do aterro de Campinas, na campanha de 2006.

Tabela 6.5.32 - Resumo das taxas de emissão solo-ar - Campinas 2006

\begin{tabular}{|c|c|c|}
\hline Sítio amostrado & Gás & $T_{x} E\left(g \cdot m^{-2} \cdot d^{-1}\right)$ \\
\hline \multirow[t]{2}{*}{$\mathrm{P}_{1}$} & $\mathrm{CH}_{4}$ & 83,77 \\
\hline & $\mathrm{CO}_{2}$ & 64,81 \\
\hline \multirow[t]{2}{*}{$\mathrm{P}_{2}$} & $\mathrm{CH}_{4}$ & 117,93 \\
\hline & $\mathrm{CO}_{2}$ & 165,86 \\
\hline \multirow[t]{2}{*}{$\mathrm{P}_{3}$} & $\mathrm{CH}_{4}$ & 21,23 \\
\hline & $\mathrm{CO}_{2}$ & 236,15 \\
\hline \multirow[t]{2}{*}{$\mathrm{P}_{4}$} & $\mathrm{CH}_{4}$ & 175,85 \\
\hline & $\mathrm{CO}_{2}$ & 425,34 \\
\hline
\end{tabular}

1) Cálculo da taxa de emissão média do Metano $\left(T_{x} E_{m(}\left(C_{4}\right)\right)$ nos sítios $\left(P_{n}\right)$ :

$$
T_{x} E_{m}\left(C H_{4}\right)=\left(P_{1}+P_{2}+P_{3}+P_{4}\right) / 4=99,70 \mathrm{~g} \cdot \mathrm{m}^{-2} \cdot \mathrm{d}^{-1}
$$

2) Taxa de emissão média total do metano $\left(\mathrm{TxE}_{\mathrm{m}(\mathrm{t})(\mathrm{CH} 4)}\right)$ no aterro:

$$
\begin{gathered}
\Rightarrow T_{x} E_{m(t)}=T_{x} E_{m}\left(99,70 \mathrm{~g} \cdot \mathrm{m}^{-2} \cdot \mathrm{d}^{-1}\right) \cdot A_{a t}\left(260.000 \mathrm{~m}^{2}\right) \cdot 365 \mathrm{~d} \cdot 10^{-6}=\text { Ton } \cdot \mathrm{a}^{-1} \\
\Rightarrow T_{\mathbf{x}} E_{m(t)}\left(\mathbf{C H}_{4}\right)=9.461,53 \mathrm{t} \cdot \mathrm{a}^{-1}
\end{gathered}
$$

Em que: $T_{x} E=$ Taxa de emissão

$$
\mathrm{T}_{\mathrm{x}} \mathrm{E}_{\mathrm{m}}=\text { Taxa de Emissão média }\left(g \cdot m^{-2} \cdot d^{-1}\right)
$$

$$
\mathrm{A}_{\mathrm{at}}=\text { Área do aterro }\left(\mathrm{m}^{2}\right)
$$


$T_{x} E_{m(t)}=$ Taxa de Emissão média total para $2006\left({\left.\text { Toneladas } \cdot a n o^{-1}\right)}^{-1}\right.$

365 = fator de conversão de dias para ano

$10^{-6}=$ fator de conversão de mg para Tonelada

3) Cálculo da taxa de emissão média do dióxido de carbono $\left(T_{x} E_{m}(C O 2)\right)$ nos sítios $\left(P_{n}\right)$ :

$$
\Rightarrow T_{x} E_{m}\left(C O_{2}\right)=\left(P_{1}+P_{2}+P_{3}+P_{4}\right) 4=223,04 g \cdot m^{-2} \cdot d^{-1}
$$

4) Cálculo da taxa de emissão média total do dióxido de carbono $\left(\operatorname{TxE}_{m(t)(\mathrm{CO} 2)}\right)$ no aterro:

$$
\Rightarrow \mathrm{T}_{\mathrm{x}} \mathrm{E}_{\mathrm{m}(\mathrm{t})}\left(\mathrm{CO}_{2}\right)=\mathbf{2 1 . 1 6 6 , 5 0 \mathrm { t } \cdot \mathbf { a } ^ { - 1 }}
$$

\section{$\mathrm{C}_{2}$ ) Campinas 2007}

$\mathbf{P}_{1}\left(\mathrm{G} ; \mathrm{V}_{\mathrm{G}}=33.200 \mathrm{~mL} ; \mathrm{A}_{\mathrm{G}}=0,664 \mathrm{~m}^{2}\right)$

a) Tabela com tempos de coleta e massas correspondentes, gráfico com equações de retas e inclinações:

Tabela 6.5.33 - Sítio de coleta $\mathbf{P}_{\mathbf{1}}$ - Campinas 2007: tempos de coleta e massas $(\mu g)$ para $\mathrm{CH}_{4}$ e $\mathrm{CO}_{2}$.

\begin{tabular}{ccc}
\hline Tempo $(\boldsymbol{m i n})$ & Massa do $\mathrm{CH}_{4}(\mu \boldsymbol{g})$ & Massa do $\mathrm{CO}_{2}(\boldsymbol{\mu} \boldsymbol{g})$ \\
\hline 0 & 10,2160 & 7,4112 \\
3 & 14,0966 & 17,9892 \\
6 & 14,0108 & 73,3208 \\
12 & 20,2817 & 31,2063 \\
\hline
\end{tabular}




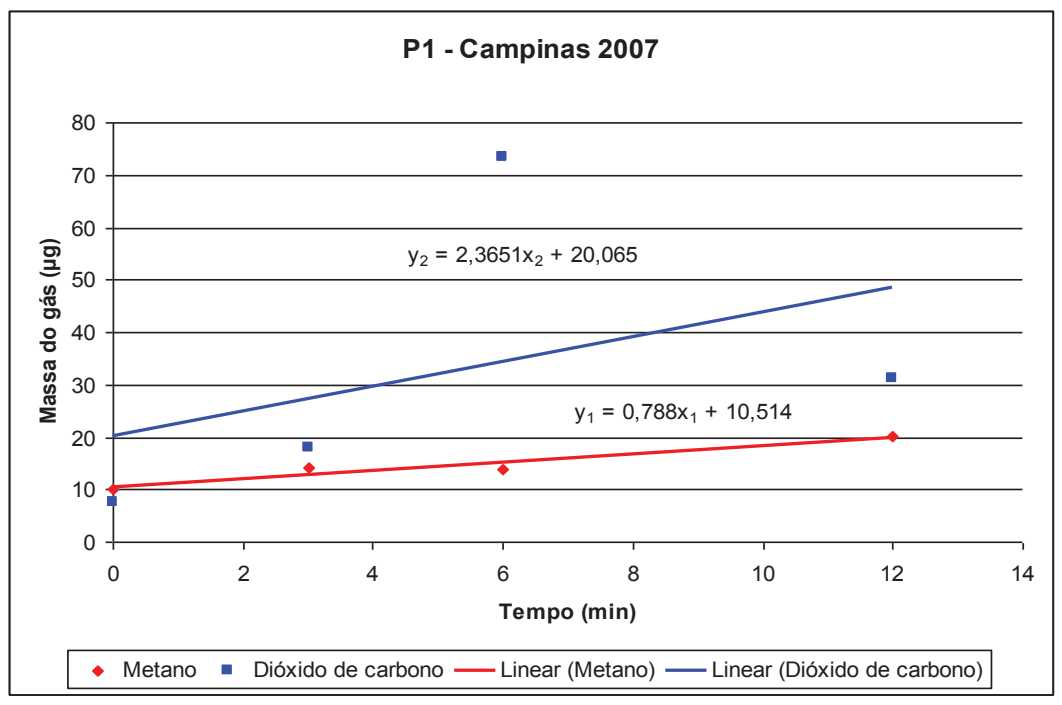

Gráfico 6.5.28 - Sítio $P_{1}$ - Campinas 2007. Equações de retas e inclinações para $\mathrm{CH}_{4}$ e $\mathrm{CO}_{2}$.

Equações das retas:

$$
\begin{aligned}
& y_{1}=0,788 x_{1}+10,514 \text { Equação do metano } \\
& y_{2}=2,3651 x_{2}+20,065 \text { Equação do dióxido }
\end{aligned}
$$

b) Cálculo da taxa de emissão:

$\left.b_{1}\right)$ Metano:

$$
\operatorname{Tx} E\left(\mathrm{CH}_{4}\right)=\frac{0,788 \mu g\left(\mathrm{CO}_{2}\right) \times 33.200 \mathrm{~mL} \times 1440 \mathrm{~min} \times g}{m L \times \min \times 0,664 \mathrm{~m}^{2} \times \operatorname{dia} \times 10^{6} \mu \mathrm{g}}
$$

$$
\operatorname{TxE}\left(\mathrm{CH}_{4}\right)=56,74 \mathrm{~g} \times \mathrm{m}^{-2} \cdot \mathrm{d}^{-1}\left(\mathrm{CH}_{4}\right) \text { No sítio de coleta } \mathrm{P}_{1} \text {. }
$$

$\mathrm{b}_{2}$ ) Dióxido de carbono: $\operatorname{Tx} E\left(\mathrm{CO}_{2}\right)=\frac{2,3651 \mu \mathrm{g}\left(\mathrm{CO}_{2}\right) \times 33.200 \mathrm{~mL} \times 1440 \mathrm{~min} \times \mathrm{g}}{\mathrm{mL} \times \min \times 0,664 \mathrm{~m}^{2} \times \operatorname{dia} \times 10^{6} \mu \mathrm{g}}$

$$
\operatorname{TxE}\left(\mathrm{CO}_{2}\right)=170,29 \mathrm{~g} \times \mathrm{m}^{-2} \cdot \mathrm{d}^{-1}\left(\mathrm{CO}_{2}\right) \text { No sítio de coleta } \mathrm{P}_{1} \text {. }
$$


$\mathbf{P}_{2}\left(p ; V_{P}=1.200 m L ; A_{P}=0,01815 m^{2}\right)$

a) Tabela com tempos de coleta e massas correspondentes, gráfico com equações de retas e inclinações:

Tabela 6.5.34 - Sítio de coleta $\mathbf{P}_{\mathbf{2}}$ - Campinas 2007: tempos de coleta e massas $(\mu \mathrm{g})$ para $\mathrm{CH}_{4}$ e $\mathrm{CO}_{2}$.

\begin{tabular}{rcr}
\hline Tempo (min) & Massa do $\mathrm{CH}_{4}(\mu \mathrm{g})$ & Massa do $\mathrm{CO}_{2}(\mu \mathrm{g})$ \\
\hline 0 & 13,5528 & 18,0192 \\
3 & 13,8192 & 17,5837 \\
6 & 17,6068 & 26,0632 \\
12 & 21,8323 & 36,5167 \\
\hline
\end{tabular}

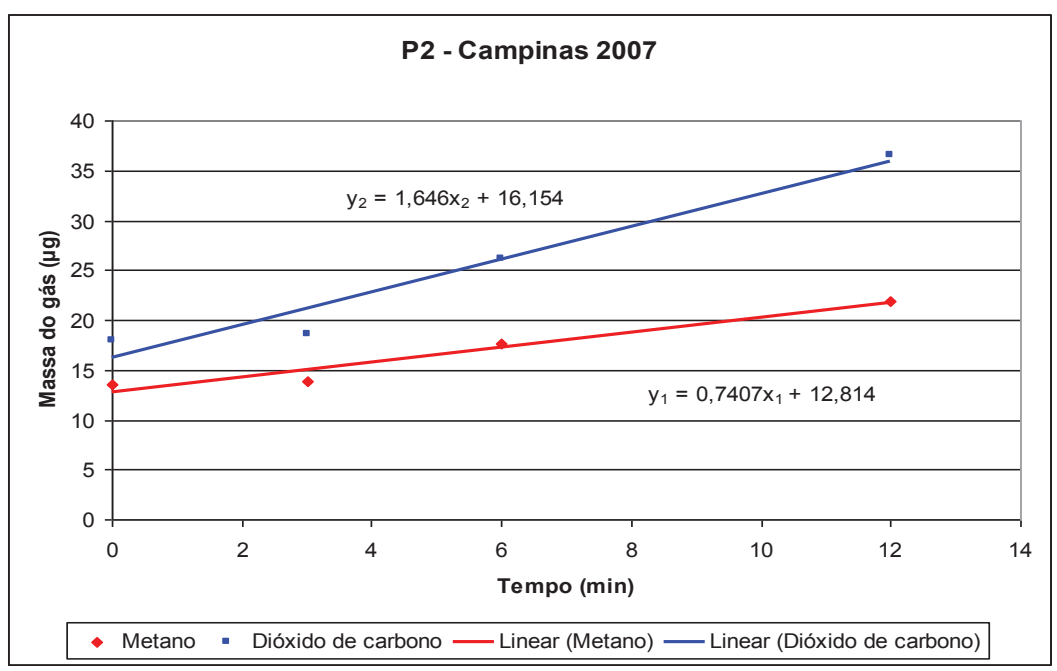

Gráfico 6.5.29 - Sítio $P_{2}$ - Campinas 2007. Equações de retas e inclinações para $\mathrm{CH}_{4}$ e $\mathrm{CO}_{2}$.

Equações das retas:

$$
\begin{aligned}
& y_{1}=0,7407 x_{1}+12,814 \text { Equação do metano } \\
& y_{2}=1,646 x_{2}+16,154 \text { Equação do dióxido }
\end{aligned}
$$

b) Cálculo da taxa de emissão: 
b $)$ Metano: $\quad \operatorname{Tx} E\left(\mathrm{CH}_{4}\right)=\frac{0,7407 \mu \mathrm{g}\left(\mathrm{CO}_{2}\right) \times 1.200 \mathrm{~mL} \times 1440 \mathrm{~min} \times \mathrm{g}}{\mathrm{mL} \times \min \times 0,01815 \mathrm{~m}^{2} \times \operatorname{dia} \times 10^{6} \mu \mathrm{g}}$

$$
\operatorname{TxE}\left(\mathrm{CH}_{4}\right)=70,52 \mathrm{~g} \times \mathrm{m}^{-2} \cdot \mathrm{d}^{-1}\left(\mathrm{CH}_{4}\right) \text { No sítio de coleta } \mathrm{P}_{2} \text {. }
$$

$\mathrm{b}_{2}$ ) Dióxido de carbono: $\operatorname{Tx} E\left(\mathrm{CO}_{2}\right)=\frac{1,646 \mu \mathrm{g}\left(\mathrm{CO}_{2}\right) \times 1.200 \mathrm{~mL} \times 1440 \mathrm{~min} \times \mathrm{g}}{\mathrm{mL} \times \min \times 0,01815 \mathrm{~m}^{2} \times \operatorname{dia} \times 10^{6} \mu \mathrm{g}}$

$$
\operatorname{Tx} E\left(\mathrm{CO}_{2}\right)=156,71 \mathrm{~g} \times \mathrm{m}^{-2} \cdot \mathrm{d}^{-1}\left(\mathrm{CO}_{2}\right) \text { No sítio de coleta } \mathrm{P}_{2} \text {. }
$$

$\mathbf{P}_{3}\left(\mathrm{G} ; \mathrm{V}_{\mathrm{G}}=33.200 \mathrm{~mL} ; \mathrm{A}_{\mathrm{G}}=0,664 \mathrm{~m}^{2}\right)$

a) Tabela com tempos de coleta e massas correspondentes, gráfico com equações de retas e inclinações:

Tabela 6.5.35 - Sítio de coleta $\mathbf{P}_{\mathbf{3}}$ - Campinas 2007: tempos de coleta e massas $(\mu g)$ para $\mathrm{CH}_{4}$ e $\mathrm{CO}_{2}$.

\begin{tabular}{rlr}
\hline Tempo (min) & Massa do $\mathrm{CH}_{\mathbf{4}}(\mu \mathrm{g})$ & Massa do $\mathrm{CO}_{2}(\mu \mathrm{g})$ \\
\hline 0 & 0 & 8,4154 \\
3 & 10,7772 & 11,5545 \\
6 & 10,9031 & 9,7736 \\
12 & 11,1704 & 11,0867 \\
\hline
\end{tabular}




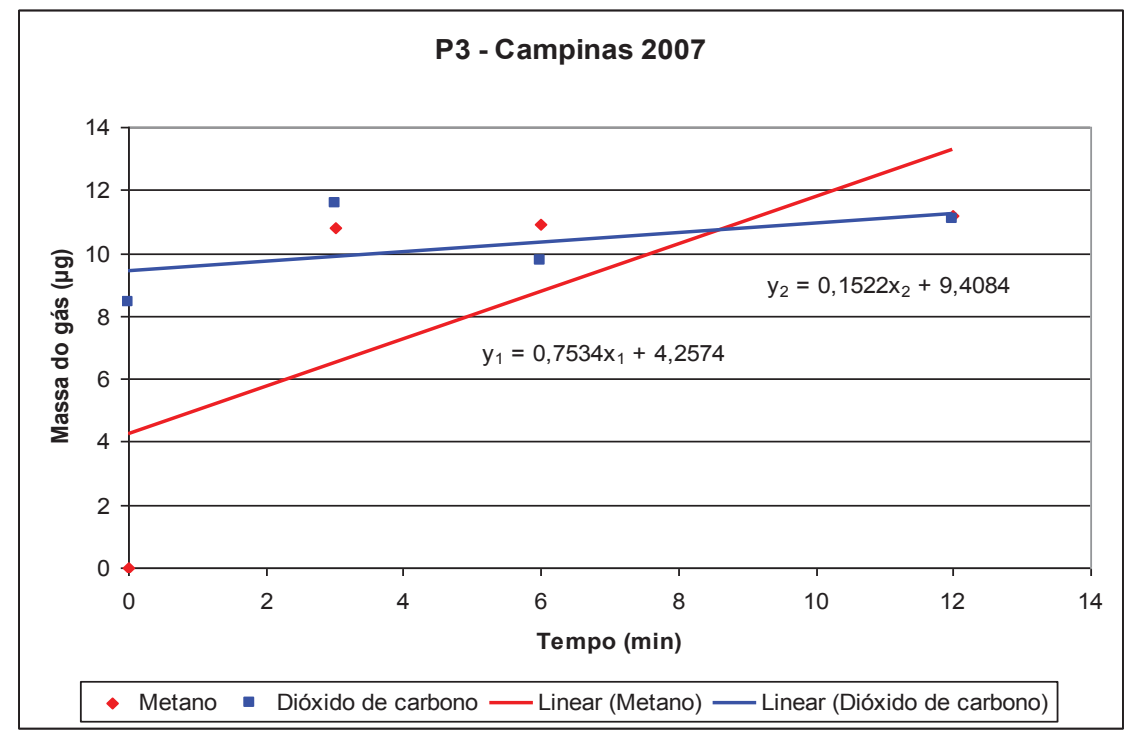

Gráfico 6.5.30 - Sítio $\mathrm{P}_{3}$ - Campinas 2007. Equações de retas e inclinações para $\mathrm{CH}_{4}$ e $\mathrm{CO}_{2}$.

Equações das retas:

$$
\begin{aligned}
& y_{1}=0,7534 x_{1}+4,2574 \text { Equação do metano } \\
& y_{2}=0,1522 x_{2}+9,4084 \text { Equação do dióxido }
\end{aligned}
$$

b) Cálculo da taxa de emissão:

b 1) Metano: $\quad \operatorname{TxE}\left(\mathrm{CH}_{4}\right)=\frac{0,7534 \mu \mathrm{g}\left(\mathrm{CO}_{2}\right) \times 33.200 \mathrm{~mL} \times 1440 \mathrm{~min} \times \mathrm{g}}{\mathrm{mL} \times \min \times 0,664 \mathrm{~m}^{2} \times \operatorname{dia} \times 10^{6} \mathrm{~g}}$

$$
\operatorname{TxE}\left(\mathrm{CH}_{4}\right)=54,25 \mathrm{~g} \times \mathrm{m}^{-2} \cdot \mathrm{d}^{-1}\left(\mathrm{CH}_{4}\right) \text { No sítio de coleta } \mathrm{P}_{3} .
$$

$\mathrm{b}_{2}$ ) Dióxido de carbono: $\operatorname{Tx} E\left(\mathrm{CO}_{2}\right)=\frac{0,1522 \mu \mathrm{g}\left(\mathrm{CO}_{2}\right) \times 33.200 \mathrm{~mL} \times 1440 \mathrm{~min} \times \mathrm{g}}{\mathrm{mL} \times \min \times 0,664 \mathrm{~m}^{2} \times \operatorname{dia} \times 10^{6} \mu \mathrm{g}}$

$$
\operatorname{TxE}\left(\mathrm{CO}_{2}\right)=10,96 \mathrm{~g} \times \mathrm{m}^{-2} \cdot \mathrm{d}^{-1}\left(\mathrm{CO}_{2}\right) \quad \text { No sítio de coleta } \mathrm{P}_{3} \text {. }
$$


$\mathbf{P}_{4}\left(p ; V_{P}=1.200 m L ; A_{P}=0,01815 m^{2}\right)$

a) Tabela com tempos de coleta e massas correspondentes, gráfico com equações de retas e inclinações:

Tabela 6.5.36 - Sítio de coleta $\mathbf{P}_{\mathbf{4}}$ - Araraquara 2007: tempos de coleta e massas $(\mu g)$ para $\mathrm{CH}_{4}$ e $\mathrm{CO}_{2}$.

\begin{tabular}{rcr}
\hline Tempo (min) & Massa do $\mathrm{CH}_{4}(\mu \mathrm{g})$ & Massa do $\mathrm{CO}_{2}(\mu \mathrm{g})$ \\
\hline 0 & 10,3784 & 8,3574 \\
3 & 10,5345 & 10,4580 \\
6 & 10,9806 & 11,4107 \\
12 & 11,0573 & 10,9022 \\
\hline
\end{tabular}

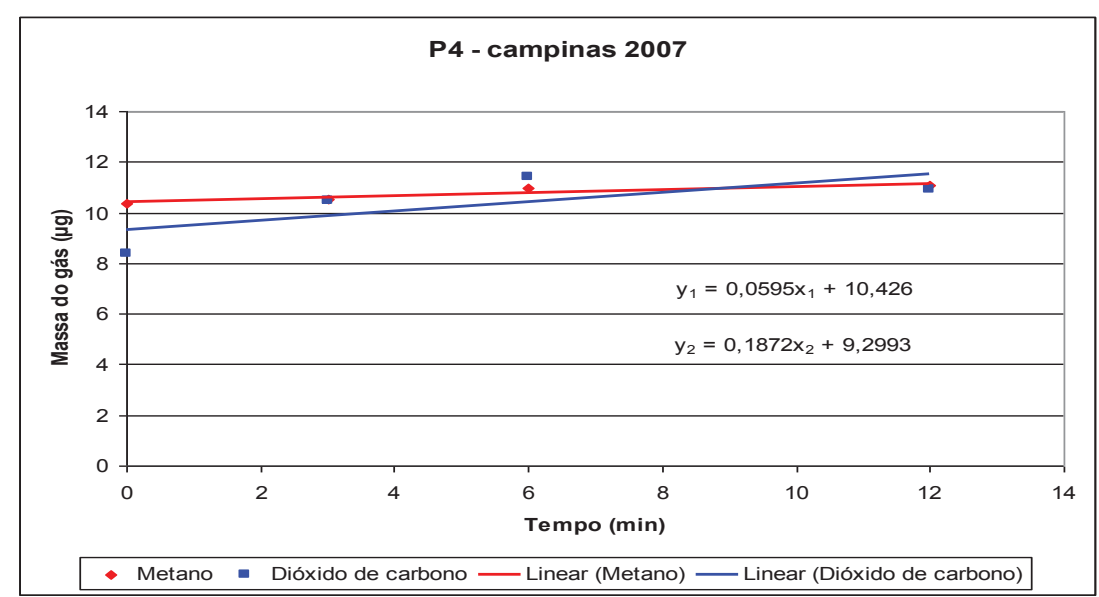

Gráfico 6.5.31 - Sítio $\mathbf{P}_{\mathbf{4}}$ - Campinas 2007. Equações de retas e inclinações para $\mathrm{CH}_{4}$ e $\mathrm{CO}_{2}$.

Equações das retas:

$$
\begin{aligned}
& y_{1}=0,0595 x_{1}+10,426 \text { Equação do metano } \\
& y_{2}=0,1872 x_{2}+9,2993 \text { Equação do dióxido }
\end{aligned}
$$

b) Cálculo da taxa de emissão:

b) Metano: $\quad \operatorname{Tx} E\left(\mathrm{CH}_{4}\right)=\frac{0,0595 \mu \mathrm{g}\left(\mathrm{CO}_{2}\right) \times 1.200 \mathrm{~mL} \times 1440 \mathrm{~min} \times \mathrm{g}}{\mathrm{mL} \times \min \times 0,01815 \mathrm{~m}^{2} \times \operatorname{dia} \times 10^{6} \mu \mathrm{g}}$ 


$$
\text { TxE }\left(\mathrm{CH}_{4}\right)=156,73 \mathrm{~g} \times \mathrm{m}^{-2} \cdot \mathrm{d}^{-1}\left(\mathrm{CH}_{4}\right) \text { No sítio de coleta } \mathrm{P}_{4} \text {. }
$$

$\mathrm{b}_{2}$ ) Dióxido de carbono: $\operatorname{Tx} E\left(\mathrm{CO}_{2}\right)=\frac{0,1872 \mu \mathrm{g}\left(\mathrm{CO}_{2}\right) \times 1.200 \mathrm{~mL} \times 1440 \mathrm{~min} \times \mathrm{g}}{\mathrm{mL} \times \min \times 0,01815 \mathrm{~m}^{2} \times \operatorname{dia} \times 10^{6} \mu \mathrm{g}}$

$$
\operatorname{Tx} E\left(\mathrm{CO}_{2}\right)=17,80 \mathrm{mg} \times \mathrm{m}^{-2} \cdot \mathrm{d}^{-1}\left(\mathrm{CO}_{2}\right) \quad \text { No sítio de coleta } \mathrm{P}_{4} \text {. }
$$

$P_{5}\left(G ; V_{G}=33.200 m L ; A_{G}=0,664 m^{2}\right)$

a) Tabela com tempos de coleta e massas correspondentes, gráfico com equações de retas e inclinações:

Tabela 6.5.37 - Sítio de coleta $\mathbf{P}_{\mathbf{5}}$ - Campinas 2007: tempos de coleta e massas $(\mu g)$ para $\mathrm{CH}_{4}$ e $\mathrm{CO}_{2}$.

\begin{tabular}{rrr}
\hline Tempo (min) & Massa do $\mathrm{CH}_{4}(\mu \mathrm{g})$ & Massa do $\mathrm{CO}_{2}(\mu \mathrm{g})$ \\
\hline 0 & 10,5427 & 8,2051 \\
3 & 19,0932 & 27,7196 \\
6 & 33,7041 & 65,6180 \\
12 & 27,4530 & 48,3413 \\
\hline
\end{tabular}

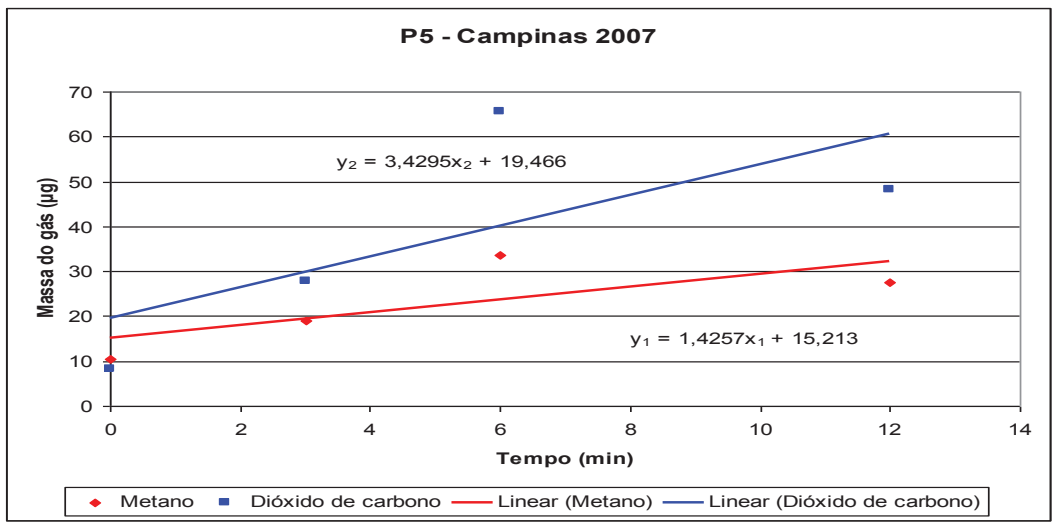

Gráfico 6.5.32 - Sítio $P_{5}$ - Campinas 2007. Equações de retas e inclinações para $\mathrm{CH}_{4}$ e $\mathrm{CO}_{2}$. 
Equações das retas:

$$
\begin{aligned}
& y_{1}=1,4257 x_{1}+15,213 \quad \text { Equação do metano } \\
& y_{2}=3,4295 x_{2}+19,466 \quad \text { Equação do dióxido }
\end{aligned}
$$

b) Cálculo da taxa de emissão:

b ) Metano:

$$
\operatorname{Tx} E\left(\mathrm{CH}_{4}\right)=\frac{1,4257 \mu g\left(\mathrm{CO}_{2}\right) \times 33.200 \mathrm{~mL} \times 1440 \mathrm{~min} \times g}{\mathrm{~mL} \times \min \times 0,664 \mathrm{~m}^{2} \times \operatorname{dia} \times 10^{6} \mathrm{~g}}
$$

$$
\operatorname{TxE}\left(\mathrm{CH}_{4}\right)=102,65 \mathrm{~g} \times \mathrm{m}^{-2} \cdot \mathrm{d}^{-1}\left(\mathrm{CH}_{4}\right) \text { No sítio de coleta } \mathrm{P}_{5} \text {. }
$$

$\mathrm{b}_{2}$ ) Dióxido de carbono: $\operatorname{Tx} E\left(\mathrm{CO}_{2}\right)=\frac{3,4295 \mu \mathrm{g}\left(\mathrm{CO}_{2}\right) \times 33.200 \mathrm{~mL} \times 1440 \mathrm{~min} \times \mathrm{g}}{\mathrm{mL} \times \min \times 0,664 \mathrm{~m}^{2} \times \operatorname{dia} \times 10^{6} \mu \mathrm{g}}$

$$
\operatorname{TxE}\left(\mathrm{CO}_{2}\right)=246,93 \mathrm{~g} \times \mathrm{m}^{-2} \cdot \mathrm{d}^{-1}\left(\mathrm{CO}_{2}\right) \text { No sítio de coleta } \mathrm{P}_{5} \text {. }
$$

$\mathbf{P}_{6}\left(p ; V_{P}=1.200 m L ; A_{P}=0,01815 m^{2}\right)$

a) Tabela com tempos de coleta e massas correspondentes, gráfico com equações de retas e inclinações:

Tabela 6.5.38 - Sítio de coleta $\mathbf{P}_{6}$ - Campinas 2007: tempos de coleta e massas $(\mu g)$ para $\mathrm{CH}_{4}$ e $\mathrm{CO}_{2}$.

\begin{tabular}{rcr}
\hline Tempo (min) & Massa do $\mathrm{CH}_{\mathbf{4}}(\mu \mathrm{g})$ & Massa do $\mathrm{CO}_{\mathbf{2}}(\boldsymbol{\mu g})$ \\
\hline 0 & 10,2270 & 8,1772 \\
3 & 15,1578 & 22,2000 \\
6 & 19,0183 & 28,8140 \\
12 & 13,3785 & 17,4185 \\
\hline
\end{tabular}




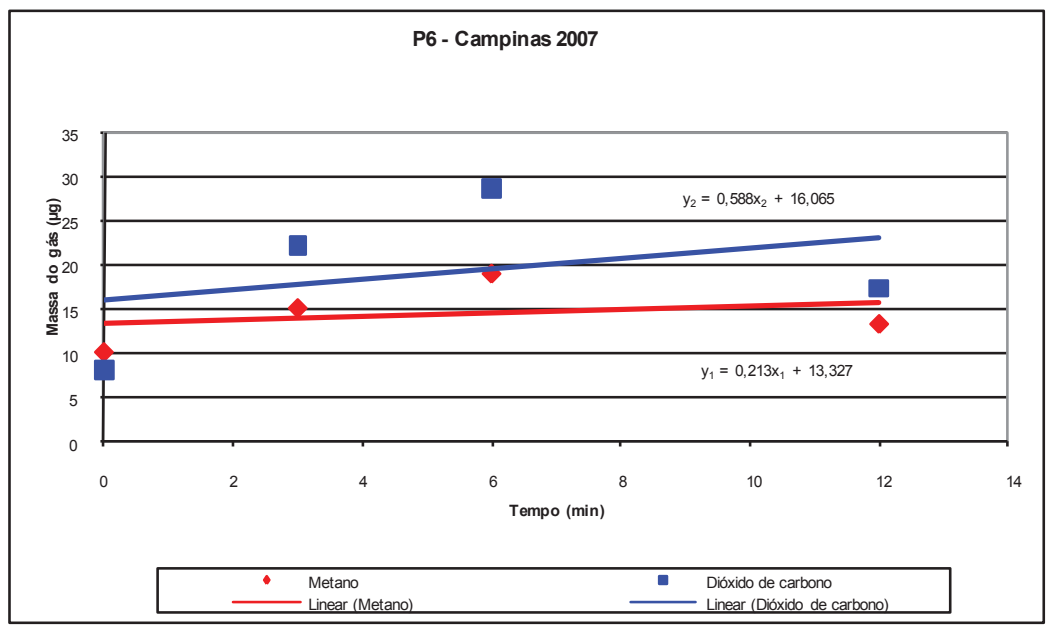

Gráfico 6.5.33 - Sítio $\mathbf{P}_{6}$ - Campinas 2007. Equações de retas e inclinações para $\mathrm{CH}_{4}$ e $\mathrm{CO}_{2}$.

Equações das retas:

$$
\begin{aligned}
& y_{1}=0,213 x_{1}+13,327 \text { Equação do metano } \\
& y_{2}=0,588 x_{2}+16,065 \text { Equação do dióxido }
\end{aligned}
$$

b) Cálculo da taxa de emissão:

$\left.b_{1}\right)$ Metano:

$$
\begin{aligned}
& \operatorname{Tx} E\left(\mathrm{CH}_{4}\right)=\frac{0,213 \mu g\left(\mathrm{CO}_{2}\right) \times 1.200 \mathrm{~mL} \times 1440 \mathrm{~min} \times \mathrm{g}}{m L \times \min \times 0,01815 \mathrm{~m}^{2} \times \operatorname{dia} \times 10^{6} \mu \mathrm{g}} \\
& \operatorname{TxE}\left(\mathrm{CH}_{4}\right)=20,28 \mathrm{~g} \times \mathrm{m}^{-2} \cdot \mathrm{d}^{-1}\left(\mathrm{CH}_{4}\right) \text { No sítio de coleta } \mathrm{P}_{6} .
\end{aligned}
$$

$\mathrm{b}_{2}$ ) Dióxido de carbono: $\operatorname{Tx} E\left(\mathrm{CO}_{2}\right)=\frac{0,588 \mu \mathrm{g}\left(\mathrm{CO}_{2}\right) \times 1.200 \mathrm{~mL} \times 1440 \mathrm{~min} \times \mathrm{g}}{\mathrm{mL} \times \min \times 0,01815 \mathrm{~m}^{2} \times \operatorname{dia} \times 10^{6} \mu \mathrm{g}}$

$$
\operatorname{Tx} E\left(\mathrm{CO}_{2}\right)=55,98 \mathrm{~g} \times \mathrm{m}^{-2} \cdot \mathrm{d}^{-1}\left(\mathrm{CO}_{2}\right) \quad \text { No sítio de coleta } \mathrm{P}_{6} .
$$

$\mathbf{P}_{7}\left(\mathrm{G} ; \mathrm{V}_{\mathrm{G}}=33.200 \mathrm{~mL} ; \mathrm{A}_{\mathrm{G}}=0,664 \mathrm{~m}^{2}\right)$

a) Tabela com tempos de coleta e massas correspondentes, gráfico com equações de retas e inclinações: 
Tabela 6.5.39 - Sítio de coleta $\mathbf{P}_{\mathbf{7}}$ - Campinas 2007: tempos de coleta e massas $(\mu \mathrm{g})$ para $\mathrm{CH}_{4}$ e $\mathrm{CO}_{2}$.

\begin{tabular}{rcr}
\hline Tempo (min) & Massa do $\mathrm{CH}_{\mathbf{4}}(\mu \mathrm{g})$ & Massa do $\mathrm{CO}_{\mathbf{2}}(\boldsymbol{\mu g})$ \\
\hline 0 & 10,5007 & 9,3230 \\
3 & 25,1600 & 49,2661 \\
6 & 27,3060 & 61,7236 \\
12 & 29,3983 & 53,2205 \\
\hline
\end{tabular}

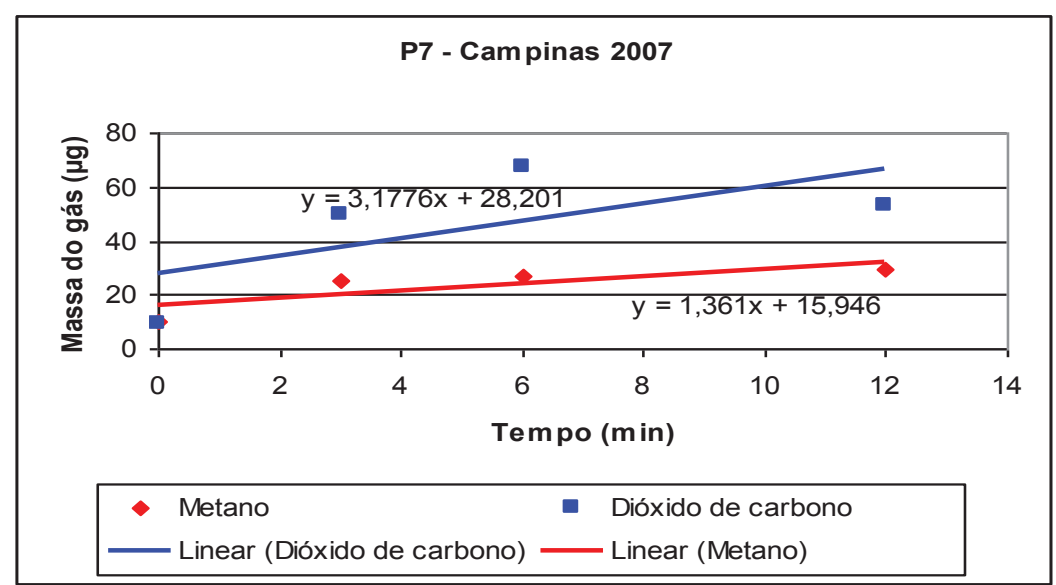

Gráfico 6.5.34 - Sítio $\mathbf{P}_{7}$ - Campinas 2007. Equações de retas e inclinações para $\mathrm{CH}_{4}$ e $\mathrm{CO}_{2}$.

Equações das retas:

$$
\begin{aligned}
& y_{1}=1,361 x_{1}+15,946 \text { Equação do metano } \\
& y_{2}=3,1776 x_{2}+28,201 \text { Equação do dióxido }
\end{aligned}
$$

b) Cálculo da taxa de emissão:

b1) Metano: $\quad \operatorname{Tx} E\left(\mathrm{CH}_{4}\right)=\frac{1,361 \mu \mathrm{g}\left(\mathrm{CO}_{2}\right) \times 33.200 \mathrm{~mL} \times 1440 \mathrm{~min} \times \mathrm{g}}{\mathrm{mL} \times \min \times 0,664 \mathrm{~m}^{2} \times \operatorname{dia} \times 10^{6} \mathrm{~g}}$

$$
\operatorname{TxE}\left(\mathrm{CH}_{4}\right)=98,00 \mathrm{~g} \times \mathrm{m}^{-2} \cdot \mathrm{d}^{-1}\left(\mathrm{CH}_{4}\right) \text { No sítio de coleta } \mathrm{P}_{7} \text {. }
$$

$\mathrm{b}_{2}$ ) Dióxido de carbono: $\operatorname{Tx} E\left(\mathrm{CO}_{2}\right)=\frac{3,1776 \mu \mathrm{g}\left(\mathrm{CO}_{2}\right) \times 33.200 \mathrm{~mL} \times 1440 \mathrm{~min} \times \mathrm{g}}{\mathrm{mL} \times \min \times 0,664 \mathrm{~m}^{2} \times \operatorname{dia} \times 10^{6} \mu \mathrm{g}}$ 
$\operatorname{TxE}\left(\mathrm{CO}_{2}\right)=228,79 \mathrm{~g} \times \mathrm{m}^{-2} \cdot \mathrm{d}^{-1}\left(\mathrm{CO}_{2}\right)$ No sítio de coleta $\mathrm{P}_{7}$.

$\mathbf{P}_{8}\left(\mathrm{G} ; \mathrm{V}_{\mathrm{G}}=33.200 \mathrm{~mL} ; \mathrm{A}_{\mathrm{G}}=0,664 \mathrm{~m}^{2}\right)$

a) Tabela com tempos de coleta e massas correspondentes, gráfico com equações de retas e inclinações:

Tabela 6.5.40 - Sítio de coleta $\mathbf{P}_{\mathbf{8}}$ - Campinas 2007: tempos de coleta e massas $(\mu \mathrm{g})$ para $\mathrm{CH}_{4}$ e $\mathrm{CO}_{2}$.

\begin{tabular}{ccc}
\hline Tempo (min) & Massa do $\mathrm{CH}_{\mathbf{4}}(\mu \mathrm{g})$ & Massa do $\mathrm{CO}_{\mathbf{2}}(\mu \mathrm{g})$ \\
\hline 0 & 0 & 7,6773 \\
3 & 10,3684 & 7,8318 \\
6 & 10,4341 & 8,0420 \\
12 & 11,5100 & 14,8000 \\
\hline
\end{tabular}

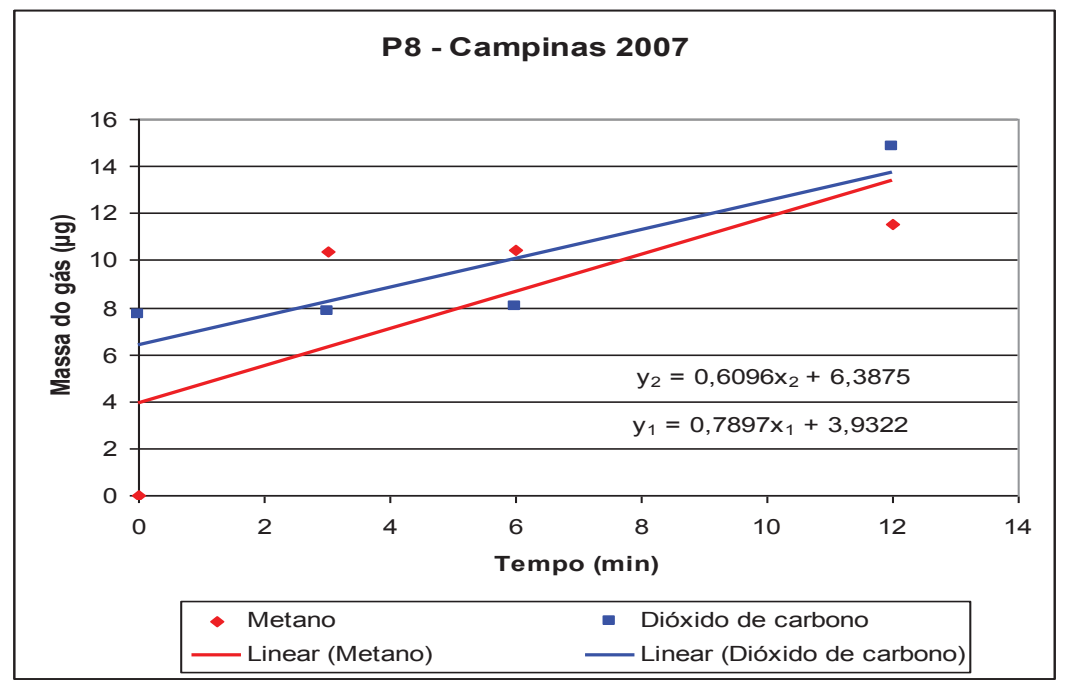

Gráfico 6.5.35 - Sítio $\mathbf{P}_{\mathbf{8}}$ - Campinas 2007. Equações de retas e inclinações para $\mathrm{CH}_{4}$ e $\mathrm{CO}_{2}$. 
Equações das retas:

$$
\begin{aligned}
& y_{1}=0,7897 x_{1}+3,9322 \text { Equação do metano } \\
& y_{2}=0,6096 x_{2}+6,3875 \text { Equação do dióxido }
\end{aligned}
$$

b) Cálculo da taxa de emissão:

$b_{1}$ ) Metano:

$$
\begin{aligned}
& \operatorname{Tx} E\left(\mathrm{CH}_{4}\right)=\frac{0,7897 \mu g\left(\mathrm{CO}_{2}\right) \times 33.200 \mathrm{~mL} \times 1440 \mathrm{~min} \times g}{m L \times \min \times 0,664 \mathrm{~m}^{2} \times \operatorname{dia} \times 10^{6} \mathrm{~g}} \\
& \operatorname{TxE}\left(\mathrm{CH}_{4}\right)=56,86 \mathrm{~g} \times \mathrm{m}^{-2} \cdot \mathrm{d}^{-1}\left(\mathrm{CH}_{4}\right) \text { No sítio de coleta } \mathrm{P}_{8} .
\end{aligned}
$$

$\mathrm{b}_{2}$ ) Dióxido de carbono: $\operatorname{Tx} E\left(\mathrm{CO}_{2}\right)=\frac{0,6096 \mu \mathrm{g}\left(\mathrm{CO}_{2}\right) \times 33.200 \mathrm{~mL} \times 1440 \mathrm{~min} \times \mathrm{g}}{\mathrm{mL} \times \min \times 0,664 \mathrm{~m}^{2} \times \operatorname{dia} \times 10^{6} \mu \mathrm{g}}$

$$
\operatorname{TxE}\left(\mathrm{CO}_{2}\right)=43,90 \mathrm{~g} \times \mathrm{m}^{-2} \cdot \mathrm{d}^{-1}\left(\mathrm{CO}_{2}\right) \text { No sítio de coleta } \mathrm{P}_{8} \text {. }
$$

$\mathbf{P}_{9}\left(G ; V_{G}=33.200 m L ; A_{G}=0,664 m^{2}\right)$

a) Tabela com tempos de coleta e massas correspondentes, gráfico com equações de retas e inclinações:

Tabela 6.5.41 - Sítio de coleta $\mathbf{P}_{\mathbf{9}}$ - Campinas 2007: tempos de coleta e massas $(\mu g)$ para $\mathrm{CH}_{4}$ e $\mathrm{CO}_{2}$.

\begin{tabular}{rlr}
\hline Tempo (min) & Massa do $\mathrm{CH}_{\mathbf{4}}(\boldsymbol{\mu g})$ & Massa do $\mathrm{CO}_{\mathbf{2}}(\boldsymbol{\mu} \boldsymbol{g})$ \\
\hline 0 & 0 & 7,6130 \\
3 & 10,3082 & 8,5162 \\
6 & 12,9123 & 18,4420 \\
12 & 13,3001 & 21,7720 \\
\hline
\end{tabular}




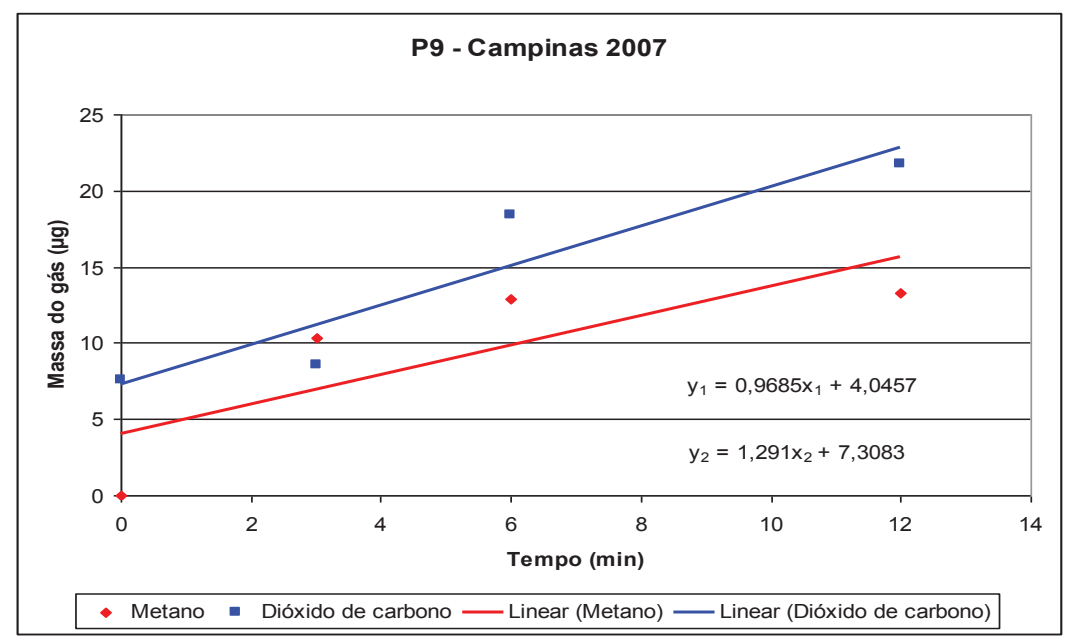

Gráfico 6.5.36- Sítio $\mathbf{P}_{\mathbf{9}}$ - Campinas 2007. Equações de retas e inclinações para $\mathrm{CH}_{4}$ e $\mathrm{CO}_{2}$.

Equações das retas:

$$
\begin{aligned}
& y_{1}=0,9685 x_{1}+4,0457 \text { Equação do metano } \\
& y_{2}=1,291 x_{2}+7,3083 \quad \text { Equação do dióxido }
\end{aligned}
$$

b) Cálculo da taxa de emissão:

b) Metano: $\quad \operatorname{Tx} E\left(\mathrm{CH}_{4}\right)=\frac{0,9685 \mu \mathrm{g}\left(\mathrm{CO}_{2}\right) \times 33.200 \mathrm{~mL} \times 1440 \mathrm{~min} \times \mathrm{g}}{\mathrm{mL} \times \min \times 0,664 \mathrm{~m}^{2} \times \operatorname{dia} \times 10^{6} \mathrm{~g}}$

$$
\operatorname{TxE}\left(\mathrm{CH}_{4}\right)=69,73 \mathrm{~g} \times \mathrm{m}^{-2} \cdot \mathrm{d}^{-1}\left(\mathrm{CH}_{4}\right) \text { No sítio de coleta } \mathrm{P}_{9} \text {. }
$$

$\mathrm{b}_{2}$ ) Dióxido de carbono: $\operatorname{Tx} E\left(\mathrm{CO}_{2}\right)=\frac{1,291 \mu \mathrm{g}\left(\mathrm{CO}_{2}\right) \times 33.200 \mathrm{~mL} \times 1440 \mathrm{~min} \times \mathrm{g}}{\mathrm{mL} \times \min \times 0,664 \mathrm{~m}^{2} \times \operatorname{dia} \times 10^{6} \mu \mathrm{g}}$

$$
\operatorname{TxE}\left(\mathrm{CO}_{2}\right)=92,95 \mathrm{~g} \times \mathrm{m}^{-2} \cdot \mathrm{d}^{-1}\left(\mathrm{CO}_{2}\right) \text { No sítio de coleta } \mathrm{P}_{9} .
$$

$\mathbf{P}_{10}\left(\mathrm{G} ; \mathrm{V}_{\mathrm{G}}=33.200 \mathrm{~mL} ; \mathrm{A}_{\mathrm{G}}=0,664 \mathrm{~m}^{2}\right)$

a) Tabela com tempos de coleta e massas correspondentes, gráfico com equações de retas e inclinações: 
Tabela 6.5.42 - Sítio de coleta $\mathbf{P}_{10}$ - Campinas 2007: tempos de coleta e massas $(\mu \mathrm{g})$ para $\mathrm{CH}_{4}$ e $\mathrm{CO}_{2}$.

\begin{tabular}{ccc}
\hline Tempo (min) & Massa do $\mathrm{CH}_{\mathbf{4}}(\boldsymbol{\mu g})$ & Massa do $\mathrm{CO}_{\mathbf{2}}(\boldsymbol{\mu} \boldsymbol{g})$ \\
\hline 0 & 0 & 8,0592 \\
3 & 10,3465 & 8,1150 \\
6 & 15,1532 & 16,3435 \\
12 & 15,6386 & 22,2805 \\
\hline
\end{tabular}

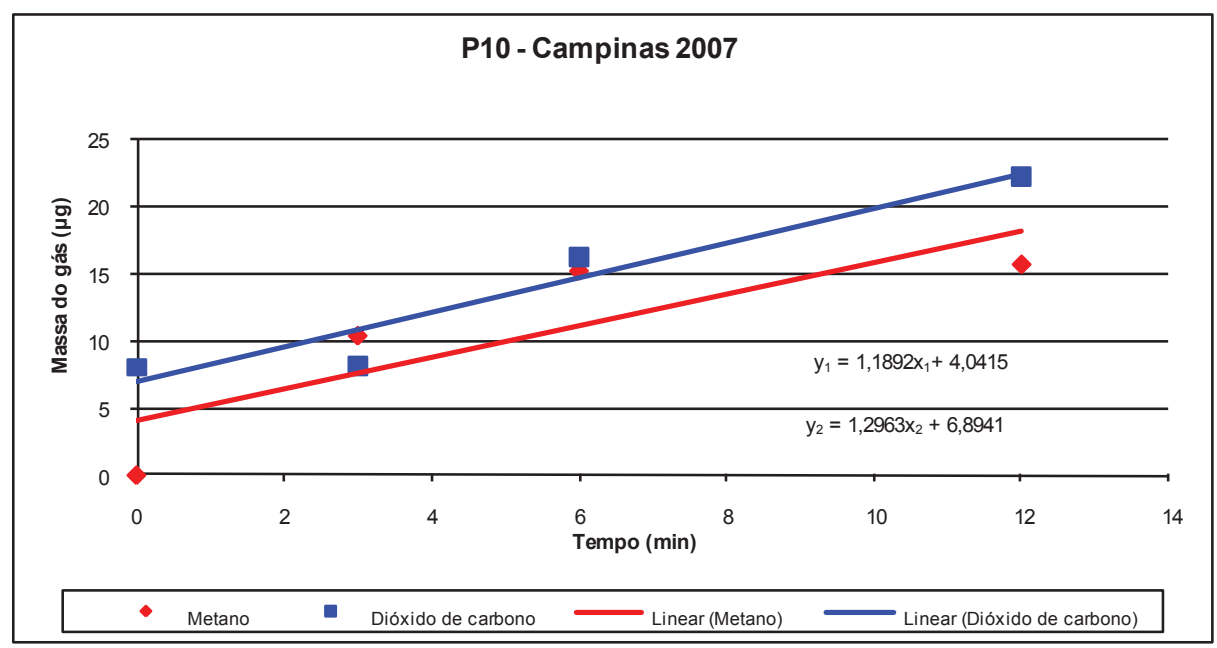

Gráfico 6.5.37 - Sítio $\mathbf{P}_{\mathbf{1 0}}$ - Campinas 2007. Equações de retas e inclinações para $\mathrm{CH}_{4}$ e $\mathrm{CO}_{2}$.

Equações das retas:

$$
\begin{aligned}
& y_{1}=1,1892 x_{1}+4,0415 \text { Equação do metano } \\
& y_{2}=1,2963 x_{2}+6,8941 \text { Equação do dióxido }
\end{aligned}
$$

b) Cálculo da taxa de emissão:

b) Metano: $\quad \operatorname{Tx} E\left(\mathrm{CH}_{4}\right)=\frac{1,1892 \mu \mathrm{g}\left(\mathrm{CO}_{2}\right) \times 33.200 \mathrm{~mL} \times 1440 \mathrm{~min} \times \mathrm{g}}{\mathrm{mL} \times \min \times 0,664 \mathrm{~m}^{2} \times \operatorname{dia} \times 10^{6} \mathrm{~g}}$

$$
T \times E\left(\mathrm{CH}_{4}\right)=85,62 \mathrm{~g} \times \mathrm{m}^{-2} \cdot \mathrm{d}^{-1}\left(\mathrm{CH}_{4}\right) \text { No sítio de coleta } \mathrm{P}_{10} \text {. }
$$


$b_{2}$ ) Dióxido de carbono: $\operatorname{TxE}\left(\mathrm{CO}_{2}\right)=\frac{1,2963 \mu \mathrm{g}\left(\mathrm{CO}_{2}\right) \times 33.200 \mathrm{~mL} \times 1440 \mathrm{~min} \times \mathrm{g}}{\mathrm{mL} \times \min \times 0,664 \mathrm{~m}^{2} \times \operatorname{dia} \times 10^{6} \mu \mathrm{g}}$

$$
\operatorname{Tx} E\left(\mathrm{CO}_{2}\right)=93,33 \mathrm{~g} \times \mathrm{m}^{-2} \cdot \mathrm{d}^{-1}\left(\mathrm{CO}_{2}\right) \text { No sítio de coleta } \mathrm{P}_{10} \text {. }
$$

\section{Aterro de Campinas - Emissão solo-ar campanha 2007:}

A tabela 6.5 .43 , resume as taxas de emissão solo-ar, medidas para $\mathrm{CH}_{4}$ e CO 2 , em cada sítio $\mathbf{P}_{\mathbf{n}}$ do aterro de Campinas, na campanha de 2007.

Tabela 6.5.43 - Resumo das taxas de emissão solo-ar - Campinas 2007

\begin{tabular}{|c|c|c|}
\hline Sítio amostrado & \multicolumn{2}{|c|}{ Gás $T_{x} E\left(g \cdot m^{-2} \cdot d^{-1}\right)$} \\
\hline \multirow{2}{*}{$\mathrm{P}_{1}$} & $\mathrm{CH}_{4}$ & 56,74 \\
\hline & $\mathrm{CO}_{2}$ & 170,29 \\
\hline \multirow{2}{*}{$\mathrm{P}_{2}$} & $\mathrm{CH}_{4}$ & 70,52 \\
\hline & $\mathrm{CO}_{2}$ & 156,71 \\
\hline \multirow{2}{*}{$P_{3}$} & $\mathrm{CH}_{4}$ & 54,25 \\
\hline & $\mathrm{CO}_{2}$ & 10,96 \\
\hline \multirow{2}{*}{$\mathrm{P}_{4}$} & $\mathrm{CH}_{4}$ & 156,73 \\
\hline & $\mathrm{CO}_{2}$ & 17,80 \\
\hline \multirow{2}{*}{$\mathrm{P}_{5}$} & $\mathrm{CH}_{4}$ & 102,65 \\
\hline & $\mathrm{CO}_{2}$ & 246,93 \\
\hline \multirow{2}{*}{$P_{6}$} & $\mathrm{CH}_{4}$ & 20,28 \\
\hline & $\mathrm{CO}_{2}$ & 55,98 \\
\hline \multirow{2}{*}{$\mathrm{P}_{7}$} & $\mathrm{CH}_{4}$ & 98,00 \\
\hline & $\mathrm{CO}_{2}$ & 228,79 \\
\hline \multirow{2}{*}{$P_{8}$} & $\mathrm{CH}_{4}$ & 56,86 \\
\hline & $\mathrm{CO}_{2}$ & 43,90 \\
\hline \multirow{2}{*}{$P_{9}$} & $\mathrm{CH}_{4}$ & 69,73 \\
\hline & $\mathrm{CO}_{2}$ & 92,95 \\
\hline \multirow{2}{*}{$P_{10}$} & $\mathrm{CH}_{4}$ & 85,62 \\
\hline & $\mathrm{CO}_{2}$ & 93,33 \\
\hline
\end{tabular}


1) Cálculo da taxa de emissão média do Metano $\left(T_{x} E_{m(C H 4)}\right)$ nos sítios $\left(P_{n}\right)$ :

$$
\mathrm{T}_{\mathrm{x}} \mathrm{E}_{\mathrm{m}}\left(\mathrm{CH}_{4}\right)=\left(\mathrm{P}_{1} \ldots+\mathrm{P}_{10}\right) / 10=77,14 \mathrm{~g} \cdot \mathrm{m}^{-2} \cdot \mathrm{d}^{-1}
$$

2) Taxa de emissão média total do metano $\left(\mathrm{T}_{x} \mathrm{E}_{\mathrm{m}(\mathrm{t})(\mathrm{CH} 4)}\right)$ no aterro:

$$
\begin{gathered}
\Rightarrow \operatorname{TxE}_{m(t)}=T_{x} E_{m}\left(77,14 g \cdot m^{-2} \cdot d^{-1}\right) \cdot A_{a t}\left(260.000 m^{2}\right) \cdot 365 d \cdot 10^{-6}=t \cdot a^{-1} \\
\Rightarrow T_{x} E_{m(t)}\left(C H_{4}\right)=7.320,58 \mathrm{t} \cdot a^{-1}
\end{gathered}
$$

Em que: $T_{x} E_{m}=$ Taxa de Emissão média $\left(g \cdot m^{-2} \cdot d^{-1}\right)$

$$
\begin{aligned}
\mathrm{A}_{\mathrm{at}} & =\text { Área do aterro }\left(m^{2}\right) \\
\mathrm{T}_{\mathrm{x}} \mathrm{E}_{\mathrm{m}(\mathrm{t})} & =\text { Taxa de Emissão média total para } 2007\left(\text { Toneladas·ano }^{-1}\right) \\
365 & =\text { fator de conversão de dias } \mathrm{p} \text { ano } \\
10^{-6} & =\text { fator de conversão de } g \text { para Ton }
\end{aligned}
$$

3) Cálculo da taxa de emissão média do dióxido de carbono $\left(T_{x} E_{m(C O 2)}\right)$ nos sítios $\left(P_{n}\right)$ :

$$
\mathrm{T}_{\mathrm{x}} \mathrm{E}_{\mathrm{m}}\left(\mathrm{CO}_{2}\right)=\left(\mathrm{P}_{1}+\ldots+\mathrm{P}_{10}\right) / 10=111,76 \mathrm{~g} \cdot \mathrm{m}^{-2} \cdot \mathrm{d}^{-1}
$$

4) Cálculo da taxa de emissão média total do dióxido de carbono ( $\left.T_{x} E_{m(t)(C O 2)}\right)$ no aterro:

$$
\Rightarrow \mathrm{T}_{\mathrm{x}} \mathrm{E}_{\mathrm{m}(\mathrm{t})}=10.606,02 \mathrm{t} \cdot \mathrm{a}^{-1}
$$

Emissão Total Média ( $\left.E_{t} \underline{M}\right)$ solo-ar do aterro de Campinas: Consideradas as campanhas 2006 e 2007:
1) Para o Metano: $\quad E_{t} M\left(\mathrm{CH}_{4}\right)=8.391,05 t \cdot a^{-1}$
2) Para o Dióxido de Carbono: $\mathrm{E}_{\mathrm{t}} \mathrm{M}\left(\mathrm{CO}_{2}\right)=15.886,26 \mathrm{t} \cdot \mathrm{a}^{-1}$ 


\subsection{1-D) Aterro de Jaú}

\section{D) Aterro de Jaú 2006}

$\mathbf{P}_{1}\left(\mathrm{G} ; \mathrm{V}_{\mathrm{G}}=33.200 \mathrm{~mL}\right.$ e $\left.\mathrm{A}_{\mathrm{G}}=0,664 \mathrm{~m}^{2}\right)$

a) Tabela com tempos de coleta e massas correspondentes, gráfico com equações de retas e inclinações:

Tabela 6.5.44 - Sítio de coleta $\mathbf{P}_{\mathbf{1}}$ - Jaú 2006: tempos de coleta e massas $(\mu g)$ para $\mathrm{CH}_{4}$ e $\mathrm{CO}_{2}$.

\begin{tabular}{ccc}
\hline Tempo (min) & Massa do $\mathrm{CH}_{\mathbf{4}}(\mu \mathrm{g})$ & Massa do $\mathrm{CO}_{2}(\mu \mathrm{g})$ \\
\hline 0 & 10,9104 & 8,0700 \\
3 & 11,8137 & 9,9602 \\
6 & 23,3160 & 60,3011 \\
12 & 27,9265 & 50,5342 \\
\hline
\end{tabular}

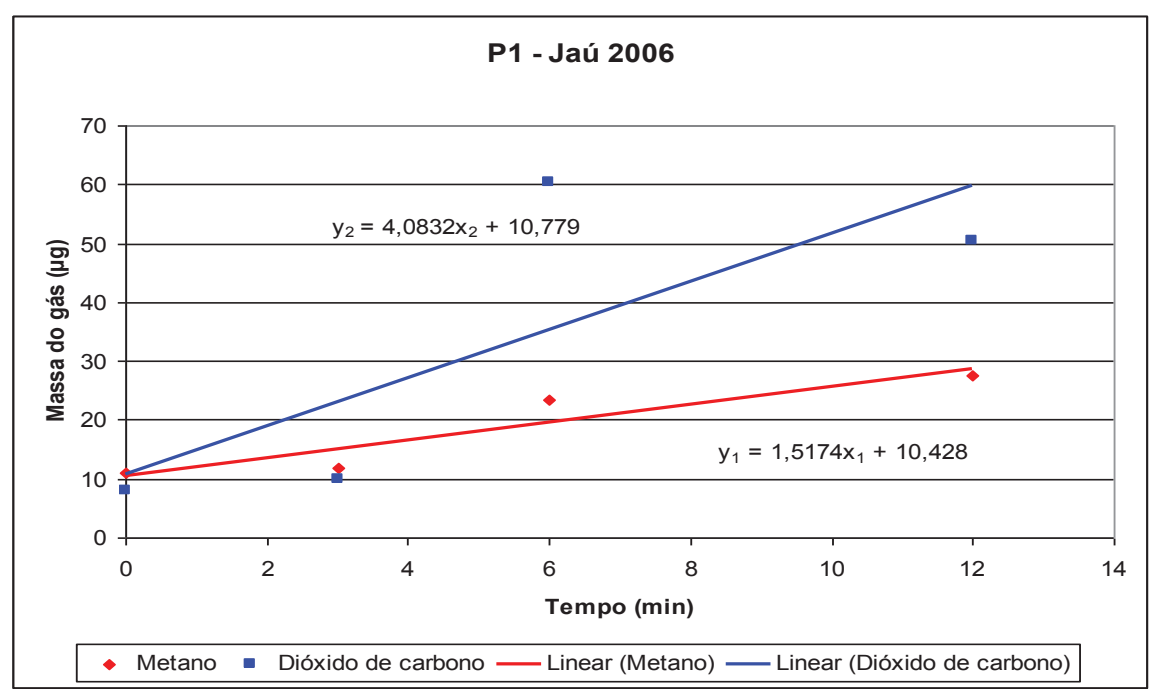

Gráfico 6.5.38 - Sítio $\mathbf{P}_{\mathbf{1}}$ - Jaú 2006. Equações de retas e inclinações para $\mathrm{CH}_{4}$ e $\mathrm{CO}_{2}$.

Equações das retas:

$$
\begin{aligned}
& y_{1}=1,5174 x_{1}+10,428 \text { Equação do metano } \\
& y_{2}=4,0832 x_{2}+10,779 \text { Equação do dióxido }
\end{aligned}
$$


b) Cálculo da taxa de emissão:

$\left.b_{1}\right)$ Metano:

$$
\operatorname{TxE}\left(\mathrm{CH}_{4}\right)=\frac{1,1535 \mu \mathrm{g}\left(\mathrm{CH}_{4}\right) \times 33.200 \mathrm{~mL} \times 1440 \mathrm{~min} \times \mathrm{g}}{\mathrm{mL} \times \min \times 0,664 \mathrm{~m}^{2} \times \operatorname{dia} \times 10^{6} \mu \mathrm{g}}
$$

$$
=83,05 \mathrm{~g} \times \mathrm{m}^{-2} \cdot d^{-1}\left(\mathrm{CH}_{4}\right) \quad \text { No sítio de coleta } \mathrm{P}_{1} \text {. }
$$

Em que: $\quad T_{x} E\left(C_{4}\right)=$ Taxa de emissão de metano no sítio;

$1,1535 \mu \mathrm{g} \cdot \mathrm{min}^{-1} \cdot \mathrm{mL}^{-1}=$ Inclinação da reta do gráfico de metano;

33.200 mL = Volume da câmara de coleta (grande);

1440 min = número de minutos $\cdot d_{i a}^{-1}$;

$10^{6}=$ fator de conversão de $\mu \mathrm{g}$ para $g ; \mathrm{e}$,

0,664 $m^{2}=$ Área da base da câmara de coleta (grande).

$b_{2}$ ) Dióxido de carbono:

$$
\begin{gathered}
\operatorname{TxE}\left(\mathrm{CO}_{2}\right)=\frac{4,0832 \mu \mathrm{g}\left(\mathrm{CO}_{2}\right) \times 33.200 \mathrm{~mL} \times 1440 \mathrm{~min} \times \mathrm{g}}{\mathrm{mL} \times \min \times 0,664 \mathrm{~m}^{2} \times \operatorname{dia} \times 10^{6} \mu \mathrm{g}} \\
=294,01 \mathrm{~g} \times \mathrm{m}^{-2} \cdot \mathrm{d}^{-1}\left(\mathrm{CO}_{2}\right) \quad \text { No sítio de coleta } \mathrm{P}_{1} .
\end{gathered}
$$

Em que: $\quad T_{x} E\left(C_{2}\right)=$ Taxa de emissão de dióxido de carbono no sítio;

0,9002 $\mu \mathrm{g} \cdot \mathrm{min}^{-1} \cdot \mathrm{mL}^{-1}=$ Inclinação da reta do gráfico de dióxido de carbono;

33.200 mL = Volume da câmara de coleta (grande);

$1440 \min =$ número de minutos $\cdot \mathrm{dia}^{-1}$;

$10^{6}=$ fator de conversão de $\mu g$ para $g ;$ e,

0,664 $m^{2}=$ Área da base da câmara de coleta (grande). 
$\mathbf{P}_{2}\left(p ; V_{P}=1200 m L\right.$ e $\left.A_{P}=0,01815 m^{2}\right)$

a) Tabela com tempos de coleta e massas correspondentes, gráfico com equações de retas e inclinações:

Tabela 6.5.45 - Sítio de coleta $\mathbf{P}_{\mathbf{2}}$ - Jaú 2006: tempos de coleta e massas $(\mu \mathrm{g})$ para $\mathrm{CH}_{4}$ e $\mathrm{CO}_{2}$.

\begin{tabular}{ccc}
\hline Tempo (min) & Massa do $\mathrm{CH}_{\mathbf{4}}(\mu \mathrm{g})$ & Massa do $\mathrm{CO}_{2}(\mu \mathrm{g})$ \\
\hline 0 & 0 & 11,3742 \\
3 & 13,8613 & 11,9600 \\
6 & 17,6533 & 20,0104 \\
12 & 18,5183 & 26,9200 \\
\hline
\end{tabular}

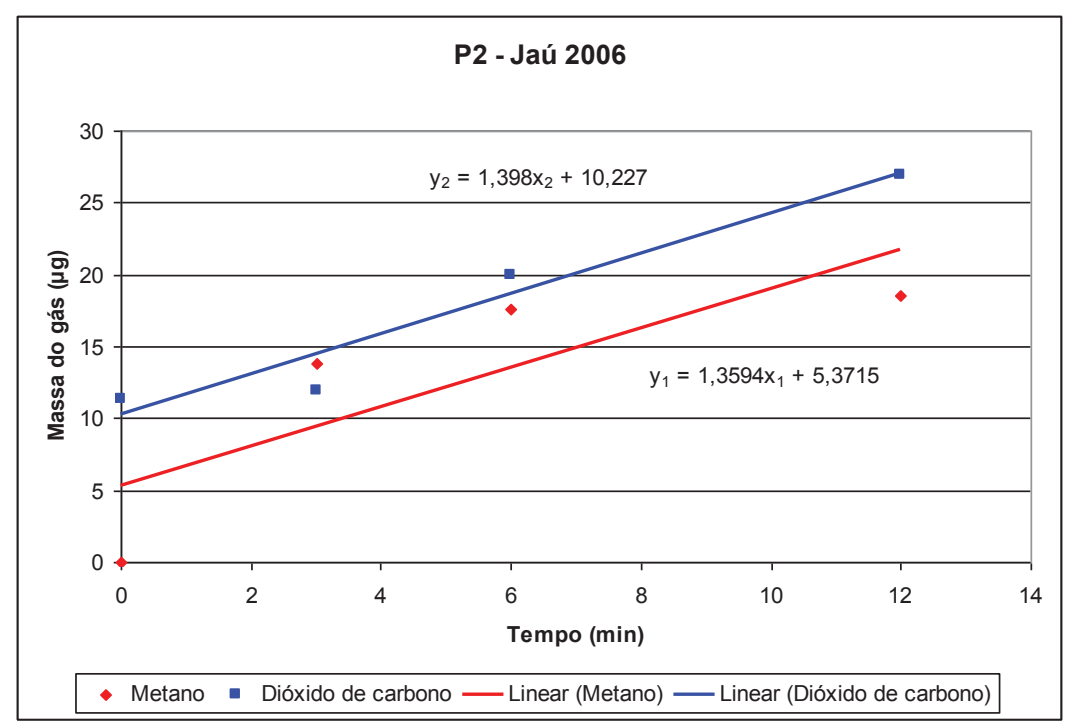

Gráfico 6.5.39 - Sítio $\mathbf{P}_{\mathbf{2}}$ - Jaú 2006. Equações de retas e inclinações para $\mathrm{CH}_{4}$ e $\mathrm{CO}_{2}$.

Equações das retas:

$$
\begin{aligned}
& y_{1}=1,3594 x_{1}+5,3715 \text { Equação do metano } \\
& y_{2}=1,398 x_{2}+10,227 \text { Equação do dióxido }
\end{aligned}
$$

b) Cálculo da taxa de emissão: 
b $)$ Metano: $\quad \operatorname{TxE}\left(\mathrm{CH}_{4}\right)=\frac{1,3594 \mu \mathrm{g}\left(\mathrm{CO}_{2}\right) \times 1.200 \mathrm{~mL} \times 1440 \mathrm{~min} \times \mathrm{g}}{\mathrm{mL} \times \min \times 0,01815 \mathrm{~m}^{2} \times \operatorname{dia} \times 10^{6} \mu \mathrm{g}}$

$$
\operatorname{TxE}\left(\mathrm{CH}_{4}\right)=129,42 \mathrm{~g} \times \mathrm{m}^{-2} \cdot \mathrm{d}^{-1}\left(\mathrm{CH}_{4}\right) \text { No sítio de coleta } \mathrm{P}_{2} \text {. }
$$

$\left.\mathrm{b}_{2}\right)$ Dióxido de carbono: $\operatorname{Tx} E\left(\mathrm{CO}_{2}\right)=\frac{1,398 \mu \mathrm{g}\left(\mathrm{CO}_{2}\right) \times 1.200 \mathrm{~mL} \times 1440 \mathrm{~min} \times \mathrm{g}}{\mathrm{mL} \times \min \times 0,01815 \mathrm{~m}^{2} \times \operatorname{dia} \times 10^{6} \mu \mathrm{g}}$

$$
\operatorname{Tx} E\left(C_{2}\right)=133,10 \mathrm{~g} \times \mathrm{m}^{-2} \cdot d^{-1}\left(C_{2}\right) \quad \text { No sítio de coleta } \mathrm{P}_{2} \text {. }
$$

$\mathbf{P}_{3}\left(\mathrm{G} ; \mathrm{V}_{\mathrm{G}}=33.200 \mathrm{~mL}\right.$ e $\left.\mathrm{A}_{\mathrm{G}}=0,664 \mathrm{~m}^{2}\right)$

a) Tabela com tempos de coleta e massas correspondentes, gráfico com equações de retas e inclinações:

Tabela 6.5.46 - Sítio de coleta $\mathbf{P}_{\mathbf{3}}$ - Jaú 2006: tempos de coleta e massas $(\mu g)$ para $\mathrm{CH}_{4}$ e $\mathrm{CO}_{2}$.

\begin{tabular}{ccc}
\hline Tempo (min) & Massa do $\mathrm{CH}_{4}(\mu g)$ & Massa do $\mathrm{CO}_{2}(\mu g)$ \\
\hline 0 & 0 & 9,7457 \\
3 & 11,0801 & 9,8959 \\
6 & 11,3009 & 11,4235 \\
12 & 18,4116 & 32,1783 \\
\hline
\end{tabular}




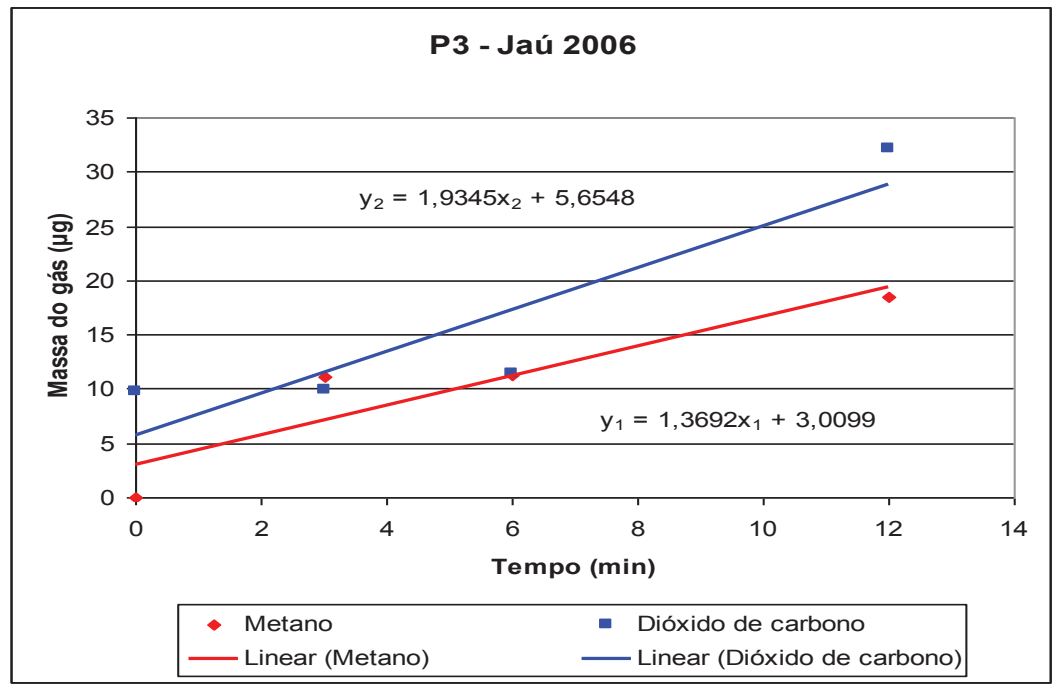

Gráfico 6.5.40 - Sítio $\mathbf{P}_{\mathbf{3}}$ - Jaú 2006. Equações de retas e inclinações para $\mathrm{CH}_{4}$ e $\mathrm{CO}_{2}$.

Equações das retas:

$$
\begin{aligned}
& y_{1}=1,3692 x_{1}+3,0099 \text { Equação do metano } \\
& y_{2}=1,9345 x_{2}+5,6548 \text { Equação do dióxido }
\end{aligned}
$$

b) Cálculo da taxa de emissão:

b) Metano: $\quad \operatorname{Tx} E\left(\mathrm{CH}_{4}\right)=\frac{1,3692 \mu g\left(\mathrm{CO}_{2}\right) \times 33.200 \mathrm{~mL} \times 1440 \mathrm{~min} \times \mathrm{g}}{\mathrm{mL} \times \min \times 0,664 \mathrm{~m}^{2} \times \mathrm{dia} \times 10^{6} \mu \mathrm{g}}$

$$
\operatorname{Tx} E\left(\mathrm{CH}_{4}\right)=72,00 \mathrm{~g} \times \mathrm{m}^{-2} \cdot d^{-1}\left(\mathrm{CH}_{4}\right) \text { No sítio de coleta } \mathrm{P}_{3} \text {. }
$$

$\left.\mathrm{b}_{2}\right)$ Dióxido de carbono: $\operatorname{Tx} E\left(\mathrm{CO}_{2}\right)=\frac{1,9345 \mu \mathrm{g}\left(\mathrm{CO}_{2}\right) \times 33.200 \mathrm{~mL} \times 1440 \mathrm{~min} \times g}{\mathrm{~mL} \times \min \times 0,664 \mathrm{~m}^{2} \times \operatorname{dia} \times 10^{6} \mu \mathrm{g}}$

$$
\operatorname{TxE}\left(\mathrm{CO}_{2}\right)=139,28 \mathrm{mg} \times \mathrm{m}^{-2} \cdot \mathrm{d}^{-1}\left(\mathrm{CO}_{2}\right) \text { No sítio de coleta } \mathrm{P}_{3} \text {. }
$$


$\mathbf{P}_{4}\left(\mathrm{G} ; \mathrm{V}_{\mathrm{G}}=33.200 \mathrm{~mL}\right.$ e $\left.\mathrm{A}_{\mathrm{G}}=0,664 \mathrm{~m}^{2}\right)$

a) Tabela com tempos de coleta e massas correspondentes, gráfico com equações de retas e inclinações:

Tabela 6.5.47 - Sítio de coleta $\mathbf{P}_{\mathbf{4}}$ - Jaú 2006: tempos de coleta e massas $(\mu g)$ para $\mathrm{CH}_{4}$ e $\mathrm{CO}_{2}$.

\begin{tabular}{ccc}
\hline Tempo $(\boldsymbol{m i n})$ & Massa do $\mathrm{CH}_{4}(\mu g)$ & Massa do $\mathrm{CO}_{2}(\mu \boldsymbol{g})$ \\
\hline 0 & 10,3447 & 8,9218 \\
3 & 10,3647 & 11,3592 \\
6 & 16,3677 & 24,4561 \\
12 & 12,9013 & 16,5000 \\
\hline
\end{tabular}

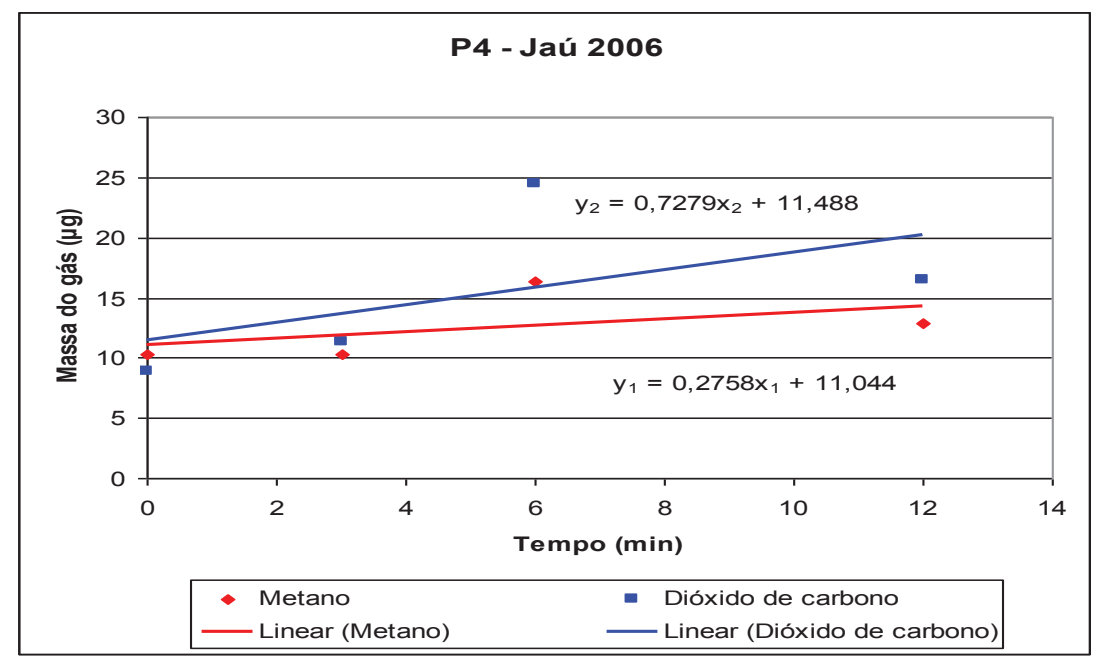

Gráfico 6.5.41 - Sítio $P_{4}$ - Jaú 2006. Equações de retas e inclinações para $\mathrm{CH}_{4}$ e $\mathrm{CO}_{2}$.

Equações das retas:

$$
\begin{aligned}
& y_{1}=0,2758 x_{1}+11,044 \text { Equação do metano } \\
& y_{2}=0,7279 x_{2}+11,488 \text { Equação do dióxido }
\end{aligned}
$$

b) Cálculo da taxa de emissão: 
$\left.b_{1}\right)$ Metano:

$$
\begin{aligned}
& \operatorname{Tx} E\left(\mathrm{CH}_{4}\right)=\frac{0,2758 \mu g\left(\mathrm{CO}_{2}\right) \times 33.200 \mathrm{~mL} \times 1440 \mathrm{~min} \times \mathrm{g}}{m L \times \min \times 0,664 \mathrm{~m}^{2} \times \operatorname{dia} \times 10^{6} \mu \mathrm{g}} \\
& \operatorname{TxE}\left(\mathrm{CH}_{4}\right)=19,86 \mathrm{~g} \times \mathrm{m}^{-2} \cdot \mathrm{d}^{-1}\left(\mathrm{CH}_{4}\right) \text { No sítio de coleta } \mathrm{P}_{4} .
\end{aligned}
$$

$b_{2}$ ) Dióxido de carbono: $\operatorname{Tx} E\left(\mathrm{CO}_{2}\right)=\frac{0,7279 \mu \mathrm{g}\left(\mathrm{CO}_{2}\right) \times 33.200 \mathrm{~mL} \times 1440 \mathrm{~min} \times \mathrm{g}}{\mathrm{mL} \times \min \times 0,664 \mathrm{~m}^{2} \times \operatorname{dia} \times 10^{6} \mu \mathrm{g}}$

$$
\operatorname{Tx} E\left(\mathrm{CO}_{2}\right)=52,41 \mathrm{~g} \times \mathrm{m}^{-2} \cdot \mathrm{d}^{-1}\left(\mathrm{CO}_{2}\right) \text { No sítio de coleta } \mathrm{P}_{4} \text {. }
$$

$\mathbf{P}_{5}\left(p ; V_{P}=1.200 m L\right.$ e $\left.A_{P}=0,01815 m^{2}\right)$

a) Tabela com tempos de coleta e massas correspondentes, gráfico com equações de retas e inclinações:

Tabela 6.5.48 - Sítio de coleta $\mathbf{P}_{\mathbf{5}}$ - Jaú 2006: tempos de coleta e massas $(\mu \mathrm{g})$ para $\mathrm{CH}_{4}$ e $\mathrm{CO}_{2}$.

\begin{tabular}{ccc}
\hline Tempo (min) & Massa do $\mathrm{CH}_{4}(\mu \mathrm{g})$ & Massa do $\mathrm{CO}_{2}(\mu \mathrm{g})$ \\
\hline 0 & 0 & 9,9452 \\
3 & 11,0810 & 10,8957 \\
6 & 11,0912 & 10,9386 \\
12 & 11,2900 & 11,2176 \\
\hline
\end{tabular}




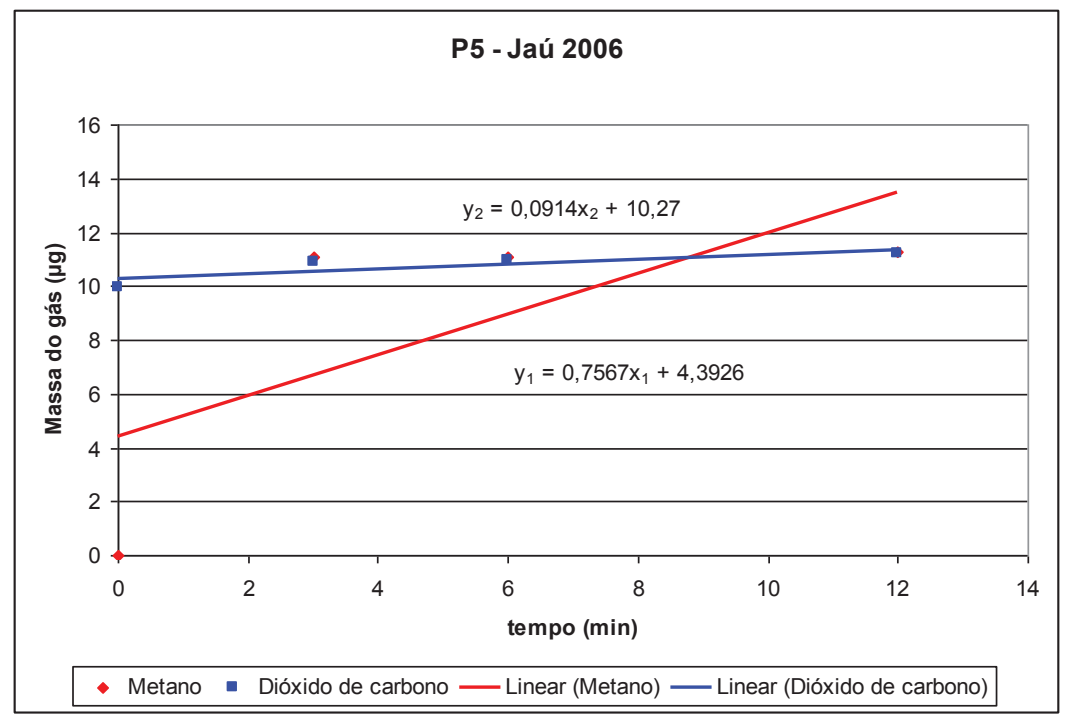

Gráfico 6.5.42 - Sítio $\mathbf{P}_{5}$ - Jaú 2006. Equações de retas e inclinações para $\mathrm{CH}_{4}$ e $\mathrm{CO}_{2}$.

Equações das retas:

$$
\begin{aligned}
& y_{1}=0,7567 x_{1}+4,3926 \text { Equação do metano } \\
& y_{2}=0,0914 x_{2}+10,27 \text { Equação do dióxido }
\end{aligned}
$$

b) Cálculo da taxa de emissão:

b) Metano: $\quad \operatorname{TxE}\left(\mathrm{CH}_{4}\right)=\frac{0,7567 \mu \mathrm{g}\left(\mathrm{CO}_{2}\right) \times 1.200 \mathrm{~mL} \times 1440 \mathrm{~min} \times \mathrm{g}}{\mathrm{mL} \times \min \times 0,01815 \mathrm{~m}^{2} \times \operatorname{dia} \times 10^{6} \mu \mathrm{g}}$

$$
\operatorname{TxE}\left(\mathrm{CH}_{4}\right)=72,04 \mathrm{~g} \times \mathrm{m}^{-2} \cdot \mathrm{d}^{-1}\left(\mathrm{CH}_{4}\right) \text { No sítio de coleta } \mathrm{P}_{5} \text {. }
$$

$\mathrm{b}_{2}$ ) Dióxido de carbono: $\operatorname{Tx} E\left(C \mathrm{CO}_{2}\right)=\frac{0,0914 \mu \mathrm{g}\left(\mathrm{CO}_{2}\right) \times 1.200 \mathrm{~mL} \times 1440 \mathrm{~min} \times \mathrm{g}}{\mathrm{mL} \times \min \times 0,01815 \mathrm{~m}^{2} \times \operatorname{dia} \times 10^{6} \mu \mathrm{g}}$

$$
\operatorname{Tx} E\left(\mathrm{CO}_{2}\right)=8,70 \mathrm{~g} \times \mathrm{m}^{-2} \cdot \mathrm{d}^{-1}\left(\mathrm{CO}_{2}\right) \text { No sítio de coleta } \mathrm{P}_{5} \text {. }
$$


c) Aterro de Jaú - Emissão solo-ar campanha 2006:

A tabela 6.5 .49 , resume as taxas de emissão solo-ar, medidas para $\mathrm{CH}_{4}$ e $\mathrm{CO}_{2}$, em cada sítio $\mathbf{P}_{\mathbf{n}}$ do aterro de Jaú, na campanha de 2006.

Tabela 6.5.49 - Resumo das taxas de emissão solo-ar - Jaú 2006

\begin{tabular}{clr}
\hline Sítio amostrado & \multicolumn{1}{c}{ Gás } & $\mathrm{T}_{\mathbf{x}} \mathbf{E}\left(\boldsymbol{g} \cdot \boldsymbol{m}^{-\mathbf{2}} \cdot \boldsymbol{d}^{-\mathbf{1}}\right)$ \\
\hline $\mathrm{P}_{1}$ & $\mathrm{CH}_{4}$ & 83,05 \\
& $\mathrm{CO}_{2}$ & 294,01 \\
$\mathrm{P}_{2}$ & $\mathrm{CH}_{4}$ & 129,42 \\
& $\mathrm{CO}_{2}$ & 133,10 \\
& $\mathrm{CH}_{4}$ & 72,00 \\
$\mathrm{P}_{3}$ & $\mathrm{CO}_{2}$ & 139,28 \\
& $\mathrm{CH}_{4}$ & 19,86 \\
$\mathrm{P}_{4}$ & $\mathrm{CO}_{2}$ & 52,41 \\
& $\mathrm{CH}_{4}$ & 72,04 \\
\hline $\mathrm{P}_{5}$ & $\mathrm{CO}_{2}$ & 8,70 \\
\hline
\end{tabular}

1) Cálculo da taxa de emissão média do Metano $\left(T_{x} E_{m(C H 4)}\right)$ nos sítios $\left(P_{n}\right)$ :

$$
\mathrm{T}_{\mathrm{x}} \mathrm{E}_{\mathrm{m}}\left(\mathrm{CH}_{4}\right)=\left(\mathrm{P}_{1}+\ldots+\mathrm{P}_{5}\right) / 5=75,30 \mathrm{~g} \cdot \mathrm{m}^{-2} \cdot \mathrm{d}^{-1}
$$

2) Taxa de emissão média total do metano $\left(T_{x} E_{m(t)(C H 4)}\right)$ no aterro:

$$
\begin{gathered}
\Rightarrow T_{x} E_{m(t)}=T_{x} E_{m}\left(75,30 \mathrm{~g} \cdot \mathrm{m}^{-2} \cdot \mathrm{d}^{-1}\right) \cdot \mathrm{A}_{\mathrm{at}}\left(48.400 \mathrm{~m}^{2}\right) \cdot 365 \mathrm{~d} \cdot 10^{-6}=\mathrm{t} \cdot \mathrm{a}^{-1} \\
\Rightarrow \mathrm{T}_{\mathbf{x}} \mathrm{E}_{\mathrm{m}(\mathrm{t})}\left(\mathrm{CH}_{4}\right)=1.330,25 \mathrm{t} \cdot \mathrm{a}^{-1}
\end{gathered}
$$

Em que: $T_{x} E_{m}=$ Taxa de Emissão média $\left(g \cdot m^{-2} \cdot d^{-1}\right) ; A_{a t}=$ Área do aterro $\left(m^{2}\right)$

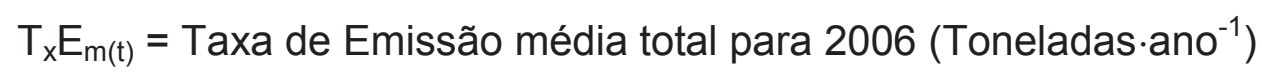




$$
\begin{aligned}
& 365=\text { fator de conversão de dias } p \text { ano } \\
& 10^{-6}=\text { fator de conversão de } g \text { para Ton }
\end{aligned}
$$

3) Cálculo da taxa de emissão média do dióxido de carbono $\left(T_{x} E_{m(C O 2)}\right)$ nos sítios $\left(P_{n}\right)$ :

$$
T_{x} E_{m}\left(C O_{2}\right)=\left(P_{1}+\ldots+P_{5}\right) / 5=125,50 \mathrm{~g} \cdot \mathrm{m}^{-2} \cdot \mathrm{d}^{-1}
$$

4) Cálculo da taxa de emissão média total do dióxido de carbono ( $\left.T_{x} E_{m(t)(C O 2)}\right)$ no aterro:

$$
\Rightarrow T_{x} E_{m(t)}\left(C O_{2}\right)=2.217,08 t \cdot a^{-1}
$$




\section{D2) Campanha 2007}

$\mathbf{P}_{1}\left(\mathrm{G} ; \mathrm{V}_{\mathrm{G}}=33.200 \mathrm{~mL} ; \mathrm{A}_{\mathrm{G}}=0,664 \mathrm{~m}^{2}\right)$

a) Tabela com tempos de coleta e massas correspondentes, gráfico com equações de retas e inclinações:

Tabela 6.5.50 - Sítio de coleta $\mathbf{P}_{\mathbf{1}}$ - Jaú 2007: tempos de coleta e massas $(\mu \mathrm{g})$ para $\mathrm{CH}_{4}$ e $\mathrm{CO}_{2}$

\begin{tabular}{ccc}
\hline Tempo (min) & Massa do $\mathrm{CH}_{\mathbf{4}}(\mu \mathrm{g})$ & Massa do $\mathrm{CO}_{\mathbf{2}}(\boldsymbol{\mu g})$ \\
\hline 0 & 0 & 8,0034 \\
3 & 10,4542 & 8,1043 \\
6 & 11,0837 & 8,5484 \\
12 & 10,9067 & 10,8000 \\
\hline
\end{tabular}

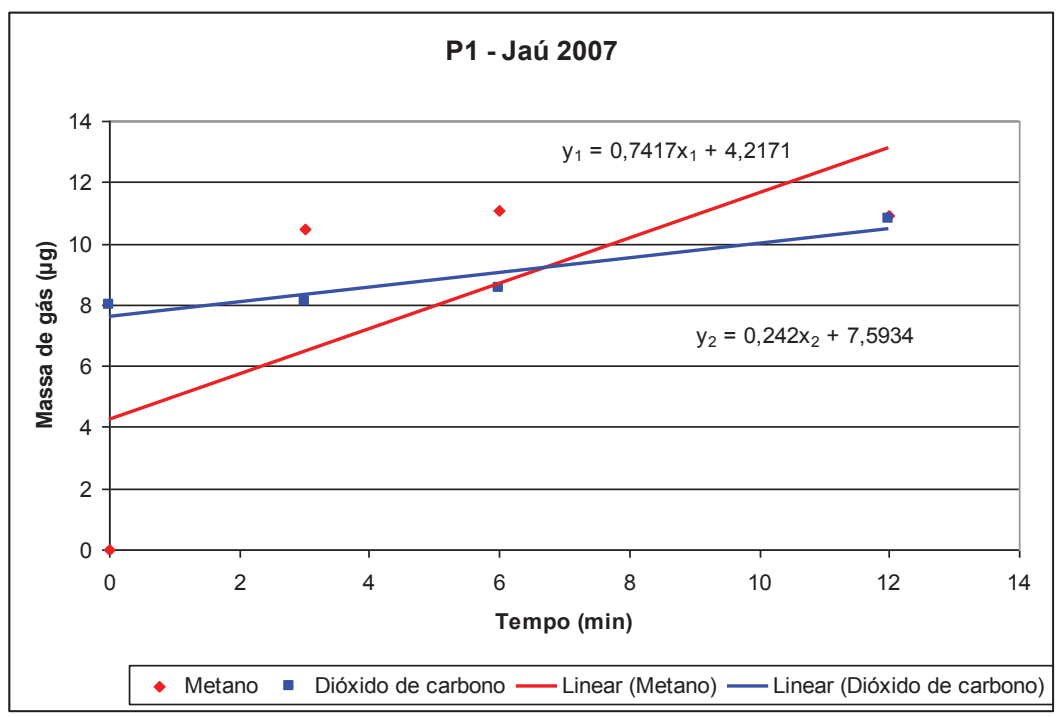

Gráfico 6.5.43 - Sítio $\mathbf{P}_{\mathbf{1}}$ - Jaú 2007. Equações de retas e inclinações para $\mathrm{CH}_{4}$ e $\mathrm{CO}_{2}$.

Equações das retas:

$$
\begin{aligned}
& y_{1}=0,7417 x_{1}+4,2171 \text { Equação do metano } \\
& y_{2}=0,242 x_{2}+7,5934 \text { Equação do dióxido }
\end{aligned}
$$


b) Cálculo da taxa de emissão:

$\left.b_{1}\right)$ Metano:

$$
\begin{gathered}
\operatorname{TxE}\left(\mathrm{CH}_{4}\right)=\frac{0,7417 \mu \mathrm{g}\left(\mathrm{CO}_{2}\right) \times 33.200 \mathrm{~mL} \times 1440 \mathrm{~min} \times \mathrm{g}}{\mathrm{mL} \times \min \times 0,664 \mathrm{~m}^{2} \times \operatorname{dia} \times 10^{6} \mu \mathrm{g}} \\
\operatorname{TxE}\left(\mathrm{CH}_{4}\right)=53,40 \mathrm{~g} \times \mathrm{m}^{-2} \cdot \mathrm{d}^{-1}\left(\mathrm{CH}_{4}\right) \text { No sítio de coleta } \mathrm{P}_{1} .
\end{gathered}
$$

$b_{2}$ ) Dióxido de carbono: $\operatorname{Tx} E\left(\mathrm{CO}_{2}\right)=\frac{0,242 \mu g\left(\mathrm{CO}_{2}\right) \times 33.200 \mathrm{~mL} \times 1440 \mathrm{~min} \times g}{\mathrm{~mL} \times \min \times 0,664 \mathrm{~m}^{2} \times \operatorname{dia} \times 10^{6} \mu \mathrm{g}}$

$$
\operatorname{TxE}\left(\mathrm{CO}_{2}\right)=17,42 \mathrm{~g} \times \mathrm{m}^{-2} \cdot \mathrm{d}^{-1}\left(\mathrm{CO}_{2}\right) \text { No sítio de coleta } \mathrm{P}_{1} \text {. }
$$

$\mathbf{P}_{2}\left(\mathrm{p} ; \mathrm{VP}=1.200 \mathrm{~mL} ; \mathrm{A}_{\mathrm{P}}=0,01815 \mathrm{~m}^{2}\right)$

a) Tabela com tempos de coleta e massas correspondentes, gráfico com equações de retas e inclinações:

Tabela 6.5.51 - Sítio de coleta $\mathbf{P}_{\mathbf{2}}$ - Jaú 2007: tempos de coleta e massas $(\mu g)$ para $\mathrm{CH}_{4}$ e $\mathrm{CO}_{2}$.

\begin{tabular}{ccc}
\hline Tempo $(\boldsymbol{m i n})$ & Massa do $\mathrm{CH}_{4}(\mu \mathrm{g})$ & Massa do $\mathrm{CO}_{2}(\mu \mathrm{g})$ \\
\hline 0 & 10,8866 & 8,5806 \\
3 & 10,4523 & 10,0375 \\
6 & 12,6140 & 13,0371 \\
12 & 11,6111 & 9,7736 \\
\hline
\end{tabular}




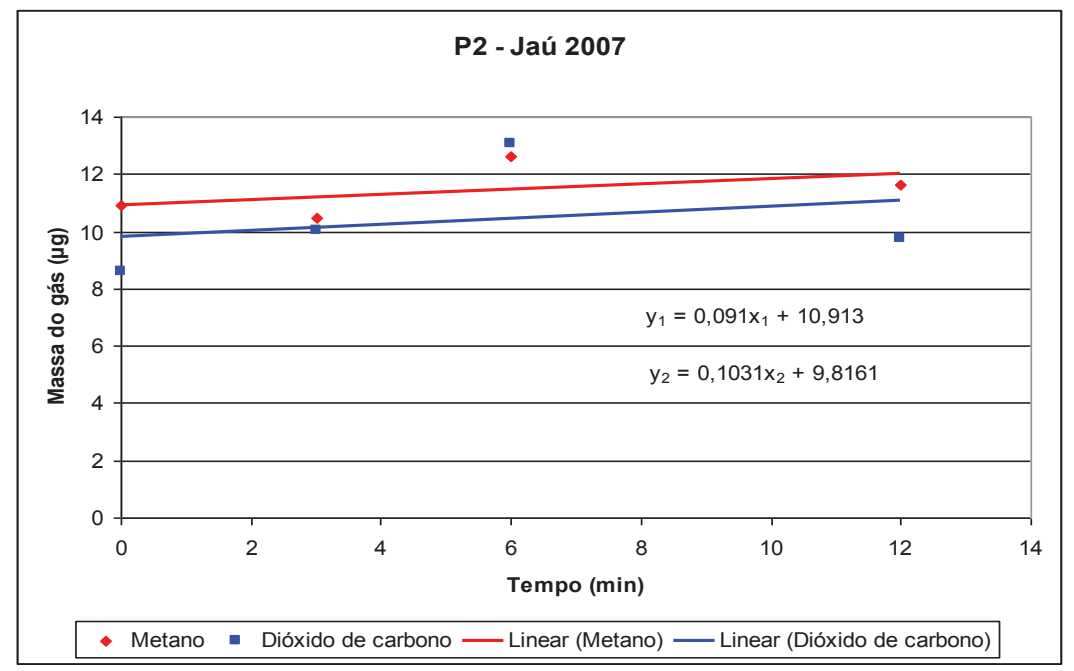

Gráfico 6.5.44 - Sítio $\mathbf{P}_{\mathbf{2}}$ - Jaú 2007. Equações de retas e inclinações para $\mathrm{CH}_{4}$ e $\mathrm{CO}_{2}$.

Equações das retas:

$$
\begin{aligned}
& y_{1}=0,091 x_{1}+10,913 \text { Equação do metano } \\
& y_{2}=0,1031 x_{2}+9,8161 \text { Equação do dióxido }
\end{aligned}
$$

b) Cálculo da taxa de emissão:

b ) Metano: $\quad \operatorname{Tx} E\left(\mathrm{CH}_{4}\right)=\frac{0,091 \mu \mathrm{g}\left(\mathrm{CO}_{2}\right) \times 1.200 \mathrm{~mL} \times 1440 \mathrm{~min} \times \mathrm{g}}{\mathrm{mL} \times \min \times 0,01815 \mathrm{~m}^{2} \times \operatorname{dia} \times 10^{6} \mu \mathrm{g}}$

$$
\mathrm{Tx} E\left(\mathrm{CH}_{4}\right)=8,66 \mathrm{~g} \times \mathrm{m}^{-2} \cdot \mathrm{d}^{-1}\left(\mathrm{CH}_{4}\right) \text { No sítio de coleta } \mathrm{P}_{2} \text {. }
$$

$\mathrm{b}_{2}$ ) Dióxido de carbono: $\operatorname{Tx} E\left(\mathrm{CO}_{2}\right)=\frac{0,1031 \mu \mathrm{g}\left(\mathrm{CO}_{2}\right) \times 1.200 \mathrm{~mL} \times 1440 \mathrm{~min} \times \mathrm{g}}{\mathrm{mL} \times \min \times 0,01815 \mathrm{~m}^{2} \times \operatorname{dia} \times 10^{6} \mu \mathrm{g}}$

$$
\operatorname{Tx} E\left(\mathrm{CO}_{2}\right)=9,81 \mathrm{~g} \times \mathrm{m}^{-2} \cdot \mathrm{d}^{-1}\left(\mathrm{CO}_{2}\right) \text { No sítio de coleta } \mathrm{P}_{2} \text {. }
$$


$\mathbf{P}_{3}\left(\mathrm{G} ; \mathrm{V}_{\mathrm{G}}=33.200 \mathrm{~mL} ; \mathrm{A}_{\mathrm{G}}=0,664 \mathrm{~m}^{2}\right)$

a) Tabela com tempos de coleta e massas correspondentes, gráfico com equações de retas e inclinações:

Tabela 6.5.52 - Sítio de coleta $\mathbf{P}_{3}$ - Jaú 2007: tempos de coleta e massas $(\mu g)$ para $\mathrm{CH}_{4}$ e $\mathrm{CO}_{2}$.

\begin{tabular}{ccc}
\hline Tempo (min) & Massa do $\mathrm{CH}_{4}(\mu \mathrm{g})$ & Massa do $\mathrm{CO}_{2}(\mu \mathrm{g})$ \\
\hline 0 & 0 & 7,6301 \\
3 & 10,7051 & 8,7000 \\
6 & 12,8566 & 12,2110 \\
12 & 12,4789 & 10,5000 \\
\hline
\end{tabular}

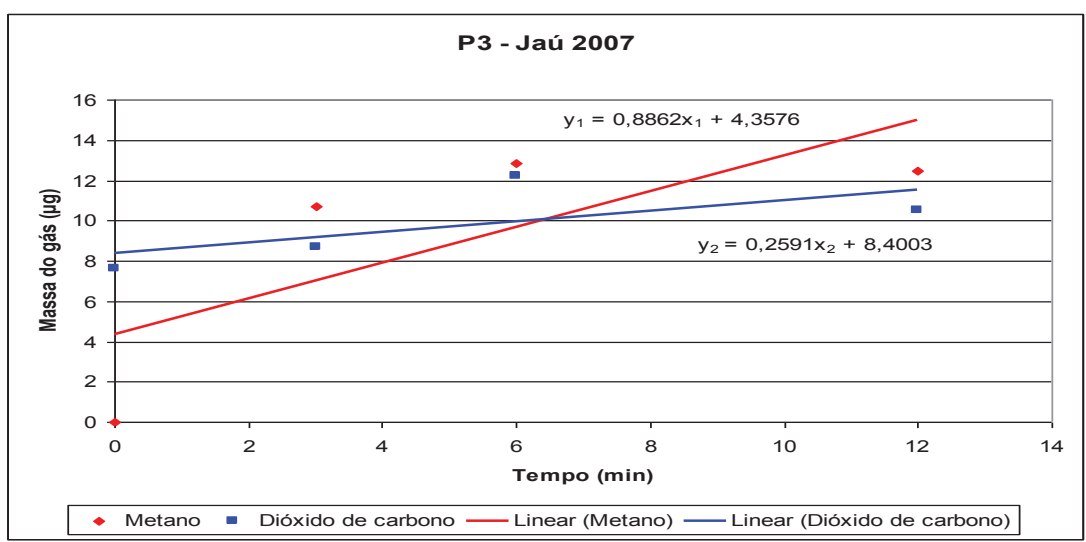

Gráfico 6.5.45 - Sítio $\mathbf{P}_{\mathbf{3}}$ - Jaú 2007. Equações de retas e inclinações para $\mathrm{CH}_{4}$ e $\mathrm{CO}_{2}$.

Equações das retas:

$$
\begin{aligned}
& y_{1}=0,8862 x_{1}+4,3576 \text { Equação do metano } \\
& y_{2}=0,2591 x_{2}+8,4003 \text { Equação do dióxido }
\end{aligned}
$$

b) Cálculo da taxa de emissão:

$\left.b_{1}\right)$ Metano:

$$
\operatorname{TxE}\left(\mathrm{CH}_{4}\right)=\frac{0,8862 \mu \mathrm{g}\left(\mathrm{CO}_{2}\right) \times 33.200 \mathrm{~mL} \times 1440 \mathrm{~min} \times \mathrm{g}}{\mathrm{mL} \times \min \times 0,664 \mathrm{~m}^{2} \times \operatorname{dia} \times 10^{6} \mu \mathrm{g}}
$$


$T \times E\left(\mathrm{CH}_{4}\right)=63,80 \mathrm{~g} \times \mathrm{m}^{-2} \cdot \mathrm{d}^{-1}\left(\mathrm{CH}_{4}\right)$ No sítio de coleta $\mathrm{P}_{3}$.

$\mathrm{b}_{2}$ ) Dióxido de carbono: $\operatorname{Tx} E\left(C \mathrm{CO}_{2}\right)=\frac{0,2591 \mu \mathrm{g}\left(\mathrm{CO}_{2}\right) \times 33.200 \mathrm{~mL} \times 1440 \mathrm{~min} \times \mathrm{g}}{\mathrm{mL} \times \min \times 0,664 \mathrm{~m}^{2} \times \operatorname{dia} \times 10^{6} \mu \mathrm{g}}$

$$
\operatorname{TxE}\left(\mathrm{CO}_{2}\right)=18,65 \mathrm{~g} \times \mathrm{m}^{-2} \cdot \mathrm{d}^{-1}\left(\mathrm{CO}_{2}\right) \text { No sítio de coleta } \mathrm{P}_{3} \text {. }
$$

$\mathbf{P}_{4}\left(p ; V_{P}=1.200 m L ; A_{P}=0,01815 m^{2}\right)$

a) Tabela com tempos de coleta e massas correspondentes, gráfico com equações de retas e inclinações:

Tabela 6.5.53 - Sítio de coleta $\mathbf{P}_{\mathbf{4}}$ - Jaú 2007: tempos de coleta e massas $(\mu \mathrm{g})$ para $\mathrm{CH}_{4}$ e $\mathrm{CO}_{2}$.

\begin{tabular}{ccc}
\hline Tempo (min) & Massa do $\mathrm{CH}_{4}(\mu \mathrm{g})$ & Massa do $\mathrm{CO}_{2}(\mu \mathrm{g})$ \\
\hline 0 & 10,2826 & 7,7138 \\
3 & 10,5000 & 7,9970 \\
6 & 11,2735 & 11,1618 \\
12 & 12,6486 & 13,2001 \\
\hline
\end{tabular}

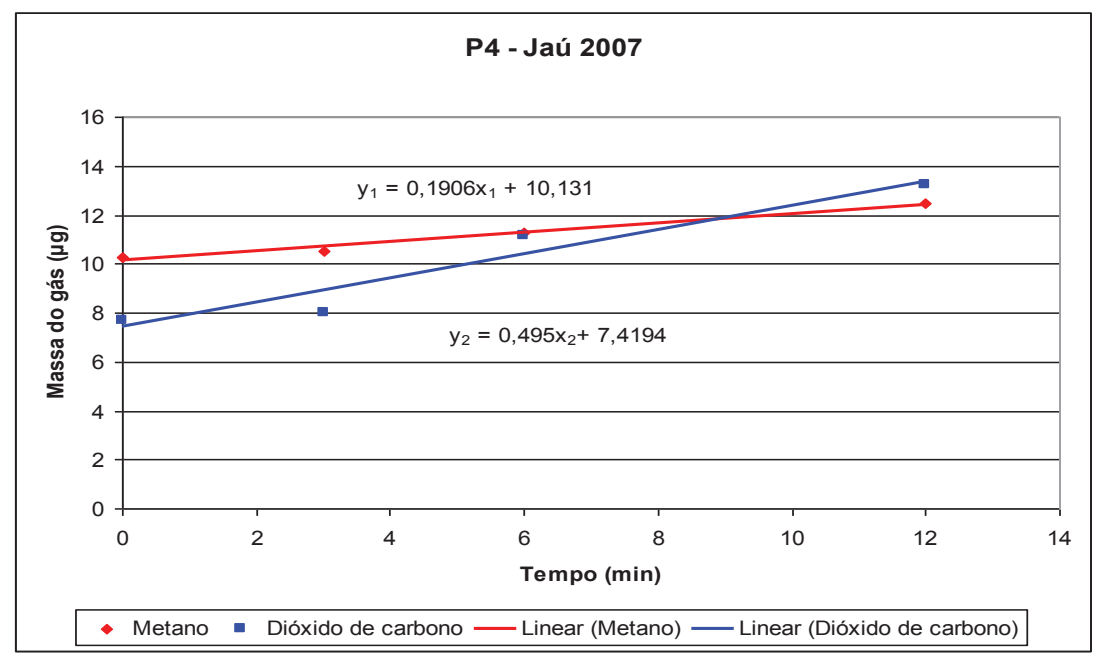

Gráfico 6.5.46 - Sítio $\mathbf{P}_{\mathbf{4}}$ - Jaú 2007. Equações de retas e inclinações para $\mathrm{CH}_{4}$ e $\mathrm{CO}_{2}$. 
Equações das retas:

$$
\begin{aligned}
& y_{1}=0,1906 x_{1}+10,131 \text { Equação do metano } \\
& y_{2}=0,495 x_{2}+7,4194 \text { Equação do dióxido }
\end{aligned}
$$

$\left.b_{1}\right)$ Metano:

$$
\operatorname{TxE}\left(\mathrm{CH}_{4}\right)=\frac{0,1906 \mu \mathrm{g}\left(\mathrm{CO}_{2}\right) \times 1.200 \mathrm{~mL} \times 1440 \mathrm{~min} \times g}{\mathrm{~mL} \times \min \times 0,01815 \mathrm{~m}^{2} \times \operatorname{dia} \times 10^{6} \mu \mathrm{g}}
$$

$$
T x E\left(\mathrm{CH}_{4}\right)=18,15 \mathrm{~g} \times \mathrm{m}^{-2} \cdot \mathrm{d}^{-1}\left(\mathrm{CH}_{4}\right) \text { No sítio de coleta } \mathrm{P}_{4} \text {. }
$$

$b_{2}$ ) Dióxido de carbono: $\quad \operatorname{Tx} E\left(\mathrm{CO}_{2}\right)=\frac{0,495 \mu \mathrm{g}\left(\mathrm{CO}_{2}\right) \times 1.200 \mathrm{~mL} \times 1440 \mathrm{~min} \times \mathrm{g}}{\mathrm{mL} \times \min \times 0,01815 \mathrm{~m}^{2} \times \operatorname{dia} \times 10^{6} \mu \mathrm{g}}$

$$
\operatorname{TxE}\left(\mathrm{CO}_{2}\right)=47,13 \mathrm{~g} \times \mathrm{m}^{-2} \cdot \mathrm{d}^{-1}\left(\mathrm{CO}_{2}\right) \text { No sítio de coleta } \mathrm{P}_{4} \text {. }
$$

$P_{5}\left(G ; V_{G}=33.200 m L ; A_{G}=0,664 m^{2}\right)-$ Jaú 2007

a) Tabela com tempos de coleta e massas correspondentes, gráfico com equações de retas e inclinações:

Tabela 6.5.54 - Sítio de coleta $\mathbf{P}_{5}$ - Jaú 2007: tempos de coleta e massas $(\mu \mathrm{g})$ para $\mathrm{CH}_{4}$ e $\mathrm{CO}_{2}$.

\begin{tabular}{ccc}
\hline Tempo $(\boldsymbol{m i n})$ & Massa do $\mathrm{CH}_{4}(\mu \mathrm{g})$ & Massa do $\mathrm{CO}_{2}(\mu \mathrm{g})$ \\
\hline 0 & 0 & 7,4134 \\
3 & 10,9168 & 8,3382 \\
6 & 11,5564 & 12,2883 \\
12 & 10,6202 & 10,2606 \\
\hline
\end{tabular}




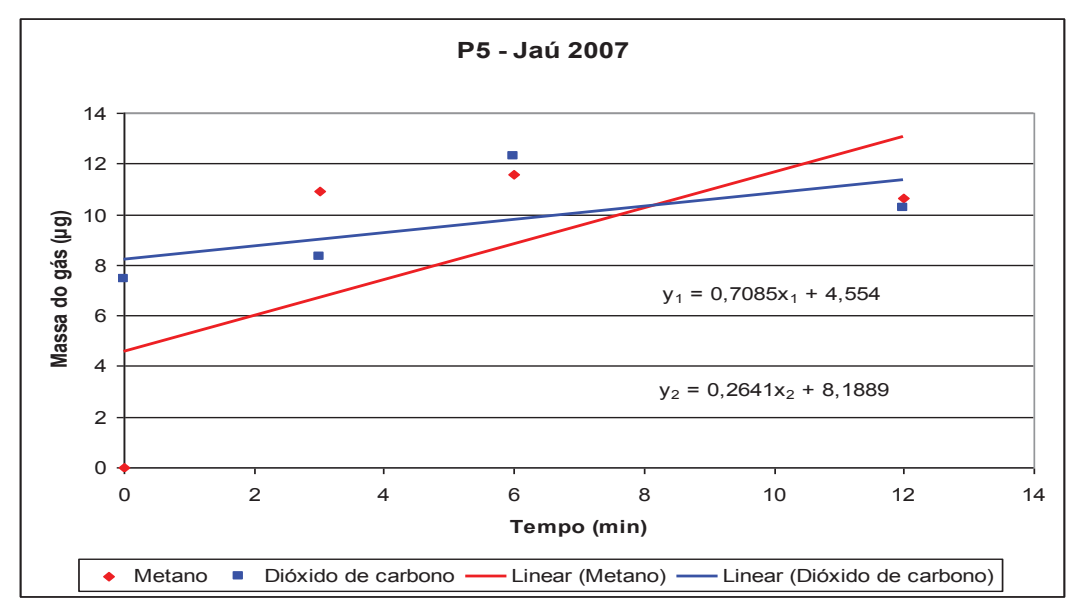

Gráfico 6.5.47 - Sítio $\mathbf{P}_{\mathbf{5}}$ - Jaú 2007. Equações de retas e inclinações para $\mathrm{CH}_{4}$ e $\mathrm{CO}_{2}$.

Equações das retas:

$$
\begin{aligned}
& y_{1}=0,7085 x_{1}+4,554 \quad \text { Equação do metano } \\
& y_{2}=0,2641 x_{2}+8,1889 \quad \text { Equação do dióxido }
\end{aligned}
$$

b) Cálculo da taxa de emissão:

b) Metano: $\quad \operatorname{Tx} E\left(\mathrm{CH}_{4}\right)=\frac{0,7085 \mu \mathrm{g}\left(\mathrm{CO}_{2}\right) \times 33.200 \mathrm{~mL} \times 1440 \mathrm{~min} \times \mathrm{g}}{\mathrm{mL} \times \min \times 0,664 \mathrm{~m}^{2} \times \operatorname{dia} \times 10^{6} \mu \mathrm{g}}$

$$
\operatorname{TxE}\left(\mathrm{CH}_{4}\right)=51,01 \mathrm{~g} \times \mathrm{m}^{-2} \cdot d^{-1}\left(\mathrm{CH}_{4}\right) \text { No sítio de coleta } \mathrm{P}_{5} \text {. }
$$

$\mathrm{b}_{2}$ ) Dióxido de carbono: $\operatorname{Tx} E\left(C \mathrm{CO}_{2}\right)=\frac{0,2641 \mu \mathrm{g}\left(\mathrm{CO}_{2}\right) \times 33.200 \mathrm{~mL} \times 1440 \mathrm{~min} \times \mathrm{g}}{\mathrm{mL} \times \min \times 0,664 \mathrm{~m}^{2} \times \operatorname{dia} \times 10^{6} \mu \mathrm{g}}$

$$
\operatorname{Tx} E\left(\mathrm{CO}_{2}\right)=19,01 \mathrm{~g} \times \mathrm{m}^{-2} \cdot \mathrm{d}^{-1}\left(\mathrm{CO}_{2}\right) \text { No sítio de coleta } \mathrm{P}_{5}
$$

$\mathbf{P}_{6}\left(\mathrm{G} ; \mathrm{V}_{\mathrm{G}}=33.200 \mathrm{~mL} ; \mathrm{A}_{\mathrm{G}}=0,664 \mathrm{~m}^{2}\right)$

a) Tabela com tempos de coleta e massas correspondentes, gráfico com equações de retas e inclinações: 
Tabela 6.5.55 - Sítio de coleta $\mathbf{P}_{\mathbf{6}}$ - Jaú 2007: tempos de coleta e massas $(\mu g)$ para $\mathrm{CH}_{4}$ e $\mathrm{CO}_{2}$.

\begin{tabular}{ccc}
\hline Tempo (min) & Massa do $\mathrm{CH}_{\mathbf{4}}(\mu \mathrm{g})$ & Massa do $\mathbf{C O}_{\mathbf{2}}(\mu \mathrm{g})$ \\
\hline 0 & 10,3264 & 7,7760 \\
3 & 12,2289 & 11,1918 \\
6 & 12,5227 & 12,8955 \\
12 & 12,5363 & 10,5224 \\
\hline
\end{tabular}

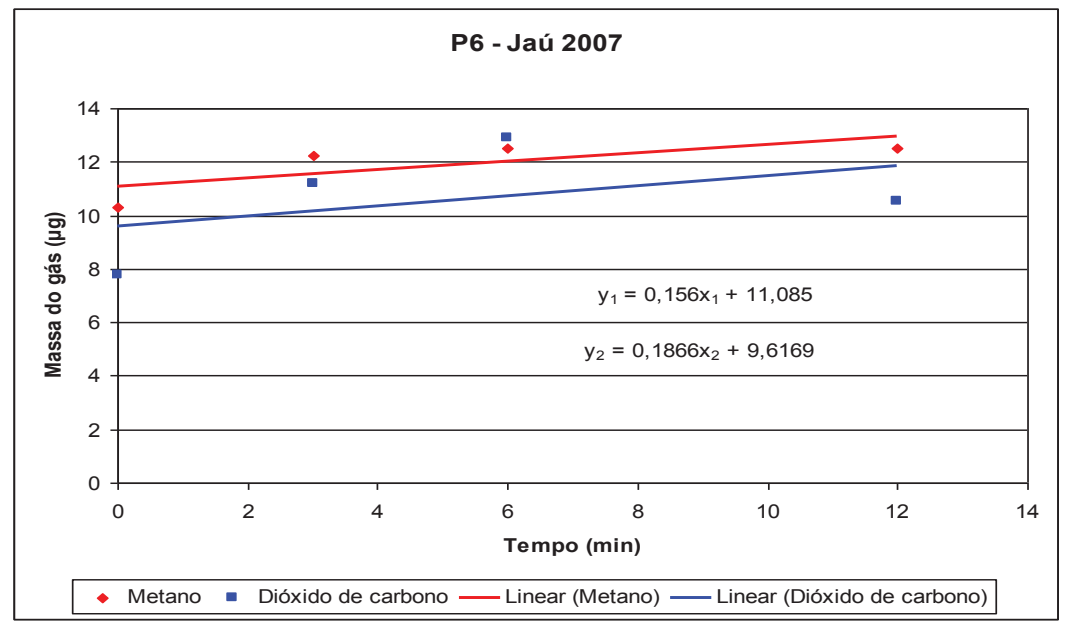

Gráfico 6.5.48 - Sítio $\mathbf{P}_{6}$ - Jaú 2007. Equações de retas e inclinações para $\mathrm{CH}_{4}$ e $\mathrm{CO}_{2}$.

Equações das retas:

$$
\begin{aligned}
& y_{1}=0,156 x_{1}+11,085 \text { Equação do metano } \\
& y_{2}=0,1866 x_{2}+9,6169 \text { Equação do dióxido }
\end{aligned}
$$

b) Cálculo da taxa de emissão:

b) Metano: $\quad \operatorname{Tx} E\left(\mathrm{CH}_{4}\right)=\frac{0,156 \mu \mathrm{g}\left(\mathrm{CO}_{2}\right) \times 33.200 \mathrm{~mL} \times 1440 \mathrm{~min} \times \mathrm{g}}{\mathrm{mL} \times \min \times 0,664 \mathrm{~m}^{2} \times \operatorname{dia} \times 10^{6} \mu \mathrm{g}}$

$$
\operatorname{TxE}\left(\mathrm{CH}_{4}\right)=11,23 \mathrm{~g} \times \mathrm{m}^{-2} \cdot \mathrm{d}^{-1}\left(\mathrm{CH}_{4}\right) \text { No sítio de coleta } \mathrm{P}_{6} \text {. }
$$

$\mathrm{b}_{2}$ ) Dióxido de carbono: $\operatorname{Tx} E\left(C \mathrm{CO}_{2}\right)=\frac{0,1866 \mu \mathrm{g}\left(\mathrm{CO}_{2}\right) \times 33.200 \mathrm{~mL} \times 1440 \mathrm{~min} \times \mathrm{g}}{\mathrm{mL} \times \min \times 0,664 \mathrm{~m}^{2} \times \operatorname{dia} \times 10^{6} \mu \mathrm{g}}$ 


$$
\operatorname{TxE}\left(\mathrm{CO}_{2}\right)=13,43 \mathrm{~g} \times \mathrm{m}^{-2} \cdot \mathrm{d}^{-1}\left(\mathrm{CO}_{2}\right) \text { No sítio de coleta } \mathrm{P}_{6} \text {. }
$$

c) Aterro de Jaú - Emissão solo-ar campanha 2007:

A tabela 6.5.56, a seguir, resume a emissão solo-ar de $\mathrm{CH}_{4}$ e $\mathrm{CO}_{2}$, em cada sítio $\mathbf{P}_{\mathbf{n}}$, do aterro de Jaú na campanha de 2007.

Tabela 6.5.56 - Resumo da emissão solo-ar - Jaú 2007

\begin{tabular}{ccc}
\hline Sítio amostrado & Gás & $T_{\mathbf{x}} \mathbf{E}\left(\boldsymbol{g} \cdot \boldsymbol{m}^{-\mathbf{2}} \cdot \boldsymbol{d}^{-\mathbf{1}}\right)$ \\
\hline $\mathrm{P}_{1}$ & $\mathrm{CH}_{4}$ & 53,40 \\
& $\mathrm{CO}_{2}$ & 17,42 \\
\hline $\mathrm{P}_{2}$ & $\mathrm{CH}_{4}$ & 8,66 \\
& $\mathrm{CO}_{2}$ & 9,81 \\
\hline $\mathrm{P}_{3}$ & $\mathrm{CH}_{4}$ & 63,80 \\
& $\mathrm{CO}_{2}$ & 18,65 \\
\hline $\mathrm{P}_{4}$ & $\mathrm{CH}_{4}$ & 18,15 \\
& $\mathrm{CO}_{2}$ & 47,13 \\
& $\mathrm{CH}_{4}$ & 51,01 \\
$\mathrm{P}_{5}$ & $\mathrm{CO}_{2}$ & 19,01 \\
& $\mathrm{CH}_{4}$ & 11,23 \\
\hline $\mathrm{P}_{6}$ & $\mathrm{CO}_{2}$ & 13,43 \\
\hline
\end{tabular}

1) Cálculo da taxa de emissão média do Metano $\left(T_{x} E_{m(C H 4)}\right)$ nos sítios $\left(P_{n}\right)$ :

$$
\mathrm{T}_{\mathrm{x}} \mathrm{E}_{\mathrm{m}}\left(\mathrm{CH}_{4}\right)=\left(\mathrm{P}_{1}+\ldots+\mathrm{P}_{6}\right) / 6=41,25 \mathrm{~g} \cdot \mathrm{m}^{-2} \cdot \mathrm{d}^{-1}
$$


2) Taxa de emissão média total do metano $\left(\mathrm{T}_{x} \mathrm{E}_{\mathrm{m}(\mathrm{t})(\mathrm{CH} 4)}\right)$ no aterro:

$$
\begin{gathered}
\Rightarrow \mathrm{TX}_{\mathrm{m}(\mathrm{t})}=\mathrm{T}_{\mathrm{x}} \mathrm{E}_{\mathrm{m}}\left(41,25 \mathrm{~g} \cdot \mathrm{m}^{-2} \cdot \mathrm{d}^{-1}\right) \cdot \mathrm{A}_{\mathrm{at}}\left(48.400 \mathrm{~m}^{2}\right) \cdot 365 \mathrm{~d} \cdot 10^{-6}=728,72 \mathrm{t} \cdot \mathrm{a}^{-1} \\
\Rightarrow \mathrm{T}_{\mathbf{x}} \mathrm{E}_{\mathrm{m}(\mathrm{t})}\left(\mathbf{C H}_{4}\right)=\mathbf{7 2 8 , 7 2} \mathbf{t} \cdot \mathbf{a}^{-1}
\end{gathered}
$$

Em que: $T_{x} E_{m}=$ Taxa de Emissão média $\left(g \cdot m^{-2} \cdot d^{-1}\right)$

$$
\begin{gathered}
\mathrm{A}_{\mathrm{at}}=\text { Área do aterro }\left(\mathrm{m}^{2}\right) \\
\mathrm{T}_{\mathrm{x}} \mathrm{E}_{\mathrm{m}(\mathrm{t})}=\text { Taxa de Emissão média total para } 2006\left({\text { Toneladas } \left.\cdot a n 0^{-1}\right)}\right) \\
365=\text { fator de conversão de dias para ano } \\
10^{-6}=\text { fator de conversão de g para Tonelada }
\end{gathered}
$$

3) Cálculo da taxa de emissão média do dióxido de carbono $\left(T_{x} E_{m(C O 2)}\right)$ nos sítios $\left(P_{n}\right)$ :

$$
\Rightarrow T_{x} E_{m}\left(C O_{2}\right)=\left(P_{1}+\ldots+P_{6}\right) / 6=34,37 \mathrm{~g} \cdot \mathrm{m}^{-2} \cdot \mathrm{d}^{-1}
$$

4) Cálculo da taxa de emissão média total do dióxido de carbono ( $\left.T_{x} E_{m(t)(C O 2)}\right)$ no aterro:

$$
\Rightarrow T_{x} E_{m(t)}=602,16 t \cdot a^{-1}
$$

Emissão Total Média ( $\left.E_{t} \underline{M}\right)$ solo-ar do aterro de Jaú: Consideradas as campanhas 2006 e 2007:

1) Metano: $\quad E_{t} M\left(\mathrm{CH}_{4}\right)=1.773,66$ Ton $\cdot a^{-1}$

2) Dióxido de carbono: $\mathrm{E}_{t} \mathrm{M}\left(\mathrm{CO}_{2}\right)=1.409,70 \mathrm{Ton} \cdot \mathrm{a}^{-1}$ 


\subsection{1-E) Aterro de Ribeirão Bonito}

\section{$\left.E_{1}\right)$ Campanha 2006}

$\mathbf{P}_{1}\left(\mathrm{G} ; \mathrm{V}_{\mathrm{G}}=33.200 \mathrm{~mL}\right.$ e $\left.\mathrm{A}_{\mathrm{G}}=0,664 \mathrm{~m}^{2}\right)$

a) Tabela com tempos de coleta e massas correspondentes, gráfico com equações de retas e inclinações:

Tabela 6.5.57 - Sítio de coleta $\mathbf{P}_{\mathbf{1}}$ - Ribeirão Bonito 2006: tempos de coleta e massas $(\mu \mathrm{g})$ para $\mathrm{CH}_{4}$ e $\mathrm{CO}_{2}$.

\begin{tabular}{ccc}
\hline Tempo (min) & Massa do $\mathrm{CH}_{\mathbf{4}}(\mu \mathrm{g})$ & Massa do $\mathrm{CO}_{\mathbf{2}}(\mu \mathrm{g})$ \\
\hline 0 & 11,4825 & 9,4800 \\
3 & 11,4990 & 10,3465 \\
6 & 11,5000 & 10,7349 \\
12 & 11,8923 & 10,6683 \\
\hline
\end{tabular}

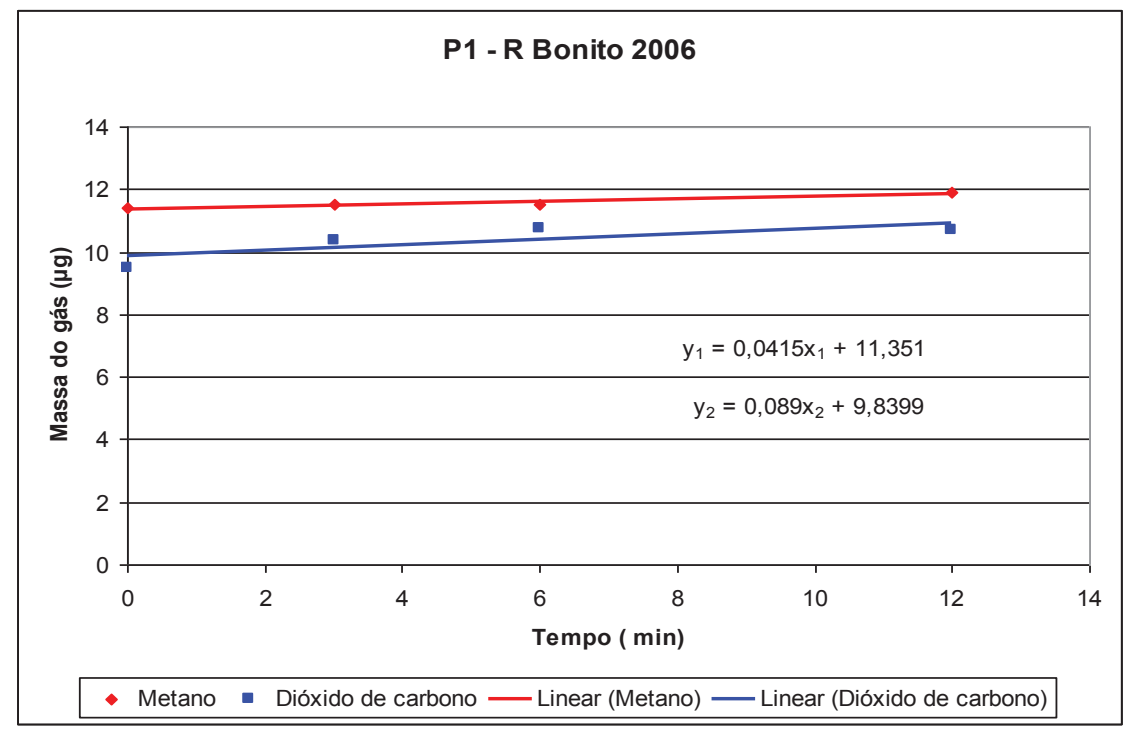

Gráfico 6.5.49 - Sítio $\mathbf{P}_{\mathbf{1}}$ - Ribeirão Bonito 2006. Equações de retas e inclinações para $\mathrm{CH}_{4}$ e $\mathrm{CO}_{2}$.

Equações das retas:

$$
y_{1}=0,0415 x_{1}+11,351 \text { Equação do metano }
$$


$y_{2}=0,089 x_{2}+9,8399$ Equação do dióxido

b) Cálculo da taxa de emissão:

$\left.b_{1}\right)$ Metano:

$$
\operatorname{TxE}\left(\mathrm{CH}_{4}\right)=\frac{0,0415 \mu \mathrm{g}\left(\mathrm{CH}_{4}\right) \times 33.200 \mathrm{~mL} \times 1440 \mathrm{~min} \times g}{m L \times \min \times 0,664 \mathrm{~m}^{2} \times \operatorname{dia} \times 10^{6} \mu \mathrm{g}}
$$

$\operatorname{TxE}\left(\mathrm{CH}_{4}\right)=3,00 \mathrm{~g} \times \mathrm{m}^{-2} \cdot \mathrm{d}^{-1}\left(\mathrm{CH}_{4}\right) \quad$ No sítio de coleta $\mathrm{P}_{1}$.

Em que: $\quad T_{x} E\left(C_{4}\right)=$ Taxa de emissão de metano no sítio;

$1,1535 \mu \mathrm{g} \cdot \mathrm{min}^{-1} \cdot \mathrm{mL}^{-1}=$ Inclinação da reta do gráfico de $\mathrm{CH}_{4}$;

33.200 $\mathrm{mL}=$ Volume da câmara de coleta (grande);

1440 min = número de minutos $\cdot$ dia $^{-1}$;

$10^{6}=$ fator de conversão de $\mu \mathrm{g}$ para $g$; e,

0,664 $m^{2}$ = Área da base da câmara de coleta (grande).

$\mathrm{b}_{2}$ ) Dióxido de carbono: $\operatorname{Tx} E\left(\mathrm{CO}_{2}\right)=\frac{0,089 \mu \mathrm{g}\left(\mathrm{CO}_{2}\right) \times 33.200 \mathrm{~mL} \times 1440 \mathrm{~min} \times \mathrm{g}}{\mathrm{mL} \times \min \times 0,664 \mathrm{~m}^{2} \times \operatorname{dia} \times 10^{6} \mu \mathrm{g}}$

$$
\operatorname{Tx} E\left(C_{2}\right)=6,41 \mathrm{~g} \times \mathrm{m}^{-2} \cdot d^{-1}\left(C_{2}\right) \quad \text { No sítio de coleta } \mathrm{P}_{1} \text {. }
$$

Em que: $\quad T_{\mathrm{x}} \mathrm{E}\left(\mathrm{CO}_{2}\right)=$ Taxa de emissão de dióxido de carbono no sítio;

$0,089 \mu \mathrm{g} \cdot \mathrm{min}^{-1} \cdot \mathrm{mL}^{-1}=$ Inclinação da reta do gráfico de $\mathrm{CO}_{2}$;

33.200 $\mathrm{mL}=$ Volume da câmara de coleta (grande);

$1440 \min =$ número de $\operatorname{minutos} \cdot \mathrm{dia}^{-1}$;

$10^{6}=$ fator de conversão de $\mu \mathrm{g}$ para $g ; \mathrm{e}$,

$0,664 m^{2}=$ Área da base da câmara de coleta (grande). 
$\mathbf{P}_{2}\left(\mathrm{p} ; \mathrm{VP}=1200 \mathrm{~mL}\right.$ e $\left.A P=0,01815 \mathrm{~m}^{2}\right)$

a) Tabela com tempos de coleta e massas correspondentes, gráfico com equações de retas e inclinações:

Tabela 6.5.58 - Sítio de coleta $\mathbf{P}_{\mathbf{2}}-\mathrm{R}$ Bonito 2006: tempos de coleta e massas $(\mu \mathrm{g})$ para $\mathrm{CH}_{4}$ e $\mathrm{CO}_{2}$.

\begin{tabular}{ccc}
\hline Tempo (min) & Massa do $\mathrm{CH}_{4}(\mu g)$ & Massa do $\mathrm{CO}_{2}(\mu g)$ \\
\hline 0 & 10,3030 & 7,6236 \\
3 & 10,4824 & 8,2695 \\
6 & 10,9076 & 9,4754 \\
12 & 11,0728 & 9,5290 \\
\hline
\end{tabular}

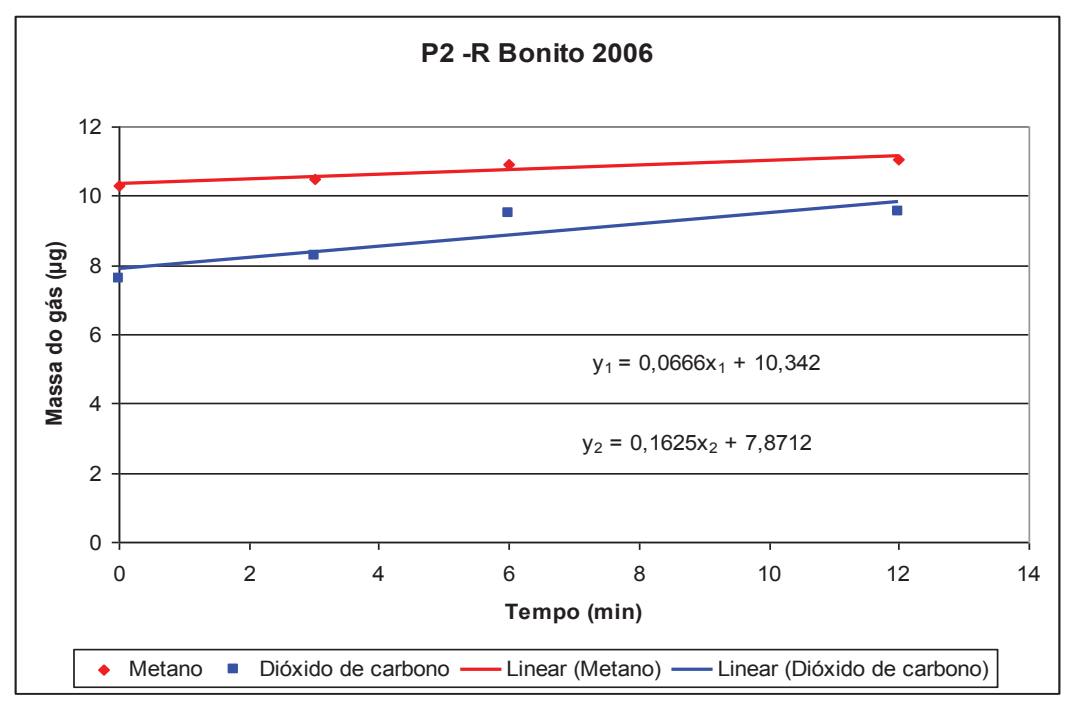

Gráfico 6.5.50 - Sítio $\mathbf{P}_{\mathbf{2}}-\mathrm{R}$ Bonito 2006. Equações de retas e inclinações para $\mathrm{CH}_{4}$ e $\mathrm{CO}_{2}$.

Equações das retas:

$$
\begin{aligned}
& y_{1}=0,0666 x_{1}+10,342 \text { Equação do metano } \\
& y_{2}=0,1625 x_{2}+7,8712 \text { Equação do dióxido }
\end{aligned}
$$


b) Cálculo da taxa de emissão:

$\left.b_{1}\right)$ Metano:

$$
\begin{aligned}
& \operatorname{TxE}\left(\mathrm{CH}_{4}\right)=\frac{0,0666 \mu g\left(\mathrm{CO}_{2}\right) \times 1.200 \mathrm{~mL} \times 1440 \mathrm{~min} \times \mathrm{g}}{\mathrm{mL} \times \min \times 0,01815 \mathrm{~m}^{2} \times \operatorname{dia} \times 10^{6} \mu \mathrm{g}} \\
& \operatorname{Tx} E\left(\mathrm{CH}_{4}\right)=6,34 \mathrm{~g} \times \mathrm{m}^{-2} \cdot \mathrm{d}^{-1}\left(\mathrm{CH}_{4}\right) \text { No sítio de coleta } \mathrm{P}_{2} .
\end{aligned}
$$

$b_{2}$ ) Dióxido de carbono: $\operatorname{Tx} E\left(\mathrm{CO}_{2}\right)=\frac{0,1625 \mu \mathrm{g}\left(\mathrm{CO}_{2}\right) \times 1.200 \mathrm{~mL} \times 1440 \mathrm{~min} \times g}{\mathrm{~mL} \times \min \times 0,01815 \mathrm{~m}^{2} \times \operatorname{dia} \times 10^{6} \mu \mathrm{g}}$

$$
\operatorname{Tx} E\left(\mathrm{CO}_{2}\right)=15,47 \mathrm{mg} \times \mathrm{m}^{-2} \cdot \mathrm{d}^{-1}\left(\mathrm{CO}_{2}\right) \text { No sítio de coleta } \mathrm{P}_{2} \text {. }
$$

$\mathbf{P}_{3}\left(\mathrm{G} ; \mathrm{V}_{\mathrm{G}}=33.200 \mathrm{~mL}\right.$ e $\left.\mathrm{A}_{\mathrm{G}}=0,664 \mathrm{~m}^{2}\right)$

a) Tabela com tempos de coleta e massas correspondentes, gráfico com equações de retas e inclinações:

Tabela 6.5.59 - Sítio de coleta $\mathbf{P}_{3}-\mathbf{R}$ Bonito 2006: tempos de coleta e massas $(\mu g)$ para $\mathrm{CH}_{4}$ e $\mathrm{CO}_{2}$.

\begin{tabular}{rcr}
\hline Tempo (min) & Massa do $\mathrm{CH}_{4}(\mu \mathrm{g})$ & Massa do $\mathrm{CO}_{2}(\mu \mathrm{g})$ \\
\hline 0 & 11,3840 & 8,9732 \\
3 & 11,8584 & 10,1340 \\
6 & 11,2471 & 10,5803 \\
12 & 11,5000 & 9,8851 \\
\hline
\end{tabular}




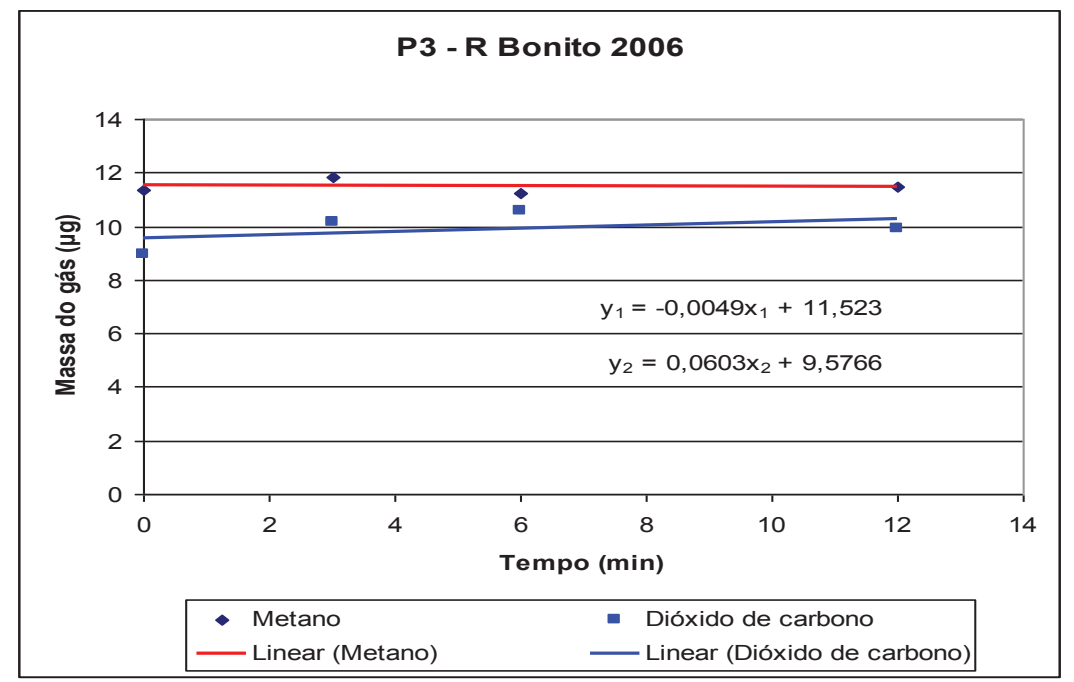

Gráfico 6.5.51 - Sítio $\mathbf{P}_{3}-\mathrm{R}$ Bonito 2006. Equações de retas e inclinações para $\mathrm{CH}_{4}$ e $\mathrm{CO}_{2}$.

Equações das retas:

$$
\begin{aligned}
& y_{1}=-0,0049 x_{1}+11,523 \text { Equação do metano } \\
& y_{2}=0,6003 x_{2}+9,5766 \text { Equação do dióxido }
\end{aligned}
$$

b) Cálculo da taxa de emissão:

$\left.b_{1}\right)$ Metano:

$$
\begin{gathered}
\operatorname{Tx} E\left(\mathrm{CH}_{4}\right)=\frac{0,0049 \mu g\left(\mathrm{CO}_{2}\right) \times 33.200 \mathrm{~mL} \times 1440 \mathrm{~min} \times \mathrm{g}}{\mathrm{mL} \times \min \times 0,664 \mathrm{~m}^{2} \times \operatorname{dia} \times 10^{6} \mu \mathrm{g}} \\
\operatorname{Tx}\left(\mathrm{CH}_{4}\right)=0,35 \mathrm{~g} \times \mathrm{m}^{-2} \cdot \mathrm{d}^{-1}\left(\mathrm{CH}_{4}\right) \text { No sítio de coleta } \mathrm{P}_{3} .
\end{gathered}
$$

$\mathrm{b}_{2}$ ) Dióxido de carbono: $\operatorname{Tx} E\left(\mathrm{CO}_{2}\right)=\frac{0,6003 \mu \mathrm{g}\left(\mathrm{CO}_{2}\right) \times 33.200 \mathrm{~mL} \times 1440 \mathrm{~min} \times \mathrm{g}}{\mathrm{mL} \times \min \times 0,664 \mathrm{~m}^{2} \times \operatorname{dia} \times 10^{6} \mu \mathrm{g}}$

$$
\operatorname{Tx} E\left(\mathrm{CO}_{2}\right)=43,22 \mathrm{~g} \times \mathrm{m}^{-2} \cdot \mathrm{d}^{-1}\left(\mathrm{CO}_{2}\right) \text { No sítio de coleta } \mathrm{P}_{3} \text {. }
$$


$\mathbf{P}_{4}\left(p ; V_{P}=1.200 m L\right.$ e $\left.A_{P}=0,01815 m^{2}\right)$

a) Tabela com tempos de coleta e massas correspondentes, gráfico com equações de retas e inclinações:

Tabela 6.5.60 - Sítio de coleta $\mathbf{P}_{\mathbf{4}}-\mathrm{R}$ Bonito 2006: tempos de coleta e massas $(\mu \mathrm{g})$ para $\mathrm{CH}_{4}$ e $\mathrm{CO}_{2}$.

\begin{tabular}{ccc}
\hline Tempo (min) & Massa do $\mathrm{CH}_{\mathbf{4}}(\mu \mathrm{g})$ & Massa do $\mathrm{CO}_{\mathbf{2}}(\mu \mathrm{g})$ \\
\hline 0 & 10,2717 & 7,6494 \\
3 & 10,3940 & 8,4304 \\
6 & 1,09113 & 9,5719 \\
12 & 11,3530 & 10,9558 \\
\hline
\end{tabular}

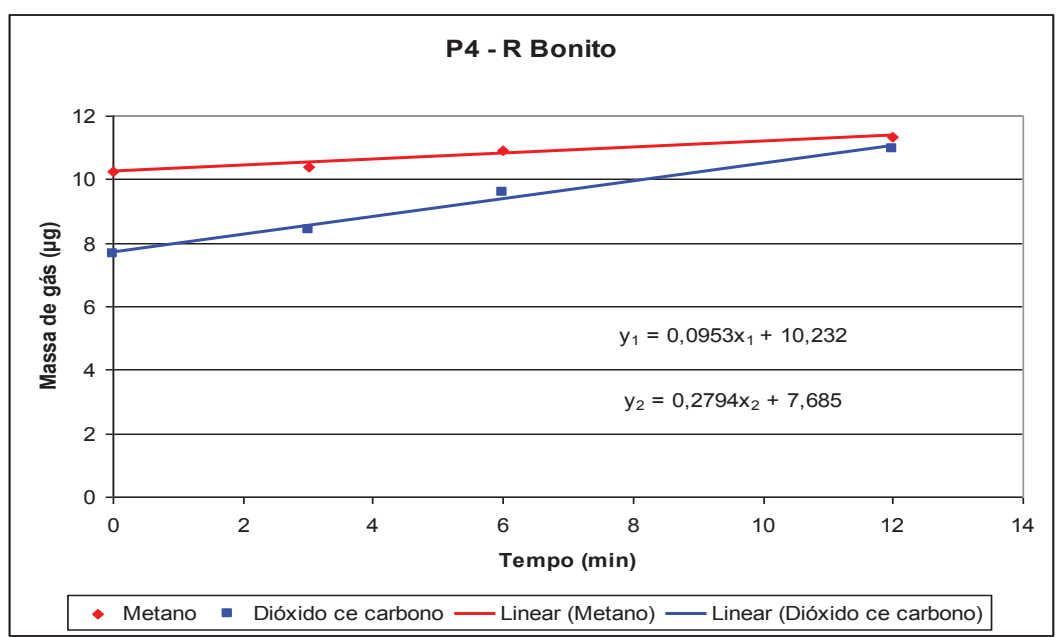

Gráfico 6.5.52 - Sítio $\mathbf{P}_{4}-\mathrm{R}$ Bonito 2006. Equações de retas e inclinações para $\mathrm{CH}_{4}$ e $\mathrm{CO}_{2}$.

Equações das retas:

$$
\begin{aligned}
& y_{1}=0,0953 x_{1}+10,232 \text { Equação do metano } \\
& y_{2}=0,2794 x_{2}+7,685 \text { Equação do dióxido }
\end{aligned}
$$

b) Cálculo da taxa de emissão: 
$\left.b_{1}\right)$ Metano:

$$
\begin{aligned}
& \operatorname{Tx} E\left(\mathrm{CH}_{4}\right)=\frac{0,0953 \mu g\left(\mathrm{CO}_{2}\right) \times 1.200 \mathrm{~mL} \times 1440 \mathrm{~min} \times \mathrm{g}}{\mathrm{mL} \times \min \times 0,01815 \mathrm{~m}^{2} \times \operatorname{dia} \times 10^{6} \mu \mathrm{g}} \\
& \operatorname{TxE}\left(\mathrm{CH}_{4}\right)=9,07 \mathrm{~g} \times \mathrm{m}^{-2} \cdot \mathrm{d}^{-1}\left(\mathrm{CH}_{4}\right) \text { No sítio de coleta } \mathrm{P}_{4} .
\end{aligned}
$$

$\mathrm{b}_{2}$ ) Dióxido de carbono: $\operatorname{Tx} E\left(\mathrm{CO}_{2}\right)=\frac{0,2794 \mu \mathrm{g}\left(\mathrm{CO}_{2}\right) \times 1.200 \mathrm{~mL} \times 1440 \mathrm{~min} \times \mathrm{g}}{\mathrm{mL} \times \min \times 0,01815 \mathrm{~m}^{2} \times \operatorname{dia} \times 10^{6} \mu \mathrm{g}}$

$$
\operatorname{Tx} E\left(\mathrm{CO}_{2}\right)=26,60 \mathrm{~g} \times \mathrm{m}^{-2} \cdot \mathrm{d}^{-1}\left(\mathrm{CO}_{2}\right) \text { No sítio de coleta } \mathrm{P}_{4} \text {. }
$$

$\mathbf{P}_{5}\left(\mathrm{G} ; \mathrm{V}_{\mathrm{G}}=33.200 \mathrm{~mL}\right.$ e $\left.A_{G}=0,664 \mathrm{~m}^{2}\right)$

a) Tabela com tempos de coleta e massas correspondentes, gráfico com equações de retas e inclinações:

Tabela 6.5.61 - Sítio de coleta $\mathbf{P}_{\mathbf{5}}-\mathrm{R}$ Bonito 2006: tempos de coleta e massas $(\mu \mathrm{g})$ para $\mathrm{CH}_{4}$ e $\mathrm{CO}_{2}$.

\begin{tabular}{ccc}
\hline Tempo $(\boldsymbol{m i n})$ & Massa do $\mathrm{CH}_{4}(\mu \mathrm{g})$ & Massa do $\mathrm{CO}_{2}(\mu \mathrm{g})$ \\
\hline 0 & 10,8346 & 9,2865 \\
3 & 11,1732 & 10,1426 \\
6 & 12,1869 & 13,9060 \\
12 & 12,3411 & 14,0584 \\
\hline
\end{tabular}




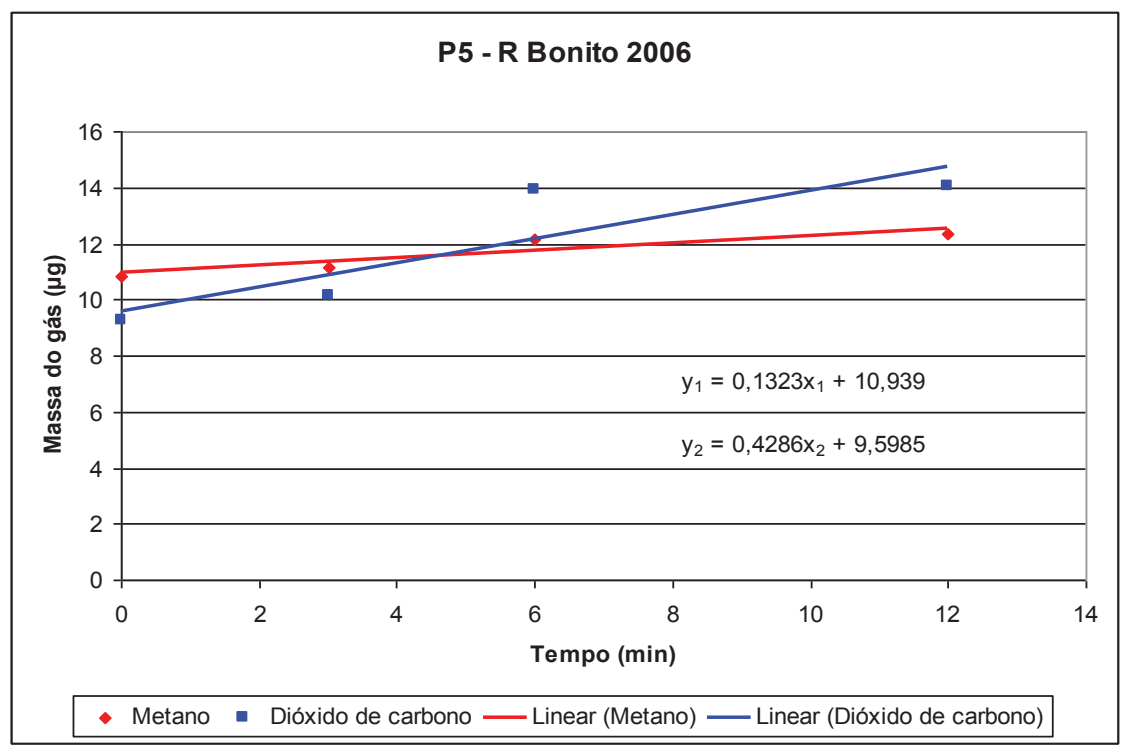

Gráfico 6.5.53 - Sítio $\mathbf{P}_{5}-\mathrm{R}$ Bonito 2006. Equações de retas e inclinações para $\mathrm{CH}_{4}$ e $\mathrm{CO}_{2}$.

Equações das retas:

$$
\begin{aligned}
& y_{1}=0,1323 x_{1}+10,939 \text { Equação do metano } \\
& y_{2}=0,4286 x_{2}+9,5985 \text { Equação do dióxido }
\end{aligned}
$$

b) Cálculo da taxa de emissão:

$b_{1}$ ) Metano:

$$
\begin{aligned}
& \operatorname{Tx} E\left(\mathrm{CH}_{4}\right)=\frac{0,1323 \mu g\left(\mathrm{CO}_{2}\right) \times 33.200 \mathrm{~mL} \times 1440 \mathrm{~min} \times \mathrm{g}}{\mathrm{mL} \times \min \times 0,664 \mathrm{~m}^{2} \times \operatorname{dia} \times 10^{6} \mu \mathrm{g}} \\
& \operatorname{Tx}\left(\mathrm{CH}_{4}\right)=9,52 \mathrm{~g} \times \mathrm{m}^{-2} \cdot \mathrm{d}^{-1}\left(\mathrm{CH}_{4}\right) \text { No sítio de coleta } \mathrm{P}_{3} .
\end{aligned}
$$

$\mathrm{b}_{2}$ ) Dióxido de carbono: $\operatorname{TxE}\left(\mathrm{CO}_{2}\right)=\frac{0,4286 \mu \mathrm{g}\left(\mathrm{CO}_{2}\right) \times 33.200 \mathrm{~mL} \times 1440 \mathrm{~min} \times \mathrm{g}}{\mathrm{mL} \times \min \times 0,664 \mathrm{~m}^{2} \times \operatorname{dia} \times 10^{6} \mu \mathrm{g}}$

$$
\operatorname{Tx} E\left(\mathrm{CO}_{2}\right)=30,86 \mathrm{~g} \times \mathrm{m}^{-2} \cdot \mathrm{d}^{-1}\left(\mathrm{CO}_{2}\right) \text { No sítio de coleta } \mathrm{P}_{3} \text {. }
$$




\section{Emissão solo-ar 2006 - aterro de Ribeirão bonito:}

A tabela 6.5.62, resume as taxas de emissão solo-ar, medidas para $\mathrm{CH}_{4}$ e $\mathrm{CO}_{2}$, em cada sítio $\mathbf{P}_{\mathbf{n}}$ do aterro de Ribeirão Bonito, na campanha de 2006.

Tabela 6.5.62 - Resumo da emissão solo-ar - Ribeirão Bonito 2006

\begin{tabular}{ccr}
\hline Sítio amostrado & Gás & $\mathrm{T}_{\mathbf{x}} \mathrm{E}\left(\boldsymbol{g} \cdot \boldsymbol{m}^{-\mathbf{2}} \cdot \boldsymbol{d}^{-\mathbf{1}}\right)$ \\
\hline $\mathrm{P}_{1}$ & $\mathrm{CH}_{4}$ & 3,00 \\
& $\mathrm{CO}_{2}$ & 6,14 \\
& $\mathrm{CH}_{4}$ & 6,34 \\
$\mathrm{P}_{2}$ & $\mathrm{CO}_{2}$ & 15,42 \\
& $\mathrm{CH}_{4}$ & 0,35 \\
$\mathrm{P}_{3}$ & $\mathrm{CO}_{2}$ & 43,22 \\
& $\mathrm{CH}_{4}$ & 9,07 \\
$\mathrm{P}_{4}$ & $\mathrm{CO}_{2}$ & 26,60 \\
& $\mathrm{CH}_{4}$ & 9,52 \\
\hline $\mathrm{P}_{5}$ & $\mathrm{CO}_{2}$ & 30,86 \\
\hline
\end{tabular}

1)Cálculo da taxa de emissão média do Metano $\left(T_{x} E_{m(C H 4)}\right)$ nos sítios $\left(P_{n}\right)$ :

$$
\mathrm{T}_{\mathrm{x}} \mathrm{E}_{\mathrm{m}}\left(\mathrm{CH}_{4}\right)=\left(\mathrm{P}_{1}+\ldots+\mathrm{P}_{5}\right) / 5=5,66 \mathrm{~g} \cdot \mathrm{m}^{-2} \cdot \mathrm{d}^{-1}
$$

2)Taxa de emissão média total do metano $\left(\mathrm{T}_{\mathrm{x}} \mathrm{E}_{\mathrm{m}(\mathrm{t})(\mathrm{CH} 4)}\right)$ no aterro:

$$
\begin{gathered}
\Rightarrow \mathrm{T}_{\mathrm{x}} \mathrm{E}_{\mathrm{m}(\mathrm{t})}=\mathrm{T}_{\mathrm{x}} \mathrm{E}_{\mathrm{m}}\left(5,66 \mathrm{~g} \cdot \mathrm{m}^{-2} \cdot \mathrm{d}^{-1}\right) \cdot \mathrm{A}_{\mathrm{at}}\left(40.000 \mathrm{~m}^{2}\right) \cdot 365 \mathrm{~d} \cdot 10^{-6}=\mathrm{t} \cdot \mathrm{a}^{-1} \\
\Rightarrow \mathbf{T}_{\mathbf{x}} \mathbf{E}_{\mathrm{m}(\mathrm{t})}\left(\mathrm{CH}_{\mathbf{4}}\right)=\mathbf{8 2 , 6 4} \mathbf{t} \cdot \mathbf{a}^{-1}
\end{gathered}
$$

Em que: $T_{x} E=$ Taxa de emissão; $T_{x} E_{m}=$ Taxa de Emissão média $\left(g \cdot m^{-2} \cdot d^{-1}\right)$ 


$$
\begin{aligned}
\mathrm{A}_{\mathrm{at}} & =\text { Área do aterro }\left(m^{2}\right) \\
\mathrm{T}_{\mathrm{x}} \mathrm{E}_{\mathrm{m}(\mathrm{t})} & =\text { Taxa de Emissão média total para } 2006\left({\text { Toneladas } \left.\cdot a n o^{-1}\right)}\right) \\
365 & =\text { fator de conversão de dias para ano } \\
10^{-6} & =\text { fator de conversão de } g \text { para } t
\end{aligned}
$$

4)Cálculo da taxa de emissão média do dióxido de carbono $\left(T_{x} E_{m(C O 2)}\right)$ nos sítios $\left(P_{n}\right)$ :

$$
\begin{aligned}
& \Rightarrow T_{x} E_{m}\left(C O_{2}\right)=\left(P_{1}+\ldots+P_{5}\right) / 5=24,46 \mathrm{~g} \cdot \mathrm{m}^{-2} \cdot \mathrm{d}^{-1} \\
& \Rightarrow \mathbf{T}_{\mathbf{x}} \mathbf{E}_{\mathbf{m}(\mathrm{t})}=\mathbf{3 7 5 , 1 2} \mathrm{t} \cdot \mathbf{a}^{-1}
\end{aligned}
$$

\section{E2) Campanha 2007}

$\mathbf{P}_{1}\left(\mathrm{G} ; \mathrm{V}_{\mathrm{G}}=33.200 \mathrm{~mL} ; \mathrm{A}_{\mathrm{G}}=0,664 \mathrm{~m}^{2}\right)$

a) Tabela com tempos de coleta e massas correspondentes, gráfico com equações de retas e inclinações:

Tabela 6.5.63 - Sítio de coleta $\mathbf{P}_{\mathbf{1}}$ - Ribeirão Bonito 2007: tempos de coleta e massas $(\mu g)$ para $\mathrm{CH}_{4}$ e $\mathrm{CO}_{2}$.

\begin{tabular}{ccc}
\hline Tempo $(\boldsymbol{m i n})$ & Massa do $\mathrm{CH}_{4}(\mu \mathrm{g})$ & Massa do $\mathrm{CO}_{2}(\mu \mathrm{g})$ \\
\hline 0 & 10,3538 & 9,6151 \\
3 & 10,4012 & 10,3207 \\
6 & 10,4532 & 13,9254 \\
12 & 10,9797 & 14,4704 \\
\hline
\end{tabular}




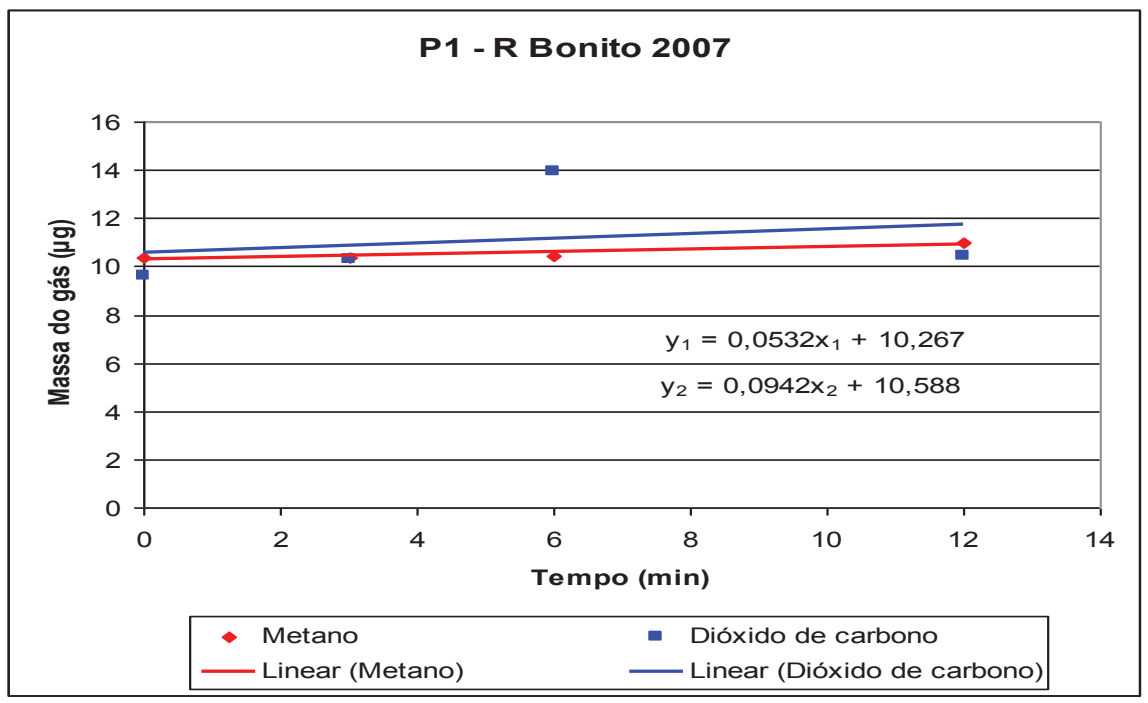

Gráfico 6.5.54 - Sítio $\mathbf{P}_{\mathbf{1}}$ - Ribeirão Bonito 2007. Equações de retas e inclinações para $\mathrm{CH}_{4}$ e $\mathrm{CO}_{2}$.

Equações das retas:

$$
\begin{aligned}
& y_{1}=0,0532 x_{1}+10,267 \text { Equação do metano } \\
& y_{2}=0,0942 x_{2}+10,588 \text { Equação do dióxido }
\end{aligned}
$$

b) Cálculo da taxa de emissão:

$\left.b_{1}\right)$ Metano:

$$
\begin{aligned}
& \operatorname{Tx} E\left(\mathrm{CH}_{4}\right)=\frac{0,0532 \mu g\left(\mathrm{CO}_{2}\right) \times 33.200 \mathrm{~mL} \times 1440 \mathrm{~min} \times \mathrm{g}}{\mathrm{mL} \times \min \times 0,664 \mathrm{~m}^{2} \times \operatorname{dia} \times 10^{6} \mu \mathrm{g}} \\
& \operatorname{Tx}\left(\mathrm{CH}_{4}\right)=3,83 \mathrm{~g} \times \mathrm{m}^{-2} \cdot \mathrm{d}^{-1}\left(\mathrm{CH}_{4}\right) \text { No sítio de coleta } \mathrm{P}_{1} .
\end{aligned}
$$

$\mathrm{b}_{2}$ ) Dióxido de carbono: $\operatorname{Tx} E\left(\mathrm{CO}_{2}\right)=\frac{0,0942 \mu \mathrm{g}\left(\mathrm{CO}_{2}\right) \times 33.200 \mathrm{~mL} \times 1440 \mathrm{~min} \times \mathrm{g}}{\mathrm{mL} \times \min \times 0,664 \mathrm{~m}^{2} \times \operatorname{dia} \times 10^{6} \mu \mathrm{g}}$

$$
\operatorname{Tx} E\left(C_{2}\right)=4,50 \mathrm{~g} \times \mathrm{m}^{-2} \cdot \mathrm{d}^{-1}\left(\mathrm{CO}_{2}\right) \text { No sítio de coleta } \mathrm{P}_{1} \text {. }
$$


$\mathbf{P}_{\mathbf{2}}\left(\mathrm{p} ; \mathrm{V}_{\mathrm{P}}=1.200 \mathrm{~mL} ; \mathrm{A}_{\mathrm{P}}=0,01815 \mathrm{~m}^{2}\right)$

a) Tabela com tempos de coleta e massas correspondentes, gráfico com equações de retas e inclinações:

Tabela 6.5.64 - Sítio de coleta $\mathbf{P}_{\mathbf{2}}-\mathrm{R}$ Bonito 2007: tempos de coleta e massas $(\mu g)$ para $\mathrm{CH}_{4}$ e $\mathrm{CO}_{2}$.

\begin{tabular}{rcr}
\hline Tempo $(\boldsymbol{m i n})$ & Massa do $\mathrm{CH}_{4}(\mu g)$ & Massa do $\mathrm{CO}_{2}(\mu \mathrm{g})$ \\
\hline 0 & 10,3200 & 9,7028 \\
3 & 10,4405 & 9,5569 \\
6 & 10,4000 & 9,4410 \\
12 & 10,2872 & 12,7410 \\
\hline
\end{tabular}

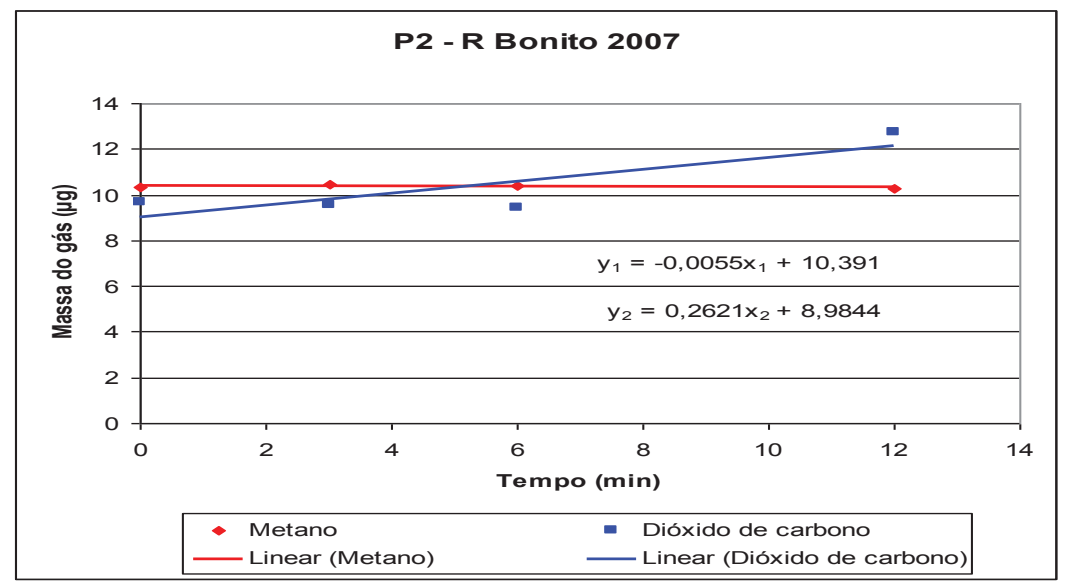

Gráfico 6.5.55 - Sítio $\mathbf{P}_{\mathbf{2}}-\mathrm{R}$ Bonito 2007. Equações de retas e inclinações para $\mathrm{CH}_{4}$ e $\mathrm{CO}_{2}$.

Equações das retas:

$$
\begin{aligned}
& y_{1}=-0,0055 x_{1}+10,391 \text { Equação do metano } \\
& y_{2}=0,2621_{2}+8,9844 \text { Equação do dióxido }
\end{aligned}
$$

b) Cálculo da taxa de emissão:

$\left.b_{1}\right)$ Metano:

$$
\operatorname{TxE}\left(\mathrm{CH}_{4}\right)=\frac{0,0055 \mu \mathrm{g}\left(\mathrm{CO}_{2}\right) \times 1.200 \mathrm{~mL} \times 1440 \mathrm{~min} \times \mathrm{g}}{\mathrm{mL} \times \min \times 0,01815 \mathrm{~m}^{2} \times \operatorname{dia} \times 10^{6} \mu \mathrm{g}}
$$




$$
\operatorname{TxE}\left(\mathrm{CH}_{4}\right)=0,53 \mathrm{~g} \times \mathrm{m}^{-2} \cdot \mathrm{d}^{-1}\left(\mathrm{CH}_{4}\right) \text { No sítio de coleta } \mathrm{P}_{2} \text {. }
$$

$\mathrm{b}_{2}$ ) Dióxido de carbono: $\operatorname{Tx} E\left(\mathrm{CO}_{2}\right)=\frac{0,2621 \mu \mathrm{g}\left(\mathrm{CO}_{2}\right) \times 1.200 \mathrm{~mL} \times 1440 \mathrm{~min} \times \mathrm{g}}{\mathrm{mL} \times \min \times 0,01815 \mathrm{~m}^{2} \times \operatorname{dia} \times 10^{6} \mu \mathrm{g}}$

$$
\operatorname{TxE}\left(\mathrm{CO}_{2}\right)=24,95 \mathrm{~g} \times \mathrm{m}^{-2} \cdot \mathrm{d}^{-1}\left(\mathrm{CO}_{2}\right) \text { No sítio de coleta } \mathrm{P}_{2} \text {. }
$$

$\mathbf{P}_{3}\left(\mathrm{G} ; \mathrm{V}_{\mathrm{G}}=33.200 \mathrm{~mL} ; \mathrm{A}_{\mathrm{G}}=0,664 \mathrm{~m}^{2}\right)$

a) Tabela com tempos de coleta e massas correspondentes, gráfico com equações de retas e inclinações:

Tabela 6.5.65 - Sítio de coleta $\mathbf{P}_{\mathbf{3}}-\mathrm{R}$ Bonito 2007: tempos

de coleta e massas $(\mu \mathrm{g})$ para $\mathrm{CH}_{4}$ e $\mathrm{CO}_{2}$.

\begin{tabular}{rcr}
\hline Tempo (min) & Massa do $\mathrm{CH}_{4}(\mu \mathrm{g})$ & Massa do $\mathrm{CO}_{2}(\mu \mathrm{g})$ \\
\hline 0 & 10,6478 & 9,4517 \\
3 & 13,9351 & 11,8548 \\
6 & 24,9930 & 39,0851 \\
12 & 18,7045 & 23,8253 \\
\hline
\end{tabular}

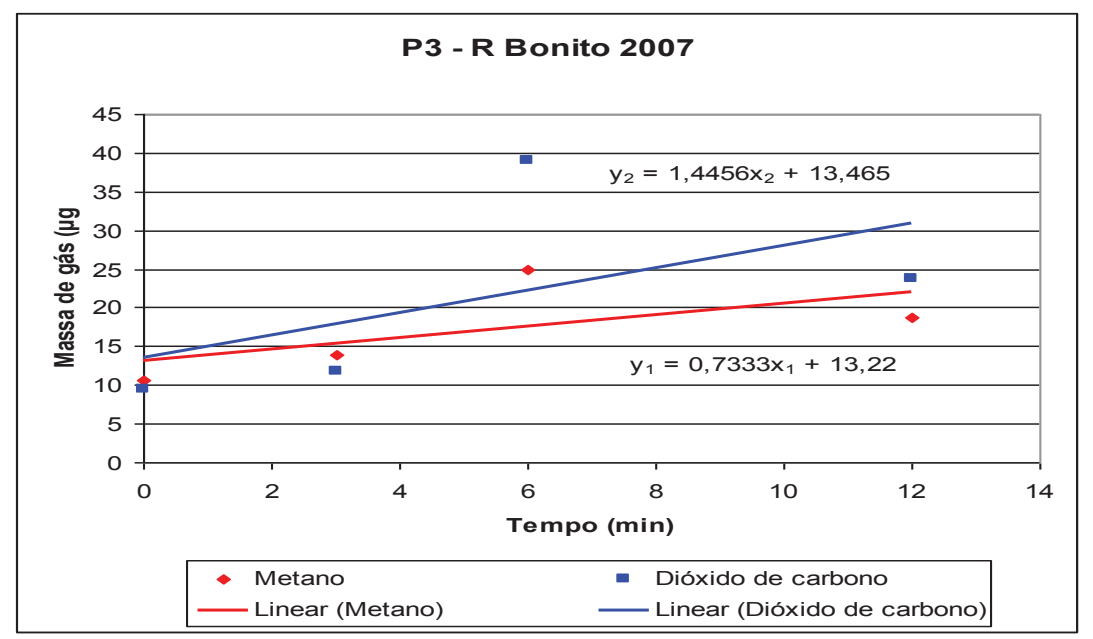

Gráfico 6.5.56 - Sítio $\mathbf{P}_{\mathbf{3}}-\mathrm{R}$ Bonito 2007. Equações de retas e inclinações para $\mathrm{CH}_{4}$ e $\mathrm{CO}_{2}$. 
Equações das retas:

$$
\begin{aligned}
& y_{1}=0,7333 x_{1}+13,22 \quad \text { Equação do metano } \\
& y_{2}=1,4456 x_{2}+13,465 \quad \text { Equação do dióxido }
\end{aligned}
$$

b) Cálculo da taxa de emissão:

$\left.b_{1}\right)$ Metano:

$$
\begin{aligned}
& \operatorname{Tx} E\left(\mathrm{CH}_{4}\right)=\frac{0,7333 \mu g\left(\mathrm{CO}_{2}\right) \times 33.200 \mathrm{~mL} \times 1440 \mathrm{~min} \times \mathrm{g}}{\mathrm{mL} \times \min \times 0,664 \mathrm{~m}^{2} \times \operatorname{dia} \times 10^{6} \mu \mathrm{g}} \\
& \operatorname{Tx}\left(\mathrm{CH}_{4}\right)=52,80 \mathrm{~g} \times \mathrm{m}^{-2} \cdot \mathrm{d}^{-1}\left(\mathrm{CH}_{4}\right) \text { No sítio de coleta } \mathrm{P}_{3} .
\end{aligned}
$$

$\mathrm{b}_{2}$ ) Dióxido de carbono: $\operatorname{Tx} E\left(C \mathrm{CO}_{2}\right)=\frac{1,4456 \mu \mathrm{g}\left(\mathrm{CO}_{2}\right) \times 33.200 \mathrm{~mL} \times 1440 \mathrm{~min} \times g}{\mathrm{~mL} \times \min \times 0,664 \mathrm{~m}^{2} \times \operatorname{dia} \times 10^{6} \mu \mathrm{g}}$

$$
\operatorname{Tx} E\left(C \mathrm{CO}_{2}\right)=104,10 \mathrm{~g} \times \mathrm{m}^{-2} \cdot \mathrm{d}^{-1}\left(\mathrm{CO}_{2}\right) \text { No sítio de coleta } \mathrm{P}_{3} \text {. }
$$

$\mathbf{P}_{4}\left(\mathrm{G} ; \mathrm{V}_{\mathrm{G}}=33.200 \mathrm{~mL} ; \mathrm{A}_{\mathrm{G}}=0,664 \mathrm{~m}^{2}\right)$

a) Tabela com tempos de coleta e massas correspondentes, gráfico com equações de retas e inclinações:

Tabela 6.5.66 - Sítio de coleta $\mathbf{P}_{\mathbf{4}}-\mathrm{R}$ Bonito 2007: tempos de coleta e massas $(\mu \mathrm{g})$ para $\mathrm{CH}_{4}$ e $\mathrm{CO}_{2}$.

\begin{tabular}{ccc}
\hline Tempo $(\boldsymbol{m i n})$ & Massa do $\mathrm{CH}_{\mathbf{4}}(\mu \mathrm{g})$ & Massa do $\mathrm{CO}_{\mathbf{2}}(\boldsymbol{\mu g})$ \\
\hline 0 & 10,3438 & 8,7995 \\
3 & 10,7553 & 13,6078 \\
6 & 11,0782 & 11,8935 \\
12 & 11,2462 & 12,0458 \\
\hline
\end{tabular}




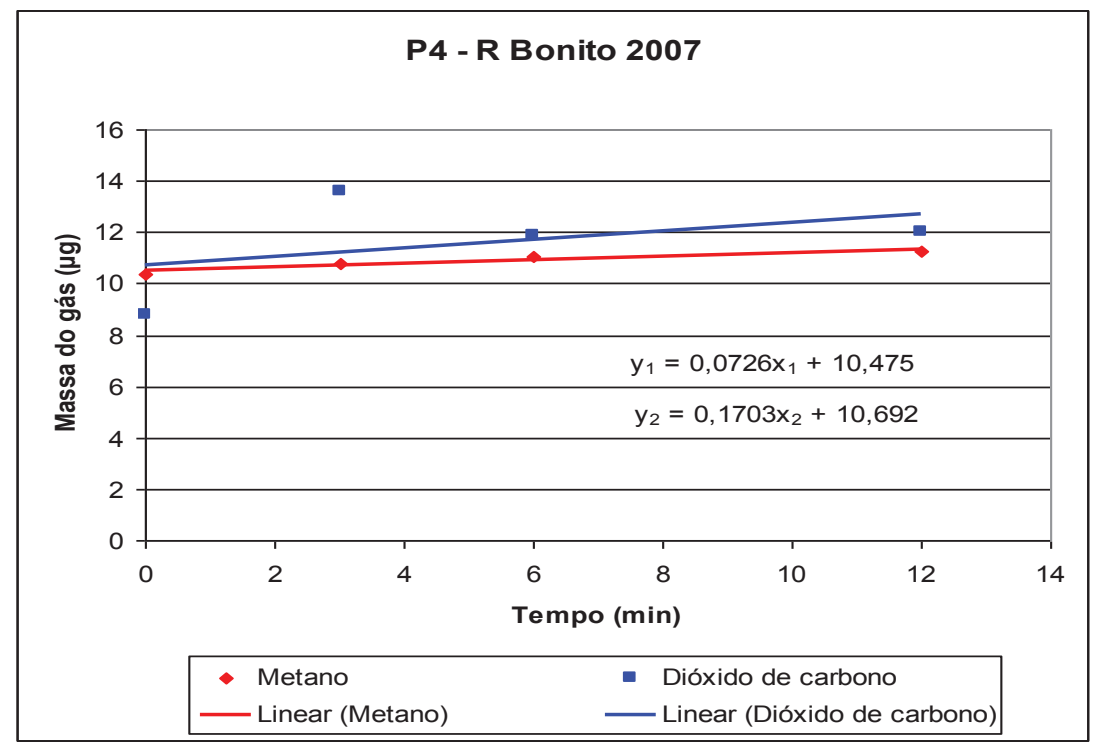

Gráfico 6.5.57 - Sítio $\mathbf{P}_{\mathbf{4}}-\mathrm{R}$ Bonito 2007. Equações de retas e inclinações para $\mathrm{CH}_{4}$ e $\mathrm{CO}_{2}$.

Equações das retas:

$$
\begin{aligned}
& y_{1}=0,0726 x_{1}+10,475 \quad \text { Equação do metano } \\
& y_{2}=0,1703 x_{2}+10,692 \quad \text { Equação do dióxido }
\end{aligned}
$$

b) Cálculo da taxa de emissão:

b ) Metano:

$$
\begin{aligned}
& \operatorname{Tx} E\left(\mathrm{CH}_{4}\right)=\frac{0,0726 \mu g\left(\mathrm{CO}_{2}\right) \times 33.200 \mathrm{~mL} \times 1440 \mathrm{~min} \times \mathrm{g}}{\mathrm{mL} \times \min \times 0,664 \mathrm{~m}^{2} \times \operatorname{dia} \times 10^{6} \mu \mathrm{g}} \\
& \operatorname{Tx}\left(\mathrm{CH}_{4}\right)=5,23 \mathrm{~g} \times \mathrm{m}^{-2} \cdot \mathrm{d}^{-1}\left(\mathrm{CH}_{4}\right) \text { No sítio de coleta } \mathrm{P}_{4} .
\end{aligned}
$$

$\mathrm{b}_{2}$ ) Dióxido de carbono: $\operatorname{TxE}\left(\mathrm{CO}_{2}\right)=\frac{0,1703 \mu \mathrm{g}\left(\mathrm{CO}_{2}\right) \times 33.200 \mathrm{~mL} \times 1440 \mathrm{~min} \times \mathrm{g}}{\mathrm{mL} \times \min \times 0,664 \mathrm{~m}^{2} \times \operatorname{dia} \times 10^{6} \mu \mathrm{g}}$

$$
\operatorname{TxE}\left(\mathrm{CO}_{2}\right)=12,26 \mathrm{~g} \times \mathrm{m}^{-2} \cdot \mathrm{d}^{-1}\left(\mathrm{CO}_{2}\right) \text { No sítio de coleta } \mathrm{P}_{4} \text {. }
$$


$P_{5}\left(G ; V_{G}=33.200 m L ; A_{G}=0,664 m^{2}\right)$

a) Tabela com tempos de coleta e massas correspondentes, gráfico com equações de retas e inclinações:

Tabela 6.5.67 - Sítio de coleta $\mathbf{P}_{\mathbf{5}}-\mathrm{R}$ Bonito 2007: tempos de coleta e massas $(\mu g)$ para $\mathrm{CH}_{4}$ e $\mathrm{CO}_{2}$.

\begin{tabular}{rlr}
\hline Tempo $(\boldsymbol{m i n})$ & Massa do $\mathrm{CH}_{4}(\mu \mathrm{g})$ & Massa do $\mathrm{CO}_{2}(\mu \mathrm{g})$ \\
\hline 0 & 0 & 9,4668 \\
3 & 11,0515 & 10,5224 \\
6 & 12,2654 & 7,7352 \\
12 & 11,7718 & 7,7000 \\
\hline
\end{tabular}

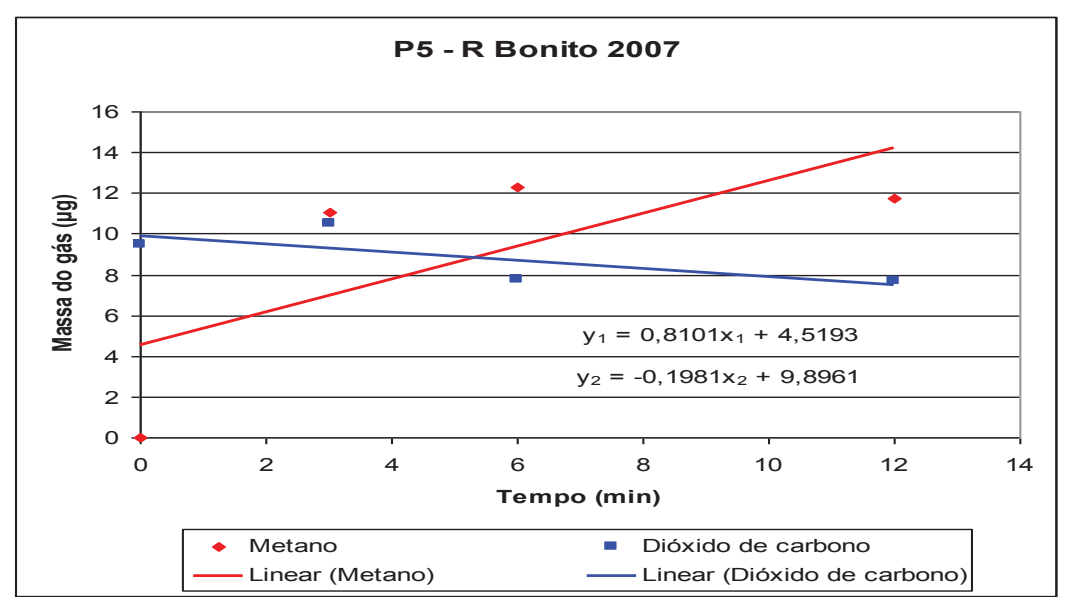

Gráfico 6.5.58 - Sítio $\mathbf{P}_{\mathbf{5}}-\mathrm{R}$ Bonito 2007. Equações de retas e inclinações para $\mathrm{CH}_{4}$ e $\mathrm{CO}_{2}$.

Equações das retas:

$$
\begin{aligned}
& y_{1}=0,8101 x_{1}+4,5193 \text { Equação do metano } \\
& y_{2}=-0,1981 x_{2}+9,9861 \text { Equação do dióxido }
\end{aligned}
$$

b) Cálculo da taxa de emissão:

b 1) Metano: $\quad \operatorname{Tx} E\left(\mathrm{CH}_{4}\right)=\frac{0,8101 \mu g\left(\mathrm{CO}_{2}\right) \times 33.200 \mathrm{~mL} \times 1440 \mathrm{~min} \times \mathrm{g}}{\mathrm{mL} \times \min \times 0,664 \mathrm{~m}^{2} \times \operatorname{dia} \times 10^{6} \mu \mathrm{g}}$ 


$$
\operatorname{Tx}\left(\mathrm{CH}_{4}\right)=58,33 \mathrm{~g} \times \mathrm{m}^{-2} \cdot \mathrm{d}^{-1}\left(\mathrm{CH}_{4}\right) \text { No sítio de coleta } \mathrm{P}_{5} \text {. }
$$

$\mathrm{b}_{2}$ ) Dióxido de carbono: $\operatorname{Tx} E\left(\mathrm{CO}_{2}\right)=\frac{0,1981 \mu \mathrm{g}\left(\mathrm{CO}_{2}\right) \times 33.200 \mathrm{~mL} \times 1440 \mathrm{~min} \times \mathrm{g}}{\mathrm{mL} \times \min \times 0,664 \mathrm{~m}^{2} \times \operatorname{dia} \times 10^{6} \mu \mathrm{g}}$

$$
\operatorname{TxE}\left(\mathrm{CO}_{2}\right)=14,26 \mathrm{~g} \times \mathrm{m}^{-2} \cdot \mathrm{d}^{-1}\left(\mathrm{CO}_{2}\right) \text { No sítio de coleta } \mathrm{P}_{5} \text {. }
$$

$\mathbf{P}_{6}\left(\mathrm{p} ; \mathrm{V}=1.200 \mathrm{~mL} ; \mathrm{A}=0,01815 \mathrm{~m}^{2}\right)$

a) Tabela com tempos de coleta e massas correspondentes, gráfico com equações de retas e inclinações:

Tabela 6.5.68 - Sítio de coleta $\mathbf{P}_{6}-\mathrm{R}$ Bonito 2007: tempos de coleta e massas $(\mu \mathrm{g})$ para $\mathrm{CH}_{4}$ e $\mathrm{CO}_{2}$.

\begin{tabular}{ccc}
\hline Tempo $(\boldsymbol{m i n})$ & Massa do $\mathrm{CH}_{\mathbf{4}}(\mu \mathrm{g})$ & Massa do $\mathrm{CO}_{2}(\mu g)$ \\
\hline 0 & - & - \\
3 & 10,2881 & 8,1528 \\
6 & 10,8003 & 13,4190 \\
12 & 12,1915 & 21,7741 \\
\hline
\end{tabular}

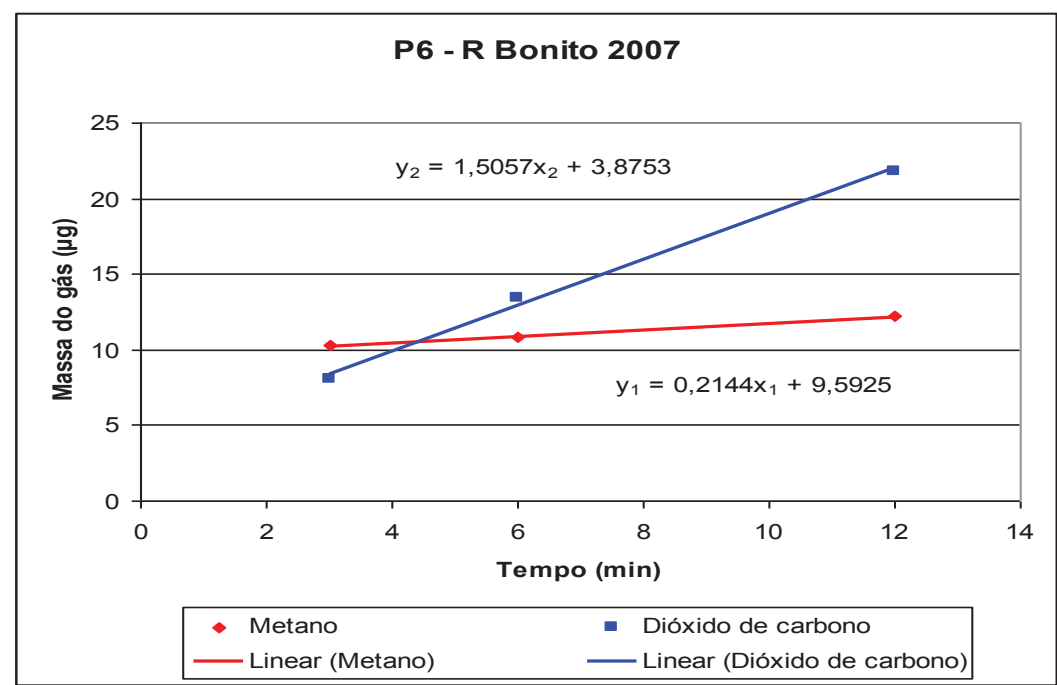

Gráfico 6.5.59 - Sítio $\mathbf{P}_{6}-\mathrm{R}$ Bonito 2007. Equações de retas e inclinações para $\mathrm{CH}_{4}$ e $\mathrm{CO}_{2}$. 
Equações das retas:

$$
\begin{aligned}
& y_{1}=0,2144 x_{1}+9,5925 \text { Equação do metano } \\
& y_{2}=1,5057 x_{2}+3,8753 \text { Equação do dióxido }
\end{aligned}
$$

b) Cálculo da taxa de emissão:

$\left.b_{1}\right)$ Metano:

$$
\begin{aligned}
& \operatorname{Tx} E\left(\mathrm{CH}_{4}\right)=\frac{0,2144 \mu g\left(\mathrm{CO}_{2}\right) \times 1.200 \mathrm{~mL} \times 1440 \mathrm{~min} \times g}{m L \times \min \times 0,01815 \mathrm{~m}^{2} \times \operatorname{dia} \times 10^{6} \mu g} \\
& \operatorname{TxE}\left(\mathrm{CH}_{4}\right)=20,41 \mathrm{~g} \times \mathrm{m}^{-2} \cdot d^{-1}\left(\mathrm{CH}_{4}\right) \text { No sítio de coleta } \mathrm{P}_{6} .
\end{aligned}
$$

$\mathrm{b}_{2}$ ) Dióxido de carbono: $\operatorname{Tx} E\left(\mathrm{CO}_{2}\right)=\frac{1,5057 \mu \mathrm{g}\left(\mathrm{CO}_{2}\right) \times 1.200 \mathrm{~mL} \times 1440 \mathrm{~min} \times \mathrm{g}}{\mathrm{mL} \times \min \times 0,01815 \mathrm{~m}^{2} \times \operatorname{dia} \times 10^{6} \mu \mathrm{g}}$

$$
\operatorname{Tx} E\left(\mathrm{CO}_{2}\right)=143,35 \mathrm{~g} \times \mathrm{m}^{-2} \cdot \mathrm{d}^{-1}\left(\mathrm{CO}_{2}\right) \text { No sítio de coleta } \mathrm{P}_{6} \text {. }
$$




\section{Aterro de Ribeirão Bonito - Emissão solo-ar campanha 2007:}

A tabela 6.5.69, resume as taxas de emissão solo-ar, medidas para $\mathrm{CH}_{4}$ e $\mathrm{CO}_{2}$, em cada sítio $\mathbf{P}_{\mathbf{n}}$ do aterro de Ribeirão Bonito, na campanha de 2007.

Tabela 6.5.69 - Resumo das taxas de emissão solo-ar - Ribeirão Bonito 2007

\begin{tabular}{crr}
\hline Sítio amostrado & Gás & $T_{\mathbf{x}} \mathbf{E}\left(\boldsymbol{g} \cdot \mathbf{m}^{-\mathbf{2}} \cdot \mathbf{d}^{-1}\right)$ \\
\hline $\mathrm{P}_{1}$ & $\mathrm{CH}_{4}$ & 3,83 \\
& $\mathrm{CO}_{2}$ & 4,50 \\
\hline $\mathrm{P}_{2}$ & $\mathrm{CH}_{4}$ & 0,53 \\
& $\mathrm{CO}_{2}$ & 24,95 \\
& $\mathrm{CH}_{4}$ & 52,80 \\
$\mathrm{P}_{3}$ & $\mathrm{CO}_{2}$ & 104,10 \\
& $\mathrm{CH}_{4}$ & 5,23 \\
$\mathrm{P}_{4}$ & $\mathrm{CO}_{2}$ & 12,26 \\
& $\mathrm{CH}_{4}$ & 58,33 \\
& $\mathrm{CO}_{2}$ & 14,26 \\
$\mathrm{P}_{5}$ & $\mathrm{CH}_{4}$ & 20,41 \\
& $\mathrm{CO}_{2}$ & 143,35 \\
\hline $\mathrm{P}_{6}$ & & \\
\hline
\end{tabular}

1)Cálculo da taxa de emissão média do Metano $\left(T_{x} E_{m(C H 4)}\right)$ nos sítios $\left(P_{n}\right)$ :

$$
\mathrm{T}_{\mathrm{x}} \mathrm{E}_{\mathrm{m}}\left(\mathrm{CH}_{4}\right)=\left(\mathrm{P}_{1}+\ldots+\mathrm{P}_{6}\right) / 6=32,26 \mathrm{~g} \cdot \mathrm{m}^{-2} \cdot \mathrm{d}^{-1}
$$

2)Taxa de emissão média total do metano $\left(\mathrm{T}_{x} \mathrm{E}_{\mathrm{m}(\mathrm{t})(\mathrm{CH} 4)}\right)$ no aterro:

$$
\begin{aligned}
& \Rightarrow T x_{m(t)}=T_{x} E_{m}\left(32,26 \mathrm{~g} \cdot \mathrm{m}^{-2} \cdot \mathrm{d}^{-1}\right) \cdot A_{a t}\left(40.000 \mathrm{~m}^{2}\right) \cdot 365 \mathrm{~d} \cdot 10^{-6}=471,00 \mathrm{t} \cdot \mathrm{a}^{-1} \\
& \Rightarrow T_{x} E_{m(t)}\left(C_{4}\right)=471,00 t \cdot a^{-1}
\end{aligned}
$$


Em que: $T_{x} E_{m}=$ Taxa de Emissão média $\left(g \cdot m^{-2} \cdot d^{-1}\right)$

$$
\begin{aligned}
\mathrm{A}_{\mathrm{at}} & =\text { Área do aterro }\left(\mathrm{m}^{2}\right) \\
\mathrm{T}_{\mathrm{x}} \mathrm{E}_{\mathrm{m}(\mathrm{t})} & =\text { Taxa de Emissão média total para } 2007\left({\text { Toneladas } \left.\cdot a n 0^{-1}\right)}\right. \\
365 & =\text { fator de conversão de dias } p \text { ano; } \\
10^{-6} & =\text { fator de conversão de } g \text { para } T
\end{aligned}
$$

3)Cálculo da taxa de emissão média do dióxido de carbono $\left(T_{x} E_{m(C O 2)}\right)$ nos sítios $\left(P_{n}\right)$ :

$$
\mathrm{T}_{\mathrm{x}} \mathrm{E}_{\mathrm{m}}\left(\mathrm{CO}_{2}\right)=\left(\mathrm{P}_{1}+\ldots+\mathrm{P}_{6}\right) / 6=50,57 \mathrm{~g} \cdot \mathrm{m}^{-2} \cdot \mathrm{d}^{-1}
$$

4)Cálculo da taxa de emissão média total do dióxido de carbono $\left(T_{x} E_{m(t)(C O 2)}\right)$ no aterro:

$$
\Rightarrow T_{x} E_{m(t)}=738,32 t \cdot a^{-1}
$$

Emissão Total Média ( $\left.E_{t} \underline{M}\right)$ solo-ar do aterro de Ribeirão Bonito: Consideradas as campanhas, 2006 e 2007:

1) Metano: $\quad E_{t} M\left(\mathrm{CH}_{4}\right)=\mathbf{2 7 6 , 8 2} \mathbf{t} \cdot \mathbf{a}^{-1}$

2) Dióxido de carbono: $\mathrm{E}_{\mathrm{t}} \mathrm{M}\left(\mathrm{CO}_{2}\right)=\mathbf{5 5 6 , 7 1} \mathbf{t} \cdot \mathbf{a}^{-1}$ 


\subsection{1-F) Aterro de Ribeirão Preto}

\section{$\left.F_{1}\right)$ Campanha 2006}

$\mathbf{P}_{1}\left(\mathrm{G} ; \mathrm{V}_{\mathrm{G}}=33.200 \mathrm{~mL}\right.$ e $\left.A_{G}=0,664 \mathrm{~m}^{2}\right)$

a) Tabela com tempos de coleta e massas correspondentes, gráfico com equações de retas e inclinações:

Tabela 6.5.70 - Sítio de coleta $\mathbf{P}_{\mathbf{1}}$ - Ribeirão Preto 2006: tempos de coleta e massas $(\mu \mathrm{g})$ para $\mathrm{CH}_{4}$ e $\mathrm{CO}_{2}$.

\begin{tabular}{ccc}
\hline Tempo $(\boldsymbol{m i n})$ & Massa do $\mathrm{CH}_{4}(\mu \mathrm{g})$ & Massa do $\mathrm{CO}_{2}(\boldsymbol{\mu} \boldsymbol{g})$ \\
\hline 0 & 0 & 7,7846 \\
3 & 10,3611 & 8,2008 \\
6 & 17,4343 & 16,3542 \\
12 & 12,9000 & 22,2805 \\
\hline
\end{tabular}

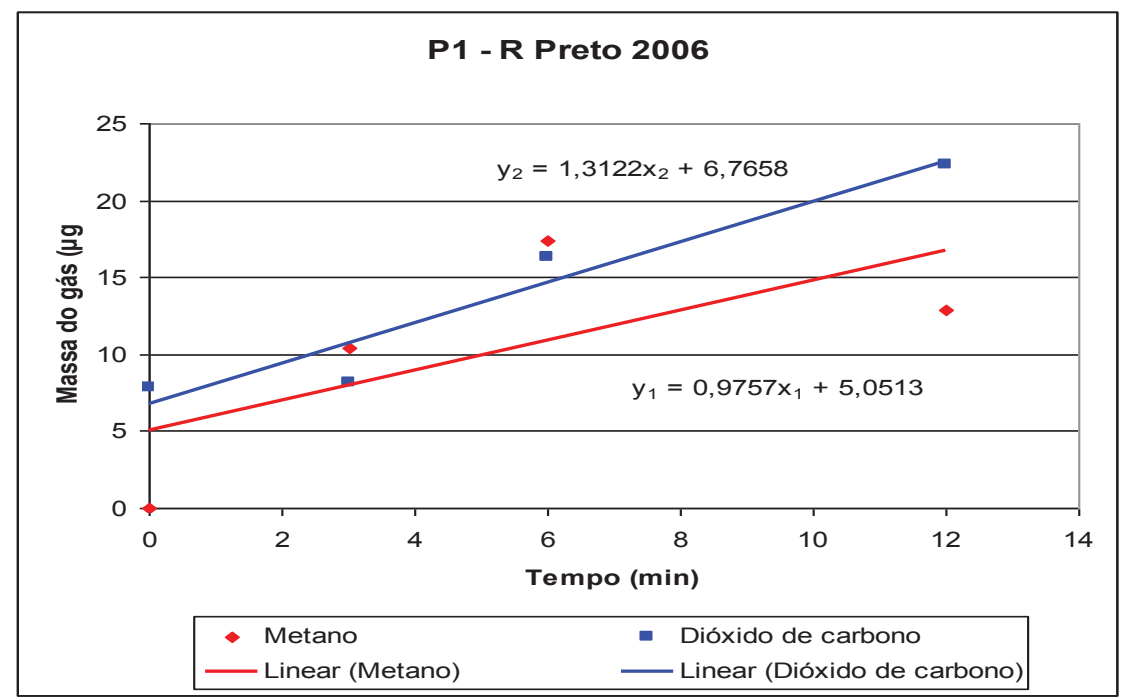

Gráfico 6.5.60 - Sítio $\mathbf{P}_{\mathbf{1}}$ - Ribeirão Preto 2006. Equações de retas e inclinações para $\mathrm{CH}_{4}$ e $\mathrm{CO}_{2}$.

Equações das retas:

$$
\begin{aligned}
& y_{1}=0,9757 x_{1}+5,0513 \text { Equação do metano } \\
& y_{2}=1,3122 x_{2}+6,7658 \text { Equação do dióxido }
\end{aligned}
$$


b) Cálculo da taxa de emissão:

b ) Metano: $\quad \operatorname{TxE}\left(\mathrm{CH}_{4}\right)=\frac{0,9757 \mu g\left(\mathrm{CH}_{4}\right) \times 33.200 \mathrm{~mL} \times 1440 \mathrm{~min} \times g}{\mathrm{~mL} \times \min \times 0,664 \mathrm{~m}^{2} \times \operatorname{dia} \times 10^{6} \mu \mathrm{g}}$ $=70,25 \mathrm{~g} \times \mathrm{m}^{-2} \cdot \mathrm{d}^{-1}\left(\mathrm{CH}_{4}\right) \quad$ No sítio de coleta $\mathrm{P}_{1}$.

Em que: $\quad \mathrm{T}_{\mathrm{x}} \mathrm{E}\left(\mathrm{CH}_{4}\right)=$ Taxa de emissão de metano no sítio;

$1,1535 \mu \mathrm{g} \cdot \mathrm{min}^{-1} \cdot \mathrm{mL}^{-1}=$ Inclinação da reta do gráfico de metano;

33.200 $\mathrm{mL}=$ Volume da câmara de coleta (grande);

$1440 \min =$ número de minutos $\cdot \mathrm{dia}^{-1}$;

$10^{-6}=$ fator de conversão de $\mu \mathrm{g}$ para g; e,

$0,664 \mathrm{~m}^{2}=$ Área da base da câmara de coleta (grande).

$b_{2}$ ) Dióxido de carbono: $\operatorname{Tx} E\left(\mathrm{CO}_{2}\right)=\frac{1,3122 \mu g\left(\mathrm{CO}_{2}\right) \times 33.200 \mathrm{~mL} \times 1440 \mathrm{~min} \times g}{\mathrm{~mL} \times \min \times 0,664 \mathrm{~m}^{2} \times \operatorname{dia} \times 10^{6} \mu \mathrm{g}}$ $=94,48{\mathrm{~g} \times \mathrm{m}^{-2} \cdot \mathrm{d}^{-1}\left(\mathrm{CO}_{2}\right)}$ No sítio de coleta $\mathrm{P}_{1}$.

Em que: $\quad T_{x} E\left(\mathrm{CO}_{2}\right)=$ Taxa de emissão de dióxido de carbono no sítio;

$0,9002 \mu \mathrm{g} \cdot \mathrm{min}^{-1} \cdot \mathrm{mL}^{-1}=$ Inclinação da reta do gráfico de $\mathrm{CO}_{2}$;

33.200 $\mathrm{mL}$ = Volume da câmara de coleta (grande);

$1440 \min =$ número de minutos $\cdot \mathrm{dia}^{-1}$;

$10^{6}=$ fator de conversão de $\mu \mathrm{g}$ para $\mathrm{g} ; \mathrm{e}$,

0,664 $m^{2}=$ Área da base da câmara de coleta (grande). 
$\mathbf{P}_{2}\left(p ; V_{P}=1200 m L\right.$ e $\left.A_{P}=0,01815 m^{2}\right)$

a) Tabela com tempos de coleta e massas correspondentes, gráfico com equações de retas e inclinações:

Tabela 6.5.71 - Sítio de coleta $\mathbf{P}_{\mathbf{2}}$ - Araraquara 2006: tempos de coleta e massas $(\mu \mathrm{g})$ para $\mathrm{CH}_{4}$ e $\mathrm{CO}_{2}$.

\begin{tabular}{ccc}
\hline Tempo $(\boldsymbol{m i n})$ & Massa do $\mathrm{CH}_{4}(\mu \mathrm{g})$ & Massa do $\mathrm{CO}_{2}(\mu \mathrm{g})$ \\
\hline 0 & 10,5509 & 9,2693 \\
3 & 10,9925 & 10,7112 \\
6 & 11,3575 & 10,3000 \\
12 & 11,6230 & 14,7880 \\
\hline
\end{tabular}

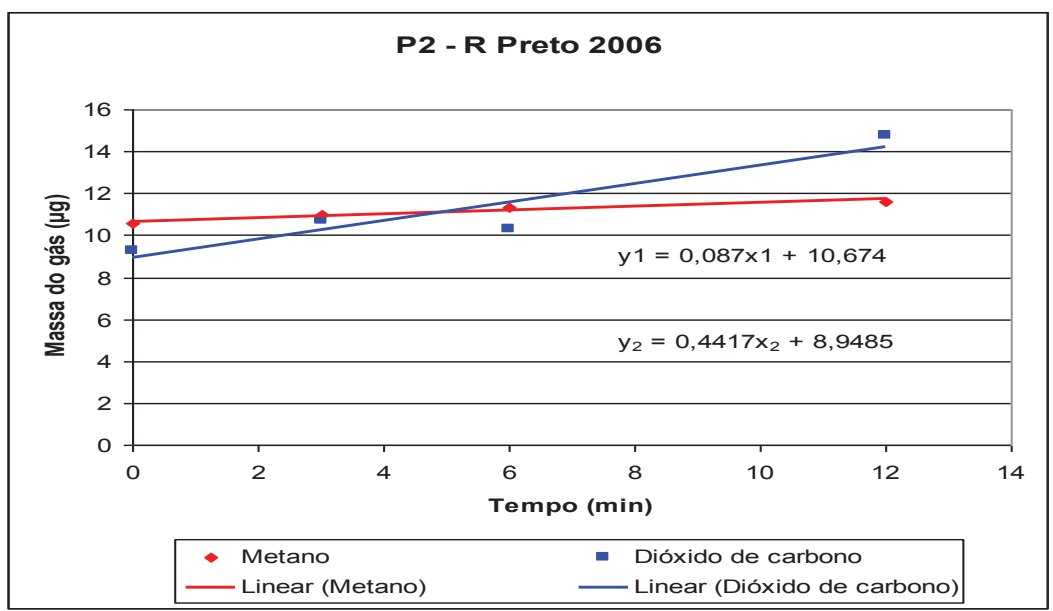

Gráfico 6.5.61 - Sítio $\mathbf{P}_{\mathbf{2}}-\mathrm{R}$ Preto 2006. Equações de retas e inclinações para $\mathrm{CH}_{4}$ e $\mathrm{CO}_{2}$.

Equações das retas:

$$
\begin{aligned}
& y_{1}=0,087 x_{1}+10,674 \text { Equação do metano } \\
& y_{2}=0,4417 x_{2}+8,9485 \text { Equação do dióxido }
\end{aligned}
$$

b) Cálculo da taxa de emissão:

b 1) Metano: $\quad \operatorname{Tx} E\left(\mathrm{CH}_{4}\right)=\frac{0,087 \mu g\left(\mathrm{CO}_{2}\right) \times 1.200 \mathrm{~mL} \times 1440 \mathrm{~min} \times g}{\mathrm{~mL} \times \min \times 0,01815 \mathrm{~m}^{2} \times \operatorname{dia} \times 10^{6} \mu \mathrm{g}}$ 


$$
\operatorname{Tx} E\left(\mathrm{CH}_{4}\right)=8,28 \mathrm{~g} \times \mathrm{m}^{-2} \cdot \mathrm{d}^{-1}\left(\mathrm{CH}_{4}\right) \text { No sítio de coleta } \mathrm{P}_{2} \text {. }
$$

$\mathrm{b}_{2}$ ) Dióxido de carbono: $\operatorname{Tx} E\left(\mathrm{CO}_{2}\right)=\frac{0,4417 \mu \mathrm{g}\left(\mathrm{CO}_{2}\right) \times 1.200 \mathrm{~mL} \times 1440 \mathrm{~min} \times \mathrm{g}}{\mathrm{mL} \times \min \times 0,01815 \mathrm{~m}^{2} \times \operatorname{dia} \times 10^{6} \mu \mathrm{g}}$

$$
\operatorname{TxE}\left(\mathrm{CO}_{2}\right)=42,05 \mathrm{~g} \times \mathrm{m}^{-2} \cdot \mathrm{d}^{-1}\left(\mathrm{CO}_{2}\right) \text { No sítio de coleta } \mathrm{P}_{2} \text {. }
$$

$\mathbf{P}_{3}\left(\mathrm{G} ; \mathrm{V}_{\mathrm{G}}=33.200 \mathrm{~mL}\right.$ e $\left.\mathrm{A}_{\mathrm{G}}=0,664 \mathrm{~m}^{2}\right)$

a) Tabela com tempos de coleta e massas correspondentes, gráfico com equações de retas e inclinações:

Tabela 6.5.72 - Sítio de coleta $\mathbf{P}_{\mathbf{3}}-\mathrm{R}$ Preto 2006: tempos de coleta e massas $(\mu g)$ para $\mathrm{CH}_{4}$ e $\mathrm{CO}_{2}$.

\begin{tabular}{ccc}
\hline Tempo $(\boldsymbol{m i n})$ & Massa do $\mathrm{CH}_{\mathbf{4}}(\mu \mathrm{g})$ & Massa do $\mathrm{CO}_{2}(\mu \mathrm{g})$ \\
\hline 0 & 11,4962 & 12,5543 \\
3 & 11,2015 & 15,8000 \\
6 & 10,7845 & 16,2600 \\
12 & 10,7380 & 12,0600 \\
\hline
\end{tabular}

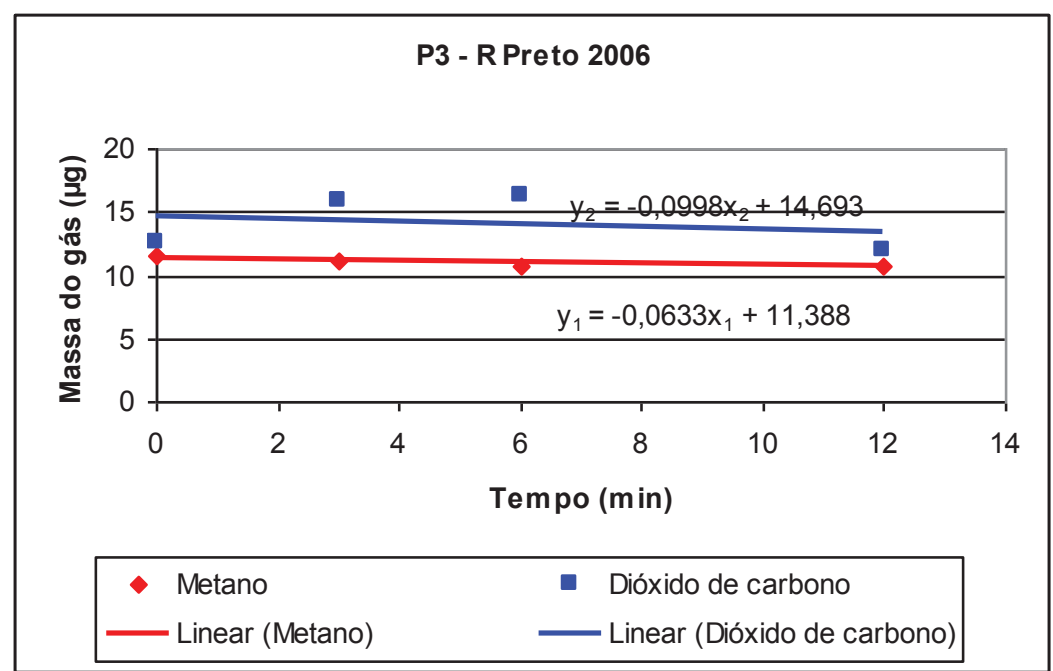

Gráfico 6.5.62 - Sítio $\mathbf{P}_{\mathbf{3}}-\mathrm{R}$ Preto 2006. Equações de retas e inclinações para $\mathrm{CH}_{4}$ e $\mathrm{CO}_{2}$. 
Equações das retas:

$$
\begin{aligned}
& y_{1}=-0,0633 x_{1}+11,388 \text { Equação do metano } \\
& y_{2}=-0,0998 x_{2}+14,693 \text { Equação do dióxido }
\end{aligned}
$$

b) Cálculo da taxa de emissão:

$\left.b_{1}\right)$ Metano:

$$
\begin{aligned}
& \operatorname{Tx} E\left(\mathrm{CH}_{4}\right)=\frac{0,0633 \mu g\left(\mathrm{CO}_{2}\right) \times 33.200 \mathrm{~mL} \times 1440 \mathrm{~min} \times \mathrm{g}}{\mathrm{mL} \times \min \times 0,664 \mathrm{~m}^{2} \times \operatorname{dia} \times 10^{6} \mu g} \\
& \operatorname{Tx}\left(\mathrm{CH}_{4}\right)=4,56 \mathrm{~g} \times \mathrm{m}^{-2} \cdot \mathrm{d}^{-1}\left(\mathrm{CH}_{4}\right) \text { No sítio de coleta } \mathrm{P}_{3} .
\end{aligned}
$$

$b_{2}$ ) Dióxido de carbono: $\operatorname{TxE}\left(\mathrm{CO}_{2}\right)=\frac{0,0998 \mu g\left(\mathrm{CO}_{2}\right) \times 33.200 \mathrm{~mL} \times 1440 \mathrm{~min} \times g}{\mathrm{~mL} \times \min \times 0,664 \mathrm{~m}^{2} \times \operatorname{dia} \times 10^{6} \mu \mathrm{g}}$

$$
\operatorname{Tx} E\left(\mathrm{CO}_{2}\right)=7,18 \mathrm{~g} \times \mathrm{m}^{-2} \cdot \mathrm{d}^{-1}\left(\mathrm{CO}_{2}\right) \text { No sítio de coleta } \mathrm{P}_{3} \text {. }
$$

$\mathbf{P}_{4}\left(\mathrm{G} ; \mathrm{V}_{\mathrm{G}}=33.200 \mathrm{~mL}\right.$ e $\left.\mathrm{A}_{\mathrm{G}}=0,664 \mathrm{~m}^{2}\right)$

a) Tabela com tempos de coleta e massas correspondentes, gráfico com equações de retas e inclinações:

Tabela 6.5.73 - Sítio de coleta $\mathbf{P}_{\mathbf{4}}-\mathbf{R}$ Preto 2006: tempos de coleta e massas $(\mu \mathrm{g})$ para $\mathrm{CH}_{4}$ e $\mathrm{CO}_{2}$.

\begin{tabular}{ccc}
\hline Tempo $(\boldsymbol{m i n})$ & Massa do $\mathrm{CH}_{4}(\mu \mathrm{g})$ & Massa do $\mathrm{CO}_{2}(\mu \mathrm{g})$ \\
\hline 0 & 10,9067 & 9,2822 \\
3 & 10,3739 & 10,1812 \\
6 & 15,0364 & 21,1390 \\
12 & 13,9525 & 22,1560 \\
\hline
\end{tabular}




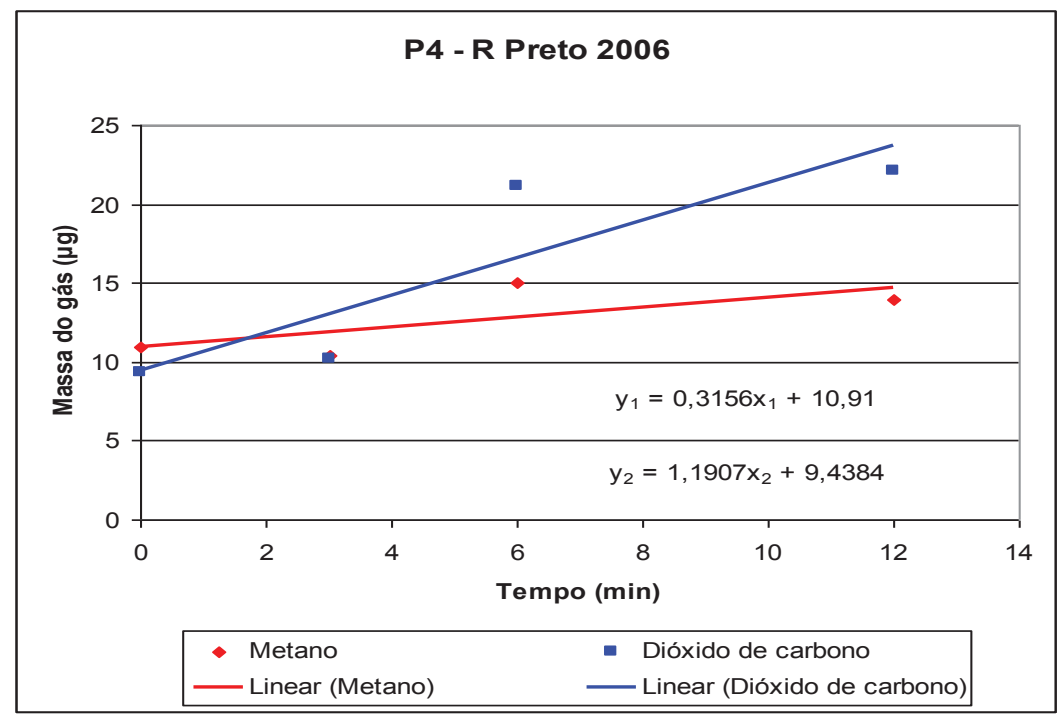

Gráfico 6.5.63 - Sítio $\mathbf{P}_{\mathbf{4}}-\mathrm{R}$ Preto 2006. Equações de retas e inclinações para $\mathrm{CH}_{4}$ e $\mathrm{CO}_{2}$.

Equações das retas:

$$
\begin{aligned}
& y_{1}=0,3156 x_{1}+10,91 \text { Equação do metano } \\
& y_{2}=1,1907 x_{2}+9,4384 \text { Equação do dióxido }
\end{aligned}
$$

b) Cálculo da taxa de emissão:

b 1) Metano: $\quad \operatorname{Tx} E\left(\mathrm{CH}_{4}\right)=\frac{0,3156 \mu \mathrm{g}\left(\mathrm{CO}_{2}\right) \times 33.200 \mathrm{~mL} \times 1440 \mathrm{~min} \times \mathrm{g}}{\mathrm{mL} \times \min \times 0,01815 \mathrm{~m}^{2} \times \operatorname{dia} \times 10^{6} \mu \mathrm{g}}$

$$
\operatorname{Tx} E\left(\mathrm{CH}_{4}\right)=22,72 \mathrm{~g} \times \mathrm{m}^{-2} \cdot d^{-1}\left(\mathrm{CH}_{4}\right) \text { No sítio de coleta } \mathrm{P}_{4} \text {. }
$$

$\mathrm{b}_{2}$ ) Dióxido de carbono: $\operatorname{Tx} E\left(\mathrm{CO}_{2}\right)=\frac{1,1907 \mu g\left(\mathrm{CO}_{2}\right) \times 33.200 \mathrm{~mL} \times 1440 \mathrm{~min} \times g}{\mathrm{~mL} \times \min \times 0,01815 \mathrm{~m}^{2} \times \operatorname{dia} \times 10^{6} \mu \mathrm{g}}$

$$
\operatorname{TxE}\left(\mathrm{CO}_{2}\right)=85,73 \mathrm{~g} \times \mathrm{m}^{-2} \cdot \mathrm{d}^{-1}\left(\mathrm{CO}_{2}\right) \text { No sítio de coleta } \mathrm{P}_{4} \text {. }
$$


$\mathbf{P}_{5}\left(p ; V_{P}=1.200 m L\right.$ e $\left.A_{P}=0,01815 m^{2}\right)$

a) Tabela com tempos de coleta e massas correspondentes, gráfico com equações de retas e inclinações:

Tabela 6.5.74 - Sítio de coleta $\mathbf{P}_{5}-\mathrm{R}$ Preto 2006: tempos de coleta e massas $(\mu g)$ para $\mathrm{CH}_{4}$ e $\mathrm{CO}_{2}$.

\begin{tabular}{ccc}
\hline Tempo (min) & Massa do $\mathrm{CH}_{\mathbf{4}}(\mu \mathrm{g})$ & Massa do $\mathrm{CO}_{\mathbf{2}}(\mu \mathrm{g})$ \\
\hline 0 & 0 & 8,2115 \\
3 & 17,2245 & 25,4281 \\
6 & 17,9289 & 28,0844 \\
12 & 18,4000 & 28,7045 \\
\hline
\end{tabular}

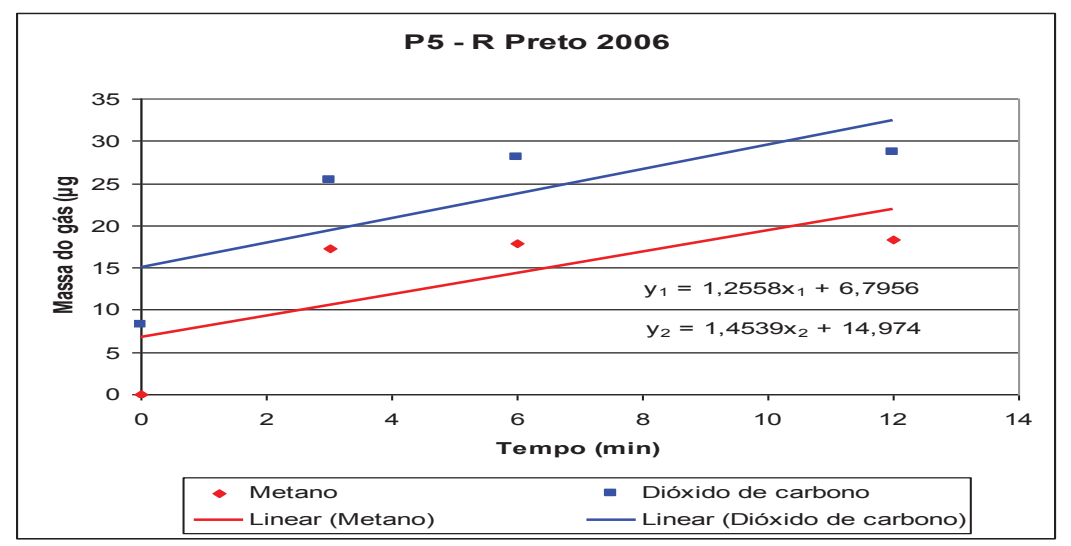

Gráfico 6.5.64 - Sítio $\mathbf{P}_{5}-\mathrm{R}$ Preto 2006. Equações de retas e inclinações para $\mathrm{CH}_{4}$ e $\mathrm{CO}_{2}$.

Equações das retas:

$$
\begin{aligned}
& y_{1}=1,2558 x_{1}+6,7958 \text { Equação do metano } \\
& y_{2}=1,4539 x_{2}+14,974 \text { Equação do dióxido }
\end{aligned}
$$

b) Cálculo da taxa de emissão:

b ) Metano: $\quad \operatorname{Tx} E\left(\mathrm{CH}_{4}\right)=\frac{1,2558 \mu \mathrm{g}\left(\mathrm{CO}_{2}\right) \times 1.200 \mathrm{~mL} \times 1440 \mathrm{~min} \times g}{\mathrm{~mL} \times \min \times 0,01815 \mathrm{~m}^{2} \times \operatorname{dia} \times 10^{6} \mu \mathrm{g}}$ 


$$
\operatorname{Tx} E\left(\mathrm{CH}_{4}\right)=119,56 \mathrm{~g} \times \mathrm{m}^{-2} \cdot \mathrm{d}^{-1}\left(\mathrm{CH}_{4}\right) \text { No sítio de coleta } \mathrm{P}_{5} \text {. }
$$

$\mathrm{b}_{2}$ ) Dióxido de carbono: $\operatorname{Tx} E\left(\mathrm{CO}_{2}\right)=\frac{1,4539 \mu \mathrm{g}\left(\mathrm{CO}_{2}\right) \times 1.200 \mathrm{~mL} \times 1440 \mathrm{~min} \times \mathrm{g}}{\mathrm{mL} \times \min \times 0,01815 \mathrm{~m}^{2} \times \operatorname{dia} \times 10^{6} \mu \mathrm{g}}$

$$
\operatorname{TxE}\left(\mathrm{CO}_{2}\right)=138,42 \mathrm{~g} \times \mathrm{m}^{-2} \cdot \mathrm{d}^{-1}\left(\mathrm{CO}_{2}\right) \text { No sítio de coleta } \mathrm{P}_{5} \text {. }
$$

\section{Aterro de Ribeirão Preto - Emissão solo-ar campanha 2006:}

A tabela 6.5.75, resume as taxas de emissão solo-ar, medidas para $\mathrm{CH}_{4}$ e $\mathrm{CO}_{2}$, em cada sítio $\mathbf{P}_{\mathbf{n}}$ do aterro de Ribeirão Preto, na campanha de 2006.

Tabela 6.5.75 - Resumo da emissão solo-ar - Ribeirão Preto 2006

\begin{tabular}{ccc}
\hline Sítio amostrado & Gás & $T_{\mathbf{x}} \mathbf{E}\left(\boldsymbol{g} \cdot \boldsymbol{m}^{-\mathbf{2}} \cdot \boldsymbol{d}^{-\mathbf{1}}\right)$ \\
\hline & $\mathrm{CH}_{4}$ & 70,25 \\
$\mathrm{P}_{1}$ & $\mathrm{CO}_{2}$ & 94,48 \\
& $\mathrm{CH}_{4}$ & 8,28 \\
\hline $\mathrm{P}_{2}$ & $\mathrm{CO}_{2}$ & 42,05 \\
& $\mathrm{CH}_{4}$ & 4,56 \\
\hline $\mathrm{P}_{3}$ & $\mathrm{CO}_{2}$ & 7,18 \\
& $\mathrm{CH}_{4}$ & 22,72 \\
& $\mathrm{CO}_{2}$ & 85,73 \\
$\mathrm{P}_{4}$ & $\mathrm{CH}_{4}$ & 119,56 \\
& $\mathrm{CO}_{2}$ & 138,42 \\
\hline
\end{tabular}

$\left.\mathrm{c}_{1}\right)$ Metano 
$\mathrm{T}_{\mathrm{X}} \mathrm{E}=\mathrm{Taxa}$ de emissão

$\Rightarrow \mathrm{T}_{\mathrm{x}} \mathrm{E}_{\mathrm{m}}\left(\mathrm{CH}_{4}\right)=\left(\mathrm{P}_{1}+\ldots+\mathrm{P}_{5}\right) / 5=45,07 \mathrm{~g} \cdot \mathrm{m}^{-2} \cdot \mathrm{d}^{-1}$

$\Rightarrow \mathrm{TX}_{\mathrm{m}(\mathrm{t})}=\mathrm{T}_{\mathrm{x}} \mathrm{E}_{\mathrm{m}}\left(45,07 \mathrm{~g} \cdot \mathrm{m}^{-2} \cdot \mathrm{d}^{-1}\right) \cdot \mathrm{A}_{\mathrm{at}}\left(218.000 \mathrm{~m}^{2}\right) \cdot 365 \mathrm{~d} \cdot 10^{-6}=3.586,22$ Ton $\cdot \mathrm{a}^{-1}$

$$
\Rightarrow \mathrm{T}_{\mathrm{x}} \mathrm{E}_{\mathrm{m}(\mathrm{t})}\left(\mathrm{CH}_{4}\right)=3.586,22 \text { Ton }^{-1} \mathrm{a}^{-1}
$$

Em que: $\mathrm{T}_{\mathrm{x}} \mathrm{E}_{\mathrm{m}}=$ Taxa de Emissão média $\left(g \cdot m^{-2} \cdot d^{-1}\right) ; \mathrm{A}_{\mathrm{at}}=$ Área do aterro $\left(m^{2}\right)$

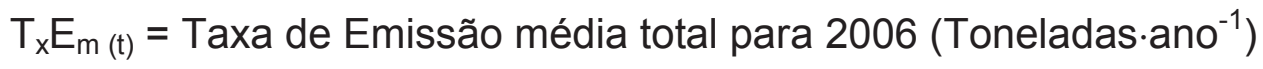

365 = fator de conversão de dias para ano

$10^{-6}=$ fator de conversão de $g$ para Ton

$\mathrm{C}_{2}$ ) Dióxido de carbono (cálculos/dados idem)

$$
\begin{gathered}
\Rightarrow T_{x} E_{m}\left(C O_{2}\right)=\left(P_{1}+\ldots+P_{5}\right) / 5=73,57 \mathrm{~g} \cdot \mathrm{m}^{-2} \cdot \mathrm{d}^{-1} \\
\Rightarrow T_{x} E_{m(t)}=5.853,96 \mathrm{t} \cdot \mathbf{a}^{-1}
\end{gathered}
$$

\section{F2) Campanha 2007}

$\mathbf{P}_{1}\left(\mathrm{G} ; \mathrm{V}_{\mathrm{G}}=33.200 \mathrm{~mL} ; \mathrm{A}_{\mathrm{G}}=0,664 \mathrm{~m}^{2}\right)$

a) Tabela com tempos de coleta e massas correspondentes, gráfico com equações de retas e inclinações:

Tabela 6.5.76 - Sítio de coleta $\mathbf{P}_{\mathbf{1}}$ - Ribeirão Preto 2007: tempos de coleta e massas $(\mu \mathrm{g})$ para $\mathrm{CH}_{4}$ e $\mathrm{CO}_{2}$.

\begin{tabular}{ccc}
\hline Tempo (min) & Massa do $\mathrm{CH}_{\mathbf{4}}(\mu \mathrm{g})$ & Massa do $\mathrm{CO}_{2}(\mu \mathrm{g})$ \\
\hline 0 & 6,3793 & 8,9000 \\
3 & 10,3711 & 8,1500 \\
6 & 12,4241 & 16,3628 \\
12 & 12,8666 & 16,7770 \\
\hline
\end{tabular}




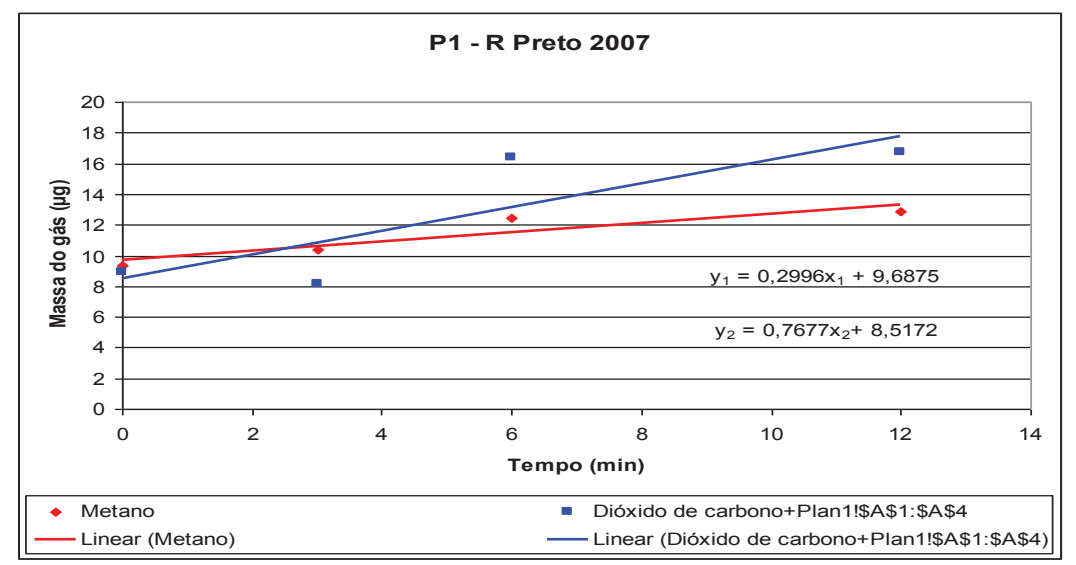

Gráfico 6.5.65 - Sítio $\mathbf{P}_{\mathbf{1}}$ - Ribeirão Preto 2007. Equações de retas e inclinações para $\mathrm{CH}_{4}$ e $\mathrm{CO}_{2}$.

Equações das retas:

$$
\begin{aligned}
& y_{1}=0,2996 x_{1}+9,6875 \text { Equação do metano } \\
& y_{2}=0,7677 x_{2}+8,5172 \text { Equação do dióxido }
\end{aligned}
$$

b) Cálculo da taxa de emissão:

b 1) Metano: $\quad \operatorname{Tx} E\left(\mathrm{CH}_{4}\right)=\frac{0,2996 \mu \mathrm{g}\left(\mathrm{CO}_{2}\right) \times 33.200 \mathrm{~mL} \times 1440 \mathrm{~min} \times g}{\mathrm{~mL} \times \min \times 0,664 \mathrm{~m}^{2} \times \operatorname{dia} \times 10^{6} \mu \mathrm{g}}$

$$
\operatorname{Tx} E\left(\mathrm{CH}_{4}\right)=21,57 \mathrm{~g} \times \mathrm{m}^{-2} \cdot \mathrm{d}^{-1}\left(\mathrm{CH}_{4}\right) \text { No sítio de coleta } \mathrm{P}_{1} \text {. }
$$

$\mathrm{b}_{2}$ ) Dióxido de carbono: $\operatorname{Tx} E\left(\mathrm{CO}_{2}\right)=\frac{0,7677 \mu \mathrm{g}\left(\mathrm{CO}_{2}\right) \times 33.200 \mathrm{~mL} \times 1440 \mathrm{~min} \times \mathrm{g}}{\mathrm{mL} \times \min \times 0,664 \mathrm{~m}^{2} \times \operatorname{dia} \times 10^{6} \mu \mathrm{g}}$

$$
\operatorname{Tx} E\left(\mathrm{CO}_{2}\right)=55,28 \mathrm{~g} \times \mathrm{m}^{-2} \cdot \mathrm{d}^{-1}\left(\mathrm{CO}_{2}\right) \text { No sítio de coleta } \mathrm{P}_{1} \text {. }
$$

$\mathbf{P}_{2}\left(p ; V_{P}=1.200 m L ; A_{P}=0,01815 m^{2}\right)$

a) Tabela com tempos de coleta e massas correspondentes, gráfico com equações de retas e inclinações: 
Tabela 6.5.77 - Sítio de coleta $\mathbf{P}_{\mathbf{2}}-\mathrm{R}$ Preto 2007: tempos de coleta e massas $(\mu \mathrm{g})$ para $\mathrm{CH}_{4}$ e $\mathrm{CO}_{2}$.

\begin{tabular}{ccc}
\hline Tempo (min) & Massa do $\mathrm{CH}_{\mathbf{4}}(\mu \mathrm{g})$ & Massa do $\mathrm{CO}_{\mathbf{2}}(\boldsymbol{\mu g})$ \\
\hline 0 & 10,3620 & 7,9000 \\
3 & 10,4514 & 8,1107 \\
6 & 12,5893 & 15,7105 \\
12 & 17,0365 & 24,7115 \\
\hline
\end{tabular}

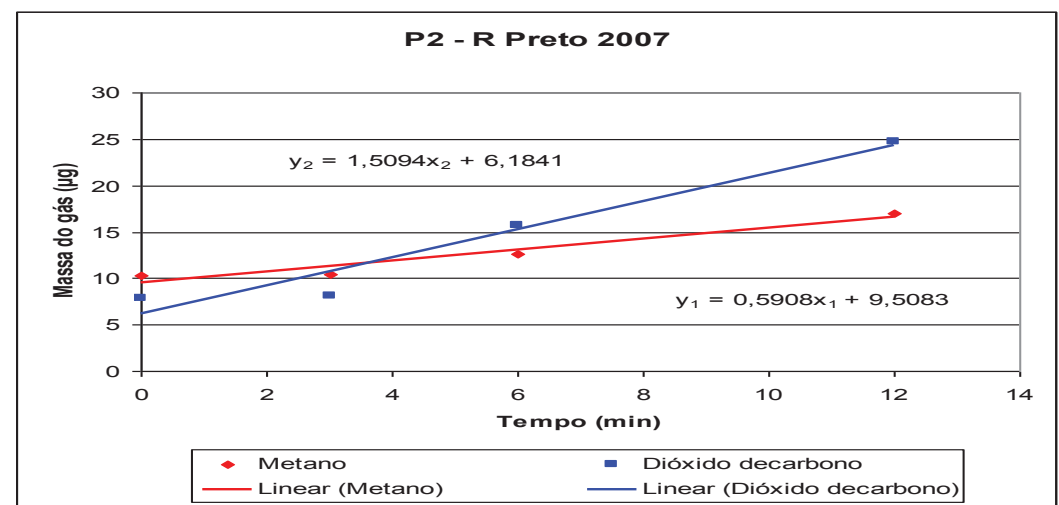

Gráfico 6.5.66 - Sítio $\mathbf{P}_{\mathbf{2}}-\mathrm{R}$ Preto 2007. Equações de retas e inclinações para $\mathrm{CH}_{4}$ e $\mathrm{CO}_{2}$.

Equações das retas:

$$
\begin{aligned}
& y_{1}=0,5908 x_{1}+9,5083 \text { Equação do metano } \\
& y_{2}=1,5094_{2}+6,1841 \quad \text { Equação do dióxido }
\end{aligned}
$$

b) Cálculo da taxa de emissão:

$\left.b_{1}\right)$ Metano:

$$
\begin{aligned}
& \operatorname{Tx} E\left(\mathrm{CH}_{4}\right)=\frac{0,5908 \mu g\left(\mathrm{CO}_{2}\right) \times 1.200 \mathrm{~mL} \times 1440 \mathrm{~min} \times \mathrm{g}}{\mathrm{mL} \times \min \times 0,01815 \mathrm{~m}^{2} \times \operatorname{dia} \times 10^{6} \mu \mathrm{g}} \\
& \operatorname{TxE}\left(\mathrm{CH}_{4}\right)=56,25 \mathrm{~g} \times \mathrm{m}^{-2} \cdot \mathrm{d}^{-1}\left(\mathrm{CH}_{4}\right) \text { No sítio de coleta } \mathrm{P}_{2} .
\end{aligned}
$$

$\mathrm{b}_{2}$ ) Dióxido de carbono: $\operatorname{Tx} E\left(\mathrm{CO}_{2}\right)=\frac{1,5094 \mu \mathrm{g}\left(\mathrm{CO}_{2}\right) \times 1.200 \mathrm{~mL} \times 1440 \mathrm{~min} \times \mathrm{g}}{\mathrm{mL} \times \min \times 0,01815 \mathrm{~m}^{2} \times \operatorname{dia} \times 10^{6} \mu \mathrm{g}}$

$$
\operatorname{Tx} E\left(\mathrm{CO}_{2}\right)=143,70 \mathrm{~g} \times \mathrm{m}^{-2} \cdot \mathrm{d}^{-1}\left(\mathrm{CO}_{2}\right) \text { No sítio de coleta } \mathrm{P}_{2} \text {. }
$$


$\mathbf{P}_{3}\left(\mathrm{G} ; \mathrm{V}_{\mathrm{G}}=33.200 \mathrm{~mL} ; \mathrm{A}_{\mathrm{G}}=0,664 \mathrm{~m}^{2}\right)$

a) Tabela com tempos de coleta e massas correspondentes, gráfico com equações de retas e inclinações:

Tabela 6.5.78 - Sítio de coleta $\mathbf{P}_{\mathbf{3}}-\mathbf{R}$ Preto 2007: tempos de coleta e massas $(\mu \mathrm{g})$ para $\mathrm{CH}_{4}$ e $\mathrm{CO}_{2}$.

\begin{tabular}{ccc}
\hline Tempo $(\boldsymbol{m i n})$ & Massa do $\mathrm{CH}_{4}(\boldsymbol{\mu g})$ & Massa do $\mathrm{CO}_{2}(\mu \boldsymbol{g})$ \\
\hline 0 & 12,5683 & 15,6140 \\
3 & 12,5720 & 16,6740 \\
6 & 14,3750 & 19,0666 \\
12 & 13,9989 & 16,2126 \\
\hline
\end{tabular}

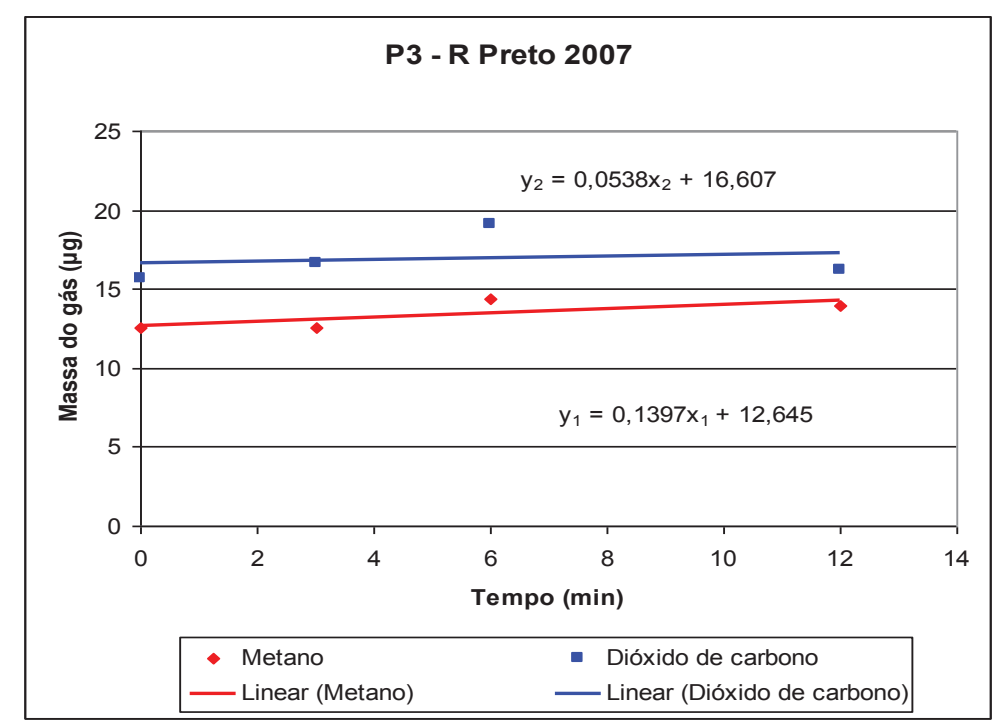

Gráfico 6.5.67 - Sítio $\mathbf{P}_{\mathbf{3}}-\mathrm{R}$ Preto 2007. Equações de retas e inclinações para $\mathrm{CH}_{4} \mathrm{e} \mathrm{CO}$.

Equações das retas:

$$
\begin{aligned}
& y_{1}=0,1397 x_{1}+12,645 \text { Equação do metano } \\
& y_{2}=0,0538 x_{2}+16,607 \text { Equação do dióxido }
\end{aligned}
$$


b) Cálculo da taxa de emissão:

b ) Metano:

$$
\begin{aligned}
& \operatorname{Tx} E\left(\mathrm{CH}_{4}\right)=\frac{0,1397 \mu g\left(\mathrm{CO}_{2}\right) \times 33.200 \mathrm{~mL} \times 1440 \mathrm{~min} \times g}{\mathrm{~mL} \times \min \times 0,664 \mathrm{~m}^{2} \times \operatorname{dia} \times 10^{6} \mu g} \\
& \operatorname{Tx}\left(\mathrm{CH}_{4}\right)=10,06 \mathrm{~g} \times \mathrm{m}^{-2} \cdot \mathrm{d}^{-1}\left(\mathrm{CH}_{4}\right) \text { No sítio de coleta } \mathrm{P}_{3} .
\end{aligned}
$$

$\mathrm{b}_{2}$ ) Dióxido de carbono: $\operatorname{Tx} E\left(\mathrm{CO}_{2}\right)=\frac{0,0538 \mu \mathrm{g}\left(\mathrm{CO}_{2}\right) \times 33.200 \mathrm{~mL} \times 1440 \mathrm{~min} \times \mathrm{g}}{\mathrm{mL} \times \min \times 0,664 \mathrm{~m}^{2} \times \operatorname{dia} \times 10^{6} \mu \mathrm{g}}$

$$
\operatorname{Tx} E\left(\mathrm{CO}_{2}\right)=3,87 \mathrm{~g} \times \mathrm{m}^{-2} \cdot \mathrm{d}^{-1}\left(\mathrm{CO}_{2}\right) \text { No sítio de coleta } \mathrm{P}_{3} \text {. }
$$

$\mathbf{P}_{4}\left(\mathrm{p} ; \mathrm{V}_{\mathrm{P}}=1.200 \mathrm{~mL} ; \mathrm{A}_{\mathrm{P}}=0,01815 \mathrm{~m}^{2}\right)$

a) Tabela com tempos de coleta e massas correspondentes, gráfico com equações de retas e inclinações:

Tabela 6.5.79 - Sítio de coleta $\mathbf{P}_{\mathbf{4}}-\mathrm{R}$ Preto 2007: tempos de coleta e massas $(\mu g)$ para $\mathrm{CH}_{4}$ e $\mathrm{CO}_{2}$.

\begin{tabular}{ccc}
\hline Tempo (min) & Massa do $\mathrm{CH}_{4}(\mu g)$ & Massa do $\mathrm{CO}_{2}(\mu g)$ \\
\hline 0 & 10,7526 & 10,5396 \\
3 & 10,6258 & 10,4173 \\
6 & 27,0000 & 50,0235 \\
12 & 24,6408 & 43,2000 \\
\hline
\end{tabular}




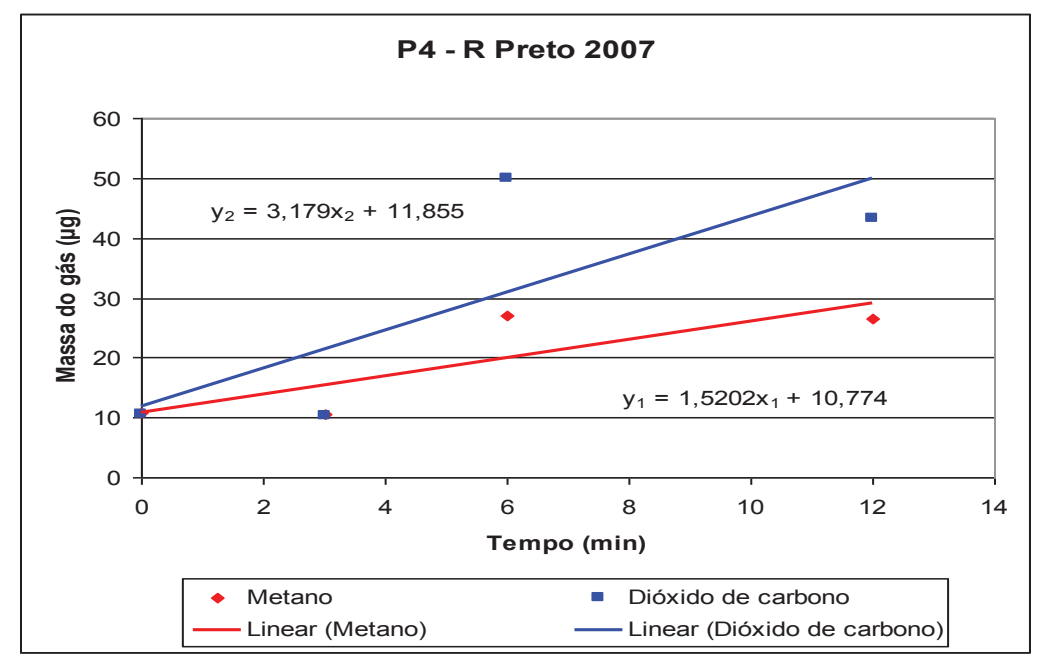

Gráfico 6.5.68 - Sítio $\mathbf{P}_{4}-\mathrm{R}$ Preto 2007. Equações de retas e inclinações para $\mathrm{CH}_{4}$ e $\mathrm{CO}_{2}$.

Equações das retas:

$$
\begin{aligned}
& y_{1}=1,5202 x_{1}+10,774 \text { Equação do metano } \\
& y_{2}=3,179 x_{2}+11,855 \text { Equação do dióxido }
\end{aligned}
$$

b) Cálculo da taxa de emissão:

b 1) Metano: $\quad \operatorname{Tx} E\left(\mathrm{CH}_{4}\right)=\frac{1,5202 \mu \mathrm{g}\left(\mathrm{CO}_{2}\right) \times 1.200 \mathrm{~mL} \times 1440 \mathrm{~min} \times \mathrm{g}}{\mathrm{mL} \times \min \times 0,01815 \mathrm{~m}^{2} \times \operatorname{dia} \times 10^{6} \mu \mathrm{g}}$ $\operatorname{TxE}\left(\mathrm{CH}_{4}\right)=144,73 \mathrm{~g} \times \mathrm{m}^{-2} \cdot \mathrm{d}^{-1}\left(\mathrm{CH}_{4}\right)$ No sítio de coleta $\mathrm{P}_{4}$.

$\mathrm{b}_{2}$ ) Dióxido de carbono: $\operatorname{Tx} E\left(\mathrm{CO}_{2}\right)=\frac{3,179 \mu \mathrm{g}\left(\mathrm{CO}_{2}\right) \times 1.200 \mathrm{~mL} \times 1440 \mathrm{~min} \times \mathrm{g}}{\mathrm{mL} \times \min \times 0,01815 \mathrm{~m}^{2} \times \operatorname{dia} \times 10^{6} \mu \mathrm{g}}$

$$
\operatorname{TxE}\left(\mathrm{CO}_{2}\right)=302,66 \mathrm{~g} \times \mathrm{m}^{-2} \cdot \mathrm{d}^{-1}\left(\mathrm{CO}_{2}\right) \text { No sítio de coleta } \mathrm{P}_{4} \text {. }
$$


$\mathbf{P}_{5}\left(\mathrm{G} ; \mathrm{V}_{\mathrm{G}}=33.200 \mathrm{~mL} ; \mathrm{A}_{\mathrm{G}}=0,664 \mathrm{~m}^{2}\right)$

a) Tabela com tempos de coleta e massas correspondentes, gráfico com equações de retas e inclinações:

Tabela 6.5.80 - Sítio de coleta $\mathbf{P}_{\mathbf{5}}-\mathrm{R}$ Preto 2007: tempos de coleta e massas $(\mu \mathrm{g})$ para $\mathrm{CH}_{4}$ e $\mathrm{CO}_{2}$.

\begin{tabular}{ccc}
\hline Tempo (min) & Massa do $\mathrm{CH}_{4}(\mu \mathrm{g})$ & Massa do $\mathrm{CO}_{2}(\mu \mathrm{g})$ \\
\hline 0 & 10,4633 & 7,0691 \\
3 & 10,6613 & 10,6812 \\
6 & 25,5200 & 48,0216 \\
12 & 24,3400 & 43,0360 \\
\hline
\end{tabular}

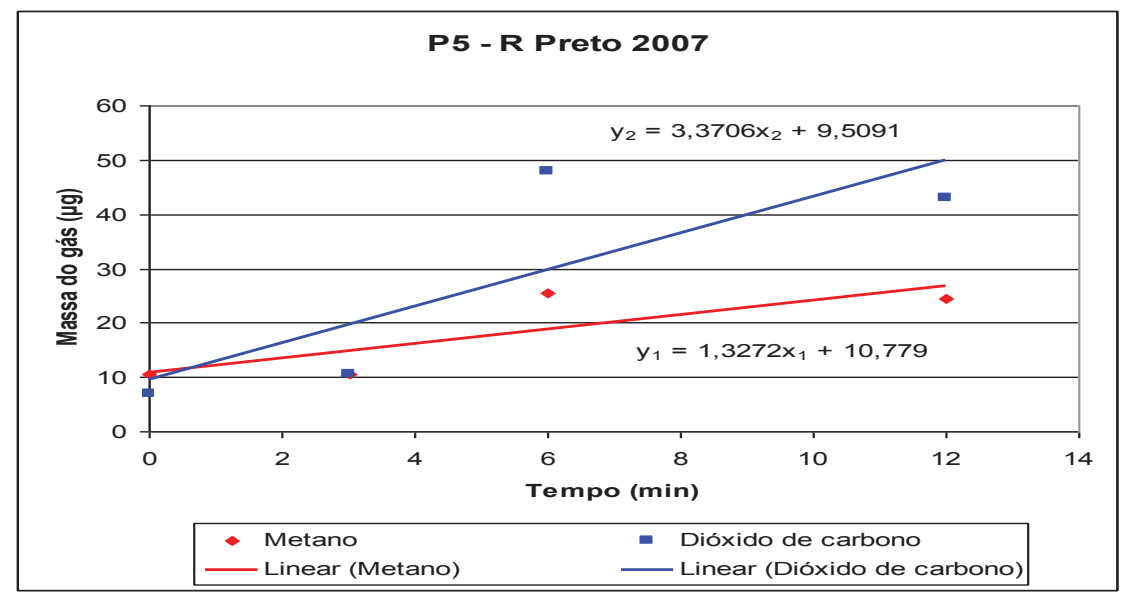

Gráfico 6.5.69 - Sítio $P_{5}-R$ Preto 2007. Equações de retas e inclinações para $\mathrm{CH}_{4}$ e $\mathrm{CO}_{2}$.

Equações das retas:

$$
\begin{aligned}
& y_{1}=1,3272 x_{1}+10,779 \text { Equação do metano } \\
& y_{2}=3,3706 x_{2}+9,5091 \text { Equação do dióxido }
\end{aligned}
$$

b) Cálculo da taxa de emissão:

b) Metano: $\quad \operatorname{Tx} E\left(\mathrm{CH}_{4}\right)=\frac{1,3272 \mu \mathrm{g}\left(\mathrm{CO}_{2}\right) \times 33.200 \mathrm{~mL} \times 1440 \mathrm{~min} \times \mathrm{g}}{\mathrm{mL} \times \min \times 0,664 \mathrm{~m}^{2} \times \operatorname{dia} \times 10^{6} \mu \mathrm{g}}$ 
$\operatorname{TxE}\left(\mathrm{CH}_{4}\right)=95,56 \mathrm{~g} \times \mathrm{m}^{-2} \cdot \mathrm{d}^{-1}\left(\mathrm{CH}_{4}\right)$ No sítio de coleta $\mathrm{P}_{5}$.

$\mathrm{b}_{2}$ ) Dióxido de carbono: $\operatorname{Tx} E\left(\mathrm{CO}_{2}\right)=\frac{3,3706 \mu \mathrm{g}\left(\mathrm{CO}_{2}\right) \times 33.200 \mathrm{~mL} \times 1440 \mathrm{~min} \times g}{\mathrm{~mL} \times \min \times 0,664 \mathrm{~m}^{2} \times \operatorname{dia} \times 10^{6} \mu \mathrm{g}}$

$$
\operatorname{Tx} E\left(\mathrm{CO}_{2}\right)=242,68 \mathrm{~g} \times \mathrm{m}^{-2} \cdot \mathrm{d}^{-1}\left(\mathrm{CO}_{2}\right) \text { No sítio de coleta } \mathrm{P}_{3} \text {. }
$$

$\mathbf{P}_{6}\left(\mathrm{G} ; \mathrm{V}_{\mathrm{G}}=33.200 \mathrm{~mL} ; \mathrm{A}_{\mathrm{G}}=0,664 \mathrm{~m}^{2}\right)$

a) Tabela com tempos de coleta e massas correspondentes, gráfico com equações de retas e inclinações:

Tabela 6.5.81 - Sítio de coleta $\mathbf{P}_{6}-\mathrm{R}$ Preto 2007: tempos de coleta e massas $(\mu \mathrm{g})$ para $\mathrm{CH}_{4}$ e $\mathrm{CO}_{2}$.

\begin{tabular}{ccc}
\hline Tempo (min) & Massa do $\mathrm{CH}_{4}(\mu g)$ & Massa do $\mathrm{CO}_{2}(\mu g)$ \\
\hline 0 & 10,4295 & 8,2095 \\
3 & 13,4835 & 17,4464 \\
6 & 18,1000 & 27,3785 \\
12 & 10,7133 & 10,4800 \\
\hline
\end{tabular}

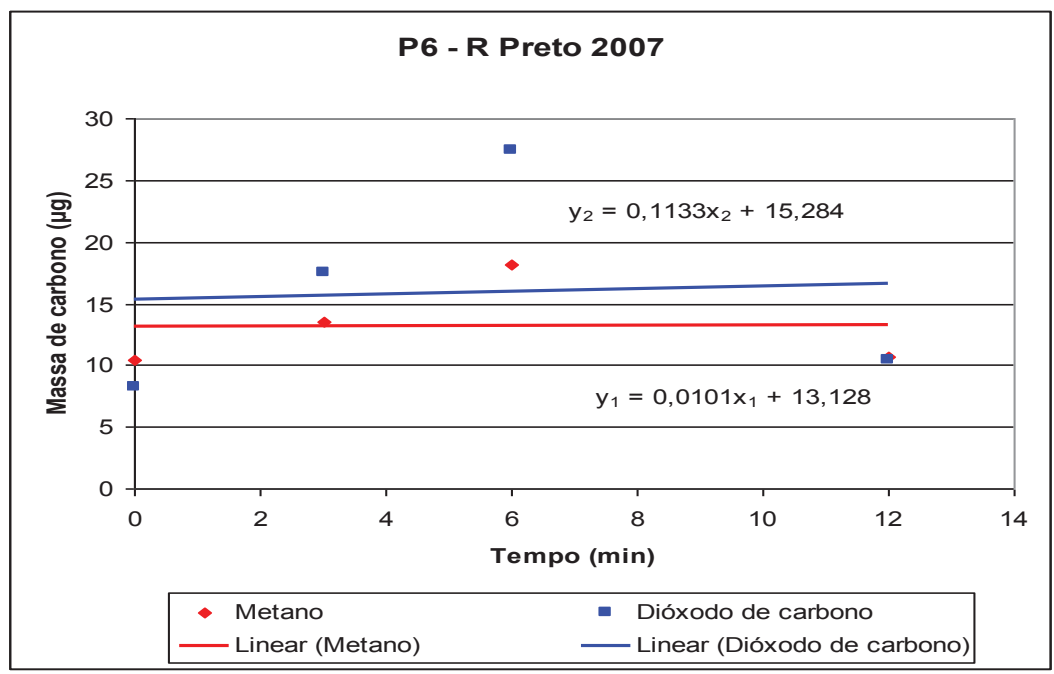

Gráfico 6.5.70 - Sítio $\mathbf{P}_{6}-\mathrm{R}$ Preto 2007. Equações de retas e inclinações para $\mathrm{CH}_{4}$ e $\mathrm{CO}_{2}$. 
Equações das retas:

$$
\begin{aligned}
& y_{1}=0,0101 x_{1}+13,128 \text { Equação do metano } \\
& y_{2}=0,1133 x_{2}+15,284 \text { Equação do dióxido }
\end{aligned}
$$

b) Cálculo da taxa de emissão:

$\left.b_{1}\right)$ Metano:

$$
\operatorname{Tx} E\left(\mathrm{CH}_{4}\right)=\frac{0,0101 \mu \mathrm{g}\left(\mathrm{CO}_{2}\right) \times 33.200 \mathrm{~mL} \times 1440 \mathrm{~min} \times g}{\mathrm{~mL} \times \min \times 0,664 \mathrm{~m}^{2} \times \operatorname{dia} \times 10^{6} \mu \mathrm{g}}
$$

$$
\operatorname{TxE}\left(\mathrm{CH}_{4}\right)=0,72 \mathrm{~g} \times \mathrm{m}^{-2} \cdot \mathrm{d}^{-1}\left(\mathrm{CH}_{4}\right) \text { No sítio de coleta } \mathrm{P}_{6} \text {. }
$$

$\mathrm{b}_{2}$ ) Dióxido de carbono: $\operatorname{Tx} E\left(\mathrm{CO}_{2}\right)=\frac{0,1133 \mu \mathrm{g}\left(\mathrm{CO}_{2}\right) \times 33.200 \mathrm{~mL} \times 1440 \mathrm{~min} \times \mathrm{g}}{\mathrm{mL} \times \min \times 0,664 \mathrm{~m}^{2} \times \operatorname{dia} \times 10^{6} \mu \mathrm{g}}$

$$
\operatorname{Tx} E\left(\mathrm{CO}_{2}\right)=8,16 \mathrm{~g} \times \mathrm{m}^{-2} \cdot \mathrm{d}^{-1}\left(\mathrm{CO}_{2}\right) \text { No sítio de coleta } \mathrm{P}_{6} \text {. }
$$

$\mathbf{P}_{7}\left(\mathrm{G} ; \mathrm{V}_{\mathrm{G}}=33.200 \mathrm{~mL} ; \mathrm{A}_{\mathrm{G}}=0,664 \mathrm{~m}^{2}\right)$

a) Tabela com tempos de coleta e massas correspondentes, gráfico com equações de retas e inclinações:

Tabela 6.5.82 - Sítio de coleta $\mathbf{P}_{\mathbf{7}}-\mathrm{R}$ Preto 2007: tempos de coleta e massas $(\mu \mathrm{g})$ para $\mathrm{CH}_{4}$ e $\mathrm{CO}_{2}$.

\begin{tabular}{ccc}
\hline Tempo (min) & Massa do $\mathrm{CH}_{\mathbf{4}}(\mu \mathrm{g})$ & Massa do $\mathrm{CO}_{\mathbf{2}}(\boldsymbol{\mu g})$ \\
\hline 0 & 11,0244 & 11,4815 \\
3 & 12,4031 & 16,2040 \\
6 & 15,0638 & 21,1400 \\
12 & 14,7363 & 17,9527 \\
\hline
\end{tabular}




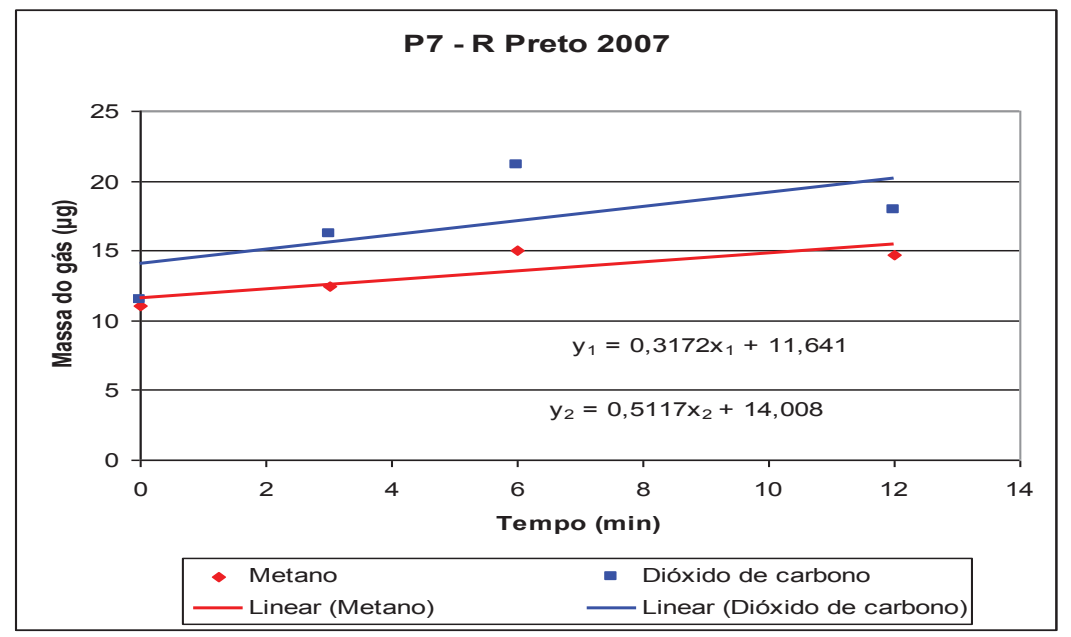

Gráfico 6.5.71 - Sítio $\mathbf{P}_{\mathbf{7}}-\mathrm{R}$ Preto 2007. Equações de retas e inclinações para $\mathrm{CH}_{4}$ e $\mathrm{CO}_{2}$.

Equações das retas:

$$
\begin{aligned}
& y_{1}=0,3172 x_{1}+11,641 \quad \text { Equação do metano } \\
& y_{2}=0,5117 x_{2}+14,008 \text { Equação do dióxido }
\end{aligned}
$$

b) Cálculo da taxa de emissão:

$b_{1}$ ) Metano:

$$
\begin{aligned}
& \operatorname{Tx} E\left(\mathrm{CH}_{4}\right)=\frac{0,3172 \mu g\left(\mathrm{CO}_{2}\right) \times 33.200 \mathrm{~mL} \times 1440 \mathrm{~min} \times \mathrm{g}}{m L \times \min \times 0,664 \mathrm{~m}^{2} \times \operatorname{dia} \times 10^{6} \mu \mathrm{g}} \\
& \operatorname{TxE}\left(\mathrm{CH}_{4}\right)=22,84 \mathrm{~g} \times \mathrm{m}^{-2} \cdot \mathrm{d}^{-1}\left(\mathrm{CH}_{4}\right) \text { No sítio de coleta } \mathrm{P}_{7} .
\end{aligned}
$$

$\mathrm{b}_{2}$ ) Dióxido de carbono: $\operatorname{Tx} E\left(\mathrm{CO}_{2}\right)=\frac{0,5117 \mu g\left(\mathrm{CO}_{2}\right) \times 33.200 \mathrm{~mL} \times 1440 \mathrm{~min} \times g}{\mathrm{~mL} \times \min \times 0,664 \mathrm{~m}^{2} \times \operatorname{dia} \times 10^{6} \mu \mathrm{g}}$

$$
\operatorname{Tx} E\left(\mathrm{CO}_{2}\right)=36,84 \mathrm{~g} \times \mathrm{m}^{-2} \cdot \mathrm{d}^{-1}\left(\mathrm{CO}_{2}\right) \text { No sítio de coleta } \mathrm{P}_{7} \text {. }
$$


$\mathbf{P}_{8}\left(\mathrm{G} ; \mathrm{V}_{\mathrm{G}}=33.200 \mathrm{~mL} ; \mathrm{A}_{\mathrm{G}}=0,664 \mathrm{~m}^{2}\right)$

a) Tabela com tempos de coleta e massas correspondentes, gráfico com equações de retas e inclinações:

Tabela 6.5.83 - Sítio de coleta $\mathbf{P}_{\mathbf{8}}-\mathbf{R}$ Preto 2007: tempos de coleta e massas $(\mu g)$ para $\mathrm{CH}_{4}$ e $\mathrm{CO}_{2}$.

\begin{tabular}{ccc}
\hline Tempo $(\boldsymbol{m i n})$ & Massa do $\mathrm{CH}_{4}(\mu \boldsymbol{g})$ & Massa do $\mathrm{CO}_{2}(\mu \mathrm{g})$ \\
\hline 0 & 10,3520 & 8,3146 \\
3 & 10,4213 & 8,5442 \\
6 & 10,3446 & 10,0804 \\
12 & 12,323 & 11,5244 \\
\hline
\end{tabular}

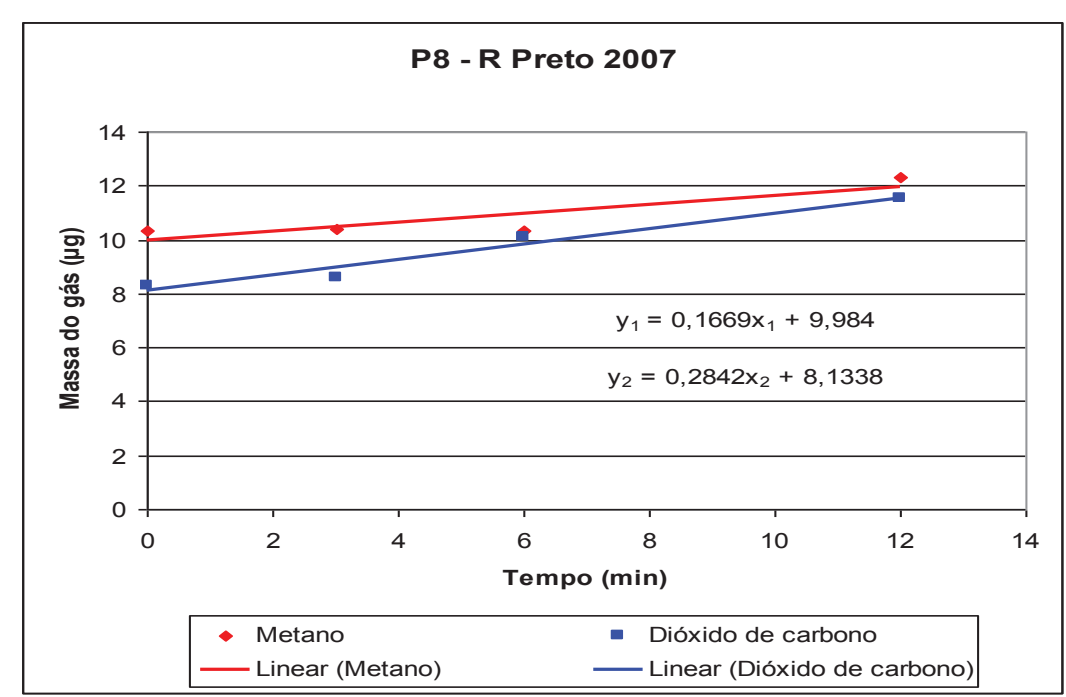

Gráfico 6.5.72 - Sítio $\mathbf{P}_{\mathbf{8}}-\mathrm{R}$ Preto 2007. Equações de retas e inclinações para $\mathrm{CH}_{4}$ e $\mathrm{CO}_{2}$.

Equações das retas:

$$
\begin{aligned}
& y_{1}=0,1669 x_{1}+9,984 \text { Equação do metano } \\
& y_{2}=0,2842 x_{2}+8,1338 \text { Equação do dióxido }
\end{aligned}
$$

b) Cálculo da taxa de emissão:

$\left.b_{1}\right)$ Metano:

$$
\operatorname{TxE}\left(\mathrm{CH}_{4}\right)=\frac{0,1669 \mu \mathrm{g}\left(\mathrm{CO}_{2}\right) \times 33.200 \mathrm{~mL} \times 1440 \mathrm{~min} \times \mathrm{g}}{\mathrm{mL} \times \min \times 0,664 \mathrm{~m}^{2} \times \operatorname{dia} \times 10^{6} \mu \mathrm{g}}
$$




$$
\operatorname{TxE}\left(\mathrm{CH}_{4}\right)=12,02 \mathrm{~g} \times \mathrm{m}^{-2} \cdot \mathrm{d}^{-1}\left(\mathrm{CH}_{4}\right) \text { No sítio de coleta } \mathrm{P}_{8} \text {. }
$$

$b_{2}$ ) Dióxido de carbono: $\operatorname{Tx} E\left(\mathrm{CO}_{2}\right)=\frac{0,2842 \mu g\left(\mathrm{CO}_{2}\right) \times 33.200 \mathrm{~mL} \times 1440 \mathrm{~min} \times g}{\mathrm{~mL} \times \min \times 0,664 \mathrm{~m}^{2} \times \operatorname{dia} \times 10^{6} \mu \mathrm{g}}$

$$
\operatorname{Tx} E\left(\mathrm{CO}_{2}\right)=20,46 \mathrm{~g} \times \mathrm{m}^{-2} \cdot \mathrm{d}^{-1}\left(\mathrm{CO}_{2}\right) \text { No sítio de coleta } \mathrm{P}_{8} \text {. }
$$

\section{Aterro de Ribeirão Preto - Emissão solo-ar campanha 2007:}

A tabela 6.5.84, a seguir, resume a emissão solo-ar de $\mathrm{CH}_{4}$ e $\mathrm{CO}_{2}$, em cada sítio $\mathbf{P}_{\mathbf{n}}$, do aterro de Ribeirão Preto na campanha de 2007.

Tabela 6.5.84 - Resumo da emissão solo-ar - Ribeirão Preto 2007

\begin{tabular}{ccc}
\hline Sítio amostrado & \multicolumn{1}{c}{ Gás $\mathbf{T}_{\mathbf{x}} \mathbf{E}\left(\boldsymbol{g} \cdot \boldsymbol{m}^{-\mathbf{2}} \cdot \boldsymbol{d}^{-1}\right)$} \\
\hline $\mathrm{P}_{1}$ & $\mathrm{CH}_{4}$ & 21,57 \\
& $\mathrm{CO}_{2}$ & 55,28 \\
$\mathrm{P}_{2}$ & $\mathrm{CH}_{4}$ & 56,25 \\
& $\mathrm{CO}_{2}$ & 143,70 \\
& $\mathrm{CH}_{4}$ & 10,06 \\
$\mathrm{P}_{3}$ & $\mathrm{CO}_{2}$ & 3,87 \\
& $\mathrm{CH}_{4}$ & 144,73 \\
$\mathrm{P}_{4}$ & $\mathrm{CO}_{2}$ & 302,66 \\
& $\mathrm{CH}_{4}$ & 95,56 \\
$\mathrm{P}_{5}$ & $\mathrm{CO}_{2}$ & 242,68 \\
& $\mathrm{CH}_{4}$ & 0,72 \\
$\mathrm{P}_{6}$ & $\mathrm{CO}_{2}$ & 8,16 \\
& $\mathrm{CH}_{4}$ & 22,84 \\
$\mathrm{P}_{7}$ & $\mathrm{CO}_{2}$ & 36,84 \\
& $\mathrm{CH}_{4}$ & 12,02 \\
\hline $\mathrm{P}_{8}$ & $\mathrm{CO}_{2}$ & 20,46 \\
\hline
\end{tabular}


1)Cálculo da taxa de emissão média do Metano $\left(T_{x} E_{m(C H 4)}\right)$ nos sítios $\left(P_{n}\right)$ :

$$
\mathrm{T}_{\mathrm{x}} \mathrm{E}_{\mathrm{m}}\left(\mathrm{CH}_{4}\right)=\left(\mathrm{P}_{1}+\ldots+\mathrm{P}_{8}\right) / 8=45,47 \mathrm{~g} \cdot \mathrm{m}^{-2} \cdot \mathrm{d}^{-1}
$$

2)Taxa de emissão média total do metano $\left(T_{x} E_{m(t)(C H 4)}\right)$ no aterro:

$$
\begin{aligned}
& \Rightarrow \mathrm{T}_{\mathrm{x}} \mathrm{E}_{\mathrm{m}(\mathrm{t})}=\mathrm{T}_{\mathrm{x}} \mathrm{E}_{\mathrm{m}}\left(45,47 \mathrm{~g} \cdot \mathrm{m}^{-2} \cdot \mathrm{d}^{-1}\right) \cdot \mathrm{A}_{\mathrm{at}}(218.000) \cdot 365 \mathrm{~d} \cdot 10^{-6}=3.618,05 \text { Ton } \cdot \mathrm{a}^{-1} \\
& \Rightarrow T_{x} E_{m(t)}\left(C_{4}\right)=3.618,05 t \cdot a^{-1}
\end{aligned}
$$

Em que: $\mathrm{T}_{\mathrm{x}} \mathrm{E}_{\mathrm{m}}=$ Taxa de Emissão média $\left(g \cdot m^{-2} \cdot d^{-1}\right) ; \mathrm{A}_{\mathrm{at}}=$ Área do aterro $\left(m^{2}\right)$

$$
\mathrm{T}_{\mathrm{x}} \mathrm{E}_{\mathrm{m}(\mathrm{t})}=\text { Taxa de Emissão média total para } 2007\left({\text { Toneladas } \left.\cdot a n o^{-1}\right)}^{-1}\right.
$$

365 = fator de conversão de dias para ano

$10^{-6}=$ fator de conversão de $g$ para Tonelada

3)Cálculo da taxa de emissão média do dióxido de carbono $\left(T_{x} E_{m(C O 2)}\right)$ nos sítios $\left(P_{n}\right)$ :

$$
\mathrm{T}_{\mathrm{x}} \mathrm{E}_{\mathrm{m}}\left(\mathrm{CO}_{2}\right)=\left(\mathrm{P}_{1}+\ldots+\mathrm{P}_{8}\right) / 8=101,70 \mathrm{~g} \cdot \mathrm{m}^{-2} \cdot \mathrm{d}^{-1}
$$

4)Cálculo da taxa de emissão média total do dióxido de carbono $\left(\mathrm{T}_{\mathrm{x}} \mathrm{E}_{\mathrm{m}(\mathrm{t})(\mathrm{CO} 2)}\right)$ no aterro:

$$
\Rightarrow T_{x} E_{m(t)}=8.092,27 t \cdot a^{-1}
$$

Emissão Total Média ( $\left.E_{t} \underline{M}\right)$ solo-ar do aterro de Ri Preto: Consideradas as campanhas 2006 e 2007 :
1) Metano: $\quad E_{t} \mathbf{M}\left(\mathrm{CH}_{4}\right)=3.602,13 \mathrm{t} \cdot \mathrm{a}^{-1}$
2) Dióxido de carbono: $\mathrm{E}_{\mathrm{t}} \mathrm{M}\left(\mathrm{CO}_{2}\right)=6.973,11 \mathrm{t} \cdot \mathrm{a}^{-1}$ 


\subsection{1-G) Aterro de São Carlos}

\section{G) Campanha 2006}

$P_{1}\left(G ; V_{G}=33.200 m L\right.$ e $\left.A_{G}=0,664 m^{2}\right)$

a) Tabela com tempos de coleta e massas correspondentes, gráfico com equações de retas e inclinações:

Tabela 6.5.85 - Sítio de coleta $\mathbf{P}_{\mathbf{1}}$ - São Carlos 2006: tempos de coleta e massas $(\mu g)$ para $\mathrm{CH}_{4}$ e $\mathrm{CO}_{2}$.

\begin{tabular}{ccc}
\hline Tempo (min) & Massa do $\mathrm{CH}_{4}(\mu \mathrm{g})$ & Massa do $\mathrm{CO}_{2}(\mu \mathrm{g})$ \\
\hline 0 & 11,2744 & 13,3074 \\
3 & 14,7226 & 20,8800 \\
6 & 18,9654 & 25,9173 \\
12 & 25,2800 & 45,7644 \\
\hline
\end{tabular}

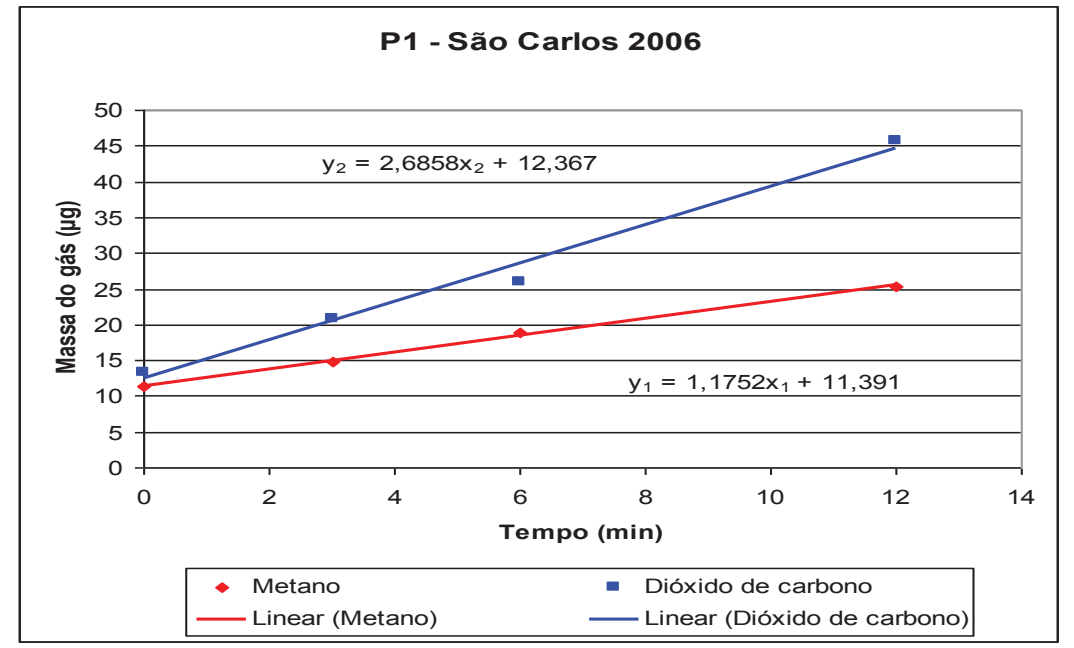

Gráfico 6.5.73 - Sítio $\mathbf{P}_{\mathbf{1}}$ - São Carlos 2006. Equações de retas e inclinações para $\mathrm{CH}_{4}$ e $\mathrm{CO}_{2}$.

Equações das retas:

$$
\begin{aligned}
& y_{1}=1,1752 x_{1}+11,391 \text { Equação do metano } \\
& y_{2}=2,6858 x_{2}+12,367 \text { Equação do dióxido }
\end{aligned}
$$


b) Cálculo da taxa de emissão:

b) Metano: $\quad \operatorname{TxE}\left(\mathrm{CH}_{4}\right)=\frac{1,1752 \mu \mathrm{g}\left(\mathrm{CH}_{4}\right) \times 33.200 \mathrm{~mL} \times 1440 \mathrm{~min} \times \mathrm{g}}{\mathrm{mL} \times \min \times 0,664 \mathrm{~m}^{2} \times \operatorname{dia} \times 10^{6} \mu \mathrm{g}}$

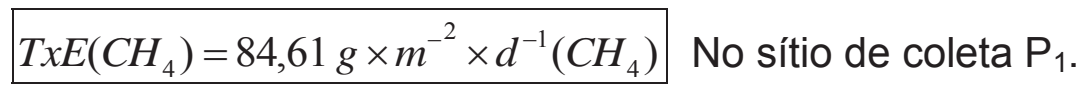

Em que: $\quad T_{x} E\left(\mathrm{CH}_{4}\right)=$ Taxa de emissão de metano no sítio;

$1,1752 \mu \mathrm{g} \cdot \mathrm{min}^{-1} \cdot \mathrm{mL}^{-1}=$ Inclinação da reta do gráfico de metano;

$33.200 \mathrm{~mL}$ = Volume da câmara de coleta (grande);

$1440 \min =$ número de minutos $\cdot \mathrm{dia}^{-1}$;

$10^{6}=$ fator de conversão de $\mu g$ para $g ;$ e,

0,664 $m^{2}$ = Área da base da câmara de coleta (grande).

b $_{2}$ Dióxido de carbono: $\operatorname{Tx}\left(\mathrm{CO}_{2}\right)=\frac{2,6858 \mu \mathrm{g}\left(\mathrm{CO}_{2}\right) \times 33.200 \mathrm{~mL} \times 1440 \mathrm{~min} \times g}{\mathrm{~mL} \times \min \times 0,664 \mathrm{~m}^{2} \times \operatorname{dia} \times 10^{6} \mu \mathrm{g}}$

$$
=193,38 \mathrm{~g} \times \mathrm{m}^{-2} \cdot d^{-1}\left(\mathrm{CO}_{2}\right) \quad \text { No sítio de coleta } \mathrm{P}_{1} \text {. }
$$

Em que: $\quad \mathrm{T}_{\mathrm{x}} \mathrm{E}\left(\mathrm{CO}_{2}\right)=$ Taxa de emissão de dióxido de carbono no sítio;

$2,6858 \mu \mathrm{g} \cdot \mathrm{min}^{-1} \cdot \mathrm{mL}^{-1}=$ Inclinação da reta do gráfico de dióxido de carbono;

33.200 $\mathrm{mL}$ = Volume da câmara de coleta (grande);

$1440 \mathrm{~min}=$ número de minutos $\cdot \mathrm{dia}^{-1}$;

$10^{6}=$ fator de conversão de $\mu g$ para $g ; \mathrm{e}$,

0,664 $m^{2}=$ Área da base da câmara de coleta (grande). 
$P_{2}\left(p ; V_{P}=1200 m L\right.$ e $\left.A_{P}=0,01815 m^{2}\right)$

a) Tabela com tempos de coleta e massas correspondentes, gráfico com equações de retas e inclinações:

Tabela 6.5.86 - Sítio de coleta $\mathbf{P}_{\mathbf{2}}$ - São Carlos 2006: tempos de coleta e massas $(\mu g)$ para $\mathrm{CH}_{4}$ e $\mathrm{CO}_{2}$.

\begin{tabular}{ccc}
\hline Tempo $(\mathbf{m i n})$ & Massa do $\mathrm{CH}_{4}(\mu \mathrm{g})$ & Massa do $\mathrm{CO}_{2}(\mu \mathrm{g})$ \\
\hline 0 & - & - \\
3 & 11,0719 & 11,3184 \\
6 & 11,1138 & 11,3513 \\
12 & 13,9774 & 19,8967 \\
\hline
\end{tabular}

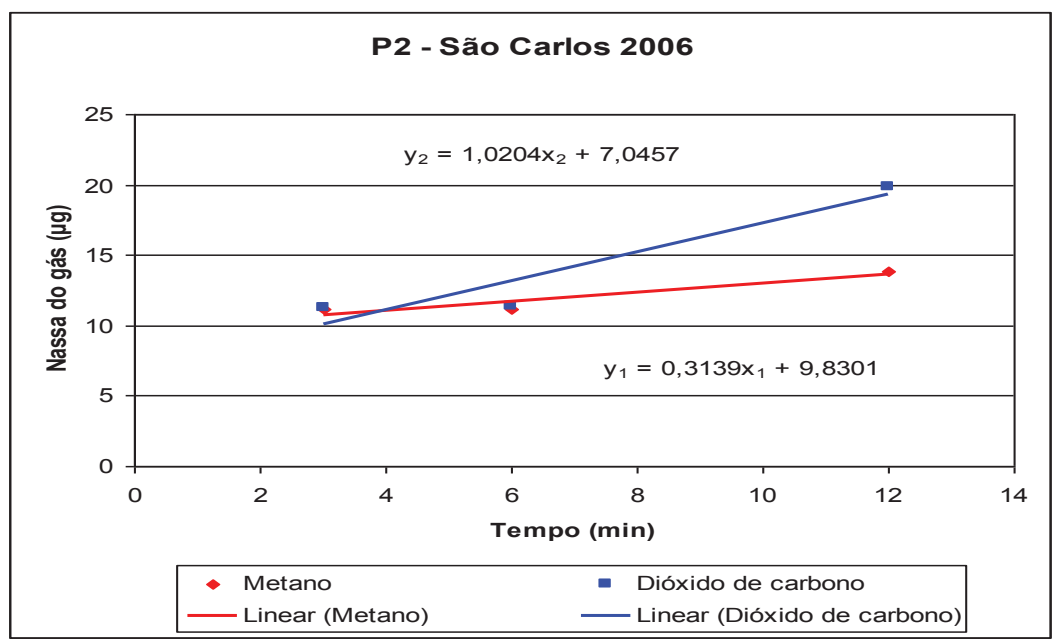

Gráfico 6.5.74 - Sítio $\mathbf{P}_{\mathbf{2}}$ - São Carlos 2006. Equações de retas e inclinações para $\mathrm{CH}_{4}$ e $\mathrm{CO}_{2}$.

Equações das retas:

$$
\begin{aligned}
& y_{1}=0,3139 x_{1}+9,8301 \text { Equação do metano } \\
& y_{2}=1,0204 x_{2}+7,0457 \text { Equação do dióxido }
\end{aligned}
$$

b) Cálculo da taxa de emissão: 
$b_{1}$ ) Metano:

$$
\operatorname{Tx}\left(\mathrm{CH}_{4}\right)=\frac{0,3139 \mu \mathrm{g}\left(\mathrm{CH}_{4}\right) \times 1.200 \mathrm{~mL} \times 1440 \mathrm{~min} \times \mathrm{g}}{\mathrm{mL} \times \min \times 0,01815 \mathrm{~m}^{2} \times \operatorname{dia} \times 10^{6} \mu \mathrm{g}}
$$

$$
\mathrm{Tx}\left(\mathrm{CH}_{4}\right)=29,88 \mathrm{~g} \times \mathrm{m}^{-2} \cdot \mathrm{d}^{-1}\left(\mathrm{CH}_{4}\right) \text { No sítio de coleta } \mathrm{P}_{2} \text {. }
$$

$\mathrm{b}_{2}$ ) Dióxido de carbono: $\operatorname{Tx}\left(\mathrm{CO}_{2}\right)=\frac{1,0204 \mu \mathrm{g}\left(\mathrm{CO}_{2}\right) \times 1.200 \mathrm{~mL} \times 1440 \mathrm{~min} \times \mathrm{g}}{\mathrm{mL} \times \min \times 0,01815 \mathrm{~m}^{2} \times \operatorname{dia} \times 10^{6} \mu \mathrm{g}}$

$$
\operatorname{Tx}\left(\mathrm{CO}_{2}\right)=97,15 \mathrm{~g} \times \mathrm{m}^{-2} \cdot d^{-1}\left(\mathrm{CO}_{2}\right) \quad \text { No sítio de coleta } \mathrm{P}_{2} \text {. }
$$

$\mathbf{P}_{3}\left(\mathrm{G} ; \mathrm{V}_{\mathrm{G}}=33.200 \mathrm{~mL}\right.$ e $\left.\mathrm{A}_{\mathrm{G}}=0,664 \mathrm{~m}^{2}\right)$

a) Tabela com tempos de coleta e massas correspondentes, gráfico com equações de retas e inclinações:

Tabela 6.5.87 - Sítio de coleta $\mathbf{P}_{\mathbf{3}}$ - São Carlos 2007: tempos de coleta e massas $(\mu g)$ para $\mathrm{CH}_{4}$ e $\mathrm{CO}_{2}$.

\begin{tabular}{ccc}
\hline Tempo $(\min )$ & Massa do $\mathrm{CH}_{4}(\mu g)$ & Massa do $\mathrm{CO}_{2}(\mu \mathrm{g})$ \\
\hline 0 & 10,6467 & 10,5010 \\
3 & 10,9780 & 9,4818 \\
6 & 11,0774 & 11,5824 \\
12 & 20,6343 & 38,2054 \\
\hline
\end{tabular}




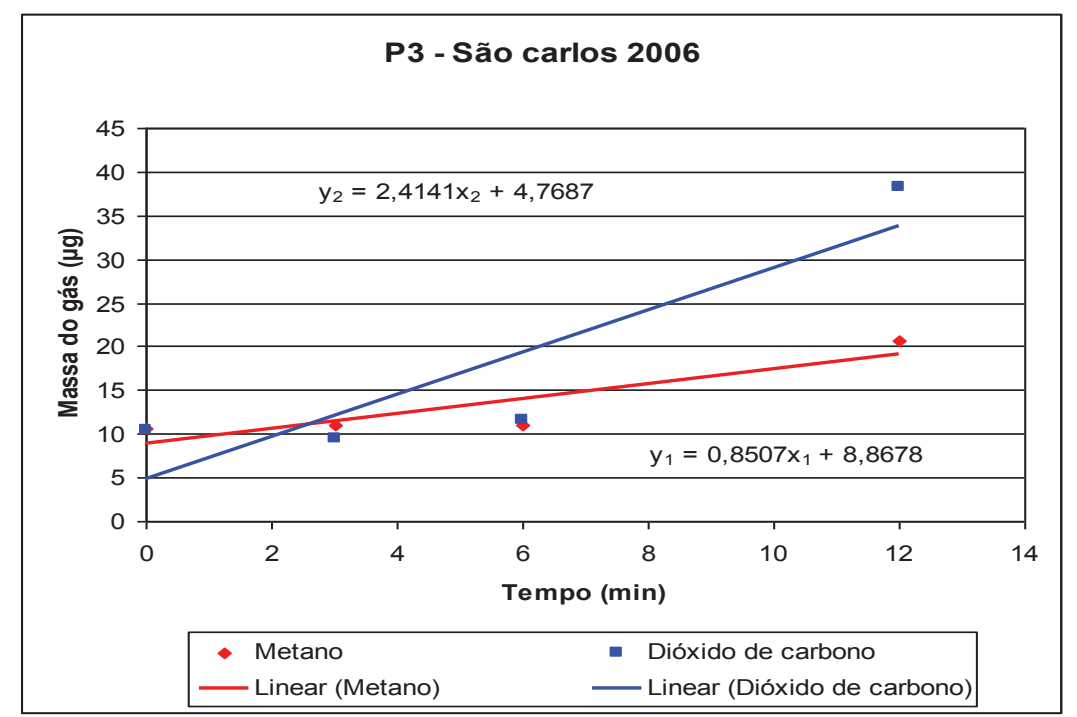

Gráfico 6.5.75 - Sítio $\mathbf{P}_{3}$ - São Carlos 2006. Equações de retas e inclinações para $\mathrm{CH}_{4}$ e $\mathrm{CO}_{2}$.

Equações das retas:

$$
\begin{aligned}
& y_{1}=0,8507 x_{1}+8,8678 \text { Equação do metano } \\
& y_{2}=2,4141 x_{2}+4,7687 \text { Equação do dióxido }
\end{aligned}
$$

$\left.b_{1}\right)$ Metano:

$$
\operatorname{TxE}\left(\mathrm{CH}_{4}\right)=\frac{0,8507 \mu g\left(\mathrm{CH}_{4}\right) \times 33.200 \mathrm{~mL} \times 1440 \mathrm{~min} \times g}{m L \times \min \times 0,664 \mathrm{~m}^{2} \times \operatorname{dia} \times 10^{6} \mu \mathrm{g}}
$$

$$
\operatorname{TxE}\left(\mathrm{CH}_{4}\right)=61,25 \mathrm{~g} \times \mathrm{m}^{-2} \cdot d^{-1}\left(\mathrm{CH}_{4}\right) \text { No sítio de coleta } \mathrm{P}_{3} \text {. }
$$

$\mathrm{b}_{2}$ ) Dióxido de carbono: $\operatorname{Tx} E\left(\mathrm{CO}_{2}\right)=\frac{2,4141 \mu \mathrm{g}\left(\mathrm{CO}_{2}\right) \times 33.200 \mathrm{~mL} \times 1440 \mathrm{~min} \times \mathrm{g}}{\mathrm{mL} \times \min \times 0,664 \mathrm{~m}^{2} \times \operatorname{dia} \times 10^{6} \mu \mathrm{g}}$

$$
\operatorname{Tx}\left(\mathrm{CO}_{2}\right)=173,81 \mathrm{~g} \times \mathrm{m}^{-2} \cdot \mathrm{d}^{-1}\left(\mathrm{CO}_{2}\right) \quad \text { No sítio de coleta } \mathrm{P}_{3} \text {. }
$$


$\mathbf{P}_{4}\left(\mathrm{G} ; \mathrm{V}_{\mathrm{G}}=33.200 \mathrm{~mL}\right.$ e $\left.\mathrm{A}_{\mathrm{G}}=0,664 \mathrm{~m}^{2}\right)$

a) Tabela com tempos de coleta e massas correspondentes, gráfico com equações de retas e inclinações:

Tabela 6.5.88 - Sítio de coleta $\mathbf{P}_{\mathbf{4}}$ - São Carlos 2006: tempos de coleta e massas $(\mu \mathrm{g})$ para $\mathrm{CH}_{4}$ e $\mathrm{CO}_{2}$.

\begin{tabular}{ccc}
\hline Tempo (min) & Massa do $\mathrm{CH}_{\mathbf{4}}(\mu \mathrm{g})$ & Massa do $\mathrm{CO}_{\mathbf{2}}(\mu \mathrm{g})$ \\
\hline 0 & - & - \\
3 & 10,8785 & 10,4022 \\
6 & 11,1741 & 10,7183 \\
12 & 11,2726 & 10,7735 \\
\hline
\end{tabular}

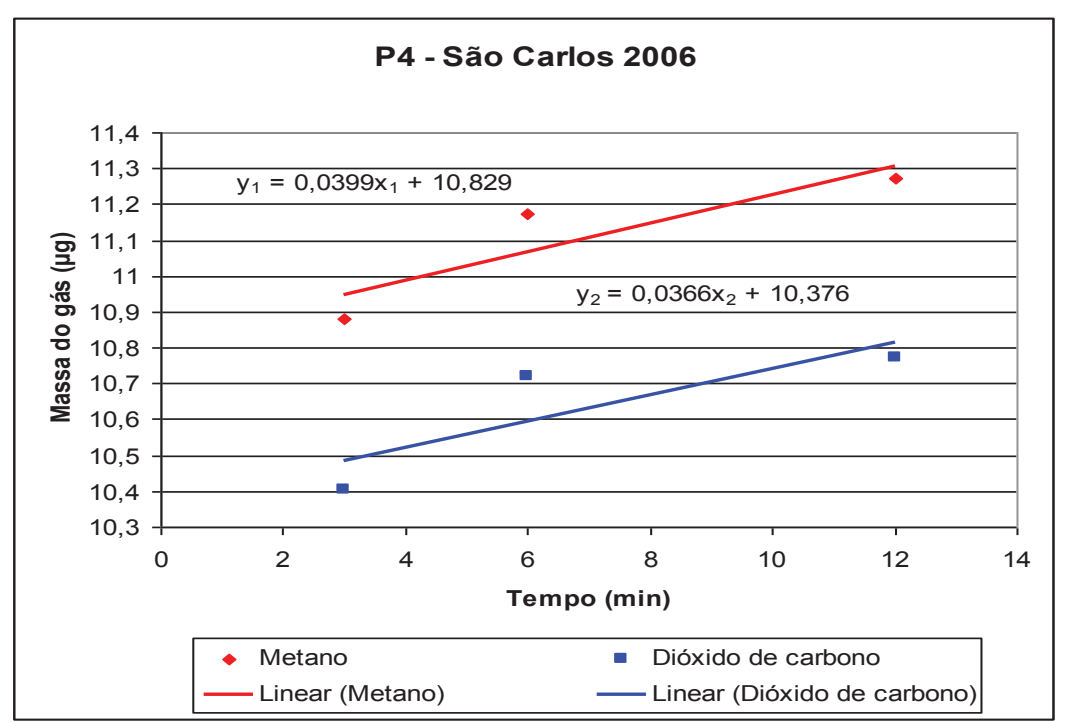

Gráfico 6.5.76 - Sítio $\mathbf{P}_{4}$ - São Carlos 2006. Equações de retas e inclinações para $\mathrm{CH}_{4}$ e $\mathrm{CO}_{2}$.

Equações das retas:

$$
\begin{aligned}
& y_{1}=0,0399 x_{1}+10,829 \text { Equação do metano } \\
& y_{2}=0,0366 x_{2}+10,376 \text { Equação do dióxido }
\end{aligned}
$$


b) Cálculo da taxa de emissão:

$\left.b_{1}\right)$ Metano:

$$
\operatorname{TxE}\left(\mathrm{CH}_{4}\right)=\frac{0,0399 \mu \mathrm{g}\left(\mathrm{CO}_{2}\right) \times 1.200 \mathrm{~mL} \times 1440 \mathrm{~min} \times g}{\mathrm{~mL} \times \min \times 0,01815 \mathrm{~m}^{2} \times \operatorname{dia} \times 10^{6} \mu \mathrm{g}}
$$

$$
\operatorname{TxE}\left(\mathrm{CH}_{4}\right)=3,80 \mathrm{~g} \times \mathrm{m}^{-2} \cdot \mathrm{d}^{-1}\left(\mathrm{CH}_{4}\right) \text { No sítio de coleta } \mathrm{P}_{4} \text {. }
$$

$b_{2}$ ) Dióxido de carbono: $\quad \operatorname{Tx} E\left(\mathrm{CO}_{2}\right)=\frac{0,0366 \mu g\left(\mathrm{CO}_{2}\right) \times 1.200 \mathrm{~mL} \times 1440 \mathrm{~min} \times g}{\mathrm{~mL} \times \min \times 0,01815 \mathrm{~m}^{2} \times \operatorname{dia} \times 10^{6} \mu \mathrm{g}}$

$$
\operatorname{Tx} E\left(\mathrm{CO}_{2}\right)=3,48 \mathrm{~g} \times \mathrm{m}^{-2} \cdot \mathrm{d}^{-1}\left(\mathrm{CH}_{4}\right) \text { No sítio de coleta } \mathrm{P}_{4} \text {. }
$$

\section{Aterro de São Carlos - Emissão solo-ar campanha 2006:}

A tabela 6.5 .89 , resume as taxas de emissão solo-ar, medidas para $\mathrm{CH}_{4}$ e $\mathrm{CO}_{2}$, em cada sítio $\mathbf{P}_{\mathbf{n}}$ do aterro de São Carlos, na campanha de 2006.

Tabela 6.5.89 - Resumo das taxas de emissão solo-ar - São Carlos 2006

\begin{tabular}{ccc}
\hline Sítio amostrado & Gás & $\mathrm{T}_{\mathbf{x}} \mathbf{E}\left(\boldsymbol{g} \cdot \boldsymbol{m}^{-\mathbf{2}} \cdot \boldsymbol{d}^{-1}\right)$ \\
\hline $\mathrm{P}_{1}$ & $\mathrm{CH}_{4}$ & 84,61 \\
& $\mathrm{CO}_{2}$ & 193,38 \\
& $\mathrm{CH}_{4}$ & 29,88 \\
$\mathrm{P}_{2}$ & $\mathrm{CO}_{2}$ & 97,15 \\
& $\mathrm{CH}_{4}$ & 61,25 \\
$\mathrm{P}_{3}$ & $\mathrm{CO}_{2}$ & 173,81 \\
& $\mathrm{CH}_{4}$ & 3,80 \\
\multirow{2}{*}{$\mathrm{P}_{4}$} & $\mathrm{CO}_{2}$ & 3,48 \\
\hline
\end{tabular}


1) Cálculo da taxa de emissão média do Metano $\left(T_{x} E_{m(C H 4)}\right)$ nos sítios $\left(P_{n}\right)$ :

$$
\mathrm{T}_{\mathrm{x}} \mathrm{E}_{\mathrm{m}}\left(\mathrm{CH}_{4}\right)=\left(\mathrm{P}_{1}+\ldots+\mathrm{P}_{4}\right) / 4=44,88 \mathrm{~g} \cdot \mathrm{m}^{-2} \cdot \mathrm{d}^{-1}
$$

2) Taxa de emissão média total do metano $\left(\mathrm{T}_{x} \mathrm{E}_{\mathrm{m}(\mathrm{t})(\mathrm{CH} 4)}\right)$ no aterro:

$$
\begin{aligned}
\Rightarrow \mathrm{T}_{\mathrm{x}} \mathrm{E}_{\mathrm{m}(\mathrm{t})}= & \mathrm{T}_{\mathrm{x}} \mathrm{E}_{\mathrm{m}}\left(44,88 \mathrm{~g} \cdot \mathrm{m}^{-2} \cdot \mathrm{d}^{-1}\right) \cdot \mathrm{A}_{\mathrm{at}}(180.000) \cdot 365 \mathrm{~d} \cdot 10^{-6}=2.948,61 \mathrm{t} \cdot \mathrm{a}^{-1} \\
& \Rightarrow \mathrm{T}_{\mathrm{x}} \mathrm{E}_{\mathrm{m}(\mathrm{t})}\left(\mathrm{CH}_{\mathbf{4}}\right)=2.948,61 \mathrm{t} \cdot \mathrm{a}^{-1}
\end{aligned}
$$

Em que: $T_{x} E_{m}=$ Taxa de Emissão média $\left(g \cdot m^{-2} \cdot d^{-1}\right)$

$$
A_{a t}=\text { Área do aterro }\left(\mathrm{m}^{2}\right)
$$

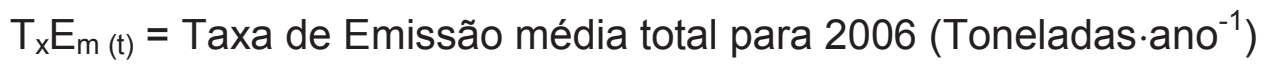

365 = fator de conversão de dias $p$ ano

$10^{-6}=$ fator de conversão de $g$ para Ton

3) Cálculo da taxa de emissão média do dióxido de carbono $\left(T_{x} E_{m(C O 2)}\right)$ nos sítios $\left(P_{n}\right)$ :

$$
\mathrm{T}_{\mathrm{x}} \mathrm{E}_{\mathrm{m}}\left(\mathrm{CO}_{2}\right)=\left(\mathrm{P}_{1}+\ldots+\mathrm{P}_{4}\right) 4=116,95 \mathrm{~g} \cdot \mathrm{m}^{-2} \cdot \mathrm{d}^{-1}
$$

4) Cálculo da taxa de emissão média total do dióxido de carbono $\left(T_{x} E_{m(t)(C O 2)}\right)$ no aterro:

$$
\Rightarrow T_{x} E_{m(t)}=7.683,61 t \cdot a^{-1}
$$




\section{$\mathbf{G}_{2}$ ) Aterro de São Carlos 2007}

$\mathbf{P}_{1}\left(\mathrm{G} ; \mathrm{V}_{\mathrm{G}}=33.200 \mathrm{~mL} ; \mathrm{A}_{\mathrm{G}}=0,664 \mathrm{~m}^{2}\right)$

a) Tabela com tempos de coleta e massas correspondentes, gráfico com equações de retas e inclinações:

Tabela 6.5.90 - Sítio de coleta $\mathbf{P}_{\mathbf{1}}$ - São Carlos 2007: tempos de coleta e massas $(\mu g)$ para $\mathrm{CH}_{4}$ e $\mathrm{CO}_{2}$.

\begin{tabular}{ccc}
\hline Tempo $(\boldsymbol{m i n})$ & Massa do $\mathrm{CH}_{4}(\mu \mathrm{g})$ & Massa do $\mathrm{CO}_{2}(\mu \mathrm{g})$ \\
\hline 0 & 10,2142 & 10,6340 \\
3 & 11,7352 & 15,4423 \\
6 & 22,2046 & 38,5165 \\
12 & 13,4060 & 20,0147 \\
\hline
\end{tabular}

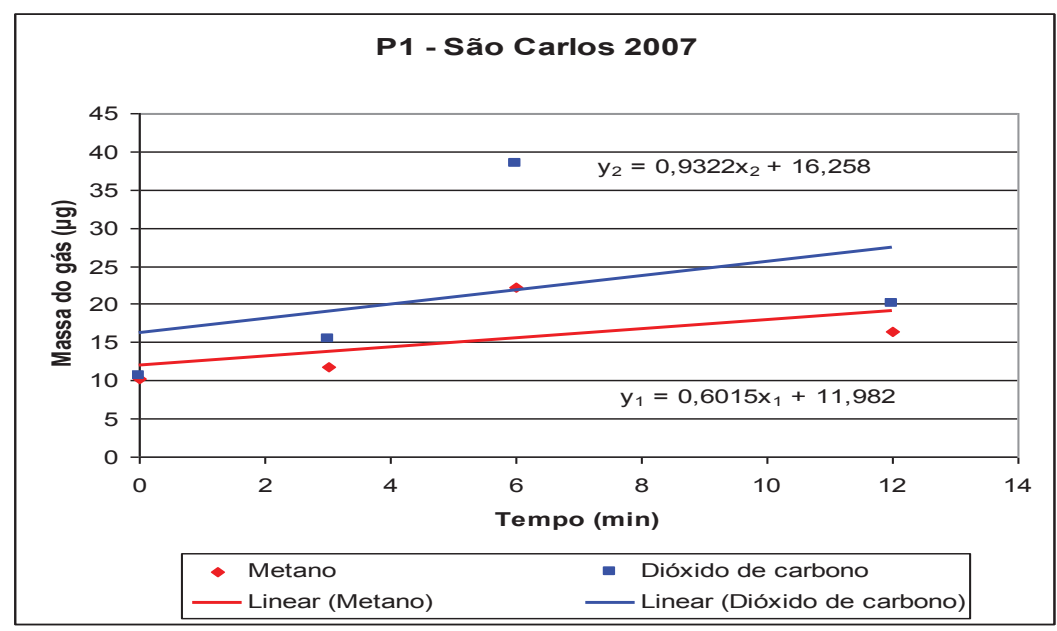

Gráfico 6.5.77 - Sítio $\mathbf{P}_{1}$ - São Carlos 2007. Equações de retas e inclinações para $\mathrm{CH}_{4}$ e $\mathrm{CO}_{2}$.

Equações das retas:

$$
\begin{aligned}
& y_{1}=0,6015 x_{1}+11,982 \text { Equação do metano } \\
& y_{2}=0,9322 x_{2}+16,258 \text { Equação do dióxido }
\end{aligned}
$$


b) Cálculo da taxa de emissão:

$\left.b_{1}\right)$ Metano:

$$
\begin{aligned}
& \operatorname{TxE}\left(\mathrm{CH}_{4}\right)=\frac{0,6015 \mu g\left(\mathrm{CH}_{4}\right) \times 33.200 \mathrm{~mL} \times 1440 \mathrm{~min} \times \mathrm{g}}{\mathrm{mL} \times \min \times 0,664 \mathrm{~m}^{2} \times \operatorname{dia} \times 10^{6} \mu \mathrm{g}} \\
& \operatorname{TxE}\left(\mathrm{CH}_{4}\right)=43,31 \mathrm{~g} \times \mathrm{m}^{-2} \cdot \mathrm{d}^{-1}\left(\mathrm{CH}_{4}\right) \text { No sítio de coleta } \mathrm{P}_{3} .
\end{aligned}
$$

$\mathrm{b}_{2}$ ) Dióxido de carbono: $\operatorname{Tx} E\left(\mathrm{CO}_{2}\right)=\frac{0,9322 \mu \mathrm{g}\left(\mathrm{CO}_{2}\right) \times 33.200 \mathrm{~mL} \times 1440 \mathrm{~min} \times \mathrm{g}}{\mathrm{mL} \times \min \times 0,664 \mathrm{~m}^{2} \times \operatorname{dia} \times 10^{6} \mu \mathrm{g}}$

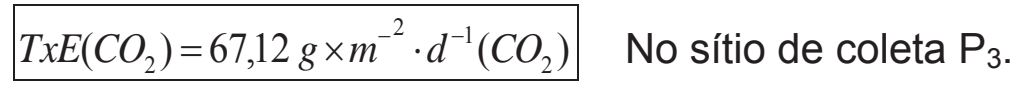

$\mathbf{P}_{2}\left(p ; V_{P}=1.200 m L ; A_{P}=0,01815 m^{2}\right)$

a) Tabela com tempos de coleta e massas correspondentes, gráfico com equações de retas e inclinações:

Tabela 6.5.91 - Sítio de coleta $\mathbf{P}_{\mathbf{2}}$ - São Carlos 2007: tempos de coleta e massas $(\mu \mathrm{g})$ para $\mathrm{CH}_{4}$ e $\mathrm{CO}_{2}$.

\begin{tabular}{ccc}
\hline Tempo (min) & Massa do $\mathrm{CH}_{\mathbf{4}}(\mu \mathrm{g})$ & Massa do $\mathrm{CO}_{\mathbf{2}}(\boldsymbol{\mu g})$ \\
\hline 0 & 10,5100 & 9,0162 \\
3 & 10,3584 & 19,3690 \\
6 & 27,9265 & 50,5342 \\
12 & 10,8711 & 13,0330 \\
\hline
\end{tabular}




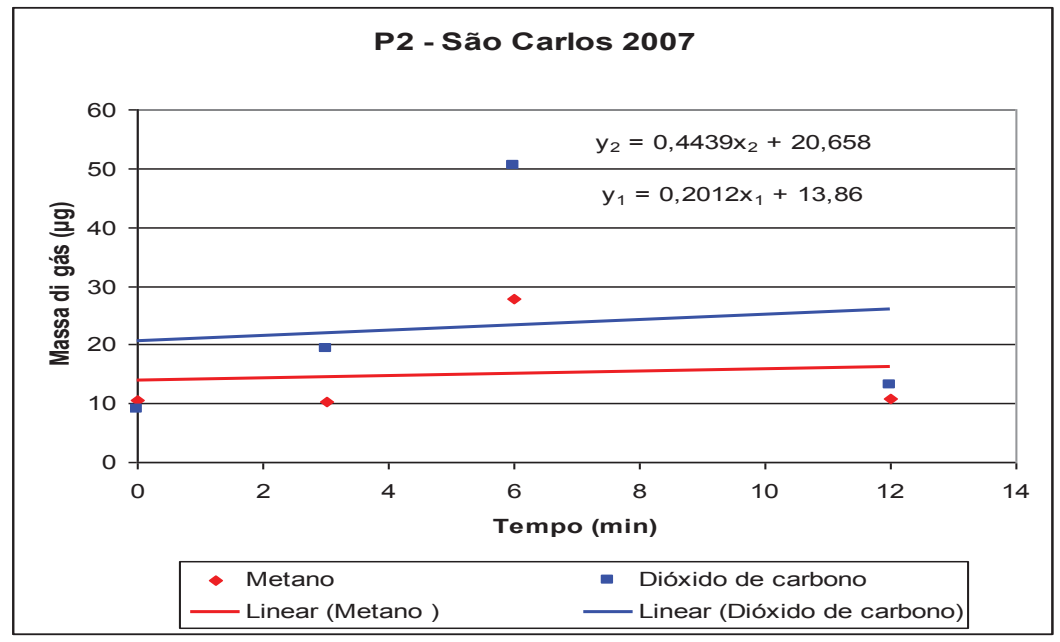

Gráfico 6.5.78 - Sítio $\mathbf{P}_{\mathbf{2}}$ - São Carlos 2007. Equações de retas e inclinações para $\mathrm{CH}_{4}$ e $\mathrm{CO}_{2}$.

Equações das retas:

$$
\begin{aligned}
& y_{1}=0,4439 x_{1}+20,658 \text { Equação do metano } \\
& y_{2}=0,2012 x_{2}+13,86 \quad \text { Equação do dióxido }
\end{aligned}
$$

b) Cálculo da taxa de emissão:

$\left.b_{1}\right)$ Metano:

$$
\begin{aligned}
& \operatorname{Tx} E\left(\mathrm{CH}_{4}\right)=\frac{0,4439 \mu g\left(\mathrm{CH}_{4}\right) \times 1.200 \mathrm{~mL} \times 1440 \mathrm{~min} \times \mathrm{g}}{\mathrm{mL} \times \min \times 0,01815 \mathrm{~m}^{2} \times \operatorname{dia} \times 10^{6} \mu \mathrm{g}} \\
& \operatorname{TxE}\left(\mathrm{CH}_{4}\right)=42,26 \mathrm{~g} \times \mathrm{m}^{-2} \cdot \mathrm{d}^{-1}\left(\mathrm{CH}_{4}\right) \text { No sítio de coleta } \mathrm{P}_{2} .
\end{aligned}
$$

$\mathrm{b}_{2}$ ) Dióxido de carbono: $\operatorname{Tx} E\left(\mathrm{CO}_{2}\right)=\frac{0,2012 \mu \mathrm{g}\left(\mathrm{CO}_{2}\right) \times 1.200 \mathrm{~mL} \times 1440 \mathrm{~min} \times \mathrm{g}}{\mathrm{mL} \times \min \times 0,01815 \mathrm{~m}^{2} \times \mathrm{dia} \times 10^{6} \mu \mathrm{g}}$

$$
\operatorname{Tx} E\left(C_{2}\right)=19,15 \mathrm{~g} \times \mathrm{m}^{-2} \cdot \mathrm{d}^{-1}\left(\mathrm{CO}_{2}\right) \quad \text { No sítio de coleta } \mathrm{P}_{2} \text {. }
$$


$\mathbf{P}_{3}\left(\mathrm{G} ; \mathrm{V}_{\mathrm{G}}=33.200 \mathrm{~mL} ; \mathrm{A}_{\mathrm{G}}=0,664 \mathrm{~m}^{2}\right)$

a) Tabela com tempos de coleta e massas correspondentes, gráfico com equações de retas e inclinações:

Tabela 6.5.92 - Sítio de coleta $\mathbf{P}_{\mathbf{3}}$ - São Carlos 2007: tempos de coleta e massas $(\mu \mathrm{g})$ para $\mathrm{CH}_{4}$ e $\mathrm{CO}_{2}$.

\begin{tabular}{ccc}
\hline Tempo (min) & Massa do $\mathrm{CH}_{4}(\mu g)$ & Massa do $\mathrm{CO}_{2}(\mu g)$ \\
\hline 0 & 11,1800 & 20,7056 \\
3 & 11,4323 & 14,5520 \\
6 & 15,6076 & 26,6704 \\
12 & 25,0049 & 47,9937 \\
\hline
\end{tabular}

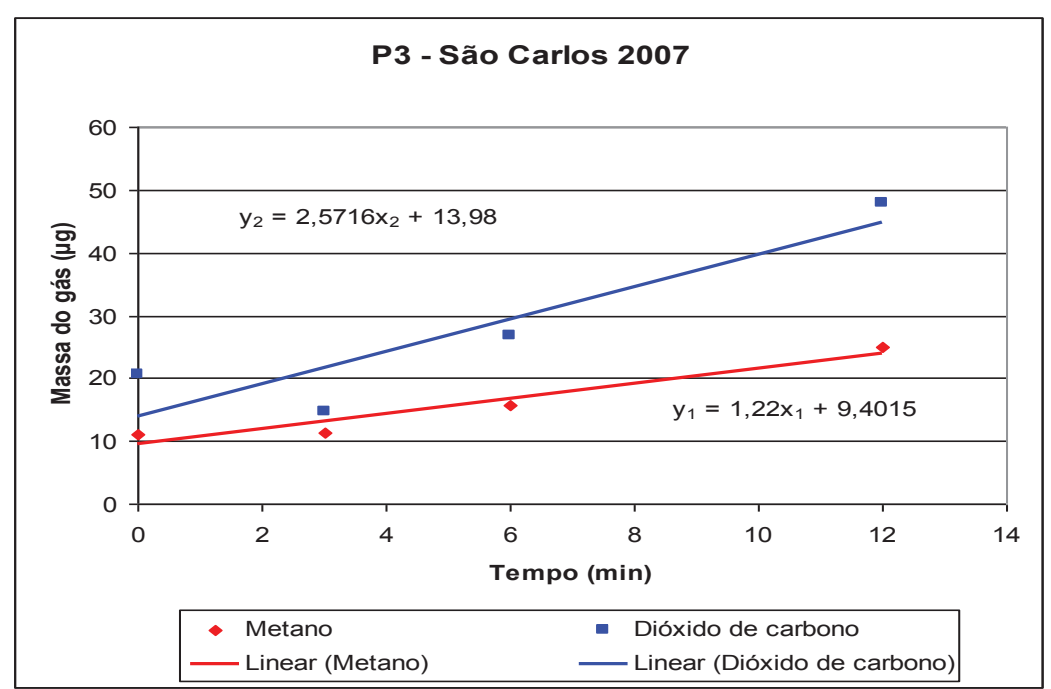

Gráfico 6.5.79 - Sítio $\mathbf{P}_{\mathbf{3}}$ - São Carlos 2007. Equações de retas e inclinações para $\mathrm{CH}_{4}$ e $\mathrm{CO}_{2}$.

Equações das retas:

$$
\begin{aligned}
& y_{1}=1,22 x_{1}+9,4015 \text { Equação do metano } \\
& y_{2}=2,5716 x_{2}+13,98 \text { Equação do dióxido }
\end{aligned}
$$


b) Cálculo da taxa de emissão:

$\left.b_{1}\right)$ Metano:

$$
\begin{aligned}
& \operatorname{TxE}\left(\mathrm{CH}_{4}\right)=\frac{1,22 \mu g\left(\mathrm{CH}_{4}\right) \times 33.200 \mathrm{~mL} \times 1440 \mathrm{~min} \times \mathrm{g}}{\mathrm{mL} \times \min \times 0,664 \mathrm{~m}^{2} \times \operatorname{dia} \times 10^{6} \mu \mathrm{g}} \\
& \operatorname{TxE}\left(\mathrm{CH}_{4}\right)=87,84 \mathrm{~g} \times \mathrm{m}^{-2} \cdot \mathrm{d}^{-1}\left(\mathrm{CH}_{4}\right) \text { No sítio de coleta } \mathrm{P}_{3} .
\end{aligned}
$$

b) Dióxido de carbono: $\operatorname{Tx} E\left(\mathrm{CO}_{2}\right)=\frac{2,571 \mu \mathrm{g}\left(\mathrm{CO}_{2}\right) \times 33.200 \mathrm{~mL} \times 1440 \mathrm{~min} \times g}{\mathrm{~mL} \times \min \times 0,664 \mathrm{~m}^{2} \times \operatorname{dia} \times 10^{6} \mu \mathrm{g}}$

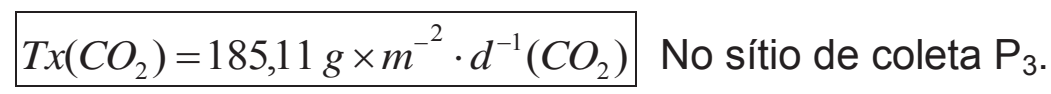

$\mathbf{P}_{4}\left(\mathrm{G} ; \mathrm{V}_{\mathrm{G}}=33.200 \mathrm{~mL} ; \mathrm{A}_{\mathrm{G}}=0,664 \mathrm{~m}^{2}\right)$

a) Tabela com tempos de coleta e massas correspondentes, gráfico com equações de retas e inclinações:

Tabela 6.5.93 - Sítio de coleta $\mathbf{P}_{\mathbf{4}}$ - São Carlos 2007: tempos de coleta e massas $(\mu \mathrm{g})$ para $\mathrm{CH}_{4}$ e $\mathrm{CO}_{2}$.

\begin{tabular}{ccc}
\hline Tempo $(\mathrm{min})$ & Massa do $\mathrm{CH}_{4}(\mu \mathrm{g})$ & Massa do $\mathrm{CO}_{2}(\mu \mathrm{g})$ \\
\hline 0 & 10,3000 & 11,1318 \\
3 & 12,0144 & 15,0025 \\
6 & 16,6570 & 33,5708 \\
12 & 10,8182 & 15,6226 \\
\hline
\end{tabular}




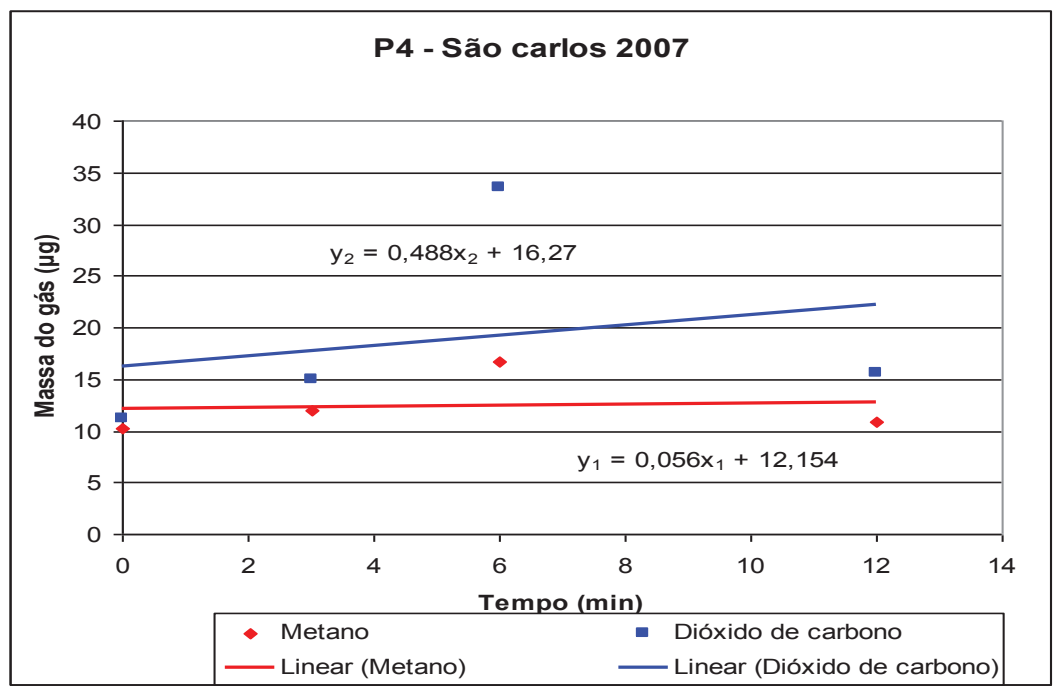

Gráfico 6.5.80 - Sítio $P_{4}$ - São Carlos 2007. Equações de retas e inclinações para $\mathrm{CH}_{4}$ e $\mathrm{CO}_{2}$.

Equações das retas:

$$
\begin{aligned}
& y_{1}=0,056 x_{1}+12,154 \text { Equação do metano } \\
& y_{2}=0,488 x_{2}+16,27 \text { Equação do dióxido }
\end{aligned}
$$

b) Cálculo da taxa de emissão:

b 1) Metano: $\quad \operatorname{Tx} E\left(\mathrm{CH}_{4}\right)=\frac{0,056 \mu \mathrm{g}\left(\mathrm{CH}_{4}\right) \times 33.200 \mathrm{~mL} \times 1440 \mathrm{~min} \times \mathrm{g}}{\mathrm{mL} \times \min \times 0,664 \mathrm{~m}^{2} \times \operatorname{dia} \times 10^{6} \mu \mathrm{g}}$

$$
\operatorname{Tx} E\left(\mathrm{CH}_{4}\right)=4,03 \mathrm{~g} \times \mathrm{m}^{-2} \cdot \mathrm{d}^{-1}\left(\mathrm{CH}_{4}\right) \text { No sítio de coleta } \mathrm{P}_{4} \text {. }
$$

$\mathrm{b}_{2}$ ) Dióxido de carbono: $\operatorname{Tx} E\left(\mathrm{CO}_{2}\right)=\frac{0,488 \mu \mathrm{g}\left(\mathrm{CO}_{2}\right) \times 33.200 \mathrm{~mL} \times 1440 \mathrm{~min} \times \mathrm{g}}{\mathrm{mL} \times \min \times 0,664 \mathrm{~m}^{2} \times \operatorname{dia} \times 10^{6} \mu \mathrm{g}}$

$$
\operatorname{Tx}\left(\mathrm{CO}_{2}\right)=35,14 \mathrm{~g} \times \mathrm{m}^{-2} \cdot \mathrm{d}^{-1}\left(\mathrm{CO}_{2}\right) \quad \text { No sítio de coleta } \mathrm{P}_{4} \text {. }
$$


$\mathbf{P}_{5}\left(\mathrm{G} ; \mathrm{V}_{\mathrm{G}}=33.200 \mathrm{~mL} ; \mathrm{A}_{\mathrm{G}}=0,664 \mathrm{~m}^{2}\right)$

a) Tabela com tempos de coleta e massas correspondentes, gráfico com equações de retas e inclinações:

Tabela 6.5.94 - Sítio de coleta $\mathbf{P}_{\mathbf{5}}$ - São Carlos 2007: tempos de coleta e massas $(\mu g)$ para $\mathrm{CH}_{4}$ e $\mathrm{CO}_{2}$.

\begin{tabular}{ccc}
\hline Tempo $(\boldsymbol{m i n})$ & Massa do $\mathrm{CH}_{4}(\mu \mathrm{g})$ & Massa do $\mathrm{CO}_{2}(\mu \mathrm{g})$ \\
\hline 0 & 10,1905 & 7,4284 \\
3 & 11,1294 & 12,6595 \\
6 & 12,2444 & 13,4800 \\
12 & 12,3236 & 14,3266 \\
\hline
\end{tabular}

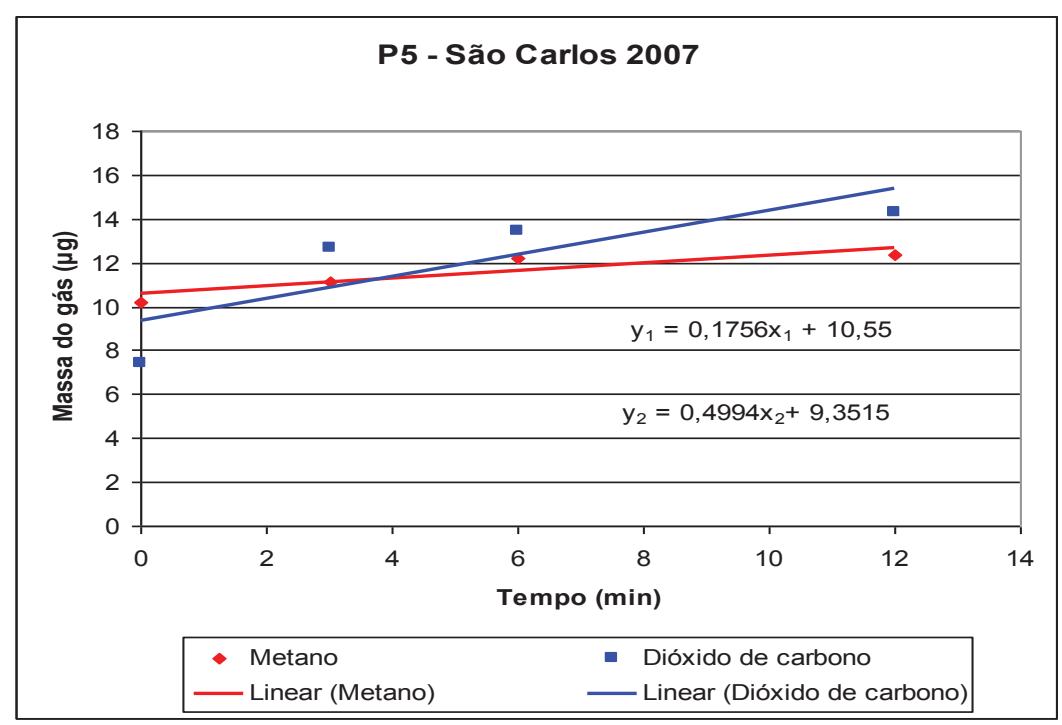

Gráfico 6.5.81 - Sítio $\mathbf{P}_{\mathbf{5}}$ - São Carlos 2007. Equações de retas e inclinações para $\mathrm{CH}_{4}$ e $\mathrm{CO}_{2}$.

Equações das retas:

$$
\begin{aligned}
& y_{1}=0,1756 x_{1}+10,55 \text { Equação do metano } \\
& y_{2}=0,4994 x_{2}+9,3515 \text { Equação do dióxido }
\end{aligned}
$$


b) Cálculo da taxa de emissão:

b ) Metano:

$$
\begin{aligned}
& \operatorname{Tx} E\left(\mathrm{CH}_{4}\right)=\frac{0,1756 \mu g\left(\mathrm{CH}_{4}\right) \times 33.200 \mathrm{~mL} \times 1440 \mathrm{~min} \times \mathrm{g}}{\mathrm{mL} \times \min \times 0,664 \mathrm{~m}^{2} \times \operatorname{dia} \times 10^{6} \mu \mathrm{g}} \\
& \operatorname{TxE}\left(\mathrm{CH}_{4}\right)=12,65 \mathrm{~g} \times \mathrm{m}^{-2} \cdot \mathrm{d}^{-1}\left(\mathrm{CH}_{4}\right) \text { No sítio de coleta } \mathrm{P}_{5} .
\end{aligned}
$$

$\mathrm{b}_{2}$ ) Dióxido de carbono: $\operatorname{Tx} E\left(\mathrm{CO}_{2}\right)=\frac{0,4994 \mu \mathrm{g}\left(\mathrm{CO}_{2}\right) \times 33.200 \mathrm{~mL} \times 1440 \mathrm{~min} \times g}{\mathrm{~mL} \times \min \times 0,664 \mathrm{~m}^{2} \times \operatorname{dia} \times 10^{6} \mu \mathrm{g}}$

$$
\operatorname{TxE}\left(\mathrm{CO}_{2}\right)=35,95 \mathrm{~g} \times \mathrm{m}^{-2} \cdot \mathrm{d}^{-1}\left(\mathrm{CO}_{2}\right) \quad \text { No sítio de coleta } \mathrm{P}_{5} \text {. }
$$

\section{Aterro de São Carlos - Emissão solo-ar campanha 2007:}

A tabela 6.5.95, resume as taxas de emissão solo-ar para $\mathrm{CH}_{4}$ e $\mathrm{CO}_{2}$, em cada sítio $\mathbf{P}_{\mathbf{n}}$ do aterro de São Carlos, na campanha de 2007.

Tabela 6.5.95 - Resumo das taxas de emissão solo-ar - São Carlos 2007

\begin{tabular}{ccc}
\hline Sítio amostrado & Gás & $T_{\mathbf{x}} E\left(\boldsymbol{g} \cdot \boldsymbol{m}^{-\mathbf{2}} \cdot \boldsymbol{d}^{-\mathbf{1}}\right)$ \\
\hline $\mathrm{P}_{1}$ & $\mathrm{CH}_{4}$ & 43,31 \\
& $\mathrm{CO}_{2}$ & 67,12 \\
& $\mathrm{CH}_{4}$ & 42,26 \\
$\mathrm{P}_{2}$ & $\mathrm{CO}_{2}$ & 19,15 \\
& $\mathrm{CH}_{4}$ & 87,84 \\
$\mathrm{P}_{3}$ & $\mathrm{CO}_{2}$ & 185,11 \\
& $\mathrm{CH}_{4}$ & 4,03 \\
$\mathrm{P}_{4}$ & $\mathrm{CO}_{2}$ & 35,14 \\
& $\mathrm{CH}_{4}$ & 12,65 \\
\hline $\mathrm{P}_{5}$ & $\mathrm{CO}_{2}$ & 35,95 \\
\hline
\end{tabular}


1) Cálculo da taxa de emissão média do Metano $\left(T_{x} E_{m(C H 4)}\right)$ nos sítios $\left(P_{n}\right)$ :

$$
\mathrm{T}_{\mathrm{x}} \mathrm{E}_{\mathrm{m}}\left(\mathrm{CH}_{4}\right)=\left(\mathrm{P}_{1}+\ldots+\mathrm{P}_{5}\right) / 5=38,02 \mathrm{~g} \cdot \mathrm{m}^{-2} \cdot \mathrm{d}^{-1}
$$

2) Taxa de emissão média total do metano $\left(\mathrm{T}_{x} \mathrm{E}_{\mathrm{m}(\mathrm{t})(\mathrm{CH} 4)}\right)$ no aterro:

$$
\begin{aligned}
& \Rightarrow T_{x} E_{m(t)}\left(C H_{4}\right)=T_{x} E_{m}\left(38,02 g \cdot m^{-2} \cdot d^{-1}\right) \cdot A_{a t}\left(180.000 m^{2}\right) \cdot 365 d \cdot 10^{-6}=2.497,91 \mathrm{t} \cdot a^{-1} \\
& \Rightarrow \mathrm{T}_{\mathrm{x}} \mathrm{E}_{\mathrm{m}(\mathrm{t})}\left(\mathrm{CH}_{4}\right)=2.497,91 \mathrm{t} \cdot \mathrm{a}^{-1}
\end{aligned}
$$

Em que: $T_{x} E_{m}=$ Taxa de Emissão média $\left(g \cdot m^{-2} \cdot d^{-1}\right)$

$$
\mathrm{A}_{\mathrm{at}}=\text { Área do aterro }\left(m^{2}\right)
$$

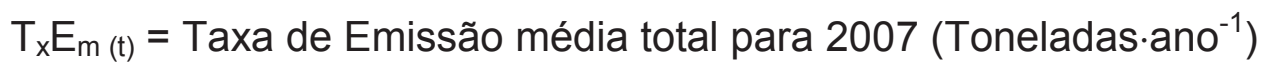

$$
365 \text { = fator de conversão de dias } p \text { ano }
$$

$10^{-6}=$ fator de conversão de mg para Ton

3) Cálculo da taxa de emissão média do dióxido de carbono $\left(T_{x} E_{m(C O 2)}\right)$ nos sítios $\left(P_{n}\right)$ :

$$
\mathrm{T}_{\mathrm{x}} \mathrm{E}_{\mathrm{m}}\left(\mathrm{CO}_{2}\right)=\left(\mathrm{P}_{1}+\ldots+\mathrm{P}_{5}\right) / 5=68,50 \mathrm{~g} \cdot \mathrm{m}^{-2} \cdot \mathrm{d}^{-1}
$$

4) Cálculo da taxa de emissão média total do dióxido de carbono $\left(T_{x} E_{m(t)(C O 2)}\right)$ no aterro:

$$
\Rightarrow T_{x} E_{m(t)}=4.500,45 t \cdot a^{-1}
$$

Emissão Total Média ( $\left.E_{t} \underline{M}\right)$ solo-ar do aterro de São Carlos: Consideradas as campanhas, 2006 e 2007.
1) Metano: $\quad E_{t} M\left(\mathrm{CH}_{4}\right)=\mathbf{2 . 7 2 3 , 2 9} \mathrm{t} \cdot \mathrm{a}^{-1}$
2) Dióxido de carbono: $\mathrm{E}_{\mathrm{t}} \mathrm{M}\left(\mathrm{CO}_{2}\right)=6.092,03 \mathrm{t} \cdot \mathrm{a}^{-1}$ 


\subsection{1-H) Aterro Bandeirantes}

\section{$\mathrm{H}_{1}$ ) Aterro Bandeirantes 2007 - Única}

$\mathbf{P}_{1}\left(\mathrm{G} ; \mathrm{V}_{\mathrm{G}}=33.200 \mathrm{~mL} ; \mathrm{A}_{\mathrm{G}}=0,664 \mathrm{~m}^{2}\right)$

a) Tabela com tempos de coleta e massas correspondentes, gráfico com equações de retas e inclinações:

Tabela 6.5.96 - Sítio de coleta $\mathbf{P}_{\mathbf{1}}$ - Bandeirantes 2007: tempos de coleta e massas $(\mu g)$ para $\mathrm{CH}_{4}$ e $\mathrm{CO}_{2}$.

\begin{tabular}{ccc}
\hline Tempo (min) & Massa do $\mathrm{CH}_{4}(\mu \mathrm{g})$ & Massa do $\mathrm{CO}_{2}(\mu \mathrm{g})$ \\
\hline 0 & 10,7352 & 9,2393 \\
3 & 10,8684 & 10,3078 \\
6 & 14,5839 & 26,1600 \\
12 & 23,5021 & 45,9404 \\
\hline
\end{tabular}

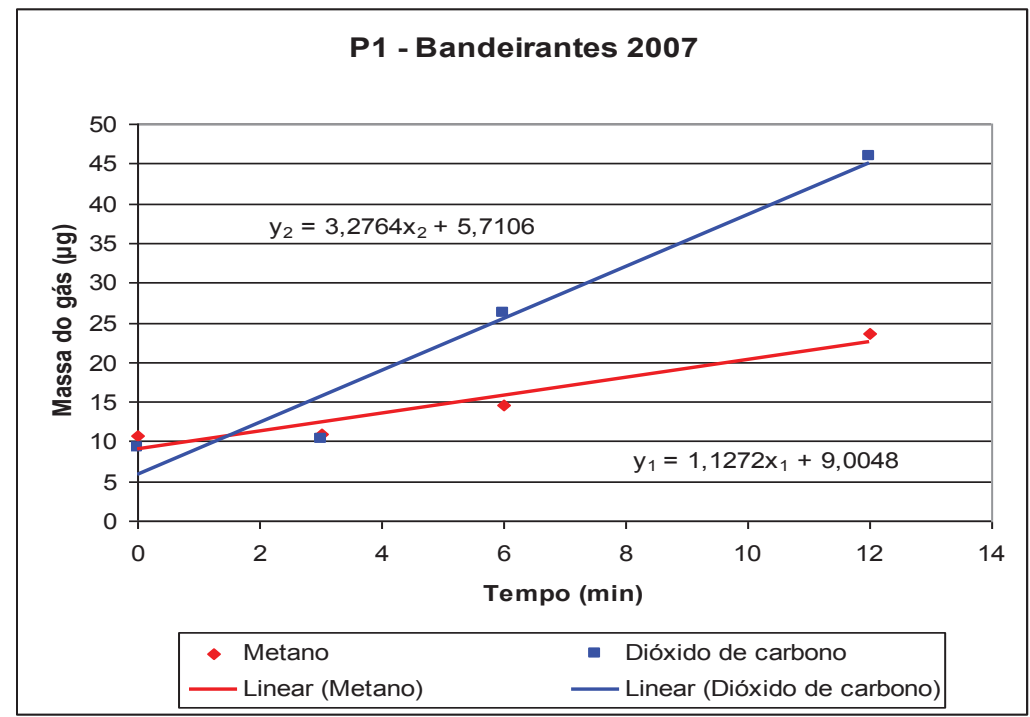

Gráfico 6.5.82 - Sítio $\mathbf{P}_{\mathbf{1}}$ - Bandeirantes 2007. Equações de retas e inclinações para $\mathrm{CH}_{4}$ e $\mathrm{CO}_{2}$.

Equações das retas:

$$
y_{1}=1,1272 x_{1}+9,0048 \text { Equação do metano }
$$


b) Cálculo da taxa de emissão:

b) Metano: $\operatorname{Tx} E\left(\mathrm{CH}_{4}\right)=\frac{1,1272 \mu \mathrm{g}\left(\mathrm{CH}_{4}\right) \times 33.200 \mathrm{~mL} \times 1440 \mathrm{~min} \times \mathrm{g}}{\min \times \mathrm{mL} \times 0,664 \mathrm{~m}^{2} \times \operatorname{dia} \times 10^{6} \mu \mathrm{g}}$

$$
=81,16 \mathrm{~g} \times \mathrm{m}^{-2} \cdot d^{-1}\left(\mathrm{CH}_{4}\right) \quad \text { No sítio de coleta } \mathrm{P}_{1} \text {. }
$$

Em que: $\quad T_{x} E\left(\mathrm{CH}_{4}\right)=$ Taxa de emissão de metano no sítio;

$1,1272 \mu \mathrm{g} \cdot \mathrm{min}^{-1} \cdot \mathrm{mL}^{-1}=$ Inclinação da reta do gráfico de metano;

33.200 mL = Volume da câmara de coleta (grande);

$1440 \mathrm{~min}=$ número de minutos $\cdot \mathrm{dia}^{-1}$;

$10^{6}=$ fator de conversão de $\mu g$ para $g ; \mathrm{e}$,

0,664 $m^{2}=$ Área da base da câmara de coleta (grande).

$b_{2}$ ) Dióxido de carbono: $\mathrm{Tx} E\left(\mathrm{CO}_{2}\right)=\frac{3,2764 \mu \mathrm{g}\left(\mathrm{CO}_{2}\right) \times 33.200 \mathrm{~mL} \times 1440 \mathrm{~min} \times g}{\mathrm{~mL} \times \min \times 0,664 \mathrm{~m}^{2} \times \operatorname{dia} \times 10^{6} \mu \mathrm{g}}$

$$
T_{x} E=235,90 \mathrm{~g} \times \mathrm{m}^{-2} \cdot d^{-1}\left(\mathrm{CO}_{2}\right) \quad \text { No sítio de coleta } \mathrm{P}_{1} \text {. }
$$

Em que: $\quad \mathrm{T}_{\mathrm{x}} \mathrm{E}\left(\mathrm{CO}_{2}\right)=$ Taxa de emissão de dióxido de carbono no sítio;

3,2764 $\mu \mathrm{g} \cdot \mathrm{mL}^{-1}=$ Inclinação da reta do gráfico de dióxido de carbono;

$33.200 \mathrm{~mL}=$ Volume da câmara de coleta (grande);

$1440 \mathrm{~min}=$ número de minutos $\cdot \mathrm{dia}^{-1}$;

$10^{6}=$ fator de conversão de $\mu g$ para g; e,

0,664 $m^{2}=$ Área da base da câmara de coleta (grande). 
$P_{2}\left(p ; V_{P}=1.200 m L ; A_{P}=0,01815 m^{2}\right)$

a) Tabela com tempos de coleta e massas correspondentes, gráfico com equações de retas e inclinações:

Tabela 6.5.97 - Sítio de coleta $\mathbf{P}_{\mathbf{2}}$ - Bandeirantes 2007: tempos de coleta e massas $(\mu \mathrm{g})$ para $\mathrm{CH}_{4}$ e $\mathrm{CO}_{2}$.

\begin{tabular}{ccc}
\hline Tempo (min) & Massa do $\mathrm{CH}_{4}(\mu \boldsymbol{g})$ & Massa do $\mathrm{CO}_{2}(\mu \boldsymbol{g})$ \\
\hline 0 & 11,1075 & 10,7005 \\
3 & 11,5345 & 10,3422 \\
6 & 24,2339 & 35,7078 \\
12 & 40,6304 & 68,7613 \\
\hline
\end{tabular}

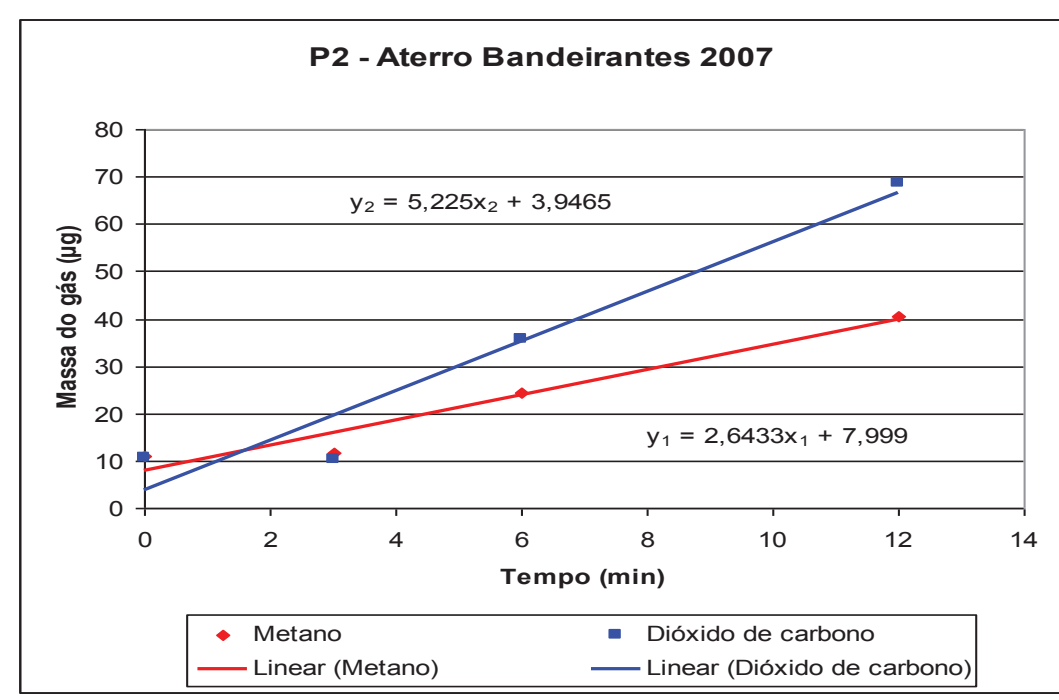

Gráfico 6.5.83 - Sítio $\mathbf{P}_{\mathbf{2}}$ - Bandeirantes 2007. Equações de retas e inclinações para $\mathrm{CH}_{4}$ e $\mathrm{CO}_{2}$.

Equações das retas:

$$
\begin{aligned}
& y_{1}=2,6433 x_{1}+7,999 \text { Equação do metano } \\
& y_{2}=5,225 x_{2}+3,9465 \text { Equação do dióxido }
\end{aligned}
$$

b) Cálculo da taxa de emissão:

$\left.b_{1}\right)$ Metano: 


$$
\begin{aligned}
\operatorname{Tx} E\left(\mathrm{CH}_{4}\right) & =\frac{2,6433 \mu g\left(\mathrm{CH}_{4}\right) \times 1.200 \mathrm{~mL} \times 1440 \mathrm{~min} \times \mathrm{g}}{\mathrm{mL} \times \min \times 0,01815 \mathrm{~m}^{2} \times \operatorname{dia} \times 10^{6} \mu \mathrm{g}} \\
& =251,66 \mathrm{~g} \times \mathrm{m}^{-2} \cdot \mathrm{d}^{-1}\left(\mathrm{CH}_{4}\right) \quad \text { No sítio de coleta } \mathrm{P}_{2} .
\end{aligned}
$$

Em que: $\quad \mathrm{T}_{\mathrm{x}} \mathrm{E}\left(\mathrm{CH}_{4}\right)=$ Taxa de emissão de metano no sítio;

$1,1272 \mu \mathrm{g} \cdot \mathrm{min}^{-1} \cdot \mathrm{mL}^{-1}=$ Inclinação da reta do gráfico de metano;

$1.200 \mathrm{~mL}=$ Volume da câmara de coleta (pequena);

$1440 \min =$ número de $\operatorname{minutos} \cdot \mathrm{dia}^{-1}$;

$10^{6}=$ fator de conversão de $\mu g$ para $g ;$ e,

0,01815 $m^{2}$ = Área da base da câmara de coleta (pequena).

$\mathrm{b}_{2}$ ) Dióxido de carbono: $\operatorname{Tx} E\left(\mathrm{CO}_{2}\right)=\frac{5,225 \mu \mathrm{g}\left(\mathrm{CO}_{2}\right) \times 1.200 \mathrm{~mL} \times 1440 \mathrm{~min} \times \mathrm{g}}{\mathrm{mL} \times \min \times 0,01815 \mathrm{~m}^{2} \times \operatorname{dia} \times 10^{6} \mu \mathrm{g}}$

$$
=497,45 \mathrm{~g} \times \mathrm{m}^{-2} \cdot \mathrm{d}^{-1}\left(\mathrm{CO}_{2}\right) \text { No sítio de coleta } \mathrm{P}_{2} \text {. }
$$

Em que: $\quad T_{x} E\left(\mathrm{CO}_{2}\right)=$ Taxa de emissão de dióxido de carbono no sítio;

5,225 $\mu \mathrm{g} \cdot \mathrm{min}^{-1} \cdot \mathrm{mL}^{-1}=$ Inclinação da reta do gráfico de dióxido de carbono;

$1.200 \mathrm{~mL}=$ Volume da câmara de coleta (pequena);

$1440 \min =$ número de $\operatorname{minutos} \cdot \mathrm{dia}^{-1}$;

$10^{6}=$ fator de conversão de $\mu g$ para g; e,

0,01815 $m^{2}$ = Área da base da câmara de coleta (pequena). 
$\mathbf{P}_{3}\left(\mathrm{G} ; \mathrm{V}_{\mathrm{G}}=33.200 \mathrm{~mL} ; \mathrm{A}_{\mathrm{G}}=0,664 \mathrm{~m}^{2}\right)$

a) Tabela com tempos de coleta e massas correspondentes, gráfico com equações de retas e inclinações:

Tabela 6.5.98 - Sítio de coleta $\mathbf{P}_{\mathbf{3}}$ - Bandeirantes 2007: tempos de coleta e massas $(\mu g)$ para $\mathrm{CH}_{4}$ e $\mathrm{CO}_{2}$.

\begin{tabular}{rcc}
\hline Tempo (min) & Massa do $\mathrm{CH}_{4}(\mu \mathrm{g})$ & Massa do $\mathrm{CO}_{2}(\mu \mathrm{g})$ \\
\hline 0 & - & - \\
3 & 15,1505 & 31,6741 \\
6 & 85,4267 & 168,2673 \\
12 & 35,5226 & 56,5098 \\
\hline
\end{tabular}

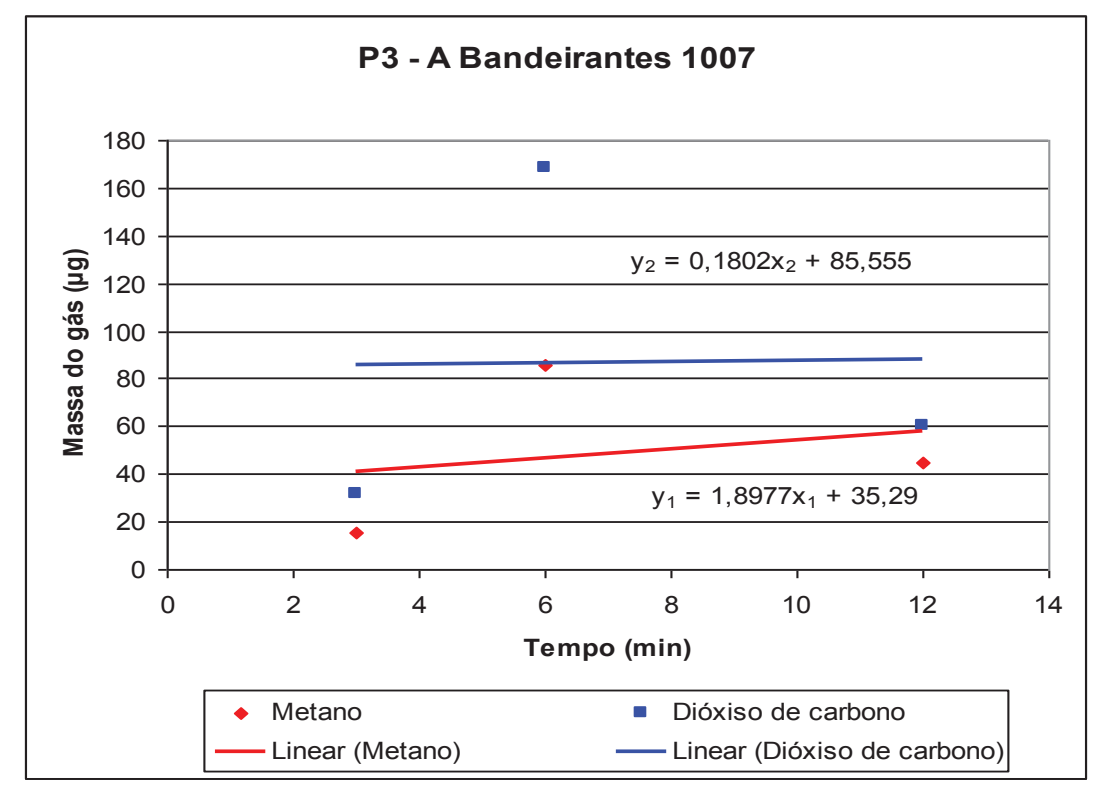

Gráfico 6.5.84 - Sítio $\mathbf{P}_{\mathbf{3}}$ - Bandeirantes 2007. Equações de retas e inclinações para $\mathrm{CH}_{4}$ e $\mathrm{CO}_{2}$.

Equações das retas:

$$
\begin{aligned}
& y_{1}=1,8977 x_{1}+35,29 \text { Equação do metano } \\
& y_{2}=0,1802 x_{2}+85,555 \text { Equação do dióxido }
\end{aligned}
$$


b) Cálculo da taxa de emissão:

b) Metano: $\operatorname{TxE}\left(\mathrm{CH}_{4}\right)=\frac{1,8977 \mu g\left(\mathrm{CH}_{4}\right) \times 33.200 \mathrm{~mL} \times 1440 \mathrm{~min} \times g}{\mathrm{~mL} \times \min \times 0,664 \mathrm{~m}^{2} \times \operatorname{dia1} 0^{6} \mu \mathrm{g}}$

$$
=136,46 \mathrm{~g} \times \mathrm{m}^{-2} \cdot \mathrm{d}^{-1}\left(\mathrm{CH}_{4}\right) \quad \text { No sítio de coleta } \mathrm{P}_{3} \text {. }
$$

$b_{2}$ ) Dióxido de carbono: $\operatorname{TxE}\left(\mathrm{CO}_{2}\right)=\frac{0,1802 \mu \mathrm{g}\left(\mathrm{CO}_{2}\right) \times 33.200 \mathrm{~mL} \times 1440 \mathrm{~min} \times \mathrm{g}}{\mathrm{mL} \times \min \times 0,664 \mathrm{~m}^{2} \times \operatorname{dia} \times 10^{6} \mu \mathrm{g}}$

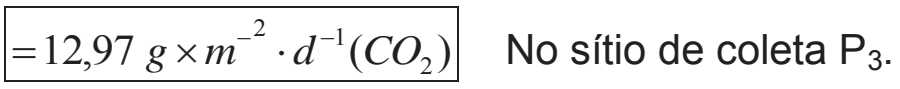

$\mathbf{P}_{4}\left(\mathrm{p} ; \mathrm{V}_{\mathrm{P}}=1.200 \mathrm{~mL} ; \mathrm{A}_{\mathrm{P}}=0,01815 \mathrm{~m}^{2}\right)$

a) Tabela com tempos de coleta e massas correspondentes, gráfico com equações de retas e inclinações:

Tabela 6.5.99 - Sítio de coleta $\mathbf{P}_{\mathbf{4}}$ - Bandeirantes 2007: tempos de coleta e massas $(\mu g)$ para $\mathrm{CH}_{4}$ e $\mathrm{CO}_{2}$.

\begin{tabular}{ccc}
\hline Tempo $(\min )$ & Massa do $\mathrm{CH}_{4}(\mu \mathrm{g})$ & Massa do $\mathrm{CO}_{2}(\mu \mathrm{g})$ \\
\hline 0 & 11,0983 & 12,0994 \\
3 & 12,2462 & 14,0434 \\
6 & 11,0920 & 18,6007 \\
12 & 34,2680 & 61,3693 \\
\hline
\end{tabular}




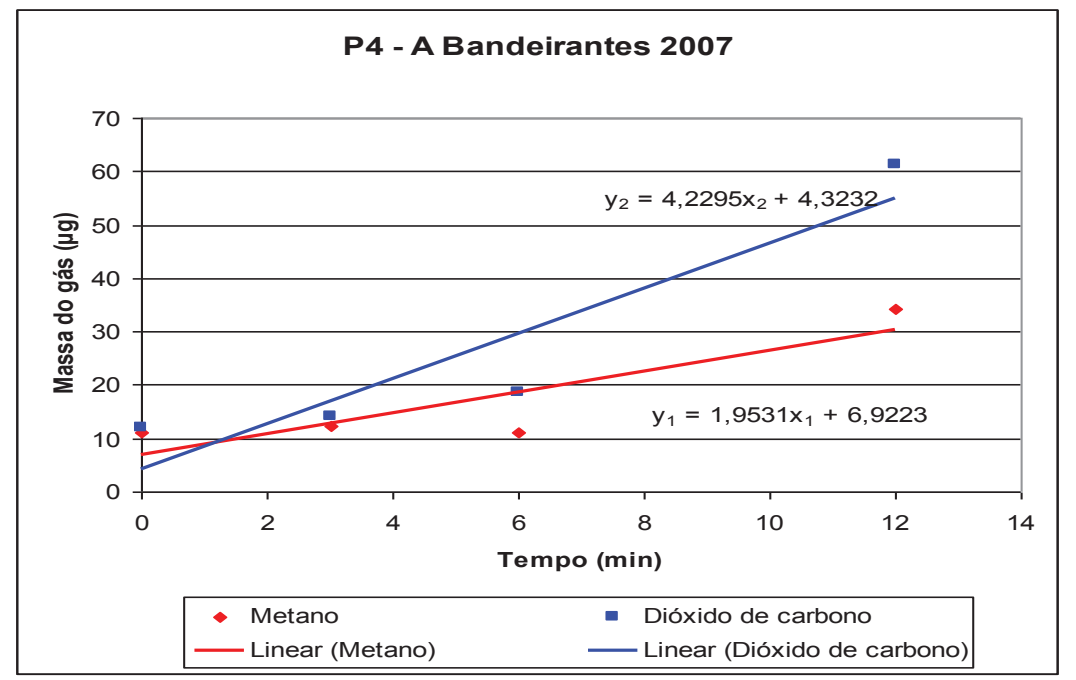

Gráfico 6.5.85 - Sítio $\mathbf{P}_{\mathbf{4}}$ - Bandeirantes 2007. Equações de retas e inclinações para $\mathrm{CH}_{4}$ e $\mathrm{CO}_{2}$.

Equações das retas:

$$
\begin{aligned}
& y_{1}=1,9531 x_{1}+6,9223 \text { Equação do metano } \\
& y_{2}=4,2295 x_{2}+4,3232 \text { Equação do dióxido }
\end{aligned}
$$

b) Cálculo da taxa de emissão:

b) Metano: $\quad \operatorname{Tx} E\left(\mathrm{CH}_{4}\right)=\frac{1,9531 \mu \mathrm{g}\left(\mathrm{CH}_{4}\right) \times 1.200 \mathrm{~mL} \times 1440 \mathrm{~min} \times \mathrm{g}}{\mathrm{mL} \times \min \times 0,01815 \mathrm{~m}^{2} \times \operatorname{dia} \times 10^{6} \mu \mathrm{g}}$

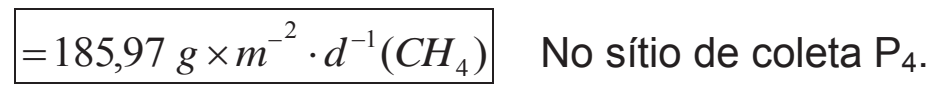

b) Dióxido de carbono: $\operatorname{Tx} E\left(\mathrm{CO}_{2}\right)=\frac{4,2295 \mu \mathrm{g}\left(\mathrm{CO}_{2}\right) \times 1.200 \mathrm{~mL} \times 1440 \mathrm{~min} \times \mathrm{g}}{\mathrm{mL} \times \min \times 0,01815 \mathrm{~m}^{2} \times \operatorname{dia} \times 10^{6} \mu \mathrm{g}}$

$$
=402,67{\mathrm{~g} \times \mathrm{m}^{-2} \cdot \mathrm{d}^{-1}\left(\mathrm{CO}_{2}\right)} \text { No sítio de coleta } \mathrm{P}_{4} \text {. }
$$


$\mathbf{P}_{5}\left(\mathrm{G} ; \mathrm{V}_{\mathrm{G}}=33.200 \mathrm{~mL} ; \mathrm{A}_{\mathrm{G}}=0,664 \mathrm{~m}^{2}\right)$

a) Tabela com tempos de coleta e massas correspondentes, gráfico com equações de retas e inclinações:

Tabela 6.5.100 - Sítio de coleta $\mathbf{P}_{\mathbf{5}}$ - Bandeirantes 2007: tempos de coleta e massas $(\mu g)$ para $\mathrm{CH}_{4}$ e $\mathrm{CO}_{2}$.

\begin{tabular}{ccc}
\hline Tempo (min) & Massa do $\mathrm{CH}_{4}(\mu \mathrm{g})$ & Massa do $\mathrm{CO}_{2}(\mu \mathrm{g})$ \\
\hline 0 & 11,0062 & 13,7900 \\
3 & 11,1111 & 12,0136 \\
6 & 37,5455 & 67,3688 \\
12 & 34,6612 & 60,6852 \\
\hline
\end{tabular}

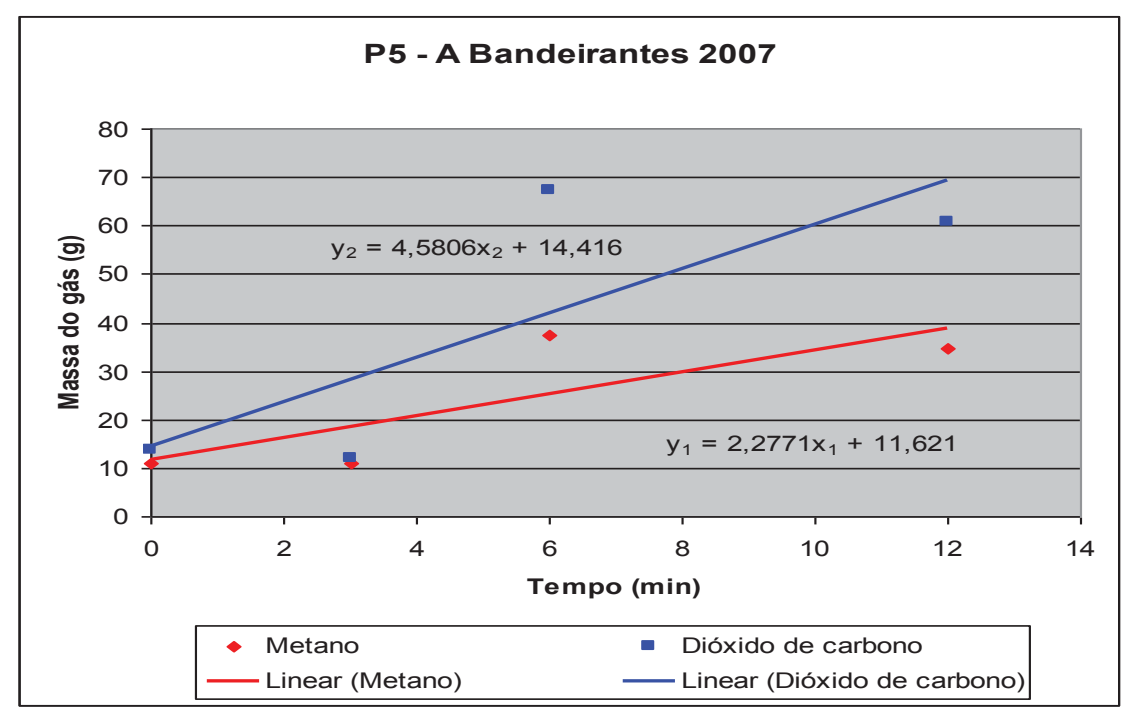

Gráfico 6.5.86 - Sítio $\mathbf{P}_{\mathbf{5}}$ - Bandeirantes 2007. Equações de retas e inclinações para $\mathrm{CH}_{4} \mathrm{e} \mathrm{CO}_{2}$.

Equações das retas:

$$
\begin{aligned}
& y_{1}=2,2771 x_{1}+11,621 \text { Equação do metano } \\
& y_{2}=4,5806 x_{2}+14,416 \text { Equação do dióxido }
\end{aligned}
$$


b) Cálculo da taxa de emissão:

$\left.b_{1}\right)$ Metano:

$$
\begin{gathered}
\operatorname{TxE}\left(\mathrm{CH}_{4}\right)=\frac{2,2771 \mu \mathrm{g}\left(\mathrm{CH}_{4}\right) \times 33.200 \mathrm{~mL} \times 1440 \mathrm{~min} \times \mathrm{g}}{\mathrm{mL} \times \min \times 0,664 \mathrm{~m}^{2} \times \operatorname{dia} \times 10^{6} \mu \mathrm{g}} \\
=163,95 \mathrm{~g} \times \mathrm{m}^{-2} \cdot \mathrm{d}^{-1}\left(\mathrm{CH}_{4}\right) \quad \text { No sítio de coleta } \mathrm{P}_{5} .
\end{gathered}
$$

$\mathrm{b}_{2}$ ) Dióxido de carbono: $\operatorname{Tx} E\left(\mathrm{CO}_{2}\right)=\frac{4,5806 \mu \mathrm{g}\left(\mathrm{CO}_{2}\right) \times 33.200 \mathrm{~mL} \times 1440 \mathrm{~min} \times \mathrm{g}}{\mathrm{mL} \times \min \times 0,664 \mathrm{~m}^{2} \times \operatorname{dia} \times 10^{6} \mu \mathrm{g}}$

$$
=329,80 \mathrm{~g} \times \mathrm{m}^{-2} \cdot \mathrm{d}^{-1}\left(\mathrm{CO}_{2}\right) \quad \text { No sítio de coleta } \mathrm{P}_{5} \text {. }
$$

$\mathbf{P}_{6}\left(\mathrm{G} ; \mathrm{V}_{\mathrm{G}}=33.200 \mathrm{~mL} ; \mathrm{A}_{\mathrm{G}}=0,664 \mathrm{~m}^{2}\right)$

a) Tabela com tempos de coleta e massas correspondentes, gráfico com equações de retas e inclinações:

Tabela 6.5.101 - Sítio de coleta $\mathbf{P}_{6}$ - Bandeirantes 2007: tempos de coleta e massas $(\mu \mathrm{g})$ para $\mathrm{CH}_{4}$ e $\mathrm{CO}_{2}$.

\begin{tabular}{ccc}
\hline Tempo (min) & Massa do $\mathrm{CH}_{4}(\mu \mathrm{g})$ & Massa do $\mathrm{CO}_{2}(\mu \mathrm{g})$ \\
\hline 0 & 10,8657 & 10,8464 \\
3 & 28,6181 & 46,7235 \\
6 & 33,5864 & 71,4970 \\
12 & 23,5586 & 37,0853 \\
\hline
\end{tabular}




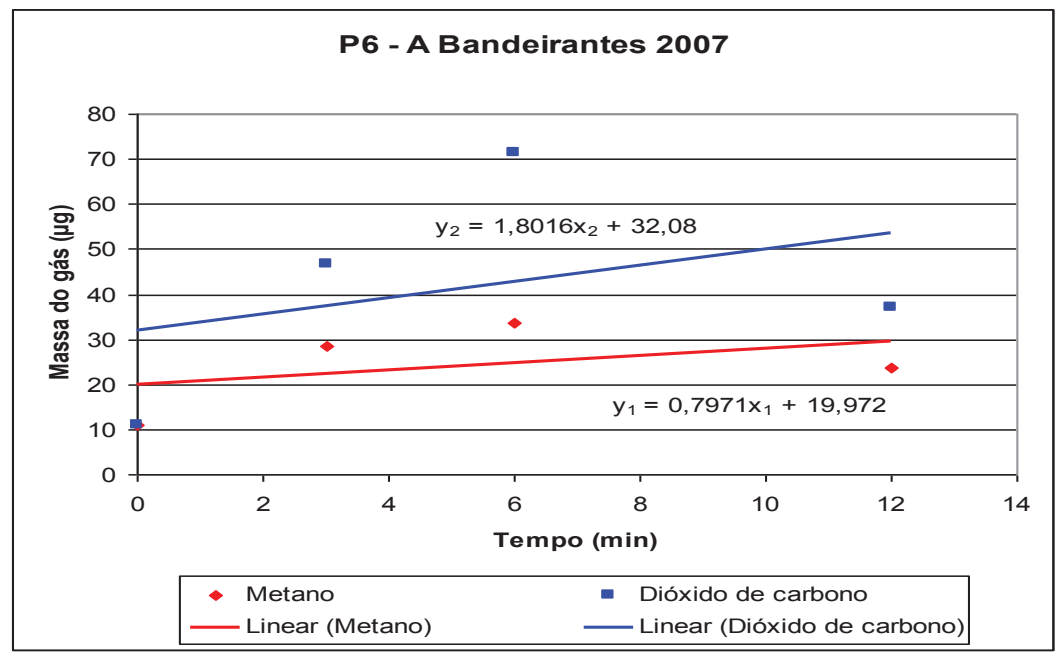

Gráfico 6.5.87 - Sítio $\mathbf{P}_{6}$ - Bandeirantes 2007. Equações de retas e inclinações para $\mathrm{CH}_{4}$ e $\mathrm{CO}_{2}$.

Equações das retas:

$$
\begin{aligned}
& y_{1}=0,7971 x_{1}+19,972 \text { Equação do metano } \\
& y_{2}=1,8016 x_{2}+32,08 \quad \text { Equação do dióxido }
\end{aligned}
$$

b) Cálculo da taxa de emissão:

b 1) Metano: $\quad \operatorname{Tx} E\left(\mathrm{CH}_{4}\right)=\frac{0,7971 \mu \mathrm{g}\left(\mathrm{CH}_{4}\right) \times 33.200 \mathrm{~mL} \times 1440 \mathrm{~min} \times \mathrm{g}}{\mathrm{mL} \times \min \times 0,664 \mathrm{~m}^{2} \times \operatorname{dial0}^{6} \mu \mathrm{g}}$

$=57,50 \mathrm{~g} \times \mathrm{m}^{-2} \cdot \mathrm{d}^{-1}\left(\mathrm{CH}_{4}\right) \quad$ No sítio de coleta $\mathrm{P}_{6}$.

$\mathrm{b}_{2}$ ) Dióxido de carbono: $\operatorname{TxE}\left(\mathrm{CO}_{2}\right)=\frac{1,8016 \mu \mathrm{g}\left(\mathrm{CO}_{2}\right) \times 33.200 \mathrm{~mL} \times 1440 \mathrm{~min} \times g}{\mathrm{~mL} \times \min \times 0,664 \mathrm{~m}^{2} \times \operatorname{dia} \times 10^{6} \mu \mathrm{g}}$ $=129,72 \mathrm{mg} \times \mathrm{m}^{-2} \cdot \mathrm{d}^{-1}\left(\mathrm{CO}_{2}\right) \quad$ No sítio de coleta $\mathrm{P}_{6}$. 
$\mathbf{P}_{7}\left(\mathrm{G} ; \mathrm{V}_{\mathrm{G}}=33.200 \mathrm{~mL} ; \mathrm{A}_{\mathrm{G}}=0,664 \mathrm{~m}^{2}\right)$

a) Tabela com tempos de coleta e massas correspondentes, gráfico com equações de retas e inclinações:

Tabela 6.5.102 - Sítio de coleta $\mathbf{P}_{\mathbf{7}}$ - Bandeirantes 2007: tempos de coleta e massas $(\mu g)$ para $\mathrm{CH}_{4}$ e $\mathrm{CO}_{2}$.

\begin{tabular}{ccc}
\hline Tempo (min) & Massa do $\mathrm{CH}_{\mathbf{4}}(\mu \mathrm{g})$ & Massa do $\mathrm{CO}_{2}(\mu \mathrm{g})$ \\
\hline 0 & 10,9131 & 10,0847 \\
3 & 28,1026 & 45,2130 \\
6 & 44,3915 & 79,1376 \\
12 & 11,2763 & 11,4793 \\
\hline
\end{tabular}

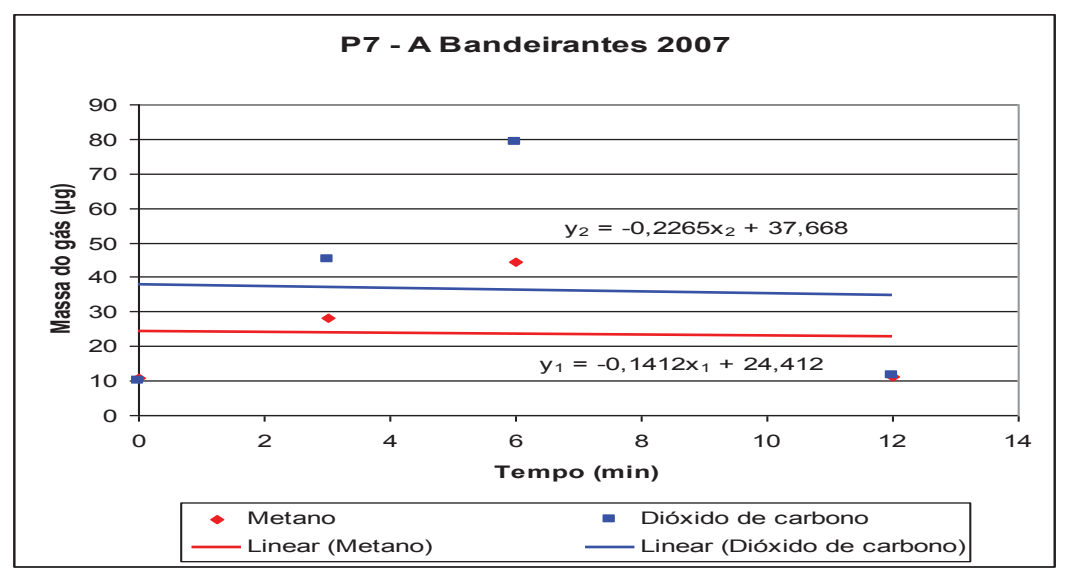

Gráfico 6.5.88 - Sítio $\mathbf{P}_{7}$ - Bandeirantes 2007. Equações de retas e inclinações para $\mathrm{CH}_{4}$ e $\mathrm{CO}_{2}$.

Equações das retas:

$$
\begin{aligned}
& y_{1}=-0,1412 x_{1}+24,412 \quad \text { Equação do metano } \\
& y_{2}=-0,2265 x_{2}+37,665 \quad \text { Equação do dióxido }
\end{aligned}
$$

b) Cálculo da taxa de emissão:

b $)$ Metano: $\quad \operatorname{Tx} E\left(\mathrm{CH}_{4}\right)=\frac{0,1412 \mu \mathrm{g}\left(\mathrm{CH}_{4}\right) \times 33.200 \mathrm{~mL} \times 1440 \mathrm{~min} \times \mathrm{g}}{\mathrm{mL} \times \min \times 0,664 \mathrm{~m}^{2} \times \operatorname{dia} \times 10^{6} \mu \mathrm{g}}$ 


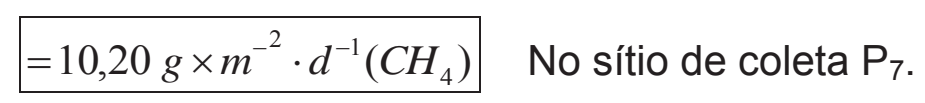

$b_{2}$ ) Dióxido de carbono: $\operatorname{TxE}\left(\mathrm{CO}_{2}\right)=\frac{0,2265 \mu \mathrm{g}\left(\mathrm{CO}_{2}\right) \times 33.200 \mathrm{~mL} \times 1440 \mathrm{~min} \times \mathrm{g}}{\mathrm{mL} \times \min \times 0,664 \mathrm{~m}^{2} \times \operatorname{dia} \times 10^{6} \mu \mathrm{g}}$

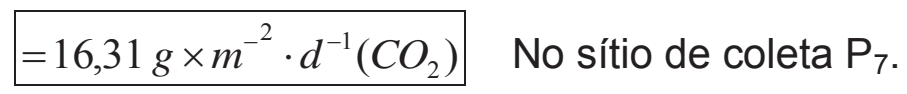

Obs.: O sinal negativo significa que na coleta houve uma reabsorção do GAS pelo aterro

$\mathbf{P}_{8}\left(p ; V_{P}=1.200 m L ; A_{P}=0,01815 m^{2}\right)$

a) Tabela com tempos de coleta e massas correspondentes, gráfico com equações de retas e inclinações:

Tabela 6.5.103 - Sítio de coleta $\mathbf{P}_{\mathbf{8}}$ - Bandeirantes 2007: tempos de coleta e massas $(\mu g)$ para $\mathrm{CH}_{4}$ e $\mathrm{CO}_{2}$.

\begin{tabular}{ccc}
\hline Tempo $(\boldsymbol{m i n})$ & Massa do $\mathrm{CH}_{4}(\mu \mathrm{g})$ & Massa do $\mathrm{CO}_{2}(\mu \mathrm{g})$ \\
\hline 0 & 10,6458 & 9,7907 \\
3 & 10,7982 & 10,9987 \\
6 & 24,6417 & 40,3767 \\
12 & 12,0208 & 10,5524 \\
\hline
\end{tabular}




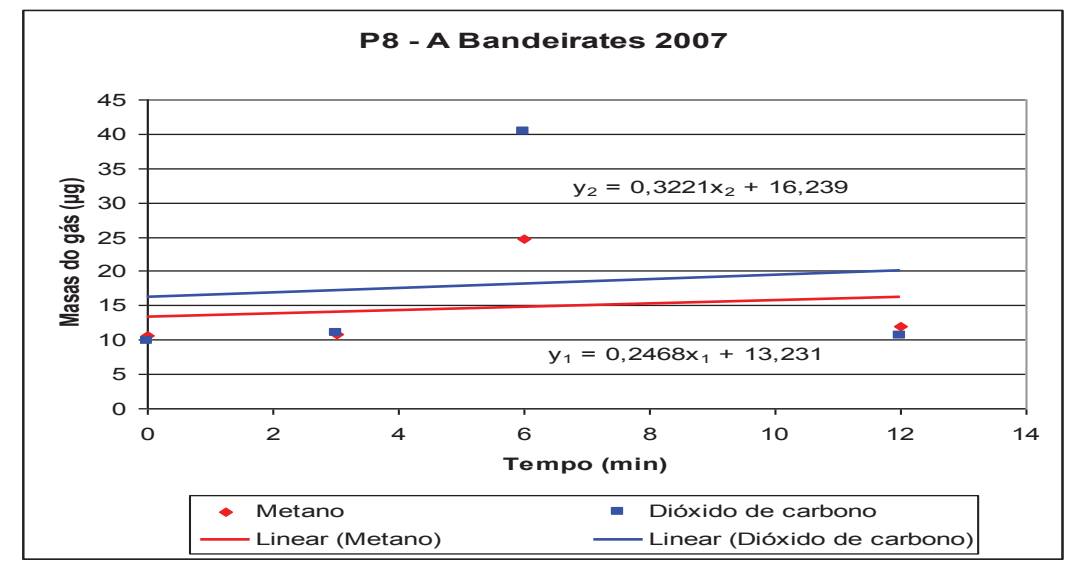

Gráfico 6.5.89 - Sítio $\mathbf{P}_{\mathbf{8}}$ - Bandeirantes 2007. Equações de retas e inclinações para $\mathrm{CH}_{4}$ e $\mathrm{CO}_{2}$.

Equações das retas:

$$
\begin{aligned}
& y_{1}=0,2468 x_{1}+13,231 \text { Equação do metano } \\
& y_{2}=0,3221 x_{2}+16,239 \text { Equação do dióxido }
\end{aligned}
$$

b) Cálculo da taxa de emissão:

$b_{1}$ ) Metano:

$$
\begin{gathered}
\operatorname{TxE}\left(\mathrm{CH}_{4}\right)=\frac{0,2468 \mu \mathrm{g}\left(\mathrm{CH}_{4}\right) \times 1.200 \mathrm{~mL} \times 1440 \mathrm{~min} \times \mathrm{g}}{\mathrm{mL} \times \min \times 0,01815 \mathrm{~m}^{2} \times \operatorname{dia} \times 10^{6} \mu \mathrm{g}} \\
=23,50 \mathrm{~g} \times \mathrm{m}^{-2} \cdot \mathrm{d}^{-1}\left(\mathrm{CH}_{4}\right) \quad \text { No sítio de coleta } \mathrm{P}_{8} .
\end{gathered}
$$

$\mathrm{b}_{2}$ ) Dióxido de carbono: $\operatorname{Tx} E\left(\mathrm{CO}_{2}\right)=\frac{0,3221 \mu \mathrm{g}\left(\mathrm{CO}_{2}\right) \times 1.200 \mathrm{~mL} \times 1440 \mathrm{~min} \times \mathrm{g}}{\mathrm{mL} \times \min \times 0,01815 \mathrm{~m}^{2} \times \operatorname{dia} \times 10^{6} \mu \mathrm{g}}$

$$
=30,66 \mathrm{~g} \times \mathrm{m}^{-2} \cdot \mathrm{d}^{-1}\left(\mathrm{CO}_{2}\right) \quad \text { No sítio de coleta } \mathrm{P}_{8} \text {. }
$$


$P_{9}\left(p ; V_{P}=1.200 m L ; A_{P}=0,01815 m^{2}\right)$

a) Tabela com tempos de coleta e massas correspondentes, gráfico com equações de retas e inclinações:

Tabela 6.5.104 - Sítio de coleta $\mathbf{P}_{\mathbf{9}}$ - Bandeirantes 2007: tempos de coleta e massas $(\mu \mathrm{g})$ para $\mathrm{CH}_{4}$ e $\mathrm{CO}_{2}$.

\begin{tabular}{ccc}
\hline Tempo $(\boldsymbol{m i n})$ & Massa do $\mathrm{CH}_{4}(\mu \mathrm{g})$ & Massa do $\mathrm{CO}_{2}(\mu \mathrm{g})$ \\
\hline 0 & 11,0080 & 10,3830 \\
3 & 18,0813 & 26,4408 \\
6 & 18,8532 & 27,2519 \\
12 & 24,1371 & 39,2395 \\
\hline
\end{tabular}

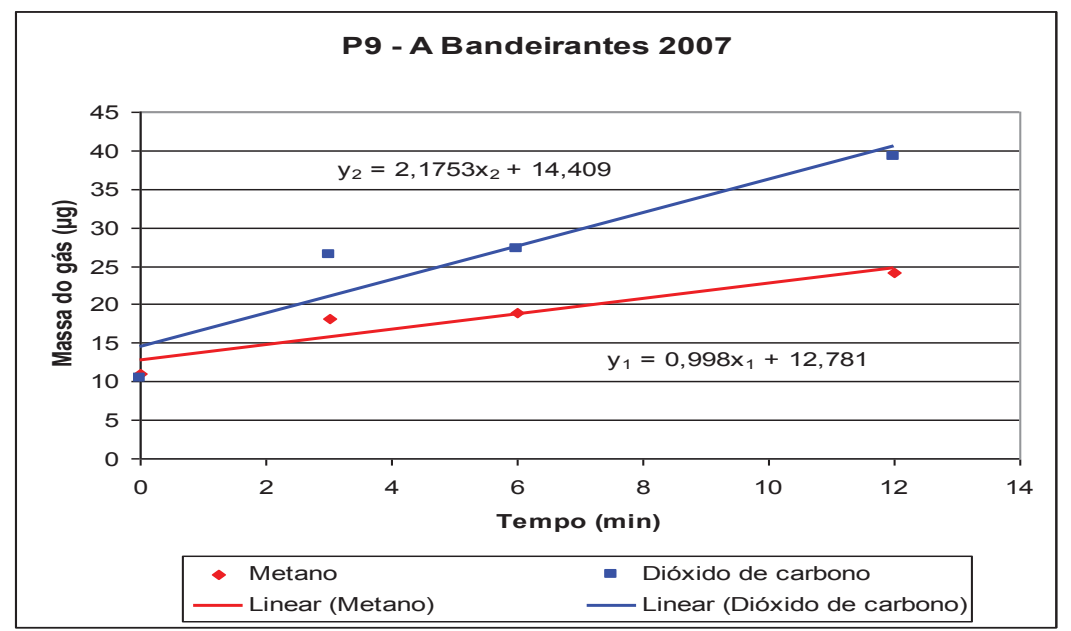

Gráfico 6.5.90 - Sítio $\mathbf{P}_{\mathbf{9}}$ - Bandeirantes 2007. Equações de retas e inclinações para $\mathrm{CH}_{4}$ e $\mathrm{CO}_{2}$.

Equações das retas:

$$
\begin{aligned}
& y_{1}=0,998 x_{1}+12,781 \text { Equação do metano } \\
& y_{2}=2,1753 x_{2}+14,409 \text { Equação do dióxido }
\end{aligned}
$$

b) Cálculo da taxa de emissão:

$b_{1}$ ) Metano:

$$
\operatorname{TxE}\left(\mathrm{CH}_{4}\right)=\frac{0,998 \mu \mathrm{g}\left(\mathrm{CH}_{4}\right) \times 1.200 \mathrm{~mL} \times 1440 \mathrm{~min} \times \mathrm{g}}{\mathrm{mL} \times \min \times 0,01815 \mathrm{~m}^{2} \times \operatorname{dia} \times 10^{6} \mu \mathrm{g}}
$$




$$
=95,05 \mathrm{~g} \times \mathrm{m}^{-2} \cdot \mathrm{d}^{-1}\left(\mathrm{CH}_{4}\right) \quad \text { No sítio de coleta } \mathrm{P}_{9} \text {. }
$$

$\mathrm{b}_{2}$ ) Dióxido de carbono: $\operatorname{Tx} E\left(\mathrm{CO}_{2}\right)=\frac{2,1753 \mu \mathrm{g}\left(\mathrm{CO}_{2}\right) \times 1.200 \mathrm{~mL} \times 1440 \mathrm{~min} \times \mathrm{g}}{\mathrm{mL} \times \min \times 0,01815 \mathrm{~m}^{2} \times \operatorname{dia} \times 10^{6} \mu \mathrm{g}}$

$$
=207,10 \mathrm{~g} \times \mathrm{m}^{-2} \cdot \mathrm{d}^{-1}\left(\mathrm{CO}_{2}\right) \quad \text { No sítio d coleta } \mathrm{P}_{9} \text {. }
$$

$\mathbf{P}_{10}\left(\mathrm{G} ; \mathrm{V}_{\mathrm{G}}=33.200 \mathrm{~mL} ; \mathrm{A}_{\mathrm{G}}=0,664 \mathrm{~m}^{2}\right)$

a) Tabela com tempos de coleta e massas correspondentes, gráfico com equações de retas e inclinações:

Tabela 6.5.105 - Sítio de coleta $\mathbf{P}_{\mathbf{1 0}}$ - Bandeirantes 2007: tempos de coleta e massas $(\mu g)$ para $\mathrm{CH}_{4}$ e $\mathrm{CO}_{2}$.

\begin{tabular}{ccc}
\hline Tempo (min) & Massa do $\mathrm{CH}_{\mathbf{4}}(\mu \mathrm{g})$ & Massa do $\mathrm{CO}_{\mathbf{2}}(\mu \mathrm{g})$ \\
\hline 0 & 11,1467 & 11,0073 \\
3 & 13,0583 & 14,3460 \\
6 & 40,5510 & 74,0224 \\
12 & 18,0813 & 25,9666 \\
\hline
\end{tabular}

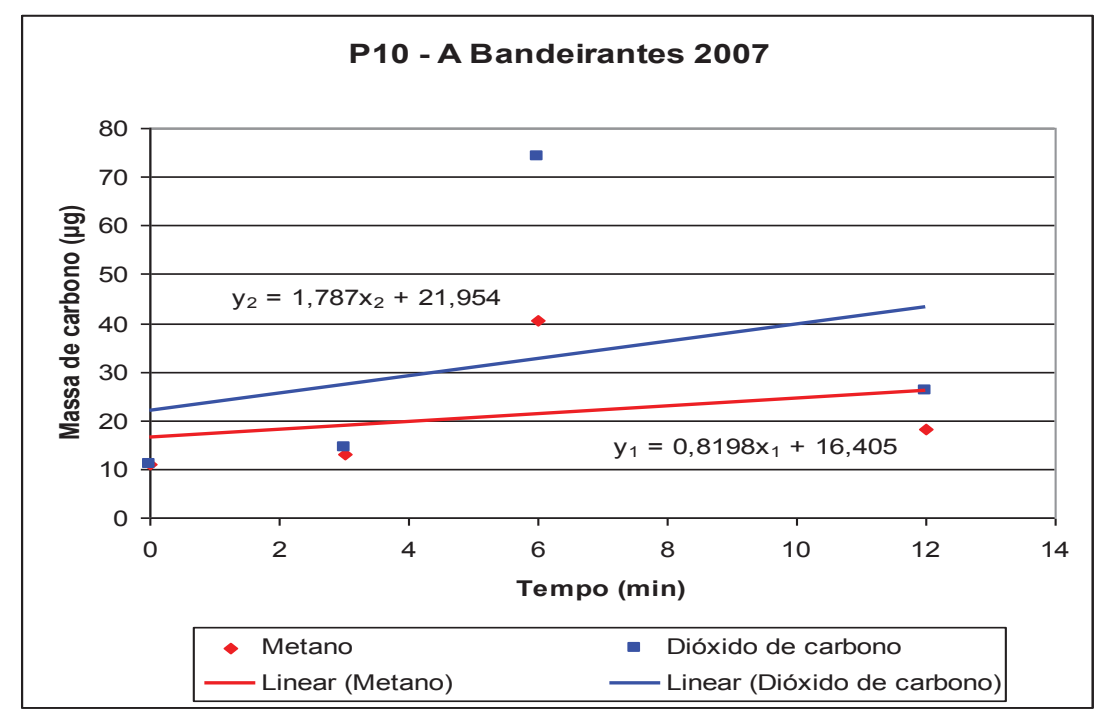

Gráfico 6.5.91 - Sítio $\mathbf{P}_{10}$ - Bandeirantes 2007. Equações de retas e inclinações para $\mathrm{CH}_{4}$ e $\mathrm{CO}_{2}$. 
Equações das retas:

$$
\begin{aligned}
& y_{1}=0,8198 x_{1}+16,405 \text { Equação do metano } \\
& y_{2}=1,787 x_{2}+21,954 \text { Equação do dióxido }
\end{aligned}
$$

b) Cálculo da taxa de emissão:

$\left.b_{1}\right)$ Metano:

$$
\begin{gathered}
\operatorname{Tx} E\left(\mathrm{CH}_{4}\right)=\frac{0,8198 \mu \mathrm{g}\left(\mathrm{CH}_{4}\right) \times 33.200 \mathrm{~mL} \times 1440 \mathrm{~min} \times \mathrm{g}}{\mathrm{mL} \times \min \times 0,664 \mathrm{~m}^{2} \times \operatorname{dia} \times 10^{6} \mu \mathrm{g}} \\
=591,02 \mathrm{~g} \times \mathrm{m}^{-2} \cdot \mathrm{d}^{-1}\left(\mathrm{CH}_{4}\right) \quad \text { No sítio de coleta } \mathrm{P}_{10} .
\end{gathered}
$$

$\mathrm{b}_{2}$ ) Dióxido de carbono: $\operatorname{Tx} E\left(\mathrm{CO}_{2}\right)=\frac{1,787 \mu g\left(\mathrm{CO}_{2}\right) \times 33.200 \mathrm{~mL} \times 1440 \mathrm{~min} \times \mathrm{g}}{\mathrm{mL} \times \min \times 0,664 \mathrm{~m}^{2} \times \operatorname{dia} \times 10^{6} \mu \mathrm{g}}$

$$
=128,66 \mathrm{~g} \times \mathrm{m}^{-2} \cdot \mathrm{d}^{-1}\left(\mathrm{CO}_{2}\right) \text { No sítio de coleta } \mathrm{P}_{10} \text {. }
$$

$\mathbf{P}_{11}\left(\mathrm{G} ; \mathrm{V}_{\mathrm{G}}=33.200 \mathrm{~mL} ; \mathrm{A}_{\mathrm{G}}=0,664 \mathrm{~m}^{2}\right)$

a) Tabela com tempos de coleta e massas correspondentes, gráfico com equações de retas e inclinações:

Tabela 6.5.106 - Sítio de coleta $\mathbf{P}_{\mathbf{1 1}}$ - Bandeirantes 2007: tempos de coleta e massas $(\mu \mathrm{g})$ para $\mathrm{CH}_{4}$ e $\mathrm{CO}_{2}$.

\begin{tabular}{ccc}
\hline Tempo $(\boldsymbol{m i n})$ & Massa do $\mathrm{CH}_{4}(\boldsymbol{\mu} \boldsymbol{g})$ & Massa do $\mathrm{CO}_{2}(\boldsymbol{\mu} \boldsymbol{g})$ \\
\hline 0 & 10,8292 & 10,7326 \\
3 & 10,9797 & 13,4254 \\
6 & 10,7900 & 14,4961 \\
12 & 16,1058 & 36,8300 \\
\hline
\end{tabular}




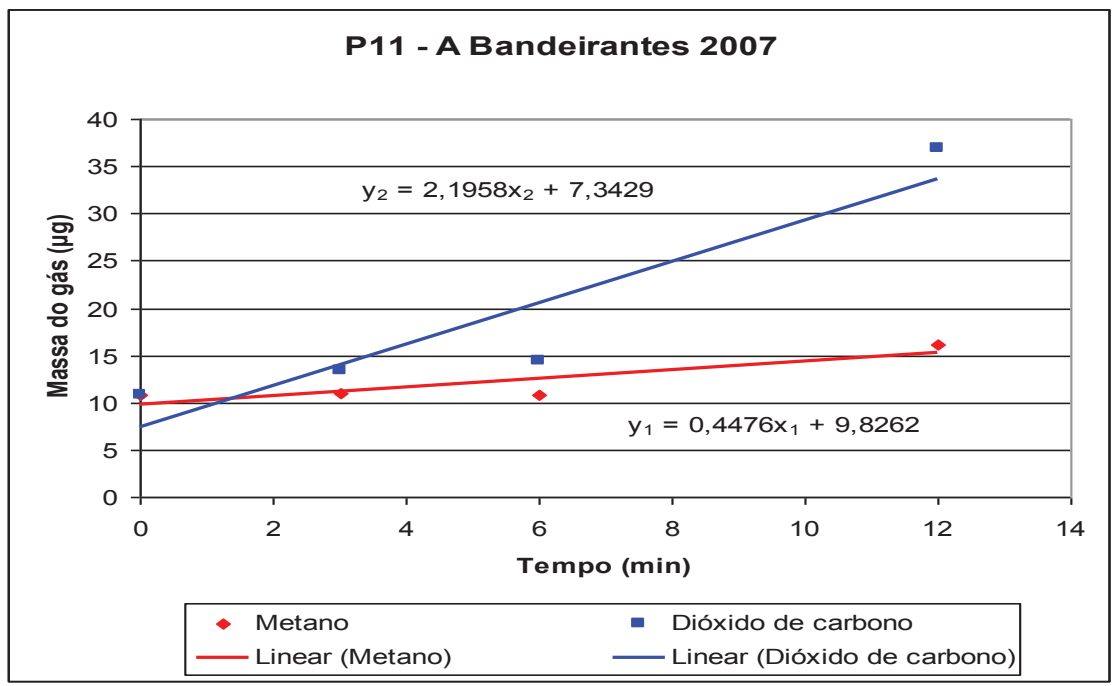

Gráfico 6.5.92 - Sítio $\mathbf{P}_{\mathbf{1 1}}$ - Bandeirantes 2007. Equações de retas e inclinações para $\mathrm{CH}_{4}$ e $\mathrm{CO}_{2}$.

Equações das retas:

$$
\begin{aligned}
& y_{1}=0,4476 x_{1}+9,8262 \text { Equação do metano } \\
& y_{2}=2,1958 x_{2}+7,3429 \quad \text { Equação do dióxido }
\end{aligned}
$$

b) Cálculo da taxa de emissão:

$\left.b_{1}\right)$ Metano:

$$
\mathrm{TxE}\left(\mathrm{CH}_{4}\right)=\frac{0,4476 \mu g\left(\mathrm{CH}_{4}\right) \times 33.200 \mathrm{~mL} \times 1440 \mathrm{~min} \times g}{m L \times \min \times 0,664 \mathrm{~m}^{2} \times \operatorname{dia} \times 10^{6} \mu \mathrm{g}}
$$

$$
=32,23 \mathrm{~g} \times \mathrm{m}^{-2} \cdot \mathrm{d}^{-1}\left(\mathrm{CH}_{4}\right) \text { No sítio de coleta } \mathrm{P}_{11} \text {. }
$$

$\mathrm{b}_{2}$ ) Dióxido de carbono: $\operatorname{Tx} E\left(C \mathrm{CO}_{2}\right)=\frac{2,1958 \mu \mathrm{g}\left(\mathrm{CO}_{2}\right) \times 33.200 \mathrm{~mL} \times 1440 \mathrm{~min} \times \mathrm{g}}{\mathrm{mL} \times \min \times 0,664 \mathrm{~m}^{2} \times \operatorname{dia} \times 10^{6} \mu \mathrm{g}}$

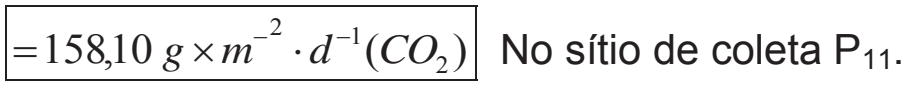


Aterro Bandeirantes - Emissão solo-ar campanha 2007:

A tabela 6.5.107, resume as taxas de emissão solo-ar, medidas para $\mathrm{CH}_{4}$ e $\mathrm{CO}_{2}$, em cada sítio $\mathbf{P}_{\mathbf{n}}$ do aterro Bandeirantes, na campanha de 2007.

Tabela 6.5.107 - Resumo as taxas de emissão solo-ar - Bandeirantes 2007

\begin{tabular}{|c|c|c|}
\hline Sítio amostrado & Gás & $\mathrm{T}_{\mathrm{x}} \mathrm{E}\left(m g \cdot m^{-2} \cdot d^{-1}\right)$ \\
\hline \multirow{2}{*}{$\mathrm{P}_{1}$} & $\mathrm{CH}_{4}$ & 81,16 \\
\hline & $\mathrm{CO}_{2}$ & 235,90 \\
\hline \multirow{2}{*}{$\mathrm{P}_{2}$} & $\mathrm{CH}_{4}$ & 251,66 \\
\hline & $\mathrm{CO}_{2}$ & 487,45 \\
\hline \multirow{2}{*}{$\mathrm{P}_{3}$} & $\mathrm{CH}_{4}$ & 136,46 \\
\hline & $\mathrm{CO}_{2}$ & 12,97 \\
\hline \multirow{2}{*}{$\mathrm{P}_{4}$} & $\mathrm{CH}_{4}$ & 185,97 \\
\hline & $\mathrm{CO}_{2}$ & 402,67 \\
\hline \multirow{2}{*}{$\mathrm{P}_{5}$} & $\mathrm{CH}_{4}$ & 163,95 \\
\hline & $\mathrm{CO}_{2}$ & 329,80 \\
\hline \multirow{2}{*}{$P_{6}$} & $\mathrm{CH}_{4}$ & 57,50 \\
\hline & $\mathrm{CO}_{2}$ & 129,72 \\
\hline \multirow{2}{*}{$\mathrm{P}_{7}$} & $\mathrm{CH}_{4}$ & 10,20 \\
\hline & $\mathrm{CO}_{2}$ & 16,31 \\
\hline \multirow{2}{*}{$\mathrm{P}_{8}$} & $\mathrm{CH}_{4}$ & 23,50 \\
\hline & $\mathrm{CO}_{2}$ & 30,66 \\
\hline \multirow{2}{*}{$\mathrm{P}_{9}$} & $\mathrm{CH}_{4}$ & 95,05 \\
\hline & $\mathrm{CO}_{2}$ & 207,10 \\
\hline \multirow{2}{*}{$P_{10}$} & $\mathrm{CH}_{4}$ & 591,02 \\
\hline & $\mathrm{CO}_{2}$ & 128,66 \\
\hline \multirow{2}{*}{$P_{11}$} & $\mathrm{CH}_{4}$ & 32,23 \\
\hline & $\mathrm{CO}_{2}$ & 158,10 \\
\hline
\end{tabular}


1) Cálculo da taxa de emissão média do Metano $\left(T_{x} E_{m(C H 4)}\right)$ nos sítios $\left(P_{n}\right)$ :

$$
\mathrm{T}_{\mathrm{x}} \mathrm{E}_{\mathrm{m}}\left(\mathrm{CH}_{4}\right)=\left(\mathrm{P}_{1}+\ldots+\mathrm{P}_{11}\right) / 11=148,20 \mathrm{~g} \cdot \mathrm{m}^{-2} \cdot \mathrm{d}^{-1}
$$

2) Taxa de emissão média total do metano $\left(T_{x} E_{m(t)(C H 4)}\right)$ no aterro:

$$
\begin{aligned}
\Rightarrow T_{x} E_{m(t)}\left(C_{4}\right)=T_{x} E_{m}(148,20) \cdot A_{a t}\left(1.400 .000 m^{2}\right) \cdot 365 d \cdot 10^{-6}=t \cdot a^{-1} \\
\Rightarrow T_{x} E_{m(t)}\left(C_{4}\right)=75.730,20 ~ t \cdot a a^{-1}
\end{aligned}
$$

Em que: $T_{x} E_{m}=$ Taxa de Emissão média $\left(\mathrm{mg} \cdot \mathrm{m}^{-2} \cdot \mathrm{d}^{-1}\right)$

$$
\mathrm{A}_{\mathrm{at}}=\text { Área do aterro }\left(\mathrm{m}^{2}\right)
$$

$T_{x} E_{m(t)}=$ Taxa de Emissão média total para $2006\left({\left.\text { Toneladas } \cdot a n o^{-1}\right)}^{-1}\right.$

365 = fator de conversão de dias $p$ ano

$10-6$

$$
=\text { fator de }
$$

conversão de mg para Ton

3)Cálculo da taxa de emissão média do dióxido de carbono $\left(T_{x} E_{m(C O 2)}\right)$ nos sítios $\left(P_{n}\right)$ :

$$
\mathrm{T}_{\mathrm{x}} \mathrm{E}_{\mathrm{m}}\left(\mathrm{CO}_{2}\right)=\left(\mathrm{P}_{1}+\ldots+\mathrm{P}_{11}\right) / 11=149,34 \mathrm{~g} \cdot \mathrm{m}^{-2} \cdot \mathrm{d}^{-1}
$$

3) Cálculo da taxa de emissão média total do dióxido de carbono $\left(T_{x} E_{m(t)(C O 2)}\right)$ no aterro:

$$
\begin{aligned}
& \Rightarrow T_{x} E_{m(t)}\left(C O_{2}\right)=T_{x} E_{m}(149,34) \cdot A_{a t}\left(1.400 .000 m^{2}\right) \cdot 365 d \cdot 10^{-6}=t \cdot a^{-1} \\
& \Rightarrow T_{x} E_{m(t)}\left(C_{2}\right)=\mathbf{7 6 . 3 1 2 , 7 4 ~ t \cdot a - 1}
\end{aligned}
$$




\subsection{Cálculo da emissão dos dissipadores verticais, nos aterros que dispunham de tais:}

Nesta sessão foram desenvolvidos os cálculos para a determinação da emissão ou fluxo estimativo, em toneladas por ano (t. $\left.\mathrm{a}^{-1}\right)$, pelos dissipadores naqueles aterros que dispunham de tais.

Para cada dissipador(D) escolhido, em cada aterro, os cálculos foram feitos considerando: o volume $(\mathrm{V}, \mathrm{mL})$ do GAS coletado e o tempo (min), decorrido para o preenchimento do saco coletor (min) - que forneceram a vazão (v) - e as massas $(\mu \mathrm{g})$ dos dois gases, obtidas da analise cromatográfica (Sessão 6.3).

$\mathrm{Na}$ determinação da massa $\left(\mathrm{M}, \mathrm{t} . \mathrm{a}^{-1}\right)$ emitida de cada gás, foi aplicada a equação:

$$
M_{(D, g) \text { anual }}(\text { gás })=\frac{M(\text { gás; } \mu g) \times v\left(m L . \min ^{-1}\right) \times 1440 \mathrm{~min} \times 365 d \times t}{m L \times d \times 10^{12} \mu g \times a}
$$

Em que: $M_{(D, g) a n u a l}=$ massa anual do gás considerado, emitida pelo dissipador $\left(\mathrm{t} . \mathrm{a}^{-1}\right)$. Os índices $\mathbf{D}$ (dissipador) e $\mathbf{g}$ (gás) específico(1= $\mathrm{CH}_{4}$ e $2=\mathrm{CO}_{2}$ ). $\mathrm{M}=$ massa do gás considerado, obtida da analise cromatográfica $\left(\mu \mathrm{g} \cdot m \mathrm{~L}^{-1}\right)$

v = vazão do GAS em cada dissipador, estimada na coleta: volume coletado no saco pelo tempo de preenchimento - $\mathrm{V}(\mathrm{mL}) / \mathrm{t}(\mathrm{min})$;

e, os fatores de conversão:

1440 min por dia, 
$10^{12}$ conversão de $\mu$ g para toneladas e 365 dias por ano.

\subsection{1 - Aterro de Araraquara}

\section{A 1 Campanha 2006}

\section{1) Dissipador $\left(D_{1}\right)$}

$\left(\mathrm{V}=50 \mathrm{~L} ; \mathrm{t}=2,00 \mathrm{~min}\right.$; massas cromatográficas: $\mathrm{CH}_{4}=58,0781 \mu \mathrm{g}$ e $\left.\mathrm{CO}_{2}=110,7730 \mu \mathrm{g}\right)$

a) Vazão(v) $=50 L / 2,00 \mathrm{~min} \Rightarrow v=\underline{25,00 L \cdot \mathrm{min}^{-1} \text { do GAS. }}$.

1) Cálculo para a emissão $\mathrm{CH}_{4}$ no dissipador:

$$
\begin{aligned}
& \text { Equação: } \quad M_{(1.1) \text { anual }}\left(\mathrm{CH}_{4}\right)=\frac{M\left(\mathrm{CH}_{4} ; \mu g\right) \times V(\mathrm{~mL}) \times 1440 \mathrm{~min} \times 365 d \times t}{m L \times \min \times d \times 10^{-12} \mu g \times a} \\
& M_{(1.1)_{\text {anual }}}\left(\mathrm{CH}_{4}\right)=\frac{58,0781 \mu g\left(\mathrm{CH}_{4}\right) \times 25.000 \mathrm{~mL} \times 1440 \mathrm{~min} \times 365 \mathrm{~d} \times t}{\mathrm{~mL} \times \min \times d \times 10^{12} \mu g \times a} \\
& \mathrm{M}_{(1.1) \text { anual }}\left(\mathrm{CH}_{4}\right)=\underline{\mathbf{0 , 7 6 3 t} \cdot \mathbf{a}^{-1}}\left(\mathrm{CH}_{4}\right)
\end{aligned}
$$

2) Cálculo para a emissão de $\mathrm{CO}_{2}$ no dissipador:

$$
\text { Equação: } \quad \begin{aligned}
M_{(1.2)_{\text {anual }}}\left(\mathrm{CO}_{2}\right)=\frac{M\left(C \mathrm{C}_{2} ; \mu \mathrm{g}\right) \times V(\mathrm{~mL}) \times 1440 \mathrm{~min} \times 365 \mathrm{~d} \times t}{\mathrm{~mL} \times \min \times d \times 10^{12} \mu \mathrm{g} \times a} \\
M_{(1.2)_{\text {anual }}}\left(\mathrm{CO}_{2}\right)=\frac{110,773 \mu g\left(\mathrm{CO}_{2}\right) \times 25.000 \mathrm{~mL} \times 1440 \mathrm{~min} \times 365 \mathrm{~d} \times t}{\mathrm{~mL} \times \mathrm{min} \times d \times 10^{12} \mu \mathrm{g} \times a} \\
\mathrm{M}_{(1.2)_{\text {anual }}}\left(\mathrm{CO}_{2}\right)=\underline{\mathbf{1 , 4 5 5} t \cdot \mathrm{a}^{-1}}\left(\mathrm{CO}_{2}\right)
\end{aligned}
$$

Em que:

$$
\begin{aligned}
& M_{(1.1) \text { anual }}\left(\mathrm{CH}_{4}\right)=\text { Massa anual de metano emitida pelo } D_{1}\left(t \cdot a^{-1}\right) \\
& M_{(1.2) \text { anual }}\left(\mathrm{CO}_{2}\right)=\text { Massa anual de dióxido emitida pelo } D_{1}\left(\mathrm{t} \cdot a^{-1}\right)
\end{aligned}
$$


2) $D_{2}$

(40L em 1,50min; M. cromatográficas: $\mathrm{CH}_{4}=71,7702 \mu \mathrm{g} \mathrm{e} \mathrm{CO}_{2}=122,6167 \mu \mathrm{g}$ )

a) $v=60 L / 1,02 \min \Rightarrow v=\underline{58.823,52 \mathrm{~mL} \cdot \mathrm{min}^{-1} \text { de GAS. }}$

Então; para o dreno 2, temos:

1) $M_{(2.1)_{\text {anual }}}\left(\mathrm{CH}_{4}\right)=\frac{71,7702 \mu \mathrm{g}\left(\mathrm{CH}_{4}\right) \times 58.823,52 \mathrm{~mL} \times 1440 \mathrm{~min} \times 365 \mathrm{~d} \times t}{\mathrm{~mL} \times \min \times d \times 10^{12} \mu \mathrm{g} \times a}$

$$
\mathrm{M}_{(2.1) \text { anual }}\left(\mathrm{CH}_{4}\right)=\underline{\mathbf{2 , 2 1 9} t \cdot a^{-1}}\left(\mathrm{CH}_{4}\right)
$$

2) $M_{(2.2)_{\text {anual }}}\left(\mathrm{CO}_{2}\right)=\frac{122,6167 \mu \mathrm{g}\left(\mathrm{CO}_{2}\right) \times 58.823,52 \mathrm{~mL} \times 1440 \mathrm{~min} \times 365 \mathrm{~d} \times t}{\mathrm{~mL} \times \min \times d \times 10^{-12} \mu \mathrm{g} \times a}$

$$
\mathrm{M}_{(2.2) \text { anual }}\left(\mathrm{CO}_{2}\right)=\underline{\mathbf{3 , 7 9 1} t \cdot \mathrm{a}^{-1}}\left(\mathrm{CO}_{2}\right)
$$

3) $D_{3}$

(50L em 1,60min; M. cromatográficas: $\mathrm{CH}_{4}=145,6390 \mu$ e $\mathrm{CO}_{2}=310,5035 \mu \mathrm{g}$.)

a) $V=50 L / 1,60 \min \Rightarrow V=\underline{31,25 L \cdot \min ^{-1} \text { de GAS. }}$

1) $M_{(3.1)_{\text {anual }}}\left(\mathrm{CH}_{4}\right)=\frac{145,6390 \mu \mathrm{g}\left(\mathrm{CH}_{4}\right) \times 31.250 \mathrm{~mL} \times 1440 \mathrm{~min} \times 365 d \times t}{m L \times \min \times d \times 10^{12} \mu \mathrm{g} \times a}$

$\mathrm{M}_{(3.1) \text { anual }}\left(\mathrm{CH}_{4}\right)=\underline{\mathbf{2 , 3 9 2} t \cdot \mathrm{a}^{-1}}\left(\mathrm{CH}_{4}\right)$

2) $M_{(3.2)_{\text {anual }}}\left(\mathrm{CO}_{2}\right)=\frac{310,5035 \mu \mathrm{g}\left(\mathrm{CO}_{2}\right) \times 31.250 \mathrm{~mL} \times 1440 \mathrm{~min} \times 365 \mathrm{~d} \times t}{\mathrm{~mL} \times \min \times d \times 10^{-12} \mu \mathrm{g} \times a}$

$\mathrm{M}_{(3.2) \text { anual }}\left(\mathrm{CO}_{2}\right)=\underline{\mathbf{5 , 1 0 0 t} \cdot \mathrm{a}^{-1}}\left(\mathrm{CO}_{2}\right)$ 


\section{$\underline{A_{2}}$ ) Aterro de Araraquara 2007}

\section{1) Dissipador $\left(D_{1}\right)$}

(60L em 1,42min; M. cromatográficas: $\mathrm{CH}_{4}=167,8731 \mu \mathrm{g}$ e $\left.\mathrm{CO}_{2}=366,0625 \mu \mathrm{g}\right)$

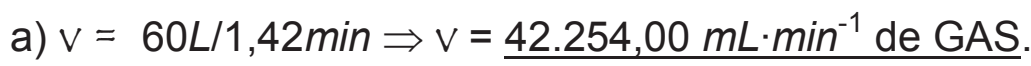

1) $M_{(1.1) \text { anual }}\left(\mathrm{CH}_{4}\right)=\frac{167,8731 \mu \mathrm{g}\left(\mathrm{CH}_{4}\right) \times 42.254,00 \mathrm{~mL} \times 1440 \mathrm{~min} \times 365 \mathrm{~d} \times t}{\mathrm{~mL} \times \min \times d \times 10^{12} \mu \mathrm{g} \times a}$

$$
\mathrm{M}_{(1.1) \text { anual }}\left(\mathrm{CH}_{4}\right)=\underline{\mathbf{3 , 7 2 8} t \cdot \mathrm{a}^{-1}}\left(\mathrm{CH}_{4}\right)
$$

2) $M_{(1.2)_{\text {anual }}}\left(\mathrm{CO}_{2}\right)=\frac{366,0625 \mu \mathrm{g}\left(\mathrm{CO}_{2}\right) \times 42.255,00 \mathrm{~mL} \times 1440 \mathrm{~min} \times 365 \mathrm{~d} \times t}{\mathrm{~mL} \times \min \times d \times 10^{-12} \mu \mathrm{g} \times a}$

$$
\mathrm{M}_{(1.2) \text { anual }}\left(\mathrm{CO}_{2}\right)=\underline{\mathbf{8 , 1 3 0} t \cdot \mathrm{a}^{-1}}\left(\mathrm{CO}_{2}\right)
$$

2) $D_{2}$

(60L em 1,30min; M. cromatográficas: $\mathrm{CH}_{4}=29,8691 \mu \mathrm{g}$ e $\mathrm{CO}_{2}=63,2664 \mu \mathrm{g}$ ).

a) $v=60 L / 1,30 \mathrm{~min} \Rightarrow v=\underline{46.154,00 L \cdot \mathrm{min}^{-1} \mathrm{de} \text { GAS. }}$

1) $M_{(2.1) \text { anual }}\left(\mathrm{CH}_{4}\right)=\frac{29,8691 \mu \mathrm{g}\left(\mathrm{CH}_{4}\right) \times 46.154 \mathrm{~mL} \times 1440 \mathrm{~min} \times 365 d \times t}{\mathrm{~mL} \times \min \times d \times 10^{12} \mu \mathrm{g} \times a}$

$$
\mathrm{M}_{(2.1) \text { anual }}\left(\mathrm{CH}_{4}\right)=\underline{\mathbf{0 , 7 2 5} t \cdot \mathbf{a}^{-1}}\left(\mathrm{CH}_{4}\right)
$$

2) $M_{(2.2)_{\text {anual }}}\left(\mathrm{CO}_{2}\right)=\frac{63,2664 \mu \mathrm{g}\left(\mathrm{CO}_{2}\right) \times 46.154 \mathrm{~mL} \times 1440 \mathrm{~min} \times 365 \mathrm{~d} \times t}{\mathrm{~mL} \times \min \times d \times 10^{-12} \mu \mathrm{g} \times a}$

$$
\mathrm{M}_{(2.2) \text { anual }}\left(\mathrm{CO}_{2}\right)=\underline{1,535 t \cdot a^{-1}}\left(\mathrm{CO}_{2}\right)
$$


3) $D_{3}$

(50L em 1,08min; M. cromatográficas: $\mathrm{CH}_{4}=23,4546 \mu$ e $\mathrm{CO}_{2}=50,0450 \mu \mathrm{g}$ )

a) $v=50 L / 1,08 \min \Rightarrow v=\underline{46,297 L \cdot \min ^{-1} \text { de GAS. }}$

$$
\begin{aligned}
& \text { 1) } M_{(3.1)_{\text {anual }}}\left(\mathrm{CH}_{4}\right)=\frac{23,4546 \mu g\left(\mathrm{CH}_{4}\right) \times 46.297 \mathrm{~mL} \times 1440 \mathrm{~min} \times 365 \mathrm{~d} \times t}{\mathrm{~mL} \times \min \times d \times 10^{12} \mu \mathrm{g} \times a} \\
& \mathrm{M}_{(3.1) \text { anual }}\left(\mathrm{CH}_{4}\right)=\underline{\mathbf{0 , 5 7 1} \mathrm{t} \cdot \mathrm{a}^{-1}\left(\mathrm{CH}_{4}\right)} \\
& \text { 2) } M_{(3.2)_{\text {anual }}}\left(\mathrm{CO}_{2}\right)=\frac{50,0450 \mu \mathrm{g}\left(\mathrm{CO}_{2}\right) \times 46.297 \mathrm{~mL} \times 1440 \mathrm{~min} \times 365 \mathrm{~d} \times t}{\mathrm{~mL} \times \min \times d \times 10^{-12} \mu \mathrm{g} \times a} \\
& \mathrm{M}_{(3.2)_{\text {anual }}}\left(\mathrm{CO}_{2}\right)=\underline{\mathbf{1 , 2 1 8} \cdot \mathrm{a}^{-1}\left(\mathrm{CO}_{2}\right)}
\end{aligned}
$$

$A_{3}$ ) Cálculo da Taxa de Emissão média $\left(T_{x} E_{m}\right)$ dos dissipadores(D) amostrados, nas duas campanhas:

$$
\begin{aligned}
& \mathrm{T}_{\mathrm{x}} \mathrm{E}_{\mathrm{m}}\left(\mathrm{CH}_{4}\right)=(0,763+2,219+2,392+3,728+0,725+0,571) / 6=\underline{\mathbf{1 , 7 3 3 t} \cdot \mathrm{a}^{-1}} \\
& \mathrm{~T}_{\mathrm{x}} \mathrm{E}_{\mathrm{m}}\left(\mathrm{CO}_{2}\right)=(1,455+1,791+5,100+8,130+1,535+1,218) / 6=\underline{\mathbf{3 , 5 3 8 t} \cdot \mathrm{a}^{-1}}
\end{aligned}
$$

O aterro dispõe de $\mathbf{8 1}$ dissipadores:

\section{$A_{4}$ ) Cálculo da Taxa de Emissão Média estimada para o Aterro - $T_{x} E_{m}(A t)$}

$$
\begin{aligned}
& T_{x} E_{m}(\mathrm{At})\left(\mathrm{CH}_{4}\right)=1,733 \mathrm{t} \cdot \mathrm{a}^{-1} \times 81=140,37 \mathrm{t} \cdot \mathrm{a}^{-1} \\
& T_{x} E_{m}(\mathrm{At})\left(\mathrm{CO}_{2}\right)=3,538 \mathrm{t} \cdot \mathrm{a}^{-1} \times 81=\underline{286,58 \mathrm{t} \cdot \mathrm{a}^{-1}}
\end{aligned}
$$

Obs.: (Nas duas campanhas desse trabalho foi observado que o aterro controlado de Araraquara não estava queimando o GAS). 


\subsection{2 - Aterro de Campinas}

\section{$\left.\underline{C}_{1}\right)$ Aterro de Campinas 2006}

\section{1) Dissipador $\left(D_{1}\right)$}

(60L em 1,50min; Áreas cromatográficas: $\mathrm{CH}_{4}=37,1194 \mu \mathrm{g}$ e $\mathrm{CO}_{2}=74,3786 \mu \mathrm{g}$ )

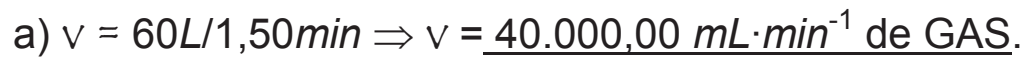

Então; para o dissipador $D_{1}$, temos:

1) $M_{(1.1)_{\text {anual }}}\left(\mathrm{CH}_{4}\right)=\frac{37,1194 \mu \mathrm{g}\left(\mathrm{CH}_{4}\right) \times 40.000 \mathrm{~mL} \times 1440 \mathrm{~min} \times 365 \mathrm{~d} \times t}{\mathrm{~mL} \times \min \times d \times 10^{12} \mu \mathrm{g} \times a}$

$$
\mathrm{M}_{(1.1) \text { anual }}\left(\mathrm{CH}_{4}\right)=\underline{\mathbf{0 , 7 8 0} t \cdot \mathrm{a}^{-1}}\left(\mathrm{CH}_{4}\right)
$$

2) $M_{(1.2)_{\text {anual }}}\left(\mathrm{CO}_{2}\right)=\frac{74,3786 \mu \mathrm{g}\left(\mathrm{CO}_{2}\right) \times 40.000 \mathrm{~mL} \times 1440 \mathrm{~min} \times 365 \mathrm{~d} \times t}{\mathrm{~mL} \times \min \times d \times 10^{-12} \mu \mathrm{g} \times a}$

$$
\mathrm{M}_{(1.2) \text { anual }}\left(\mathrm{CO}_{2}\right)=\underline{1,564 t \cdot a^{-1}}\left(\mathrm{CO}_{2}\right)
$$

2) $D_{2}$

(60L em 1,02min; M. cromatográficas: $\mathrm{CH}_{4}=126,9337 \mu \mathrm{g}$ e $\mathrm{CO}_{2}=304,2211 \mu \mathrm{g}$ )

a) $v=60 L / 1,02 \min \Rightarrow v=58.823 L \cdot \min ^{-1}$ de GAS.

1) $M_{(2.1)_{\text {anual }}}\left(\mathrm{CH}_{4}\right)=\frac{126,9337 \mu \mathrm{g}\left(\mathrm{CH}_{4}\right) \times 58.823 \mathrm{~mL} \times 1440 \mathrm{~min} \times 365 d \times t}{\mathrm{~mL} \times \min \times d \times 10^{12} \mu \mathrm{g} \times a}$

$$
\mathrm{M}_{(2.1) \text { anual }}\left(\mathrm{CH}_{4}\right)=\underline{3,924 t \cdot \mathrm{a}^{-1}}(\mathrm{CH} 4)
$$

2) $M_{(2.2)_{\text {anual }}}\left(\mathrm{CO}_{2}\right)=\frac{304,2211 \mu \mathrm{g}\left(\mathrm{CO}_{2}\right) \times 58.823 \mathrm{~mL} \times 1440 \mathrm{~min} \times 365 \mathrm{~d} \times t}{\mathrm{~mL} \times \min \times d \times 10^{-12} \mu \mathrm{g} \times a}$

$$
\mathrm{M}_{(2.2) \text { anual }}\left(\mathrm{CO}_{2}\right)=\underline{\mathbf{9}, 406 \mathrm{t} \cdot \mathrm{a}^{-1}}\left(\mathrm{CO}_{2}\right)
$$




\section{$\left.\underline{\mathrm{C}}_{2}\right)$ Aterro de Campinas 2007}

\section{1) Dissipador $\left(D_{1}\right)$}

(60L em 2,20min; M. cromatográficas: $\mathrm{CH}_{4}=37,5491 \mu \mathrm{g}$ e $\left.\mathrm{CO}_{2}=75,83555 \mu g\right)$

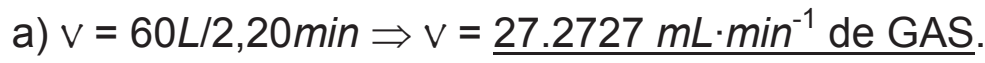

1) $M_{(1.1) \text { anual }}\left(\mathrm{CH}_{4}\right)=\frac{37,5491 \mu g\left(\mathrm{CH}_{4}\right) \times 27.273 \mathrm{~mL} \times 1440 \mathrm{~min} \times 365 d \times t}{\mathrm{~mL} \times \min \times d \times 10^{12} \mu g \times a}$

$$
\mathrm{M}_{(1.1) \text { anual }}(\mathrm{CH} 4)=\underline{\mathbf{0 , 5 3 8} t \cdot \mathrm{a}^{-1}}(\mathrm{CH} 4)
$$

2) $M_{(1.2)_{\text {anual }}}\left(\mathrm{CO}_{2}\right)=\frac{75,8355 \mu \mathrm{g}\left(\mathrm{CO}_{2}\right) \times 27.273 \mathrm{~mL} \times 1440 \mathrm{~min} \times 365 \mathrm{~d} \times t}{\mathrm{~mL} \times \min \times d \times 10^{12} \mu \mathrm{g} \times a}$

$$
\mathrm{M}_{(1.2) \text { anual }}\left(\mathrm{CO}_{2}\right)=\underline{\mathbf{1 , 0 8 7} t \cdot a^{-1}}\left(\mathrm{CO}_{2}\right)
$$

2) $D_{2}$

(50L em 1,60min; M. cromatográficas: $\mathrm{CH}_{4}=62,0472 \mu \mathrm{g}$ e $\mathrm{CO}_{2}=144,5000 \mu \mathrm{g}$ )

a) $v=50 \mathrm{~L} / 1,60 \mathrm{~min} \Rightarrow v=\underline{31.250 \mathrm{~mL} \cdot \mathrm{min}^{-1} \mathrm{de} \text { GAS. }}$

$$
\begin{gathered}
\text { 1) } M_{(2.1)_{\text {anual }}}\left(\mathrm{CH}_{4}\right)=\frac{62,0472 \mu g\left(\mathrm{CH}_{4}\right) \times 31.250 \mathrm{~mL} \times 1440 \mathrm{~min} \times 365 \mathrm{~d} \times t}{\mathrm{~mL} \times \min \times d \times 10^{12} \mu g \times a} \\
\mathrm{M}_{(2.1) \text { anual }}(\mathrm{CH} 4)=\underline{\mathbf{1 , 0 1 9} t \cdot \mathrm{a}^{-1}\left(\mathrm{CH}_{4}\right)}
\end{gathered}
$$

2) $M_{(2.2)_{\text {anual }}}\left(\mathrm{CO}_{2}\right)=\frac{144,5000 \mu \mathrm{g}\left(\mathrm{CO}_{2}\right) \times 31.250 \mathrm{~mL} \times 1440 \mathrm{~min} \times 365 \mathrm{~d} \times t}{\mathrm{~mL} \times \min \times d \times 10^{-12} \mu \mathrm{g} \times a}$

$$
\mathrm{M}_{(2.2) \text { anual }}\left(\mathrm{CO}_{2}\right)=\underline{\mathbf{2 , 3 7 3} t \cdot \mathrm{a}^{-1}}\left(\mathrm{CO}_{2}\right)
$$


3) $D_{3}$

(60L em 1,50min; M. cromatográficas: $\mathrm{CH}_{4}=41,7920 \mu \mathrm{g}$ e $\mathrm{CO}_{2}=92,5000 \mu g$ )

a) $v=50 L / 1,60 \mathrm{~min} \Rightarrow v=\underline{31.250 \mathrm{~mL} \cdot \mathrm{min}^{-1} \mathrm{de} \text { GAS. }}$

$$
\begin{gathered}
\text { 1) } M_{(3.1) \text { anual }}\left(\mathrm{CH}_{4}\right)=\frac{41,7920 \mu g\left(\mathrm{CH}_{4}\right) \times 31.250 \mathrm{~mL} \times 1440 \mathrm{~min} \times 365 d \times t}{m L \times \min \times d \times 10^{12} \mu \mathrm{g} \times a} \\
\mathrm{M}_{(3.1) \text { anual }}\left(\mathrm{CH}_{4}\right)=\underline{\mathbf{0 , 6 8 6 ~ t} \cdot \mathrm{a}^{-1}}\left(\mathrm{CH}_{4}\right)
\end{gathered}
$$$$
\text { 2) } M_{(3.2)_{\text {anual }}}\left(\mathrm{CO}_{2}\right)=\frac{92,5000 \mu \mathrm{g}\left(\mathrm{CO}_{2}\right) \times 31.250 \mathrm{~mL} \times 1440 \mathrm{~min} \times 365 \mathrm{~d} \times t}{\mathrm{~mL} \times \min \times d \times 10^{-12} \mu \mathrm{g} \times a}
$$

$$
\mathrm{M}_{(3.2) \text { anual }}\left(\mathrm{CO}_{2}\right)=\underline{1,519 t \cdot \mathrm{a}^{-1}}\left(\mathrm{CO}_{2}\right)
$$

4) $D_{4}$

(60L em 1,05min; M. cromatográficas: $\mathrm{CH}_{4}=41,2000 \mu \mathrm{g}$ e $\mathrm{CO}_{2}=93,1121 \mu \mathrm{g}$ )

a) $v=60 L / 1,05 \min \Rightarrow v=\underline{57.143 \mathrm{~mL} \cdot \min ^{-1} \mathrm{de} \mathrm{GAS}}$

$$
\begin{aligned}
& \text { 1) } M_{(4.1)_{\text {anual }}}\left(\mathrm{CH}_{4}\right)=\frac{41,20 \mu \mathrm{g}\left(\mathrm{CH}_{4}\right) \times 57.143 \mathrm{~mL} \times 1440 \mathrm{~min} \times 365 d \times t}{\mathrm{~mL} \times \min \times d \times 10^{12} \mu \mathrm{g} \times a} \\
& \mathrm{M}_{(4.1) \text { anual }}\left(\mathrm{CH}_{4}\right)=\underline{1,237 t \cdot a^{-1}}\left(\mathrm{CH}_{4}\right) \\
& \text { 2) } M_{(4.2)_{\text {anual }}}\left(\mathrm{CO}_{2}\right)=\frac{93,1121 \mu \mathrm{g}\left(\mathrm{CO}_{2}\right) \times 57.143 \mathrm{~mL} \times 1440 \mathrm{~min} \times 365 d \times t}{\mathrm{~mL} \times \min \times d \times 10^{-12} \mu \mathrm{g} \times a} \\
& \mathrm{M}_{(4.2) \text { anual }}\left(\mathrm{CO}_{2}\right)=\underline{\mathbf{2}, 796 t \cdot \mathrm{a}^{-1}}\left(\mathrm{CO}_{2}\right)
\end{aligned}
$$

$\mathrm{C}_{3}$ ) Cálculo da Taxa de Emissão média $\left(\mathrm{T}_{\mathrm{x}} \mathrm{E}_{\mathrm{m}}\right)$ dos dissipadores(D) amostrados, nas duas campanhas:

$$
\begin{aligned}
& \mathrm{T}_{\mathrm{x}} \mathrm{E}_{\mathrm{m}}\left(\mathrm{CH}_{4}\right)=(0,780+3,924+0,538+1,019+0,686+1,237) / 6=\underline{\mathbf{1 , 3 6 4 t} \cdot \mathrm{a}^{-1}} \\
& \mathrm{~T}_{\mathrm{x}} \mathrm{E}_{\mathrm{m}}\left(\mathrm{CO}_{2}\right)=(1,564+9,406+1,087+2,373+1,519+2,796) / 6=\underline{\mathbf{3 , 1 2 4} \boldsymbol{t} \cdot \mathbf{a}^{-1}}
\end{aligned}
$$


O aterro de Campinas dispõe de $\mathbf{1 1 0}$ drenos

$C_{4}$ ) Cálculo da Taxa de Emissão Média estimada para o Aterro $-T_{x} E_{m}(A t)$

$$
\begin{aligned}
& T_{x} E_{m}(\mathrm{At})\left(\mathrm{CH}_{4}\right)=\mathbf{1 , 3 6 4 t} \cdot a^{-1} \times 110=\underline{150,04 t \cdot a^{-1}} \\
& T_{x} E_{m}(\mathrm{At})\left(\mathrm{CO}_{2}\right)=\mathbf{3 , 1 2 4 t} \cdot a^{-1} \times 110=\underline{\mathbf{3 4 3 , 6 4 t} \cdot a^{-1}}
\end{aligned}
$$

Obs.: (Nas duas campanhas deste trabalho foi observado que o aterro de Campinas estava queimando o GAS, no entanto constavam entre três e cinco queimadores/dissipadores apagados. Naqueles acesos, chama bastante vigorosa). 


\subsection{3 - Aterro de Jaú \\ Di $)$ Campanha 2006}

(60L em 1,05min; M. cromatográficas: $\mathrm{CH}_{4}=43,9417 \mu \mathrm{g}$ e $\mathrm{CO}_{2}=111,6225 \mu \mathrm{g}$ )

a) $v=60 L / 1,05 \min \Rightarrow v=\underline{57.143 L \cdot \min ^{-1} \text { de GAS. }}$

1) $M_{(1.1) \text { anual }}\left(\mathrm{CH}_{4}\right)=\frac{43,9417 \mu g\left(\mathrm{CH}_{4}\right) \times 57.143 \mathrm{~mL} \times 1440 \mathrm{~min} \times 365 d \times t}{m L \times \min \times d \times 10^{12} \mu \mathrm{g} \times a}$

$$
M_{(1.1) \text { anual }}\left(\mathrm{CH}_{4}\right)=\underline{1,320 t \cdot a^{-1}}\left(\mathrm{CH}_{4}\right)
$$

2) $M_{(1.2)_{\text {anual }}}\left(\mathrm{CO}_{2}\right)=\frac{111,6225 \mu \mathrm{g}\left(\mathrm{CO}_{2}\right) \times 57.143 \mathrm{~mL} \times 1440 \mathrm{~min} \times 365 \mathrm{~d} \times t}{\mathrm{~mL} \times \min \times d \times 10^{-12} \mu \mathrm{g} \times a}$

$$
\mathrm{M}_{(1.2) \text { anual }}\left(\mathrm{CO}_{2}\right)=\underline{\mathbf{3 , 3 5 2} t \cdot \mathrm{a}^{-1}}\left(\mathrm{CO}_{2}\right)
$$

\section{2 Lampanha 2007}

(60L em 0,58min; M. cromatográficas: $\mathrm{CH}_{4}=24,6280 \mu \mathrm{g}$ e $\left.\mathrm{CO}_{2}=45,8000 \mu \mathrm{g}\right)$

a) $v=60 L / 1,02 \min \Rightarrow v=\underline{58.824 L \cdot \min ^{-1} \text { de GAS. }}$

$$
\begin{gathered}
\text { 1) } M_{(1.1)_{\text {anual }}}\left(\mathrm{CH}_{4}\right)=\frac{24,6280 \mu g\left(\mathrm{CH}_{4}\right) \times 58.824 \mathrm{~mL} \times 1440 \mathrm{~min} \times 365 \mathrm{~d} \times t}{\mathrm{~mL} \times \min \times d \times 10^{12} \mu \mathrm{g} \times a} \\
\mathrm{M}_{(1.1) \text { anual }}\left(\mathrm{CH}_{4}\right)=\underline{\mathbf{0 , 7 6 2} t \cdot \mathrm{a}^{-1}\left(\mathrm{CH}_{4}\right)}
\end{gathered}
$$$$
\text { 2) } M_{(1.2)_{\text {anual }}}\left(\mathrm{CO}_{2}\right)=\frac{45,8000 \mu \mathrm{g}\left(\mathrm{CO}_{2}\right) \times 58.824 \mathrm{~mL} \times 1440 \mathrm{~min} \times 365 d \times t}{\mathrm{~mL} \times \min \times d \times 10^{-12} \mu \mathrm{g} \times a}
$$

$$
\mathrm{M}_{(1.2) \text { anual }}\left(\mathrm{CO}_{2}\right)=\underline{1,416 t \cdot \mathrm{a}^{-1}\left(\mathrm{CO}_{2}\right.} 2
$$

\section{$D_{3}$ ) Taxa de Emissão media $\left(T_{x} E_{m}\right)$ do dreno nas duas campanhas:}

$$
\begin{aligned}
& \mathrm{T}_{\mathrm{x}} \mathrm{E}_{\mathrm{m}}\left(\mathrm{CH}_{4}\right)=(1,320+0,762) / 2=\underline{\mathbf{1 , 0 4 1} \mathrm{t} \cdot \mathrm{a}^{-1}}\left(\mathrm{CH}_{4}\right) \\
& \mathrm{T}_{\mathrm{x}} \mathrm{E}_{\mathrm{m}}\left(\mathrm{CO}_{2}\right)=(3,352+1,416) / 2=\underline{\mathbf{2 , 3 8 4} \mathrm{t} \cdot \mathrm{a}^{-1}}\left(\mathrm{CO}_{2}\right)
\end{aligned}
$$




\subsection{4 - Aterro de Ribeirão Preto}

\section{$\underline{F}_{1}$ Aterro de Ribeirão Preto 2006}

\section{1) Dissipador $\left(D_{1}\right)$}

( $60 \mathrm{~L}$ em 1,23 min; M. cromatográficas: $\mathrm{CH}_{4}=133,7715 \mu \mathrm{g}$ e $\left.\mathrm{CO}_{2}=311,2400 \mu \mathrm{g}\right)$

a) $v=60 \mathrm{~L} / 1,23 \mathrm{~min} \Rightarrow v=\underline{48.780 \mathrm{~mL} \cdot \mathrm{min}^{-1} \mathrm{de} G A S}$.

1) $M_{(1.1) \text { anual }}\left(\mathrm{CH}_{4}\right)=\frac{133,7715 \mu g\left(\mathrm{CH}_{4}\right) \times 48.780 \mathrm{~mL} \times 1440 \mathrm{~min} \times 365 \mathrm{~d} \times t}{\mathrm{~mL} \times \min \times d \times 10^{12} \mu \mathrm{g} \times a}$

$$
\mathrm{M}_{(1.1) \text { anual }}\left(\mathrm{CH}_{4}\right)=\underline{\mathbf{3 , 4 3 0 t} t \mathrm{a}^{-1}}\left(\mathrm{CH}_{4}\right)
$$

2) $M_{(1.2) \text { anual }}\left(\mathrm{CO}_{2}\right)=\frac{311,2400 \mu g\left(\mathrm{CO}_{2}\right) \times 48.780 \mathrm{~mL} \times 1440 \mathrm{~min} \times 365 d \times t}{\mathrm{~mL} \times \min \times d \times 10^{-12} \mu g \times a}$

$$
\mathrm{M}_{(1.2) \text { anual }}\left(\mathrm{CO}_{2}\right)=\underline{\mathbf{7 , 9 8 0} t \cdot \mathrm{a}^{-1}}\left(\mathrm{CO}_{2}\right)
$$

2) $D_{2}$

(60L em 1,16min; M. cromatográficas: $\mathrm{CH}_{4}=130,1455 \mu \mathrm{g}$ e $\mathrm{CO}_{2}=310,7438 \mu \mathrm{g}$ )

a) Vazão: $60 L / 1,16 \mathrm{~min} \Rightarrow V=\underline{51,724 L \cdot \mathrm{min}^{-1} \mathrm{de} G A S}$.

1) $M_{(1.1) \text { anual }}\left(\mathrm{CH}_{4}\right)=\frac{130,1455 \mu g\left(\mathrm{CH}_{4}\right) \times 51.724 \mathrm{~mL} \times 1440 \mathrm{~min} \times 365 d \times t}{\mathrm{~mL} \times \min \times d \times 10^{12} \mu \mathrm{g} \times a}$

$$
M(1.1) \text { anual }(\mathrm{CH} 4)=\underline{3,538 t \cdot a^{-1}}(\mathrm{CH} 4)
$$

2) $M_{(1.2)_{\text {anual }}}\left(\mathrm{CO}_{2}\right)=\frac{310,7438 \mu \mathrm{g}\left(\mathrm{CO}_{2}\right) \times 51.724 \mathrm{~mL} \times 1440 \mathrm{~min} \times 365 d \times t}{\mathrm{~mL} \times \min \times d \times 10^{-12} \mu \mathrm{g} \times a}$

$$
\mathrm{M}_{(1.2) \text { anual }}\left(\mathrm{CO}_{2}\right)=\underline{\mathbf{8 , 4 4 8} t \cdot \mathrm{a}^{-1}}\left(\mathrm{CO}_{2}\right)
$$


3) $D_{3}$

(60L em 1,22 min; M. cromatográficas: $\mathrm{CH}_{4}=232,3453 \mu \mathrm{g}$ e $\mathrm{CO}_{2}=529,3903 \mu \mathrm{g}$ )

a) $v=60 \mathrm{~L} / 1,02 \mathrm{~min} \Rightarrow v=\underline{49,180 \mathrm{~L} \cdot \mathrm{min}^{-1} \mathrm{de} \mathrm{GAS}}$.

$$
\begin{gathered}
\text { 1) } M_{(3.1)_{\text {anual }}}\left(\mathrm{CH}_{4}\right)=\frac{232,3453 \mu \mathrm{g}\left(\mathrm{CH}_{4}\right) \times 58.823 \mathrm{~mL} \times 1440 \mathrm{~min} \times 365 \mathrm{~d} \times t}{\mathrm{~mL} \times \min \times d \times 10^{12} \mu \mathrm{g} \times a} \\
\mathrm{M}_{(1.1) \text { anual }}\left(\mathrm{CH}_{4}\right)=\underline{\mathbf{7 , 1 8 3} \mathrm{t}^{-1}\left(\mathrm{CH}_{4}\right)} \\
\text { 2) } M_{(3.2)_{\text {anual }}}\left(\mathrm{CO}_{2}\right)=\frac{529,3903 \mu \mathrm{g}\left(\mathrm{CO}_{2}\right) \times 58.823 \mathrm{~mL} \times 1440 \mathrm{~min} \times 365 \mathrm{~d} \times t}{\mathrm{~mL} \times \mathrm{min} \times \mathrm{d} \times 10^{-12} \mu \mathrm{g} \times a} \\
\mathrm{M}_{(1.2) \text { anual }}\left(\mathrm{CO}_{2}\right)=\underline{\mathbf{1 6 . 3 6 7} \mathrm{t} \cdot \mathrm{a}^{-1}\left(\mathrm{CO}_{2}\right)}
\end{gathered}
$$

\section{$\underline{F}_{2}$ L Aterro de Ribeirão Preto 2007}

1) $D_{1}$

(60L em 2,01min; M. cromatográficas: $\mathrm{CH}_{4}=132,3235 \mu \mathrm{g}$ e $\mathrm{CO}_{2}=280,9800 \mu \mathrm{g}$ )

a) $v=60 L / 2,01 \mathrm{~min} \Rightarrow V=29.850 \mathrm{~mL} \cdot \mathrm{min}^{-1}$ de GAS.

1) $M_{(1.1)_{\text {anual }}}\left(\mathrm{CH}_{4}\right)=\frac{132,3235 \mu \mathrm{g}\left(\mathrm{CH}_{4}\right) \times 29.850 \mathrm{~mL} \times 1440 \mathrm{~min} \times 365 d \times t}{\mathrm{~mL} \times \min \times d \times 10^{12} \mu \mathrm{g} \times a}$

$$
\mathrm{M}_{(1.1) \text { anual }}(\mathrm{CH} 4)=\underline{\mathbf{2}, 076 t \cdot a^{-1}}\left(\mathrm{CH}_{4}\right)
$$

2) $M_{(1.2)_{\text {anual }}}\left(\mathrm{CO}_{2}\right)=\frac{280,9800 \mu \mathrm{g}\left(\mathrm{CO}_{2}\right) \times 29.850 \mathrm{~mL} \times 1440 \mathrm{~min} \times 365 \mathrm{~d} \times t}{\mathrm{~mL} \times \min \times d \times 10^{-12} \mu \mathrm{g} \times a}$

$$
\mathrm{M}_{(1.2) \text { anual }}\left(\mathrm{CO}_{2}\right)=\underline{\mathbf{4 , 4 0 8} \mathrm{t} \cdot \mathrm{a}^{-1}}\left(\mathrm{CO}_{2}\right)
$$


2) $D_{2}$

(50L em 1,28min; M. cromatográficas: $\mathrm{CH}_{4}=162,4806 \mu \mathrm{g}$ e $\mathrm{CO}_{2}=349,2472 \mu \mathrm{g}$ )

a) $v=50 L / 1,28 \min \Rightarrow v=\underline{39,062 L \cdot \min ^{-1} \text { de GAS. }}$

1) $M_{(2.1)_{\text {anual }}}\left(\mathrm{CH}_{4}\right)=\frac{162,4806 \mu \mathrm{g}\left(\mathrm{CH}_{4}\right) \times 39.062 \mathrm{~mL} \times 1440 \mathrm{~min} \times 365 d \times t}{m L \times \min \times d \times 10^{12} \mu \mathrm{g} \times a}$

$\mathrm{M}_{(2.1) \text { anual }}\left(\mathrm{CH}_{4}\right)=\underline{3,336 t \cdot a^{-1}}\left(\mathrm{CH}_{4}\right)$

2) $M_{(2.2)_{\text {anual }}}\left(\mathrm{CO}_{2}\right)=\frac{349,2472 \mu \mathrm{g}\left(\mathrm{CO}_{2}\right) \times 39.062 \mathrm{~mL} \times 1440 \mathrm{~min} \times 365 d \times t}{\mathrm{~mL} \times \min \times d \times 10^{-12} \mu \mathrm{g} \times a}$

$\mathrm{M}_{(2.2) \text { anual }}\left(\mathrm{CO}_{2}\right)=\underline{\mathbf{7 , 1 7 0} t \cdot \mathrm{a}^{-1}}\left(\mathrm{CO}_{2}\right)$

3) $D_{3}$

(60L em 1,05min; M. cromatográficas: $\mathrm{CH}_{4}=164,2006 \mu \mathrm{g}$ e $\mathrm{CO}_{2}=360,6449 \mu g$ )

a) $v=60 L / 1,05 \min \Rightarrow v=\underline{57,143 L \cdot \min ^{-1} \text { de GAS. }}$

1) $M_{(3.1)_{\text {anual }}}\left(\mathrm{CH}_{4}\right)=\frac{164,2006 \mu \mathrm{g}\left(\mathrm{CH}_{4}\right) \times 57.143 \mathrm{~mL} \times 1440 \mathrm{~min} \times 365 d \times t}{m L \times \min \times d \times 10^{12} \mu \mathrm{g} \times a}$

$\mathrm{M}_{(3.1) \text { anual }}\left(\mathrm{CH}_{4}\right)=\underline{4,932 t \cdot a^{-1}}\left(\mathrm{CH}_{4}\right)$

2) $M_{(3.2)_{\text {anual }}}\left(\mathrm{CO}_{2}\right)=\frac{360,6449 \mu \mathrm{g}\left(\mathrm{CO}_{2}\right) \times 57.143 \mathrm{~mL} \times 1440 \mathrm{~min} \times 365 d \times t}{\mathrm{~mL} \times \min \times d \times 10^{-12} \mu \mathrm{g} \times a}$

$\mathrm{M}_{(3.2) \text { anual }}\left(\mathrm{CO}_{2}\right)=\underline{10,832 t \cdot a^{-1}}\left(\mathrm{CO}_{2}\right)$ 
4) $D_{4}$

(60L em 1,31min; M. cromatográficas: $\mathrm{CH}_{4}=62,9000 \mu \mathrm{g}$ e $\left.\mathrm{CO}_{2}=132,9459 \mu \mathrm{g}\right)$

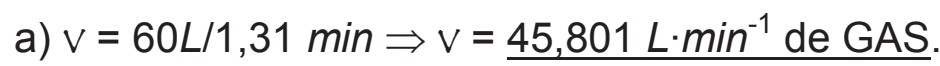

$$
\begin{aligned}
& \text { 1) } M_{(4.1)_{\text {anual }}}\left(\mathrm{CH}_{4}\right)=\frac{62,9000 \mu \mathrm{g}\left(\mathrm{CH}_{4}\right) \times 45.801 \mathrm{~mL} \times 1440 \mathrm{~min} \times 365 \mathrm{~d} \times t}{\mathrm{~mL} \times \min \times d \times 10^{12} \mu \mathrm{g} \times a} \\
& \mathrm{M}_{(4.1) \text { anual }}\left(\mathrm{CH}_{4}\right)=\underline{\mathbf{1 , 5 1 4 t} \cdot \mathrm{a}^{-1}\left(\mathrm{CH}_{4}\right)} \\
& \text { 2) } M_{(4.2)_{\text {anual }}}\left(\mathrm{CO}_{2}\right)=\frac{132,9459 \mu \mathrm{g}\left(\mathrm{CO}_{2}\right) \times 45.801 \mathrm{~mL} \times 1440 \mathrm{~min} \times 365 \mathrm{~d} \times t}{\mathrm{~mL} \times \min \times d \times 10^{-12} \mu \mathrm{g} \times a} \\
& \mathrm{M}_{(4.2)_{\text {anual }}}\left(\mathrm{CO}_{2}\right)=\underline{\mathbf{3 , 2 0 0 t} \cdot \mathrm{a}^{-1}\left(\mathrm{CO}_{2}\right)}
\end{aligned}
$$

$\left.F_{3}\right)$ Taxa de Emissão media dos dissipadores medidos $\left(T_{x} E_{m}\right)$ :

$\mathrm{T}_{\mathrm{x}} \mathrm{E}_{\mathrm{m}}\left(\mathrm{CH}_{4}\right)=(3,430+3,538+7,183+2,076+3,336+4,932+1,514) / 7=\underline{\mathbf{3 , 7 1 5} \boldsymbol{t} \cdot \mathbf{a}^{\mathbf{1}}}$

$\mathrm{T}_{\mathrm{x}} \mathrm{E}_{\mathrm{m}}\left(\mathrm{CO}_{2}\right)=(7,98+8,448+16,367+4,408+7,17+10,832+3,3) / 7=\underline{\mathbf{8 , 3 4 3} \boldsymbol{t} \cdot \mathbf{a}^{-\mathbf{1}}}$

O aterro de Ribeirão Preto dispõe de 85 dissipadores:

$\left.F_{4}\right)$ Cálculo da Taxa de Emissão Média do Aterro $-T_{x} E_{m}(A t)$

$$
\begin{aligned}
& \operatorname{TxEm}(\mathrm{At})\left(\mathrm{CH}_{4}\right)=\mathbf{3 , 7 1 5 t} \cdot \mathrm{a}^{-1} \times \mathbf{8 5}=\underline{\mathbf{3 1 5 , 7 7 t} \cdot \mathbf{a}^{-1}} \\
& \operatorname{TxEm}(\mathrm{At})\left(\mathrm{CO}_{2}\right)=\mathbf{8 , 3 4 3 t} \cdot \mathrm{a}^{-1} \times \mathbf{8 5}=\mathbf{7 0 9 , 1 5 t \cdot \mathbf { a } ^ { - 1 }}
\end{aligned}
$$

Obs.: (Nas duas campanhas deste trabalho foi observado que o aterro de Ribeirão Preto não estava queimando o GAS. Nenhum dreno aceso e muitos desmoronados). 


\subsection{5 - Aterro de São Carlos}

\section{$\left.\underline{\mathbf{G}}_{1}\right)$ Campanha 2006}

\section{1) Dissipador $\left(D_{1}\right)$}

(60L em 1,14min; M. cromatográficas: $\mathrm{CH}_{4}=240,5000 \mu g$ e $\mathrm{CO}_{2}=550,9175 \mu g$ )

a) $v=60 L / 1,14 \mathrm{~min} \Rightarrow v=\underline{52,631 L \cdot \mathrm{min}^{-1} \mathrm{de} G A S}$.

1) $M_{(1.1) \text { anual }}\left(\mathrm{CH}_{4}\right)=\frac{240,5000 \mu \mathrm{g}\left(\mathrm{CH}_{4}\right) \times 52.631 \mathrm{~mL} \times 1440 \mathrm{~min} \times 365 \mathrm{~d} \times \mathrm{Ton}}{\mathrm{mL} \times \min \times d \times 10^{12} \mu \mathrm{g} \times \text { ano }}$

$$
\mathrm{M}_{(1.1) \text { anual }}\left(\mathrm{CH}_{4}\right)=\underline{\mathbf{6 , 6 5 3} t \cdot a^{-1}}\left(\mathrm{CH}_{4}\right)
$$

2) $M_{(1.2)_{\text {anual }}}\left(\mathrm{CO}_{2}\right)=\frac{550,9175 \mu \mathrm{g}\left(\mathrm{CO}_{2}\right) \times 52.631 \mathrm{~mL} \times 1440 \mathrm{~min} \times 365 \mathrm{~d} \times t}{\mathrm{~mL} \times \min \times d \times 10^{-12} \mu \mathrm{g} \times a}$

$$
\mathrm{M}_{(1.2) \text { anual }}\left(\mathrm{CO}_{2}\right)=\underline{15,239 t \cdot a^{-1}}\left(\mathrm{CO}_{2}\right)
$$

2) $D_{2}$

( $60 \mathrm{~L}$ em 1,12min; M. cromatográficas: $\mathrm{CH}_{4}=218,5264 \mu \mathrm{g}$ e $\mathrm{CO}_{2}=624,5320 \mu \mathrm{g}$ )

a) $v=60 L / 1,12 \mathrm{~min} \Rightarrow v=\underline{53.571 L \cdot \mathrm{min}^{-1} \mathrm{de} G A S}$.

1) $M_{(2.1)_{\text {anual }}}\left(\mathrm{CH}_{4}\right)=\frac{218,5264 \mu \mathrm{g}\left(\mathrm{CH}_{4}\right) \times 53.571 \mathrm{~mL} \times 1440 \mathrm{~min} \times 365 \mathrm{~d} \times t}{\mathrm{~mL} \times \min \times d \times 10^{12} \mu \mathrm{g} \times a}$

$$
\mathrm{M}_{(2.1) \text { anual }}\left(\mathrm{CH}_{4}\right)=\underline{\mathbf{6 , 1 5 3} t \cdot a^{-1}}\left(\mathrm{CH}_{4}\right)
$$

2) $M_{(2.2)_{\text {anual }}}\left(\mathrm{CO}_{2}\right)=\frac{624,5320 \mu g\left(\mathrm{CO}_{2}\right) \times 53.571 \mathrm{~mL} \times 1440 \mathrm{~min} \times 365 \mathrm{~d} \times t}{\mathrm{~mL} \times \min \times d \times 10^{-12} \mu \mathrm{g} \times a}$

$$
\mathrm{M}_{(2.2) \text { anual }}\left(\mathrm{CO}_{2}\right)=\underline{\mathbf{1 7 , 5 8 6} t \cdot \mathrm{a}^{-1}}\left(\mathrm{CO}_{2}\right)
$$


3) $D_{3}$

(50L em 1,32min; M. cromatográficas: $\mathrm{CH}_{4}=33,2379 \mu \mathrm{g}$ e $\mathrm{CO}_{2}=67,4000 \mu \mathrm{g}$ )

a) $v=60 L / 1,02 \min \Rightarrow v=\underline{58.823 \mathrm{~mL} \cdot \mathrm{min}^{-1} \mathrm{de} \text { GAS. }}$

1) $M_{(3.1)_{\text {anual }}}\left(\mathrm{CH}_{4}\right)=\frac{33,2379 \mu \mathrm{g}\left(\mathrm{CH}_{4}\right) \times 58.823 \mathrm{~mL} \times 1440 \mathrm{~min} \times 365 d \times t}{\mathrm{~mL} \times \min \times d \times 10^{12} \mu \mathrm{g} \times a}$

$\mathrm{M}_{(3.1) \text { anual }}\left(\mathrm{CH}_{4}\right)=\underline{\mathbf{1 , 0 2 8} t \cdot \mathrm{a}^{-1}}\left(\mathrm{CH}_{4}\right)$

2) $M_{(3.2)_{\text {anual }}}\left(\mathrm{CO}_{2}\right)=\frac{67,4000 \mu \mathrm{g}\left(\mathrm{CO}_{2}\right) \times 58.823 \mathrm{~mL} \times 1440 \mathrm{~min} \times 365 \mathrm{~d} \times t}{\mathrm{~mL} \times \min \times d \times 10^{-12} \mu \mathrm{g} \times a}$

$\mathrm{M}_{(3.2) \text { anual }}\left(\mathrm{CO}_{2}\right)=\underline{\mathbf{2 , 0 8 4} t \cdot \mathrm{a}^{-1}}\left(\mathrm{CO}_{2}\right)$ 


\section{$\underline{\mathrm{G}}_{2}$ ) Aterro de São Carlos 2007}

\section{1) Dissipador $\left(D_{1}\right)$}

(60L em 2,09min; M. cromatográficas: $\mathrm{CH}_{4}=250,0600 \mu \mathrm{g}$ e $\mathrm{CO}_{2}=567,8000 \mu \mathrm{g}$ )

a) $v=60 L / 2,09 \min \Rightarrow v=\underline{28,708 L \cdot \min ^{-1} \text { de GAS. }}$

1) $M_{(1.1)_{\text {anual }}}\left(\mathrm{CH}_{4}\right)=\frac{250,0600 \mu \mathrm{g}\left(\mathrm{CH}_{4}\right) \times 28.708 \mathrm{~mL} \times 1440 \mathrm{~min} \times 365 \mathrm{~d} \times t}{\mathrm{~mL} \times \min \times d \times 10^{12} \mu g \times a}$

$$
\mathrm{M}_{(1.1) \text { anual }}\left(\mathrm{CH}_{4}\right)=\underline{3,773 t \cdot a^{-1}}\left(\mathrm{CH}_{4}\right)
$$

2) $M_{(1.2)_{\text {anual }}}\left(\mathrm{CO}_{2}\right)=\frac{567,8000 \mu \mathrm{g}\left(\mathrm{CO}_{2}\right) \times 28.708 \mathrm{~mL} \times 1440 \mathrm{~min} \times 365 \mathrm{~d} \times t}{\mathrm{~mL} \times \min \times d \times 10^{-12} \mu \mathrm{g} \times a}$

$$
\mathrm{M}_{(1.2) \text { anual }}\left(\mathrm{CO}_{2}\right)=\underline{\mathbf{8 , 5 6 7} t \cdot \mathrm{a}^{-1}\left(\mathrm{CO}_{2}\right)}
$$

2) $D_{2}$

(50L em 1,16min; M. cromatográficas: $\mathrm{CH}_{4}=180,9767 \mu g$ e CO${ }_{2}=421,2075 \mu g$ )

a) $v=50 L / 1,16 \min \Rightarrow v=\underline{43,103 L \cdot \min ^{-1} \text { de GAS. }}$

1) $M_{(2.1)_{\text {anual }}}\left(\mathrm{CH}_{4}\right)=\frac{180,9767 \mu \mathrm{g}\left(\mathrm{CH}_{4}\right) \times 43.103 \mathrm{~mL} \times 1440 \mathrm{~min} \times 365 \mathrm{~d} \times t}{\mathrm{~mL} \times \min \times d \times 10^{12} \mu \mathrm{g} \times a}$

$$
\mathrm{M}_{(2.1) \text { anual }}\left(\mathrm{CH}_{4}\right)=\underline{\mathbf{4 , 1 0 0 t} \cdot \mathrm{a}^{-1}}\left(\mathrm{CH}_{4}\right)
$$

2) $M_{(2.2)_{\text {anual }}}\left(\mathrm{CO}_{2}\right)=\frac{421,2075 \mu \mathrm{g}\left(\mathrm{CO}_{2}\right) \times 43.103 \mathrm{~mL} \times 1440 \mathrm{~min} \times 365 \mathrm{~d} \times t}{\mathrm{~mL} \times \min \times d \times 10^{-12} \mu \mathrm{g} \times a}$

$$
\mathrm{M}_{(2.2) \text { anual }}\left(\mathrm{CO}_{2}\right)=\underline{\mathbf{9 , 5 4 2} t \cdot a^{-1}}\left(\mathrm{CO}_{2}\right)
$$


3) $D_{3}$

(60L em 1,31 min; M. cromatográficas: $\mathrm{CH}_{4}=110,5307 \mu \mathrm{g}$ e $\mathrm{CO}_{2}=259,8494 \mu \mathrm{g}$.)

a) $v=60 L / 1,31 \mathrm{~min} \Rightarrow v=\underline{45,801 L \cdot \min ^{-1} \text { de GAS. }}$

$$
\begin{aligned}
& \text { 1) } M_{(3.1)_{\text {anual }}}\left(\mathrm{CH}_{4}\right)=\frac{110,5307 \mu g\left(\mathrm{CH}_{4}\right) \times 45.801 \mathrm{~mL} \times 1440 \mathrm{~min} \times 365 \mathrm{~d} \times t}{\mathrm{~mL} \times \min \times d \times 10^{12} \mu \mathrm{g} \times a} \\
& \mathrm{M}_{(3.1) \text { anual }}\left(\mathrm{CH}_{4}\right)=\underline{\mathbf{2 , 6 6 0 ~ t} \cdot \mathrm{a}^{-1}\left(\mathrm{CH}_{4}\right)} \\
& \text { 2) } M_{(3.2)_{\text {anual }}}\left(\mathrm{CO}_{2}\right)=\frac{259,8494 \mu g\left(\mathrm{CO}_{2}\right) \times 45.801 \mathrm{~mL} \times 1440 \mathrm{~min} \times 365 \mathrm{~d} \times t}{\mathrm{~mL} \times \min \times d \times 10^{-12} \mu \mathrm{g} \times a} \\
& \mathrm{M}_{(3.2)_{\text {anual }}}\left(\mathrm{CO}_{2}\right)=\underline{\mathbf{6 , 2 5 5} \mathrm{t} \cdot \mathrm{a}^{-1}\left(\mathrm{CO}_{2}\right)}
\end{aligned}
$$

$G_{3}$ ) Taxa de Emissão media $\left(T_{x} E_{m}\right)$ dos dissipadores amostrados:

$$
\begin{aligned}
& \mathrm{T}_{\mathrm{x}} \mathrm{E}_{\mathrm{m}}\left(\mathrm{CH}_{4}\right)=(6,653+6,153+1,028+3,773+4,1+2,66) / 6=\underline{\mathbf{4 , 0 6 1} t \cdot \mathrm{a}^{-1}} \\
& \mathrm{~T}_{\mathrm{x}} \mathrm{E}_{\mathrm{m}}\left(\mathrm{CO}_{2}\right)=(15,239+17,586+2,084+8,567+9,542+6,255) / 6=\underline{\mathbf{9 , 8 7 8} t \cdot \mathrm{a}^{-1}} \\
& \text { O aterro dispõe de } 17 \text { drenos. }
\end{aligned}
$$

$\mathrm{G}_{4}$ ) Cálculo da Taxa média de Emissão Média do Aterro $-\mathrm{T}_{\mathrm{x}} \mathrm{E}_{\mathrm{m}}(\mathrm{At})$ )

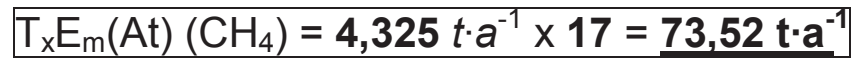

$$
\begin{aligned}
& T_{x} E_{m}(A t)\left(C O_{2}\right)=9,755 t \cdot a^{-1} \times 17=\underline{165,83 t \cdot a^{-1}}
\end{aligned}
$$

Obs.: Nas duas campanhas foi observado que o aterro de São Carlos estava queimando o GAS. Todos os queimadores com muita chama. Para a coleta das amostra neste aterro, foi necessária a intervenção de operadores, que apagavam a chama dos queimadores escolhidos, no início da manhã, para que ao fim da amostragem solo-ar, se pudesse coletar nestes queimadores. Logo após os mesmos eram reacesos. 


\subsection{6 - Aterro Bandeirantes - Campanha Única 2007}

\section{1) Dissipador $\left(D_{1}\right)$}

(60L em 0,52min; M. cromatográficas: $\mathrm{CH}_{4}=161,3127 \mu \mathrm{g}$ e $\mathrm{CO}_{2}=335,9850 \mu \mathrm{g}$ )

a) $v: 60 L / 0,52 \min \Rightarrow v=\underline{115,384 L \cdot \min ^{-1} \text { de GAS. }}$

1) $M_{(1.1)_{\text {anual }}}\left(\mathrm{CH}_{4}\right)=\frac{161,3127 \mu g\left(\mathrm{CH}_{4}\right) \times 115.384 \mathrm{~mL} \times 1440 \mathrm{~min} \times 365 d \times t}{m L \times \min \times d \times 10^{12} \mu \mathrm{g} \times a}$

$$
\mathrm{M}_{(1.1) \text { anual }}\left(\mathrm{CH}_{4}\right)=\underline{\mathbf{9 , 7 8 3} t \cdot a^{-1}}\left(\mathrm{CH}_{4}\right)
$$

2) $M_{(1.2)_{\text {anual }}}\left(\mathrm{CO}_{2}\right)=\frac{335,9850 \mu \mathrm{g}\left(\mathrm{CO}_{2}\right) \times 115.384 \mathrm{~mL} \times 1440 \mathrm{~min} \times 365 \mathrm{~d} \times t}{\mathrm{~mL} \times \min \times d \times 10^{-12} \mu \mathrm{g} \times a}$

$$
\mathrm{M}_{(1.2) \text { anual }}\left(\mathrm{CO}_{2}\right)=\underline{\mathbf{2 0}, 376 t \cdot \mathrm{a}^{-1}}\left(\mathrm{CO}_{2}\right)
$$

2) $D_{2}$

(50L em 1,16min; M. cromatográficas: $\mathrm{CH}_{4}=165,4662 \mu \mathrm{g}$ e $\mathrm{CO}_{2}=340,7000 \mu \mathrm{g}$ )

a) $v=50 L / 1,16 \min \Rightarrow v=\underline{42,857 L \cdot \min ^{-1} \text { de GAS. }}$

1) $M_{(2.1)_{\text {anual }}}\left(\mathrm{CH}_{4}\right)=\frac{165,4662 \mu \mathrm{g}\left(\mathrm{CH}_{4}\right) \times 43.103 \mathrm{~mL} \times 1440 \mathrm{~min} \times 365 \mathrm{~d} \times t}{\mathrm{~mL} \times \min \times d \times 10^{12} \mu \mathrm{g} \times a}$

$$
\mathrm{M}_{(2.1) \text { anual }}\left(\mathrm{CH}_{4}\right)=\underline{3,748 t \cdot a^{-1}}\left(\mathrm{CH}_{4}\right)
$$

2) $M_{(2.2)_{\text {anual }}}\left(\mathrm{CO}_{2}\right)=\frac{340,7000 \mu g\left(\mathrm{CO}_{2}\right) \times 43.103 \mathrm{~mL} \times 1440 \mathrm{~min} \times 365 d \times t}{m L \times \min \times d \times 10^{-12} \mu \mathrm{g} \times a}$

$$
\mathrm{M}_{(2.2) \text { anual }}\left(\mathrm{CO}_{2}\right)=\underline{\mathbf{7 , 7 1 8 t} t \cdot a^{-1}}\left(\mathrm{CO}_{2}\right)
$$


3) $D_{3}$

(50L em 1,01min; M. cromatográfica.: $\mathrm{CH}_{4}=199,5412 \mu$ e $\mathrm{CO}_{2}=414,8000 \mu \mathrm{g}$.)

a) $v: 50 L / 1,01 \mathrm{~min} \Rightarrow v=\underline{49,505 L \cdot \mathrm{min}^{-1} \mathrm{de} G A S}$.

$$
\begin{aligned}
& \text { 1) } M_{(3.1) \text { anual }}\left(\mathrm{CH}_{4}\right)=\frac{199,5412 \mu \mathrm{g}\left(\mathrm{CH}_{4}\right) \times 49.505 \mathrm{~mL} \times 1440 \mathrm{~min} \times 365 \mathrm{~d} \times t}{\mathrm{~mL} \times \min \times d \times 10^{12} \mu \mathrm{g} \times a} \\
& \mathrm{M}_{(3.1) \text { anual }}\left(\mathrm{CH}_{4}\right)=\underline{\mathbf{5 , 1 9 2} \mathrm{t} \cdot \mathrm{a}^{-1}\left(\mathrm{CH}_{4}\right)} \\
& \text { 2) } M_{(3.2)_{\text {anual }}}\left(\mathrm{CO}_{2}\right)=\frac{414,8000 \mu \mathrm{g}\left(\mathrm{CO}_{2}\right) \times 49.505 \mathrm{~mL} \times 1440 \mathrm{~min} \times 365 \mathrm{~d} \times t}{\mathrm{~mL} \times \min \times d \times 10^{-12} \mu \mathrm{g} \times a} \\
& \mathrm{M}_{(3.2)_{\text {anual }}}(\mathrm{CO} 2)=\underline{\mathbf{1 0 , 7 9 3} \mathrm{t} \cdot \mathrm{a}^{-1}\left(\mathrm{CO}_{2}\right)}
\end{aligned}
$$

4) $D_{4}$

(60L em 1,10min; M. cromatográficas.: $\mathrm{CH}_{4}=168,9325 \mu \mathrm{g}$ e $\left.\mathrm{CO}_{2}=348,9500 \mu \mathrm{g}\right)$

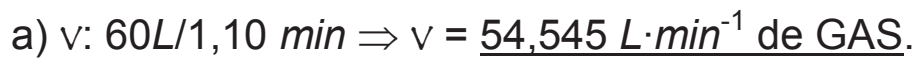

$$
\begin{gathered}
\text { 1) } M_{(1.1)_{\text {anual }}}\left(\mathrm{CH}_{4}\right)=\frac{168,9325 \mu \mathrm{g}\left(\mathrm{CH}_{4}\right) \times 54.545 \mathrm{~mL} \times 1440 \mathrm{~min} \times 365 \mathrm{~d} \times t}{\mathrm{~mL} \times \min \times d \times 10^{12} \mu \mathrm{g} \times a} \\
\mathrm{M}_{(1.1) \text { anual }}\left(\mathrm{CH}_{4}\right)=\underline{\mathbf{4 , 8 4 3} t \cdot \mathrm{a}^{-1}\left(\mathrm{CH}_{4}\right)}
\end{gathered}
$$

2) $M_{(1.2)_{\text {anual }}}\left(\mathrm{CO}_{2}\right)=\frac{348,9500 \mu \mathrm{g}\left(\mathrm{CO}_{2}\right) \times 54.545 \mathrm{~mL} \times 1440 \mathrm{~min} \times 365 \mathrm{~d} \times t}{\mathrm{~mL} \times \min \times d \times 10^{-12} \mu \mathrm{g} \times a}$

$$
\left.\mathrm{M}_{(1.2) \text { anual }}\left(\mathrm{CO}_{2}\right)=\underline{10,004 t \cdot \mathrm{a}^{-1}\left(\mathrm{CO}_{2}\right.}\right)
$$

4) Taxa de Emissão media dos dissipadores medidos $\left(T_{x} E_{m}\right)$ :

$$
\begin{aligned}
& \mathrm{T}_{\mathrm{x}} \mathrm{E}_{\mathrm{m}}\left(\mathrm{CH}_{4}\right)=(9,783+3,748+5,192+4,843) / 4=\underline{\mathbf{5 , 8 9 1} \mathrm{t} \cdot \mathrm{a}^{-1}}\left(\mathrm{CH}_{4}\right) \\
& \mathrm{T}_{\mathrm{x}} \mathrm{E}_{\mathrm{m}}\left(\mathrm{CO}_{2}\right)=(20,376+7,718+10,793+10,004) / 4=\underline{\mathbf{1 2 , 2 2 3} \mathrm{t} \cdot \mathrm{a}^{-1}}\left(\mathrm{CO}_{2}\right)
\end{aligned}
$$




\section{DISCUSSÃO DOS RESULTADOS}

"Se não podemos compreender o mínimo de uma flor ou de um inseto, como poderemos compreender o máximo do Universo!"

Marquês de Maricá

Nas secções seguintes, são discutidos os resultados obtidos para os cálculos das concentrações de metano $\left(\mathrm{CH}_{4}\right)$ e dióxido de carbono $\left(\mathrm{CO}_{2}\right)$ no ar ambiente dos aterros, para a emissão solo-ar e para a emissão dos dissipadores; esta, para aqueles aterros que dispunham de tais.

\subsection{Concentrações de metano $\left(\mathrm{CH}_{4}\right)$ e de dióxido de carbono $\left(\mathrm{CO}_{2}\right)$ no ar ambiente dos aterros}

A tabela 7.1.1a e o gráfico 7.1.1, seguintes, mostram, em síntese, os resultados obtidos para as concentrações $(p p m)$ do metano e do dióxido de carbono no ar ambiente dos aterros, para cada campanha, a concentração média por gás e aterro e a concentração média total (última linha Tab. 7.1.1a).

Foi observado que as concentrações médias $\left(\mathrm{C}_{\mathrm{m}}\right)$ para metano $\left(\mathrm{CH}_{4}\right)$ e para dióxido de carbono $\left(\mathrm{CO}_{2}\right)$ no ar ambiente dos aterros, para as duas campanhas foram, respectivamente, de 17.596 ppm e 5.552 ppm. 
Tabela 7.1.1a - Resumo das concentrações $(\mathrm{C})$ medidas para metano $\left(\mathrm{CH}_{4}\right)$ e dióxido de carbono $\left(\mathrm{CO}_{2}\right)$ no ar ambiente dos aterros em cada campanha, a concentração média $\left(\mathrm{C}_{\mathrm{m}}\right)$ por aterro e a concentração média total nos aterros.

\begin{tabular}{|c|c|c|c|c|}
\hline Aterro & Gás & $\mathrm{C}($ ppm) 2006 & $\mathrm{C}($ ppm) 2007 & $\mathrm{C}_{\mathrm{m}}(p p m)$ \\
\hline \multirow{2}{*}{ Araraquara } & $\mathrm{CH}_{4}$ & 18.170 & 17.615 & 17.892 \\
\hline & $\mathrm{CO}_{2}$ & 6.415 & 5.052 & 5.733 \\
\hline \multirow{2}{*}{ Brotas } & $\mathrm{CH}_{4}$ & 17.522 & 17.216 & 17.369 \\
\hline & $\mathrm{CO}_{2}$ & 5.039 & 4.673 & 4.856 \\
\hline \multirow{2}{*}{ Campinas } & $\mathrm{CH}_{4}$ & 17.032 & 16.931 & 16.981 \\
\hline & $\mathrm{CO}_{2}$ & 4.590 & 4.508 & 4.549 \\
\hline \multirow{2}{*}{ Jaú } & $\mathrm{CH}_{4}$ & 16.852 & 18.094 & 17.473 \\
\hline & $\mathrm{CO}_{2}$ & 6.359 & 6.513 & 6.436 \\
\hline \multirow{2}{*}{ R. Bonito } & $\mathrm{CH}_{4}$ & 18.166 & 17.297 & 17.731 \\
\hline & $\mathrm{CO}_{2}$ & 5.638 & 6.615 & 6.126 \\
\hline \multirow{2}{*}{ R. Preto } & $\mathrm{CH}_{4}$ & 18.048 & 17.028 & 17.538 \\
\hline & $\mathrm{CO}_{2}$ & 5.755 & 4.702 & 5.228 \\
\hline \multirow{2}{*}{ São Carlos } & $\mathrm{CH}_{4}$ & 18.139 & 18.232 & 18.185 \\
\hline & $\mathrm{CO}_{2}$ & 5.854 & 6.025 & 5.939 \\
\hline \multirow{2}{*}{$\begin{array}{l}\text { Concentração } \\
\text { Média Total }\end{array}$} & $\mathrm{CH}_{4}$ & 17.704 & 17.359 & 17.596 \\
\hline & $\mathrm{CO}_{2}$ & 5.664 & 5.441 & 5.552 \\
\hline
\end{tabular}

Estes resultados mostraram que as concentrações de $\mathrm{CH}_{4}$ e $\mathrm{CO}_{2}$ no ar ambiente dos aterros sanitários ou lixões são muito maiores que aquelas registradas em locais distantes (background) destes ambientes; como já relatadas neste trabalho, de 1,8 ppm e de 375 ppm, respectivamente (SIKAR and LA SCALA JR., 2004; BAIRD, 2002; AVALA, KICHHOFF e PAVÃO, 1999; HOUGHTON et al, 1995; KHALIL and RASMUSSEN, 1987).

As diferenças, entre o dado da literatura e os resultados obtidos neste trabalho, corresponderam a um fator de quase dez mil vezes mais para o metano e de quinze vezes mais para o dióxido de carbono, em ambientes utilizados para a 
disposição de resíduos sólidos urbanos.

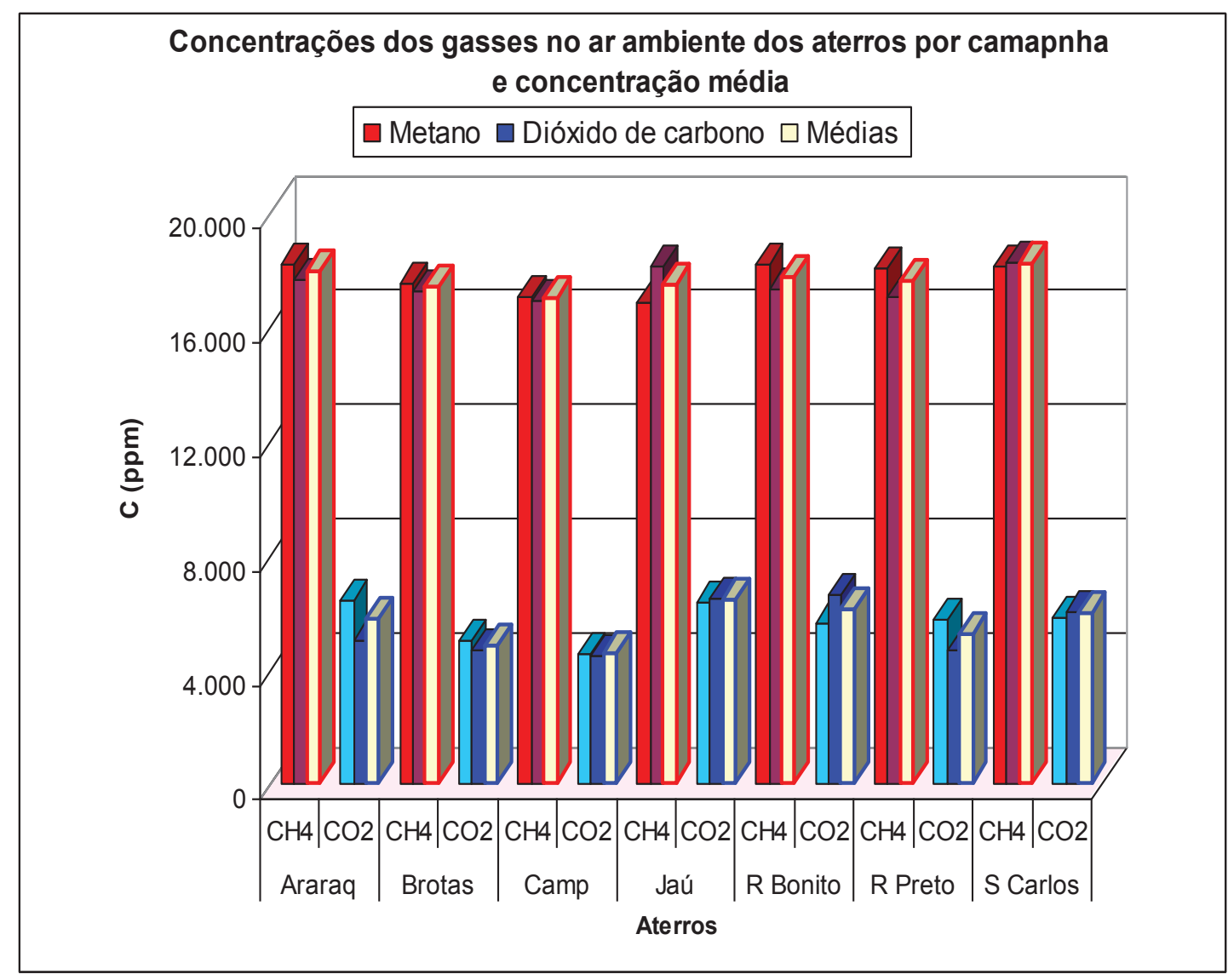

Gráfico 7.1.1 - Concentrações de metano e dióxido de carbono no ar ambiente dos aterros, por campanha e as concentrações médias.

Estes resultados mostraram que no ambiente dos aterros sanitários ou lixões estudados, as concentrações destes dois gases não apresentaram diferenças significativas, variando um pouco mais, apenas, com relação ao dióxido de carbono.

Estes resultados também mostraram que a atmosfera ambiente de aterros sanitários, considerados adequados - Campinas, São Carlos e São Paulo com práticas de disposição recomendadas como corretas ou mais apropriadas, não diferiu dos lixões e aterros controlados, ou considerados inadequados - Araraquara, 
Brotas, Jaú, Ribeirão Bonito e Ribeirão Preto.

Como só se fez uma campanha para o aterro Bandeirantes, em São Paulo - Capital, mostra-se na tabela 7.1.1b, que a inclusão deste aterro, no que diz respeito à concentração dos gases no ar ambiente dos aterros, não alterou a magnitude dos resultados dos demais, pois resultou uma leve queda na concentração de metano (17.596 ppm para 17.028 ppm), com uma diferença para menos de 568 ppm de metano, ou aproximadamente, 3\%; mas elevou ainda mais a concentração do dióxido de carbono, aumentando a média junto aos demais aterros de 5.552 para 6.203 ppm; uma diferença de 652 ppm, ou 10,5\%. Quer para um gás quer para o outro, mesmo nas diferenças, são valores extremamente grandes, em se tratando de poluição ambiental por estes gases.

Tabela 7.1.1b - Resumo das concentrações (C) medidas de $\mathrm{CH}_{4}$ e $\mathrm{CO}_{2}$ no ar ambiente dos aterros, considerando o aterro Bandeirantes na campanha 2007.

\begin{tabular}{l|r|r|r}
\hline Gás & $\begin{array}{c}\mathrm{C}_{\mathrm{m}} \text { dos outros } \\
\text { aterros } \\
(\mathbf{2 0 0 6 / 2 0 0 7 )}\end{array}$ & $\begin{array}{c}\text { Bandeirantes } \\
(\mathbf{2 0 0 7 )}\end{array}$ & $\mathbf{C}_{\mathrm{m}}(\mathbf{p p m})$ \\
\hline $\mathrm{CH}_{4}$ & 17.596 & 16.460 & $\mathbf{1 7 . 0 2 8}$ \\
$\mathrm{CO}_{2}$ & 5.552 & 6.855 & $\mathbf{6 . 2 0 3}$ \\
\hline
\end{tabular}

Excetuando-se o aterro Bandeirantes, a concentração média máxima registrada para o metano foi de 18.185 ppm para o aterro de São Carlos e a mínima registrada foi de $16.981 \mathrm{ppm}$ para o aterro de Campinas. A diferença entre a concentração máxima e mínima foi de 6,62 \% ou 1.204 ppm de metano. Já para o dióxido de carbono, a concentração média máxima medida foi de 6.436 ppm para o aterro de Jaú e a mínima de 4.549 ppm para o aterro de Campinas. Neste caso 
registrou-se uma diferença percentual de 29,32 \%, ou 1.887 ppm de dióxido de carbono.

As concentrações dos dois gases analisados; para aqueles aterros que se poderia considerar como menores; ou mesmo com operação deficitária; estiveram dentro dos limites máximo e mínimo daqueles considerados maiores ou grandes aterros. Todos impactaram muito e negativamente a atmosfera dos locais aonde instalados.

Este resultado, acredita-se, possa ser extrapolado para qualquer espaço que se destine ao armazenamento de resíduos sólidos urbanos. Quer se opere estes locais, seguindo ou não, normas e procedimentos vigentes e próprios para tais.

O aterro Bandeirantes é um dos aterros sanitários que apresentou operação das mais completas, seja para o âmbito nacional ou mundial. Dispõe, como já mostrado, da usina termelétrica (UTEB) com aproveitamento e queima do GAS para a produção de eletricidade, com um sistema de sucção do GAS, compactação e recobrimento, dentro dos parâmetros recomendados pela engenharia. Mesmo assim, apresentou concentrações do ar ambiente do aterro de $\mathrm{CH}_{4}$ e $\mathrm{CO}_{2}$ em níveis que não o diferenciaram dos outros aterros ou lixões. Isto mostra que, independente das operações desenvolvidas no manejo e disposição final dos resíduos sólidos urbanos nestes equipamentos, o ambiente em que estão implantados sofre sério impacto deletério, sendo totalmente modificado e poluído pelo GAS.

Efetivamente, nenhuma grande diferença foi constatada, no que diz respeito à concentração de metano, nos ambientes dos diferentes aterros. O 
montante de lixo, a operação e controles dispensados pareceram não influenciaram na concentração dos gases no ambiente.

Mesmos aqueles depósitos de operação menos cuidadosa, com IQR Índice de Qualidade de aterros de Resíduos - baixo e enquadramento inadequado; casos dos depósitos de Jaú (CETESB, 2000 a 2007), Araraquara (CETESB, 2007) e Ribeirão Preto (CETESB, 2006 a 2007); apresentaram concentrações que não diferem daqueles operados segundo as melhores normas vigentes; casos dos aterros de Campinas (CETESB, 2002 a 2007); São Carlos (CETESB, 2005 a 2007) e do aterro Bandeirantes (CETESB, 2000 a 2006), com IQR's altos e enquadramentos adequados. Vide tabela 5.3.

Individualmente, ressalta-se a maior concentração média máxima de $\mathrm{CO}_{2}$ registrada para o aterro de Jaú. Aterro este que se apresentou em situação das mais críticas. Nas duas campanhas ali empreendidas, presenciaram-se muitos resíduos orgânicos - principalmente, materiais e sobras da indústria calçadista e despejos de batatas em decomposição - em locais onde o aterro já estaria encerrado. Entretanto, em relação à concentração ambiente de metano, não diferiu dos demais. Poder-se-ia inferir que a degradação aeróbica destes resíduos influenciou na concentração ambiente do $\mathrm{CO}_{2}$. No entanto, presenciaram-se também, muito material orgânico disposto, pós-encerramento, em áreas do aterro de Ribeirão Preto; mas para este, aquela inferência referente ao aterro de Jaú, não se confirmou. No aterro de Ribeirão Preto a média da concentração ambiente para $\mathrm{CO}_{2}$ esteve dentro dos limites médios, para o conjunto.

Por outro lado, há que se estudar com mais atenção, a concentração média máxima de metano registrada no caso do aterro de São Carlos, de 18.185 ppm, bem como os seus resultados para as duas campanhas. Estiveram acima da 
média para o conjunto e da média daqueles aterros que lhe são similares. Este aterro apresentou boas práticas de disposição, com compactação e cobertura vegetal onde se apresentou encerrado. No entanto, superou os demais, com a maior concentração ambiente registrada para metano. Para o dióxido de carbono, também resultou com valores acima da média. Aliás, no que dia respeito à quantidade de resíduos aterrada, este aterro apresentou valores bem abaixo daqueles que Ihe são similares, como, p ex., os aterros de Araraquara, Campinas e Ribeirão Preto.

Os gráficos 7.1 .2 e 7.1.3, seguintes, mostram de forma mais clara, as concentrações médias medidas para metano e dióxido de carbono, respectivamente, nos ambientes dos aterros.

Ficou bem ilustrado a pouca diferença nas concentrações dos dois gases, individualmente, tanto para cada aterro, como para cada campanha intervalo de um ano - especialmente, em se tratando do metano. Para este gás, as diferenças percentuais medidas apresentaram valores de $6,6 \%$, se comparadas a média máxima de São Carlos (18.185 ppm) com a média mínima de Campinas (16.981 ppm), ou ainda, a média máxima de São Carlos com a média mínima do aterro Bandeirantes (16.460 ppm), que resultou em uma diferença de 9,5\%. 


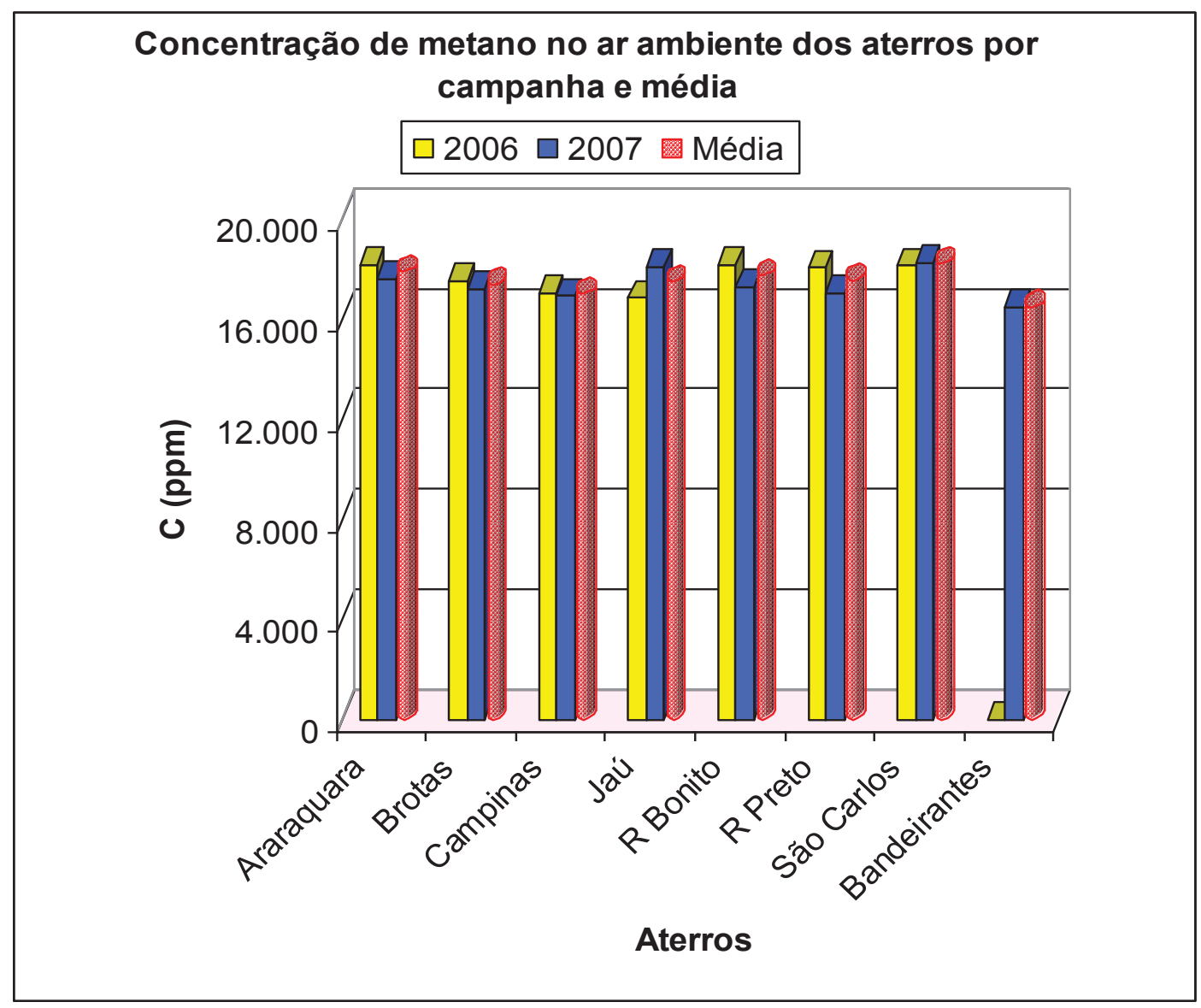

Gráfico 7.1.2 - Concentrações de metano $\left(\mathrm{CH}_{4}\right)$ no ar ambiente dos aterros por campanha e concentração média.

Já para o dióxido de carbono, a média máxima do aterro Bandeirantes (6.855 ppm) diferiu da média mínima do aterro de Campinas (4508 ppm) em 33,6\%; ou ainda; se compararmos a média máxima de Jaú (6.436ppm) com a média mínima de Campinas, que resultou em 29,3\% de diferença.

Em se tratando de poluição ambiental por estes gases, as diferenças registradas, de no máximo 10\% para metano e em torno de 30\% para dióxido de carbono, diante dos valores nominais tão altos registrados, é realmente muito significativo o impacto ambiental dos aterros, nas suas atmosferas e ambientes de entorno. 


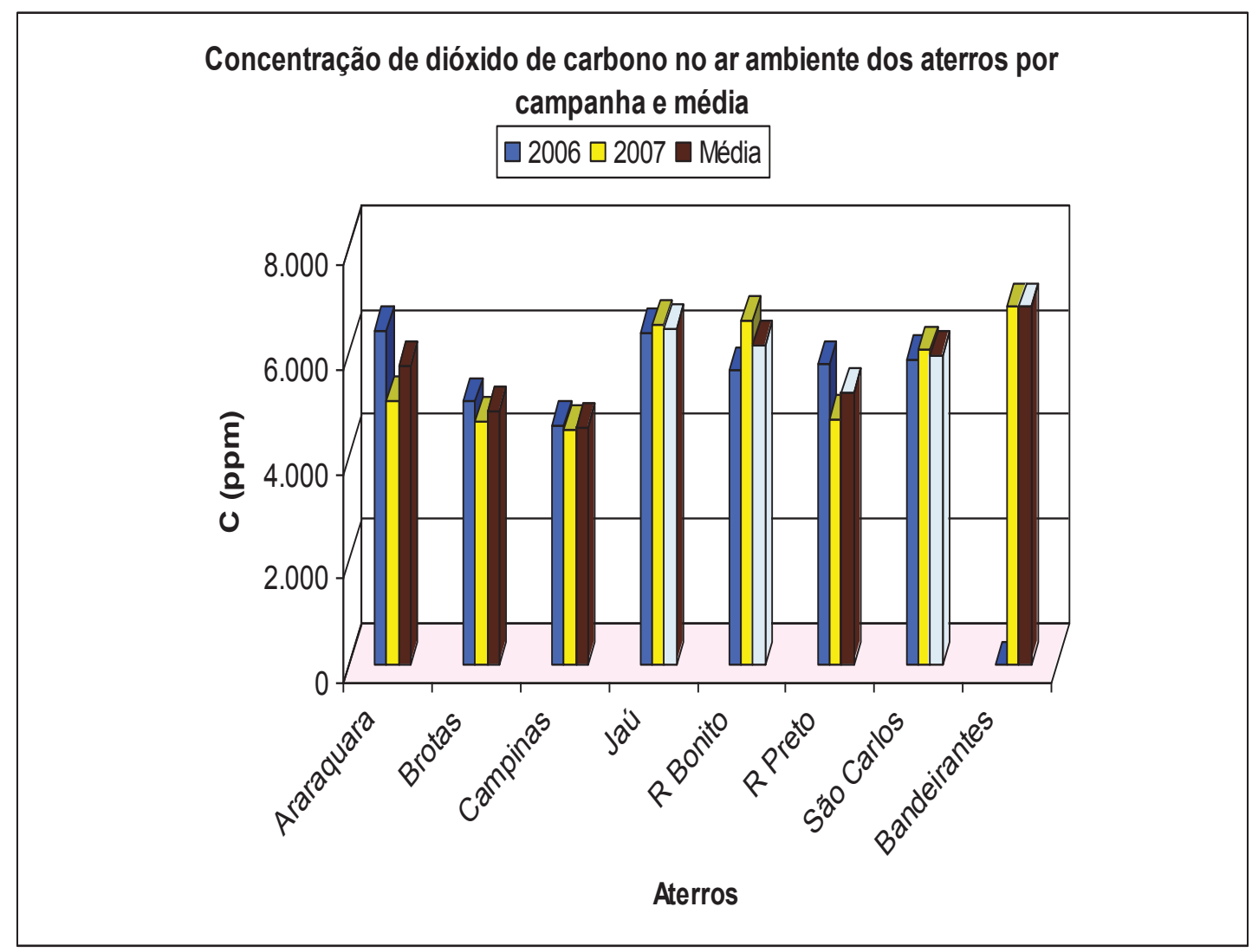

Gráfico 7.1.3 - Concentrações de dióxido de carbono $\left(\mathrm{CO}_{2}\right)$ no ar ambiente dos aterros, por campanha e concentração média.

As concentrações médias medidas para o dióxido de carbono estiveram sempre abaixo daquelas medidas para metano, com diferenças que variaram em torno de até quatro vezes a menor. Por exemplo, a máxima concentração registrada para metano no aterro de São Carlos com a mínima de dióxido de carbono registrada para o aterro de Campinas. Isto pode ser visualizado melhor no gráfico 7.1.4.

Pode-se inferir que a 'dinâmica da química' do dióxido de carbono é tal, especificamente, na atmosfera dos aterros de resíduos sólidos urbanos, que este gás, ao contrário do metano, encontra 'sumidouros' próprios, resultando na 
diferença constatada. A solubilidade deste gás em água e talvez a absorção pela vegetação de cobertura do aterro e do seu entorno, são possíveis variáveis a serem consideradas.

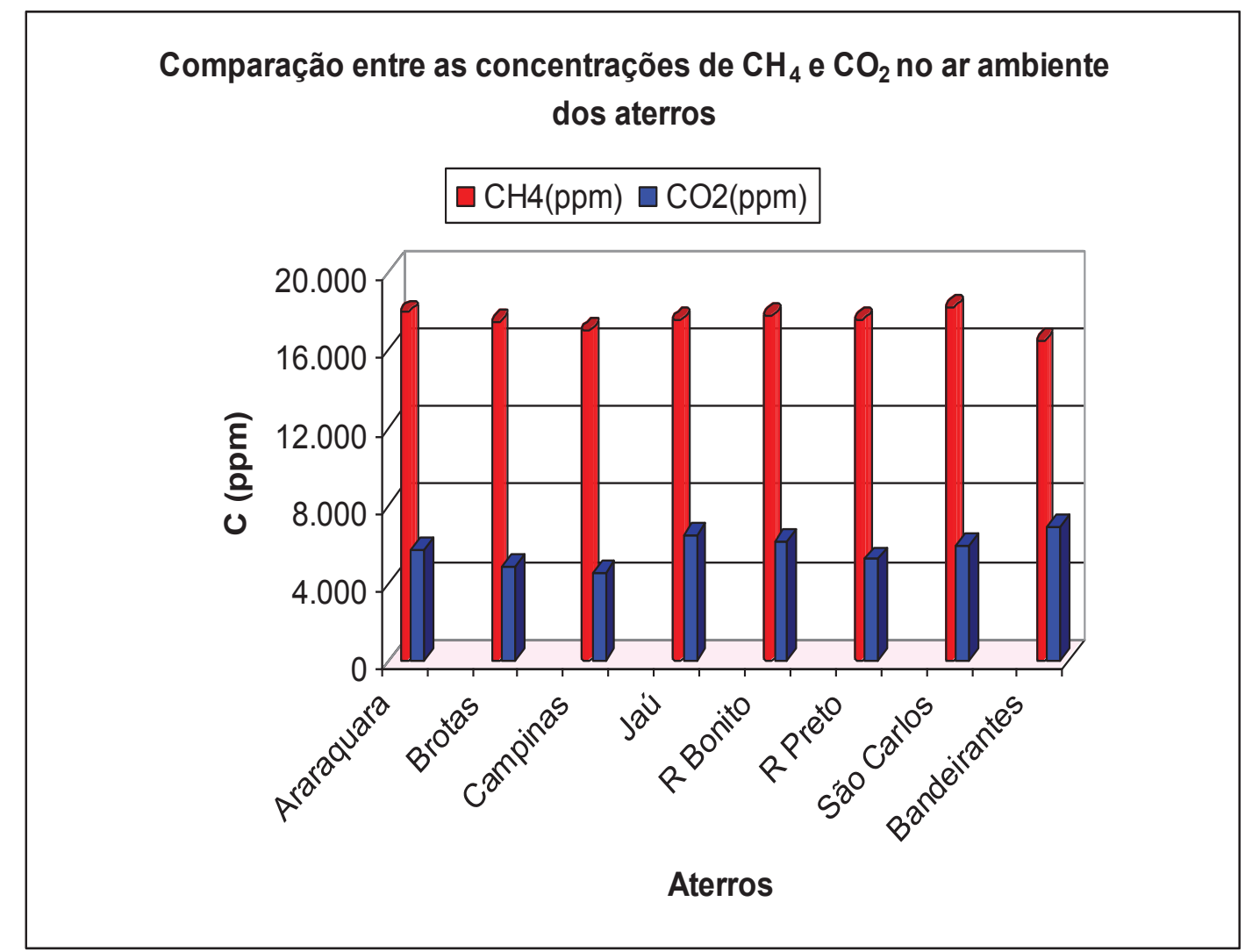

Gráfico 7.1.4 - Comparação entre as concentrações médias de metano e dióxido de carbono, por aterro.

Portanto, ficou bem caracterizado o quanto um aterro sanitário ou qualquer outro espaço que se Ihe assemelhe, para a disposição de resíduos sólidos urbanos, impacta significativa e deleteriamente a atmosfera local, com concentrações de gases como metano e dióxido de carbono, em valores que ultrapassam, exageradamente, qualquer daquelas medidas, quando feitas para locais que não apresentam estes equipamentos de disposição. 
Igualmente, diante da questão do aquecimento global, ambos os gases estão presentes no ambiente dos aterros e são dispersos para a atmosfera terrestre, em quantidades consideráveis, reforçando o efeito estufa antrópico. Isto deve induzir tomadas de decisões nas quais se repensem a gestão e o gerenciamento dos RSU`s, especialmente, quanto ao seu tratamento e à sua disposição final, para que os impactos a partir dos aterros sejam minimizados o máximo possível. Especial atenção deve ser dispensada para o metano, com seu potencial de aquecimento global 23 vezes maior que o dióxido de carbono (IPCC, 2006). 


\subsection{Emissão solo-ar de metano $\left(\mathrm{CH}_{4}\right)$ e de dióxido de carbono $\left(\mathrm{CO}_{2}\right)$ pelos aterros}

Para a emissão solo-ar a variabilidade da taxa de emissão pontual para cada sítio $\left(P_{n}\right)$ de coleta, em cada aterro, foi das mais significativas.

Isto ficou explícito tanto na variação da proporção $\mathrm{CH}_{4} / \mathrm{CO}_{2}$, em um mesmo sítio, como na emissão de um sítio $\left(P_{n}\right)$ para outro, em um aterro específico, tanto quanto para os aterros entre si e de uma campanha para outra.

Pelos resultados, observou- se variações acentuadas na proporção dos dois gases. Alguns sítios emitiram muito mais metano que dióxido de carbono e vice-versa. Em outros, levando-se em consideração os tempos de coletas e os resultados cromatográficos, notou-se que nas tomadas iniciais da coleta, emitiram uma maior quantidade para metano, p. ex., e nas tomadas finais, apresentavam maior emissão para o dióxido de carbono. A recíproca também esteve presente.

Isto pode ser observado em vários dos gráficos e tabelas constantes da secção 6.5 deste trabalho. Veja-se o caso dos $\mathrm{P}_{1}$ e $\mathrm{P}_{2}$, Brotas 2006. $\mathrm{P}_{2}, \mathrm{P}_{3}, \mathrm{P}_{5}, \mathrm{e}$ $P_{6}$, Brotas 2007. $P_{3}$ Campinas 2006. $P_{3}$ e $P_{4}$ Campinas 2007. $P_{5}$ Jaú 2006. $P_{1}, P_{3}$, $P_{4}$ e $P_{5}$, Jaú 2007. $P_{5}$ Ribeirão Bonito 2006. $P_{2}, P_{5}$ e $P_{6}$, Ribeirão Bonito 2007. $P_{2}$ e $P_{4}$, Ribeirão Preto 2006. $P_{1}$ e $P_{2}$, Ribeirão Preto 2007. $P_{2}$ e $P_{3}$, São Carlos 2006. $P_{5}$, São Carlos 2007. $P_{1}, P_{2}, P_{4}$ e $P_{11}$, aterro Bandeirantes 2007.

Neste aspecto, também não se registrou diferenças entre os vários aterros. Todos apresentaram o mesmo comportamento, mesmo que para situações de gerenciamento da disposição bem diferentes. 
Outros sítios ainda mostraram um comportamento de possível absorção do GAS pelo próprio solo do aterro. Vejam-se os casos, p ex., de $\mathrm{P}_{3}$ e $\mathrm{P}_{7}$, Ribeirão Preto, 2006 (Tabela 6.5.72 e Gráfico 6.5.62) e Bandeirantes, 2007(Tabela 6.5.102 e gráfico 6.5.88), respectivamente. O sinal negativo para o coeficiente angular das retas indica um decréscimo no 'enriquecimento' da câmara de coleta, que em momento anterior apresentava maior conteúdo dos dois gases. Ainda nesse viés de comportamento, observou-se que alguns sítios foram bem característicos, com um aumento do conteúdo dos gases, principalmente dos tempos 0' a 3'ou 6'; e depois diminuíram, sensivelmente, a massa de GAS.

Ainda, observando-se os resultados da emissão solo-ar nos sítios pontuais - vide tabela 7.2.1(síntese da emissão pontual solo-ar, onde também se destacam as taxas máximas e mínimas, por aterro e campanha, além das médias máximas e mínimas) - resultou que alguns sítios emitiram quantidades muito reduzidas, enquanto outros emitiram quantidades muito maiores, comparativamente. Este resultado pode significar que dependendo do local do ponto de coleta, a influência na emissão seja muito grande.

Pode-se inferir que: se a câmara de coleta for posta em local onde a compactação e a cobertura finais, foram deficientes, por outro lado, se existiam rachaduras no solo de cobertura, ou ainda, 'canais' próprios para a migração do GAS, idem se, naquele local específico, na massa de lixo enterrada, preponderou materiais orgânicos - esta coleta foi favorecida com muita emissão. Entretanto, se o sítio de coleta coincidiu com local onde a compactação e a cobertura finais, foram mais consistentes; ou naquele ponto específico preponderou, p. ex., maior disposição de resíduos inorgânicos - como resíduos da construção e demolição (RCD), p.ex. - esta coleta foi desfavorecida e captou menos GAS. 
Determinados sítios apresentaram aumento de massa dos gases nas câmaras de coleta com variação linear, com o tempo de coleta. Outros apresentaram aumento de massa nos tempos iniciais da coleta; de 0 até 6 minutos e na 'tomada' de 12 minutos, apresentaram diminuição de massa, indicando que o enriquecimento da câmara com o GAS, parece chegar a um limite de saturação, quando ao invés de continuar efluindo do aterro, o GAS retorna ao solo, pela influência da câmara.

Observando-se as tabelas-resumo da emissão solo-ar, taxas pontuais $\left(P_{n}^{\prime}\right.$ s) - itens (c) da subsecção 6.5.1( $A_{1}$ e $A_{2} ; B_{1}$ e $B_{2} ; \ldots, G_{1}$ e $G_{2} ;$ e $\left.H\right)$; correspondentes às campanhas 2006 e 2007; para os aterros na ordem utilizada neste trabalho, ou seja: Araraquara, Brotas, Campinas, Jaú, Ribeirão Bonito, Ribeirão Preto, São Carlos e Bandeirantes - bem como a tabela 7.2.1, seguinte, pode-se inferir que na emissão solo-ar, os aterros maiores e com maiores quantidades de resíduos aterradas, modo geral, foram 'mais produtivos', emitiram quantidades maiores de gases que aqueles menores, em extensão e quantidades de resíduos depositadas, relativamente. Veja-se o caso dos aterros Bandeirantes, de Campinas e de Ribeirão Preto; que apresentaram as maiores taxas médias de emissão pontual.

O aterro Bandeirantes, mesmo considerando-se a campanha única, em 2007, mas com o maior número de sítios $\left(P_{n}\right)$ de coleta, apresentou a maior taxa média, tanto para metano como para dióxido de carbono, com valores de 148,20 g. $m^{-2} \cdot d^{-1}$ e $149,34 \mathrm{~g} \cdot \mathrm{m}^{-2} \cdot \mathrm{d}^{-1}$, respectivamente, como pode ser observado nas tabelas 7.2.1 e 7.2.2. Foi também uma das taxas médias mais uniformes entre os dois gases, com 50\% para cada. Vide coluna cinco da tabela 7.2.2 - média total. 


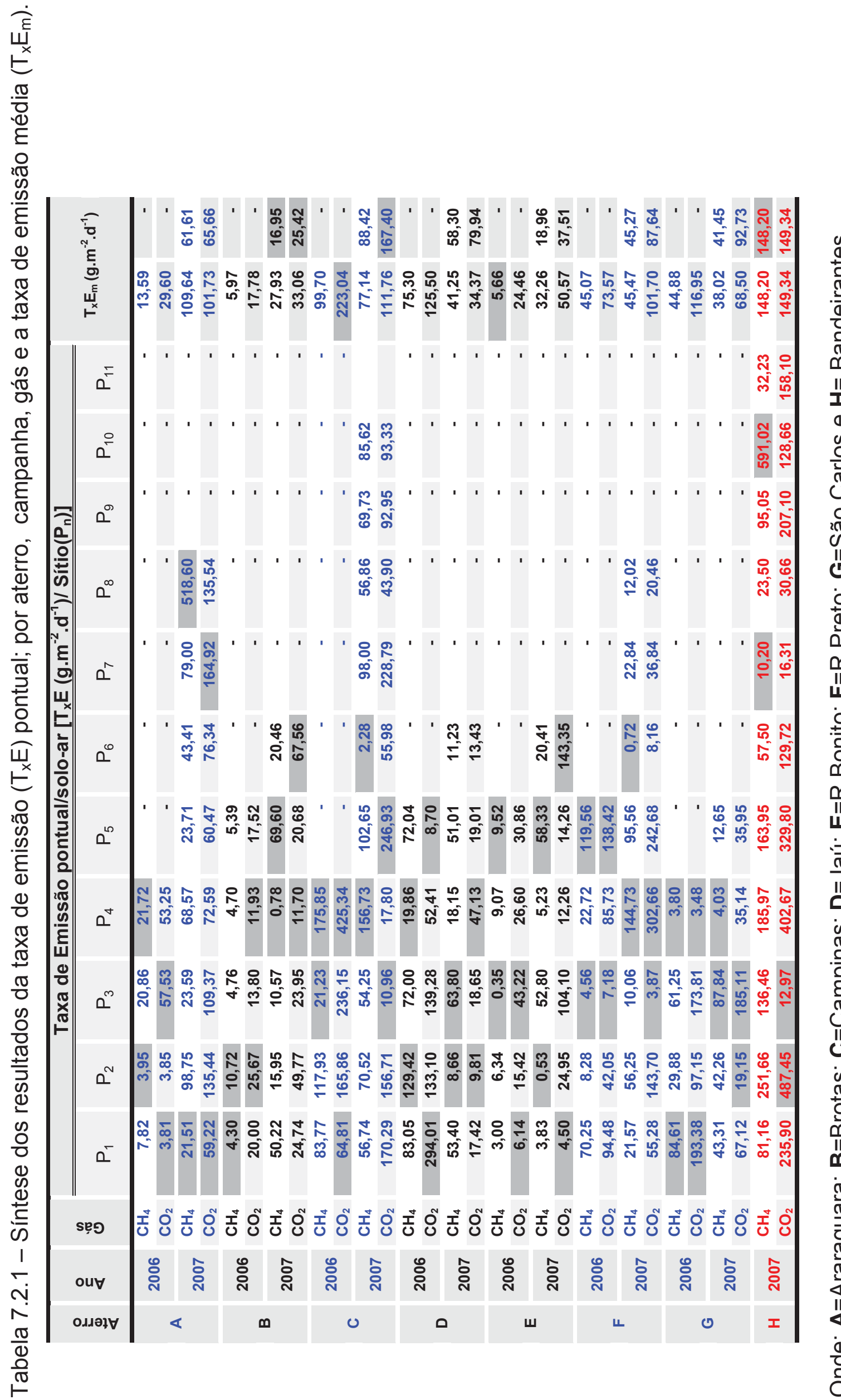


Pontualmente, as taxas de emissão do Bandeirantes variaram de 10,20 mg.m $\mathrm{m}^{-2} \cdot \mathrm{d}^{-1}$ de $\mathrm{CH}_{4}$ no sítio $\mathrm{P}_{7}$ a $591,02 \mathrm{mg} \cdot \mathrm{m}^{-2} \cdot \mathrm{d}^{-1}$ de $\mathrm{CH}_{4}$ no sítio $\mathrm{P}_{10}$, com uma diferença de 98\%, em massa. Em relação ao dióxido de carbono esta variação foi de $12,97 \mathrm{mg} \cdot \mathrm{m}^{-2} \cdot \mathrm{d}^{-1}$ no sítio $\mathrm{P}_{3}$ a $487,45 \mathrm{mg} \cdot \mathrm{m}^{-2} \cdot \mathrm{d}^{-1}$ no sítio $\mathrm{P}_{2}$, com diferença de 97\%, em massa.

Novamente, vale salientar que o sistema de sucção do GAS, existente no aterro para alimentar a UTEB, também parece não influenciar na emissão solo-ar do mesmo; que, como para a concentração do ar ambiente do local; apresentou taxas de emissão semelhante aos demais aterros, inclusive, com variabilidades semelhantes, quer para os dois gases quer para os sítios de coleta, entre si.

Depois do Bandeirantes, os aterros de Campinas, Ribeirão Preto e São Carlos, em geral, foram os que apresentaram as maiores taxas médias de emissão solo-ar - com massas medidas em $m g \cdot m^{-2} \cdot d^{-1}-$ respectivamente, para $\mathrm{CH}_{4}$ e $\mathrm{CO}_{2}$ de: 88,42 e167,40; 45,27 e 87,64; 41,45 e 92,73, como pode ser observado nas tabelas 7.2 .1 e 7.2.2.

Os aterros em valas de Brotas e Ribeirão Bonito, que apresentaram os menores quantitativos de resíduos dispostos; com 25.289 e 32.000 toneladas; respectivamente, resultaram nas menores taxas médias de emissão solo-ar. Estas foram de $16,95 \mathrm{mg} \cdot \mathrm{m}^{-2} \cdot \mathrm{d}^{-1}$ de $\mathrm{CH}_{4}$ e $25,42 \mathrm{mg} \cdot \mathrm{m}^{-2} \cdot \mathrm{d}^{-1}$ de $\mathrm{CO}_{2}$ para Brotas e 18,96 mg.m $\mathrm{m}^{-2} \cdot \mathrm{d}^{-1}$ de $\mathrm{CH}_{4}$ e $37,51 \mathrm{mg} \cdot \mathrm{m}^{-2} \cdot \mathrm{d}^{-1}$ de $\mathrm{CO}_{2}$ para Ribeirão Bonito. Tabelas 7.2.1 e 7.2.2.

Pontualmente, as taxas de emissão também variaram significativamente. Desde valores mínimos de $0,53 \mathrm{~g} \cdot \mathrm{m}^{-2} \cdot \mathrm{d}^{-1}$ de $\mathrm{CH}_{4}\left(\mathrm{P}_{4}-\right.$ Ribeirão Bonito -2007); 0,72 g.m $\mathrm{m}^{-2} \cdot \mathrm{d}^{-1}$ de $\mathrm{CH}_{4}\left(\mathrm{P}_{6}-\right.$ Ribeirão Preto -2007); 0,78 g.m $\mathrm{m}^{-2} \cdot \mathrm{d}^{-1} \mathrm{CH}_{4}$ $\left(\mathrm{P}_{4}\right.$ - Brotas -2007) a valores máximos de 591,02 g.m .d $^{-1} \mathrm{CH}_{4}\left(\mathrm{P}_{10}\right.$ 
Bandeirantes -2007); 518,60 g.m $\mathrm{m}^{-2} \cdot \mathrm{d}^{-1} \mathrm{CH}_{4}\left(\mathrm{P}_{8}-\right.$ Araraquara - 2007); $175 \mathrm{~g} \cdot \mathrm{m}^{-2} \cdot \mathrm{d}^{-1}$ $\mathrm{CH}_{4}\left(\mathrm{P}_{4}-\right.$ Campinas -2006). Tabela 7.2.1.

Para o dióxido de carbono, este aspecto não foi diferente. Resultaram variações desde valores mínimos de 3,48 g.m. . $^{-2} \cdot \mathrm{d}^{-1} \mathrm{CO}_{2}\left(\mathrm{P}_{2}\right.$ - São Carlos -2006); 3,81 g.m $m^{-2} \cdot d^{-1} \mathrm{CO}_{2}\left(\mathrm{P}_{1}-\right.$ Araraquara -2006) ou 3,87 g.m $\mathrm{m}^{-2} \cdot \mathrm{d}^{-1} \mathrm{CO}_{2}\left(\mathrm{P}_{3}-\mathrm{R}\right.$ Preto -2007) a valores máximos de 487,45 g.m $\mathrm{m}^{-2} \cdot \mathrm{d}^{-1} \mathrm{CO}_{2}\left(\mathrm{P}_{2}-\right.$ Bandeirantes -2007$) ; 425,34 \mathrm{~g} \cdot \mathrm{m}^{-2} \cdot \mathrm{d}^{-1}$ $\mathrm{CO}_{2}\left(\mathrm{P}_{4}\right.$ - Campinas -2006), ou, 302,66 g.m $\mathrm{m}^{-2} \cdot \mathrm{d}^{-1} \mathrm{CO}_{2}\left(\mathrm{P}_{4}\right.$ - Ribeirão Preto -2007). Tabela 7.2.1.

A tabela 7.2.2, mostra a taxa média calculada para a emissão solo-ar dos aterros, e a média total das duas campanhas, excetuando-se o aterro Bandeirantes com só uma campanha. 
Tabela 7.2.2 - Taxa de emissão média $\left(T_{x} E_{m}\right)$ solo-ar para os aterros e a média total.

\begin{tabular}{|c|c|c|c|c|}
\hline Aterro & Gás & $\begin{array}{l}\mathrm{T}_{\mathrm{x}} \mathrm{E}_{\mathrm{m}}(2006) \\
\left(g \cdot m^{-2} \cdot d^{-1}\right)\end{array}$ & $\begin{array}{l}\mathrm{T}_{\mathrm{x}} \mathrm{E}_{\mathrm{m}}(2007) \\
\left(g \cdot m^{-2} \cdot d^{-1}\right)\end{array}$ & $\begin{array}{l}\text { Média Total } \\
\left(g \cdot m^{-2} \cdot d^{-1}\right)\end{array}$ \\
\hline \multirow{2}{*}{ Araraquara } & $\mathrm{CH}_{4}$ & 13,59 & 109,64 & 61,61 \\
\hline & $\mathrm{CO}_{2}$ & 29,60 & 101,73 & 65,66 \\
\hline \multirow{2}{*}{ Brotas } & $\mathrm{CH}_{4}$ & 5,97 & 27,93 & 16,95 \\
\hline & $\mathrm{CO}_{2}$ & 17,78 & 33,06 & 25,42 \\
\hline \multirow{2}{*}{ Campinas } & $\mathrm{CH}_{4}$ & 99,70 & 77,14 & 88,42 \\
\hline & $\mathrm{CO}_{2}$ & 223,04 & 111,76 & 167,40 \\
\hline \multirow{2}{*}{ Jaú } & $\mathrm{CH}_{4}$ & 75,30 & 41,25 & 58,30 \\
\hline & $\mathrm{CO}_{2}$ & 125,50 & 34,37 & 79,94 \\
\hline \multirow{2}{*}{ R Bonito } & $\mathrm{CH}_{4}$ & 5,66 & 32,26 & 18,96 \\
\hline & $\mathrm{CO}_{2}$ & 24,46 & 50,57 & 37,51 \\
\hline \multirow{2}{*}{ R Preto } & $\mathrm{CH}_{4}$ & 45,07 & 45,47 & 45,27 \\
\hline & $\mathrm{CO}_{2}$ & 73,57 & 101,70 & 87,64 \\
\hline \multirow{2}{*}{ S Carlos } & $\mathrm{CH}_{4}$ & 44,88 & 38,02 & 41,45 \\
\hline & $\mathrm{CO}_{2}$ & 116,95 & 68,50 & 92,73 \\
\hline \multirow{2}{*}{ Bandeirantes } & $\mathrm{CH}_{4}$ & - & 148,20 & 148,20 \\
\hline & $\mathrm{CO}_{2}$ & - & 149,34 & 149,34 \\
\hline
\end{tabular}

Estes parâmetros - taxa de emissão média $\left(T_{x} E_{m}\right)$ e média total - se mostraram mais práticos para a comparação da emissão solo-ar entre os aterros, uma vez que, na emissão média total, está embutido um fator que acarreta grandes variações que é o tamanho da área de disposição (Vide tabela 7.2.4). 
O gráfico 7.2.1, mostra os resultados da taxa de emissão média por campanha e a média total, ficando bem claro as variações registradas e já relatadas, anteriormente.

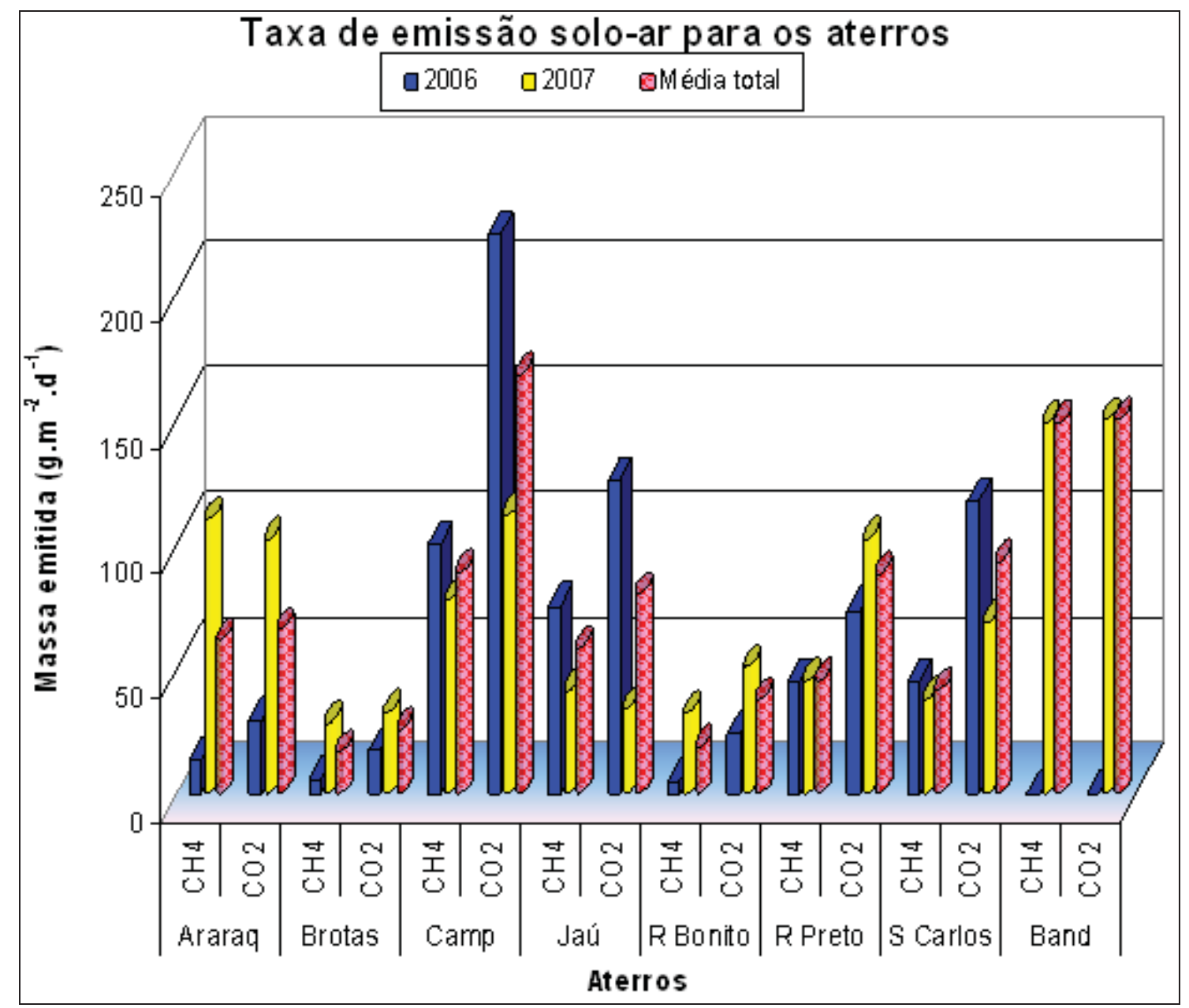

Gráfico 7.2.1 - Taxas de emissão média solo-ar e a média total, para os aterros.

O gráfico 7.2.1 ainda confirma que a variabilidade na emissão solo-ar esteve presente também entre uma campanha e outra, tanto em cada aterro, quanto entre eles. Mesmo sem que se tenha detectado variáveis outras, a não ser a 
‘dinâmica intrínseca’ de cada um, como dito por Schalch (1992) - cada aterro é um aterro - que tivessem influenciado este comportamento.

O clima, modo geral, a pluviosidade, em particular, e o método de trabalho, como possíveis variáveis que poderiam interferir na emissão do solo dos aterros, estiveram iguais. Fazia parte, inicialmente, desta proposta de trabalho, pesquisar a possível influência da chuva - analisar período seco e chuvoso - mas, nos dois anos nos quais a pesquisa foi desenvolvida, não aconteceram chuvas em quantidades que permitissem atingir tal intento.

Os aterros de Araraquara, Brotas e Ribeirão Bonito produziram, na emissão solo-ar, bem menos metano que dióxido de carbono na campanha de 2006, em ralação à de 2007. Os valores nominais e as diferenças percentuais, para mais, entre as campanhas, constam da tabela 7.2.3a.

Tabela 7.2.3a - Valores medidos da maior emissão solo-ar em 2007 e a diferença percentual por campanha.

\begin{tabular}{l|l|c|c}
\hline Aterro & Gás & $\begin{array}{r}\text { Valor nominal } \\
(\mathbf{2 0 0 6} \rightarrow \mathbf{2 0 0 7 )}\end{array}$ & $\begin{array}{c}\text { Diferença \% } \\
\text { para mais }\end{array}$ \\
\hline Araraquara & $\mathrm{CH}_{4}$ & $13,59 \rightarrow \mathbf{1 0 9 , 6 4}$ & 87,60 \\
& $\mathrm{CO}_{2}$ & $29,60 \rightarrow \mathbf{1 0 1 , 7 3}$ & 71,00 \\
\hline Brotas & $\mathrm{CH}_{4}$ & $5,97 \rightarrow \mathbf{2 7 , 9 3}$ & 78,62 \\
& $\mathrm{CO}_{2}$ & $17,78 \rightarrow \mathbf{3 3 , 0 6}$ & 46,21 \\
\hline Ribeirão Bonito & $\mathrm{CH}_{4}$ & $5,66 \rightarrow \mathbf{3 2 , 2 6}$ & 82,45 \\
& $\mathrm{CO}_{2}$ & $24,46 \rightarrow \mathbf{5 0 , 5 7}$ & 51,63 \\
\hline \hline Ribeirão Preto* & $\mathrm{CH}_{4}$ & $45,07 \rightarrow 45,47$ & 1,00 \\
\hline & $\mathrm{CO}_{2}$ & $73,57 \rightarrow 101,70$ & 27,66 \\
\hline O aterro de Ribeirão Preto fugiu a este comportamento no que diz \\
\hline \\
respeito à emissão de metano.
\end{tabular}


Como se pode notar na tabela 7.2.3a, última linha, o aterro de Ribeirão Preto fugiu ao comportamento dos outros três, neste grupo, com diferença de menos de $1 \%$ a maior na campanha 2007 em relação a 2006 . Com relação ao dióxido de carbono, este aterro também apresentou diferença percentual bem menor, $27,66 \%$, distante das diferenças dos outros. Essas diferenças podem ser melhor visualizadas no gráfico 7.2.2.

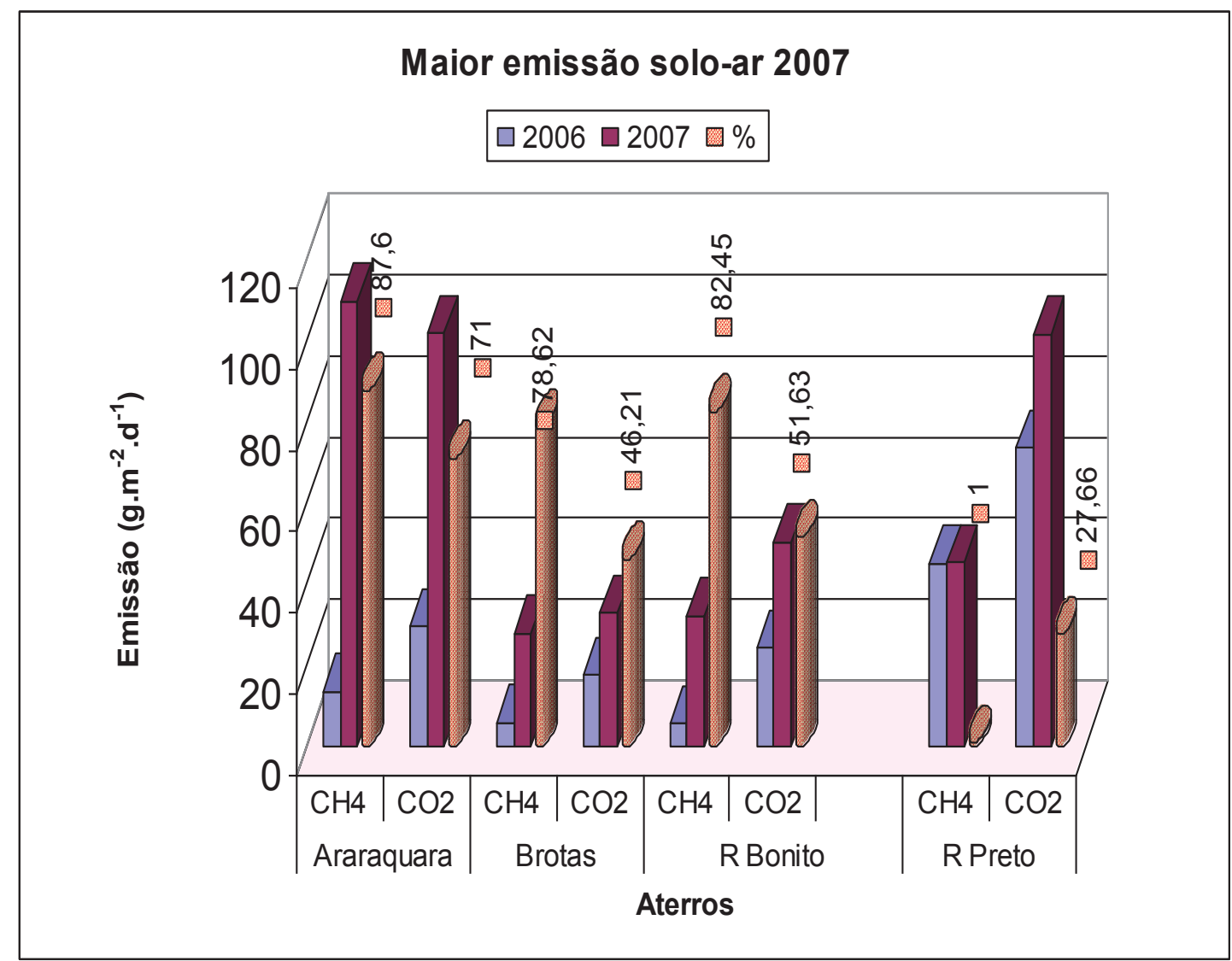

Gráfico 7.2.2 - Aterros com maior emissão na campanha de 2007. Destaque para as diferenças percentuais e diferenças registradas no aterro de Ribeirão Preto.

O gráfico 7.2.2 explicita as maiores emissões para os aterros mais 
produtivos em 2007. Mostra também as diferenças percentuais, evidenciando serem mínimas em relação ao gás metano e com maior variabilidade no que diz respeito ao dióxido de carbono. Neste aspecto, nos quantitativos medidos, também não se detectou grandes diferenças na emissão. A diferença percentual para o metano foi menos que $10 \%$, para os três aterros. Já para o dióxido de carbono, neste grupo, esta diferença foi maior, em torno de $25 \%$.

Em média, o aterro de Araraquara produziu $13,59 \mathrm{~g} \cdot \mathrm{m}^{-2} \cdot \mathrm{d}^{-1}$ de metano em 2006 e aumentou esta produção para 109,64 g.m. . $^{-2} \cdot{ }^{-1}$ em 2007, com uma diferença percentual de $87,60 \%$. Para o dióxido de carbono, a emissão medida em 2006 foi de $29,69 \mathrm{~g} \cdot \mathrm{m}^{-2} \cdot \mathrm{d}^{-1}$ e em 2007 de $101,73 \mathrm{~g} \cdot \mathrm{m}^{-2} \cdot \mathrm{d}^{-1}$, com diferença percentual de $71,00 \%$.

Já os aterros de Campinas, Jaú e São Carlos diminuíram as suas emissões na campanha de 2007, em relação à de 2006. A tabela 7.2.3b, mostra estes resultados evidenciando que a ‘queda de produção' observada foi bem menor, relativamente, que o aumento de emissão anotado para aqueles aterros que foram mais produtivos em 2007.

Tabela 7.2.3b - Valores medidos da maior emissão solo-ar em 2006 e diferença percentual por campanha.

\begin{tabular}{l|c|c|c}
\hline Aterro & Gás & $\begin{array}{c}\text { Valor nominal } \\
(\mathbf{2 0 0 6} \rightarrow \mathbf{2 0 0 7 )}\end{array}$ & $\begin{array}{c}\text { Diferença \% } \\
\text { para menos }\end{array}$ \\
\hline Campinas & $\mathrm{CH}_{4}$ & $\mathbf{9 9 , 7 0} \rightarrow 77,14$ & 22,63 \\
& $\mathrm{CO}_{2}$ & $\mathbf{2 2 3 , 0 4} \rightarrow 111,76$ & 50,00 \\
\hline \multirow{2}{*}{ Jaú } & $\mathrm{CH}_{4}$ & $\mathbf{7 5 , 3 0} \rightarrow 41,25$ & 45,22 \\
& $\mathrm{CO}_{2}$ & $\mathbf{1 2 5 , 5 0} \rightarrow 34,26$ & 72,70 \\
\hline \multirow{2}{*}{ São Carlos } & $\mathrm{CH}_{4}$ & $\mathbf{4 4 , 8 8} \rightarrow 38,02$ & 15,28 \\
& $\mathrm{CO}_{2}$ & $\mathbf{1 1 6 , 9 5} \rightarrow 68,50$ & 41,43 \\
\hline \hline
\end{tabular}


Neste grupo, a maior queda de produção do metano foi anotada no aterro de Jaú, com 45,22\% e a menor para o aterro de São Carlos, com 15,28\%, uma diferença de $31 \%$. Estas diferenças são mostradas também no gráfico 7.2.3, a seguinte.

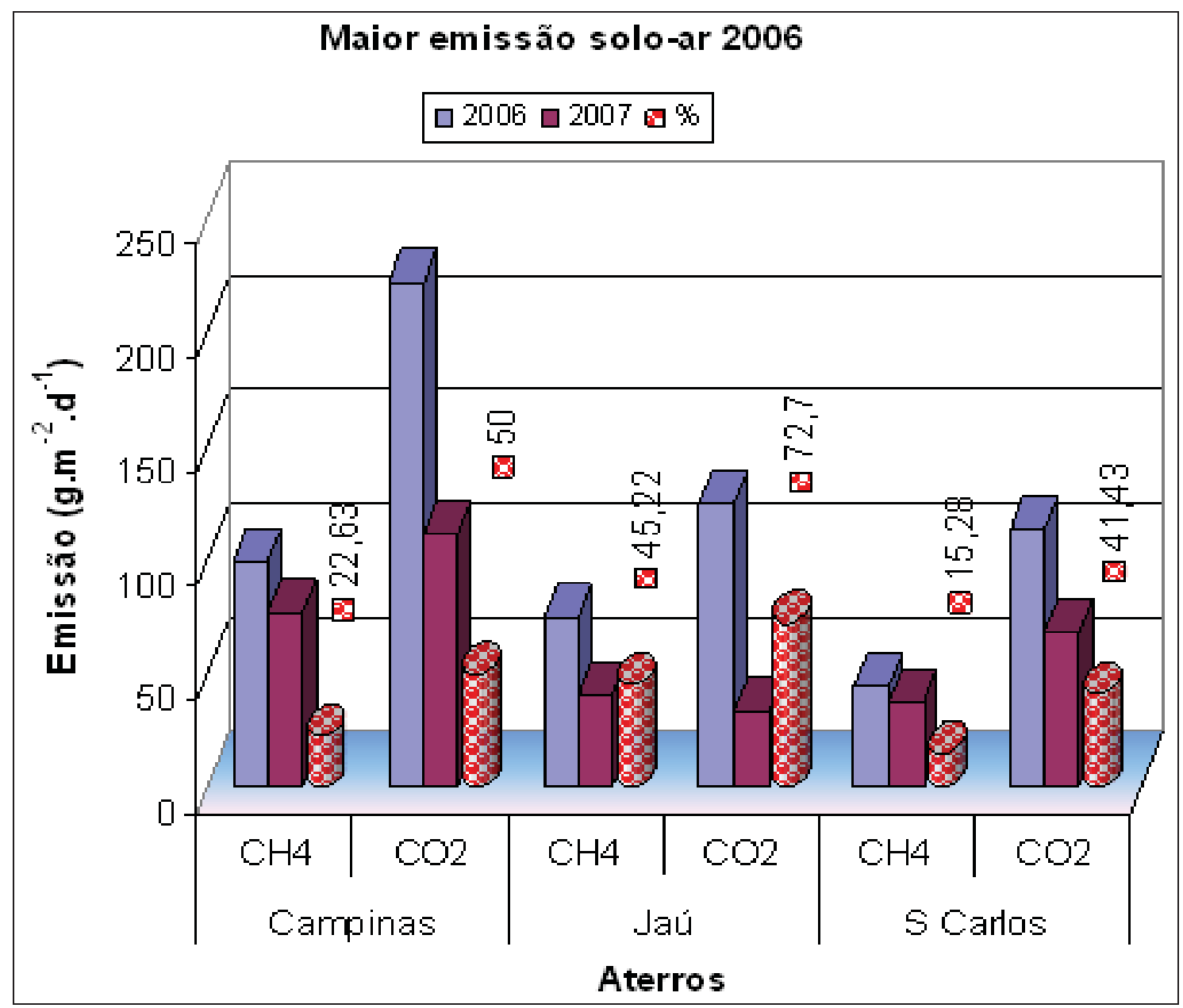

Gráfico 7.2.3 - Aterros com maior emissão na campanha de 2006. Destaque para as diferenças percentuais.

A emissão média solo-ar das duas campanhas por aterro, gás e a emissão estimada para cada aterro, como um todo, constam da tabela 7.2.4. Para estes cálculos, entrou o fator área de disposição de cada aterro, o que, 
proporcionalmente, leva a grandes diferenças da emissão para cada um deles e da emissão estimada.

Tabela 7.2.4 - Emissão média solo-ar de cada campanha e emissão estimada para os aterros estudados (em toneladas por ano) e a proporção percentual entre os dois gases.

\begin{tabular}{|c|c|c|c|c|c|}
\hline \multirow{2}{*}{ Aterro } & \multirow{2}{*}{ Gás } & \multicolumn{2}{|c|}{ Emissão média $\left(t \cdot a^{-1}\right)$} & \multirow{2}{*}{$\begin{array}{c}\text { Emissão } \\
\text { estimada } \\
\left(t \cdot a^{-1}\right)\end{array}$} & \multirow{2}{*}{$\begin{array}{l}\text { Proporção } \\
\text { Percentual } \\
\text { (em massa) }\end{array}$} \\
\hline & & 2006 & 2007 & & \\
\hline \multirow{2}{*}{ Araraquara } & $\mathrm{CH}_{4}$ & 396,83 & $3.201,49$ & $1.799,16$ & 48,41 \\
\hline & $\mathrm{CO}_{2}$ & 864,61 & $2.970,52$ & $1.917,56$ & 51,59 \\
\hline \multirow{2}{*}{ Brotas } & $\mathrm{CH}_{4}$ & 117,66 & 550,50 & 334,08 & 40,00 \\
\hline & $\mathrm{CO}_{2}$ & 350,44 & 651,61 & 501,02 & 60,00 \\
\hline \multirow{2}{*}{ Campinas } & $\mathrm{CH}_{4}$ & $9.461,53$ & $7.320,58$ & $8.391,05$ & 34,60 \\
\hline & $\mathrm{CO}_{2}$ & $21.166,50$ & $10.606,02$ & $15.886,26$ & 65,40 \\
\hline \multirow{2}{*}{ Jaú } & $\mathrm{CH}_{4}$ & $1.330,25$ & 728,72 & $1.029,48$ & 42,20 \\
\hline & $\mathrm{CO}_{2}$ & $2.217,08$ & 602,16 & $1.409,70$ & 57,80 \\
\hline \multirow{2}{*}{ R Bonito } & $\mathrm{CH}_{4}$ & 82,64 & 471,00 & 276,82 & 33,22 \\
\hline & $\mathrm{CO}_{2}$ & 375,12 & 738,32 & 556,71 & 66,78 \\
\hline \multirow{2}{*}{ R Preto } & $\mathrm{CH}_{4}$ & $3.586,22$ & $3.618,05$ & $3.602,14$ & 34,07 \\
\hline & $\mathrm{CO}_{2}$ & $5.853,96$ & $8.092,27$ & $6.973,11$ & 65,93 \\
\hline \multirow{2}{*}{ São Carlos } & $\mathrm{CH}_{4}$ & $2.948,61$ & $2.497,91$ & $2.723,20$ & 30,90 \\
\hline & $\mathrm{CO}_{2}$ & $7.683,61$ & $4.500,45$ & $6.092,03$ & 69,10 \\
\hline \multirow{2}{*}{ Bandeirantes } & $\mathrm{CH}_{4}$ & - & $75.730,20$ & $75.730,20$ & 49,80 \\
\hline & $\mathrm{CO}_{2}$ & - & $76.312,74$ & $76.312,74$ & 50,20 \\
\hline
\end{tabular}

De um modo geral, para a emissão solo-ar, média e estimada para cada aterro, preponderou uma grande variabilidade nos resultados. As diferenças da emissão para aterros diferentes são consideráveis, embora se depreenda da tabela 7.2.4 e gráfico 7.2.1, que os maiores aterros emitiram muito mais que os menores.

Para a emissão solo-ar, o aterro de Campinas foi o que mais emitiu; 
entre aqueles que the são semelhantes, em tamanho e quantidade de resíduos depositada, como os aterros de Araraquara, Ribeirão Preto e São Carlos.

Especialmente, na campanha de 2006, o aterro de Campinas apresentou a máxima emissão média de 9.461,53 toneladas por ano para $\mathrm{CH}_{4}$ e de 21.166,50 toneladas por ano para $\mathrm{CO}_{2}$. Esta emissão medida foi muito maior que aquela registrada para os demais aterros, com exceção para o Bandeirantes, que na campanha única de 2007 apresentou uma emissão solo-ar de 75.730 t.a ${ }^{-1}$ para metano e de 76.312 t.a-1 para dióxido de carbono.

Como as taxas médias de emissão do aterro Bandeirantes $\left(148,42 \mathrm{~g} \cdot \mathrm{m}^{-2} \cdot \mathrm{d}^{-1} \mathrm{CH}_{4}\right.$ e $\left.149,34 \mathrm{~g} \cdot \mathrm{m}^{-2} \cdot \mathrm{d}^{-1} \mathrm{CO}_{2}\right)$ e do aterro de Campinas $\left(88,42 \mathrm{~g} \cdot \mathrm{m}^{-}\right.$ ${ }^{2} \cdot d^{-1} \mathrm{CH}_{4}$ e 167,40 g.m. . $^{-2} \cdot \mathrm{d}^{-1} \mathrm{CO}_{2}$ ) - Tabela 7.2 .2 - não foram muito diferentes, na ordem de grandeza das emissões calculadas, infere-se que o montante de resíduos depositados, a área de deposição e a idade do aterro, e, a altura da montanha de lixo, no aterro Bandeirantes, sejam possíveis fatores que influenciaram na disparidade entre as emissões estimadas.

O gráfico 7.2.4, seguinte, mostra a emissão solo-ar por campanha e a emissão estimada. Veja-se que, se excluído o aterro Bandeirantes, para a emissão solo-ar, ficam bem caracterizadas as diferenças deste processo, para os aterros menores (Brotas, Ribeirão Bonito e Jaú) em comparação àqueles de maior porte, ou intermediários. 


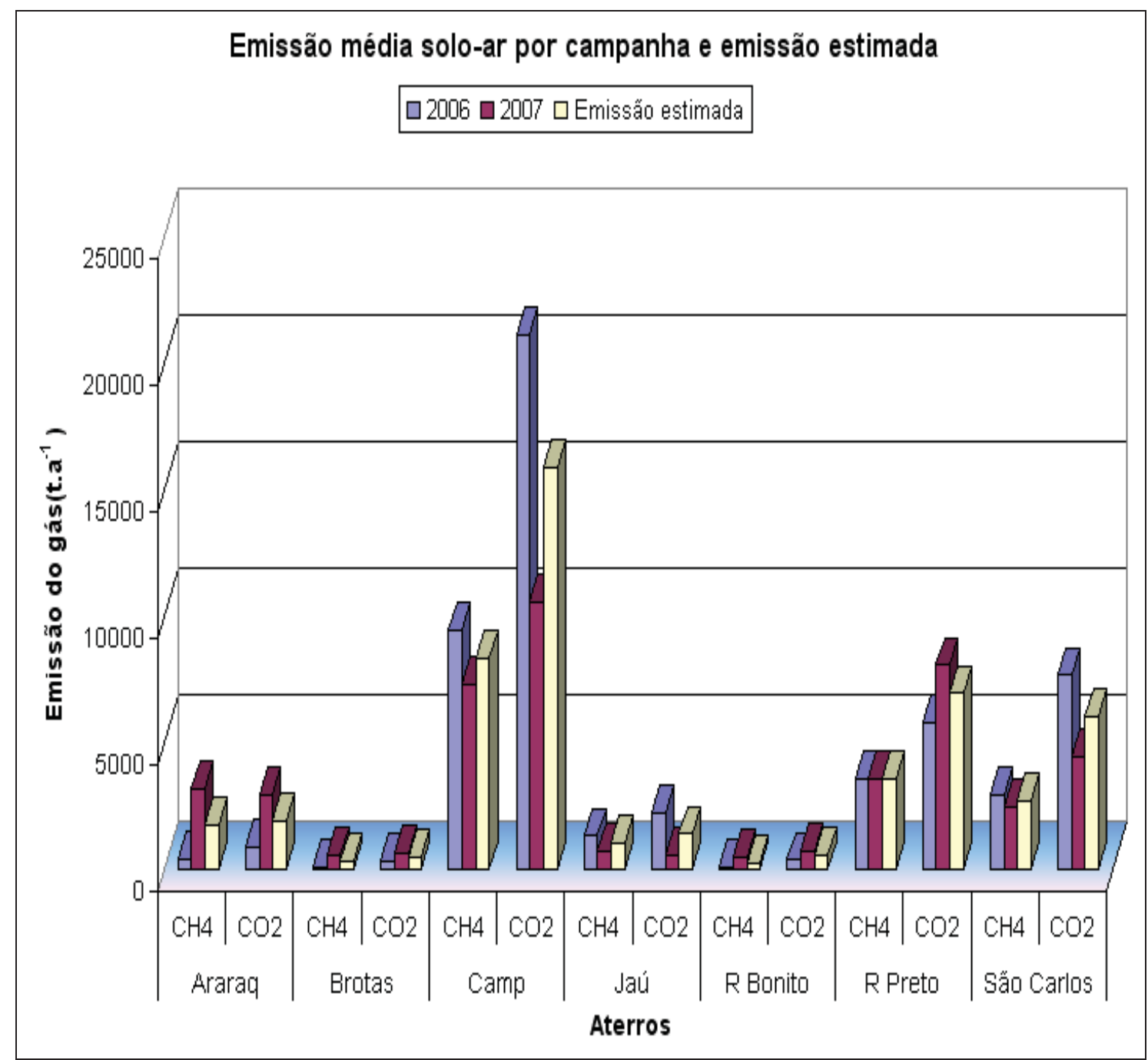

Gráfico 7.2.4 - Emissão média solo-ar por campanha e aterros.

Pela análise dos resultados, se tomados os oito aterros estudados e divididos em três blocos, resultaria um primeiro bloco que se denominaria de "aterros pequenos", formado pelos aterros de Brotas, Jaú e Ribeirão Bonito, com áreas de disposição variando entre $40.000 \mathrm{~m}^{2}$ (Ribeirão Bonito) a $54.000 \mathrm{~m}^{2}$ (Brotas) e uma quantidade de resíduos disposta variando entre 25.000 (Brotas) a 670.000 (Jaú), toneladas.

Neste bloco a emissão estimada individual variou, em média, entre 276,82 toneladas por ano (Ribeirão Bonito) e 1.029,40 toneladas por ano de 
metano, caso de Jaú. Considerando os três juntos, teriam emitido, em média, 546,79 toneladas de metano por ano. Para o dióxido de carbono, a emissão individual esteve entre 501,02 toneladas por ano, caso de Brotas e 1.409,48 toneladas por ano para o aterro de Jaú. Os três juntos teriam emitido, em média, 822,22 toneladas-ano de dióxido de carbono.

Um segundo bloco seria formado pelos aterros de Araraquara, São Carlos, Ribeirão Preto e Campinas; com áreas de disposição variando entre 80.000 $\mathrm{m}^{2}$, caso de Araraquara a $260.000 \mathrm{~m}^{2}$, caso de Campinas. A quantidade de resíduos disposta neste bloco variou entre 608.907 toneladas (São Carlos) e 4.334.717 toneladas (Campinas). O aterro de Campinas foi o de maior emissão, com valores médios estimados de $8.391,15$ toneladas por ano para $\mathrm{CH}_{4}$ e 15.886,26 toneladas por ano de $\mathrm{CO}_{2}$, enquanto o aterro controlado de Araraquara apresentou a menor emissão estimada em 1.799,16 toneladas por ano para metano e 1.917,56 toneladas por ano de dióxido de carbono. Os quantitativos do aterro de Campinas, bem maiores que os dos outros três deste bloco, parecem mostrar alguma correlação com a extensão do aterro e a maior quantidade de resíduos disposta; esta, em média, o dobro dos demais.

Ainda do aterro de Campinas, a emissão estimada mostrou que a quantidade de $\mathrm{CO}_{2}$ foi da ordem de duas vezes a de $\mathrm{CH}_{4}$, tanto por campanha como em média.

Para estes quatro aterros a massa estimada para a emissão de metano foi sempre menor que para dióxido de carbono. As diferenças entre metano e dióxido de carbono foram de: $55 \%$ no aterro de São Carlos; $48 \%$ no aterro de Ribeirão Preto; 47\% no aterro de Campinas e de 7\% no aterro de Araraquara. Observou-se que, para o aterro de Araraquara, a proporção dos dois gases esteve 
bem próxima da igualdade, com ligeira superação do dióxido.

Os gráficos 7.2.5, (a) e (b), mostram as contribuições percentuais de metano $\left(\mathrm{CH}_{4}\right)$ e dióxido de carbono $\left(\mathrm{CO}_{2}\right)$ na emissão solo-ar para os aterros. Vejase que a inclusão do aterro Bandeirantes, com emissão muito maior para os dois gases, fez alterar os percentuais médios, aumentando, inclusive, a participação do metano, de $35 \%$ para $46 \%$.

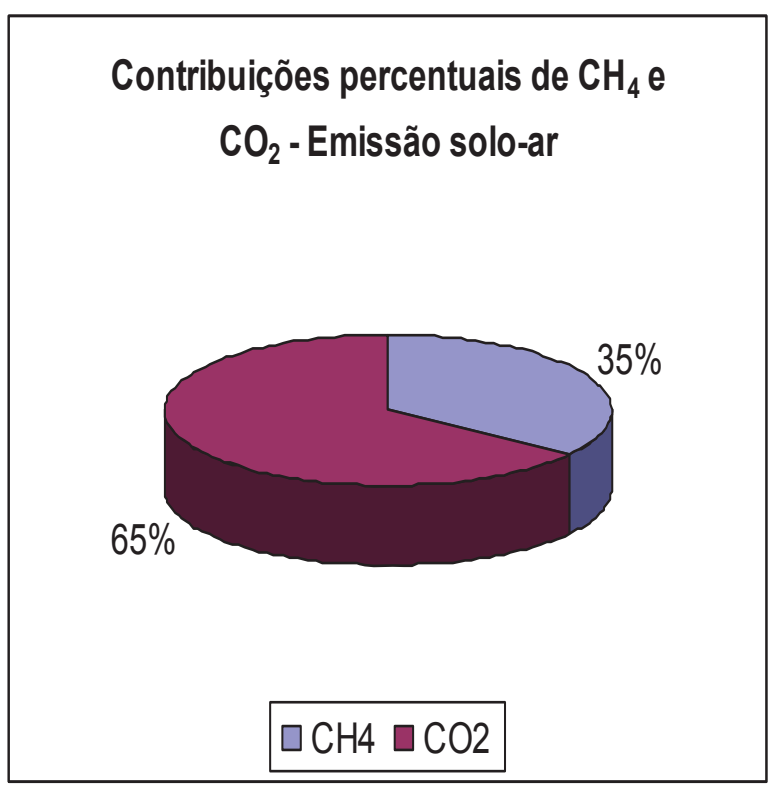

(a)

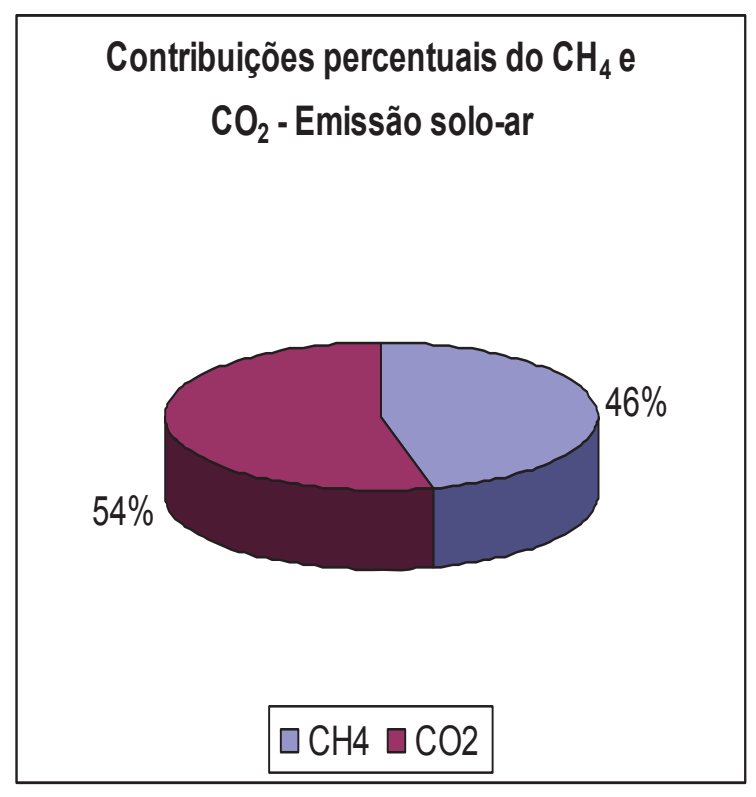

(b)

Gráfico 7.2.5 - Contribuições percentuais de $\mathrm{CH}_{4}$ e $\mathrm{CO}_{2}$, na emissão solo-ar dos aterros. Sem (a) e Com (b) o aterro Bandeirantes.

A tabela 7.2 .5 , mostra os resultados para a emissão solo-ar dos aterros, considerando-se a população coberta pela coleta e a área de disposição dos aterros, por habitante por ano. 
Tabela 7.2.5 - Emissão solo-ar, população coberta pela coleta, área de disposição e número de habitantes por hectare de aterro.

\begin{tabular}{|c|c|c|c|c|c|}
\hline \multirow[b]{2}{*}{ Aterro } & \multirow{2}{*}{$\begin{array}{l}\text { População } \\
\text { coberta } \\
\text { p/Coleta }\end{array}$} & \multirow{2}{*}{$\begin{array}{l}\text { Área de } \\
\text { disposição } \\
\text { (ha) }\end{array}$} & \multirow{2}{*}{$\begin{array}{l}\text { Hab. por } \\
\text { hectare de } \\
\text { aterro }\end{array}$} & \multicolumn{2}{|r|}{ Emissão } \\
\hline & & & & Gás & $\mathrm{Kg} \cdot \mathrm{hab}^{-1} \cdot \mathrm{ha}^{-1} \cdot \mathrm{a}^{-1}$ \\
\hline \multirow{2}{*}{ Araraquara } & \multirow{2}{*}{197.034} & \multirow{2}{*}{8,00} & \multirow{2}{*}{$24.629,25$} & $\mathrm{CH}_{4}$ & 73,04 \\
\hline & & & & $\mathrm{CO}_{2}$ & 77,85 \\
\hline \multirow{2}{*}{ Brotas } & \multirow{2}{*}{21.695} & \multirow{2}{*}{5,40} & \multirow{2}{*}{$4.017,59$} & $\mathrm{CH}_{4}$ & 83,15 \\
\hline & & & & $\mathrm{CO}_{2}$ & 124,70 \\
\hline \multirow{2}{*}{ Campinas } & \multirow{2}{*}{1.045 .706} & \multirow{2}{*}{26,00} & \multirow{2}{*}{$40.219,46$} & $\mathrm{CH}_{4}$ & 208,63 \\
\hline & & & & $\mathrm{CO}_{2}$ & 395,00 \\
\hline \multirow{2}{*}{ Jaú } & \multirow{2}{*}{123.374} & \multirow{2}{*}{4,84} & \multirow{2}{*}{$25.490,49$} & $\mathrm{CH}_{4}$ & 40,39 \\
\hline & & & & $\mathrm{CO}_{2}$ & 55,30 \\
\hline \multirow{2}{*}{ R Bonito } & \multirow{2}{*}{11.821} & \multirow{2}{*}{4,00} & \multirow{2}{*}{$2.955,25$} & $\mathrm{CH}_{4}$ & 93,67 \\
\hline & & & & $\mathrm{CO}_{2}$ & 188,40 \\
\hline \multirow{2}{*}{ R Preto } & \multirow{2}{*}{551.312} & \multirow{2}{*}{21,80} & \multirow{2}{*}{$25.289,54$} & $\mathrm{CH}_{4}$ & 142,43 \\
\hline & & & & $\mathrm{CO}_{2}$ & 275,73 \\
\hline \multirow{2}{*}{ São Carlos } & \multirow{2}{*}{214.760} & \multirow{2}{*}{18,00} & \multirow{2}{*}{$11.931,11$} & $\mathrm{CH}_{4}$ & 228,24 \\
\hline & & & & $\mathrm{CO}_{2}$ & 510,60 \\
\hline \multirow{2}{*}{ Bandeirantes } & \multirow{2}{*}{4.200 .000} & \multirow{2}{*}{140,00} & \multirow{2}{*}{$30.000,00$} & $\mathrm{CH}_{4}$ & $2.524,34$ \\
\hline & & & & $\mathrm{CO}_{2}$ & $2.543,76$ \\
\hline
\end{tabular}

Nos gráficos seguintes; 7.2.6 a 7.2.12, buscou-se encontrar alguma correlação da emissão solo-ar, entre variáveis como: taxa de emissão total dos aterros, emissão estimada e emissão do número de habitantes por hectare de aterro com área de disposição, número de habitantes por hectare de disposição nos aterros, quantidade de resíduos depositada e idade dos aterros. Os resultados não apontaram para tendências melhor definidas entre estas variáveis. 


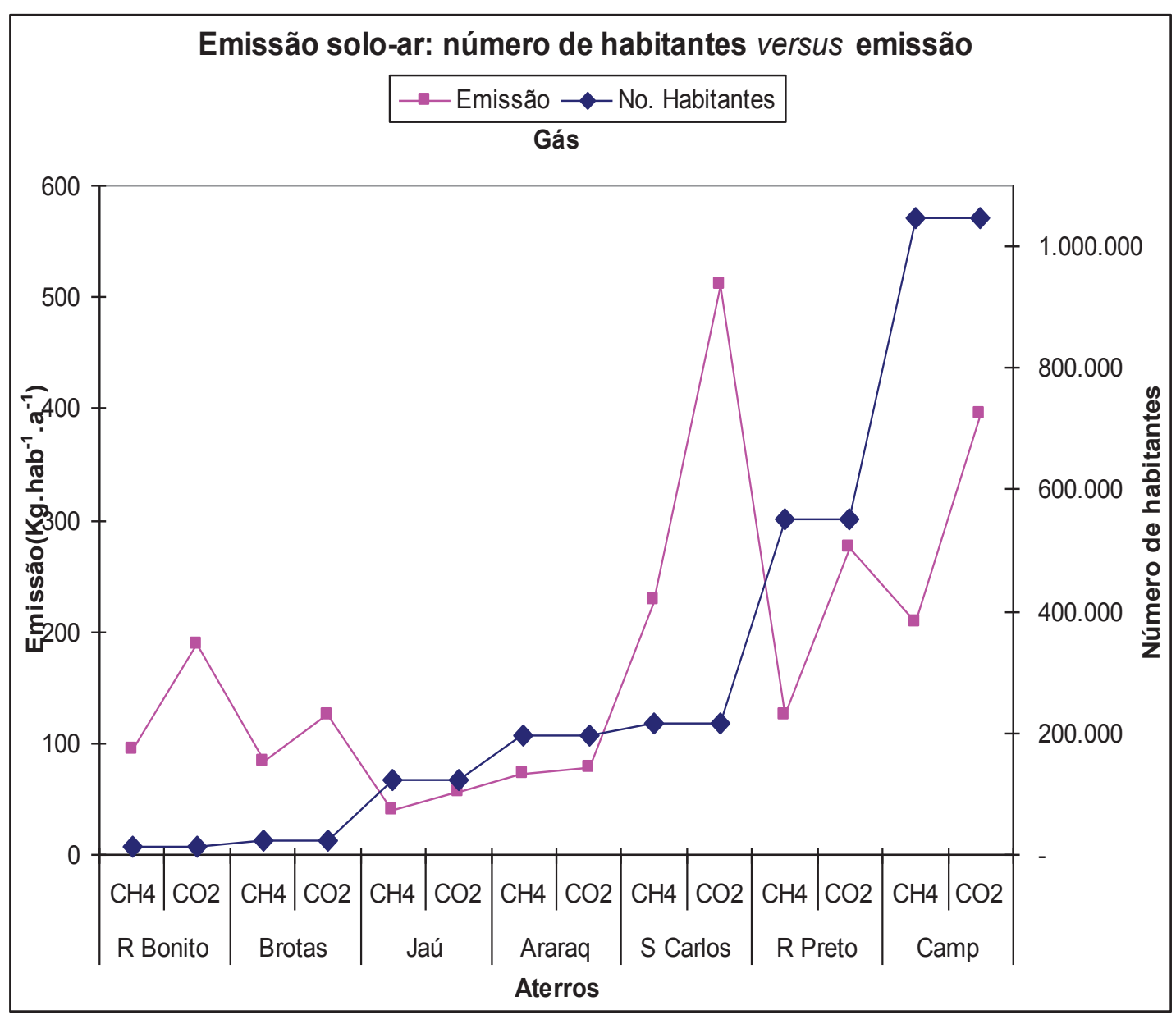

Gráfico 7.2.6 - Emissão solo-ar por aterro e número de habitantes cobertos pela coleta.

No gráfico 7.2.6, excluído o aterro Bandeirantes, a variação da emissão não ficou clara quando correlacionada com o número de habitantes cobertos pela coleta destinada aos aterros. Apenas os aterros de Jaú e Araraquara mostraram alguma tendência, muito tênue, para as duas variáveis. Destacam-se picos de altas para a emissão do aterro de São Carlos, para os dois, com incremento maior para o $\mathrm{CO}_{2} \mathrm{e}$ picos de baixas para a emissão do aterro de Ribeirão Preto, especialmente para $\mathrm{CH}_{4}$, ambos com populações semelhantes. 


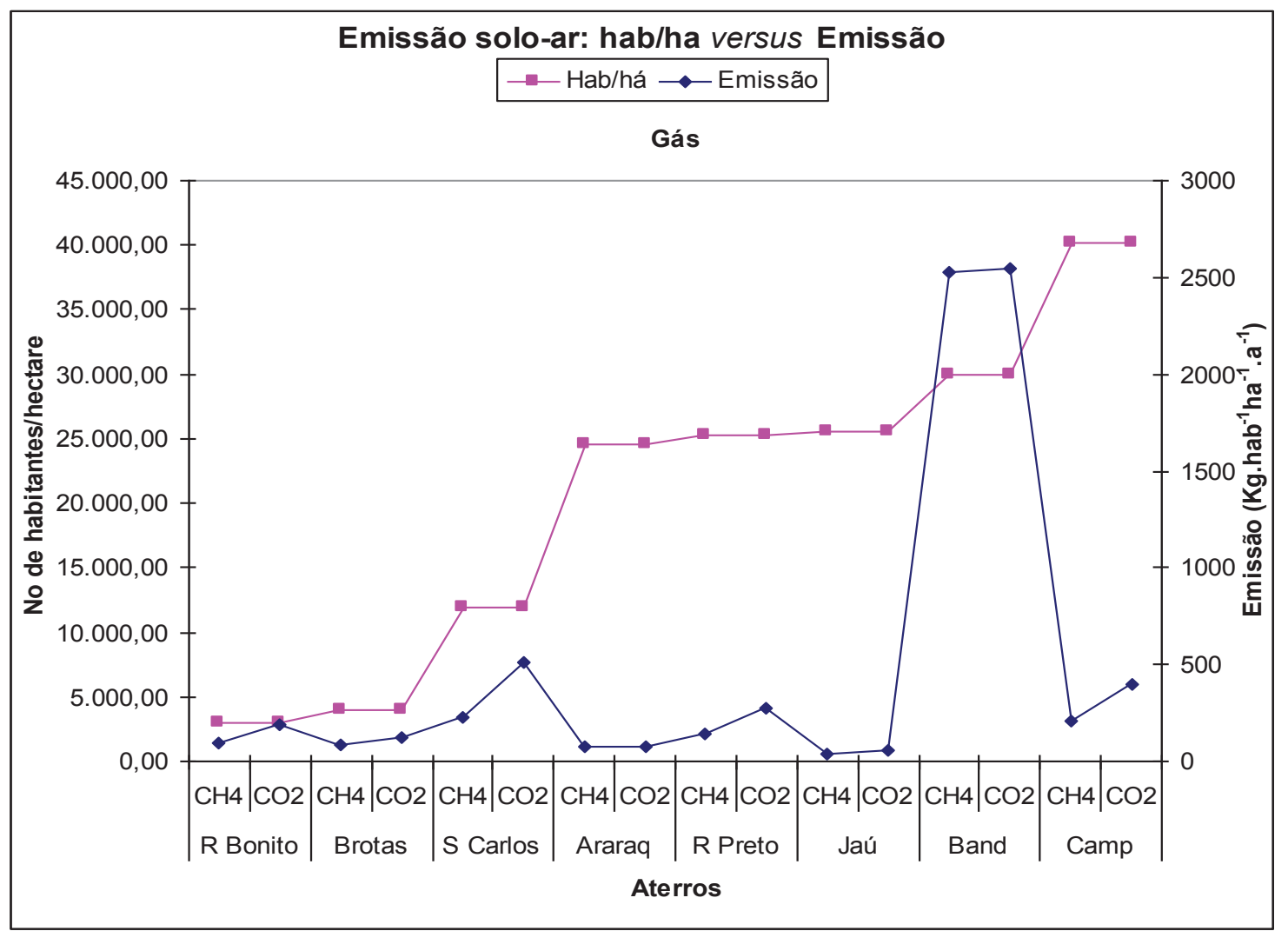

Gráfico 7.2.7 - Emissão solo-ar por aterro e número de habitantes por hectare de aterro.

O gráfico 7.2.7 mostra que também não resultou uma correlação direta da variação da emissão solo-ar com o número de habitantes por hectare de área dos aterros. O gráfico apresenta uma leve proporcionalidade entre emissão e número de habitantes por área nos aterros de Ribeirão Bonito, Brotas e São Carlos. Mas, ao aumento da razão número de habitantes por área nos aterros de Araraquara, Ribeirão Preto e Jaú, não correspondeu a aumentos nas emissões. Pelo contrário, levou a uma queda desta variável. Para o aterro Bandeirantes, resultou um forte aumento - maior emissão neste parâmetro - e para o aterro de Campinas, a maior relação número de habitantes por hectare de aterro, a emissão também caiu, inversamente proporcional. 


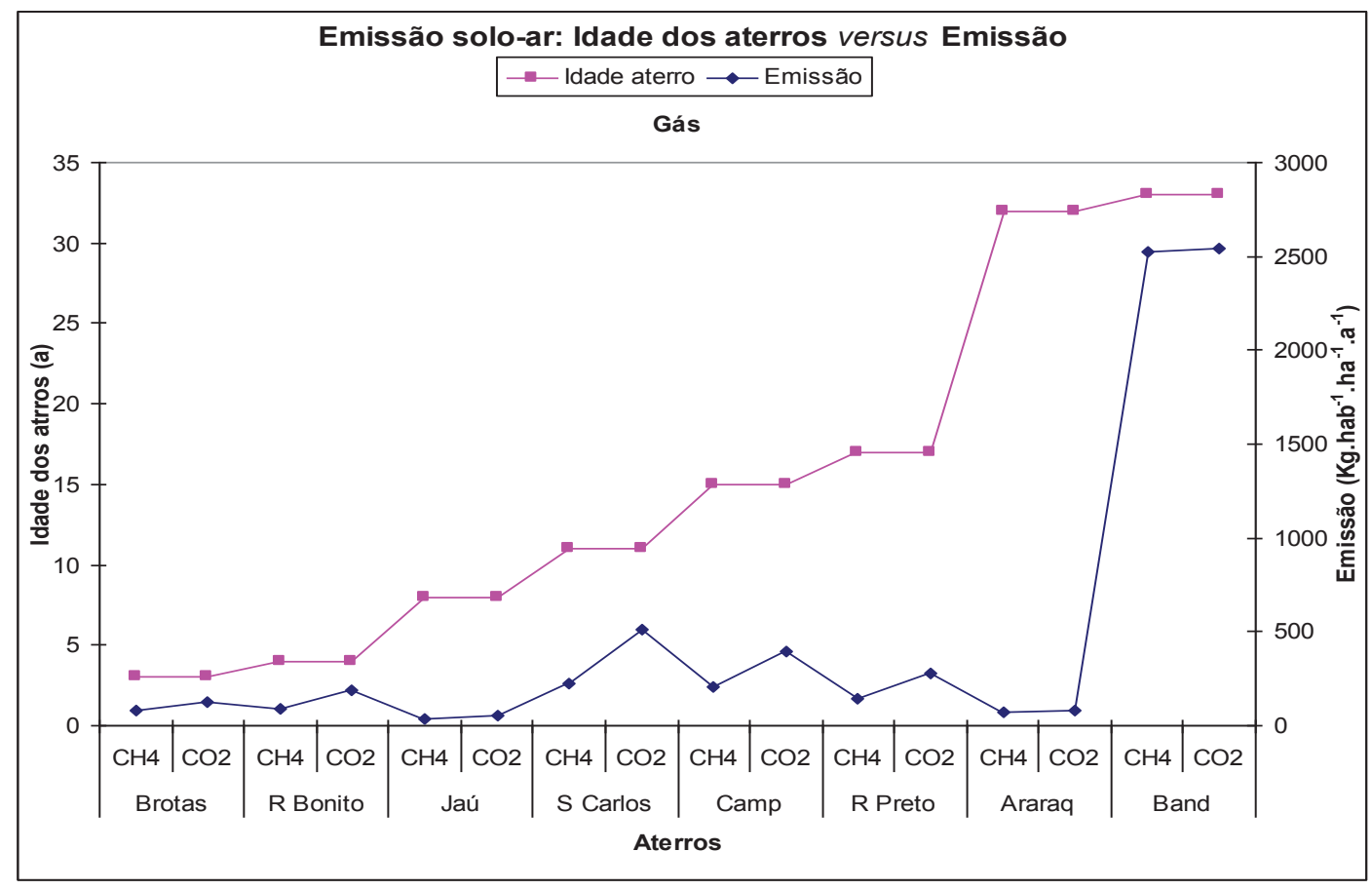

Gráfico 7.2.8 - Emissão solo-ar por habitante/área e idade dos aterros.

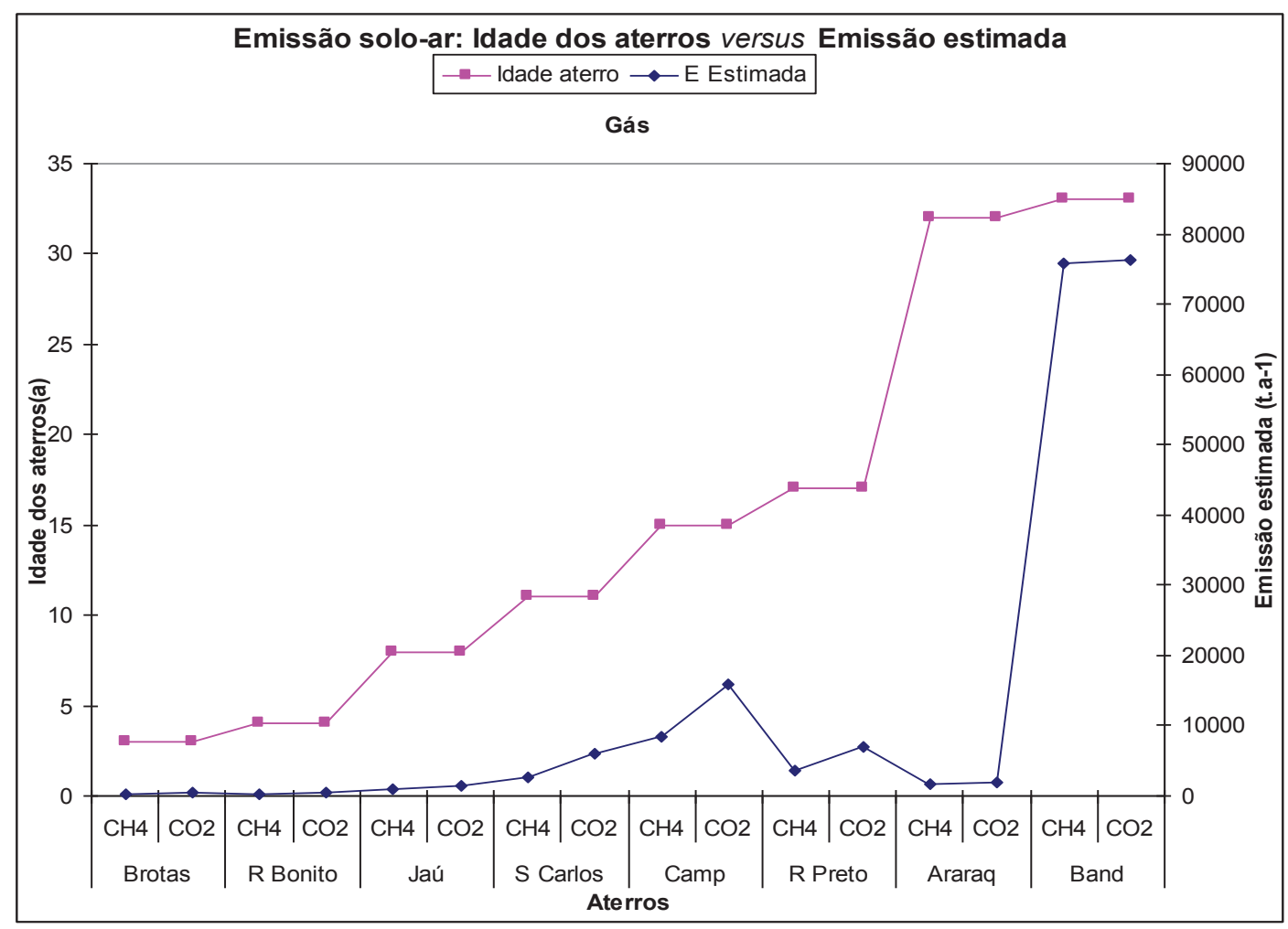

Gráfico 7.2.9 - Emissão estimada solo-ar e idade dos aterros. 
Nos gráficos 7.2.8 e 7.2.9, foram traçadas as relações idade dos aterros e a emissão (em massa por habitante e área de aterro - Kg.hab. ${ }^{-1} \mathrm{ha}^{-1} \cdot \mathrm{a}^{-1}$ ) e a emissão estimada por aterro $\left(\mathrm{t} . \mathrm{a}^{-1}\right)$, respectivamente. Novamente, não apareceu uma tendência de correlação bem definida. Para os aterros de Brotas, Ribeirão Bonito, Jaú e São Carlos, os dois gráficos mostraram alguma semelhança, com uma leve proporcionalidade na emissão versus idade dos aterros, a partir daí, isto não se confirma. Especialmente, para os aterros de Araraquara e Bandeirantes, com idades iguais, e emissões completamente distintas.

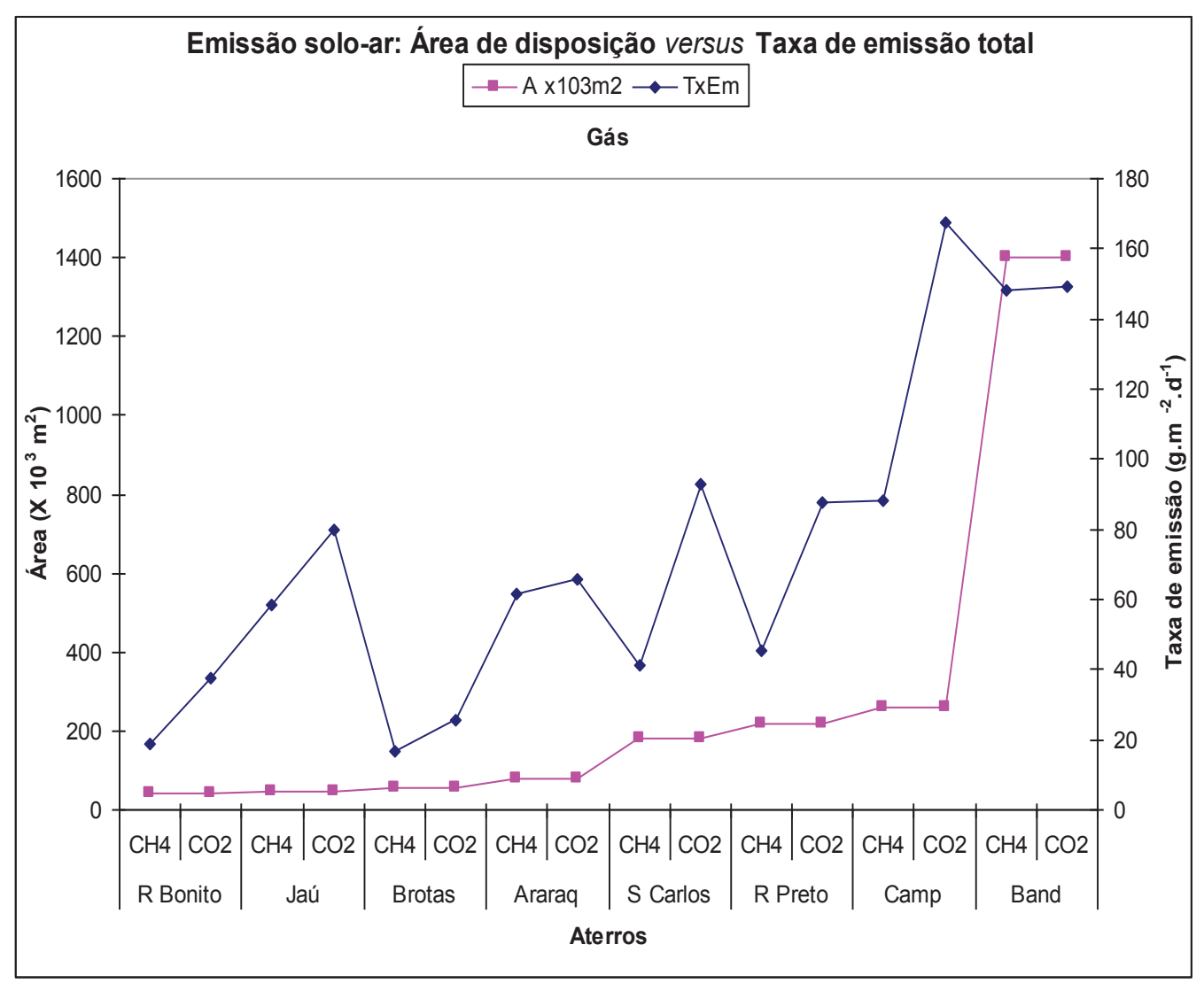

Gráfico 7.2.10 - Relaciona a taxa de emissão total (solo-ar) com a área de disposição dos aterros.

Também no que diz respeito à relação área de disposição versus taxa 
de emissão total, gráfico 7.2.10, anterior, não ficou evidenciada nenhuma tendência mais geral. Embora se depreenda deste gráfico que o aumento da área de disposição aumenta a emissão, como naturalmente esperado.

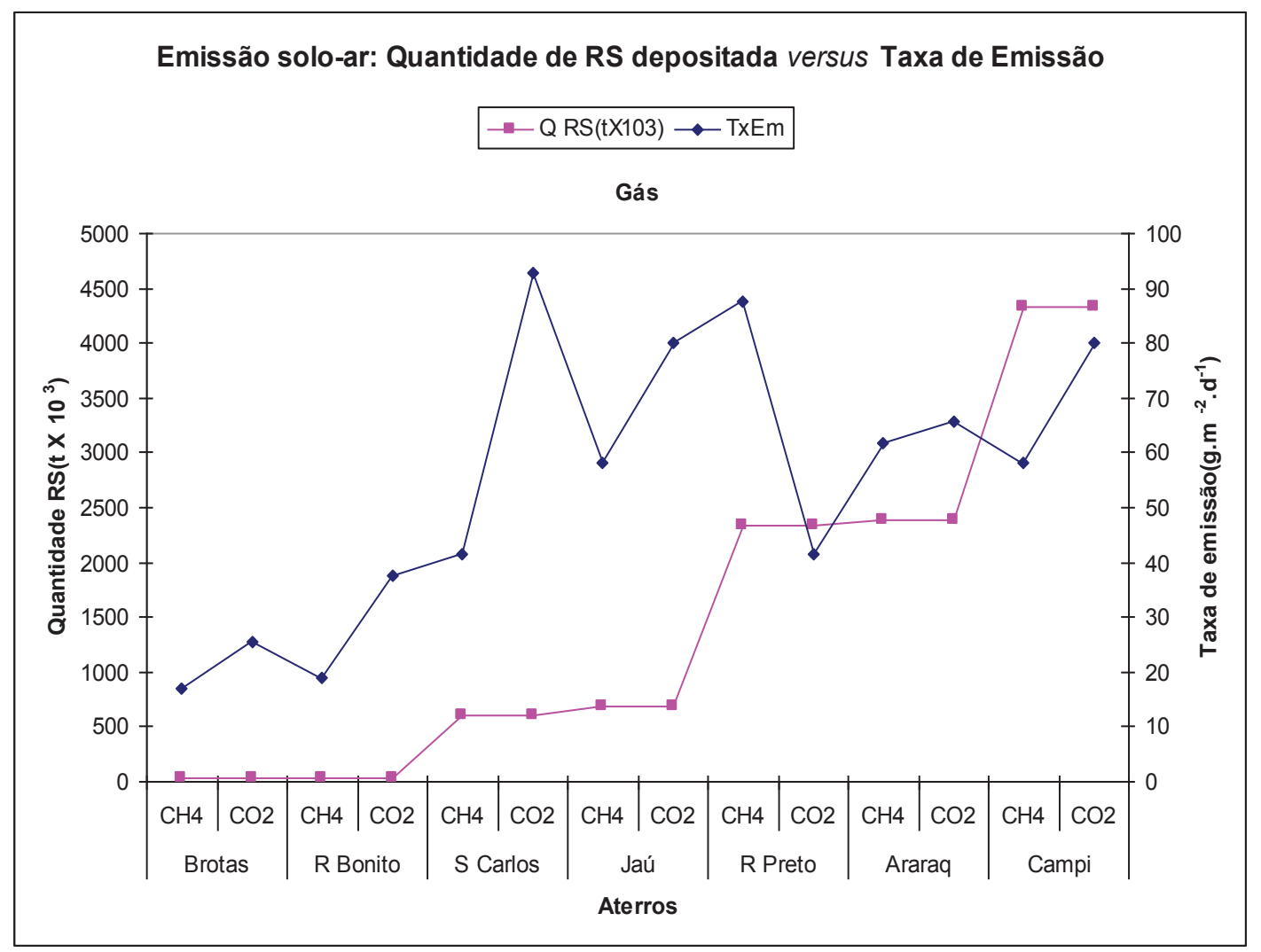

Gráfico 7.2.11 - Relaciona a quantidade de resíduos depositada e a taxa de emissão total (solo-ar).

Para a relação quantidade de resíduos disposta com a taxa de emissão média dos aterros, gráfico 7.2.11, mostra novamente a variabilidade desta taxa, medida em $g \cdot m^{-2} \cdot d^{-1}$, não apresentou correlação com a massa de resíduos. Idem para a relação massa de resíduos com a emissão estimada dos aterros, medida em $t . a^{-1}$, gráfico 7.2.12. 


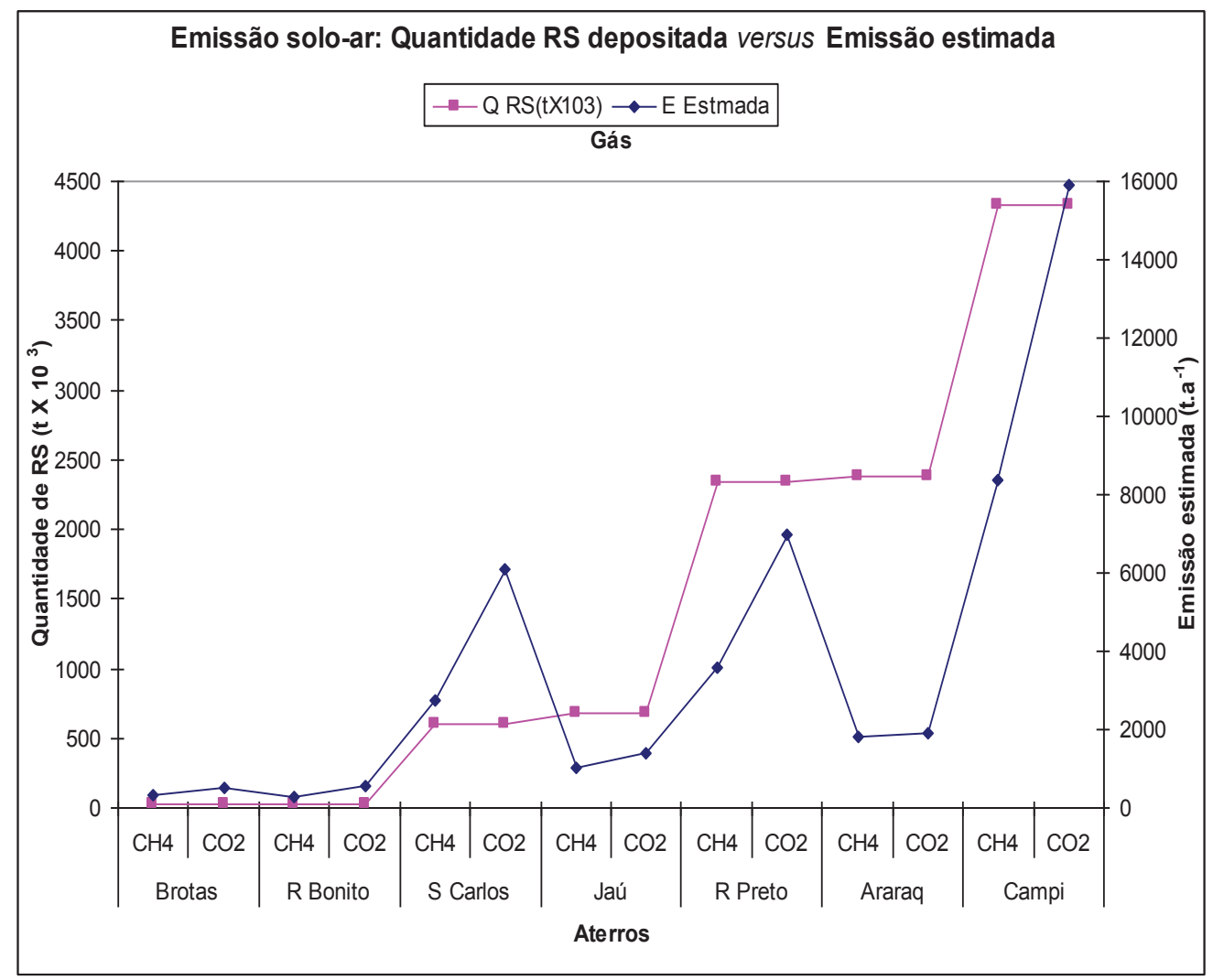

Gráfico 7.2.12 - Relaciona quantidade de RS depositada e emissão estimada (solo-ar).

Com se pôde observar da série de gráficos, a variabilidade preponderante na emissão solo-ar de aterros de resíduos sólidos urbanos, é muito significativa e parece independer de condições quaisquer para o processo.

Pelos resultados deste trabalho notou-se que, quer para aqueles aterros sanitários bem construídos e bem gerenciados, quer para lixões e/ou aterros controlados, o processo da emissão solo-ar de gases por estes equipamentos de disposição final, segue 'regras próprias' a cada um e não se detectou correlações entre variáveis deste processo, que se possa generalizar para tais.

Há que se aprofundar estudos nesta área, a fim de que se possam estabelecer tendências dos processos de emissão e assim, aprimorar ou projetar 
políticas públicas na questão dos resíduos sólidos urbanos, para que sejam minimizados os impactos ambientais que podem causar. 


\subsection{Estimativa da emissão a partir dos queimadores verticais nos aterros que apresentaram estes equipamentos}

A medida estimativa para a emissão pelos queimadores dos aterros foi aquela que talvez tenha os resultados mais distantes da realidade. Nos quatro aterros equipados com tais, a saber: Araraquara, Campinas, Ribeirão Preto e São Carlos; foram escolhidos entre dois e quatro dissipadores, por campanha, em posições o mais centralizado possível no espaço dos aterros. O número de dissipadores medidos foi muito pequeno o que pode tornar os resultados menos representativos.

Por outro lado, enquanto para os sítios de coleta $\left(P_{n}\right)$ da emissão soloar; embora determinados geograficamente em cada aterro; possam ter acontecidos pequenos desvios na localização, entre uma campanha e outra, para os dissipadores esta possibilidade não existe e a medição em cada campanha foi feita no mesmo dissipador. Se modificações aconteceram de uma para outra campanha, estas estariam ligadas à própria dinâmica interna de cada aterro, com já ressaltado.

A tabela 7.3.1, mostra os aterros com seus números totais de queimadores, quantos deles foram escolhidos para a pesquisa e o percentual que representaram para o aterro. $\mathrm{O}$ aterro de São Carlos foi o que apresentou maior quantidade de queimadores medidos, relativamente, com uma percentagem de $17,7 \%$ e $35,0 \%$, considerando-se, a quantidade escolhida por campanha e total.Ressalte-se, este aterro apresentou a menor quantidade deles. $\mathrm{O}$ menor percentual ficou com o aterro de Campinas, que dos seus 110 queimadores, foram 
escolhidos dois e quatro, por campanha, representando $2 \%$ e 5,5\% do total, respectivamente.

Tabela 7.3.1 - Número de queimadores total e escolhidos nos aterros e o percentual que representaram.

\begin{tabular}{|c|c|c|c|c|}
\hline \multirow[t]{2}{*}{ Aterro } & \multirow{2}{*}{$\begin{array}{l}\text { Queimadores } \\
\text { por aterro }\end{array}$} & \multicolumn{2}{|c|}{ Queimadores escolhidos } & \multirow{2}{*}{$\begin{array}{c}\text { Percentual } \\
\text { Ano/total }\end{array}$} \\
\hline & & 2006 & 2007 & \\
\hline Araraquara & 81 & 3 & 3 & 4,0 e $8,0 \%$ \\
\hline Campinas & 110 & 2 & 4 & 2,0 e $5,5 \%$ \\
\hline R Preto & 85 & 3 & 4 & 3,5 e $8,0 \%$ \\
\hline S Carlos & 17 & 3 & 3 & 17,7 e $35,0 \%$ \\
\hline
\end{tabular}

A tabela 7.3.2, mostra os resultados obtidos da medição da emissão a partir dos dissipadores verticais, estruturas próprias para a captação e tratamento finais do GAS.

Para o caso do aterro Bandeirantes; que tem seus drenos adaptados e conectados para o sistema de coleta do GAS na alimentação da UTEB; a emissão não é "natural", como nos outros aterros. As coletas que foram feitas dos drenos deste aterro, se deram a partir de válvulas na saída dos drenos, que apresentavam pressão muito grande. Portanto, extrapolações e estimativas da emissão a partir dos drenos deste aterro, foram desconsideradas.

Entretanto, ficou evidente que a emissão média dos drenos medida para metano no Bandeirantes, de 5,887 toneladas por ano, na campanha única de 2007, não se diferenciou em muito de aterros como São Carlos e Ribeirão Preto, 
nas campanhas de 2006, com 5,138 toneladas e 4,263 toneladas, por ano, respectivamente. Em relação ao dióxido de carbono, a diferença resultou em quantitativos maiores, mas, também sem grandes diferenças.

Também foi desconsiderado o ‘dreno’ do aterro de Jaú, que foi ali instalado para efeitos de pesquisa anterior a esta (LOPES, 2007). Trata-se de um tubo de PVC enterrado no lixo para captação de chorume, mas se revelou tão produtivo em GAS, quanto os drenos comuns dos outros aterros. Os resultados da emissão deste dreno estiveram; quer nas duas campanhas, individualmente, quer na média; bem semelhantes aos aterros de Araraquara e de Campinas, p. ex.; ou seja, dentro dos limites daqueles aterros equipados com drenos verticais.

A tabela 7.3.2 e o gráfico 7.3.1, seguintes, mostram os resultados obtidos para a emissão média por campanha e a emissão estimada para cada aterro, em toneladas por ano. 
Tabela 7.3.2 - Emissão Média Total dos dissipadores nos aterros em que existem.

\begin{tabular}{|c|c|c|c|c|c|}
\hline \multirow[b]{2}{*}{ Aterro } & \multirow[b]{2}{*}{ Gás } & \multicolumn{2}{|c|}{ E. média $\left(t \cdot a^{-1}\right)$} & \multirow{2}{*}{$\begin{array}{c}\text { E. média }\left(t . a^{-1}\right) \\
2006+2007\end{array}$} & \multirow{2}{*}{$\begin{array}{l}\text { Emissão estimada } \\
\text { para o aterro }\left(t . a^{-1}\right)\end{array}$} \\
\hline & & 2006 & 2007 & & \\
\hline \multirow{2}{*}{ Araraquara } & $\mathrm{CH}_{4}$ & 1,387 & 1,674 & 1,530 & 123,93 \\
\hline & $\mathrm{CO}_{2}$ & 2,757 & 3,627 & 3,193 & 258,63 \\
\hline \multirow{2}{*}{ Campinas } & $\mathrm{CH}_{4}$ & 2,352 & 0,918 & 1,635 & 179,85 \\
\hline & $\mathrm{CO}_{2}$ & 5,485 & 2,050 & 3,767 & 414,37 \\
\hline \multirow{2}{*}{ Jaú* } & $\mathrm{CH}_{4}$ & 1,358 & 1,339 & 1,348 & - \\
\hline & $\mathrm{CO}_{2}$ & 3,451 & 2,490 & 2,971 & - \\
\hline \multirow{2}{*}{ Ribeirão Preto } & $\mathrm{CH}_{4}$ & 4,263 & 2,062 & 3,612 & 307,31 \\
\hline & $\mathrm{CO}_{2}$ & 9,894 & 6,397 & 8,145 & 692,32 \\
\hline \multirow{2}{*}{ São Carlos } & $\mathrm{CH}_{4}$ & 5,138 & 3,511 & 4,325 & 73,52 \\
\hline & $\mathrm{CO}_{2}$ & 11,388 & 8,121 & 9,755 & 165,83 \\
\hline \multirow{2}{*}{ Bandeirantes** } & $\mathrm{CH}_{4}$ & - & 5,887 & - & - \\
\hline & $\mathrm{CO}_{2}$ & - & 12,212 & - & - \\
\hline
\end{tabular}

*Não se trata de queimador ou dissipador de GAS, é apenas um dreno de PVC que serviu a uma pesquisa anterior (LOPES, 2007).

${ }^{* *}$ Como o aterro Bandeirantes tem seus drenos adaptados para a coleta do GAS para a UTEB, a emissão destes não é 'natural', como nos outros aterros. Portanto, não dá para fazer extrapolações da emissão dos mesmos para o aterro como um todo. 


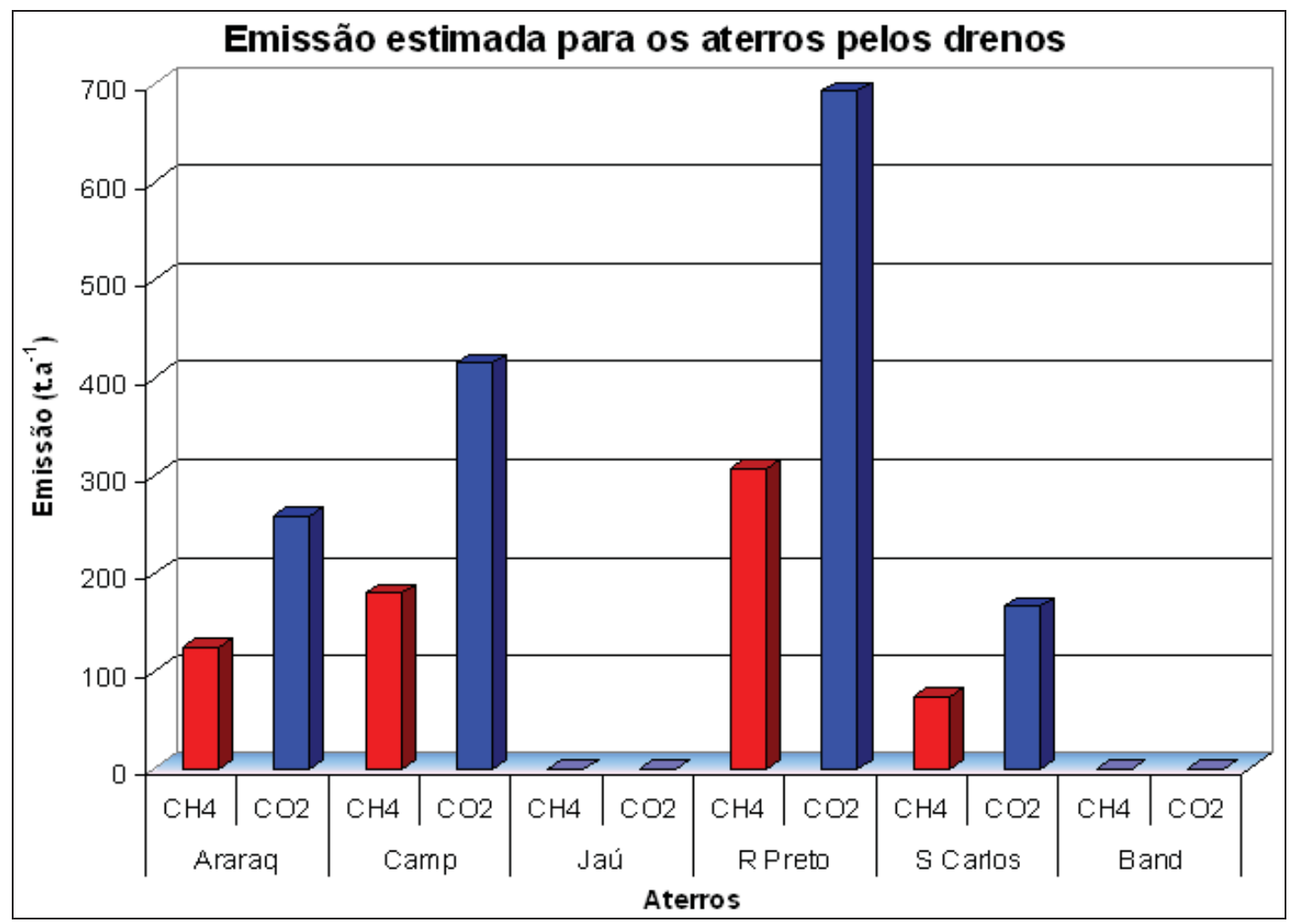

Gráfico 7.3.1 - Emissão estimada para os aterros, por gás, a partir dos dissipadores verticais.

Os gráficos 7.3.2 e 7.3.3, mostram as proporções entre a emissão dos dissipadores, estimadas para os aterros, e a quantidade de resíduos sólidos dispostas. Também destes gráficos depreende-se não haver correlação entre estas variáveis. Os aterros de Araraquara e Ribeirão Preto, com quantidades semelhantes de resíduos resultaram com quantitativos da emissão diferentes entre si. O aterro de Campinas, com o dobro de massa de lixo, em relação aos de Araraquara e Ribeirão Preto, emitiu igual ou menos que estes. 


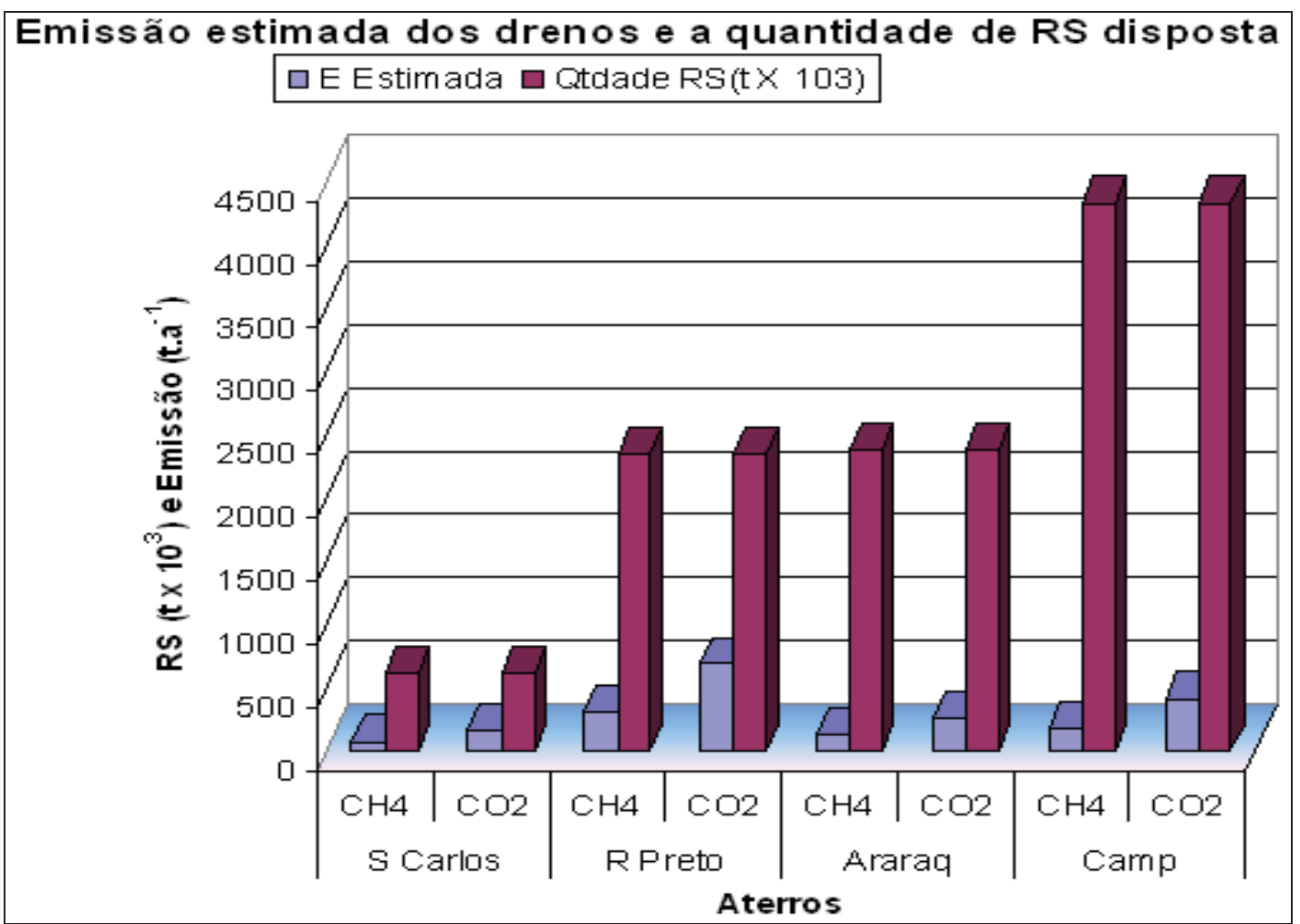

Gráfico 7.3.2 - Proporções entre a emissão estimada pelos dissipadores e a quantidade de resíduos dispostas nos aterros.

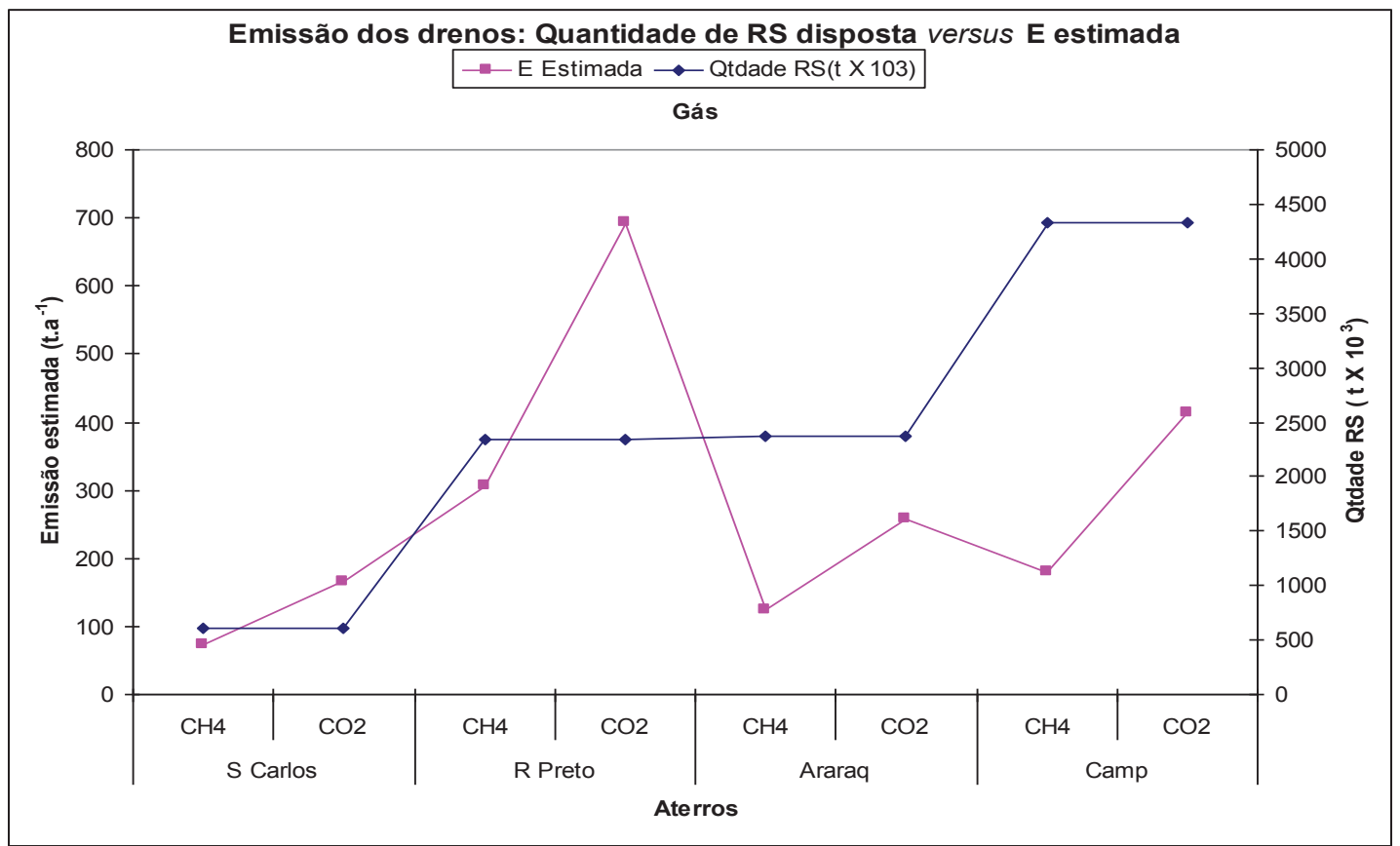

Gráfico 7.3.3 - Relação entre quantidades de RS e Emissão estimadas para os dissipadores. 


\subsection{Emissão estimada total para os aterros}

Reunindo a emissão estimada solo-ar e a emissão estimada para os dissipadores verticais, a tabela 7.4.1, apresenta a emissão estimada total por aterro, em média, por gás e contribuição percentual de cada gás.

Tabela 7.4.1 - Emissão estimada(t. $\left.\mathbf{a}^{-1}\right)$ total solo-ar, por dissipadores(quando presentes) e a contribuição percentual de cada gás.

\begin{tabular}{|c|c|c|c|c|c|}
\hline Aterro & Gás & $\begin{array}{l}\text { E estimada } \\
\text { solo-ar }\end{array}$ & $\begin{array}{c}\text { E estimada } \\
\text { dissipadores }\end{array}$ & $\begin{array}{c}\text { E estimada } \\
\text { total }\end{array}$ & $\begin{array}{l}\% \text { de cada } \\
\text { gás }\end{array}$ \\
\hline \multirow{2}{*}{ Araraquara } & $\mathrm{CH}_{4}$ & $1.799,16$ & 123,93 & 961,54 & 46,92 \\
\hline & $\mathrm{CO}_{2}$ & $1.917,56$ & 258,63 & $1.088,10$ & 53,08 \\
\hline \multirow{2}{*}{ Brotas } & $\mathrm{CH}_{4}$ & 334,08 & - & 334,08 & 41,00 \\
\hline & $\mathrm{CO}_{2}$ & 501,02 & - & 501,02 & 59,00 \\
\hline \multirow{2}{*}{ Campinas } & $\mathrm{CH}_{4}$ & $8.397,05$ & 179,85 & $4.285,45$ & 34,50 \\
\hline & $\mathrm{CO}_{2}$ & $15.886,26$ & 414,32 & $8.150,29$ & 65,50 \\
\hline \multirow{2}{*}{ Jaú } & $\mathrm{CH}_{4}$ & $1.029,48$ & - & $1.029,48$ & 42,20 \\
\hline & $\mathrm{CO}_{2}$ & $1.409,70$ & - & $1.409,70$ & 57,80 \\
\hline \multirow{2}{*}{ R Bonito } & $\mathrm{CH}_{4}$ & 276,82 & - & 276,82 & 33,21 \\
\hline & $\mathrm{CO}_{2}$ & 556,71 & - & 556,71 & 66,79 \\
\hline \multirow{2}{*}{ R Preto } & $\mathrm{CH}_{4}$ & $3.602,14$ & 307,31 & $1.954,73$ & 33,77 \\
\hline & $\mathrm{CO}_{2}$ & $6.973,11$ & 692,32 & $3.832,71$ & 66,23 \\
\hline \multirow{2}{*}{ S Carlos } & $\mathrm{CH}_{4}$ & $2.723,20$ & 73,52 & $1.462,86$ & 31,86 \\
\hline & $\mathrm{CO}_{2}$ & $6.092,03$ & 165,83 & $3.128,93$ & 68,14 \\
\hline \multirow{2}{*}{ Bandeirantes } & $\mathrm{CH}_{4}$ & $75.730,20$ & - & $75.730,20$ & 49,80 \\
\hline & $\mathrm{CO}_{2}$ & $76.312,74$ & - & $76.312,74$ & 50,20 \\
\hline
\end{tabular}


Pelos resultados deste trabalho, a tabela 7.4.1, mostra que o aterro Bandeirantes emitiu sozinho, numa única campanha solo-ar, uma massa de 152.042,94 toneladas por ano dos dois gases. Esta emissão é superior em $68,00 \%$, à emissão conjunta dos demais aterros, nas duas campanhas, considerando as suas emissões solo-ar e dos dissipadores; estes quando presentes.

O gráfico 7.4.1, mostra as emissões totais dos dois gases para o conjunto dos aterros sem e com a inclusão do aterro Bandeirantes.

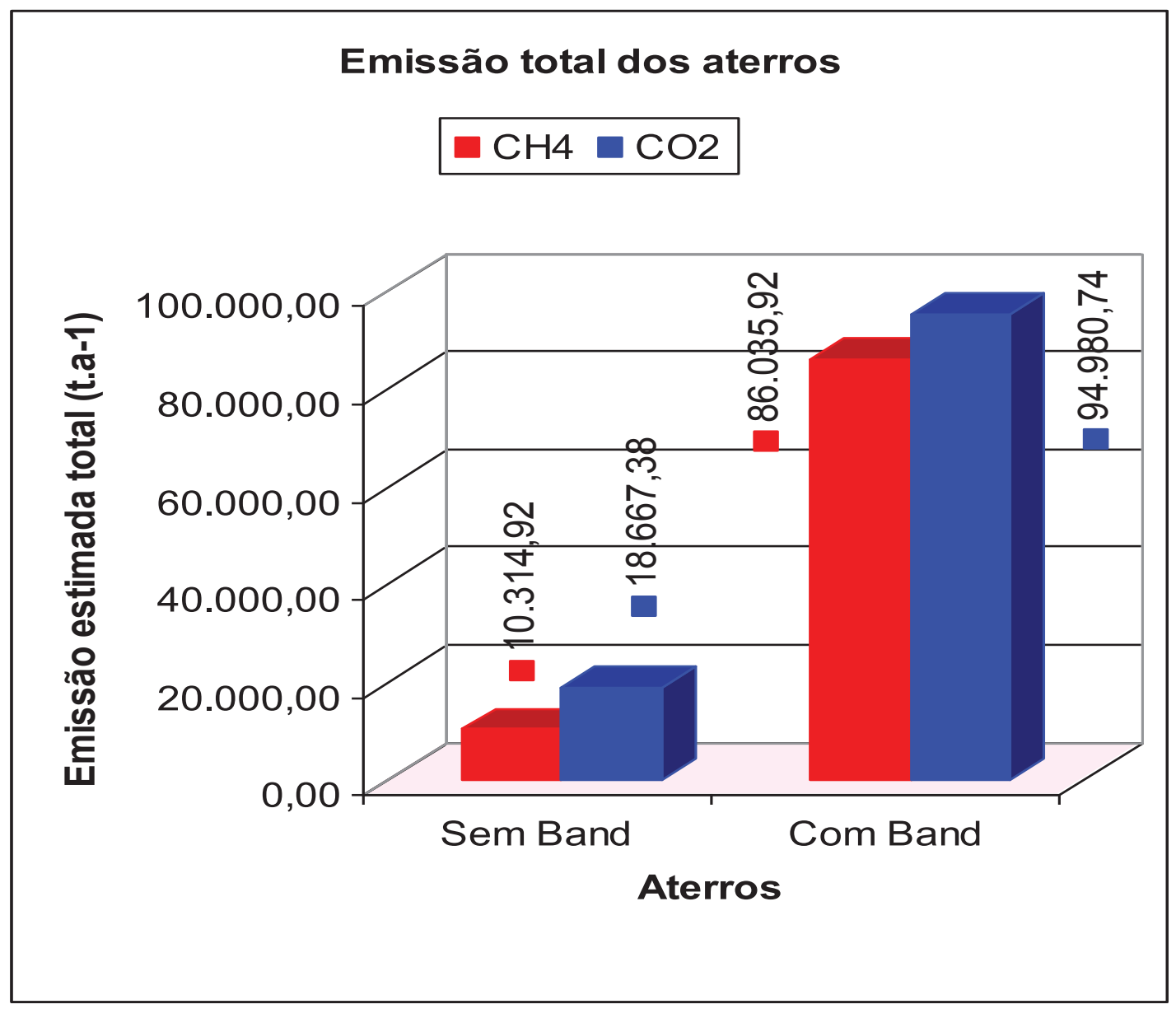

Gráfico 7.4.1 - Emissão total estimada para os aterros sem e com a inclusão do aterro Bandeirantes. 
O gráfico 7.4.2, mostra as emissões estimativas solo-ar e dos dissipadores verticais e a emissão total, por gás e aterro; para aqueles aterros onde nas duas campanhas, se fez o estudo de ambas.

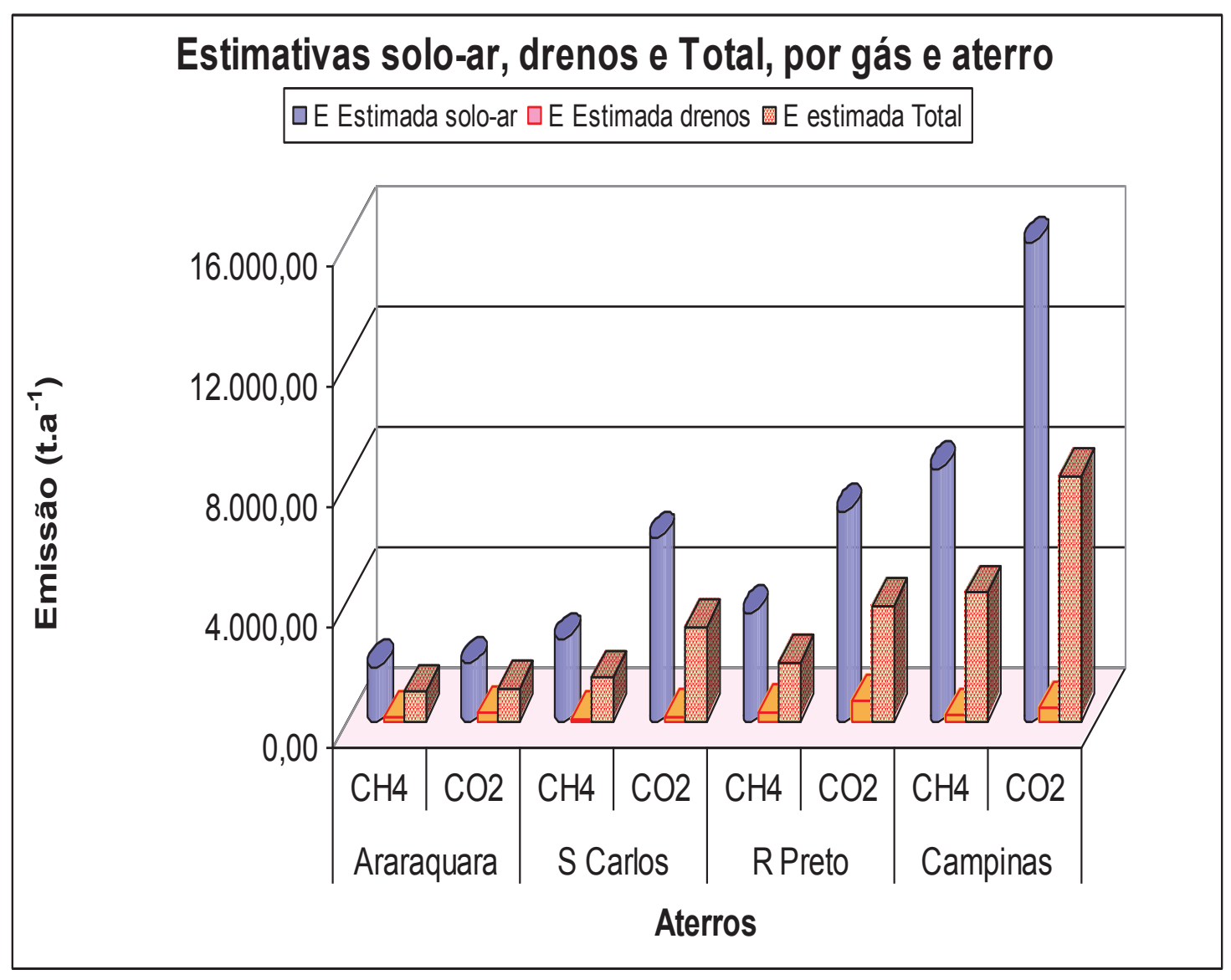

Gráfico 7.4.2 - Emissões estimativas solo-ar, dos dissipadores e a estimativa total, nos quatro aterros que dispunha de queimadores.

Deste gráfico ficou evidente a diferença entre a emissão solo-ar, muito maior, e a emissão pelos queimadores. É possível que esta última esteja subestimada, como consequência do número reduzido de dissipadores amostrados em cada um destes aterros. 


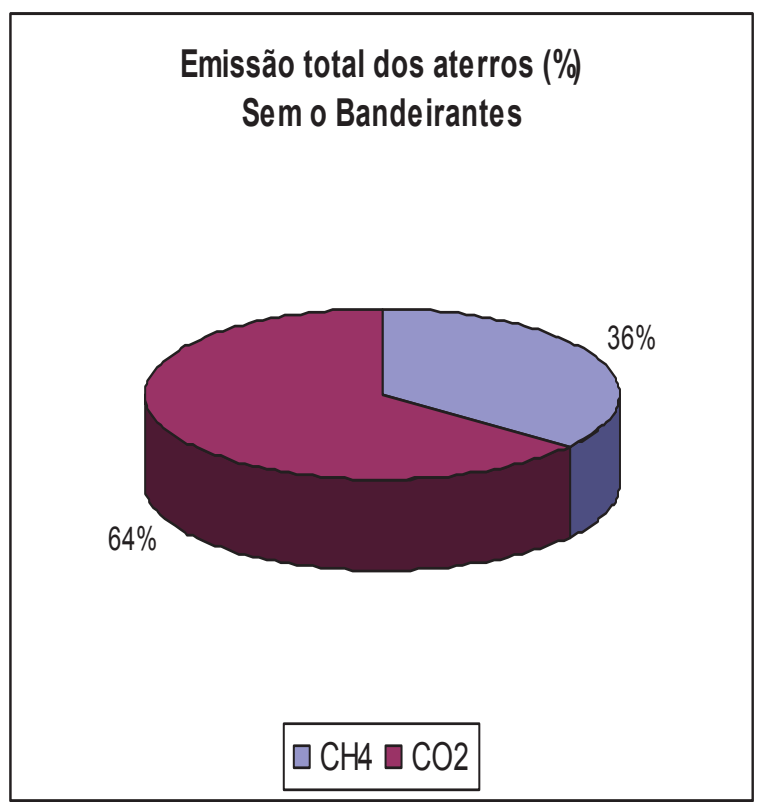

(a)

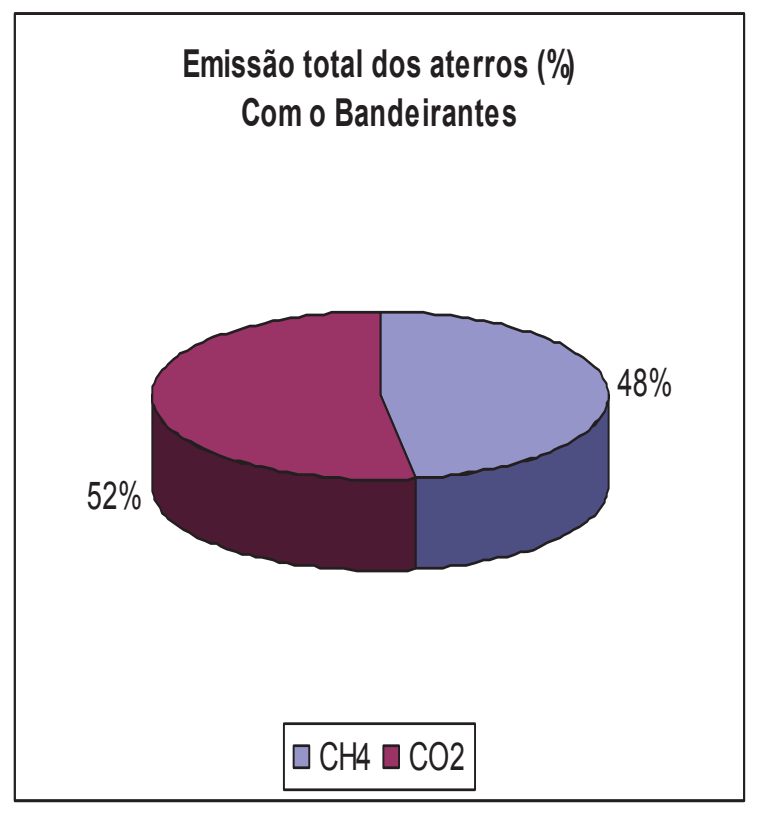

(b)

Gráficos 7.4.3 - Contribuições percentuais dos aterros na emissão total do metano $\left(\mathrm{CH}_{4}\right)$ e do dióxido de carbono $\left(\mathrm{CO}_{2}\right)$, sem (a) e com (b) a inclusão do aterro Bandeirantes.

Os gráficos 7.4.3, (a) e (b), mostram as contribuições percentuais na emissão total dos aterros para metano $\left(\mathrm{CH}_{4}\right)$ e dióxido de carbono $\left(\mathrm{CO}_{2}\right)$, deixando evidente mais uma vez que a emissão do aterro Bandeirantes contribuiu, significativamente, e aumentou o percentual do metano de $36 \%$ para $48 \%$.

No gráfico 7.4.4, buscou-se uma correlação entre a estimativa total da emissão com as quantidades de resíduos sólidos dispostas nos aterros. Depreendese do gráfico que não houve correlação. Os pontos em que estão mostrando aumentos de emissão não têm relação direta com aumentos da massa de resíduos depositada. Ao contrário, p. ex., a queda observada na emissão dos dois gases para o aterro de Araraquara, é inversa com o aumento na sua massa de resíduos. Idem, para a emissão de metano no aterro de Ribeirão Preto. 


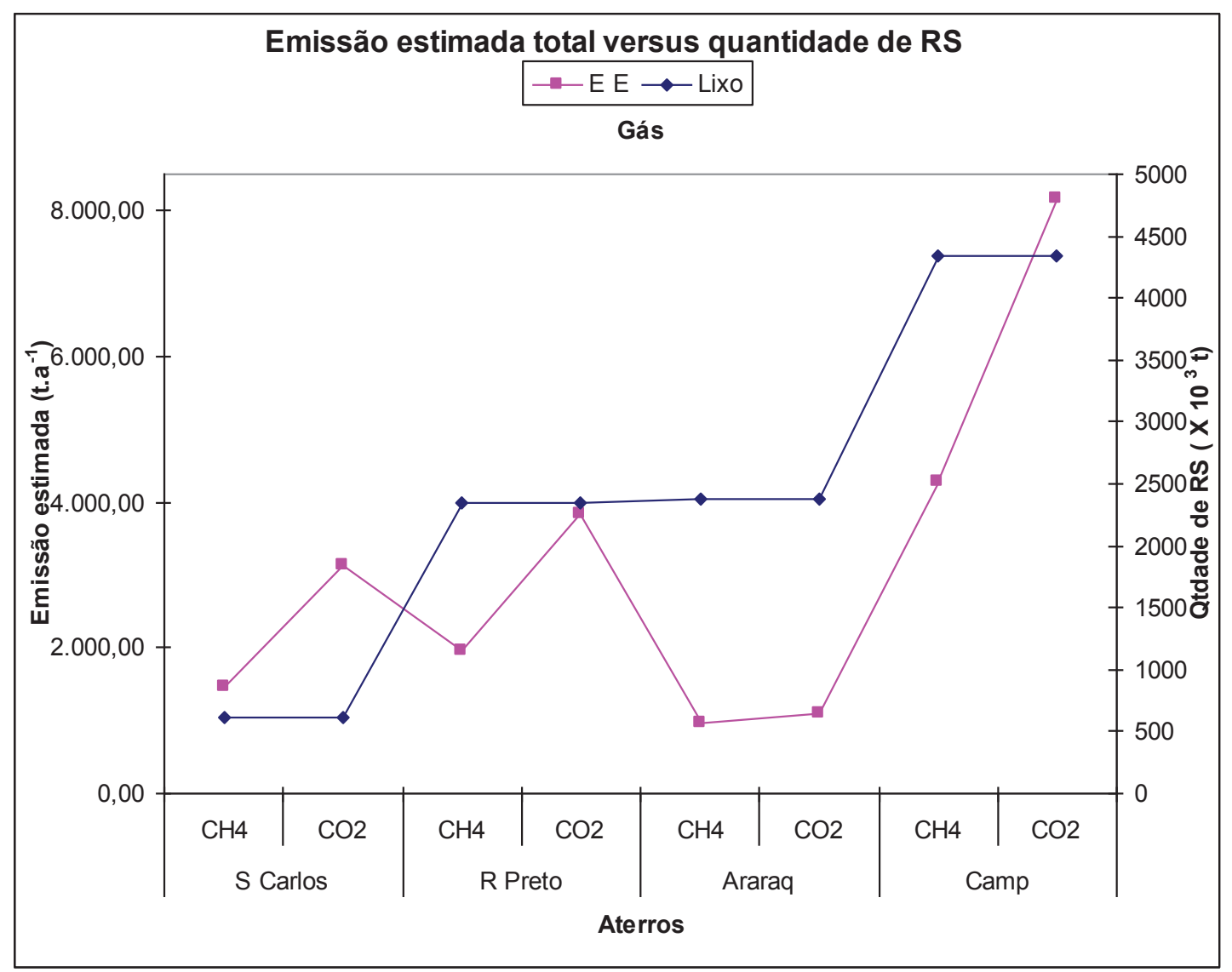

Gráfico 7.4.4 - Emissão estimada total em relação à quantidade de resíduos sólidos nos aterros.

Para o aterro de Campinas, mesmo surgindo uma tendência de aumento da emissão com o correspondente aumento da massa de resíduos deste aterro em relação aos outros, este incremento foi muito mais significativo para o dióxido de carbono que para o metano. 


\section{CONCLUSÕES}

“AH, SE EU PUDESSE DIZER TUDO QUE TENHO TRANCADO NO PEITO.

MAS NÃO POSSO.

EU NÃO POSSO NEM CHORAR.

EU ACHO QUE, SE EU CHORASSE, IRIAM SAIR PEDRAS DOS MEUS OLHOS." VINICIUS DE MORAIS

Considerando a importância dos constituintes do Gás de Aterros Sanitários (GAS) - ou aterros controlados ou lixões - na indução do efeito estufa antrópico, torna-se imperioso o desenvolvimento de pesquisas que resultem em melhor compreensão e dimensionamento do impacto real causado por estes equipamentos de disposição de RSU.

É necessário também o surgimento de tecnologias novas, capazes de mitigar a emissão deste GAS, especialmente, do metano, com potencial de aquecimento global da ordem de vinte e três vezes maior que o dióxido de carbono.

No que diz respeito às emissões de metano $\left(\mathrm{CH}_{4}\right)$ e dióxido de carbono $\left(\mathrm{CO}_{2}\right)$ pelos aterros de resíduos sólidos urbanos, a partir dos objetivos propostos e dos resultados obtidos por este trabalho, pode-se concluir que os aterros, independentes do gerenciamento e operação a eles dispensados, se grandes ou pequenos, com maiores ou menores quantidades de resíduos dispostas, geram um ambiente deletério e impactante, uma vez que:

1. As concentrações destes gases no ar ambiente dos mesmos foram muito superiores àquelas registradas em ambientes onde estes equipamentos não estão presentes. Para o metano, resultou uma concentração de, aproximadamente, 18.000 ppm, ou seja, dez mil vezes maior que a concentração de locais distantes 
(background) dos aterros. Para o dióxido de carbono a concentração esteve em torno de $5.500 \mathrm{ppm}$, quinze vezes maior que aquelas medidas fora destes equipamentos de disposição de RSU.

2. Os resultados das medidas para as concentrações de $\mathrm{CH}_{4}$ e $\mathrm{CO}_{2}$ na atmosfera dos aterros mostraram que as diferenças dos valores, de um aterro para outro, não ultrapassaram $10 \%$ para o metano e 30\% para o dióxido de carbono. Acredita-se que estes resultados possam ser extrapolados para quaisquer espaços que se destinem à disposição de resíduos sólidos urbanos.

3. Os valores medidos para as concentrações destes dois gases no ar ambiente dos aterros parecem indicar que, o gerenciamento e a operação dispensados, ou não, a estes equipamentos não influenciaram nas mesmas. Que em quaisquer situações, estes depósitos oferecem impactos de poluição ambiental em níveis muito significativos.

4. Os valores obtidos para as concentrações dos dois gases no aterro Bandeirantes, semelhantes aos demais, pareceu indicar que o sistema de sucção do GAS, que alimenta a UTEB, não influenciou nesta emissão, para aquele aterro.

5. Os resultados indicaram que, IQR's altos ou baixos, enquadramento adequado ou inadequado para estes depósitos de RSU, não influíram nas concentrações de metano e dióxido de carbono no ar ambiente dos aterros. Estes resultados apontaram para que, se incluam também as concentrações ambientes, nos parâmetros de avaliação dos aterros.

6. Os resultados encontrados para a concentração do dióxido de carbono no ar ambiente dos aterros estiveram sempre menores que para o metano. Isto pareceu indicar que a 'dinâmica' da química do $\mathrm{CO}_{2}$ é tal, especialmente, na 
atmosfera dos aterros, que este gás encontra 'sumidouros preferenciais', resultando na diferença constatada. Igualmente, na emissão solo-ar, os maiores quantitativos produzidos foram para $\mathrm{CO}_{2}$, que 'não se confirmaram na atmosfera local'. Pode-se inferir que a solubilidade aquosa do $\mathrm{CO}_{2}$, a sua absorção pela vegetação de cobertura e de entorno e a pouca capacidade reativa do $\mathrm{CH}_{4}$ nas condições do espaço dos aterros, são variáveis a serem consideradas.

7. Os resultados obtidos para a emissão solo-ar nos aterros mostraram uma variabilidade muito grande. Esta variação ficou evidente na proporção $\mathrm{CH}_{4} / \mathrm{CO}_{2}$, em um mesmo sítio de coleta, entre os sítios, entre os aterros e de uma campanha para outra. Isto pareceu confirmar que cada aterro tem sua dinâmica intrínseca no processo de degradação do resíduo depositado.

8. A presença das câmaras de coleta do GAS, independente se a pequena ou a grande, pareceu interferir no fluxo do GAS nos sítios de coleta da emissão solo-ar. Pareceu que o enriquecimento da câmara pelo GAS atingiu um ponto de saturação, quando o GAS pareceu ser reabsorvido pelo solo do aterro.

9. Os resultados da coleta solo-ar mostraram que a dinâmica própria de cada aterro é tal que ocasiona uma grande variabilidade no processo de emissão dos gases, não tendo sido possível estabelecer correlações entre variáveis do mesmo.

10. A emissão dos dissipadores verticais também mostrou variabilidade considerável, e pareceu também independer do tamanho do aterro, quantidades de resíduos disposta, população coberta pela coleta ou, número de habitantes por área de aterro.

11. Nos três aspectos estudados neste trabalho - concentrações no 
ambiente do aterro, emissão solo-ar e emissão pelos dissipadores - os resultados mostraram que a operação dispensada a estes espaços destinados à disposição de resíduos sólidos urbanos não pareceu influenciar na emissão dos gases.

12. Os resultados apontaram que o fluxo de metano e dióxido de carbono 'para a atmosfera terrestre', a partir destes sistemas de disposição de resíduos sólidos urbanos, é significativo e merece cada vez mais atenção e pesquisas para sua total compreensão e aplicação de tecnologias que possam mitigar ao máximo esta emissão antropogênica de gases indutores do aquecimento global.

Espera-se que os resultados obtidos possam contribuir para uma melhor compreensão do fluxo de carbono para natureza, a partir destes sistemas de disposição de RSU's e com o inventário brasileiro de emissões de gases estufa a partir de aterros de resíduos urbanos. 


\section{SUGESTÕES PARA TRABALHOS FUTUROS}

"PARTE COM A AZEITONA MADURA, AGRADECENDO À ESTAÇÃO QUE A TROUXE E À ÁRVORE QUE A ALIMENTOU”. MARCO AURÉLIO ANTONINO (ROMANO)

Os resultados obtidos neste trabalho e a constante preocupação com a questão ambiental; que se manifesta a cada dia mais séria e inquietante; entendese apontar para pesquisas que possam, cada vez mais, esclarecer o ciclo do carbono na natureza e a contribuírem para que fontes de emissões antropogênicas sejam objeto de atenção permanente da ciência e da tecnologia, para as suas mitigação.

A significativa emissão dos gases metano e dióxido de carbono por aterros de resíduos sólidos urbanos - quer no fluxo solo-ar, quer pelos dissipadores - e as suas concentrações em níveis absurdos no ar ambiente dos aterros, permitem-se sugerir, como expectativas de pesquisas a ser desenvolvidas nesta área, o seguinte:

- Buscar aperfeiçoar ainda mais a metodologia, acurando o método, especialmente, com um cromatógrafo de maior sensibilidade, para que a medição seja cada vez mais precisa;

- Desenvolver pesquisas similares a esta, em um mesmo aterro, com campanhas mais frequentes para medição cada vez mais precisa;

- Desenvolver pesquisa similar a esta, com campanhas em épocas chuvosas e secas, alternadamente, para mensurar a influência da água na emissão do GAS; 
- Desenvolver pesquisas similares a esta, em aterros de latitudes variadas, para que se mensure a influência da latitude na emissão dos aterros;

- Desenvolver estudos que busquem materiais com potencial de oxidação do metano na cobertura de aterros;

- Desenvolver trabalhos com a microbiologia para a inoculação de microorganismos que possam alimentar-se/oxidar metano - "barreira" metanotrófica - na cobertura de aterros, evitando o lançamento deste gás para a atmosfera, como já é tendência desde final da década passada (LIOTTE, 2007, ISLAM et al., 2008; HOLMES et al.,1999 ; HANSON and HANSON,1996 ); entre outros;

- Desenvolver pesquisa que compreenda e discuta a dinâmica do GAS quando captada nas câmaras de coleta, tendo aumento inicial da concentração/massa e em seguida tendência a diminuição (reabsorção pelo aterro);

- Desenvolver pesquisas junto à área de saúde, para buscar detectar as reações fisico-orgânicas que as altas concentrações medidas possam acarretar no pessoal de operação dos aterros e em seu entorno. 


\section{REFERÊNCIAS}

“È DIFÍCIL REMOVER AS CAUSAS DA MISÉRIA?!...

MAIS UMA RAZÃO PARA CUIDARMOS DA REDUÇÃO DE SEUS FEITOS". VILFREDO PARETO (ITALIANO)

ABRELPE (2005). Associação Brasileira de Empresas de Limpeza Pública e Resíduos Especiais. Panorama dos Resíduos Sólidos no Brasil. (2007). Panorama dos Resíduos Sólidos no Brasil.

AGA (2006). Analytical Gas Chromatographic. Disponível em: < http://hiq.aga.com.br/international/web/lg/br/likelgspgbr.nsf/DocByAlias/anal_gaschr om >. Acesso em: 27 dez 2006.

ALVALA, P. C., KIRCHHOFF, V.W.J.H. e PAVÃO, H. G. (1999). "Metano na Atmosfera: Produção de metano em regiões de queimadas e áreas alagadas". BioTecnologia, Ciência e Desenvolvimento, 7, 40-43, 1999.

AMBIENTEBRASIL (2007). Estatísticas da Reciclagem Brasil. Disponível em: < http://www.ambientebrasil.com.br/composer.php3?base=./residuos/index.php3\&cont eudo=./residuos/estatisticas.html > Acesso em: 08 dez.2008.

AMORA, A. S. (1997). Dicionário Soares Amora da Língua Portuguesa. Primeira Edição. Editora Saraiva. São Paulo.

AQUINO, A. R. de (2008). A Química e o Lixo - Disponível em: < http://www.eca.usp.br/nucleos/njr/voxscientiae/aquino1.html > Acesso em: 15 mar.2008.

ARAÚJO, M. S. (2008). Publicação eletrônica [mensagem pessoal]. Mensagem 
recebida por < zeberto@sc.usp.br >. Em: 29 jun. 2008.

ASSADOURIAN, E. (2003). "Consumption Patterns Contribute to Mortality", in Worldwatch Institute, 2003.

ASSOCIAÇÃO BRASILEIRA DE NORMAS TÉCNICA (1984). NBR 8419. Apresentação de projetos de aterros sanitários de resíduos sólidos urbanos - São Paulo.

(2004). NBR 10.004: Resíduos Sólidos - Classificação. São Paulo.

(2004). NBR 10.005: Procedimento para obtenção de extrato lixiviado de resíduos sólidos. São Paulo.

(2004). NBR 10.006: Procedimento para obtenção de extrato solubilizado de resíduos sólidos. São Paulo.

(2004). NBR 10.007: Amostragem de resíduos sólidos. São Paulo.

AULETE, C. (2004). Dicionário contemporâneo da língua portuguesa. Editor responsável Paulo Geiger; apresentação Evanildo Bechara. Editora Nova Fronteira. Rio de Janeiro.

AZEVEDO, F. de C. (1988). Nosso Futuro Comum - Comissão Mundial sobre Meio Ambiente e Desenvolvimento. Rio de Janeiro: Fundação Getúlio Vargas.

BAIRD, C. (2002). Química Ambiental. Tradução: Maria Angeles Lobo Recio e Luiz Carlos Marques Carrera. 2a . Edição. Porto Alegre: Bookman.

BALL, D. W. (2002). Formation and vibrational spectrum of trifluorometyl sulfur 
pentacloride, $\mathrm{CF}_{3} \mathrm{SF}_{5}$, a new greenhouse gas. Gaussian-2 and Gaussian-3 calculations. Journal of Molecular Structure (Theochem) 578, 29-34.

BALMFORD, A.; BRUNER, A. COOPER, P; COSTANZA, R.; FARBER, S.; GREEN, R. E.; JENKINS, M.; JEFFERISS, P.; JESSAMY, V.; MADDEN, J.; MUNRO, K.; MYERS, N.; NAEEM, S.; PAAVOLA, J.; RAYMENT, M.; ROSENDO, S.; ROUGHGARDEN, J.; TRUMPER, K. and TURNER, R.K. (2002) Economic Reasons for Conserving Wild Nature. Science 9 Aug.

BASTOS, V. P. (2008). Catador: profissão: um estudo do processo de construção identitária do catador de lixo ao profissional catador. Jardim Gramacho, de 1996 aos dias atuais. Tese (Doutorado em Serviço Social). Pontifícia Universidade Católica do Rio de Janeiro. Rio de Janeiro.

BEES. Bees 3.0. Building for Environmental and Economic Sustainability. National Institute of Standards a Technology (Nist). Disponível em: < http://www.bfrt.nist.gov/oae/softwere/bees/bees.html >. Acesso em: 15 fev.2009.

BIDONE, F. R. A. e POVINELLI, J. (1999). Conceitos básicos de resíduos sólidos. São Carlos: EESC / USP.

BOECKX, P.; van CLEEMPUT O. (2000). Methane oxidation in landfill covers soils. Trace Gas Emissions and Plants. Kluwer Academic Publishers, Dordrecht, p. 197213.

BOFF, L. (1999). Saber cuidar: ética do humano - compaixão pela terra. Editora Vozes. Petrópolis, RJ.

BOGNER, J. E. (1986). "Gas Movement Through Fractured Landfill Cover 
Materials," proceedings of the Ninth Annual Madison Waste Conference Department of Engineering Professional Development, University of Wisconsin - Madison, September 9-10.

BOEIRA, S. L. (2002). Ecologia Política: Guerreiro Ramos e Fritjof Capra. Ambiente \& Sociedade. No. 10. Campinas. São Paulo.

BORGES, J. C. \& HIPÓLITO, D.A. (2008). Uma descoberta que mudou o mundo. Out. Revista Ciência Hoje. Disponível em: < http://cienciahoje.uol.com.br/129622 > Acesso em: 03 dez.2008.

BRASIL (2002). Ministério do Meio Ambiente. Avaliação Ambiental Estratégica. Brasília. MMA/SQA.

(2006). Secretaria Nacional de Saneamento Ambiental. O MDL nos empreendimentos de manejo de resíduos sólidos urbanos. Saneamento para todos. $3^{\circ}$ volume. Ministério das Cidades.

Ministério das Relações Exteriores. Meio Ambiente - Rio-92: Conferência das Nações Unidas sobre Meio Ambiente e Desenvolvimento. Disponível em: http://www2.mre.gov.br/cdBrasil/itamaraty/web/port/relext/mre/agintern/meioamb/apr esent.htm > Acesso em 15 ago.2008. . PORTARIA MA N . 961/98. Série I. Ministério do Ambiente. Disponível em: < http://diario.vlex.pt/vid/portaria-novembro-33202483 > Acesso em: 20 dez.2007. . PORTARIA MINTER N $53 / 79$. Ministério do Interior. Disponível em: < 
http://www.cpfl.com.br/parceiros_tecnologica/.../

diretrizes $\% 20$ ambientais\%20para\%20empresas\%2cC... > Acesso em: 16 set. 2007.

. RESOLUÇÃO CONAMA N N ${ }^{0}$ 237/97. Ministério do Meio Ambiente.

Disponível em: <www.mma.gov.br/port/conama/res97/res237/97.html> Acesso em: 05 dez.2008.

. RESOLUÇÃO CONAMA N0. 308/2002. Ministério do meio Ambiente.

Disponível em: <www.mma.gov.br/port/conama/res02/res30802.html > Acesso em: 05 dez.2008.

(2006). Fundação Nacional de Saúde. Orientações técnicas para apresentação de projetos de resíduos sólidos urbanos. Funasa. Brasília.

(2007). Secretaria de Educação Continuada, Alfabetização e Diversidade (SECAD/MEC). Educação Ambiental: aprendizes de sustentabilidade. Cadernos SECAD/MEC. Brasília.

BROTAS (2007). Prefeitura Municipal de Brotas. Secretaria do Meio Ambiente.

Disponível em: <http://www.brotas.sp.gov.br/page.php?p=ambiente.php>. Acesso em: 15 set. 2007.

BUCKERIDGE, M. S. \& AIDAR, M. P. M. (2005). O efeito estufa e seu impacto sobre a biodiversidade. Seção de Fisiologia e Bioquímica de Plantas. Instituto de Botânica. Links Novo. Disponível em: < http://meio_ambiente.com.via6.com > Acesso em: 15 set. 2007. 
CABRAL, A. E. B. (2007). Modelagem de propriedades mecânicas e de durabilidade de concretos produzidos com agregados reciclados, considerando-se a variabilidade da composição do RCD. São Carlos-SP. Tese (Doutorado). Escola de Engenharia de São Carlos da Universidade de São Paulo.

CALDERONI, S. (2001). Gestão de resíduos sólidos na América Latina e Caribe: instrumentos econômicos para políticas públicas. Projeto BRA-94-016 (I). Rio de Janeiro: MMA, PNUD.

CAPRA, F. (1997). A Teia da Vida - Uma Nova Compreensão Científica dos Sistemas Vivos. São Paulo. "Ecologia Profunda - Um Novo Paradigma" capítulo 1. Editora Cultrix. Tradução: Newton Roberval Eichemberg.

CASSETI, V. (1991). A Essência da Questão Ambiental. Boletim Goiano de Geografia. 11(1). Jan./Dez.

CENTRO DE GEstÃo E ESTUdOS EstRATÉGICOS (2008). Manual de Capacitação sobre Mudança do Clima e Projetos de Mecanismo de Desenvolvimento Limpo (MDL). Brasília-DF.

CHUNG, Shan-Shan \& POON, Chi-sun (1998). The attitudes of Guangzhou citizens on waste reduction and environmental issues. Resources, Conservation and Recycling, vol. 22, n. 5. Disponível em: <http://www.sciencedirect.com> Acesso em: 05 out.2006.

ClOLA, R. (1985). Fundamentos da Cromatografia a Gás. Segunda Edição Revisada e Ampliada. Editora Edgard Blücher Ltda.

CMDL (2002). Climate Monitoring and Diagnostic Laboratory Summary Report (26), 
2000-2001. KING, D. B. and SCHNELL, R. C. (Eds.). U. S. Department of Commerce. National Oceanic and Atmospheric Administration. Boulder CO.

CODE OF FEDERAL REGULATIONS (1992). 40 CFR 257.2. Protection of environment. The office of the Federal Register National Archives and Records Administration, Washington DC, USA.

COMPANHIA AMBIENTAL DO ESTADO DE SÃO PAULO (CETESB) (2006). Inventário Estadual de Resíduos Sólidos Domiciliares 2005/Cetesb. Série Relatórios. Governo do Estado de São Paulo. Secretaria do Meio Ambiente. São Paulo.

(2008). Inventário Estadual de Resíduos Sólidos Domiciliares:

relatório 2007/Cetesb. Série Relatórios. Governo do Estado de São Paulo. Secretaria do Estado do Meio Ambiente. São Paulo.

CONSCIÊNCIA AMBIENTAL (2004). Citando: RODRIGUES, F.L. e GRAVINATTO, V.M., em "LIXO - De onde? Para onde vai?". Ed. Moderna. São Paulo. Disponível em: < http://www.lixo.com.br > Acesso em 23 mai. 2006.

CONSTRUMAQ SÃO CARLOS Ind. e Com. Ltda. (2006). Manual de uso das ampolas gasométricas. Disponível em: < elizabeth@linkway.com.br >. Acesso em 27 set. 2006.

COREY, R. D. (Edit). Principles and Practices of Incineration (1980). Wiley Interscience.

CONVENÇÃO-QUADRO DAS NAÇÕES UNIDAS PARA A MUDANÇA DO CLIMA (CQNUMC, 2001). Banco de dados de GEE. Inventários on-line. Disponível em: 
<http://www.unfccc.de>. Acesso em: 23 mai. 2007.

DEMAJOROVIC, J. (1995). Da política tradicional de tratamento do lixo à política de gestão de resíduos sólidos. As novas prioridades. Revista de Administração de Empresas. São Paulo, v. 35, n.3.

DICKINSON, R. E. and CICERONE, R. J. (1986). Future global warming from atmospheric trace gases. Nature. 319(6049): 109-115.

DUMNING, A. (1992). How Much Is Enough? (Nova York: W.W. Norton \& Company).

EC (2005). European Commission. Waste generated and treated in Europe. Data 1995-2003. Disponível em:

<http://epp.eurostat.ec.europa.eu/cache/ITY_OFFPUB/KS-69-05-755/EN/KS-69-05755-EN.PDF>. Acesso em: 12 set.2008.

ELO 27. (2005). Meio Ambiente. Especialistas apontam caminhos para o problema do lixo urbano. Workshop "Lixo Urbano - Tendências e Soluções". São Paulo. Disponível em: <http://www.revistaelo.com.br/downloads/facto-lixoutil.doc> Acesso: 29 ago. 2006.

ENVIRONMENTAL PROTECTION AGENCY (1995). Standards of Performance for New Stationary Sources and Guidelines for existing Sources Municipal Wastes Combustors. 40 CFR Part 60. Federal Register, vol. 60 No. 243, 65387-653XX. Disponível em: <http://www.epa.gov/ttn/atw/243/ciwi/fr01de00.pdf> Acesso em: 20 mai. 2006.

Methane. Disponível em: < www.epa.gov/methane/ >. Acesso em: 03 
out. 2008.

(1999). Pollution prevention Act. Washington: U.S.EPA.

ESTADO DO MUNDO (2004). Worldwatch Institute (WWI)/Universidade Livre da Mata Atlântica (UMA). Disponível em: <http://www.wwiuma.org.br/em2004_htm> Acesso em: 20 set. 2006.

(2005). Worldwatch Institute (WWI)/Universidade Livre da Mata Atlântica (UMA). Disponível em: <http://www.wwiuma.org.br/em2005_htm> Acesso em: 16 dez. 2008.

FADINI, P. S. \& ALMERINDA, A. B. (2001). Lixo: Desafios e Compromissos. Cadernos Temáticos de Química Nova na Escola. São Paulo: USP. № 01, p.918, maio.

FARQUHAR, G.J., ROVERS F.A., (1973). Gas production during refuse decomposition. Water, Air and Soil Pollution. V. 2, 14, p. 483-495.

FECURI, A. C. (2004). Aterros sanitários municipais e o biogás. Jus Navigandi. Ano 8, $\mathrm{n}^{\circ}$. 429. Teresina, 9 set. Disponível em: < http://jus2.uol.com.br/doutrina/texto/asp?id=5673> Acesso em: 20 mar.2007.

FENKER, E. (2007). Impacto Ambiental e Dano Ambiental - Artigo Técnico - 20. Seminário sobre Sustentabilidade. UNIFAE/Centro Universitário São Francisco. Curitiba, PR. Disponível em: $<$ http://www.ambientebrasil.com.br/noticias/index.php3?action=ler\&id> Acesso em 24 dez.2007. 
FGV. Fundação Getúlio Vargas (1992). Nosso Futuro Comum - Comissão Mundial Sobre Meio Ambiente e Desenvolvimento, $2^{a}$ Edição, Rio de Janeiro.

FIGUEIREDO, N. J. V. (2007). Utilização do biogás de aterro sanitário para geração de energia elétrica e iluminação a gás - estudo de caso. (Trabalho de Graduação Interdisciplinar). Universidade Presbiteriana Mackenzie. Escola de Engenharia, Departamento de Engenharia Mecânica. São Paulo.

BRITO FILHO, L. F. de (2005). Estudo de Gases em Aterros de Resíduos Sólidos Urbanos. Rio de Janeiro. Dissertação (Mestrado). Engenharia Civil. COPPE/Universidade Federal do Rio de Janeiro.

FIORILLO, C.A.P. (2003). Curso de Direito Ambiental Brasileiro. 4a . Ed. Editora Saraiva.

FORTEZA et al. (2004). Characterization of bottom ash in municipal solid waste incinerators for its use in road base. Waste Management. Vol.22, 899-909.

FREUDENRICH, C. Como funcionam os aterros? Tradução HowStuffWorks Brazil. Disponível em: <http://ambiente.hsw.uol.com.br/aterros.htm> Acesso em: 10 out.2008.

FURTADO, M. (2005). Controle da Poluição do ar. Nova regulamentação incentiva combate aos NOx's. Química e Derivados. Novembro.

FUNDO ESTADUAL DE RECURSOS HÍDRICOS DE SÃO PAILO - FEHIDRO/ Sistema Integrado de Gerenciamento de Recursos Hídricos de São Paulo [SIGRH]/Rede das Águas. Disponível em <http://www.rededasaguas.org.br> Acesso 
em 31 jul.2006.

GARDNER, G.; ASSADOURIAN, E. and SARIN, R. O (2004). Estado do Consumo Hoje. Em: O Estado do Mundo. Capitulo 1. Pags. 03 a 24.

GARDNER, G. e SAMPAT, P. (2003). Mind over Matter: Recasting the Role of Materials in Our Lives. Worldwatch Paper 144 (Washington, DC: Worldwatch Institute).

GORES/DAAE. Gerência de Operações do Sistema de Resíduos Sólidos. Araraquara-SP (2007). Agamemnon Brunetti Junior, comunicações/informações pessoais.

GRABBE J.

O.

The

Club

of

Rome.

Disponível em: < http://www.mega.nu/somans.html> Acesso em: 24 set.2008.

GRIBBIN, J. (1988). Inside Science: The greenhouse effect. New Scientist. 22 oct.

GUTIERREZ, M. B. S. (1998). A eqüidade nas negociações internacionais entre países desenvolvidos e em desenvolvimento para a redução dos gases de efeito estufa: principais critérios e implicações. IPEA. Rio de Janeiro-RJ. Disponível em: < http://www.ipea.gov.br/pub/td/td0550.pdf > Acesso em 26 mar.2007.

HALWEIL, B. e NIERENBERG, D. (2004). Rumos para uma Economia Menos Consumista. In: Estado do Mundo. Capitulo 5. WWI.

HAM, R. (1979). "Recovery, Processing and Utilization of Gas from Sanity Landfills". EPA 600/2-79-001.

HANSON, R.S. and HANSON, T.E. (1996). Methanotrophic bacteria. Microbiology 
Reviews, v.60, p.439-471.

HARTENSTEIN, H. U. and HORVAY, M. (1996). Overview of municipal solid waste incineration industry in west Europe (based on the Germany experience). Journal of hazardous Materials, vol. 47, Issues 1-3, pages 17-30.

HJELMER, O. (1996). Disposal strategies for municipal solid waste incineration residues. Journal of Hazardous Materials 47: 345-368.

HOEKS, J. (1983). Significance of biogas production in waste tips. Waste Management \& Research. Journal of the solid wastes ad Public Cleaning Association, ISWA, V. 1, p. 323-335.

HOLMES, A.J.; ROSLEV, P.; MCDONALD, I.R.; IVERSEN, N.; HENRIKSEN, K.; MURRELL, J.C. (1999). Characterization of Methanotrophic bacterial populations in soils showing atmospheric methane uptake. Applied Environmental Microbiology, v.65, p.3312-3318.

HOUGHTON, J. T. et al. (1995). Climate Change 1994 - Radiative Forcing of Climate Change. Cambridge, U.K., Cambridge University press.

IANNONE, R. A. (1992). A Revolução Industrial. Editora Moderna. 10a. Edição.

IBAÑEZ, R. (2000). Characterization and management of incinerator waste. Journal of Hazardous Materials. A 79, 215-227.

IBUKI, T.; SHIMADA, Y.; HASHIMOTO, R.; NAGAOKA, S.; HINO, M.; OKADA, K.; SUZUKI, I. H.; MORISHITA, Y.; TAMENORI, Y. (2005). Photofragmentation of C, F and S K-shell excited CF3SF5 studied by PEPICO and PIPICO spectroscopy. 
Chemical Physics 314: 119-126.

IGLESIAS, E. (200). Estado do consumo e o consumo sustentável. Apresentação. In: Estado do Mundo 2004. Worldwatch Institute. Disponível em: < http://www.wwiuma.org.br/em2004_eiglesias.htm > Acesso em 12 out.2007.

IMBELLONI, R. (2004). Benefícios ambientais da geração de energia a partir de GAS. In: Landfill Gás. Disponível em < http://www.lixo.com.br >. Acesso em 15 mar.2006.

INSTITUTO BRASILEIRO DE GEOGRAFIA E ESTATÍSTICA (2000) (a). Censo 2000. Disponível em < http://www.ibge.gov.br > Acesso em 08 mai. 2006.

2000 (b) PNSB - Pesquisa Nacional de Saneamento Básico / Fundação Instituto Brasileiro de Geografia e Estatística. Número de distritos com serviço de limpeza urbana e/ou coleta de lixo, por percentual de lixo coletado.

(2000) (c). Censo 2005. Diretoria de Pesquisas, Coordenadoria de Contas Nacionais. Disponível em < http://www.ibge.gov.br > Acesso em 08 jul. 2006.

(2005) (d). Diretoria de Pesquisas, Coordenadoria de Contas acionais.

Disponível em $<$ http://www.ibge.gov.br/home/estatistica/economia/pibmunicipios/2003/tab01.pdf > Acesso em 08 jul. 2006.

(e). Disponível em: $<$ http://www.ibge.gov.br/busca/search?q=Popula\%E7\%E3o+mundial\&entqr=0\&output

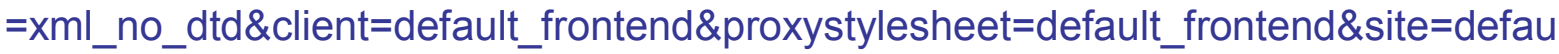


It_collection\&ud=1\&oe=iso-8859-1\&ie=iso-8859-1\&Submit.x=12\&Submit. $y=8 \quad$ >. Acesso em: 10 dez. 2008.

(f). Disponível

em:

$<$ http://www.ibge.gov.br/home/estatistica/populacao/estimativa2008/POP_2008_TCU. pdf >. Acesso em: 12 dez. 2008.

INTERGOVERNAMENTAL PANEL ON CLIMATE CHANGE (1996), Módulo 6 - Lixo - Guia para Inventários Nacionais de Gases de Efeito Estufa, Volume 2: Livro de Trabalho.

IPCC (1996). Climate Change 1995: The Science of Climate Change. J.T. Houghton, L. G. Meira Filho, B. A. Callander, N. Harris, A. Kattenberg and K. Maskell(eds.). Cambridge University Press, Cambridge, UK.

IPCC (2001). Climate Change 2001: The Scientific Basis. J. T. Houghton, Y. Ding, D. J. Griggs, M. Noguer, P. J. van der Linden, X. Dai, K. Maskell and C. A. Johnson (eds.). Cambridge University Press. Cambridge, UK.

(2001). Climate Change, Synthesis Report.

(2002). Climate Change. Synthesis Report. ATCHA, S.Y. and SON, T. V. In: Opportunities with Landfill Gas. World Resources Institute (WRI), Washington, DC, September.

(2006). A Technical Papers. Disponível em: <

http://www.ipcc.ch/pdf/technical-papers/ccw/appendix3.pdf >. Acesso em 20 set 2008.

INSTITUTO DE PESQUISAS TECNOLÓgICAS (2000). Lixo Municipal: 
Gerenciamento Integrado. 2a . Edição. São Paulo: IPT/CEMPRE.

IPV - ÍNDICE do PLANETA VIVO (2002). WWF Internacional, PNUMA e Redefining Progress. Living Planet Report. Disponível em: < www.panda.org/news_facts/ publications/general/livingplanet/index.cfm > Acesso em: 25 set.2006.

ITURRI, E. A. Z. (2006). Uma proposta para a base de apoio dos drenos de gás. Simpósio Internacional de Tecnologias e Tratamentos de Resíduos Sólidos, Rio de Janeiro.

JAFFRIN, A.; BENTOUNES, N. ; JOAN, A. M. ; MAKHLOUF, S. (2003). Landfill Biogas for heating Greenhouses and providing Carbon Dioxide Supplement for Plat Growth. Biosystems Engineering, 113-123.

JAMES, B. (1997). Lixo e reciclagem. Tradução Dirce Carvalho de Campos; revisão técnica José Carlos Sariego. São Paulo: Scipione. (Coleção preserve o mundo).

KGATHI, D.L. \& BOLAANE, B. (2001). Instruments for sustainable solid waste management in Botswana. Waste Management \& Researches, vol. 19, n. 4, 342353.

KHALIL, M. A. K. and RASMUSSEN, R. A. (1987). Atmospheric methane trends over the last 10,000 years. Atmospheric Environment, 21, 2445-2452, 1987.

KIGHTLEY, D.; NEDWELL, D. B.; COOPER, M. (1995). Capacity for methane oxidation in landfill cover soils measured in laboratory-scale soil microcosms. Applied and Environmental Microbiology, v.61, p.592-601. 
KORHONEN, M-R. and DAHLBO, H. (2007). Reducing Greenhouse Gas Emissions by Recycling Plastics and Textiles into Products. The Finnish Environment 30. Helsinki.

KUMAR, S.; GAIKWAD, S. A.; SHEKDAR, A.V.; KSHIRSAGAR, P.S. and SINGH, R.N. (2004). Estimation method for national methane emission from solid waste landfills. Atmospheric Environment 38: 3481-3487

LANÇAS, F. M. (1993). Cromatografia em Fase Gasosa. São Carlos-SP, Brasil: Acta.

LAUB, R. J. and PECSOK, R. L. (1945). Physicochemical applications of gas chromatography. A Wiley-Interscience Publication. John Wiley \& Sons. New York.

LASZLO, E. (2001). Macrotransição: O desafio para o terceiro milênio. São Paulo, Axis Mundi.

LEBLOW, V. P. (1960). The Waste Makers (Nova York: David Mckay.

LEITE, P. R. (2003). Logística reversa: meio ambiente e competitividade. Printice Hall. São Paulo.

LEITE, W.C.A. (1997). Estudo da gestão de resíduos sólidos: uma proposta de modelo tomando a unidade de gerenciamento de recursos hídricos (UGRHI-5) como referencia. São Carlos-SP. Tese (Doutorado). Escola de Engenharia de São Carlos. Universidade de São Paulo.

LEIS, H. R. (1999). A modernidade insustentável. As críticas do ambientalismo à sociedade contemporânea. Petrópolis, Vozes/Edufsc. 
LENCASTRE, M. P. A. (2006). Ética ambiental e educação nos novos contextos da ecologia humana. Revista Lusófona de Educação, 8.

LIOTTE, R. G. (2007). Ocorrência de bactérias metanotróficas em amostras de aterros sanitários através da determinação do potencial de oxidação do metano e da caracterização de culturas enriquecidas. Dissertação ( Mestrado em Ciências Microbiologia). Instituto de Ciências biomédicas. Universidade de São Paulo. São Paulo, 2007.

LIXO (2006). Disponível em: http://www.lixo.com.br. Acesso em: 23 mai. 2006.

LOPES, A. A. (2007). Estudo da gestão integrada dos resíduos sólidos urbanos na bacia do Tietê - Jacaré (UGRHJ-13). São Carlos-SP. Tese (Doutorado). Escola de Engenharia de São Carlos. Universidade de São Paulo.

LUTZENBERGER, J. (1985). Ecologia: do jardim ao poder. Porto Alegre: L\&PM Editores, 105p..

MARQUES, A. C. M. (2001). Compactação e Compressibilidade de Resíduos Sólidos Urbanos. São Carlos-SP. Tese (Doutorado). Escola de Engenharia de São Carlos. Universidade de São Paulo.

MASTNY, L. (2002). "Cruise Industry Buoyant”, em Worldwatch Institute, Sinais Vitais (Salvador: UMA Editora, 2002).

(2004). Comprando para as Pessoas e o Planeta. Estado do Mundo. Capítulo 6.

MASSUKADO, L. M. (2004). Sistema de Apoio à Decisão: Avaliação de Cenários de 
Gestão Integrada de Resíduos Sólidos Urbanos Domiciliares. São Carlos-SP. Dissertação (Mestrado). Universidade Federal de São Carlos-UFSCar.

MATA-ALVAREZ, J.; MACÉ, S. and LLABRÉS, P. (2000). Anaerobic digestion of organic solid waste. An overview of research achievement and perspectives. Bioresource Technology, 74, 3-16.

MATOS, T.F.L. (2006). Diagnóstico dos Resíduos Poliméricos nos Resíduos Sólidos Domiciliares Gerados em São Carlos-SP. São Carlos-SP. Dissertação (Mestrado). Escola de Engenharia de São Carlos. Universidade de São Paulo.

MCBEAN, E.A.; ROVERS, F.A.; FARQUHAR, G.J. (1995). Solid waste landfill engineering and design. New Jersey. Prentice Hall PTR. Englewood Cliffs.

McCORMICK, J. (1992). Rumo ao paraíso. A história do movimento ambientalista. Rio de Janeiro.

MELLIS, C. (2004). Fórum Continuado de Energia. Unibanco (2004). < Carlos.mellis@unibanco.com.br >. Acesso em: 23 ago.2007.

MENDES, M. (2002). O ecologista movido a confrontos. Caderno Donna. Zero Hora. 14 abril.

MENEZES, R.A.A., BESSA, I., MENEZES, M. A. (1999). O Plasma Térmico Solução final para os resíduos perigosos. Associação Brasileira de Metalurgia e Materiais (ABM). Seminário de Meio Ambiente, São Paulo.

MENIN, D. F. (2000). Ecologia de A a Z - Pequeno Dicionário de Ecologia. Ed. LP\&M. 
MINAMISAKO, D. C.(2009). Prefeitura Municipal de São Carlos. Divisão de gestão de Resíduos Sólidos. E-mail: <douglasambusp@yahoo.com.br>. Em 27 ago. 2009.

MITCHELL, J. F. B. (1989). The "greenhouse" effect and climate change. Reviews of Geophysics 27(1).

MITCHELL et al (1995). Nature 376. In: $\mathrm{CO}_{2} /$ Climate Report. Issue 97-1. Canadian Climate Center. 1997.

MORELLI, L. Ambientalistas denunciam união entre CONSEMA/SP e empresários do lixo. Instituto para Defesa da Vida. Disponível em: < http://www.maxpressnet.com.br/noticia.asp?TIPO=PA\&SQINF=298739 > Acesso em: 18 dez.2007.

ORGANIZAÇÃO PARA A COOPERAÇÃO E DESENVOLVIMENTO ECONOMICO (2002). Towards Sustainable Consumption: An Economic Conceptual Framework (Paris: Environment Directorate, jun).

OLIVEIRA, W. Engracia de. (1969) Introdução ao problema de lixo. Revista DAE, São Paulo, n. 74, 58-69.

ONU/FAO. Organização de Alimento e Agricultura das Nações Unidas (FAO). FAOSTAT Statistical Database. Disponível em: < http://www.apps.fao.org > Acesso em: 23 ago.2008.

ONU (2004). Divisão de População das Nações Unidas. Disponível em: < http://www.esa.un.org/unpp > Acesso em: 17 set.2008.

PARKER, A. (1983). Behavior of wastes in landfill methane generation. In: Holmes 
J.R., ed. Practical waste management. Chichester, England. John Wiley \& Sons.

PASSINATO, C. de B. (2008). O Lixo e o Meio Ambiente - Panorama Internacional. Wordpress. $\quad 2008 . \quad$ Jul. Disponível em: $<\quad$ http://crispassinato.wordpress.com/2008/07/15/o-lixo-e-o-meio-ambientepanorama-internacional/ > Acesso em: 31 ago.2008.

PEER, R.L.; THORNEOLE, S. A.; EPPERSON, D.L. (1993). A comparation of methods for estimating global methane emission from landfills. Chemosphere, v. 26, n. 1-4, p. 387-400, Jan-Feb.

PECORA, V. (2006). Implantação de uma unidade demonstrativa de geração de energia elétrica a partir do biogás de tratamento do esgoto residencial da USP Estudo de Caso. Dissertação (Mestrado). Programa Interunidades de PósGraduação em Energia (PIPGE) do Instituto de Eletrotécnica e Energia (IEE) da Universidade de São Paulo, São Paulo.

PNUD (1998). Human Development Report 1998 (Nova York: Oxford University Press).

PNUMA (2005). In: Global Environment Outlook: meio ambiente para o desenvolvimento (GEO-4). $\quad$ Disponível em: http://www.unep.org/geo/geo4/media/index.asp > ou em: < http://www.onubrasil.org.br/view_news.php?id=6107 >. Acesso em: 10 set. 2009.

PETTS, W. (1994). Incineration as a waste management option. In Hester, R.E. \& Harrison, R.M. Editors. Waste Incineration and the Environment. Royal Society of Chemistry. 
PIRES, T. M. (2009). Prefeitura Municipal de Campinas. Secretaria de Serviços

Públicos. Departamento de Limpeza Urbana (DLU). E-mail: <tmpires@ig.com.br>. Em 11 ago. 2009.

PROGRAMA NACIONAL DE EDUCAÇÃO AMBIENTAL - PNEA. Disponível em: <http://www.mma.gov.br/port/sdi/ea/busca/det_reg.cfm?idr=3861\&idm=9\%20> Acesso em: 21 abril 2007.

PROTOCOLO DE QUIOTO. À Convenção sobre Mudanças do Clima (CQUMC). Editado e traduzido pelo Ministério da Ciência e Tecnologia (MCT) com o apoio do Ministério das Relações Exteriores (MRE) da República Federativa do Brasil. Originalmente, Secretariado da Convenção sobre o Clima/PNUMA, setembro de 2002.

PUGLIESI, E. (2006). Gestão e gerenciamento de resíduos de serviços de saúde: proposta de modelo para as unidades da Irmandade Santa Casa de Misericórdia de São Carlos, SP. São Carlos, 2006. Exame de Qualificação. Escola de Engenharia de São Carlos. Universidade de São Paulo.

QIN, W.; EGOLFOPOULOS, F.N. and TSOTSIS, T. T. (2001). Fundamental and environmental aspects of landfill gas utilization for power generation. Chemical Engineering Journal, 82: 157-172.

RAMANATHAN, V.; CICERONE, R. J.; SINGH, H. B. and KIEHL, J. T. (1985). Trace Gas Trends and Their Potential Role in Climate Change. Journal of Geophysical Research, vol. 90, D3, 5547-5566.

READ, A. D. (1999). A weekly doorstep recycling collection, I had no idea we could! 
Overcoming the local barriers to participation. Resources, Conservation and Recycling, vol. 26, n. 6, 217-249. Disponível em: < http://www.sciencedirect.com > Acesso em: 11/09/2007.

REAMS, M. A. \& TEMPLET, P. H. (1996). Political and environmental equity issues to municipal waste incineration sitting. Journal of Hazardous Waste. Vol. 47, pag. 313-323.

REDE DA ÁGUAS. Disponível em: < http://www.rededasaguas.org.br > Acesso em: 15 ago. 2005.

RENNER, M. (2003). Investimentos anuais adicionais necessários, de, "Military Expenditures on the Rise". In: Worldwatch Institute.

RICUPERO, R. (2007). Uma injustiça do tamanho do mundo. Folha de São Paulo de 15/04/07.

RIOUX, J. P. (1975). A Revolução Industrial: 1780-1880. Livraria Pioneira Editora.

ROSA, L. P. (Coordenador); MUYLAERT, M. S. (Coordenadora); OLIVEIRA, A. S. de; PEREIRA, A. S.; CAMPOS, C. P. de e RIBEIRO, L. (2001). Contribuições Históricas por países nas Emissões de três Gases de Efeito estufa (GEE). Relatório Preliminar ao MCT. Equipe do IVIG/COPPE/EFRJ: Projeto IVIG/COPPE/UFRJ 2747-A. Rio de Janeiro-RJ.

ROSA, LUIZ P. et al. (2003). Fontes Renováveis de Energia no Brasil - Geração de Energia a partir de Resíduos do Lixo e Óleos Vegetais. Rio de Janeiro, Brasil.

ROSE, J. L. (2009). Análise comparativa entre as reduções da emissão de metano 
em camadas oxidativas experimentais. Rio de Janeiro (2009). Tese (Doutorado). Programa de Pós-Graduação em Engenharia Civil. UFRJ/COPPE.

ROTHSTEIN, E. (2003). "A World of Buy, Buy, Buy, from A to Z", New York Times, 19/07/03.

SCHALCH, V. (1992). Análise Comparativa do Comportamento de dois Aterros Sanitários Semelhantes e Correlações dos Parâmetros do Processo de Digestão Anaeróbia. São Carlos-SP. Tese (Doutorado). Escola de Engenharia de São Carlos. Universidade de São Paulo.

SC - SECRETARIA DE COMUNICAÇÃO DE JAÚ. 2006. Disponível em: <http//:www.jau.sp.gov.br> Acesso em: 29/08/2006.

SENAGA, M. (2004). Termelétrica do Aterro Bandeirantes reduz emissão de $\mathrm{CO}_{2}$ $\begin{array}{llll}\text { para } & \text { a } & \text { Atmosfera. } & \text { Disponível }\end{array}$ <http://www.ambiente.sp.gov.br/destaque/2004/marco/25_termeletrica.htm.> Acesso em: 04 mar.2006.

SIKAR, E. and LA SCALA Jr. (2004). Methane and carbon dioxide seasonal cycles at Brazilian inland sites. Journal of Atmospheric Chemistry. 47: 101-106.

SIKAR, E.; SANNTOS, M. A., MATVIENKO, B.; SILVA, M. B.; ROCHA, C . H. E. D., SANTOS, E.; BENTES Jr., A. P. and ROSA, L. P.(2005). Greenhouse gases and inicitial findings on the carbon circulations in two reservoirs and their watersheds. Verh. Internat. Verein. Limnol., 29, 573-576. Stuttgart.

SILVA, M. M. P. da. (2004). Explorando o lixo na escola. Jornal Mundo Jovem. 
Porto Alegre-RS. Setembro/2004. № 350, 2-3.

SONNEMANN, G. (2003). Divisão de Tecnologia, Indústria e Economia, PNUMA.

SOUZA, M. P. de (2000). Instrumentos de Gestão Ambiental: fundamentos e práticas. Editora Riani Costa.

SPOKAS, K.; BOGNER, J.; CHANTON, J.P.; MORCET, M.; ARAN, C. ; GRAFF, C. ; MOREAU-LE GOLVAN ; Y. and HEBE, I. ((2006). Methane mass balance at three landfill sites: What is the efficiency of capture by gas collection systems? Waste Management 26: 516-525.

STERN, D. I. and KAUFMANN, R. K. (1996). Estimates of global anthropogenic methane emissions 1860-1993. Chemosphere. 33: 159-167.

STURGES, W.T., WALLINGTON, T. J., HURLEY, M.D., SHINE, K. P., SHIRA, K., ENGEL, A., ORAM, D.E., PENKETT, S.A., MULVANEY, R. and BRENNINKMEIJER, C.A.M. (2000). - A Potent Greenhouse Gas Identified in the Atmosphere: $\mathrm{SF}_{5} \mathrm{CF}_{3}$. Science, vol. 289.

TAUB, E. A. (2003). - DVD's Meant for buying but Not for Keeping. New York Times, 21.07.

TCHOBANOGLOUS G., THEISEN H., VIGIL S. (1993). Integrated solid waste management - Engineering principles and management issues. McGraw-Hill, Inc.

TCHOBANOGLOUS, G. et. al., (1994). Gestión integral de resíduos sólidos. Madrid: Mcgraw-Hill/Interamericana de España.

TENÓRIO, J. A. S e ESPINOSA, D. C. R. (2004). Controle Ambiental de Resíduos. 
In: PHILIPPHI JR.; ROMERO, M. A. e BRUNA, G. C. Curso de Gestão Ambiental. Coleção Ambiental. Barueri-SP.

THE ECONOMIST. Maio de 2003, pp. 69-71. Cosméticos e perfumes, de "Pots of Promise".

THOMAS, V. Destruição ambiental ameaça crescimento. Folha de São Paulo de 20/09/2007.

UE - UNIÃO EUROPÉIA (2005). Diretiva 2000/76/CE Relativa à Incineração de

Resíduos Sólidos Urbanos. Disponível em: < http://europa.eu.it/scadplus/leg/es/lvb/128072.htm > Acesso em: 16 mar. 2006.

USEPA - UNITED STATES ENVIEONMENTAL PROTECTION AGENCY (2006).

Methane: Science. Disponível em <http://www.epa.gov/methane/scientific.html> .Acesso em 15 set. 2008.

VALLE, C. E. (1995). Qualidade Ambiental: O desafio de Ser Competitivo Protegendo o Meio Ambiente. São Paulo: Pioneira.

Qualidade ambiental: Iso 14000. São Paulo-SP. Editora Senac, $5^{a}$. Edição, 2004.

van Elk, A. G. H. P. (2007). Redução de emissões na disposição final. Mecanismo de Desenvolvimento Limpo aplicado a Resíduos Sólidos. Caderno 3. Coordenação de Karin Segala. Rio de Janeiro: IBAM.

van GERVEN, T. et al. (2005). Management of incinerator residues in Flanders (Belgium) and neighboring countries. A comparation. Waste Management. No. 25. 
VIEIRA, J. B. (2008) - Origens do desperdício e a coexistência pacífica atual com a sociedade pós-moderna. Disponível em: < http://www.cenedcursos.com.br/aquestao-dos-residuos-industriais.html> Acesso em: 16 jun. 2008.

VOGT, C. (2002). Os Ciclos da Vida. Disponível em: < http://www.comciencia.br >. SBPC/Labjor - Brasil. Acesso em: 10 ago.

WISE, Donald L. (1987). (Edit) - Bioenvironmental systems. Florida CRC Press.

WORLD COMMISSION ON ENVIRONMENT AND DEVELOPMENT. [The Brundtland Report]. (1987). Our Common Future. New York: Oxford University Press.

WORLD RESOURCES INSTITUTE (WRI) (2002). Opportunities with Landfill Gas. Sept. Disponível em: < http://pdf.wri.org >. Acesso em: 23 mai 2006. (1992). World resources: a guide to the global environment-toward sustainable development. Oxford: Oxford University Press.

WUEBBLES, D.J.; HAYHOE, K. (2002). Atmospheric methane and global change. Earth-Science Reviews, v. 57, n.3-4, p. 177-210, May.

WWF (2007). Mudanças Climáticas: Consequencias Desastrosas. Disponível em: < http://assets.wwf.org.br/downloads/2vs3graus.pdf > Acesso em 29 out. 2008.

WWF INTERNATIONAL, PNUMA AND REDEFINING PROGRRSS. Living Planet Report 2002. Disponível em: <http://www.panda.org/news_facts/publications/general/livingplanet/idex.cfm> Acesso em: 10 dez. 2008. 
ZAMORANO, M.; PÉREZ, J.I.P.; PAVÉS, I.A. and RIDAO, A.R. (2007). Study of energy potential of biogas produced by an urban waste landfill in Southern Spain. Renewable ad sustainable Energy Reviews. 11: 909-922.

ZHANG et al. (2002). Waste ashes for use in agricultural production II. Contents of minor ad trace metals. The Sciences of Total Environment. 286: 11-118.

ZIMMERMAN, P. R.; GREENBERG, J. P. and WESTBERG, C. E. (1998). Journal Geophysical Research. 93 (D2), 1407-1416. 
ANEXOS

BERTO NETO, J. (2009). - Medidas da Emissão de Gases de oito aterros de resíduos sólidos urbanos do Estado de São Paulo - Brasil. Tese apresentada ao PPG-SEA/CRHEA - EESC/USP. São Carlos-SP, Dez. 2009. 


\section{ANEXo A}

\section{SíTIOS CONSULTADOS NA INTERNET E DE IMPORTÂNCIA PARA AS QUESTÕES AMBIENTAIS}

$<$ http://www.mma.gov.br >

$<$ http://www.mct.gov.br >

$<$ http://www.mct.gov.br/clima >

$<$ http://cdm.unfccc.int >

$<$ http://unfccc.int/2860.php >

$<$ http://bmf.con.br >

< http://www.esrl.noaa.gov/gmd/ccgg/trends/ >

< http://habitat.igc.org/open-gates/wced-ocf.htm. >

$<$ http://jworky.gsfc.nasa.gov/ >

< http://www.epa.gov/docs/ozone/index.html >

$<$ http://www.nbs.ac.uk/public/icd >

< http://www.wmo.ch/web/arep/ozobull.html >

< http://www.wmo.ch/web/arep/nho3.html >

< http://www.atm.ch.cam.ac.uk/acmsu/studio.html >

< http://www.doe.ca/ozone/index.html >

< http://acs.environmental.duq.edu/acsenv/envchem.htm >

< http://www.epa.gov/airs/criteria.html >

< http://www.epa.gov/ogwDw/wot/appa.html > 
< http://www.wri.org:80/wri/enved/trends/atm-10f.html >

< http://www.cetesb.sp.gov.br >

< http://www.open.gov.uk/doh//airpol/airpol17.htm >

< http://cdiac.esd.ornl.gov/pns/top10.html >

< http://www.giss.nssa.gov/research/observe/surftemp.html >

< http://www.globalchange.org/samplei.html >

< http://www.erin.gov.au/climate/greenhouse >

< http://wmo.ch/web/arep/ozobull.html >

< http://www.greenpeace.org./ctox.html >

< http://www.epa.gov/airprogm/oar/mercury.html >

< http://www.plasticsresource.com >

$<$ http://www.wri.org >

< http://www.co2science.org/journal/v7/v7n31c3.htm >

< http://www.worldbank.org >

$<$ http://www.lixo.com.br >

< http://www.wwf.org.br/pantanal/default.htm >

< http://www.centroclima.org.br >

$<$ http://www.if.usp.br >

< http://www.cnpma.embrapa.br >

$<$ www.cempre.org.br >

$<$ www.greenpeace.com.br > 
$<$ http://www.ipcc.ch/ >

< http://yosemite.epa.gov/oar/globalwarming.nsf/ >

< http://europa.eu.int/comm/environment/climat/home_en.htm > 


\section{ANEXO B}

Documentos importantes da Legislação Brasileira, com foco Ambiental, em ordem cronológica.

\begin{tabular}{|c|c|c|}
\hline Norma & Âmbito & Conteúdo \\
\hline $\begin{array}{l}\text { Decreto } \mathrm{n}^{0} \\
50.887 / 61\end{array}$ & Federal & $\begin{array}{l}\text { Regula o lançamento de resíduos tóxicos } \\
\text { ou oleosos nas águas interiores ou } \\
\text { litorâneas do país e dá outras providências } \\
\text { (Alterado pela Lei } 6.513 / 77 \text { ) }\end{array}$ \\
\hline Lei $n^{0} .5 .318 / 67$ & Federal & $\begin{array}{l}\text { Instituiu a Política Nacional de } \\
\text { Saneamento e cria o CNS }\end{array}$ \\
\hline $\begin{array}{l}\text { Decreto Lei } n^{0} \text {. } \\
1413 / 75\end{array}$ & Federal & $\begin{array}{l}\text { Dispõe sobre o controle da poluição do } \\
\text { meio ambiente s partir de atividades } \\
\text { industriais }\end{array}$ \\
\hline $\begin{array}{l}\text { Lei } n^{0} .997- \\
31 / 05 / 1076\end{array}$ & Estadual/São Paulo & $\begin{array}{l}\text { Dispõe sobre o controle da poluição no } \\
\text { meio ambiente }\end{array}$ \\
\hline $\begin{array}{l}\text { Decreto } \mathrm{n}^{0} \\
8.468 / 76\end{array}$ & Estadual/São Paulo & $\begin{array}{l}\text { Regulamenta a Lei } 997 \text { e dispõe sobre a } \\
\text { poluição do solo }\end{array}$ \\
\hline $\begin{array}{l}\text { Decreto } n^{0} \\
10.229 / 77\end{array}$ & Estadual/São Paulo & $\begin{array}{l}\text { Complementa dispositivos ao Decreto } \\
8.468 / 76\end{array}$ \\
\hline $\begin{array}{l}\text { Portaria } \\
\text { Ministério do } \\
\text { Interior } n^{0} .53 / 79\end{array}$ & Federal & $\begin{array}{l}\text { Dispõe normas para projetos específicos } \\
\text { de tratamento e disposição de RSU, bem } \\
\text { como fiscalização da implantação, } \\
\text { operação e manutenção }\end{array}$ \\
\hline Lei $n^{0} .6 .902 / 81$ & Federal & $\begin{array}{l}\text { Dispõe sobre a criação de estações } \\
\text { ecológicas, Áreas de Proteção Ambientais } \\
\text { e dá outras providências }\end{array}$ \\
\hline Lei $n^{0} .6 .938 / 81$ & Federal & $\begin{array}{l}\text { Dispõe sobre a política Nacional de Meio } \\
\text { Ambiente. Constitui o SISNAMA }\end{array}$ \\
\hline $\begin{array}{l}\text { A Lei } n^{0} \\
6938 / 1981\end{array}$ & Federal & $\begin{array}{l}\text { Institui a Política Nacional de meio } \\
\text { Ambiente }\end{array}$ \\
\hline NBR $n^{0} .8849 / 85$ & Federal & $\begin{array}{l}\text { Apresentação de projetos de aterros } \\
\text { controlados de resíduos sólidos urbanos }\end{array}$ \\
\hline $\begin{array}{l}\text { Resolução } \\
\text { CNEN n }{ }^{0} .605 / 85\end{array}$ & Federal & $\begin{array}{l}\text { Aprova a norma experimental: gerência de } \\
\text { rejeitos radioativos em instalações que } \\
\text { tratem com radioativos }\end{array}$ \\
\hline $\begin{array}{l}\text { Resolução } \\
\text { CONAMA n }{ }^{0} \text {. } \\
1 / 86\end{array}$ & Federal & $\begin{array}{l}\text { Estabelece Responsabilidades e critérios } \\
\text { para os Estudos de Impactos Ambientais } \\
\text { (EIA's) e Relatórios de Impactos } \\
\text { Ambientais (RIMA's) }\end{array}$ \\
\hline $\begin{array}{l}\text { Resolução } \\
\text { CONAMA n }{ }^{0} \\
11 / 86\end{array}$ & Federal & Altera a Resolução $\mathrm{n}^{0} .1(\mathrm{em} 18.03 .86)$ \\
\hline $\begin{array}{l}\text { Decreto } n^{0} \text {. } \\
96.044 / 88\end{array}$ & Federal & $\begin{array}{l}\text { Regulamenta o transporte rodoviário de } \\
\text { produtos perigosos e dá outras } \\
\text { providências }\end{array}$ \\
\hline
\end{tabular}




\begin{tabular}{|c|c|c|}
\hline $\begin{array}{l}\text { Resolução } \\
\text { CONAMA } \\
n^{0} .6 / 88\end{array}$ & Federal & $\begin{array}{l}\text { Obriga os inventários qualiquantitativos } \\
\text { dos resíduos gerados pelas empresas }\end{array}$ \\
\hline $\begin{array}{l}\text { Constituição } \\
\text { Federal do Brasil } \\
\text { de } 1988\end{array}$ & Federal & $\begin{array}{l}\text { Artigos } n^{0 S} .23,24,196 \text { e } 225 \text {-c/ incisos; } \\
\text { mesmo sem mencionar "lixo", apresenta } \\
\text { preocupação com a saúde do cidadão, } \\
\text { mediante proposição de políticas públicas } \\
\text { sociais e econômicas, bem como de } \\
\text { defesa e conservação do ambiente } \\
\text { natural, mantendo-o, ecologicamente, } \\
\text { equilibrado, estabelecendo competências. }\end{array}$ \\
\hline $\begin{array}{l}\text { Decreto } \mathrm{n}^{0} \\
99.274 / 90\end{array}$ & Federal & Regulamenta o SISNAMA \\
\hline $\begin{array}{l}\text { Resolução } \\
\text { CONAMA } n^{0} \\
3 / 90\end{array}$ & Federal & $\begin{array}{l}\text { Dispõe sobre os padrões de qualidade do } \\
\text { ar }\end{array}$ \\
\hline $\begin{array}{l}\text { Resolução } \\
\text { CONAMA } n^{0} \\
6 / 91\end{array}$ & Federal & $\begin{array}{l}\text { Desobriga a incineração ou qualquer outro } \\
\text { tratamento de queima de RSS's, portos e } \\
\text { aeroportos, ressalvados os casos } \\
\text { previstos em lei e acordos internacionais. }\end{array}$ \\
\hline $\begin{array}{l}\text { Resolução } \\
\text { CONAMA n } \\
8 / 91\end{array}$ & Federal & $\begin{array}{l}\text { Veta entrada de materiais residuais } \\
\text { destinados à disposição final e incineração } \\
\text { no país. }\end{array}$ \\
\hline NBR n ${ }^{0} .8419 / 92$ & Federal & $\begin{array}{l}\text { Apresentação de projetos de aterros } \\
\text { sanitários de resíduos sólidos urbanos }\end{array}$ \\
\hline $\begin{array}{l}\text { Resolução } \\
\text { CONAMA n }{ }^{0} \\
5 / 93\end{array}$ & Federal & $\begin{array}{l}\text { Dispõe sobre o tratamento e disposição } \\
\text { finais de RSS's, Portos, Aeroportos, } \\
\text { Terminais Rodoviários e Ferroviários. }\end{array}$ \\
\hline $\begin{array}{l}\text { NBR } n^{0} \\
12.807 / 93\end{array}$ & Federal & RSS's - Terminologia \\
\hline $\begin{array}{l}\text { NBR } n^{0} \\
12.808 / 93\end{array}$ & Federal & RSS's - Classificação \\
\hline $\begin{array}{l}\text { NBR } n^{0} \\
12.809 / 93\end{array}$ & Federal & Manuseio de RSS's - Procedimentos \\
\hline $\begin{array}{l}\text { NBR } n^{0} \\
12.810 / 93\end{array}$ & Federal & Coleta de RSS's - Procedimentos \\
\hline Lei $n^{0} .8 .999 / 94$ & Federal & $\begin{array}{l}\text { Veta utilização de embalagens } \\
\text { descartáveis espumadas cujo processo de } \\
\text { fabricação tenha-se usado CFC's como } \\
\text { expansor. }\end{array}$ \\
\hline $\begin{array}{l}\text { Resolução } \\
\text { CONAMA n }{ }^{0} \text {. } \\
23 / 96\end{array}$ & Federal & $\begin{array}{l}\text { Estabelece critérios para importação e } \\
\text { exportação de resíduos sólidos, } \\
\text { estabelecendo a sua classificação. }\end{array}$ \\
\hline $\begin{array}{l}\text { Resolução } \\
\text { CONAMA n } \\
237 / 97\end{array}$ & Federal & $\begin{array}{l}\text { Dispõe sobre o sistema de Licenciamento } \\
\text { Ambiental, a regulamentação dos seus } \\
\text { aspectos como estabelecidos pela Política } \\
\text { Nacional do Meio Ambiente. }\end{array}$ \\
\hline
\end{tabular}




\begin{tabular}{|c|c|c|}
\hline Lei $n^{0} .9 .433 / 97$ & Federal & $\begin{array}{l}\text { Criou o Sistema Nacional de } \\
\text { Gerenciamento de Recursos Hídricos - } \\
\text { Determina responsabilidades } \\
\text { Institucionais e os Instrumentos de Gestão } \\
\text { de Bacias Hidrográfica e Proteção da } \\
\text { qualidade e uso sustentável da água }\end{array}$ \\
\hline Lei $n^{0} .9 .605 / 98$ & Federal & $\begin{array}{l}\text { Estabelece ações penais e administrativas } \\
\text { derivadas de condutas e atividades } \\
\text { lesivas ao Ambiente Natural e dá outras } \\
\text { providências (Lei dos Crimes Ambientais) }\end{array}$ \\
\hline $\begin{array}{l}\text { Deliberação } \\
\text { CONAMA } n^{0} . \\
13 / 98\end{array}$ & Federal & $\begin{array}{l}\text { Aprova diretrizes para a disposição de } \\
\text { lodos de ETE's }\end{array}$ \\
\hline $\begin{array}{l}\text { Portaria } \mathrm{n}^{0} . \\
961 / 98\end{array}$ & Estadual/São Paulo & $\begin{array}{l}\text { Regulamentação dos processos de } \\
\text { operações com Resíduos industriais, } \\
\text { Sólidos Urbanos entre outros. }\end{array}$ \\
\hline Lei $n^{0} .9 .795 / 99$ & Federal & $\begin{array}{l}\text { Regula a Educação Ambiental, institui a } \\
\text { política Nacional de Educação Ambiental } \\
\text { e dá outras providências. }\end{array}$ \\
\hline $\begin{array}{l}\text { Resolução } \\
\text { CONAMA } n^{0} \\
257 / 99\end{array}$ & Federal & $\begin{array}{l}\text { Dispõe sobre uso de pilhas e baterias que } \\
\text { produzam em decomposição: Chumbo, } \\
\text { Cádmio, Mercúrio e seus compostos... } \\
\text { etc., e eletro-eletrônicos. }\end{array}$ \\
\hline Lei $n^{0} .12 .493 / 99$ & Estadual/Paraná & $\begin{array}{l}\text { Estabelece princípios, procedimentos, } \\
\text { normas e critérios referentes a geração, } \\
\text { acondicionamento, armazenamento, } \\
\text { coleta, transporte, tratamento e } \\
\text { destinação final dos resíduos sólidos no } \\
\text { Estado do Paraná, visando controle da } \\
\text { poluição, da contaminação e a } \\
\text { minimização de seus impactos ambientais } \\
\text { e adota outras providências. }\end{array}$ \\
\hline $\begin{array}{l}\text { Lei } n^{0} . \\
10.888 / 2001\end{array}$ & Federal & $\begin{array}{l}\text { Dispõe sobre o descarte final de resíduos } \\
\text { potencialmente perigosos dos RSU's } \\
\text { (pilhas, baterias, lâmpadas fluorescentes, } \\
\text { frascos de aerossóis...) que contenham } \\
\text { metais pesados e dá outras previdências. }\end{array}$ \\
\hline $\begin{array}{l}\text { Resolução } \\
\text { CONAMA } n^{0} \\
283 / 2001\end{array}$ & Federal & $\begin{array}{l}\text { Dispõe sobre o tratamento e destinação } \\
\text { finais dos RSS's. }\end{array}$ \\
\hline $\begin{array}{l}\text { Lei } n^{0} \text {. } \\
13.103 / 2001\end{array}$ & Estadual/Ceará & $\begin{array}{l}\text { Dispõe sobre a política de resíduos } \\
\text { sólidos no Estado do Ceará }\end{array}$ \\
\hline $\begin{array}{l}\text { Lei } n^{0} \\
10.438 / 2002\end{array}$ & Federal & $\begin{array}{l}\text { Institui o Programa de Incentivos às } \\
\text { Fontes Alternativas de Energia Elétrica - } \\
\text { PROINFA }\end{array}$ \\
\hline $\begin{array}{l}\text { Resolução } \\
\text { Conjunta } \\
\text { SMA/SS } n^{0} \\
1 / 2002\end{array}$ & Federal & $\begin{array}{l}\text { Dispõe sobre tintura ou retalhamento de } \\
\text { pneumáticos para fins de disposição em } \\
\text { aterros sanitários e dá outras providências }\end{array}$ \\
\hline
\end{tabular}




\begin{tabular}{|c|c|c|}
\hline $\begin{array}{l}\text { Resolução } \\
\text { CONAMA n } \\
307 / 2002\end{array}$ & Federal & $\begin{array}{l}\text { Dispõe sobre diretrizes, critérios e } \\
\text { procedimentos para a gestão dos RCD's }\end{array}$ \\
\hline $\begin{array}{l}\text { Resolução } \\
\text { CONAMA n } \\
308 / 2002\end{array}$ & Federal & $\begin{array}{l}\text { Regula o Licenciamento Ambiental para } \\
\text { Sistemas de disposição final de RSU's } \\
\text { gerados em municípios de pequeno porte. } \\
\text { Assim, segundo as diretrizes dessas } \\
\text { resoluções, devem ser requeridas as } \\
\text { seguintes licenças: }\end{array}$ \\
\hline $\begin{array}{l}\text { Resolução } \\
\text { CONAMA } n^{0} \\
313 / 2002\end{array}$ & Federal & $\begin{array}{l}\text { Dispõe sobre o Inventário Nacional de } \\
\text { Resíduos Sólidos Industriais }\end{array}$ \\
\hline $\begin{array}{l}\text { Resolução } \\
\text { CIMGC } n^{0} \text {. } \\
1 / 2003\end{array}$ & Federal & $\begin{array}{l}\text { Da Comissão Interministerial de } \\
\text { Mudanças Global do Clima (CIMGC), } \\
\text { visando implementar os objetivos da } \\
\text { CQNUMC, e dá outras providências. }\end{array}$ \\
\hline $\begin{array}{l}\text { Lei } n^{0} \text {. } \\
4191 / 2003\end{array}$ & $\begin{array}{l}\text { Estadual/Rio de } \\
\text { Janeiro }\end{array}$ & $\begin{array}{l}\text { Dispõe sobre a Política Estadual de } \\
\text { Resíduos Sólidos e dá outras } \\
\text { Providências. }\end{array}$ \\
\hline $\begin{array}{l}\text { Resolução } \\
\text { ANVISA/RDC } n^{0} \text {. } \\
33 / 2003\end{array}$ & Federal & $\begin{array}{l}\text { Dispõe sobre o regulamento técnico para } \\
\text { gerenciamento de RSSS }\end{array}$ \\
\hline $\begin{array}{l}\text { NBR } n^{0} \\
10.004 / 2004\end{array}$ & Federal & Classificação de resíduos sólidos \\
\hline $\begin{array}{l}\text { NBR } n^{0} \\
10.005 / 2004\end{array}$ & Federal & Lixiviação de resíduos - procedimentos \\
\hline $\begin{array}{l}\text { NBR } n^{0} \\
10.006 / 2004\end{array}$ & Federal & $\begin{array}{l}\text { Solubilização de resíduos - } \\
\text { procedimentos }\end{array}$ \\
\hline $\begin{array}{l}\text { NBR } n^{0} \\
10.007 / 2004\end{array}$ & Federal & Amostragem de resíduos \\
\hline $\begin{array}{l}\text { Lei } n^{0} \\
2.336 / 2004\end{array}$ & $\begin{array}{l}\text { Municipal/Diadema/ } \\
\text { São Paulo }\end{array}$ & $\begin{array}{l}\text { Institui o Sistema para gestão sustentável } \\
\text { de resíduos sólidos do município de } \\
\text { Diadema e dá outras providências. }\end{array}$ \\
\hline $\begin{array}{l}\text { Resolução } \\
\text { CONAMA } \\
n^{0} .357 / 2005\end{array}$ & Federal & $\begin{array}{l}\text { Dispõe sobre a classificação dos corpos } \\
\text { de água e diretrizes ambientais para o seu } \\
\text { enquadramento, estabelece condições e } \\
\text { padrões de lançamento de efluentes, e dá } \\
\text { outras providências. }\end{array}$ \\
\hline $\begin{array}{l}\text { Lei } n^{0} \\
11.107 / 2005\end{array}$ & Federal & $\begin{array}{l}\text { Dispõe sobre normas gerais de } \\
\text { contratação de consórcios públicos e dá } \\
\text { outras providências }\end{array}$ \\
\hline $\begin{array}{l}\text { ACM0001/Versã } \\
\text { o 2/2005 }\end{array}$ & CQNUMC/MDL & $\begin{array}{l}\text { Revisa metodologia consolidada aprovada } \\
\text { de linha da base ACM0001. "Metodologia } \\
\text { consolidada de linha de base para } \\
\text { atividades de projetos com gás de aterro". }\end{array}$ \\
\hline $\begin{array}{l}\text { Resolução } \\
\text { CIMGC nº } \\
\text { 2/2005 }\end{array}$ & Federal & $\begin{array}{l}\text { Altera Res. } \mathrm{n}^{0} \cdot 1 / 2003 \text {. Aprova } \\
\text { procedimentos para atividades de Projetos } \\
\text { de Florestamento e Reflorestamento, no } \\
\text { âmbito do MDL/Protocolo de Quioto e dá } \\
\text { outras providências. }\end{array}$ \\
\hline
\end{tabular}




\begin{tabular}{|c|c|c|}
\hline $\begin{array}{l}\text { Resolução } \\
\text { CIMGC } n^{0} \\
3 / 2006\end{array}$ & Federal & $\begin{array}{l}\text { Estabelece procedimentos para a } \\
\text { aprovação de atividades de projetos de } \\
\text { pequena escala no âmbito do } \\
\text { MDL/Protocolo de Quioto e dá outras } \\
\text { providências. }\end{array}$ \\
\hline $\begin{array}{l}\text { Resolução } \\
\text { CIMGC } n^{0} \\
4 / 2006\end{array}$ & Federal & $\begin{array}{l}\text { Altera as Resoluções } n^{0} \cdot 1 \text { e } n^{0} .3 \text {, da } \\
\text { mesma Comissão, e dá outras } \\
\text { providências. }\end{array}$ \\
\hline $\begin{array}{l}\text { Resolução } \\
\text { CIMGC n⿳0. } \\
\text { 5/2007 }\end{array}$ & Federal & $\begin{array}{l}\text { Revisa definições de atividades de } \\
\text { Projetos de pequena escala no âmbito do } \\
\text { MDL/Protocolo de Quioto, e dá outras } \\
\text { providências. }\end{array}$ \\
\hline $\begin{array}{l}\text { Resolução } \\
\text { CIMGC n } \\
6 / 2007\end{array}$ & Federal & $\begin{array}{l}\text { Altera Res. } \mathrm{n}^{0} .2 \text { em relação à versão do } \\
\text { documento de concepção de projeto do } \\
\text { Conselho Executivo do MDL. }\end{array}$ \\
\hline $\begin{array}{l}\text { Decreto } n^{0} \\
5.940 / 2006\end{array}$ & Federal & $\begin{array}{l}\text { Institui a separação dos Resíduos } \\
\text { Recicláveis descartados pelos Órgãos e } \\
\text { Entidades da Administração Pública } \\
\text { Federal, direta e indireta, na fonte } \\
\text { geradora, e a sua destinação às } \\
\text { Associações e Cooperativas dos } \\
\text { catadores de recicláveis, e dá outras } \\
\text { providências. }\end{array}$ \\
\hline $\begin{array}{l}\text { Lei } n^{0} \text {. } \\
12.300 / 2006\end{array}$ & Estadual/São Paulo & $\begin{array}{l}\text { Institui a política Estadual de Resíduos } \\
\text { Sólidos e define princípios e diretrizes }\end{array}$ \\
\hline $\begin{array}{l}\text { Lei } n^{0} \text {. } \\
11.445 / 2007\end{array}$ & Federal & 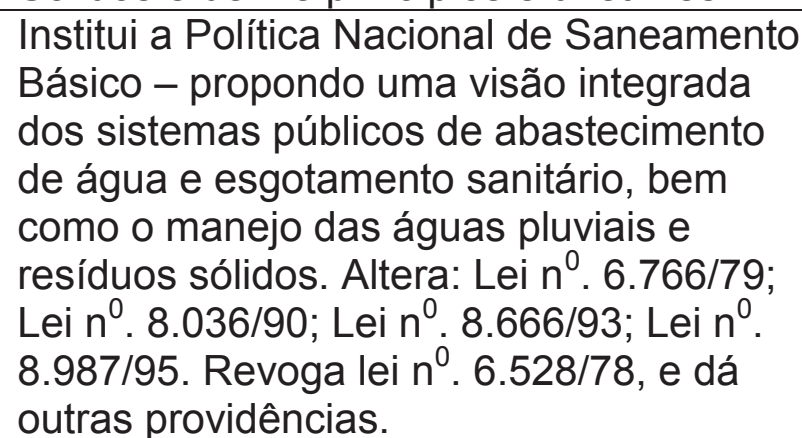 \\
\hline $\begin{array}{l}\text { Lei } \mathrm{n}^{0} \text {. } \\
12.528 / 2007\end{array}$ & Estadual/São Paulo & $\begin{array}{l}\text { Obriga a implantação do processo de } \\
\text { coleta seletiva de lixo em "shopping } \\
\text { centers" e outros estabelecimentos que } \\
\text { especifica, do Estado de São Paulo }\end{array}$ \\
\hline $\begin{array}{l}\mathrm{PL} \mathrm{n}^{0} \\
\text { 58/MMA/2007 }\end{array}$ & Federal & $\begin{array}{l}\text { Propõe instituir a política Nacional de } \\
\text { Resíduos Sólidos e dá outras } \\
\text { providências. }\end{array}$ \\
\hline $\begin{array}{l}\text { Lei } n^{0} \text {. } \\
14.023 / 2007\end{array}$ & Estadual/Ceará & $\begin{array}{l}\text { Dispõe que } 25 \% \text { da arrecadação do ICMS } \\
\text { estadual seremos destinados às áreas da } \\
\text { educação }(18 \%) \text {, saúde ( } 5 \%) \text { e meio } \\
\text { ambiente }(2 \%) \text {. }\end{array}$ \\
\hline $\begin{array}{l}\text { Decreto } \\
\text { Presidencial } n^{0} \\
6.514 / 2008\end{array}$ & Federal & Regulamenta a Lei de Crimes Ambientais \\
\hline
\end{tabular}




\section{ANEXO C \\ CURVAS DE CALIBRAÇÃO DO CROMATÓGRAFO}

1) $\underline{\text { CURVA PARA } \mathrm{CO}_{2}}$

O VOLUME DE $\mathrm{CO}_{2}$ É 30\% DO VOLUME INJETADO.

\begin{tabular}{|l|l|l|l|l|}
\hline $\begin{array}{l}\text { CURVA PARA DIÓXIDO DE CARBONO - } \\
\text { SETEMBRO/2006 }\end{array}$ & $\mathrm{R}=62,3$ & $\mathrm{P}=695 \mathrm{mmHg}$ & $\mathrm{T}=301 \mathrm{~K}$ \\
\hline
\end{tabular}

\begin{tabular}{|c|c|c|}
\hline VOL. EXATO DE CO $\mathrm{CO}_{2}(\mu \mathrm{L})$ & ÁREA $\mathrm{CO}_{2}$ & VoL. $\mathrm{CO}_{2}$ (L) \\
\hline 6 & 1138,0 & 0,000006 \\
\hline 12 & 2684,0 & 0,000012 \\
\hline 30 & 24166,0 & 0,00003 \\
\hline 60 & 42364,0 & 0,00006 \\
\hline 120 & 93404,7 & 0,00012 \\
\hline 180 & 131365,5 & 0,00018 \\
\hline 240 & 179168,0 & 0,00024 \\
\hline 300 & 232816,0 & 0,0003 \\
\hline
\end{tabular}

\begin{tabular}{cr}
\hline MOLS CO & \multicolumn{1}{c}{ ÁREA CO } \\
\cline { 2 - 2 } $2,26715 \mathrm{E}^{-07}$ \\
$4,53429 \mathrm{E}^{-07}$ & 1138,0 \\
$1,13357 \mathrm{E}^{-06}$ & 2684,0 \\
$2,26715 \mathrm{E}^{-06}$ & 24166,0 \\
$4,53429 \mathrm{E}^{-06}$ & 42364,0 \\
$6,80144 \mathrm{E}^{-06}$ & 93404,7 \\
$9,06859 \mathrm{E}^{-06}$ & 131365,5 \\
$1,13357 \mathrm{E}^{-05}$ & 2328168,0 \\
\hline
\end{tabular}

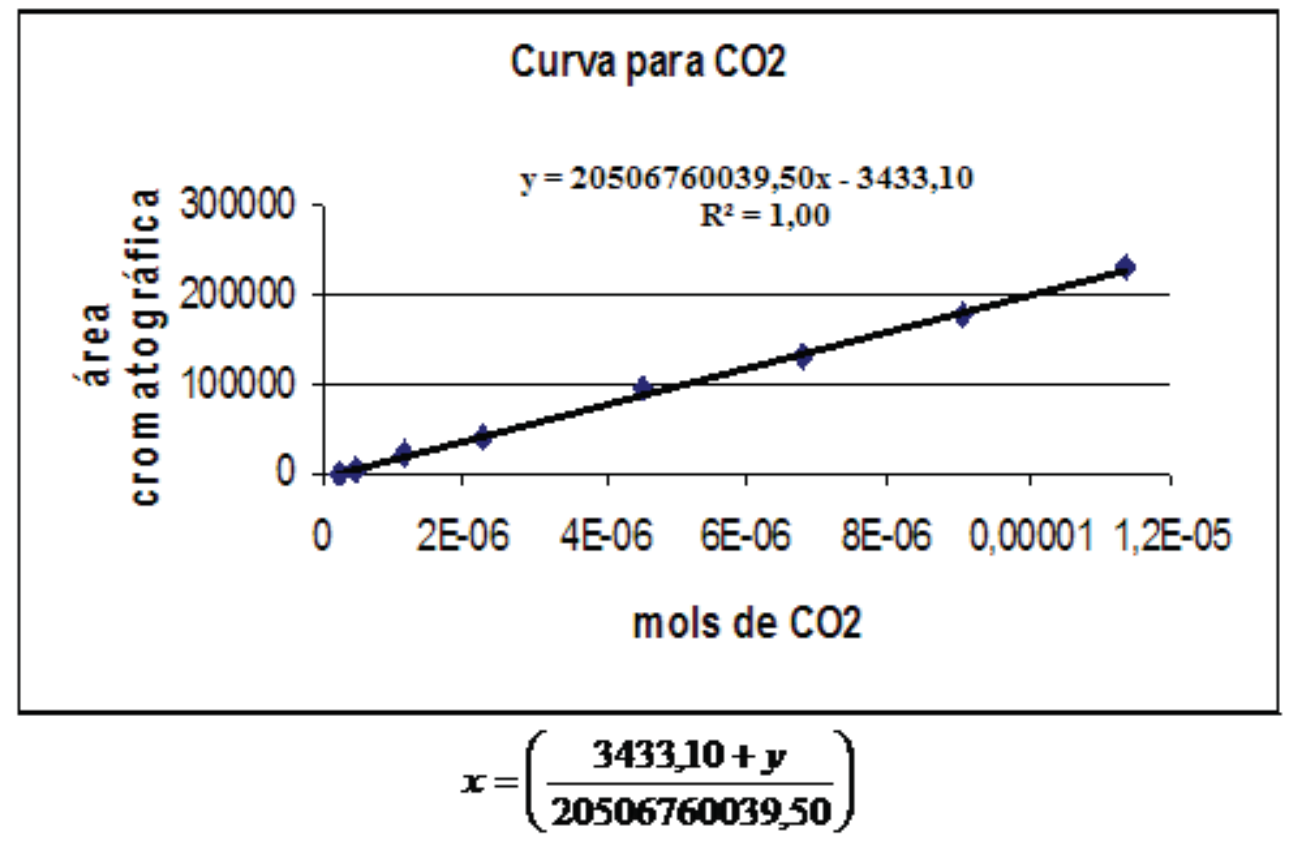

BERTO NETO, J. (2009). - Medidas da Emissão de Gases de oito aterros de resíduos sólidos urbanos do Estado de São Paulo - Brasil. Tese apresentada ao PPG-SEA/CRHEA - EESC/USP. São Carlos-SP, Dez. 2009. 


\section{2) CuRva para $\mathrm{CH}_{4}$}

\begin{tabular}{|l|l|l|l|l|}
\hline CURVA PARA METANO $\left(\mathrm{CH}_{4}\right)$ & PV $=\mathbf{n R T}$ & $\mathrm{R}=62,3$ & $\mathrm{P}=695 \mathrm{mmHg}$ & $\mathrm{T}=301 \mathrm{~K}$ \\
\hline
\end{tabular}

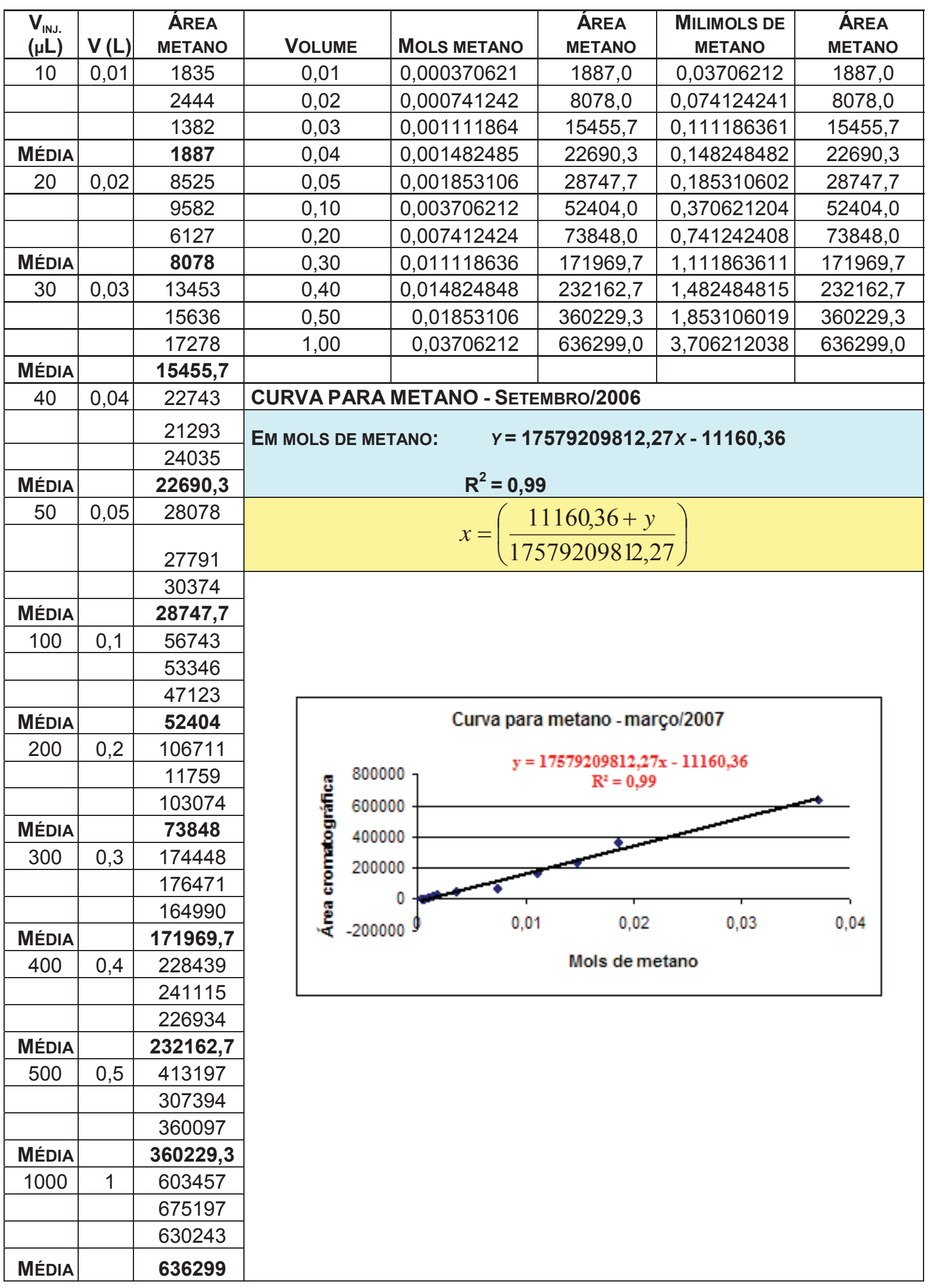

